
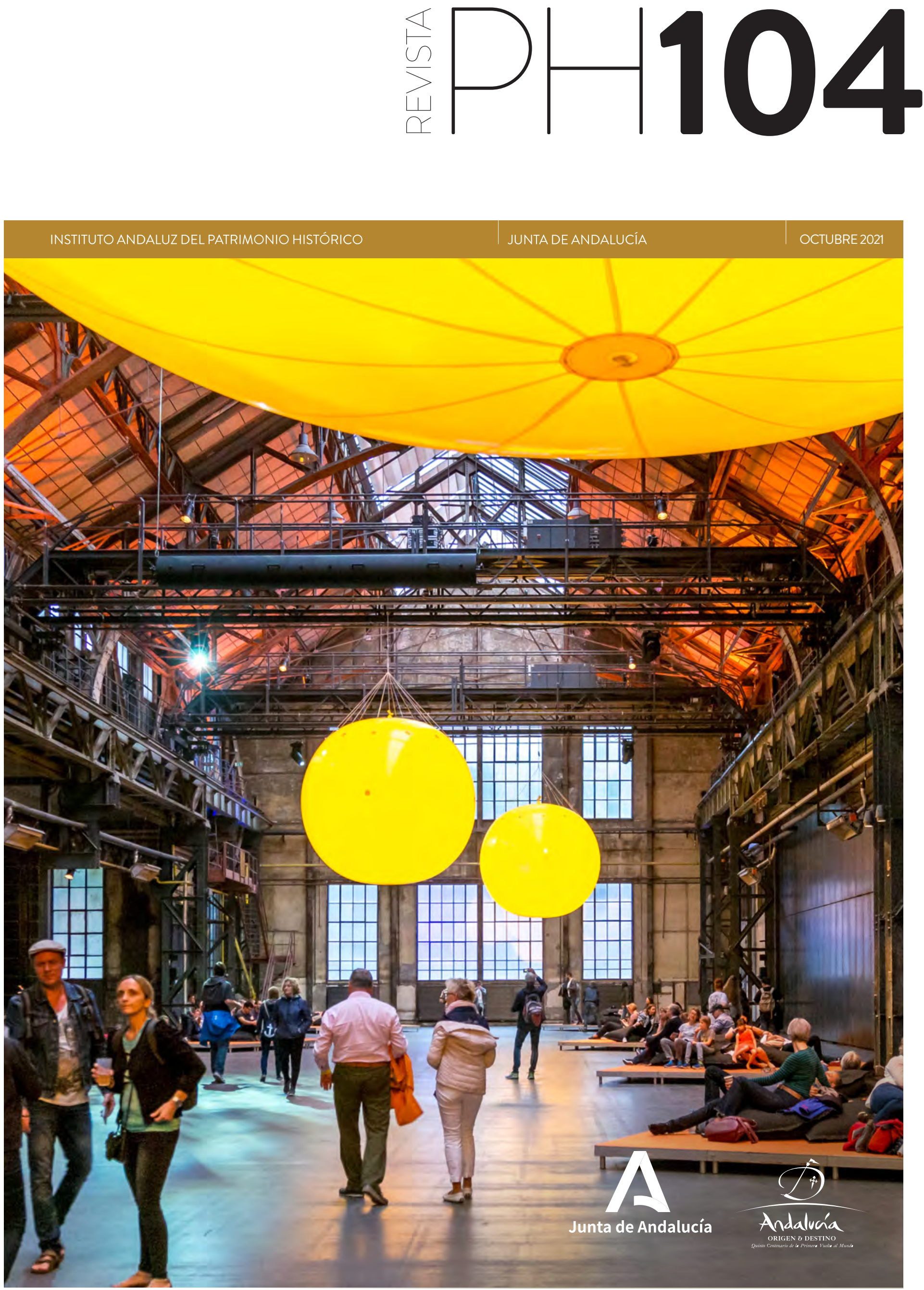



\section{$\mathrm{PH} 1044_{\text {sumario }}$}

monográfico Buenas prácticas en conservación y revitalización del patrimonio cultural desde los Objetivos del Desarrollo Sostenible (ODS)

Coordinación: Ignacio González-Varas Ibáñez, Escuela de Arquitectura de Toledo, Universidad de Castilla-La Mancha

Apoyo a la coordinación: Marta García de Casasola Gómez, Dpto. de Historia, Teoría y Composición Arquitectónicas, Universidad de Sevilla*

actualidad

002 Cultura, desarrollo sostenible y creatividad: una reflexión desde la Red Española para el Desarrollo Sostenible (REDS)

Alfons Martinell Sempere

006 Hispania Nostra premia a través de tres categorías las buenas prácticas en la conservación del patrimonio cultural y natural

Antonio Zárate Martín

009 EI IAPH celebra el II Encuentro Patrimonio de Proximidad, centrado en los cuidados del patrimonio y su comunidad

Isabel Luque Ceballos

013 La Comisión Europea reconoce la contribución del Museo Cal de Morón a la salvaguardia del patrimonio cultural europeo

Manuel Gil Ortiz

015 El proyecto europeo SoPHIA reflexiona sobre la calidad de las intervenciones en el patrimonio histórico y cultural

Alberto Cerezo Soto

018 AMMA galardona la excelencia y la innovación en la práctica profesional de la museología y la museografía en Andalucía

Santiago Campuzano Guerrero, M. ${ }^{a}$ Dolores Cebrián Sotomayor, Elena López Gil y Sol Martín

020 La asociación Ponte...nas ondas! coloca el patrimonio cultural inmaterial en la agenda política conjunta de España y Portugal

Santiago Veloso Troncoso, Esmeralda Maria Rodrigues de Carvalho, Xerardo Pereiro Pérez y Xosé Manuel Cid Fernández

022 CREhAR en la era digital. La primera cátedra UNESCO en el campo emergente del patrimonio contemporáneo Mar Loren-Méndez

025 Áreas escasamente pobladas del sur europeo convergen en el proyecto LIVHES en torno al patrimonio cultural inmaterial

Alfredo Asiáin Ansorena

artículos

*Cuando comenzó la gestación de este número, Marta García de Casasola Gómez ocupaba la jefatura del Centro de Intervención del IAPH

028 Buenas prácticas: concepto, sentido y aplicación para la valoración y gestión de sistemas patrimoniales complejos

Ignacio González-Varas Ibáñez

058 Patrimonio colectivo. Comunidades, participación y sostenibilidad

Beatriz Santamarina Campos

078 Memoria e identidad de las comunidades portadoras en el desarrollo de buenas prácticas de salvaguardia del PCl

María Pía Timón Tiemblo y Antonio Muñoz Carrión

104 Herramientas técnicas y principios básicos en el proceso de planificación turística de los sitios patrimoniales

María José Viñals

126 Las infraestructuras de transporte: buenas prácticas en la recuperación y gestión del patrimonio territorial

José Luis Lalana Soto, Rita Ruiz Fernández y Francisco Javier Rodríguez Lázaro 
144 La reutilización del patrimonio construido, nuevos usos, buenas prácticas Francisco Javier Soria López

164 Patrimonio y sostenibilidad. Las buenas prácticas en la rehabilitación energética de edificios patrimoniales

Albert Cuchí Burgos

180 La agricultura tradicional como legado agroecológico para la humanidad Miguel A. Altieri

proyectos y experiencias

198 La rehabilitación de la Ciudad de los Ángeles de Secundino Zuazo y la gestión vecinal en la recuperación del patrimonio

Francisco Javier González González, Miguel Lasso de la Vega y Daniel Morcillo Álvarez

214 El Plan Medellín Centro y las buenas prácticas en la gestión integrada de la ciudad Ángel Luis Fernández Muñoz

234 Los inventarios del patrimonio cultural inmaterial: del caso del Montseny a la actualidad Lluís García Petit

246 El patrimonio inmaterial y la construcción de paz: la actividad del Centro de Memoria, Paz y Reconciliación de Bogotá D.C.

José Antequera Guzmán

258 El Museu Faller de València: buenas prácticas comunitarias y en gestión del turismo Gil-Manuel Hernàndez i Martí

270 La Ruta 66 en Estados Unidos: allanando el camino para la protección y gestión de las carreteras históricas

Kaisa Barthuli y Michael Romero Taylor

284 La Calzada México-Tacuba: retos en la regeneración y reactivación de un camino histórico Gerardo A. Hernández Septién

296 Carta de Reutilización del Patrimonio Edificado. Propuesta de principios y nuevas prácticas

Francisco Haroldo Alfaro Salazar

308 Buenas prácticas para la conservación y revitalización del patrimonio conventual de Toledo

Ignacio González-Varas Ibáñez

324 Energía y medioambiente para la habitabilidad en la ciudad histórica de Santiago de Compostela. 1994-2012

Ángel Panero Pardo

342 El análisis de riesgos en los centros históricos: estudio de las fortificaciones urbanas de centro histórico de Sevilla

Rocío Ortiz Calderón, Mónica Moreno Falcón, Javier Becerra Luna, Samuel Corona Corrales y Pilar Ortiz Calderón

362 La Red Andaluza de Semillas, buenas prácticas en el mantenimiento sostenible del ecosistema agrario

Juan José Soriano Niebla

376 Conocimientos locales y desarrollo sostenible en Perú. El proyecto SIPAM Agrosistemas de alta montaña

debate Beatriz Pérez Galán

390 Patrimonio cultural y cambio climático (introdución) coordina: Alejandro García Hermida 
Patrimonio y cambio climático Alejandro García Hermida

400 Cambio climático y patrimonio arbóreo monumental: un paisaje cultural amenazado Francisca Ramón Fernández

403 Water-Wise Cities, ¿puede el patrimonio cultural del agua aportar estrategias ante el futuro cambio hidrológico?

Celia López-Bravo y José Peral López

406 El patrimonio intangible de la arquitectura tradicional: un recurso en la lucha contra el cambio climático

Mónica Alcindor

409 Amenazas sobre los paisajes y actividades salineras del suroeste español por el cambio climático

Antonio Fajardo de la Fuente

413 Incendios en paisajes patrimoniales naturales: análisis y evaluación de riesgos en fortificaciones mediante el uso del Global Wildfire Information System

Mónica Moreno Falcón, Rocío Ortiz Calderón y Pilar Ortiz Calderón

420 Arquitectura por el cambio climático José Franqueira Baganha

424 Arquitectura tradicional y sostenibilidad. Arquitectura industrial e insostenibilidad Jaime de Hoz Onrubia

426 Patrimonio rural y cambio climático

José Manuel Baena Gallé

429 Programa de estudios para una arquitectura sostenible y sensible al patrimonio Pedro Paulo Palazzo

432 El valor patrimonial del SIPAM

José Damián Ruiz Sinoga

434 Paisajes rurales y energías renovables. Un patrimonio cultural bajo amenaza Anna Martínez Durán y Montserrat Villaverde Rey

438 ¿Cómo crees que afecta el cambio climático al patrimonio cultural? Robert Adam

441 Cambio climático y evaluación de riesgo para el patrimonio cultural Mauro G. García Santa Cruz, M. Jimena García Santa Cruz y Guillermo R. García

446 ¿Cómo se puede reducir el impacto del cambio climático en la preservación de edificios patrimoniales?

Carmen M. ${ }^{a}$ Muñoz González y Jonathan Ruiz Jaramillo

448 Seguridad cultural, Venecia y el acqua alta

Xira Ruiz Campillo y M. ${ }^{\text {a }}$ Pilar Montero Vilar

452 Aprender de la arquitectura anónima Olga Muñoz i Frigola

454 Repensar la ciudad. Cuando el cambio climático pone en evidencia la desprotección de patrimonio. Inundaciones urbanas en la ciudad de La Plata Alejandra González Biffis

458 Actuaciones prometedoras frente al cambio climático: la patrimonialización del valle del Darro y la rehabilitación de las acequias de "careo" de Sierra Nevada Isabel Ordieres Díez

460 Arquitectura de gran escala y sostenibilidad Julián García Muñoz 
Bajo la arena. Cambio climático y el pasado invisible del Uruguay. ¿Hablamos de patrimonio?

Laura Brum Bulanti

467 ¿De qué manera puede el patrimonio cultural convertirse en herramienta para la lucha contra el cambio climático? Teófilo Victoria y Ricardo Lopez

reseñas

470 Martinell Sempere, A. y García Haro, M. (dir) Hacia una cultura sostenible. Guía práctica para integrar la Agenda 2030 en el sector cultural

Por Patricia Pérez Muncunill

472 López Morales, F.J. (coord.) El patrimonio cultural inmaterial: usos sustentables del patrimonio

Por José Miguel Marín Prieto

González-Varas, I. Conservación del patrimonio cultural. Teoría, historia, principios y normas

Por Jesús Ángel Sánchez Rivera

476 Valero Matas, J.A. Patrimonio cultural, sostenibilidad y desarrollo humano en lo rural Por Silvia Isabel Quinto Fernández

Pavón Benito, J. (dir.) El patrimonio cultural en la era digital

Por Ana Isabel Castro Carbonell

480 Revert, X. (coord.) Valencia: Patrimonio cultural y Objetivos de Desarrollo Sostenible Por Sofía L. Arellano Velázquez

Espacio Jahrhunderthalle Bochum, en la antigua planta industrial de gas de Bochumer Verein (Alemania), se ha convertido en un espacio para la cultura, los negocios y el entretenimiento | foto Michael Becker

Revista PH (ISSN 23-40-7565) es una publicación en línea cuatrimestral (febrero, junio y octubre), destinada a los profesionales e invesigadores del patrimonio histórico/cultural.

Sus contenidos están disponibles, de manera gratuita y sin restricciones, en el sitio web www.iaph. es/revistaph. En esa misma dirección encontrará publicadas las contribuciones de la etapa impresa.

Este fichero constituye una recopilación de todos los artículos del número, que pretende facilitar la descarga e impresión personal, pero no es, en ningún caso, una versión impresa de la publicación periódica digital.

Revista PH se edita bajo una licencia creative commons 3.0 BY-NC-ND, por lo que usted es libre de difundir su contenido siempre que cite claramente la fuente original, no utilice la obra para fines comerciales y no altere o transforme la obra.

\section{\begin{tabular}{l|l|l} 
Junta de & $\begin{array}{l}\text { Consejería de Cultura y } \\
\text { Andalucía }\end{array}$ & $\begin{array}{l}\text { Instituto Andaluz del } \\
\text { Patrimonio Histórico }\end{array}$
\end{tabular}}




\title{
Cultura, desarrollo sostenible y creatividad: una reflexión desde la Red Española para el Desarrollo Sostenible (REDS)
}

\begin{abstract}
¿Se puede concebir el desarrollo sostenible sin tener en cuenta las múltiples dimensiones culturales? ¿Qué se entiende por sostenibilidad desde la cultura, las políticas culturales contemporáneas y la gestión cultural profesional? ¿Cómo sensibilizar a los profesionales de la cultura para incorporar la sostenibilidad a sus valores y principios? Alfons Martinell, director de la Comunidad de conocimiento y práctica sobre cultura y desarrollo sostenible de la Red Española para el Desarrollo Sostenible (REDS) nos plantea estas preguntas, al tiempo que reflexiona sobre la ausencia de un objetivo cultural entre los 17 Objetivos de Desarrollo Sostenible (ODS) y nos invita a trabajar para una mayor integración del sector cultural en las dinámicas que está generando la Agenda 2030.
\end{abstract}

Alfons Martinell Sempere | Red Española para el Desarrollo Sostenible (REDS)

URL de la contribución <http://www.iaph.es/revistaph/index.php/revistaph/article/view/5005>

Cada vez existe un mayor consenso científico sobre el hecho de que hemos entrado en una nueva era geológica denominada Antropoceno por el impacto que la actividad humana ha tenido sobre los ecosistemas terrestres. Casi podríamos decir que una característica de esta nueva era geológica del Antropoceno es la capacidad del ser humano de acabar con lo diferente para que todo sea igual. Imperan los paisajes de monocultivos culturales, educacionales, sociales, económicos y, por supuesto, medioambientales. Una de las soluciones a estos desafíos más sobresaliente de los últimos años es la Agenda 2030, titulada Transformar nuestro mundo. En septiembre de 2015, los 193 países que conforman la Asamblea de Naciones Unidas acordaron por unanimidad adoptar un plan de acción a escala global para luchar contra los grandes desafíos de la humanidad: el cambio climático, las desigualdades, el hambre... Esta hoja de ruta es la Agenda 2030 de Desarrollo Sostenible. La agenda se desarrolla en un marco temporal de 15 años (2016-2030) y plantea 17 Objetivos de Desarrollo Sostenible (ODS) y 169 metas que todos los Estados firmantes se han comprometido a cumplir.

El concepto de sostenibilidad, procedente de las ciencias de la naturaleza, no tiene un buen nivel de conceptualización en el sector cultural, que no está acostumbrado a trabajar con esta idea. La noción de sostenibilidad cultural comporta desconcierto en el sector cultural y se vive como algo alejado de su realidad.

Sin embargo, las relaciones entre cultura y desarrollo tienen unos amplios antecedentes en el ámbito de las políticas culturales territoriales y en los discursos multilaterales de Naciones Unidas. Muchas veces los planteamientos que relacionan cultura y desarrollo com-

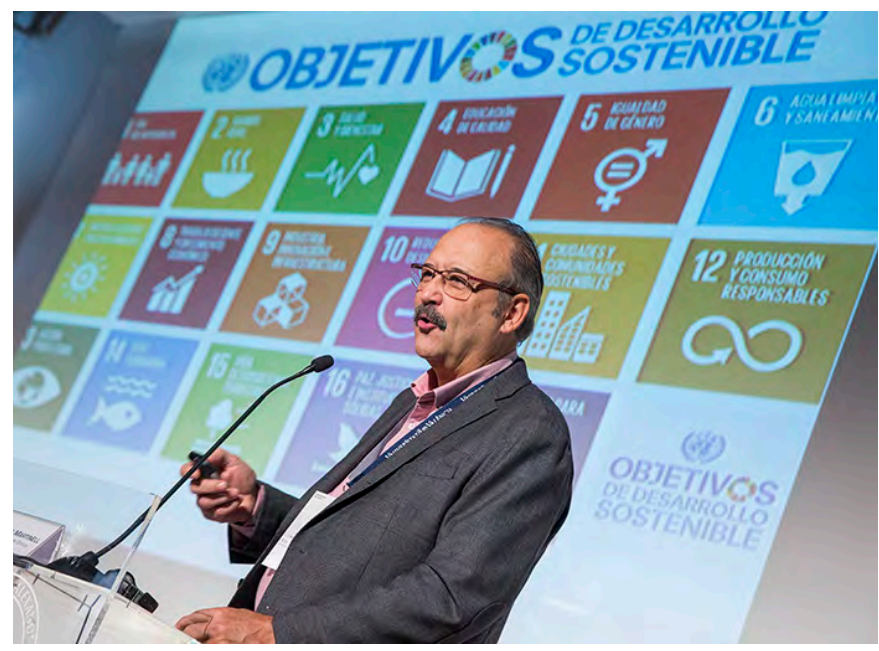

Alfons Martinell, durante unas jornadas de REDS (2018) | fuente REDS 


\title{
\#CulturaSostenible
}

\section{$\oplus 0$}

\author{
Hazte sostenible Noticias Recursos Alianzas Somos Preguntas frecuentes Contacto
}

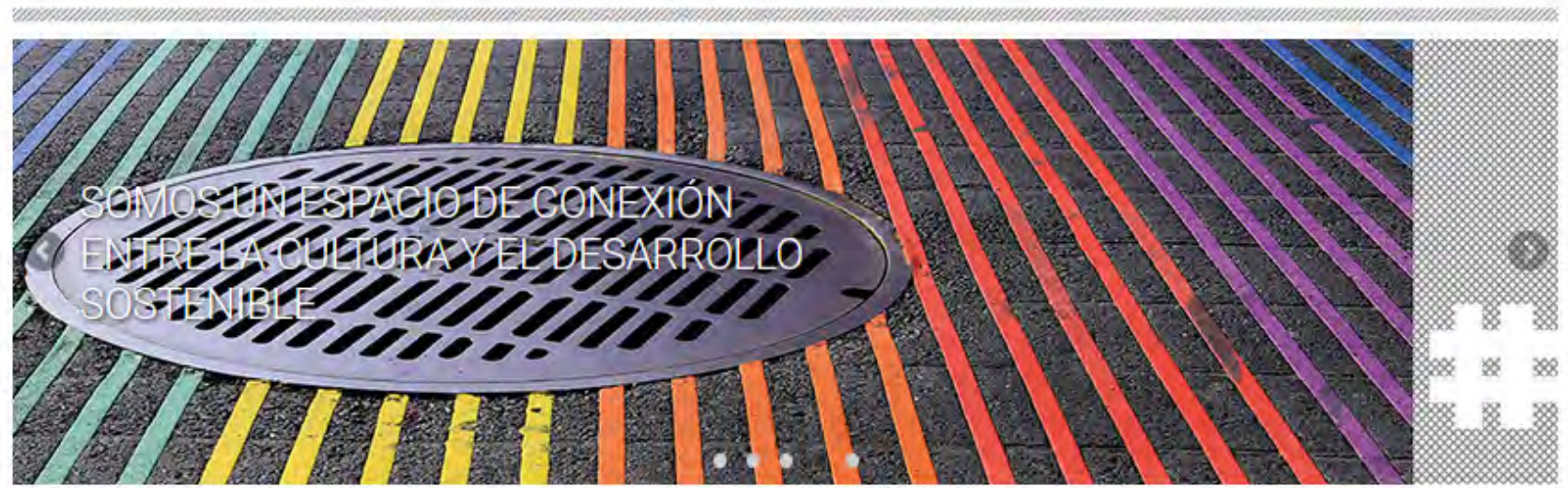

Plataforma \#CulturaSostenible

prenden un componente declarativo y poco aplicado, lo cual puede incidir en su escasa inclusión en las políticas de desarrollo activas. Diferentes iniciativas y prácticas nos presentan un escenario distinto y más elaborado para proponer una nueva generación de argumentaciones que incluyan las diferentes dimensiones culturales en las políticas de desarrollo.

En la actualidad es evidente que para alcanzar los ODS y la Agenda 2030 es imprescindible incorporar el amplio y diverso mundo de la cultura y las humanidades.

Los valores fundamentales de la comunidad internacional expresados en los 17 ODS no incorporan directamente un objetivo cultural, lo cual expresa la dificultad de ciertos círculos para entender la cultura en el mundo contemporáneo. Pero el marco del Objetivo de Desarrollo Sostenible 17 -Revitalizar la Alianza Mundial para el Desarrollo Sostenible- nos permite fomentar alianzas inclusivas de sectores que no se encuentran reflejados directamente en la formulación de los objetivos y muy poco en sus metas. En este sentido es fundamental integrar las aportaciones de la cultura al desarrollo como una innovación y adecuación dentro de las líneas tradicionales de la cooperación al desarrollo y del desarrollo local.

\section{Cultura y REDS}

La Red Española para el Desarrollo Sostenible (REDS) ${ }^{1}$ trabaja en la integración de la Agenda 2030 en el sector cultural y creativo desde su fundación. Entre las principales acciones que ha llevado a cabo se encuentran las tres ediciones de las jornadas sobre sostenibilidad e instituciones culturales -encuentros pioneros para sensibilizar, movilizar y ofrecer herramientas prácticas al sector en torno a la Agenda 2030-. En 2019 lanzó la primera web en español dedicada íntegramente a las relaciones entre cultura y desarrollo sostenible (culturasostenible. org). En 2020 y 2021 editó las publicaciones: Cultura y desarrollo sostenible. Aportaciones al debate sobre la dimensión cultural de la Agenda 2030; Hacia una cultura sostenible. Guía práctica para integrar la Agenda 2030 en el sector cultural; y coordinó el monográfico sobre cultura y desarrollo sostenible que se incluye en el número 21 de la Revista Periférica². Además, REDS ha impulsado la creación de la plataforma \#CulturaSostenible y promueve la Declaración de la Cultura en apoyo a la Agenda 2030, firmada a día de hoy, por más de 500 personas y organizaciones culturales.

En el actual contexto de la pandemia que vivimos, la cultura ha sido considerada un actor fundamental en la reconstrucción pos-COVID. En este sentido, REDS 
acoge, desde el año 2019, la Comunidad de conocimiento y práctica en torno a la cultura y el desarrollo sostenible (CyD). Esta comunidad está formada por un grupo de expertos multidisciplinares nacionales e internacionales que busca generar reflexiones, conversaciones y acciones concretas que ayuden a construir una narrativa compartida vinculando la cultura con el desarrollo sostenible en el marco del contexto actual. El objetivo principal es agrupar y movilizar a profesionales y responsables de cultura y cooperación a reflexionar conjuntamente sobre el desarrollo cultural sostenible y la sostenibilidad en los sistemas culturales. Es decir, crear comunidad en un campo muy atomizado, y, en ocasiones, aislado.

Algunas de las cuestiones que se plantea la comunidad para avanzar en la reflexión y la práctica son:

$>$ En la contemporaneidad de unas sociedades globalizadas, ¿es posible concebir el desarrollo sostenible sin tener en cuenta las múltiples dimensiones culturales?

$>$ En los valores e intenciones que plantean los ODS, no se ha incluido un objetivo específicamente cultural, pero sí algunas metas. Sin embargo, ¿puede concebirse una alianza sin la cultura, sus agentes, sus instituciones o actores?

$>$ ¿Cómo se entiende la sostenibilidad desde los amplios referentes de la cultura, las políticas culturales contemporáneas y la gestión cultural profesional?

$>$ ¿Qué elementos metodológicos se pueden proponer para el diseño de políticas culturales sostenibles?

$>$ ¿Cómo sensibilizar a los profesionales de la cultura para incorporar la sostenibilidad a sus valores y principios?

Estas y otras preguntas evidenciaron la necesidad de profundizar en este campo para una mayor integración del sector cultural en las dinámicas que está generando la Agenda 2030 y replantear los aportes de la cultura en los ODS que reclaman algunas actualizaciones a través de:
$>$ La recuperación de los conocimientos y experiencias de tantos años a nivel local, nacional e internacional en estrategias y actuaciones de incidencia e impactos de la cultura en el desarrollo.

$>$ La inversión en actualizar los objetivos y fines de las estrategias de cultura en el desarrollo, de acuerdo con el contexto actual por medio de:

a. El análisis de la realidad de la cultura contemporánea con base en el nuevo valor de la interdependencia de internet, las redes sociales, la economía de los intangibles y economía creativa, la diversidad cultural y el aumento de la multiculturalidad de las realidades nacionales. Y proponer sus posibles aportes a la cultura como activos de las sociedades.

b. Un replanteamiento de estrategias concretas en los diferentes ámbitos y sectores culturales para el desarrollo.

$>$ La formulación de unos amplios recursos metodológicos con un enfoque cultural para el desarrollo.

$>$ Incidir en la necesidad de incorporar sectores culturales, artísticos, humanísticos y de estudios sociales al concepto y prácticas de la sostenibilidad en la sociedad contemporánea y en la construcción de futuros.

En este amplio marco de acción de la dimensión cultural del desarrollo sostenible, se inscribe la economía creativa tal y como se ha definido por parte de la UNESCO y UNCTAD (Conferencia de las Naciones Unidas sobre Comercio y Desarrollo) que profundiza sobre los aportes directos e indirectos de la creatividad al bienestar y a un futuro mejor.

Dentro de las diferentes dimensiones culturales al desarrollo sostenible contemplamos la contribución directa de las industrias culturales, los productos culturales y la creatividad en general que representa un aporte importante a la riqueza de un país en su PIB y en el empleo. De la misma manera, bajo la definición de ciudades creativas, se ha creado una forma de entender la relación entre creatividad y territorio fomentando unas polí- 
ticas culturales que aprovechen al máximo el potencial de la creatividad. Todo ello representa un insumo y una oportunidad para las sociedades más desfavorecidas para encontrar caminos para el bienestar colectivo.

\section{NOTAS}

1. REDS es la antena de la Red de Soluciones para el Desarrollo Sostenible (SDSN, por sus siglas en inglés) en España desde el 2015. Su misión es apoyar la difusión e implementación de la Agenda 2030 y los Objetivos de Desarrollo Sostenible (ODS) en nuestro país, favoreciendo así a su incorporación en las políticas públicas, en el ámbito empresarial y el comportamiento de la sociedad en general. Uno de los ejes de trabajo de REDS es promover la dimensión cultural de la Agenda 2030 y movilizar al sector cultural, ofreciendo herramientas y espacios donde conectar cultura y desarrollo sostenible. Más información en www.reds-sdsn.es y culturasostenible.org.

2. Los tres títulos pueden descargarse en la web: [1] Martinell, A. (coord.) (2021) Cultura y Desarrollo Sostenible. Aportaciones al debate sobre la dimensión cultural de la Agenda 2030. Disponible en: https://reds-sdsn. es/nueva-publicacion-cultura-desarrollo-sostenible. Dicho libro se reseñó en revista PH 102 (https://doi. org/10.33349/2021.102.4813). [2] Martinell Sempere, A. y García Haro, M. (2021) Hacia una cultura sostenible. Guía práctica para integrar la Agenda 2030 en el sector cultural. Disponible en: https://reds-sdsn.es/publicacionhacia-una-cultura-sostenible-guia-practica-para-integrarla-agenda-2030-en-el-sector-cultural. Encontrará una recensión del libro en este mismo número de revista PH 104 (https://doi.org/10.33349/2021.104.4971). [3] Martinell, A. (coord.) (2020) Monográfico 1: Cultura y Desarrollo Sostenible. Periférica Internacional. Revista para el análisis de la cultura y del territorio, n. ${ }^{\circ} 21$. Disponible en: https:// revistas.uca.es/index.php/periferica/issue/view/435. 


\title{
Hispania Nostra premia a través de tres categorías las buenas prácticas en la conservación del patrimonio cultural y natural
}

\begin{abstract}
Desde 2011 la asociación Hispania Nostra junto con la Fundación Banco Santander convocan los premios a las buenas prácticas en conservación del patrimonio cultural y natural con el objetivo de destacar proyectos y actuaciones ejemplares de salvaguarda. Las candidaturas cada vez más numerosas consolidan unos galardones que se extienden más allá de la puesta en valor patrimonial, premiando la importancia que estas acciones tienen en relación con el desarrollo sostenible, el crecimiento económico, la mejora de la calidad de vida y del medioambiente. Presentamos las actuaciones ganadoras en 2021.
\end{abstract}

Antonio Zárate Martín | Instituto Universitario de Ciencias Ambientales, Universidad Complutense de Madrid

URL de la contribución <http://www.iaph.es/revistaph/index.php/revistaph/article/view/5004>

Los premios Hispania Nostra reconocen el creciente interés de la sociedad por la conservación y puesta en valor de los valores patrimoniales, y la importancia de las acciones acometidas en ese contexto para el desarrollo sostenible, el crecimiento económico, la mejora de la calidad de vida y del medioambiente. Con esos objetivos, los premios se agrupan en tres categorías: una dedicada a la intervención en el territorio o en el paisaje; otra a la conservación del patrimonio como factor de desarrollo económico y social; y una tercera que atiende a la señalización y difusión del patrimonio cultural y natural. Todas las candidaturas presentadas son de gran calidad e interés técnico y profesional, y muestran apoyos sociales, entusiasmo e ilusiones colectivas, siempre con las perspectivas de la inclusión social y el equilibrio ambiental.

Las candidaturas premiadas en 2021 han sido: las actuaciones de rehabilitación en el entorno del Camino de Santiago francés a su paso por el entorno del embalse de Yesa, en Ruesca (Zaragoza), en la primera categoría; la rehabilitación y reconstrucción de edificio hospitalario y anexos de la Isla del Rey en el Puerto de Mahón para centro cultural, y el proyecto de gestión del patrimonio Real Maestranza de Caballería de Ronda (RMR), en la segunda; y Andando Córdoba, en la tercera. Se trata de actuaciones desarrolladas en ámbitos espaciales diferentes y de naturaleza distinta, pero cada una de ellas supone una aportación concreta a la conservación y difusión de los valores patrimoniales de la cul- tura europea, un instrumento de crecimiento económico para los entornos locales y un soporte para la resiliencia medioambiental.

El premio a las actuaciones de rehabilitación en el marco del Camino de Santiago francés a su paso por el entorno del embalse de Yesa, presentado por la Confederación Hidrográfica del Ebro y el Gobierno de Aragón, reconoce su contribución al desarrollo a partir de las relaciones entre patrimonio, paisaje y territorio. El proyecto se centra en la localidad de Ruesta, al norte de la provincia de Zaragoza, atravesada por el Camino de Santiago francés y en abandono tras la construcción del embalse de Yesa en 1960, situación que provocó la desaparición de los cultivos del valle y la expulsión de la población. Las labores de rehabilitación realizadas garantizan la recuperación del conjunto y contribuyen a mejorar el Camino de Santiago francés en este entorno. A través del fomento del turismo mediante la propuesta de un camping y de las actividades de conservación, mantenimiento y recuperación, destacando la restauración de la calle del centro de Ruesta y de las ermitas de San Jacobo (Santiago) de Ruesta, de San Juan de Ruesta y de San Juan de Sigüés (BIC asociados al Camino de Santiago), se consigue fijar población en los municipios próximos.

Galardonada en la segunda categoría, la rehabilitación y reconstrucción del edificio hospitalario y anexos de la Isla del Rey en el Puerto de Mahón (Menorca) para cen- 


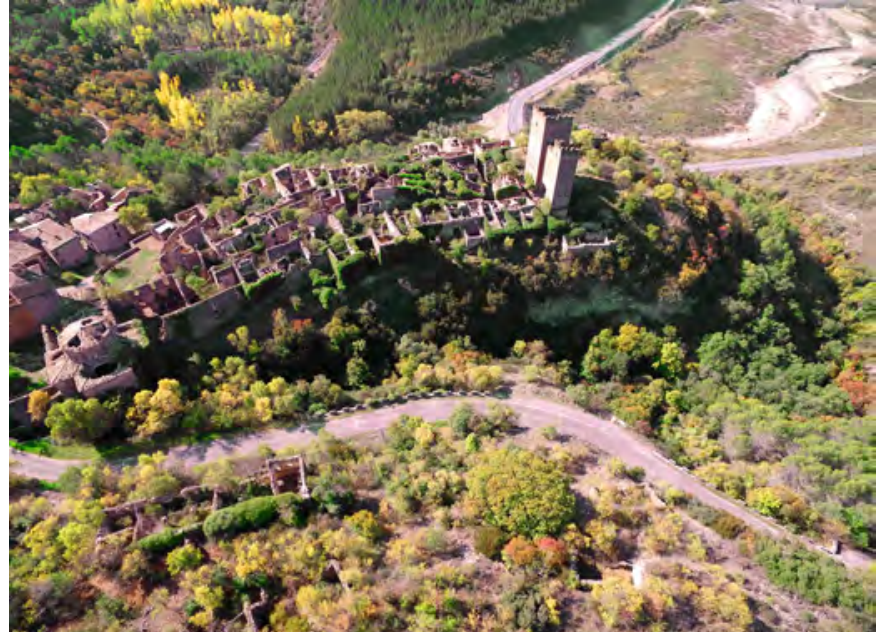

Vista de Ruesta (Zaragoza) desde dron | foto Sebastián Arquitectos

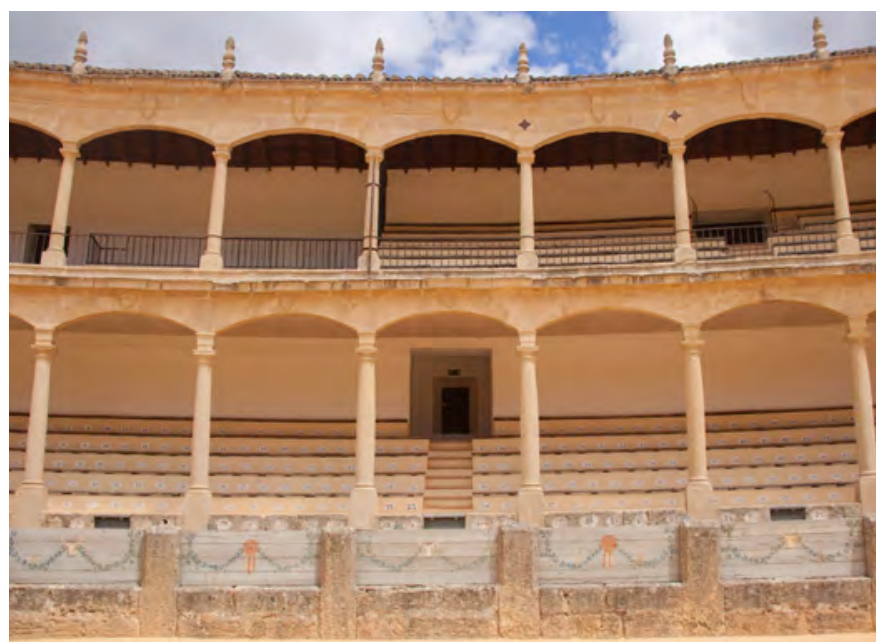

Plaza de Toros de Ronda (Málaga) | foto ChrisGoldNY

tro cultural recupera un elemento relevante de valor patrimonial y paisajístico, aparte de su significado histórico. Se trata del que fuera hospital naval británico construido en 1711 en un lugar emblemático, donde desembarcó Alfonso III en 1287 para conquistar la isla a los musulmanes. Tras pasar, también, por manos francesas, en el año 1802 revirtió definitivamente a la Corona española y siguió funcionando para el ejército español hasta 1956, siendo posteriormente abandonado el edificio y sumido en el inevitable deterioro. Lo que se ha premiado es la labor de rehabilitación iniciada en 2004 por un grupo de ciudadanos, constituidos en 2005 como Fundación Hospital de la Isla del Rey con apoyo del Ayuntamiento.

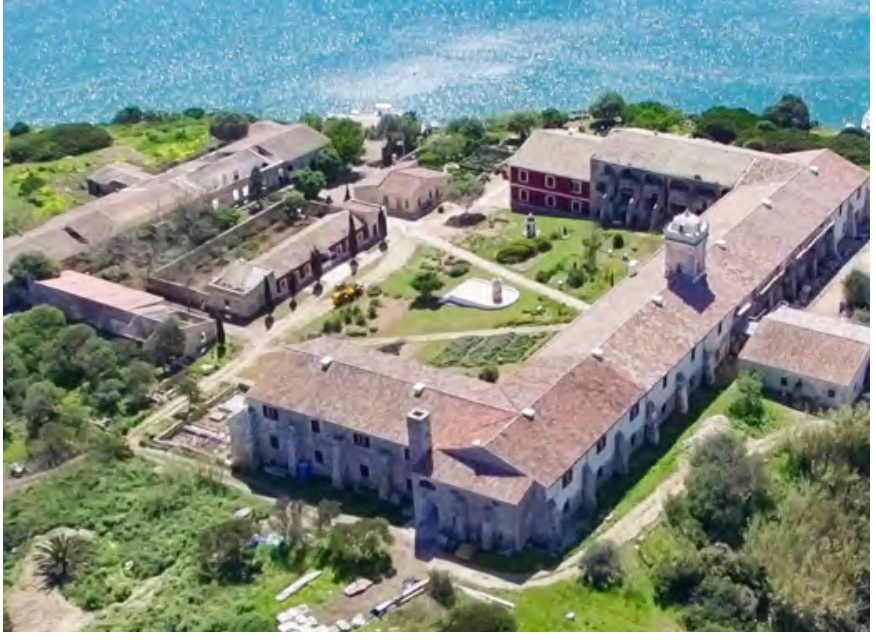

Vista aérea del Hospital en la Isla del Rey de Mahón | foto FHIR

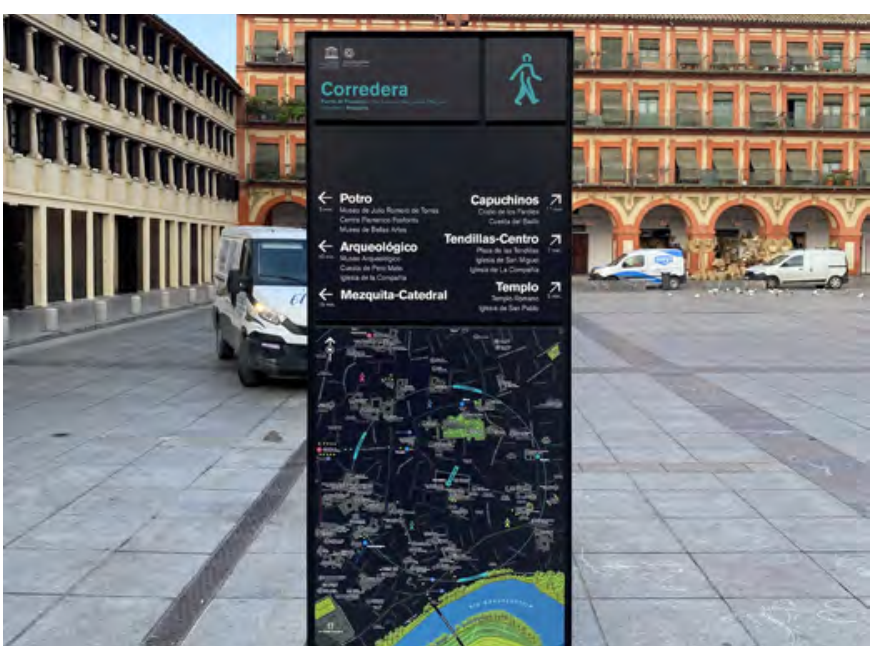

Andando Córdoba. Ejemplo de señalética en la calle | foto Luis Muñoz

Hoy el espacio funciona como centro cultural y de arte contemporáneo, centro de interpretación del Puerto de Mahón y como museo de Medicina, Cirugía y Farmacia del siglo XVIII, con una biblioteca. Se ha acondicionado también un jardín de plantas usadas en el hospital por sus propiedades medicinales que, junto con los restantes elementos del conjunto, actúa como atracción turística y, por lo tanto, de generación de riqueza.

Dentro de esa misma categoría y ex aequo fue premiado el Proyecto de gestión del patrimonio Real Maestranza de Caballería de Ronda-RMR. Se reconoce así la labor de una institución cultural fundada en 1573, indispensa- 


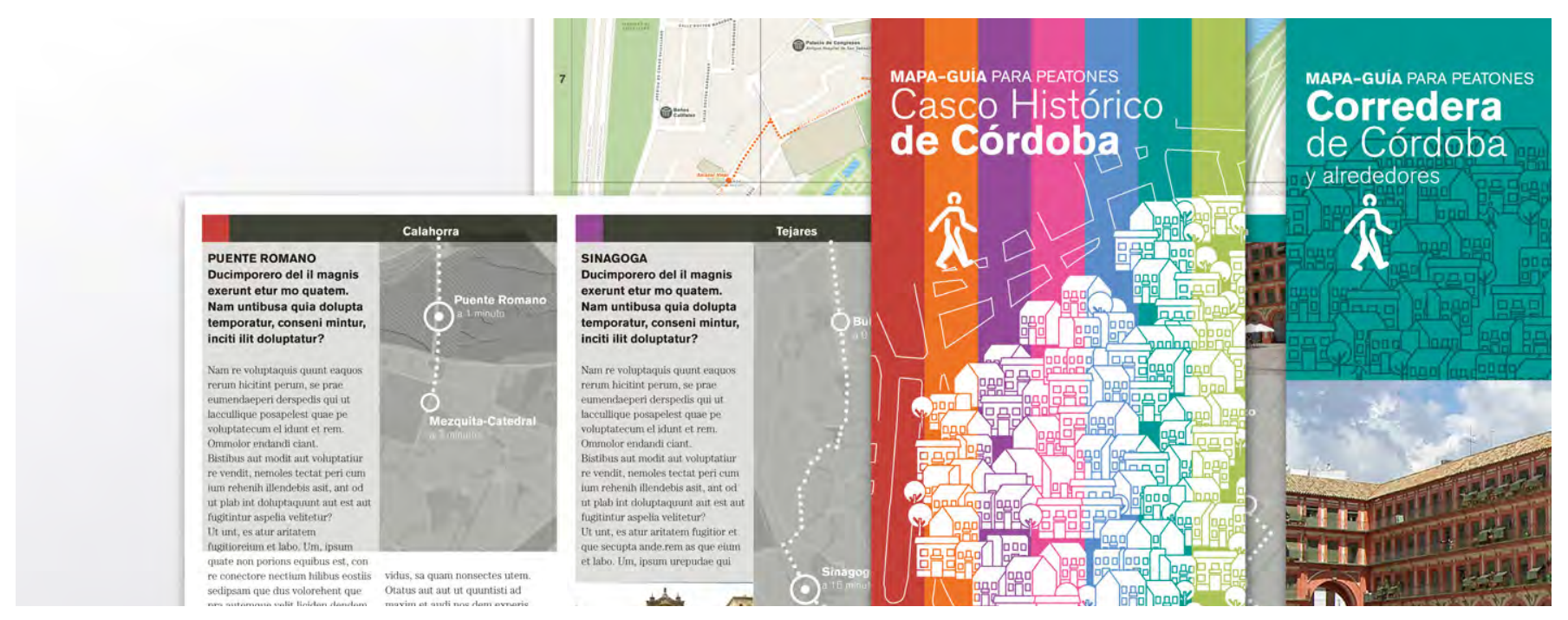

Premio a la señalización y difusión del patrimonio cultural y natural. Andando Córdoba

ble para la historia de Ronda y su entorno, y se premian tareas iniciadas en 1997 para la recuperación de edificios $\mathrm{y}$ fondos documentales de un legado secular de elevado valor patrimonial. Los trabajos comenzaron en 1996 con la reforma de la plaza de toros, y siguieron con el museo de la Tauromaquia, la nueva biblioteca, la Sala de investigación, la colección de armas antiguas, de guarniciones de Orleans, el Salón de grado, el Picadero, el Patio de caballos y la Sala de Real Maestranza. A lo largo de diez años se han recibido nueve millones de visitantes y más de cien mil espectadores y asistentes a actividades desarrolladas en la plaza y resto de instalaciones. Este movimiento genera trabajo y empleo, ha estimulado la restauración de numerosos edificios y monumentos de Ronda y la Serranía, y ha permitido multiplicar las instalaciones hoteleras y las pernoctaciones en la zona.

En Andando Córdoba, sistema de orientación y señalización para caminantes en el casco histórico de Córdoba, premiado en la tercera categoría, se reconoce el interés de un proyecto integral y multisoporte de señalización, orientación, información e interpretación del casco histórico cordobés, para facilitar su comprensión y la experiencia de la visita. A partir de un análisis estratégico se proponen siete itinerarios para residentes y foráneos, con hitos de valor patrimonial en cada uno de ellos, que parten de las puertas de la muralla y terminan en la Mezquita-Catedral. Así se pretende también distri- buir el flujo turístico por todo el casco histórico, descongestionando el entorno de la Mezquita-Catedral, lo que puede servir de modelo para otras ciudades españoles con exceso de presión turística en espacios muy concretos y reducidos, como es el caso de las ciudades patrimonio mundial. Un sistema de señalización, orientación e interpretación distribuido a lo largo de estas rutas facilita la movilidad, junto con un plano-guía y otro temático, así como una página web que recoge itinerarios, mapas, zonas y puntos de interés.

En conclusión, todas las actuaciones premiadas en 2021, como las de años anteriores, vienen a convertirse en elementos de referencia y estímulo para una sociedad que aprecia su pasado y desea transmitirlo a las generaciones futuras como parte de sus señas de identidad colectiva. Las candidaturas son cada vez más numerosas, como prueba de ese interés de la sociedad por la salvaguarda de sus valores patrimoniales, y los premios concedidos por Hispania Nostra se consolidan, de este modo, como máximo galardón de prestigio, cumpliendo una importante función de apoyo a la conservación de nuestro patrimonio cultural y al desarrollo económico y social de los lugares desde criterios de sostenibilidad, resiliencia y equilibrio medioambiental. 


\section{El IAPH celebra el II Encuentro Patrimonio de Proximidad, centrado en los cuidados del patrimonio y su comunidad}

Los encuentros de patrimonio de proximidad, organizados por el Instituto Andaluz del Patrimonio Histórico (IAPH), constituyen una línea abierta de trabajo que pretende visibilizar las iniciativas y los agentes implicados en la activación del patrimonio cultural desde lo local, especialmente en Andalucía, para reflexionar, crear redes y compartir conocimientos y experiencias. El proyecto se inició en 2018; tuvo un segundo hito en 2019 en la Casa del Pumarejo de Sevilla; y se ha concretado en 2021 con la celebración de un segundo encuentro -virtual, por las circunstancias de la pandemia- en torno a los cuidados del patrimonio y su comunidad. En total se expusieron más de cuarenta experiencias sobre la activación del patrimonio cultural, en cuya valoración y selección intervino la denominada Comunidad de agentes redactívate.

Isabel Luque Ceballos | Dirección de Investigación y Transferencia, Instituto Andaluz del Patrimonio Histórico

URL de la contribución <http://www.iaph.es/revistaph/index.php/revistaph/article/view/5006>

Tras el I Encuentro Patrimonio de Proximidad en 2018, tuvo lugar al año siguiente una reunión en la Casa del Pumarejo (Sevilla), en la que se analizaron las aportaciones de la primera convocatoria ${ }^{1}$. Los agentes diversos implicados en la activación del patrimonio se plantearon cuatro retos: cómo trabajar la investigación aplicada al territorio y la salvaguarda del patrimonio; cómo crear un mapa de agentes equilibrado; cómo alcanzar el retorno social y la relevancia para la población local; y, finalmente, cómo conseguir una gestión relacional, compartida. Y como continuación, el II Encuentro Patrimonio de Proximidad, recientemente celebrado, ha pretendido difundir las conclusiones acerca de los retos del Pumarejo, desde una visión compartida de "hacer patrimonio" y con la intención de crear conciencia sobre el cambio de modelo en su gestión.

A este planteamiento con vocación relacional se sumó el tiempo extraño de emergencia sanitaria que vivimos, en el que la activación patrimonial se ha convertido en refugio frente a la desconexión personal, a la vez que en nexo de hiperconexión a través de las redes. El patrimonio es una forma de reencontrarnos y reconocernos y está cumpliendo en esta etapa una función de vínculo social. Por todo ello se propuso el lema "los cuidados del patrimonio y su comunidad". El esfuerzo de los agentes por mantener y mantenerse en el día a día y de las comunidades por conectarse a través del patrimonio ha supuesto una revisión y reflexión sobre el ecosistema profesional, patrimonial, del conocimiento y su soporte social. Todo ello se focalizó en un cambio de herramienta; el encuentro se adaptó al entorno virtual y apostó por una convocatoria abierta de vídeos y proyectos en torno a cuatro grandes temas: educación formal e informal; investigación aplicada al territorio; ecosistemas de agentes en el proceso patrimonial; y creatividad destinada al patrimonio y a la comunidad.

\section{Comunidad de agentes redactívate}

Con motivo de este llamamiento para el II Encuentro Patrimonio de Proximidad, se pensó cómo contar con la comunidad de agentes que se reconocieron en el I Encuentro (2018) y en la siguiente reunión del Pumarejo (2019). Para ello se solicitó la colaboración de algunos de los ponentes de las mesas redondas, ejemplos de buenas prácticas y agentes que habían contado sus experiencias, miembros de la comunidad del conocimiento, de asociaciones o colectivos profesionales y sociales y de las instituciones de la Administración pública. En definitiva, se constituyó un nuevo grupo heterogéneo, que compartió el proceso inicial de valoración de proyectos y vídeos para el II Encuentro Patrimonio de Proximidad, 


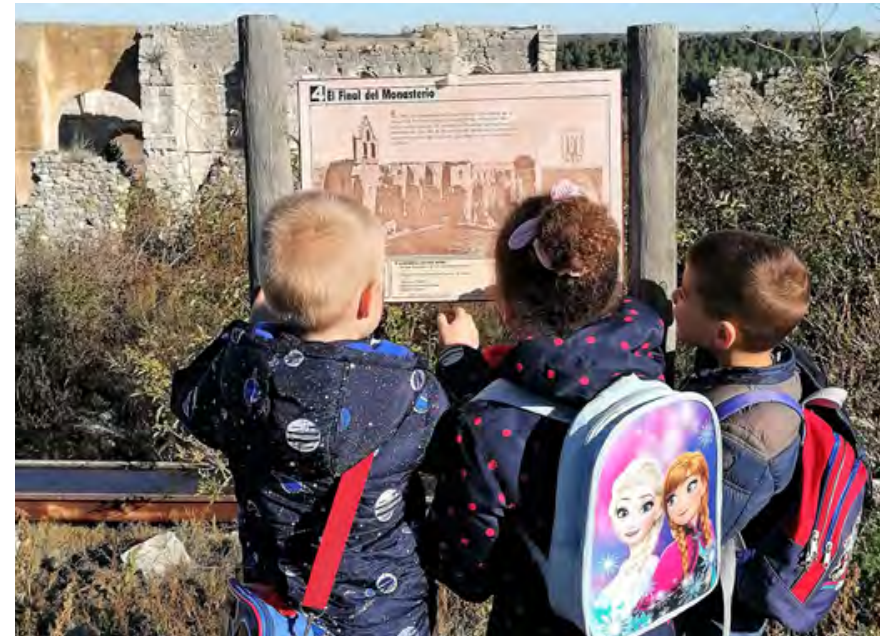

Actividades de la comunidad educativa. El calabacín errante, Valladolid | foto Marta Herrarte Sanz

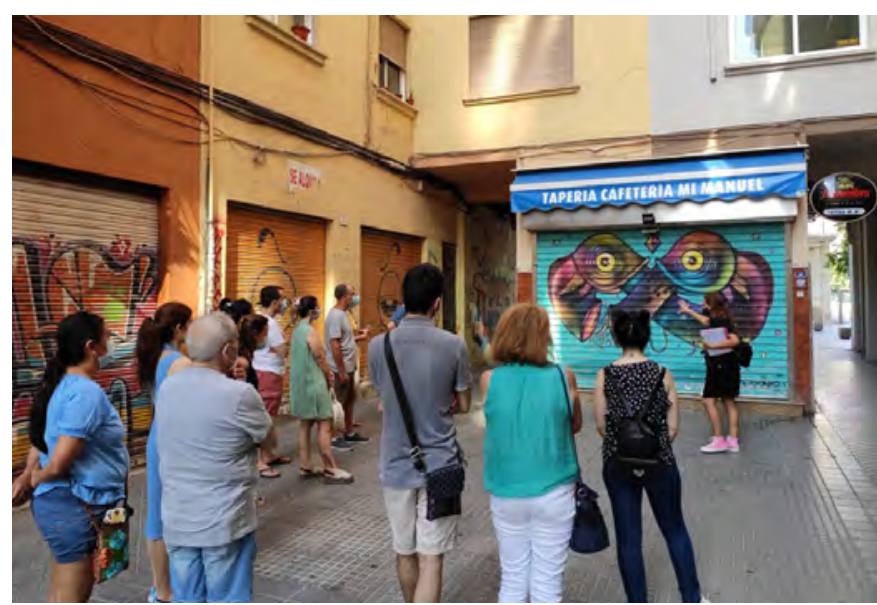

Explicando el Soho de Málaga | foto Experiencia Street Art Málaga

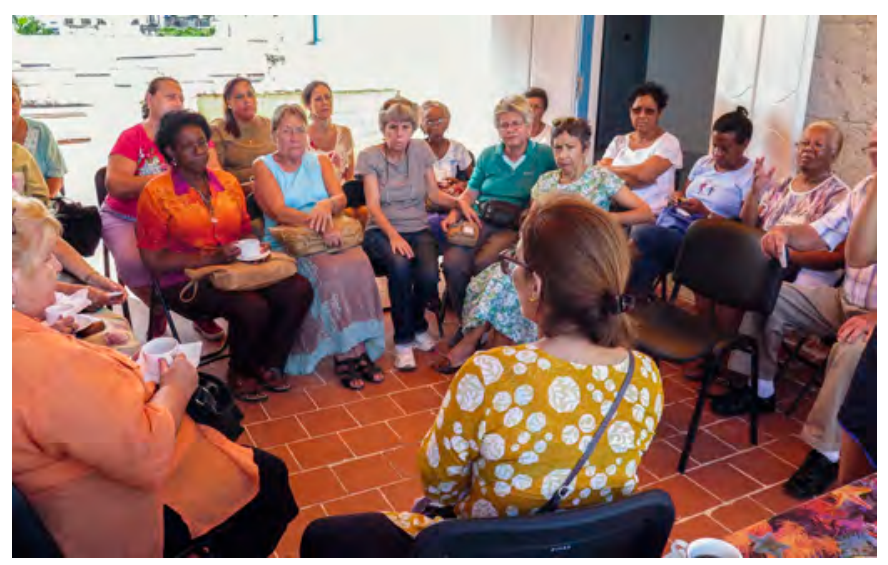

Taller de Té de intercambio, Cuba | foto Palacio del Segundo Cabo y al que agradecemos habernos acompañarnos en este camino.

En total se expusieron más de 40 experiencias -de las cuales 27 procedían de la convocatoria de vídeos y proyectos- sobre la activación del patrimonio cultural, repartidas entre las mesas redondas, el noticiario de patrimonio y el mural on line. En esta exposición ocuparon un lugar relevante las noticias sobre la actualidad de las buenas prácticas presentadas en la primera edición, para generar continuidad en el proceso y demostrar cómo las iniciativas de patrimonio pueden tener futuro. Adrián Yánez, de la Asociación Andaluza de Profesionales de la Gestión Cultural (GECA), se encargó de diseñar esta sección.

\section{Cuatro bloques temáticos}

Ángel Portolés (Proyecto Patrimoni, Universidad Jaume I) abrió el primer bloque del II Encuentro, destinado a la educación formal e informal. En su intervención nos recordó que el concepto de patrimonio cultural se estaba quedando pequeño y que, para llevarlo al límite, era necesario pensar en acompañamiento, en proyectos integrales de educación patrimonial, en proyectos comunitarios, en redes y personas. La educación desde el patrimonio supone un proceso híbrido, formal y no formal, un proceso activo y de largo recorrido, de ida y vuelta, de descubrimiento, con la participación comunitaria, no solo en la figura del visitante. Esta es la garantía de pervivencia del proyecto. En este contexto Ángel se pregunta quiénes se identifican como los expertos en estos nuevos marcos de aprendizaje y apuesta por incluir a las comunidades patrimoniales para construir este concepto de patrimonio de límites líquidos.

El patrimonio en educación constituye una forma de vida y de profesionalización, desde el marco local y municipal, una apuesta por el patrimonio inclusivo y cercano, una forma de unir relaciones, de reciprocidad; en definitiva, una herramienta para la comunidad patrimonial. Los vídeos realizados por distintas comunidades educativas que acompañaron la intervención de Portolés fueron hilvanados por Rosario Castro García (Programa Sentir y vivir el patrimonio, Consejería de Educación de la Junta de Andalucía). 
Guadalupe Jiménez Esquinas (Universidad de Santiago de Compostela) abordó el tema "Investigación y comunidad en patrimonio". Comenzó su reflexión con la idea de que somos las personas las que damos valor a los conceptos; por lo tanto, el conocimiento recorre un camino de ida y vuelta, de la sociedad para la sociedad. La comunidad debe ser partícipe del proceso de investigación, a pesar de los peligros de la participación y todo el camino que queda por hacer hasta la gobernanza. El énfasis se ha de poner en el máximo beneficio para el interés general, para el bien común. Para Jiménez Esquinas la comunidad del patrimonio la forman, con todas las cautelas y dudas que esto genera, el grupo de personas que se preocupa de que se cuide el patrimonio cultural y cree beneficios sociales. Esta reflexión fue acompañada durante el II Encuentro de una mesa redonda, coordinada por Yolanda González Campos (IAPH).

La red de personas, afectos, emociones y patrimonios correspondió a Gema Carrera Díaz (Instituto Andaluz del Patrimonio Histórico) y Rubén Alonso (Antropoloops), que hablaron al alimón de cómo el mapa se centra en el proceso social para ofrecer modelos alternativos al crecimiento socioeconómico establecido. Ambos invitaron a los agentes del territorio a participar de forma colaborativa en la Red de agentes del patrimonio cultural de Andalucía. También esta sesión estuvo acompañada de ejemplos audiovisuales sobre los cuidados de nuestro patrimonio.

"Creatividad, patrimonio y futuro" se denominó la última mesa, presentada por Ignacio Muñiz Jaén, director del Ecomuseo del río Caicena, en Almedinilla (Córdoba), y Juan López López, videocreador. El binomio contemporaneidad e historia nos conduce a la conclusión de que sin memoria, no hay futuro, pero también hace falta la creatividad para buscar caminos para abran la mente; que enriquezcan las miradas desde lo sensorial, subjetivo, simbólico y afectivo. La mesa redonda, facilitada por Valle Pérez Cano (IAPH) ayudó a tejer algunas de las experiencias presentadas.

\section{Conclusiones}

De las conclusiones extraídas durante esta intensa jornada virtual se pueden destacar que los límites del patri-

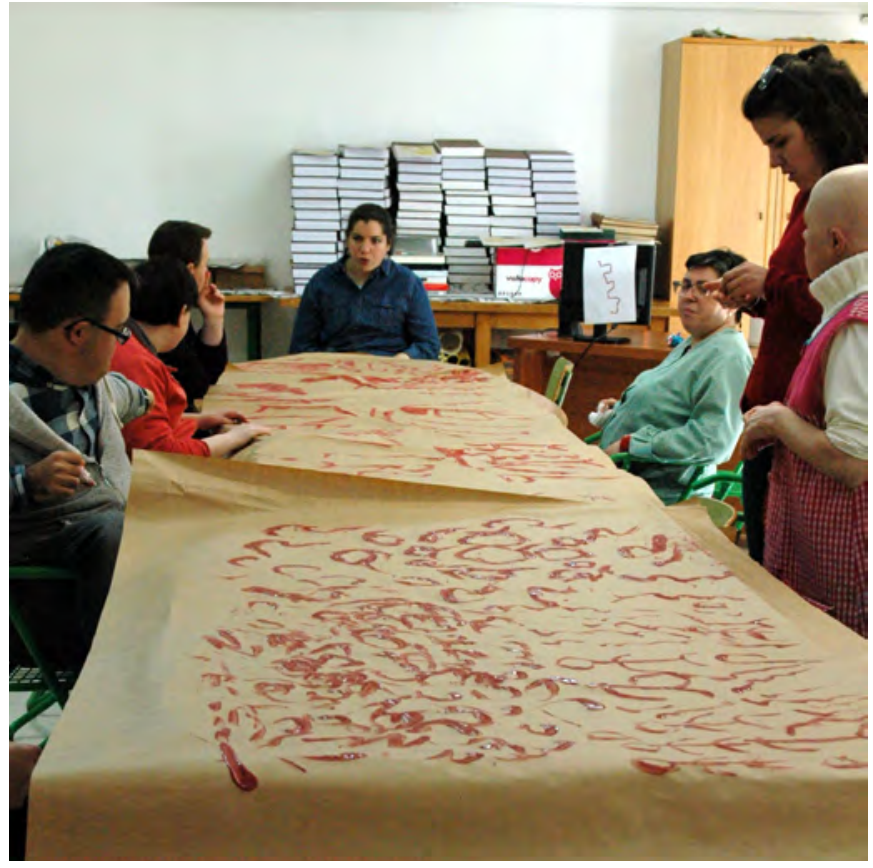

Arte capacitado. Museo de la Alcazaba, Loja (Granada) | foto Rosana Cansino

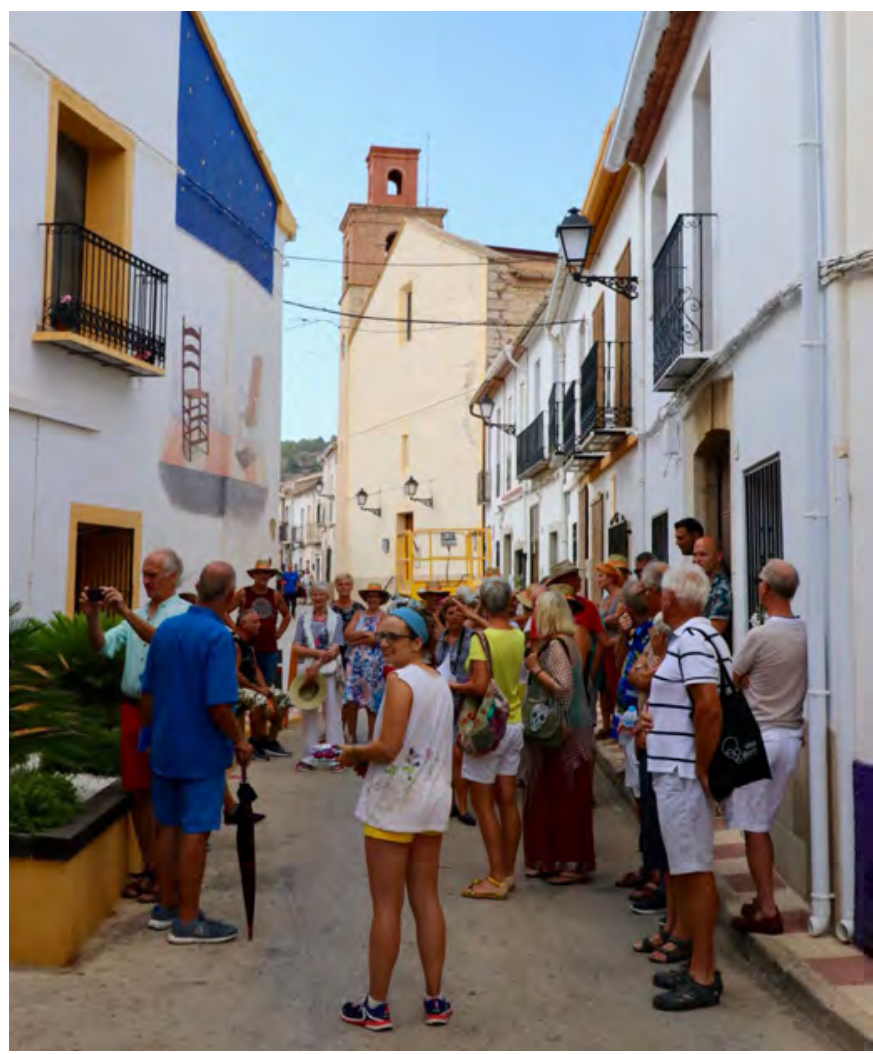

Museo Abierto, proyecto en Senija (Alicante) | foto Tourist Info Vall del Pop 
monio se han quedado pequeños y urge reformularlos para ligarlos a la comunidad, a las emociones, a la educación como aliada y de forma integral. Confirmamos que es necesario buscar formas de gestión relacional, de tejer redes y de extender el conocimiento de las buenas prácticas porque aún queda mucho camino por recorrer, mucho trabajo por hacer para llegar a la gobernanza, muchas mentalidades por abrir para compartir creatividad y memoria, para construir caminos que hagan visibles los patrimonios ocultos, los discursos silenciados y diferentes de los establecido, de lo meramente turístico.

El patrimonio como un proceso en sí nos abre las puertas para reflexionar y trabajar en el marco de un camino siempre inacabado; una reflexión que siempre queda por hacer, porque siempre hay rincones a los que llegar, personas con las que debatir. Esta forma de entender el pasado y la memoria material e inmaterial implica una construcción en continua evolución y transformación; se trata de una construcción viva. Por todo esto seguimos trabajando las buenas prácticas y expandiendo el conocimiento en un camino de ida y vuelta.

\section{NOTAS}

1. Más información del desarrollo del I Encuentro (2018) y la reunión del Pumarejo (2019) podemos encontrarla en revista PH 101 (2020) y revista PH 96 (2019): "Redactívate: mediación y reconocimiento a las personas del patrimonio cultural-local" (https://doi. org/10.33349/2020.101.4729) y "El IAPH bucea y difunde las buenas prácticas para la activación del patrimonio cultural" (https://doi.org/10.33349/2019.96.4356). Asimismo, hay abundante documentación disponible en el Repositorio de Activos Digitales del IAPH (https://repo sitorio.iaph.es/handle/11532/326411; https://repositorio. iaph.es/handle/11532/327676).

\section{Comunidad redactívate}

Grupo evaluador

> Juan José Alarcón Bocanegra, Asociación Los Dólmenes, Valencina (Sevilla).

> Rubén Ballano, Sentir y vivir el patrimonio, Consejería de Educación y Deporte, Junta de Andalucía.

$>$ Rosario Castro, Sentir y vivir el patrimonio, Consejería de Educación y Deporte, Junta de Andalucía.

> Gema Carrera Díaz, IAPH, Consejería de Cultura y Patrimonio Histórico, Junta de Andalucía y Asoc. Andaluza de Antropología.

> Beatriz Castellano Bravo, IAPH, Consejería de Cultura y Patrimonio Histórico, Junta de Andalucía.

> Aniceto Delgado Méndez, IAPH, Consejería de Cultura y Patrimonio Histórico, Junta de Andalucía y Asociación Andaluza de Antropología.

> Víctor Fernández Salinas, Dpto. Geografía Humana, Universidad de Sevilla.

> Yolanda González-Campos, IAPH, Consejería de Cultura y Patrimonio Histórico, Junta de Andalucía.

> Susana Limón Rodríguez, IAPH, Consejería de Cultura y Patrimonio Histórico, Junta de Andalucía.

> Mariela Maitane, Asociación Herstóricas (Granada).

> Nieves Medina Rosales, Proyecto Patrimonio, Aroche (Huelva).

> María Morente del Monte, Museo de Málaga.

> Jaime Moreno Tamarán, Consejería de Cultura y Patrimonio Histórico.

> Ignacio Muñiz Jaén, Ecomuseo del río Caicena, Almedinilla (Córdoba).

> Valle Pérez Cano, IAPH, Consejería de Cultura y Patrimonio Histórico, Junta de Andalucía.

> Myriam Olmedo Morales, IAPH, Consejería de Cultura y

Patrimonio Histórico, Junta de Andalucía.

> Antonio Ortega Ruiz, Universidad Internacional de Andalucía, Baeza (Jaén).

> Maribel Rodríguez Achútegui, Museo de La Rinconada y Asociación para la Interpretación del Patrimonio (AIP).

> Julio Rodríguez Bisquert, IAPH, Consejería de Cultura y Patrimonio Histórico, Junta de Andalucía.

> Carlos Romero Moragas, IAPH, Consejería de Cultura y Patrimonio Histórico, Junta de Andalucía.

> David Ruiz García, Colección Museográfica de Gilena (Sevilla). $>$ Jesús Rull Pereda, Aula de cine, Agencia Andaluza de Instituciones Culturales, Consejería de Cultura y Patrimonio Histórico, Junta de Andalucía.

> Juan Manuel Salas Rojas, Consejería de Agricultura, Pesca y Desarrollo Sostenible, Junta de Andalucía

> Pilar Tassara Andrade, Agencia Andaluza de Instituciones

Culturales, Consejería de Cultura y Patrimonio Histórico, Junta de Andalucía.

> Luz Vega Zabala, Consejería de Agricultura, Pesca y Desarrollo Sostenible, Junta de Andalucía.

> Adrián Yánez, comunicador cultural y Asociación Andaluza de Profesionales de la Gestión Cultural. 


\section{$\mathrm{PH} 104$}

\section{La Comisión Europea reconoce la contribución del Museo Cal de Morón a la salvaguardia del patrimonio cultural europeo}

El jurado de los Premios de Patrimonio Europeo/Premios Europa Nostra 2021 ha destacado el aspecto intergeneracional del trabajo de la Asociación Cultural Hornos de la Cal de Morón, propietaria del Museo, así como el exitoso enfoque de la economía circular. La Comisión Europea reconoce con el galardón entregado el pasado 23 de septiembre, dentro de la categoría "Educación, formación y sensibilización", la importante labor de preservación, difusión y conservación de la cultura de la cal en el marco de las acciones sostenibles en Europa. La asociación Hornos de la Cal viene colaborando activamente con el programa de formación del Instituto Andaluz del Patrimonio Histórico desde 2013.

Manuel Gil Ortiz | Museo Cal de Morón

URL de la contribución <http://www.iaph.es/revistaph/index.php/revistaph/article/view/5002>

El proyecto premiado se presentó bajo el título La Cal artesanal de Morón. Recuperación y difusión de sus saberes y bienes asociados en el marco de las acciones sostenibles en Europa y está vinculado, dentro de las áreas previstas en la convocatoria, a las estructuras y sitios de patrimonio industrial. Entre los veinticuatro proyectos reconocidos en 2021 figuran seis españoles: rehabilitación de la torre de las aguas de Besòs (Barcelona) y de la masía Mas de Burot (Horta de Sant Joan, Tarragona); Art-risk, un software de inteligencia artificial aplicado a la restauración preventiva de edificios patrimoniales; Valencia en la memoria, tres refugios de la Guerra Civil; Heritage Hub, compartido con Finlandia; y el Museo Cal de Morón.

\section{Museo Cal de Morón}

La Asociación Cultural Hornos de la Cal de Morón, entidad de carácter privado sin ánimo de lucro, compuesta por siete amigos de la localidad de Morón de la Frontera (Sevilla), es la propietaria del Museo desde el que se ha desarrollado un extenso programa para preservar, conservar y difundir la cultura de la cal en esta zona.

Las actuaciones realizadas han tenido dos vertientes principales: la salvaguarda del patrimonio inmaterial, basada en la actividad de los caleros, y la salvaguarda del patrimonio material, representada en las actuaciones en la aldea Caleras de la Sierra. Estas han consistido
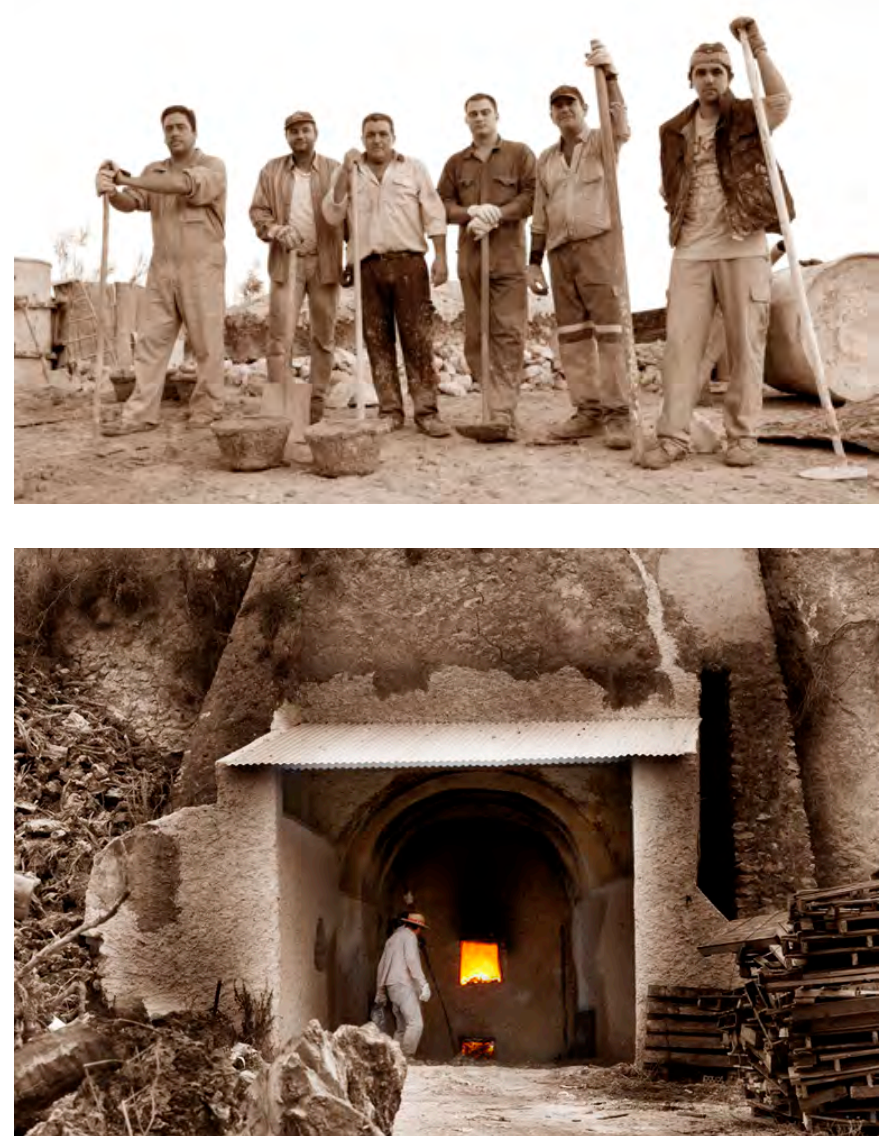

Caleros activos en 2021 y detalle de horno en aldea Caleras de la Sierra | fotos Manuel Gil Ortiz 
en la puesta en valor de los hornos y en actividades de difusión en el Museo. Una de sus actividades principales ha sido conservar y restaurar los bienes inmuebles de la cultura del trabajo y de la vida cotidiana de sus trabajadores relacionados con la producción tradicional de la cal, en colaboración con los caleros artesanos de la zona.

En el Museo Cal de Morón se trabaja intensamente en tres pilares fundamentales: formación, educación y turismo cultural.

> Formación: se ofrecen cursos a profesionales de toda España para recuperar oficios tradicionales relacionados con técnicas de construcción sostenible, especialmente las relacionadas con la cal artesanal. La colaboración en este apartado con el IAPH comenzó en 2013 y en 2021 se van a llevar a cabo un total de 4 cursos dentro del programa de formación anual del Instituto.

> Educación: interesantes visitas guiadas, con el desarrollo de talleres de pintura al fresco para alumnos desde los niveles de primaria a enseñanzas universitarias.

> Turismo: visitas culturales a todos los niveles, en las que se muestra un espacio vivo que nos acerca a la cultura de la cal, una de las señas de identidad más importante de Andalucía. A través de los testimonios y experiencias de los propios caleros, se descubren el procedimiento de elaboración artesanal de la cal, su historia, usos, herramientas e iconografía y la relaciones con los habitantes de la zona.

En la actualidad las diferentes actividades desarrolladas por la asociación apenas reciben apoyo económico institucional, solo una pequeña aportación del Ayuntamiento de Morón de la Frontera.

La sostenibilidad ambiental es fundamental para las actividades de la asociación, ya que se busca ampliar el papel de la cal producida tradicionalmente en la construcción bioclimática. Se trabaja con la naturaleza en lugar de en contra de ella. En colaboración con socios académicos, la asociación lleva a cabo investigaciones sobre las cualidades de absorción de $\mathrm{CO}_{2}$ de la cal, por lo que se pone así de manifiesto su compromiso con la innovación sostenible en el campo de los materiales de construcción.

Este proyecto supone un ejemplo de respuesta a la decadencia y despoblación rural, un problema que está presente en casi toda Europa. La conservación de un paisaje cultural etnográfico, incluido su patrimonio material e inmaterial, declarado por Unesco en 2011 Patrimonio Cultural Inmaterial de la Humanidad. La experiencia ha fijado la población al territorio mediante la creación de un nicho importante de empleo, con una actividad y un producto sostenible desde el punto de vista medioambiental, dado que sus técnicas aprovechan los recursos naturales autóctonos.

La cal tradicional con sus excelentes propiedades como virucida, fungicida, bactericida y su condición de ignífuga, además de facultades de adecuación térmica y aislante, parece ideal para mantener ambientes sanos y desinfectados. Esta eficacia ha sido demostrada a lo largo de la historia y, gracias al trabajo, entre otros, de la Asociación Cultural Hornos de la Cal de Morón, fue inscrita en 1993 en el Inventario de Arquitectura Popular de Andalucía y, en 2009, en el Catálogo General del Patrimonio Histórico Andaluz como BIC, con la tipología jurídica de lugar de interés etnológico. Un año después, en 2010, el Atlas del Patrimonio Inmaterial de Andalucía registró la actividad.

El galardón recientemente concedido impulsará la creación de una red de centros europeos que difunda este patrimonio cultural, que rescate y ponga en valor los hornos históricos ubicados en cada territorio y elabore medidas conjuntas de recuperación y salvaguarda de la cultura de la cal y sus oficios milenarios presente en toda la Unión Europea, especialmente de la ribera mediterránea, cuya principal imagen identitaria debe mucho a este producto en sus distintas aplicaciones en la arquitectura tanto monumental como popular. 


\section{$\mathrm{PH} 104$}

acculidad

\section{El proyecto europeo SoPHIA reflexiona sobre la calidad de las intervenciones en el patrimonio histórico y cultural}

El proyecto SoPHIA, financiado bajo el programa Horizonte 2020 y liderado por la Universidad Roma Tre, busca proponer un modelo holístico de evaluación de impacto en las intervenciones sobre el patrimonio histórico y cultural, estructurado en torno a tres elementos: las cuatro dimensiones del desarrollo sostenible, los usuarios y el tiempo. Con una duración de dos años, el proyecto se concreta a partir de una primera fase de recopilación y análisis de la literatura, políticas y metodologías, para el diseño de un primer modelo de evaluación de impacto; de una segunda fase de testeo (casos de estudio) para ajustar el modelo; y de una última con propuestas de recomendaciones para el desarrollo de políticas públicas y de programas operativos.

Alberto Cerezo Soto | Fundació Interarts per a la Cooperació Cultural Internacional

URL de la contribución <http://www.iaph.es/revistaph/index.php/revistaph/article/view/5007>

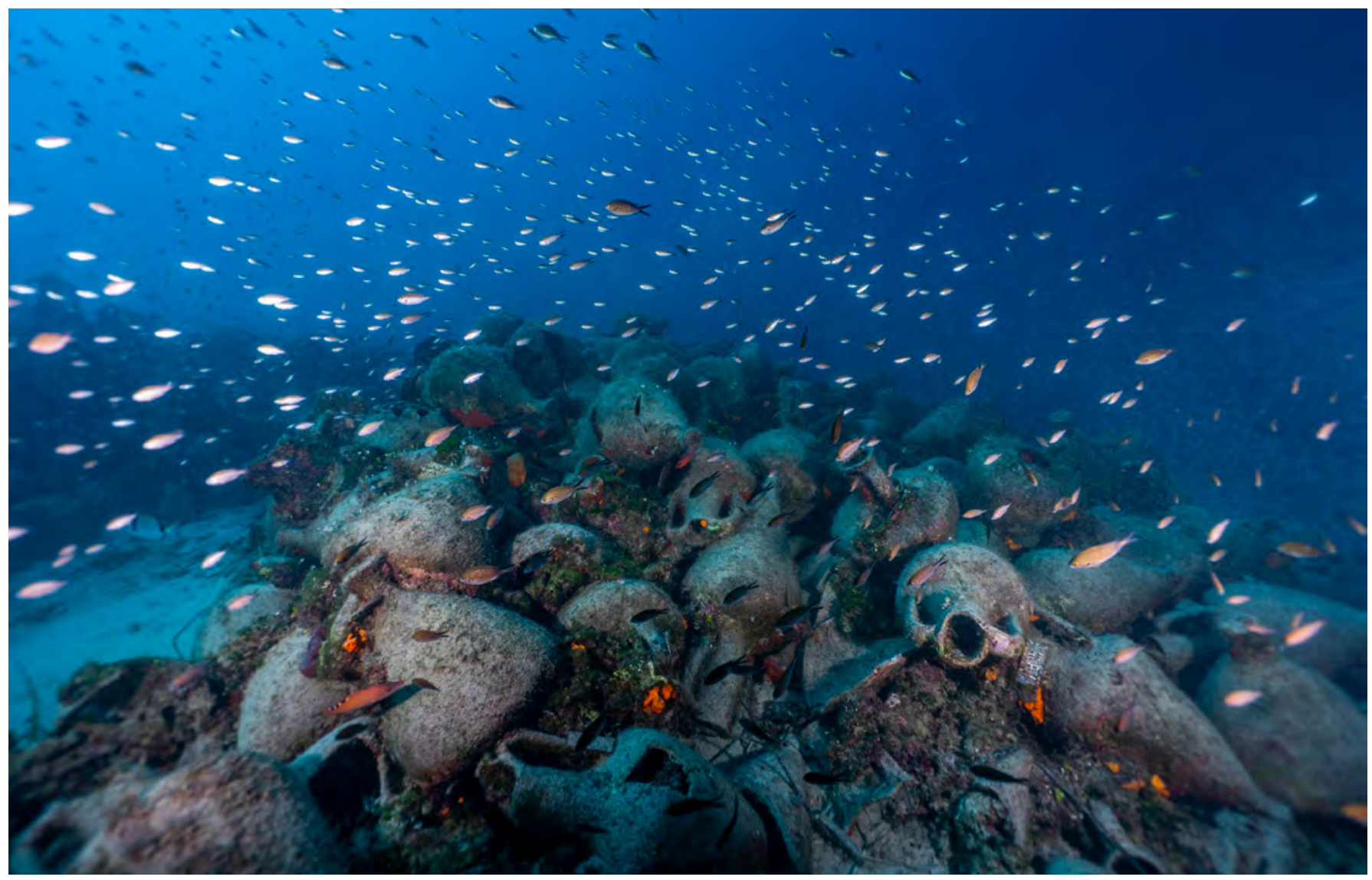

Naufragio en Peristera, Grecia (Ministerio Griego de Cultura y Deportes, Dirección de Antigüedades Subacuáticas), caso de estudio en SoPHIA

| foto Università della Calabria, DIMEG (Matteo Collina) 


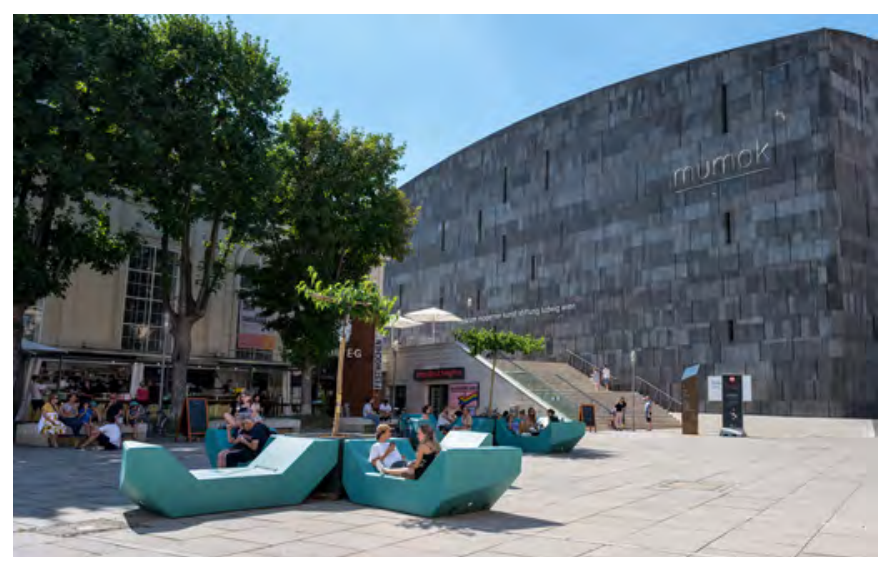

Barrio de los Museos en Viena, caso de estudio SoPHIA | foto Sandor Somkuti

SoPHIA, proyecto desarrollado como plataforma social para la evaluación holística de impacto del patrimonio, está estructurado basándose en tres elementos: las cuatro dimensiones del desarrollo sostenible (economía, sociedad, medio ambiente y cultura); los usuarios (las personas que fruyen del patrimonio); y el tiempo (entendido en su dimensión longitudinal). A lo largo de sus dos años de duración (2020-2021), se concreta a partir de una primera fase de recopilación y análisis de la literatura, políticas y metodologías para el diseño de un primer modelo de evaluación de impacto; de una segunda fase de testeo (casos de estudio) para ajustar el modelo; y de una última con propuestas de recomendaciones para el desarrollo de políticas públicas y de programas operativos. La manera en que el patrimonio cultural es preservado y potenciado es un factor clave en la definición de la identidad europea y su lugar en el mundo. Documentos marco o normativos, tales como el Convenio Europeo del Paisaje (2000) y la Convención de Faro (2005), el Año Europeo del Patrimonio Cultural (2018) y el Marco Europeo de Acción del Patrimonio Cultural (2019), confirman la importancia de evaluar el impacto de las intervenciones en patrimonio cultural, pero también establecen criterios cualitativos y estándares compartidos sobre los que basar dichas evaluaciones. No solo por una importancia relativa al ejercicio mismo sino porque existe un consenso sobre el hecho de que el patrimonio cultural contribuye a muchos de los objetivos de las políticas públicas como la cohesión social, la diversidad y el bienestar individual y colectivo, al crecimiento económico y a la sostenibilidad medioam-

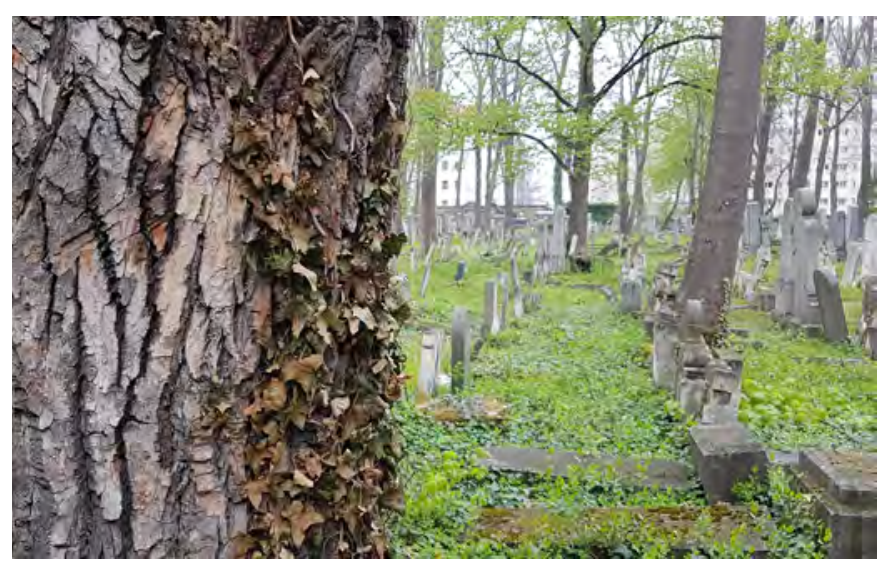

Cementerio Judío Währing, Austria, caso de estudio | foto Monika Bargmann

biental. En otras palabras, el patrimonio cultural ha dejado de considerarse como un ente per se para pasar a ser parte consubstancial de muchas otras dimensiones de las políticas públicas.

Si bien existen algunos ejemplos exitosos de evaluación de impacto, como Impacts 08 de la Capital Europea de la Cultura Liverpool, los actuales modelos de evaluación no proponen un marco exhaustivo que abarque la complejidad de los impactos de las intervenciones sobre el patrimonio cultural. Métodos bien conocidos como la Evaluación de Impacto Ambiental (EIA) o la Evaluación de Impacto del Patrimonio (HIA), a pesar de ser reconocidos y ampliamente aplicados a nivel europeo, no llegan a capturar la naturaleza multidimensional y el alcance de una intervención en patrimonio.

Desde esta perspectiva, SoPHIA ${ }^{1}$ es un proyecto innovador que aborda cuestiones sensibles y de actualidad tanto a nivel europeo como local. De la mencionada revisión inicial de la literatura, resultó un análisis detallado de los métodos de evaluación de impacto actualmente en uso y que sirvió para entender las brechas y oportunidades en los distintos enfoques. Entre otros hallazgos, se identificó la necesidad de emplear metodologías cualitativas y cuantitativas en la evaluación del impacto social del patrimonio cultural y de fortalecer los sistemas de gobernanza para un diálogo constructivo entre la sociedad y las agencias gubernamentales (dimensión social); se ahondó en la relación entre sociedad, individuos y comunidades, y patrimonio para el bienestar 


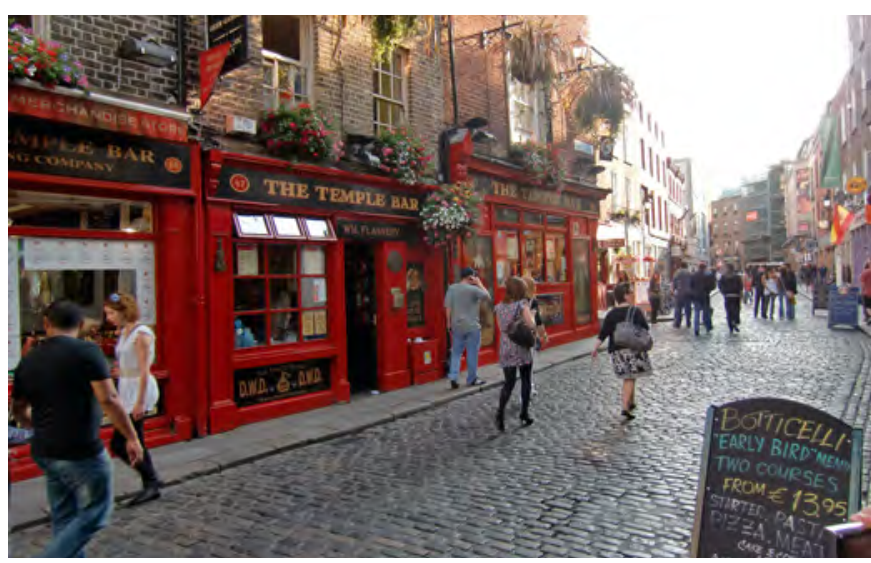

Distrito Cultural Temple Bar (Dublín) caso de estudio SoPHIA | foto Ulrika

y el mantenimiento de la memoria histórica (dimensión cultural); se analizó el concepto de "valor" para entender cuáles de los efectos de las intervenciones tienen connotaciones negativas que suelen ser subestimadas (dimensión económica); se abordó la cuestión de la sostenibilidad, incluyendo temas como el cambio climático, la masificación turística y el crecimiento global urbano (dimensión medioambiental).

Basado en este análisis inicial y en consultas sistemáticas con la comunidad de expertos, se ha diseñado una primera propuesta de modelo de evaluación de impacto que abarca:

$>$ Las conexiones potenciales entre las dimensiones del desarrollo sostenible (económica, social, medioambiental y cultural), así como de las consecuencias no previstas resultado de las intervenciones.

$>$ La involucración de los usuarios (las personas que fruyen del patrimonio) en los procesos de evaluación de impacto, entendiendo que es crucial un ejercicio de fertilización cruzada para una evaluación inclusiva, efectiva y sostenible.

$>$ La perspectiva longitudinal en el tiempo -ex ante, in itinere y ex post- para una gestión y procesos de monitoreo eficientes.

El modelo SoPHIA de evaluación de impacto ha sido testado en doce sitios a lo largo de Europa representativos de la diversidad patrimonial, a saber, un paisaje histórico, dos museos, dos programas, tres distritos culturales, un lugar de memoria, un centro histórico urbano, una isla y un monasterio. De los casos se desprende la complejidad de cada intervención, pero también se apuntan conclusiones interesantes: cómo el patrimonio mejora la calidad de vida de las comunidades; cómo al tiempo contribuye al desarrollo turístico y económico a través de nuevos emprendimientos; y cómo las distintas narrativas que se desprenden contribuyen a dar sentido a una comunidad y fortalecen los procesos de cohesión social.

En este momento, el modelo está siendo ajustado y mejorado a partir de un proceso de consultas. En su última fase, SoPHIA propondrá recomendaciones para el desarrollo de políticas públicas y programas operativos que incluyan las evaluaciones de impacto en las intervenciones sobre el patrimonio cultural desde un enfoque cualitativo.

Como plataforma social, SoPHIA reúne a una comunidad más allá de las instituciones formalmente ligadas al proyecto. Tomadores de decisión, profesionales y académicos son miembros del Consejo Consultivo y del cuerpo de partes interesadas, los stakeholders. Son personas procedentes de toda Europa y vinculadas a instituciones públicas y privadas, universidades y centros de investigación, así como organizaciones de la sociedad civil. Su acercamiento al patrimonio histórico y cultural es muy diverso en términos de especializaciones y enfoques y de misiones y responsabilidades. La comunidad SoPHIA se reúne en los talleres y conferencias del proyecto, son consultados e invitados a discutir en sesiones propuestas regularmente. Además de contribuir activamente al proyecto, la plataforma social se convierte en una herramienta efectiva de diseminación, acercando a sus miembros a la cuestión de la evaluación de impacto

\section{NOTAS}

1. Todos los informes (disponibles en inglés) del proyecto SoPHIA son públicos y pueden ser consultados y descargados desde la sección Archive de la página web del proyecto: https://sophiaplatform.eu/en/archive 


\section{AMMA galardona la excelencia y la innovación en la práctica profesional de la museología y la museografía en Andalucía}

La Asociación de Museólogos y Museógrafos de Andalucía (AMMA) ha lanzado en 2021 los premios EXPONE a las buenas prácticas e innovación en museos y exposiciones de Andalucía. Conscientes de cómo se han transformado las dinámicas de difusión del patrimonio cultural ante las dificultades sobrevenidas por la crisis sanitaria mundial, la AMMA quiere reconocer con este premio independiente, el valor, el esfuerzo y la excelencia en la práctica profesional de la museología y la museografía a los museos y centros expositivos andaluces, dar visibilidad a los proyectos desarrollados, presentarlos ante el público y distinguir a los profesionales del sector.

Santiago Campuzano Guerrero | Gestor cultural y museólogo

M. ${ }^{a}$ Dolores Cebrián Sotomayor | Mediadora cultural

Elena López Gil | Museógrafa

Sol Martín | Gestora cultural y museóloga

URL de la contribución <http://www.iaph.es/revistaph/index.php/revistaph/article/view/5008>

Con las cinco categorías convocadas por los premios EXPONE (premio especial del público, a la mejor estrategia de comunicación, a la mejor exposición virtual, a la mejor exposición, y honorífico a la mejor trayectoria profesional), la Asociación de Museólogos y Museógrafos de Andalucía (AMMA) ha querido reconocer la calidad en el enfoque del proyecto, el grado de consecución de los objetivos propuestos, la adecuación al contexto y lo oportuno que ha sido su desarrollo.

\section{Premio especial del público}

Los destinatarios finales, los visitantes, votaron este premio, ya que son el centro de todo buen proyecto y los que le dan sentido. El público también ha tenido que adaptarse a los nuevos tiempos y convertirse en "público digital", participando muy activamente en las redes sociales.

Por la reflexión que ofrece sobre el paisaje, y por la capacidad de aglutinar en un mismo proyecto la visión creativa del arte actual con las particularidades del enclave arqueológico en el que se desarrolla, el público decidió que merecía ser galardonada en esta categoría la exposición La filosofía del paseante, organizada por el Conjunto Arqueológico de Baelo Claudia con obras del artista Román Lokati.

\section{Premio a la mejor estrategia de comunicación}

Este premio reconoce la labor de comunicación que han desarrollado los y las profesionales que, detrás de webs, redes sociales, noticias en prensa y actividades, buscan y piensan en la mejor manera de llegar al público. Han tenido que transformarse más que cualquier otro perfil profesional $y$, a veces, lo han hecho con más voluntad que medios, por eso es doblemente importante resaltar esta categoría.

Por su capacidad para reelaborar los códigos relacionales desde el ámbito de la comunicación, por su permeabilidad a unos públicos que demandaban nuevas formas de seguir presentes en el museo, y por su agilidad a la hora de responder ante la nueva situación, el premio para a la mejor estrategia de comunicación fue otorgado al Museo de Bellas Artes de Sevilla y su apuesta por lo digital.

\section{Premio a la mejor exposición virtual}

Se dirige a las nuevas maneras de generar conocimiento que han proliferado en nuestros museos desde el primer confinamiento por la crisis sanitaria en marzo de 2020 , que conllevó el cierre de museos y centros de exposiciones. Con las exposiciones virtuales se ha conseguido 

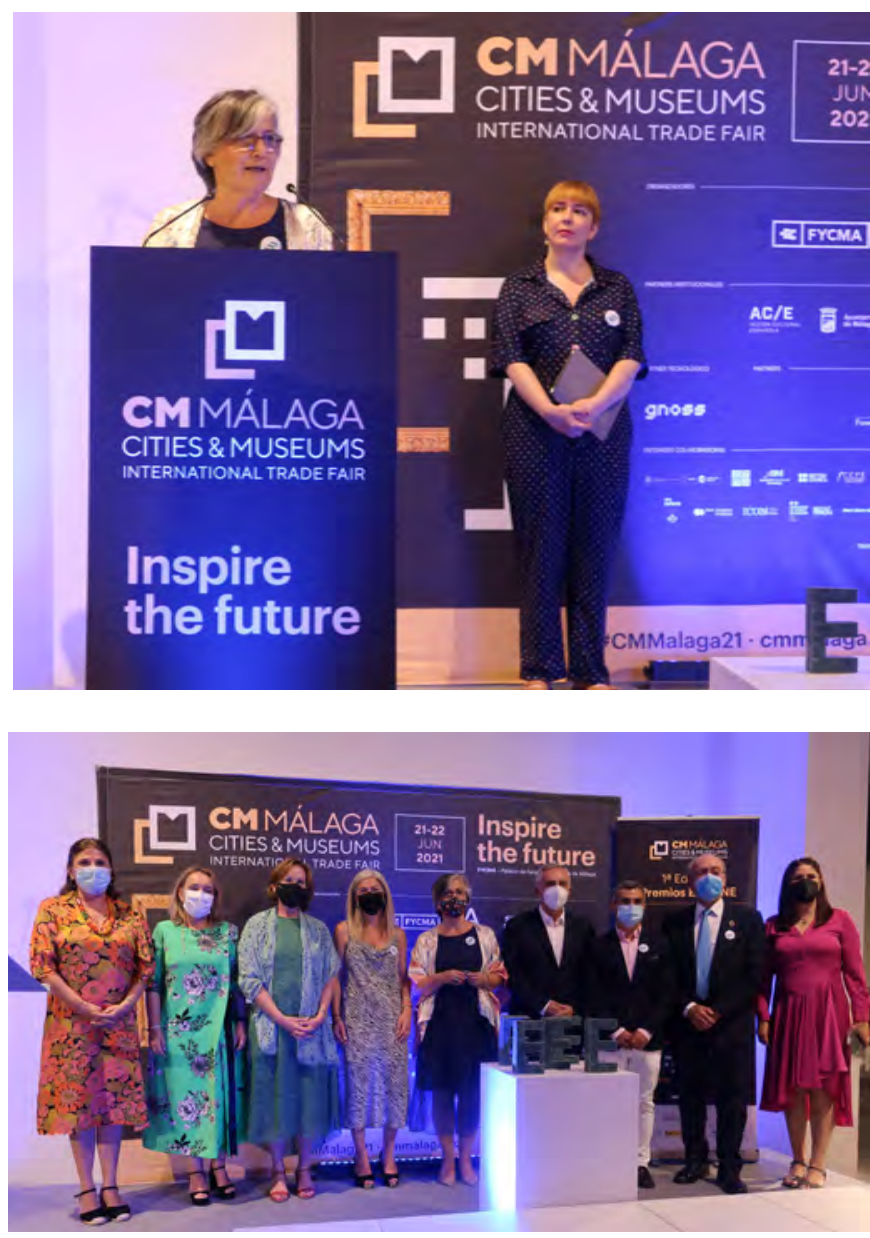

Entrega de los premios EXPONE 2021. Arriba, Elena López Gil, presidenta de la AMMA. Debajo, autoridades asistentes al acto, junto con los galardonados | fotos Asociación de Museólogos y Museógrafos de Andalucía

trasladar los contenidos de las colecciones al interior de los hogares de los visitantes, rompiendo cualquier tipo de barrera y límite geográfico o temporal. Y todo parece indicar que estos nuevos públicos y estas nuevas formas de asistir a una exposición van a quedarse y revolucionar para siempre la esfera expositiva.

Por llevar a su comunidad el resultado de una ardua investigación y de una extraordinaria interpretación del yacimiento arqueológico, por permitir la comprensión del bien y garantizar el acceso público a la información, el premio a la mejor exposición virtual se concede a la Recreación 3D de la villa romana del Salar, proyecto de la Delegación Territorial de Fomento, Infraestructuras, Ordenación del Territorio, Cultura y Patrimonio Histórico en Granada.

\section{Premio a la mejor exposición}

Este galardón distingue uno de los lenguajes predilectos que la museología dispone para contar historias y desarrollar los argumentos que permitirán al público acceder al conocimiento y enamorarse de los relatos: las exposiciones presenciales. En los últimos tiempos "lo presencial" ha tenido que sortear escenarios jamás previstos y esta situación ha llevado a la comunidad profesional encargada cargo de museos y centros de exposiciones a sacar lo mejor de sí misma.

Por su apuesta por un modelo de gestión cultural de calidad y sostenible en el municipio, por las altas cuotas de participación ciudadana conseguida - hasta el punto de que todos los vecinos forman parte activa del proyectoy por su singularidad -es considerado el único pueblo museo del mundo- el proyecto ganador en esta categoría es Genalguacil, pueblo museo.

\section{Premio honorífico a la trayectoria profesional}

Destinado a reconocer la trayectoria de alguien para quien los museos, el arte y la creación han sido una constante en su vida, y su vida una constante en los museos. En esta primera edición de los premios EXPONE, la AMMA se ha sentido muy honrada de reconocer con el premio EXPONE Honorífico a la trayectoria profesional a José Lebrero Stals, actual director del Museo Picasso Málaga. Por la excelencia de su carrera investigadora, por la extraordinaria capacidad de imprimir carácter y profundidad a las instituciones que ha dirigido y por la altísima calidad de las exposiciones que ha comisariado.

La entrega de los galardones correspondientes a esta primera edición tuvo lugar en un acto celebrado en la feria internacional CM Málaga-cities \& museums 2021. 


\section{La asociación Ponte...nas ondas! coloca el patrimonio cultural inmaterial en la agenda política conjunta de España y Portugal}

Con la presentación oficial conjunta en 2021, por parte de los gobiernos de España y Portugal, de su candidatura para la inscripción en el Registro de Buenas Prácticas de Salvaguarda del Patrimonio Cultural de la Unesco, Ponte....nas Ondas! ha visto reconocido su trabajo de más de dos décadas con el patrimonio cultural inmaterial. Este ha sido empleado por la asociación gallego-portuguesa como un instrumento educativo fundamental para la salvaguarda, transmisión y continuidad intergeneracional. De esta forma se ha contribuido al crecimiento económico y mejora del bienestar y calidad de vida de las poblaciones de la Eurorregión Galicia y norte de Portugal.

Santiago Veloso Troncoso | IES Terra de Turonio (Gondomar, Pontevedra)

Esmeralda Maria Rodrigues de Carvalho | Escuela Secundaria Muralhas do Minho (Valença do Minho, Portugal)

Xerardo Pereiro Pérez | Dpto. de Economia, Sociologia e Gestão, Universidade de Tras-Os-Montes e Alto Douro (Portugal)

Xosé Manuel Cid Fernández | Dpto. Análise e intervención psicosocioeducativa, Universidade de Vigo

URL de la contribución <http://www.iaph.es/revistaph/index.php/revistaph/article/view/5003>

Ponte...nas ondas! (puente a través de las ondas-colócate en las ondas), asociación sociopedagógica que integra docentes e investigadores de Galicia y Portugal, cuenta ya con una historia de 26 años ${ }^{1}$. Su trabajo se centra fundamentalmente en el patrimonio cultural inmaterial $(\mathrm{PCl})$ y la educación patrimonial a través de una red de escuelas, docentes, investigadores y organizaciones del ámbito territorial de la euroregión Galicia-Norte de Portugal. El pasado 15 de marzo del año 2021, los gobiernos de España y Portugal presentaron conjuntamente en la Unesco la candidatura de Ponte... nas Ondas! para su inscripción en el Registro de Buenas Prácticas de Salvaguarda del PCI. La propuesta llevaba por título "Portuguese-Galician Border ICH: A Safeguarding Model Created by Ponte...nas ondas!".

Ponte...nas ondas! constituye un buen ejemplo de salvaguarda del $\mathrm{PCl}$, que contribuye a los objetivos de desarrollo sostenible, porque -en primer lugar- ha identificado el continuum del $\mathrm{PCl}$ gallego-portugués, más allá de fronteras estatales, mucho antes de la proclamación por la Unesco de las obras maestras del patrimonio cultural inmaterial en el año 2001, y antes de la entrada en vigor de la Convención para la salvaguardia del patrimonio cultural inmaterial de 2003.

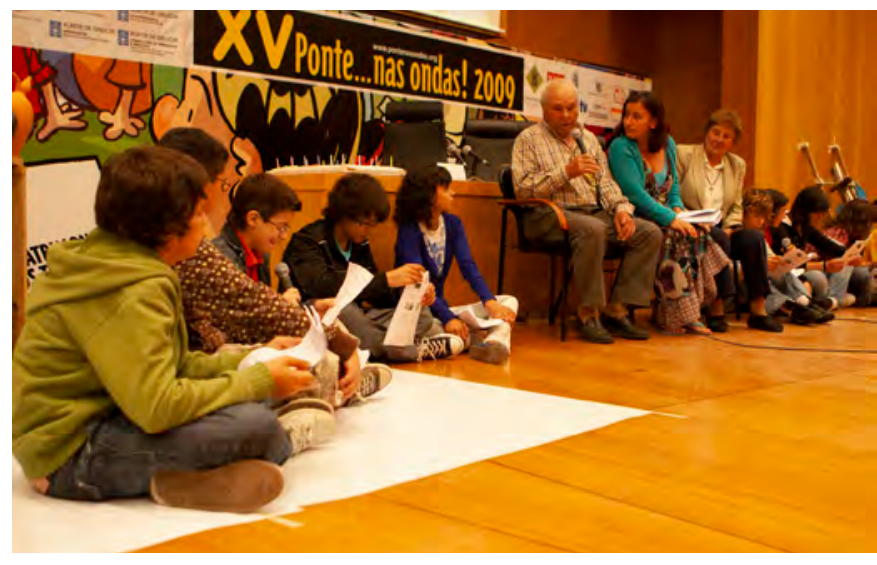

Entrevista a un portador del patrimonio en una jornada de Ponte...nas ondas! | foto Ponte...nas ondas! (Chus Álvarez)

En segundo lugar, ha llevado el patrimonio cultural inmaterial a las aulas escolares a través -por ejemplo- de programas de radio escolares en red; lo ha valorado y lo ha valorizado, garantizando su conocimiento, su transmisión intergeneracional y su conservación dinámica.

En tercer lugar, ha colocado el $\mathrm{PCl}$ en la agenda política pública de Galicia, España y Portugal, no como un elemento de la herencia cultural del pasado, sino como un componente del presente y un instrumento de futuro para 
la educación patrimonial, la cohesión social y la práctica de una interculturalidad saludable socialmente. Buena muestra de ello es la colaboración en el proyecto de instituciones, universidades y centros de investigación gallego-portugueses, tales como la Xunta de Galicia, el INCIPIT-CSIC, la Universidad de Vigo, la Universidad de Santiago de Compostela, la UTAD (Universidade de Trás-os-Montes e Alto Douro) o la Universidad Fernando Pessoa.

En cuarto lugar, el trabajo de Ponte...nas ondas! ha contribuido al bienestar y a la calidad de vida de las comunidades con las cuales trabaja porque ha visibilizado y revitalizado el patrimonio cultural inmaterial para un aprovechamiento social y económico de las poblaciones de una forma ecológica y responsablemente sostenible. Ejemplos de ello son la investigación, producción y transferencia de saberes del $\mathrm{PCl}$ sobre los pescadores del río Miño que preservan las pesqueras de origen romano para la pesca de la lamprea o el sable, y las técnicas de pesca y conservación del pescado; las "sargaceiras" (recogedoras de algas para abono de fincas, alimentación, cosmética, medicina) que trabajan en la costa de Galicia y de Portugal; las "redeiras" (reparación de artes de pesca artesanal) que contribuyen a preservar un ecosistema y un modo de vida sustentable en la costa; o los cantos improvisados -cantares ao desafio ou desgarradas-, ya presentes en los trovadores medievales, se adoptan y redefinen como una nueva forma de

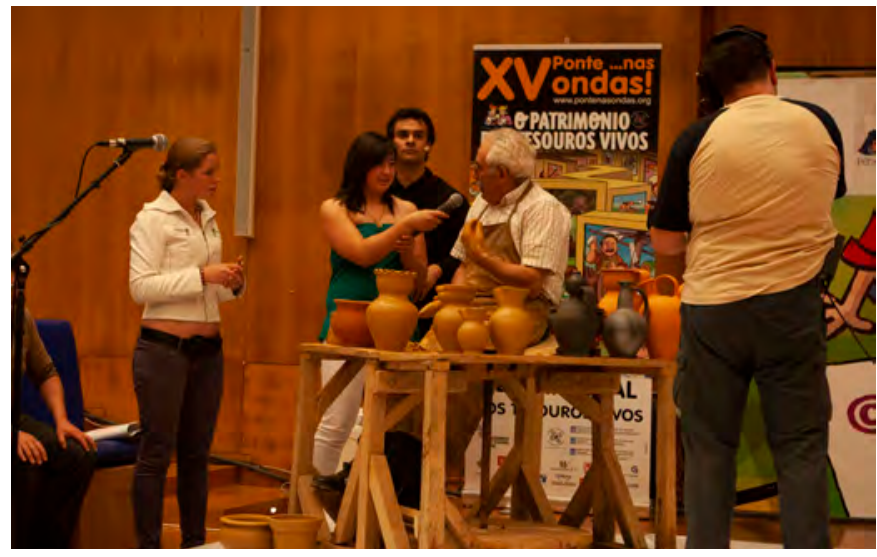

Presencia de portadores en la XV Edición de Ponte...nas ondas! dedicada a los Tesoros Humanos Vivos | foto Ponte...nas ondas! (Chus Álvarez) expresión festiva comunitaria, lúdica y educativa tanto en Galicia como en Portugal. Al igual que los narradores orales constituyen ya una actualización de expresiones del $\mathrm{PCl}$ con una gran proyección social y una dimensión económica cada vez más importante.

En síntesis, Ponte...nas ondas! es una organización ejemplar en la identificación, reconocimiento, transmisión, educación patrimonial y dinamización de comunidades por medio de un patrimonio cultural inmaterial transnacional y transfronterizo. Pero, además, adapta y adecua los ODS a contextos culturales específicos en su diversidad sociocultural, garantizando los derechos culturales de diversidad e identidad cultural.

Además de la contribución a la educación patrimonial, con sus ventajas sociales y económicas, Ponte...nas ondas!, a través de una pedagogía activa, participativa, crítica, que sitúa en el centro del proceso educativo al alumnado de los diferentes niveles escolares, y a los portadores del saber tradicional, favorece la inclusión de alumnado que presenta algún tipo de diversidad en el ámbito escolar, así como la inclusión de las personas mayores en la sociedad, al tomar conciencia del interés que despierta el patrimonio que atesoran en las nuevas generaciones, en un proceso que acaba por ser intergeneracional y comunitario.

La puesta en valor de la cultura rural constituye otro de los valores que destaca Ponte...nas ondas!, con sus repercusiones en el desarrollo de una conciencia ambiental, favorable a un futuro sostenible.

\section{NOTAS}

1. Webs asociadas a Ponte...nas ondas!: http://pontena sondas.org/ponte-nas-ondas/; http://patrimoniodefuturo. webs.uvigo.es/ 


\title{
CREhAR en la era digital. La primera cátedra UNESCO en el campo emergente del patrimonio contemporáneo
}

\begin{abstract}
Residenciada en la Universidad de Sevilla y vinculada a su Escuela de Arquitectura, CREhAR (Creative Research and Education in heritage Assessment and Regeneration) in the Digital Era es la primera cátedra UNESCO del mundo especializada en patrimonio contemporáneo. CREhAR dinamiza una red internacional, de la que forman parte universidades, instituciones públicas, empresas, asociaciones y otras cátedras, preocupada por la identificación, valoración y conservación del más modesto e invisibilizado patrimonio construido, que ha sido señalado por la UNESCO como un espacio de oportunidad.
\end{abstract}

Mar Loren-Méndez | Directora de la Cátedra UNESCO CREhAR, Universidad de Sevilla

URL de la contribución <http://www.iaph.es/revistaph/index.php/revistaph/article/view/5010>

CREhAR. En la frontera de los estudios patrimoniales Las cátedras UNESCO se erigen como centros de reflexión y centros de acción. En concreto, afrontan la responsabilidad de trabajar en los nuevos desafíos de la sociedad, para contribuir a su desarrollo y resiliencia y evitar las contradicciones implícitas en el concepto de desarrollo sostenible. En última instancia aspiran a convertirse en polos de excelencia y de innovación en campos de emergencia. Para afrontarlos deben actuar como puentes entre la academia, las instituciones y la comunidad, por lo que cada cátedra UNESCO está a cargo de construir redes internacionales que, lejos de la introspección académica o institucional, aseguren la participación activa de la comunidad. Por tanto, la cooperación a nivel mundial fundamentada en lo social está en la base de la dinámica y en la misma esencia de las cátedras. Todo ello las convierte en espacios idóneos para trabajar de manera activa y transversal en el campo del patrimonio cultural y contribuir a los pilares de la sostenibilidad-económico, social, ambiental-, con un énfasis integrador fundamental en la cultura como cuarto pilar.

\section{La urgencia como oportunidad. Nuestro quehacer en} el patrimonio arquitectónico contemporáneo

En 2019, la Unesco aprueba establecer en Andalucía la cátedra Unesco Built Urban Heritage in the Digital Era, CREhAR (Creative Research and Education on heritage Assessment and Regeneration). Esta se centra en la identificación, valorización y conservación de la parte más invisibilizada e incluso denostada del patrimonio construido: arquitecturas sin autoría reconocida, sin programas representativos y localizadas en territorios considerados periféricos. La preocupación por este patrimonio no excepcional -de ahí la h minúscula de sus siglas- se presenta como tarea urgente y también como un fascinante desafío para la cátedra CREhAR.

El patrimonio contemporáneo se trata del más numeroso de entre los denominados "no excepcionales" (European Commission 2004; UNESCO 2012): en efecto, a pesar de que la humanidad ha construido más en estos últimos 200 años que en el resto de su larga historia, este patrimonio construido, componente integral de nuestro entorno, es poco conocido y valorado por la ciudadanía y el menos apreciado y protegido por las instituciones, lo que le hace sumamente vulnerable y en peligro de desaparecer. Aunque somos testigos de una labor creciente de reconocimiento singularizado en patrimonios contemporáneos como el industrial, el patrimonio residencial, los cementerios o incluso las infraestructuras, entre otros, queda una labor ingente por hacer en este campo.

Esta escasa presencia de nuestro patrimonio del siglo XIX y XX no ha pasado inadvertido a la Unesco. En 2003, en el contexto del Modern Heritage Program, instó a una actitud proactiva en pro de aquellos patrimonios menos representados en la Lista de Patrimonio Mundial, poniendo como ejemplo significativo el patrimonio con- 


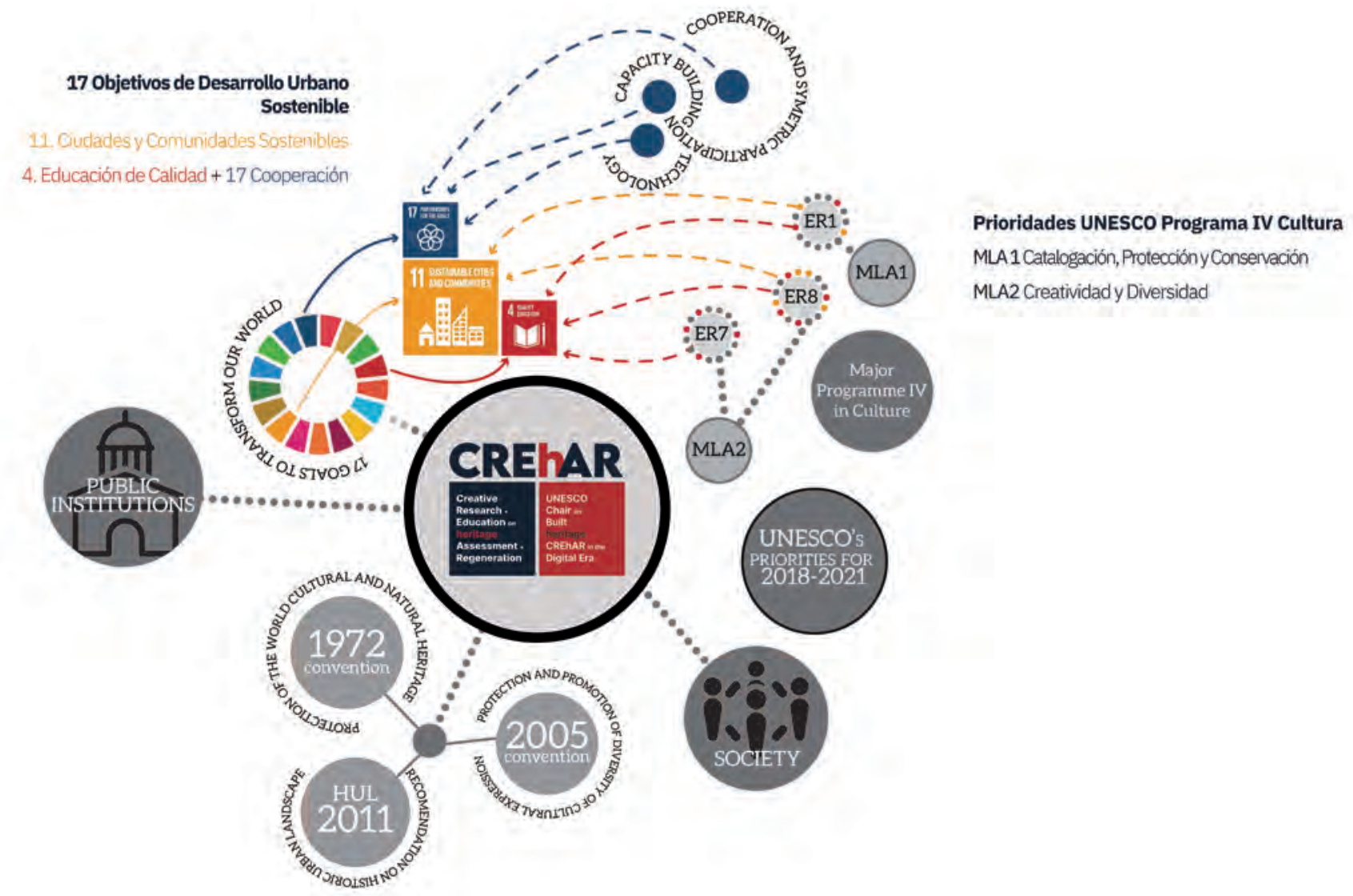

Diagrama de la cátedra Unesco CREhAR en el marco de los programas, convenciones y recomendaciones de la Unesco y de los ODS de la ONU | conceptualización Mar Loren-Méndez; diseño gráfico Pedro García Agenjo

temporáneo. En 2017 Unesco fue más allá y lo consideró campo de auténtica oportunidad investigadora y económica ante la lentitud de su incorporación a la Lista de Patrimonio.

Tras este esfuerzo de equilibrio, de conservar nuestro patrimonio menos representado, subyace una idea: el patrimonio de nuestro entorno construido se aleja ya del monumento y es la diversidad cultural lo que se identifica como principal valor de nuestro patrimonio arquitectónico, urbano y territorial.

Una red actualizada y en igualdad. La cooperación para la salvaguarda de la diversidad cultural

El patrimonio se aborda en CREhAR desde el diálogo en los diferentes países, clave para identificar la singularidad patrimonial y, consecuentemente, asegurar la pro- tección internacional de la diversidad cultural, promover el respeto por todas las culturas y, en última instancia, contribuir a la paz mundial. La aproximación a este patrimonio diverso se efectúa desde la cooperación internacional: la cátedra promueve la simetría en el proceso de cooperación, por lo que evita jerarquías de centro y periferia en el diálogo intercultural, en la línea de lo que recoge la Carta de Cracovia. La cátedra CREhAR contribuye así al enriquecimiento de las relaciones humanas, a una celebración comunitaria de un patrimonio compartido.

En esa diversidad cultural, la participación en igualdad de mujeres y hombres en el campo concreto del patrimonio contemporáneo asegura, sin duda, una mayor riqueza e integridad en los procesos patrimoniales. De esta forma, se contribuye no solo al logro de aspiraciones colectivas, 
sino a dar soporte a objetivos individuales, tanto en formación, como en investigación y docencia.

La aproximación al patrimonio debe caracterizarse indefectiblemente por la constante actualización de los estudios patrimoniales. CREhAR se compromete con la difícil, y a veces imposible tarea, de la actualidad patrimonial desde la condición multiescalar del patrimonio, la interdisciplinariedad para abordar la complejidad patrimonial y la importancia del patrimonio intangible.

Se alinea así con las distintas declaraciones y prioridades de los programas Unesco, en la línea innovadora de cultura y patrimonio como vector fundamental de los ODS.

\section{Patrimonio, creatividad y nuevas tecnologías. Creación en el campo metodológico}

La cátedra CREhAR se posiciona de manera decidida en el uso de la tecnología desde la participación y la transferencia global del conocimiento, en la relación no solo instrumental sino conceptual con el patrimonio. Las TIC se incorporan así no como una moda o requisito de los tiempos, sino para maximizar la accesibilidad a la educación y la investigación patrimonial, cuestión clave para colaborar en la construcción de ese espacio de cooperación simétrica de los distintos agentes y de su patrimonio.

Así mismo, los continuos y acelerados cambios operados en los estudios patrimoniales sitúan a la investigación metodológica y a la innovación en procesos y estrategias en la frontera de los estudios patrimoniales. Si hay un componente envolvente en esta aproximación a la vanguardia de los estudios patrimoniales es la creatividad. Sin duda central en un campo en permanente transformación. La creatividad fundamenta el diseño de nuevos procesos particularizados para esos patrimonios emergentes; la creatividad se incorpora con fuerza en todos y cada uno de las fases del proceso. La cátedra CREhAR conecta así a través del patrimonio urbano las dos líneas de acción del programa de cultura de la Unesco: patrimonio y creatividad.

En nuestro abordaje, la creatividad no resulta opuesta al conocimiento racional; por el contrario, el auténtico conocimiento exige la integración de razón y emoción para entender nuestro entorno. El proyecto patrimonial constituye un proceso global, que implica tanto investigar y documentar como valorar, además de intervenir. Por tanto, la creatividad no es exclusiva de la faceta de intervención como puede inferirse de una interpretación limitada desde la acción de la arquitectura, sino que debe acompañar todo el proceso, desde la búsqueda e interpretación de las fuentes documentales, a la identificación de valores, la experiencia del lugar o su intervención.

La frontera del patrimonio continuamente se mueve, pero lo grande no debe entorpecer ver lo menudo, lo más frágil, lo más invisible y sin embargo aquello que más nos emociona.

\section{BIBLIOGRAFÍA}

- Consejo de Europa (2000) Convenio Europeo del Paisaje. Florencia. Disponible en: https://rm.coe.int/16802f3fbd [Consulta: 08/09/2021]

- European Commission (2004) SUIT: Sustainable development of Urban historical areas through an active Integration within Towns. Guidance for the Environmental Assessment of the impacts of certain plans, programmes or projects upon the heritage value of historical areas, in order to contribute to their long-term sustainability. Luxembourg: Office for Official Publications of the European Communities. Disponible en: https://op.europa.eu/es/publication-detail/-/ publication/c0fe3aca-1639-4554-aca7-d3dccdb2158d [Consulta: 08/09/2021]

- Oers, R. V. y Haraguchi, S. (ed.) (2003) Identification and documentation of modern heritage. Paris: UNESCO World Heritage Centre. Disponible en https://whc.unesco.org/ document/12 [Consulta: 08/09/2021]

- UNESCO (2021) Programas UNITWIN y de Cátedras UNESCO. Disponible en: https://es.unesco.org/programaunitwin-catedras [Consulta: 01/09/2021]

- UNESCO (2012) Recomendación sobre el paisaje urbano histórico, con inclusión de un glosario de definiciones. En Actas de la Conferencia General, 36 ${ }^{a}$ reunión, París, 25 de octubre - 10 de noviembre de 2011, v. 1: Resoluciones, p. 65. Disponible en http://maya.puec.unam.mx/planmanejoch/ Docum_Extern/06.pdf [Consulta: 08/09/2021]

- UNESCO (2000) Carta de CRACOVIA 2000. Principios para la Conservación y Restauración del Patrimonio Construido. Disponible en: https://www.iaph.es/export/sites/ default/galerias/documentacion_migracion/Documento_ PC/1267693158625_ph50-114.pdf [Consulta: 08/09/2021] 


\title{
Áreas escasamente pobladas del sur europeo convergen en el proyecto LIVHES en torno al patrimonio cultural inmaterial
}

\begin{abstract}
Nueve socios de ocho regiones europeas pertenecientes a Francia, España y Portugal aúnan sus esfuerzos en la valorización global del patrimonio cultural inmaterial como motor de desarrollo local sostenible. El proyecto LIVHES, que comenzó en noviembre de 2020 y concluirá a finales de abril de 2023, apuesta por un modelo de trabajo participativo para generar una guía de buenas prácticas de valorización. Los socios testarán esta metodología en una experiencia innovadora en cada territorio y, a través de la reflexión en mesas transnacionales, transferirán los resultados al conjunto del espacio europeo SUDOE.
\end{abstract}

Alfredo Asiáin Ansorena | Dpto. de Ciencias Humanas y de la Educación, Universidad Pública de Navarra

URL de la contribución <http://www.iaph.es/revistaph/index.php/revistaph/article/view/5011>

LIVHES es un proyecto SUDOE (Programa de Cooperación Interreg V-B Europa Suroccidental) que responde a una necesidad europea y a un reto territorial compartido por las áreas escasamente pobladas del sur europeo: encontrar e implementar nuevas fórmulas de revalorizar su importante patrimonio cultural inmaterial (PCl) como herramienta de desarrollo sostenible y factor de identidad y cohesión territoriales.

En este sentido, la Convención para la salvaguardia del Patrimonio Cultural Inmaterial recoge explícitamente que: "se tendrá en cuenta únicamente el patrimonio cultural inmaterial que sea compatible con los instrumentos internacionales de derechos humanos existentes y con los imperativos de respeto mutuo entre comunidades, grupos e individuos y de desarrollo sostenible" (UNESCO 2003).

Derechos humanos, interculturalidad e inclusión y desarrollo sostenible eran y son, por tanto, los estímulos y el horizonte que deben guiar los procesos de patrimonialización y las medidas de salvaguarda de este patrimonio vivo. Suponen, de facto, un llamamiento a la apropiación crítica del pasado que aliente la evolución de las comunidades, grupos o individuos portadores y de los propios bienes inmateriales, evolución ajustada a los tempos y ritmos de las personas que los transmiten y respetuosa con su protagonismo y con la propiedad colectiva de estos conocimientos, valores y expresiones tradicionales irremplazables (WIPO 2010).
Desarrollo sostenible y salvaguardia del PCl comparten, cada uno a su escala, esta apropiación crítica del pasado, para proyectar un futuro que asegure la transmisión transgeneracional -es decir, más allá de la generación de reemplazo, a medio o largo plazo-, desde postulados éticos de justicia y de sostenibilidad ambiental, económica y social. Si el desarrollo sostenible busca modelos de desarrollo caracterizados por el equilibrio, que propicien la equidad social, la viabilidad económica y el respeto y protección del medio ambiente y de su biodiversidad (Mensah y Casadevall 2019), la salvaguardia del $\mathrm{PCl}$, por su parte, alienta el dinamismo cultural, la evolución e innovación, con la observancia de unos principios éticos (UNESCO 2015a) para asegurar la diversidad cultural (UNESCO 2005).

Las acciones que propuso la Convención (UNESCO 2003), a saber, identificación y documentación, salvaguardia, promoción y difusión, y protección y revitalización, han generado, además de la inscripción entusiasta de bienes en la Lista Representativa del Patrimonio Cultural Inmaterial de la Humanidad, una difusión de buenas prácticas de salvaguardia en otra lista, mucho menos numerosa, pero quizás más interesante. En el caso de España, por ejemplo, han sido destacadas las buenas prácticas de la Escuela de Pusol de Elche (2009), la artesanía de la cal de Morón de la Frontera (2011) y los inventarios en Reserva de la Biosfera de Montseny (2013). 
Inspirado en estas y otras buenas prácticas, el proyecto LIVHES, sin embargo, pretende explorar la última de las acciones, la revitalización, en conexión con los usos sociales del $\mathrm{PCl}$. No se trata de una visión parcial ni mercantilista (García-Canclini 1999), sino de una perspectiva de valoración global del $\mathrm{PCl}$ como motor de desarrollo local sostenible social, económica y medioambientalmente (UNESCO 2014 y 2015b; Bandarin 2015; Soini y Dessein 2016; Martinell y García Haro 2021). Estos usos, equilibrados y evaluados, son en sí mismos también medidas eficaces e innovadoras de salvaguardia.

Responde, por una parte, a necesidades y diagnósticos socioeconómicos compartidos por ocho territorios europeos (Pyrénées Atlantiques-Nouvelle Aquitaine; Pyrénées Haut Garonnaisses-Occitanie; Cataluña; Navarra; Teruel, Burgos; Región Transfronteriza Rio Minho; y municipio portugués de Barcelos). La progresiva despoblación, el envejecimiento poblacional, los desequilibrios territoriales, el estancamiento económico, la falta de oportunidades laborales para la juventud, etc. son amenazas comunes para el desarrollo y la cohesión territoriales. Pero también hace frente, por otra parte, a los problemas de transmisión y vitalidad de su patrimonio, especialmente del $\mathrm{PCl}$, tan vulnerable porque está intrínsecamente unido a las personas portadoras y a su relevo generacional (Asiáin 2013).

Con el Pôle Métropolitain Pays de Béarn como jefe de filas, el proyecto LIVHES coordina a 9 socios de las ocho regiones europeas mencionadas anteriormente, entidades con tres perfiles complementarios: organismos públicos y autoridades locales, asociaciones de desarrollo local y territorial, y centros de investigación y universidades. Esta interdisciplinariedad permite combinar conocimiento y experiencia tanto en campos científico-técnicos de salvaguarda y valorización del PCl como en proyectos de desarrollo local sostenible. Cuenta, por último, como beneficiarios asociados, con organismos científicos y culturales de Francia, España y Portugal. Comenzó en noviembre de 2020 y finalizará a finales de abril de 2023.

La cooperación está planteada en dos escalas interrelacionadas: en cada territorio, con la creación y participa-

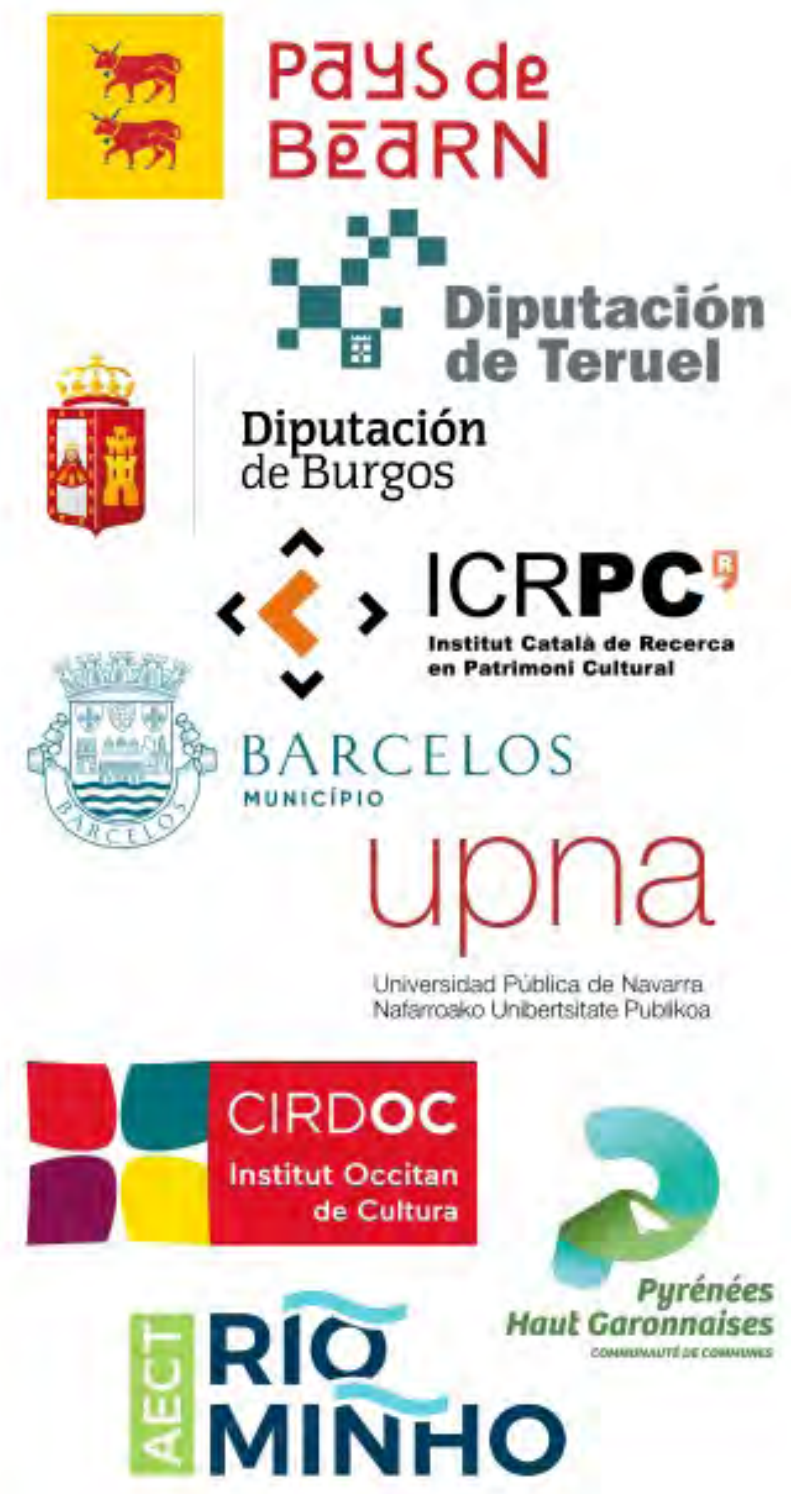

Logotipos de los socios del proyecto LIVHES

ción de grupos de trabajo territoriales compuestos por portadores, agentes locales y regionales competentes en PCl y desarrollo local; y en el ámbito internacional, con la realización de mesas transnacionales de intercambio y transferencia.

Esa dinámica que va de lo local a lo global aspira a alcanzar cuatro grandes objetivos: en primer lugar, identificar, seleccionar y estudiar las mejores prácticas en 
torno a la valorización del $\mathrm{PCl}$ como motor de desarrollo local; desarrollar, en segundo lugar, una metodología común y una estrategia adaptada a cada región participante; en tercer lugar, experimentar y evaluar la metodología propuesta mediante su aplicación en experiencias o acciones piloto innovadoras; y, por último, difundir la metodología y los modelos de estos proyectos, a través de la creación de un foro transnacional de $\mathrm{PCl}$ y de una red de trabajo asociada a él.

La metodología de trabajo, diseñada por el Institut Occitan de Cultura (CIRDOC), cuenta con la colaboración de la Fundació Institut Català de Recerca en Patrimoni Cultural de Cataluña y de la Cátedra de patrimonio inmaterial de Navarra de la Universidad Pública de Navarra. Apuesta por un modelo participativo (Arjones 2015) con la creación de grupos territoriales con cuya ayuda se generará, en primer lugar, un diagnóstico consolidado sobre los retos y oportunidades del $\mathrm{PCl}$ como motor de desarrollo sostenible, y un mapa de actores y soluciones innovadoras en cada territorio; y posteriormente, a través de la reflexión en las mesas transnacionales, se transferirá al conjunto del espacio europeo SUDOE.

Desde el punto de vista de los resultados esperables, hay que diferenciar las dos escalas: en cada territorio o región participante, a partir de su diagnóstico territorial sobre el estado del $\mathrm{PCl}$, sus amenazas, retos y oportunidades, se diseñará un plan de acción para su implementación a medio y largo plazo basado en la guía de buenas prácticas y en las conclusiones de la experiencia piloto innovadora desarrollada.

Desde el punto de vista de los resultados transferibles transnacionales, a partir de las mesas y talleres programados, se elaborará una Guía Metodológica de buenas prácticas para el desarrollo de procesos de valorización del Patrimonio para crear desarrollo sostenible en los territorios periféricos o de baja población del territorio SUDOE; y se impulsarán un Observatorio internacional sobre este tema y una Red de Territorios impulsores de nuevos modelos de desarrollo local sostenible.

\section{BIBLIOGRAFÍA}

- Arjones, A. (2015) Apuntes para un Manual de buenas prácticas para la participación ciudadana en la gestión del patrimonio cultural en Andalucía. Periférica Internacional. Revista para el análisis de la cultura y el territorio, n. ${ }^{\circ} 16$

- Asiáin, A. (2013) El patrimonio cultural inmaterial: estado de la cuestión en el décimo aniversario de la Convención de la UNESCO (con una mirada especial a Navarra). Cuadernos de Etnología y Etnografía de Navarra, n. ${ }^{\circ} 88$, pp. 125-168

- Bandarin, F. (2015) Sustainability in the world heritage convention: The making of a policy framework. En: Albert, M-T (ed.) Perceptions of sustainability in heritage studies. Berlin: De Gruyter, pp. 35-46

- García Canclini, N. (1999) Los usos sociales del patrimonio cultural. En: Aguilar Criado, E. (coor.) Patrimonio etnológico: nuevas perspectivas de estudio. Sevilla: Consejería de Cultura

- Martinell, A. y García Haro, M. (coord.) (2021) Hacia una cultura sostenible. Guía práctica para integrar la Agenda 2030 en el sector. sl: Red Española para el Desarrollo Sostenible

- Mensah, J.y Casadevall, S.R. (2019) Sustainabledevelopment: Meaning, history, principles, pillars, and implications for human action: Literature review. Cogent Social Sciences, 5 (1)

- Soini, K., \& Dessein, J. (2016) Culture-sustainability relation: Towards a conceptual framework. Sustainability, 8(2), p. 167

- UNESCO (2003) Convención para la Salvaguardia del Patrimonio Cultural Inmaterial. Disponible en: http://unesdoc. unesco.org/images/0013/001325/132540s.pdf [Consulta: 31/ 07/2021]

- UNESCO (2005) Convención sobre la Protección y la Promoción de la Diversidad de las Expresiones Culturales. Disponible en: http://unesdoc.unesco.org/images/0014/001429/142919s.pdf [Consulta: 31/07/2021]

- UNESCO (2014) Declaración de Florencia sobre Cultura. Creatividad y Desarrollo Sostenible. Investigación. Innovación. Oportunidades. Disponible en: http://unesdoc.unesco.org/ images/0023/002303/230394s.pdf [Consulta: 31/07/2021]

- UNESCO (2015a) Principios éticos para la Salvaguardia del Patrimonio Cultural Inmaterial. Disponible en: https://ich. unesco.org/doc/src/2003_Convention-Ethical_principles-ES. pdf [Consulta: 31/07/2021]

- UNESCO (2015b) Patrimonio Mundial y desarrollo sostenible. $20^{a}$ Reunión de la Asamblea General de los Estados Partes en la Convención para la Protección del Patrimonio Mundial, Cultural y Natural. 13. . WHC-15/20.GA/13. Disponible en: http://whc.unesco.org/archive/2015/whc15-20ga-13-es.pdf [Consulta: 31/07/2021]

- WIPO (2010) Intergovernmental Committee on Intellectual Property and Genetic Resources, Traditional Knowledge and Folklore. Disponible en: https://www.wipo.int/meetings/en/ details.jsp?meeting_id=11222 [Consulta: 31/07/2021] 


\section{Buenas prácticas: concepto, sentido y aplicación para la valoración y gestión de sistemas patrimoniales complejos}

Ignacio González-Varas Ibáñez | Área de Composición Arquitectónica, Universidad de Castilla-La Mancha

URL de la contribución <www.iaph.es/revistaph/index.php/revistaph/article/view/5009>

\section{RESUMEN}

El concepto de buenas prácticas (best practices) alcanza en nuestros días una aplicación cada vez más amplia en el campo de las ciencias sociales. También está muy presente en el ámbito de la gestión del patrimonio cultural, especialmente en las dos últimas décadas. A pesar de ser un concepto de carácter eminentemente práctico, pragmático, operativoy empírico, pensamos que las buenas prácticas no pueden desligarse de los contenidos teóricos y metodológicos del conjunto de disciplinas que integran el patrimonio cultural. El actual concepto holístico e integrado del patrimonio propone un cambio de paradigma con el tránsito desde una protección de objetos aislados hacia una salvaguardia en redes, lo que hace que hoy entendamos el patrimonio cultural como una conformación de sistemas complejos. No cabe duda de que estas conquistas conceptuales abren posibilidades inéditas y sitúan al patrimonio cultural en el centro de amplios procesos económicos, sociales y ecológicos, pero también es cierto que hacen cada vez más compleja la gestión del patrimonio cultural, de modo que, en este contexto, las buenas prácticas adquieren una especial relevancia para la difusión de experiencias innovadoras, eficientes y sostenibles en la gestión del patrimonio cultural. En este texto se analizan el sentido y alcance de las buenas prácticas en las actuales encrucijadas del patrimonio cultural, se vinculan con los objetivos del desarrollo sostenible y con los nuevos modelos de gestión del patrimonio, se establecen criterios para la identificación de buenas prácticas y se reflexiona sobre la acción desarrollada por algunas instituciones en el impulso y difusión de buenas prácticas.

\section{Palabras clave}

Buenas prácticas | Desarrollo sostenible | Gestión cultural | Objetivos de Desarrollo Sostenible (ODS) | Patrimonio cultural | Sistemas patrimoniales | 


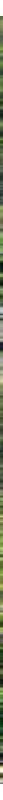

Good practices: concept, sense and applying for the valuation and management of complex patrimonial systems

\section{ABSTRACT}

The concept of good practices (best practices) has reached a remarkable degree in our times in the field of social sciences. It is also very present in the field of cultural heritage management, especially in the last two decades. Despite being an eminently practical, pragmatic and empirical concept, we believe that good practices cannot be separated from the theoretical and methodological contents of the entirety academic disciplines that make up cultural heritage. The current holistic and integrated concept of cultural heritage proposes a paradigm shift with the transition from a protection of isolated objects to a safeguarding in networks, wich means that today we understand cultural heritage as a conformation of complex systems. There is no doubt that these new concepts open up new possibilities and place cultural heritage at the center of broad economic, social and ecological processes, but it is also true that they make the management of cultural heritage increasingly complex, so that, in this context, good practices acquiere a special relevance for the dissemination of innovative experiences in the management of cultural heritage. This paper examines the meaning and the scope of the good practices in the current crossroads of cultural heritage, links the concept of good practices with the sustainable development goals and with the new models of heritage management, provides criteria for the identificaction of good practices and reflects on the actions developed by some institutions in promoting and disseminating good practices.

\section{Keywords}

Best Practices | Sustainable Development | Cultural Management | Cultural Heritage | Sustainable Development Goals (SDG) | Patrimonial systems |

Cómo citar: González-Varas Ibáñez, I. (2021) Buenas prácticas: concepto, sentido y aplicación para la valoración y gestión de sistemas patrimoniales complejos. Revista PH, n. ${ }^{0}$ 104, pp. 28-57. Disponible en: <www.iaph.es/revistaph/index.php/revistaph/article/view/5009> DOI 10.33349/2021.104.5009

Enviado: 28/05/2021 | Aceptado: 19/07/2021 | Publicado: 01/10/2021 
Zona arqueológica de Teotihuacán. La Unesco implantó en 2008 el programa de Educación para el Patrimonio Mundial de la Unesco como iniciativa de Voluntarios del Patrimonio Mundial (WHV) en colaboración con el Comité Coordinador del Servicio Voluntario Internacional (CCSVS) para involucrar a los jóvenes en la preservación del patrimonio mundial. En la zona arqueológica de Teotihuacán, el Instituto Nacional de Antropología e Historia de México (INAH) desarrolló desde 2011 el proyecto Jóvenes Guardianes de Teotihuacán que ha involucrado a voluntarios internacionales para monitorear y vincular a los jóvenes que circundan el sitio precolombino con su patrimonio cultural. La Unesco incorporó estas actividades al programa World Heritage Volunteers en 2015 y constituyen un reconocido ejemplo de buenas prácticas en la gestión del patrimonio cultural | foto Ignacio González-Varas Ibáñez
El concepto de buenas prácticas ha alcanzado una considerable difusión en una gran diversidad de ámbitos. Esta expresión, como traducción literal de las locuciones inglesas good practices o best practices, nos muestra desde el primer momento su orientación decididamente empírica, pragmática y ejecutiva que privilegia los procesos, las operaciones y los resultados frente a las construcciones teóricas o especulativas. Las buenas prácticas encontraron su primera aplicación en el ámbito anglosajón de la economía y el mundo de los negocios y su uso se orientó hacia la implementación de métodos y procedimientos dirigidos a mejorar la productividad de las empresas o de sus procesos, a estimular el desarrollo de las capacidades de sus empleados o bien a obtener una mejor satisfacción de sus clientes o de los usuarios de sus servicios. El concepto de buenas prácticas se asocia desde estas primeras formulaciones a atributos como la eficacia y la eficiencia. Pero desde mediados de los años noventa su utilización se ha extendido a otros campos. Así ha sido y es muy frecuente su empleo en la pedagogía y la didáctica y las buenas prácticas se han utilizado en estos ámbitos para exponer experiencias adecuadas para su aplicación en los procesos educativos; de hecho, si sondeamos en los repositorios bibliográficos, la literatura crítica más abundante en torno al concepto y definición de buenas prácticas la encontraremos en las ciencias de la educación. Las compilaciones realizadas por algunos

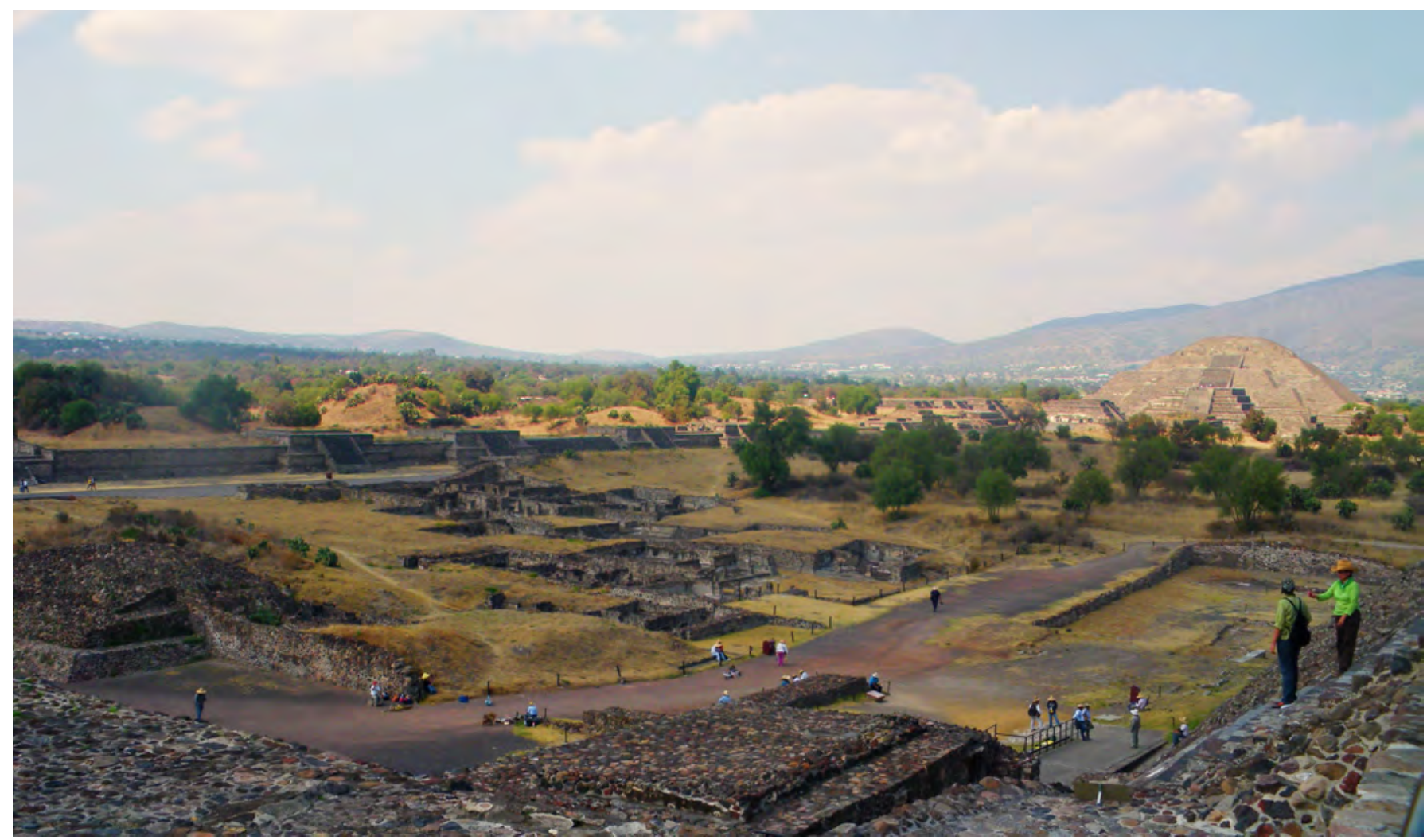


especialistas en este campo siguen siendo de utilidad para aproximarse a este concepto (González Ramírez 2007; Jerí Rodríguez 2008). Para nuestros propósitos, también reviste un especial interés la aplicación instrumental de las buenas prácticas en el sector de la administración y las políticas públicas sociales, donde cada vez es más frecuente que distintos organismos, instituciones y administraciones recurran a ejemplificar procesos de gestión a través de las buenas prácticas o que incluso compilen códigos deontológicos de buenas prácticas para regular su propia actividad (Ausín Díez 2018). Las buenas prácticas se han aplicado igualmente de modo temprano a disciplinas como el urbanismo, ámbito en el que, como es sabido, intervienen numerosos agentes y se cruzan intereses muy diversos. De hecho, una de las primeras aplicaciones de buenas prácticas al urbanismo se produjo en la Conferencia de Naciones Unidas Hábitat II que se celebró en Estambul en junio de 1996. Este evento fue convocado con el propósito de fomentar acciones para la mejora de las condiciones de vida en las ciudades, la planificación urbana y las políticas de desarrollo sostenible. En este contexto se aplicó el Programa de Buenas Prácticas de Naciones Unidas como herramienta para el desarrollo de políticas sociales. Este programa dio lugar a la compilación en España del primer catálogo español sobre buenas prácticas que ha gozado de varias ediciones (Ministerio de Obras Públicas, Transporte y Medio Ambiente 1996 y ss; Hernández Aja, 2001 y ss.).

También nos podemos aproximar a la expresión buenas prácticas a partir de su análisis léxico-semántico. Vemos cómo esta locución está constituida por la suma de un sustantivo y un adjetivo. El sustantivo no plantea demasiados problemas de interpretación, pues, como apuntamos más arriba, las "prácticas" nos remiten a acciones, realizaciones concretas, actos o experiencias, en lugar de ideas o concepciones teóricas o abstractas. Mayores dificultades interpretativas presenta el adjetivo que califica a las prácticas: el adjetivo "buenas" es valorativo y, por tanto, susceptible de provocar diversas interpretaciones, comenzando por las posibilidades de usar el adjetivo en su grado positivo (good practices), y expresar así solo la cualidad buena o positiva de una práctica determinada, o bien en el grado superlativo (best practices). En su uso tanto común como académico, por lo general se prefiere recurrir al positivo "buenas prácticas", al comparativo "mejores prácticas" o incluso, de modo implícito, al superlativo relativo "las mejores prácticas", en cuanto se asignan a estas el grado máximo de la cualidad en comparación con las demás y de ahí se derivan algunas de las cualidades fundamentales de las buenas prácticas, como son la eficacia, la eficiencia, la conveniencia y la ejemplaridad. En cualquier caso, el concepto de buenas prácticas nos remite siempre a un modo de actuar recto, correcto y adecuado.

Quizá llegados a este punto, pueda ser el momento de escoger una primera definición de buenas prácticas que nos sirva para avanzar en nuestros propósitos. Entre las muchas que se han realizado, nos inclinamos por repro- 
ducir aquí la ofrecida por la FAO en 2014, pues se trata de una definición precisa y sintética de este concepto. Esta definición nos permitirá contar desde estas primeras líneas con una descripción del concepto de buenas prácticas lo suficientemente amplia y genérica como para poder ser utilizada en cualquier contexto, incluido nuestro campo específico del patrimonio cultural:

"Una buena práctica no es tan solo una práctica que se define buena en sí misma, sino que es una práctica que se ha demostrado que funciona bien y produce buenos resultados, y, por lo tanto, se recomienda como modelo. Se trata de una experiencia exitosa, que ha sido probada y validada, en un sentido amplio, que se ha repetido y que merece ser compartida con el fin de ser adoptada por el mayor número de personas" (FAO 2014).

En esta primera aproximación al concepto de buenas prácticas también nos interesa observar cómo esta cualidad puede aplicarse o resolverse en dos campos distintos, pero complementarios: por un lado, dentro del ámbito metodológico de una disciplina científica o de un saber o conjunto de saberes; y, por otro lado, dentro de la esfera moral o ética en la que se desarrollan las actividades humanas.

En el primer sentido, la expresión buenas prácticas nos remite a una adecuada aplicación de determinadas reglas o instrucciones que se ajustan a los postulados metodológicos de uno o varios campos del conocimiento y que se utilizan con el fin de obtener unos resultados eficientes, contrastados y correctos. Así son juzgadas como "buenas" aquellas prácticas que, siguiendo reglas y procedimientos admitidos, consiguen alcanzar los objetivos de la disciplina.

Pero pronto se despliegan los interrogantes sobre qué es bueno o sobre quién está capacitado para decidir acerca de la bondad de una práctica determinada: en efecto, lo que se considera bueno depende de distintos factores, como, por ejemplo, quién lo juzga, cómo es el objeto sobre el que se aplica el juicio o cuál es el contexto, la posición o la ideología desde la que se emite ese veredicto. Por lo tanto, podemos deducir que la expresión buenas prácticas tiene asimismo implicaciones morales o éticas, en cuanto nos remite a juicios de moralidad (Cabré Castellví 2010). Desde esta perspectiva, las buenas prácticas se vinculan con una manera de hacer honesta, recta y acorde con principios u objetivos éticos o morales. Estos principios derivan tanto del sistema de valores y de los principios y objetivos de una disciplina o de un saber, como de las pautas de conducta y los códigos morales establecidos por un grupo humano. Esta vinculación de las buenas prácticas con el quehacer metodológico y con el universo ético también tiene una considerable repercusión en el campo del patrimonio cultural. Veámoslo. 


\section{LAS BUENAS PRÁCTICAS EN LAS ACTUALES ENCRUCIJADAS DEL PATRIMONIO CULTURAL}

La disciplinas científicas, sociales y humanísticas que se agrupan en el ámbito de la preservación y/o gestión del patrimonio cultural se definen, como tantas otras, en torno a un conjunto de reglas o normas que guían sus procesos y orientan sus acciones y los juicios sobre lo que es correcto o incorrecto; esto es, las buenas prácticas (y su reverso, las "malas prácticas") son definidas y juzgadas como tales dentro de una escala de valores que es compartida por los distintos actores que intervienen en el campo del patrimonio cultural, bien sean estos los técnicos y los científicos, los gestores y administradores, las instituciones y los políticos o las propias comunidades y grupos sociales. Las disciplinas implicadas en la conservación del patrimonio cultural han ejemplificado desde sus orígenes sus postulados teóricos y conceptuales en el ámbito empírico de la práctica. La voluntad de trasvasar la teoría a la praxis ha contado con el apoyo de numerosos documentos normativos u orientativos, como cartas, recomendaciones, declaraciones, principios, convenciones o leyes que forman un rico y diverso corpus normativo. Estos principios se han desplegado a su vez a través de una inagotable casuística que trata de explicitar de modo eficaz y correcto los preceptos y métodos de cada disciplina. Pero debemos apresurarnos a constatar que este conocimiento práctico no es un hacer aislado, sino que está íntimamente vinculado a la reflexión teórica. La práctica evoluciona en paralelo a las respuestas otorgadas acerca de las preguntas fundamentales que unifican a cada una de las disciplinas implicadas en el patrimonio cultural; es decir, los interrogantes acerca de qué es el patrimonio, cuáles son sus valores y por qué el patrimonio cultural es un componente fundamental de nuestras sociedades son preguntas todas ellas inseparables de las respuestas que ofrezcamos acerca del cómo actuar o de cuáles son procedimientos y métodos más apropiados para conseguir una conservación y gestión adecuadas de ese patrimonio cultural previamente identificado y descrito por el conocimiento teórico.

Las buenas prácticas en el campo de la conservación del patrimonio cultural están orientadas, por tanto, por el alcance y sentido que otorgamos al propio patrimonio cultural. Y, como hemos tratado en diferentes ocasiones, es un hecho unánimemente reconocido que el patrimonio cultural ha experimentado en las últimas décadas un considerable incremento y expansión en sus tipos y formas, así como en sus objetivos, métodos y modelos de gestión (González-Varas Ibáñez 2015, 2018). Los tipos y formas del patrimonio se han ampliado en escala física y han ensanchado sus dominios desde los monumentos y ciudades al paisaje y el territorio, con el consiguiente incremento en paralelo de las dificultades de gestión de sistemas territoriales amplios, complejos y variados. Pero también se asiste a un desplazamiento del interés desde el objeto hacia el sujeto: vemos cómo la dis- 
cusión se centra hoy no tanto o no solo en el conjunto de bienes, materiales e inmateriales, que integran el patrimonio cultural y observamos cómo el debate se desarrolla más bien en torno a cómo los ciudadanos o las comunidades reconocen este patrimonio, lo valoran, lo aprecian y lo integran en sus modos de vida. De esta manera, y si nos trasladamos al campo más operativo de las buenas prácticas, podemos comprobar cómo las instituciones implicadas con la conservación del patrimonio cultural cada vez están más interesadas en el desarrollo de acciones de reconocimiento, valoración y activación de este patrimonio en el seno de las comunidades. Como he afirmado recientemente, "ya no solo interesan las acciones directas o indirectas llevadas a cabo por los técnicos del patrimonio cultural para la conservación del objeto material o inmaterial, el bien cultural, sino que también la preocupación se viene centrando asimismo en los grupos, comunidades o individuos que crean, mantienen, transmiten o transforman el patrimonio cultural" (González-Varas Ibáñez 2021).

Las políticas en torno a los bienes culturales han pasado de concentrarse únicamente en la conservación o el mantenimiento técnico del patrimonio a buscar los modos más adecuados para articular su gestión de acuerdo con planteamientos sociales, económicos y ecológicos más amplios. Podemos afirmar que la gestión del patrimonio cultural ha experimentado un tránsito desde los objetos singulares a los sistemas patrimoniales. Hoy pensamos que el patrimonio no obedece tanto a una consideración de elementos únicos, singulares o extraordinarios, como al tratamiento de conjuntos estructurados a través de elementos relacionados entre sí y que alcanzan su pleno significado en el contexto social, territorial, ambiental y natural en el que se ubican y desarrollan. También es importante subrayar que se trata de sistemas complejos cuya conservación involucra al medio físico y biológico, a la economía y a las políticas públicas y, en general, al conjunto de la sociedad. Lo que ocurra en estos ámbitos próximos en los que se encuentra inmerso el patrimonio cultural afectará de modo inevitable al propio patrimonio, a su significación y a su mantenimiento y/o transformación. Este conjunto funciona, por tanto, como un sistema complejo o totalidad organizada en la cual los elementos no son separables. Por eso, estos elementos, antes que ser estudiados y tratados aisladamente, deben ser considerados ante todo en cuanto sistema y en función de sus interrelaciones.

Podemos mencionar un ejemplo destacado de buenas prácticas en este sentido que venimos mencionando de sistema patrimonial complejo que integra el patrimonio en su marco paisajístico, natural y social. Fijamos así nuestra atención en el acueducto del Padre Tembleque, una imponente infraestructura ideada para la canalización de agua que está situada en el estado de Hidalgo y que esta considerada como la obra de ingeniería hidráulica más representativa del virreinato de Nueva España. El acueducto fue concebido por iniciativa del fraile franciscano Francisco de Tembleque que 

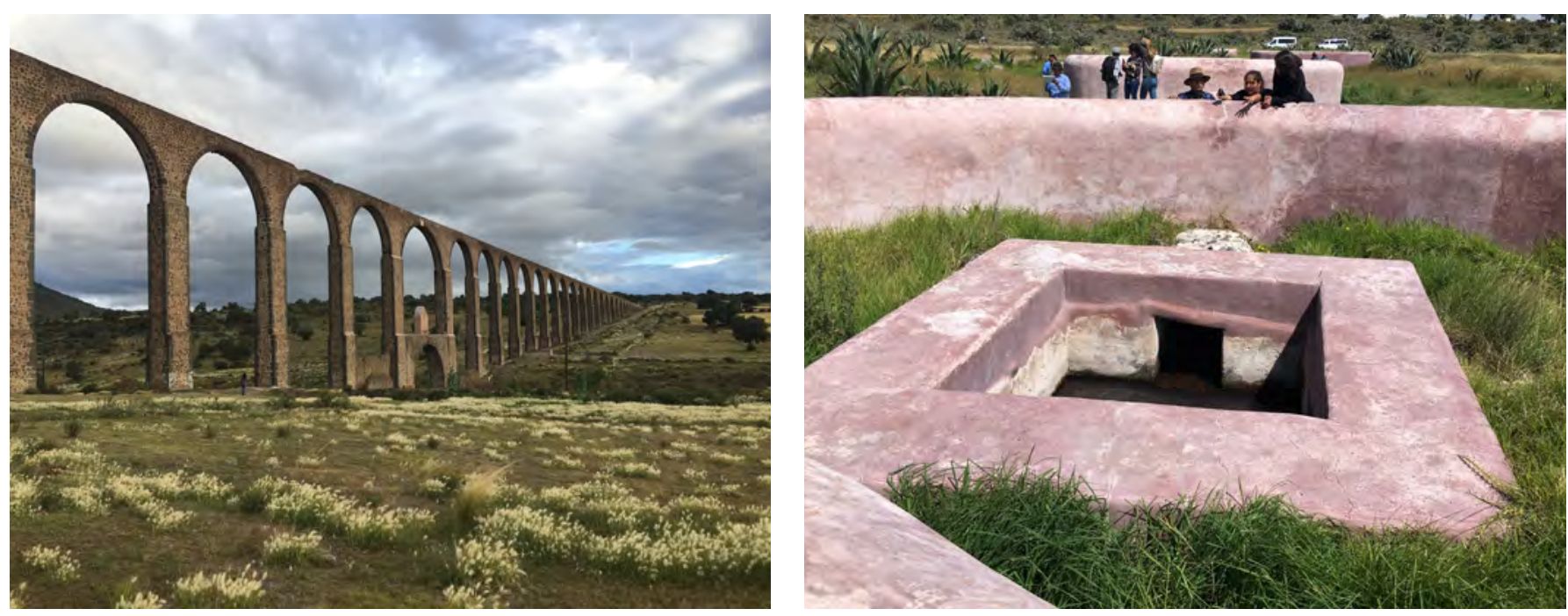

Acueducto del padre Tembleque, arquería mayor de Santiago de Tepeyahualco (1554-1571)

Ojos de los manantiales que surten de agua al acueducto en la falda del volcán Tecajete (México) | fotos Ignacio González-Varas Ibáñez llegó a la Nueva España en 1542, y que, una década más tarde y durante varios años, entre 1554 y 1571, dirigió la construcción de esta infraestructura hidráulica que fue levantada por 40 comunidades indígenas. Esta obra fue declarada Patrimonio Cultural Mundial en 2015. La declaración tuvo como objetivo superar la noción restringida centrada únicamente en valorar y proteger su elemento más llamativo, la arquería mayor o arquería monumental de Santiago de Tepeyahualco, que es una impresionante obra de 68 arcos de medio punto extendida en una longitud de 904 metros y que alcanza su cota más alta en 38,75 metros, para considerar la implantación global del acueducto en su sistema territorial. En efecto, la declaración, más allá de la proeza técnica de las arquerías, incluye la longitud total de la obra hidráulica que abarca otras seis arquerías más y que, con el resto de obras de canalización y transporte de agua, alcanza una longitud total de 48 kilómetros, la mayor parte realizada mediante canalizaciones subterráneas que se extienden desde los manantiales u ojos situados en las faldas del volcán Tecajete hasta la histórica localidad de Otumba, situada ya en el estado de México, y que cuenta además con una bifurcación adicional de diez kilómetros destinada a abastecer de agua a las poblaciones de Zacuala y Zempoala. Este sistema integra la obra hidráulica en su marco natural y social, comenzando con el área de su nacimiento a los pies del mencionado cerro volcánico de Tecajete, un cono de escoria volcánico, con su amplio cráter formado por fragmentos piroclásticos sueltos, protección que se extiende a las distintas zonas paisajísticas del acueducto que atraviesan el yermo Altiplano mexicano. Las labores de mantenimiento y conservación, en consecuencia, se han extendido a todo el sistema y han liberado al acueducto de elementos añadidos y han procedido al desazolve de arena en los canales y cajas de agua y a la limpieza del entorno, con la restauración de los apantles, las cajas de agua y los areneros del conjunto hidráulico, además procederse a la 

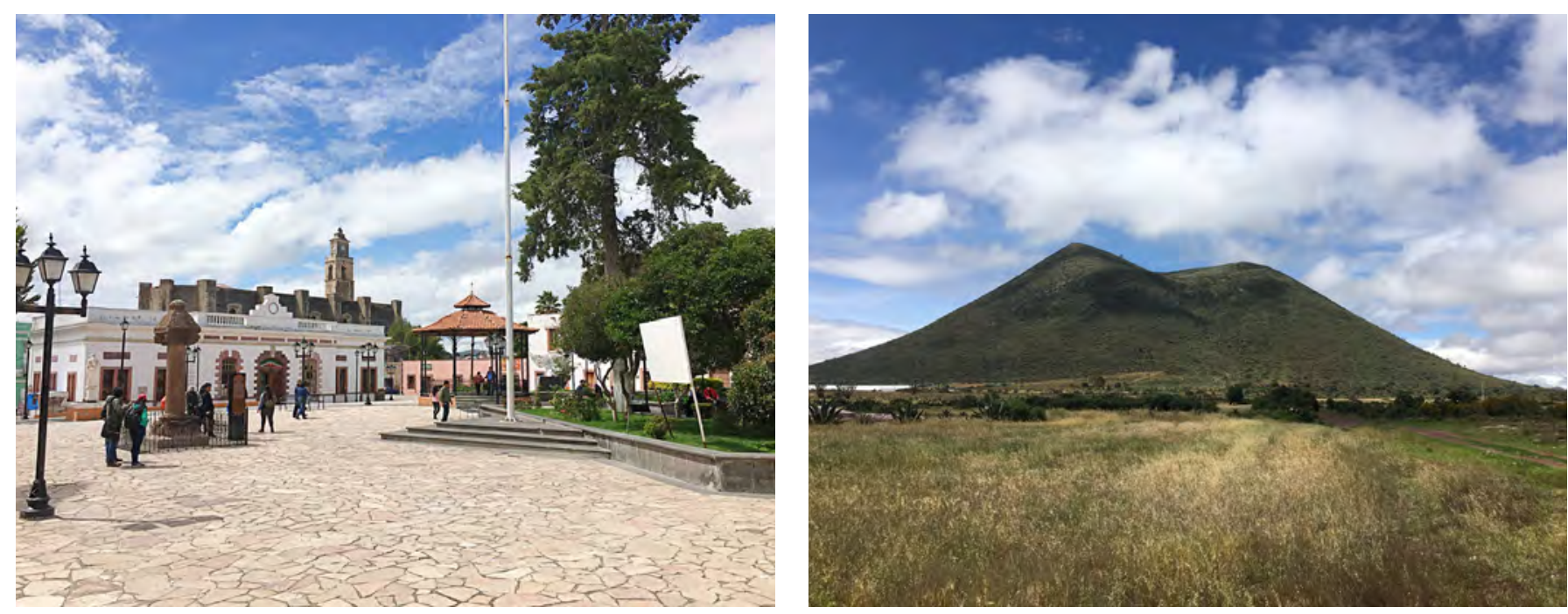

Plaza Mayor de Zempoala, estado de Hidalgo

Volcán Tecajete, municipio de Zempoala, estado de Hidalgo, México | fotos Ignacio González-Varas Ibáñez identificación y protección de los 90 glifos que fueron incorporados al acueducto por la mano indígena y que constituyen un valioso testimonio antropológico; y, lo que también es importante, en todas estas acciones se ha realizado una intensa labor en buscar la implicación de las comunidades y poblados por las que discurre esta obra hidráulica para hacerles partícipes de su cuidado y mantenimiento.

Vemos cómo se ha llegado así en nuestros días a una visión holística del patrimonio, esto es, un planteamiento que concibe la realidad del patrimonio como un todo distinto de la suma de las partes que lo componen. Esta visión holística, compleja, sistémica y expansiva del patrimonio cultural no cabe duda de que abre perspectivas inéditas. Pero también hay que decir que este planteamiento, a la vez que sitúa al patrimonio cultural en el centro de los procesos económicos y sociales, también hace emerger nuevos y considerables desafíos en cuanto a la complejidad que asume su gestión. Por eso, las buenas prácticas, en este nuevo contexto, se han erigido en instrumentos sumamente eficaces de gestión, ya que pueden llegar a establecer modelos eficaces y eficientes, reproducibles, transferibles o replicables; y al mismo tiempo, la buenas prácticas se erigen como recursos metodológicos que pueden servir tanto para ejecutar y lograr los objetivos de las disciplinas que convergen en el patrimonio cultural, como incluso para poner en discusión y renovar sus propios contenidos teóricos a través de los ejemplos y modelos desarrollados que, con sus propuestas metodológicas, pueden contribuir a abrir nuevas perspectivas de entendimiento del propio patrimonio cultural. De este modo, podemos decir que las buenas prácticas se encuentran en medio de las encrucijadas actuales del patrimonio cultural. Con su casuística, las buenas prácticas abordan y desarrollan temas cruciales y críticos en nuestros días y en nuestras sociedades, como pueden ser, entre 
otros, los vínculos entre cultura y desarrollo, los deslizamientos entre la sostenibilidad y la rentabilidad en la conservación del legado patrimonial, las discusiones acerca de las presiones del turismo masivo sobre el patrimonio cultural, las tensiones entre memoria y patrimonio, la crisis de los discursos institucionales centralistas y las disyuntivas entre participación ciudadana en la planificación del patrimonio o los modos de dar cabida a los distintos actores que están involucrados en el patrimonio a través una gestión inclusiva y participativa.

\section{BUENAS PRÁCTICAS EN PATRIMONIO CULTURAL Y LOS OBJETIVOS DEL DESARROLLO SOSTENIBLE (ODS)}

Vemos, por tanto, cómo la comprensión y gestión del patrimonio cultural se debate entre dos polos extremos. Por un lado, la necesidad de contar con un marco conceptual muy amplio que resulte asentado sobre principios globales o universales o que, al menos, gocen de amplia aceptación; y, por otro lado, el establecimiento de pautas de actuación concretas y precisas que nos permitan contar con experiencias válidas y contrastadas para gestionar el patrimonio cultural de un modo adecuado. No cabe duda de que, como venimos argumentando, el marco conceptual global y las experiencias particulares han de interrelacionarse y retroalimentarse. La reflexión sobre la potencialidad e incidencia de las buenas prácticas en la gestión del patrimonio cultural pensamos que es de especial importancia en nuestros días, cuando somos plenamente conscientes del lazo inescindible que anuda la preservación y salvaguardia del patrimonio cultural y natural con el paradigma y los Objetivos del Desarrollo Sostenible. Hoy se entiende que el desarrollo sostenible está en la base y orienta de modo ubicuo casi todas las políticas de desarrollo en sus distintos niveles local, regional, nacional o global. Esta estrecha relación se ha reforzado también de modo especialmente intenso en el campo del patrimonio cultural. Son numerosas las aportaciones y estudios que tratan y consideran el importante papel que puede ejercer el patrimonio cultural para la implementación y consecución de los ODS. Estos principios, como todos sabemos, se han venido estableciendo en las distintas cumbres internacionales que se han sucedido en estas décadas, desde la Cumbre de la Tierra, convocada en junio de 1992 por la Conferencia de Naciones Unidas sobre Medio Ambiente y Desarrollo en Río de Janeiro, y de la que surgió el Protocolo de Kyoto (1997), hasta las Cumbres de Johannesburgo o de Río + 20 (2012), con el ulterior desarrollo de la llamada Agenda pos-2015 traducida en los Objetivos de Desarrollo Sostenible adoptados por Naciones Unidas para el período 2015-2030.

En respuesta a este amplio movimiento internacional, el Centro de Patrimonio Mundial de la Unesco realizó en 2011 varias adiciones a las Directrices prácticas para la aplicación de la Convención del Patrimonio Mundial con la fina- 


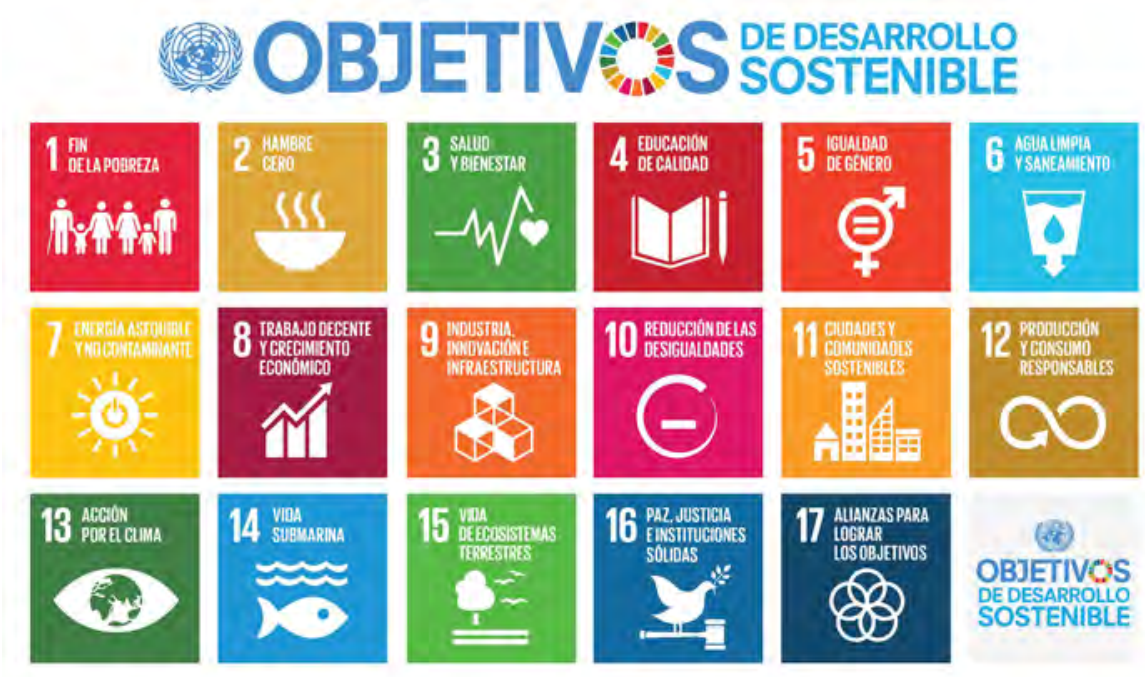

Objetivos del Desarrollo Sostenible. Póster promocional | fuente ONU

lidad de refrendar el mantenimiento del valor universal excepcional de estos bienes culturales y garantizar la sostenibilidad de cualquier acción planificada sobre los bienes del Patrimonio Mundial. Estas adiciones han estado orientadas por la afirmación del principio fundamental de que los sistemas de gestión de estos bienes "deben integrar los principios del desarrollo sostenible" (UNESCO 2011, § 6, 112, 119 y 132, anexos 5, 4b y 5e).

La conservación, valoración y transmisión del patrimonio cultural a las generaciones futuras es juzgada como un fin legítimo y válido en sí mismo que, por supuesto, no necesitaría de ulteriores justificaciones. Pero también hoy entendemos que este primer imperativo ético se puede extender más allá hasta llegar a plantearnos el interrogante de cuál puede ser la contribución del patrimonio cultural para la consecución de los objetivos económicos, sociales y ambientales del desarrollo sostenible. Dicho de otra manera: aceptamos como principio fundamental que el patrimonio cultural es un legado insustituible que recibimos $y$, como tal, hemos de asumir la responsabilidad de su custodia, legado y transmisión a las generaciones futuras; pero tampoco se nos escapa que de este precepto se pueden desprender acciones que, a la vez que parten de la preservación del patrimonio como finalidad primera y primaria, también pueden contribuir de modo importante al fomento de la calidad de vida y el bienestar humano. En efecto, las acciones que tienen como objetivo inicial o prioritario la conservación del patrimonio podrán también ser susceptibles de crear riqueza, empleo, oportunidades de promoción social u otros beneficios materiales o espirituales para las distintas sociedades o comunidades. Las buenas prácticas integran así estos dos aspectos éticos que señalábamos más arriba. Es decir, por un lado, el referente ético de carácter universal, en cuanto las buenas prácticas en el uni- 
verso del patrimonio cultural las podemos entender como acciones humanas correctas en cuanto a sus finalidades y principios (ética) y que pueden dar lugar a códigos de comportamiento (moral). Y, por otro lado, las buenas prácticas como acciones que aplican de un modo recto y correcto los principios de distintos saberes y disciplinas para logran un aumento de la calidad de vida de las comunidades. En suma, las buenas prácticas quedan encerradas dentro de una doble esfera ética: por un lado, la preservación del patrimonio cultural como un imperativo ético per se; y, por otro lado, y derivado de esta reflexión previa, como experiencias positivas acerca de cómo se debe actuar para desarrollar acciones metodológicamente correctas situadas en el nivel de la praxis; y de estas últimas acciones, como decimos, asimismo pueden derivarse importantes beneficios socioeconómicos y ambientales, pues las buenas prácticas deben contribuir a la mejora de la calidad del vida de las personas, un compromiso, como vemos, también susceptible de ser definido y argumentado en la esfera ética.

Las buenas prácticas en los sistemas de gestión del patrimonio pueden establecer caminos adecuados para esta finalidad de carácter más operativo en cuanto inciden en los tres pilares que orientan las políticas del desarrollo sostenible, esto es, en el crecimiento económico -en cuanto a la contribución del patrimonio cultural a la mejora del bienestar humano y el aumento de la calidad de vida-, en la inclusión social -como enriquecimiento de las relaciones humanas y el logro de las aspiraciones individuales y grupales a través del patrimonio cultural compartido- y en el equilibrio ambiental -en cuanto el patrimonio cultural puede ser un factor importante en la protección de la integridad y resiliencia de los sistemas ecológicos-. Algunos autores, como Giovanni Boccardi, lo vienen exponiendo desde hace más de una década (Boccardi 2007) y otros más recientemente como, por ejemplo, Peter Bille Larsen o William Logan (Larsen y Logan 2018). Dentro de esta visión holística del patrimonio cultural que, como vimos en el apartado anterior, integra a las buenas prácticas en el núcleo del funcionamiento y gestión de sistemas sociales, económicos y ecológicos complejos, se asume el importante papel que estas pueden desarrollar en la esfera del patrimonio cultural y dentro del desafío global de la sostenibilidad que la humanidad afronta en nuestros tiempos.

\section{LAS BUENAS PRÁCTICAS Y LOS NUEVOS MODELOS DE GESTIÓN DEL PATRIMONIO}

El ámbito más habitual de uso de las buenas prácticas queda establecido, por tanto, en la implementación de modelos y procesos de gestión del patrimonio cultural. La visión holística e integrada del patrimonio, así como la conexión de la gestión del patrimonio con los Objetivos del Desarrollo Sostenible, no cabe duda de que han dado un vuelco a los métodos de ges- 
tión. Los profesionales del patrimonio asumen el carácter interdisciplinar que presenta la gestión del patrimonio cultural y atienden a sus vinculaciones ramificadas con otros múltiples aspectos económicos, sociales y ambientales, una gestión que se desarrolla dentro de sistemas complejos. Se han renovado por completo los modelos de gestión del patrimonio cultural en casi todos sus parámetros respecto a los esquemas tradicionales. Así, los objetivos de la gestión de áreas y lugares culturales ya no se centran únicamente en la conservación estricta, sino que se administran asimismo a partir de objetivos sociales, económicos y medioambientales más amplios; esto es, se consideran a los bienes culturales como realidades insertas en sistemas dinámicos que implican la necesidad de una conservación activa. Los valores que tradicionalmente se han identificado en el patrimonio cultural y que son reconocidos por las instituciones y los técnicos -los valores históricos, artísticos, científicos, culturales, etc.- se complementan con los valores más cambiantes y difusos otorgados por la sociedad o por las comunidades. De este modo, si la gestión se venía centrando en los visitantes y los turistas, hoy en día se tiene cada vez más en cuenta a la población local, en consideración del valor que el patrimonio asume como elemento fundamental de la identidad comunitaria. Por otro lado, los objetivos de las distintas disciplinas implicadas con el patrimonio cultural ya no se orientan solo a la protección, preservación o conservación, sino que se expanden a la rehabilitación, reutilización y revitalización, con la posibilidad de introducir el cambio como criterio de gestión y planificación.

Como consecuencia de todo esto, también observamos cómo han variado en paralelo los sistemas de gobernanza: estos, de estar protagonizados por

Centro histórico de La Habana. Implicación de las comunidades locales en la valoración del patrimonio cultural en el programa Rutas y Andares | foto Oficina del Historiador de la Ciudad de La Habana (Néstor Martí)

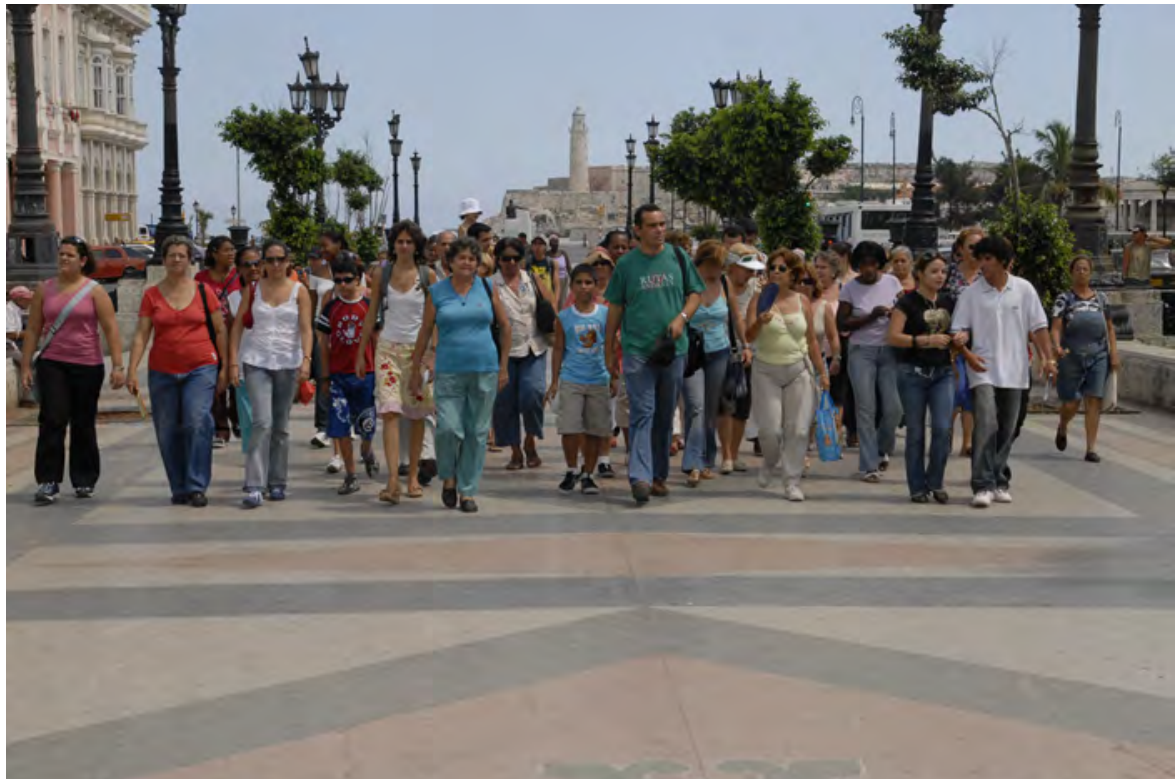


las administraciones y las instituciones públicas, han pasado a buscar modelos de gobernanza integrados que involucren a las comunidades locales y otros grupos de interés; esto es, se trata de la implantación de una gestión participativa y colectiva que debe conducir hacia un aprovechamiento de los conocimientos locales y, a la vez, a una disminución de los niveles de control por parte de la administración para tomar decisiones de manera conjunta o colectiva. Los nuevos modelos de gestión del patrimonio también buscan un marco físico y territorial más amplio que evite acotar al patrimonio en áreas delimitadas como islas para plantear una gestión de redes ampliadas y ramificadas; una gestión que, desde el punto de vista físico, no solo ha de incluir a los edificios y monumentos, sino también los espacios libres, la orografía y las formaciones físicas, la naturaleza y el carácter y tradiciones del lugar. Por ello se ha concedido cada vez más importancia a los componentes inmateriales o intangibles del patrimonio cultural: se entiende que los lugares patrimoniales no pueden aislarse del mantenimiento, transmisión o transformación de las prácticas económicas tradicionales, de las dinámicas sociales o de las percepciones de los lugares ejercidas por parte de las comunidades; por eso se insiste en articular modelos de gestión que atiendan no solo a la preservación del paisaje visual o de las características físicas de estos lugares, sino que también protejan los usos tradicionales y las necesidades de los residentes y usuarios habituales. Unos modelos de gestión que, en suma, asimilan el cambio y las modificaciones y tratan de anticipar las necesidades sociales y los procesos económicos a medio y largo plazo. Los nuevos modelos de gestión requieren del caudal de conocimientos y experiencias transmitidos a través de las buenas prácticas para guiar y encaminar adecuadamente estos procesos complejos.

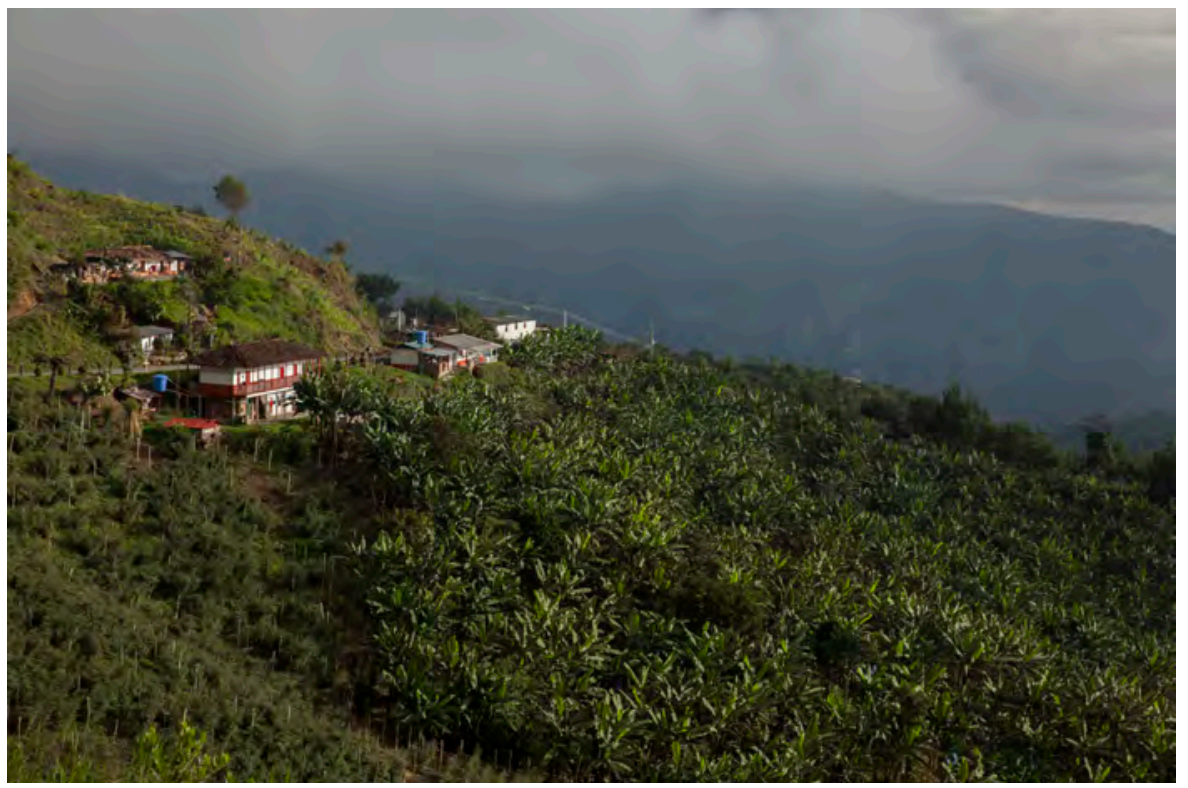

Paisaje cultural cafetero de Colombia. Municipio de Aguadas, departamento de Caldas | foto Dirección de Patrimonio y Memoria del Ministerio de Cultura de Colombia (Patricia Rincón) 


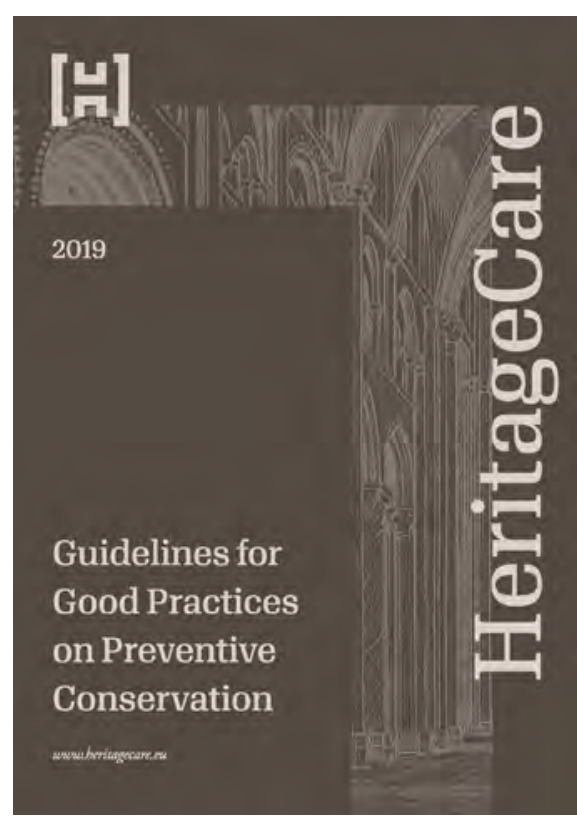

Programa HeritageCARE (2016-2019). Guía de Buenas Prácticas en Conservación Preventiva

\section{CRITERIOS PARA LA IDENTIFICACIÓN DE BUENAS PRÁCTICAS EN GESTIÓN DEL PATRIMONIO CULTURAL}

El reconocimiento y difusión de aquellas acciones y experiencias que han sido juzgadas positivas tanto por sus buenos resultados como por su capacidad para ser transferidas a otros contextos ha llevado a que cada vez sean más frecuentes las publicaciones que identifican y difunden buenas prácticas. Estas buenas prácticas se juzgan como tales porque tienen un impacto tangible y mensurable en la mejora de los sistemas de gestión y planificación del patrimonio cultural y en los efectos positivos que provocan sobre el patrimonio y sobre las comunidades; unas buenas prácticas que, por tanto, pueden servir de modelos o referentes para adoptar decisiones acertadas en estos ámbitos de la actividad humana. Otro factor que subraya esta potencialidad ejemplificadora de las buenas prácticas es su capacidad para integrar el trabajo desarrollado por los diferentes actores que intervienen en el patrimonio cultural: las buenas prácticas pueden ser propuestas o desarrolladas tanto por investigadores, técnicos y profesionales, como por el voluntariado, agrupaciones de ciudadanos o por las propias comunidades locales. Estos colectivos pueden desarrollar su labor en distintos entornos, como las administraciones públicas, las fundaciones y las empresas, las organizaciones no gubernamentales o las asociaciones, por ejemplo. Así ha ocurrido con el proyecto HeritageCARE, en el que diversas entidades de España, Francia y Portugal han colaborado para generar una estrategia conjunta para la conservación preventiva del patrimonio cultural en el Sudeste de Europa y durante tres años, de 2016 a 2019, un equipo multidisciplinar de distintas entidades y centros de investigación ha trabajado para implementar una metodología fundamentada en buenas prácticas para el mantenimiento de los edificios históricos a través de un proyecto cofinanciado por el Fondo Europeo de Desarrollo Regional dentro del programa Interreg-SUDOE.

Las buenas prácticas, en definitiva, fusionan la reflexión con la praxis, conforman un proceso, procedimiento o método de actuación que se juzga correcto y aceptado, se adaptan a criterios éticos consensuados y a los valores de las entidades que las promueven, se orientan a la consecución de los objetivos de la sostenibilidad, se ajustan a un sistema en su diseño, desarrollo, contraste y evaluación, se desenvuelven en un contexto determinado, y, por tanto, han de ser flexibles, transferibles o exportables a otros contextos que presentan situaciones o características similares o análogas. Sintetizando la abundante literatura existente al respecto, así como haciendo uso del concepto habitual de buenas prácticas asimilado por la mayor parte de la comunidad internacional y expuesto en los documentos de la Unesco y otras instituciones internacionales, podemos intentar definir a continuación algunos de los rasgos que nos permitan identificar las buenas prácticas, tanto en su sentido general como en su aplicación particular al ámbito del patrimonio cultural. 
> Innovación/Creatividad: las buenas prácticas se definen como experiencias creativas e innovadoras que aportan soluciones originales y diferentes frente a un problema o un objetivo; la innovación puede desarrollarse en varios aspectos: innovación funcional, con la implementación de nuevos modos o procesos de actuación en la gestión del patrimonio cultural; innovación estructural, con el desarrollo de nuevos sistemas de organización que modifiquen los esquemas técnicos, financieros o humanos habitualmente utilizados en la gestión del patrimonio cultural; innovación de comportamientos, con la modificación de los patrones de conducta de los distintos agentes que intervienen en el patrimonio cultural; innovación relacional, con la transformación de las formas de interacción con el entorno o con otros agentes encargados del patrimonio; innovación metodológica, con el desarrollo de nuevos esquemas y métodos de trabajo.

> Eficacia/eficiencia: el resultado de la aplicación de buenas prácticas debe ser eficaz, en cuanto alcanza los objetivos propuestos de antemano y también porque producen un impacto positivo y tangible sobre el patrimonio cultural, sobre su entorno físico o ambiental o sobre la comunidad o los tejidos sociales asociados al mismo; estos efectos deben ser susceptibles de medirse a través de sistemas de evaluación que establezcan indicadores cuantitativos y cualitativos que comparen el estado anterior y posterior a la aplicación de la buena práctica y que enumeren y describan los cambios introducidos; también ha de considerarse la eficiencia de las buenas prácticas: estas lo serán si logran sus objetivos a través del uso más apropiado y sostenible de los recursos humanos, económicos y materiales disponibles.

> Sostenibilidad/durabilidad: las buenas prácticas en patrimonio cultural muchas veces están orientadas por la consecución de los ODS, como hemos expuesto más arriba; pero la sostenibilidad también se entiende como durabilidad, esto es, como posibilidad de prolongar y continuar en el tiempo la experiencia de una manera sostenible y prolongada; y asimismo durabilidad en cuanto a su potencialidad para desarrollar nuevas acciones o experiencias derivadas de la inicial.

> Reproducibilidad/transferibilidad: las buenas prácticas surgen como respuesta a una problemática planteada en un determinado contexto físico, administrativo, cultural y social, esto es, dentro de un sistema particular, pero pueden superar esta condición específica y erigirse en modelos o referentes susceptibles de reproducirse o replicarse en otros lugares o bajo otras circunstancias, de manera que se alcanzaría así otro de los rasgos fundamentales de una buena práctica, como es la transferibilidad de la experiencia en cuanto a sus aspectos fundamentales que deberían poder repetirse y replicarse en un contexto diferente al original con las consiguientes adaptaciones y modificaciones resultado de esta adaptación a otro contexto; de ahí que en las buenas prácticas, para alcanzar esta condición de transferibi-

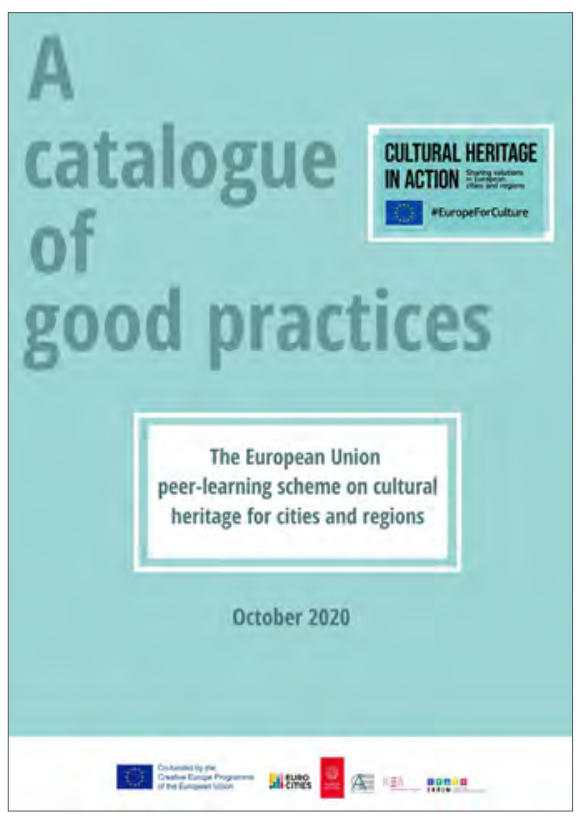

A catalogue of good practices. Programa Cultural Heritage in Action. Unión Europea 
lidad, deberá primar la universalidad y claridad de sus ideas fundamentales, tendrán que realizar una cuidadosa planificación de los procesos y métodos desarrollados y habrán de procurar una utilización eficiente de los recursos empleados.

> Transversalidad/Interdisciplinariedad: las buenas prácticas dirigidas a la consecución de los Objetivos de Desarrollo Sostenible en el campo del patrimonio cultural deberán proponer experiencias de carácter transversal e interdisciplinar que integren distintos campos de conocimiento y que interrelacionen diferentes saberes, desde los populares o tradicionales, hasta los conocimientos académicos de distintas disciplinas comprometidas con el patrimonio cultural, así como, en ocasiones, los métodos e instrumentos proporcionados por las nuevas tecnologías para lograr de este modo una visión de conjunto y una gestión lo más amplia y sistémica posible que permita llegar a una intervención holística e integrada de la complejidad de elementos estructurales en los que se ven inmersos los bienes culturales entendidos, como definíamos más arriba, como sistemas complejos.

> Implicación de la ciudadanía/procesos participativos: las buenas prácticas, como venimos diciendo, suelen ser producto de la implicación de los distintos profesionales, instituciones y personas comprometidas con el patrimonio cultural, de tal manera que han de fomentar los procesos participativos que suponen un considerable esfuerzo en la coordinación para potenciar y llevar esta colaboración de acuerdo con un modelo participativo; por eso mismo, las buenas prácticas deben potenciar la acción comunitaria, de manera que no solo se han de centrar en la implantación de criterios de calidad y eficiencia en los procesos de gestión, sino que también han de asumir como uno de sus principales cometidos la satisfacción de las necesidades de las personas y las comunidades y el incremento de su calidad de vida dentro de una visión comunitaria de las políticas patrimoniales que fomente la implicación de la ciudadanía y el trabajo en red para lograr comunidades más cohesionadas y más conscientes del valor de su patrimonio cultural.

\section{BANCOS DE BUENAS PRÁCTICAS EN PATRIMONIO CULTURAL, EL PAPEL DE LAS INSTITUCIONES}

Teniendo en cuenta el impacto que pueden llegar a alcanzar las buenas prácticas en su papel de instrumentos metodológicos y operativos eficaces y eficientes para la gestión innovadora y creativa del patrimonio cultural, cada vez son más las instituciones, administraciones públicas y operadores privados que fomentan el desarrollo de estas experiencias (véase, por ejemplo, Castillo Mena 2012, 2015, 2018). Surgen así unas bases de datos configuradas a modo de Bancos de Buenas Prácticas (BBP) que recopilan y difunden estas experiencias e iniciativas. Estos repositorios de buenas prácticas 
tienen una utilidad muy amplia y diversa. En primer lugar, permiten recopilar y sistematizar experiencias e iniciativas para su transferencia a otros contextos. Pero también pueden servir de fuentes documentales para obtener datos o como herramientas metodológicas para profundizar en la gestión y planificación. $Y$ asimismo es frecuente su uso como recursos para impulsar canales de comunicación que posibiliten el intercambio de experiencias entre técnicos, investigadores, políticos o, en general, entre los diversos agentes sociales que se ocupan del patrimonio cultural. Así se ha estudiado esta incidencia de los bancos de buenas prácticas para el estímulo de acciones comunitarias y sociales (Gradaille Pernas y Caballo Villar 2016). Todas estas experiencias resultan compiladas en una documentación diversa que puede estar constituida por materiales muy variados, como, por ejemplo, cuadernos o concursos de experiencias, observatorios vinculados a diferentes instituciones o congresos o programas de buenas prácticas desarrollados en los distintos niveles local, regional, nacional o internacional, que configuran bancos de datos generalmente de fácil acceso, pues la difusión es, como hemos visto, otro de los requisitos fundamentales de las buenas prácticas. Y también es frecuente que las instituciones que promueven buenas prácticas establezcan modelos, normas o plantillas para su presentación. Estos modelos suelen incluir datos como los siguientes: el título, el ámbito temático y geográfico de la buena práctica, el agente promotor y el contexto de desarrollo, la descripción y sus características en cuanto a sus objetivos, destinatarios y beneficiarios, la metodología seguida, los recursos humanos, económicos y de infraestructuras utilizados para su implementación, los resultados, impactos y beneficios asociados a la buena práctica, las dificultades surgidas en el proceso de desarrollo, los sistemas de evaluación y validación utilizados, los elementos necesarios para su sostenibilidad tanto a nivel institucional y social como económico y ambiental, las condiciones para su reproducibilidad y transferibilidad en su adaptación a otros contextos y la documentación y recursos para su difusión que suelen contemplar diversos formatos, como manuales de formación, directrices, códigos, guías, fichas técnicas, carteles, fotografías, documentos de vídeo y audio y sitios de internet. Se trata, en suma, de compilar experiencias que se adaptan a los criterios que hemos citado, esto es, buenas prácticas innovadoras, eficaces, sostenibles, transferibles, interdisciplinares e integradoras desde el punto de vista social y comunitario.

La Unesco ha desarrollado en colaboración con sus tres organismos consultivos (ICCROM, ICOMOS y IUCN) importantes acciones de estímulo de la gestión integrada del patrimonio cultural que se han estructurado, como es sabido, en torno a sus dos grandes documentos normativos, la Convención del Patrimonio Mundial de 1972 y la Convención para la Salvaguardia del Patrimonio Cultural Inmaterial de 2003. El desarrollo de directrices y orientaciones para la aplicación de estos documentos ha dado lugar a la publicación de unos conocidos manuales para la gestión del patrimonio natural
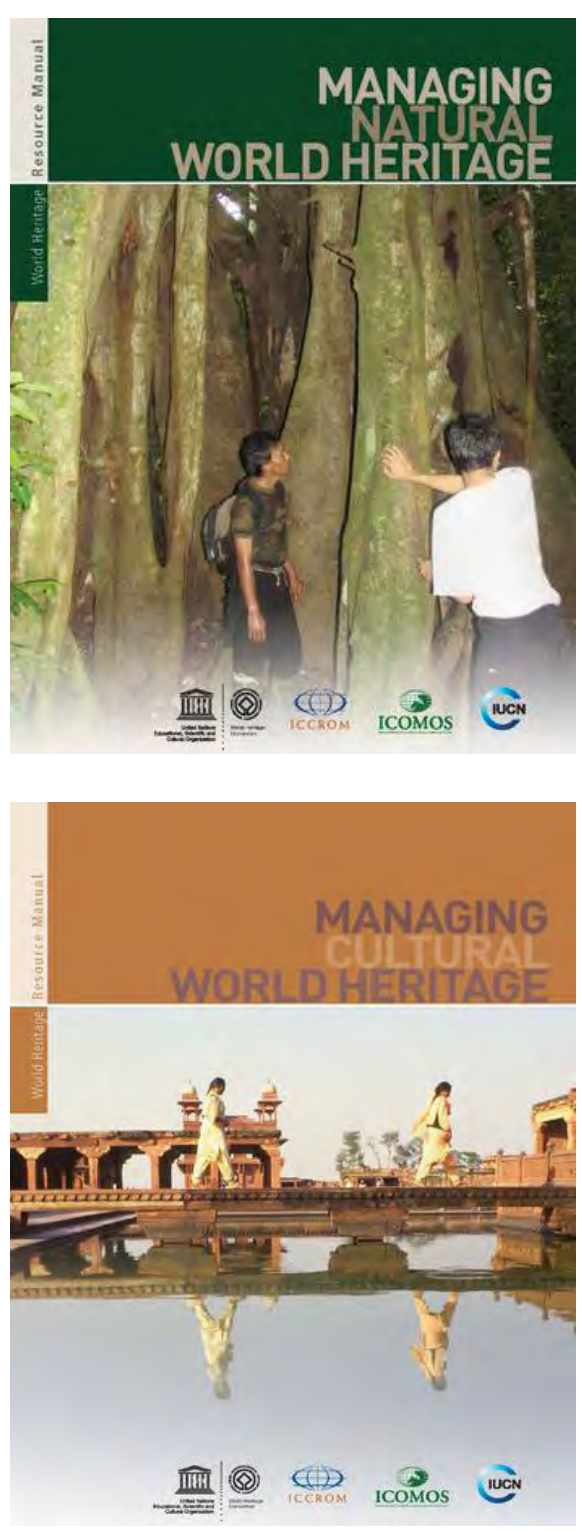

Manuales de la Unesco para la gestión de patrimonio mundial natural y cultural. 2012 y 2013 
(UNESCO 2012) y del patrimonio cultural (UNESCO 2013). Estos manuales han sido compilados, como se indica en su preámbulo, "con la finalidad de brindar directrices concretas sobre la aplicación de la Convención a los Estados partes, las autoridades encargadas de la protección del patrimonio, las autoridades locales, los administradores de sitios y las comunidades locales vinculadas a los sitios del Patrimonio Mundial, así como a otras partes interesadas en el proceso de reconocimiento y preservación de estos sitios" (UNESCO 2013, 1). En esta línea de actuación, este organismo internacional ha asumido plenamente en las últimas dos décadas la potencialidad que revisten las buenas prácticas para lograr una gestión correcta e innovadora del patrimonio cultural e implementar los métodos desarrollados en sus directrices, orientaciones y manuales de acuerdo con los principios expresados en las dos convenciones señaladas. Además de agrupar y compilar numerosos bancos de buenas prácticas, la Unesco fomenta el reconocimiento a la calidad e innovación de las prácticas o experiencias desarrolladas en su programa Recognition best practices in World Heritage management. Se trata de una iniciativa que fue demandada por el Comité del Patrimonio Mundial en 2012, en el marco del cuarenta aniversario de la Convención del Patrimonio Mundial. Respondiendo a esta petición, se abrió una solicitud mundial de presentación de propuestas de buenas prácticas que hubieran demostrado innovación y creatividad en la gestión de lugares declarados Patrimonio Mundial: se recibieron entonces veintitrés candidaturas que fueron evaluadas por un comité de diez miembros que distinguió a la gestión de la ciudad histórica de Vigan en Filipinas como best practice ya que, con medios relativamente limitados, fue capaz de lograr una correcta integración de las comunidades locales en numerosos aspectos de la conservación sostenible del lugar. En esta página web de Unesco pueden consultarse las fichas de las buenas prácticas seleccionadas que cubren un amplio espectro de casos entre los que, por ejemplo, se encuentran buenas prácticas de gestión desarrolladas en la regulación turística del valle de Jiuzhaigou a través de la Jiuzhaigou United Operation Company con gestión participativa y beneficios compartidos; los proyectos de renovación urbana llevados a cabo en las áreas urbanas históricas de Estambul; los novedosos sistemas de financiación y las presentaciones multimedia de la Iglesia de Boyana en Bulgaria; las políticas de paisaje emprendidas para la gestión de los monumentos históricos de las ciudades de Kyoto, Uji y Otsu; el programa de vigilantes del patrimonio llevados a cabo a través de voluntariado y la estrategia educativa derivada de la gestión del paisaje cultural del café en Colombia; el Plan Maestro para la Revitalización Integral de La Habana Vieja y su sistema de fortificaciones adscrito a la reputada Oficina del Historiador de La Habana; o el desarrollo de nuevas oportunidades de empleo y de implicación de la población local en la gestión de la Tierra del Incienso de Omán. España obtuvo el reconocimiento de dos candidaturas, el Parque Nacional del Teide, por sus innovaciones en la aplicación de los estándares ambientales, su programa de educación e 

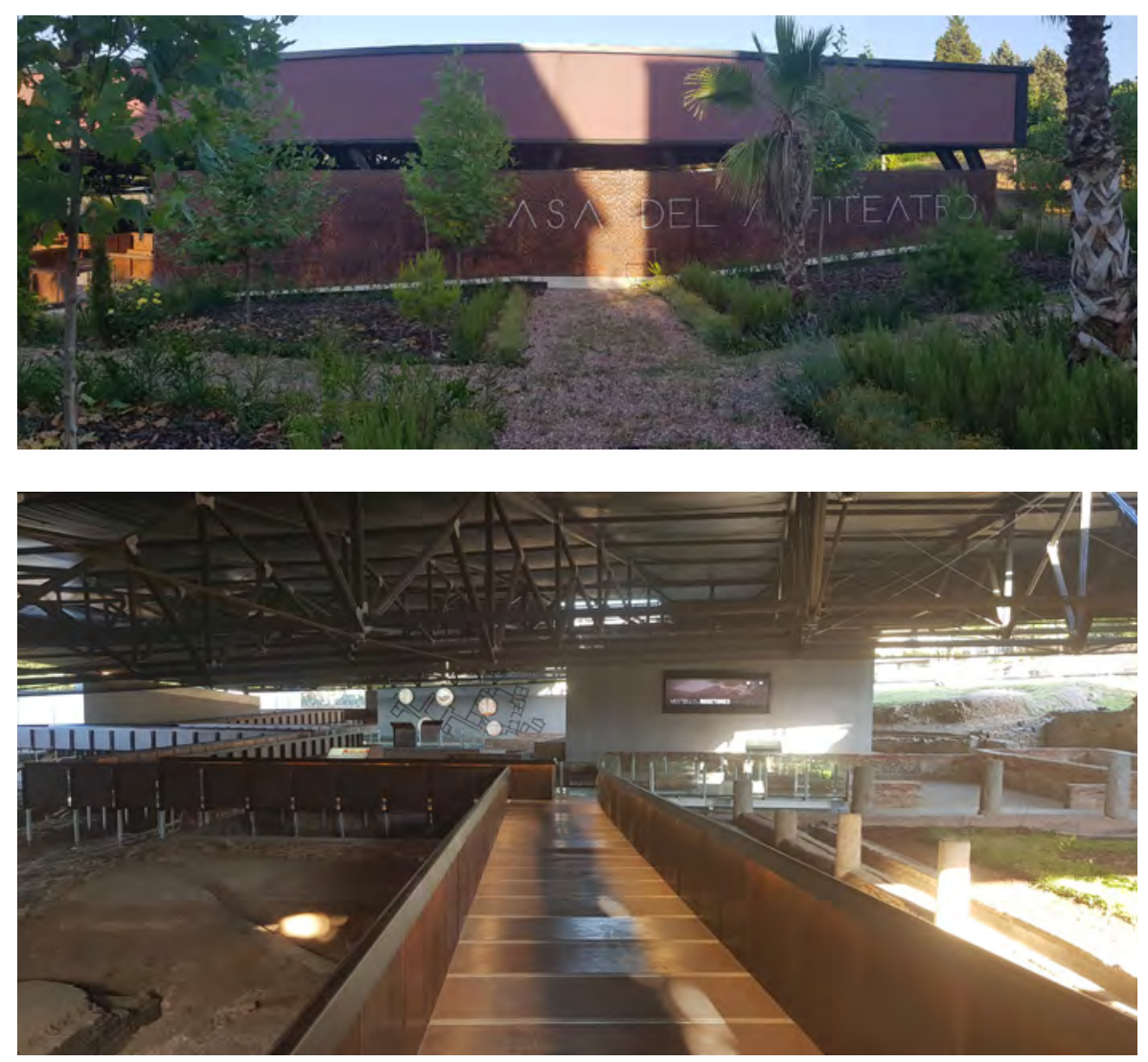

interpretación y el control del uso público implementado en este parque, y el conjunto arqueológico de Mérida, en este caso, por la actividad desarrollada por el Consorcio de la Ciudad Monumental de Mérida y su estrategia de gestión integral que incluye la investigación, la formación, el desarrollo urbano y económico sostenible, su plan especial de protección y asimismo por la creación de modelos de patrocinio privado. También tenemos que hacer mención en este punto a las medidas desarrollas para aplicar la Convención para la Salvaguardia del Patrimonio Inmaterial de 2003 que estableció desde 2009, como desarrollo del artículo 18 de la Convención, el Registro de Buenas Prácticas de Salvaguardia. En ese mismo año se seleccionó como mejor práctica el programa de educación y formación desarrollado para el batik indonesio en Pekalongan, una técnica de teñido que es utilizada para colorear tejidos, mientras que en 2011 se seleccionó el Museo vivo del Fandango propuesto por Brasil, mientras que en 2020 se han seleccionado las prácticas musicales tradicionales Aixan/kahsigo del pueblo de nama en Namibia, las técnicas del Barniz de Pasto-Mopa en Putumayo y Nariño en Colombia y la elaboración manual del sa'eed en el Alto Egipto. No cabe duda de que las buenas prácticas asumen un papel aún más trascendental, si cabe, en este campo de la salvaguardia del patrimonio inmaterial,
Casa del Anfiteatro de Mérida tras su reapertura en junio de 2020 | foto Consorcio de la Ciudad Monumental de Mérida (Félix Palma) 


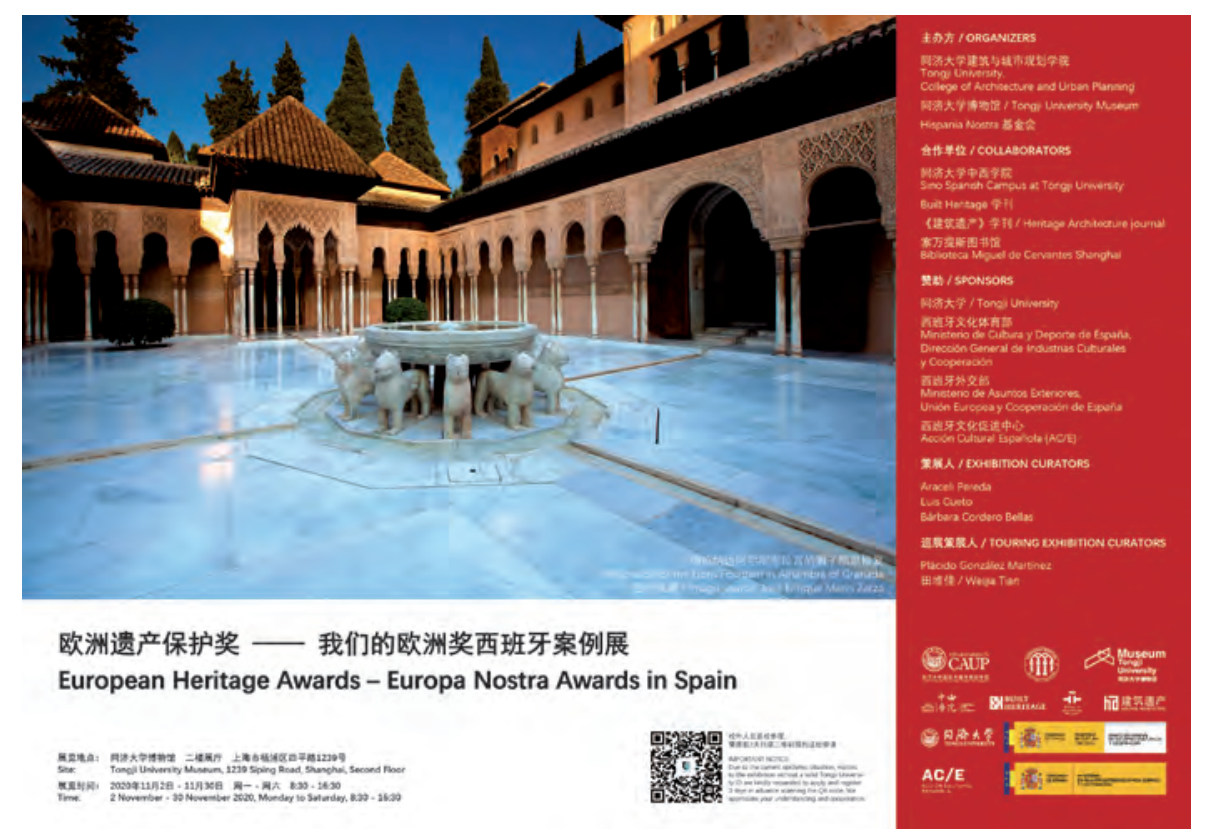

Euroepan Heritage Awards \& Europa Nostra Awards. Cartel con la publicación de los premios en España con la restauración de la fuente y patio de los leones de la Alhambra de Granada a apartir de la imagen de José Enrique Martín Zarza, KALAM

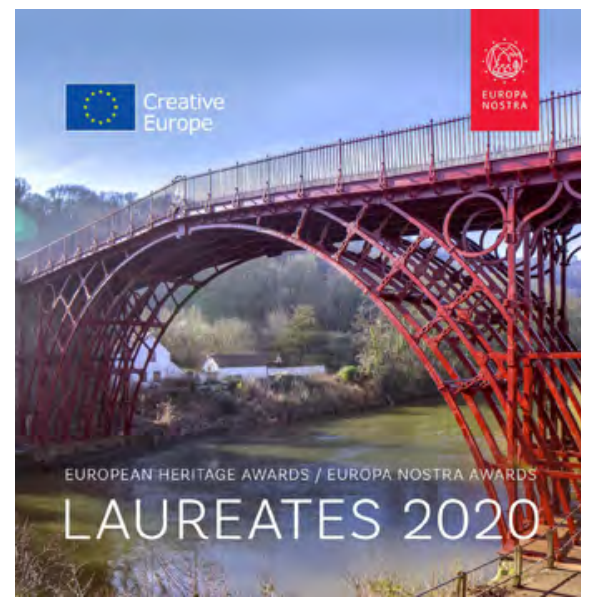

European Heritage Awards \& Europa Nostra Awards. Cartel con la proclamación de los premiados en la edición 2020 pues al tratarse de un patrimonio vivo, dinámico, cambiante y evolutivo, el desafío se centra en conseguir que este patrimonio continúe siendo representativo e identificativo para la comunidad para que así pueda seguir recreándose y transmitiéndose entre generaciones.

En el ámbito europeo, las instituciones que se ocupan del patrimonio cultural, como la Unión Europea, el Consejo de Europa o Europa Nostra, asimismo promueven y estimulan el intercambio de buenas prácticas. Europa Nostra, por ejemplo, lleva más de cuarenta años reconociendo buenas prácticas en patrimonio cultural a través de sus Premios Europa Nostra (EUROPA NOSTRA). Pero podemos detenernos con algo más de detalle en la actividad del Consejo de Europa que asimismo cuenta con una larga tradición en este campo. El Consejo de Europa ha publicado desde hace décadas documentos de gran trascendencia y difusión, como la Carta Europea del Patrimonio Arquitectónico (1975), la Declaración de Ámsterdam (1975), la Convención de Granada (1985), el Convenio Europeo del Paisaje (2000), la Convención de Faro sobre el Valor del Patrimonio Cultural para la Sociedad (2005) o la Declaración de Namur (2015). Además, ha desarrollado iniciativas muy conocidas como el Programa de Capitales Culturales Europeas (1985), el Programa de Itinerarios Culturales Europeos (1987), las Jornadas Europeas de Patrimonio (1991) o el Programa de Ciudades Interculturales (RECI) (2008). Todas estas actuaciones incorporan bancos de buenas prácticas como parte fundamental de su estructura metodológica para favorecer el intercambio de experiencias. En este sentido, el Consejo de Europa ha desarrollado herramientas como la plataforma VALOR para la divulgación 


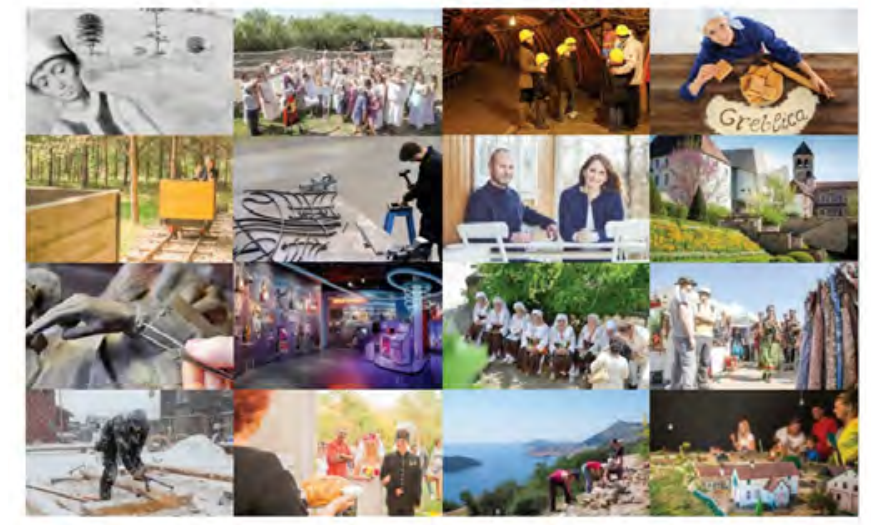

EUROPEAN HERITAGE STRATEGY FOR THE $21^{\text {IT }}$ CENTURY

\section{THE GOLDEN COLLECTION} OF GOOD PRACTICES

de los resultados de los proyectos desarrollados y en 2014 se solicitó la utilización de este recurso para incluir asimismo ejemplos de buenas prácticas susceptibles de ser extraídos de los proyectos relacionados con el patrimonio cultural que fueran realizados de acuerdo con el FEDER (COE plataforma VALOR). Pero en este ámbito de las buenas prácticas debemos destacar el papel desempeñado por el Programa Estrategia 21 que el Consejo de Europa ha puesto en marcha en abril 2017 a través de una Recomendación que redefine el papel del patrimonio cultural en Europa: con una marcada voluntad de acción, este programa proporciona directrices muy concretas para promover la gestión del patrimonio cultural europeo a través de las buenas prácticas (COE 2017). Este documento establece una serie de recomendaciones agrupadas en tres capítulos: el social, el territorial y económico, y el dedicado al conocimiento y la educación, y cada uno de ellos está ilustrado por buenas prácticas, pues el Comité de Ministros del Consejo de Europa pretende lograr la implicación de las administraciones públicas, las asociaciones y la sociedad civil en la aplicación de la Estrategia 21 a través de ejemplos concretos de acciones que se incluyen en el banco de buenas prácticas. Sería prolijo tratar de recoger un espectro completo de las instituciones y las administraciones internacionales, nacionales, regionales y locales que han recurrido y recurren a las buenas prácticas para la difusión y transferencia de sus actividades y hemos de limitarnos únicamente a señalar el potencial de estos recursos para promover y desarrollar los principios, criterios y objetivos de la conservación del patrimonio centrados en procurar una gobernanza más participativa y un enfoque integrado de la gestión. 


\section{ESTRUCTURA Y CONTENIDOS DEL NÚMERO MONOGRÁFICO}

Quisiera terminar este artículo introductorio con unas breves notas acerca de los criterios que hemos mantenido para la organización de la estructura y contenidos de este número monográfico dedicado a las buenas prácticas en conservación y revitalización del patrimonio cultural. El cometido de seleccionar una serie de temas, proyectos y experiencias que ilustraran y desarrollaran el concepto, sentido y aplicación del concepto de buenas prácticas para la gestión y valoración del patrimonio cultural podría desembocar en una inagotable compilación de casos y propuestas, tan amplio, rico y variado es este campo, como hemos podido comprobar en las páginas anteriores. Para tratar de evitar una dispersión de contenidos, hemos tratado de acotar el tratamiento en torno a siete ejes temáticos que se corresponden con los siete artículos que abren este número. Así se han propuesto para su análisis por parte de los especialistas aquí congregados algunos de los campos de actividad del patrimonio cultural que, por su novedad y complejidad, pensamos presentan mayores desafíos en cuanto a su gestión. Veremos cómo en estos ámbitos la metodología de las buenas prácticas se erige en instrumento metodológico fundamental para el desarrollo de temas y problemas que vinculan al patrimonio cultural con algunos de sus aspectos y disciplinas sectoriales y con los principios y Objetivos del Desarrollo Sostenible. A cada uno de estos siete ejes temáticos se les asocian proyectos o experiencias que, en la segunda parte de este número, tratan de explicitar y desarrollar aún más estos campos a través de ejemplos de buenas prácticas. A pesar de esta vinculación de los artículos con los proyectos y experiencias debemos precisar que, por supuesto, cada contribución puede leerse y valorarse como una aportación autónoma en sí misma. También creemos necesario mencionar que se ha buscado un desarrollo que integre ámbitos temáticos a diversas escalas y en diversos lugares, con una especial preocupación por prolongar las experiencias desde el ámbito regional andaluz y la escala nacional que incluyen reflexiones y experiencias de varias comunidades autónomas, hasta llegar al escenario latinoamericano, con la presencia de autores y temas de México, Colombia y Ecuador. Esto nos ha permitido observar distintas propuestas procedentes de diferentes latitudes, pero todas ellas enraizadas en un tronco cultural común que hace que las reflexiones y ejemplos de buenas prácticas se desplieguen en un contorno amplio, pero a la vez conexo y relacionado. A continuación, nos detenemos en trazar una breve mención de cada uno de estos siete núcleos temáticos.

1. Buenas prácticas y participación comunitaria: hemos mencionado cómo la búsqueda de modelos de gobernanza participativa que involucren a las comunidades locales es uno de los retos que afronta la gestión del patrimonio, como desarrolla con detenimiento Beatriz Santamarina Campos, autora que cuenta con amplia dedicación a estas temáticas que viene cultivando desde el departamento de Sociología y Antropología Social de la 
Universidad de Valencia y que plantea en este número una atractiva aproximación crítica acerca del papel de las comunidades en la pertenencia, dominio y apropiación de lo patrimonial. Las buenas prácticas asumen este reto de contar con la participación local y conseguir la integración de los distintos agentes, instituciones y actores vinculados con el patrimonio cultural. Los dos proyectos que ejemplifican esta cuestión así lo desarrollan, como son las buenas prácticas en gestión vecinal llevadas a cabo en la Ciudad de los Ángeles de Secundino Zuazo en Madrid, interesante en muchos aspectos, pero especialmente porque se trata del reconocimiento de valores patrimoniales por parte de la comunidad local de un conjunto de arquitectura contemporánea de carácter popular situado en un barrio de expansión, como desarrollan Francisco Javier González, Miguel Lasso de la Vega y Daniel Morcillo. Y, por otro lado, Ángel Luis Fernández, arquitecto que actuó como asesor de la Alcaldía de Medellín, nos propone un salto de escala con la interesante referencia al "urbanismo social" desarrollado en Medellín a través del Plan Especial de Manejo y Protección del Centro Tradicional que aplicó el programa "corredores de vida" y definió una serie de "áreas de identidad homogénea" a través de la intervención en dos componentes fundamentales, el espacio público y la edificación, ambos orientados por el objetivo de aumentar la calidad de vida de los ciudadanos.

2. Buenas prácticas y patrimonio inmaterial: también hemos mencionado en este texto introductorio las dificultades que plantea la salvaguardia del patrimonio inmaterial, tanto por tratarse de un patrimonio vivo, dinámico, cambiante y evolutivo, como por estar este patrimonio íntimamente ligado a sus creadores, mantenedores y transmisores, como apuntan y desarrollan con acertados argumentos María Pía Timón, del Instituto de Patrimonio Cultural de España, y Antonio Muñoz Carrión, profesor de la Universidad Complutense de Madrid, en su artículo que nos habla de este patrimonio desde la perspectiva sociológica y antropológica. Esta situación se refleja asimismo en la primera de las experiencias que aquí se comentan, como es la focalizada en los inventarios del patrimonio inmaterial del Montseny y su registro como buena práctica, proyecto pionero iniciado en 2009 , inscrito en 2013 el Registro de Buenas Prácticas de la Convención para la Salvaguardia del Patrimonio Inmaterial de la Unesco y continuado desde 2017 a través del Proyecto de Dinamización del Inventario del Patrimonio Cultural Inmaterial del Parque Natural del Montseny y Reserva de la Biosfera, con la explicitación de buenas prácticas que se han transferido a otros contextos, tal como detalla con precisión Lluís García Petit, director del Instituto del Patrimonio Cultural Inmaterial. En la otra experiencia que agrupamos en este apartado, el patrimonio inmaterial asume un grado altamente sensible, pues se vincula a la memoria de las víctimas del conflicto armado en Colombia, un contexto en el que el patrimonio inmaterial está sustentado en la recopilación de testimonios, aserciones y reflexiones rememorativas orientadas hacia la búsqueda de verdad, justicia y reparación, esto es, el patrimonio inmaterial 
como puente para la construcción de la paz, como expone José Antequera Guzmán, coordinador del Centro de Memoria, Paz y Reconciliación de Bogotá.

3. Buenas prácticas y turismo cultural: el turismo ha sido tantas veces ensalzado como motor de oportunidades y desarrollo para el patrimonio cultural como denostado por los efectos que su desarrollo incontrolado puede provocar sobre los lugares afectados por su presencia, de modo que se hace imprescindible contar con buenas prácticas para su gestión, como expone María José Viñals, geógrafa y profesora de la Universidad Politécnica de Valencia, que ha indagado con profundidad en el equilibrio que el turismo tiene que mantener con el patrimonio y la sostenibilidad para buscar la compatibilidad de los objetivos de la política turística con los de la política cultural. Este equilibrio se ha demostrado se ha alcanzado de modo especialmente meditado a través de las buenas prácticas comunitarias y en gestión del turismo que han sido llevadas a cabo en el Museu Faller de Valencia, según relata Gil-Manuel Hernàndez i Martí, director de esta institución surgida en 1971, un museo cuyos fondos principales, los ninots indultados, se crean precisamente por votación popular y que ha desarrollado un cuidadoso programa para las visitas turísticas, pero también para otros colectivos que se ocupan del tema de la fiesta como componente fundamental del patrimonio inmaterial.

4. Buenas prácticas en paisajes e infraestructuras de comunicación: el considerable salto que el patrimonio ha protagonizado al asumir plenamente la escala territorial, con el desarrollo de las figuras patrimoniales del paisaje cultural, de los itinerarios y rutas culturales y de las infraestructuras de transporte y comunicación que se despliegan en el territorio, es analizado por los profesores Francisco Javier Rodríguez y Rita Ruiz, de la Universidad de Castilla-La Mancha, en colaboración con José Luis Lalana, del Instituto de Urbanística de Valladolid, cuyas líneas de investigación se vienen centrando en el patrimonio a escala territorial y, especialmente, el relativo a las obras públicas. Es este último campo, el de las rutas de comunicación desplegadas en el territorio, en el que se enmarcan las dos experiencias propuestas que exponen las buenas prácticas desarrolladas en torno a dos importantes infraestructuras territoriales ubicadas en el continente americano. Por un lado, Kaisa Barthuli y Michael Romero Taylor, del National Park Service de Estados Unidos de Norteamérica, nos exponen los programas y actuaciones pioneras emprendidas para la rehabilitación y puesta en valor de la mítica US Route 66, fijada desde 1926 con un recorrido de 2448 millas que discurren entre Chicago y Los Ángeles, y cuya valoración se ha desarrollado a través de numerosas acciones, como el fomento y aprecio de los valores paisajísticos y escénicos vinculados a esta infraestructura de transporte y, asimismo, a través del desarrollo de las oportunidades que resultan para las comunidades que se emplazan a lo largo de este itinera- 
rio. Por otro lado, Gerardo A. Hernández Septién, profesor de la Universidad Iberoamericana de Ciudad de México y que ha asumido responsabilidades en la Dirección General de Sitios y Monumentos del Patrimonio Cultural, nos pone en contacto con la Calzada México-Tacuba, otro importante corredor histórico de gran interés patrimonial, en cuanto esta calzada es considerada la vía más antigua del continente americano, que, con casi diez kilómetros de longitud plenamente insertos en el área metropolitana de México, presenta considerables desafíos para su rescate y puesta en valor como se nos expone en la presentación de un proyecto que se encuentra en sus primeras fases de desarrollo y que promete ofrecer ricas e interesantes derivaciones.

5. Buenas prácticas en reutilización del patrimonio construido: la reutilización del patrimonio, su uso contemporáneo, son cuestiones que se convierten en un imperativo ético en nuestros días por la imperiosa necesidad de procurar un aprovechamiento más eficiente de los recursos físicos y energéticos presentes en la ciudad y el territorio a través del desarrollo de la cultura de la reutilización y reciclaje del patrimonio construido abandonado o inutilizado, una temática a la que se viene dedicando desde hace tiempo el profesor Javier Soria López en la Universidad Autónoma Metropolitana de México y que, como apunta, concibe la reutilización como una acción de diseño sostenible y de fuerte compromiso social. De este mismo entorno académico surge también la primera experiencia de buenas prácticas que se presenta en este apartado y que consiste en el interesante documento cuya génesis y desarrollo expone el profesor Francisco Haroldo Alfaro, redactado como Carta de Reutilización del Patrimonio Edificado o Principios para la Reutilización que fue publicada en el contexto de un foro académico organizado en 2018 y que, en sus doce puntos, se erige como un verdadero decálogo de buenas prácticas para la recuperación y reutilización del patrimonio construido. Desde estos enunciados, y compartiendo estos principios, se expone el proyecto de investigación para la continuidad de uso y/o reutilización de un sistema patrimonial complejo, como es el constituido por los conventos de la ciudad de Toledo que estudia el grupo de investigación CLAUSTRAT en el intento de definir pautas de buenas prácticas tanto para su reconocimiento e investigación, como para su tratamiento y gestión.

6. Buenas prácticas en rehabilitación energética y tecnología aplicada al patrimonio cultural: la construcción tradicional asume una doble consideración como vehículo de conocimiento e instrumento de transformación sostenible tal como expone con brillantez el artículo planteado por Alberto Cuchí Burgos, profesor de la Escuela de Arquitectura del Vallès, y que asume el proyecto de rehabilitación energética de edificios patrimoniales no solo como una intervención orientada al realce de las cualidades patrimoniales, sino como una crítica certera sobre los objetivos y la legitimidad de los enfoques que presenta esa misma rehabilitación energética. Las experiencias desa- 
rrolladas durante varias décadas con el Programa Puente de Rehabilitación del Consorcio de Santiago de Compostela han demostrado igualmente la necesidad de buenas prácticas de contención que posibiliten una mayor eficiencia y un menor gasto energético en la gestión de la ciudad histórica, en esa simbiosis entre energía y medioambiente para la habitabilidad en los conjuntos históricos, tal como expone Ángel Panero Pardo, arquitecto director de la Oficina Técnica-Taller de Proyectos del Consorcio de Santiago de Compostela. La tecnología proporciona herramientas fundamentales para el análisis y tratamiento del patrimonio cultural, de tal manera que es necesario difundir su uso a través de ejemplos de buenas prácticas, como las desarrolladas por el departamento de Sistemas Físicos, Químicos y Naturales de la Universidad Pablo de Olavide de Sevilla que ha desarrollado un novedoso sistema de análisis multi-riesgo aplicado a la muralla almohade del Alcázar y la ciudad de Sevilla con la aplicación de sistemas de información geográfica, de inteligencia artificial y de modelos de consulta a expertos tipo DELPHI cuya implementación puede ser transferible a otras ciudades y otros posibles tipos de patrimonio: una muestra, por tanto, de cómo los avances tecnológicos pueden contribuir de modo decisivo a la preservación y mantenimiento de nuestro patrimonio cultural.

7. Buenas prácticas en patrimonio agrícola: los sistemas de patrimonio agrario y cultural han sido reconocidos y apoyados por la actividad desarrollada por la FAO, con el apoyo del Fondo para el Medio Ambiente Mundial, el Fondo Internacional para el Desarrollo Agrario a través de la gestión de los llamados Sistemas Ingeniosos del Patrimonio Agrícola Mundial (SIPAM); esos sistema, entre otros objetivos, buscan establecer bancos de buenas prácticas para favorecer la conservación dinámica y la biodiversidad cultural y agrícola de los ecosistemas en una red que comprende un conjunto de sistemas agrícolas tradicionales extendido por todo el mundo, cuya gestión adecuada puede contribuir a la producción de alimentos y al mantenimiento y mejora de las actividades rurales, una temática en la que se ha comprometido desde hace décadas el profesor Miguel Altieri, de la Universidad de Berkeley. Los dos proyectos que congregamos para cerrar este número monográfico complementan esta visión desde dos experiencias diferentes. Por un lado, Beatriz Pérez Galán, profesora de antropología social y cultural de la Universidad Nacional de Educación a Distancia (UNED) nos explica la actividad desarrollada por las comunidades agrarias del sur andino peruano a través del proyecto Agroescosistemas de alta montaña, de Machupicchu al lago Titicaca, un proyecto integrado en el programa SIPAM, una experiencia que comienza con la evocación de la metáfora del surco de la siembra, el wachu, un surco más profundo y con lomos altos, y que es toda una invitación para su lectura. Y por otra parte, Juan José Soriano Niebla, del Instituto de Investigación y Formación Agraria y Pesquera de la Junta de Andalucía, se centra en las buenas prácticas que viene desarrollando la Red Andaluza de Semillas (RAS), una organización que, como apunta Soriano Niebla, se 
ha centrado en "la recuperación de variedades locales y el saber campesino tradicional" y el fomento de "los sistemas alimentarios campesinos y agroecológicos, como fuente de alimentos asequibles y saludables y como medio de vida digno para quienes los cultivan", una interesante visión que ha concedido el protagonismo a los agricultores locales y a los hortelanos tradicionales de Andalucía, con un enfoque que asume la producción de alimentos desde la promoción de la sostenibilidad ambiental y la equidad social e intergeneracional.

Estos son, de modo sumario, los temas de este número y que, como hemos visto, han tratado de agrupar y desarrollar estudios, proyectos y experiencias en torno a la cuestión central de las buenas prácticas y el patrimonio cultural. No quisiera finalizar sin antes agradecer a los autores que hemos mencionado su generosa acogida y participación con sus valiosas aportaciones, reflexiones y contribuciones que son las que realmente han construido y desarrollado los contenidos fundamentales de este número; con muchos de ellos ya habíamos podido intercambiar ideas, pláticas y vivencias, en España y América, y con otros tenemos la confianza de iniciar a través de esta colaboración inéditas sendas guiados por el común interés hacia el conocimiento y valoración del patrimonio cultural. Del mismo modo, también tenemos que agradecer la presencia de Alejandro García Hermida, que ha puesto todo su empeño y buen hacer en la coordinación del debate acerca de la temática patrimonio cultural y cambio climático. En estas líneas finales debo asimismo destacar de modo muy especial el inestimable apoyo a la coordinación de este número brindado por Marta García de Casasola Gómez, hasta julio de 2021 jefa del Centro de Intervención del Instituto Andaluz del Patrimonio Histórico, con quien que hemos compartido gratos momentos, fructíferos debates y numerosas conversaciones que han sido decisivas para perfilar y desarrollar conjuntamente la estructura y contenidos de este número. Y, por último, agradecer la confianza depositada por el Instituto Andaluz de Patrimonio Histórico al proponerme la coordinación de este número que ha sido posible a partir de la profesionalidad, soporte y seguimiento demostrados en todo momento por el equipo de redacción de la revista $P H$. 


\section{BIBLIOGRAFÍA}

- Ausín Díez, T. (2018) Buenas Prácticas (Códigos de). Eunomía. Revista en Cultura de la Legalidad, n. ${ }^{\circ}$ 15, pp. 239-248

- Boccardi, G. (2007) World Heritage and Sustainability. Concern for social, economic and environmental aspects within the policies and processes of the World Heritage Convention. Londres: MSc. Dissertation, University College of London

- Cabré Castellví, M.T. (2010) Terminología y buenas prácticas. Publifarum, n. ${ }^{\circ} 12$, Atti Convengo Assiterm 2009. Disponible en: http://www.farum.it/publifarum/ezine_ articles.php?art_id=161 [Consulta: 09/06/2021]

- Castillo, A. (ed.) (2012) / Congreso Internacional de Buenas Prácticas en Patrimonio Mundial. Mahón, Menorca, 9 a 13 de abril de 2012. Madrid: Universidad Complutense de Madrid, Servicio de Publicaciones. Disponible en: http://www.congresopatrimoniomundialmenorca.cime.es/ WebEditor/Pagines/file/Libro_Ponencias.pdf [Consulta: 09/06/2021]

- Castillo Mena, A. (coord.) (2015) Actas del Segundo Congreso Internacional de Buenas Prácticas en Patrimonio Mundial: Personas y comunidades (Mahón, Menorca, 29 -30 de abril, 1 y 2 de mayo de 2015). Madrid: Universidad Complutense de Madrid, Servicio de Publicaciones. Disponible en. https://eprints.ucm.es/id/eprint/35074/ [Consulta: 09/06/2021]

- Castillo Mena, A. (ed.) (2018) III Congreso Internacional de Buenas Prácticas en Patrimonio Mundial. Acciones integrales. Mahón, Menorca, 2 a 5 de mayo de 2018. Madrid: Universidad Complutense de Madrid, Servicio de Publicaciones. Disponible en: https://eprints.ucm.es/id/ eprint/55524/2/BPPM18-final.pdf [Consulta: 09/06/2021]

- COE [Council of Europe] (2017) Recommendation of the Committee of Ministers of member States on the European Cultural Heritage Strategy for the 21st century. Estrasburgo, Council of Europe, 22 de febrero de 2017. Disponible en: https://rm.coe.int/16806f6a03 [Consulta: 09/06/2021]

- COE [Council of Europe] (2021) Strategy 21-Good practices. Disponible en: https://www.coe.int/en/web/ culture-and-heritage/strategy-21-good-practices [Consulta: 09/06/2021]

- COE [Council of Europe] (2021) Europe for Citizens Programme. Disponible en: http://ec.europa.eu/ programmes/europe-for-citizens/projects/ [Consulta: 09/06/2021]

- Europa Nostra (2021) The Europa Nostra Awards. Disponible en: https://www.europanostra.org/our-work/ awards/ [Consulta: 09/06/2021]

- FAO [Food and Agriculture Organization of the United
Nations] (2014) Plantilla de buenas prácticas. Disponible en: http://www.fao.org/3/ap784s/ap784s.pdf [Consulta: 09/06/2021]

- González Ramírez, T. (2007) El concepto de "buenas prácticas": origen y desarrollo. Comunicación y Pedagogía: nuevas tecnologías y recursos didácticos, n. ${ }^{\circ} 222$, pp. 32 35

- González-Varas Ibáñez, I. (2015) Patrimonio cultural. Conceptos, debates y problemas. Madrid: Cátedra

- González-Varas Ibáñez, I. (2018) Conservación del Patrimonio Cultural. Teoría, historia, principios y normas. Madrid: Cátedra

- González-Varas Ibáñez, I. (2021) La cultura de la memoria y la expansión del patrimonio cultural. Algunas encrucijadas actuales. Diálogos en Patrimonio Cultural, n. ${ }^{\circ}$ 3

- Gradaille Pernas, R. y Caballo Villar, M.B. (2016) Las buenas prácticas como recurso para la acción comunitaria: criterios de identificación y búsqueda. Contextos educativos, n. ${ }^{0} 19$, pp. $75-88$

- Hernández Aja, A. (2001) Informe sobre las Buenas Prácticas Españolas y su relación con la aplicación del Programa Hábitat en España. En: III Catálogo de Buenas Prácticas Españolas. Valencia: Instituto Juan de Herrera

- Jerí Rodríguez, J. (2008) Buenas prácticas en el ámbito educativo y su orientación a la gestión del conocimiento. Educación, vol. XVII, n. ${ }^{\circ} 32,2008$, pp. 29-48

- Larsen, P.B. y Logan, W. (ed.) (2018) World Heritage and Sustainable Development. New Directions in World Heritage Management. Londres: Routledge

- Ministerio de Obras Públicas, Transporte y Medio Ambiente (1996) La construcción de la ciudad sostenible. Primer catálogo español de buenas prácticas. Madrid: Ministerio de Obras Públicas, Transportes y Medio Ambiente

- Stovel, H. (ed.) (2004) Monitoring World Heritage. Cuadernos del Patrimonio Mundial, n. ${ }^{\circ} 10$

- UNESCO [United Nations Educational, Scientific and Cultural Organization] (2012) Managing Natural World Heritage. París: UNESCO World Heritage Centre. Disponible en: https://whc.unesco.org/en/managingnatural-world-heritage/ [Consulta: 09/06/2021]

- UNESCO [United Nations Educational, Scientific and Cultural Organization] (2013) Managing Cultural World Heritage. París: UNESCO, World Heritage Centre. Disponible en: https://whc.unesco.org/en/managingcultural-world-heritage/ [Consulta: 09/06/2021]

- UNESCO. World Heritage Committee (2010) World 
Heritage Convention and sustainable development. WHC10/34.COM/5D. Disponible en: http://whc.unesco.org/ document/104536 [Consulta: 10/06/2021]

- UNESCO. World Heritage Committee (2011) Operational Guidelines for the Implementation of the World Heritage Convention. Directrices prácticas para la aplicación de la Convención del Patrimonio Mundial. París: World Heritage Centre

- UNESCO [United Nations Educational, Scientific and Cultural Organization] (2013) World Heritage and Best Practices. World Heritage, n. ${ }^{\circ} 67$

- UNESCO [United Nations Educational, Scientific and Cultural Organization] (2021) La reconnaissance de la meilleure pratique en gestion du patrimoine mondial. Disponible en: https://whc.unesco.org/fr/recognition-ofbest-practices/ [Consulta: 09/06/2021] 


\title{
Patrimonio colectivo. Comunidades, participación y sostenibilidad
}

\author{
Beatriz Santamarina Campos | Dpto. de Sociología y Antropología Social, \\ Universitat de València \\ URL de la contribución <www.iaph.es/revistaph/index.php/revistaph/article/view/5000>
}

\section{RESUMEN}

El patrimonio cultural se nos presenta como un campo de intervención y gobierno en constante mutación. Lejos de ser sustantivo, sea este calificado como material, natural e inmaterial, es una realidad sociohistórica mediada por las condiciones sociales de producción. Desde una perspectiva crítica, en este artículo, hacemos una aproximación al patrimonio colectivo poniendo atención a las transformaciones experimentadas en las últimas décadas. La entrada de la democratización patrimonial y el giro participativo a raíz de la Convención para la Salvaguardia del Patrimonio Cultural Inmaterial (París, 2003) parece no haber tenido el calado esperado. El papel activo otorgado a las llamadas "comunidades portadoras" en las activaciones y gestión patrimonial se ha reducido a lo retórico, produciéndose una contradicción entre las proclamas y las prácticas lanzados por los discursos patrimoniales autorizados. Y esto no es extraño, en juego está la posesión, propiedad y titularidad, de los bienes. De ahí, que los conflictos por la disputa de lo patrimonial sean cada vez más numerosos, imponiéndose regímenes patrimoniales que responden a las lógicas imperantes del mercado. Hoy, más que nunca, la degradación ecosistémica nos obliga a replantear el patrimonio colectivo como una herramienta para lograr la sostenibilidad, siguiendo los Objetivos de Desarrollo Sostenible formulados globalmente para la Agenda 2030. Desde nuestra perspectiva, el reto para alcanzar un patrimonio colectivo democrático, colaborativo y sostenible pasa por un cambio radical en los regímenes patrimoniales actuales.

\section{Palabras clave}

Comunidad | Dominación | Empoderamiento | Gobernanza | Objetivos de desarrollo sostenible | Participación ciudadana | Patrimonio colectivo | Poder | Sostenibilidad | 


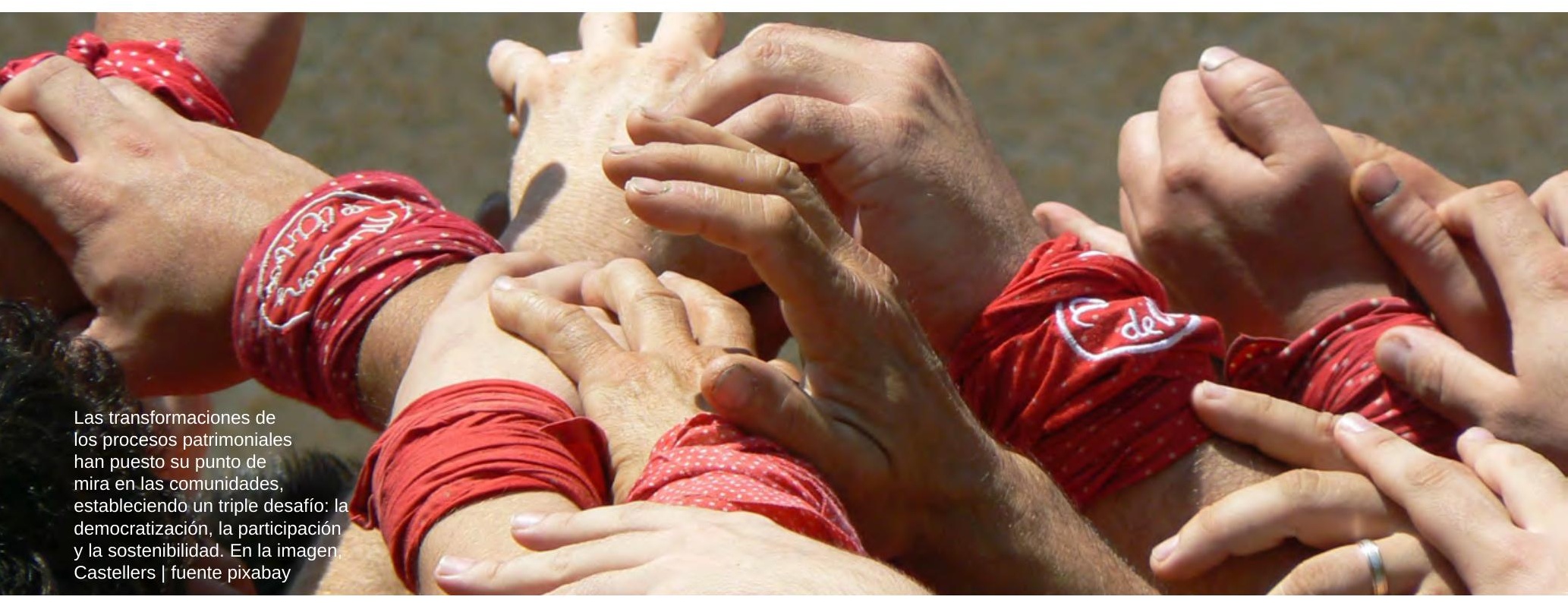

\section{Collective heritage. Communities, participation and sustainability}

\section{ABSTRACT}

Cultural heritage is presented to us as a field of intervention and governance in constant mutation. Far from being substantive, whether qualified as tangible, natural, or intangible, it is a socio-historical reality mediated by the social conditions of production. From a critical perspective, in this article, we approach collective heritage by focusing on the transformations experienced in recent decades. The entry of heritage democratization and the participatory turn following the Convention for the Safeguarding of the Intangible Cultural Heritage (2003) seem not to have had the expected impact. The active role given to the so-called 'bearer communities' in heritage activations and management has been reduced to rhetoric, producing a contradiction between the proclamations and practices launched by the authorized heritage discourses. This is not strange; at stake is the possession and ownership of goods. Consequently, conflicts concerning the dispute over property are becoming more and more numerous, with imposing patrimonial regimes that respond to the logic of the prevailing market. Today, more than ever, socio-ecosystemic degradation forces us to rethink collective heritage as a tool to achieve sustainability, following the Sustainable Development Goals formulated globally for the 2030 Agenda. From our perspective, the challenge of achieving a democratic, collaborative, and sustainable collective heritage involves a radical change in current heritage regimes.

\section{Keywords}

Community | Domination | Empowerment | Governance | Sustainable Development Goals | Citizen Participation | Collective Heritage | Power | Sustainability |

Cómo citar: Santamarina Campos, B. (2021) Patrimonio colectivo. Comunidades, participación y sostenibilidad. Revista PH, n. ${ }^{\circ}$ 104, pp. 58-77. Disponible en: <www.iaph.es/revistaph/index.php/revistaph/article/view/5000> DOI 10.33349/2021.104.5000

Enviado: 27/07/2021 | Aceptado: 28/07/2021 | Publicado: 01/10/2021 


\section{INTRODUCCIÓN: EL PATRIMONIO COLECTIVO}

1

Siguiendo a Geismar (2015), el concepto de régimen patrimonial es útil porque permite aproximarse al patrimonio colectivo desde la política y la gobernanza.
El patrimonio cultural es un concepto confuso y, a su vez, brillante. Si bien parece fácil la identificación semántica del término patrimonio, su calificativo cultural conlleva parejas enormes dificultades. En realidad, toda fragmentación del patrimonio es cultural, porque cualquier disección que se practique siempre obedece a una determinada praxis cultural. Sin embargo, la separación del patrimonio cultural en material, natural e inmaterial, como objetos y sujetos de fiscalización, tiene una larga tradición en el mundo occidental. Desde el siglo XIX se consolidó esta triple desmembración del patrimonio colectivo apareciendo el llamado patrimonio cultural (material), encapsulado en los monumentos; el patrimonio natural, circunscrito a los parques naturales; y el (incómodo) folklore, bien representado en los parques costumbristas escandinavos. El patrimonio decimonónico sentó las bases de una separación forzada y casi imposible, amparada en el conocimiento científico y muy eficaz en términos políticos. Quizás, lo más destacable del proceso es que asimiló y presentó el patrimonio colectivo en términos de patrimonio cultural, reservando esta denominación para la definición humanista de cultura (Pavone 2008; Santamarina Campos y Mármol 2019). Los usos del pasado se tornaron en herramientas, de una enorme eficacia simbólica, para el Estado nación (Anderson 1983). El nacionalismo bebió del romanticismo, se aprovechó de la compartimentación científica y supo sacar partido a los distintos patrimonios para legitimar sus proyectos políticos: el genio creativo, la naturaleza patria o el espíritu del pueblo fueron fuentes inagotables para consolidar el esqueleto de proyectos identitarios a través de símbolos elevados a marcadores nacionales (Daniels 1993; Choay 1996; Prats 1997; González-Varas 1999; Poulot 2006; Casado de Otaola 2010). De hecho, fueron utilizados, según conveniencia, para asentar las bases de los primeros regímenes patrimoniales ${ }^{1}$, articulados a través de un pasado y tradición naturalizados (Lowenthal 1998; Hobsbawm y Ranger 2005).

No vamos a entrar en ello. Pero sí, de una forma breve y sintética, hemos querido arrancar mirando a la primera configuración de lo que llamaremos, a partir de ahora, patrimonio colectivo; porque en ella encontramos las claves para poder acercarnos a comprender el papel o el peso otorgado a las comunidades, así como las implicaciones del patrimonio en el alcance de los objetivos de desarrollo sostenible (ONU 2015). Desde nuestro punto de vista, el enredo conceptual forma parte del éxito de su formulación. Nadie podrá negar que la expresión "patrimonio cultural" es un enunciado tan enrevesado, vago y permeable, como sobreentendido. Los potentes imaginarios de poder, encapsulados en lo patrimonial, permiten definir su realidad escudados en criterios de verdad de carácter axiomático (Foucault 1980) y ratificados en la autenticidad (Frigolé 2014; Mármol y Estrada 2018). El patrimonio colectivo, como realidad dada, se desliga de sus condiciones sociales de producción (Mármol 2017). Su plasticidad espacio-temporal y 
su capacidad de adaptación muestran cómo, en realidad, el mismo carecería de todo sentido sin agencias y agentes patrimonializadores (Hernández i Martí et ál. 2005; Montenegro Riveros 2010). Pese a los cambios experimentados (Ariño Villarroya 2002; González-Varas 2015), el trasfondo no ha cambiado en substancia (Santamarina Campos 2013). La llamada "democratización patrimonial" y la manida participación pueden tener efectos perversos (Noyes 2011) o ser simplemente "patrimonio participativo 2.0 a coste cero" (Quintero Morón y Sánchez-Carretero 2017, 61).

Ahora bien, las mutaciones sufridas responden a exigencias del contexto socioeconómico y a las demandas de colectivos marginados de los regímenes patrimoniales (no marginales). Con respecto a lo primero, el patrimonio colectivo es una realidad sociohistórica, mediada por las relaciones y medios sociales de producción, donde se seleccionan ciertos acervos culturales, elevándolos a la categoría de patrimonio colectivo. Por tanto, lejos de las visiones sustantivistas del patrimonio (Davallon 2014), lo consideramos un proceso en constante transformación y una forma más de gobierno (Bendix, Eggert y Peselmann 2013; Cesari 2013; Coombe y Weiss 2015; Alonso González 2017). Y en relación a lo segundo, las peticiones de comunidades o colectivos han venido sucediéndose, sobre todo, desde el último tercio del siglo pasado ${ }^{2}$, quedándose la mayoría de ellas en respuestas circunscritas al ámbito de lo políticamente correcto (Gómez Ferri 2004; Albert Rodrigo 2005; Quintero Morón y Sánchez-Carretero 2021). Por poner un ejemplo, en la esfera internacional, donde dicta los preceptos globalizados la Organización de las Naciones Unidas para la Educación, la Ciencia y la Cultura (Unesco), el calado esperado, sobre todo tras la Convención para la Salvaguardia del Patrimonio Cultural Inmaterial (París, 2003), ha quedado, aparentemente, en papel mojado ${ }^{3}$.

Sin duda, lo apuntado complica sobre manera una aproximación rápida al patrimonio colectivo, aunque ayuda a situarlo como un campo ideológico y político (Kuutma 2013; Tauschek 2013; Geismar 2015). Las versiones autorizadas del patrimonio colectivo o el llamado discurso patrimonial autorizado (AHD) ${ }^{4}$ no solo responden a las cosmovisiones occidentales, sino que también contribuyen a legitimar y consolidar las hegemonías (Smith 2006; Labadi 2007; Winter 2014) ${ }^{5}$. Las activaciones patrimoniales suponen un proceso de discriminación y control de valores a través de la jerarquización de distintos géneros culturales. Y la asignación de sentidos siempre responde a regímenes políticos (patrimoniales) (Bendix, Eggert y Peselmann 2013; Geismar 2015). En el patrimonio está en juego el capital simbólico, en términos bourdianos, tras la distinción, la diferencia y la exclusividad está la disputa real de la producción, distribución y circulación de bienes (materiales, inmateriales y naturales). Más allá de cuestionar el qué, para qué, a quién o para quién, bajo tecnologías de representaciones, el patrimonio colectivo faculta para observar la pugna y apropiación del capital social, cul-
2

En realidad, desde 1960, ya podemos empezar a rastrear la petición de la democratización de distintos ámbitos o la presión para que se reconozcan los derechos de autor y el conocimiento local (vinculado a la biodiversidad) y las políticas culturales (Kurin 2004).

3

Volveremos al papel hegemónico ocupado por la Unesco y la Convención del 2003 más adelante.

4

Utilizamos sus siglas en inglés (Authorized Heritage Discourse). Acuñado por Smith, el AHD "is the dominant Western discourse about heritage that works to naturalize a range of assumptions about the nature and meaning of heritage" (Smith 2006, 4).

5

De ahí que hayamos empezado diciendo que el concepto "patrimonio cultural" es brillante, porque la categoría goza de gran aceptación social a la vez que esconde su naturaleza política. 
tural y económico (Bourdieu 1991, 1997, 1998; García Canclini 1999), como un campo conflictivo (Tunbridge y Ashworth 1996; Sánchez-Carretero 2017; Santamarina y Mármol 2020). La perspectiva crítica del patrimonio permite atender a los procesos desigualitarios en su producción, a los desplazamientos generados por la sustracción o silenciamiento de comunidades y grupos, a las resistencias forjadas por las distintas racionalidades impuestas y a las relaciones de dominación establecidas a partir de las lógicas de clasificación y dependencia (Bendix 2009; Heinich 2010; Bortolotto 2011; Mármol, Morell y Chalcraft 2015; González-Varas 2015; Mármol, Siniscalchi y Estrada 2016; Sánchez-Carretero 2017; Santamarina y Mompó 2021).

En este artículo, prestaremos especial atención, en primer lugar, a cómo las transformaciones de los procesos patrimoniales han puesto su punto de mira en las comunidades, estableciendo un triple desafío: la democratización, la participación y la sostenibilidad. En segundo lugar, atenderemos al patrimonio colectivo como un instrumento potencial para alcanzar los objetivos del desarrollo sostenible, a través de una apuesta política y real transformadora. $\mathrm{Y}$, por último, cerraremos con unas breves conclusiones, donde el reto para alcanzar un patrimonio colectivo democrático, colaborativo y sostenible pasa por un cambio radical en los regímenes patrimoniales actuales.

\section{DE LA COMUNIDAD IMAGINADA A LA COMUNIDAD PORTADORA, DEL TENER AL SER PATRIMONIAL}

6

Todavía minoritario (Quintero-Morón 2020; Bingham et ál. 2021)

7

Su papel ideológico es indiscutible en la conservación, salvaguardia y gestión patrimonial. Este ha ido creciendo a través de sus convenciones y recomendaciones, generando una creciente burocratización. Sus criterios y preceptos, secundados por la mayoría de países, son visibles en las políticas nacionales y locales, como veremos en el apartado siguiente (Ashworth y Van der Aa 2006; Askew 2010; Nielsen 2011; Villaseñor y Zolla 2012).
Hoy, la maquinaria patrimonial ha traído consigo nuevas propuestas de gestión y de gobernanza, en principio, con el objetivo de democratizar el ámbito patrimonial. Pero, lejos de alcanzar el propósito, se reproducen las fórmulas de normalización e institucionalización patrimonial, entrando en un mentís los discursos y las prácticas. Esto genera múltiples paradojas al reproducir las desigualdades estructurales que son, precisamente, las que se quieren evitar. A pesar del trabajo de participación implementado en algunas administraciones o desplegado desde ámbitos científicos ${ }^{6}$, éste acaba en pura retórica con la imposición de objetos y sujetos, sean estos sitios, lugares, memorias, o conocimientos. El patrimonio neoliberal vigente, con la explosión patrimonial y la centralidad del mercado, entra en contradicción con los propios postulados lanzados desde la Unesco. Este organismo ha sido fundamental para la regulación y protección de los bienes patrimoniales, a la par que un instrumento para la homogenización e imposición de las formas patrimoniales (Herzfeld 2004) ${ }^{7}$. En cualquier caso, ha atendido a las demandas y ha contribuido a los cambios experimentados situando "la democratización de la gestión como un elemento fundamental de los actuales Estados" (Quintero-Morón y Sánchez-Carretero 2017, 57). Entre los giros patrimoniales más destacables está la voluntad de convertir a las comunidades en protagonistas de su patrimonio, a través del llamado giro participativo 


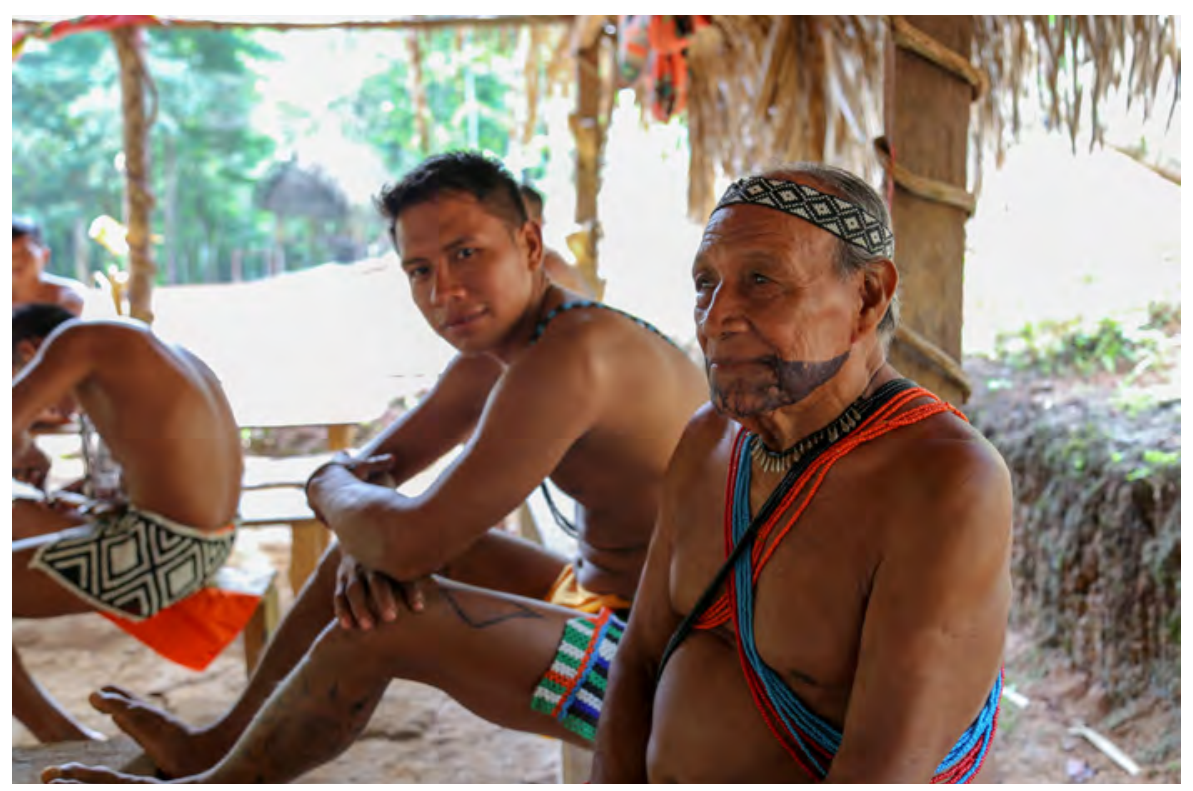

(Sánchez-Carretero et ál. 2019), coincidiendo con un movimiento de calado entre el tener y el ser patrimonial (Santamarina y Mármol 2020).

Para entender el papel conferido a las comunidades locales, hay que retrotraerse a la Convención para la Salvaguardia del Patrimonio Cultural Inmaterial. En ella la Unesco establecía un viraje importante. De una parte, reconocía, por primera vez, al patrimonio inmaterial como categoría a salvaguardar; de otra, dotaba a las comunidades de un peso notable. Nos centraremos en lo segundo, las comunidades, sin entrar en una discusión teórica sobre este polisémico, frágil, imaginado, fragmentado y reificado concepto (Hall 2003, 2010; Bauman 2001, 2004, 2005). No obstante, esa comunidad imaginada vinculada al Estado nación referida por Anderson (1983) es sustituida aquí por unas pretendidas comunidades ${ }^{8}$ portadoras de lo patrimonial: locales, diversas, reales, concretas y situadas espacio-temporalmente, uniformes y bienintencionadas, con capacidad de aglutinar un todo armónico (sin fisuras) y patrimonial (Waterton y Smith 2010; Quintero Morón y Sánchez-Carretero 2017; Quintero-Morón 2020) ${ }^{9}$. Al margen de reproducir los cánones decimonónicos, en una escala menor o microescala, esa vuelta a la esencialización e idealización remite, en muchos casos, a la fantasía del buen salvaje.

El propio documento contenía hasta diez veces la palabra "comunidades". Ya en su preámbulo, recogía la necesidad de "un diálogo renovado entre las comunidades" y, explícitamente, se decía: "Reconociendo que las comunidades, en especial las indígenas, los grupos y en algunos casos los individuos desempeñan un importante papel en la producción, la salvaguardia, el man-
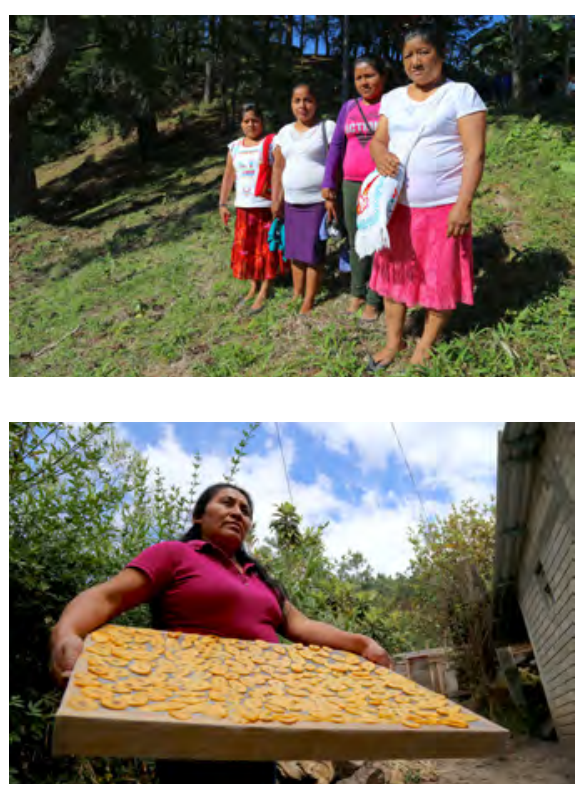

Las pretendidas comunidades portadoras de lo patrimonial implica una esencialización e idealización que remite, en muchos casos, a la fantasía del buen salvaje. En las imágenes, pueblos Indígenas y comunidades locales en Panamá (izquierda) y Oaxaca, México, a la derecha | fotos Banco Mundial América Latina y el Caribe

8

El texto hace referencia a comunidades $y$ grupos (e incluso individuos, un guiño a otras prácticas), aquí usaremos comunidad local para referirnos a ambos.

Para una mayor profundización sobre la utilización del término comunidad en la Unesco de puede acudir a Hertz (2015) y Quintero Morón y Sánchez-Carretero (2017). 
10

No entraremos a analizar "en especial las indígenas", tan solo queremos señalar su significativa alusión. En gran medida su inclusión respondía a los movimientos dados, a finales del XX, después de las presiones y demandas de numerosos colectivos, como el Decenio de la ONU para las poblaciones Autóctonas y Minoritarias o el borrador de la Declaración de la ONU sobre derechos de los pueblos autóctonos (Aikawa 2004)

\section{1}

La creatividad traspasaba así los límites de exclusivo genio creativo.
La llamada "democratización patrimonial" y la manida participación pueden tener efectos perversos o ser simplemente "patrimonio participativo 2.0 a coste cero". En la foto, VII Expo Colchane que organizan las comunidades junto al municipio | foto Gobierno Regional de Tarapacá (Chile) tenimiento y la recreación del patrimonio cultural inmaterial, contribuyendo con ello a enriquecer la diversidad cultural y la creatividad humana"10. Por primera vez, este organismo internacional consagrado a velar por el patrimonio colectivo hablaba de la importancia de las comunidades, como agentes portadores, productores y dinámicos, vehiculándolas además con la diversidad y la creatividad ${ }^{11}$. De facto, el artículo 1 platicaba sobre las finalidades de la Convención y, en su punto 2 (b), establecía el "respeto del patrimonio cultural inmaterial de las comunidades".

El artículo 11 confería a los Estados parte la labor de "identificar y definir los distintos elementos del patrimonio cultural inmaterial presentes en su territorio, con participación de las comunidades, los grupos y las organizaciones no gubernamentales pertinentes". Dejando al margen la sorprendente equiparación, al menos en plano discursivo, entre las comunidades y las organizaciones no gubernamentales, se asignaba a los Estados la función de garantizar la participación de las comunidades en la difícil tarea de inventariar y catalogar el patrimonio inmaterial (Mármol, Roigé y Estrada 2011). El artículo 15 daba un paso más firme en este reconocimiento y, bajo el epígrafe "Participación de las comunidades, grupos e individuos", exhortaba a los Estados parte a "lograr una participación lo más amplia posible de las comunidades, los grupos y, si procede, los individuos que crean, mantienen y transmiten ese patrimonio y de asociarlos activamente a la gestión del mismo". Ya no se trataba tan solo de otorgarles un papel dinámico en las activaciones, había que incluirlas también en la gestión patrimonial, un campo reservado hasta el momento a técnicos, burócratas y expertos. Además, este reconocimiento a las comunidades locales, como portadoras

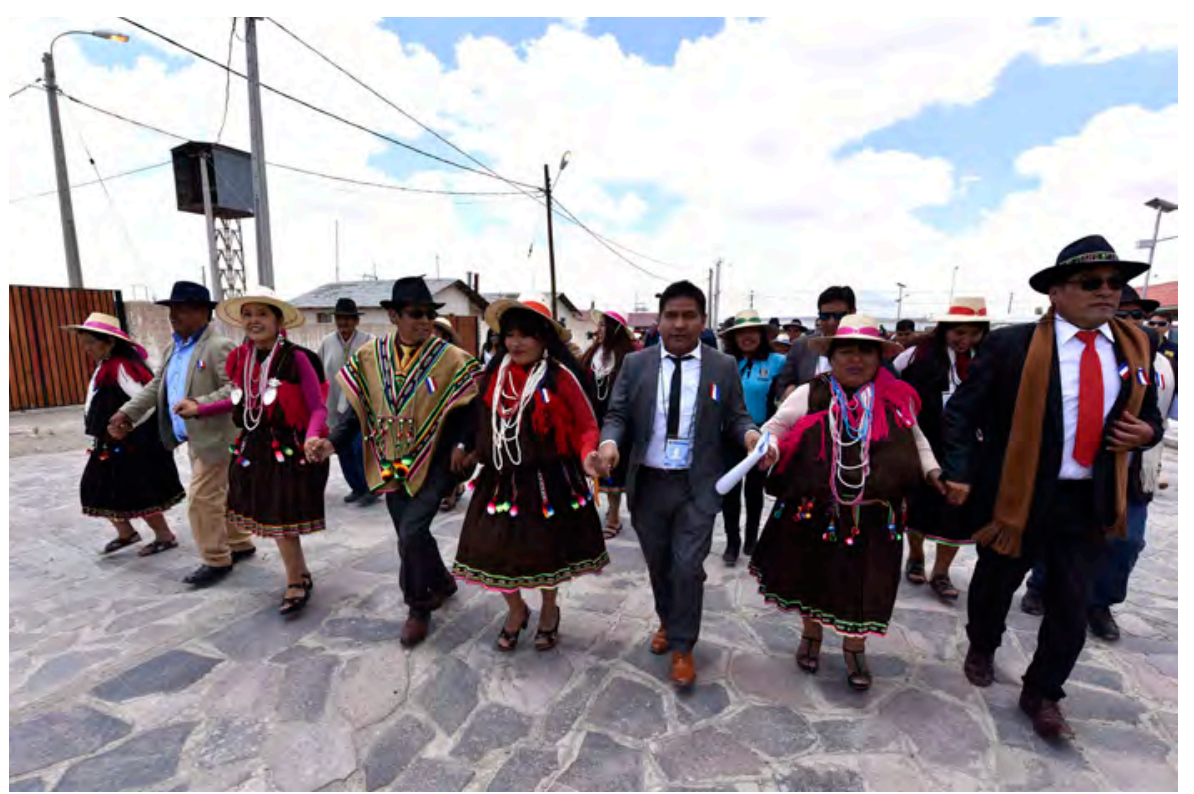


indiscutibles de su patrimonio, se traducía en la necesidad de incorporar en los expedientes el apoyo explícito de las mismas para elevar cualquier petición de inclusión en la Lista de Patrimonio Cultural Inmaterial.

Con todo no ha reportado cambios sustanciales. La pretendida "comunidad" portadora no deja de ser una amalgama discursiva que obvia los conflictos internos y las reivindicaciones dispares, del mismo modo que los manejos patrimoniales conllevan litigios y demandas. Sus engañosas naturalizaciones -tanto de la comunidad como del patrimonio presentados ambos como realidades sustantivas- no pueden encubrir las disputas por posesión de los bienes, sean materiales, inmateriales o naturales. Los conflictos patrimoniales son habituales porque chocan entre sí agentes y agencias con lógicas, intereses y prácticas heterogéneas y, en muchos casos, antagónicas. Si hablamos del papel de las "comunidades" en los procesos patrimoniales éste es doble: dinámico y crítico. Las comunidades tienen capacidad para proponer activaciones patrimoniales, como sujetos/objetos activos, bien por su propio interés o bien como coyuntura política. Los distintos patrimonios contenidos en una comunidad pueden ser reivindicados, reinventados o adjudicados por sus diferentes miembros. Además, algunos colectivos pueden poner en jaque las declaraciones patrimoniales, al discutir el trasfondo de la pretendida patrimonialización, sea esta local, estatal o internacional, y reclamar para sí lo patrimonializado poniendo en evidencia cómo dentro de las comunidades se pueden tener visiones encontradas sobre su patrimonio. Por poner un ejemplo, la comunidad fallera se presenta como portadora categórica de su patrimonio material e inmaterial y se da por hecho que el mundo fallero en su conjunto celebró la proclama de su fiesta como Patrimonio Cultural Inmaterial de la Humanidad ${ }^{12}$. No obstante, tras esa pretendida uniformidad, aparecieron movimientos en contra de la declaratoria como el colectivo Falles Populars i Combatives, quienes se posicionaron con una fuerte carga satírica, propia del universo fallero, frente al Patrimoney y a la Unasco, reclamando sus fiestas como propias y locales y alertando sobre el riesgo del mercadeo de la cultura (Santamarina y Mármol 2020). La que hemos denominado la "oportunidad política del patrimonio" puede ayudar a entender cómo el patrimonio colectivo puede transformarse en un potente activo político, con una gran capacidad de movilización. Dentro de una misma comunidad, en diferentes contextos y por distintos agentes, podemos observar su versatilidad, como instrumento legitimador, como arma reivindicativa o como herramienta alternativa para articular identidades y territorios (Santamarina y Mompó 2021).

Abrir a la participación, en sentido amplio, es poner sobre la mesa la legitimidad sobre pertenencia, dominio y apropiación de lo patrimonial. Y esto, evidentemente, es peliagudo y restringe el alcance de la propuesta normativa de la participación. No es extraño que el giro participativo se haya quedado en una aspiración de corte ético. Las preguntas "qué es" y "de quién es" lo
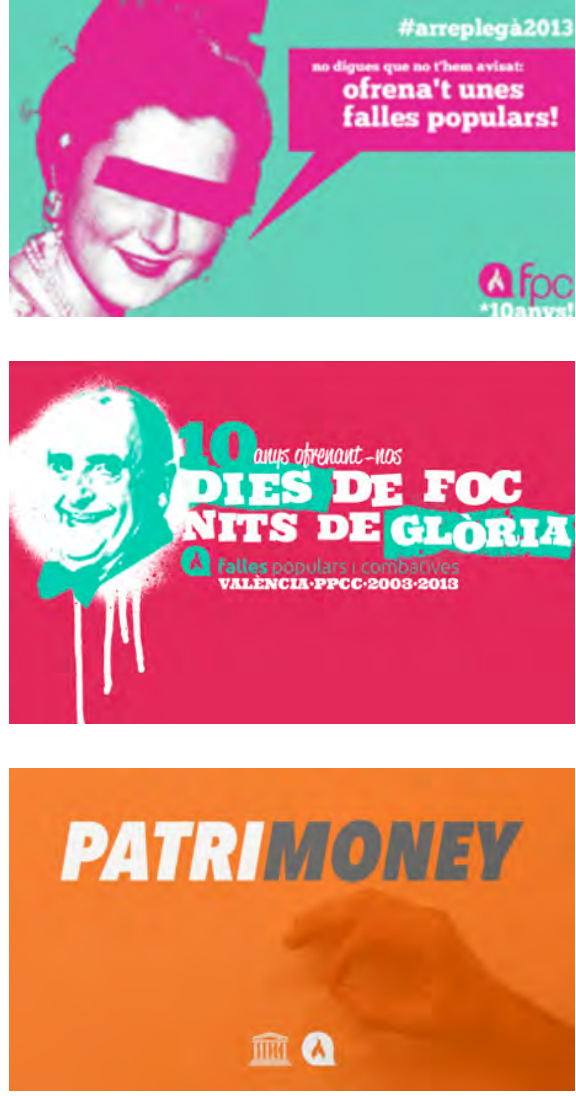

Diferentes carteles del colectivo Falles Populars y Combatives de Valencia

12

El Espacio Cultural de la fiesta de las Fallas fue incluido en 2016 en la Lista Representativa del Patrimonio Cultural Inmaterial de la Humanidad. 
La bibliografía, en este sentido, es amplísima. Para una revisión del caso español se puede acudir a Beltrán y Santamarina (2016).

14

En el informe no estaban todos los datos actualizados por lo que se daba por hecho que se había alcanzado, en 2021, con la protección de la superficie terrestre (17\%) y marina (10\%) pactada en el Convenio.

15

En este sentido "gentrification is seen as a manifestation of more generalised and indeed globalised processes of capitalist 'uneven development”' (Phillips et ál. 2008, 57).
El modelo patrimonial de la naturaleza se ha basado en una triple expropiación: del territorio, de las condiciones sociales de producción y de los conocimientos y memorias. En la imagen, cartel reivindicativo en Canadá en contra de la expansión de un parque nacional | foto Beatriz Santamarina Campos patrimonial ponen en tela de juicio la titularidad y propiedad de los bienes. Lejos de referirnos al patrimonio colectivo como algo simbólico, su activación tiene efectos reales y prácticos sobre las comunidades. El "para quién es" y "para qué es" acaban situando al artefacto patrimonial en las lógicas político-económicas imperantes. Numerosos ejemplos nos muestran cómo, de forma recurrente, ha habido tensiones entre las comunidades y los usos o regímenes patrimoniales. El caso del patrimonio natural, quizás, sea el más evidente. A lo largo del planeta, encontramos numerosos ejemplos de una oposición abierta a la declaración de un área protegida ${ }^{13}$. La patrimonialización de la naturaleza ha supuesto la reordenación territorial de más del $16,64 \%$ de la superficie terrestre y del 7,74 \% del medio marino en el mundo, un aumento de más de 21 millones de $\mathrm{km}^{2}$, tan solo en la última década, según recoge el último Protected Planet Report 2020 (Bingham et ál. 2021). Se espera cumplir así con la Meta 11 Aichi adoptada en el Convenio sobre la Diversidad Biológica en $2010^{14}$. Este crecimiento drástico, iniciado en las décadas anteriores, es un fenómeno con importantes repercusiones sociopolíticas, jurídicas y económicas sobre las comunidades locales. El modelo patrimonial de la naturaleza se ha basado en una triple expropiación: del territorio, de las condiciones sociales de producción y de los conocimientos y memorias. Hasta el punto de que algunos autores consideran que, en algunos casos, ha provocado bien "refugiados de la conservación", bien "gentrificación de lo natural" (Dowie 2009; Phillips et ál. 2008; Santamarina Campos 2009) ${ }^{15}$. El propio informe Protected Planet reconocía la falta de datos sobre el manejo y la gobernanza, así como la necesidad de implantar una gobernanza equitativa. Además, establecía que solo a través de ella sería posible alcanzar una conservación eficaz (Bingham et ál. 2021). Admitía así que la protección no implica conservación -la denominación acuñada de "parques de papel" remite a ello- y que, sin el principio de equidad, no es posible garantizarla.

Los mismos procesos de conflicto los encontramos, en diferentes niveles y contextos, en el patrimonio material o inmaterial generados por la expropia-

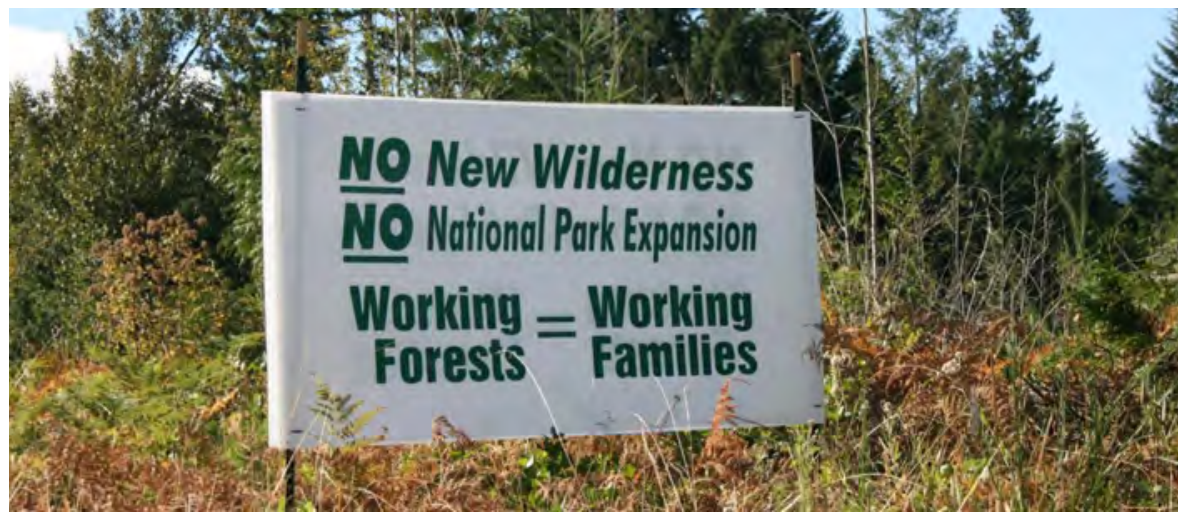




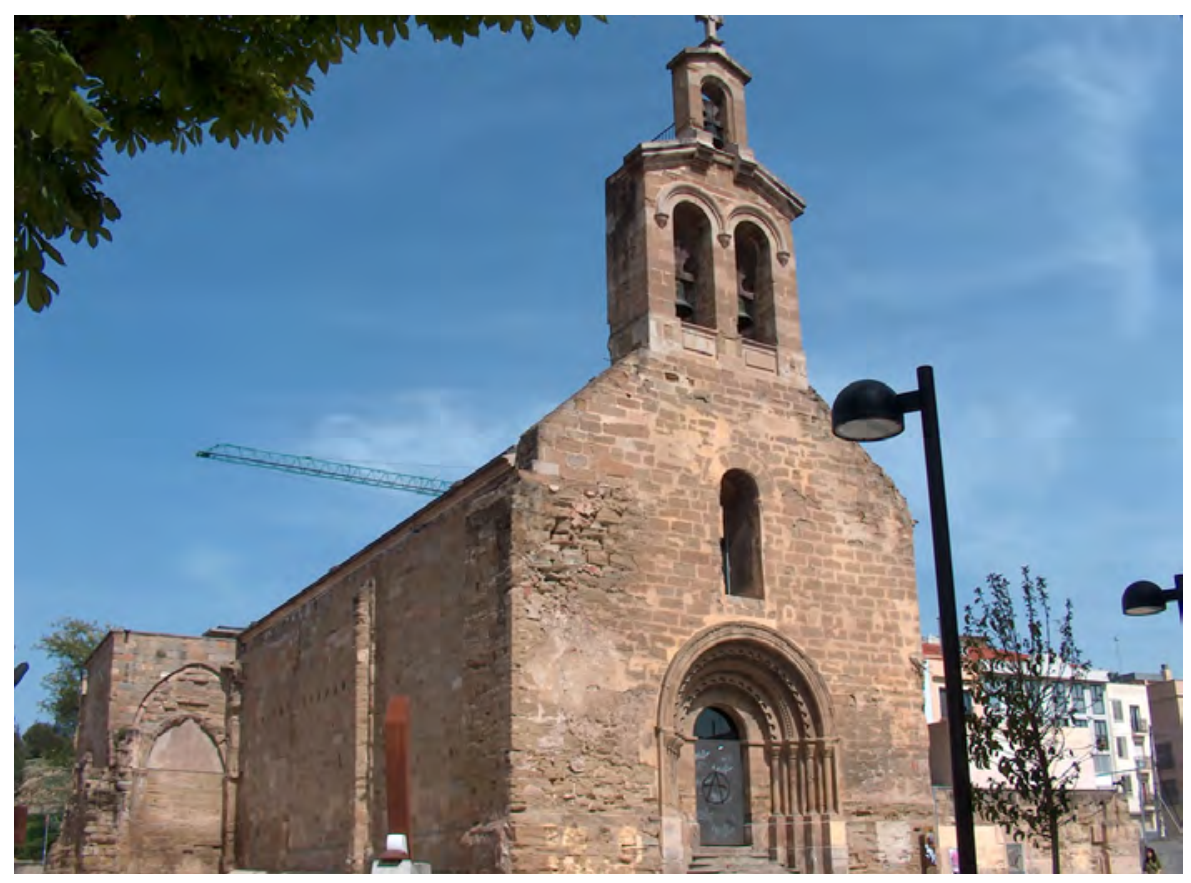

ción y reapropiación de los bienes por agentes externos, en muchos casos, avalados por expertos lo que legitima la propia sustracción. Múltiples ejemplos, en nuestro país, son repertorio de las tensiones generadas. Si más arriba hacíamos mención a las desavenencias generadas en una supuesta comunidad festiva por su patrimonio inmaterial, replicada en otras partes del mundo, lo mismo sucede con el material. Veámoslo a otro nivel, la Dama de Elche, los legajos de Catalunya o el Gernika de Picasso han sido objeto de disputa entre el Estado español y las administraciones autonómicas o locales (Santamarina Campos 2008). Del mismo modo, existen disputas entre las administraciones autonómicas. Pensemos, por ejemplo, en la portada románica de la iglesia de San Martín (Lleida), reclamada a Catalunya tanto por el Gobierno de Aragón, como por el pueblo oscense de El Tormillo. O entre locales, como sucede con la voluntad de recuperar la antigua iglesia románica de Santa María de Leorio, con parte en la vecina parroquia de La Pedrera (Asturias). E incluso entre otras instituciones, como el pleito por 111 obras entre las diócesis de Barbastro y Lleida. Este pequeño muestrario es significativo de la pugna por lo bienes patrimoniales. Contiendas, cada día más habituales, en una tesitura de inflación patrimonial, de versatilidad en la patrimonialización colectiva -con activaciones y demandas patrimoniales fuera de las esferas tradicionales de fabricación patrimonial, entrando nuevos objetos y sujetos- y de intensificación del consumo patrimonial (Santamarina y Vizcaíno 2021). Su rentabilidad ha acentuado los conflictos mostrando la competición por sus activos. En este particular paisaje, ¿puede el discurso patrimonial autorizado ceder espacio de poder para

Portada románica de la iglesia de San Martín (Lleida), reclamada a Catalunya tanto por el Gobierno de Aragón, como por el pueblo oscense de El Tormillo | foto João Carvalho 
16

"On the one hand, the taking over of bureaucratic paternalism by civil society has encouraged debate and activism as a counter-hegemonic approach toward radical socia transformation. On the other hand, the 'political decapitation' (Leal 2007) of participation will eventually create communities as enterprises claiming and managing collective intellectual property rights over traditional knowledge and complying with neoliberal models (Yúdice 2004, 6-7). Individual actors and communities may have good reasons to bolster their cultural identity by increasing its salability" (Adell et ál. 2015, 10).

\section{7}

"A los efectos de la presente Convención, se tendrá en cuenta únicamente el patrimonio cultural inmaterial que sea compatible con los instrumentos internacionales de derechos humanos existentes y con los imperativos de respeto mutuo entre comunidades, grupos e individuos y de desarrollo sostenible" (Disposiciones generales, Artículo 2) la participación? La participación supone tomar parte y recibir parte de algo. Participar implica acción y reconocimiento para entrar en los entresijos del dominio patrimonial. Y ello no es baladí, está en juego definir qué y quién es el portador, legítimo y titular, y quién y por qué debe ser su garante y gestor.

Dicho esto, la entrada (inocente) de la participación, suponía en principio, un vuelco normativo, con numerosos alcances jurídicos, económicos, políticos y sociales. La ambigüedad estaba servida efectuándose lecturas más éticas que políticas y sin implicaciones con impacto. De ahí, que la inherente ambivalencia del "nuevo paradigma participativo" haya sido ampliamente señalada y discutida (Adell et ál. 2015, 10) ${ }^{16}$. En nuestro país, el debate entre participación y patrimonio también ha sacado a luz los lindes, las contradicciones, los riesgos, así como las oportunidades (Cortés-Vázquez, JiménezEsquinas y Sánchez-Carretero 2017; Quintero Morón y Sánchez-Carretero 2017; Quintero-Morón 2020; Carrera Díaz 2019; Sánchez-Carretero et ál. 2019; Sánchez-Carretero y Roura-Expósito 2021; Quintero Morón y SánchezCarretero 2021). De estos trabajos se desprende, tal y como apuntábamos más arriba, cómo la participación, hasta ahora, ha sido mínima y utilizada como maquillaje de las políticas patrimoniales. En palabras de QuinteroMorón y Sánchez-Carretero "no ha producido una mayor presencia de las comunidades locales en los procesos de toma de decisión (...) el efecto de empoderamiento para las 'comunidades, grupos y en algunos casos individuos', que supuestamente traería consigo el giro participativo, dista mucho de haberse producido" $(2017,60)$. Los límites de la participación junto con el cambio en los acentos ontológicos (del tener al ser), identitarios (las comunidades locales portadoras), económicos (bienes y servicios envasados) y tecno-científicos (aumento de especialistas y burocratización) complejizan el panorama actual. La producción de usos del pasado es ahora más lucrativa que nunca, por ello se hacen urgentes medidas para garantizar una gobernanza sostenible. Y la sostenibilidad está recogida en la propia Convención del 2003, apareciendo en su abertura y en su cierre. Atendamos ahora a su centralidad, a su urgente necesidad y a su modulación en la Agenda 2030 instada por la Asamblea General de la Organización de Naciones Unidas (ONU).

\section{HACIA UN PATRIMONIO COLECTIVO SOSTENIBLE}

No deja de sorprender que, en el preámbulo de la Convención, se afirmara que el patrimonio cultural inmaterial es "garante del desarrollo sostenible". Desde nuestra consideración, darlo por hecho supone volver a traer a colación la imagen del buen salvaje. Más interesante resulta que, en el artículo 2 , tras la definición del patrimonio inmaterial, se exprese, entre otros requisitos $^{17}$, la obligatoriedad de su compatibilidad con el desarrollo sostenible. Su aparición respondía a la institucionalización internacional de su fórmula, desde el Informe Brutland (1987), como instrumento de catalización para 
los problemas medio ambientales. Dejando de lado la polémica del término y su forzada inclusión en la Convención, rescataremos aquí la sostenibilidad como un elemento fundamental para alcanzar la democratización y, por ende, la participación patrimonial. En lo que sigue, entenderemos la sostenibilidad como un paradigma posible y realizable articulado en los principios de responsabilidad, justicia e igualdad.

En 2015 la ONU presentaba la Agenda 2030 para el Desarrollo Sostenible. El documento desplegaba un plan de acción consensuado "a favor de las personas, el planeta y la prosperidad"18 a través de diecisiete Objetivos para el Desarrollo Sostenible (ODS) y con ciento sesenta y nueve metas socioeconómicas y ambientales. Las medidas y los objetivos permiten innumerables análisis y ser aplicados en todos los ámbitos de trabajo. Entre ellos podemos observar cómo el patrimonio colectivo puede convertirse en herramienta para alcanzar los ODS, más que ser de entrada compatible con los mismos. Su contribución, en la conservación o salvaguardia como contenedor de nuestro mejor legado para el futuro, pasa por responder a los principios básicos de la sostenibilidad para garantizar su protección.

La clasificación en material, inmaterial y natural puede ser útil a la hora de vincular los distintos patrimonios con los ODS. Por poner un ejemplo, el objetivo 15, "Proteger, restaurar y promover la utilización sostenible de los ecosistemas terrestres, gestionar de manera sostenible los bosques, combatir la desertificación y detener y revertir la degradación de la tierra, y frenar la pérdida de diversidad biológica" podemos ligarlo con la conservación del patrimonio natural. Aunque, esta aparente ventaja, puede traducirse en dificultad, al menos, en dos sentidos. Por un lado, los ODS pueden estar relacionados con los tres patrimonios: garantizar "una vida saludable y promover el bienestar" (ver objetivo 3) estaría unido al patrimonio natural, con las desiguales concepciones ecosistémicas ${ }^{19}$; al inmaterial, con diferentes cosmovisiones sobre el bienestar20; y al material, con las variadas arquitecturas y bienes coligados. Por otro lado, los ODS no se pueden conquistar si no se encaran los objetivos encadenados, de igual modo que la compartimentación patrimonial tampoco ayuda a esbozar políticas de (co)gestión con una visión integradora del territorio.

En las últimas décadas, la fábrica patrimonial ha respondido con creces a las exigencias del capital y de la economía creativa funcionando a la perfección el dueto patrimonio/turismo en el mercado global de los intangibles (Comaroff y Comaroff 2009; Boltanski y Chiapello 2006; Mármol y Santamarina 2019) ${ }^{21}$. En este contexto, la Unesco certifica el patrimonio y con ello garantiza la recepción de capitales (Meskell 2013, 2014). Ahora bien, su seno perpetúa las asimetrías ${ }^{22}$ calcando las desigualdades internacionales (Meskell et ál. 2015; Meskell y Brumann 2015). Todo ello sumado a la imposición de una única versión del patrimonio hegemónico y una excesiva burocratización,

\section{8}

Disponible en: https://www.un.org/sustainabledevelopment/es/2015/09/la-asamblea-general-adopta-la-agenda-2030-para-el-desarrollosostenible

19

Variedades ontológicas, por ejemplo, en la representación de lo humano y no humano.

20

Reparemos, como muestra, en el modelo del "buen vivir" (Sumak Kawsay).

21

El patrimonio al servicio del marcado es algo que públicamente no se reconoce (Hafstein 2009).

22

Tanto en su estructura política como en la toma de decisiones. 
23

Dejamos fuera las candidaturas pluriestatales e incluimos el Registro de Buenas Prácticas de Salvaguardia.

24

También debe tenerse en cuenta la sintonía entre los gobiernos estatal y autonómico; en el caso valenciano esto es manifiesto.

25

La mayoría de los bienes se concentran en espacios urbanos.

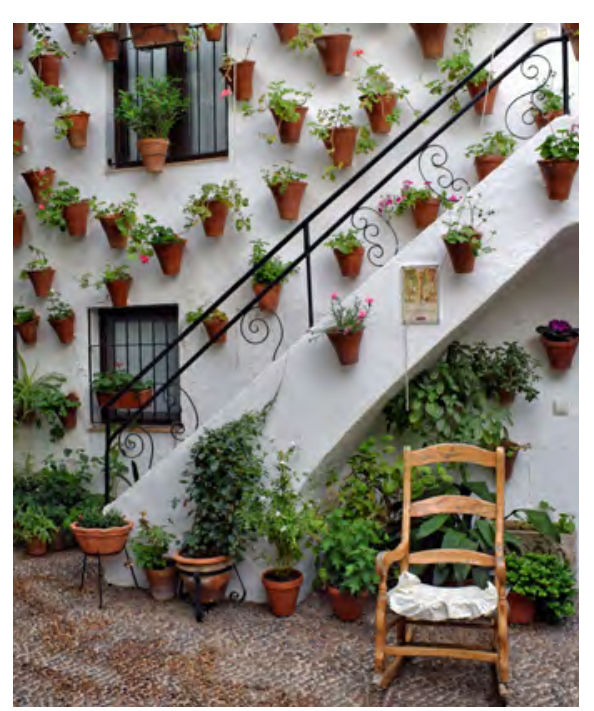

Las activaciones responden más a la oferta y demanda (turística) que a una salvaguardia de la extraordinaria diversidad. En la foto, Patios de Córdoba, declarados por la Unesco Patrimonio Cultural Inmaterial de la Humanidad | foto Jocelyn Erskine-Kellie lo que abre un abismo entre países (Martínez, Baraja y Molinero 2019). El resultado es obvio: países condecorados, países marginados. En realidad, en estos momentos, podemos afirmar que las listas de Patrimonio Mundial (1972) y de la Humanidad (2003) son obstáculos para poner el patrimonio colectivo al servicio de la sostenibilidad. En primer lugar, porque reproduce el sistema neocapitalista y neoliberal contribuyendo a la concentración de capitales. En segundo lugar, porque impide la pluralidad de sentidos, afectos y emociones del patrimonio colectivo. $Y$, en tercer lugar, porque reduce lo patrimonial a los dictados de los cuerpos técnicos y al acopio de informes y papeleo.

El esquema se repite, a otra escala, al descender a lo estatal y lo local. Veamos lo sucedido en España y en la Comunidad Valenciana, en el caso del patrimonio inmaterial. En la última década, la presentación de candidaturas y las declaraciones han ido en aumento. En la esfera estatal ${ }^{23}$, si atendemos, a los expedientes presentados para su incorporación en Lista de Patrimonio Cultural Inmaterial $(\mathrm{PCl})$ de la Humanidad, observaremos cómo se han enfrentado las comunidades autónomas (CC.AA.) entre ellas, en su afán por obtener el sello Unesco (Santamarina en prensa). Las CC.AA. más beneficiadas han sido las que tienen mayores recursos o un sector turístico muy consolidado, concentrándose en el arco mediterráneo. De los quince bienes incluidos en la Lista de $\mathrm{PCl}$ en el Estado español, cinco están en la Comunidad Valenciana, tres en Catalunya y tres Andalucía ${ }^{24}$. En lo local, los municipios valencianos, con más recursos, son los que presentan un mayor número de expedientes y, en conjunto, son las capitales de las provincias y de las comarcas las más beneficiadas (Santamarina 2017). Esto se traduce en una discriminación ${ }^{25}$, estatal y local, que aumenta las desigualdades territoriales. Además, en ambos casos, la mayoría de los bienes declarados pertenecen al ámbito de lo festivo, por ejemplo, en la Lista $\mathrm{PCl}$, nos encontramos el Misterio de Elche, La Patum de Berga, los Castells, el Flamenco, el Canto de la Sibila, la fiesta de la Mare de Déu de Algemesí, las Fallas, los Patios de Córdoba, las Tamborradas o los Caballos del Vino. Esto supone relegar otros espacios patrimonializables y nos habla de la noción restringida del patrimonio inmaterial relacionada con la visión folclórica y, sobre todo, con el sector turístico por su capacidad imantadora. Las activaciones responden más a la oferta y demanda (turística) que a una salvaguardia de la extraordinaria diversidad española o valenciana, y revela la inexistencia de una política efectiva para la salvaguardia inmaterial. Hoy el mercado coloca el patrimonio colectivo como un gran activo económico (Bendix 2009; Timothy 2018). La pugna por tener y ser patrimonio establece una competición exógena, entre países, y endógena, entre el Estado y las CC.AA., entre las CC.AA. y las localidades y entre los distintos actores de las comunidades.

Después de lo visto hasta el momento, cabe plantearse ¿hay en lo patrimonial patrones de desarrollo? ¿son estos sostenibles? Con respecto a la pri- 

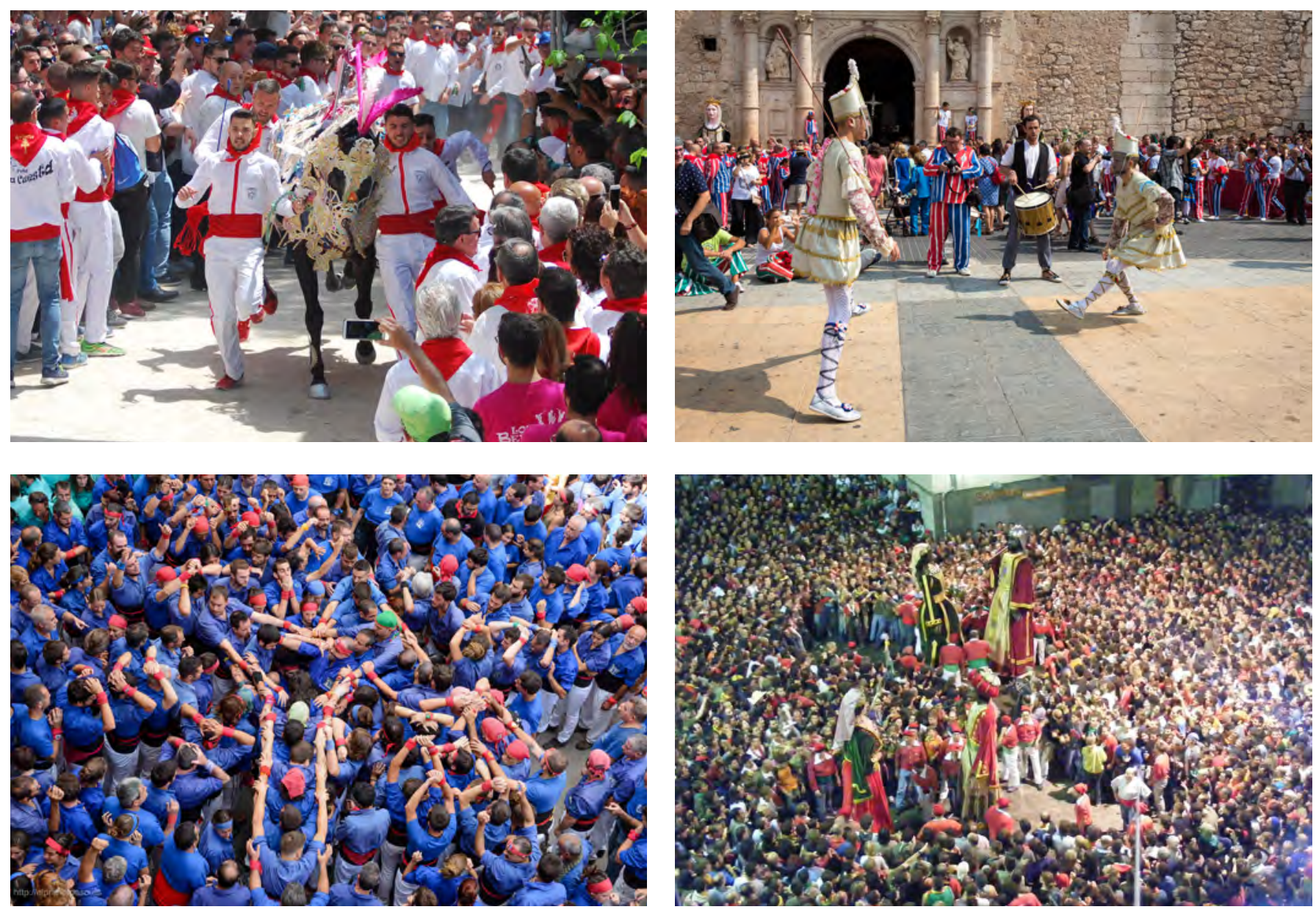

La mayoría de los bienes declarados pertenecen al ámbito de lo festivo, por ejemplo, en la Lista $\mathrm{PCl}($...) Esto supone relegar otros espacios

mera pregunta, podemos contestar afirmativamente. El problema radica en patrimonializables y nos habla de la noción restringida del patrimonio inmaterial relacionada con la visión folclórica y, sobre todo, con el sector turístico por su capacidad imantadora. En las imágenes, Caballos del vino, fiesta de la Mare de Déu de Algemesí, los Castells y La Patum de Berga | fotos (de arriba a abajo y de izquierda a derecha) Conchi Arroyo, Rafa Esteve, El primer paso blog. Ràdio Berga y menos aún que integre los ODS. Y formulemos las últimas, ¿puede contribuir el patrimonio colectivo a la sostenibilidad? Desde nuestra visión, sí. La maquinaría patrimonial puede ponerse al servicio de la sostenibilidad. ¿Cómo? Su activación debe pasar por someterse y respetar los lugares y las personas a través de su protagonismo activo y de reconocer, asimismo, la enorme fragilidad del patrimonio colectivo. La mediación, en primera instancia, y participación social, en segunda, deben convertirse en instrumentos fundamentales en las activaciones y la cogestión. Solo así se puede lograr proteger y sostener a los lugares y personas, porque la protección en sí misma no asegura ni la conservación ni la salvaguardia. El principio del beneficio económico para unos pocos, pilar del sistema actual, y la ganancia 
patrimonial, debe mudarse hacia la máxima del beneficio social redistributivo y equitativo. $Y$ esto pasa: primero, por reconocer la titularidad y la propiedad de los bienes donde la responsabilidad y la justicia prime por encima de la expropiación; segundo, por estimular modelos de producción sostenibles y respetuosos donde los locales sean sus impulsores y protagonistas; $y$, tercero, por promover y contribuir a la igualdad entre todas y todos, al respeto a las distintas formas identitarias y a la dignidad de lo humano (y no humano). Todo ello está contemplado en los ODS y puede sintetizarse en garantizar la biodiversidad, entendida en sentido amplio, es decir, englobando a la diversidad cultural. Para alcanzar las metas y los ODS, el patrimonio colectivo debe redefinirse en todos los ámbitos (políticos, técnicos, económicos y sociales).

\section{(IN) CONCLUSIONES}

Hoy, la crisis socioecosistémica globalizada nos apremia a cambiar las lógicas imperantes en nuestro sistema político-económico. El patrimonio colectivo es una baza hacia la sostenibilidad, al promover la conservación y salvaguardia de la biodiversidad. Las comunidades deben participar activamente en la definición del lugar donde viven y de aquello que les representa de forma plural (la forma de ser, el modo de hacer y la manera de sentir) y deben ser agentes polifónicos en las decisiones sobre su patrimonio.

Para lograrlo, el primer paso es reconocer la titularidad del patrimonio, en sus distintos formatos, y la mediación dentro de las propias comunidades y con las administraciones. A partir de ahí, la participación debe entrar en escena y su éxito pasa por renovar, entre otros factores, a los cuerpos técnicos y disciplinarios. La participación comporta el empoderamiento y el reconocimiento de una pluralidad de sentidos, por tanto, las parcelas de poder deben reconfigurarse poniendo el acento en el territorio(s), la memoria(s), el conocimiento(s) y la identidad(es). El mayor peligro del giro participativo es el desgaste y frustración social ante promesas diluidas. Obviamente, la participación real supone una auténtica transformación en el gobierno de lo patrimonial, dado que implica una cesión de poder, un reconocimiento de derechos y propiedades y una cotutela en la gestión. Y, al mismo tiempo, conlleva desarticular, ontológica, epistemológica y metodológicamente, las codificaciones ejercidas desde el AHD (cultura/naturaleza; material/inmaterial).

La cimentación de nuevos patrimonios apoyados en la mediación y la participación, para alcanzar modelos de gobernanza sostenible, son fundamentales para frenar la degradación socioecológica. Alimentar la diferencia y la biodiversidad socioecosistémica es cardinal para dar alcance a la sostenibilidad y la mejor apuesta para la conservación y la salvaguardia patrimonial. Sin duda, el patrimonio colectivo es un campo privilegiado para la aplicación de la Agenda 2030, siendo un medio más para garantizar la sostenibilidad. 
El desplazamiento de la posesión, propiedad y titularidad patrimonial hacia la comunidad y su implicación en la gestión, desprendida de las normativas de la Unesco, es trascendental y debe materializarse. La definición de los sujetos (de quién es, para quién es) y de los objetos (el qué es, para qué es) de los procesos patrimoniales es el punto de partida hacia a la apertura. Parafraseando a Quintero-Morón, el giro participativo y los objetivos para el desarrollo sostenible son una oportunidad "para repolitizar la participación y orientarla a procesos de equidad y justicia social" $(2020,140)$. 


\section{BIBLIOGRAFÍA}

- Adell, N., Bendix, R., Bortolotto, Ch. y Tauschek, M. (2015) Between Imagined Communities and Communities of Practice: Participation, Territory and the Making of Heritage. Göetingen: Universitätsverlag Göttingen

- Aikawa, N. (2004) Visión histórica de la Preparación de la Convención Internacional de la UNESCO para la Salvaguardia del Patrimonio Cultural Inmaterial. Museum International, n. ${ }^{\circ} 221$, pp. $140-153$

- Albert Rodrigo, M. (2005) El patrimonio cultural y la sociedad civil. En: Hernández i Martí, G.M., Santamarina Campos, B., Moncusí Ferré, A. y Albert Rodrigo, M. (coord.) La memoria construida. Patrimonio cultural y modernidad. Valencia: Tirant Lo Blanch, pp. 193-223

- Alonso González, P. (2017) El antipatrimonio. Fetichismo y dominación en Maragatería. Madrid: CSIC

- Anderson, B. (1983) Imagined communities: reflections on the origins and spread of capitalism. Londres: Verso

- Ariño Villarroya, A. (2002) La expansión del patrimonio cultural. Revista de Occidente, n. ${ }^{\circ} 250$, pp. 129-150

- Ashworth, G.J. y Van der Aa, B.J. (2006) Strategy and policy for the world heritage convention: goals, practices and future solutions. En: Leask, A. y Fyall, A. (ed.) Managing world heritage sites. London: Elsevier, pp. 147-158

- Askew, M. (2010) The magic list of global status: UNESCO, World Heritage and the agendas of states. Heritage and Globalisation. En: Labadi, S. y Long, C. (ed.) Heritage and globalization. Londres: Routledge, pp. 19-44

- Beltrán, O. y Santamarina, B. (2016) Antropología de la conservación en España. Revista antropología social, vol. 25, n. ${ }^{\circ}$, pp. $85-109$

- Bauman, Z. (2001) Community: Seeking Safety in an Insecure World. Cambridge: Polity Press

- Bauman, Z. (2004) Identity. Cambridge: Polity Press

- Bauman, Z. (2005) Modernidad y ambivalencia. Barcelona: Anthropos

- Bauman, Z. (2017) Retrotopia. Cambridge: Polity Press

- Bendix, R., Eggert, A. y Peselmann, A. (ed.) (2013) Heritage Regimes and the State. Göttingen: Universitätsverlag Göttingen

- Bendix, R. (2009) Heritage between Economy and Politics: An Assessment from the Perspective of Cultural Anthropology. En: Smith, L. y Akagawa, N. (ed.) Intangible Heritage. Londres: Routledge, pp. 253-269

- Bingham, H.C., Lewis, E., Tayleur, J., Cunningham, C., Kingston, N., Burgess, N., Ash, N., Sandwith, T. y MacKinnon, K. (ed) (2021) Protected Planet Report 2020. Cambridge: UNEP-WCMC: Disponible en: https://livereport. protectedplanet.net/ [Consulta: 29/07/2021]

- Boltanski, L y Chiapello, E. (2002) El nuevo espíritu del capitalismo. Madrid: Akal

- Bortolotto, Ch. (2011) (ed.) Le patrimoine culturel immatériel: enjeux d'une nouvelle catégorie. París: Maison des Sciences de l'Homme

- Bourdieu, P. (1998) La distinción. Criterio y bases sociales del gusto. Madrid: Taurus

- Bourdieu, P. (1991) El sentido práctico. Madrid: Taurus

- Bourdieu, P. (1997) Razones prácticas. Sobre la teoría de la acción. Barcelona: Anagrama

- Boym, S. (2016) El futuro de la nostalgia. Madrid: Antonio Machado Libros

- Carrera Díaz, G. (2019) Participación social, patrimonialización "expandida" y nuevos sujetos patrimoniales. En: Sánchez-Carretero, C., MuñozAlbadalejo, J., Ruiz-Blanch, A. y Roura-Expósito, J. (ed.) El imperativo de la participación en la gestión patrimonial. Madrid: CSIC, pp. 217-235

- Casado de Otaola, S. (2010) Naturaleza Patria. Ciencia y sentimiento de la naturaleza en la España del regeneracionismo. Madrid: Fundación Jorge Juan-Marcial Pons

- Cesari, C. de (2013) Thinking Through Heritage Regimes. En: Bendix, R., Eggert, A. y Peselmann, A. (ed.) Heritage Regimes and the State. Göttingen: Universitatsverlag Gottingen, pp. 399-413

- Comaroff, J. y Comaroff, J. (1991) Of Revelation and Revolution. Chicago: University of Chicago Press

- Comaroff, J. y Comaroff, J. (2009) Etnicidad S.A. Madrid: Katz

- Coombe, R.J. y Weiss, L. (2015) Neoliberalism, Heritage Regimes, and Cultural Rights. En: Meskell, L. (ed.) Global Heritage: A Reader. Oxford: Wiley-Blackwell, pp. 43-69

- Cortés-Vázquez, J.A., Jiménez-Esquinas, G. y SánchezCarretero, C. (2017) Heritage and participatory governance: An analysis of political strategies and social fractures in Spain. Anthropology Today, vol. 33, n. ${ }^{\circ}$ 1, pp. 15-18

- Choay, F. (1996) L'allégorie du patrimoine. París: Seuil

- Daniels, S. (1993) Fields of Vision: Landscape Imaginary and National Identity in England and the United States. Princeton: Princeton University Press

- Davallon, J. (2014) El juego de la patrimonialización. En: Roigé, X., Frigolé, J. y Mármol, C. del (coord.) Construyendo el patrimonio cultural y natural. Parques, museos y patrimonio rural. Valencia: Germania, pp. 47-76 
- Dowie, M. (2009) Conservation refugees: the hundred year conflict between global conservation and native peoples. Cambridge: MIT Press

- Foucault, M. (1980) Power/knowledge: Selected interviews and other writings, 1972-1977. Nueva York: Pantheon Books

- Frigolé, J. (2014) Retóricas de la autenticidad en el capitalismo avanzado. Endoxa , n. ${ }^{\circ} 33$, pp. 37-60. Disponible en: https://doi.org/10.5944/endoxa.33.2014.13564 [Consulta: 28/07/2021]

- García Canclini, N. (1999) Los usos sociales del patrimonio cultural. En: Aguilar Criado, E. (coord.) Patrimonio Etnológico. Nuevas perspectivas de estudio. Granada: Junta de Andalucía, Instituto Andaluz del Patrimonio Histórico, pp.16-33

- Geismar, H. (2015) Anthropology and heritage regimes. Annual Review of Anthropology, vol. 44, pp. 7185. Disponible en: https://www.annualreviews.org/doi/abs/ 10.1146/annurev-anthro-102214-014217 [Consulta: 28/07/ 2021]

- Gómez Ferri, J. (2004) Del patrimonio a la identidad. La sociedad civil como activadora patrimonial en la ciudad de Valencia. Gazeta de Antropología, vol. 20, n. ${ }^{\circ}$ 9. Disponible en: http://www.ugr.es/ pwlac/G20_09Javier_Gomez_Ferri. html [Consulta: 28/07/2021]

- González-Varas, I. (1999) Conservación de bienes culturales: teoría, principios y normas. Madrid: Cátedra

- González-Varas, I. (2015) Patrimonio cultural: conceptos, debates y problemas. Madrid: Cátedra

- Hafstein, V. (2009) Intangible Heritage as a List. From Masterpieces to Representation. En: Smith, L. y Akagawa, N. (ed.) Intangible Heritage. New York: Routledge, pp. 93-111

- Hall, S. (2003) Who Needs 'Identity'? En: Hall S. y Du Gay, P. (ed.) Questions of Cultural Identity. London: Sage, pp. 1-17

- Hall, S. (2010) Identidad cultural y diáspora. En: Restrepo, E., Walsh, C. y Vich, V. de. Sin garantías: Trayectorias y problemáticas en estudios culturales. Popoyán: Envión editors, pp. 349-361

- Hall, S. (2003) Who Needs 'Identity'? En: Hall S. y Du Gay, P. (ed.) Questions of Cultural Identity. London: Sage, pp. $1-17$

- Haskel, J. y Westlake, S. (2017) Capitalism without Capital: The Rise of the Intangible Economy. Nueva York: Princeton University Press

- Heinich, N. (2010) La fabrique du patrimoine. De la cathédrale à la petite cuillère. París: Maison des Sciences de l'Homme
- Hernández i Martí, G.M., Santamarina Campos, B., Moncusí Ferré, A. y Albert Rodrigo, M. (2005) La memoria construida. Patrimonio cultural y modernidad. Valencia: Tirant Lo Blanch

- Herzfeld, M. (2004) The Body Impolitic: Artisans and Artifice in the Global Hierarchy of Value. Chicago: University of Chicago Press

- Hobsbawm, E. y Ranger, T. (2005) La invención de la tradición. Barcelona: Crítica

- Kurin, R. (2004) La salvaguardia del patrimonio cultural inmaterial en la Convención de la UNESCO de 2003: una valoración crítica. Museum International, n. ${ }^{0} 221$, pp. 68-81

- Kuutma, K. (2013) Between arbitration and engineering: Concepts and contingencies in the shaping of heritage regimes. En: Bendix, R., Eggert, A. y Peselmann, A. (ed.) Heritage Regimes and the State. Göttingen: Universitätsverlag Göttingen, pp. 21-36

- Labadi, S. (2007) Representations of the nation and cultural diversity in discourses on World Heritage. Journal of Social Archaeology, vol. 7, n. ${ }^{\circ}$ 2, pp. 147-170

- Lowenthal, D. (1998) El pasado es un país extraño. Barcelona: Akal

- Mármol, C. del, Morell, M. y Chalcraft, J. (ed.) (2015) The making of heritage: Seduction and disenchantment. London: Routledge

- Mármol, C. del, Roigé, X. y Estrada, F. (2011) Safeguarding Intangible Cultural Heritage? A critical perspective on the inventory of Intangible Cultural Heritage in Catalonia. En: Lira, Sérgio, Amoêda, R., Pinheiro, C. (coord.) Sharing Cultures 2011. Portugal: Green Lines Institute for Sustainable Development, pp. 481-490

- Mármol, C. del (2017) Pasados locales, políticas globales: procesos de patrimonialización en un valle del Pirineo catalán. Valencia: Neopatria

- Mármol, C. del y Estrada F. (2018) Naturalizing culture in the Pyrenees: Heritage processes in rural contexts. En: Arregui, A., Mackenthun, G. y Wodianka, S. (ed.) Decolonizing Heritage: Natures, Cultures and the Asymmetries of Memory. Münster: Waxmann Verlag, pp. 219-236

- Mármol, C. (Del), Frigolé, J. y Narotzky, S. (ed.) (2010) Los lindes del patrimonio. Consumo y valores del pasado. Barcelona: Icaria

- Mármol, C. del, Siniscalchi, V. y Estrada, F. (2016) Reflecting on heritage and power: dynamics, strategies and appropriations in the Catalan Pyrenees and the French Alps. International Journal of Heritage Studies, vol. 22, n. ${ }^{\circ}$ 5, pp. 341-354

- Mármol, C. del y Santamarina, B. (2019) Seeking 
Authenticity: Heritage and Value within the Intangible Economy. Journal of Mediterranean Studies, vol. 28, n. ${ }^{\circ}$, pp. 117-132

- Martínez, M., Baraja, E. y Molinero, F. (2019) Criterios de la UNESCO para la Declaración de Regiones Vitícolas como Paisaje Cultural. AGE, vol. 80, n. ${ }^{\circ} 2614$, pp. 1-33

- Meskell, L. y Brumann, C. (2015) UNESCO and new world orders. En: Meskell, L. (ed.) Global Heritage. Malden: John Wiley \& Sons, pp. 22-42

- Meskell, L., Liuzza, C., Bertacchini, E. y Saccone, D. (2015). Multilateralism and UNESCO World Heritage: Decision-Making, States Parties and Political Processes. International Journal of Heritage Studies, vol. 21, n. $^{0} 5$, pp. 423-40

- Meskell, L. (2013) UNESCO's World Heritage Convention at 40: Challenging the economic and political order of international heritage conservation. Current Anthropology, vol. 54, n. ${ }^{\circ} 4$, pp. 483-494

- Meskell, L. (2014) States of conservation: Protection, politics, and pacting within UNESCO's world heritage committee. Anthropological Quarterly, vol. 87, n. ${ }^{0} 1$, pp. 217-243

- Montenegro Riveros, M. (2010) La patrimonialización como protección contra la mercantilización: paradojas de las sanciones culturales de lo igual y lo diferente. Revista Colombiana de Antropología, vol. 46, n. ${ }^{\circ}$ 1, pp. 115-131

- Noyes, D. (2011) La fête ou le fétiche, le geste ou la gestion. Du patrimoine culturel immatériel comme effet pervers de la démocratisation. En: Bortolotto, Ch. (ed.) Le patrimoine culturel immatériel: enjeux d'une nouvelle catégorie. Paris: Éditions de la Maison des sciences de l'homme, 2011, pp. 125-148

- ONU [Organización de las Naciones Unidas] (2015) Transformar nuestro mundo: la Agenda 2030 para el Desarrollo Sostenible. Disponible en: https://unctad. org/meetings/es/SessionalDocuments/ares70d1_es.pdf [Consulta: 29/07/2021]

- Pavone, V. (2008) From the Labyrinth of the World to the Paradise of the Heart: Science and Humanism in UNESCO's Approach to Globalization. New York: Lexington

- Phillips, M., Page, S., Saratsi, E., Tansey, K., y Moore K. (2008) Diversity, scale and green landscapes in the gentrification process: Traversing ecological and social science perspectives. Applied geography, vol. 28, n. $^{\circ} 1$, pp. 54-76

- Poulot, D. (2006) Une histoire du patrimoine en Occident, XVIII-XIX siècle. Du monuments auX valeurs. París: Presses Universitaires de France

- Prats, L. (1997) Antropología y patrimonio. Barcelona: Ariel
- Quintero Morón, V. y Sánchez-Carretero, C. (2021) La salvaguarda del $\mathrm{PCl}$ : trenzando acompañamiento etnográfico y procesos participativos. En: Carrera, G. (ed.) La salvaguarda del patrimonio cultural inmaterial como acuerdo social. Sevilla: Instituto Andaluz del Patrimonio Histórico (en prensa)

- Quintero-Morón, V. (2009) Los sentidos del patrimonio. Alianzas y conflictos en la construcción del patrimonio etnológico andaluz. Sevilla: Fundación Blas Infante

- Quintero-Morón, V. (2020) La participación en patrimonio y sus protagonistas. Límites, contradicciones y oportunidades. Revista $\mathrm{PH}, \mathrm{n}^{\circ}{ }^{\circ}$ 101. Disponible en: https://www.iaph.es/revistaph/index.php/revistaph/article/ view/4687 [Consulta: 29/07/2021]

- Quintero-Morón, V. y Sánchez-Carretero, C. (2017) Los verbos de la participación social y sus conjugaciones: contradicciones de un patrimonio democratizador. Revista Andaluza de Antropología, vol. 12, pp. 48-69

- Roigé, X. y Frigolé, J. (ed.) (2010) Constructing cultural and natural heritage. Parks, Museums and Rural Heritage. Girona: Institut Català de Recerca en Patrimoni Cultural

- Sánchez-Carretero, C. (2017) Hacia una antropología de conflicto aplicada al patrimonio. En: Santamarina Campos, B. (coord.) Geopolíticas patrimoniales. De culturas, naturalezas e inmaterialidades. Una mirada etnográfica. Valencia: Neopatria, pp. 215-230

- Sánchez-Carretero, C. y Roura-Expósito, J. (2021) Participación: usos, límites y riesgos en los proyectos patrimoniales. En: Arrieta Urtizberea, I. y Díaz Balerdi, I. (ed.) Patrimonio y museos locales: temas clave para su gestión. Tenerife: PASOS, pp. 339-357

- Sánchez-Carretero, C., Muñoz, J., Ruiz, A. y Roura, J. (ed.) (2019) El imperativo de la participación en la gestión patrimonial. Madrid: CSIC

- Santamarina Campos, B. (2008) Moros y cristianos. De la batalla festiva a la discursiva. Gazeta de Antropología, 2008, vol. 24, n. ${ }^{0}$ 1. Disponible en: https://www.ugr. es/ pwlac/G24 16Beatriz Santamarina_Campos.html [Consulta: 29/07/2021]

- Santamarina Campos, B. (2009) De parques y naturalezas. Enunciados, cimientos y dispositivos. Disparidades. Revista de Antropología, vol. 64, n. ${ }^{\circ} 1$, pp. 297-324. Disponible en: https://doi.org/10.3989/ rdtp.2009.78 [Consulta: 29/07/2021]

- Santamarina Campos, B. (2013) Los mapas geopolíticos de la Unesco: entre la distinción y la diferencia están las asimetrías. El éxito (exótico) del patrimonio inmaterial. Revista de Antropología Social, vol. 22, pp. 263-286. Disponible en: https://doi.org/10.5209/rev_RASO.2013. v22.43191 [Consulta: 28/07/2021] 
- Santamarina, B. (2021) The Global Competition of the Intangible. UNESCO as a Producer of Heritage Brands. Heritage \& Society (en prensa)

- Santamarina, B. (2017) El patrimonio inmaterial en el país valenciano: una explosión muy tangible. Revista Andaluza de Antropología, n. ${ }^{\circ} 12$, pp. 117-143. Disponible en: http://dx.doi.org/10.12795/RAA.2017.12.06 [Consulta: 29/07/2021]

- Santamarina Campos, B. y Mármol, C. del (2017) Ciudades creativas y pueblos con encanto: los nuevos procesos patrimoniales del siglo XXI. Revista de Dialectología y Tradiciones Populares, vol. 72 , n. ${ }^{\circ}$ 2, pp. 359-377. Disponible en: http://dra.revistas.csic.es/index. php/dra/article/view/547 [Consulta: 28/07/2021]

- Santamarina, B. y Mármol, C. del (2020) Para algo que era nuestro... Ahora es de toda la humanidad: El patrimonio mundial como expresión de conflictos. Chungara. Revista de Antropología Chilena, vol. 52, n. 1, pp. 161-173

- Santamarina, B., y Mompó, E. (2021) The Political Opportunity of Heritage: Appropriations, Memories, and Identities in Cabanyal. Anthropological Quarterly, vol. 94, n. ${ }^{\circ} 1$, pp. 34-64

- Santamarina, B., y Vizcaíno, T. (2021) Consuming the past into the present: The case of the Iberians (Valencia, Spain). International Journal of Cultural Property, pp. 1-16. Disponible en: https://doi.org/10.1017/S0940739120000302 [Consulta: 29/07/2021]

- Smith, L. (2006) Uses of heritage. New York: Routledge

- Tauschek, M. (2013) The bureaucratic texture of national patrimonial policies. En: Bendix, R., Eggert, A. y Peselmann, A. (ed.) Heritage Regimes and the State. Göttingen: Universitätsverlag Göttingen, pp. 195-212

- Timothy, D.J. (2018) Making sense of heritage tourism: Research trends in a maturing field of study. Tourism Management Perspectives, n. ${ }^{\circ} 25$, pp. 177-180

- Tunbridge, J. y Ashworth G. (1996) Dissonant Heritage: The Management of the Past as a Resource in Conflict. New York: John Wiley \& Sons

- UNESCO [Organización de las Naciones Unidas para la Educación, la Ciencia y la Cultura] (2003) Convención para la Salvaguardia del Patrimonio Cultural Inmaterial. París, 17 de octubre de 2003. Disponible en: http://portal.unesco.org/ es/ev.php-URL_ID=17716\&URL_DO=DO_TOPIC\&URL_ SECTION=201.h̄tml [Consulta: 29/07/2021]

- Villasenor Alonso, I. y Zolla Marquez, E. (2012) Del patrimonio cultural inmaterial o la patrimonialización de la cultura, Cultura y representaciones sociales. Revista del Instituto de Investigaciones Sociales, vol. 6, n. ${ }^{\circ} 12$, pp. $75-$ 101
- Waterton, E. y Smith, L. (2010) The recognition and misrecognition of community heritage. International Journal of Heritage Studies, vol. 16, n. ${ }^{\circ}$ 1-2, pp. 4-15

- Winter, T. (2014) Beyond Eurocentrism? Heritage conservation and the politics of difference. International Journal of Heritage Studies, vol. 20, n. ${ }^{\circ} 2$, pp. 123-137 


\title{
Memoria e identidad de las comunidades portadoras en el desarrollo de buenas prácticas de salvaguardia del $\mathrm{PCl}$
}

\author{
María Pía Timón Tiemblo | Plan Nacional de Salvaguarda del Patrimonio Cultural \\ Inmaterial, Instituto del Patrimonio Cultural de España \\ Antonio Muñoz Carrión | Facultad de Bellas Artes, Universidad Complutense de \\ Madrid \\ URL de la contribución <www.iaph.es/revistaph/index.php/revistaph/article/view/4973>
}

\section{RESUMEN}

El artículo introduce la importancia de las comunidades portadoras en las manifestaciones culturales inmateriales, cuyo reconocimento por los grupos e individuos les otorga la dimensión identitaria. La propia definición que se hace de patrimonio cultural inmaterial en la Convención para la Salvaguardia del Patrimonio Cultural Inmaterial de la Unesco, 2003, incluye como premisa para que pueda ser considerado como tal, su reconocimentos por el colectivo, lo que coloca a quienes hacen posible este tipo de patrimonio vivo del lado de los sujetos activos de su producción.

Esta doctrina ha contribuido a que las distintas administraciones tengan en cuenta a dichos colectivos. En este sentido se mencionan normas, como la Ley 5/2016, del patrimonio cultural de Galicia y la Ley 18/2019 de salvaguardia del patrimonio cultural inmaterial de las Illes Balears, en las que el reconocimiento de los portadores se concreta en la participación en los órganos de gestión. Y se profundiza en ejemplos de buenas prácticas en los que los portadores vivos de las manifestaciones que han sido capaces de transmitirlas y hacerlas viables para que en la actualidad puedan ser celebradas.

\section{Palabras clave}

Buenas prácticas | Comunidades | Identidad | Memoria | Participación | Portadores | Patriminio cultural inmaterial (PCI) | Salvaguardia | 


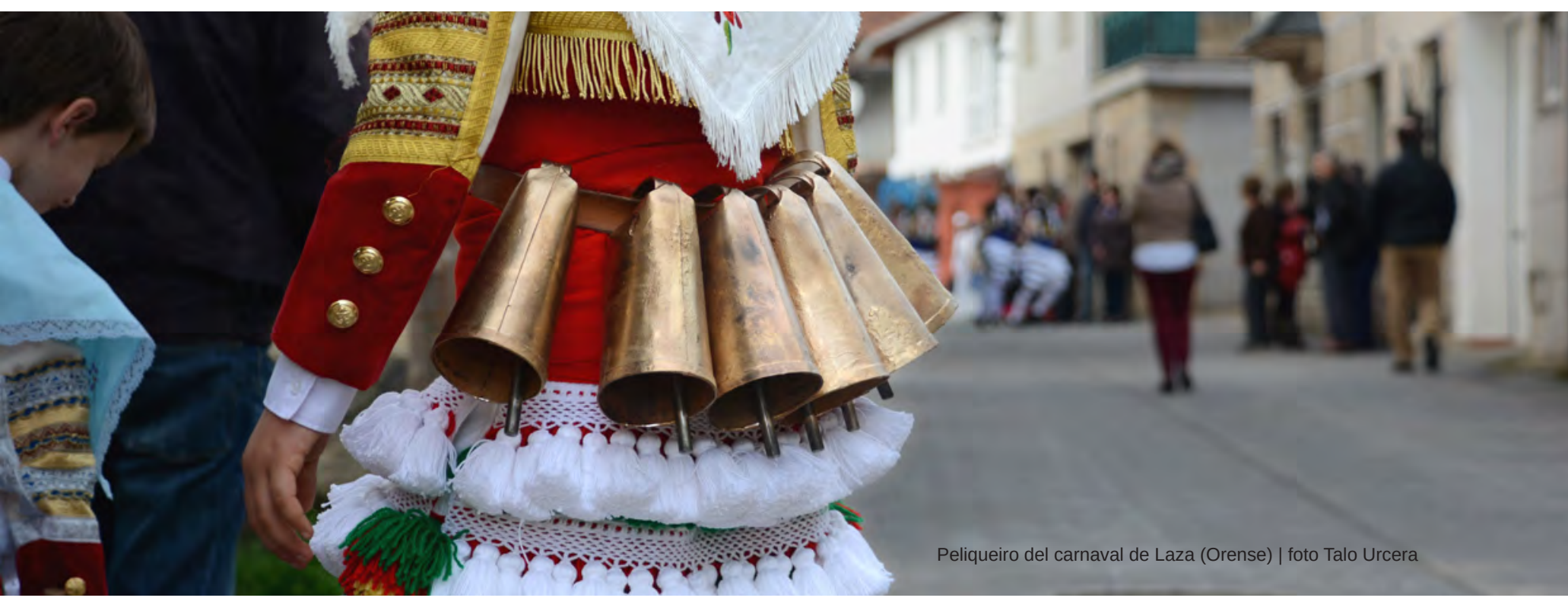

\section{Memory and identity of the bearers communities in the development of good practices to safeguard the $\mathrm{ICH}$}

\section{ABSTRACT}

The article introduces the importance of communities as the bearers in intangible cultural manifestations, which obtain their identity dimension when they are recognized by the community.. The definition of intangible cultural heritage in the Unesco Convention for the Safeguarding of the Intangible Cultural Heritage (2003) includes as a premise that cultural heritage must be recognized by the collective. In this sense, the community that makes living heritage possible is considered an active subject of its production.

This doctrine has contributed to the administrations taking these groups into consideration. The article mentions regulations, such as Law 5/2016, of the cultural heritage of Galicia and Law 18/2019 of the safeguarding of the intangible cultural heritage of the Balearic Islands, in which the recognition of the bearers is specified in the participation in the governing bodies. In addition, examples of good practices are mentioned in which the living bearers of the intangible cultural heritage have been able to transmit cultural manifestations and make them viable so that they can be celebrated today.

\section{Key words}

Good practices | Communities | Identity | Memory | Participation | Intangible cultural heritage | Safeguard |

Cómo citar: Timón Tiemblo, M.P y Muñoz Carrión, A. (2021) Memoria e identidad de las comunidades portadoras en el desarrollo de buenas practicas de salvaguardia del PCI. Revista PH, n. ${ }^{\circ}$ 104, 2021, pp. 78-102 <www.iaph.es/revistaph/index.php/revistaph/article/view/4973> DOI 10.33349/2021.104.4973

Enviado: 02/06/2021 | Aceptado: 19/07/2021 | Publicado: 01/10/2021 


\section{COMUNIDADES PORTADORAS: LA RAZÓN DE SER DEL PATRIMONIO VIVO}

Las manifestaciones culturales inmateriales están estrechamente vinculadas con los sujetos portadores. La propia definición que se hace de patrimonio cultural inmaterial $(\mathrm{PCl})$ en la Convención para la Salvaguardia del Patrimonio Cultural Inmaterial de la Unesco (2003) incluye como premisa para que pueda ser considerado como tal, que las comunidades, los grupos y en algunos casos los individuos, es decir sus portadores, reconozcan estas manifestaciones como parte integrante de su patrimonio cultural, lo que le otorga esa fuerte dimensión identitaria. Esta nueva concepción, aceptada internacionalmente desde hace casi dos décadas, coloca a los que hacen posible este tipo de patrimonio vivo del lado de los sujetos activos de su producción.

Estas comunidades van a ser las que mantengan, transmitan, reconozcan, valoren y salvaguarden dichas manifestaciones como titulares y transmisoras de las mismas. De ellas ha dependido y dependerá el cambio o la permanencia en el tiempo de estas prácticas. De igual manera son las que, por otro lado, las recrean constantemente, capaces de autorregularlas y generar mecanismos de adaptación a entornos naturales, sociales, económicos, mediáticos, políticos, culturales e históricos siempre cambiantes e imprevisibles. A diferencia de otros tipos de patrimonio, incluso del etnográfico, el cultural inmaterial está vivo gracias a estas comunidades portadores que han sido capaces de conseguir que siga siendo viable, expresándolo y transmitiéndolo a las siguientes generaciones hasta hoy, lo que le confiere

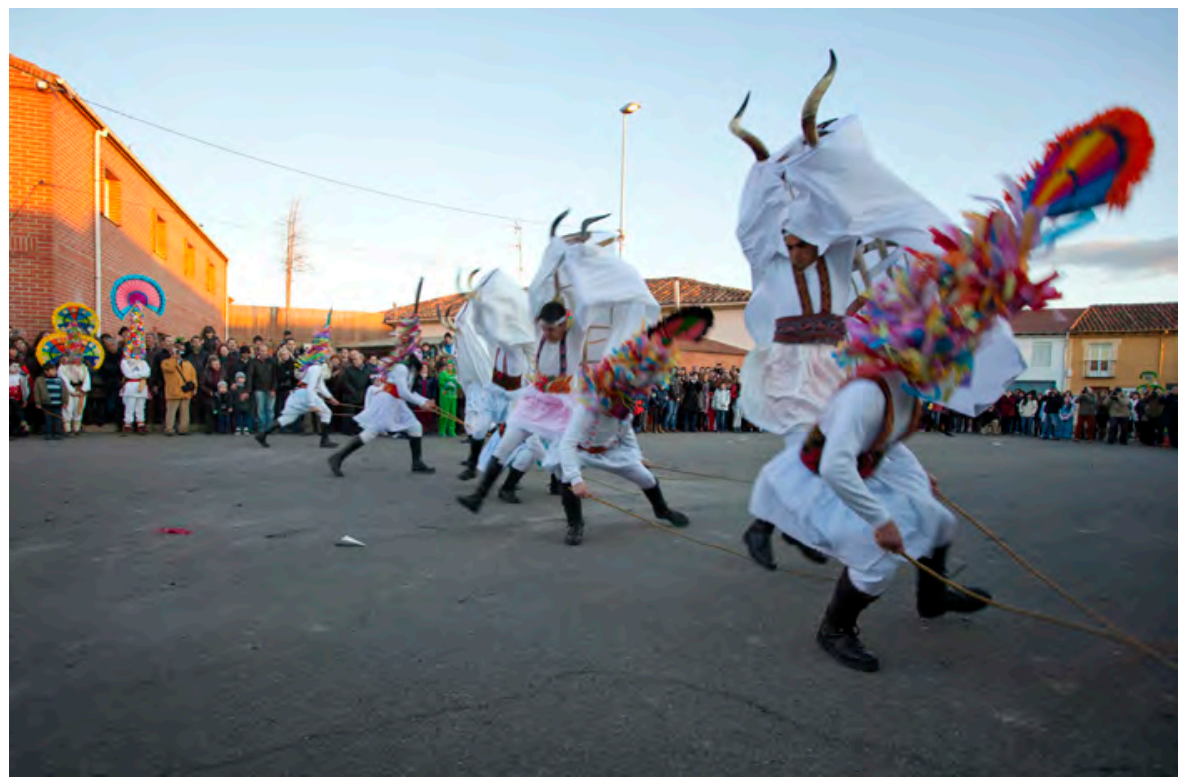


el carácter de continuidad y actualidad. De ahí que el patrimonio cultural inmaterial además de vincularse, al igual que el resto de los patrimonios, con los bienes muebles, inmuebles y conocimientos, se encuentre estrechamente unido, además de con la dimensión identitaria, con la emocional de los sujetos portadores, así como con la voluntad colectiva de permanecer en el tiempo.

El mantenimiento y viabilidad de este tipo de patrimonio se debe, por tanto, al esfuerzo organizado y continuado por parte de estos colectivos implicados, o de personas particulares, todos ellos portadores vivos de estas manifestaciones que han sido capaces de transmitirlo y hacerlo viable en un largo camino para poder ser en la actualidad celebrado, vivido o rememorado por todos.

\section{LA PARTICIPACIÓN ACTIVA DE LAS COMUNIDADES PORTADORAS EN LAS POLÍTICAS DE SALVAGUARDIA DEL PCI}

Si analizamos los documentos que forman parte de nuestro ordenamiento jurídico podemos comprobar que la vinculación de los portadores con la salvaguardia y gestión del patrimonio cultural inmaterial en los mismos es escasa y bastante reciente.

Considerando como aceptable el significado que tiene el concepto de salvaguardia en la Convención para la Salvaguardia del Patrimonio Cultural Inmaterial de la Unesco, con mayor rotundidad afirmaremos la fuerte relación que se establece y debe establecerse entre esas acciones propuestas con los portadores. El término "salvaguardia" se define en dicha Convención como "las medidas encaminadas a garantizar la viabilidad del patrimonio cultural inmaterial. Comprenden la identificación, la documentación, la investigación, la preservación, la protección, la promoción, el reconocimiento, la transmisión, la difusión y la revitalización de este patrimonio en sus diferentes aspectos". Huelga señalar la importancia que tienen en cada una de estas acciones las comunidades portadoras, es decir, aquellos grupos o personas que lo reconocen como parte integrante de su patrimonio cultural.

Además de la importancia conceptual que establece la Convención en este campo, no solo en cuanto a la definición de lo que es patrimonio cultural inmaterial y de lo que debe entenderse por salvaguardia, también avanza en otros aspectos. Si analizamos su artículo 11 veremos que, dentro de las funciones que se designan para los Estados Partes en el plano nacional, dice en su apartado a): "Adoptar las medidas necesarias para garantizar la salvaguardia del $\mathrm{PCl}$ presente en su territorio". Este será uno de los mandatos en los que se fundamenta el desarrollo del Plan Nacional de 
Museo del esparto. Cieza (Murcia) | foto Antonio Muñoz Carrión

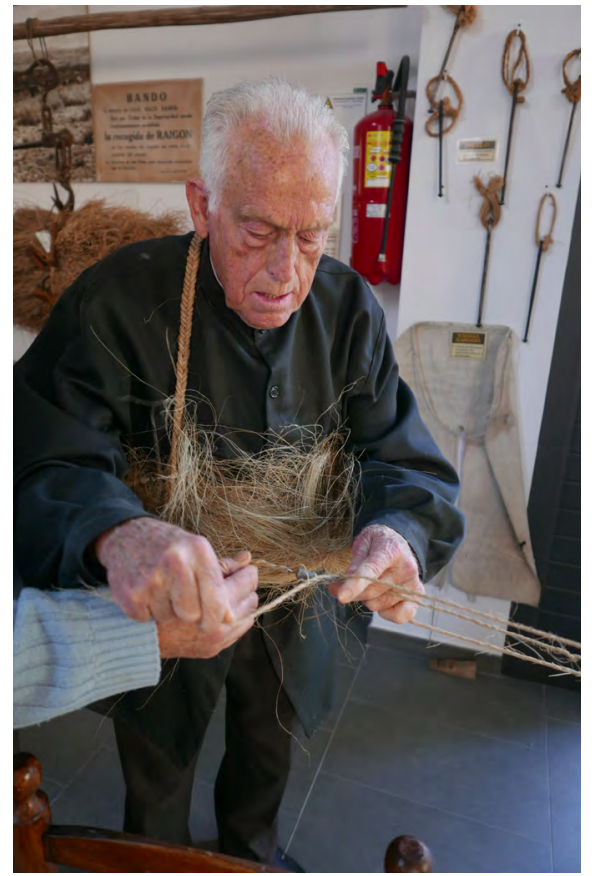

Salvaguardia del Patrimonio Cultural Inmaterial. En el siguiente epígrafe se pone de manifiesto la importancia de las comunidades portadoras en las acciones relativas a la identificación y definición de las distintas manifestaciones de un territorio (apartado b): "Identificar y definir los distintos elementos del PCl presentes en su territorio, con participación de las comunidades, los grupos y las organizaciones no gubernamentales pertinentes". Será en su artículo 15 donde se establezca la importancia de la participación de las comunidades, grupos e individuos portadores, no solo en las acciones de salvaguardia, sino también en la gestión de este tipo de patrimonio: "Cada Estado Parte tratará de lograr una participación lo más amplia posible de las comunidades, los grupos y si procede los individuos que crean, mantienen y transmiten ese patrimonio y de asociarlo activamente a la gestión del mismo".

Toda esta doctrina ha contribuido a que las distintas administraciones tengan en cuenta a dichos colectivos. Los formularios establecidos para valorar las candidaturas de inclusión en las Listas Representativas de Patrimonio Cultural Inmaterial de la Humanidad de la Unesco incluyen determinados epígrafes vinculados directamente con los portadores, e incluso determinan la forma de percepción de los mismos. De hecho, en este contexto se valora enormemente el número de asociaciones, colectivos y demás portadores, vinculados con el elemento, que apoyan dicha candidatura, así como si la iniciativa y propuesta parte estos agentes. Ocurre igual con la declaración de bienes culturales inmateriales, incluso con aquellos con categoría de "catalogados" por parte de las Comunidades Autónomas, o de "manifestación representativa" por parte de la Administración General del Estado. Para este último caso se prevé también el trámite de audiencia a las comunidades portadoras del bien en su proceso de tramitación. Incluso en cualquier tipo de incoación, para su declaración, se requiere la petición previa de las comunidades portadoras y organizaciones representativas del bien.

De la misma manera, se expresa en varios documentos españoles el protagonismo y la participación que deben desempeñar en la salvaguardia estas comunidades. La propia Ley de salvaguardia del Patrimonio Cultural Inmaterial 10/2015 así lo establece de manera genérica en su articulado, y en el propio documento del Plan Nacional de Salvaguardia del Patrimonio Cultural Inmaterial también se pone de manifiesto como premisa de partida.

En este sentido no podemos dejar de mencionar dos normas de gran interés: la Ley 5/2016, del patrimonio cultural de Galicia y la Ley 18/2019 de salvaguardia del patrimonio cultural inmaterial de las Illes Balears.

En ambas se establece que en la declaraciones de bienes de interés cultural inmaterial podrán identificarse y reconocerse, reflejándose en dichos expedientes de declaración a aquellas personas que sean significativas por su 
especial contribución y vinculación con la manifestación cultural inmaterial que se declara: maestros y maestras, sobre los que descargan la mayoría de los conocimientos; comunidades, los grupos de personas que mantienen vivas las expresiones del patrimonio cultural inmaterial; y aquellas organizaciones que tienen entre sus objetivos el mantenimiento, la transmisión y otras medidas de salvaguarda de ese patrimonio cultural inmaterial. Es palpable la implicación que se les otorga, tanto con el reconocimiento (por ejemplo el de maestros: maestro artesano de una determinada artesanía, maestro de la danza, de tal instrumento musical, etc.), como con la gestión y salvaguardia del mismo.

En estas normas la participación y reconocimiento va más allá en los bienes declarados de interés cultural inmaterial, como es la creación de órganos de gestión con representantes de sus portadores para garantizar su viabilidad y salvaguardia.

En las dos leyes se contempla que para cada bien del patrimonio cultural inmaterial que sea declarado de interés cultural podrá establecerse el reconocimiento o la creación de un órgano de gestión específico que, por resultar representativo de las comunidades y organizaciones reconocidas, esté legitimado para proponer y establecer las medidas que resulten más adecuadas para la salvaguardia y transmisión de sus valores culturales. No podemos olvidar, tal como venimos reiterando, que buena parte de los portadores (entre los que incluimos comunidades, grupos, organizaciones o personas) son los que conocen, valoran, recrean, actualizan y transmiten este patrimonio. Su voluntad es la condición para la continuidad y solo es posible si sus actores la mantienen operativa y garantizan su viabilidad. Por todo ello, consideramos importante la creación para los BIC inmateriales de un órgano de gestión, que incluya representantes de determinados colectivos o personas significativas por su especial contribución o vinculación con estos bienes, que esté legitimado para proponer acciones específicas de salvaguardia.

A estos órganos de gestión se les otorga con dichas normas una serie de funciones entre las que destacamos:

> La transmisión y difusión, entre las comunidades, asociaciones, organizaciones e instituciones, de las acciones y actividades desarrolladas o previstas, vinculadas con el bien.

> La monitorización del estado del bien y de sus valores culturales, así como la comunicación de las situaciones de riesgo o de las amenazas a que pueda verse sometido.

$>$ La propuesta de reconocimiento de maestros y maestras, comunidades u organizaciones en el ámbito del bien del PCl protegido.
Bica de nata del entroido de Laza (Orense) | foto Antonio Muñoz Carrión

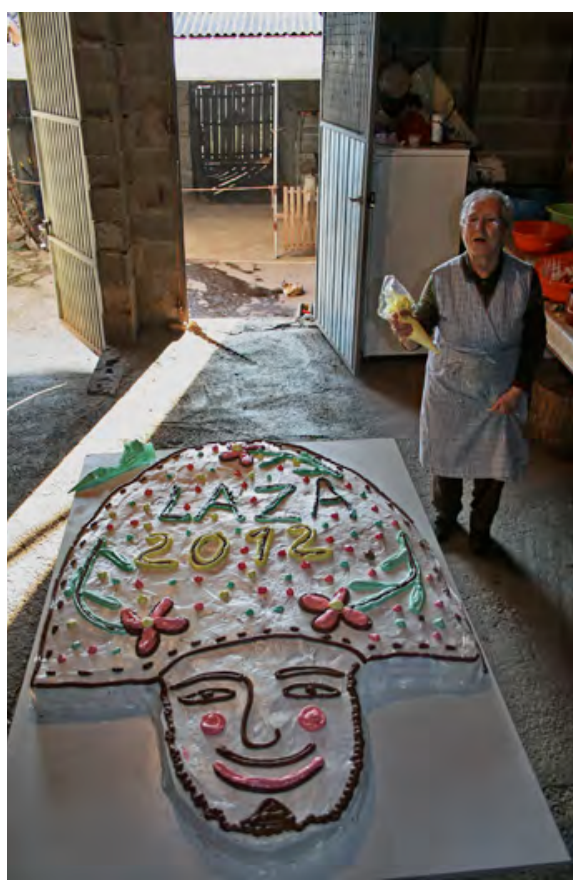


$>$ La realización de propuestas específicas de medidas de salvaguarda

Señalamos el ejemplo específico de Galicia, donde son declaradas BIC las técnicas constructivas de la carpintería de ribera (Decreto 52/2019, de 9 de mayo) por ser una manifestación del patrimonio cultural inmaterial vinculada fuertemente con las comunidades marineras y las fluviales.

En la propia justificación de la incoación se resalta la importancia de las comunidades: "desarrollaron unos conocimientos y unos procesos propios y originales que variaron en el tiempo, depurándose y adaptándose a diversas circunstancias, siendo el resultado de la experiencia de sus constructores y de sus usuarios, de las condiciones del agua y de su función concreta, bien para la pesca, para el paso, para el transporte o para el ocio.... Este conjunto de saberes fue, y aún es, transmitido de forma tradicional, de generación en generación, de persona a persona. El saber de la carpintería de ribera, en la actualidad, es también la única herramienta para mantener vivas embarcaciones que pertenecen a la historia pasada y presente de las comunidades, de las personas y también de la propia navegación, y que no podrían seguir en uso y tener un futuro sin esos conocimientos".

Por otro lado se refleja en el expediente de la incoación la riqueza en Galicia de grupos y asociaciones que tienen entre sus objetivos la protección, mantenimiento y difusión de las embarcaciones tradicionales, de los barcos históricos y la cultura marítima y fluvial. Destacan la Asociación Galega de Carpintería de Ribeira (Agalcari), que reúne unos 20 astilleros y carpinterías de ribera, y a la Federación Galega pola Cultura Marítima e Fluvial (Culturmar), que agrupa unos 45 colectivos de dinamización cultural.

Es muy interesante cómo en dicho documento se reflejan las acciones de salvaguardia llevadas a cabo por estas entidades: las de inventario, difusión e investigación para recuperar embarcaciones; así como actividades y otras tareas de formación entre las que es necesario destacar las concentraciones, encuentros y regatas.

Siguiendo esta línea, no sorprende, por tanto, que en dicha manifestación se incluya para su salvaguardia el órgano de gestión referido, integrado por ocho o nueve miembros que acrediten su conocimiento de la materia. Uno de los objetivos es que los portadores de la manifestación ostenten una mayoría del total de los miembros de estos órganos.

Los integran dos personas en representación de los portadores y maestros carpinteros de ribera y otras dos en representación de los usuarios de las embarcaciones tradicionales. También un miembro del Colegio de Ingenieros Navales de Galicia y otro designado por Puertos de Galicia. De la misma manera una persona de prestigio reconocido en el campo de las técnicas 
constructivas de la carpintería de ribera y de las embarcaciones tradicionales, nombrada por la Dirección General del Patrimonio Cultural, y técnico de la Dirección General del Patrimonio Cultural, que ejercerá, al mismo tiempo, las funciones de secretariado y dará traslado a la Administración de la información que corresponda.

Queda claro que a partir de ahora resulta ineludible que las distintas normas y documentos, que se publiquen en España, vinculados con el patrimonio cultural inmaterial deben incluir formalmente la participación activa de los citados actores en los órganos de gestión.

En el caso de esta manifestación cultural de Galicia sabemos de las dificultades que inicialmente están teniendo para poner en práctica dicho mandato, pero esperamos que se superen y se pueda llevar a cabo esta ejemplar iniciativa para que sirva de referencia y contribuya a salvaguardar este patrimonio con la merecida participación de las comunidades portadoras.

\section{EJEMPLOS DE DISEÑOS DE BUENAS PRÁCTICAS DONDE LOS PORTADORES DE LA TRADICIÓN RECOBRAN EL PROTAGONISMO}

\section{Nuevas prácticas de un colectivo que desea renacer: los esparteros}

Como es sabido, la cultura del esparto y el oficio de los últimos esparteros comenzó su declive en España desde los años sesenta aproximadamente, a partir de la sustitución de esta fibra por el plástico, lo que redujo la venta y las exportaciones de objetos realizados con esta planta esteparia que prolifera en zonas de España y en los países del norte de África. Sin embargo, los saberes relativos a la espartería, como proceso de transformación artesana, han permanecido hasta hoy en la memoria viva de muchos ancianos y también las herramientas para su tratamiento, que constituyen por otra parte, un fabuloso patrimonio cultural industrial.

El mundo del esparto sufre en nuestros días un proceso de revitalización protagonizado por los que en su día fueron esparteros y que todavía son capaces de transmitir sus saberes, y también por grupos de personas que están reclamando el testigo de dichos conocimientos.

Hoy en día esta fibra natural tiene todavía multitud de usos y goza de enorme aceptación en una sociedad cada vez más ecologista, sin olvidar los beneficios demostrados de los espartizales ante el grave problema de la desertización y el cambio climático, ya que es una planta capaz de fijar los suelos y de sobrevivir en terrenos pobres y muy secos situados a nivel del mar, y en España hasta los 800 metros sobre el mismo. Quizás es única porque soporta unas temperaturas de entre $-20^{\circ} \mathrm{C} y+50^{\circ} \mathrm{C}$. Además, sus productos 


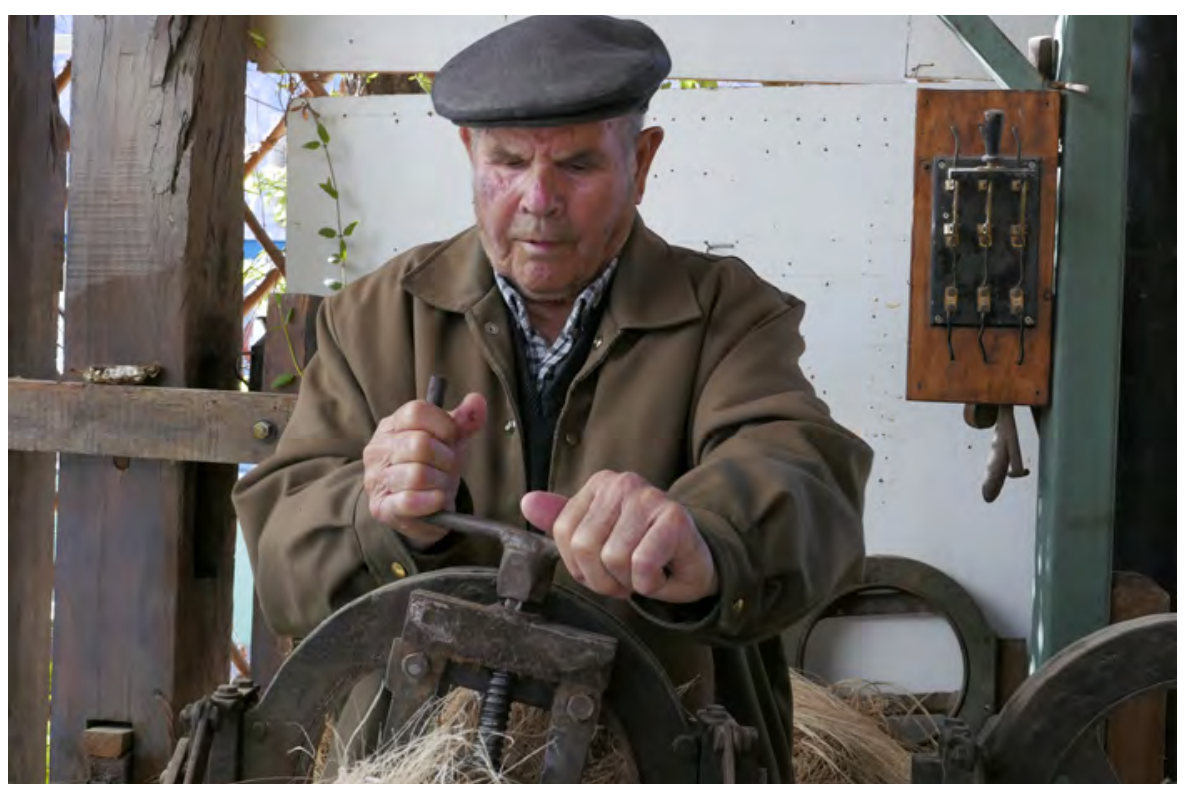

derivados son de larga duración, muy económicos y, sobre todo, biodegradables y no contaminantes.

Seleccionamos solo algunos casos representativos, de los muchos existentes en España, para mostrar cómo se están llevando a cabo acciones de recuperación del uso del esparto desde los propios conocedores y de los artesanos, que nunca han dejado de valorar y mantener vivos todos los conocimientos acumulados durante milenios.

En primer lugar, debemos mencionar el pueblo que más esparto facturaba en la década de los cincuenta y sesenta del siglo pasado, que es Cieza (Murcia), una comunidad que ha logrado abrir un museo vivo sobre esta temática, en donde se ha instalado la asociación de esparteros que movilizó a la población para que donasen desinteresadamente utensilios, maquinaria, fotografías antiguas y documentos que todo visitante puede contemplar. También han compilado cultura oral, con anécdotas y vivencias sobre este trabajo. El museo lo interpretan ellos mismos, realizando muestras de la mayor parte de los procesos. En sus instalaciones el visitante puede revivir estas técnicas ancestrales, pudiendo tocar las fibras u olerlas, aproximándose a esta planta no solo a través del conocimiento sino también de los sentidos.

Otro caso de custodia colectiva de los citados conocimientos tradicionales son los "corros", reuniones de personas de diferente sexo, edad y condición que, sentados en circulo, trabajan, aprenden y enseñan a trenzar el esparto y otras técnicas esparteras del proceso. Además de transmitir e intercam- 
biar los conocimientos de unos a otros los corros sirven para socializar. En estas reuniones y talleres se revitaliza la identidad del oficio de espartero, recordando el valor ecológico de esta fibra y facilitándose también la inclusión social. El resultado es que los interesados acaban conociendo y familiarizándose de nuevo con procesos como la recogida, el secado, el cocido, el picado, el tintado, el rastrillado, el ensamblaje y cosido de piezas. José Fajardo, en la Universidad Popular de Albacete, ha configurado un corro, el denominado Comando Pleita, que es el núcleo que moviliza diferentes talleres de enorme éxito.

También cabe destacar cómo trabaja otro corro, la Brigada de los 15 ramales, desde el Museo de la Biodiversidad de Ibi (Alicante), que ha llegado a lograr la participación en sus jornadas prácticas sobre esparto de 1800 personas, gracias a su motivación para difundir esta cultura y su apertura para compartir conocimientos que tradicionalmente se solían ocultar como secretos de esta artesanía.

Espartalacant es otro colectivo digno de mención por haber creado un Aula abierta, apoyada por el Ayuntamiento de Alicante, desde la que se revalorizan y difunden conocimientos a otros grupos de esparteros de esta cultura milenaria basada en tejer tanto crudo como en picado, y de hacerlo con técnicas tan diversas, como filet, cordeta, cincho, pleita, cofín, etc.

En Sesma el programa Landarte, apoyado por la artista Marijose Recalde y por el Servicio de Museos del Gobierno de Navarra, comenzó difundiendo

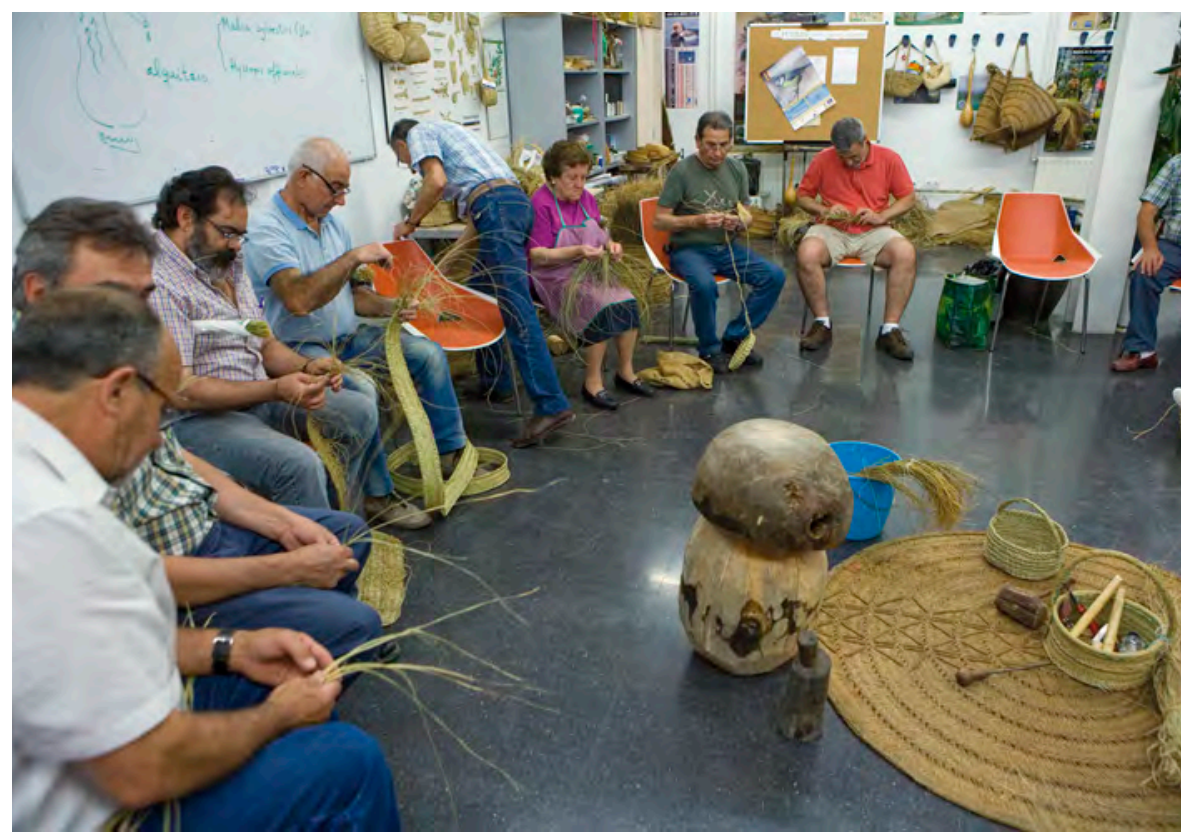




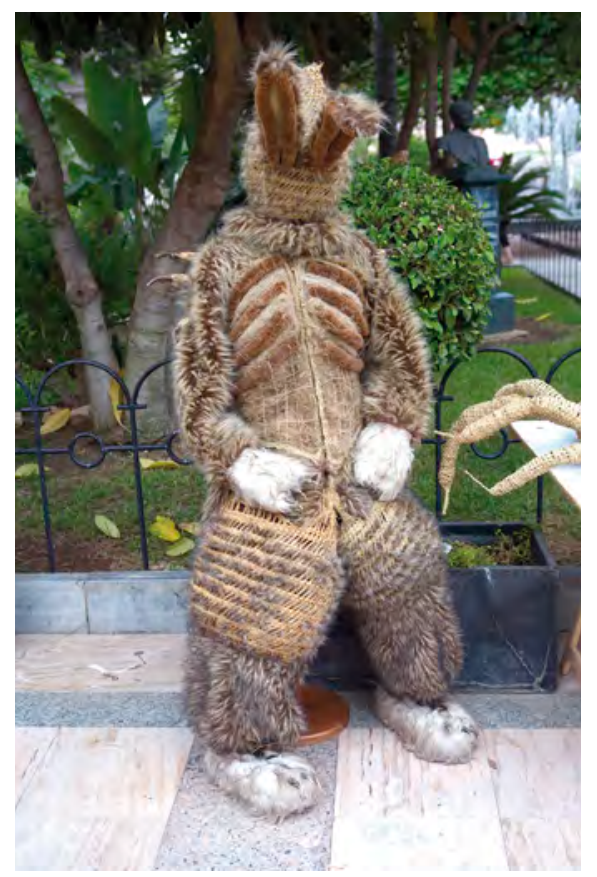

Mussona del carnaval de Águilas (Murcia) | foto Pascal Janin la relación entre el arte y la ruralidad para incluir finalmente otra dimensión sumamente interesante: la interculturalidad. En Sesma hay afincada una numerosa comunidad marroquí que conoce bien la cultura del esparto en su país y que se ha integrado en el programa intercambiando conocimientos con los vecinos sobre la misma fibra, pero desde otra tradición artesana diferente. El resultado de este proceso han sido nuevos proyectos, como la creación de estructuras livianas de uso práctico, articuladas incluso a otros materiales, toldos, cubiertas, sombrillas, etc. A su vez muchos de estos productos son utilizados en la romería de la virgen de Almuza, celebrada en junio, un recorrido milenario al que asisten centenares de romeros, con lo cual se están produciendo, además, sinergias importantes entre diversas manifestaciones del patrimonio local. Landarte se ha celebrado durante tres ediciones, pero ha quedado suspendido en 2020 y 2021 a causa de las normativas relacionadas con la COVID-19.

Otro caso interesante resultó de la invitación, a mujeres marroquíes, del etnógrafo, y mediador cultural en el seno de la cultura espartera, Pascal Janin (a quien agradecemos la inestimable información aportada para la descripción de estas buenas prácticas sobre el esparto) a participar en la fabricación de colmenas de esparto, cerrando así sistémicamente un ciclo natural en el que se vinculan dos mundos en peligro de extinción, el esparto y la supervivencia de las abejas, habiéndose creando de este modo un proceso de integración intercultural entre sesmeros y artesanas marroquíes.

Por último, cabe destacar otro proyecto protagonizado por la familia aguileña Román, los moris, y otros esparteros locales en Águilas (Murcia). Los moris han trabajado desde 1925 el esparto y hoy han hecho posible la recuperación de la técnica del hilado en crudo, gracias a que su familia la conocía e hilaba hasta los años 60 del siglo pasado para la flota y las redes de pesca. La familia Román llegó a exportar sus productos al País Vasco y Barcelona, e incluso a Inglaterra y Escocia, hasta que se impuso el plástico. La cordelería ha sido siempre un elemento fundamental para tareas relacionadas con la supervivencia humana y los moris han logrado recuperar, enseñar y difundir, entre alumnos y profesores de jardinería del IES Europa y otros interesados, al menos 15 tipos de cuerda diferentes apropiadas para usos específicos: grupias, libanés, calamentos de boya, malletas de barco, calabrotes, cuerdas de bol, ternas, fascal, caloma, etc.

\section{El proyecto participativo del Museo Transfronterizo de la Máscara Ibérica de Velilla de la Reina (León)}

El Ayuntamiento de Cimanes del Tejar tiene una población de 719 habitantes repartidos en seis pueblos, algunos de los cuales celebran el antruejo (carnaval), aunque es el de Velilla de la Reina el más reconocido y el que cuenta con una historia acreditada de continuidad durante siglos. Su celebración es 
una de las más arcaicas y reconocidas del noroeste peninsular. Esto significa que todas las generaciones que componen la comunidad han interiorizado el ritual y lo asumen en el ámbito familiar como un elemento identitario de la población. Desde la infancia, cada individuo aprende de los mayores a percibir no solo los momentos de la fiesta, sino la trastienda de la misma, en la que se han de preparar las originales máscaras usadas en el antruejo. En Velilla de la Reina la preparación del ritual se extiende a una gran parte del año, sobre todo a partir de Navidad, y existe una participación generalizada en la fiesta, lo que supone un proceso añadido de socialización.

Entablan esta relación con el diseño de la fiesta desde la infancia y, de manera diferencial, en cada edad, los individuos participantes interiorizan lentamente la manifestación y la hacen propia en todos los momentos de su ciclo vital. El resultado de todas las actividades relacionadas con la preparación de las máscaras, y también las de la escenografía de la fiesta durante el ciclo, no solo tiene como efecto la asunción colectiva del ritual final, sino que pone de manifiesto la relevancia de las actividades más insignificantes de la preparación, esas que no suelen ser recogidas en las crónicas ni en los documentales.

Precisamente por el valor que tiene el antruejo en esta zona, el Ayuntamiento de Cimanes del Tejar puso en marcha el proyecto de creación del Museo Transfronterizo de la Máscara Ibérica. En su primera fase se ha rehabilitado la antigua iglesia de San Pelayo, ubicada en Velilla de la Reina, un
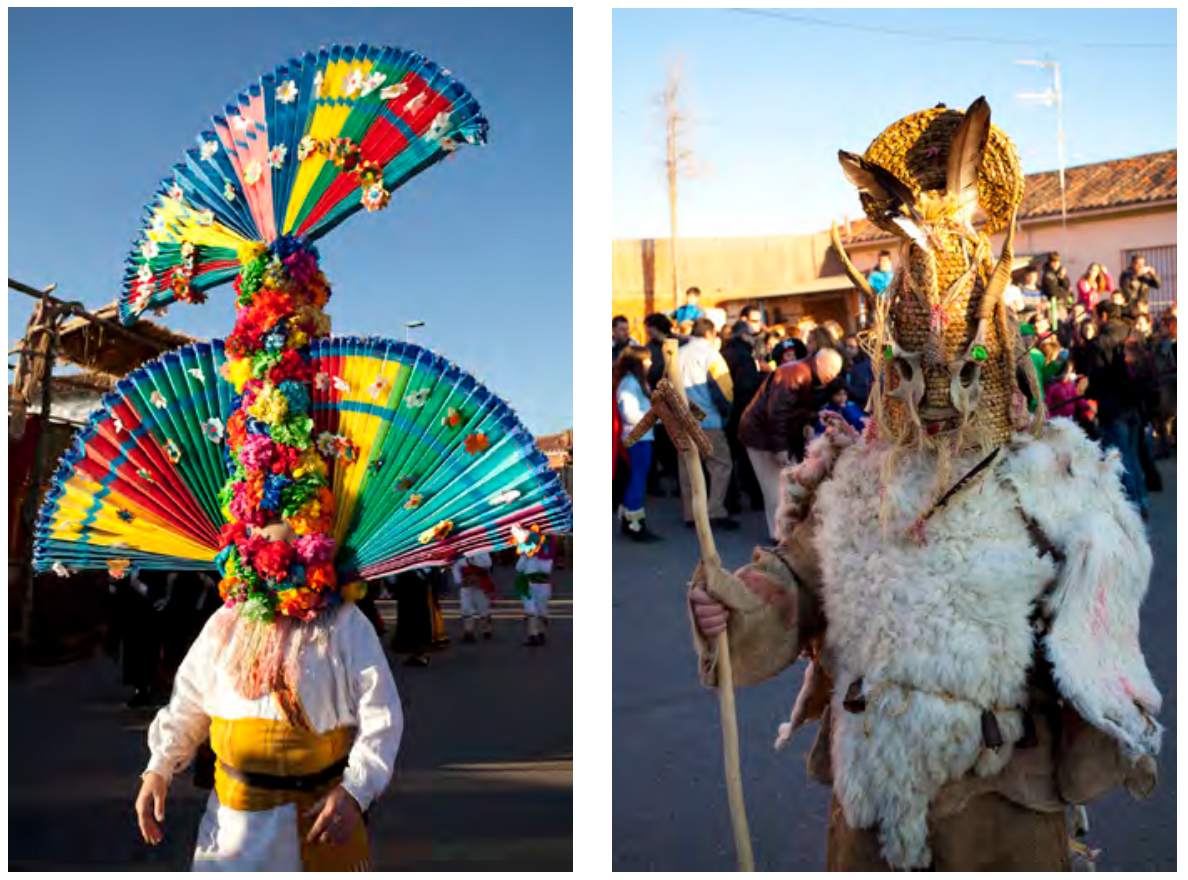


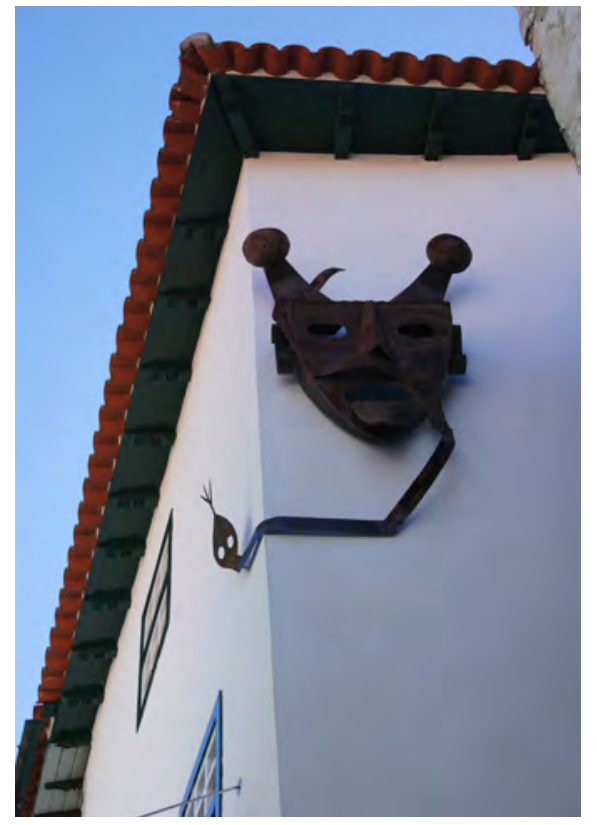

Museu Ibérico da Máscara e do traje en Bragança, Portugal. Fachada y detalle de máscaras | fotos David Samuel Santos

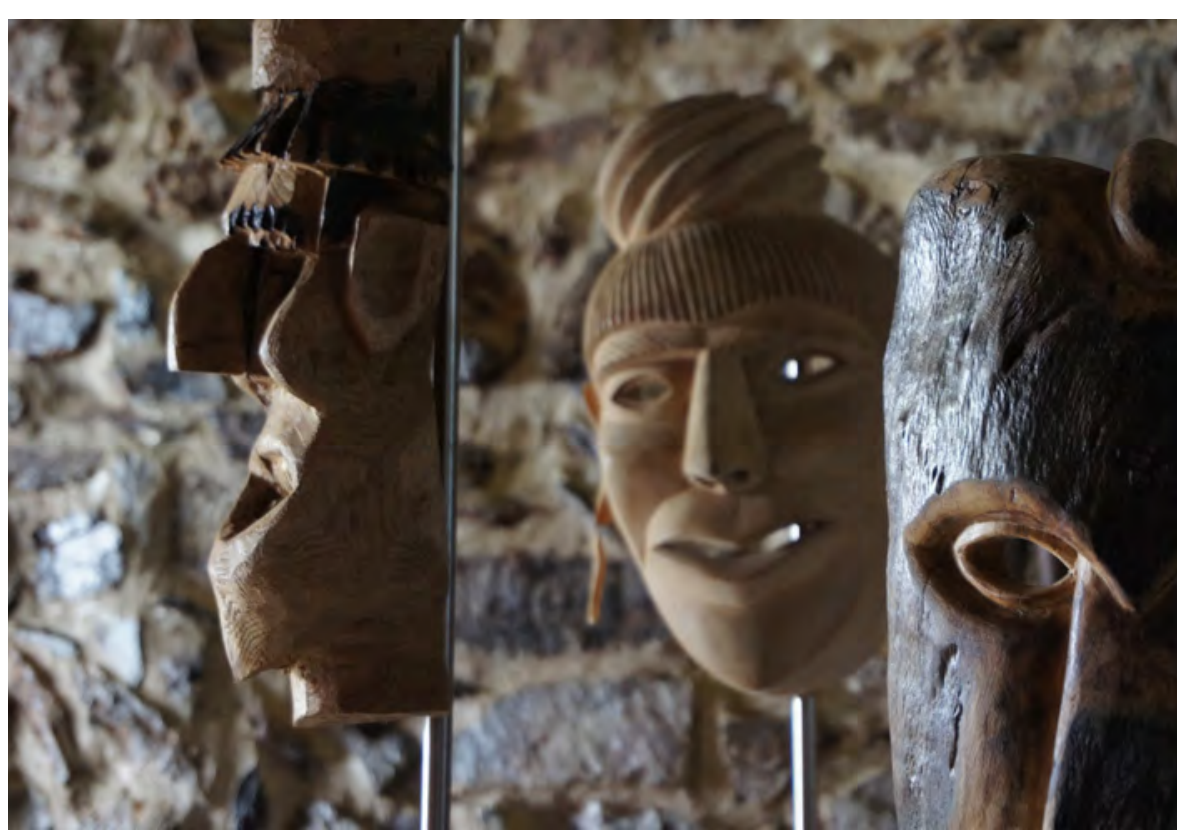

edificio de valor histórico cuyos orígenes datan de los siglos XII y XIII, pero que estaba en un estado casi ruinoso desde principios de los años ochenta del siglo XX. Gracias a una subvención del Instituto Leonés de Cultura se ha recuperado este espacio de unos 200 metros cuadrados. Velilla de la Reina instalará en su seno el Museo Transfronterizo de la Máscara Ibérica. La idea inicial es la creación de una red, a través de los portadores de esta tradición, que conecte los territorios del noroeste español que poseen estas manifestaciones festivas, especialmente Castilla y León (sobre todo León y Zamora) y Galicia (Orense) con el norte y centro de Portugal, estableciendo contacto permanente con el Museu Iberico da Mascara e do Traje en Bragança (Portugal).

El Ayuntamiento de Cimanes del Tejar se planteó, como parte fundamental del su plan museológico, qué tipo de museo interesaba al pueblo y cuáles eran los temas que los organizadores y participantes en la fiesta consideraban relevantes, por lo que se inició un proceso de planificación del museo basado en la participación social, contando con el asesoramiento de un equipo especializado en museos en donde estaban integrados antropólogos para el trabajo de campo y análisis de contenidos de la voz de los protagonistas del antruejo.

Las conclusiones a las que llegaron fue poner en marcha una investigación para estudiar las condiciones bajo las cuales la comunidad de Velilla de la Reina es la que decide qué desea mostrar en el museo. Este objetivo exigía que los habitantes de la comunidad, y sobre todo los participantes activos, 
estuvieran representados y construyesen parte del discurso museológico marco, a partir del cual se expresaría la narrativa local sobre la fiesta.

Dicha investigación fue financiada, a partir de las ayudas en régimen de concurrencia competitiva para proyectos de salvaguardia del patrimonio cultural inmaterial, por la Subdirección General del Instituto de Patrimonio Cultural de España, del Ministerio de Cultura y Deporte.

El título de este trabajo previo es: Proceso participativo para la investigación y posterior generación de contenidos sobre el Antruejo de Velilla de la Reina. Se encuentra en curso y está siguiendo tres líneas de acción:

$>$ En la primera fase se ha iniciado un inventario para recopilar de forma ordenada los registros orales y otra clase de documentación, en diferentes formatos, acerca de esta manifestación festiva. Las entrevistas y reuniones con grupos de la población han sido filmadas y quedan como referentes vivos para las futuras generaciones.

$>$ En la segunda, existe un proyecto en fase de diseño que establecerá una estrategia online que consiste en compartir el proceso de participación social, a la vez que se divulgan contenidos de la manifestación festiva, para que las personas relacionadas con esta fiesta tengan un espacio virtual donde seguir aportando información y dialogando entre ellas. Además se pretende construir una red de relaciones con otras comisiones y asociaciones de este tipo de rituales, que podrán seguir el desarrollo del proyecto desde cero, con el protagonismo de los participantes en esta manifestación festiva, estableciendo lazos permanentes entre los diferentes lugares que comparten la misma tipología de patrimonio inmaterial.

> Por último, la tercera línea de acción supone la traslación de la información extraída sobre la fiesta, tanto de fuentes secundarias como primarias, es decir, las voces vivas de la comunidad, al plan museológico primero y museográfico después.

En todas las líneas de acción se expresa la necesidad de que el proceso de creación de este museo tenga su origen y su desarrollo en la participación directa de los implicados en el antruejo a través de aportaciones espontáneas que se van registrando. El objeto final es establecer una metodología que desde el inicio sea compartida y se pueda convertir, eventualmente, en una referencia para futuros proyectos de musealización de patrimonio vivo en poblaciones con características similares, ya que, los problemas de los museos monográficos en el mundo rural suelen ser muy parecidos.

Sabemos que las manifestaciones del patrimonio cultural vivo exigen, por tradición, líneas de acción asignadas a grupos de edad y el problema de estas 
comunidades, sitas en la denominada España vaciada, es, desde la década de los ochenta del siglo $\mathrm{XX}$, la proliferación de personas mayores y muy mayores y la casi ausencia de generaciones jóvenes residentes en el pueblo.

A este sesgo poblacional hay que sumar, desde hace más de un año, las dificultades que comporta la pandemia de la COVID-19, lo que podría exigir cambios obligados en contra de la voluntad de los portadores de una tradición que se viene celebrando durante siglos. Por tanto, el hecho de recopilar toda la documentación dispersa y de custodiarla en el propio museo, e incluso compartirla en el futuro portal del Internet del museo, contribuirá a que sus participantes cuenten con el referente de lo que han deseado para su antruejo hasta este momento.

El nuevo museo se concibe como un lugar de encuentro de los participantes, y también de rememoración. Un museo inspirado en las motivaciones de sus protagonistas en el presente puede reforzar la conciencia colectiva local. Pero también creará un espacio para conocer y acceder a otros antruejos, entroidos, carnavales o fiestas de invierno, con los que se pretende establecer una red permanente de comunicación e interacción. El proyecto incluye compartir con los protagonistas de otras tradiciones similares toda la experiencia del diseño del nuevo museo, al que se pretende incorporar manifestaciones festivas del noroeste español, de manera que el proceso de desarrollo de esta institución estará abierto a crear una red tanto de manera física como online.

Los objetivos que persigue el Museo Transfronterizo de la Máscara Ibérica se sitúan en diversos niveles, no solo en el propio de la museología, también:

$>$ En primer lugar se ha promovido una reflexión por parte de los distintos portadores de la tradición acerca de qué quieren mostrar en el nuevo museo sobre su fiesta y qué otros rituales del noroeste peninsular formarían parte del mismo.

$>$ En segundo lugar, en un futuro próximo, se identificará qué papel pueden jugar el museo y sus tecnologías informáticas a la hora de establecer este intercambio entre los portadores de la tradición local y otros protagonistas de fiestas del ciclo de invierno afines a este patrón de celebración.

$>$ En tercer lugar, el trabajo de campo previo, realizado con metodologías cualitativas propias de la antropología, se convierte en el instrumento director a la hora de establecer el esquema de guión de contenidos basado en los intereses de los portadores de la tradición, que se incorporará al plan museológico y que servirá finalmente para elaborar el plan museográfico del futuro museo. 


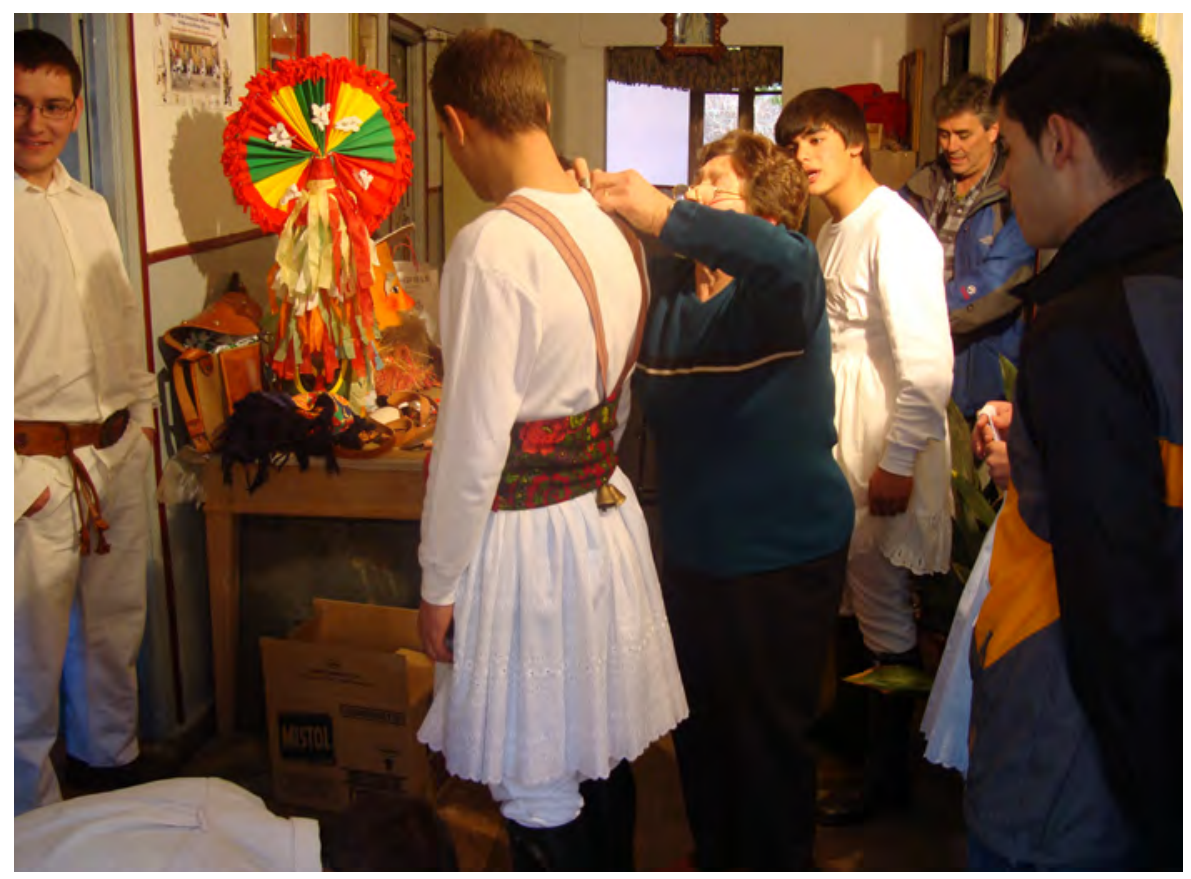

Antruejo de Velilla de la Reina (León) | foto Emiliano Blanco Fernández

La metodología cualitativo-participativas utilizada para dar voz a los habitantes del término municipal ha empleado las siguientes técnicas:

$>$ Entrevistas en profundidad a los protagonistas más destacados y valorados por los portadores de la tradición.

$>$ Reuniones de grupo semidirigidas con los organizadores más destacados de la fiesta y con personas mayores y jóvenes de ambos sexos.

$>$ Y finalmente, se ha recogido, de voz de los mayores, información exhaustiva de datos del proceso de preparación previo al ritual. Posteriormente se realizará esta misma actividad a propósito del propio ritual, para consignarla en los documentos que irá elaborando el museo de forma progresiva.

En paralelo en el proyecto está previsto que se realicen próximamente los trabajos para el diseño, la catalogación y gestión de inventarios de manera que se organice la citada documentación en diferentes formatos (fotografías, vídeos, escritos o testimonios orales). Además de estructurar un plan de contenidos online para la difusión.

En cuanto a la orientación de los contenidos, el proyecto pretende hacer aflorar, desde sus inicios, las temáticas más relegadas e incluso obviadas, que se consideran fundamentales para entender la dinámica de esta celebración anual y las funciones que cumple. La obsesión actual por recurrir a la cul- 


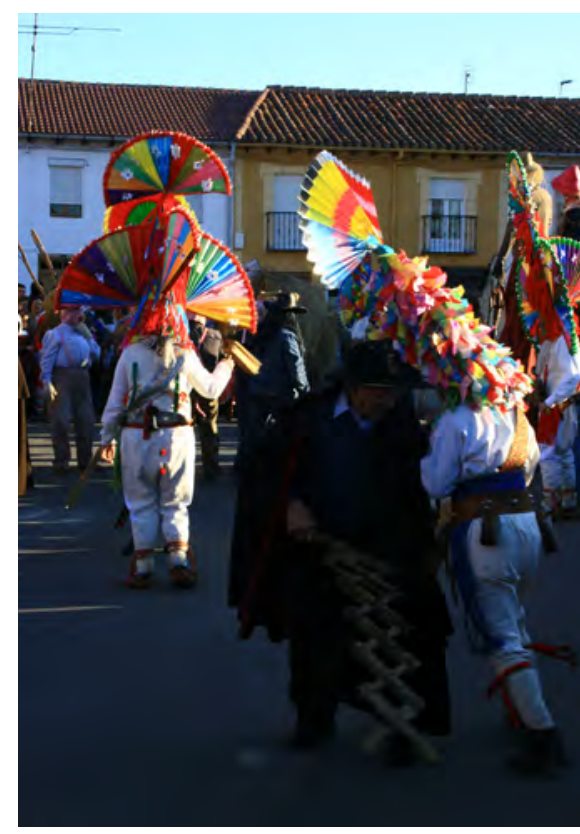

Antruejo de Velilla de la Reina (León) | foto Nuria Fernández Casaña tura del espectáculo en cualquier manifestación pública ha dejado de lado toda microactividad de carácter informal que no goce de suficiente visibilidad, aunque sea indispensable para la celebración. Esta es una carencia de muchos de los museos centrados en fiestas y rituales creados hasta la fecha.

El proyecto pretende considerar también, siguiendo la demanda de los protagonistas, las actividades llevadas a cabo "entre bastidores" durante el ciclo anual, y que son absolutamente indispensables para la celebración de la fiesta. Por tanto, se visibilizarán e integrarán en el relato museológico tanto los elementos materiales significativos como el propio trabajo organizado colectivamente o de forma individual, ya que ambos aspectos contribuyen a hacer del antruejo, y de otras manifestaciones festivas, una experiencia para los sentidos (sonidos especiales, sabores y platos culinarios propios de antruejo, etc.). También se registrarán sistemáticamente las actividades de difusión que los portadores del antruejo realizan a propósito de los elementos fundamentales de la fiesta en diversos lugares, como la asistencia a muestras de expresiones tradicionales de la cultura tradicional en Portugal, Bulgaria y en multitud de ciudades españolas.

Asimismo, se dará relevancia y se visibilizará a los protagonistas decisivos que hacen posible la celebración, aunque su participación se suela relegar tanto en los discursos museológicos como en los mediáticos. Estos "maestros" locales cumplen por su experiencia un papel fundamental en la transmisión generacional, aunque hoy se vea reducido al simple asesoramiento y no participen directamente en la fiesta. Igualmente, desde el momento de la recogida de sus voces, se ha destacado el trabajo "oculto" de la mayoría de las mujeres de todas las edades en la puesta en marcha de la celebración cada año.

Respecto a los públicos, en el Museo Transfronterizo los principales destinatarios son los propios portadores de esta tradición, que por primera vez dispondrán de un relato consensuado construido por ellos a partir de la ayuda que pueden proporcionar las técnicas cualitativas de investigación etnográfica.

También serán destinatarias fundamentales las instituciones que han contribuido a la creación del museo, con el objeto de que apoyen los intereses actuales de los protagonistas del antruejo.

Gracias a las conexiones online, y a la red que se establecerá para incorporar otras manifestaciones festivas a este museo, las instituciones museísticas interesadas y las comisiones de otras fiestas similares, serán igualmente destinatarias porque podrán acceder, tanto en línea como de forma presencial, a la especificidad de este antruejo, así como a la propia voz de sus protagonistas y participantes. El museo estará abierto y receptivo a toda aportación que, en esa misma línea, realicen los implicados en cualquier actividad relacionada con la fiesta. 
Por otra parte, los emigrados, oriundos de la zona, serán considerados destinatarios muy importantes porque podrán conocer, antes de retornar al pueblo cada año para la celebración, todas las decisiones, dificultades y expectativas de quienes llevan a cabo directamente la preparación del antruejo.

Lo mismo ocurrirá con los visitantes interesados, así como con todos los medios de comunicación (televisión, radio, prensa escrita...). De esta manera el público nacional o internacional que se acerque con curiosidad a contemplar el desarrollo de la fiesta, o quien visite el pueblo a lo largo del año, en los momentos que no hay fiesta, podrá acceder, a través del discurso museológico establecido, a lo que sienten y desean para su antruejo los y las protagonistas del mismo, lo que propiciará un conocimiento más profundo y sostenible de las manifestaciones festivas incluidas en el museo, así como un reconocimiento de la competencia comunicativa de los portadores de este patrimonio vivo.

\section{El entroido de Laza (Orense) y la forma de recuperar parte de su memoria colectiva a través de imágenes}

Otro caso, en proceso experimental en curso todavía, se refiere a la toma de conciencia histórica de una celebración caracterizada por su continuidad en el tiempo y que pretende reivindicar principalmente la visión y la memoria de los mayores, que hoy van quedando relegadas a causa de los rápidos cambios que sufren los rituales.

Las manifestaciones vividas bajo el orden ritual se derivan de experiencias que configuran un imaginario colectivo aprendido y sentido desde la infancia, compartido intergeneracionalmente y con reglas propias y autónomas reafirmadas en cada celebración, pero también en constante renovación creativa a instancia de sus protagonistas. Sin embargo, en ocasiones la narrativa colectiva tiene dificultades para establecerse.

La frase más repetida por los portadores de este tipo de tradiciones suele ser del tipo: "esta emoción que surge de la celebración no la puedo expresar con palabras, hay que vivirla y sentirla para poder entenderla, hay que ser de aquí". Esa confrontación entre la experiencia colectiva interior y la imagen e interpretación posterior suele desdibujarse con el tiempo. Se trata de invocar el proceso festivo desde el recuerdo provocado por imágenes del mismo.

La práctica que se ha llevado a cabo con una comunidad, a propósito de su fiesta más importante, ha sido diseñada y creada respondiendo a una demanda formal e informal de algunos de sus portadores, $y$ ha tenido como consecuencia el reencuentro de los protagonistas consigo mismos a través de la rememoración de periodos anteriores identificados por su cronología. 
El ejercicio se ha realizado entre agosto de 2018 y mayo de 2021 con los vecinos de Laza (Orense) a propósito de su entroido, que es como denominan su fiesta de carnaval, una de las más ancestrales de España. La hipótesis inicial bajo la que este proyecto se diseñó, en contacto con miembros de la asociación que organiza el entroido y otros vecinos significativos, se centró en la recuperación visual de momentos festivos del pasado. Muchos mayores de la comunidad sabían que existían miles de fotografías sobre su fiesta que habían sido realizadas desde hacía muchos años. Deseaban acceder a esas imágenes para compartirlas con sus hijos y nietos, para redescubrir lo que ellos casi habían olvidado y los más jóvenes ignoraban.

La experiencia comenzó con la restitución a la comunidad de miles de fotografías realizadas en los días de celebración desde finales de los años setenta del pasado siglo, cuando el entroido no era apenas visitado y solo lo celebraban entre los miembros de la comunidad y sin apenas miradas exteriores. Las fotografías plasman escenas que muchos desconocían por no haberlas presenciado o por no recordarlas, y actos protagonizados por personas significativas que ya no viven.

Dichas imágenes dan cuenta de momentos especiales de la preparación de todo tipo de críticas grotescas, de actividades diversas, individuales o colectivas, en la plaza pública, etc. La trama entre bastidores y los actos llevados a la plaza del pueblo cada año han sido registrados durante todo ese tiempo en más de 3000 diapositivas y en 50 películas filmadas en Super 8, en color, donde han quedado fijadas las peculiaridades de la fiesta a lo largo del ciclo de vida de casi tres generaciones de habitantes del pueblo.

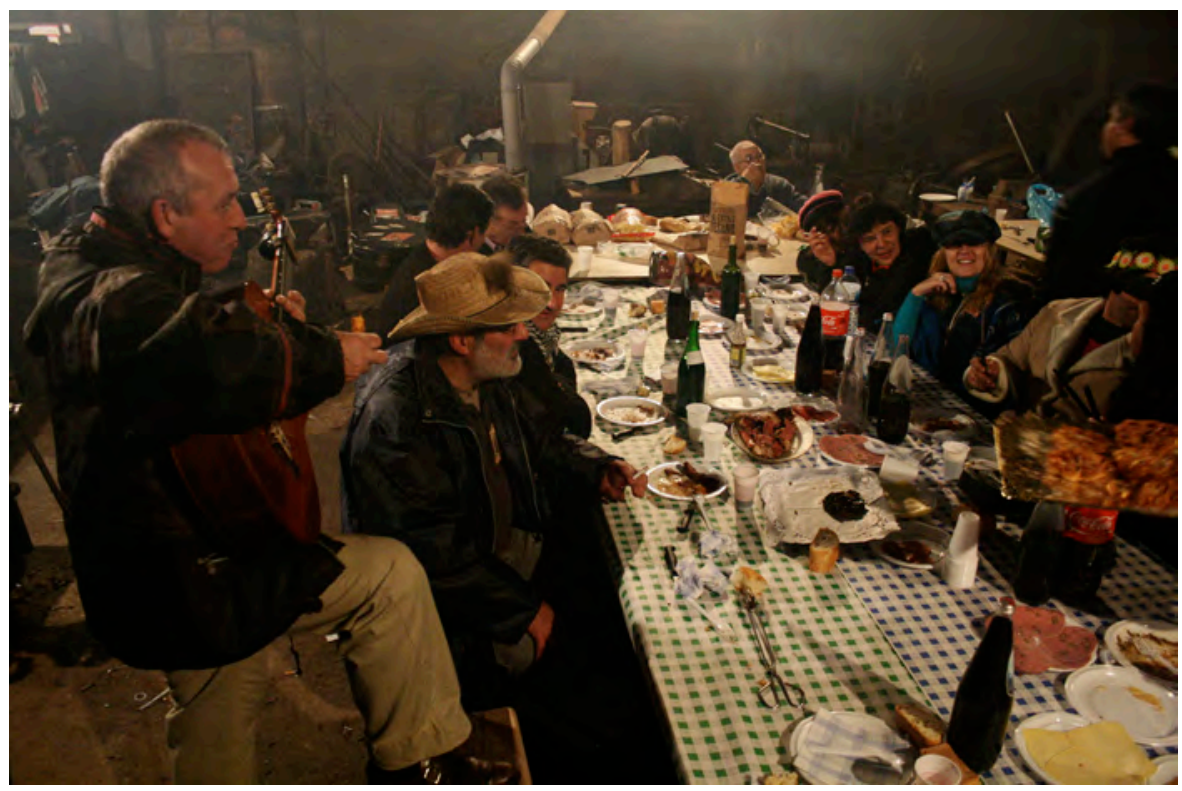


Por tanto, en este momento, en el pueblo de Laza cada vecino con acceso a Internet cuenta con un banco de imágenes referidas a lo sucedido en su plaza pública durante el entroido en los últimos 43 años, aunque haya también imágenes anteriores a esa fecha proporcionadas por los propios vecinos que han acabado participando en ese proyecto.

Obviamente, la experiencia empezó a arrojar sus frutos desde el principio, pero poco a poco se han ido elaborando respuestas e interpretaciones con la perspectiva temporal. Tras el largo periodo que media entre las celebraciones registradas en las primeras fotografías y el momento presente, quienes fueron sus protagonistas y espectadores han acabado reparando hoy en muchos detalles fotografiados entonces, y lo han hecho de manera peculiar y renovada, con la perspectiva del presente, que siempre es diferente a la del pasado. Ciertamente, lo que entonces no se supo apreciar o no se le otorgó significación por la propia inmediatez, desde el presente y al hilo, tanto de los cambios introducidos en la fiesta como de lo que sigue permaneciendo, los vecinos del pueblo han podido tomar conciencia de muchos de los motivos profundos que los han impulsado durante este largo periodo a mantener siempre viva su celebración, aun en aquellas condiciones de enorme penuria y de desajuste demográfico producidas por la emigración de los jóvenes.

Para llevar a cabo la práctica, en el verano de 2018 el autor de las diapositivas y películas, tras el acuerdo con miembros de la asociación del entroido y de vecinos implicados en tema, que habían expresado su deseo de recuperar todo ese material, se anunció una proyección de 700 imágenes

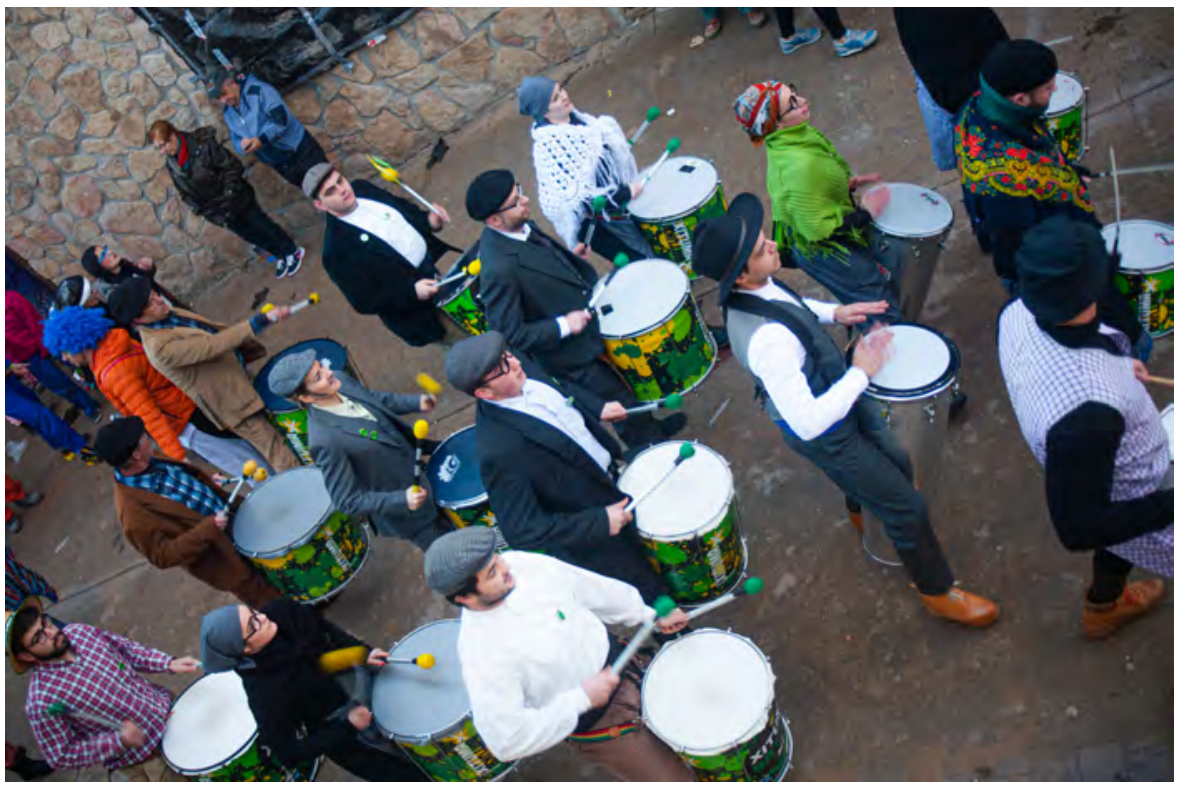

Banda de tambores llegando a la plaza de Laza (Orense) durante el Entroido | foto James Davis 
del periodo señalado en la plaza pública del pueblo, explicando a los asistentes que todas ellas se devolverían progresivamente, tras ser digitalizadas. El canal a través del cual se han devuelto ha sido un grupo cerrado de Facebook creado para este fin, cuyo nombre es Laza: Entroido de mi memoria (con 1246 miembros). Desde 2018 hasta abril de 2021 se han publicado unas 25 imágenes semanales o una película de Super 8 de unos tres minutos. Para el citado acto público, y gracias a la colaboración del Ayuntamiento que proporcionó el aforo de la plaza y las sillas para centenares de asistentes y cortó a el fluido eléctrico para la correcta visualización, se llevó a cabo la presentación de una pequeña parte del material visual causando en los asistentes un gran impacto emocional. Las imágenes procedían del archivo de la tesis doctoral de Antonio Muñoz Carrión, iniciada en 1977. Tras dos años y ocho meses de devolución semanal de dichas imágenes a través de la citada red social, todos los lazanos, sus familiares, y los amigos, tanto los que viven en el pueblo como los que no, cuentan ya con dicho material.

Los resultados del proyecto están siendo de orden muy diferente. En primer lugar, se ha logrado la rememoración colectiva del pasado por parte de los vecinos y la visualización por los jóvenes de cómo era la fiesta antiguamente. Muchos lazanos han quedado sorprendidos al contemplar los escenarios de celebración y su transformación en el tiempo. Han identificado el estado urbanístico del pueblo en el que vivieron y sus cambios durante el periodo, han ahondado en su propia kinésica y proxémica, en sus atuendos y vestimentas, en sus propias modalidades de acción, en el ritmo de la fiesta,

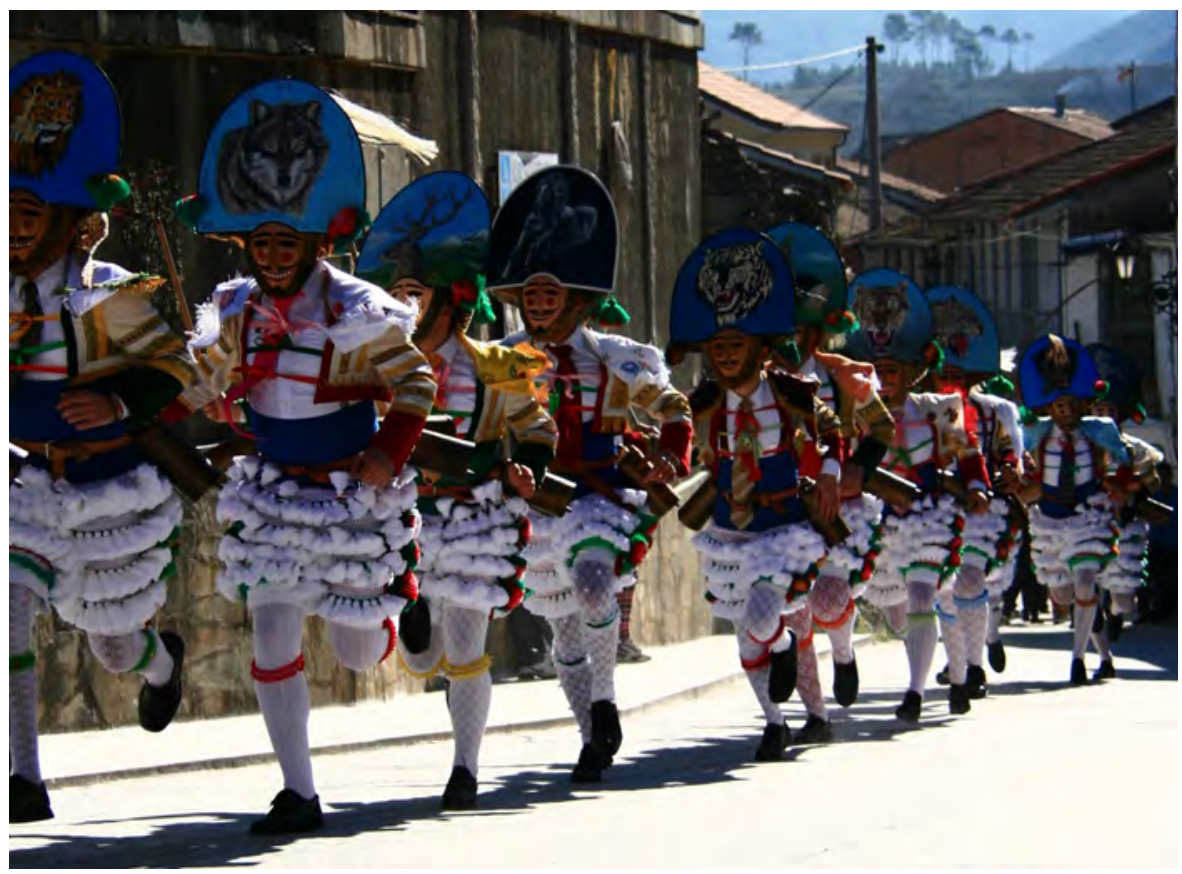


etc. En las primeras imágenes las calles eran de barro, los participantes solo contaban con elementos básicos usados y viejos, pero que eran preparados con enorme creatividad. Muchos participantes adultos, que eran niños entonces, pueden ahora reconocer y contemplar a sus padres, abuelos, y familiares ya desaparecidos, protagonizando gestas creativas inimaginables para ellos desde el día de hoy, de las cuales tenían solo una vaga idea producida por relatos orales.

Los participantes en el entroido han logrado calar, gracias a la mirada desde la distancia temporal, en el espíritu grotesco y crítico de las temáticas parodiadas y comprenderlas en relación a los aconteceres históricos, sociales y políticos relativos a cada momento de celebración en los que se crearon y vivieron. Los cambios, imperceptibles para los participantes, ahora, desde la perspectiva del tiempo, y gracias a la secuencia temporal de las imágenes, han sido percibidos, identificando en ellos cambios acerca de lo que era básico y está anclado a la fiesta y lo que es accesorio y por ello se ha ido transformando sutilmente.

La participación de los lazanos ha sido generalizada, tanto por parte de los residentes en el pueblo como de los emigrados a diferentes partes de España, de Europa y hasta a países americanos. Algo muy importante de esta práctica es que algunos vecinos se han animado a compartir en ese grupo imágenes inéditas de sus álbumes de familia. Otros han realizado comentarios sobre detalles desconocidos o casi olvidados de la celebración, que han sorprendido a muchos habitantes del pueblo, especialmente a los más jóvenes.

Estos resultados, y otros que siguen apareciendo todavía, han reforzado la identidad intergeneracional y local $\mathrm{y}$, gracias al material recién restituido y compartido, se ha incrementado la toma de conciencia de su propia especificidad. Se ha creado un foro colectivo y activo de informaciones, interpretaciones y respuestas emocionales, que queda plasmado públicamente en Facebook y que está renovando los valores que subyacen a esta tradición.

A este proyecto de devolución de imágenes a sus legítimos propietarios solo se han unido cinco fotógrafos profesionales o semiprofesionales, externos a la comunidad, que también han publicado fotografías y vídeos en el citado grupo de Facebook.

Las muestras de satisfacción y de agradecimiento por parte de los habitantes, a través de sus comentarios a las imágenes y de los likes, expresa públicamente y con sus propias palabras y en su propia lengua, infinidad de matices sobre sus sentimientos. Por ejemplo, esto se aprecia en muchas imágenes en que aparecen las mujeres y sus formas de participación, muchas veces

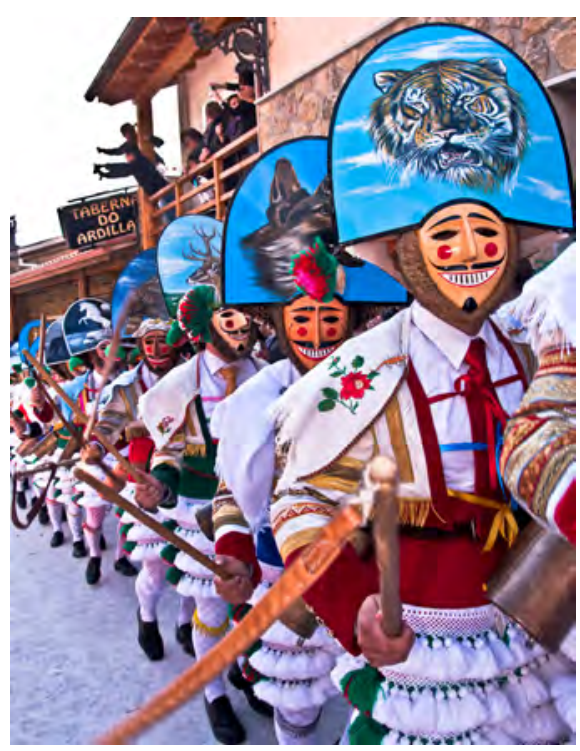

Entroido de Laza | foto Foxspain 
"entre bastidores" durante décadas pasadas, y que ahora se visibilizan gracias a las imágenes recuperadas.

La práctica arroja también como primer resultado provisional la satisfacción y emoción, sin reservas, de todos los protagonistas respecto a su patrimonio vivo. También demuestra el deseo de recuperar el material registrado en su día por los de fuera de la comunidad, con o sin permiso, ya que les permite seguir reinterpretando el sentido de su celebración desde un punto de vista renovado. Asimismo, los comentarios en Facebook dejan constancia por escrito, en gallego generalmente, de una enorme diversidad de matices sobre las vivencias derivadas de los temas, gestos y acciones ahora conocidos por todos, así como del consenso entre los participantes en relación a su identificación con la fiesta. Supone, por último, una nueva forma de toma de conciencia, por parte de los portadores y participantes de la celebración, que refuerza los lazos en la actualidad y expresa la voluntad de permanecer unidos en relación a dicho patrimonio vivo.

\section{CONCLUSIONES}

Es evidente que el patrimonio cultural inmaterial está vivo gracias a las comunidades portadoras que han sido capaces de conseguir que siga siendo operativo, viable e identitario. Ellas lo han mantenido, lo han recreado y autorregulado en función de las nuevas exigencias de su comunidad, lo han valorado y lo han transmitido y salvaguardado. Es por ello que en las últimas décadas, tanto los documentos internacionales como los de nuestro ordenamiento jurídico interno, han puesto de manifiesto la importancia de los portadores, no solo por su vinculación con estas manifestaciones culturales inmateriales, sino como colectivo que debe estar implicado en las acciones de gestión y salvaguarda de este tipo de patrimonio.

La Convención de la Unesco de 2003, la Ley de Salvaguardia del Patrimonio Cultural Inmaterial 10/2015, el Plan Nacional, así como los procedimiento de declaración e inclusión de este tipo de bienes en inventarios, catálogos o listas representativas establecen determinados epígrafes vinculados directamente con estos portadores, valorándose enormemente el número de asociaciones y colectivos implicados con el elemento que apoya dicha declaración o candidatura, así como si la iniciativa y propuesta parte de ellos.

En este sentido resaltamos dos normas de gran interés es España, siguiendo la doctrina de la Convención: la Ley 5/2016, del patrimonio cultural de Galicia y la Ley 18/2019 de salvaguardia del patrimonio cultural inmaterial de las Illes Balears. En ambas se establece que en las declaraciones de bienes de interés cultural inmaterial podrán identificarse y reconocerse a aquellas personas que sean significativas por su especial contribución y vinculación con 
la manifestación cultural inmaterial que se declara: maestros y maestras, los grupos de personas que mantienen vivas estas expresiones y las organizaciones implicadas. Esta participación y reconocimiento va más allá, con la creación de órganos de gestión en dichas administraciones donde se incluye a representantes de los portadores para garantizar de manera más directa la viabilidad y salvaguardia del bien.

Son muchos los grupos de portadores de distintas manifestaciones de patrimonio cultural inmaterial a lo largo del territorio español que están desarrollando iniciativas de buenas prácticas que contribuyen al disfrute, perpetuación y difusión de las mismas. Los tres casos citados en estas páginas comparten el hecho de que son grupos de personas quienes tomar la iniciativa, para conocer una actividad ancestral que estaba cayendo en desuso, como la espartería, en el primero de los casos. El antruejo de Velilla de la Reina participa en la propia definición e interpretación de sí mismo en un museo que lo va a acoger y lo hace a través de las voces de sus protagonistas, pertenecientes a distintas generaciones. Sus relatos sientan las bases del discurso museológico y museográfico. Los habitantes de Laza, en el tercer caso citado, se han reconocido a sí mismos en un periodo muy dilatado de tiempo a través de miles de imágenes y de decenas de películas realizadas durante más de cuarenta años. Estos materiales visuales han funcionado como de espejo de la celebración en sentido global, trascendiendo su vivencia subjetiva. A la vez, les ha permitido acceder a una visión de los cambios festivos que han ido introduciendo espontáneamente a lo largo del tiempo. Finalmente, ha recordado las identidades asumidas y las emociones experimentadas a partir de su participación como individuos en cada momento de su ciclo vital.

Estos y otros muchos casos de la actualidad comparten la peculiaridad de adaptarse a las normativas citadas más arriba que se refieren al proceso de valorización de la producción cultural, siendo ahora las instituciones administrativas las que pueden colaborar en la perpetuación de este tipo de patrimonio mediante la escucha de las necesidades de sus protagonistas y prestando la ayuda que sus portadores requieran en todos los órdenes en los que estas prácticas precisan de un apoyo exterior para consolidarse y difundirse.

En los tres casos referidos, el patrimonio inmaterial regenera los lazos entre los individuos construyendo un "nosotros" integrador en relación a la espartería, al antruejo o al entroido. También reformulan desde la cultura viva compartida la voluntad de seguir juntos. Integran a toda persona que sienta el deseo de participar y crean un orgullo identitario que mueve a cada grupo a difundir todo aquello que se ha recuperado, mantenido y proyectado hacia el futuro como obra cultural derivada de la creatividad y del hacer de sus participantes. 


\section{BIBLIOGRAFÍA}

- Decreto 52/2019, de 9 de mayo, por el que se declaran bien de interés cultural las técnicas constructivas de la carpintería de ribera. Diario Oficial de Galicia, n. ${ }^{\circ} 99$, de 27 de mayo de 2019. Disponible en: https://www.xunta.gal/dog/ Publicados/2019/20190527/AnuncioG0535-200519-0001 es.html [Consulta: 15/06/2021]

- Ley $10 / 2015$, de 26 de mayo, para la salvaguardia del Patrimonio Cultural Inmaterial. Boletín Oficial del Estado, n. ${ }^{0} 126$, de 27 de mayo de 2015. Disponible en: https://www. boe.es/diario_boe/txt.php?id=BOE-A-2015-5794 [Consulta: 15/06/2021]

- Ley 5/2016, de 4 de mayo, del patrimonio cultural de Galicia. Diario Oficial de Galicia, n. ${ }^{\circ} 92$, de 16 de mayo de 2016. Disponible en: https://www.boe.es/buscar/pdf/2016/ BOE-A-2016-5942-consolidado.pdf [Consulta: 15/06/2021]

- Ley $18 / 2019$, de 8 de abril, de salvaguardia del patrimonio cultural inmaterial de las Illes Balears. Boletín Oficial del Estado, n. ${ }^{0} 109$, de 7 de mayo de 2019. Disponible en: https:// www.boe.es/diario_boe/txt.php?id=BOE-A-2019-6703 [Consulta: 15/06/2021]

- Ministerio de Educación, Cultura y Deporte [MECD] (2015) Plan Nacional de Salvaguardia del Patrimonio Cultural Inmaterial. Madrid, 2015. Disponible en: https://oibc. oei.es/uploads/attachments/182/CULTURA_INMATERIAL. pdf [Consulta: 15/06/2021]

- Ministerio de Educación, Cultura y Deporte [MECD] (2017) Plan de salvaguarda de la cultura del esparto. Madrid, 2017. Disponible en: https://es.calameo.com/ read/00007533535c877749d8e [Consulta: 15/06/2021]

- Organización de las Naciones Unidas para la Educación, la Ciencia y la Cultura [UNESCO] (2003) Convención para la Salvaguardia del Patrimonio Cultural Inmaterial. París, 17 de octubre de 2003. Disponible en: http://www. culturaydeporte.gob.es/dam/jcr:82769ea9-0f7c-4a4c98ad-ba9f04c07ee9/convencion-de-2003.pdf [Consulta: $15 / 06 / 2021]$ 


\section{Herramientas técnicas y principios básicos en el proceso de planificación turística de los sitios patrimoniales}

María José Viñals | Centro de Investigación Arquitectura, Patrimonio y Gestión para

el Desarrollo Sostenible, Universitat Politècnica de València

URL de la contribución <www.iaph.es/revistaph/index.php/revistaph/article/view/4969>

\section{RESUMEN}

Este trabajo tiene como objetivo identificar las herramientas técnicas y buenas prácticas que deben tenerse en cuenta para la planificación turística de sitios y/o elementos del patrimonio natural y cultural, especialmente en la fase de puesta en valor de los mismos. Además, se analizan los principios básicos para garantizar una adecuada y ética implementación de las mismas.

Este tema se inscribe en el contexto de la necesidad de planificar y gestionar el turismo en sitios patrimoniales desde una perspectiva de conservación y protección de los bienes, desde el reconocimiento de la importancia del patrimonio como motor de desarrollo local, y desde la necesidad de crear productos turísticos de calidad, responsables y respetuosos con su entorno natural, cultural y social que además satisfagan las expectativas de los visitantes.

La metodología de trabajo se ha centrado especialmente en la Investigación de las Ciencias del Diseño, ya que a partir de la detección de problemas en sitios y destinos turísticos patrimoniales, se presentan resultados de soluciones (herramientas técnicas) que ya han sido aplicadas con éxito y evaluadas por el equipo investigador a lo largo del desarrollo de numerosos proyectos en diversos países tanto en espacios naturales como en sitios culturales.

\section{Palabras clave}

Buenas prácticas | Destinos turísticos | Herramientas técnicas | Patrimonio cultural | Patrimonio natural | Planificación | Puesta en valor | Principios técnicos | Principios éticos | Sitios patrimoniales | Turismo | 


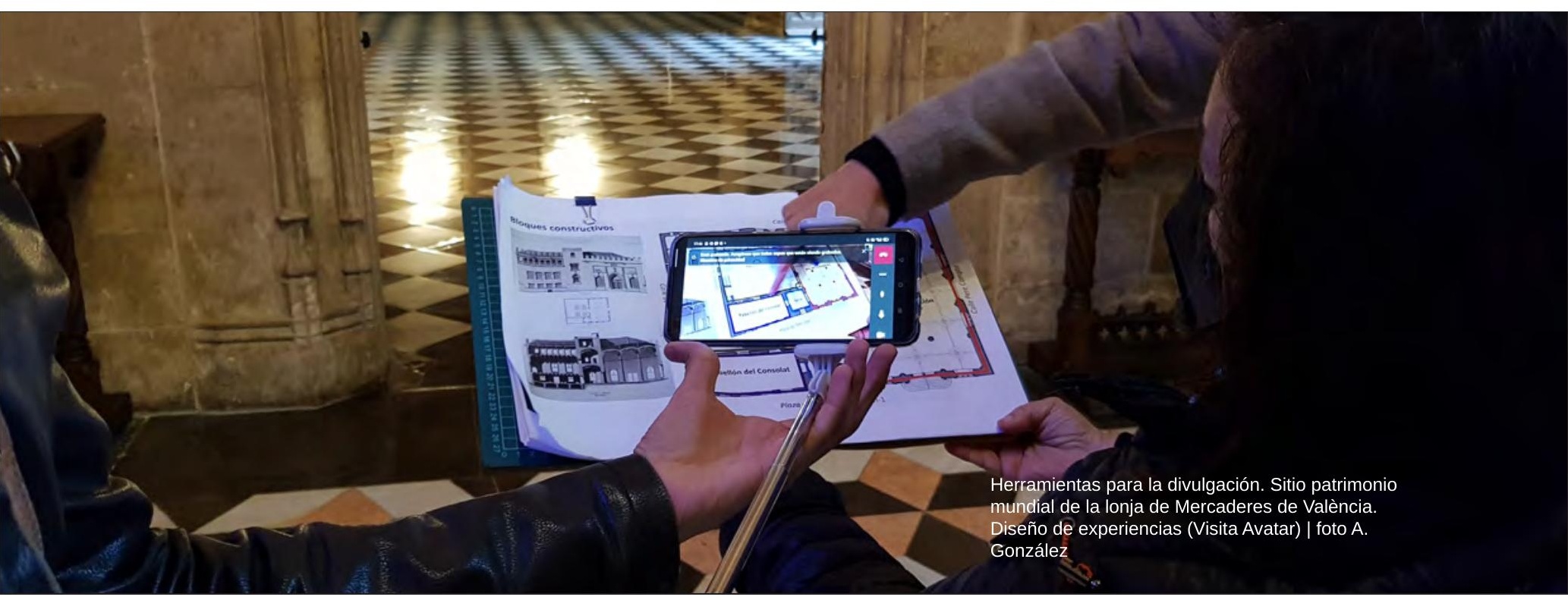

\section{Technical Tools and basic principles in Tourism Planning of Heritage Sites}

\section{ABSTRACT}

This paper aims to identify the technical tools and best practices that should be taken into account for tourism planning of natural and cultural heritage sites, especially in the enhancement phase. In addition, it discusses the basic principles to ensure their proper and ethical implementation.

The context in which this topic is framed is the need to plan and manage tourism in heritage sites from a perspective of conservation and protection of the assets, from the recognition of the importance of heritage assets as a driver of local development, and from the need to create quality tourism products that are responsible and respectful of their natural, cultural and social environment and that also meet the expectations of visitors.

The work methodology has focused especially on Design Science Research, since, based on the detection of problems in heritage tourism sites and destinations, the results of solutions (technical tools) are presented that have already been successfully applied and evaluated by the research team throughout the development of numerous projects in different countries, both in natural and cultural sites.

\section{Key words}

Best Practices | Tourism | Planning Tools | Enhancement Tools | Cultural Heritage | Natural Heritage | Technical Principles | Ethical Principles | Heritages Sites | Tourism |

Cómo citar: Viñals Blasco, M.J. (2021) Herramientas técnicas y principios básicos en el proceso de planificación turística de los sitios patrimoniales. Revista $\mathrm{PH}, \mathrm{n} .{ }^{\circ}$ 104, 2021, pp. 104-125 <www.iaph.es/revistaph/index.php/revistaph/article/view/4969> DOI 10.33349/2021.104.4969

Enviado: 18/06/2021 | Aceptado: 19/07/2021 | Publicado: 01/10/2021 


\section{INTRODUCCIÓN}

El auge del turismo patrimonial basado en importantes recursos naturales y culturales desde hace décadas ha brindado a muchos lugares la oportunidad de diversificar su oferta recreativa y su economía. Sin embargo, la presencia de activos naturales y culturales excepcionales no garantiza por sí sola la presencia de visitantes y turistas. Paralelamente, hemos asistido a la devastación y degradación de algunos sitios patrimoniales debido a la falta o inadecuación de una planificación turística sostenible basada en la rigurosidad técnica y la profesionalidad.

La planificación turística de bienes o sitios patrimoniales de alto valor se aborda desde una doble perspectiva. En primer lugar, debe garantizar a largo plazo la conservación de los recursos; en segundo lugar, el patrimonio debe contemplarse como un elemento de dinamización socioeconómica de las sociedades que lo albergan. Por ello, se necesita llevar a cabo un proceso de planificación basado en herramientas técnicas y en una implementación coherente y eficiente de las mismas, con fundamentos técnicos y éticos. La causa estriba en la exigencia de afrontar nuevos paradigmas emergentes de gestión y la salvaguarda del patrimonio en un contexto de gran presión turística sobre los atractivos patrimoniales.

Hay que señalar que la planificación y la gestión sostenibles del turismo supone uno de los retos más acuciantes en relación con el futuro de la Convención del Patrimonio Mundial, por lo que resulta un objetivo crucial del Programa de Patrimonio Mundial y Turismo Sostenible de la Unesco (2011). Otras instituciones como la Organización Mundial del Turismo (OMT), el Consejo Internacional de Monumentos y Sitios (ICOMOS), la Unión Internacional para la Conservación de la Naturaleza (UICN) y muchas otras llevan tiempo identificando la necesidad de desarrollar herramientas de mejora para la planificación y gestión turística como forma de garantizar la conservación de los elementos y sitios patrimoniales y también para ofrecer, a su vez, una visita de calidad a la altura del valor excepcional universal de los sitios.

Las herramientas de planificación turística del patrimonio no están, generalmente, consideradas de forma integral en los manuales técnicos; habitualmente se encuentra información académica sobre el desarrollo específico de planes de gestión turística para sitios patrimoniales. Resulta más frecuente la publicación de trabajos científicos dedicados a buenas prácticas de planificación y gestión turística a partir de casos de estudio y también el desarrollo y aplicación individualizada de herramientas (inventarios de atractivos, catálogos de protección, etc.) y trabajos que abordan medidas correctivas para reconducir situaciones no deseadas (estudios de capacidad de carga recreativa, análisis de impactos sobre los recursos, estudio de frecuentación y movilidad de los flujos de visitantes, etc.). Pese a la relevan- 


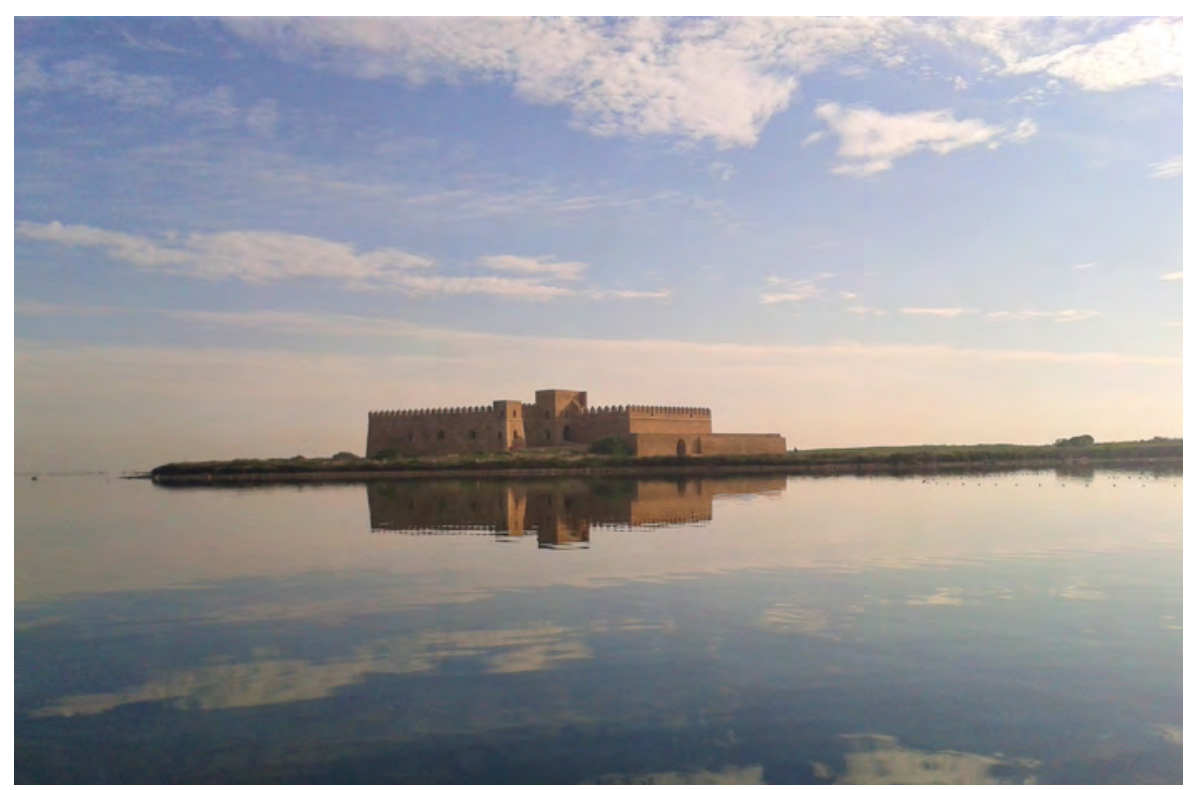

cia del tema, hay que decir que no ha sido hasta el siglo XXI cuando se ha abordado científicamente de forma integral el tema del diseño y análisis de herramientas de planificación y gestión turística de elementos patrimoniales. Como antecedente a esta situación, tenemos los trabajos de Hall y McArthur (1998) y el de Wight (1998) que abordaron enfoques y herramientas generales que tienen el potencial de abordar importantes cuestiones de planificación y gestión del turismo sostenible en relación con los recursos naturales y culturales. Ya en el siglo XXI, y con un carácter integrador, destaca, como institución pionera en el estudio y desarrollo conceptual de herramientas de planificación turística de elementos patrimoniales, la Unesco. Pedersen, experto vinculado a esta institución, publicó en 2002 Managing Tourism at World Heritage Sites: a Practical Manual for World Heritage Site Managers, un trabajo muy completo y de referencia en este ámbito. El Programa de Naciones Unidas para el Medio Ambiente, junto con la Organización Mundial de Turismo (UNEP y UNWTO 2005), llevó a cabo una labor muy relevante también en este contexto en los primeros años de este siglo. Posteriormente, la Unesco (s.f.) editó un manual online de herramientas de gestión turística y De Ascaniis et ál. incidieron de nuevo en el tema de la planificación y gestión de sitios patrimoniales en trabajos encargados por la Unesco (De Ascaniis, Gravari-Barbas y Cantoni 2018). En este contexto, hay que mencionar el manual desarrollado por el Departamento de Medioambiente y Patrimonio del Gobierno Australiano (2008) que destaca por su carácter práctico y aplicado en el abordaje de este tema. En España, destacan los trabajos de Martos Molina (2016) y el de Viñals et ál. (2017) que presentan también un manual práctico que desarrolla las diferentes herramientas de planificación y gestión turística del patrimonio.
Isla de Chikly y fuerte de Santiago, Túnez. Valoración de la capacidad de carga recreativa (herramienta de planificación) | foto I. MartínezSanchís 
Basándose en la experiencia adquirida en el desarrollo de proyectos de planificación turística de sitios patrimoniales y, en aras de secuenciar ordenadamente el proceso la planificación, la autora de este trabajo agrupa las diversas herramientas en tres grandes bloques:

a) las herramientas de conservación y protección;

b) las herramientas de puesta en valor turístico;

c) las herramientas de dinamización socioeconómica.

Una correcta planificación y gestión del patrimonio debe seguir esta secuencia lógica y ordenada de acciones; por tanto, no se puede desarrollar el proceso de puesta en valor turístico ni de dinamización socioeconómica si previamente no se han establecido los mecanismos de conservación y protección.

En el primer bloque, están las herramientas propias de los especialistas de cada una de las disciplinas específicas de acuerdo con el tipo de patrimonio (arqueológico, arquitectónico, ecológico, urbanístico, etc.) y existe una literatura científica muy razonable como para abordar su aplicación. También se incluye en este grupo las herramientas de protección jurídica (normativas, políticas de patrimonio, registro del patrimonio, etc.) que son tratadas por los expertos en los aspectos legales del patrimonio. Existe mucha bibliografía sobre cómo desarrollar planes de conservación y gestión del patrimonio. El plan director constituye uno de los instrumentos más habituales aunque, por el momento, en España, no tiene consideración normativa y se encuentra en

Ciudad colonial de Gracias (Lempira) en Honduras. Diseño del patrón de la visita en el centro histórico una situación de indefinición legal. Los instrumentos de protección si están | foto M.J. Viñals
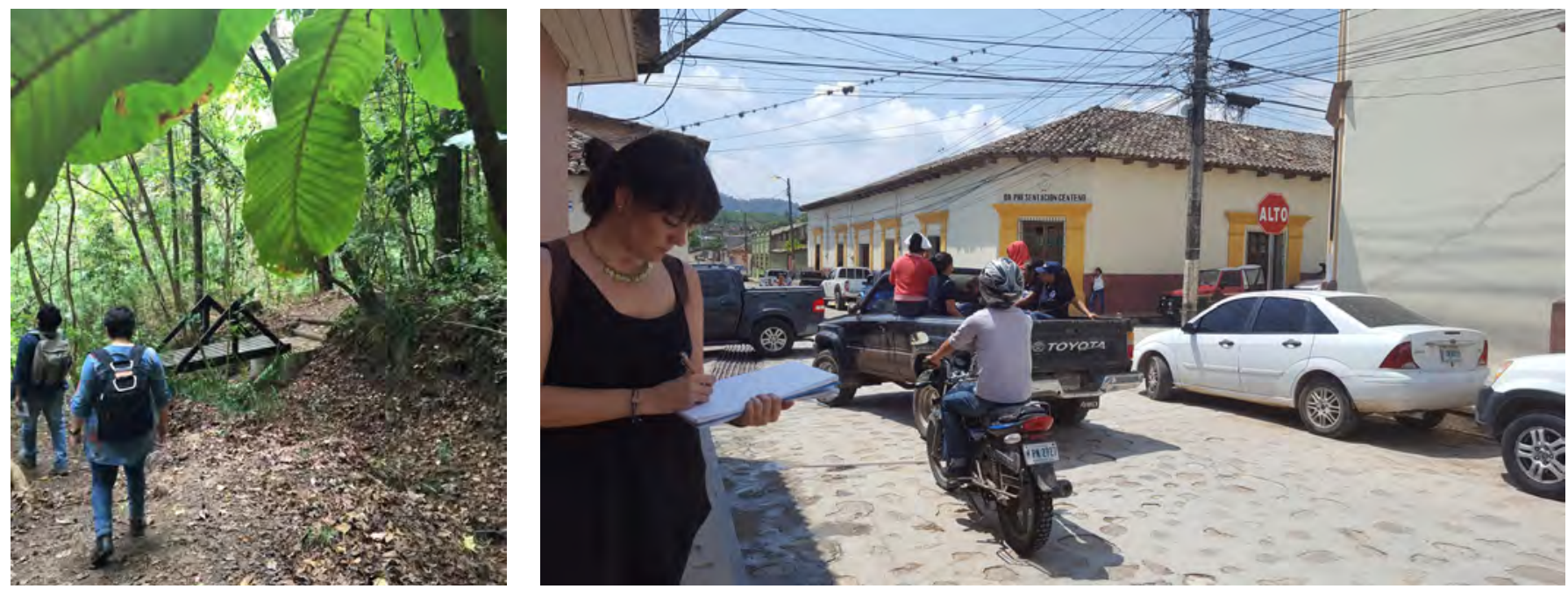
fijados amparándose en la normativa patrimonial y la urbanística (estatal, autonómica y local). Así, tenemos bienes de interés cultural (BIC) recogidos en la Ley de Patrimonio Histórico Española de 25 de junio de 1985, bienes protegidos por inventarios y catálogos autonómicos, los catálogos urbanísticos de protecciones y los planes especiales de protección, ambos de carácter municipal.

Las herramientas de puesta en valor turístico que se incluyen en el segundo bloque son aquellas que facilitan la transformación de los recursos naturales y culturales en atracciones turísticas. Este proceso resulta muy abstracto si no se concreta en la aplicación de una serie de instrumentos técnicos que conduzcan finalmente a la posibilidad de abrir las puertas al público para la visita. Pearce (1991) y posteriormente Gunn (2002) describen este proceso cuando se refieren a los atractivos turísticos como aquellos lugares o sitios que se planifican y gestionan para el desarrollo de actividades recreativas y el disfrute de los visitantes. A ellos, se suman las interesantes aportaciones de Richards y Munsters (2010) sobre los métodos de investigación en turismo cultural. Hay que señalar, no obstante que, desde una perspectiva técnica, se detecta una falta de profesionales de alto nivel en este campo del conocimiento ya que no existe habitualmente, al menos en nuestro país, una oferta formativa universitaria especializada en este tema (Viñals y Teruel 2021). El análisis de este bloque de herramientas de puesta en valor y los principios asociados a su implementación va a ser el foco de atención de este trabajo.

En relación al papel del patrimonio como dinamizador de la economía local, hay que destacar que los recursos naturales y culturales son uno de los hitos identitarios de muchas comunidades locales y la base para movilizar
Herramientas de planificación:

Señalización de itinerarios ecuestres en el Parque Natural del Túria, València | foto M.J. Viñals

Marjal de Gandia, València. Diseño de senderos accesibles | foto M. Oñorbe
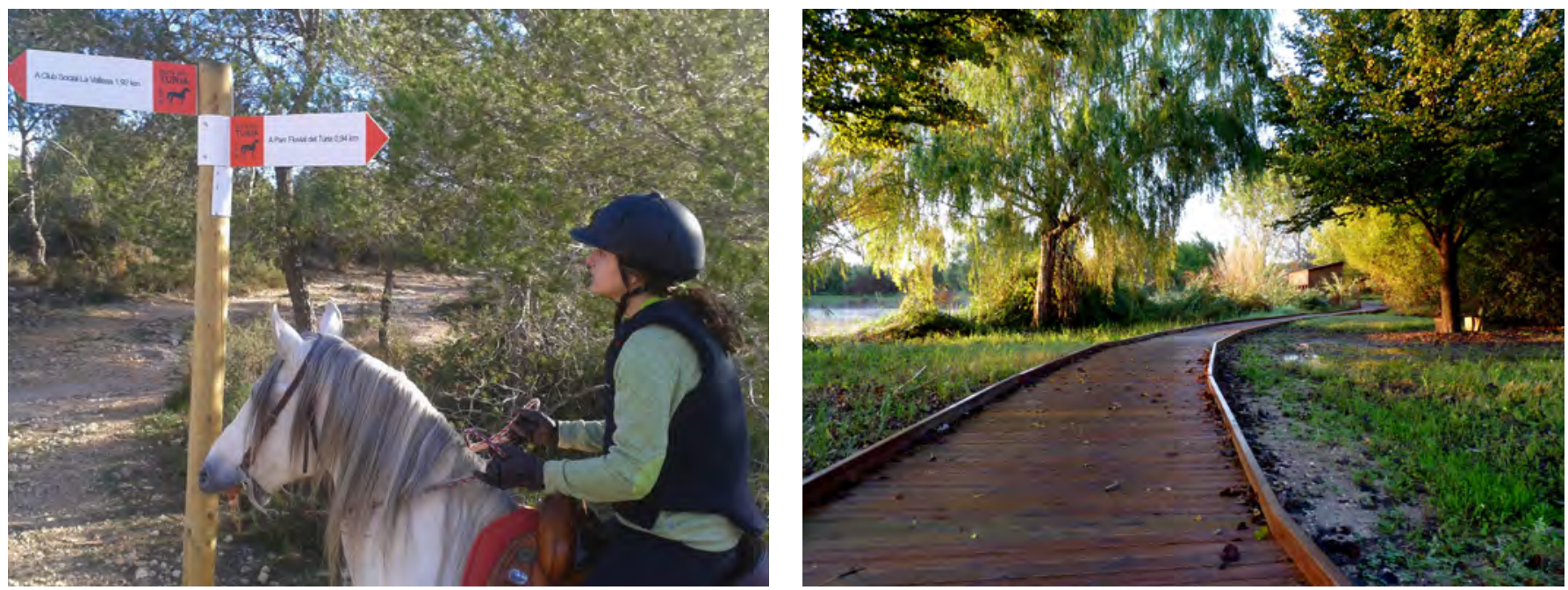
la economía de ciertos territorios. Este estímulo ha ido normalmente de la mano del sector turístico, que, con mayor o menor acierto, ha actuado como catalizador en el desarrollo de algunos lugares. Por ello, en este bloque las herramientas estarán enfocadas a facilitar las relaciones que se establecerán entre el sector turístico y las administraciones responsables de los bienes. Hay que comentar que se trata de un tema cada vez más consolidado (Baycan y Girard 2011; Lähdesmäki 2014; Historic England 2018; Della Spina 2019). Las investigaciones recientes y los proyectos en curso demuestran que la dinamización de áreas protegidas, zonas históricas y la salvaguardia del patrimonio cultural pueden abordarse conjuntamente y aportar importantes beneficios económicos a las comunidades locales. La Organización para la Cooperación y el Desarrollo Económicos y el Consejo Internacional de Museos han analizado los impactos positivos que la cultura tiene sobre el desarrollo local (OCDE e ICOM 2019) y han dado las claves de cómo maximizar el valor social y económico del patrimonio. También ha sido una estrategia emprendida por la Unión Europea, ya que el patrimonio se considera como un recurso cultural contemporáneo y vivo, por lo que se entiende que su conservación y puesta en valor abre considerables oportunidades de desarrollo local y regional. Entre las medidas importantes, se encuentra la comunicación de la Comisión sobre la necesidad de un enfoque integrado del patrimonio cultural (Comisión Europea 2014) en donde se destacan las diferentes herramientas transversales con las que cuenta la UE para apoyar la protección y la valorización intrínseca y social del patrimonio con el objetivo de facilitar el crecimiento económico y la creación de empleo.

Desde el punto de vista del patrimonio natural, se observa que ya el Plan Estratégico del Convenio sobre la Diversidad Biológica 2011-2020 y las Metas de Aichi (UNEP y CBD 2010) y la Estrategia de Biodiversidad de la UE hasta 2020 (Comisión Europea 2011) señalaban que el patrimonio natural y la biodiversidad son importantes factores de bienestar, de crecimiento socioeconómico y de articulación territorial. En cuanto al patrimonio cultural, hay que destacar la Declaración de París sobre el Patrimonio como Motor

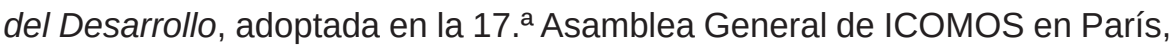
Francia (ICOMOS 2011a). Además, la cultura también fue incluida, por primera vez, dentro de los Objetivos de Desarrollo Sostenible de la Agenda de Desarrollo Sostenible 2030 durante la 70. a Asamblea General de la ONU (Organización de Naciones Unidas 2015). Hay que mencionar que uno de los ejemplos más notorios del desarrollo socioeconómico asociado al patrimonio deriva de la reutilización de edificios históricos, ya que está comprobado que proporciona una base para la regeneración de muchas ciudades y territorios (Pendlebury y Porfyriou 2017). Esta estrategia ha sido liderada por administraciones públicas tales como la Cámara de los Comunes del Reino Unido (House of Commons 2004). Así, se observa en la conclusión del Parliamentary Select Committee que ya estudiaba el papel de los edificios históricos en la regeneración urbana. 
Por estas razones, la planificación y puesta en valor del patrimonio como atractivo turístico adquiere una importancia estratégica para los destinos (Bowitz y lbenholt 2009) y muchas de las convocatorias públicas sobre patrimonio y subvenciones para proyectos centran sus objetivos en estas cuestiones.

La hipótesis de partida de este trabajo se fundamenta pues en el hecho de que usar responsablemente los elementos patrimoniales supone un acicate para su conservación, para el mantenimiento de la identidad cultural de un territorio y para generar riqueza económica. Sin embargo, la clave de todo se encuentra en "el uso responsable" que se haga de los bienes. Por ello, este artículo tiene como objetivo dar a conocer una serie de herramientas de puesta en valor que han sido ya experimentadas con éxito y garantizan una utilización turística racional y respetuosa del patrimonio.

\section{METODOLOGÍA}

Este trabajo se enmarca en los métodos de investigación cualitativa y se ha basado en una revisión bibliográfica sobre el proceso de puesta en valor turístico del patrimonio desde una perspectiva integrada y en el marco de la planificación y conservación preventiva de los sitios patrimoniales. Se considera oportuno desarrollar este proceso como un sistema integral de apoyo al desarrollo de la planificación y gestión turística porque, tal como apuntan Reitsamer y Brunner-Sperdin (2015), los visitantes perciben los sitios como un todo, de forma holística.

Como el objetivo principal de este trabajo se centra en identificar un sistema de herramientas, el método seguido ha sido el de la Investigación de la Ciencia del Diseño (Aken 2004) que se enmarca en la investigación prescriptiva. Por lo tanto, los resultados presentados, han sido fruto de aplicar las cinco etapas sugeridas por este autor -1) identificar el problema; 2) comprender el problema; 3) desarrollar una solución; 4) implementar la solución; y 5) evaluar la solución- en diversos sitios patrimoniales, tanto naturales como culturales a lo largo de estos años.

\section{RESULTADOS}

\section{Sistema de herramientas de puesta en valor turístico}

El proceso de puesta en valor turístico del patrimonio, como ya se ha mencionado, se integra en una estrategia general de planificación y gestión de los elementos patrimoniales individualmente o a nivel de un destino patrimonial (territorio). Se caracteriza por ser un procedimiento integral, flexible que 
Borj El Loutani, Ghar El Melh, Túnez. Reutilización de edificio histórico para Centro Nacional de Humedales | foto M.J. Viñals

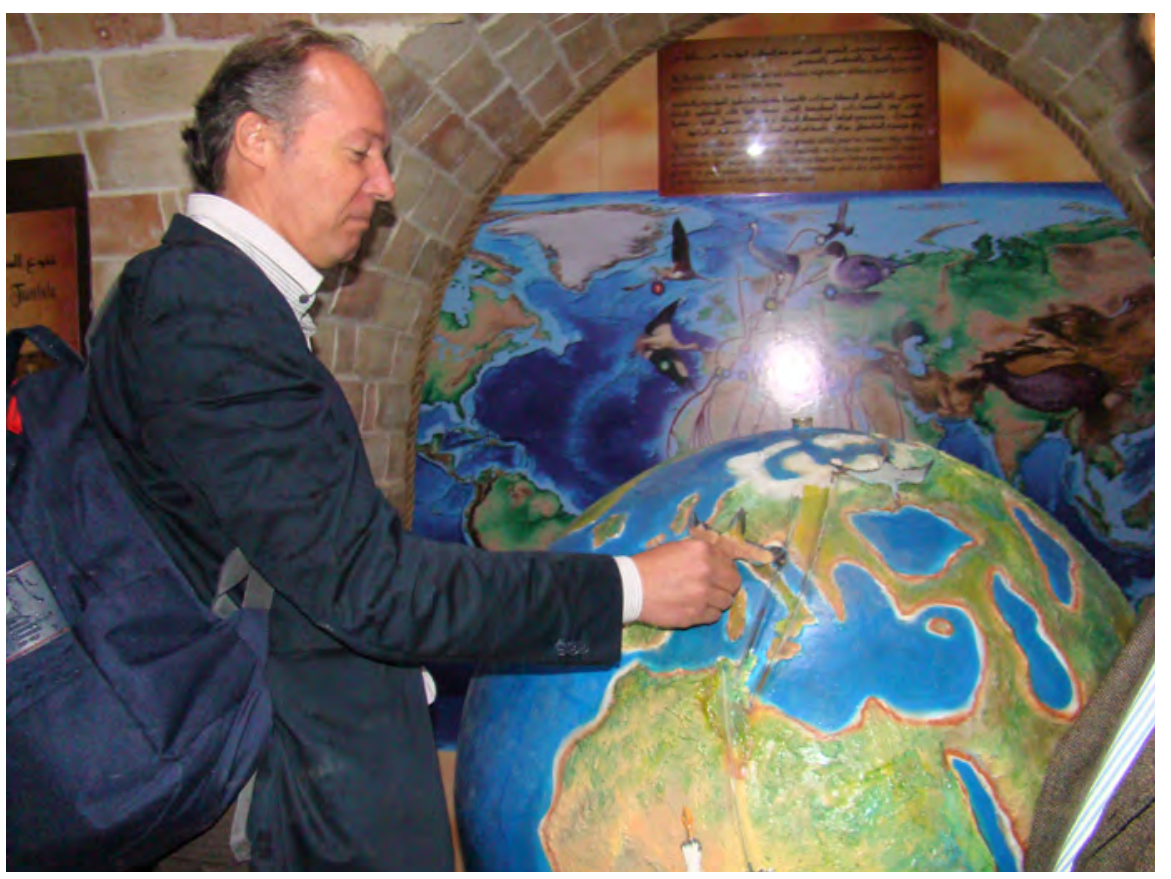

puede adaptarse a las especificidades de contextos complejos, además de permitir interactuar con conocimientos heterogéneos e incorporar los valores locales asociados a los diferentes sitios.

Hay que señalar la existencia de manifiestas reservas que muchos gestores del patrimonio muestran cuando las administraciones planean desarrollar actividades turísticas en los sitios patrimoniales. Se pueden señalar muchos ejemplos de sitios patrimoniales de gran valor en los que desarrollos turísticos inadecuados han provocado el deterioro, a veces irreversible, de elementos de gran valor. No hay que olvidar, por ejemplo, que después de designarse un sitio como Patrimonio Mundial, la popularidad del lugar aumenta y, por lo tanto, el interés por visitarlo también (Yang y Lin 2014). Por estas razones, la Unesco considera actualmente que abordar la gestión eficaz del turismo en los sitios, de forma coherente con la protección, la conservación y la gestión del valor universal excepcional, forma parte de las nominaciones (UNESCO 2011). Peltier (2017) señalaba que la mitad de los sitios designados como Patrimonio Mundial no tenían plan de gestión turística y no llevaban a cabo acciones suficientes para evitar los impactos negativos del turismo de masas. Por tanto, como se observa es, en estos momentos, una acción prioritaria que se ha de emprender en los sitios patrimoniales.

El proceso de puesta en valor se inicia con un análisis preciso de las condiciones de partida del sitio o elemento para disponer de una valoración patri- 
monial ex-ante y de las actividades recreativas y factores que intervienen en los sitios. De esta manera, se podrá conocer cuáles serán las herramientas que se han de implementar y con qué prioridad. Estas herramientas están pensadas para ser instrumentos de gestión preventiva, pero, en muchas ocasiones, se aplican como medidas correctoras una vez que aparecen problemas por falta o inadecuada planificación.

Basándonos en estudios previos y en el desarrollo de proyectos empíricos llevados a cabo por el equipo de investigación, en la tabla de la p. 115 se proponen las herramientas de puesta en valor agrupadas según su propósito.

Entre las herramientas de planificación del lugar, se incluyen aquellas de aplicabilidad a un territorio en su conjunto y las que se desarrollan específicamente en un sitio individualizado (monumento, yacimiento arqueológico, museo, etc.). El Inventario de elementos patrimoniales constituye la más básica y fundamental de todas las herramientas, ya que incluye toda la información relacionada con el elemento patrimonial. Además, a partir de los inventarios se desarrollan otras herramientas, entre ellas, las legales de protección. La información contenida en un inventario debe estar actualizada para que funcione como una herramienta eficaz.

Para llevar a cabo la toma de decisiones en relación a la puesta en valor de los elementos patrimoniales, se ha de proceder a su evaluación, tanto desde un punto de vista de sus valores y atributos inherentes ${ }^{1}$ (Valoración intrínseca del patrimonio), como desde el punto de vista turístico (Valoración turística del patrimonio), si va a asumir la visita pública u otras actividades recreativas.

Según Viñals et ál. (2017), los principales criterios para evaluar el valor intrínseco son: la significancia, la representatividad, la singularidad, la naturalidad/integridad, la autenticidad y la contextualización. La significancia es el criterio más importante utilizado por la Unesco para evaluar el valor universal excepcional de los elementos del patrimonio (UNESCO 2005). Para la valoración turística se utilizarán: atractividad, resistencia (versus fragili$\mathrm{dad} /$ vulnerabilidad), disponibilidad, accesibilidad in situ, viabilidad y valores educativos. Hay que señalar que un alto valor intrínseco del recurso no tiene por qué coincidir con un alto valor turístico. Así, por ejemplo, un recurso con una alta significancia ecológica, histórica o social puede no resultar atractivo para los visitantes.

A nivel de destino turístico, el Estudio de las infraestructuras, transportes y servicios básicos, así como conocer los Prestatarios de servicios turísticos que operan en la zona resulta fundamental ya que sin su presencia la actividad turística no existiría, aunque hubiera importantes atractivos patrimoniales.
1

Un recurso natural, por ejemplo, puede ser evaluado desde la perspectiva geológica, geomorfológica, geográfica, hidrológica, paleontológica, biológica, ecológica y/o astronómica, entre otros, mientras que un elemento cultural puede ser evaluado desde el punto de vista arquitectónico, arqueológico, urbanístico, etnográfico, artístico, histórico, sociocultural, científico, tecnológico, etc. 
En cuanto a las herramientas que se aplican a elementos específicos están la Viabilidad técnica, legal y económica del uso recreativo que analiza las posibilidades de reutilización adaptativa para el uso recreativo de un bien patrimonial. La Zonificación y usos potenciales, el Análisis del acceso físico al sitio, la Valoración de la capacidad de carga recreativa y el Diseño del patrón de la visita tienen un marcado carácter espacial y están en la base del diseño de otras herramientas relacionadas con la gestión de visitantes. La Capacidad de carga recreativa es problamente la herramienta de mayor reconocimiento y aplicación y sobre la que más literatura científica existe desde que Stankey y Manning (1986) consolidaron este concepto en la gestión de espacios naturales. Por otra parte, el elemento patrimonial debe proporcionar un acceso ordenado y adecuado mediante el desarrollo de un Patrón de la visita al espacio físico, de manera que se proponga un recorrido o itinerario y así se eviten situaciones de congestión y desagrado a los visitantes y, también, impactos inadecuados en zonas sensibles. Estos aspectos se encuentran muy relacionados con la gestión de la capacidad de carga en el lugar.

La Predicción y valoración de impactos al patrimonio resulta fundamental para garantizar la conservación del sitio. La herramienta formal Evaluación de impacto ambiental (EIA) se utiliza para la identificación y para la evaluación de los impactos en recursos naturales. También está la Evaluación de impacto patrimonial (EIP) realizada para los bienes culturales (ICOMOS 2011b), aunque su práctica se encuentra menos extendida. Desde el punto de vista de la puesta en valor turístico, conviene evaluar anticipadamente los efectos negativos potenciales de la actividad; es decir, proceder a un análisis de predicción de los impactos sobre el patrimonio y así, la mitigación de los mismos estará integrada en el diseño de las actividades turísticas. Hay países como Australia que establecen directrices muy valiosas al respecto (Australian Government 2019).

Sobre el Diseño de experiencias recreativas hay que señalar que una experiencia va más allá de una actividad recreativa; el enfoque pretende crear una conexión emocional entre el bien patrimonial y los visitantes. Por ello debe planificarse cuidadosamente (Carballo et ál. 2015; Kim y Fesenmaier 2015; Scott, Gao, y Ma 2017; Moscardo 2019). La experiencia debe resultar especial, espectacular y memorable ya que constituye el componente más creativo de la oferta y la verdadera motivación para que los turistas y excursionistas visiten un destino; además, proporciona identidad turística a un lugar. El desarrollo de experiencias y actividades turísticas requiere de la existencia de ciertos servicios y equipamientos básicos y recreativos (Diseño de equipamientos recreativos) para garantizar la seguridad, confort y disfrute de los visitantes. Por otra parte, las experiencias turísticas deben adecuarse al territorio y sus recursos. En su diseño se debe considerar la accesibilidad universal, el menor impacto sobre los recursos y prever las medidas pre- 


\begin{tabular}{|c|c|c|}
\hline \multirow[b]{2}{*}{ CATEGORÍA } & \multicolumn{2}{|c|}{ HERRAMIENTAS } \\
\hline & Destino (territorio) & $\begin{array}{c}\text { Sitio patrimonial } \\
\text { (edificio, parque natural, etc.) }\end{array}$ \\
\hline Planificación del lugar & $\begin{array}{l}\text { Inventario de elementos patrimoniales. } \\
\text { Valoración Intrínseca del patrimonio. } \\
\text { Valoración turística del patrimonio. } \\
\text { Estudio de infraestructuras, transportes y } \\
\text { servicios. } \\
\text { Inventario prestatarios de servicios turísti- } \\
\text { cos. }\end{array}$ & $\begin{array}{c}\text { Viabilidad técnica y legal del uso recreativo. } \\
\text { Zonificación y usos potenciales. } \\
\text { Análisis del acceso físico al sitio. } \\
\text { Valoración de la capacidad de carga } \\
\text { recreativa. } \\
\text { Diseño del patrón de la visita. } \\
\text { Predicción y valoración de impactos al } \\
\text { patrimonio. } \\
\text { Diseño de experiencias recreativas. } \\
\text { Diseño de equipamientos recreativos. } \\
\text { Análisis del potencial turístico de las expe- } \\
\text { riencia recreativas. }\end{array}$ \\
\hline Gestión de visitantes & \multicolumn{2}{|c|}{$\begin{array}{c}\text { Análisis de la demanda potencial. } \\
\text { Análisis de confort psicológico de los visitantes. } \\
\text { Estudio de frecuentación, distribución y movilidad de los flujos. } \\
\text { Programa de interpretación del patrimonio. } \\
\text { Plan de uso público } \\
\text { (regulación de la visita pública, protocolo para la atención de visitantes, plan de emergen- } \\
\text { cias, protocolo de bioseguridad). }\end{array}$} \\
\hline $\begin{array}{c}\text { Divulgación y comunicación } \\
\text { estratégica }\end{array}$ & \multicolumn{2}{|c|}{$\begin{array}{l}\text { Plan de comunicación estratégica. } \\
\text { Campañas de sensibilización y de apoyo. } \\
\text { Formación especializada de los profesionales. }\end{array}$} \\
\hline
\end{tabular}

ventivas necesarias, como se comentaba anteriormente. Existe numerosa bibliografía sobre buenas prácticas en la construcción de estos equipamientos como los trabajos de Beyer et ál. (2005) y Andaroodi (2020).

La herramienta Análisis del potencial turístico ayuda a identificar la capacidad que la actividad recreativa tiene para dinamizar socioeconómicamente una zona o territorio; es decir, las posibilidades que tiene para convertirse en producto turístico comercializable. La UNWTO (s.f.) define producto turístico como una combinación de elementos tangibles e intangibles (recursos naturales, culturales y artificiales), los equipamientos, servicios y las actividades recreativas integradas en una experiencia global que tiene un precio de mercado y se vende a través de canales de distribución. Por ello, esta herramienta debe considerarse como un instrumento clave para orientar la toma de decisiones de las políticas de inversión pública. Se centrará pues en analizar el potencial de los atractivos existentes de la zona, la accesibilidad general y la existencia de prestatarios de servicios.

Entre las herramientas de gestión de visitantes se incluyen: Análisis de la demanda potencial, Análisis de confort psicológico de los visitantes, Estudio de frecuentación, distribución y movilidad de los flujos, Programa de inter-
Tabla 1. Herramientas de puesta en valor turístico para sitios patrimoniales.

Las herramientas de planificación son de aplicación tanto a un territorio como a un elemento individualizado. Se separan para hacer hincapié en aquellas que son más adecuadas en cada caso. 

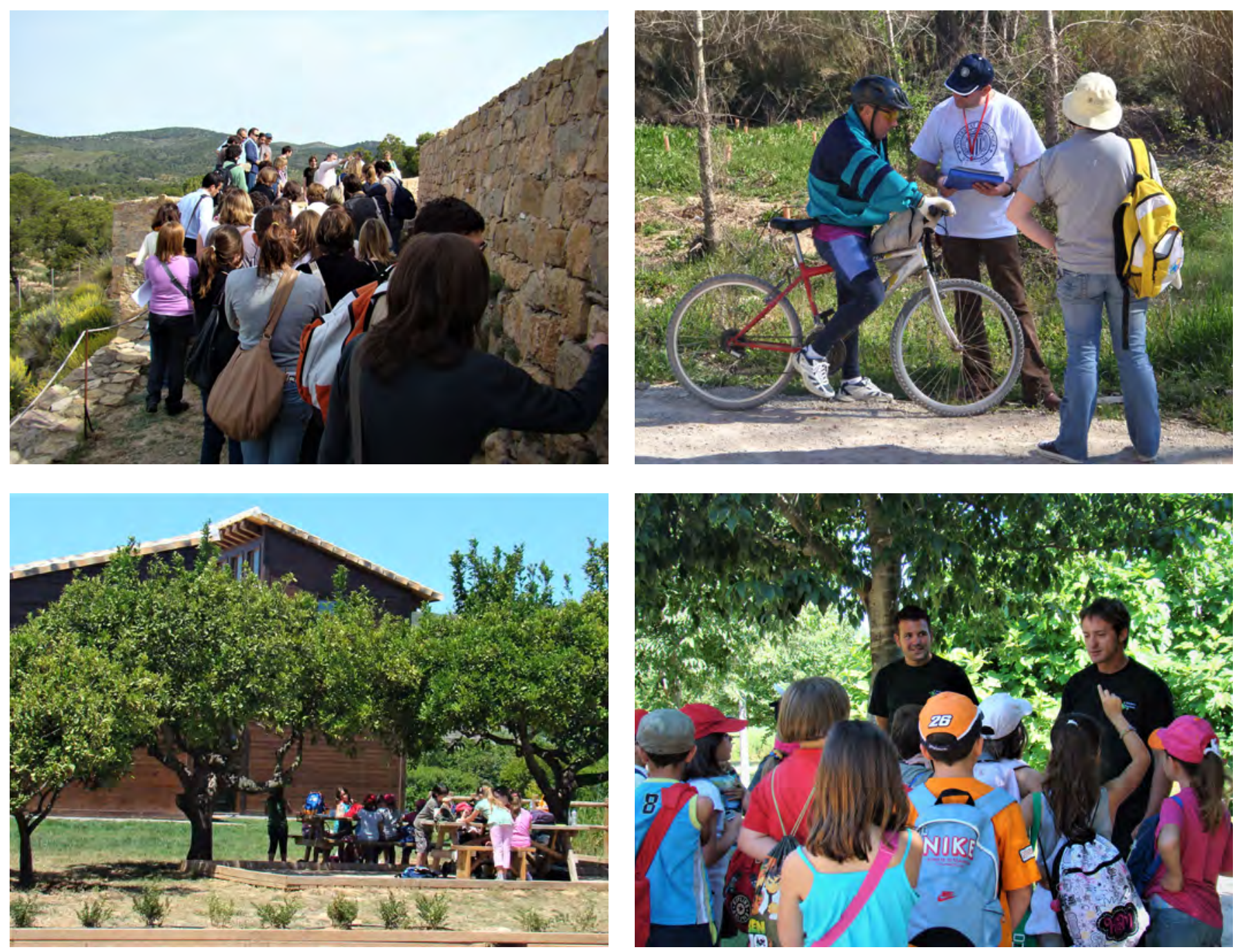

Herramientas de gestión de visitantes:

De izquierda a derecha y de arriba abajo, yacimiento ibero del Castellet de Bernabé, Llíria, València. Estudio de capacidad de carga recreativa

Parque Natural del Túria, València. Análisis de frecuentación y distribución del flujo de visitantes

Aula Natura, Gandia, València. Diseño centro de interpretación y equipamientos recreativos

Marjal de Gandia, València. Programa de interpretación del patrimonio | fotos M. J. Viñals pretación del patrimonio, Plan de uso público, Regulación de la visita pública, Protocolo para la atención de visitantes, Plan de emergencias y Protocolo de bioseguridad.

Los estudios sobre Frecuentación, distribución y movilidad de los flujos de visitantes se realizan para hacer un seguimiento de las personas (volumen de visitantes, comportamientos y movimientos, etc.), conocer los lugares que transitan y los momentos clave (franjas horarias) en que desarrollan la actividad recreativa en un atractivo o destino turístico. Se realizan con carácter correctivo cuando se detectan problemas de congestión o saturación de capacidad de carga de un atractivo o de un equipamiento (centro de interpretación, un sendero, etc.). Por otra parte, hay que recordar que el itinerario derivado del diseño del patrón de visitantes es el escenario donde se realiza 
el seguimiento y recuento de los mismos y la observación de sus comportamientos y movimientos. Eagles y McCool (2002) señalaron que se trata de un tema importante relacionado con la gestión en la mayoría de los parques naturales.

La herramienta Análisis de confort psicológico de los visitantes se centra en identificar y analizar los factores que influyen en la experiencia recreativo-turística (Viñals, Morant y Teruel 2014) y que estas autoras agrupan en:

a) físico-fisiológicos (especialmente bioclimáticos y factores de seguridad);

b) factores propios del lugar (percepción del entorno), tales como espacio geográfico (abierto, cerrado), atractivos, experiencia turística, desarrollo de la actividad (patrón de la visita, tamaño de grupo, nivel de frecuentación, etc.);

c) factores relacionados con los equipamientos y los servicios (especialmente con los servicios básicos, accesos, información e interpretación);

d) factores relacionados con los visitantes (perfil sociodemográfico, rasgos de personalidad, motivaciones, expectativas, comportamientos, etc.).

Este análisis está estrechamente ligado al Diseño de la experiencia turística y al Análisis de demanda potencial. Esta última herramienta se refiere al conjunto de personas que, individual o colectivamente, se encuentran motivadas por una serie de productos o servicios de un destino turístico con el objetivo de satisfacer sus necesidades. En los estudios de demanda turística, se diferencia en la demanda efectiva o real (número actual de personas que viajan al destino) y la demanda potencial (quienes podrían visitar el lugar en el futuro para realizar actividades turísticas). Ambos se pueden desarrollar basándose en un atractivo individual o en un destino turístico en su conjunto.

El instrumento Programa de interpretación del patrimonio resulta clave pues permite al visitante acercarse intelectual $\mathrm{y}$, sobre todo, emocionalmente al patrimonio. Muchas instituciones y administraciones públicas (Unesco, ICOMOS, UICN, US National Association for Interpretation, US National Park Service, Interpret Europe, entre otras) así lo han asumido y promueven activamente su uso en los procesos de puesta en valor del patrimonio. Uno de los principales objetivos de la interpretación del patrimonio consiste en establecer relaciones significativas entre el público y los elementos del patrimonio (Ham 1992; Beck y Cable 1998; Buschholz et ál. 2015). Para ello, se utilizan numerosas técnicas, medios y actividades, pero siempre sobre la base de proporcionar una experiencia auténtica y memorable basada en emociones y sentimientos que persigan el desarrollo de actitudes y comportamientos de respeto y valoración del patrimonio (Tilden 1957). 
Por otra parte, están los Planes de uso público, que no deben confundirse con los Planes de gestión turística, ya que estos últimos implican la consideración de los aspectos de dinamización socioeconómica y deben abordarse en una fase posterior de la planificación. Los primeros tienen como objetivo definir las condiciones en las que se llevarán a cabo las actividades recreativas en un espacio patrimonial y las líneas directrices sobre la gestión de los visitantes. Pueden ejecutarse de forma integral o segmentarse en diversos documentos como la Regulación de la visita pública, un Protocolo de atención de visitantes, un Plan de emergencias para saber cómo gestionar situaciones complejas en donde puede estar en riesgo la seguridad de los visitantes, y también un Protocolo de bioseguridad orientado a la gestión del atractivo en situaciones de riesgo de salud pública. Con ocasión de la reciente pandemia del coronavirus SARS-CoV-2, numerosos organismos de ámbito internacional (Ministerio de Cultura y Deporte. Dirección General de Bellas Artes 2020; Instituto para la Calidad Turística Española 2020; International Council of Museums 2020a, 2020b; Ministerio de Cultura y Deporte. Instituto del Patrimonio Cultural de España 2020) han incidido en la necesidad de dotarse de este protocolo en los sitios patrimoniales.

Respecto a las herramientas de comunicación estratégica y divulgación, hay que destacar el Plan de comunicación estratégica que tiene un claro carácter promocional y dinamizador. La divulgación del patrimonio resulta crucial ya que, como apunta ICOMOS (2011a), conocer es la base para crear sentimiento de orgullo para las personas y un deseo de implicarse en la protección y mejora del patrimonio. En el caso de los elementos patrimoniales públicos, la comunicación corresponde a las instituciones. Así, la administración pública tiene una responsabilidad social de informar. Los planes de comunicación incluyen estrategias y acciones comunicativas e identifican los medios para divulgar el patrimonio (offline y online). Es necesario seleccionar los más adecuados para cada tipo de audiencia teniendo en cuenta el presupuesto disponible.

Las campañas de sensibilización son herramientas específicas de comunicación estratégica que intentan influir en la percepción, creencias, actitudes y comportamientos de la población y cambiar políticas y estrategias en relación a la concienciación y comprensión sobre la conservación y protección del patrimonio y otros temas asociados con el desarrollo turístico. También constituyen una estrategia relevante de las políticas educativas. Estas campañas pueden dedicarse a públicos diversos (público en general, escolares, etc.) y se recomiendan especialmente para las personas encargadas de la toma de decisiones. Las instituciones internacionales relacionadas con el patrimonio dedican una gran atención al desarrollo de estas campañas ya que están en la propia esencia de su existencia. Existen numerosas actividades para llevar a cabo campañas de sensibilización como se puede observar en el trabajo de Shimray (2019), algunas de ellas muy creativas. 
En cuanto a la Formación especializada de profesionales, tal como define ICOMOS (2011), pretende formar a los principales actores con las capacidades necesarias para la conservación, protección, planificación y gestión turística del patrimonio. Como se mencionaba al inicio, se ha detectado la necesidad de disponer de profesionales bien preparados en el desarrollo e implementación de estas herramientas, y esto debería suponer una prioridad en los programas educativos universitarios dedicados al patrimonio.

\section{Principios básicos en la implementación de las herramientas de puesta en valor}

Las herramientas presentadas llevan años implementándose a tenor de las necesidades surgidas en los destinos y se han ido mejorando siguiendo el método heurístico del ensayo y error. Como se presentaba en el apartado de metodología, este trabajo responde a este tipo de proceso, donde se identifica un instrumento (solución), se ensaya y se mejora, tanto proposicional como procedimentalmente. Se ha analizado en apartados anteriores sucintamente el desarrollo técnico de las herramientas que, después de una fase de buenas prácticas, han logrado ya definitivamente erigirse como instrumentos técnicos. Desde el punto de vista procedimental hay que considerar también una serie de principios básicos, sobre todo, en fase de implementación, que garanticen el buen devenir y la ética del proceso.

De esta manera, el principio rector que debe regir todo proceso de diseño e implementación de herramientas de puesta en valor turístico es el de sostenibilidad. La sostenibilidad de un destino turístico se define como la capacidad del territorio para acoger población (visitante y residente) sin poner en peligro la viabilidad de sus subsistemas naturales, económicos y sociales, ni su aptitud adaptativa y de recuperación (resiliencia), cuando éstos sean sometidos a los esfuerzos derivados del proceso de desarrollo turístico (UNESCO 2014; Manrique, Tazim y Warden 2016). El Programa de Naciones Unidas para el Medio Ambiente junto con la Organización Mundial de Turismo (UNEP y UNWTO 2005) Ilamaron la atención sobre este principio y esbozaron una serie de requerimientos básicos para sugerir cómo se debía darle cumplimiento. Hay que recordar que la sostenibilidad se encuentra fuertemente relacionada con la conservación y protección de los recursos patrimoniales y la preservación de su integridad y autenticidad; por lo tanto, se trata de un principio fundamental que hay que seguir en el desarrollo de un destino turístico a largo plazo. En este sentido, Labadi et ál. (2021) han elaborado para ICOMOS unas líneas directrices para la aplicación de los objetivos de desarrollo sostenible en la gestión del patrimonio.

Adicionalmente, se sugiere adoptar una serie de principios de carácter técnico como: calidad de la información, rigor científico, enfoque integral, actualización, adaptabilidad y versatilidad, y eficacia. De esta manera, hemos de 
tener en cuenta el carácter genérico y flexible de las herramientas propuestas. Pueden considerarse como un sistema completo que puede utilizarse en su totalidad, o aplicarse parcialmente como herramientas específicas y adaptadas para mejorar aspectos concretos de la gestión patrimonial o de los visitantes. Partiendo de un modelo estándar, se han de diseñar y desarrollar específicamente para un lugar concreto, ya que las situaciones de partida y necesidades de los sitios pueden ser muy diferentes. Con todo, su desarrollo debe concebirse a partir de información veraz y de calidad, y siguiendo un método de trabajo científico y riguroso, lo cual garantizará la credibilidad, fiabilidad, y solidez de su aplicación. El rigor científico incluye la evaluación de los resultados. Por ello, será necesaria la consideración de indicadores. El Sistema Europeo de Indicadores Turísticos para la gestión sostenible de destinos (ETIS) (Unión Europea 2017) es un ejemplo de estas buenas prácticas. Este sistema se ha desarrollado para ayudar a medir el rendimiento y productividad de los destinos turísticos en relación con la sostenibilidad.

Se hará siempre necesario un enfoque integral, aunque se implementen herramientas de forma individualizada, ya que así se velará por la coherencia y por una visión holística, que considere los factores multidimensionales que intervienen en la planificación turística y que deben enmarcarse en el contexto general del ordenamiento territorial, la conservación patrimonial y la gestión de los visitantes. Además de todo esto, hay que tener en cuenta que el territorio es un sistema dinámico que evoluciona, por lo que habrá que estar pendiente de una actualización regular de los datos que permita una retroalimentación y evaluación permanente del sitio para poder tomar las decisiones adecuadas. De otro lado, se ha de cuidar la adecuación de las herramientas seleccionadas para que resulten viables, realistas, eficaces y eficientes (mantener bajos los costes operativos, facilitar el mantenimiento del sitio, etc.) a la hora de desempeñar su cometido. Estas exigencias se vinculan a la sostenibilidad de las mismas. El uso de herramientas ineficaces puede acarrear consecuencias negativas y la pérdida de oportunidades para el patrimonio, los visitantes y las partes interesadas.

Finalmente, y no por ello menos importante, están los principios orientados a los aspectos sociales que deben acompañar el diseño e implementación de estas herramientas. Así, destacan los valores de participación, inclusión, y la cooperación. Para garantizar la participación pública están los procesos participativos, instrumentos de gobernanza que van a acompañar el desarrollo de todas las herramientas anteriores ya que aseguran a largo plazo la sostenibilidad social de los proyectos, al facilitar la participación activa de la sociedad civil en los asuntos públicos. En particular, en este caso, en la puesta en valor turística del patrimonio. Este principio se inspira en estrategias de intervención transparentes, inclusivas y democráticas; sitúa a las personas en el centro de las políticas y los proyectos. ICOMOS (2011) señala que buscan el compromiso de las comunidades en los sectores del patrimonio cultural y 


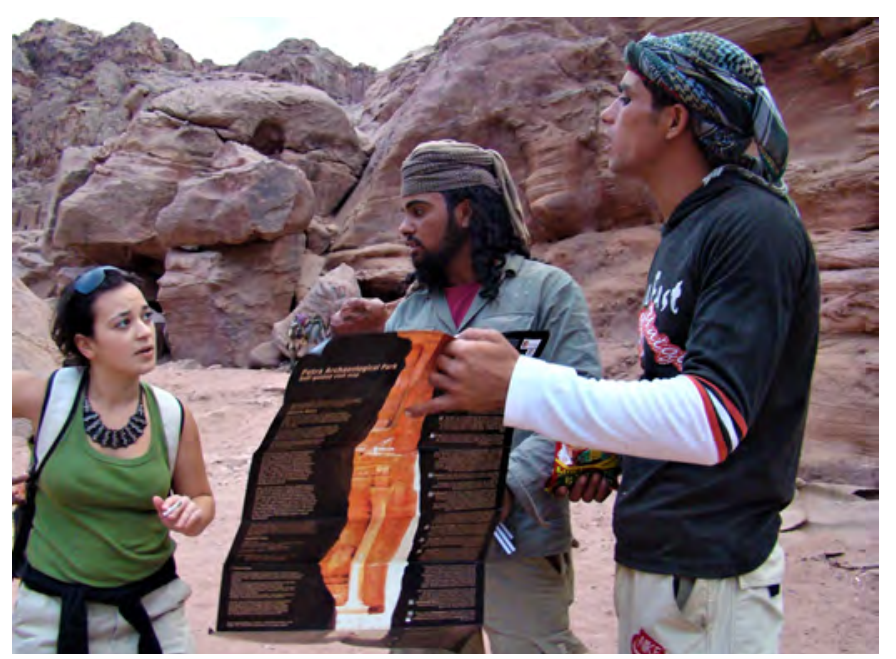

el turismo y el fomento de la creatividad, el desarrollo personal y el espíritu empresarial. Se considera que la apropiación del patrimonio por parte de las comunidades locales refuerza el tejido social y mejora su bienestar social. Por otra parte, la inclusión es un principio transversal, muy ligado al anterior, y necesario también en todos los proyectos de desarrollo del patrimonio ya que significa que todas las partes interesadas intervendrán de igual manera en los procesos participativos.

El principio de cooperación ha sido destacado por la OCDE (2020) en relación a la colaboración y coherencia que debe existir entre los diferentes estamentos gubernamentales y también haciendo referencia a la necesidad de involucrar al sector turístico (cooperación intersectorial) en la planificación estratégica. Por lo tanto, el compromiso proactivo, el entendimiento compartido y el trabajo en colaboración deben constituir una referencia para todos los actores institucionales y privados al abordar los procesos de planificación turística del patrimonio.

\section{REFLEXIONES FINALES}

Tras la presentación de diversas herramientas de planificación para la puesta en valor y gestión turística del patrimonio experimentadas por la autora y su equipo de investigación y los principios básicos para su correcta aplicación, se puede decir que los resultados obtenidos de su implementación han confirmado que el desarrollo turístico de los lugares donde se han implantado han contribuido a resolver problemas previos existentes en el sitio patrimonial, a mejorar la presentación del sitio patrimonial y la calidad de vida de los residentes. El hecho de trabajar sobre la base de los recursos patrimoniales de forma respetuosa y sostenible ha contribuido también a fomentar una 
conservación activa de los mismos y a estimular el aprecio de las comunidades locales por su patrimonio. Sin duda, no se vislumbra en el futuro otra fórmula de conocer y disfrutar el patrimonio que no sea desde una planificación eficiente, sostenible y resiliente.

Las herramientas se han ido refinando a lo largo de años de trabajo, pero sigue siendo un reto enfrentarse a un nuevo sitio patrimonial, ya que cada uno resulta siempre diferente a los anteriores. No obstante, los problemas suelen parecerse y las soluciones exitosas pueden extrapolarse con las adaptaciones necesarias ad hoc.

En estos momentos, y asumida la situación de crisis que ha conocido el sector turístico con ocasión de la pandemia de la COVID-19, el mayor reto en estos momentos, reside en dotar de la mayor resiliencia posible al sector y evitar la desconexión del público con el patrimonio. Las comunidades residentes necesitan mantener sus lazos identitarios vivos; los destinos necesitan los ingresos derivados del turismo; y los turistas necesitan alimentar su conocimiento y sus emociones. Todo esto será en parte posible si se planifican y gestionan los recursos patrimoniales al amparo de sólidas herramientas técnicas y principios éticos, sin generar unas expectativas que sobrepasen los umbrales de uso responsable de los mismos. De esta manera, los sitios tienen que ser capaces de planificar para prever las crisis, asimilar los impactos y los cambios con una respuesta eficiente y ofrecer siempre una experiencia memorable para los visitantes. 


\section{BIBLIOGRAFÍA}

- Aken, J.E. van (2004) Management Research Based on the Paradigm of the Design Sciences: The Quest for Field-Tested and Grounded Technological Rules. Journal of Management Studies, vol. 41(2), pp. 219-246

- Andaroodi, E. (2020) Analyzing the Infrastructures of Cultural Tourism in Heritage sites with an Emphasis on Architectural Design Elements. Journal of Art and Civilization of the Orient, vol. 8(27), pp. 61-74. Disponible en: http://www.jaco-sj.com/article_111396.html?lang=en [Consulta: 13/07/2021]

- Australian Government (2004) Steps to sustainable tourism. Planning a sustainable future for tourism, heritage and the environment. $1 .^{\mathrm{a}}$ ed. Canberra: Dept. of the Environment and Heritage, 66 p. Disponible en: https:// webarchive.nla.gov.au/awa/20050718170625/http://www. deh.gov.au/heritage/publications/sustainable-tourism/pubs/ steps.pdf [Consulta: 13/07/2021]

- Australian Government (2019) Environmental and Heritage Assessments. Last reviewed: 4 November 2019. Disponible en: https://www.agriculture.gov.au/forestry/ policies/rfa/about/process/environmental-heritage\#1 [Consulta: 13/07/2021]

- Baycan, T. y Girard, L.F. (2011) Heritage in socioeconomic development: Direct and indirect impacts. En ICOMOS 17th General Assembly, 2011-11-27/ 2011-12-02, Paris, France. Disponible en: http:// openarchive.icomos.org/id/eprint/1299/ [Consulta: 13/ 07/2021]

- Beck, L. y Cable, T. (1998) Interpretation for 21th Century. Fifteen Guiding Principles for Interpreting Nature and Culture. Champaign, IL, USA: Sagamore Publishing, $242 \mathrm{p}$.

- Beyer, D., Anda, M., Elber, B., Revell, G. y Spring, F. (2005) Best practice model for low-impact nature-based sustainable tourism facilities in remote areas. Gold Coast, Qld.: CRC for Sustainable Tourism, $44 \mathrm{p}$.

- Bowitz, E. y Ibenholt, K. (2009) Economic impacts of cultural heritage-Research and perspectives. Journal of Cultural Heritage, vol. 10(1), pp. 1-8

- Bucholz, J., Lackey, B., Gross, M., Zimmerman, R. (2015) The Interpreter Guidebook. Techniques for programs and presentations. 4. ${ }^{\mathrm{a}}$ ed. Stevens Point, Wisconsin: UWSP Foundation Press

- Carballo, R., Moreno-Gil, S., León, C. y Ritchie, J.R.B. (2015) La creación y promoción de experiencias en un destino turístico. Un análisis de la investigación y necesidades de actuación. Cuadernos de Turismo, n. ${ }^{\circ} 35$, enero-junio, pp. 75-94

- Comisión Europea (2011) Estrategia de la UE sobre la biodiversidad hasta 2020: nuestro seguro de vida y capital natural. $\operatorname{COM(2011)~} 244$ final. Disponible en: https://eur-lex.europa.eu/legal-content/ES/TXT/PDF /?uri=CELEX:52011DC0244\&from=CS [Consulta: 14/ 07/2021]

- Comisión Europea (2014) Hacia un enfoque integrado del patrimonio cultural europeo. $\operatorname{COM}(2014) 477$ final. Disponible en: https://eur-lex.europa.eu/legal-content/ES/ TXT/PDF/?uri=CELEX:52014DC0477\&from=DA [Consul ta: $14 / 07 / 2021]$

- De Ascaniis, S., Gravari-Barbas, M., y Cantoni, L. (2018) Tourism Management at UNESCO World Heritage Sites. Lugano: Università della Svizzera italiana. Disponible en: https://lms.fun-mooc.fr/assetv1:Paris1+16008+session01+type@asset+block@ MOOC_TmatUWHS_manual.pdf [Consulta:14/07/2021]

- Della Spina, L. (2019) Historical Cultural Heritage: Decision Making Process and Reuse Scenarios for the Enhancement of Historic Buildings. En: Calabrò, F., Della Spina, L., Bevilacqua, C. (ed.) New Metropolitan Perspectives. ISHT 2018. Smart Innovation, Systems and Technologies. Cham: Springer, pp. 442-453

- Eagles, P.F.J. y McCool, S.F. (2002) Tourism in National Parks and Protected Areas: Planning and Management. Wallingford: CABI Publishing, $320 \mathrm{p}$.

- European Commission (2017) European Tourism Indicators System for sustainable destination management. Disponible en: https://ec.europa.eu/growth/sectors/tourism/ offer/sustainable/indicators/index_en.htm [Consulta 14/07/2021]

- Grattan, N. (2004) ICCROM \& Public Advocacy: Over 10 years of working with teachers, students, the media, tourists, heritage professionals, and the general public. International Centre for the Study of the Preservation and Restoration of Cultural Property. Disponible en: https://www.iccrom.org/ sites/default/files/ICCROM 03 PublicAdvocacy-It en.pdf [Consulta: 14/07/2021]

- Gunn, C.A. y Var, T. (2002) Tourism Planning. 4th ed. New York: Routledge, 464 p.

- Hall, C.M. y McArthur, S. (1998) Integrated heritage management: Principles and Practice. London: Stationery Office, $250 \mathrm{p}$.

- Ham, S. (1992) Environmental Interpretation: A Practical Guide for People with Big Ideas and Small Budgets. Golden, CO, USA: Fulcrum Publishing

- House of Commons. ODPM: Housing, Planning, Local Government and the Regions Committee (2004) The Role of Historic Buildings in Urban Regeneration: Eleventh 
Report of Session 2003-04. London: The Stationery Office Limited, vol. I. Disponible en: https://publications. parliament.uk/pa/cm200304/cmselect/cmodpm/47/47.pdf [Consulta: 14/07/2021]

- Historic England (2018) Heritage and the Economy 2018. Disponible en: https://historicengland.org.uk/content/ heritage-counts/pub/2018/heritage-and-the-economy-2018 [Consulta: 14/07/2021]

- ICOMOS (2008) The ICOMOS Charter for the Interpretation and Presentation of Cultural Heritage Sites. 16th General Assembly of ICOMOS, Quebec, Canada, 2008. Disponible en: http://icip.icomos.org/downloads/ ICOMOS_Interpretation_Charter_ENG_04_10_08.pdf [Consulta: 14/07/2021]

- ICOMOS (2011a) Declaración de París sobre el Patrimonio como Motor del Desarrollo. 17a Asamblea General del ICOMOS, París, noviembre de 2011. Disponible en: https://www.monumentos.gob.cl/sites/ default/files/articles-55372_doc_pdf.pdf [Consulta 14/ 07/2021]

- ICOMOS (2011b) Guidance on Heritage Impact Assessments for Cultural World Heritage Properties. Disponible en: http://openarchive.icomos.org/id/e print/266/1/ICOMOS_Heritage_Impact_Assessment 2010.pdf [Consulta 14/07/2021]

- Instituto para la Calidad Turística Española (2020) Medidas para la reducción de contagio por el coronavirus SARSCoV-2. Museos y Sitios patrimoniales. Directrices y recomendaciones. Disponible en: https://www.mincotur. gob.es/es-es/COVID-19/turismo/GuiasSectorTurismo/ Guias_de_turismo.pdf [Consulta 14/07/2021]

- International Council of Museums (2020a) Museums and the Covid-19 crisis: 8 steps to supporting community resilience. Disponible en: https://icom.museum/es/news/ museos-y-covid-19-8-pasos-para-apoyar-la-resiliencia-delas-comunidades/ [Consulta 14/07/2021]

- International Council of Museums (2020b) Recommendations for the conservation of museum collections. Disponible en: https://icom.museum/es/news/ recomendaciones-par-la-conservacion-de-la-coleccionesen-los-museos/ [Consulta 14/07/2021]

- International Council of Museums (s.f.) Awarenessraising. En: Observatory on Illicit Traffic in Cultural Goods. Disponible en: https://www.obs-traffic.museum/awarenessraising [Consulta 04/05/2021]

- Kim, J.J. y Fesenmaier, D.R. (2015) Designing tourism places: Understanding the tourism experience through our senses. En: 2015 International Conference of Travel and Tourism Research Association: Advancing Tourism Research Globally. Disponible en: https://scholarworks. umass. edu/cgi/viewcontent.cgi?article $=1041 \&$ context=ttra [Consulta 14/07/2021]

- Labadi, S., Giliberto, F., Rosetti, I., Shetabi, L., Yildirim,
E. (2021) Heritage and the Sustainable Development Goals: Policy Guidance for Heritage and Development Actors. Paris: ICOMOS, $69 \mathrm{p}$.

- Lähdesmäki, T. (2014) The EU'S Explicit and Implicit Heritage Politics. European Societies, vol. 16(3), pp. 401421. Disponible en: https://www.tandfonline.com/doi///10.1 080/14616696.2014.894547?scroll=top\&needAccess=true [Consulta 14/07/2021]

- Ley 16/1985, de 25 de junio, del Patrimonio Histórico Español. Boletín Oficial del Estado, n. ${ }^{\circ} 155$, de 29/06/1985. Disponible en: https://www.boe.es/eli/es/l/1985/06/25/16/ con [Consulta 14/07/2021]

- Manrique, C., Tazim, J. y Warden, R. (2016) Heritage Tourism and Conservation: A Cultural Resilience Bridge? En Munar, A.M y Jamal, T. (ed.) Tourism Research Paradigms: Critical and Emergent Knowledges. Bingley: Emerald Publishing

- Martos Molina, M. (2016) Herramientas para la gestión turística del patrimonio cultural. Gijón: Trea

- Ministerio de Cultura y Deporte. Dirección General de Bellas Artes (2020) Planificación de medidas para la reapertura de los museos de titularidad y gestión estatal dependientes de la Dirección General de Bellas Artes. Disponible en: https://www.culturaydeporte.gob.es/dam/ jcr:6f409c61-dac0-4d66-a3f8-781ebbbcf868/planificacin-de-medidas-para-la-reapertura-de-los-museos-detitularidad-y-gesti-n-estatal-dependientes-de-la-direcci-ngeneral-de-bellas-artes.pdf [Consulta: 14/07/2021]

- Ministerio de Cultura y Deporte. IPCE (2020) Recomendaciones sobre procedimientos de desinfección en bienes culturales con motivo de la crisis por COVID-19. Disponible en: https://ipce.culturaydeporte.gob.es/dam/ jcr:3cf1e6b5-1925-440d-a514-3c60f1edadc9/anexo-recomendaciones-ipce-patrimonio-covid-19--1-.pdf [Consulta 14/07/2021]

- Moscardo, G. (2019) Connecting people with experiences. En: McCool, S.F. y Bosak, K. (ed.) A research agenda for sustainable tourism. Cheltenham, GBR: Edward Elgar, pp. 70-89

- OCDE e ICOM (2019) Cultura y Desarrollo Local: Maximizar el Impacto. Una guía para gobiernos locales, comunidades y museos. Disponible en: https://www.oecd. org/cfe/leed/OECD-ICOM-GUIDE-MUSEUMS-ES.pdf [Consulta 14/07/2021]

- Organización de Naciones Unidas (2015) Transformar nuestro mundo: la Agenda 2030 para el Desarrollo Sostenible. Resolución de la Asamblea General, 25/09/2015, 70/1. Disponible en: https://www.agenda2030 gob.es/recursos/docs/APROBACION_AGENDA_2030.pdf [Consulta 14/07/2021]

- Pearce, P. (1991) Analysing tourist attractions. Journal of Tourism Studies, vol. 2(1), pp. 46-55 
- Pedersen, A. (ed.) (2002) Managing Tourism at World Heritage Sites: a Practical Manual for World Heritage Site Managers. Paris: UNESCO World Heritage Centre. Disponible en: http://whc.unesco. org/sustainabletourismtoolkit/sites/default/files/1.\%20 UNESCO $\% 20 \% 282002 \% 29 \% 20$ WH\%20Paper\%201\%20 Managing \%20Tourism\%20at\%20WH\%20Sites.PDF [Consulta 14/07/2021]

- Peltier, D. (2017) Nearly Half of UNESCO Sites don't have Plans to Manage Overtourism Challenges. En: Skift Corporate. Disponible en: https://skift.com/2017/04/19/ nearly-half-of-unesco-sites-dont-have-plans-to-manageovertourism-challenges/ [Consulta 14/07/2021]

- Pendlebury, J. y Porfyriou, H. (2017) Heritage, urban regeneration and place-making. Journal of Urban Design, vol. 22(4), pp. 429-432. Disponible en: https://www. tandfonline.com/doi/full/10.1080/13574809.2017.1326712 [Consulta 14/07/2021]

- Reitsamer, B.F. y Brunner-Sperdin, A. (2015) Tourist destination perception and well-being: What makes a destination attractive? Journal of Vacation Marketing, vol. 23(1), pp. 55-72

- Richards, G. y Munsters, W. (ed.) (2010) Cultural tourism research methods. sl.: CAB

- Scott, N., Gao, J., y Ma, J. (2017) Visitor Experience Design. sl.: CABI, 284 p.

- Shimray, S.R. (2019) Ways to Create Awareness on Cultural Heritage: An overview. Library Philosophy and Practice, Summer 4-26-2019. Disponible en: https:// digitalcommons.unl.edu/libphilprac/2577 [Consulta: 14 /07/2021]

- Stankey, G. y Manning, R. (1986) Carrying Capacity of Recreation Settings. A Literature Review. The President's Commission on Americans Outdoors. Washington, DC: U.S. Government Printing Office

- Tilden, F. (1957) Interpreting our Heritage. Chapel Hill, USA: University of North Carolina Press, $224 \mathrm{p}$.

- UNEP y UNWTO (2005) Making Tourism more Sustainable: A Guide for Policy Makers. Disponible en: https://wedocs.unep.org/bitstream/ handle/20.500.11822/8741/-Making\%20Tourism\%20 More\%20 Sustainable_\%20 A\%20Guide \% 20 for $\% 20$ Policy $\% 20$ Makers-2005445.pdf?sequence= 3\&isAllowed=y [Consulta 14/07/2021]

- UNEP y CBD (2010) Plan Estratégico para la Diversidad Biológica 2011-2020 y las Metas de Aichi para la Diversidad Biológica. UNEP/CBD/COP/DEC/X/2, 27 de octubre de 2010. Disponible en: https://www.cbd.int/doc/decisions/ cop-10/cop-10-dec-02-es.pdf [Consulta 14/07/2021]

- UNESCO. Centro de Patrimonio Mundial (2005) Directrices Prácticas para la aplicación de la Convención del Patrimonio Mundial. WHC.05/2, 2 de febrero de 2005.
Disponible en: https://whc.unesco.org/archive/opguide05es.pdf [Consulta 14/07/2021]

- UNESCO. World Heritage Committee (2011) World Heritage Tourism Programme. WHC-12/36.COM/5E, Paris, 11 May 2012. Disponible en: https://whc.unesco. org/archive/2012/whc12-36com-5E-en.pdf [Consulta 14/07/2021]

- UNESCO. World Heritage Committee (2014) Alentar la resiliencia. Patrimonio Mundial, n. ${ }^{\circ}$ 74, pp. 4-63. Disponible en: http://unesdoc.unesco.org/ images/0023/002316/231678s.pdf [Consulta 14/07/20 21]

- UNESCO (s.f.) UNESCO World Heritage Sustainable Tourism Online Toolkit. Disponible en: http://whc.unesco. org/sustainabletourismtoolkit/ [Consulta 14/07/2021]

- UNWTO (s.f..) Product development. Disponible en: https://www.unwto.org/tourism-development-pro ducts [Consulta 22/05/2021]

- Viñals, M.J., Morant, M. y Teruel, L. (2014): Confort psicológico y experiencia turística. Casos de estudio de espacios naturales protegidos de la Comunidad Valenciana (España). Boletín de la Asociación de Geógrafos Españoles, n. ${ }^{\circ} 65$, pp. 293-316

- Viñals, M.J., Mayor, M., Martínez Sanchis, I., Teruel, L., Alonso-Monasterio, P. y Morant, M. (2017) Turismo sostenible y patrimonio: Herramientas para la planificación y gestión. Valencia: Universitat Politècnica, 191 p. Disponible en: https://riunet.upv.es/handle/10251/91732 [Consulta 14/07/2021]

- Viñals, M.J. y Teruel, L. (2021) La perspectiva de la sostenibilidad medioambiental en los estudios de máster y doctorado en turismo en España. Cuadernos de Turismo, n. ${ }^{\circ}$ 47, pp. 487-513. Disponible en: https://revistas.um.es/ turismo/article/view/474511 [Consulta 14/07/2021]

- Wight, P. (1998) Tools for sustainability analysis in planning and managing tourism and recreation in the destination. En: Hall, M.C. y Lew, A.A. (ed.) Sustainable Tourism: A Geographical Perspective. New York: Longman Limited, pp. 35-48

- Yang, C.H. y Lin, H.Y. (2014) Revisiting the relationship between World Heritage Sites and tourism. Tourism Economics, vol. 20(1), pp. 73-86 


\section{Las infraestructuras de transporte: buenas prácticas en la recuperación y gestión del patrimonio territorial}

José Luis Lalana Soto | Dpto. de Urbanismo y Representación de la Arquitectura, Escuela de Arquitectura, Universidad de Valladolid Rita Ruiz Fernández, Francisco Javier Rodríguez Lázaro | Escuela Técnica Superior de Ingeniería de Caminos, Canales y Puertos, Universidad de Castilla-La Mancha

URL de la contribución <www.iaph.es/revistaph/index.php/revistaph/article/view/4957>

\section{RESUMEN}

Las infraestructuras y redes de transporte proyectadas y construidas desde las décadas centrales del siglo XVIII constituyen un patrimonio histórico de enorme relevancia, pero su protección es todavía, en nuestro país, muy limitada. Las escasas propuestas para su recuperación se han centrado en infraestructuras que en el momento de su rehabilitación estaban abandonadas, lo que ha permitido plantear usos alternativos no condicionados por las exigencias derivadas de la necesidad del mantenimiento de la función para la que fueron proyectadas. En ocasiones, estas intervenciones se han traducido en la pérdida de elementos sustanciales, dificultando, en consecuencia, una adecuada transmisión de los valores intrínsecos de la propia obra de ingeniería a sus potenciales usuarios. Este escenario evidencia la necesidad de establecer criterios de actuación que puedan incorporarse a los proyectos de recuperación de este tipo de bienes. El artículo presenta dos propuestas de ámbito internacional -la EN2 portuguesa en el tramo comprendido entre Almodôvar y São Brás de Alportel, y el Ocho del Šargan, en Serbia-, con objeto de evaluar la posibilidad de establecer prácticas que compatibilicen, de forma integrada, la preservación y difusión patrimonial, el mantenimiento de la función transporte, y las estrategias orientadas a la activación turística y el desarrollo socioeconómico de sus corredores.

\section{Palabras clave}

Carreteras | EN2 | Conservación (Patrimonio) | Ferrocarriles | Infraestructuras de transporte | Ingeniería civil | Intervención | Obra pública | Ocho del Šargan | Portugal | Rehabilitación | Serbia | 


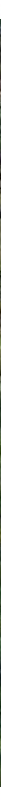

Transport infrastructure: Good practice in the recovery and management of the territorial heritage

\section{ABSTRACT}

The infrastructure and transport networks designed and built as from the mid-eighteenth century constitute historic heritage of enormous relevance. However, the protection of these roads is still very limited, in this country, and the very few conservation proposals that have been made to date, have focused on infrastructure that had been abandoned at the time of restoration. This has allowed repurposing that would have been impossible if the infrastructure had retained its original design purpose. Furthermore, these interventions have occasionally led to the loss of valuable heritage assets, which has handicapped the correct assessment of the intrinsic values of these engineering works by its potential users. This situation demonstrates the need to establish design and intervention criteria that can be incorporated in conservation and restoration projects of these types of assets and, in particular, railways and roads. In this respect, the article presents two international restoration projects -the Portuguese EN2, in the section between Almodôvar and São Brás de Alportel, and the Šargan Eight, in Serbia-in order to raise questions that could serve as the basis for alternative restoration proposals to those traditionally conducted in Spain.

\section{Key words}

Roads | EN2 | Conservation (Cultural heritage) | Railways | Historic transport infrastructure | Civil Engineering | Intervention | Public works heritage | Šargan Eight | Portugal | Rehabilitation | Serbia |

Cómo citar: Lalana Soto, J.L., Ruiz Fernández, R. y Rodríguez Lázaro, F.J. (2021) Las infraestructuras de transporte: buenas prácticas en la recuperación y gestión del patrimonio territorial. Revista PH, n. ${ }^{\circ}$ 104, pp. 126-143. Disponible en: www.iaph.es/revistaph/index.php/revistaph/article/view/4957 DOI 10.33349/2021.104.4957

Enviado: 07/06/2021 | Aceptado: 19/07/2021 | Publicado: 01/10/2021 


\section{INTRODUCCIÓN}

Las infraestructuras y redes de transporte proyectadas y construidas desde las décadas centrales del siglo XVIII constituyen un patrimonio histórico de enorme relevancia (Menéndez de Luarca y Soria 1994; Soria 1997; Martínez 1996, 2003; Navarro 2009, Nárdiz 2014a). Hoy, los restos materiales de estas infraestructuras se asocian a la consideración de la evolución de la ciencia y la tecnología, las transformaciones de las dinámicas de movimiento e intercambio de personas y bienes, o los procesos y lógicas que explican la construcción histórica del territorio.

Sin embargo, la protección de estas vías de comunicación es todavía, en nuestro país, muy limitada, y las aportaciones conceptuales y metodológicas relativas a su identificación, caracterización y valoración apenas se han traducido en la elaboración e instrumentación de textos normativos que permitan su adecuada preservación (Lalana 2012; Lalana y Santos 2016; Nárdiz 2014b; Ruiz, Rodríguez y Coronado 2017).

Por lo demás, la desatención a estos bienes y sus entornos se ha traducido en la pérdida de buena parte de este patrimonio: gran parte de las infraestructuras lineales históricas que han quedado abandonadas están experimentando un progresivo y en ocasiones irreversible deterioro, y las que se mantienen en uso siguen, por lo general, siendo alteradas sin criterios patrimoniales que permitan apoyar adecuadamente las decisiones proyectuales.

Paradójicamente, y cuando existen ya valiosísimos ejemplos de proyectos de rehabilitación de obras de escala nodal -puentes, faros, presas, etc.-, apenas contamos con experiencias de recuperación de infraestructuras y redes de transporte. Además, los escasos proyectos de intervención que se han desarrollado en nuestro país se han ocupado de corredores de mayor antigüedad -piénsese en el Camino de Santiago o la Vía de la Plata (García 1998)-, y apenas se ha atendido a los canales, ferrocarriles o carreteras construidas a partir del siglo XVIII.

1

La recuperación del canal siguió el Plan Regional de ámbito territorial del Canal de Castilla, elaborado con el apoyo del Centro de Estudios Históricos de Obras Públicas y Urbanismo del CEDEX, y aprobado por la Junta de Castilla y León en virtud del Decreto 205/2001, de 02/08/2001
En relación con los primeros, los escasos canales de transporte de cierta longitud construidos en los siglos XVIII y XIX en España declinaron tras la aparición del ferrocarril $y$, aunque afectados por fuertes procesos de deterioro, apenas sufrieron modificaciones. Su abandono ha permitido que, en los proyectos dirigidos a su recuperación, hayan podido plantearse usos alternativos alejados de los originales y ajenos a las expectativas y demandas funcionales para las que se proyectaron. Baste referirse al Canal de Castilla, cuyo proyecto de recuperación sigue siendo hoy, en nuestro país, el principal referente en materia de rehabilitación y refuncionalización de canales históricos ${ }^{1}$. En síntesis, y al igual que en el caso de otros proyectos de ámbito internacional, la intervención consistió en la restauración de algunos de sus elementos singulares -esclusas, 
dársenas, embarcaderos...-, la adecuación de los caminos de sirga para el uso de peatones y ciclistas, y el establecimiento y explotación de embarcaciones de uso turístico en un pequeño tramo del trazado (Guerra 2004).

En el caso de los ferrocarriles, buena parte de la red construida desde mediados del siglo XIX sigue manteniéndose en uso. Las mejoras introducidas a lo largo del siglo $\mathrm{XX}$ afectaron escasamente a los trazados, pero supusieron una profunda transformación de los puentes y viaductos, la superestructura -raíles, dispositivos de operación y explotación, sistemas de electrificación...-, y las instalaciones y espacios de las estaciones. La atención a la dimensión patrimonial de las líneas en uso sigue limitándose a las estructuras y los edificios de viajeros y, como en otros países, las escasas iniciativas que pudieran guardar relación con su valorización y difusión patrimonial han consistido en la explotación fija o estacional de los trazados mediante material rodante histórico con intención turística². Por lo demás, las intervenciones de refuncionalización en líneas abandonadas, convertidas en vías para tráfico no motorizado, han supuesto el desmantelamiento de las vías y, con ello, la pérdida de la legibilidad del patrimonio ferroviario ${ }^{3}$.

Por su parte, la mayoría de las carreteras construidas durante los siglos XVIII y XIX se mantienen, también hoy, en uso. Conservaron su configuración original durante un largo período de tiempo, y no fueron objeto de obras de mejora hasta el período correspondiente a la aparición y primer desarrollo del automóvil. En este sentido, las primeras modificaciones introducidas en la red principal de carreteras consistieron en la extensión de firmes alternativos al macadam, la introducción de peraltes en las alineaciones curvas y la instalación de nuevos dispositivos de contención y señalización vertical, y no fue hasta las décadas de los años cincuenta y sesenta cuando el aumento del parque móvil y la consolidación de la motorización obligaron a introducir mejoras de mayor entidad. Las principales actuaciones consistieron en la regularización y modernización sistemática de las secciones y los firmes, y en la construcción de centenares de variantes y rectificaciones de trazado para evitar el paso por las travesías y por zonas de orografía desfavorable (Rodríguez et ál. 2007). Sin embargo, y salvo en tramos de muy reducida longitud que quedaron abandonados, los trazados rectificados, más o menos transformados, siguen en servicio dando acceso a los terrenos colindantes. Hasta la fecha, y más allá de alguna actuación desarrollada para incentivar la conducción recreativa en trazados de especial interés paisajístico (Zoido 2006), no se ha implementado ningún proyecto para rehabilitar este tipo de infraestructuras en cuanto bienes patrimoniales.

Las páginas que siguen presentan dos proyectos internacionales de rehabilitación -la EN2 portuguesa en el tramo comprendido entre Almodôvar y São Brás de Alportel, y el Ocho del Šargan, en Serbia-, con intención de evaluar la posibilidad de establecer prácticas que compatibilicen, de forma inte-
2

Es el caso del Ferrocarril de Sóller, en Baleares o del Tren dels Llacs, que comunica Lleida con La Pobla de Segur.

3

La refuncionalización de líneas abandonadas para su uso como vías para tráfico no motorizado se concretó en el programa Vías Verdes, iniciado en 1993. Tiene su origen en el programa Tejido Verde, propuesto en el Plan Director de Infraestructuras 1993/2007. Con carácter previo a su puesta en marcha, se elaboró un Inventario de líneas ferroviarias en desuso que permitió identificar y catalogar $7.684 \mathrm{~km}$ de líneas abandonadas (Aycart 2001). 
grada, la preservación y difusión patrimonial, el mantenimiento de la función transporte, y las estrategias orientadas a la activación turística y el desarrollo socioeconómico de sus corredores.

\section{UNA EXPERIENCIA DE REHABILITACIÓN DE CARRETERAS: LA EN2 PORTUGUESA ENTRE ALMODÔVAR Y SÃO BRÁS DE ALPORTEL}

\section{La EN2 y el programa Estradas-Património}

Al igual que en nuestro país, la modernización de la red viaria portuguesa ha comportado, en los últimos años, evidentes beneficios para el tráfico automóvil y, del mismo modo que en España, ha generado impactos de diversa índole en las carreteras o tramos afectados por la construcción de trazados alternativos.

En el sur, el proceso de rejerarquización de la red motivó que, a partir de la década de los años noventa del pasado siglo, la práctica totalidad del tráfico que, desde Faro, discurría por la EN2 hacia Castro Verde, Ferreira do Alentejo y Montemor-o-Novo, para seguir en dirección norte o conectar con Lisboa, pasara a la N125 y la IC1 y, posteriormente, conforme entraron en servicio, a las autopistas A22 y A2/IP1.

La desatención a la conservación de la EN2 en el tramo comprendido entre Almodôvar y São Brás de Alportel, que había conectado tradicionalmente el Baixo Alentejo con el Algarve, planteó, en 1999, la necesidad de intervenir en el trazado. Frente a la adopción de un proyecto convencional de mejora, los responsables del Instituto das Estradas de Portugal, IEP, propusieron una estrategia alternativa, consistente en recuperar la carretera con criterios patrimoniales con objeto de valorizar el propio patrimonio viario y estimular iniciativas de explotación turística beneficiosas para la reactivación socioeconómica del corredor (Teixeira 2003).

La idea fue el germen del programa Estradas-Património, diseñado con intención de extender aquella primera experiencia a otras carreteras de interés histórico, paisajístico y/o patrimonial (Graça y Vasconcelos 2009). Los primeros trabajos del IEP se tradujeron en la redacción del proyecto de recuperación del tramo y la elaboración de un catálogo de carreteras que pudieran ir incorporándose al programa. El proyecto se presentó a los responsables locales en el verano de 1999, y las obras, coordinadas desde la Dirección de Carreteras de Beja, quedaron concluidas en 2002 (Entrevista 2003).

\section{Evolución histórica del tramo}

El trazado del tramo, que corresponde a la ruta tradicionalmente empleada para el tránsito de personas y mercancías desde el interior al sur de Portugal, 
no se consolidó hasta la segunda mitad del siglo XIX. Fue entonces cuando se pavimentó la calzada y se construyeron los primeros puentes.

La carretera no sufrió alteraciones hasta que, tras la creación de la Junta Autónoma de Estradas, JAE, y en paralelo al primer desarrollo del tráfico automóvil, se instrumentaron medidas para la ordenación y modernización de la red viaria portuguesa. Entre 1933 y 1937 se regularizó la sección transversal y se extendió un riego bituminoso, se construyeron los edificios de apoyo necesarios para la conservación de la carretera -casillas de peones camineros, almacenes de material, etc.-, y se instaló un primer dispositivo de elementos de defensa y señalización vertical (Aguiar 2003; Carneiro 2011). La expansión del uso del automóvil y el potencial turístico de la zona hicieron que el tramo alcanzase notables volúmenes de tráfico, consolidándose, mediado el siglo, como parte del gran eje norte-sur -EN2-, que unió Chaves y Faro.

Ya en la década de 1990, la dificultad del trazado se sumó, como se ha señalado, al acondicionamiento y construcción de ejes alternativos más aptos para la circulación de vehículos y, como consecuencia, el eje histórico de comunicación entre el Alentejo y el Algarve pasó a desempeñar una función secundaria en la estructura y explotación de la red.

\section{El proyecto de recuperación: rehabilitación, acondicionamiento y difusión}

El proyecto mantuvo la geometría de la carretera, y consideró, como parte sustancial de la recuperación, la rehabilitación de los elementos que habían transformado la infraestructura tras la aparición del automóvil. No se propuso ninguna rectificación o mejora local, y únicamente se corrigió el trazado de un pequeño número de incorporaciones e intersecciones. Las actuaciones en la sección transversal consistieron en la extensión de una capa de aglomerado en caliente en la banda de rodadura, el acondicionamiento de las cunetas, la renovación de la señalización horizontal y la instalación de los elementos de señalización vertical que se consideraron estrictamente necesarios para garantizar la seguridad de la circulación. El dispositivo de señalización siguió la normativa técnica, y no procuró ninguna similitud formal o cromática con los elementos ya existentes.

Las operaciones de rehabilitación, apoyadas en la documentación histórica disponible, se centraron en los elementos de señalización vertical, los sistemas de contención lateral, una fuente y un mirador, los edificios de conservación y las casillas de peones camineros, y las obras de fábrica.

La señalización objeto de rehabilitación incluyó los indicadores de distancia, las señales de precaución y desvío, y los postes miriamétricos, kilométricos y hectométricos. Las operaciones de restauración se limitaron a la repara-

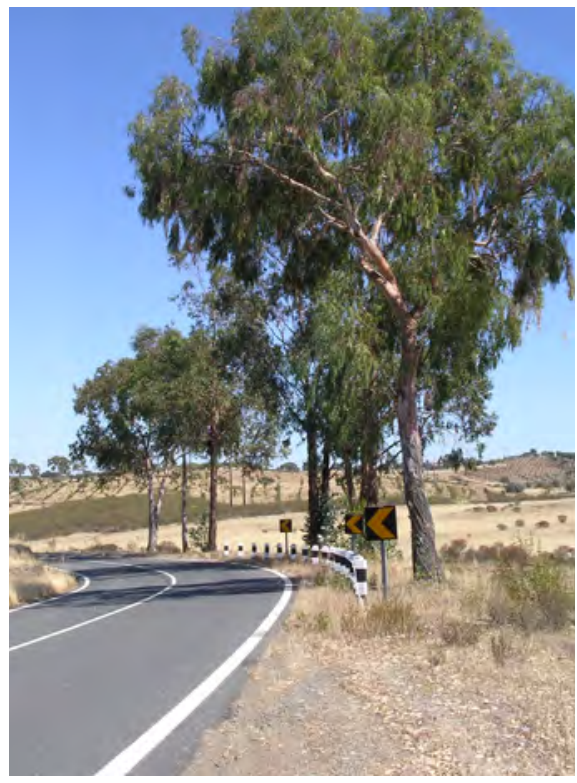

Vista del trazado de la EN2 en Portugal | foto Francisco Javier Rodríguez (2009) 

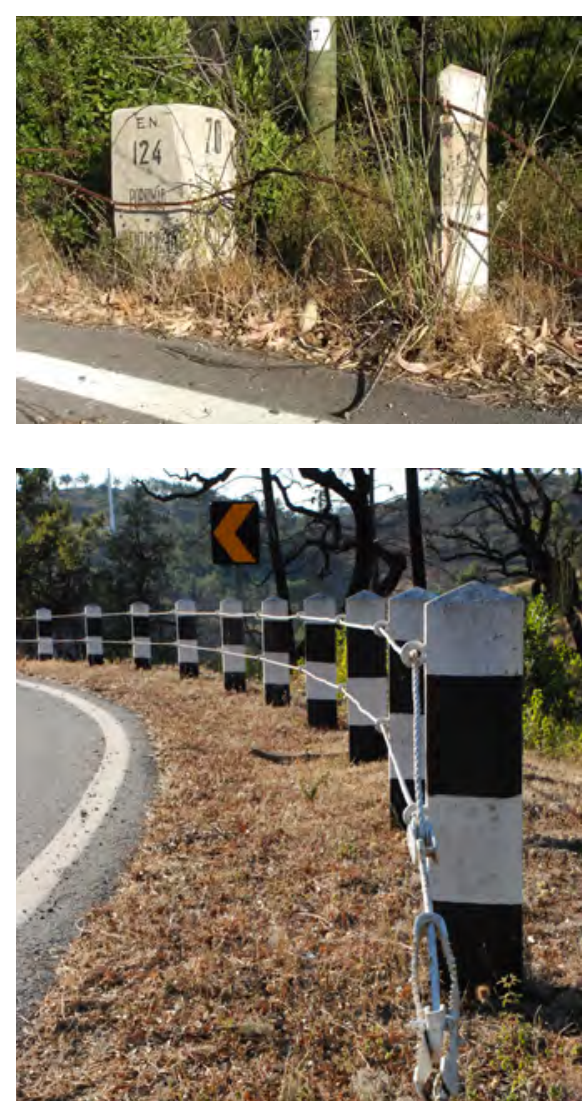

Sistemas de contención antes y después de la rehabilitación | fotos Francisco Javier Rodríguez (2009)

ción de las partes deterioradas y la recuperación de la rotulación y la pintura originales. En algunos casos, los postes más aislados se retiraron de su emplazamiento original y se reubicaron en tramos en los que, junto con los existentes, pudieron establecerse con facilidad secuencias continuas.

La recuperación de los sistemas de contención -mallas metálicas, cables tensados sobre postes de hormigón, montantes y durmientes de hormigón, barreras rígidas curvas-, se concentró en las alineaciones de menor peligro potencial para el tráfico, y los elementos de los tramos retirados que se encontraban en mejor estado de conservación fueron reutilizados para completar los que se rehabilitaron.

Los edificios de conservación y las casillas de peones camineros del tramo fueron asimismo restauradas. La rehabilitación se centró en las fachadas y los elementos exteriores, y el acondicionamiento de los espacios interiores tuvo en cuenta la posibilidad de que los edificios se refuncionalizaran como centros de interpretación o espacios disponibles para actividades y usos locales y turísticos.

El acondicionamiento de las obras de fábrica se circunscribió a la limpieza y la recuperación de las partes enlucidas, la rehabilitación de la señalización existente y la instalación de balizas con objeto de advertir al conductor del estrechamiento de la sección de la calzada. Siguiendo los objetivos perseguidos por el proyecto, no se planteó el ensanchamiento de los tableros o la rectificación de las alineaciones curvas de entrada y salida de las estructuras. Además de los edificios de servicio, se rehabilitaron el mirador de Caldeirão y la fuente de las Bicas da Serra.

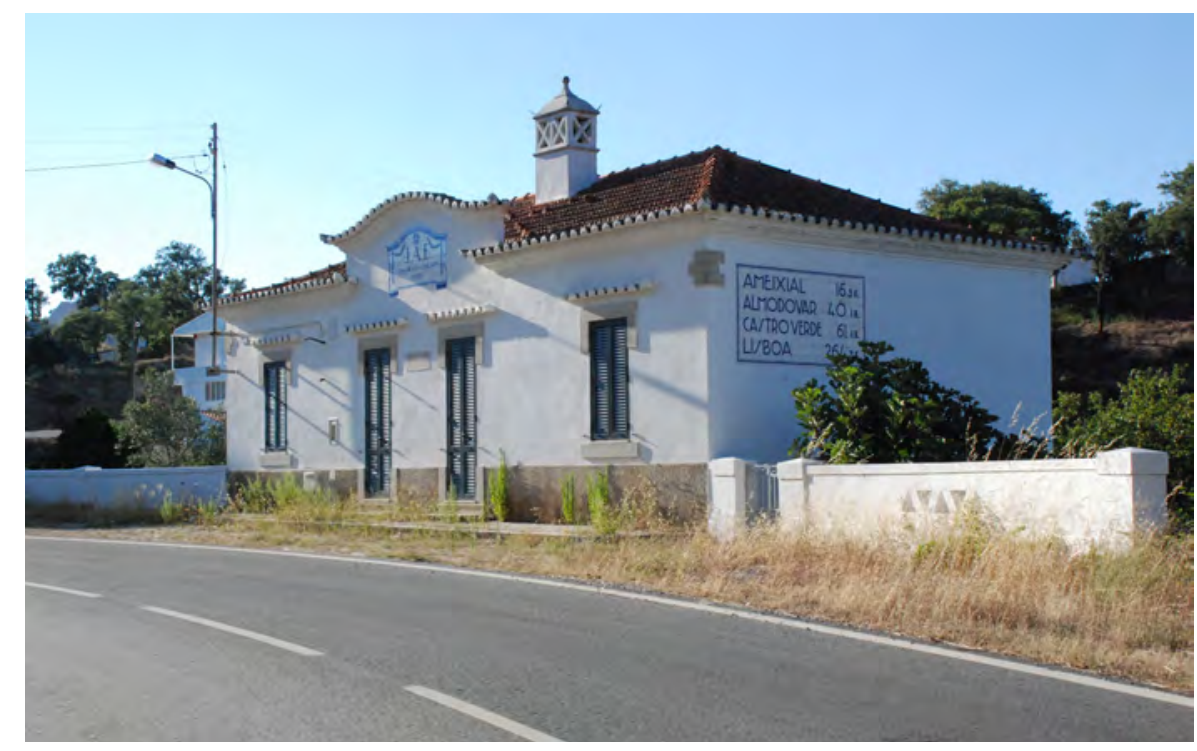


Las obras se completaron con la construcción de tres pequeñas áreas de descanso dispuestas a lo largo del itinerario, y la instalación de dos paneles informativos en los extremos del tramo. Como en el caso de la señalización vertical de acompañamiento, su diseño no buscó ninguna similitud con los elementos rehabilitados.

La difusión del proyecto, y por ende del programa, se concretó en la elaboración de una guía cuidadosamente editada. Además de ofrecer abundante información sobre la evolución histórica de la construcción de la carretera y el propio proyecto de recuperación, el texto y las imágenes exponían, con detaIle, aspectos relativos al paisaje, la fauna y la flora, el patrimonio construido y los usos y costumbres tradicionales característicos del corredor (Aguiar 2003).

\section{Resultados}

En síntesis, la rehabilitación de la EN2 en el tramo comprendido entre Almodôvar y São Brás de Alportel permitió compatibilizar el mantenimiento de la función transporte con la recuperación del itinerario como carretera histórica. Además, y habiéndose concebido como experiencia piloto, pudieron evaluarse la metodología y las estrategias del proyecto, y la viabilidad de su extensión a otras carreteras o tramos. Sea como fuere, y coincidiendo con la conclusión las obras, el IEP integró, en 2002, el Instituto para a Construção Rodoviária, ICOR, y el Instituto para a Conservação e Exploração da Rede Rodoviária, ICERR, convirtiéndose, en 2004, en Estradas Portugal. Las transformaciones a que se alude motivaron cambios en las prioridades del organismo (Carneiro 2011), y el programa Estradas-Património quedó, de hecho, en suspenso.

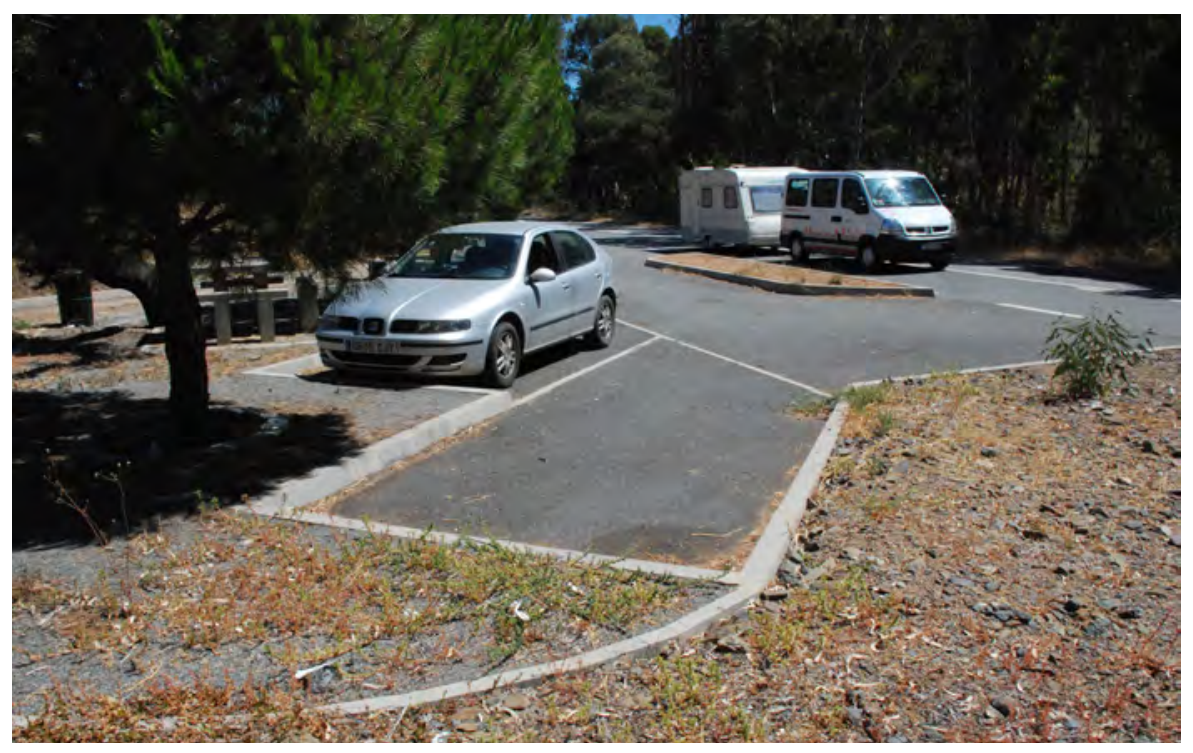

Una de las tres áreas de descanso construidas en los márgenes de la carretera y panel informativo instalado en los extremos del tramo | fotos Francisco Javier Rodríguez (2009)

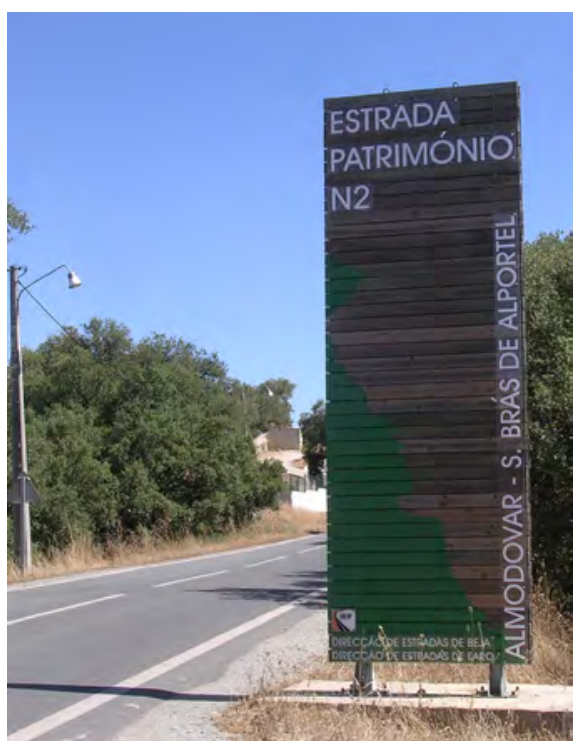




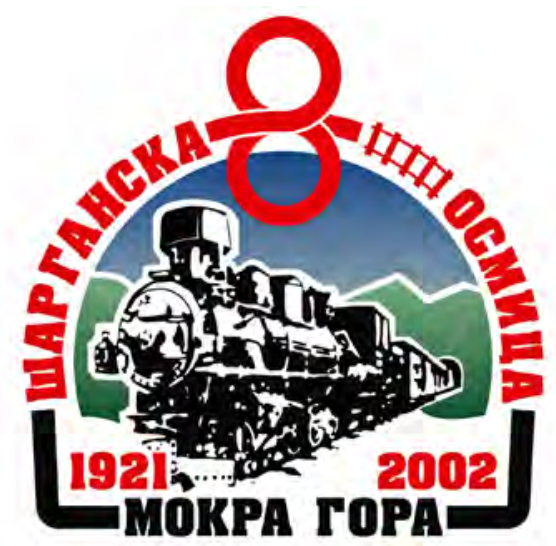

Logotipo comercial del Ocho del Šargan | fuente www.srbvoz.rs/en/nostalgija-2
La falta de continuidad del programa y, en consecuencia, de su difusión, se sumó a la escasa implicación efectiva de los municipios que pudieran haberse beneficiado de la iniciativa. No habiendo sido involucrados por la administración central en las fases de propuesta y proyecto, las autoridades y agentes locales quedaron al margen de la toma de decisiones y la asunción de responsabilidades, hecho que contribuyó al desinterés por el mantenimiento y explotación de la carretera histórica como recurso turístico. $\mathrm{Ni}$ las autoridades de Almodôvar ni las de São Brás de Alportel, activas en el esfuerzo por conservar, difundir y rentabilizar su patrimonio histórico, llegaron a asumir la EN2 como parte de semejante patrimonio.

Ya en 2016, los treinta y cinco municipios de paso de la carretera EN2 crearon la Associação de Municipios da Rota da Estrada Nacional 2 y pusieron en marcha el proyecto Rota Estrada Nacional 2. El esfuerzo de la asociación se ha centrado en la consolidación de un producto turístico orientado a la reactivación del corredor, y ha quedado articulado sobre la idea de la "ruta" -no ya de la carretera-, como soporte de actividades y experiencias. En lo que toca a la promoción, el proyecto se ha traducido en estrategias como la señalización del itinerario, el diseño de una imagen de marca, la creación de un pasaporte que puede sellarse en las localidades de paso, o la apertura de una página web en la que el viajero puede recabar información sobre los alojamientos y servicios, la gastronomía, los productos locales o el patrimonio construido y los espacios naturales que pueden visitarse a lo largo de la ruta. Más allá de que al hilo de la iniciativa se hayan recuperado algunas casillas de peones camineros, se mantenga, en algunos tramos, la señalización vertical, o se haya dispuesto un centro de interpretación de la carretera, el interés por su preservación no figura ya entre los objetivos y reclamos centrales del proyecto.

\section{UNA EXPERIENCIA DE REHABILITACIÓN DE FERROCARRILES: EL OCHO DEL ŠARGAN, EN SERBIA}

\section{El ferrocarril del Šargan}

Este tramo ferroviario está situado en Serbia occidental, muy próximo a la frontera con la República Srpska (Bosnia), y desde 2003 une, a través de un recorrido espectacular de poco más de $15 \mathrm{~km}$, las estaciones de Mokra Gora y Šargan-Vitasi. Es el fruto de una historia que podemos perfectamente calificar de atormentada -antes, durante y después de su servicio comercial activo-, en un territorio y un medio no menos difícil.

El Ocho del Šargan es el nombre comercial por el que se denomina hoy a la parte central de la sección Višegrad-Užice del ferrocarril de vía estrecha, de 760 mm de ancho, que entre 1924 y 1974 constituyó una de las vías de comunicación de Belgrado con Sarajevo y con el Adriático. 


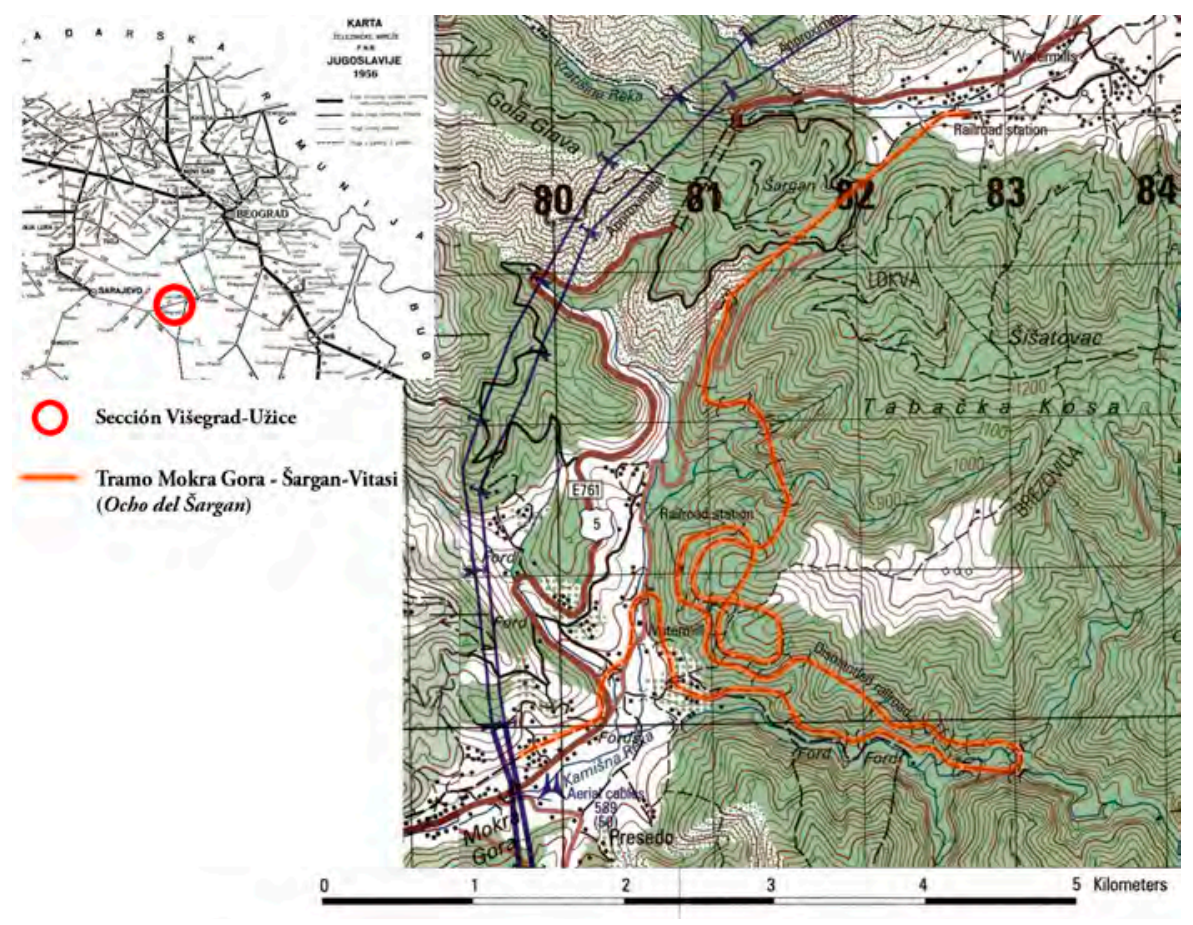

Este tramo fue recuperado por la compañía de los Ferrocarriles Serbios ŽS, Železnice Srbije, que es también la que lo explota actualmente, a través de la compañía estatal Srbija Voz, JSC, que desde 2015 se ha hecho cargo del transporte ferroviario de viajeros.

Dejando aparte los factores históricos y geográficos que dieron origen a su trazado, podemos destacar tres asuntos relevantes por lo que respecta a su recuperación. Primero, que se trata desde el principio de una intervención netamente dirigida al ferrocarril como recurso turístico; segundo, que en la interpretación de esta línea se entremezclan permanentemente cuestiones culturales, naturales, etnográficas o simbólicas, sin apenas distinción entre unas y otras, y en las cuales el patrimonio, en sentido estricto y por lo que se refiere al ferrocarril como infraestructura lineal de transporte, es más un discurso que un criterio fundamental; y tercero, relacionado con los anteriores, que la línea férrea se concibe más como una atracción que como un elemento patrimonial a preservar. En este sentido, cabe señalar que lo que hoy vemos es una reconstrucción, que efectivamente ha respetado el trazado y las obras de paso, y específicamente el ocho que le da nombre, pero la infraestructura llegó a desmantelarse. A propósito del ocho, este trazado helicoidal se trata solo como una curiosidad llamativa, y en ningún momento aparece explicación alguna sobre la importancia de esta configuración -los "lazos"- para superar las rampas en el ferrocarril, o sobre la relación directa que este caso concreto tiene con la sección extraordinariamente estrecha de
Trazado entre Mokra Gora y Šargan Vitasi | plano elaboración propia, utilizando como base el plano de la red ferroviaria de Yugoslavia en 1956 (JŽ Timetable 1956/1957), y las hojas 2982-I (Bajina Basta) y 2982-IV (Višegrad) de U.S. Defense Mapping Agency (1997): Former Yugoslavia Topographic Maps Series M709, 1:50.000 
la vía, que es la que permite radios de curva muy reducidos, aunque sea a costa de imponer una baja velocidad en la circulación.

\section{Evolución histórica de la línea Višegrad-Užice}

Como hemos señalado ya, la materialización de esta sección (VišegradUžice) fue complicada desde sus orígenes. En 1906, el Imperio Austrohúngaro buscó la conexión de Višegrad, a orillas del Drina, con la frontera serbia, llegando en 1916 hasta Mokra Gora, en ese momento con mano de obra compuesta por prisioneros de guerra, fundamentalmente rusos e italianos... pero el paso del Šargan, entre los macizos de Zlatibor y de Tara, que constituye el cierre del valle de Mokra Gora hacia el interior de Serbia, se quedó sin resolver.

En 1921, con el establecimiento del Reino de los Serbios, Croatas y Eslovenos, la conexión entre Belgrado y Sarajevo pasó a ser considerada una cuestión fundamental para el nuevo estado, y se retomaron los trabajos. El acceso de Mokra Gora al Šargan se resolvió con un trazado muy sinuoso, con rampas continuadas del $18 \%$, una veintena de túneles -el más largo de los cuales es el que da acceso a la estación de Šargan Vitasi-, y la configuración del ocho. La conexión con Užice, a unos 35 km del Šargan, permitió reducir extraordinariamente la distancia por ferrocarril entre Belgrado y Sarajevo, que hasta entonces se había resuelto por Croacia. Una solución que, según hemos mencionado, fue posible por el ancho de vía de $760 \mathrm{~mm}$, pero que conllevaba también una limitación en las prestaciones de la infraestructura, tanto en términos de carga transportada como de velocidad. No obstante, hasta la Segunda Guerra Mundial discurrió un tráfico importante por esta línea, tanto de mercancías como de viajeros, y en este último caso se llegaron a implantar, a finales de la década de 1930, automotores diésel para aumentar la velocidad comercial de los trenes de viajeros.

Tras la Segunda Guerra Mundial, en la que esta zona fue un territorio controlado por los partisanos y, por tanto, el teatro de muchas operaciones militares, comenzó la etapa de declive, en la medida en que el nuevo estado de Yugoslavia acometió obras de modernización de la infraestructura, fundamentalmente la integración de una red muy heterogénea, que se unificará adoptando el ancho internacional para las líneas más importantes, y el desarrollo de nuevos trazados para la conexión de Belgrado con Sarajevo -desde 1947, por Vrpolje y Brčko, en Croacia-, y, sobre todo, de Belgrado con el Adriático, a través de Montenegro, con destino en el puerto de Bar. Estas líneas suponían una reducción en los tiempos de viaje y prestaciones muy superiores a las ofrecidas por los diversos tipos de vía estrecha. Así, en 1969, la estación de Užice, que pasó a denominarse Titovo Užice, se reconvirtió al ancho internacional, dentro del nuevo trazado Belgrado-Bar todavía en construcción, y la línea de Višegrad, cuyo ancho no se modificó, 
pasó a ser un ramal por el que circulaban unos pocos trenes de viajeros. En 1974, concluida la nueva línea y aduciendo razones económicas, la sección Višegrad-Užice se cerró al tráfico, y el valle de Mokra Gora, un territorio accidentado y muy poco poblado, perdió su conexión ferroviaria. Quince años más tarde, en 1989, se desmantelaron las vías... y muy poco después estallaría la guerra que condujo a la desaparición de Yugoslavia.

\section{La reconstrucción del tramo de Mokra Gora a Šargan-Vitasi}

Sin embargo, el potencial turístico de esta línea era conocido y se había señalado incluso antes del cierre. A finales de la década de 1990 comenzaron algunos intentos de intervención por parte de algunas asociaciones locales y de amigos del ferrocarril, pero el impulso definitivo se dio en 1999, cuando el Ministerio de Turismo serbio aprobó oficialmente un proyecto de reconstrucción. En colaboración con el Museo de los Ferrocarriles de Belgrado se acometió la recuperación de la línea, como ferrocarril-museo turístico, encargando a Ferrocarriles Serbios tanto la reconstrucción como la operación ${ }^{4}$.

A finales de 2001 se abrió el tramo de Šargan Vitasi a la estación de Jatare pasado el ocho, en la que se encuentra el bar/restaurante para los viajeros-, se reconstruyó la estación de Mokra Gora, y en el verano de 2003 se inauguró el tramo explotado actualmente.

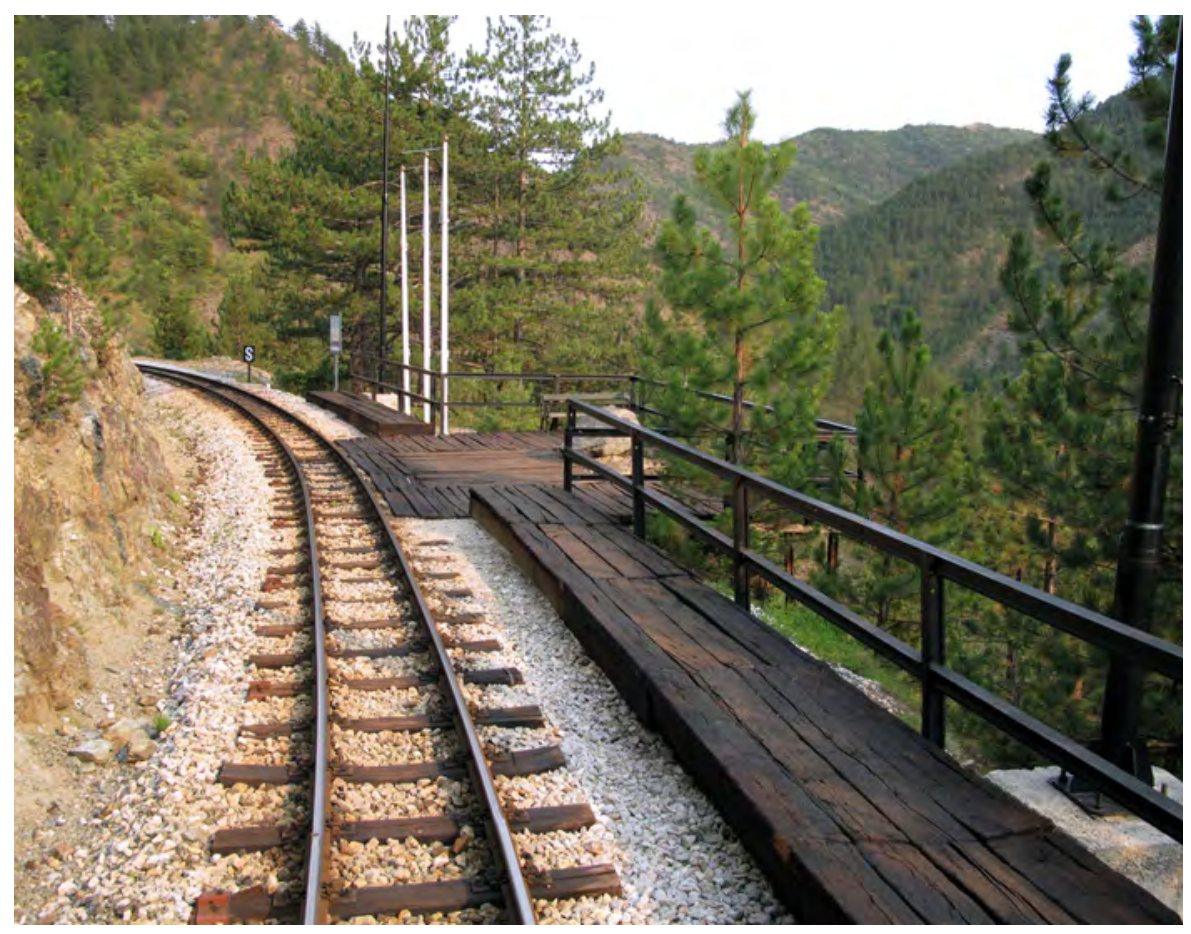

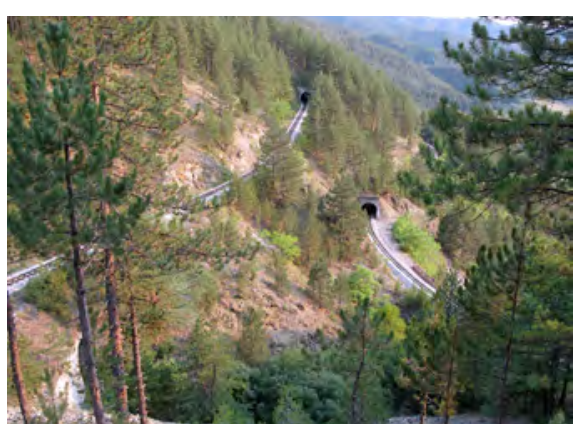

Vista de los túneles del Ocho del Šargan | foto José Luis Lalana (2012)

$$
4
$$

Además de la línea del Šargan, se reconstruyó también un ferrocarril forestal, de 600 $\mathrm{mm}$ de ancho de vía, en el fondo del valle de Mokra Gora, que hoy no se utiliza más que esporádicamente, y que no tiene conexión ferroviaria con el del Šargan.

A lo largo del trazado se instalaron varios miradores, tanto para los pasajeros del tren turístico como para las partes del recorrido que cuentan con un sendero habilitado para caminantes | foto José Luis Lalana (2012) 


\section{Resultados}

Son muchos los aspectos de la explotación que difieren notablemente de los parámetros que tuvo la línea cuando estaba activa, tanto por lo que se refiere al control del tráfico como al material rodante: las locomotoras diésel que remolcan habitualmente el tren fueron importadas de Rumanía, las de vapor, que sí son originales, necesitaron una reconstrucción completa para poder ser puestas en circulación, y los coches provienen de material conservado de otras líneas del mismo ancho de vía. A ello hay que añadir cuestiones como la velocidad, las paradas o la ausencia de problemas de gestión del tráfico, por citar solo algunas. Se llegó incluso a añadir algunos elementos, como es el caso de la estación de Golubići, que se construyó como decorado cinematográfico para la película La vida es un milagro, de Emir Kusturica.

5

Por este proyecto, Emir Kusturica obtuvo en 2005 el Premio Europeo de Arquitectura Philipe Rotthier.

6

El Parque Nacional de Tara y el Cañón del río Drina están incluidos en la Lista Indicativa de Serbia para la Lista del Patrimonio Mundial desde el año 2002.
La figura del músico y director de cine Emir Kusturica está estrechamente ligada a la difusión de este espacio, y de este ferrocarril, puesto que construyó también junto a Mokra Gora, en la colina de Mećavnik, el etno-poblado de Drvengrad $^{5}$, una mezcla de recuperación de arquitectura tradicional, museo etnográfico y hotel de lujo -denominado como la colina-, en el que suelen alojarse personalidades famosas. $Y$ es también el impulsor del festival internacional de cine (y de música) de Kustendorf, que desde 2008 se celebra anualmente.

Por otra parte, la presencia del ferrocarril ha favorecido el desarrollo de otros elementos patrimoniales y turísticos, entre los que cabe destacar el patrimonio natural. El valle de Mokra Gora estuvo incluido como entorno de protección del Parque Nacional de Tara ${ }^{6}$ desde su creación en 1981, pero en 2008 fue declarado el Parque Natural Šargan-Mokra Gora, que abarca una superficie de casi 11.000 hectáreas, una de cuyas principales atracciones es el ferrocarril del Šargan.

Y para concluir esta somera aproximación, el éxito del Ocho del Šargan ha impulsado la recuperación de otras secciones de la línea. Poco después de la inauguración del tren de Šargan, los Ferrocarriles de la República Srpska decidieron acometer la reconstrucción del tramo Mokra Gora-Višegrad, que fue inaugurado en 2010, con la presencia de autoridades serbias y de la República Srpska, aunque actualmente solo circulan por esta vía algunos trenes especiales para grupos turísticos, gestionados por los Ferrocarriles Serbios.

A modo de recapitulación final, podemos calificar los resultados como ambivalentes. En términos de respeto por el patrimonio y por la obra pública, la experiencia se podría calificar como poco valiosa, puesto que no se ha documentado - o al menos no se ha difundido ni se ha utilizado-, la situación pre- 
via a la intervención, no se transmite mensaje alguno en este sentido, y no se ha dudado en añadir elementos, en ocasiones por la evidente necesidad de resolver problemas técnicos de funcionamiento, como es el caso del material rodante, de la reconstrucción de algunas estaciones o la adaptación a una explotación con exigencias muy diferentes de las tradicionales, pero en otros casos sin otro criterio que el pintoresquismo o la creación de ambiente.

No obstante, hay que tener presente que éstos son aspectos que, aunque afectan a las condiciones de autenticidad y de integridad, podrían paliarse mediante mecanismos de interpretación del patrimonio que introdujesen la visión técnica, y con un tratamiento de formas y materiales que identificase claramente qué es lo "original" y qué lo "añadido". Pero, por encima de todo, es un ferrocarril, que funciona como tal ferrocarril y que contribuye significativamente a que se valore, tanto por la población como por los visitantes, lo que una infraestructura histórica puede significar.

Por otra parte, en términos de activación de un área económica y demográficamente deprimida, de visibilización del ferrocarril y de la obra pública, y de catalizador de proyectos territorial y conceptualmente más ambiciosos, no cabe sino señalar su éxito.

Llegados a este punto... ¿cuál de estas consideraciones debería primar para poder denominarlo como una "buena práctica"?

\section{DISCUSIÓN Y CONCLUSIONES}

Definir una buena práctica sin sombras, en una materia tan compleja y multifacética como es la del patrimonio de las infraestructuras lineales de transporte, es sin duda un asunto difícil.

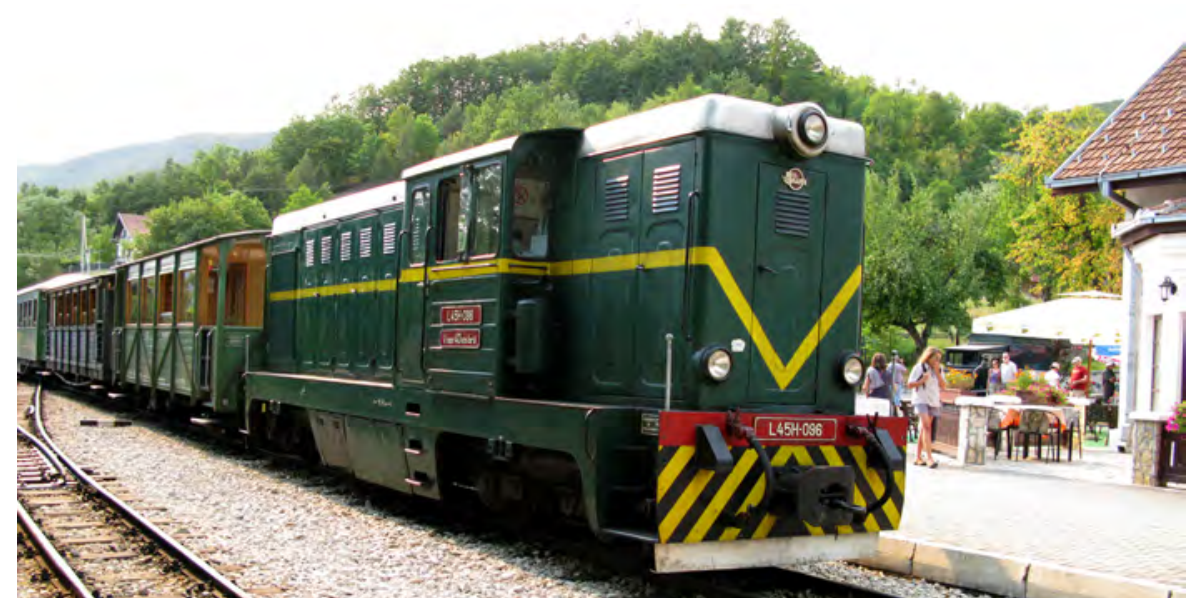

Material rodante. A la izquierda, coches de viajeros y locomotora diésel L45H-096, de origen rumano, en la estación de Mokra Gora. A la derecha, locomotora de vapor 83-052, perteneciente al Museo de los Ferrocarriles de Belgrado, que durante su servicio activo circuló por esta línea y ha sido restaurada funcionalmente. Solo circula en ocasiones determinadas, y habitualmente se expone en la estación de Šargan Vitasi, en una marquesina diseñada al efecto situada junto a las nuevas instalaciones de tracción | fotos José Luis Lalana (2012)

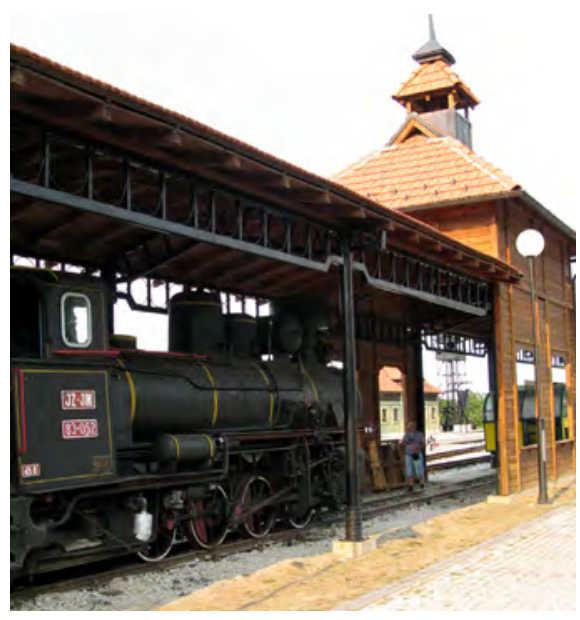


Como queda dicho a propósito de obras como el Canal de Castilla, las escasas propuestas de recuperación de infraestructuras históricas de transporte en nuestro país se han centrado, hasta la fecha, en bienes que en el momento de su rehabilitación estaban abandonados, lo que ha permitido plantear usos alternativos que no han entrado en colisión con las exigencias derivadas de la necesidad del mantenimiento de la función para la que fueron proyectadas.

En ocasiones -es el caso de las vías verdes ferroviarias-, estas intervenciones se han traducido en la pérdida de elementos sustanciales no menos relevantes que los habitualmente considerados valiosos, dificultando, en consecuencia, una adecuada transmisión de los valores intrínsecos de la propia obra de ingeniería a sus potenciales usuarios.

Este escenario evidencia la necesidad de establecer criterios patrimoniales de diseño e intervención que puedan incorporarse a los proyectos de acondicionamiento y recuperación de este tipo de infraestructuras y, especialmente, de los ferrocarriles y las carreteras. En este sentido, los casos de estudio que se han expuesto plantean ideas que pueden servir como base para ensayar propuestas de rehabilitación alternativas a las tradicionalmente desarrolladas en España.

La preservación de obras públicas lineales entraña retos muy diferentes a los que plantea la rehabilitación de las obras públicas históricas que, tradicionalmente, se han concebido como monumentos. Abordar la recuperación patrimonial de un bien territorialmente extenso, y más concretamente de una vía de comunicación, exige trabajar a diferentes escalas, y enfrentarse a elementos de muy diversa índole -desde el trazado o los puentes de mayor envergadura a las pequeñas obras de drenaje o los sistemas de señalización-, que únicamente cobran valor si se conciben como un conjunto. En tal sentido, analizar una obra lineal exige, por una parte, una adecuada comprensión de los contextos urbanos y territoriales y, por otra, entender que las obras singulares -en particular los puentes y viaductos, también las estaciones-, no son en última instancia sino nodos o fragmentos de una determinada infraestructura o red de transporte.

Resulta, asimismo, esencial comprender y valorar la evolución histórica de las infraestructuras cuya recuperación se plantea, y en consecuencia, considerar tanto los elementos que corresponden a su estado inicial como los que las han reconfigurado, produciendo alteraciones de mayor o menor entidad, a lo largo del tiempo. La atención a las transformaciones -nuevos dispositivos y sistemas de señalización y contención, modificaciones de las estructuras, instalaciones y edificios de servicio...-, permitirá interpretar los cambios derivados de las concretas exigencias funcionales de los tráficos que han soportado y documentar las inflexiones que determinan las dinámicas históricas de movilidad. 
En el caso de las infraestructuras lineales que se mantienen en uso -y en particular de las carreteras-, las intervenciones deberán garantizar el mantenimiento de sus condiciones funcionales y de seguridad. La flexibilización de los criterios de diseño y acondicionamiento, adecuados para las vías de alta capacidad pero innecesariamente rígidos para las que soportan tráficos débiles, puede permitir preservar la infraestructura histórica sin desatender aquella exigencia.

Asimismo, resulta necesario evaluar la compatibilidad de los usos turísticos, ya sea mediante la recuperación de antiguo material rodante o fomentando la conducción recreativa, con los estrictamente funcionales. Es esta una cuestión que, aunque fácil de resolver en las carreteras, mediante la instalación de apeaderos y tramos que faciliten las maniobras de adelantamiento, requiere de soluciones más complejas en el caso del ferrocarril. En función de la frecuencia de las circulaciones, y de los sistemas de control del tráfico de la línea, cabría plantear, en todo caso, estrategias orientadas a la habilitación de accesos o espacios que permitan su observación.

En relación con sus potenciales usuarios, debe considerarse el hecho de que, en el caso de la carretera, la circulación automóvil y la presencia de tramos afectados por fuertes pendientes longitudinales dificultan el tráfico de peatones y ciclistas. Por el contrario, el ferrocarril cuenta con las ventajas derivadas de la geometría del trazado y del control de las circulaciones -de velocidades y con frecuencias previsiblemente reducidas-, lo que hace más factible la instalación de bandas laterales en los márgenes de la plataforma. Sea como fuere, y aun tratándose de líneas abandonadas, parece oportuno conservar los elementos característicos de la superestructura con objeto de no comprometer el valor patrimonial de la obra de ingeniería?.

Por lo que hace al impacto territorial, la recuperación de cualquiera de estas infraestructuras puede constituir una oportunidad para incentivar la afluencia de visitantes a zonas rurales habitualmente deprimidas y en riesgo de vaciamiento. No obstante, la experiencia aconseja implicar a las autoridades y agentes locales de las poblaciones próximas a la infraestructura en las fases de planeamiento y proyecto para asegurar así un adecuada conservación, explotación y promoción de la obra como recurso turístico.

Por último, y de la misma manera que se ha planteado en el caso de otros patrimonios menos reconocidos, la recuperación de infraestructuras lineales históricas debería ir acompañada de una labor didáctica y de gestión, hasta ahora escasamente atendida, encaminada al reconocimiento y valoración de la obra de ingeniería, de las formas históricas de movilidad y de la propia función transporte.
7

Como se ha hecho en la reciente intervención del tramo final de la línea Boadilla-Barca d'Alva, la única declarada BIC en España, entre la estación internacional de La Fregeneda y el Puente Internacional sobre el río Águeda. Una interesante solución de compromiso entre la comodidad del recorrido para los visitantes, la fidelidad a su valor patrimonial como infraestructura lineal ferroviaria y la preservación del entorno.

\section{Agradecimientos}

Esta publicación se enmarca dentro del proyecto nacional de investigación financiado por el Ministerio de Ciencia, Innovación y Universidades que, liderado por la Rita Ruiz, tiene como título Análisis y definición de estrategias para la caracterización, recuperación y puesta en valor del patrimonio de las obras públicas. Una aproximación desde la escala territorial (PID2019105877RA-I00). 


\section{BIBLIOGRAFÍA}

- Aguiar, A. (coord.) (2003) Estradas-Património. EN2. Almodôvar-S. Brás de Alportel. Da Planície Alentejana ao Barrocal Algarvio. Lisboa: Instituto das Estradas de Portugal

- Associação de Municípios da Rota da Estrada Nacional 2 (2021) A estrada que nos une. Disponible en: https:// www.rotan2.pt/ [Consulta: 31/05/2021]

- Aycart, C. (2001) Vías Verdes, reutilización de ferrocarriles en desuso para movilidad sostenible, ocio y turismo. Informes de la Construcción, n. ${ }^{\circ} 475$, pp. 17-29

- Carneiro, M.I.S. (2011) As casas dos cantoneiros do Algarve: da conservação das estradas a património a conservar. Tesis de maestría inédita. Universidade Aberta Lisboa. Disponible en: https://repositorioaberto.uab.pt/bits tream/10400.2/1821/2//\%20Volume.pdf [Consulta: 01/01/20 21]

- Entrevista. Prof. António Lamas. Estradas-Património. Não podem ser "atropeladas" pela pressa da modernidade (2003) Pedra \& Cal, n. o 19, pp. 8-11 Disponible en: http://www.gecorpa.pt/Upload/Revistas/Rev19_Art02.pdf [Consulta: 20/07/2021]

- Ferrocarril de Sóller (2021) Disponible en: http://trende soller.com/ [Consulta: 31/05/2021]

- García, J.L. (1998) Documentación, problemas de conservación, planeamiento urbanístico, rehabilitación y experiencias sobre el patrimonio histórico en el Camino de Santiago y en la Ruta de la plata. En: AA.VV. Patrimonio cultural y sociedad: una relación interactiva. Curso celebrado en Valladolid, del 21 al 29 de marzo de 1997. Valladolid: Junta de Castilla y León; Consejería de Educación y Cultura, pp. 227-266

- Generalitat de Catalunya (2021) Tren dels Llacs. Disponible en: https://trendelsllacs.cat/ [Consulta: 31/05/21]

- Graça, P. y Vasconcelos, T. (2009) Estradas-Património. Conceito e Concretização em Portugal. s.l.: Estradas de Portugal, S.A.; Gabinete do Ambiente

- Guerra, R. (coord.) (2004) El Canal de Castilla: un plan regional. Valladolid: Junta de Castilla y León, 2 vol.

- JSC Serbian Railways (2021) Disponible en: http://serbian railways.com/ [Consulta: 25/05/21]

- JSCSerbianRailways(2021)MuseumandTouristRailways "Shargan Eight". Disponible en: http://serbianrailways. $\mathrm{com} /$ museum-and-tourist-railways-shargan-eight/ [Consul ta: $25 / 05 / 21$

- Nature Park "Šargan-Mokra Gora" (2021) Disponible en: http://www.parkprirodemokragora.org/index.php/en [Consulta: 27/05/21]

- Lalana, J.L. (2012) Los ferrocarriles y el patrimonio mundial. Del monumento al paisaje cultural. En: VI Con greso de Historia Ferroviaria. Vitoria 2012. Del 5 al 7 de septiembre.Disponibleen:http://www.docutren.com/Historia Ferroviaria/Vitoria2012/pdf/6046.pdf [Consulta: 20/07/2021]

- Lalana, J.L. y Santos, L. (2016) Retos metodológicos en el estudio, evaluación y tratamiento del patrimonio ferroviario. En: Actas del VI Congreso de Conservación del Patrimonio Industrial y de la Obra Pública en España. Gijón: Cicees, pp. 125-132

- Martínez, R. (1996) Los canales españoles. OP, n. ${ }^{\circ}$ 40 , pp. $52-63$

- Martínez, R. (2003) El patrimonio de las obras públicas. Revista de Obras Públicas, n. ${ }^{\circ} 3.438$, pp. 79-82

- Melo, L. (2003) Lanço da EN 2, Almodôvar e São Brás de Alportel. Recuperação da 1. ${ }^{a}$ Estrada-Património Portuguesa. Pedra \& Cal, n. ${ }^{\circ} 19$, pp. 12-13. Disponible en: http://www.gecorpa.pt/Upload/Revistas/Rev19 Art03.pdf [Consulta: 20/07/2021]

- Menéndez de Luarca, J.R. y Soria y Puig, A. (1994) E territorio como artificio cultural. Corografía histórica de Norte de la Península Ibérica. Ciudad y Territorio. Estudios Territoriales, vol. II, n. ${ }^{\circ}$ 99, pp. 63-93. Disponible en: https://recyt.fecyt.es/index.php/CyTET/article/view/83925 [Consulta: 20/07/2021]

- Nárdiz, C. (2014a) El patrimonio de las obras hidráulicas. En: Obras Hidráulicas de la Ilustración. Catálogo de la exposición (10 de julio-30 de octubre de 2014). Madrid: CEHOPU/Ministerio de Fomento, pp. 55-63

- Nárdiz, C (2014b) El discurso patrimonial de los ingenieros de caminos. Revista de Obras Públicas, n. ${ }^{\circ}$ 3.599, pp. 51-62

- Navarro, J.R. (2009) Pensar la ingeniería: antología de textos de José Antonio Fernández Ordóñez. Madrid: Colegio de Ingenieros de Caminos Canales y Puertos/ Fundación Juanelo Turriano

- Rodríguez, F.J., Coronado, J.M., Ruiz, R. y Vega, J.G. de la (2007) Análisis y valoración del patrimonio histórico de las carreteras españolas, 1748-1936. Madrid: CEHOPU/ CEDEX (Cuadernos de investigación del CEHOPU; 2)

- Ruiz, R., Rodríguez, F.J. y Coronado, J.M. (2017) Modern Roads as UNESCO World Heritage Sites: framework and proposals. International Journal of Heritage Studies, vol. 23, n. ${ }^{\circ} 4$, pp. 362-374. Disponible en: https://doi.org/10.108 0/13527258.2016.1277774 [Consulta: 20/07/2021]

- Šarganska The Shargan 8 (2021) Disponible en: http:// www.sarganskaosmica.rs/ [Consulta: 27/05/2021]

- Soria, A. (1997) Una visión territorial del patrimonio de las obras públicas. La red peninsular de parques lineales históricos. $O P$, n. ${ }^{\circ} 40$, pp. $28-37$ 
- Srbija Voz JSC (2021) Nostalgija. Disponible en: https:// www.srbvoz.rs/en/nostalgija-2/ [Consulta: 27/05/2021]

- Teixeira, E.N. (2013) Manual para a recuperação de Estradas Património. Tesis de maestría inédita. Universidade de Trás-os-Montes e Alto Douro, Vila Real. Disponible en: http://docplayer.com.br/46741579Manual-para-a-recuperacao-de-estradas-patrimonio.html [Consulta: 01/01/2021]

- Tourist Resort Mećavnik-Drvengrad (2021) Disponible en: https://mecavnik.info/en/ [Consulta: 27/05/2021]

- Zoido, F. (2006) Paisaje e infraestructuras, una relación de interés mutuo. Carreteras: revista técnica de la Asociación Española de la Carretera, n. ${ }^{\circ} 150$, pp. 190-199 


\title{
La reutilización del patrimonio construido, nuevos usos, buenas prácticas
}

\author{
Francisco Javier Soria López | División de Ciencias y Artes para el Diseño, \\ Universidad Autónoma Metropolitana (México) \\ URL de la contribución <www.iaph.es/revistaph/index.php/revistaph/article/view/4958>
}

\section{RESUMEN}

La reutilización del patrimonio edificado es una práctica de carácter histórico que ha permitido conservar inmuebles de todas las épocas a través del cambio de uso para adaptarse a nuevas necesidades de sus habitantes, trayendo al presente configuraciones arquitectónicas que reúnen valores aportados a lo largo de su existencia.

Se trata de una actividad arquitectónica que hoy día está tomando gran relevancia como un proceso de diseño sostenible pues atiende a los tres pilares esenciales, es decir, renueva el uso social de un espacio preexistente valioso, extiende la vida económica de la construcción y contribuye a disminuir el impacto ambiental que implica demoler y construir nuevamente.

La práctica de la reutilización de la preexistencia construida abarca una amplia gama de posibilidades de intervención, desde la restauración de inmuebles monumentales, la rehabilitación de edificios de valor cultural, la reconversión energética de inmuebles históricos y por supuesto la remodelación del parque edificado, opciones directamente relacionadas con sus condiciones patrimoniales.

\section{Palabras clave}

Arquitectura | Bienes inmuebles | Construcción | Diseño | Edificación | Edificios | Intervención | Reconversión energética | Rehabilitación | Reutilización | Sostenibilidad | 


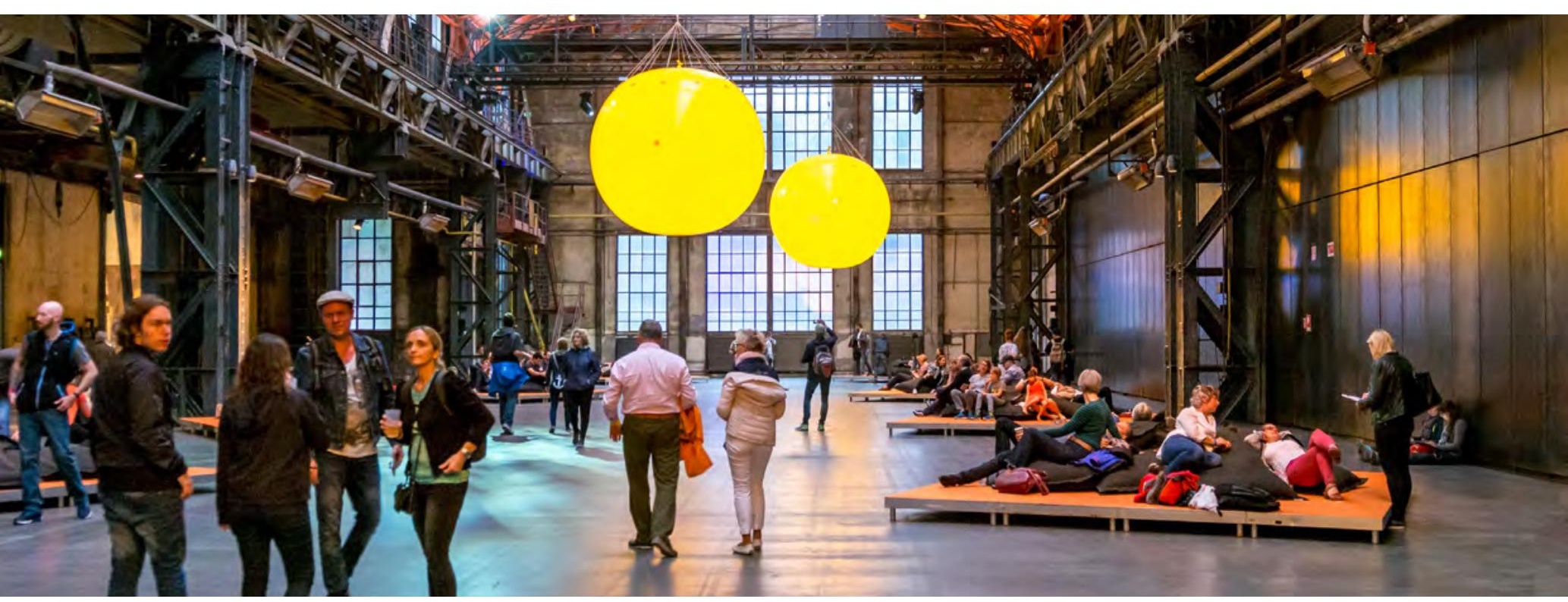

Adaptive Reuse of built heritage, new functions, good practices

\section{ABSTRACT}

The reuse of built heritage is a historical practice that has allowed the preservation of buildings of all ages by changing their function to adapt to new needs of society, bringing to the present architectural configurations that have gathered diverse values throughout time.

It is an architectural activity that today is taking on great relevance and recognition as a sustainable design process because it attends to the three essential principals, that is, it renews the social use of a valuable preexisting space, it extends the economic life of the construction and contributes to reduce the environmental impact of demolishing and building new again.

The procedure of reusing preexisting constructions enables a wide range of possibilities for intervention, including the restoration of monumental buildings, the rehabilitation of structures of cultural value, the energetic enhancement of historic properties and of course the remodeling of built spaces in general, options directly related to their heritage conditions.

\section{Key words}

Adaptive reuse | Built heritage | Sustainable design | Intervention | Sustainable rehabilitation | Energetic enhancement Historic properties |

Cómo citar: Soria López, F.J. (2021) La reutilización del patrimonio construido, nuevos usos, buenas prácticas. Revista PH, n. ${ }^{\circ} 104,2021$, pp. 144-162 <www.iaph.es/revistaph/index.php/revistaph/article/view/4958> DOI 10.33349/2021.104.4958

Enviado: 29/05/2021 | Aceptado: 14/07/2021 | Publicado: 01/10/2021 


\section{INTRODUCCIÓN}

La conservación del patrimonio edificado, al igual que muchas otras disciplinas, ha sido alcanzada por el paradigma de la sostenibilidad, un contexto donde la relación hombre-naturaleza nos ha obligado repensar todo de nuevo; desde la esfera de lo social, hasta los aspectos ambientales y, por supuesto, los procesos económicos que esa interacción requiere para mantener su viabilidad en el tiempo y en el espacio.

Cada vez más está presente la necesidad de conservar el patrimonio cultural y natural heredado de generaciones pasadas. Se trata de un tema recurrente en la política, el arte, la literatura, la educación, la ciencia, el diseño... en fin, en prácticamente todas las acciones y actividades de la sociedad. Se trata de una inquietud que ha llegado a nuestros días, instalada como un compromiso ineludible, ya que "...la posesión, la creación y el cuidado del patrimonio constituyen, en cierto sentido, una necesidad social básica. La necesidad de recordar, de reinterpretar el pasado de manera individual y colectiva, y de servirse a tal efecto de la cultura material (entre otros medios) constituye un fenómeno social integrado en la propia estructura de la modernidad" (Mason y Torre 2001, 167).

Estamos actualmente en una encrucijada importante, pues mientras que en épocas pasadas el desarrollo y evolución social, económico, tecnológico y cultural se daba en espacios de tiempo muy extendidos, en ocasiones hasta de siglos de duración, a partir de la revolución industrial y, sobre todo, durante buena parte del siglo XX y lo que va del presente, la capacidad y velocidad de innovación, transformación, pero también de destrucción que ha adquirido la humanidad se ha acelerado de manera exponencial, lo que impone a nuestra generación la responsabilidad de garantizar la preservación de la cultura y la naturaleza al menos en las condiciones en que las hemos podido conocer y disfrutar hoy día.

Por ello, abordar la reutilización del entorno construido en el marco del desarrollo sostenible empieza por reconocer el camino en paralelo que han recorrido la conservación del denominado patrimonio cultural y la preservación del medio ambiente natural (Soria y García 2017). Se trata de dos caras de una misma moneda, que parten de una inicial visión que privilegia lo excepcional y que intenta proteger y hacer permanecer aquello que se considera como lo más valioso, único o representativo, pero que, con el tiempo, se cayó en cuenta de que los denominados monumentos o las grandes reservas naturales no se pueden aislar, sino que forman parte de contextos más amplios, complejos e interrelacionados que deben respetar todos sus elementos si hemos de conseguir mejores condiciones de conservación.

Esto define en buena medida la sostenibilidad, esa visión integral que reconoce que la acción social derivada del espíritu humano se da en un lugar 


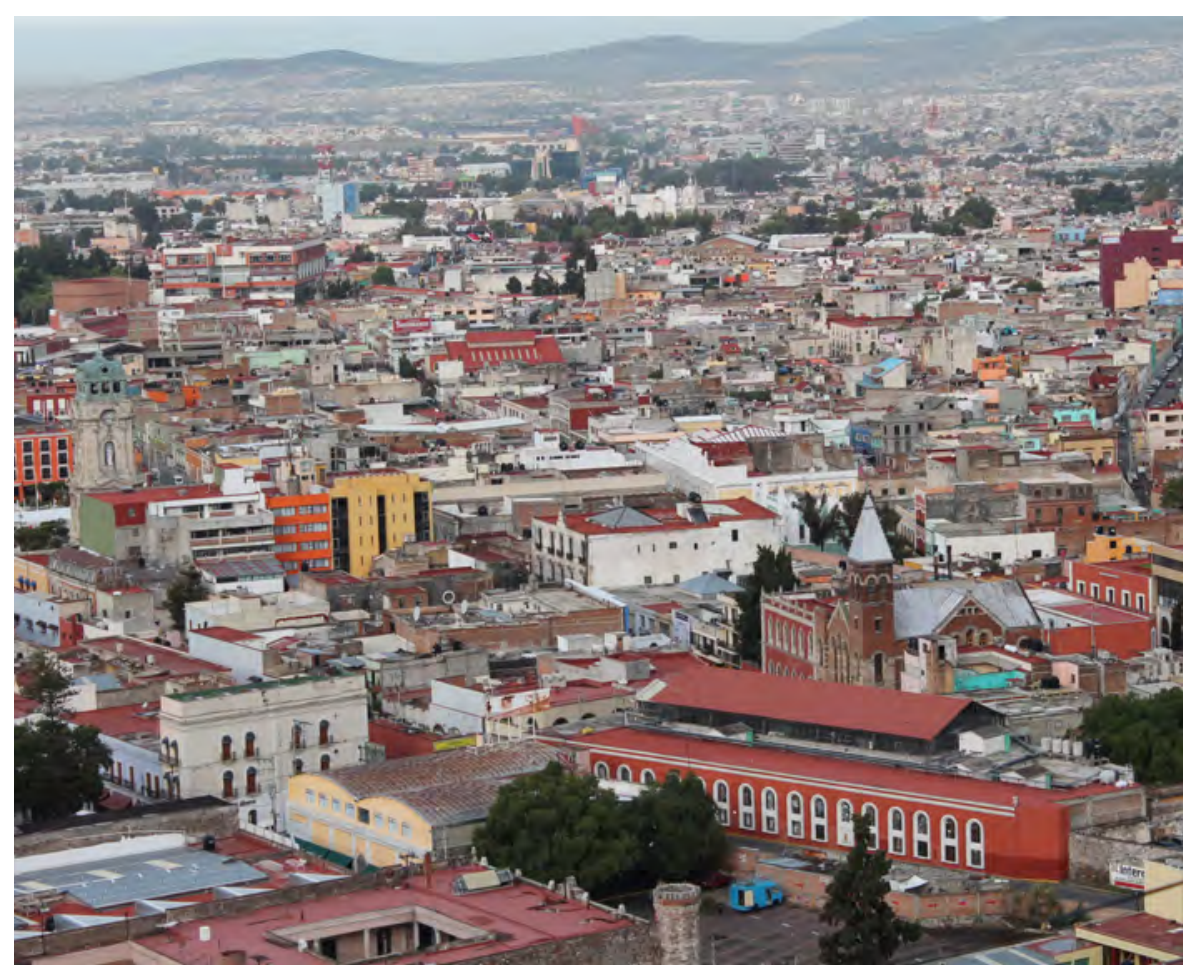

determinado, que se transforma y ocupa a lo largo del tiempo como espacio de vida adaptado para el desarrollo y bienestar de un grupo social especifico. Entender esta relación y la necesidad de mantener un enfoque holístico que debe visualizar todas las aristas del problema resulta indispensable, lo que implica entonces abordar los tres ${ }^{1}$ aspectos que caracterizan el denominado desarrollo sostenible:

1. El pilar social. Constituye la puerta de entrada al tema de la sostenibilidad, pues los seres humanos, organizados socialmente, llevan a cabo su vida encaminada "idealmente" a conseguir un bienestar físico y sicológico. Existe, desde luego, el deseo de llegar a tener una cierta calidad de vida, al satisfacer aspiraciones que el entorno cultural y natural condicionan a cada grupo social.

En ese sentido la Agenda 2030 para el desarrollo sostenible reconoce entre sus objetivos "...la necesidad de construir sociedades pacíficas, justas e inclusivas que proporcionen igualdad de acceso a la justicia y se basen en el respeto de los derechos humanos..." (Naciones Unidas 2015, 11). Desafortunadamente, la sociedad contemporánea está lejos de ese ideal de equilibrio, de vida donde habría igualdad de oportunidades, de justicia, de acceso a la educación. Hoy día la brecha entre países desarrollados y aquellos en vías de obtenerlo, se hace cada vez más grande.
El entorno construido desempeña un papel primordial en el desarrollo sostenible, ya que la ocupación del territorio, la expansión urbana y la edificación de nuevas arquitecturas impactan de una manera importante a la naturaleza, acción que se ha acelerado de manera exponencial desde mediados del siglo XX, como ocurre en la ciudad mexicana de Pachuca | foto Francisco J. Soria

Conviene remarcar que los tres pilares de la sostenibilidad implican la síntesis de una realidad mucho más compleja e interrelacionada; lo social abarca asuntos relativos a la cultura, a los derechos humanos, la pobreza, la educación, la salud entre muchos otros; la economía deriva en problemáticas de empleo, intercambio comercial, innovación tecnológica, producción, explotación de los recursos naturales y humanos; lo ambiental se refiere a la naturaleza y sus procesos, los océanos, el cambio climático, la perdida de especies, la contaminación ambiental por mencionar solo algunos. La ONU ha definido 17 objetivos del desarrollo sostenible y 169 metas específicas que detallan esta compleja y diversa realidad que enfrenta la humanidad. 
2. El pilar ambiental. La acción humana sobre el entorno natural, necesaria para la supervivencia, ha representado, simultáneamente, la transformación y destrucción progresiva de la naturaleza. Se tiene en ocasiones la falsa creencia que todas las sociedades pasadas vivían en armonía con su entorno. Realmente, en distintos momentos de la historia, en diferentes territorios, ha habido grandes crisis ambientales (casi siempre de la mano de crisis social y económica de esos mismos grupos humanos). En todo caso la gran diferencia de dichas contingencias ecológicas (sociales y económicas) se situaba en la escala; es decir que el impacto se daba en una zona muy definida del planeta y más allá, había otra fauna por cazar, madera por cortar, territorio por ocupar. La crisis ambiental parece que hoy día llega a un límite global donde los bienes naturales están comprometidos: ya no hay donde respirar aire limpio, agua potable suficiente, tierra fértil para el cultivo, ante la casi total apropiación que se ha hecho de la naturaleza. Transitar hacia un desarrollo sostenible pasa por entender que el sistema natural en el que vivimos es, en sus condiciones actuales, un sistema cerrado, que tiene unos límites y un funcionamiento específico que debemos no solo identificar y conocer, sino respetar si hemos de encontrar y recuperar el equilibrio necesario para una vida con bienestar. La aspiración principal se centra en “...preservar y utilizar sosteniblemente los océanos y los mares, los recursos de agua dulce y los bosques, las montañas y las zonas áridas, y a proteger la diversidad biológica, los ecosistemas y la flora y fauna silvestres" (Naciones Unidad 2015, 10), una carrera contra el tiempo que por ahora parece perderse.

3. El pilar económico. La actividad económica supone un factor ineludible si se ha de transitar hacia una actitud sostenible ya que resulta cada vez más difícil generar las condiciones para una vida de bienestar. Sostener un país, un estado o una ciudad mediana, incluso el más pequeño asentamiento humano, requiere actividades productivas que permitan generar la riqueza apropiada para satisfacer las necesidades básicas de su población, que van desde los aspectos físicos y biológicos (comida, agua potable y cobijo), hasta las necesidades socioculturales (educación, recreación, creencias, ritos o actividades tradicionales), que forman parte del entorno de vida social. Por ello, transitar hacia un "crecimiento económico sostenido, inclusivo y sostenible es esencial para lograr la prosperidad, lo que solo será posible si se comparte la riqueza y se combate la desigualdad de los ingresos" (Naciones Unidas 2015, 9).

En este orden de ideas, el entorno construido desempeña un papel primordial en la sostenibilidad, ya que la ocupación del territorio, la expansión urbana y la edificación de nuevas arquitecturas impactan de una manera importante en la naturaleza. Hoy en día, a raíz de la crisis ambiental y la cada vez más apremiante necesidad de aprovechar racionalmente los recursos, se está en la obligación de comprender que el medio construido debe obedecer a nue- 
vas lógicas: menor impacto, más equilibrio y mayor compatibilidad con el ambiente natural y cultural, donde el respetar, reciclar, rehabilitar y reutilizar forman parte de ese cambio necesario. En este sentido, la reutilización del patrimonio edificado gana terreno como una acción eminentemente sostenible, que inicia sus procesos desde el reconocimiento y valoración de la arquitectura preexistente; que aporta al conservar espacios de vida socialmente significativos; que disminuye la carga sobre el entorno natural y se integra a los ciclos económicos actuales al albergar nuevas funciones útiles para la sociedad contemporánea.

\section{NUEVOS USOS EN EDIFICIOS EXISTENTES: UNA PRÁCTICA HISTÓRICA SOSTENIDA}

La concepción y edificación de los espacios que habitamos implica un proceso que siempre ha estado presente en todas las sociedades. Se trata, de hecho, de una práctica histórica que permitió la aparición de los asentamientos humanos, desde los más incipientes que caracterizaron a los grupos nómadas, hasta llegar a las megalópolis actuales. Este paso y permanencia del hombre por el territorio ha dejado, como una de sus huellas más profundas, el entorno construido, con ciudades, arquitecturas e infraestructuras que, con el transcurso del tiempo, han constituido un enorme y diverso patrimonio edificado.

La evolución de la arquitectura se ha dado a partir de algún tipo de preexistencia edificada, bien como referencia para idear un nuevo espacio o, como se ha dado de manera extensa, para utilizar construcciones ya existentes para albergar una función nueva, renovar el uso ya dado o simplemente extender su existencia física. Pero se trata de una permanencia dinámica, estrechamente vinculada a la intencionalidad de conservar aquello que se considera valioso, importante o simplemente útil; algo que pensamos que no puede perderse o desaparecer, al menos no del todo.

La conservación de elementos materiales significativos no se centra solamente en su existencia física sino sobre todo en aquello que representan para un determinado grupo social; no basta, entonces, conservar el bien sino también su significado. Se puede decir que la "valorización es la llave de acceso del dispositivo" (Choay 2007, 197) cuando nos referimos al tema de la conservación y reutilización del patrimonio edificado. Estos procesos de valoración que hace la sociedad no se mantienen estáticos o permanentes; por el contrario, se muestran versátiles, relativos a tiempo y lugar, mediado por lo subjetivo y por lo mismo producto de una construcción social: todo patrimonio tiene un valor, porque éste es condición necesaria para aquél: "un bien patrimonial no es valioso por ser patrimonial, sino que es patrimonial porque es valioso" (Barreiro 2013, 36). 

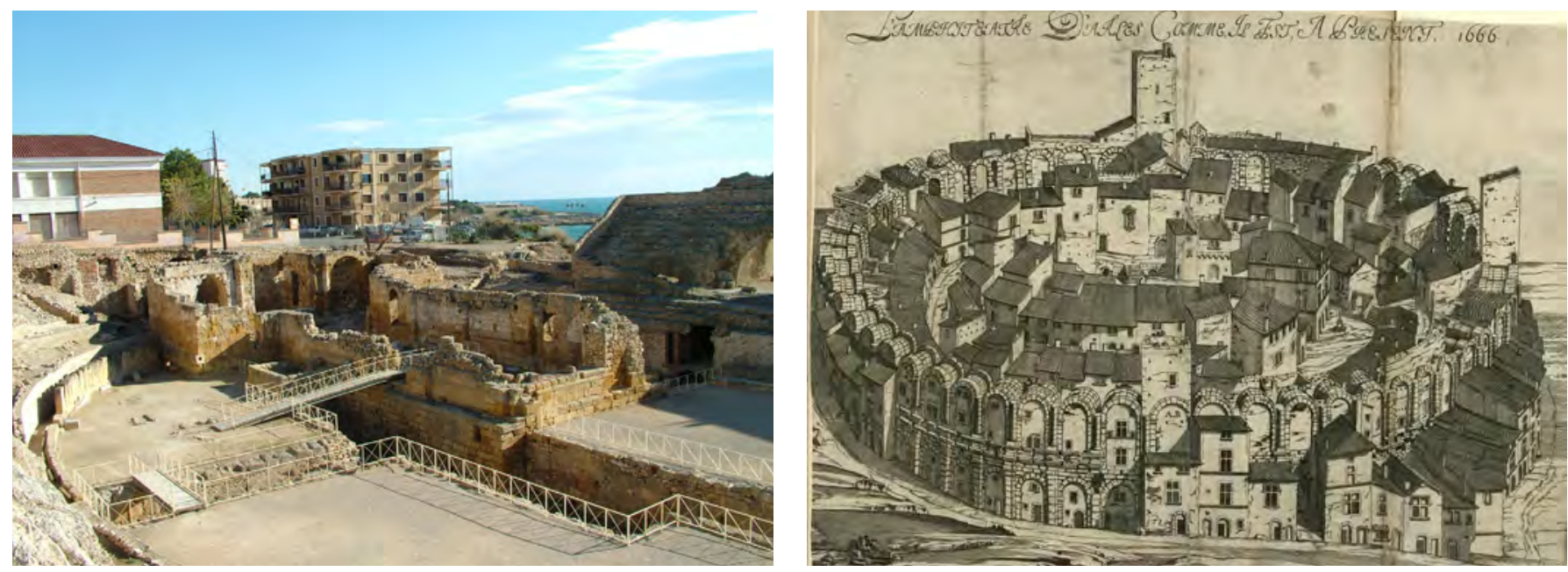

La reutilización y ocupación de espacios arquitectónicos preexistentes es un proceso que siempre ha estado presente en todas las sociedades. De hecho, esta práctica histórica permitió, con el transcurso del tiempo, configurar un enorme y diverso patrimonio edificado. A la izquierda, antigua edificación romana en Tarragona (España), ocupada posteriormente por un templo cristiano y hoy día, un sitio arqueológico de alto valor cultural | foto Francisco J. Soria

La obsolescencia de la arquitectura prevaleció en épocas pasadas ligada a procesos sociales que derivaron en formas de reutilizar edificaciones de todo tipo, incluso, como en el caso de Arlés (Francia), la posibilidad de generar una pequeña población dentro de un anfiteatro romano. En el siglo XVII, el arquitecto y artista Jacques Peytret, realizó esta extraordinaria imagen (a la derecha) que documenta este sitio histórico | fuente

PICRYLThe World's Largest Public Domain Media Source
En el ámbito del entorno construido los procesos de su reutilización han estado siempre presentes, aunque las razones para conservarlos mediante la extensión de su permanencia física han variado a lo largo de los siglos. Las motivaciones tocan distintas esferas, que, sin pretender abarcar la totalidad de las opciones, podemos ubicar como aquellas de orden material-tecnológico, simbólico-representativo, histórico-estético, funcional-económico y, de acuñación más reciente, social-ambiental.

A partir de lo anterior, se puede hablar de procesos de identificación y apreciación de lo edificado que permiten, mediante el conocimiento del contexto donde se encuentra, la temporalidad de su reconocimiento, el uso que se incorpora y la intencionalidad que hay detrás; entender la reutilización arquitectónica como una forma de valoración del patrimonio edificado.

Mucho se ha debatido sobre la intervención en lo ya construido, en el espacio arquitectónico preexistente, como una práctica histórica que la mayoría de las veces obedecía a motivaciones más de orden pragmático e ideológico que a una intención de conservar el patrimonio con fines de transmisión hacia el futuro. "Antes del siglo XIX la práctica arquitectónica confiaba en sus propios valores sincrónicos (...) El devenir histórico se manifestaba mediante la caducidad de los objetos. Lo viejo, como tal, no era motivo de valoración artística o arquitectónica..." (Gracia 2001, 59).

En épocas pasadas constituía una práctica poco cuestionada la desaparición por completo de edificios centenarios para edificar una arquitectura contemporánea de ese momento histórico; pero también se ha practicado en las ciudades hasta nuestros días la conservación y aprovechamiento de inmuebles construidos. La reutilización de la arquitectura se da justamente porque se le asigna algún tipo de valor, aunque estas razones no siempre bordaran 
la tradición histórico-estético de la visión patrimonialista forjada en los siglos XIX y XX.

En ese sentido la obsolescencia de la arquitectura preponderaba en épocas pasadas. Las grandes infraestructuras concebidas y edificadas por imperios que se pensaban eternos, pero que el tiempo terminó por dominar, se convirtieron en posibilidades de uso y re-uso de la preexistencia.

Se puede citar, como ejemplo de esta dinámica, el caso del antiguo anfiteatro romano de Arlés (Francia), el cual se reutilizó en época medieval para uso habitacional. Llegó a albergar en su interior un barrio entero, con más de doscientas casas e incluso dos iglesias (Directión du Patrimoine 2002), que transformaron el lugar, pero simultáneamente lo conservaron. Su proceso de reutilización obedeció seguramente a una valoración de sus virtudes arquitectónicas de orden espacial y estructural que ofrecían, en su forma y materialidad, seguridad y cobijo para los entonces nuevos pobladores del inmueble.

Tiempo después, dado el carácter dinámico y socialmente dirigido de los procesos de valoración, en el siglo XIX la ruina romana fue liberada de las construcciones adosadas, aplicando criterios monumentalistas de conservación, para restaurarse y convertirse en un atractivo para la contemplación. En años más recientes se ha vuelto a utilizar como centro de espectáculos.

La ideología actúa, también, como un potente motor para reconfigurar sitios altamente representativos para una sociedad determinada, resignificando el lugar para cumplir nuevas necesidades sociales. En ocasiones la intervención puede resultar más violenta, en busca de un cambio evidente, sin embargo, el proceso de valoración de la preexistencia impide a propios y extraños hacer desaparecer lo anterior y se optan, mediante la reutilización como proyecto de arquitectura, no solo resignificar el lugar, incluso renovar su función a condiciones nuevas. La mezquita de Córdoba es un ejemplo de enorme sensibilidad hacia un lugar de culto, que mantiene esa misma función, pero para una fe distinta. La simbiosis resulta increíble y las estructuras parecen fundirse, lo que constata el análisis como composición arquitectónica que hace A. Capitel $(2001,53)$ de este edificio: "Convertir la mezquita en catedral supuso entender la compleja estructura de su forma (...) analizando el modo en que era necesario someterse a ella, por un lado, y corregir su irresuelta ambigüedad espacial, por otro. La idea de salvaguardar lo antiguo sin renunciar a su transformación preside la operación arquitectónica (...) La transformación aparece, no como obligada, pero si como lógica secuela de nuevas necesidades e interpretaciones en dialéctica con la naturaleza compositiva de la arquitectura originaria".

La arquitectura tiene, como una de sus premisas fundamentales, la utilidad como espacio para habitarse, diseñada para funcionar de determinada 


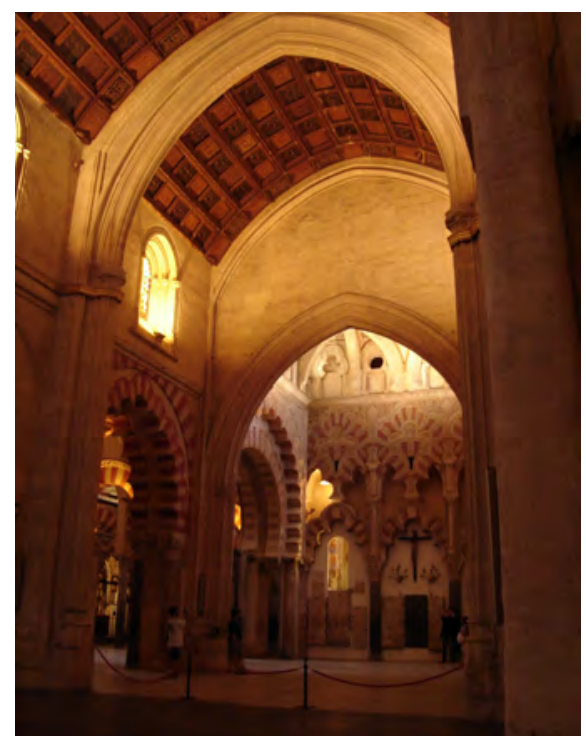

La mezquita de Córdoba constituye un ejemplo de enorme sensibilidad hacia un lugar de culto. Mantuvo su función original, pero para una fe distinta, lo que implicó un enorme desafío de conservación y transformación para lograr un equilibrio arquitectónico y funcional admirables | foto L. F. Guerrero
2.

Sin duda alguna la época pospandemia de la COVID-19 pondrá a debate nuevas formas posibles de uso de inmuebles de todo tipo desde oficinas corporativas, inmuebles comerciales y recintos escolares, hasta la misma vivienda que, como se ha experimentado en este último año y medio, deberán adaptarse a condiciones nuevas de organización y uso social de los espacios habitables a partir del impacto que el virus SARS-CoV-2 generó en el mundo entero. manera, sin renunciar a su capacidad de expresión estética. Sin embargo, el valor de uso es el elemento que articula el espacio con el sujeto quien, al habitar el lugar, le proporciona su sentido como arquitectura. La re-funcionalización del espacio patrimonial ha sido una práctica común, que surge también a partir de múltiples factores, incluso los de orden económico. La reutilización de edificaciones en distritos industriales o comerciales como viviendas y talleres para artistas en grandes ciudades como Nueva York, hacia los años 60 del siglo pasado, aparece como una alternativa barata, al ocupar espacios degradados, obsoletos y de alguna manera despreciados. Hoy día, más de medio siglo después, en cada vez más ciudades estos distritos se han revalorizado económicamente, en buena medida por el éxito de la reutilización de dichos espacios, y han incorporado nuevos usos a sectores urbanos enteros. Esta tendencia, que se mantiene en el mercado inmobiliario actual, también tiene sus efectos negativos como el de la gentrificación.

En las últimas décadas otras motivaciones han surgido para justificar la importancia de reutilizar edificaciones con valor patrimonial y tiene que ver con su valor ambiental, con la posibilidad de contribuir a reducir el impacto ambiental al extender su ciclo de vida. Un argumento reiterado reza que "el edificio más verde es el que ya está construido" (Elefante 2007, 26), pues ya aportó su cuota de gasto energético, extracción y transformación de materia prima. Aunque dicha afirmación deba matizarse, pues no se trata de una verdad absoluta, ciertamente la extensión de la vida útil de una edificación contribuye a disminuir el impacto que implica la demolición y construcción nueva.

En este contexto, el proyecto de Emscher Park en Alemania constituye probablemente uno de los casos de mayor éxito en la reutilización enfocada al valor ambiental. Se trata de una intervención sobre un territorio de más de $450 \mathrm{~km}^{2}$, a lo largo de poco más de $85 \mathrm{~km}$, que se extiende desde el río Rin, cerca de Duisburg, hasta Bönen, para reconvertir la antigua industria siderúrgica de la región del Ruhr en un enorme parque de corte socioambiental (Metropoleruhr 2013,3). No solo se cambió la imagen de una industria que degradaba el entorno al convertirse ahora en soporte físico de un parque ecológico, sino que también se combinó para albergar espacios de uso colectivo para diversas actividades sociales, culturales y recreativas, como puede apreciarse en Duisburg Nord, uno de los sitios emblemáticos de este parque regional (Soria 2006, 113-131).

El cambio de uso en edificaciones preexistentes está ganando reconocimiento social y profesional ${ }^{2}$ como una práctica contemporánea necesaria por motivaciones de orden cultural, ambiental, social y económico. Recientemente el premio Pritzker de arquitectura fue otorgado a los arquitectos A. Lacaton y J. PH. Vassal, que sostienen que "La transformación es la oportunidad de hacer más y mejor con lo que ya existe. El derribo es una 


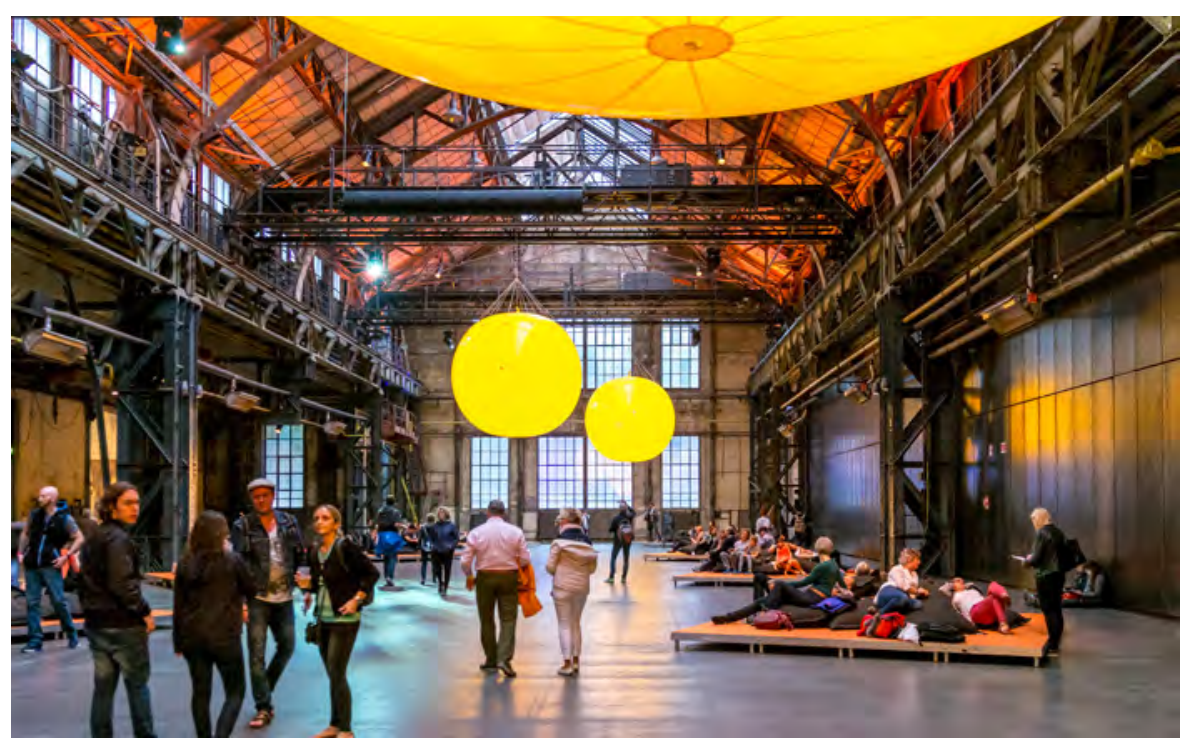

decisión fácil y de corto plazo. Es una pérdida de muchas cosas: desperdicio de energía, desperdicio de material y desperdicio de historia. Además del impacto social muy negativo" (Olivares 2021). Se trata de una postura que defiende la necesidad de conservar la preexistencia, sobre todo de espacios de construcción reciente, los cuales se convierten en lugares que impactan positivamente en la vida de sus habitantes al considerar la reutilización como un mecanismo mediante el cual se conjugan las variables de carácter económico y social (Mayorga y Soria 2014, 222).

Esto viene a confirmar que los distintos tipos de asentamientos humanos que se han desarrollado a lo largo de la historia representan el mejor testimonio de que la práctica de la reutilización del patrimonio edificado ha sido una constante. La premisa de dotar de nuevos usos a edificios existentes ha evolucionado desde épocas lejanas hasta las décadas más recientes, para convertirse, hoy día, en una acción consciente y premeditada que se orienta a conservar, resaltar y aportar valores a la preexistencia, precisamente por su condición como patrimonio.

\section{BUENAS PRÁCTICAS PARA UNA INTERVENCIÓN SUSTENTABLE EN EL PATRIMONIO EDIFICADO}

El espacio arquitectónico preexistente tiene diversas formas y tipologías que deben considerarse al abordar su intervención: desde las construcciones monumentales con reconocimiento social por su permanencia en el tiempo o la importancia de su significación, hasta edificaciones de carácter modesto desde el punto de vista estético o histórico, que forman parte cotidiana del
Las antiguas industrias siderúrgicas alemanas representaron obsolescencia y depredación del entorno natural para la sociedad hacia finales del siglo XX. La reutilización de esta infraestructura a escala regional se convirtió en un aliado para la recuperación de áreas verdes para la recreación de los habitantes. El espacio Jahrhunderthalle Bochum, en la antigua planta industrial de gas de Bochumer Verein, se ha convertido en un espacio para la cultura, los negocios y el entretenimiento | foto Michael Becker 
lugar y que pasan muchas veces desapercibidas. El elemento común a todos estos inmuebles es su uso; concretamente el proyecto de arquitectura que permite desarrollar una propuesta para que ese espacio o lugar resulte habitable de acuerdo con una nueva función.

Como se describió anteriormente, el proceso de valoración de la preexistencia edificada define su condición patrimonial. De igual manera el proceso de intervención de un inmueble o entorno construido pasa por la intencionalidad del proyecto de uso. Cada lugar tiene su especificidad y, por lo tanto, los elementos de valor que se han de conservar, así como el grado de transformación que las aportaciones para el nuevo uso y, consecuencia de ello, la nueva función, espacialidad y habitabilidad, han impreso sobre el inmueble.

No se pretende ubicar a la reutilización como el concepto dominante de la conservación del patrimonio edificado, puesto que cada campo -conservación, restauración, rehabilitación o la remodelación de arquitectura tienen sus propios ámbitos de competencia-, pero resulta evidente que conforma el elemento transversal en la ecuación, ese común denominador siempre presente, que se materializa en el proyecto de diseño que utiliza un espacio arquitectónico preexistente previamente valorado.

En este contexto de la sostenibilidad, las prácticas de la reutilización del patrimonio edificado se han ido definiendo y haciendo más evidente su diversidad y amplitud. Todas se encaminan a mejorar las condiciones de vida que la sociedad, en general, y de las personas, en particular, a través de la conservación y puesta en valor de los espacios preexistentes en función de criterios de orden social, cultural, económico y, por supuesto, ambiental. Esta abundancia de posibilidades de reutilización arquitectónica deriva justamente en formas distintas de intervenir en estos espacios:

\section{El uso y destino de lo monumental}

La noción de restaurar un edificio o un conjunto urbano está, en la actualidad, claramente identificada con la intervención de un patrimonio inmueble que destaca por su valor cultural; los aspectos históricos, estéticos, simbólicos, compositivos o materiales representativos de una época pasada deben conservarse con la mayor autenticidad posible. La restauración en el campo arquitectónico está dirigida a intervenir físicamente en un inmueble con valor cultural con el fin de garantizar su permanencia y con la finalidad de "la restitución o la mejora de su comprensión y el restablecimiento de su unidad potencial, que ha sido deteriorada o perdida por un proceso de degradación, y para que el edificio siga existiendo como objeto capaz de provocar una experiencia estética" (Martínez 2012, 25). Resulta fundamental que estas operaciones se realicen sin incurrir en alteraciones o falsificaciones de su naturaleza documental. 


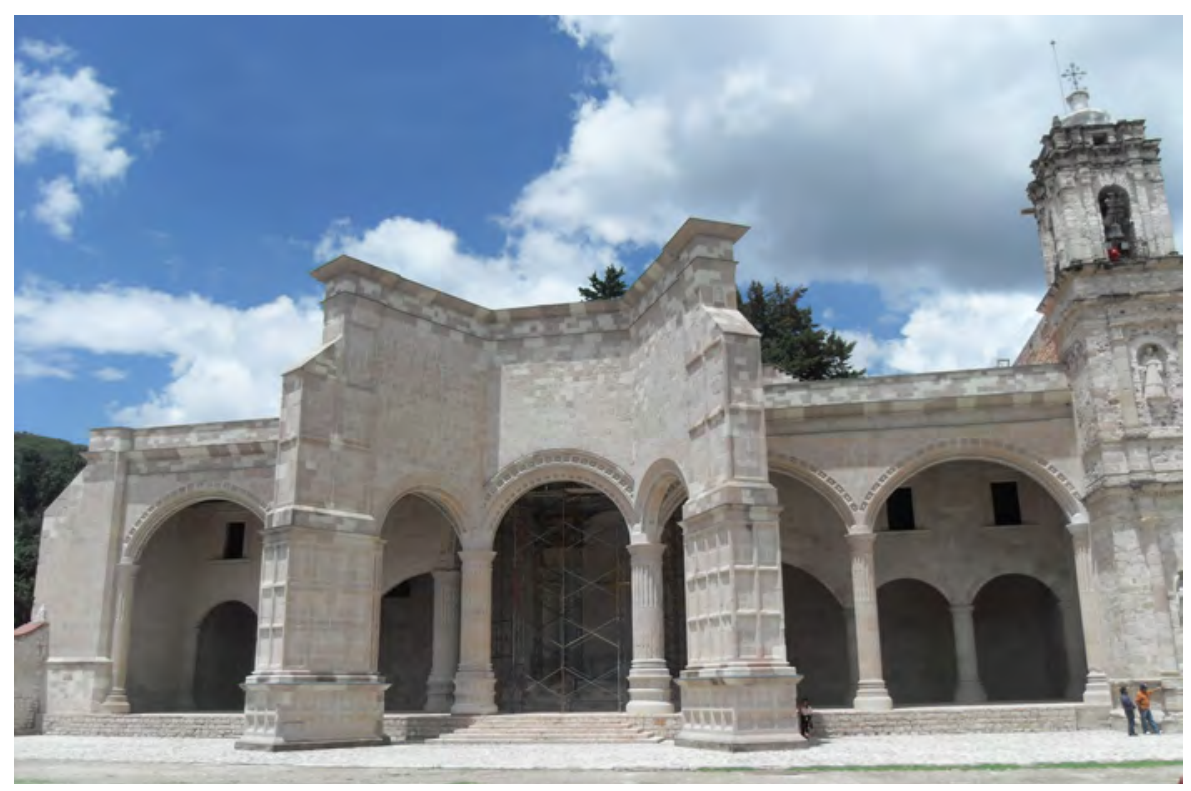

Al mismo tiempo, los diferentes documentos internacionales recomiendan siempre dedicar los edificios restaurados y conservados "a una función útil a la sociedad", pero sin perder de vista que "tal dedicación es por supuesto deseable pero no puede alterar la ordenación o decoración de los edificios" (ICOMOS 1964). El uso se hace necesario para garantizar su conservación sobre todo a largo plazo. Esto último resulta especialmente importante para el patrimonio más "modesto" el cual todavía enfrenta mayores dificultades para su valoración en relación con los grandes conjuntos y edificios de escala monumental.

El proyecto de uso, en el contexto de una restauración, debe entonces cuidar los aspectos de autenticidad e integridad del bien inmueble que se interviene, sin renunciar a incorporar elementos que garanticen su funcionamiento, seguridad y accesibilidad, siempre priorizando la compatibilidad e, igualmente, la adaptabilidad y respeto máximos hacia la preexistencia.

En ese sentido, la visión desde la reutilización puede aportar a la restauración más tradicional en su camino hacia la sostenibilidad. Mucho se ha debatido en torno a la conveniencia de reproducir, a imagen y semejanza, un inmueble de épocas pasadas cuyas fuentes o bancos de materiales ya no se encuentran disponibles ante la crisis ambiental actual. ¿Es válido restaurar un techo de vigas con árboles con siglos de existencia, abundantes en su época, pero escasos hoy día y, por lo tanto, bienes naturales dignos de conservación en sí mismos? De forma idéntica se puede decir de canteras agotadas o del uso de materiales que comprometen la salud y que hoy día ya no están permitidos.
La restauración y uso de edificaciones de carácter monumental deben considerar su viabilidad en el largo plazo, que garantice su conservación y valoración en el tiempo. El uso y rescate de técnicas y materiales tradicionales se enfrenta a cuestionamientos sobre la explotación de recursos hoy día escasos y que ponen a debate los criterios de intervención. La extraordinaria capilla abierta del siglo XVI en Teposcolula (Oaxaca, México) fue reconstruida a "imagen y semejanza" requiriendo enormes cantidades de piedra, madera y cal | foto Francisco J. Soria 
El caso de la restauración de la techumbre de Notre Dame en París abrió un debate interesante, puesto que se acudió a bosques centenarios, que aportarán los 1000 árboles necesarios para reestablecer la estructura. Esta decisión ha sido calificada por algunas voces críticas al proyecto como obsoleta y cuestionable, porque el gobierno optó “...por este dúo infernal de madera y plomo, que hizo posible el fuego y la contaminación por el plomo" (Louis 2021 , 4). El proyecto de intervención deberá incorporar, necesariamente, elementos materiales y técnicos contemporáneos que contribuyan a mejorar, entre otros aspectos, la seguridad del inmueble histórico.

La aportación del enfoque de la reutilización, de adecuar los edificios a ciertas condiciones y funciones actuales insoslayables, de manera selectiva y cuidadosa, puede contribuir a ampliar la visión de las intervenciones en inmuebles de valor cultural, que tenga también en cuenta una mirada sostenible.

\section{La rehabilitación del patrimonio edificado}

Las nociones de rehabilitación o habilitación de un objeto a su antiguo estado, largamente utilizadas en el campo de la conservación y restauración del patrimonio cultural, conllevan una idea más amplia, que supone una acción encaminada a "la recuperación de una actividad o función perdida o disminuida" (RAE 2001, 1932), que puede aplicarse a edificaciones de todas las épocas. Las posibilidades de la rehabilitación en el ámbito de la arquitectura pueden "equipararse al término 'reparación' por aplicarse a cualquier objeto, no solo a los objetos culturales (...) pero lleva implícita una fuerte componente funcional que permite establecer la equivalencia con el 'volver a poner en funcionamiento' o 'en eficiencia' (...), lo que llevaría a su aplicación especialmente en el campo de la arquitectura y el urbanismo" (DíazBerrio 2002, 44).

Persiste entonces de manera importante la idea de conservar las cualidades físicas y arquitectónicas principales -de ahí su afinidad con el ámbito de la conservación- pero, al mismo tiempo, implica acciones para mejorar las condiciones de uso, habitabilidad y seguridad, lo que representa la incorporación de elementos o cambios puntuales para adaptarlos a las nuevas funcionalidades. Este campo está dirigido en especial a un amplio espectro de inmuebles con valor histórico, arquitectónico y ambiental ubicado en zonas urbanas o rurales de valor patrimonial, que no entran en la clasificación de lo monumental pero cuya permanencia está unida indispensablemente a la preservación del entorno, la imagen y paisaje urbanos de dichos sitios.

La reutilización, en este rubro, implica un respeto importante a lo existente, a su carácter social, cultural e incluso formal y material, pero al mismo tiempo requiere de cambios o adiciones para su adecuado funcionamiento; "incluye simultáneamente la 'conservación' (...) y la 'transformación'(...) para dotarla 
[a un área urbana existente] de elementos adecuados a sus características arquitectónicas y para otorgarle mejores condiciones de habitabilidad y uso" (González-Varas 2003, 545). El proceso de diseño encaminado a rehabilitar un inmueble puede establecerse como un punto intermedio entre la restauración y la renovación, conserva las características físicas, materiales, funcionales y de apariencia principales, pero también transforma de manera selectiva.

\section{La reconversión energética de espacios preexistentes}

La crisis ambiental actual que ha generado la actividad humana para sostener sus formas de vida se ha convertido en un tema de gran importancia en el contexto mundial actual. Cómo se producen, operan e incluso desechan los entornos construidos, representa un gasto energético y consumo de recursos que requiere, cada día, mayor atención.

La reconversión en el ámbito de la conservación y reutilización arquitectónica dirige su objetivo principal a conseguir que el edificio preexistente tenga un mejor rendimiento y eficiencia desde el punto de vista energético. De esta manera reconvertir un inmueble implica, sobre todo, la incorporación de nuevas tecnologías y componentes para, a partir de mantener buena parte de su configuración preexistente, mejorar la pérdida o ganancia de temperaturas (aislamiento), incluir instalaciones eléctricas de bajo consumo energético, añadir aquellas que puedan producir energía propia, integrar sistemas de captación y ahorro de agua, entre otras infraestructuras posibles. El reto del
Los edificios patrimoniales se intervienen para mejorar su comportamiento energético, para lo que se incorporan elementos contemporáneos, en especial la envolvente de los edificios, que incluye fachadas y cubiertas. En la imagen de la izquierda una antigua capilla gótica en Girona que incorpora una techumbre metálica que contrasta con la solución tradicional de teja, pero que mejora su rendimiento ante factores climáticos

La rehabilitación de inmuebles de valor patrimonia tiene, desde el punto de vista de la sostenibilidad, el compromiso de conservar los valores de lo construido y, simultáneamente, incorporar elementos para adecuarse al nuevo uso. En la imagen de la derecha, los espejos de agua integrados a la antigua fábrica textil del siglo XIX, reutilizada como Centro de las Artes de San Agustín, en Oaxaca | fotos Francisco J. Soria
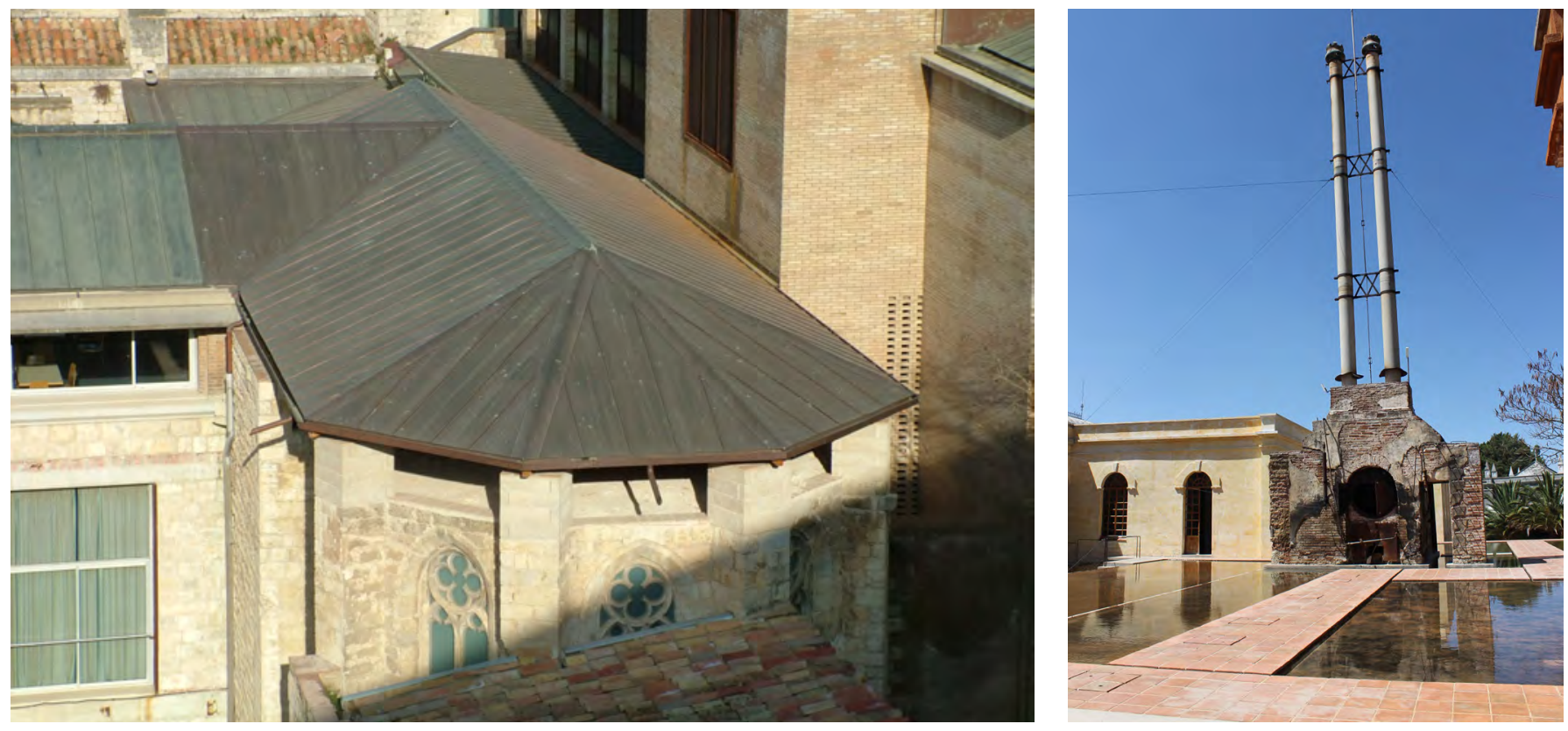
El enorme parque edificado construido a partir de la segunda mitad del siglo XX, que las instituciones especializadas no consideran inmuebles patrimoniales, está llegando al final de su vida útil. La renovación y remodelación de esta arquitectura puede contribuir a reducir el impacto ambiental al evitar construcciones nuevas y mantener una determinada imagen urbana de un sector de la ciudad, extendiendo su permanencia al ser reutilizados. Este edificio de departamentos de los años 60 del siglo pasado en Ciudad de México fue renovado en sus interiores y se le adicionó un nivel superior para extender su vida útil y mejorar las condiciones de habitabilidad y rentabilidad | foto Francisco J. Soria

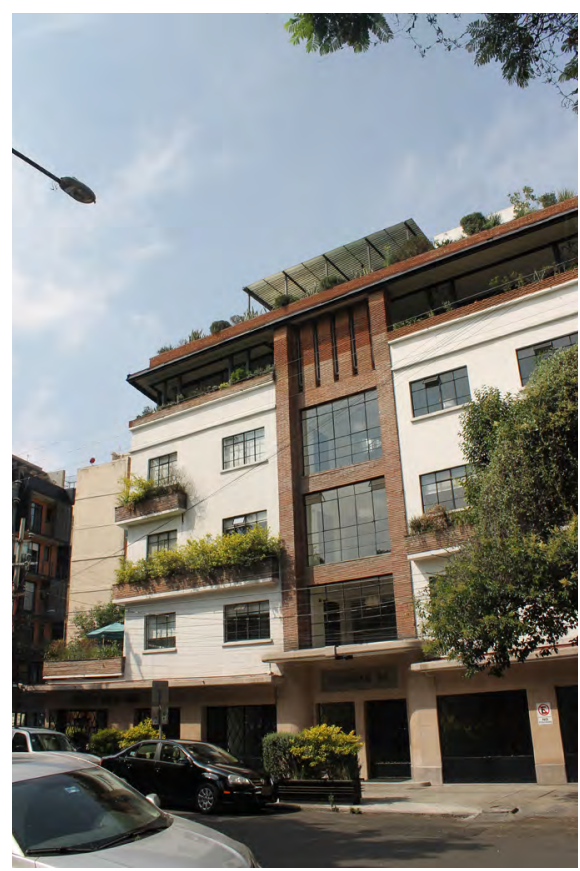

proyecto se centra en cómo integrar dichos componentes para que convivan con lo existente, pero no escatima en la sustitución de materiales o elementos "obsoletos" o en agregar lo necesario para llegar a la meta propuesta de alta eficiencia energética y re-funcionalización predeterminada. Buena parte de las acciones están encaminadas a la envolvente del edificio, fachadas, techumbres y vanos para garantizar un mejor rendimiento térmico global.

Se trata de un amplio campo de acción, que nuevamente debe incorporar el tema de la valoración, donde inmuebles de reconocida importancia cultural requieren un proceso diferente a inmuebles de valor ambiental o aquellos de orden utilitario donde las decisiones de cambios y transformaciones parecen más fáciles de tomar. Una intervención adecuada, "tiene como objetivos la mejora energética, el bajo impacto, la valoración histórica y la regeneración económica y social de las zonas urbanas. Esta nueva visión ha hecho más compleja la intervención, ya que requiere el respeto y la apreciación de las cualidades estéticas, materiales y espaciales, así como la compatibilidad y la reversibilidad de los trabajos" (Lucchi 2015, 230).

\section{La remodelación y renovación del parque edificado}

Los términos remodelar o renovar se refieren, desde el punto de vista arquitectónico, a la intervención de inmuebles que requieren acciones para modernizar o reformar su funcionamiento y apariencia. La remodelación busca intervenciones orientadas a los aspectos de carácter formal y técnico. Se encamina a mejorar o cambiar función y apariencia y, casi siempre, a sacar provecho del valor económico y de ubicación como superficie construida de un edificio determinado. Esto último se aplica, sobre todo, para espacios de carácter comercial o de oficinas que suelen cambiar de configuración en períodos relativamente cortos.

El concepto de renovación se asemeja a la idea de remodelar, ya que supone "hacer de nuevo" pero de mayor aplicación en la escala urbana y "alude a la obtención de una condición nueva (...) con una idea implícita de 'mejora' o 'actualización' que implica una ‘sustitución' de sus componentes materiales" (García-Varas 2003, 546). Se refiere sin duda a la intervención de espacios que están degradados, deteriorados o, en su caso, obsoletos y que requieren de un proceso de intervención para recuperarlos o actualizarlos a nuevas demandas de los usuarios.

Este tipo de intervención, si bien puede considerarse dentro del abanico que cubre la reutilización, se considera poco conveniente en el caso de inmuebles de valor cultural, simbólico, histórico, estético o documental. En este sentido parece claro que se trata de una práctica proyectual muy extendida pero acotada a espacios básicamente utilitarios, cuya intencionalidad se aleja de los principios de la conservación del denominado patrimonio edifi- 
cado. Por tanto "no debe aceptarse ni tomarse en consideración en materia de Conservación de Bienes Culturales (...) Si entendemos por 'remodelar' el cambiar o dar una nueva forma o volumen envolvente (...) no puede admitirse su aplicación a objetos culturales -sustancialmente históricos y estéticos" (Díaz-Berrio 2002, 45).

El proyecto de reutilización, cuando se trata de remodelar o renovar tiene, por definición, una gran libertad y amplitud en cuanto a modificar y reconfigurar las formas, funciones y apariencia de una construcción o espacio existente. Su motivación se fundamenta en aprovechar y conservar básicamente como soporte a una estructura urbana o arquitectónica existente y cambiar su aspecto y función inicial de manera sustancial, lo cual lo acerca, en cierta medida, al proyecto de nueva creación.

Sin embargo, el proceso de remodelar, renovar e incluso reciclar un espacio preexistente exige un proceso previo de valoración económica, de ubicación y -de creciente importancia hoy día- medioambiental al extender su ciclo de vida útil y evitar procesos de demolición, deshecho y construcción nueva. Por lo tanto, se trata de una alternativa viable y que debe estar en la esfera de la reutilización de un amplio espectro de edificaciones.

Estos conceptos se alinean en buena medida con el denominado "parque inmobiliario" que se refiere a los edificios de poco valor cultural, simbólico o arquitectónico, sobre todo construidos en décadas recientes (30 a 40 años a lo mucho) que no se consideran edificios patrimoniales por las instituciones especializadas. Sin embargo, se trata de un enorme recurso, de un patrimonio de valor económico y social construido a partir de un enorme gasto energético y el uso de recursos materiales, de orden familiar, empresarial o público, que conviene conservar e incrementar su ciclo de vida por razones utilitarias, económicas y por su contribución en la disminución del impacto ambiental que produce la nueva edificación.

\section{EL PROYECTO DE REUTILIZACIÓN ARQUITECTÓNICA, UNA ALTERNATIVA PARA LA CONSERVACIÓN SOSTENIBLE}

Como ya se ha señalado en líneas anteriores, este texto sostiene la premisa importante de que el proyecto de arquitectura que intencionalmente reutiliza espacios arquitectónicos con valor patrimonial contribuye a su conservación y a incrementar su ciclo de vida. En tal sentido se trata de una práctica que atraviesa proyectos que van desde la restauración, hasta la remodelación. La siguiente idea en torno al concepto de la reutilización apunta a una visión holística del término: "La reutilización se visualiza entonces, como un proyecto contemporáneo de arquitectura, que respeta y se apropia de los elementos significativos del lugar, aquellos que le dan precisamente el 'valor' 
que justifica su preservación, pero simultáneamente ha de aportar lo propio como parte del proceso de 'apreciar', 'acumular' y 'transmitir' valor. No se trata entonces de un trabajo de mera conservación del carácter patrimonial de un sitio determinado, sea este orden histórico, estético, ambiental o económico. Incluye estos valores, por supuesto, pero también implica entender e interpretar el entorno donde se actúa tanto en lo físico, como lo inmaterial, en su lógica funcional, formal y tectónica, sin olvidar la importancia de la percepción subjetiva y la significación social en la construcción y uso como nuevo espacio arquitectónico" (Soria y Guerrero 2016, 138).

Conviene destacar que interesa ubicar la reutilización del patrimonio edificado como una práctica de amplio espectro, pero selectiva en cuanto a los valores que pretende conservar y resaltar. Hablar de valor implica una diversidad de posibilidades, entre ellas las de carácter económico o de orden utilitario, hasta las de tipo cultural y simbólico que deben considerarse para cualquier proyecto de diseño.

Corresponde entonces reiterar la importancia del pilar social de la sostenibilidad, pues somos los individuos y grupos de personas, quienes desarrollamos la actividad económica o quienes damos voz a la naturaleza ante su destrucción progresiva. De la percepción, postura y forma de organización que asuma una determinada sociedad, depende su relación con su entorno cultural y natural. Este valor que asignamos a los espacios construidos que habitamos cambia en el tiempo, en función de la propia evolución social.

La reutilización del patrimonio edificado se interesa por espacios preexistentes que ofrezcan valores importantes e interesantes para el proyecto, en especial del orden arquitectónico (espacialidad, composición, funcionalidad, disposición, materialidad) y cultural y simbólico (estética, histórica, afectivos, referenciales), sin dejar de lado posibilidades ambientales y utilitarias. Pero se aleja de la remodelación, reconversión y del reciclaje, campos de mucha actividad profesional actual, pero con otras motivaciones principales y que se enfocan, sobre todo, en el denominado "parque inmobiliario" que representa un enorme recurso edificado que puede y debe aprovecharse al máximo.

Por otro lado, se entiende que la conservación, restauración y rehabilitación de bienes culturales inmuebles constituyen especialidades en sí mismas. De larga tradición, en sus metodologías incorporan el uso y destino actual del inmueble que se ha de preservar. No podría entenderse de otra manera, pues el patrimonio edificado forma parte activa de nuestros espacios de vida.

El siguiente cuadro busca ilustrar y sintetizar las ideas arriba expuestas. No debe tomarse como un esquema inamovible, pues cada caso plantea un problema específico y sus propias soluciones. Incluso los sitios pendientes de 
intervención pueden requerir en muchas ocasiones un acercamiento múltiple, en el que se mezclen o superpongan intencionalidades, soluciones y formas de intervención. Sin embargo, en términos generales, podemos señalar ciertos parámetros encaminados a conservar o transformar la preexistencia a través de un proyecto de diseño arquitectónico que propone un nuevo uso o, en su caso, el mismo uso, pero actualizado, en función de un proceso de valoración del inmueble preexistente.

La conservación del entorno construido, en especial aquel que está considerado como patrimonio por su importancia histórica, cultural, social, económica y, desde luego, ambiental, pasa entonces por su utilización como espacio habitable, capaz de albergar funciones para la sociedad contemporánea, adaptándose a las condiciones actuales -y cada vez más dinámicasde uso, pero simultáneamente, preservando sus características y valores esenciales. Supone un enorme reto, pero el contexto actual demanda soluciones concretas, sensibles y creativas. La reutilización sostenible del patrimonio edificado se convierte en un proceso de diseño e intervención que puede y debe contribuir a preservar y mejorar nuestros espacios de vida como sociedad, contribuir a disminuir el impacto negativo sobre el entorno natural y aportar al desarrollo económico de la comunidad.

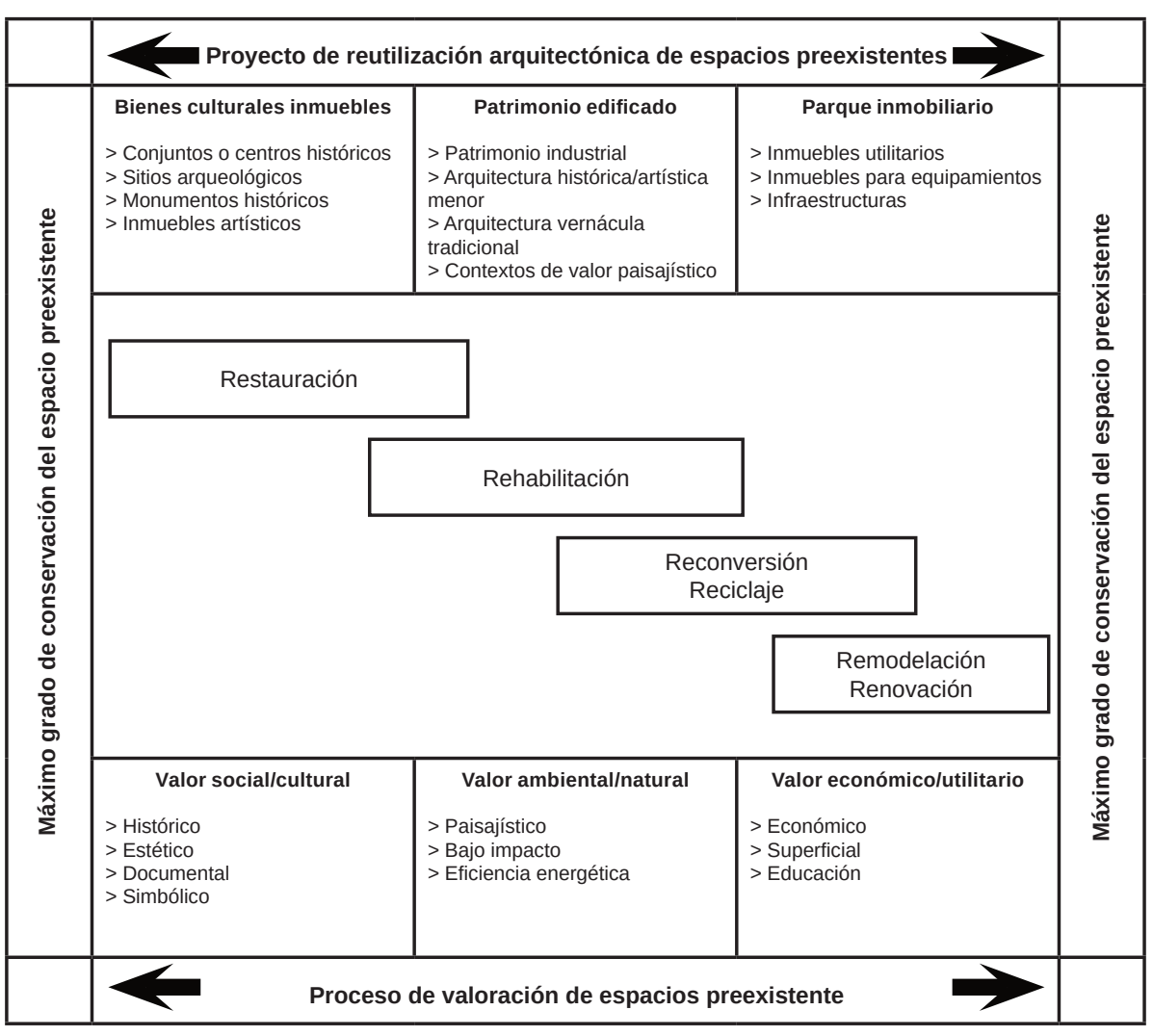




\section{BIBLIOGRAFÍA}

- Barreiro, D. (2012) Arqueología aplicada y patrimonio: memoria y utopía. Complutum, vol. 23, n. ${ }^{\circ}$ 2, pp. 33-50. Disponible en: https://doi.org/10.5209/rev_CMPL.2012.v23. n2.40874 [Consulta: 20/07/2021]

- Capitel, A. (1999) Metamorfosis de monumentos y teorías

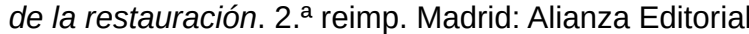

- Choay, F. (2007) Alegoría del Patrimonio. Barcelona: Gustavo Gili

- Díaz-Berrio Fernández, S. (2002) Terminología en materia de conservación del patrimonio cultural. Diseño y Sociedad, n. ${ }^{\circ}$ 13, pp. 40-47. Disponible en: https:// publicaciones.xoc.uam. mx/TablaContenidoFasciculo. php?id_fasciculo=291 [Consulta: 20/07/2021]

- Direction du Patrimoine, Ville d'Arles (2002) Patrimoine en Chantier: l'amphithéâtre. En: Site du Patrimoine d'Arles. Disponibleen: http://www. patrimoine.ville-arles.fr/document/ amphith\%C3\%A9\% C3\%A2tre\%20ar\%C3\%A8nes\% 20Arles\%20patrimoine\%20chantier.pdf [Consulta: 20/ 07/2021]

- Elefante, C. (2007) The Greenest Building Is...One That Is Already Built. Forum Journal, vol. 21, n. ${ }^{\circ}$ 4. Disponible en: http://www.ipedconference.com/referencematerials/ Article_The_Greenest_Building_Is_One_That_Is_Already_ Built_by_Cārl_Elefante_AIA_LEED_AP_Forum_Journal_ Summer_2007.pdf [Consulta: 20/07/2021]

- González-Varas, I. (2003) Conservación de bienes culturales. Teoría, historia, principios y normas. Madrid: Cátedra

- Gracia, F. de (2001) Construir en lo construido. La arquitectura como modificación. Hondarribia (Guipúzcoa): Nerea

- ICOMOS (1964) Carta Internacional sobre la Conservación y Restauración de Monumentos y Sitios (Carta de Venecia 1964). II Congreso Internacional de Arquitectos y Técnicos de Monumentos Históricos, Venecia 1964, Adaptada por ICOMOS en 1965. Disponible en: https:// www.icomos.org/charters/veni ce_sp.pdf [Consulta: 20/07/2021]

- Louis, L. (2021) Reconstrucción de Notre Dame crea polémica. Deutsche Welle, 14.04.2021. Disponible en: https://p.dw.com/p/3s1mA [Consulta: 15/05/2021]

- Lucchi, E. (2015) Sostenibilidad y eficiencia energética de los edificios históricos. revista $\mathrm{PH}, \mathrm{n}^{\circ}{ }^{\circ}$ 88. Disponible en: http://www.iaph.es/revistaph/index.php/revistaph/article/ view/3665 [Consulta: 20/07/2021]

- Martínez Monedero, M.(2012)Reciclaje dearquitecturavs restauración arquitectónica, ¿herramientas contrapuestas? Hábitat y Sociedad, n. ${ }^{\circ}$ 5, pp. 23-33. Disponible en: https:// idus.us.es/handle/11441/51920 [Consulta: 20/07/2021]
- Mason, R. y Torre, M. de la (2001) Heritage conservation and values in globalizing societies. En: World culture report 2000: Cultural diversity, conflict and pluralism. Paris: UNESCO, pp. 164-179. Disponible en: https:// unesdoc.unesco.org/ark:/48223/pf0000121058 [Consulta: 22/07/2021]

- Mayorga Trejo, V.A. y Soria López, F.J. (2015) La reutilización urbano-arquitectónica: como alternativa de diseño sustentable. En: Investigación y Diseño. México DF: UAM-X, CyAD, Publicaciones CyADvol, vol. 1. Disponible en: https://publicaciones.xoc.uam.mx/TablaContenidoLibro. php?id_libro=533 [Consulta: 20/07/2021]

- Metropoleruhr (2013) Emscher Landscape Park Visitor's Guide. Regionalverband Ruhr. Essen, 2013. Disponible en: https://shop.rvr.ruhr/media/pdf/a3/3d/a5/ Erlebnisfuehrer_Emscher_Landschaftspark_en_2013.pdf [Consulta: 20/07/2021]

- Naciones Unidas (2015) Transformar nuestro mundo: la Agenda 2030 para el Desarrollo Sostenible. A/RES/70/1. Disponible en: https://unctad.org/system/files/official-document/ ares70d1_es.pdf [Consulta: 20/07/2021]

- Olivares Baró, C (2021) Premio Pritzker 2021: aquí los proyectos de Anne Lacaton y Jean Philippe Vassal. La Razón, ed. México, 16/03/2021. Disponible en: https://www.razon. com.mx/cultura/anne-lacaton-jean-philippe-vassal-ganaronpremio-pritzker-2021-427245 [Consulta: 20/07/2021]

- Real Academia Española [RAE] (2001) Diccionario de la Lengua Española. 22. ${ }^{\mathrm{a}}$ ed. Madrid: ESPASA, vol. II

- Soria López, F.J. (2006) El diálogo ético en el proyecto sostenible. Parque Duisburg-Nord, Alemania. En: Anuario de estudios de arquitectura, historia, crítica, conservación. México D.F.: Universidad Autónoma Metropolitana

- Soria López, F.J. y García Koch, A.B. (2017) La reutilización del patrimonio edificado en el marco del desarrollo sostenible. Diseño en Síntesis, n. ${ }^{\circ}$. 57, año 24, primavera. Disponible en: https://disenoensintesisojs. xoc.uam.mx/index.php/disenoensintesis/article/view/352 [Consulta: 20/07/2021]

- Soria López, F.J. y Guerrero Baca, L.F. (2016) El proyecto de reutilización arquitectónica: hacia una valoración ampliada del patrimonio edificado. Academia XXII, vol. 7, n. ${ }^{0} 13$, febrero-junio. Disponible en: http://revistas.unam.mx/ index.php/aca/article/view/56314 [Consulta: 20/07/2021] 


\title{
Patrimonio y sostenibilidad. Las buenas prácticas en la rehabilitación energética de edificios patrimoniales
}

\author{
Albert Cuchí Burgos | Escola d'Arquitectura del Vallès, UPC Barcelona Tech \\ URL de la contribución <www.iaph.es/revistaph/index.php/revistaph/article/view/4966>
}

\section{RESUMEN}

La exigencia de sostenibilidad plantea cambios radicales en nuestra relación con el medio, demandando un futuro diferente al que nos conduce hoy en día nuestro sistema productivo industrial. En el artículo se plantea el patrimonio como el recurso clave para definir y construir el futuro $y$, por tanto, todo aquello que se considera patrimonio y todo aquello en lo que radica su valor patrimonial no es sino un relato necesario para vislumbrar y alcanzar ese futuro. Pero un futuro diferente requiere un patrimonio diferente, y supone un reto que se manifiesta ya en las demandas de ajustar el patrimonio reconocido al nuevo futuro que se persigue. La rehabilitación energética de los edificios patrimoniales es uno de esos retos desde los que se puede tirar del hilo del tipo de problemas que la construcción de un futuro sostenible nos plantea sobre el patrimonio.

\section{Palabras clave}

Edificios | Eficiencia energética | Intervención | Patrimonio edificado | Rehabilitación arquitectónica | Rehabilitación energética | Sostenibilidad | 


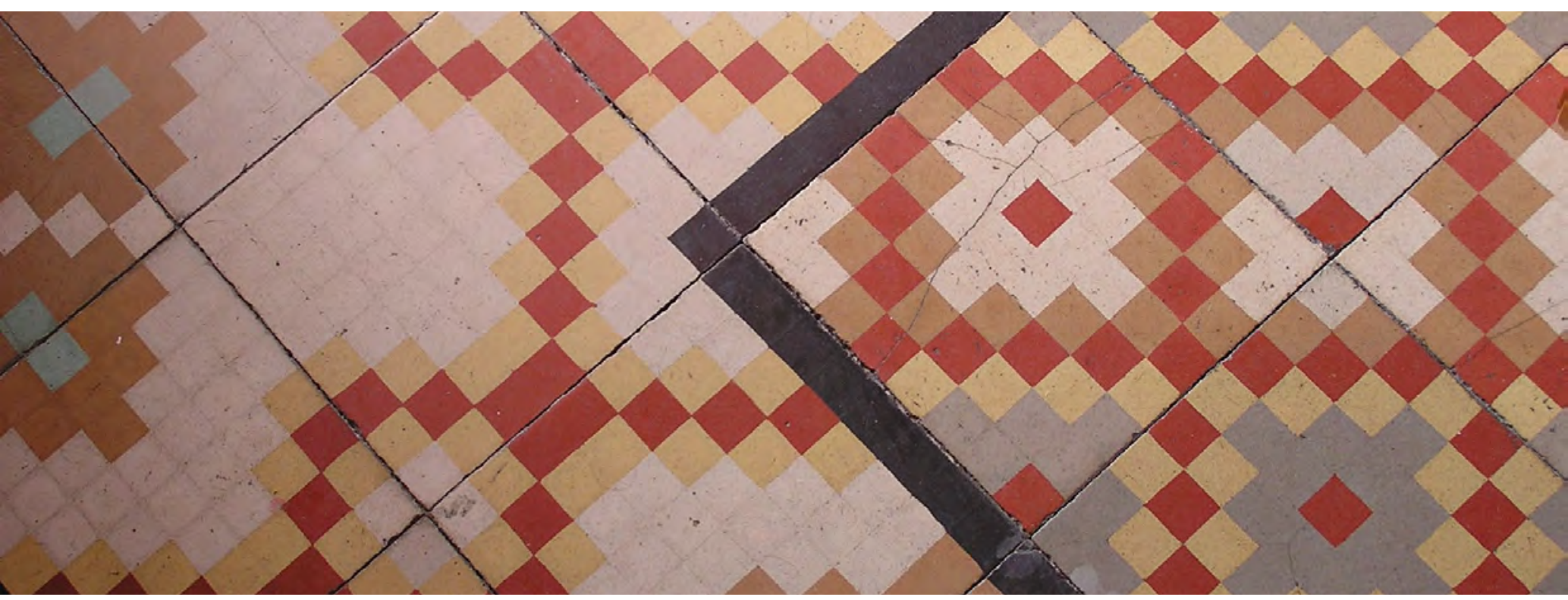

\section{Heritage and sustainability. Good practices in the energy renovation of heritage buildings}

\section{ABSTRACT}

Sustainability demands radical changes in our relationship with the environment, searching a different future from our industrial production system leads us today. In the article, heritage is considered as the key resource to define and build the future and, therefore, everything that is considered heritage and everything in which its heritage value lies is nothing more than a necessary story to achieve that future. But a different future requires a different heritage and is necessary to adjust the recognized heritage to the new future. The energy retrofit in heritage buildings is one of those challenges from which it is possible recognize the type of problems that the construction of a sustainable future poses on heritage.

\section{Keywords}

Buildings | Energy efficiency | Intervention | Heritage buildings | Architectural rehabilitation | Energy retrofit | Sustainability |

Cómo citar: Cuchí Burgos, A. (2021) Patrimonio y sostenibilidad. Las buenas prácticas en la rehabilitación energética de edificios patrimoniales. Revista PH, n. ${ }^{\circ}$ 104, pp. 164-179. Disponible en: <www.iaph.es/revistaph/index.php/revistaph/article/view/4966> DOI 10.33349/2021.104.4966

Enviado: 03/06/2021 | Aceptado: 19/07/2021 | Publicado: 01/10/2021 


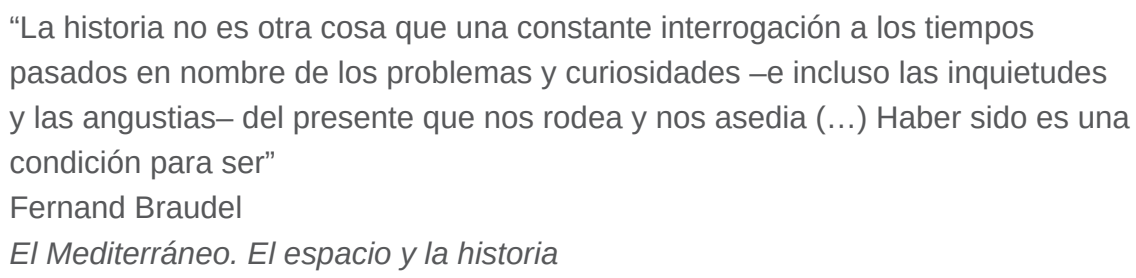

En japonés utilizan dos caracteres Kanji (de origen chino) para indicar delante (zen) y detrás (go, kō), y permitir configurar expresiones que denoten posición espacial de un sujeto, de un objeto o de una acción. Pero también, como hacemos nosotros, lo usan no solo como indicador de posición espacial sino también de posición temporal, aunque con una gran diferencia: para nosotros el futuro está delante y el pasado queda atrás, mientras que para ellos el futuro está detrás mientras que el pasado es lo que tenemos enfrente. En realidad, es mucho más lógica su interpretación espaciotemporal, puesto que no tenemos sentidos para percibir el futuro, sino solo lo que el pasado ha dejado delante nuestro.

En cierto modo y paradójicamente, Marshal McLuhan reconoció este hecho cuando enunció su crítica con la famosa frase "conducimos hacia el futuro mirando por el retrovisor", algo en realidad inevitable pues somos incapaces de percibir el futuro si no es a través de interrogar el pasado, de entender la evolución de las cosas a través de su devenir -y poder deducir así su futuro-y de hacerlo a través de lo que ha dejado ante nosotros, ante nuestros sentidos.

De esta manera y de forma genérica, el pasado no es sino el gran recurso que tenemos para intervenir nuestro futuro, e interpretándolo articulamos relatos que nos permiten construir ese futuro. Relatos que, como a las hipótesis científicas, solo se les puede exigir que sean compatibles con los hechos observados, con lo que está ante nuestros ojos. El patrimonio es, en este sentido, un conjunto de hechos sobre los que condensar y contrastar hipótesis en las que basar nuestra cotidiana construcción del futuro.

Y en ese punto está claro que decidir qué es patrimonio y qué no lo es -qué debe conservarse como un referente fáctico y qué puede (o debe) dejarse perder porque no debe ser considerado como tal- es un ejercicio de singular importancia: la legitimidad de los relatos con los que construimos el futuro se juega en esa partida. Como también lo es la caracterización del patrimonio como tal, dónde radica su valor patrimonial y, por lo tanto, cómo debe ser conservado y mantenido y rehabilitado, si es necesario.

En origen, y como su nombre indica, patrimonio es lo que nos legan nuestros padres. Un legado que nos sirve para mejorar nuestras condiciones de vida, para evitar o para hacer más productivo nuestro esfuerzo, nuestro trabajo. Y, 
también, nos da una identidad en tanto la legitimidad social de su posesión y disfrute frente a terceros deviene del reconocimiento de la filiación. Extender ese concepto a instituciones sociales más amplias, hasta llegar al patrimonio de la Humanidad, no deja de ser un ejercicio de generación de identidades, de prelaciones de unos sobre otros a la hora de reconocer la legitimidad de los relatos basados en ese patrimonio, de construir el futuro.

Cabe recordar ahora cómo Françoise Choay (2007) nos explica que los revolucionarios franceses comenzaron destruyendo sistemáticamente las pinturas, las esculturas, los edificios, todo el patrimonio que soportaba el relato del antiguo régimen, borrando así la legitimación que aportaba a la reproducción de un mundo que, ahora, debía ser destruido. Una destrucción que ha formado parte de la liturgia renovadora de tantos futuros por construir, como lo hicieron los mongoles, o Tamerlán, o los talibanes con los budas afganos o Isis en Palmira. O por la colonización occidental, destruyendo en su expansión los patrimonios de tantas culturas tradicionales.

O como ha hecho la civilización industrial que, habiendo destruido la funcionalidad del patrimonio tradicional al cambiar las bases productivas de la sociedad -primero de la sociedad occidental, ahora ya de todas las sociedades humanas-, dejó únicamente el valor identitario como posible valor patrimonial. Una reducción a mero valor identitario que ha permitido gestionar el patrimonio de una forma libre, autónoma, despojada de las restricciones que implica mantener su veracidad funcional, su utilidad como elemento productivo. Esa "libertad" ha permitido reinterpretar el pasado desde una literatura abierta a construir relatos ausentes de cualquier restricción operativa para decidir libremente qué era y qué no era patrimonio y, por ende, qué tipos de futuros podían ser legitimados y qué tratamiento era legítimo dar a los elementos patrimoniales singulares que habían sido catalogados como tales.

A partir de ahí, ustedes saben tanto como yo de hasta qué punto se ha codificado en nuestra sociedad industrial qué es patrimonial y cómo debe gestionarse.

Naturalmente, la construcción de un nuevo futuro, de un futuro sobre bases nuevas, supone un reto para el patrimonio reconocido. De hecho, un reto para lo que reconocemos del pasado. Y cuanto más radicalmente diferente al futuro para el que se ha configurado nuestro patrimonio reconocido, tanto más radical será ese nuevo reconocimiento. Y, naturalmente, se va a expresar inicialmente como conflictos sobre nuestra gestión patrimonial.

La exigencia de sostenibilidad es una demanda tremendamente significativa desde el punto de vista cultural, en el sentido etimológico de ese término: cultura, cultivo, relación con el medio. No es sino la constatación de los efectos a largo plazo de nuestro modelo productivo industrial, de la socie- 
dad industrial, a causa de la superación de los límites geobioquímicos dentro de los cuales se han desarrollado las culturas humanas. Una superación que produce transformaciones en el medio que suponen costes inasumibles para nuestra sociedad, como es el caso del cambio climático, cuyo reconocimiento como problema crucial tiene ya una aceptación social indiscutible.

Aunque intuyendo que los cambios serán indudablemente más profundos, las respuestas a retos de esta magnitud se manifiestan en primer lugar con las acciones paliativas más inmediatas, buscando remediar errores cometidos sin vernos aún capaces de replantear el problema desde la raíz. Un ejemplo de ello es la mejora de la eficiencia térmica de los edificios.

Los edificios son uno de los grandes consumidores de energía y, por tanto, responsables de emisiones de gases de efecto invernadero debido al predominio de los combustibles fósiles en la dieta energética de nuestra sociedad. La respuesta inmediata a esta situación ha sido introducir en muy poco tiempo fuertes exigencias normativas de eficiencia energética a la edificación nueva, que se exigen también a la gran rehabilitación y que ahora ya se están extendiendo a la edificación existente. Todo ello se ha planteado desde la existencia y el desarrollo de una panoplia de materiales, técnicas y sistemas que, sin ser recientes, se han consolidado como una oferta técnica capaz de dar respuesta a una demanda tan extrema como el edificio de consumo de energía casi nulo exigido por la normativa europea. De este modo, la exigencia es hija de la posibilidad de alcanzarla mediante unos procesos técnicos conocidos y aplicables de forma ¿generalizada?

Además de conspicuos consumidores de energía, los edificios son también uno de los sujetos recurrentes de calificación patrimonial, lo que plantea un problema para la gestión de ese patrimonio si la exigencia de eficiencia energética debe alcanzarles.

Fruto del comentado desarrollo de las técnicas que hacen posible implementar la eficiencia energética en edificación, la expresión más habitual de la mejora del comportamiento de los edificios es la adición de aislamiento a la envolvente de los espacios climatizados. Y eso, claro está, choca con la consideración patrimonial de edificios que han sido y son utilizados por la sociedad y que se han ajustado en sus condiciones ambientales a las exigencias que la normativa marca para el uso concreto al que son destinados.

El aislamiento térmico, en tanto la adición de capas superficiales extendidas sobre paramentos que resultan así recubiertos, se plantea como una intervención agresiva respecto a la pervivencia de elementos patrimonialmente significativos como pueden ser las fachadas de los edificios, en forma completa o bien singularizada en alguno de sus componentes, o extendida a un conjunto considerado como paisaje urbano patrimonial. 
Se plantea entonces un grave conflicto entre los valores patrimoniales y las necesidades de eficiencia energética, que trata de resolverse mediante el análisis de soluciones técnicas menos agresivas -aislamientos interiores, sistemas de climatización eficientes, etc.-y, en último caso, exonerando al edificio de cumplir con esas exigencias normativas por cuanto su valor patrimonial se considera que prima sobre el valor social que se persigue con la mejora de su eficiencia energética.

Naturalmente, eso se hace así porque la patrimonialización de esos edificios y conjuntos ha sido muy selectiva a la hora de determinar en qué radica su valor patrimonial.

En realidad, el problema de la mejora de la eficiencia energética de esos edificios patrimoniales está en que la mirada que los patrimonializa es una mirada esencialmente anatómica, que otorga la calidad patrimonial a elementos físicos, materiales o, cuanto menos, soportados directa e íntimamente por ellos. Su permanencia, la permanencia de su apariencia ligada a su materialidad, a su autenticidad basada en la continuidad en el tiempo de su realidad física, es el soporte de su calidad patrimonial. La valoración actual de lo que se ha llamado patrimonio inmaterial no hace más que resaltar, por la necesidad de adjetivarlo, que lo propio del patrimonio es la materialidad.

Ello hace que, por ejemplo, patrimonialmente no sea incoherente cambiar libremente los usos de un edificio, incluir sistemas modernos de instalaciones o equipos para soportarlos -siempre que ello no afecte directa o indirectamente a la materialidad de los elementos sobre los que se sustenta el valor patrimonial- o el hecho de mantener o restaurar esos elementos patrimoniales con técnicas muy sofisticadas y, corrientemente, muy alejadas de las que los conformaron. Incluso desmembrar el elemento patrimonial de su entorno, cuya demostración más grosera -pero en absoluto única- es la conservación de la fachada de un edificio histórico mientras el resto del edificio es demolido y substituido por otro moderno.

Cuestiones que resultan ahora muy criticables porque, frente a esa visión anatómica del patrimonio, con la exigencia de sostenibilidad pasan a valorarse aspectos más fisiológicos.

Por ejemplo, es innegable que los edificios tradicionales tienen implícita una estrategia térmica para acondicionar los espacios que los integran, aunque jamás la describirían en esos términos. Evidentemente, con exigencias alejadas de las actuales y en modo alguno explícitas en normativas o códigos técnicos como están registradas actualmente. Estrategias implícitas que abordan escalas y recursos muy amplios que, mayoritariamente, no tienen cobertura patrimonial, con lo que las estrategias implícitas de comportamiento térmico de los edificios patrimoniales no son patrimoniales y, 
por tanto, sujetas a conservación. Es más, a menudo resultan competidoras molestas para el mundo industrial.

Es el caso de lo que ahora llamamos "estrategias bioclimáticas", en las que la gestión del intercambio de energía con el entorno -mediante la inercia térmica, aprovechamiento de la radiación solar, ventilación controlada, etc., y el uso de recursos energéticos renovables del entorno- permite mejorar las condiciones interiores y que, además, está en la base de buena parte de la variedad y singularidad del patrimonio construido. Pero ninguna protección patrimonial cubre la gestión bioclimática de un edificio con lo que, aunque los elementos físicos que la permitan estén catalogados y protegidos, no lo está la misma gestión. Valga un ejemplo significativo de ello.

Los conocidos y celebrados -aunque aún no suficientemente protegidospavimentos hidráulicos modernistas de los edificios del Ensanche barcelonés (Rosselló i Nicolau 2009) no son sino el remedo veraniego de los dibujos de las alfombras que tapizaban el suelo de las viviendas durante el invierno. Alfombras que se fijaban en el borde de madera que los limita. Como se cubrían las ventanas con gruesas cortinas de terciopelo u otros materiales durante los meses fríos para completar el vestuario personal y la acción limitada del brasero y la cocina económica. Incluso a menudo las paredes se entelaban para mejorar su temperatura superficial y, con ello, la temperatura radiante de la envolvente de la habitación. En el paso de los meses fríos a los más cálidos, las viviendas del Ensanche de Barcelona -como las

Los pavimentos hidráulicos de los edificios modernistas remedan las alfombras que recubrían las estancias durante los meses fríos. Este elemento patrimonial -hoy valorado como talnos recuerda la existencia de una estrategia de confort, de uso de esos edificios, que se perdió con la introducción de los sistemas de climatización modernos pero que ahora supone un referente para redescubrir y reinterpretar las estrategias térmicas tradicionales como una parte -hoy perdida- de ese patrimonio edificado | foto Alberto Cuchí Burgos

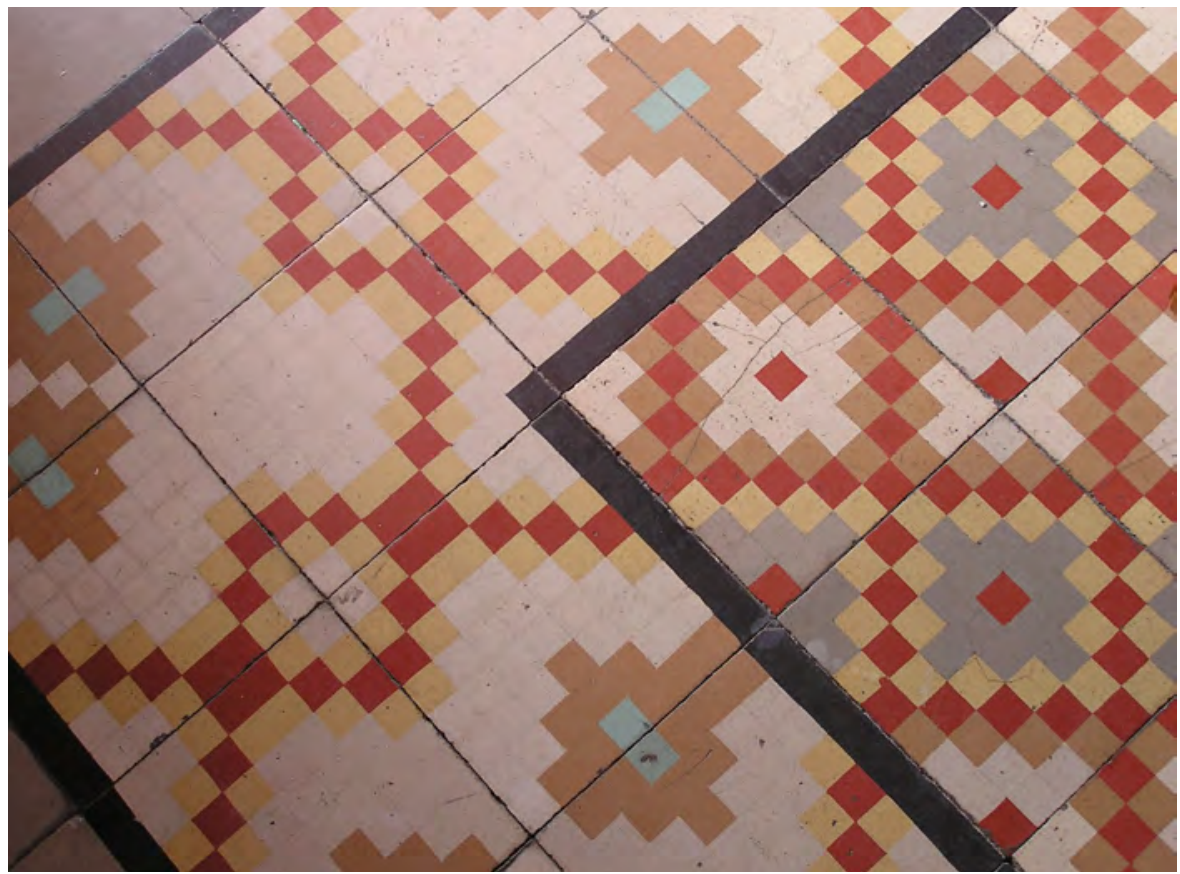


de otros lugares- se desvestían de sus "abrigos invernales" para dar paso a otra gestión térmica basada en la ventilación y la inercia.

Y aún hay más. Uno de mis recuerdos infantiles más impactantes es el de la casa de mi abuela cuando con los primeros calores, y adicionalmente al cambio de vestuario ya comentado, el mobiliario de su dormitorio y el del salón intercambiaban las habitaciones que ocupaban para aprovechar mejor las condiciones diurnas y nocturnas para ambos usos hasta que volviese el frío. Un auténtico nomadismo interior que formaba parte del patrimonio de gestión térmica de la vivienda. Todo eso acabó, claro, cuando llegó la estufa de petróleo -y más tarde la caldera de gas con sus radiadores- que trasformó en cálidas todas las épocas del año e invalidó ese patrimonio funcional.

Porque lo que tienen en común todos los modelos industriales para procurar el confort térmico es la introducción de sistemas de producción de frío y/o de calor -basados en combustibles fósiles- suficientemente potentes para obtenerlo casi en cualquier circunstancia. Y de ahí que, de momento, mejorar la eficiencia energética pase por reducir la conductibilidad térmica de la envolvente de un espacio climatizado con esas máquinas térmicas.

Y eso ha sido lo habitual con la llegada de los sistemas de clima modernos. Y acostumbra a ser aún peor. A menudo los cambios de uso que se permiten al edificio son incompatibles con el uso de esas estrategias hasta el punto de negarlas. Mientras muchas de las estrategias bioclimáticas tradicionales de invierno son compatibles con los sistemas de clima, en verano son generalmente incompatibles y o funcionan unos o lo hacen los otros: ventilación cruzada y aire acondicionado no son estrategias que se puedan simultanear. $Y$ hay que considerar que la mayoría de los nuevos usos en edificios patrimoniales son de servicios, cuyos equipos requieren de refrigeración durante la mayor parte del año y, aún peor, esos nuevos usos se instalan en densidades y configuraciones propias de los edificios modernos, inasumibles por las estrategias implícitas en los edificios tradicionales. Les explico un caso ya antiguo.

La edificación del nuevo Hospital de Sant Pau en Barcelona permitió ocupar por nuevos usos los pabellones modernistas que liberaba el traslado de las instalaciones sanitarias al nuevo edificio. Fuimos encargados por los promotores de los nuevos usos para evaluar las posibilidades de mejora de la eficiencia energética de los viejos pabellones, naturalmente mediante la oportuna intervención que respetase la calidad patrimonial de los edificios. Fue interesantísimo descubrir que Doménech i Montaner, el arquitecto del viejo Sant Pau, había organizado un sistema de calefacción y ventilación integrado en la propia fábrica de los pabellones que podía ser reinterpretado y utilizado para promover un nivel de eficiencia energética elevado, mejor incluso que la intervención al uso. Eso sí, esa reinterpretación exi- 

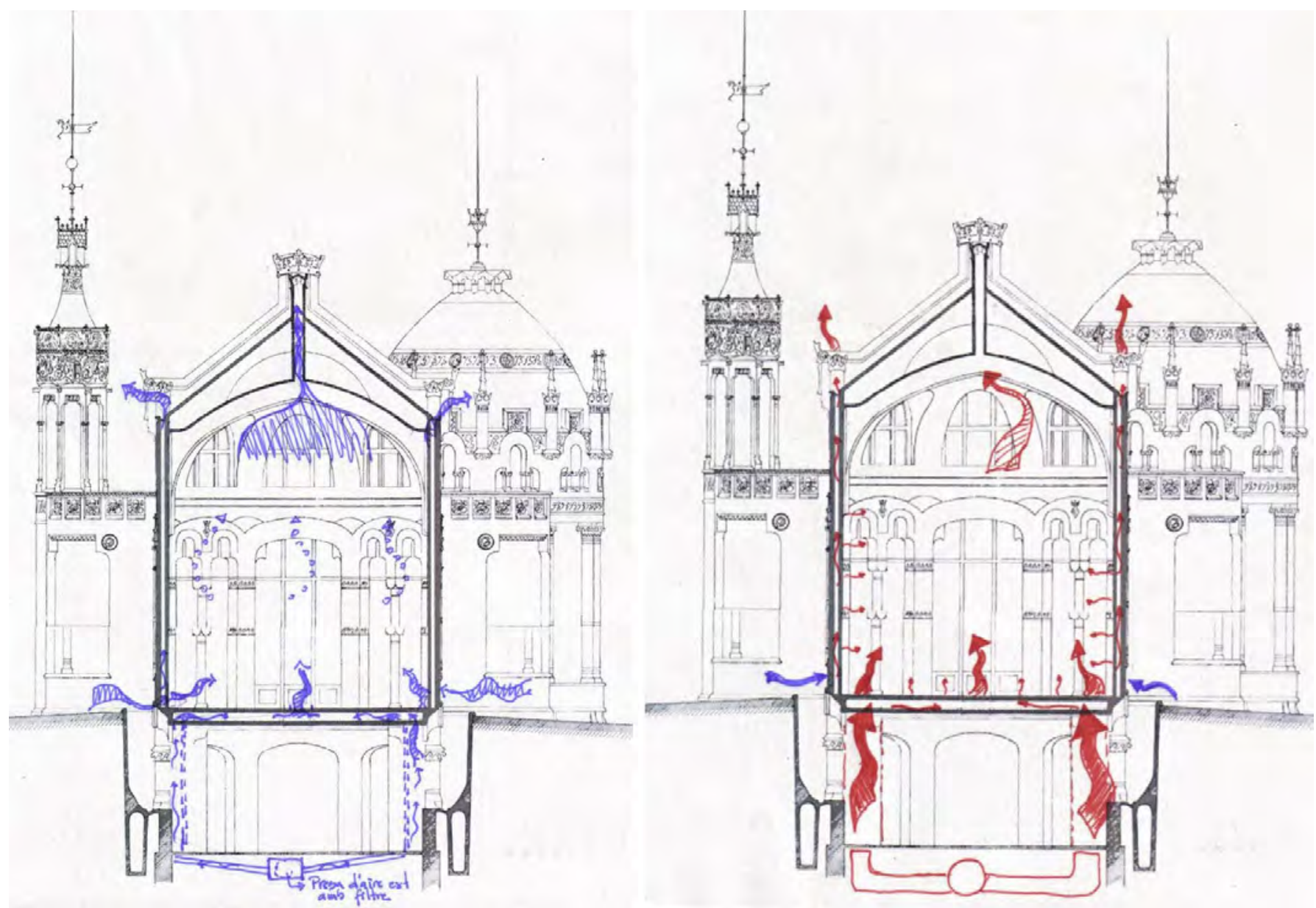

Sobre las secciones de uno de los pabellones del antiguo Hospital de Sant Pau de Domènech i Montaner, los dibujos muestran la posibilidad de reinterpretar el sofisticado sistema original de ventilación natural y de calefacción de los pabellones como soporte de la gestión térmica de sus espacios. Tanto el free-cooling mostrado en la sección izquierda como el sistema de calefacción de la sección de la derecha aprovechan la forma y funcionamiento con que fueron concebidas y construidas las cámaras dispuestas en los cerramientos del edificio, redescubriendo y activando un patrimonio funcional olvidado | planos Fabián López Plazas (Societat Orgànica)

gía considerar restricciones al modo de ocupación de los pabellones, tanto en densidad como en la forma de hacerlo. Naturalmente esa restricción no era de entrada asumible: el sistema energético de Doménech i Montaner no forma parte de su carácter patrimonial, ni es habitual imponer restricciones a los usos y densidades de usos si pueden acogerse mediante soluciones técnicas que puedan instalarse ahí sin alterar los elementos patrimoniales reconocidos. Sería como aceptar que el aseguramiento de una estructura tradicional pasase por limitar las sobrecargas en vez de reforzar sus elementos estructurales solapadamente. $Y$ no se trata de eso ¿verdad?

Aprendimos entonces que quizá los edificios patrimoniales no son meros sujetos de reconversión energética para su relleno con actividades discrecionales, sino que deberían ser contemplados como oportunidades para acoger usos que se puedan acoplar a ellos aprovechando las prestaciones ambientales que ofrecen. Un ejercicio que permite reconocer y usar estrategias que suponen descubrir un nuevo patrimonio fisiológico a nuestra disposición 


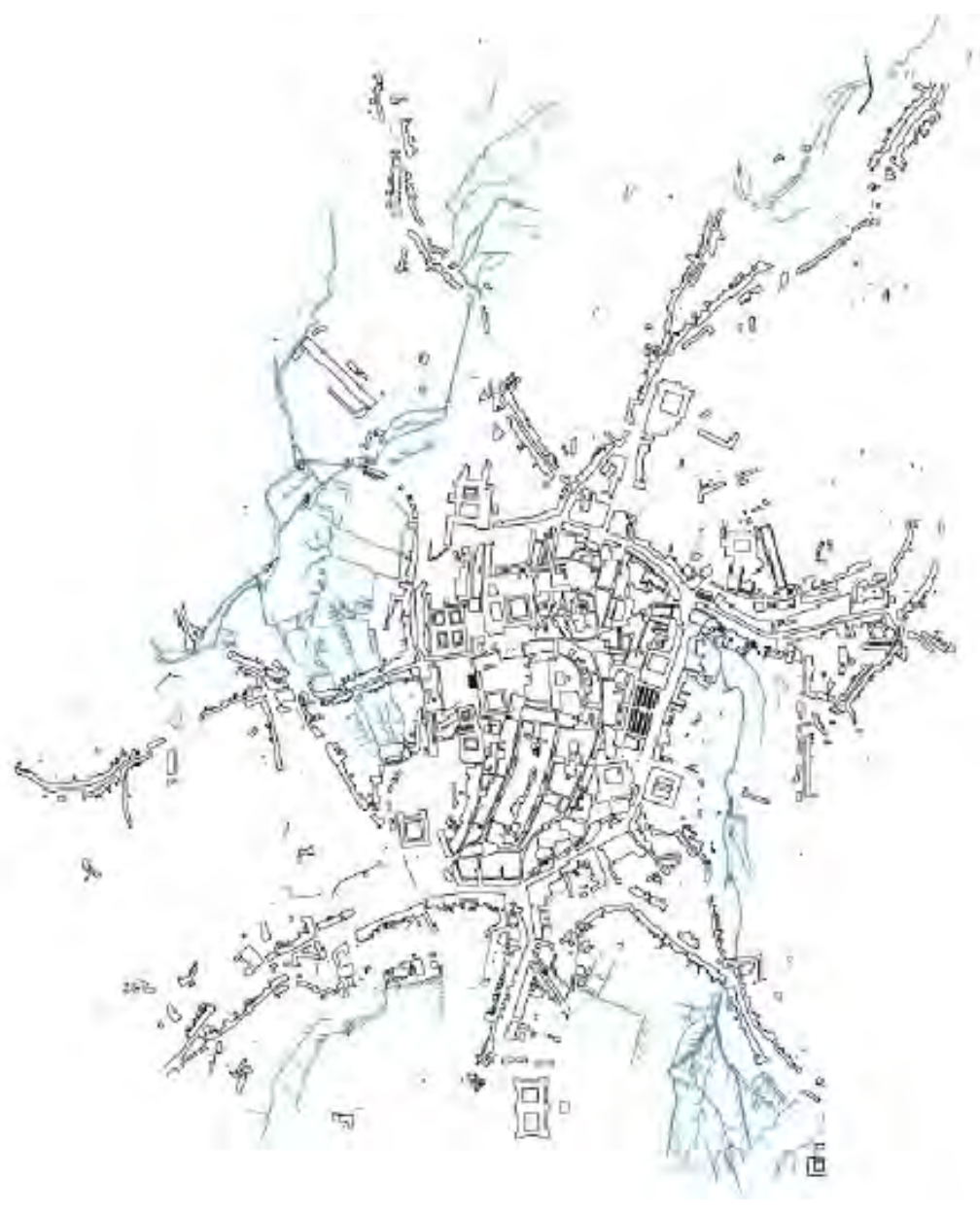

y, por cierto, muy bien adaptado a las exigencias de la sostenibilidad por cuanto generalmente pertenecen a una tradición que aún estaba obligada a usar recursos renovables. Y ahí hay un montón de sorpresas.

Santiago de Compostela, ciudad Patrimonio de la Humanidad, tiene una catedral de piedra que todo el mundo conoce. Pero también tiene una catedral de agua completamente desconocida. Como todas las ciudades pre-industriales, la gestión del agua de escorrentía urbana es una cuestión capital en la que está implicado el trazado de sus calles y numerosos elementos de control de esa escorrentía. Esa escorrentía estaba además ligada a la gestión de la materia orgánica y al reciclado de nutrientes en ciclo corto. En Santiago, la escorrentía de la almendra del núcleo antiguo acababa en dos zonas de huertos -hoy parques urbanos- que son el valle de Belvís y las huertas tras el palacio de Raxoi. Una escorrentía que se articulaba a través de diversos sistemas y elementos que formaban un conjunto funcional de una escala que comprendía toda la ciudad.
La trama de la "almendra" del centro histórico de la ciudad de Santiago de Compostela configura un sistema de gestión del agua de escorrentía que ayudado en algunas ocasiones por ingeniosos canales subterráneos, la conduce hasta dos puntos donde se usará en dos huertas: el valle de Belvís -a oriente y en la cuenca del Sar-y las huertas de Rúa das Hortas, a poniente y en la cuenca del Sarela. La gestión del agua y su relación con la materia orgánica y el abastecimiento urbano es un patrimonio que existía en todas las ciudades tradicionales y que hoy tiene un nuevo valor frente a las exigencias sostenibilistas de un drenaje sostenible y de una gestión adecuada de la materia orgánica | plano Elena Albareda Fernández (Cíclica, Space, Community, Ecology) 
1

El repositorio del Consorcio de Santiago contiene también trabajos del taller del Aula de Renovación Urbana y Rehabilitación de Santiago de Compostela relacionados con la Estrategia Verde.
Naturalmente, una catedral de agua hoy desaparecida porque el alcantarillado moderno se ha ocupado de enterrar bajo el suelo la funcionalidad de ese patrimonio. La Estrategia Verde para Santiago de Compostela (Cuchí et ált. 2010) que propusimos por encargo del Consorcio de la Ciudad de Santiago -y los proyectos que la desarrollaron en el marco del Aula de Renovación Urbana y Rehabilitación ${ }^{1}$ - mostró esa catedral y propuso recuperar su funcionalidad en una nueva visión sostenibilista, reconociendo y reactivando elementos patrimoniales que, siendo considerados como tales, habían sido apartados de su funcionamiento como sistema y, por tanto, descontextualizados.

¡Podríamos hablar de tantas ciudades tradicionales que han visto amputada la funcionalidad de su patrimonio hídrico y la desarticulación de los elementos patrimoniales que lo configuraban! Una lamentable pérdida, más ahora cuando la gestión sostenible de la escorrentía urbana requiere el uso de conceptos y técnicas que ya se habían desarrollado patrimonialmente. Pero hay casos en los que el olvido de esa gestión no permite entender nada del patrimonio que nos ha sido legado.

Cuando Eusebi Güell encarga a Antoni Gaudí la urbanización de un condominio de viviendas en la montaña Pelada, en una de las colinas que festonean el llano de Barcelona, lo hace con la idea de imitar algunos referentes ingleses -de ahí su nombre: Park Güell, con k- y lo que le está pidiendo en realidad, implícitamente, es que transforme una dinámica natural erosiva preponderante en el lugar y que responde a unas fuertes pendientes, un substrato impermeable y las lluvias torrenciales propias del clima mediterráneo, en un lugar vegetado y amable.

Gaudí reconoce el problema y lo aborda usando los instrumentos que tiene el urbanizador -básicamente la infraestructura viaria y la ordenación parcelaria- para instaurar un proceso que transforme esa dinámica de erosión en otra opuesta, controladora de la escorrentía, formadora de suelo, protectora y potenciadora de las plantas, pues la vegetación es al fin el mejor recurso contra la erosión. Su proyecto es pues el diseño de un proceso de fertilización que ha de transformar la dinámica predominante en el lugar. No el diseño de unas formas arquitectónicas concretas. De hecho, todo lo que no está recubierto de trencadís debería quedar cubierto de vegetación, mostrando el triunfo de su estrategia con la desaparición de la construcción que le daba soporte bajo un manto de vegetación.

Lamentablemente eso no se ha entendido, y continuadamente se han ido clausurando y olvidando cada una de las estrategias de Gaudí, con la necesidad -eso sí- de generar nuevas y muy impactantes infraestructuras de gestión de la escorrentía en todo el parque. Y quitando las plantas que, irremediablemente, "crecen sobre la obra del maestro" para poder contemplar 


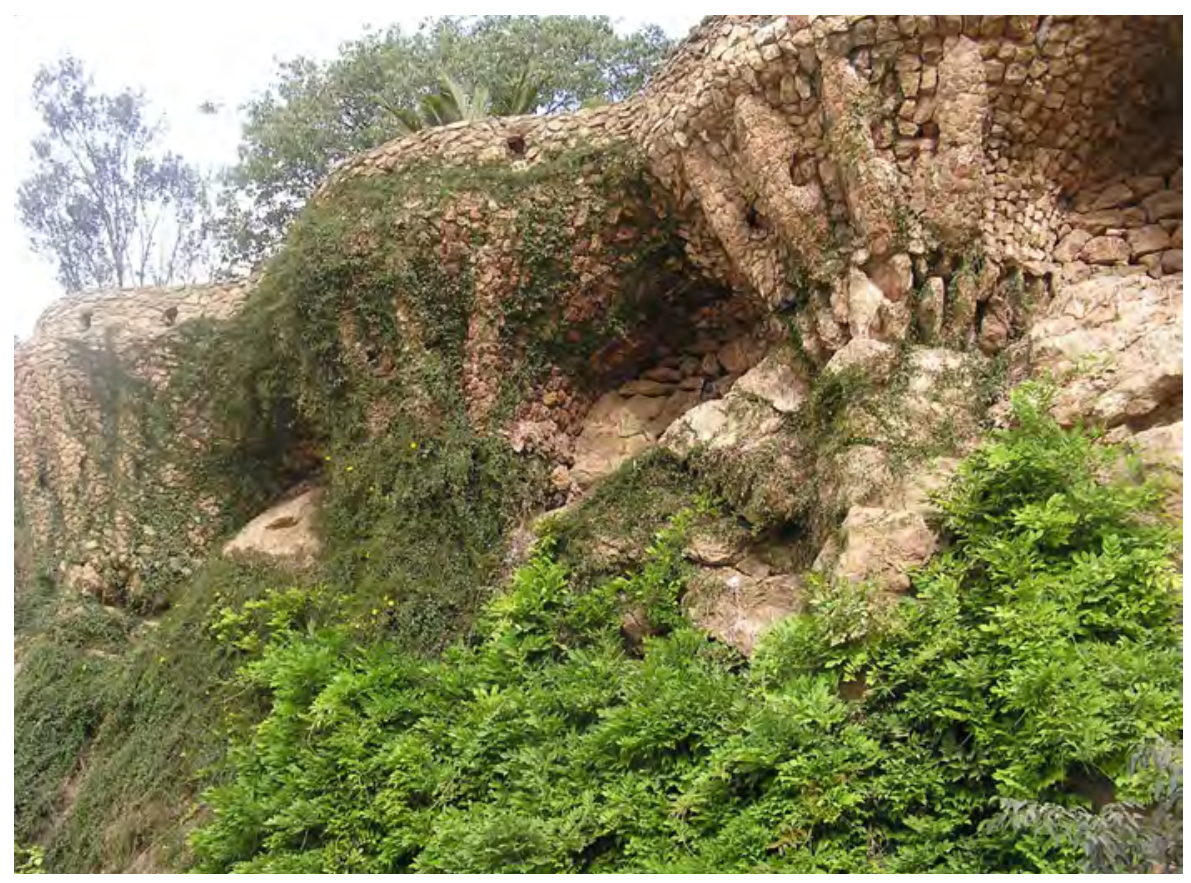

las piedras sobre las que, naturalmente, reposa el valor patrimonial. Tras los estudios que realizamos en el Park Güell (Bastos 2007), algunas veces se deja que vuelva a funcionar por un tiempo el proyecto gaudiniano en algún lugar donde aún no se ha desmontado totalmente el sistema, y las plantas recubren con presteza las piedras que le sirven de esqueleto. Aquí el verdadero elemento patrimonial es un proceso que no ha sido ni reconocido ni protegido. $\mathrm{Y}$ al resto lo han hecho Patrimonio Mundial.

Pero volvamos a la eficiencia energética y a la necesaria descarbonización de nuestra sociedad. Uno de los temas que aún no se ha introducido debidamente es la descarbonización de los materiales de construcción. Por ejemplo, la fabricación del cemento Portland, que es la base del hormigón armado que supone más del $50 \%$ del peso de nuestras construcciones convencionales, supone globalmente el $9 \%$ de las emisiones totales de $\mathrm{CO}_{2}$. Si fuese un país, sería el tercer país más emisor tras la China y los Estados Unidos de América.

De hecho, rara vez se hacen cálculos de las emisiones necesarias para fabricar los materiales con los que se va a llevar a cabo una rehabilitación energética, y poder así calcular cuántos años de los ahorros obtenidos van a ser necesarios para amortizar las emisiones generadas en esa fabricación. Necesitamos materiales descarbonizados o, cuanto menos, con trayectorias creíbles y viables hacia su descarbonización. Y, entretanto, tenemos materiales tradicionales que están ahí, dispuestos y utilizables. Un patrimonio técnico que está ahí, disponible.
La estrategia hídrica del Park Güell nos lo presenta como un proyecto que transforma la dinámica del lugar desde unos procesos donde domina la erosión como factor determinante hacia otro donde la fertilización es la clave en la configuración del espacio. El desconocimiento del proyecto ha hecho que se anulasen muchas de sus estrategias y donde perviven, como muestra esta fotografía en que la vegetación tiende a recubrir las construcciones, las plantas son comúnmente retiradas | foto Alberto Cuchí Burgos 
A finales de los años ochenta del siglo pasado, el estudio en el que trabajaba como arquitecto recibió el encargo de construir el nuevo teatro de Balaguer. Andaba yo por entonces metido en mi tesis doctoral sobre la técnica del tapial y resultó viable construir el nuevo teatro con esa técnica, que aún pervivía precariamente trajinada por unos constructores-agricultores que la mantenían para la construcción de almacenes agrícolas.

La única dificultad para construir el teatro con esa técnica fueron las normativas de construcción, diseñadas para unos materiales industriales y que son la única barrera cierta para el uso de los materiales tradicionales. De hecho, el patrimonio local construido con tapiales nos sirvió de recurso técnico al justificarse el análisis estructural del nuevo edificio sobre el estudio estructural sistemático del patrimonio existente. Eso exactamente es el patrimonio construido: un recurso técnico hoy ineludible.

También lo ha entendido el Instituto Balear de Vivienda (IBAVI), la entidad de vivienda pública de las Baleares, que ha recuperado materiales y técnicas tradicionales para construir vivienda de promoción pública, cumpliendo los estándares normativos y consiguiendo una calidad arquitectónica que hizo merecer a una de sus promociones el premio FAD de Arquitectura en 2018. Hoy continúan en esa línea, que reclama un giro radical a las normativas técnicas de edificación para que reconozcan la validez del patrimonio técnico que supone nuestro patrimonio construido pero que, sobre todo, reclama una nueva consideración del patrimonio, de en qué radica, de cómo debe ser recogido y cómo y por qué debe ser protegido.

La utilización de la técnica tradicional en el teatro de Balaguer (Lleida) fue posible gracias a la utilización no solo de la técnica en su expresión clásica, sino esencialmente gracias a que los edificios del patrimonio existentes -aunque no calificados como patrimoniales- permitieron configurar el marco técnico en el que justificar desde calidades de materiales y soluciones constructivas, hasta asegurar los coeficientes de seguridad en el cálculo estructural. El patrimonio existente es un recurso técnico de incomparable valor para poder usar esas técnicas | foto Alberto Cuchí Burgos

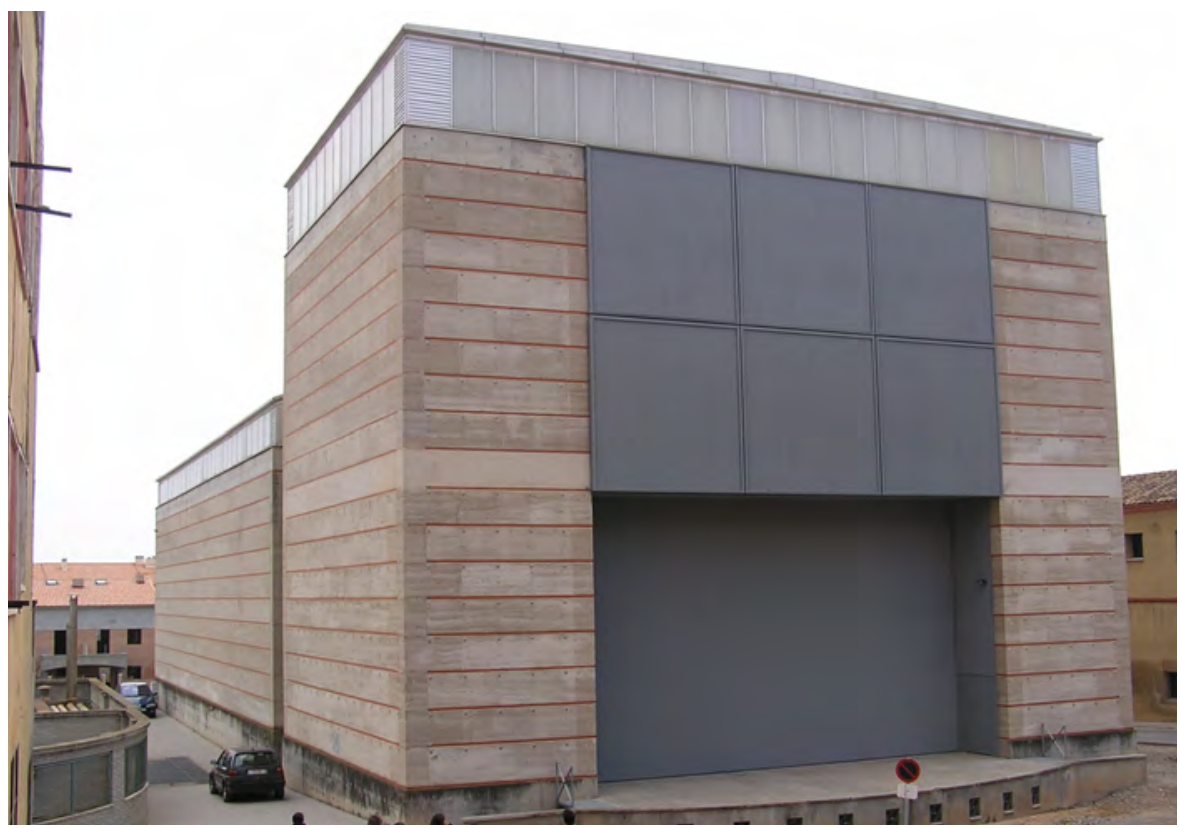




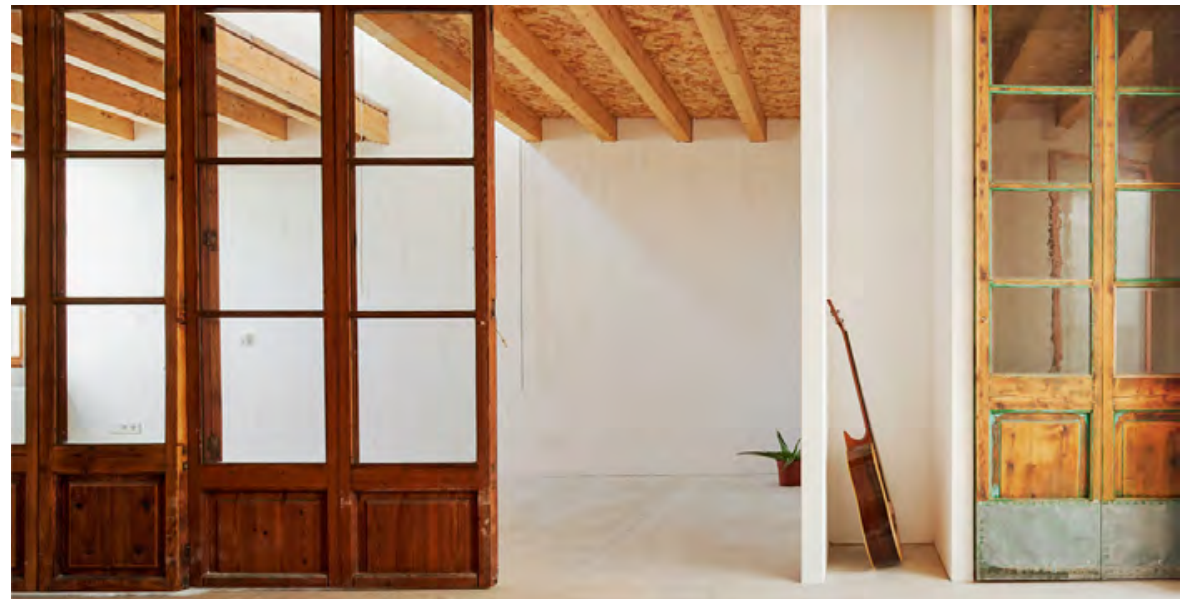

Técnicas tradicionales que tienen, además, la virtud de reactivar el territorio, de recuperar su capacidad productiva. Una recuperación que toma cada vez mayor relevancia como estrategia global de sostenibilidad una vez nos hemos dado cuenta de que nuestra sociedad industrial extrae sus recursos de lugares lejanos en el tiempo y en el espacio y de que ahí radica buena parte de su insostenibilidad. $Y$ tenemos patrimonios ejemplares que nos muestran el modelo a seguir.

Desde que el arquitecto alemán Bruno Taut habló de ellos, los templos de Ise han sido un referente de la arquitectura tradicional japonesa. Debido a la necesidad de mantener la pureza de los templos dedicados a las deidades sintoístas a las que acoge para acordarlos a las exigencias de esas divinidades, en vez de buscar materiales perdurables, que soporten el envejecimiento, los templos se reconstruyen cada 20 años con madera de cedro japonés y paja de arroz, reconstruyendo exactamente el templo existente (Vegas y Mileto 2003). Un patrimonio de más de un milenio que, curiosamente, no conserva su materialidad. ¿Qué conserva entonces?

Conserva los bosques que dan la madera, los campos que se cultivan una y otra vez para tener la paja disponible en la nueva erección del templo, las técnicas con que se construyen -y cualquier pequeña variación tecnológica sufre un análisis para asegurarse que el templo será el mismo a pesar de usar una nueva herramienta, por ejemplo- $y$, sobre todo, la voluntad social de reconstruirlos, de volver a hacerlos y mantener los recursos que permiten reconstruirlos. De mantener el territorio y la cultura que lo hacen posible.

De hecho, el responsable de la reconstrucción de los templos de Ise es el propio emperador del Japón, que demuestra de ese modo que el Japón que dejará a sus herederos es el mismo Japón que recibió de sus ancestros. Un patrimonio relevante, muy alejado de nuestro patrimonio material donde la
La recuperación de los materiales y sistemas técnicos tradicionales es posible incluso en contextos de costes reducidos y exigencias normativas rigurosas. El proyecto Reusing Posidonia del Instituto Balear de Vivienda (IBAVI) explica uno de los casos iniciales de esta experiencia que, además de conseguir un premio FAD de Arquitectura, mostró cómo existe un patrimonio en los sistemas técnicos tradicionales que no solo es un referente utilizable sino que nos conecta con la gestión del territorio. Recuperar el territorio es una de las claves de la sostenibilidad | foto IBAVI 
Los templos sintoístas de Ise nos muestran un patrimonio diferente, un patrimonio que no puede sustentarse sobre unos elementos materiales en cuya conservación radique la calidad patrimonial sino un patrimonio que protege aquello -recursos materiales, técnicas, sociedad- que justamente permite su reproducibilidad a lo largo del tiempo. Una conservación en la que el elemento material no es sino la demostración de que lo realmente patrimonial se conserva. Un entendimiento del patrimonio que sirve de ejemplo al tipo de patrimonio que nos exige una transformación sostenibilista de nuestra sociedad | foto Hidetsugu Tonomura

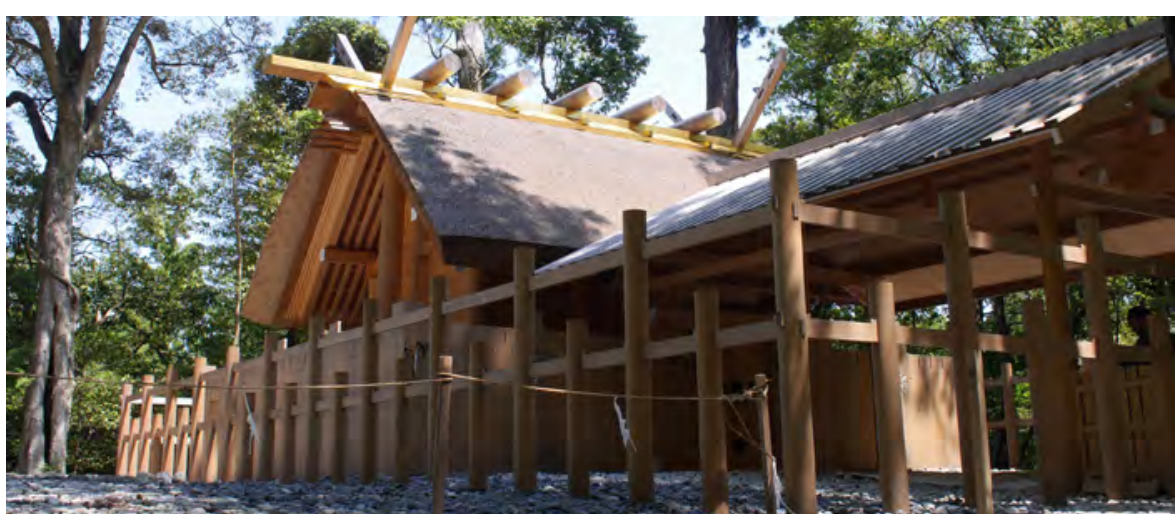

conservación física es primordial frente a un patrimonio donde lo importante es la capacidad de reproducir exnovo esa materialidad.

En conclusión, un futuro sostenible requiere de un pasado distinto al que ha venido sosteniendo el futuro hasta hoy. Requiere un patrimonio diferente, un patrimonio que le permita construir relatos que legitimen un futuro solvente frente a los retos ambientales que nos desafían. Un nuevo patrimonio que va a ser más fisiológico que anatómico; tan identitario como, y de nuevo, funcional; de sistemas más que de elementos; de autenticidad basada en su reproductibilidad y su pervivencia en un entorno que lo asegure y al que asegure su futuro, más que de conservación de su materialidad; de su relación a escalas diversas con el territorio más que de singularidad respecto a su entorno.

Ese nuevo patrimonio hay que descubrirlo. Hay que releer con nuevos ojos ese pasado que se ofrece ante nuestros sentidos, con una nueva mirada. Hay que construir ese patrimonio reinterpretando el patrimonio actual, y su adecuación a las nuevas exigencias -como la mejora de la eficiencia energética, por ejemplo- no debe ser sino una herramienta para esa reinterpretación, una oportunidad para hacerlo. Pero considerando que eso solo es un primer paso y que debe darse en la dirección adecuada.

Pero también hay que construir el nuevo patrimonio con cosas que han sido olvidadas por el modelo de patrimonialización actual. Hay que rescatar pecios del naufragio del pasado tradicional que andan por ahí, perdidos, desconectados, olvidados, sin patrimonializar. Hay que encontrarlos, y para ello es necesario salir a su encuentro, buscarlos; hay que reconectarlos entre ellos y reconectarlos al valor funcional que los liga y da sentido, como al territorio; hay que recordarlos, o sea volver a ponerlos en nuestros corazones, en nuestros objetivos e intereses. $Y$ hay que patrimonializarlos adecuadamente porque necesitamos construir un futuro diferente y porque, como decía Braudel en la cita que encabeza este artículo, "haber sido es condición para ser". 


\section{BIBLIOGRAFÍA}

- Bastos, C. (2007) Park Güell: arquitectura conformada por el agua. Gestión hídrica para la reforestación de la Montaña Pelada, en Barcelona. Tesis doctoral inédita. Universitat Politècnica de Catalunya. Disponible en: https://www.tesisenred.net/handle/10803/672129\#page $=1$ [Consulta: 22/07/2021]

- Choay, F. (2007) Alegoría del patrimonio. 3. ${ }^{a}$ ed. Barcelona: Editorial Gustavo Gili

- Cuchí, A., Albareda E., Teira, R., Castro, E., Alba, D. y Rigau, N. (2010) Estudio de las bases y el alcance de una Estrategia Verde para Santiago de Compostela. Santiago de Compostela: Consorcio de la ciudad de Santiago de Compostela, Universitat Politècnica de Catalunya. Literatura gris. Disponible en: https://transparencia. santiagodecompostela.gal/media/documentos/2010 Estrategia_Verde_de_Santiago_de_Compostela_ Cuchi_Burgōos.pdf [C̄onsulta: 22/07/2021]

- IBAVI [Instituto Balear de Vivienda] (2021) Life reusing Posidonia. Disponible en: http://reusingposidonia.com/ [Consulta: 22/07/2021]

- Rosselló i Nicolau, M. (2009) La casa Escofet: mosaics per als interiors 1900. Barcelona: Escofet. Disponible en: http://hdl.handle.net/2117/6048 [Consulta: 22/07/2021]

- Vegas, F. y Mileto, C. (2003) El espacio, el silencio y la sugestión del pasado. El santuario de Ise en Japón. Loggia, Arquitectura \& Restauración, n. ${ }^{0}$ 14-15. Disponible en: https://doi.org/10.4995/loggia.2003.3555 [Consulta: 22/07/ 2021] 


\section{La agricultura tradicional como legado agroecológico para la humanidad}

Miguel A. Altieri | Dpto. of Environmental Science, Policy, \& Management, University of California (Berkeley)

URL de la contribución <www.iaph.es/revistaph/index.php/revistaph/article/view/4960>

\section{RESUMEN}

Los sistemas agrícolas complejos, diversos y localmente adaptados desarrollados por milenios por agricultores a lo largo del mundo constituyen un patrimonio agrícola que abarca unos 10 millones de hectáreas, las cuales además de proveer de alimentos a la humanidad proveen una combinación vital de servicios sociales, culturales, ecológicos y económicos.

Estos sistemas han contribuido no solamente con extraordinarios paisajes de belleza estética, sino que también proveen alimentos a una porción significativa de la población, mientras mantienen la biodiversidad agrícola base para manejar agroecosistemas resilientes y constituyen un patrimonio cultural valioso de importancia mundial.

Muchos de los nuevos modelos de agricultura que la humanidad urgentemente necesita en una época de cambio global, para transicionar hacia formas de agricultura que sean más ecológicas, biodiversas, locales, sostenibles y socialmente justas deberán estar arraigadas en la racionalidad ecológica de la agricultura tradicional que representa ejemplos establecidos de formas acertadas de agricultura local.

\section{Palabras clave}

Agricultura tradicional | Agroecología | Patrimonio cultural | Servicios ecológicos | 


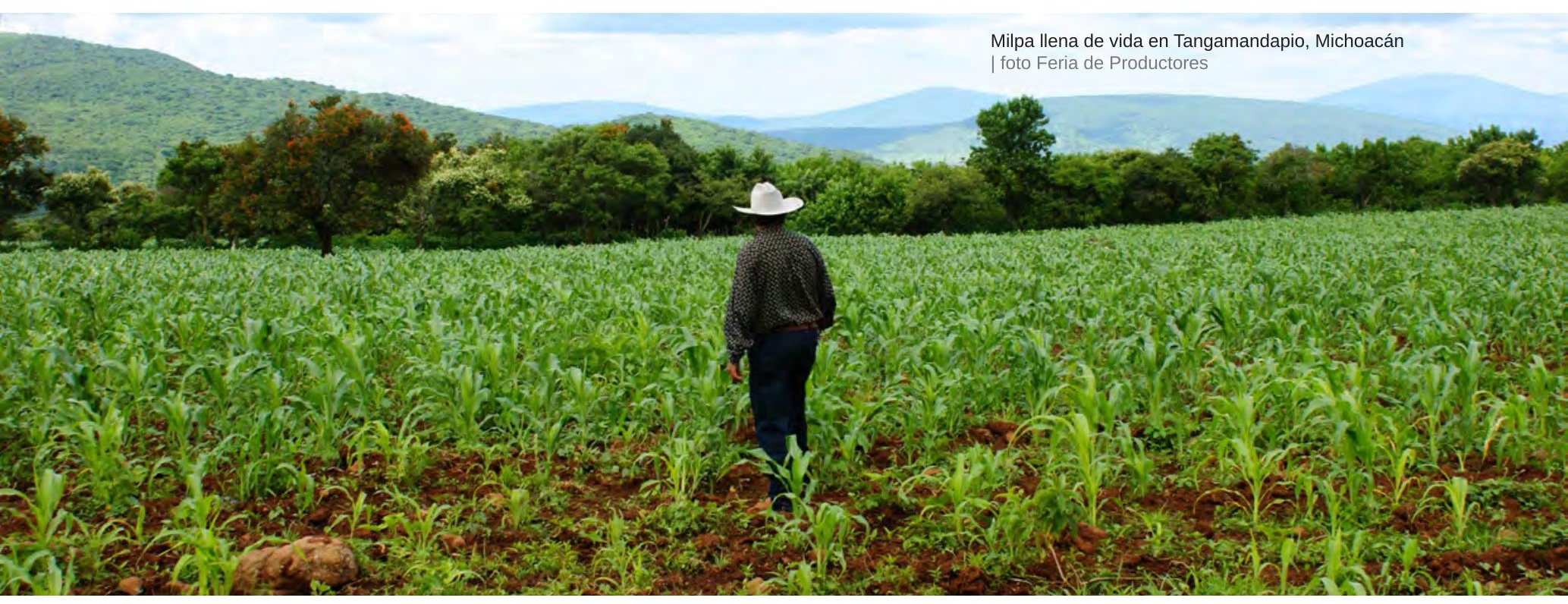

\section{Traditional agriculture: an agroecological legacy for humanity}

\section{ABSTRACT}

Complex, diverse and locally adapted agricultural systems developed for millennia by farmers throughout the world constitute an agricultural heritage that covers some 10 million hectares, which in addition to providing food to humanity provide a vital combination of social and cultural, ecological and economic services.

These systems have contributed not only with extraordinary landscapes of aesthetic beauty, but also provide food to a significant portion of the population, while maintaining the agricultural biodiversity key to manage resilient agroecosystems and constitute a valuable cultural heritage of global importance.

Many of the new models of agriculture that humanity urgently needs in a time of global change, to transition towards forms of agriculture that are more ecological, biodiverse, local, sustainable and socially just will have to be rooted in the ecological rationale of traditional agriculture that represents established examples of successful forms of local agriculture.

\section{Key words}

Traditional agriculture | Agroecology | Agricultural Heritage | Ecosystem services |

Cómo citar: Altieri, M.A. (2021) La agricultura tradicional como legado agroecológico para la humanidad. Revista PH, n. ${ }^{\circ} 104,2021$, pp. 180-197 <www.iaph. es/revistaph/index.php/revistaph/article/view/4960> DOI 10.33349/2021.104.4960

Enviado: 02/06/2021 | Aceptado: 19/07/2021 | Publicado: 01/10/2021 


\section{INTRODUCCIÓN}

Durante milenios, comunidades de agricultores tradicionales han desarrollado sistemas agrícolas complejos, diversos y localmente adaptados. Estos sistemas han sido manejados con combinaciones ingeniosas de técnicas y prácticas de eficacia comprobada, que usualmente han conducido a la seguridad alimentaria de las comunidades rurales y a la conservación de los recursos naturales y la biodiversidad. Este conjunto de agroecosistemas dispersos a lo largo del mundo constituyen un patrimonio agrícola que abarca unos 10 millones de hectáreas, los cuales además de proveer de alimentos a la humanidad proveen una combinación vital de servicios sociales, culturales, ecológicos y económicos. Estos sistemas han contribuido no solamente con extraordinarios paisajes de belleza estética, sino también en el mantenimiento de la biodiversidad agrícola, agroecosistemas resilientes y un patrimonio cultural valioso de importancia mundial. Por encima de todo, estos sistemas proveen múltiples bienes y servicios, seguridad alimentaria y los medios de subsistencia para millones de pobres y pequeños campesinos (Koohafkan y Altieri 2017).

Los sistemas agrícolas tradicionales se han ido conformando durante siglos, a partir de una co-evolución cultural y biológica y representan la experiencia acumulada de los campesinos en su interacción con el medioambiente, sin contar ni con insumos externos, ni con capitales, ni con el denominado saber científico. Haciendo uso de una autonomía ingeniosa, de un saber vivencial y de unos recursos cercanos, los campesinos han creado sistemas agrícolas sobre la base de una diversidad de cultivos, de árboles y de animales en el espacio y en el tiempo, lo que les ha permitido maximizar la seguridad de las cosechas en medios marginales y variables y con un espacio y unos recursos limitados (Wilken 1987). Estos sistemas se han desarrollado partiendo de un conocimiento basado no solo en la observación, sino también en el aprendizaje experimental. Este enfoque es obvio en la selección y obtención de variedades de semillas locales y en la experimentación con nuevos métodos de cultivo para superar determinados obstáculos bióticos y abióticos. La mayoría de los agricultores tradicionales poseen un conocimiento íntimo de sus alrededores, especialmente dentro de un radio geográfico y cultural próximo (DeWalt 1994).

La permanencia de millones de hectáreas agrícolas bajo el antiguo manejo tradicional en la forma de campos elevados, terrazas, policultivos, sistemas agroforestales, etc., documenta una estrategia agrícola indígena exitosa y constituye un tributo a la creatividad e ingenio de los agricultores tradicionales. Este microcosmos de agricultura tradicional ofrece modelos prometedores ya que promueve la biodiversidad, prospera sin agroquímicos y sostiene producciones todo el año (Denevan 1995). De seguro, muchos de los nuevos modelos de agricultura que la humanidad necesita para transicionar 


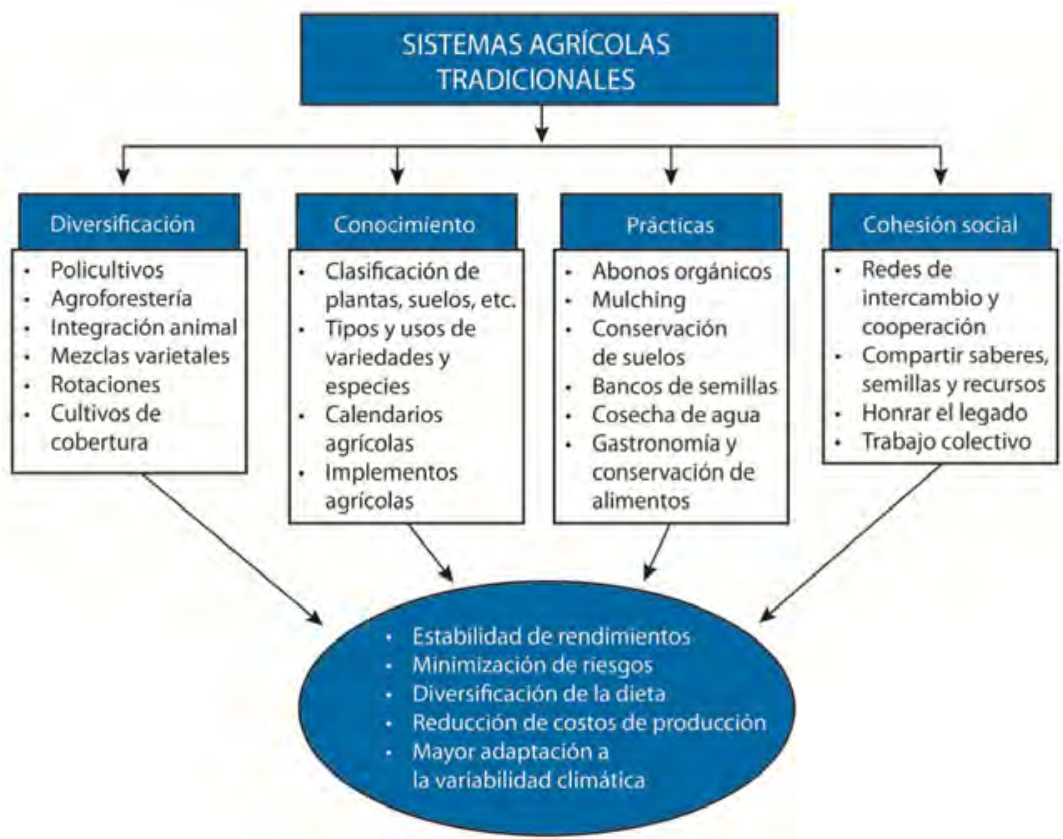

hacia formas de agricultura que sean más ecológicas, biodiversas, locales, sostenibles y socialmente justas deberán estar arraigadas en la racionalidad ecológica de la agricultura tradicional que representa ejemplos establecidos de formas acertadas de agricultura local. Tales sistemas han alimentado la mayor parte del mundo durante siglos y siguen alimentando a millones de personas en muchas partes del planeta (Altieri 2004).

A pesar de la inmensa variedad de sistemas agrícolas tradicionales, y de sus particularidades históricas y geográficas, la mayoría de los agroecosistemas tradicionales comparte, con gran parecido, los siguientes rasgos y características (Koohafkan y Altieri 2010):

$>$ Niveles muy altos de biodiversidad. Esta desempeña un papel en la regulación del funcionamiento del ecosistema y en la obtención de servicios con relevancia local y global.

> Sistemas ingeniosos de conservación de gestión de recursos edáficos e hídricos a nivel paisajístico, que mejoran la eficiencia de los agro-ecosistemas.

> Sistemas agrícolas diversificados que ofrecen una gran variedad de productos para la soberanía alimentaria local y nacional y la seguridad de los medios de vida.
Características socio-ecológicas de los sistemas agrícolas tradicionales que confieren resiliencia estabilidad productiva y soberanía alimentaria 
Sistema agroforestal rustico de café en Antioquia (Colombia) | foto M. A. Altieri

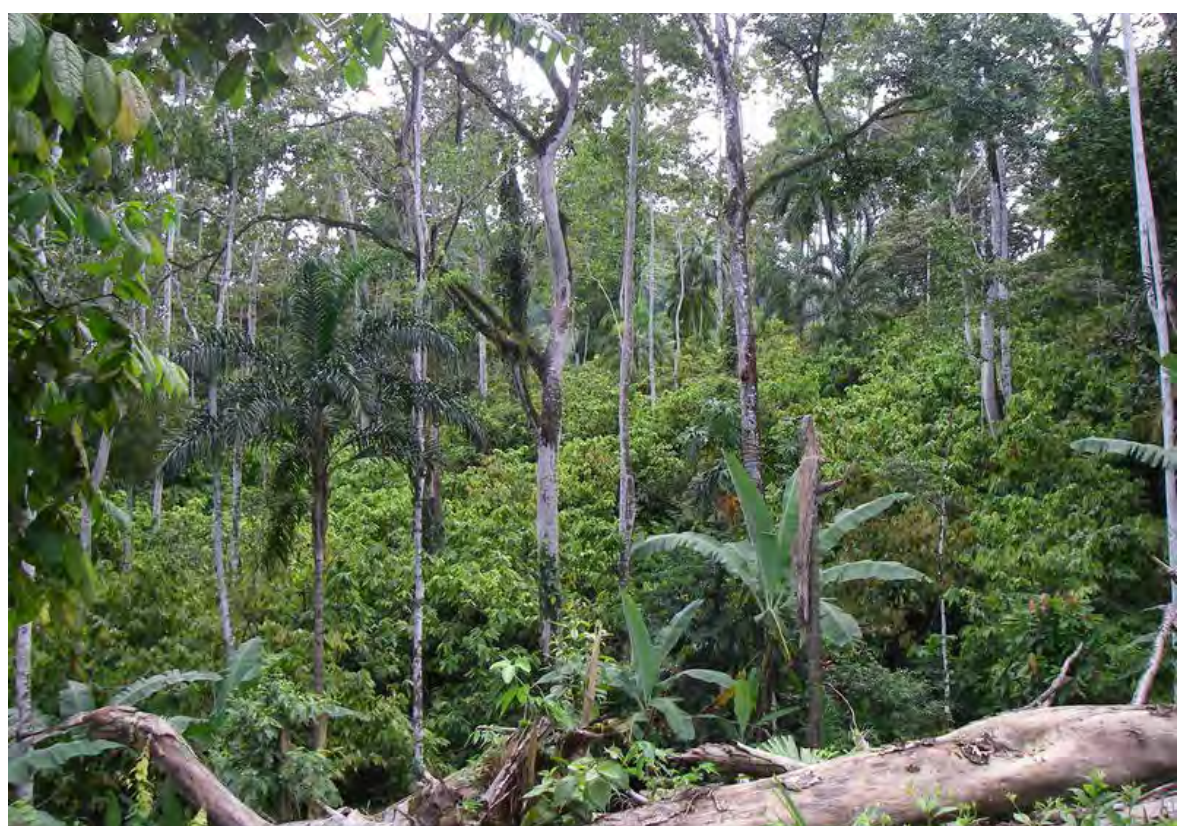

> Agroecosistemas que poseen una resistencia y una robustez para minimizar los riesgos ante la variabilidad y la estocasticidad.

$>$ Agroecosistemas alimentados por sistemas de conocimiento tradicionales con muchas innovaciones y tecnologías campesinas.

$>$ Valores culturales fuertes y formas de organización social colectivas, como instituciones consuetudinarias para la gestión agroecológica, acuerdos normativos para el acceso a los recursos y el reparto de beneficios, sistemas de valores, rituales, etc.

Dado que estos sistemas han resultado en el mantenimiento y la adaptación de paisajes excepcionales que incluye sistemas de conocimiento y biodiversidad agrícola de importancia mundial, en 2002, la FAO inició una iniciativa internacional para la gestión adaptativa de los sistemas de patrimonio agrícola de importancia mundial: Sistemas Importantes del Patrimonio Agrícola Mundial. SIPAM tiene como objetivo sentar las bases para el reconocimiento internacional, la conservación dinámica y el manejo sostenible de sistemas tradicionales, que incluyen el conocimiento etnoecológico que permite conservar, manejar y utilizar los agropaisajes y su biodiversidad agrícola. Comprender los principios y mecanismos que gobiernan la resiliencia y sostenibilidad de los SIPAM podría proveer las bases para el diseño de nuevos sistemas agrícolas capaces de producir alimentos en forma sostenible y amigable con la naturaleza (Koohafkan y Dela Cruz 2011). 


\section{LA AGRICULTURA TRADICIONAL Y CAMPESINA: EXTENSIÓN Y SIGNIFICANCIA}

Informes producidos por organizaciones como ETC Group y Grain estiman que unos 1500 millones de campesinos cultivan la tierra en alrededor de 380 millones de pequeñas fincas (menores de dos hectáreas de tamaño medio), En América Latina, las unidades de producción campesinas alcanzaron cerca de 16 millones a finales de los años ochenta, cifra que supone la ocupación de cerca de 60,5 millones de hectáreas, el 34,5\% del total la tierra cultivada. La población campesina incluye a 75 millones de personas que representan casi dos tercios de la población rural total de América Latina (Ortega 1986). Se estima que estas cifras se mantienen en la actualidad. El tamaño medio de finca de estas unidades se acerca a 1,8 hectáreas. Sin embargo, la contribución de la agricultura campesina al suministro de alimentos general en la región resulta significativa. En los años ochenta, aproximadamente el $41 \%$ de la producción agrícola destinada para consumo doméstico provino de la agricultura campesina, la cual produjo a nivel regional el $51 \%$ del maíz, el $77 \%$ de los frijoles y el $61 \%$ de las papas. Solo en Brasil, hay cerca de 4,8 millones de familias de agricultores familiares (alrededor del $85 \%$ del total de agricultores) que ocupan el $30 \%$ del total de la tierra agrícola del país. Dichas familias controlan cerca del $33 \%$ del área sembrada en maíz, el $61 \%$ en frijoles y el $64 \%$ de aquellas tierras cultivadas en yuca, lo que equivale al $84 \%$ de la yuca total y el $67 \%$ de todas las frijoles para el consumo nacional. En Ecuador, el sector campesino ocupa más del $50 \%$ del área dedicada a los cultivos alimenticios tales como maíz, frijoles, cebada y papa. En México, los campesinos ocupan, por lo menos, el $70 \%$ del área destinada al maíz y el 60 \% del área en frijoles. En Cuba, las campesinas y campesinos producen casi dos tercios de los alimentos del país en apenas un tercio de las tierras arables (Altieri y Toledo 2011).

Además del sector campesino y de los agricultores familiares, hay cerca de 50 millones de indigenas que pertenecen a unos 700 grupos étnicos, quienes viven y utilizan las regiones tropicales húmedas de la región. Cerca de 2 millones de ellos viven en el Amazonas y en México meridional. En México, la mitad de las zonas tropicales húmedas se utilizan por las comunidades indígenas y los "ejidos", en los cuales se desarrollan sistemas integrados de agricultura-silvicultura con la producción dirigida hacia la subsistencia y mercados a nivel local y regional (Toledo et ál. 1985).

África tiene aproximadamente 33 millones de fincas pequeñas, cantidad que representa el $80 \%$ de todas las fincas en la región. La mayoría de los agricultores africanos (muchos de ellos, mujeres) tienen el perfil de pequeños productores que controlan dos tercios de todas las fincas con área inferior a 2 hectáreas y el $90 \%$ de fincas menores a 10 hectáreas. La mayoría de los pequeños agricultores practican una agricultura de bajos-insumos, 
basada sobre todo en el uso de recursos locales, prácticamente sin utilización o poco uso de fertilizantes y semillas mejoradas. Esta agricultura de bajos-insumos produce la mayoría del grano; casi todas las raíces, cosechas de tubérculos y plátanos y la mayoría de legumbres (Richards 1985). Sin embargo, esta situación ha cambiado en las últimas dos décadas en tanto que la producción de alimento per cápita ha disminuido en África. Alguna vez autosuficientes en cereales, África ahora tiene que importar millones de toneladas para llenar el vacío. A pesar del incremento en las importaciones, los pequeños agricultores siguen produciendo la mayor parte del alimento de África (Richards 1985).

En Asia, solamente China posee casi la mitad de las pequeñas fincas de la región (193 millones de hectáreas), seguidas por la India con $23 \%$ y, detrás, Indonesia, Bangladesh y Vietnam. La mayoría de los más de 200 millones de agricultores que vive en Asia posee fincas con menos de 2 hectáreas de arroz. Tan solo en China hay probablemente 75 millones de agricultores de arroz, quienes aún practican métodos similares a los utilizados hace más de mil años. La mayoría del arroz producido por los pequeños agricultores asiáticos se produce en condiciones de pendiente, en terrazas inundadas o en laderas dependientes de lluvias (Hanks 1992).

Varios estudios han demostrado que los policultivos de arroz, por ejemplo arroz (Oryza sativa) con azolla (Azolla sp., ej. Azolla pinnata) o el arroz con peces (Oreochromis niloticus y Cyprinus carpio) y el arroz con patos (Anas platyrhynchos javanicus), reducen los niveles de uso de agroquímicos mientras se obtienen rendimientos de arroz similares a los de los sistemas de monocultivo convencionales. La presencia del helecho/alga Azolla en la superficie del agua de los campos de arroz pueden reducir la biomasa de malezas entre un $10 \%$ y un $22 \%$ y los peces pueden suprimir las malezas entre un $23 \%$ y un $63 \%$. La integración de patos puede reducir la biomasa de malezas entre el $27 \%$ y el $91 \%$ (Khumairoh, Groot y Lantinga 2012). Además de la supresión de malezas, los peces también pueden regular plagas como las chicharritas (cicadélidos) y enfermedades fúngicas como el tizón de la vaina (causado por Rhizoctonia solani). Los patos tienen una gama aún mayor de especies de presas que los peces, ya que también se alimentan de barrenadores del tallo, chicharritas y otros artrópodos foliares (Xie et ál. 2011).

\section{SISTEMAS AGROBIODIVERSOS}

Los sistemas agrícolas tradicionales sobresalen, entre otros aspectos, por su grado de diversidad vegetal, en forma de policultivos y sistemas agroforestales. Ambos sistemas implican una diversificación que permite mezclar cultivos anuales y arbóreos en distintos esquemas espaciales y temporales. 
Suelen mezclar una leguminosa con un cereal, lo que trae una mayor productividad de la que se obtendría de cada especie por separado, porque las leguminosas fijan nitrógeno, y porque las asociaciones usan los recursos de manera más eficiente $y$, en general, exhiben mayor resistencia a las plagas (Vandermeer 1989).

En los policultivos, las especies crecen muy juntas, permitiendo interacciones beneficiosas y ofrecer una serie de servicios ecosistémicos a los agricultores. La mayor riqueza de especies mejora el contenido en materia orgánica de los suelos, su estructura, su capacidad de retención hídrica y la cubierta, por lo que los suelos se protegen de la erosión y, a la vez, se eliminan malezas, condiciones todas ellas favorables para asegurar la producción. La diversidad de plantas cultivadas también favorece la presencia de artrópodos benéficos y la actividad microbiológica, necesarias para mejorar el reciclaje de nutrientes, la fertilidad de los suelos y la regulación de plagas. Varios estudios demuestran que estos sistemas diversificados exhiben resiliencia frente a los desastres climáticos ya que la presencia de mayor biodiversidad en los campos cultivados aumenta la capacidad adaptativa (Altieri y Nicholls 2004).

Los agricultores de Mesoamérica continúan cultivando maíz en variantes del sistema de milpa -policultivo- en múltiples agroecologías, desde zonas áridas y semiáridas, hasta las tierras altas templadas y las tierras bajas tropicales. Además de intercalar con frijol común y calabaza, el maíz puede cultivarse con habas (Vicia faba), pimientos (Capsicum spp.), Tomate (Solanum lycopersicum), papa (Solanum tuberosum) y amaranto (Amaranthus spp.) e incluso con especies silvestres (quelites) utilizadas como alimento o con fines medicinales (Francis 1986).

En los sistemas agroforestales se intercalan cultivos anuales y perennes o perennes con ganado, a veces con más de cien especies de plantas anuales y perennes y varias especies animales por parcela. Además de proporcionar productos de utilidad (materiales de construcción, leña, herramientas, medicamentos, pienso para el ganado y alimentos), los árboles suelen minimizar la pérdida de nutrientes por lixiviación y erosión, añaden materia orgánica y restauran nutrientes clave, bombeándolos desde las capas inferiores del subsuelo. Los árboles también crean condiciones micro-climáticas que protegen los cultivos y los suelos contra vicisitudes climáticas como tormentas o sequías, que aumentan con el cambio climático (Jose 2009).

En Centroamérica los Sistemas Agroforestales (SAF) de cacao albergan una biodiversidad muy significativa, que incluye 55 familias, 132 géneros y 185 especies de plantas, así como un numero substancial de especies de pájaros (190 especies), murciélagos (36) y varios mamíferos e innumerables invertebrados (Rice y Greenberg 2000). La biodiversidad aumenta en los

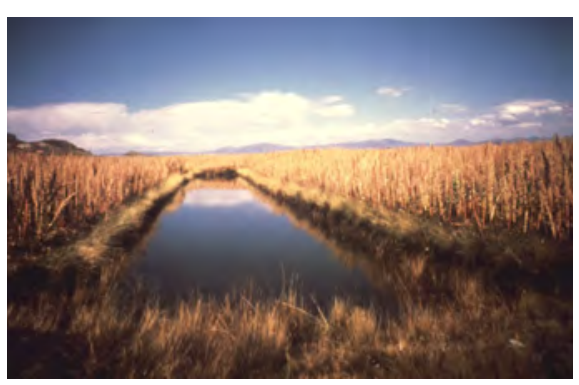

Los waru-warus en el altiplano peruano permiten la producción de cultivos a 3500 msnv en medio de heladas | foto M. C. Altieri 

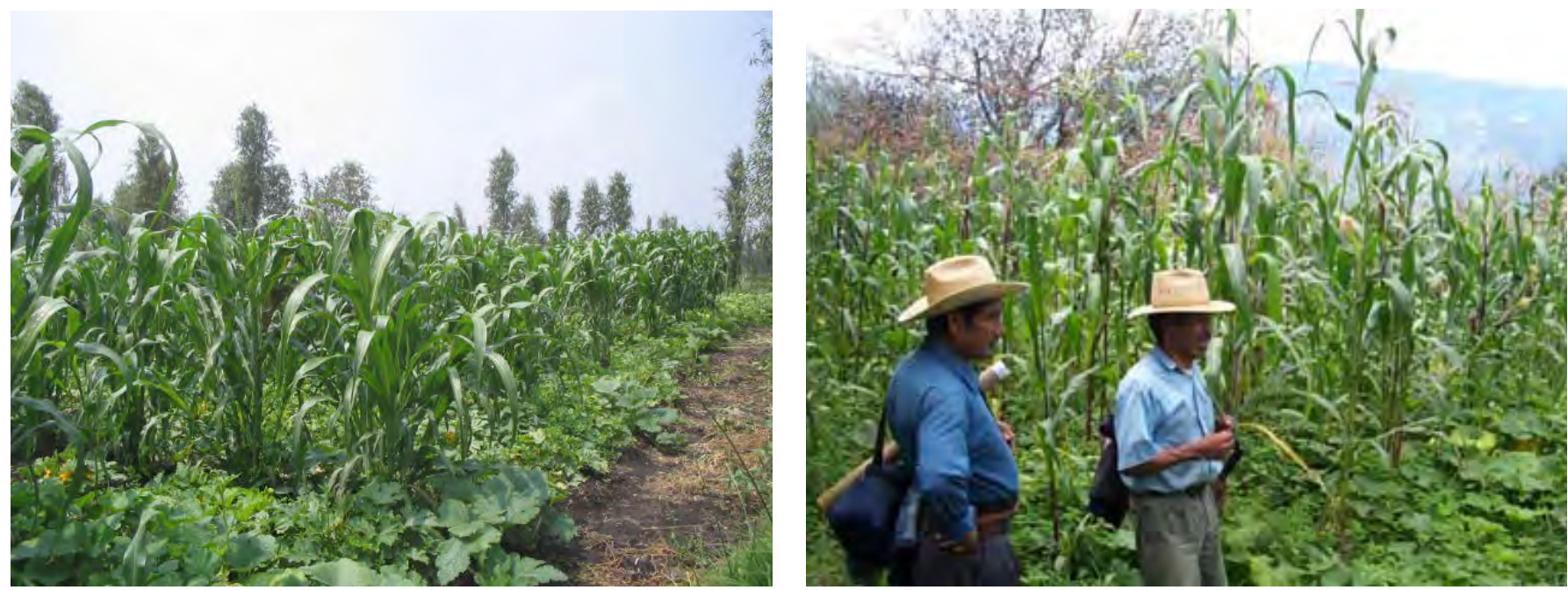

La Milpa, policultivo tradicional mesoamericano (Mexico) | fotos M. A. Altieri (izquierda) y Cesartilan (derecha)

sistemas rústicos multiestrato con un 55-60 \% de sombra y disminuye en los cacaotales con un solo estrato de sombra, máximo dos especies de árboles con una sombra de 35-40 \%. En México, las plantaciones de café bajo sombra sustentan hasta 180 especies de pájaros, entre ellas especies migratorias. Algunas de estas aves desempeñan papeles claves en el control de plagas y la dispersión de semillas (Moguel y Toledo 1999).

En los sistemas silvopastoriles multiestrato (que integran árboles y ganadería), la presencia de árboles leguminosos mejora la producción de pastos y el ciclo de nutrientes, lo que evita añadir fertilizantes químicos nitrogenados a los pastos. Los árboles de raíces profundas ayudan a recuperar nutrientes y agua de las capas profundas del subsuelo e incrementan el secuestro de carbono, tanto bajo tierra como en el follaje. La cubierta arbórea también mejora la oferta alimenticia para el ganado y, a la vez, crea condiciones microclimaticas (sombra, mayor humedad relativa, menor temperatura, etc.). De esta forma, se reduce el estrés de los animales y se mejora su producción y bienestar (Murgueitio et ál. 2011).

\section{DIVERSIDAD GENÉTICA EN LA AGRICULTURA CAMPESINA}

Se estima que los campesinos manejan unas 7000 especies de plantas cultivadas, que incluyen 2,1 millones de variedades, en su mayoría razas locales. Además, se estima que los campesinos mantienen de 50 a 60 mil especies de plantas silvestres emparentadas con los cultivos que se entrecruzan con estos, lo que produce un incremento de la heterogeneidad genética de los sistemas agrícolas. Esta inmensa diversidad genética constituye la base adaptativa de los sistemas agrícolas del ayer, hoy y mañana ya que 


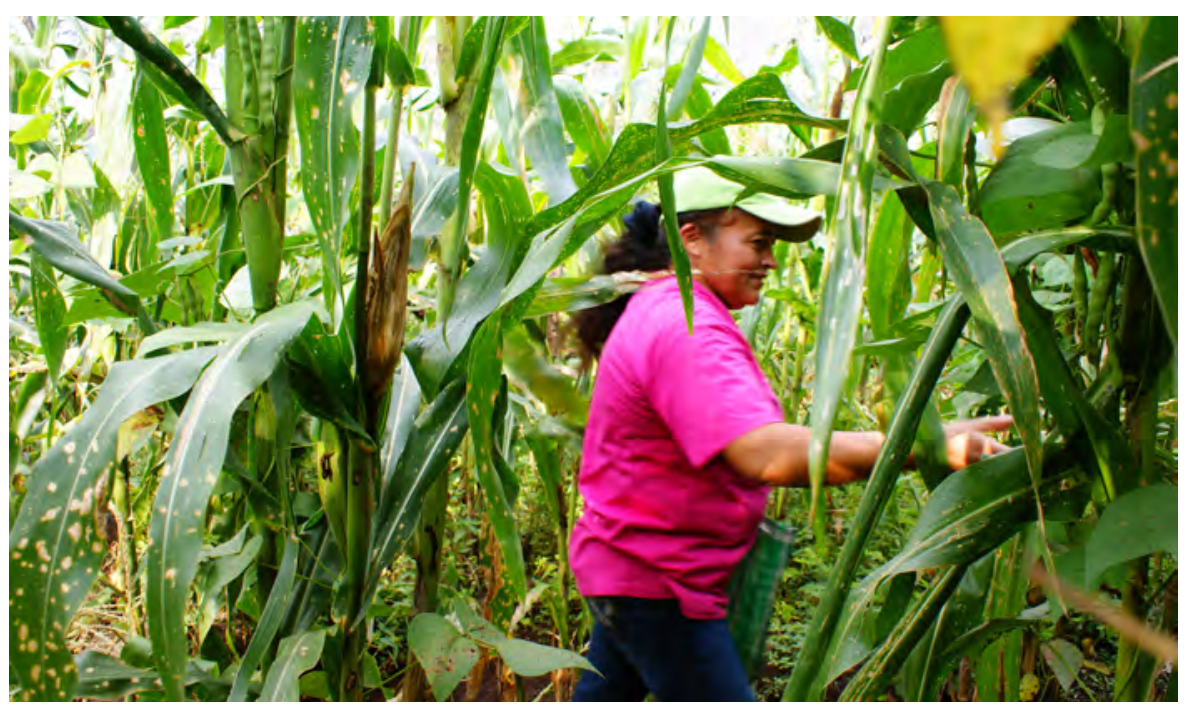

confieren defensas contra la vulnerabilidad e incrementan la seguridad de la cosecha frente a enfermedades, plagas, sequías y otras presiones. Los agricultores obtienen múltiples usos nutricionales y a la vez explotan los varios microclimas y agroecosistemas existentes en cada región, pero que difieren en la calidad del suelo, altitud, pendiente, disponibilidad de agua y otras condiciones (Clawson 1985).

Las mujeres conservan la mayoría de las variedades locales o tradicionales. Las agricultoras aprecian estas variedades por su mejor sabor y propiedades para el almacenamiento, pero también por razones culturales, como su uso simbólico en ceremonias religiosas, regalo en las bodas o recompensa en los trabajos comunitarios. Paradójicamente, tales variedades locales resultan extremadamente importantes para la agricultura industrial, porque contienen una gran cantidad de rasgos necesarios para adaptar los cultivos modernos a las plagas y enfermedades y al clima cambiante.

Gran parte de esta complejidad de los agroecosistemas tradicionales se debe al hecho de que los recursos genéticos de los cultivos suponen más que una colección de alelos y genotipos de cultivos nativos y parientes silvestres. También incluyen interacciones ecológicas como el flujo de genes a través de la polinización cruzada entre las poblaciones y especies de cultivos y la selección y gestión humanas guiadas por sistemas de conocimiento y práctica asociados con la diversidad genética, especialmente taxonomías etnobotánicas y habilidades para seleccionar variedades adaptadas a entornos heterogéneos (Altieri y Merrick 1987). Muchos agricultores "patrocinan" o promueven ciertas malezas o plantas silvestres en o alrededor de sus campos, práctica mediante la cual los agricultores pueden aumentar el flujo de genes entre los cultivos y sus parientes incorporando así varias fuentes de

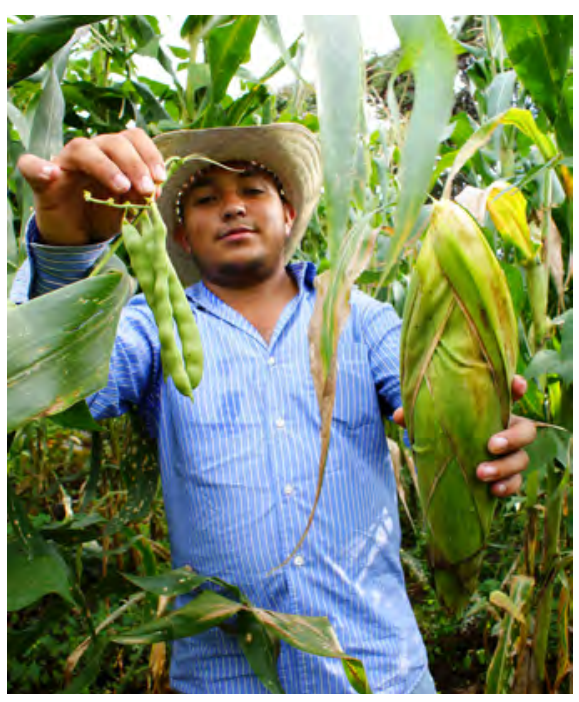

Campesinado de la milpa en Tangamandapio, Michoacán | fotos Feria de Productores 
Factores económicos y socioculturales que determinan el nivel de diversidad genética en

predios campesinos, la cual a su vez proporciona

servicios ecológicos a las familias rurales

resistencia a enfermedades y otras amenazas. Parece claro que la mantención de la diversidad genética en los campos resulta de la interaccion de una serie de factores ecológicos, climáticos, agronómicos y culturales.

En la mayoría de las regiones agrícolas del mundo permanecen agroecosistemas en los cuales los agricultores siembran múltiples variedades de cada cultivo, que brindan diversidad tanto intraespecífica como interespecífica, lo que mejora la seguridad de la cosecha. Por ejemplo, en los Andes los agricultores cultivan hasta 50 variedades de papas en sus campos y, cerca de Ayacucho, los indígenas de Quispillacta mantienen un promedio de 11 especies de cultivos y 74 ecotipos dentro de sus pequeñas parcelas (Brush 2002). De manera similar, en Tailandia e Indonesia los agricultores mantienen una diversidad alta de variedades de arroz en sus campos, adaptadas a una amplia gama de condiciones ambientales. Esta diversidad genética de cultivos tiene un efecto directo en el mantenimiento de los servicios ecosistémicos al proporcionar un mayor número de rasgos funcionales y fomentar interacciones que mantienen la biodiversidad asociada, por encima y por debajo del suelo. Al aumentar la estabilidad del ecosistema a largo plazo frente al estrés biótico y abiótico y a la variabilidad
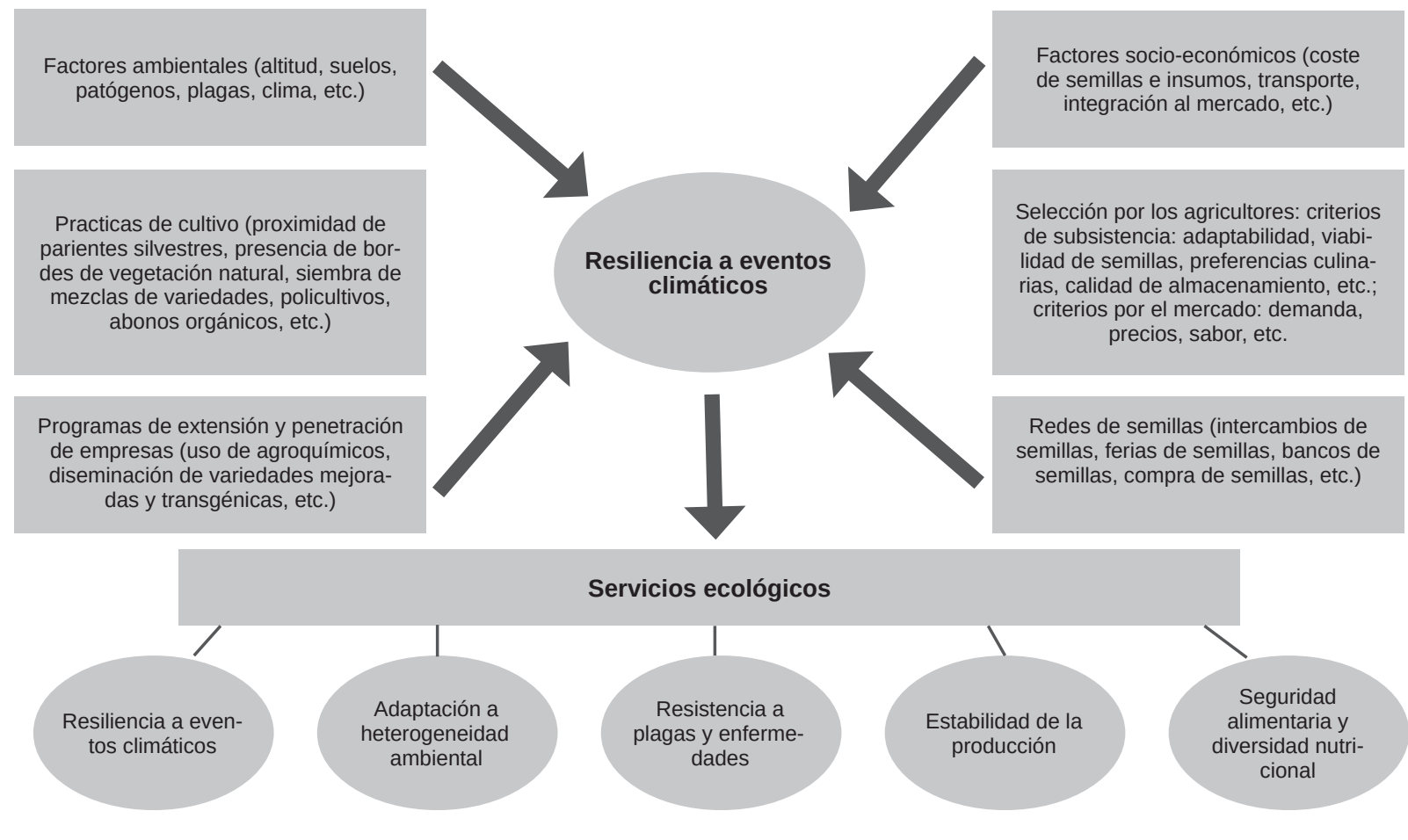
socioeconómica, la diversidad genética promueve el mantenimiento continuo de la biomasa y los servicios ecológicos que esta proporciona.

Como beneficio, la diversidad genética resultante aumenta la resistencia a cepas de enfermedades que atacan determinadas variedades del cultivo. La mezcla de diferentes variedades de cultivos puede retrasar la aparición de enfermedades, reducir la propagación de esporas portadoras de enfermedades y modificar las condiciones ambientales como la humedad, la luz, la temperatura y el movimiento del aire, de modo que sean menos favorables a la propagación de ciertas enfermedades. Un experimento a gran escala en Yunnan, China, donde se plantaron cultivos de arroz genéticamente diversificados, demostró que las variedades de arroz susceptibles a las enfermedades, al ser sembradas en mezclas con variedades resistentes tuvieron un rendimiento $89 \%$ mayor y la infestación de hongos fue $94 \%$ menos severa que cuando se manejaron en cultivos de una sola variedad. El experimento fue tan exitoso que ya no se aplicaron fungicidas después de dos años. Estos resultados ratifican que la diversificación intraespecífica de cultivos constituye un enfoque ecológico sólido para el control de enfermedades (Wolfe 1985).

\section{SISTEMAS AGRÍCOLAS TRADICIONALES COMO MODELOS DE RESILIENCIA}

Al contrario que los monocultivos de la agricultura industrial, muchos sistemas agrícolas tradicionales, que aún persisten en varios países en desarrollo, ofrecen una amplia gama de opciones y diseños de manejo que incrementan la biodiversidad funcional en los campos de cultivo, y, por consiguiente, refuerzan la capacidad de supervivencia de los agroecosistemas (Koohafkan y Altieri 2010; Toledo y Barrera-Bassols 2008). Al tener que lidiar continuamente con fenómenos meteorológicos extremos y la variabilidad climática a través de los siglos, muchos agricultores que viven en entornos hostiles en África, Asia y América Latina han desarrollado y heredado sistemas agrícolas complejos que han permitido a los pequeños agricultores familiares satisfacer sus necesidades de subsistencia en medio de la variabilidad ambiental sin depender de tecnologías agrícolas modernas (Denevan 1995).

Muchas investigadoras e investigadores han señalado que los pueblos indígenas y las comunidades locales, a pesar de su mayor exposición a los riesgos climáticos, están respondiendo activamente a las condiciones climáticas cambiantes y han demostrado su ingeniosidad y adaptación frente al cambio climático. Conservar la diversidad genética y la diversidad de especies en los campos y paisajes aledaños constituyen estrategias que permiten atenuar los riesgos en lugares sometidos a la incertidumbre meteorológica (Altieri et ál. 2013). Con la creación de diversidad temporal y espacial, los campesinos 
tradicionales aumentan la fortaleza de sus agroecosistemas a las fluctuaciones temporales del clima. Una revisión de 172 estudios de caso, así como de informes de proyectos de todo el planeta, demostró que la biodiversidad agrícola tal como la emplean los campesinos tradicionales, contribuye a la supervivencia, mediante el uso de una serie de estrategias a menudo combinadas: la protección y la restauración de los ecosistemas, el uso sostenible de los recursos hídricos y edáficos, la agroforestería, la diversificación de los sistemas agrícolas, diversos ajustes en las prácticas agrícolas y el uso de especies y variedades tolerantes al estrés (Mijatovic et ál. 2013).

Un estudio realizado en las laderas centroamericanas tras el paso del huracán Mitch (1998) sacó a la luz que los campesinos que habían llevado a cabo prácticas de diversificación agroecológica, como los cultivos de cobertura, los policultivos o sistemas agroforestales, sufrieron menos daños por causa del huracán en términos de pérdida de cosechas, erosión edáfica y formación de barrancos y cárcavas, que sus vecinos con monocultivos convencionales. El estudio, liderado por el movimiento Campesino a Campesino (CAC), movilizó un centenar de equipos de campesinos y personal técnico que llevaron a cabo observaciones comparativas de indicadores agroecológicos específicos en 1.804 fincas vecinas, convencionales y agroecológicas. El estudio involucró a 360 comunidades de 24 departamentos en Nicaragua, Honduras y Guatemala. Las parcelas agroecológicas tenían un $20 \%-40 \%$ más de capa vegetal, mayor humedad en el suelo y sufrieron menos erosión y pérdidas económicas que las parcelas vecinas convencionales (HoltGiménez 2002). De modo similar, en el Soconusco, en Chiapas (México), los sistemas de cafetales con altos niveles de complejidad y diversidad vegetal sufrieron menos daños al paso del huracán Stan (2005) que los sistemas de cafetales más simplificados (Philpott et ál. 2008). Cuarenta días después de que el huracán Ike golpease Cuba en 2008, se efectuó una investigación en las provincias de Holguín y Las Tunas, cuya conclusión fue que las fincas agroecológicas diversificadas padecieron pérdidas en torno al $50 \%$, mientras que las de los monocultivos cercanos ascendieron al 90 \%-100 \%. En la misma línea, las fincas manejadas agroecológicamente se recuperaron mucho más rápidamente del daño que las de monocultivo (Rosset et ál. 2011).

En Colombia, los sistemas silvopastorales intensivos (SSPI) suponen una forma sostenible de integración agroecológica basada en la agrosilvicultura con cría de ganado que se alimenta de herbáceas y arbustos plantados en altas concentraciones bajo árboles y palmeras. En 2009, el año más seco en el valle del Cauca, con precipitaciones un $44 \%$ inferiores a la media histórica, estos sistemas obtuvieron un buen rendimiento. A pesar de la reducción de la biomasa de los pastos en un $25 \%$, la producción de alimentos para animales proveniente de árboles y arbustos fue estable durante todo el año y neutralizó los efectos negativos de la sequía a nivel de todo el sis- 
tema. La producción láctea fue la mayor nunca antes registrada, con un sorprendente aumento del $10 \%$ respecto del cuatrienio precedente. Entretanto, en las fincas contiguas con pastizales en monocultivo se produjeron graves pérdidas de peso en los ganados y una alta mortalidad por hambre y sed (Murgueitio et ál. 2011).

Todos los estudios citados hasta aquí subrayan la importancia de aumentar la diversidad y complejidad vegetal en los sistemas agrícolas para reducir la vulnerabilidad a los fenómenos meteorológicos extremos. La literatura indica que los agroecosistemas se vuelven más resilientes si se insertan en una matriz paisajística compleja, con sistemas de cultivo heterogéneos genéticamente y diversificados, manejados con suelos ricos en materia orgánica y técnicas de conservación de agua. Mientras la mayor parte de las investigaciones se centran en la resiliencia ecológica de los agroecosistemas, bien poco se ha escrito aún sobre la resiliencia social de las comunidades rurales que manejan esos agroecosistemas. La capacidad de grupos y comunidades de adaptarse frente a una situación de estrés social, político o medioambiental externo ha de caminar en paralelo a la resiliencia ecológica. Para ser resilientes, las comunidades rurales han de demostrar su capacidad de amortiguar los trastornos con métodos agroecológicos adoptados y difundidos a través de la autoorganización, la reciprocidad y la acción colectiva. Reducir la vulnerabilidad social mediante la extensión y la consolidación de redes sociales, tanto a nivel local como regional, puede contribuir a aumentar la resiliencia de los agroecosistemas. La vulnerabilidad de las comuni-

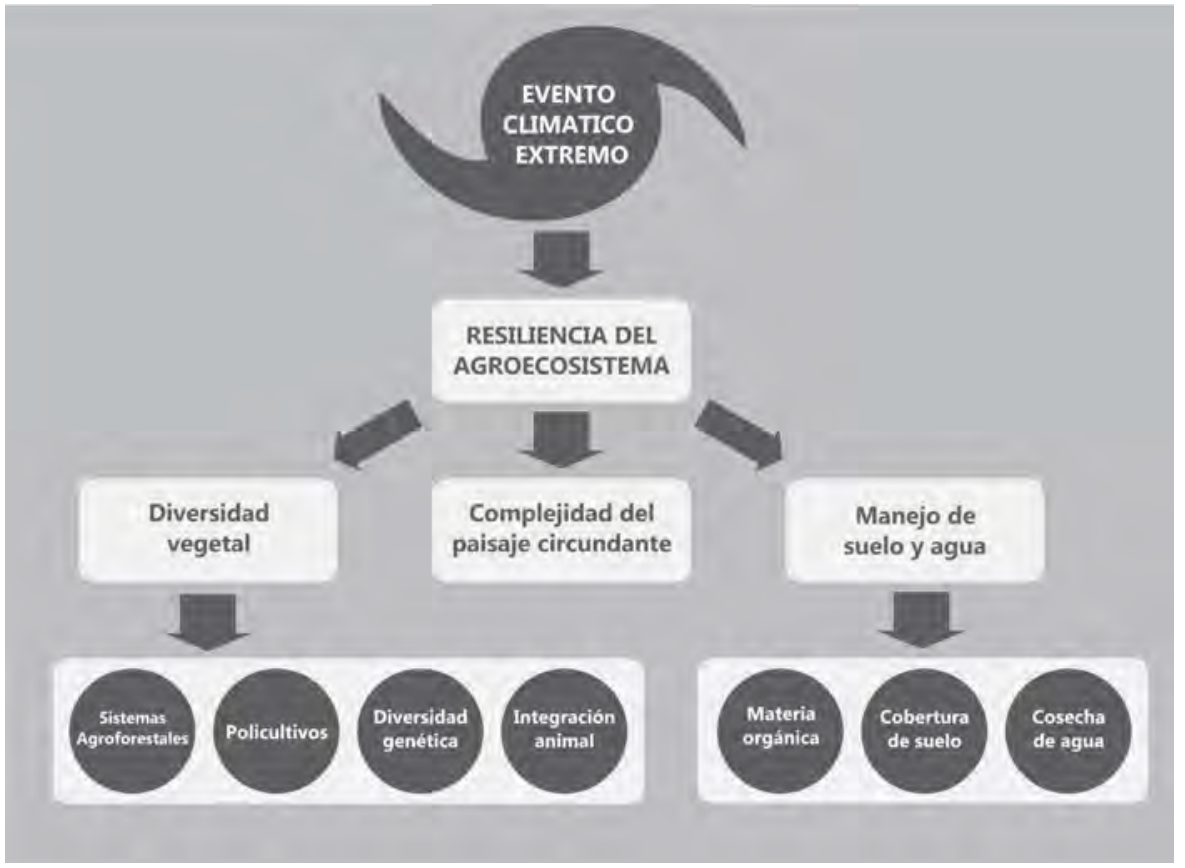


dades agrícolas depende del buen desarrollo de su capital social y natural; el nivel de ese desarrollo determinará si las familias campesinas y sus sistemas de producción seran más o menos vulnerables a los impactos climáticos (Altieri et ál. 2013). La mayoría de las comunidades tradicionales que todavía mantienen sus legados sociales y agroecológicos están dotadas con condiciones para que sus fincas respondan al cambio climático de manera resiliente.

\section{CONCLUSIONES}

En varias regiones rurales del mundo, grupos de seres humanos se han adaptado continuamente a las potencialidades y limitaciones de sus ambientes socioecologicos. Basándose en una riqueza acumulada de conocimientos tradicionales y culturales han modelado paisajes, a los que han dotado de una belleza extraordinaria. Resulta esperanzador observar que bien entrada la segunda década del siglo XXI, millones de campesinos y pequeños agricultores, familiares e indígenas siguen practicando tipologías de agricultura tradicional, que cubren no menos de 10 millones de hectáreas en todo el mundo, y que han demostrado una notable resiliencia a los continuos cambios ambientales y económicos, a la vez que contribuyen sustancialmente a la conservación de la agrobiodiversidad y la seguridad alimentaria a nivel local, regional y nacional.

Independientemente del reconocimiento por la comunidad científica, el conocimiento ancestral que ha guiado la creación de estos agropaisajes sostenibles y resilientes, constituye hoy una base sólida de conocimientos y practicas estratégicas para el desarrollo de innovaciones y tecnologías agrícolas capaces de enfrentar los desafíos que afrontará la agricultura en un futuro cercano. Hay mucho que aprender de los modos de producción autóctonos, ya que estos sistemas tienen una sólida base ecológica, mantienen una valiosa diversidad genética y conducen a la regeneración y preservación de la biodiversidad y los recursos naturales. Los métodos tradicionales parecen particularmente instructivos porque brindan una perspectiva a largo plazo sobre el manejo agrícola exitoso en condiciones de variabilidad climática. Al estudiar estos sistemas, la ciencia y las investigaciones pueden aumentar su conocimiento sobre la dinámica de sistemas complejos, especialmente la relación entre la biodiversidad y la función ecosistémica y también derivar principios prácticos para el diseño de agroecosistemas contemporáneos más sostenibles y resilientes (Altieri 2004).

Muchos de estos sistemas se enfrentan a graves amenazas de diversas fuentes, que incluyen el avance de la agricultura industrial, junto a la penetración de tecnologías foráneas y la globalización que promueve políticas para que los países ricos se deshagan de los excedentes de cereales en países 
de bajos ingresos, política que socava los mercados de los pequeños agricultores. Todas estas amenazas y problemas plantean el riesgo de pérdida de conocimiento ancestral, de una biodiversidad única y agropaisajes excepcionales, que amenaza los medios de subsistencia y la soberanía alimentaria de cientos de comunidades rurales. Lamentablemente, una vez que estos elementos claves y únicos se pierdan, el legado agrícola y los beneficios socioecológicos y culturales asociados, locales y mundiales, también se perderán para siempre.

Por esta razón, la iniciativa de FAO de conservación y gestión adaptativa de los sistemas de patrimonio agrícola de importancia mundial (SIPAM) parece clave para elevar el reconocimiento internacional y el apoyo a la conservación dinámica y la gestión sostenible de dichos sistemas, su agrobiodiversidad y acervo cultural asociados. Parece claro que se necesitan urgentemente políticas para apoyar la conservación dinámica del patrimonio agrícola y salvaguardarlos de los impulsores de cambios externos negativos. Urge asimismo proteger los bienes naturales y culturales de los sitios SIPAM del desarrollo industrial, el cual a menudo extrae mano de obra y causa también distorsión del mercado. Se ha de prestar especial atención a la introducción de variedades modernas e insumos agroquimicos para evitar alterar el equilibrio de los agroecosistemas tradicionales.

Para mejorar la viabilidad económica de estas iniciativas agroecológicas, también se deben desarrollar oportunidades equitativas en los mercados locales y regionales. La experiencia muestra que las políticas publicas pueden apoyar a la agricultura campesina si estas garantizan que las alternativas agroecológicas se adopten de manera amplia y que la producción resultante encuentre salidas garantizadas en los mercados locales. Para conservar e incluso expandir los SIPAM se debe poner especial hincapié en la participación activa de los agricultores en el proceso de innovación tecnológica y difusión a través de faros y modelos Campesino a Campesino que privilegian compartir experiencias y fortalecen la innovación local y las capacidades para la resolución de problemas. Las alianzas de organizaciones rurales con organizaciones de la sociedad civil en zonas urbanas será de suma importancia para crear conciencia entre los consumidores sobre la importancia de mantener y escalonar la agricultura campesina, no solo como fuente de alimentos frescos, sanos y accesibles, sino también como fuente de servicios ecológicos y culturales que benefician a las ciudades. 


\section{BIBLIOGRAFÍA}

- Altieri, M.A. y Merrick, L.C. (1987) In situ conservation of crop genetic resources through maintenance of traditional farming systems. Economic Botany, vol. 41, n. ${ }^{\circ} 1$, pp. 86-96

- Altieri. M.A. (2004) Linking Ecologists and Traditional Farmers in the Search for Sustainable Agriculture. Frontiers in Ecology and the Environment, vol 2, n. ${ }^{\circ} 1$, pp. 35-42

- Altieri, M.A. y Nicholls, C.I. (2004) Biodiversidad y manejo de plagas en agroecosistemas. Barcelona: Icaria

- Altieri, M.A. (2002) Agroecology: the science of natural resource management for poor farmers in marginal environments. Agriculture Ecosystems and Environment, vol. 93, pp. 1-24

- Altieri, M.A. y Toledo, V.M. (2011) The agroecological revolution in Latin America: rescuing nature, ensuring food sovereignty and empowering peasants. The Journal of Pesant Studies, vol. 38, pp. 587-612

- Altieri, M.A., Nicholls, C.I., Henao, A. y Lana, M. (2013) Agroecology and the design of climate change resilient farming systems. Agronomy for Sustainable Development, vol. 35, pp. 869-890

- Beets, W.C. (1982) Multiple cropping and tropical farming systems. Boulder: Westview Press

- Browder, J.O. (1989) Fragile Lands in Latin America: Strategies for Sustainable Development. Boulder: Westview Press

- Brush, S.B. (2000) Genes in the field: on farm conservation of crop diversity. Boca Raton, FL: Lewis Publishers

- Clawson, D.L. (1985) Harvest Security and Intraspecific Diversity in Traditional Tropical Agriculture. Economic Botany, vol. 39, pp. 56-67

- Denevan, D.M. (1995) Prehistoric Agricultural Methods as Models for Sustainability, Advanced Plant Pathology, vol. 11, pp. 21-43

- Dewalt, B.R. (1994) Using indigenous knowledge to improve agriculture and natural resource management. Human Organization, vol. 5, pp. 23-131

- Francis, C.A. (1986) Multiple Cropping Systems. New York: Mac- Millan

- Hanks, L. (1992) Rice and Man: Agricultural Ecology in Southeast Asia. Honolulu: University of Hawaii Press

- Holt-Giménez, E. (2002) Measuring farmers agroecological resistance after Hurricane Mitch in Nicaragua: a case study in participatory, sustainable land management impact monitoring. Agric. Ecosyst. Environ., vol. 93, pp. 87-105.

- Koohafkan, P. y Altieri, M.A. (2017) Forgotten agricultural heritage: reconnecting food systems and sustainable development. London, Routledge

- Koohafkan, P. y Dela Cruz, M.J. (2011) Conservation and adaptive management of Globally Important Agricultural Heritage Systems (GIAHS). Journal of Resources and Ecology, vol. 2 n. ${ }^{\circ}$, pp. $22-28$

- Khumairoh, U., Groot, J.C.J. y Lantinga, E.A. (2012) Complex agro-ecosystems for food security in a changing climate. Ecol. Evol., vol. 2, n. ${ }^{\circ} 7$, pp. 1696-1704

- Jose, S. (2009) Agroforestry for ecosystem services and environmental benefits: an overview. Agroforestry Systems, vol. 76 , pp. 1-10

- Mijatovic, D., Van Oudenhovenb, F., Eyzaguirreb, P. y Hodgkins, T. (2013) The role of agricultural biodiversity in strengthening resilience to climate change: towards an analytical framework. Int. J. Agric. Sustain., vol. 11, n. ${ }^{\circ} 2$, pp. 23-31

- Moguel, P. y Toledo, V.M. (1999) Biodiversity Conservation in Traditional Coffee Systems of Mexico. Conservation Biology, vol. 13, n. ${ }^{\circ}$ 1, pp. 11-21

- Murgueitio, E., Calle, Z., Uribe, F., Calle, A. y Solorio, B. (2011) Native trees and shrubs for the productive rehabilitation of tropical cattle ranching lands. Forestry, Ecology and Management, vol. 261, pp. 1654-1663

- Ortega, E. (1986) Peasant Agriculture in Latin America. Santiago: Joint ECLAC/ FAO Agriculture Division

- Philpott, S.M, Lin, B.B, Jha, S. y Brines S.J. (2009) A multiscale assessment of hurricane impacts on agricultural landscapes based on land use and topographic features. Agric. Ecosyst. Environ., vol. 128, pp. 12-20

- Reij, C., Scoones, I. y Toulmin, C. (1996) Sustaining the soil: indigenous soil and water conservation in Africa. London: Earthscan

- Rice, R.A. y Greenberg, R. (2000) Cacao cultivation and the conservation of biological diversity. Ambio, vol. 29, pp. 167-173

- Richards, P. (1985) Indigenous Agricultural Revolution. Boulder: Westview Press

- Rosset, P.M., Machín-Sosa, B., Roque-Jaime, A.M. y Ávila-Lozano, D.R. (2011) The Campesino-to-Campesino agroecology movement of ANAP in Cuba. J. Peasant Stud., vol. 38, n. ${ }^{\circ} 1$, pp. 161-191

- Toledo, V.M., Carabias, J., Mapes, C. y Toledo, C. (1985) Ecologia y Autosuficiencia Alimentaria. Mexico: Siglo Veintiuno

- Toledo, V.M. y Barrera-Bassols, N. (2008) La Memoria Biocultural: la importancia ecológica de las sabidurías 
tradicionales. Barcelona: ICARIA

- Vandermeer, J. (1992) The ecology of intercropping. New York, NY: Cambridge University Press

- Wilken, G.C. (1987) Good Farmers: traditional agricultural resource management in Mexico and Guatemala. Berkeley: University of California Press

- Wolfe, M.S. (1985) The current status and prospects of multiline cultivars and variety mixtures for disease resistance. Annu. Rev. Phytopathol, vol. 23, pp. 251-273

- Xie, J., Hu, L., Tang, J., Wu, X., Li, N., Yuan, Y. y Chen, X. (2011) Ecological mechanisms underlying the sustainability of the agricultural heritage rice-fish coculture system. Proceedings of the National Academy of Sciences, vol. 108, n. ${ }^{0}$ 50, pp. E1381-E1387 


\section{La rehabilitación de la Ciudad de los Ángeles de Secundino Zuazo y la gestión vecinal en la recuperación del patrimonio}

Francisco Javier González González, Miguel Lasso de la Vega | Universidad

Europea

Daniel Morcillo Álvarez | Universidad Politécnica de Madrid

URL de la contribución <www.iaph.es/revistaph/index.php/revistaph/article/view/4945>

\section{RESUMEN}

La rehabilitación de Ciudad de los Ángeles (Madrid), de Secundino Zuazo, ha supuesto toda una serie de medidas encaminadas a mejorar la habitabilidad de los edificios residenciales, al tiempo que se favorecía el entorno urbano en aspectos tan relevantes como la accesibilidad y la calidad ambiental. El proceso ha sido desarrollado por las administraciones públicas en coordinación y con la participación del movimiento vecinal, de tal manera que los valores patrimoniales existentes en el barrio han sido preservados a través de una suerte de protección ambiental. Este artículo trata de hacer un recorrido por el proceso de rehabilitación seguido, presentando los valores patrimoniales existentes en el barrio, y considerando el papel del "apego al lugar" como medio de protección indirecta del entorno.

\section{Palabras clave}

Ciudad de los Ángeles (Madrid) | Edificios residenciales | Gestión vecinal | Movimiento Moderno | Participación ciudadana | Periferia urbana | Regeneración urbana | Rehabilitación energética | Secundino Zuazo | 


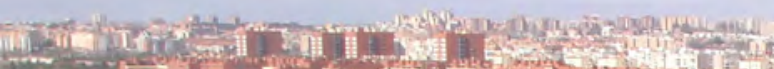
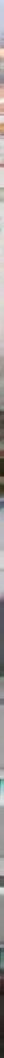

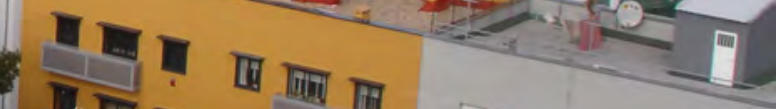

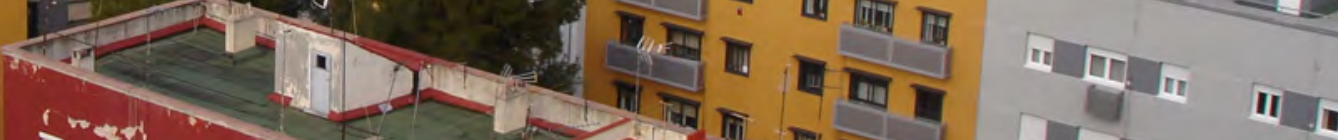

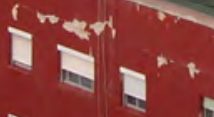

(1) II a of

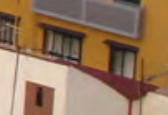
a. 1.

10 (i) in th the 0

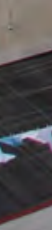

Vista general de Ciudad de los Ángeles | foto el material gráfico que ilustra este artículo pertenece a los autores 


\section{INTRODUCCIÓN. ORÍGENES DE LA REHABILITACIÓN DE CIUDAD DE LOS ÁNGELES}

La rehabilitación de barrios de la periferia contemporánea de nuestras ciudades es una práctica que se ha centrado en la mejora de las condiciones ambientales y de funcionalidad, tanto de edificios como de espacios públicos. Sin embargo, los valores patrimoniales se han quedado en un segundo plano, a pesar de que algunos de estos barrios son ejemplos de cómo el Movimiento Moderno se despliega en el espacio residencial de la ciudad. El caso de la rehabilitación de Ciudad de los Ángeles ha sido uno de los últimos barrios con valores patrimoniales reconocidos que se han mejorado en Madrid, y donde la implicación vecinal ha tenido un papel central en el proceso. Pese a que la preservación patrimonial no ha sido uno de los objetivos de la rehabilitación, el trabajo llevado a cabo ha sido discutido por los agentes implicados de tal manera que ha sido posible compatibilizar una suerte de protección ambiental con las necesidades de mejora de la habitabilidad.

El caso de Ciudad de los Ángeles es significativo en muchos aspectos, pero en lo que nos interesa, cabe resaltar que todo el proceso fuera gestionado por la Empresa Municipal de la Vivienda y Suelo de Madrid (EMVS) y consensuado permanentemente con el movimiento vecinal, a través de la Asociación de Vecinos de la Ciudad de los Ángeles (ASVEYCO). Este hecho hizo que se establecieran mecanismos de participación y control de las decisiones, lo que posibilitó la unidad de criterios y la coherencia de la intervención dentro de la lógica espacial del barrio y sus habitantes.

Localizado en el distrito de Villaverde, al sur de la ciudad de Madrid, el barrio se construye a partir de los años 1960 bajo la influencia de los industriales del entorno y desarrollado en dirección norte sur lindando con la Avenida de Andalucía. Este único punto de conexión con la ciudad y la vinculación con la industria limítrofe han determinado en gran medida el devenir del barrio y la creación de una fuerte identidad vecinal. El carácter del barrio, las homogéneas condiciones de la población y sus problemas cotidianos, laborales y sociales, así como una necesaria apropiación del espacio ante la dejación de funciones de la administración durante décadas, han permitido la construcción de una identidad muy marcada y un "apego al lugar" como respuesta colectiva a los problemas suscitados por el contexto laboral y social.

En lo relativo a la producción del espacio físico, a partir de un trazado original del estudio de Secundino Zuazo, se construye en varias fases hasta los años 1990, manteniendo, pese a ello, un carácter unitario y coherente con la estructura original. Sin embargo, el tipo de promoción y el destinatario final de las viviendas supusieron la elección de sistemas constructivos y materiales que han favorecido la aparición de daños. Las deficientes formas de 
conservación y mantenimiento que se llevaron a cabo hicieron que en los primeros años del siglo $X X$ se iniciara un proceso de movilización para la rehabilitación por parte de ASVEYCO, que terminaría convirtiéndose en su verdadero promotor e impulsor.

Así, en el año 2005 se produce la declaración del Área de Rehabilitación Integral Ciudad de Los Ángeles por Orden de la Consejería de Medio Ambiente y Ordenación de Territorio de la Comunidad de Madrid, iniciándose el proceso de rehabilitación que ha perdurado hasta el año 2018.

El área ocupa una superficie de 59,6 ha, con un total de 7.996 viviendas distribuidas en 441 bloques de los 486 que componen el área y una población estimada actual de 31.465 habitantes a fecha de la declaración del área.

La rehabilitación comprendió tanto el espacio edificado como el espacio libre público. En cuanto a la edificación, se priorizó la estabilidad estructural de los edificios, la accesibilidad y la mejora del comportamiento higrotérmico. Por otra parte, y de manera complementaria, se trazaron los objetivos sobre el entorno urbano, con la idea de eliminar las barreras arquitectónicas existentes, mejorar el medioambiente urbano y aumentar la calidad peatonal de un espacio con una sucesión de espacios libres muy compleja y generosa.

Durante este proceso se ha intervenido sobre 110 edificios, rehabilitando un total de 1.431 viviendas y 29 locales comerciales asociadas a estas. La inversión total ha consistido en 27,15 millones de euros en la rehabilitación de edificios y cerca de 16,5 millones de euros para la mejora de las infraestructuras urbanas. En todo momento se han mantenido como invariables el protagonismo y liderazgo vecinal en el proceso llevado a cabo, aspectos que son necesarios evaluar dentro de un contexto más general.

\section{SECUNDINO ZUAZO EN LA CONSTRUCCIÓN DE LA PERIFERIA MADRILEÑA: VALORES PATRIMONIALES LIGADOS A LA PRODUCCIÓN DEL ESPACIO EN CIUDAD DE LOS ÁNGELES}

A partir de 1950, la Administración Pública y su Instituto Nacional de Vivienda (INV) se convirtieron en el indudable motor de los nuevos barrios, donde se experimentó con materiales constructivos nuevos, soluciones estructurales y distribuciones de carácter mínimo, recogiendo la herencia racionalista de la República y la influencia de las actuaciones extranjeras contemporáneas, a través de las publicaciones y los viajes.

Sin embargo, los sucesivos decretos de bonificación y exención fiscal en la construcción de viviendas sociales no lograban animar al capital privado en 
Sobre la impronta del arquitecto José Fonseca en el INV, concretamente en su Sección de Arquitectura y en las ordenanzas técnicas que desde ella se elaboraron, ver Lasso de la Vega (2008).

\section{2}

Su construcción se ciñe al modelo de promoción inmobiliaria que permitió a gran parte de la población trabajadora acceder a la propiedad de su vivienda. Este paradigma se consolidaría en las décadas posteriores hasta constituir lo que Fernando Roch (2008) denominó como el modelo de propiedad universal. Por otro lado, no hay que descartar que el apoyo de los sectores industriales condicionase el diseño del barrio, apuntalado por la vasta experiencia del estudio Zuazo, y que se plasmó en un diseño urbano en donde el bloque lineal exento, de formas puras, repetitivas y con referencias industriales, se superponen con galerías comerciales de enorme plasticidad gracias a las ligeras marquesinas de hormigón sostenidas por esbeltos pilares circulares de hormigón.

3

A falta de un estudio sobre la figura del arquitecto Manuel Muñoz Monasterio, los arquitectos Carlos Ripoll y Virginia Ripoll señalan: "Muñoz Monasterio no fue un arquitecto representativo de ningún movimiento, ni promotor de ninguna corriente, desarrolló una arquitectura racionalista, sobre todo en su prime ra época de arquitecto, en los años treinta, aunque su salto cualitativo se produce en los cincuenta" (Ripoll Gómez y Ripoll Tolosana 2014).

4

Biblioteca Nacional de España, Fondo Secundino Zuazo, DIBZ/187.

5

En el Archivo de Visado del COAM se registra también la intervención de Secundino Zuazo en la ampliación del barrio en 1968 (Gutiérrez Marcos y Da Rocha 2007). esta empresa, siendo una necesidad del Estado para resolver el que era uno de sus más graves y acuciantes problemas tras la Guerra Civil, el déficit de hogares dignos para una población que había abandonado el medio rural en busca de mejores oportunidades en la capital.

Tras fallidos intentos, la Ley del 15 de julio de 1954 sobre Protección de Viviendas de Renta Limitada, que canceló los regímenes de viviendas protegidas y bonificables, amplió la movilización del crédito financiero, facilitando la participación de los particulares (Ley 84/1961) en la tarea de reconstrucción y desarrollo del parque residencial madrileño. Las reticencias se habían basado en someterse a la férrea supervisión y control del INV, interesado, con José Fonseca al frente de su Sección de Arquitectura ${ }^{1}$, en mantener unos estándares de calidad y funcionalidad que por el contrario mermaban el beneficio lucrativo. Sin embargo, entre las promociones privadas que, en el Madrid de mitad de siglo, se acogen al nuevo Plan Nacional de Viviendas de Renta Limitada (Decreto-ley de 1 de julio de 1955), la Ciudad de los Ángeles merece un lugar destacado.

Su éxito fue reconocido tempranamente por el Estado, al concedérsele la medalla de colaborador del Plan de Urgencia Social de Madrid (Elvira Peña 2003) (Decreto-ley del 13 de noviembre de 1957) a este barrio de la Carretera de Andalucía, surgido a partir de 1951 (Río Lafuente 1984) para alojar a los trabajadores de las industrias próximas, especialmente de la Fábrica Barreiros ${ }^{2}$. En este logro contribuyeron distintos factores, sintetizados en la apuesta de sus arquitectos proyectistas por convertirse en constructores, vitalizando el proceso, y la notable capacidad de aquéllos; la de Javier de Zuazo Bengoa, unida a la experiencia de quienes le acompañaron en esta aventura, Manuel Muñoz Monasterio ${ }^{3} y$, especialmente, su padre, Secundino de Zuazo Ugalde.

Y es que Zuazo es, sin duda, el referente en esta empresa urbana y constructiva, para la que fundó, aunque no participó como socio, la empresa VIRELSA (Viviendas de Renta Limitada SA), poniéndola a nombre de su hijo y sus dos yernos. Quizás lo hizo así porque ya formaba parte de otras tres promotoras: Ia Inmobiliaria de Fomento del Hogar, la Sociedad Anónima Madrileña de Gestión Inmobiliaria y una más "con Federico Turell para conservar y reparar edificios" (Sambricio 1999).

Ese papel secundario en la actividad promotora hizo que también se le supusiera en el proyecto y la construcción de la Ciudad de los Ángeles, pero basta comprobar los muchos documentos firmados de su mano entre los años 1956 y 1961, y que se conservan en su archivo, dibujos y planos de ordenación, manzanas, bloques y torres ${ }^{4}$, con tipos y categorías de viviendas, escuela, mercado y locales comerciales, en la primera, segunda y tercera fases, para comprobar su decisiva implicación 5 . 


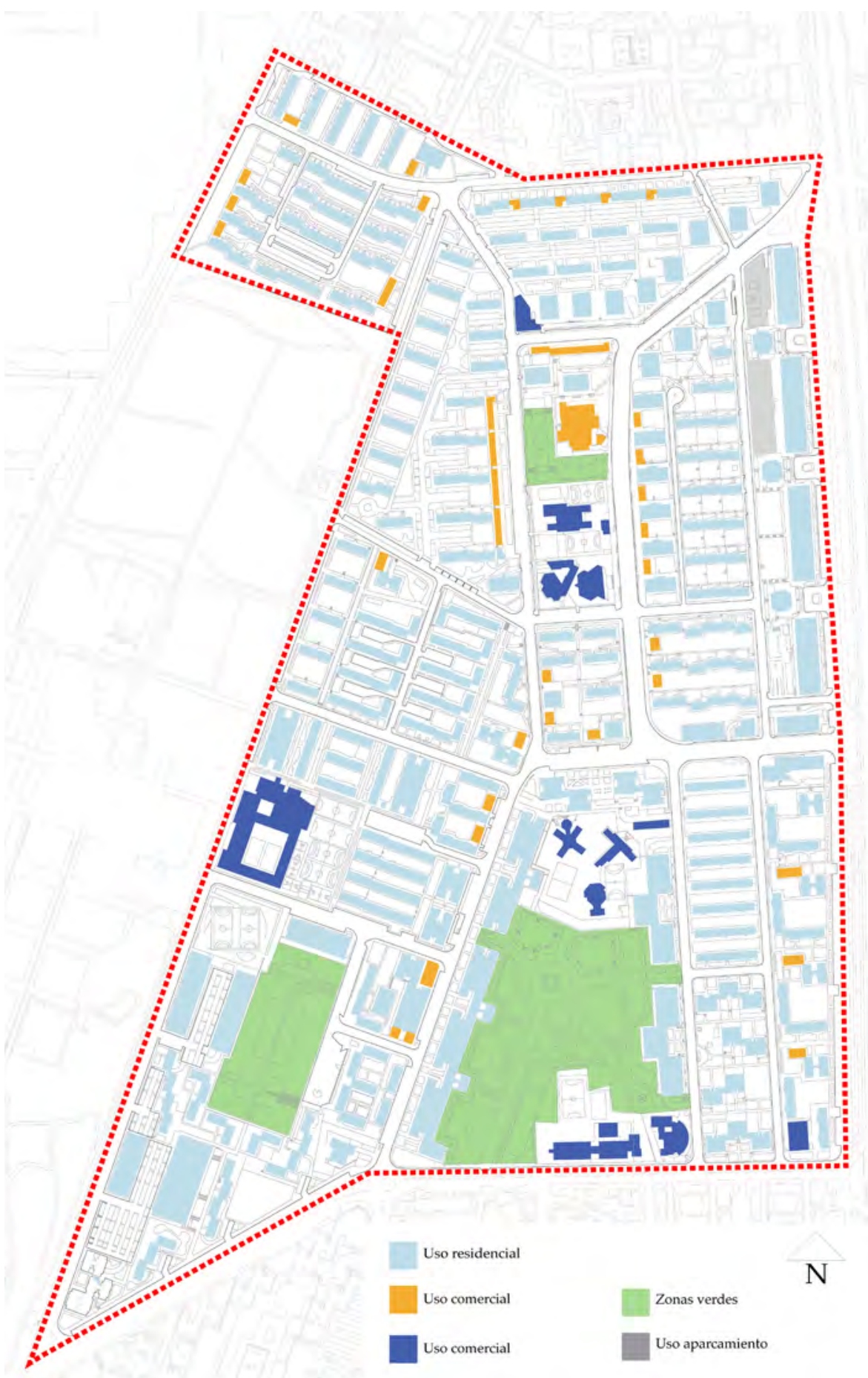

Distribución de usos 


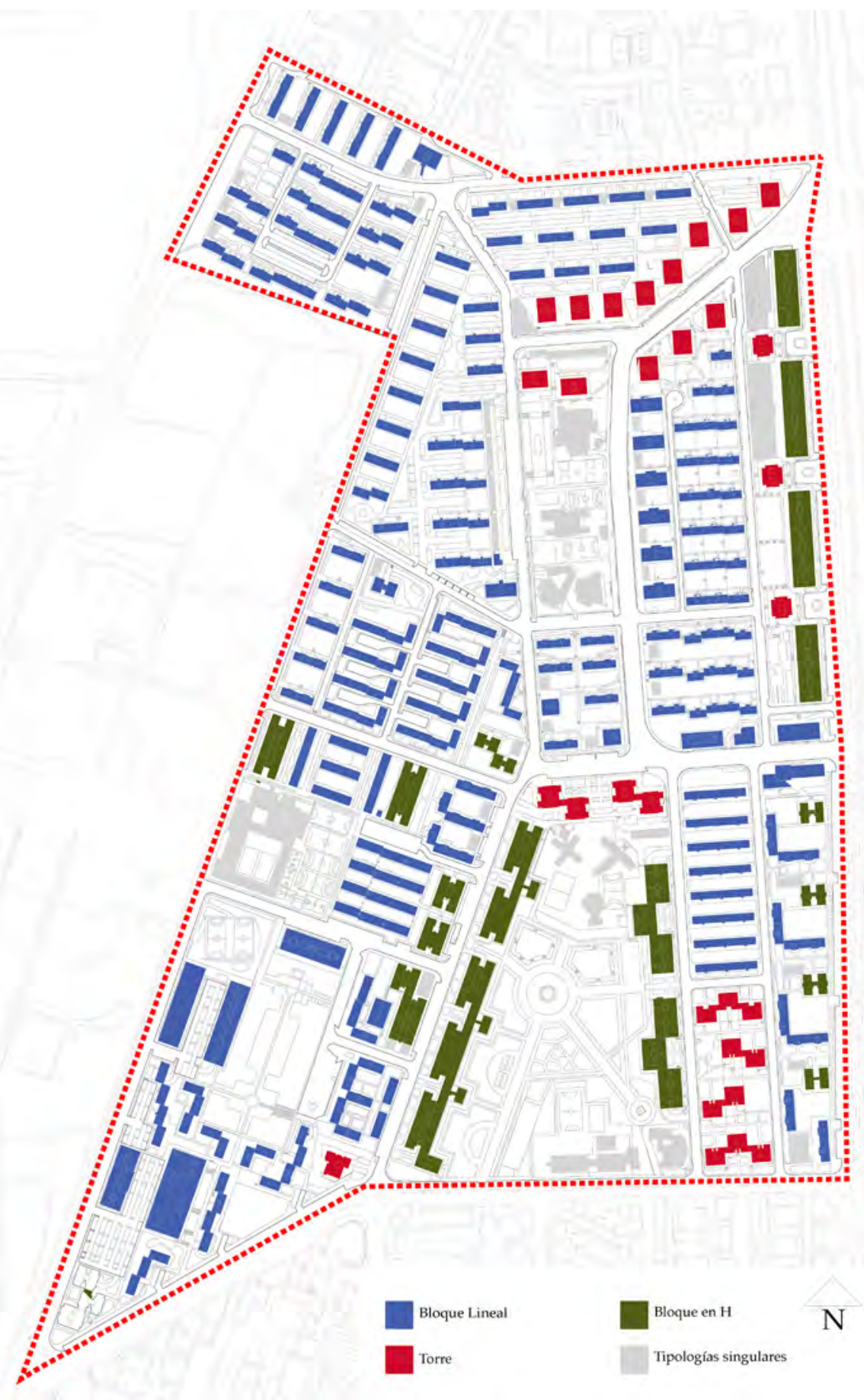


Dos constantes de su obra se reconocen en este barrio: la racionalidad, con la que vuelve su mirada a su trayectoria previa a la Guerra Civil, exilio y posterior destierro, y la importancia del espacio libre, que en la Ciudad de los Ángeles alcanza hasta el $80 \%$, con cuidados jardines aterrazados entre las edificaciones (Lasheras y Martín Moratalla 1987) ${ }^{6}$.La pureza volumétrica, la sinceridad constructiva, la ausencia de ornamento, de modo que el hueco se recorta limpiamente en el muro, la adecuada orientación e iluminación de las piezas, son preocupaciones coincidentes en otras de sus obras de este periodo de finalización de su vida profesional7, donde las referencias a sus emblemáticas Casa de las Flores (1930) y al proyecto de Nuevos Ministerios (1932) son evidentes, pero ahora resueltas con mayor libertad.

Estos valores patrimoniales del barrio están muy ligados a entenderlo como un espacio concebido para el desenvolvimiento de la vida cotidiana, convirtiendo al espacio físico en facilitador de las relaciones que constituyen el capital social del barrio. Fue concebido con una estructura fundamentada en un área central a partir del cual se organizan los polígonos que alojan fundamentalmente una tipología de bloques abiertos. Aunque el desarrollo del proyecto abarcó diferentes fases, es predominante el bloque abierto en diferentes configuraciones y orientaciones, constituyendo un entorno fácilmente reconocible de paralelepípedos puros y una gran generosidad de espacios libres. Las dotaciones y las principales zonas verdes del barrio se localizan en el área central, mediante una sucesión de lugares que facilitan la comprensión del espacio urbano y lo dotan de diversidad funcional y tipológica.

En el caso de Ciudad de los Ángeles supuso convertir a los trabajadores de las industrias adyacentes en propietarios de su vivienda, con la idea, entre otras, de mejorar las condiciones de habitabilidad de las familias ${ }^{8}$, con espacios urbanos saludables y de calidad.

Además de estas galerías, la continuidad de los bloques residenciales se consigue interponiendo entre ellos pequeños volúmenes comerciales, muchos de ellos ligados a la edificación con marquesinas de hormigón, dando muestras de la voluntad por conseguir una unidad del conjunto urbano y edificatorio propio de esta época.

\section{RECUPERACIÓN DEL PATRIMONIO Y APEGO AL LUGAR: EL PAPEL DE LA INVOLUCRACIÓN VECINAL}

Antes de valorar el tratamiento de los valores patrimoniales en la rehabilitación de Ciudad de los Ángeles, merece la pena detenerse en el concepto de "apego al lugar" 9 . La experiencia europea en regeneración urbana indica cómo la implicación vecinal en el proceso es un elemento central (Roberts y Sykes 2000; Kleinhans, Premius y Engbersen 2007; Premius 2008; Stouten
Además, otro de los valores que distingue a la Ciudad de los Ángeles, y la unen a las experiencias planificadoras de Zuazo, es el compromiso urbano de sus edificaciones, de 5 y 12 plantas, que se adaptan a la topografía, crean centralidad, con sus locales comerciales y equipamientos en la planta baja, abiertos a la vía principal, y producen una armónica disposición de sus manzanas paralelas, que es fruto de la agrupación de sus bloques abiertos, alternados con torres, enfatizadas en este caso sus cubiertas con potentes marquesinas.

$$
7
$$

El arquitecto bilbaíno Secundino Zuazo falleció el 12 de julio de 1971 en Madrid, después de una larga vida y completamente rehabilitado profesionalmente, respetado y admirado. Aunque apenas se menciona el proyecto de la Ciudad de los Ángeles, figurando en la relación de sus obras, sigue siendo imprescindible para el conocimiento de la figura del arquitecto el estudio de Lilia Maure (1987).

$$
8
$$

Es interesante para el entendimiento del papel de los industriales de Villaverde, la película dirigida por Besas en 1987 acerca del industrial Eduardo Barreiros (Barreiros, motor humano), donde se muestra su intervención en la Ciudad de los Ángeles.

\section{9}

En la literatura anglosajona suele aparecer como place-attachment. 
10

Con la preocupación sobre la recuperación de las periferias en Europa, algunos autores han retomado o continuado, según los casos, con la utilización de este concepto para, por un lado, poner de manifiesto la necesidad de institucionalizar la involucración de los vecinos en las dinámicas de transformación y mejora de sus barrios, y, por otro, comprender cómo la mejora de los espacios colectivos de los barrios (equipamientos y espacios públicos) son elementos catalizadores, generadores de ese capital social (Kearns 2004; Flint y Kearns 2006; Curley 2008; Svendsen 2010; Hudson 2012).

\section{1}

Entendemos que el capital social es el conjunto de beneficios y el modo de acceso a beneficios que tienen una serie de personas que forman parte de una red de relaciones basadas en la confianza, en las que se aplican unas normas que garantizan alguna forma de reciprocidad (Bourdieu 1980; Portes 1998; Edwards y Foley, 1999; Putnam 2000; Lin y Erikson 2008; González González 2017). Para Bourdieu, el concepto de capital social es algo más restringido: es el conjunto de recursos asociados a la posesión de una red de relaciones duraderas (Bourdieu 2000). Cuando Coleman (2000) introduce el concepto dentro del mundo académico e intelectual anglosajón, abre el camino a las aportaciones de Portes (1998), Lin (2001), Fine (2001), Putnam (2000), etc. que consideran el capital social inmerso de lleno en la esfera urbana. Putnam (2000) hace bascular e concepto hacia la confianza y la reciprocidad, lo que lleva a la aplicación del concepto en relaciones de sociabilidad más difusa, como son las vecinales.

\section{2}

El apego al lugar otorga una identidad colectiva reconocible (González González 2019). Curley (2010) muestra empíricamente cómo la pertenencia al lugar que conlleva este vínculo estimula las interacciones sociales que están en la base de la formación del capita social. La consciencia compartida de pertenecer a un lugar geográfico lleno de connotaciones predispone a construir vínculos solo
2010; González González y Stouten 2014). En la primera década del siglo XXI, Forrest y Kearns (2001), se preguntaban en su trabajo "Social cohesion, social capital and the neighbourhood", casi convertido hoy en un clásico, qué podía aportar el barrio como espacio de convivencia a la generación de capital social entre los vecinos y, de modo recíproco, qué es lo que el capital social de los vecinos aporta al mantenimiento de su espacio físico, en definitiva, a su rehabilitación ${ }^{10}$.

Además de señalar la importancia de este capital social, más operativo cuanto más institucionalmente organizado esté, los autores destacaban cómo "el apego al lugar" era un factor fruto de la convivencia en un mismo sitio identificable, y que formaba parte de una base de procesos informales sobre los que construir beneficios comunes e individuales, derivados de compartir una serie de relaciones de confianza y reciprocidad entre vecinos, y ser regidos por unas normas informales consensuadas. Estos beneficios y las relaciones que implican es lo que denominaríamos capital social ${ }^{11}$.

En continuidad de las propuestas de estos autores podemos decir que la implicación vecinal en un proceso de rehabilitación supone poner a actuar al capital social del barrio (González González 2019), lo que conlleva reforzar el denominado "apego al lugar", como reflejo de la construcción colectiva de un imaginario compartido ${ }^{12}$, que muchas veces, concuerda con los valores patrimoniales reconocidos y a preservar.

Creemos que en el caso de Ciudad de los Ángeles se da una doble implicación; por un lado, el "apego al lugar" involucra a los vecinos en la rehabilitación del barrio y, en segundo lugar, la rehabilitación, que respeta el imaginario colectivo, refuerza el sentimiento de "apego". Como conclusión: la estima de los valores patrimoniales del barrio se codifica, para los vecinos en términos de "apego al lugar, y, si este se refuerza, es que, de algún modo, se respetan dichos valores, se tienen en cuenta en la ecuación rehabilitadora. Por tanto, es un buen ejemplo de cómo el capital social del barrio es capaz de empujar el proceso de rehabilitación. En este caso, el capital social más institucionalizado se encuentra en la asociación de vecinos, ASVEYCO, y su papel de mediación entre las comunidades de propietarios y la administración local fue un elemento importante en el proceso de rehabilitación del barrio.

En Ciudad de los Ángeles, la asociación de vecinos tiene un rol complementario al del ente gestor ${ }^{13}$, ganando a lo largo del proceso un más intenso papel de representación de las comunidades implicadas en el área a rehabilitar ${ }^{14}$. Indudablemente, esta capacidad de interlocución de ASVEYCO se refleja en las propuestas de transformación física, condicionada por las características espaciales del barrio ya que el diseño urbano ha demostrado tener una clara presencia en la imagen colectiva y en la identificación de la población residente con los valores asociados a ella. De esta forma, el capital social habría 


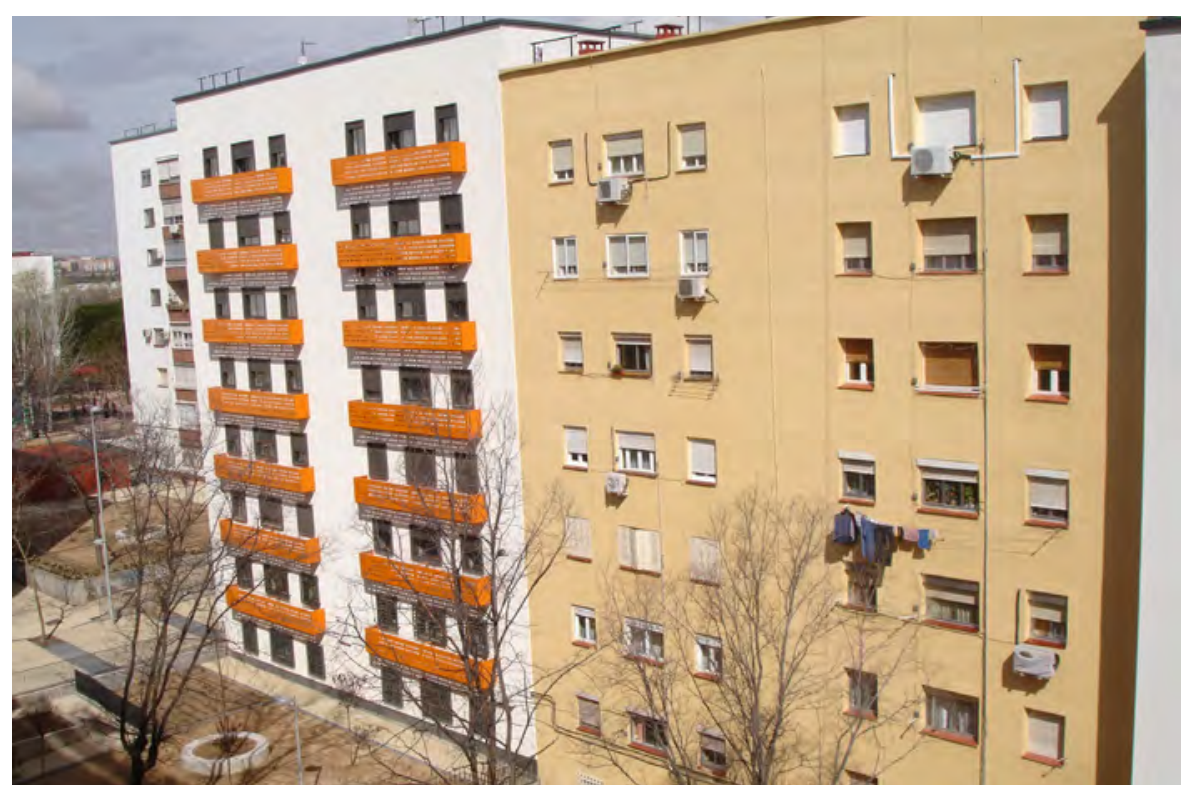

sido capaz de producir su propio espacio asimilando los valores del espacio concebido por el estudio Zuazo.

\section{Los valores patrimoniales en el proceso de rehabilitación}

En gran medida la rehabilitación de Ciudad de los Ángeles no se detuvo en los valores patrimoniales descritos hasta el momento, y no fueron considerados como objetivo dentro de la estrategia de rehabilitación adoptada por la EMVS ni por ASVEYCO (Córdoba Hernández et ál. 2020).

Pese a ello, la rehabilitación se definió en torno a unos parámetros que, a la larga, han podido influir sobre estos aspectos más de lo que hubiese podido pensarse. Cabe resaltar que en ningún momento se planteó la sustitución de la edificación y que, al contrario, se defendió su tratamiento unitario, aceptando la incorporación de elementos de color y composición de fachadas que permitiera una identificación de la población con su edificio sin que por ello se desvirtuara el sentido unitario del entorno ni la pureza volumétrica existente. Este volumen puro sí que ha sido parcialmente modificado con dos elementos que merecen su atención: las cajas de ascensores y la instalación de cubrevistas.

La instalación de ascensores en los bloques de cuatro o cinco plantas que carecían de él plantea la discusión sobre la necesidad de solventar la accesibilidad a costa de los valores arquitectónicos y urbanos de un determinado entorno o edificio. Como mencionamos, entre los objetivos para la rehabilitación de Ciudad de los Ángeles nunca se planteó esta disyuntiva y no se
A la izquierda, estado reformado del edificio de Pan y Toros 24-26 y abajo detalle de los cubrevistas de mismo edificio

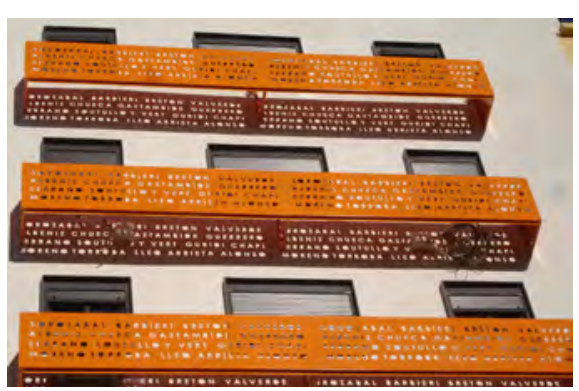

por compartir el lugar de residencia (González González 2019).

13

En el modelo habitual de gestión de las áreas de rehabilitación en Madrid, el ente gestor es la Empresa Municipal de Vivienda y Suelo (EMVS) del Ayuntamiento, que abre una Oficina de Rehabilitación en los propios barrios, y desde ella se tramitan las ayudas a las comunidades de propietarios, se ofrece información en general y se facilita apoyo técnico.

14

En el convenio firmado por el Ayuntamiento de Madrid y la Comunidad de Madrid para la declaración de Zona de Rehabilitación Integrada, se reconoce el papel de ASVEYCO, de representación vecinal. Esta mediación se inicia cuando problemas estructurales debidos a deficiencias de cimentación llevan a la asociación a convocar a 486 comunidades para pedir la declaración de ARI (Área de Rehabilitación Integral) para el barrio. La propuesta es aceptada por 248 comunidades, a las que se irán sumando más durante el proceso hasta alcanzar 411, lo que supone 7.996 viviendas. Lo significativo del caso es que el capital so- 
cial acumulado de ASVEYCO es capaz de iniciar el proceso gracias a su predicamento en el barrio, fundamentado en su defensa de los intereses de los vecinos, además de su labor como centro cultural y social local. También tiene importancia el mecanismo engrasado de relación con las comunidades en la gestión diaria. Se demostró muy útil que las relaciones de cobro de recibos habituales se hicieran directamente con las comunidades y no con los vecinos que viven en ellas. Esto supone un sistema ya maduro de toma de decisiones dentro y de interlocución hacia fuera, hacia la asociación. Otros aspectos de esta mediación es la gestión de la selección de una asistencia técnica para la petición de subvenciones y de empresas constructoras que trabajen para cada comunidad. La empresa gestora que resulta ganadora del concurso impulsado desde la asociación se encargará del desarrollo de los proyectos técnicos y de la dirección de obras de aquellas comunidades que así lo decidieran. Aunque en un principio se pretendía que este mecanismo rehabilitara los edificios de todas las comunidades, finalmente cada comunidad optó por el mecanismo de gestión que estimó adecuado, perdiendo de alguna manera la intensidad del elemento unificador de la gestión. En definitiva, la experiencia de Ciudad de los Ángeles nos remite a la gestión vecinal de un proceso complejo, como es el de la rehabilitación de un barrio, con una labor de mediación entre vecinos y administración. Esta labor no hubiera sido posible si no se contara con un músculo organizativo amplio y con medios materiales suficientes. También influye la inserción en la vida cotidiana del barrio gracias a su labor como centro social que ofrece servicios complementarios a los del ayuntamiento y otras instituciones (González González 2019).

Estado previo del edificio de La Corte del Faraón 25 (arriba izquierda) y del estado reformado (arriba derecha). Estado previo del edificio de EI Manojo de Rosas 2 (abajo izquierda) y del estado reformado (abajo derecha) generó ninguna duda respecto de las necesidades demandadas por el movimiento vecinal y la población residente. Sí se buscó, en cambio, la mayor coherencia y unidad posible (Morcillo Álvarez, Arjona Martín y Martín Acosta 2016), estableciendo áreas de movimientos en cada edificio, tras un minucioso estudio de cada tipología y modelo existente. Este trabajo fue incorporado al Plan Especial para la Instalación de Ascensores que fue aprobado en 2008 por el Ayuntamiento de Madrid.

Consideración diferente puede mostrarse en la decisión de instalar cubrevistas que organizaran la fachada de tal forma que ocultaran los aparatos de
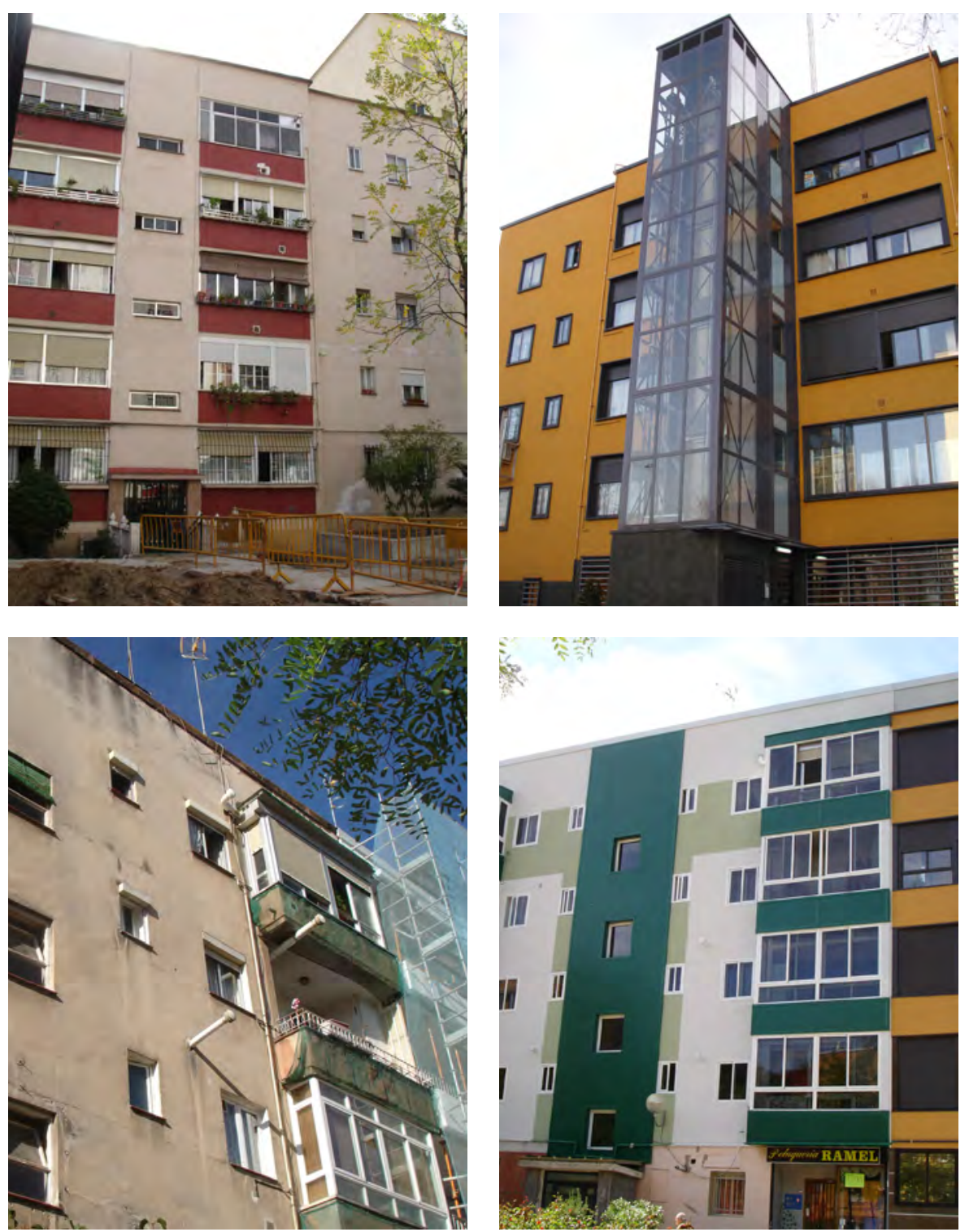
aire acondicionado, los tendederos y otros elementos fijados a las fachadas. La pérdida de la pureza compositiva puede ser discutible pero el tratamiento unitario, la voluntad repetitiva y el uso de este elemento como instrumento del nuevo lenguaje arquitectónico pueden estar en sintonía con los planteamientos industriales, repetitivos y seriados señalados anteriormente. Los cubrevistas dan un orden a la fachada que había sido perdido por la aparición de numerosos elementos ajenos al edificio.

Sin embargo, gran parte de la actuación se fundamentó en resolver los problemas derivados de la falta de conservación y mantenimiento del espacio
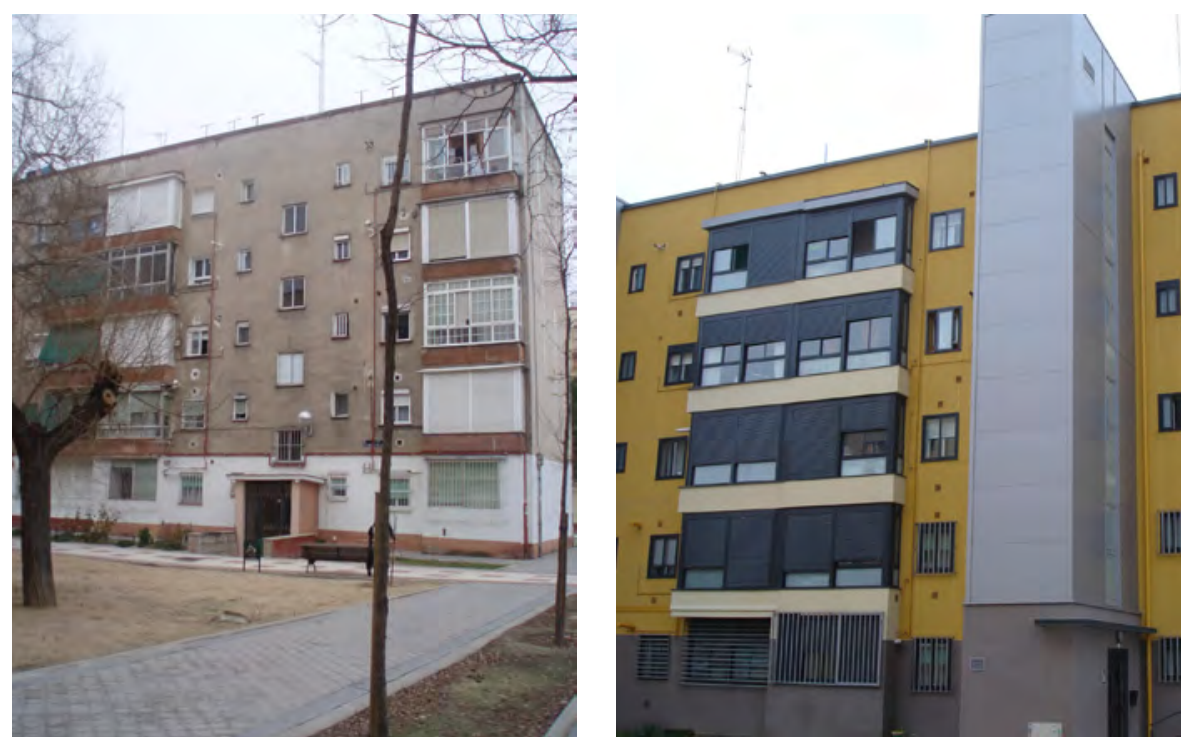

Estado previo del edificio de La Canción del Olvido 21 (arriba izquierda) y del estado reformado (arriba derecha). Estado previo del edificio de El Manojo de rosas 4 (abajo izquierda) y del estado reformado (abajo derecha)
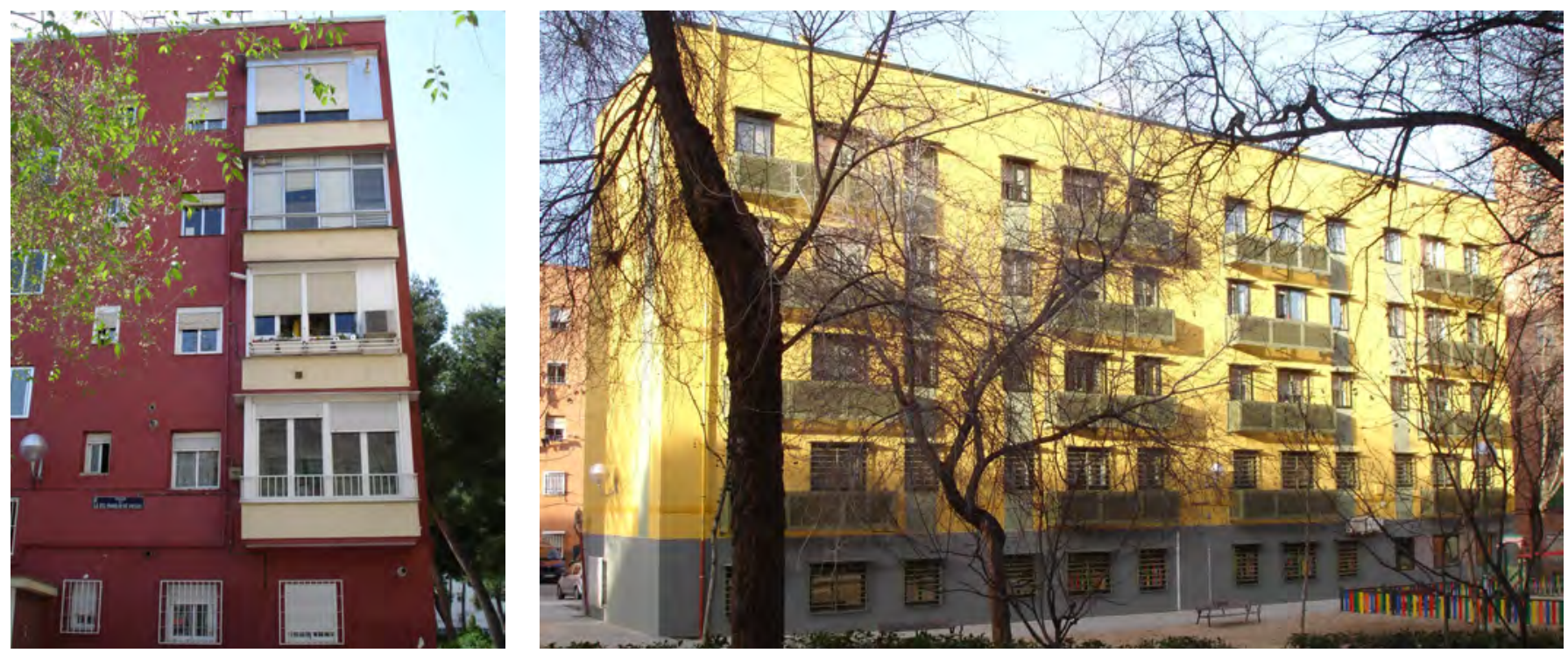
Taller de participación vecinal para la toma de decisiones
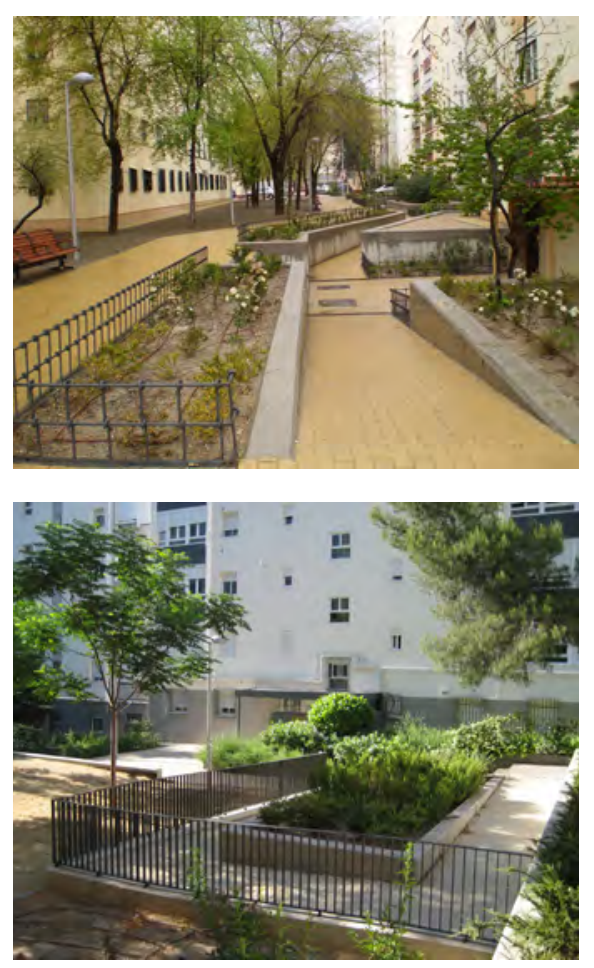

Rehabilitación urbana y solución de la accesibilidad a portales y terrazas. Calles Manojo de Rosas y Pan y Toros

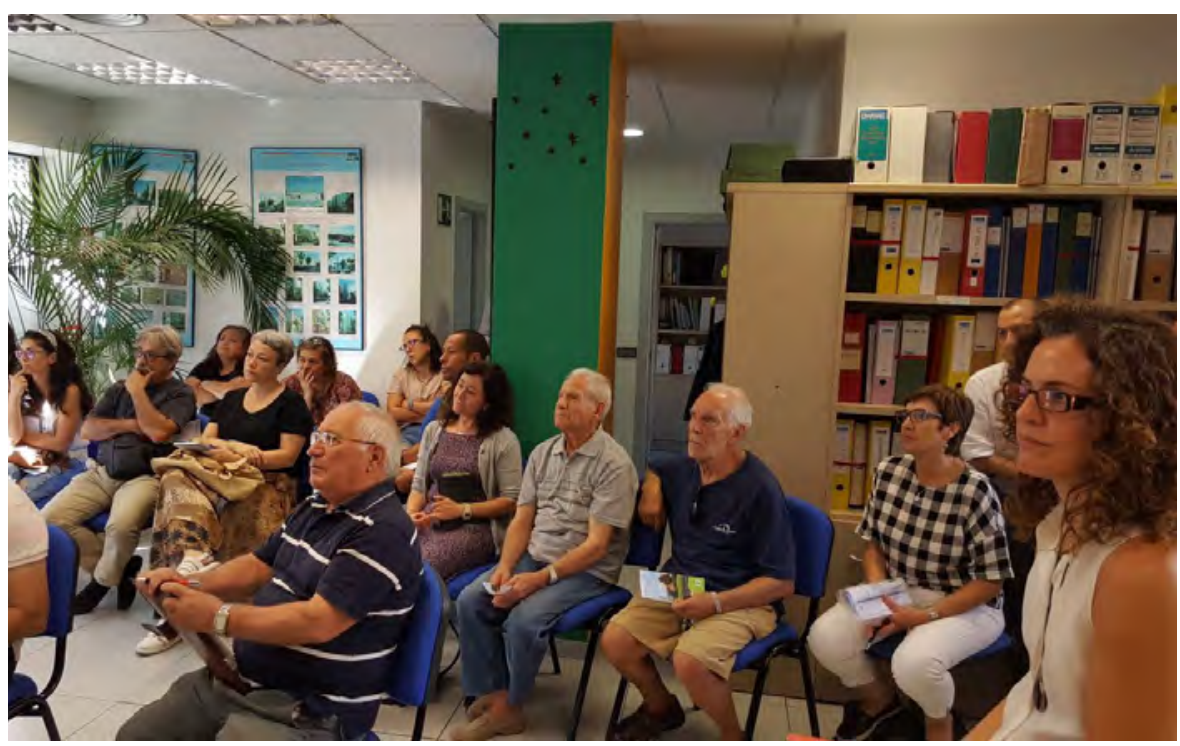

libre y que habían hecho que gran parte de ellos fueran conservados por la población. Esto provocó en el barrio un sentimiento de apropiación del espacio público y la identificación de la población con el lugar, secuencia esencial del "apego al lugar" del que ya hemos hablado.

Este hecho fue determinante en la participación de ASVEYCO y, en general, de la población residente, en el proceso de redacción de los proyectos de urbanización, no solo formando parte de la toma de decisiones en cuanto a las fases a desarrollar, sino incluso en el diseño, participando de la toma de decisiones de la elección de la vegetación, la localización del mobiliario y los usos del espacio. De esta manera, la rehabilitación ha dado un protagonismo especial al pasado de la población, sus costumbres y sentido de apropiación del espacio.

Es así como podemos entender que se ha llevado a cabo una protección ambiental del barrio derivada de la labor de vigilancia de los proyectos y la respuesta de los vecinos como parte de aceptación del resultado.

La rehabilitación del espacio público se fundamentó en resolver gran parte de los problemas de accesibilidad existentes, incorporar nuevas zonas vegetales y reducir, en general, el impacto del vehículo en un barrio de indudable calidad ambiental y que estaba absorbido por el exceso y descontrol de los aparcamientos. La unidad de actuación, a través del reconocible muro de hormigón y del adoquinado dorado, ha dotado al barrio de una imagen unitaria que ha solventado la gran fragmentación existente dado por años de descoordinación y de falta de una adecuada conservación de los generosos espacios libres. 


\section{CONCLUSIONES PARA FUTURAS INTERVENCIONES EN BARRIOS CON VALORES PATRIMONIALES CONTEMPORÁNEOS}

La rehabilitación de Ciudad de los Ángeles no ha considerado los aspectos patrimoniales como objetivos prioritarios a los que atender de modo explícito. Sin embargo, lo que podríamos considerar la "protección ambiental" del barrio se mantiene debido a la existencia de un consenso sobre "lo razonable" entre todos los agentes implicados.

Así, en lo que se refiere a los proyectos de rehabilitación de los arquitectos participantes y su control desde la administración, las propuestas intentan incorporar elementos de mejora de la habitabilidad como ascensores, tratamiento de huecos, reorganización de las instalaciones vistas en fachada, etc. Para estas rehabilitaciones se establecen unos criterios de intervención desde la gestión municipal que define el marco de esta "protección ambiental", de tal manera que se ha buscado la coherencia en la unidad del tratamiento de la fachada, incluso cuando se incorporan los ascensores, al delimitar áreas de movimiento determinadas para cada tipología.

Por otro lado, los vecinos sienten que siguen viviendo en su barrio y los cambios no son rechazados porque no transgreden su imaginario colectivo sobre lo que el barrio era, es decir, sobre sus valores patrimoniales. El "apego al lugar" sigue intacto, si no reforzado. Las innovaciones formales y espaciales no se entienden como ataques, sino como elementos de mejora, nunca como atentados contra la identidad colectiva de su barrio.

En el tratamiento de los espacios públicos queda patente esa intención de protección ambiental al haberse mantenido las trazas originales, recuperando las calles estructurantes, algo que permite reforzar la legibilidad del espacio original y reforzar los usos comerciales y los equipamientos que forman los espacios centrales del barrio. La mejora de la estancialidad y la movilidad peatonal en el barrio ha permitido reforzar los usos del espacio público contribuyendo a la producción de la identidad colectiva y el apego al lugar ${ }^{15}$.

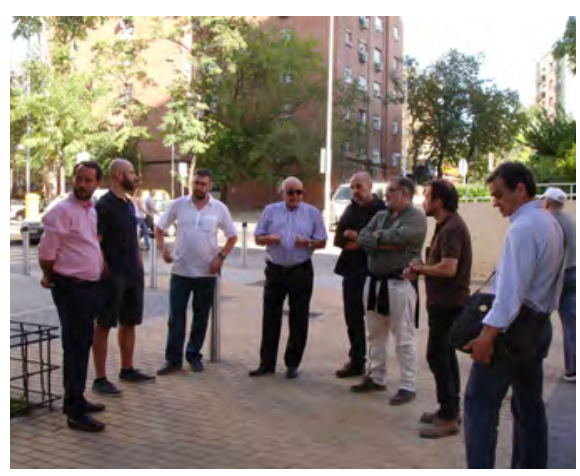

Taller técnico con vecinos. Visita a las rehabilitaciones ya ejecutadas

15

Sin menoscabo de los aciertos encontrados en el proceso de rehabilitación, sí se pueden identificar algunas deficiencias o errores que son útiles para reflexionar sobre futuras actuaciones en barrios con estas características. Así, a pesar de estos criterios aportados desde la gestión pública y que se negociaban con los arquitectos que acometían la rehabilitación, al no ser normativos, se detectan algunas malas prácticas puntuales referidas fundamentalmente a la falta de coordinación en el tratamiento de fachadas entre dos portales de un mismo bloque, el uso de materiales inadecuados y la sustitución y supresión de elementos valiosos del espacio público como las marquesinas de hormigón y las pérgolas que daban unidad compositiva entre los bloques lineales residenciales y los bloques comerciales. 


\section{BIBLIOGRAFÍA}

- Bourdieu P. (1980) Le capital social: notes provisoires. Actes de la Recherche en Sciences Sociales, vol. 31, pp. 2-3

- Coleman, J.S. (2000) Social capital in the Creation of Human Capital. En: Lesser, Eric L. (ed.) Knowledge and Social Capital. Foundations and Applications. Boston: Butterworth Heineman

- Córdoba Hernández, R., Carmona Mateos, F., Morcillo Álvarez, D., Román López, E., y Sánchez-Guevara, C. (2020) Área de Regeneración Urbana. Ciudad de los Ángeles. Ciudad y Territorio: Estudios territoriales, vol. LII, n. ${ }^{0}$ 204, pp. 349-356. Disponible en: https://doi. org/10.37230/СуTET.2020.204.11 [Consulta: 11/06/2021]

- Curley, A.M. (2010) Relocating the poor: social capital and neighborhood resources. Journal of urban affairs, n. ${ }^{\circ}$ 32, pp. 79-103. Disponible en: https://doi.org/10.1111/ j.1467-9906.2009.00475.x [Consulta: 11/06/2021]

- Edwards, B. y Foley, M. (1999) Is it time to disinvest in social capital? Journal of Public Policy, vol. 19, n. ${ }^{\circ} 2$, pp. 141-173

- Elvira Peña, J. (2003) Secundino Zuazo y la ciudad de Los Ángeles. En: Sambricio, C. (coord.) Un siglo de vivienda social: 1903-2003 [Catálogo de la exposición organizada por el Ministerio de Fomento, el Ayuntamiento de Madrid-EMV y el Consejo Económico y Social (CES)] Madrid: Nerea, vol. 2, tomo 2, pp. 92-93

- Fine, B. (2001) Social capital versus social theory: political economy and social science at the turn of the millennium. London: Routledge

- Flint, J. y Kearns, A. (2006) Housing, neighbourhood renewal and social capital: the case of registered social landlords in Scotland. European Journal of Housing Policy, vol. 6, n. $^{\circ} 1$, pp. $31-54$

- Forrest, R. y Kearns, A. (2001) Social cohesion, social capital and the neighbourhood. Urban Studies, vol. 38, n. $^{\circ}$ 12, pp. 2125-2143

- González González, F.J. y Stouten, P. (2014) Purper en Amber, Poptahof, Delft. Ciudad y Territorio, Estudios Territoriales, vol. XLVI, n. ${ }^{\circ} 179$, pp. 175-181. Disponible en: https://recyt.fecyt.es/index.php/CyTET/article/view/76298 [Consulta: 10/06/2021]

- González González, F.J. (2017) Capital social y diversidad articulada en el espacio público. Influencia de las condiciones morfológicas y funcionales de las plazas en el refuerzo de la cohesión social en barrios de Madrid con procesos de regeneración urbana. Tesis doctoral inédita. Universidad Europea de Madrid. Disponible en: http://hdl. handle.net/11268/6982 [Consulta: 11/06/2021]

- González González, F.J. (2019) Confianza y capital social en la regeneración urbana de barrios y conjuntos de viviendas. En: López-Mesa, B. (coord.) Nuevos enfoques en la rehabilitación energética de la vivienda hacia la convergencia europea: La vivienda social en Zaragoza, 1939-1979, vol. 2. Zaragoza: Prensas de la Universidad de Zaragoza, pp. 281-294 (Cátedra Zaragoza Vivienda). Disponible en: https://catedrazaragozavivienda. files.wordpress.com/2019/01/3.4-generaci\%C3\%B3nconfianza.pdf [Consulta: 11/06/2021]

- Gutiérrez Marcos, J. y Da Rocha, O. (2007) Villaverde Usera. En: Lasso de la Vega, M. (coord.) Arquitectura de Madrid. Periferia. Madrid: Fundación COAM, vol. 3, pp. 567-568

- Hudson, A. (2012) Does residential access to public space contribute to higher levels of social capital? A case study in Southern Oregon. SOU McNair Scholars Journal, vol. 8

- Kearns, A. (2004) Social capital, regeneration and urban policy. Centre for Neighbourhood-CNR Paper 15

- Kleinhans, R., Priemus, H. y Engbersen, G. (2007) Understanding social capital in recently restructured urban neighbourhoods: Two case studies in Rotterdam. Urban Studies, vol. 44, n. ${ }^{\circ}$ 5-6, pp. 1069-1091

- Lasheras, C. y Martín Moratalla, M.A. (1987) Ciudad de los Ángeles. En: Madrid proyecto Madrid 19831987. Madrid: Área de Urbanismo e Infraestructuras, Ayuntamiento de Madrid

- Lasso de la Vega, M. (2008) El Instituto Nacional de la Vivienda de Federico Mayo y José Fonseca. En: Sambricio, C. y Sánchez Lampreave, R. (ed.) 100 años de intervención pública en la vivienda y la ciudad. Madrid: Asociación Española de Promotores Públicos de Vivienda y Suelo AVS, pp. 43-72

- Ley 84/1961, de 23 de diciembre, sobre Plan Nacional de la Vivienda para el periodo 1961-1976. Boletín Oficial del Estado, n. ${ }^{\circ} 310$, de 28 de diciembre de 1961. Disponible en: https://www.boe.es/buscar/doc. php?id=BOE-A-1961-23794 [Consulta: 10/06/2021]

- Lin, N. (2001) Social capital. A theory of social structure and action. Cambridge: Cambridge University Press (Structural analysis in the social sciences; 19)

- Maure Rubio, L. (1987) Secundino Zuazo, arquitecto. Madrid: Colegio Oficial de Arquitectos de Madrid

- Morcillo Álvarez, D., Arjona Martín, C. y Martín Acosta, N. (2016) Recuperando la periferia. La rehabilitación energética de Ciudad de los Ángeles en Madrid. Ciudad y territorio: Estudios territoriales, vol. XLVIII, n. ${ }^{\circ}$ 187, pp. 57-76. Disponible en: https://apps.fomento.gob.es/CVP/ handlers/pdfhandler.ashx?idpub=BP1015 [Consulta: 11/06/ 2021] 
- Portes, A. (1998) Social Capital: Its origins and application in Modern Soiciology. Annual review of Sociology, n. ${ }^{0} 24$, pp. 1-24

- Premius, H. (2008) Vivienda Social y renovación urbana en Holanda. En: Leal, J. (de.) Rehabilitación de viviendas y renovación urbana en las grandes ciudades europeas. Madrid: Ayuntamiento de Madrid

- Putnam, R.D. (2000) Bowling Alone: The Collapse and Revival of American Community. New York: Simon \& Schuster

- Río Lafuente, I. (Del) (1984) Industria y residencia en Villaverde: génesis de un paisaje urbano en la periferia de Madrid. Madrid: Universidad Complutense

- Ripoll Gómez, C. y Ripoll Tolosana, V. (2014). La arquitectura del ocio en Manuel Muñoz Monasterio. En: Couceiro Núñez, T. (coord.) Actas del I Congreso Pioneros de la Arquitectura Moderna Española: Vigencia de su pensamiento y obra. Madrid: Fundación Alejandro de la Sota, pp. 813-822

- Roberts, P. y Sykes, H. (ed.) (2000) Urban Regeneration. A Handbook. London: Sage

- Roch Peña, F. (2008) La deriva patológica del espacio social en el modelo inmobiliario neoliberal madrileño. $X$ Coloquio Internacional de Geocrítica. Barcelona: Univer sidad de Barcelona

- Sambricio, C. (1999) La vivienda en Madrid, de 1939 al Plan de Urgencia Social, en 1959. En: La vivienda en Madrid en la década de los cincuenta: el Plan de Urgencia Social. Madrid: Electa, pp. 13-84

- Stouten, P.L. (2010) Changing contexts in urban regeneration: 30 years of modernisation in Rotterdam. Amsterdam: Techne Press

- Svendsen, G.L.H. (2010) Socio-spatial Planning in the Creation of Bridging Social Capital: The Importance of Multifunctional Centers for Intergroup Networks and Integration. International Journal of Social Inquiry, vol. 3, n. ${ }^{\circ} 2$, pp. $45-73$ 


\section{El Plan Medellín Centro y las buenas prácticas en la gestión integrada de la ciudad}

Ángel Luis Fernández Muñoz | Àrea de Investigación, Escuela Universitaria de Diseño, Innovación y Tecnología

URL de la contribución <www.iaph.es/revistaph/index.php/revistaph/article/view/4940>

\section{RESUMEN}

La transformación urbana de la ciudad de Medellín ha sido contemplada como un referente internacional de éxito. Pero, dada la situación social y económica de partida, con frecuencia la atención se ha dirigido a los espectaculares resultados obtenidos en la ordenación y revitalización de las "comunas" populares que rodean la ciudad y son el principal asentamiento del estallido de población sufrido por la urbe a partir de los años 80. Sin embargo, la última revisión del Plan de Ordenación Territorial (POT) abordó también un capítulo esencial de la aglomeración urbana: el reordenamiento y recuperación de su "centro tradicional". En la estructura de Medellín, el centro de la gran metrópoli que configuran los diversos municipios del valle de Aburrá es una extensa franja lineal asociada al río Medellín que contiene una gran variedad de tejidos muy degradados, entre los que destaca un conjunto de alta calidad urbana. Este conjunto constituye aún la referencia de centralidad y memoria -a la par que de servicios- de los habitantes de la ciudad, pese a la metamorfosis de usos y el abandono sufridos. El Plan Especial, diseñado inicialmente como un proyecto en sí mismo, e integrado después en la estructura general del POT, abordó el reequilibrio funcional del área, la recomposición de su estructura urbana, la salvaguarda del patrimonio arquitectónico antiguo y moderno y una reorganización social que diera lugar a la reocupación del abandono residencial sufrido. Todo ello a través de los singulares e innovadores procesos de regeneración que han caracterizado la recuperación de la ciudad en la última década.

\section{Palabras clave}

Espacios públicos | Centros históricos | Medellín (Colombia) | Planeamiento urbanístico | Proyecto urbano | Resiliencia | Urbanismo social | 


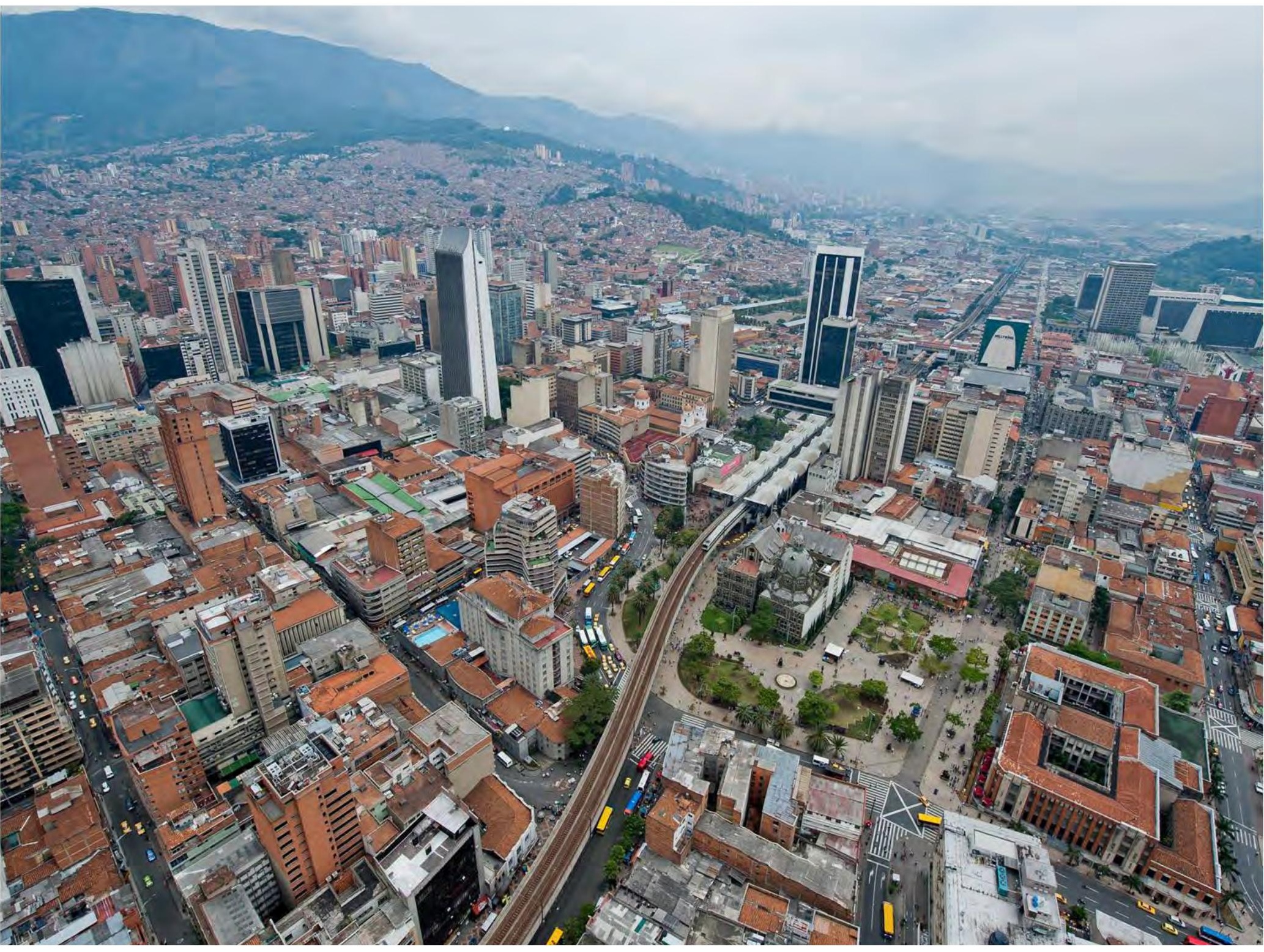

Vista del centro de Medellín | foto Alcaldía de Medellín. Dpto. de Planeación 


\section{INTRODUCCIÓN}

El singular emplazamiento geográfico de Medellín, en el fondo del privilegiado vallé de Aburrá, explica en gran medida su disposición urbana y su evolución.

El espacio del río Medellín, que recorre el valle, tiene una significación especial en la configuración de la ciudad: es, a la vez, eje viario principal, soporte de comunicaciones interestatales (albergó en el pasado una línea ferroviaria), espacio industrial, logístico y, recientemente, espacio recreativo con la operación en marcha de transformación de su entorno (Proyecto Medellín Río).

El primer crecimiento fue fruto de un gran impulso económico de la ciudad, cuyo esplendor todavía es patente en el hoy decaído centro urbano, sus calles, plazas, avenidas y arquitectura (Toro 1988). Sin embargo, a partir de 1970 la ciudad se sume en una espiral de violencia que le hará convertirse en una las ciudades más peligrosas del mundo (Vargas Velázquez y García Pinzón 2008). El consiguiente desempleo, generado por el decrecimiento económico, provocó una situación de desequilibrio y desigualdad social, de la que la ciudad solo ahora empieza a recuperarse.

Sin embargo, tras la desaparición del principal jefe de la insurgencia, Pablo Escobar, y la posterior llegada de Sergio Fajardo a la alcaldía de la ciudad, se produce un sorprendente impulso mediante mecanismos de gestión y de

Vista de Medellín | foto Alcaldía de Medellín, Dpto de Planeación

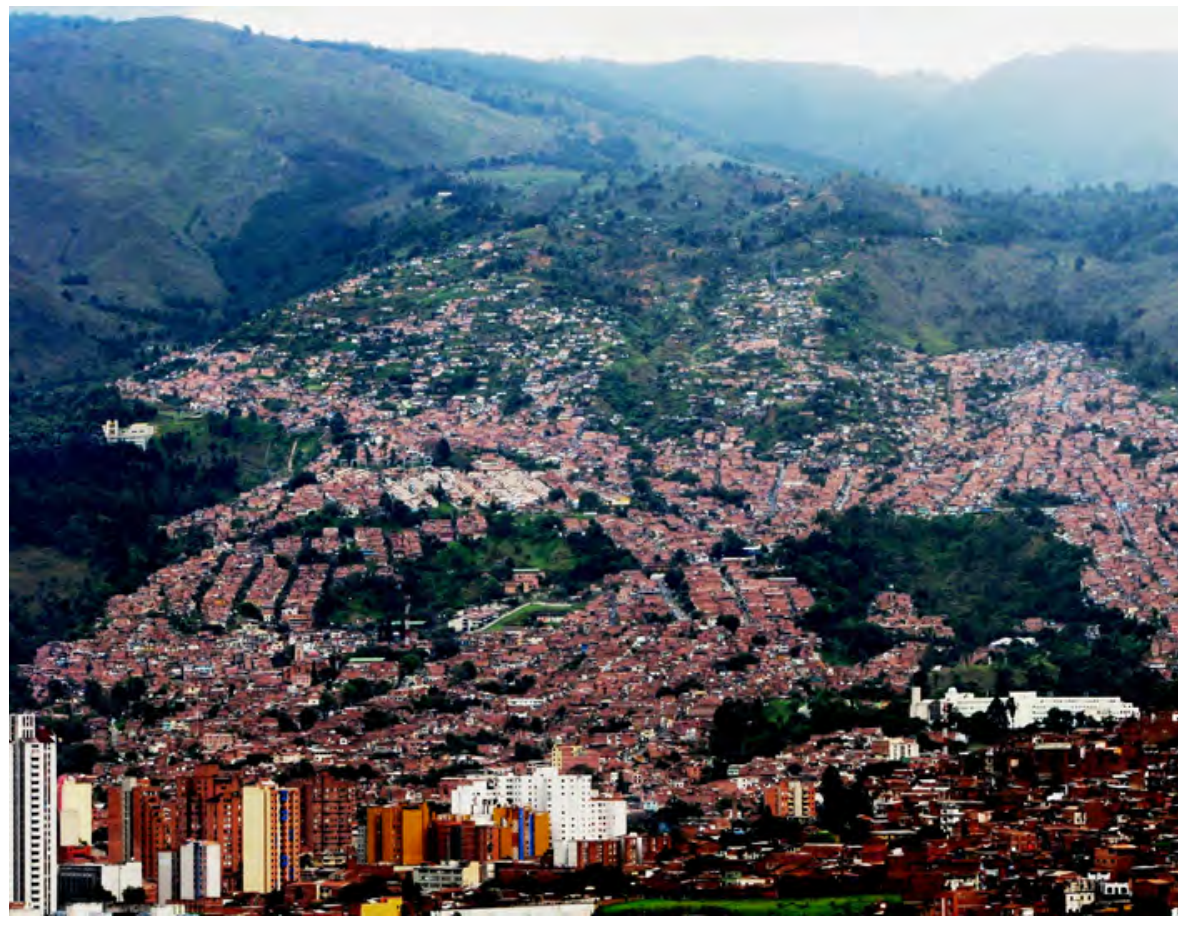


transformación, todos de diseño propio (Pérez Jaramillo 2012) y en los que políticos y ciudadanía, dando un extraordinario ejemplo de resiliencia, llevan a Medellín a convertirse en un modelo mundial de gestión urbanística y social.

Hoy Medellín es la segunda ciudad de Colombia, en permanente y estimulante competencia con Bogotá, superándola en el músculo mostrado por su modelo de desarrollo. Un modelo, el llamado "urbanismo social", que cuenta con la implicación permanente de la ciudadanía (Echeverri 2016).

\section{ANTECEDENTES DEL PLANEAMIENTO DE MEDELLÍN}

La propuesta contenida en el Plan Piloto para Medellín de José Luis Sert y Paul Lester Wiener (1950), de creación de una nueva centralidad, situada al sur del antiguo centro histórico, adyacente a él y al río -La Alpujarra- tuvo pronto una acogida favorable por parte de los responsables políticos. Pero su desarrollo supuso dejar sin contenido ni función definida al antiguo centro. Si en varios casos ello generó la aparición de notables arquitecturas de la época, también destruyó el carácter de la vieja ciudad colonial hasta entonces bien conservado.

La primera de las escuelas de arquitectura de la ciudad, la Facultad de Arquitectura de la Universidad Pontificia Bolivariana, en colaboración con el Laboratorio de Urbanismo de Barcelona de Manuel de Solá Morales, crea en 1996 el Laboratorio de Arquitectura y Urbanismo. Se investiga en nuevos instrumentos y se llevan a cabo algunas experiencias en el área central de la ciudad (Parque de los Pies Descalzos, Parque de los Deseos, transformación de la plaza Botero, reacondicionamiento de la antigua alcaldía como Museo de Antioquia), con el proyecto urbano como instrumento capaz de transformar la realidad de la ciudad.

A partir de 2004, los llamados Proyectos Urbanos Integrales (PUI), un conjunto de actuaciones para la inserción en lugares conflictivos de la ciudad de elementos revitalizadores de la actividad urbana y del tejido social que la acompaña, impulsarán la creación de dotaciones de alta calidad y, junto con un amplio paquete de medidas sociales de acompañamiento, materializarán el "urbanismo social" (EDU 2006, 2014).

Sin embargo, al poco tiempo, el papel territorial de Medellín es también abordado de modo casi simultáneo. La condición de centro económico, político y social que la ciudad asume respecto al área del valle de Aburrá, es articulada en 2006 por medio del modelo de ocupación metropolitano para el Valle de Aburrá (Área Metropolitana del Valle de Aburrá 2006, 2011), que será revisado en el BIO 2030 Plan Director Medellín, Valle de Aburrá. 

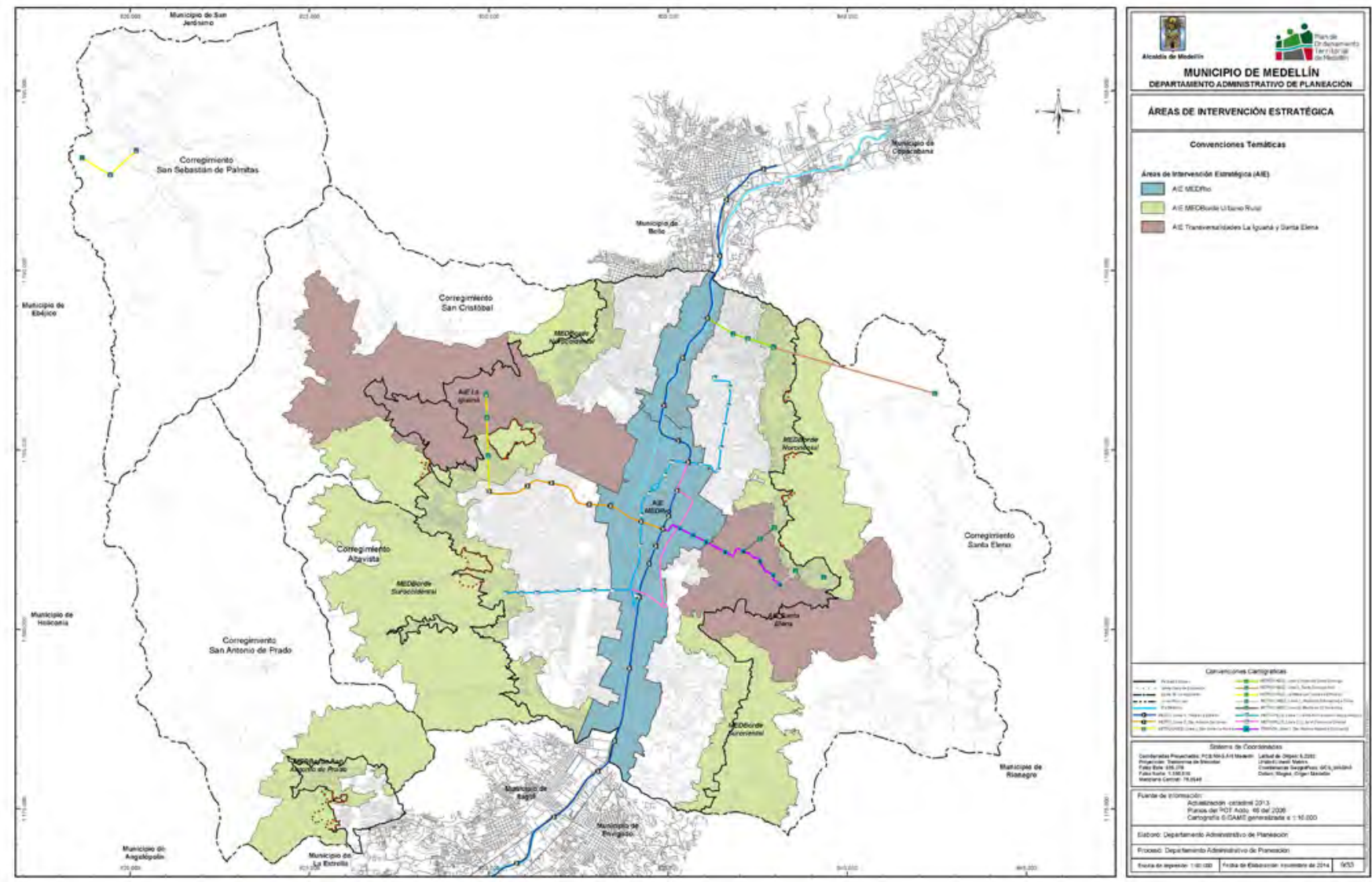

POT 2014. Áreas de Intervención Estratégica

I plano Alcaldía de Medellín. Dpto. de Planeación

\section{INNOVACIONES EN EL PLANTEAMIENTO DEL POT. EL MARCO DEL PLAN DEL CENTRO}

A partir de una combinación entre las innovaciones sugeridas por el antes mencionado Laboratorio de Arquitectura y Urbanismo y los planteamientos legales y normativos de un instrumento urbanístico oficial, se redacta la Revisión del Plan de Ordenamiento Territorial de Medellín (POT), aprobada en 2014 (Pérez Jaramillo et ál. 2015). El objetivo era operar mediante proyectos de actuación específica para áreas concretas, identificadas en la estructura del modelo de ocupación territorial como Áreas de Intervención Estratégica, de modo que fuera posible resolver sus necesidades estructurales organizando sus territorios mediante acciones estratégicas globales, que luego se desarrollaban en el interior de los propios proyectos a través de acciones muy concretas a las que el POT daría rango de determinaciones del planeamiento. Un plan concebido como un "proyecto de proyectos" en el que la articulación entre grandes y pequeñas escalas está garantizada por medio de un trabajo exhaustivo de vinculación de las determinaciones normativas (Alcaldía de Medellín. Departamento Administrativo de Planeación 2014). 


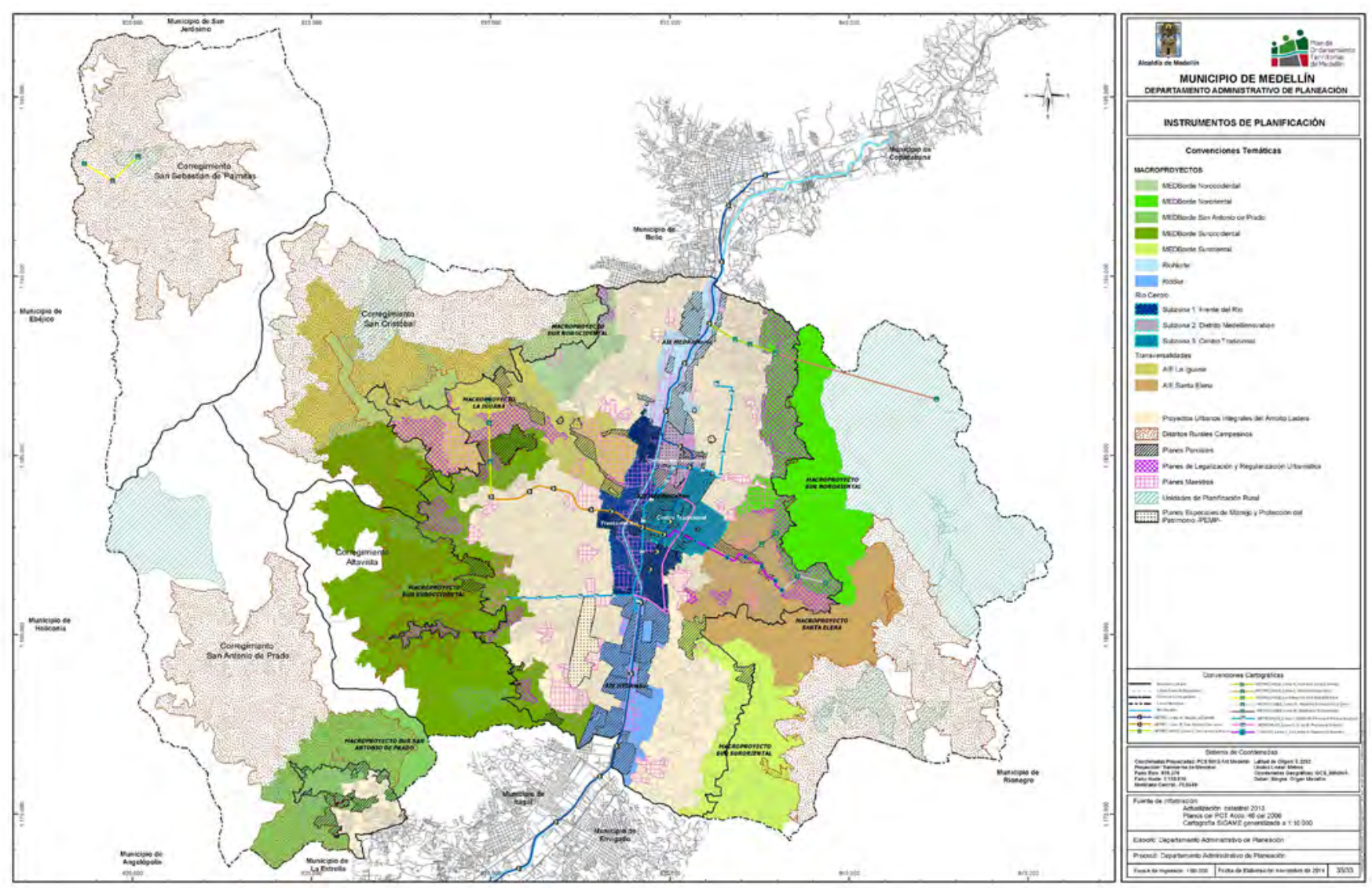

POT 2014. Instrumentos de Planificación | plano Alcaldía de Medellín. Dpto. de Planeación

El proyecto para el Área de Intervención Estratégica Medellín Río se desarrolla a través de tres grandes macroproyectos, denominados Río Norte, Río Centro y Río Sur. Es en cada uno de estos donde se produce el encuentro entre la normativa general del POT y unos planes de desarrollo que establecen determinaciones muy precisas sobre los territorios delimitados. En el marco del macroproyecto Río Centro es donde se enclava la denominada subzona Centro Tradicional, cuyas determinaciones para espacios de sustitución o desarrollo de edificaciones se establecen mediante planes parciales y, para el resto de la subzona, a través del Plan Especial de Manejo y Protección del Centro Tradicional (PEMPCT).

\section{LA SITUACIÓN PREVIA AL PLAN DEL CENTRO}

La primera dificultad del proceso seguido fue identificar cuál era el espacio final a considerar como "centro tradicional" de la ciudad, puesto que la evolución de Medellín había desarrollado un denso tejido central procedente de diversas épocas. El apoyo fundamental fue la cartografía histórica, 
Mapa de la trama de llenos y vacíos del centro tradicional | plano Alcaldía de Medellín. Dpto. de Planeación pues hasta aproximadamente 1950 la ciudad era, básicamente, un espacio bien definido constituido por lo que hoy llamamos "centro". Aunque Medellín había crecido hacia el norte y el este, conservaba bien su entorno fundacional, y esa estructura era claramente identificable en su tejido urbano. Una estructura que se mantuvo bien conservada hasta que el Plan Piloto decidió trasladar todo el conjunto institucional más allá de lo que hoy se denomina la avenida San Juan, creando el "Centro Cívico" de La Alpujarra. Como se ha comentado anteriormente, el vaciado de elementos representativos institucionales supuso el primer golpe para el proceso de degeneración de la hasta entonces bien conservada estructura social y urbana de la ciudad. La

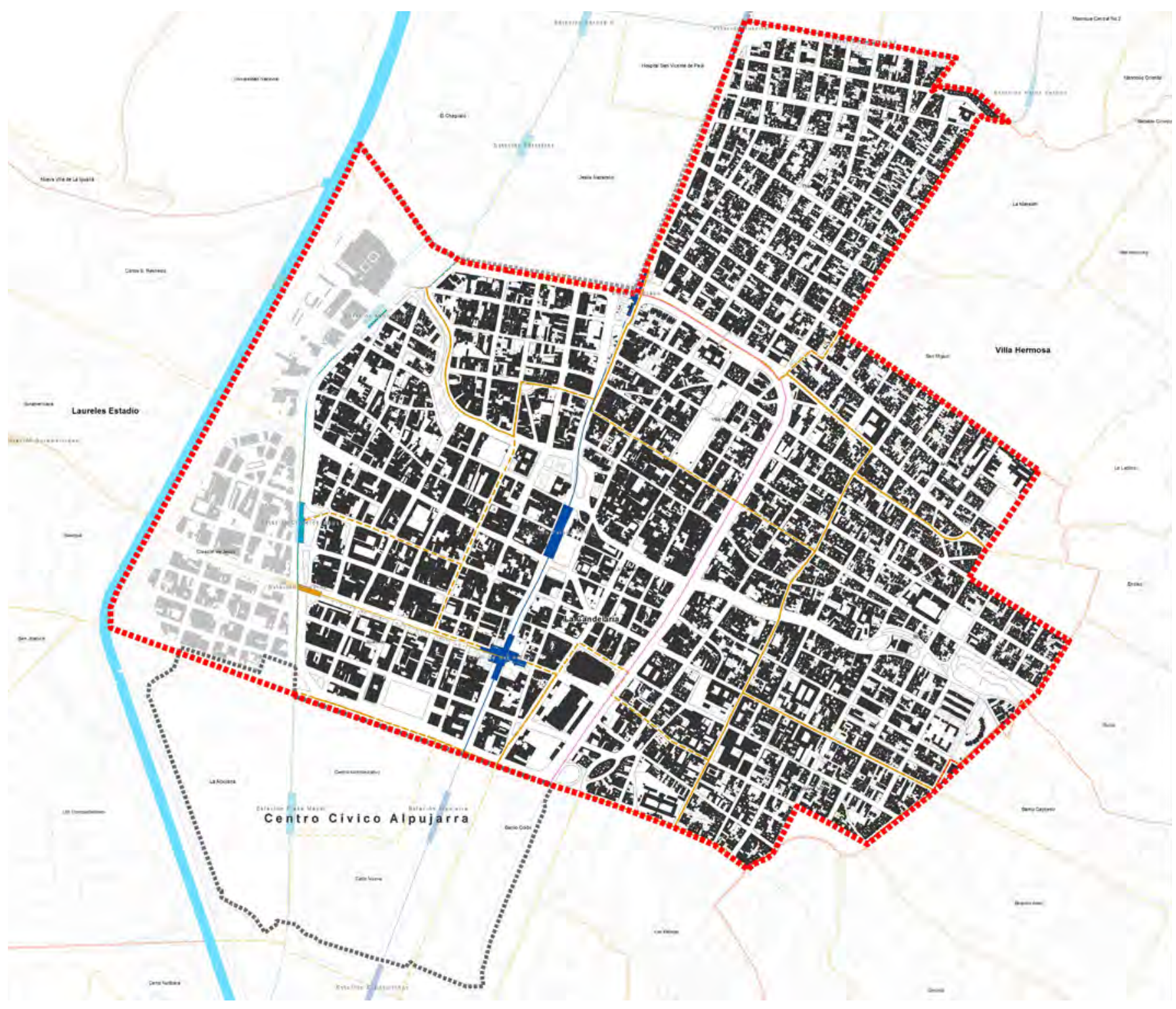


voluntad de creación de un área que concentrara las sedes representativas y administrativas -según un modelo luego bien desarrollado en tantas ciudades- produjo la pérdida de un contenido fundamental para un conjunto urbano hasta entonces bien equilibrado. Ese abandono institucional llevó aparejada la pérdida de la población que había vivido a la sombra del prestigio del área central. En el sector terciario, los grandes conjuntos edificatorios en torno a la plaza Botero y a la avenida La Playa comenzaron a ser abandonados al constituirse La Alpujarra en un motor de desarrollo hacia el sur, donde muchas compañías buscarían nuevas y renovadas sedes representativas. Este fenómeno también alcanzó al ámbito residencial de la ciudad, donde comenzó una renovación edificatoria que suprimió buena parte de las construcciones históricas, surgiendo sobre ellas grandes construcciones que intentaban seguir el modelo de desarrollo "moderno" iniciado por el nuevo centro administrativo.

Todo ello destruyó el equilibrio histórico del espacio central, abandonado ahora por muchos de sus residentes y sin encontrar reemplazo para los mismos. El Centro se convirtió en un área con fortísimos desequilibrios. Un espacio que mantiene hasta nuestros días una extraordinaria vitalidad durante el día, conservando su atractivo comercial, pero que se convierte en un ámbito mayoritariamente abandonado una vez finalizado el horario de venta al público. Un espacio, por tanto, predispuesto para su re-ocupación por colectivos y usos que aprovechan tal abandono para el desarrollo de las actividades marginales propias de las grandes metrópolis.

El "centro tradicional" es hoy un espacio claramente identificable en sus límites N (Avenida Oriental), S (Avenida San Juan) y O (Avenida del Ferrocarril), y menos claro al E, donde su límite se establece por el final de las estructuras urbanas vinculadas al último tramo de la avenida La Playa. Junto a ello se ha incluido en la delimitación final del Plan, por razones de contigüidad y de similitud en su valor patrimonial, el barrio de Prado, al norte de la avenida Oriental y articulado en torno a su eje central, la avenida Palacé.

Los estudios exploratorios de la situación de ese territorio, desarrollados por la Alcaldía de la ciudad, identificaban de manera pormenorizada una serie de problemas que son el desarrollo de las líneas generales que hemos expuesto más arriba.

El centro era percibido por los ciudadanos como un espacio fundamental, que conservaba su atractivo gracias a una concentración en él de la actividad comercial de la ciudad y de la región. Pero se había desdibujado su papel como espacio de representación, al carecer de otra actividad que no fuera la comercial, estando infrautilizada su aún visible calidad arquitectónica y urbana. 
No obstante, se había producido una importante pérdida del patrimonio inmueble y urbano del conjunto, ante una sociedad que, focalizada en problemas sociales y de supervivencia, no manifestaba especial sensibilidad hacia la sustitución de los viejos inmuebles, apreciando más bien la modernización de los espacios habitables y de servicios.

Pero lo que más llamaba la atención, pese a cualquier otra circunstancia negativa, era la sobreexplotación comercial del área durante el día. Este uso, admirablemente sostenido durante todo el año, con una actividad extrema en las épocas navideñas, tenía sus luces y sombras.

La principal virtud la constituía el reconocimiento de su papel central por parte de toda la sociedad "paisa" sin distinción de grupos sociales. También la configuración de un espacio nodal de dicha actividad en torno a lo que se conoce como "El Hueco", una extensa agrupación de "cuadras" o manzanas en las que la continuidad de la actividad en planta baja, tanto en el interior como en el exterior de las edificaciones, produce un efecto de "gran bazar" que puede llegar a constituir un importante atractivo turístico a futuro.

Del lado negativo, buena parte de esa actividad era realizada por un comercio ambulante escasamente regulado, y esa situación "desregulada" del área permitía la existencia de una población flotante marginal (los llamados habitantes de la calle), cuya actividad diaria fundamental era la supervivencia y cuya presencia interfería y hacía muy difícil el desarrollo de una vida comercial y urbana en general normales, además de generar unos índices de inseguridad y criminalidad muy elevados.

Hay que añadir que, pese a todas las dificultades, en este ámbito central se había desarrollado una importante implantación -con ampliaciones en marcha- de muchos centros educativos universitarios, lo que constituía un impor-

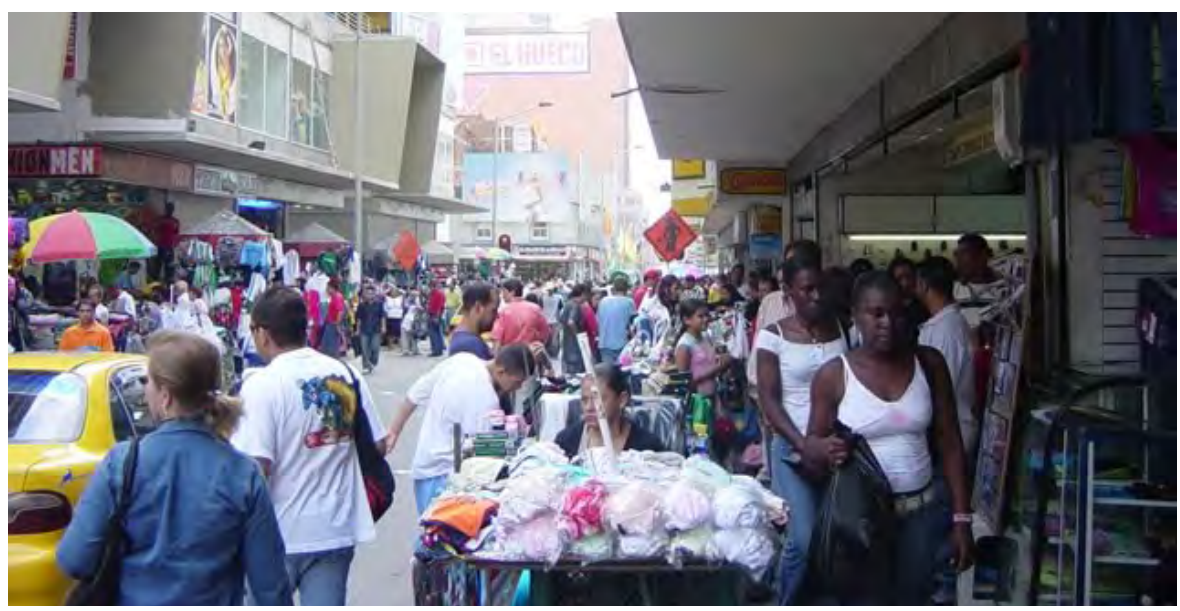




\section{Corredores de Vida}

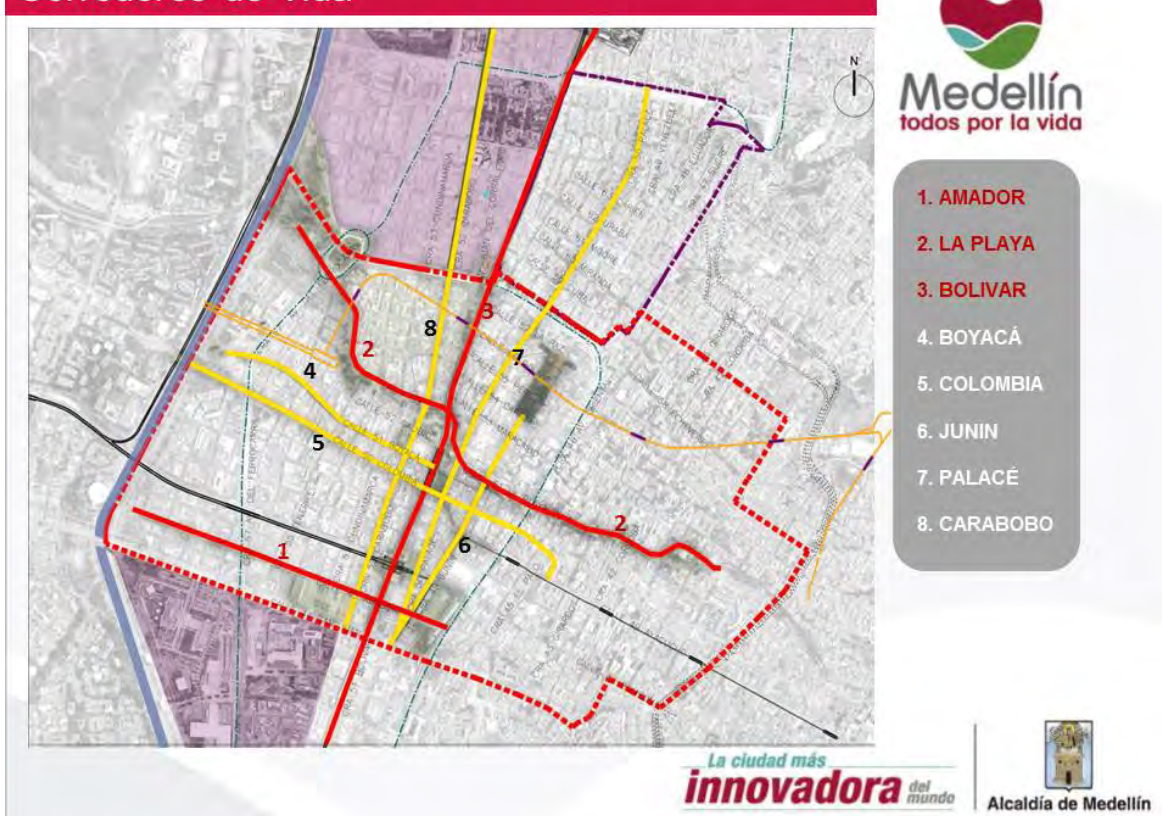

tante potencial de transformación del entorno por parte de población cualificada que, aunque también de modo temporal, acudía diariamente a la zona.

Otra actuación que constituía igualmente un posible instrumento de transformación era la existencia de una red de "mercados" municipales, instalados en un intento de fijar -con poco éxito- al comercio ambulante y que, mediante acciones de ampliación o modificación de sus usos, suponía una reserva estratégica de espacio de titularidad pública para la transformación del centro.

El tráfico de autobuses, vehículos todos de pequeño formato, también con escasa regulación y coordinación, constituía igualmente un elemento de perturbación y contaminación de la actividad diaria, como también lo era la mal organizada flota de taxis.

Pero era el metro el elemento más notable de la realidad física y social del centro (Leibler 2010), cuyo apresurado desarrollo se realizó sin consideración alguna acerca de la repercusión de su trazado, sus estaciones e infraestructuras sobre el centro de la ciudad. Y, así, nos encontramos con unas colosales estructuras de soporte de sus vías y unas enormes y sobredimensionadas estaciones que impactan negativamente sobre espacios representativos.

El resto de la movilidad no estaba sistematizada. La actuación más desarrollada eran los corredores de vida, un intento de articular unos ejes centrales de naturaleza peatonal, donde la actividad comercial tuviera una primera
Plan del Centro de Medellín: "Corredores de Vida" | fuente Alcaldía de Medellín. Dpto. de Planeación 
ordenación regulada. Pero la ausencia de carriles y espacios reservados para bicicletas, de un plan para el tránsito de los vehículos privados, de una ordenación de la importantísima logística que alimenta el gigantesco comercio, manifestaban que en ese capítulo también el centro carecía de una estructura propia.

\section{DESARROLLO Y OBJETIVOS CENTRALES}

Por medio del Programa de corredores de vida, la alcaldía de Medellín pretendía la ordenación de la actividad y la escena urbana en el centro de la ciudad previamente al desarrollo del PEMPCT. Ese programa era la parte más visible de un denominado Programa Bandera de Intervención Integral en el Centro, y se desarrollaba sobre los principales ejes tradicionales de la vieja ciudad. Además se establecía una primera caracterización de usos

Barrios y sectores del centro de Medellín | plano del área.

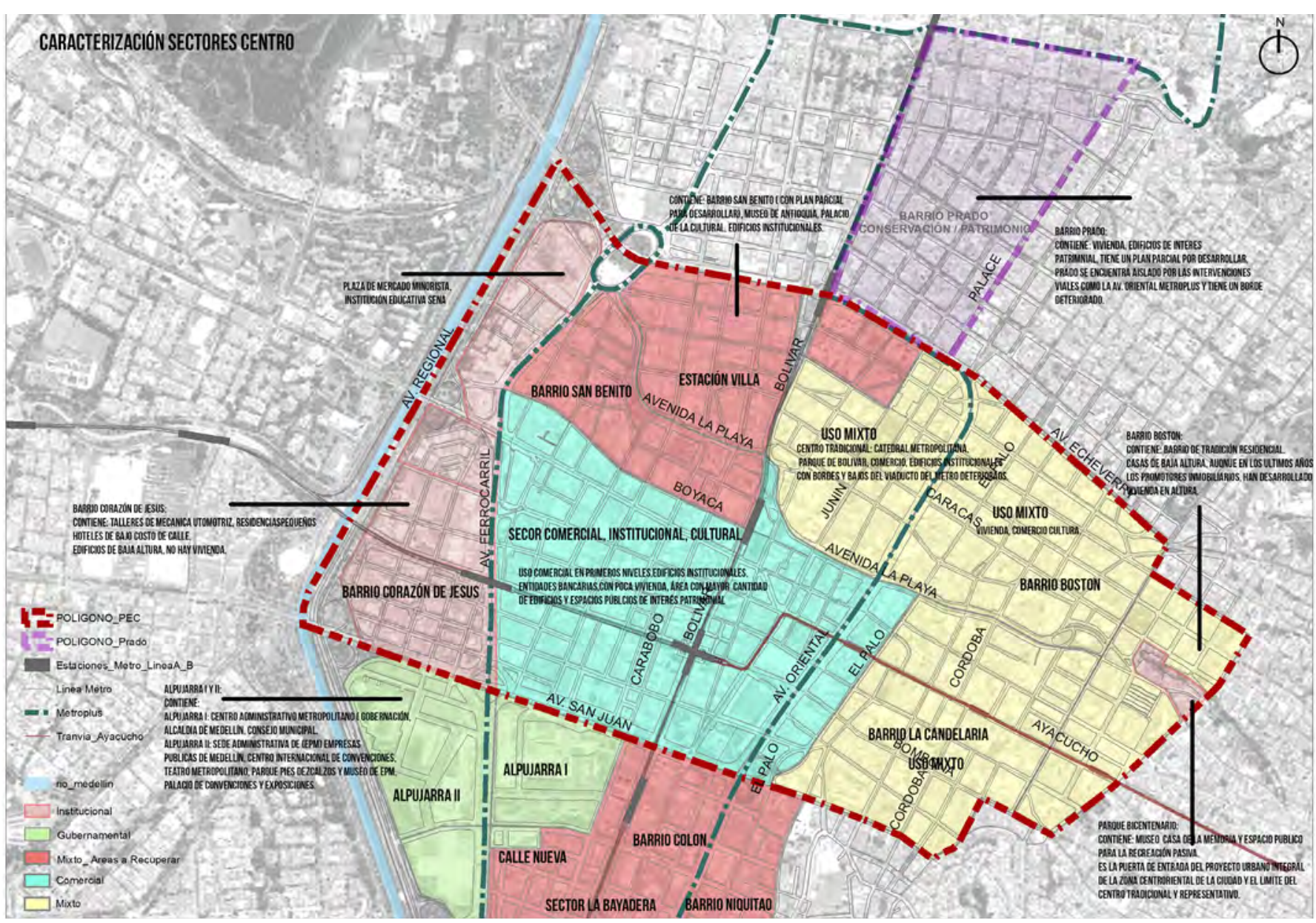


El trabajo del PEMPCT se planteó como una escala reducida de la misma estrategia seguida en el POT: una serie de proyectos urbanos que se integrarían posteriormente bajo el amparo normativo del plan territorial, pero que habrían desarrollado un nivel de precisión correspondiente a un nivel muy superior a las determinaciones habituales de un plan de ordenación urbanística.

Como argumento raíz del Plan Especial se estableció una cuestión previa: ¿cuál sería el papel fundamental del centro respecto del resto de la ciudad? Era esta una definición que debería orientar cualquier acción. Las habituales intervenciones instrumentales para ordenar, rehabilitar y potenciar un uso equilibrado del espacio central debían tener un objetivo global preciso que concretara el modo en que estas cuestione se abordaran. Aunque finalmente no bien respondida esta pregunta, los trabajos se desarrollaron bajo la ambiciosa visión de generar un ámbito para la integración social y la representación identitaria de Medellín.

Como primera herramienta de ordenación se planteó la identificación de una serie de "áreas de identidad homogénea" que compartieran una identificación común a través de su tipo de escena urbana, una estructura social uniforme y, preferentemente, una economía productiva característica. Ello debía permitir presentar al centro como un rico mosaico de espacios diversos, identificados con nitidez por los ciudadanos pero garantizando la articulación de todos en un mismo ámbito de manifiesta centralidad urbana y evitando la aparición de efectos de "frontera" entre unas áreas y otras.

Con tales criterios se establecieron varias áreas concretas y especializadas, con papeles específicos en la estructura final, que se constituían en los verdaderos actores del escenario último, organizándose, a partir de ello, un primer esquema del "Centro Tradicional" que permitió su desarrollo proyectual y normativo posterior, sirviendo de soporte al resto de contenidos que el Plan debería atender (Fernández Muñoz 2014).

Lo primero que el Plan deseaba incorporar era la extraordinaria vitalidad diurna del centro como motor de su futuro reconocimiento. El "bazar" que servía de impulso a la realidad actual debería ser preservado y potenciado, articulándolo con los nuevos elementos de racionalización y equilibrio de usos del área. De este modo, se mantendría la elevada densidad edificatoria, comercial y poblacional, pero incluyéndola dentro de una nueva lógica de tejido urbano, formado ahora por múltiples elementos sociales, económicos y de actividad que garantizaran la normalización y continuidad diaria de su vida urbana, sin renunciar a los novedosos mecanismos de innovación presentes en su espontáneo desarrollo actual.

La estructura física fundamental del centro se definió por medio de la acción sobre sus dos componentes básicos: el espacio público y la edificación. 


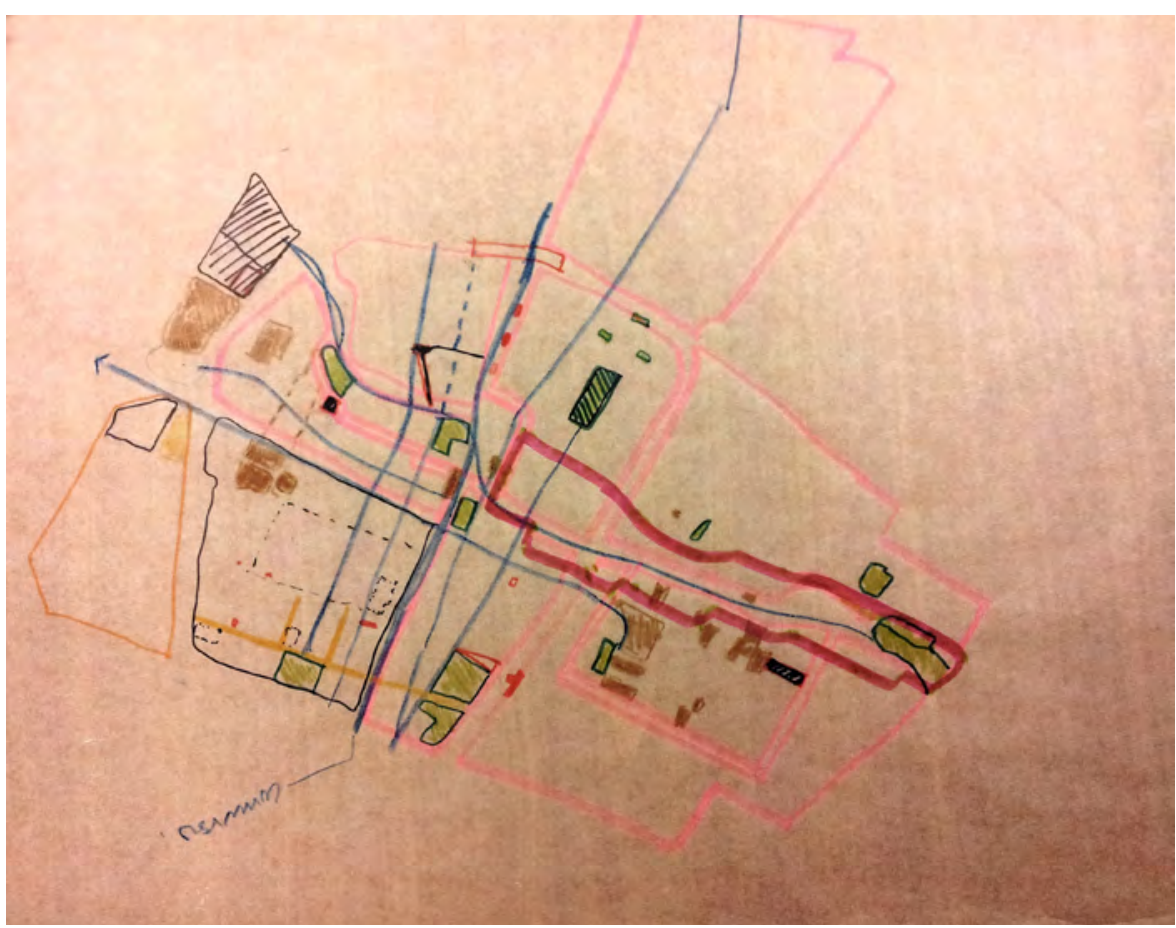

Sobre el primero, se estudiaron las oportunidades generadas tanto por las múltiples propiedades ("predios") privadas no edificadas (singularmente los espacios dedicados a aparcamientos o "parqueaderos") y el suelo público disponible, ya mencionado anteriormente, destinado a "mercados" y cuyo aprovechamiento real era en muchos casos limitado. La posibilidad de articular una estructura mixta público-privada para re-dotar al centro de un verdadero "sistema" de espacio público se fijó como un objetivo prioritario.

Entre otras ideas, se propuso acondicionar las numerosas anomalías de las tramas viaria y edificada para generar nuevos micro-espacios estanciales, que fueran colonizando la ciudad como lugares de relación social y descanso, o como alojamiento de nuevos tipos de dotaciones de pequeño formato. Un verdadero subsistema, que simplemente consistiría en hacer habitable lo que actualmente eran tan solo los restos de modificaciones parcelarias y de trazados viarios, y que acompañaría al sistema general de espacios libres del centro.

En cuanto a la edificación, se propuso una acción estratégica para recuperar el uso residencial del ámbito. Esta acción debería revertir el uso de buena parte de los edificios de viviendas y de uso terciario como simples almacenes, atrayendo a población, empresas e instituciones de modo estable, anulando así el desequilibrio diario de la actividad que provocaban las franjas horarias del uso comercial. Ello implicaba una reconsideración de la norma- 


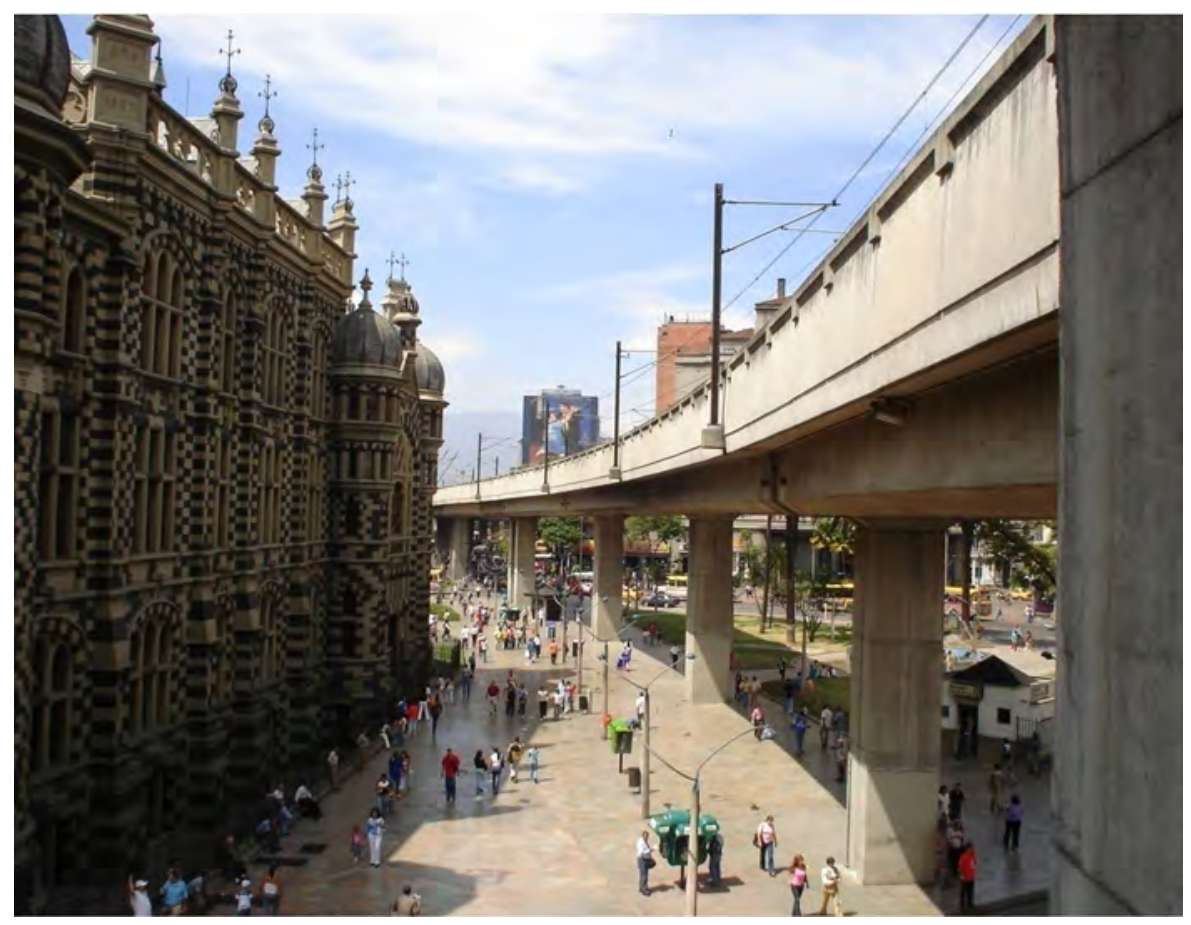

Metro. Entrada a plaza Botero | foto Alcaldía de Medellín. Dpto. de Planeación

tiva reguladora de los usos y el diseño de actuaciones que impulsaran una diversificación de los mismos para atender a las necesidades de los nuevos habitantes y trabajadores a atraer. Para esta última finalidad se planteó la reconsideración de los actuales mercados municipales o "plazas" en su formato actual, transformándolos en soporte de servicios y dotaciones públicos, mediante la intensificación de su edificabilidad y el desarrollo de novedosas propuestas arquitectónicas. En su configuración final debieran asumir el papel de pequeñas centralidades barriales y colaborar en la "fijación" de la venta ambulante.

Normalizada la actividad y el equilibrio del área, diversas instituciones deberían asentarse en ella como confirmación de la recuperación de su prestigio y "centralidad", colaborando, por medio de la aportación de una población de elevado nivel formativo, a la cualificación y el impulso a la innovación en la vida diaria. A este objetivo había de contribuir muy notablemente la red de universidades existente.

En cuanto al transporte, en colaboración con la empresa pública responsable del mismo, se diseñó un sistema de anillos perimetrales que regulaban de modo progresivamente restrictivo el acceso al área, que quedaría reservada a los medios de transporte público y los vehículos de logística, servicios públicos y de los propios residentes. Las soluciones al desmesurado impacto edificatorio de la red de metro pasaban por su enterramiento futuro 
y, por consiguiente, por la liberación del espacio público y de la modificación paisajística que produce, aunque se incluyeron algunas soluciones intermedias que fueron objeto de concursos específicos.

Todas las propuestas se concibieron bajo un objetivo central: aumentar la calidad de vida de la ciudadanía, de modo que las dotaciones y servicios de un espacio común redundaran en su mayor bienestar. Un objetivo que tenía una derivada de gran calado para ciudad, puesto que el aumento de la calidad de vida supondría, como muestran los índices internacionales, un incentivo para la instalación en la ciudad de operadores económicos de envergadura, que asociaran su imagen a esa mejora y a la capacidad de innovación de Medellín.

\section{EL PLAN ESPECIAL DE MANEJO Y PROTECCIÓN DEL CENTRO TRADICIONAL (PEMPCT)}

Como ya se señaló más arriba, la formulación final del Plan debía integrar las directrices y formatos propios del POT con su desarrollo en forma de proyecto.

PEMPCT. Estrategias de movilidad | esquema Alcaldía de Medellín. Dpto. de Planeación

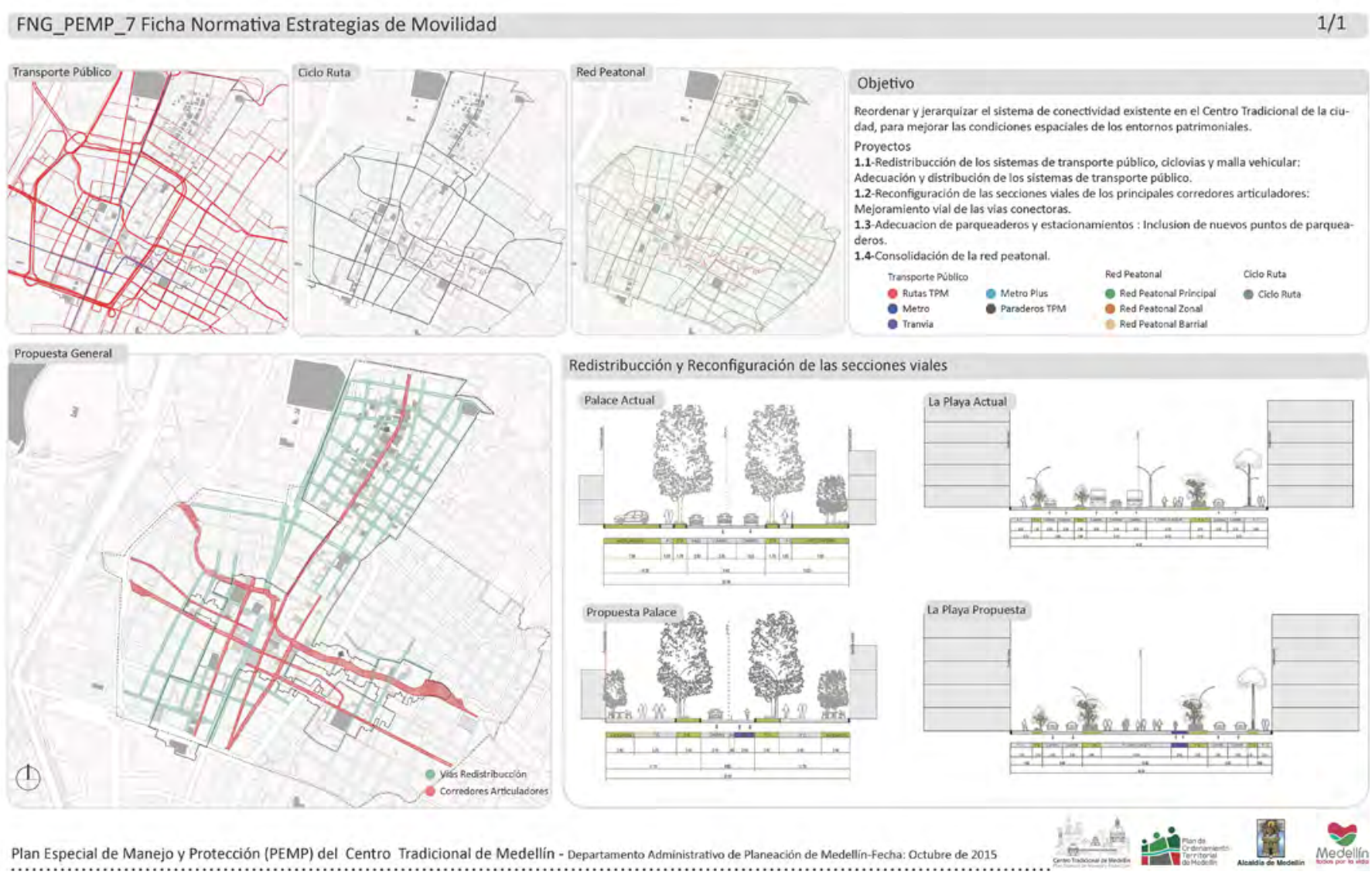


Adaptándose a ello, la normativa final define varios grados de intervención en las unidades parcelarias o "predios", calificándolos como de conservación, consolidación o renovación, estableciendo diversos grados para los dos primeros. En el caso de los bienes edificados protegidos se establecen también varias categorías que regulan la intervención en los mismos y que van desde los denominados "primeros auxilios" hasta la más bien genérica "reintegración". La ordenación de los usos busca consolidar la especificidad de las áreas homogéneas establecidas al comienzo del trabajo, pero procurando la existencia en el interior de cada área del suficiente número de actividades diversas que garanticen su vitalidad y desarrollo.

La estrategia de carácter proyectual y no tanto normativa del Plan se muestra en la determinación "predio a predio" de los aprovechamientos correspondientes, de modo que la especificidad de cada enclave tiene su propio análisis y unos resultados propios parametrizados.

En la definición de la movilidad del área se han recogido las propuestas del sistema de anillos y transversalidades concebido en la colaboración entre la

PEMPCT. Estrategia de espacios públicos |

esquema Alcaldía de Medellín. Dpto. de Planeación

FNG_PEMP_8 Ficha Normativa Estrategias de Espacio Público
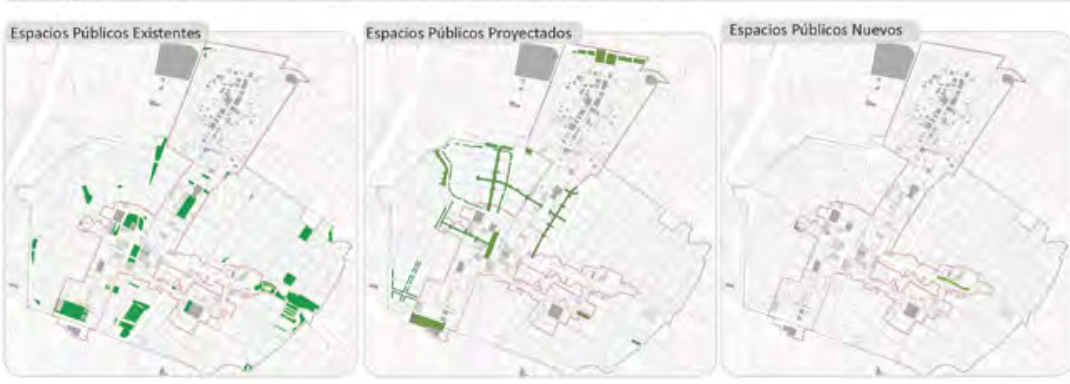

Objetivo

Mejorar la condiciones fisicas y la calidad de la red de espacios públicos asociados al sistema de esparcimiento y encuentro de la ciudad, mediante el reordenamiento, consolidación y cualificación de los ya existentes, incorporados en los entornos patrimoniales.

Proyectos:

2.1 Espacios Publicos Existentes: Definición de criterios para recuperación y mejoramiento espa.

2.2-Espacios Públicos Proyectados: Potencializar los espacios públicos proyectados por el pot. inclusión de nuevos espacios públicos para recomponer sus condiciones fisicas y colectivas.

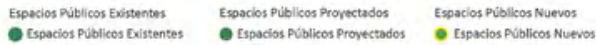

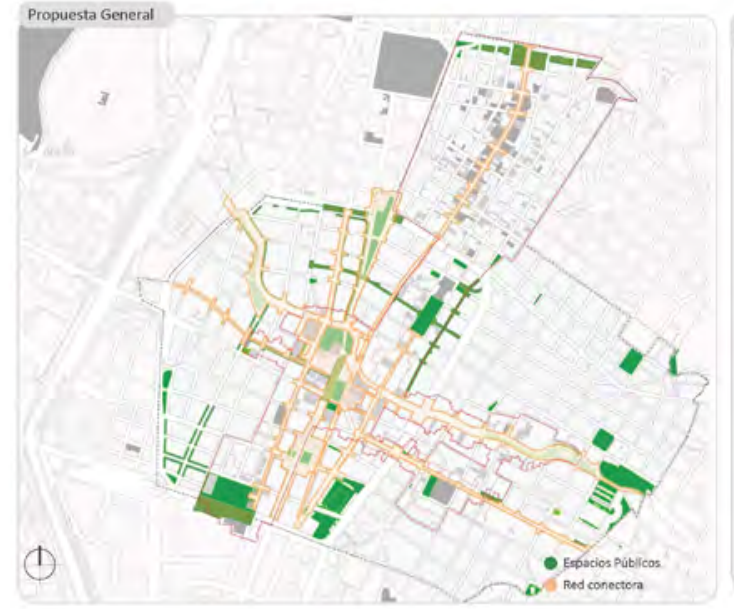

Espacios Públicos nuevos y Espacios Públicos Proyectados

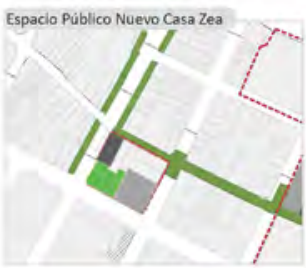

Espacio Nuevo Separador Central La Playa

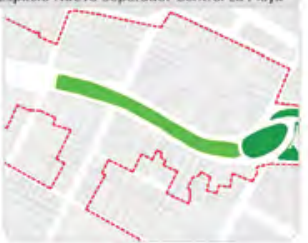

Espacio Público Existente Parque Bollivar

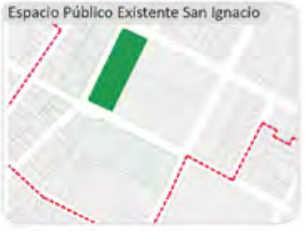

Plan Especial de Manejo y Protección (PEMP) del Centro Tradicional de Medellín - Departamento Adrón

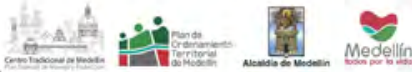


Secretaría de Movilidad de la Alcaldía, el equipo de redacción del POT y el equipo del proyecto para el Centro Tradicional. Básicamente pretende:

$>$ Articular las vías de transporte público y privado con las nuevas redes ciclistas propuestas y con la malla para vehículos privados.

$>$ Rediseñar y equilibrar, en función de usos y destinos, las secciones viarias existentes, fijando los criterios para una revisión de las características dimensionales de toda la red.

> Racionalizar la red de aparcamientos públicos e incrementar la misma en función de las restricciones circulatorias planteadas.

$>$ Ordenar la red espacios peatonales.

Las estrategias de espacio público se apoyan sobre las transversalidades detectadas desde los primeros análisis de la trama urbana, consolidando la propuesta de "corredores" N-S existente con anterioridad al Plan
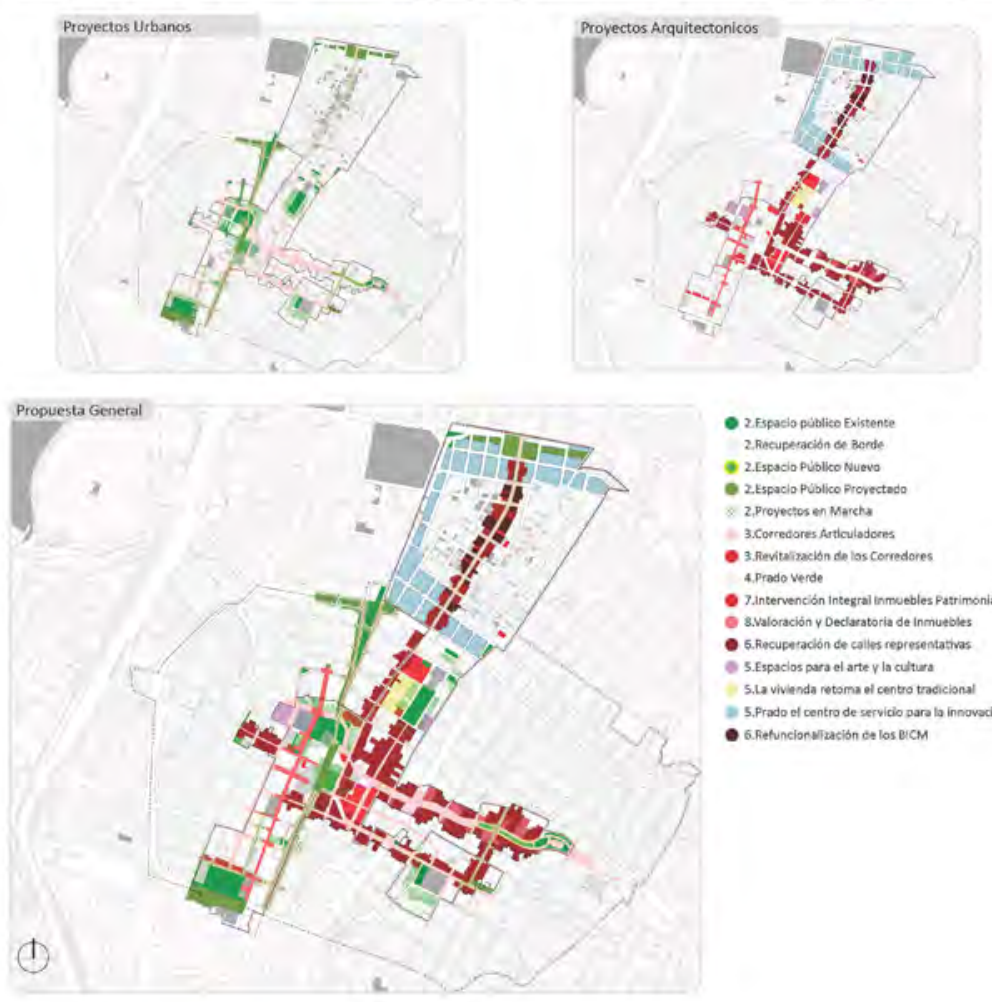

Gijetivo

Proyectos Urbanos

Planificar acciones de mejoramiento integral entorno a la reconfiguración del sistema de movilldad, la recuperación del espacio publico y colectivo, y la rehabilitación de los corredores o ejes articuadores que permitan la reconfiguración del valor del paisaje urbano asociado a ellos, para este modo darle una nueva dinámica a los sectores patrimonialies.

L.Reconfiguración de la movilidad

del espacio público y colectivo.

oún de corredores articuladores.

Mejoramiento Ambienta

des componentes ecológicos $y$ paisajisticos más representativos localizados en los sectores de interés patrimonial para găarantzar la preservación y conservación de su identidad paisajistica y botánica.

4.Manejo del componente ecologico y paisaljstico

Proyectos Arquitectonicos

Planificar medidas y acciones para la inclusión de nuevos usos y actividades que permitan reha. dinámicas propias de los sectores de interés patrimonial, con el fin

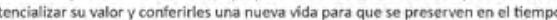

5.Rehabilitar el centro

6.Rehabilitación de los corredores articuladores a traviés de la rehabilitación integral de sus ecificaciones

Conservación del patrimonio nateralasulectonico.

(a) Integral, con el fin de contribuir a la articulación de estos elementos patrimoniales $y$ garantitar sostenibilidad integral y balanceada a través del desarrollo urbano, económico, social y cultura. 7.Intervención Integral de inmuebles patrimoniales como estrategia de recuperación de entornos utbanos.

Valoracion de nuevos BiCM

tos a Bienes de interes municipal- LCBIC, con el fin de realizar la declaratoria definitiva a BICM.

8.Valoración y declaratoria de inmuebles BiCM 
y desarrollando otras nuevas, en especial E-O. Ello garantiza el acceso fluido de la población al centro e incrementa la seguridad del propio espacio urbano.

El Plan consolida el método de trabajo que ha servido para su redacción con la inclusión de 15 Proyectos de Formulación urbanos y arquitectónicos que recogen todas las propuestas y les confieren las características de verdaderos sistemas integrados y vinculados.

Para la conservación del patrimonio edificado, además de la normativa general antes mencionada, se determinan dos ámbitos en los que la protección y sus mecanismos se establecen parcela a parcela.

Uno de ellos es el excepcional barrio Prado, cuya delicada condición de conjunto villas unifamiliares de singulares volúmenes y motivos decorativos ha exigido el mayor esfuerzo analítico y de información, a fin de concretar de manera precisa y adaptada cada una de las decisiones tomadas.

El otro ámbito incluye el resto de las zonas con bienes protegidos, donde

PEMPCT. Normativa de conservación. Barrio del Prado. Ficha característica | esquema Alcaldía de Medellín. Dpto. de Planeación
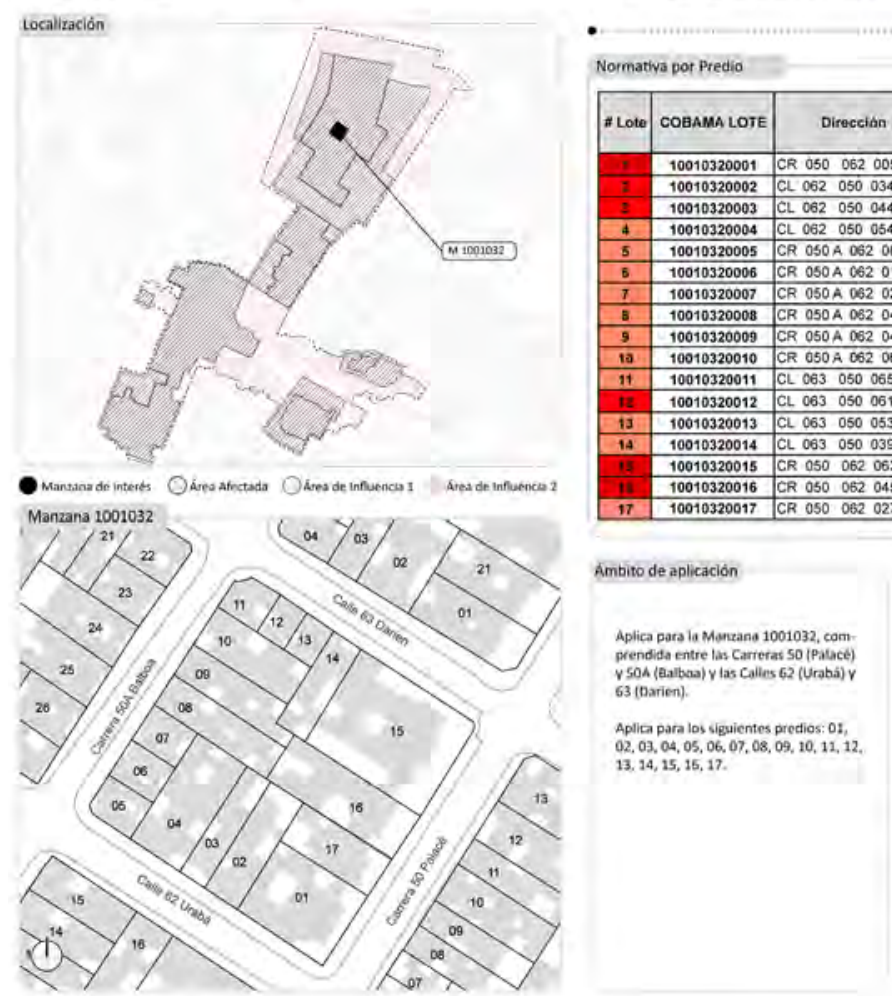

Sector de CONSERVACIÓN 1 - Área AFECTADA

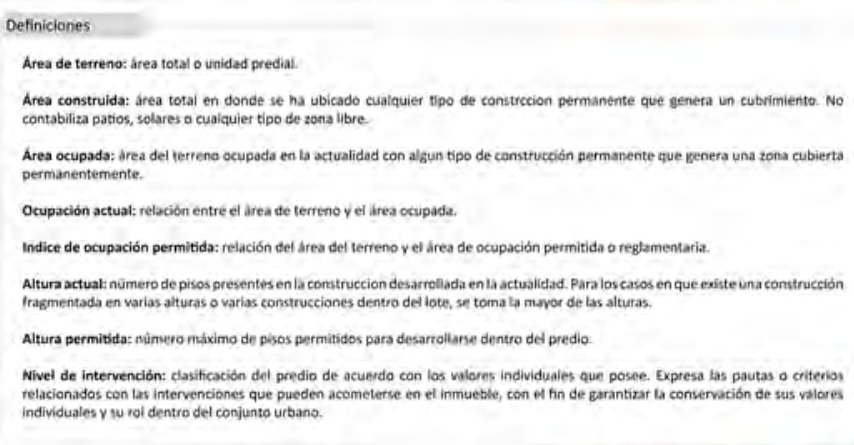


se aplica el mismo establecimiento de condiciones particularizadas para cada parcela.

Tal y como había planteado el proyecto para el centro desde sus inicios, el resultado final es la creación de una pieza de ciudad que constituye un mosaico de situaciones de pequeña escala, desde la que define la propia organización funcional por áreas homogéneas, hasta las que definen las muy caracterizadas y precisas acciones propuestas. Frente a la ciudad extensiva, resultado de las apresuradas ampliaciones urbanas desde los años 50, el centro constituye un "lugar de lugares", construido mediante episodios de lenta gestación que permitieron su delicada y cuidadosa elaboración espacial y arquitectónica, generando unos espacios de habitación colectiva que han de ponerse ahora al servicio de todos los habitantes de Medellín. A través de este Plan, de su metodología y de sus ideas la ciudad continúa en la senda de innovación y compromiso social que le han permitido renacer desde un dramático pasado reciente a una realidad actual llena de esperanza y orgullo para la ciudadanía. 


\section{BIBLIOGRAFÍA}

- Alcaldía de Medellín. Departamento Administrativo de Planeación (2014a) Áreas de intervención estratégica AIE. Medellín: Alcaldía de Medellín

- Alcaldía de Medellín (2014b) Plan de Ordenamiento Territorial para el Municipio de Medellín. Disponible en: https:// www.medellin.gov.co/irj/go/km/docs/wpccontent/Sites/ Subportal\%20del\%20Ciudadano/Planeaci\%C3\%B3n\%20 Municipal/Secciones/Servicios/Documentos/SITE/ Derogados-1999/ACUERDO\%2062_POT\%20DEROGADO. pdf [Consulta: 14/06/2021]

- Área Metropolitana del Valle de Aburrá (2011) Bio 2030 Plan Director Medellín, Valle del Aburrá. Bogotá: Mesa Editores. Disponible en: http://www.eafit.edu.co/ centros/urbam/articulos-publicaciones/Paginas/bio-2030publicacion.aspx [Consulta: 14/06/2021]

- Área Metropolitana del Valle de Aburrá (2006) Directrices metropolitanas de ordenamiento territorial "Hacia una región de ciudades". Documento técnico de soporte. Acuerdo Metropolitano. Medellín: Área Metropolitana del Valle de Aburrá. Disponible en: https://www.metropol.gov. co/planeacion/Documents/Directrices-Metropolitanas-deOrdenamiento-Territorial.pdf [Consulta: 14/06/2021]

- Echeverri, A. (2016) Medellín redraws its neighborhoods: social urbanism, 2004-11. En: Al-Asad, M. y Mehrotra, R. (ed.) Shaping Cities Emerging Models of Planning Practice. Berlín: Hatje Kantz, pp.36-53

- EDU [Empresa de Desarrollo Urbano] (2006) Proyecto Urbano Integral en la zona Nororiental de Medellín-Un modelo de transformación de ciudad. Medellín: Alcaldía de Medellín. Disponible en: http://www.edu.gov.co/images/ publicaciones/proyecto-Urbano-Integral\%20-en-la-zonaNororiental-de-Medellin.pdf [Consulta: 14/06/2021]

- EDU [Empresa de Desarrollo Urbano] (2014) Modelo de transformación urbana. Proyecto Urbano Integral -PUI-zona nororiental. Consolidación Habitacional en la Quebrada Juan Bobo. Medellín: Alcaldía de Medellín. Disponible en: http://www.edu.gov.co/images/publicaciones/Modelo_PUI_ zona_nororiental.pdf [Consulta: 14/06/2021]

- Fernández Muñoz, A.L. (2014) La Subzona Centro Tradicional de Medellín. Cuadernos de Ciudad, n. ${ }^{\circ}$ 1, pp. 22-25

- Leibler, L (2010) Un métro nommé justice: transport et justice spatiale; le cas du metrocable de Medellín, Colombie. Tesis Máster en Ciencias Sociales. Paris: Ecole des Hautes Etudes en Sciences Sociales

- Pérez Jaramillo, J. (2012) Medellín metropolitana: una aproximación a la ciudad, la crisis como oportunidad. Cuaderno urbano: espacio, cultura y sociedad, n. ${ }^{\circ} 12$, pp. 138-172

- Pérez Jaramillo, J., Patiño, J.M., Spera, G., García,
J.C., Tarchópulos, D. y Cardona, L. (2015) El Plan de Ordenamiento Territorial de Medellín 2014: un modelo territorial para la intervención estratégica. En: VII Seminario Internacional de Investigación en Urbanismo, BarcelonaMontevideo, junio 2015. Barcelona: DUOT. Disponible en: http://hdl.handle.net/2117/80323 [Consulta: 14/06/2021]

- Toro, C. (1988) Medellín: desarrollo urbano, 1880-1950. En: Orlando Melo, J. (dir.) Historia de Antioquia. Medellín: Suramericana de Seguros, pp. 299-306

- Vargas Velázquez, A. y García Pinzón, V. (2008) Violencia urbana, seguridad ciudadana y políticas públicas: la reducción de la violencia en las ciudades de Bogotá y Medellín (1991-2007). Pensamiento Iberoamericano, n. ${ }^{\circ} 2$, pp. $249-269$

- Vélez Longas, D. (2015). Macroproyecto Río Centro. Cuadernos de Ciudad, n. ${ }^{\circ}$ 4, pp. 26-39 


\section{Los inventarios del patrimonio cultural inmaterial: del caso del Montseny a la actualidad}

Lluís García Petit | Instituto del Patrimonio Cultural Inmaterial (IPACIM)

URL de la contribución <www.iaph.es/revistaph/index.php/revistaph/article/view/4946>

\section{RESUMEN}

La Metodología para el inventario del patrimonio cultural inmaterial en las reservas de la biosfera: la experiencia del Montseny fue un proyecto pionero llevado a cabo entre 2009 y 2011, que en 2013 fue inscrito en el Registro de Buenas Prácticas de la Convención para la Salvaguardia del Patrimonio Cultural Inmaterial, de la Unesco, que había entrado en vigor en 2006. El proyecto incluía una metodología, un inventario y algunas ideas para concretar la contribución del patrimonio cultural inmaterial al desarrollo sostenible. Desde entonces, el inventario del Montseny se ha ido actualizando y se han llevado a cabo otros inventarios basados en aquella metodología.

Por otra parte, el desarrollo de la Convención ha ido generando unas decisiones relacionadas con los inventarios, que en 2017 se recogieron en unas notas orientativas publicadas por la Unesco. En ellas se insiste en la participación activa de las comunidades, en su carácter inclusivo y en la necesidad de actualizarlos, entre otros. A pesar de todo, a nivel global parece que la identificación exhaustiva del patrimonio cultural inmaterial no ha merecido tanta atención como las candidaturas a la Lista Representativa del Patrimonio Cultural Inmaterial de la Humanidad.

\section{Palabras clave}

Convención para la Salvaguardia del Patrimonio Cultural Inmaterial | Desarrollo sostenible | Instituto del Patrimonio Cultural Inmaterial (IPACIM) | Inventarios | Metodología | Montseny (Barcelona) | Patrimonio inmaterial | Registro de Buenas Prácticas de la Convención para la Salvaguardia del Patrimonio Cultural Inmaterial | Reservas de la biosfera | Unesco | 


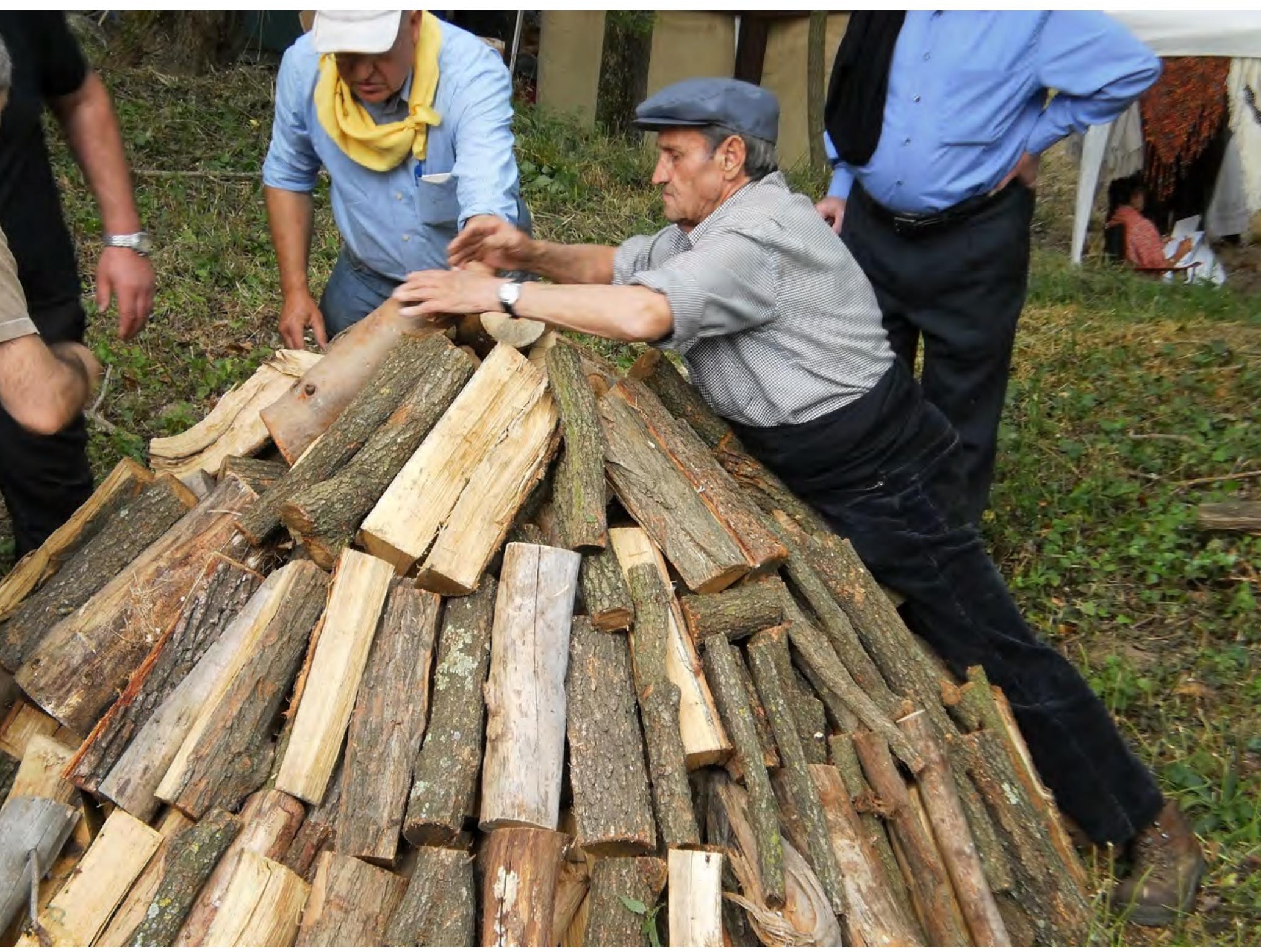

Preparación de la pila de leña para producir carbón vegetal | foto Ernest Traveria 


\section{INTRODUCCIÓN}

El día 17 de octubre de 2003, la Conferencia General de la Unesco aprobaba la Convención para la Salvaguardia del Patrimonio Cultural Inmaterial, consagrando así ese nuevo concepto que venía a ampliar el campo del patrimonio cultural. En esencia, la decisión de la Unesco venía a decir que el mantenimiento de la diversidad cultural requiere la pervivencia de todas las culturas del mundo, y que una parte fundamental de cada una de ellas es un conjunto de manifestaciones, expresiones, usos, costumbres, ritos, tradiciones orales, conocimientos, etc., que no tienen una presencia física permanente como la de los bienes muebles o inmuebles o los paisajes culturales. Además, constataba que todo ese ámbito se va deteriorando a un ritmo preocupante y globalmente se encuentra en peligro, por lo que es necesario actuar para salvaguardarlo y proteger así la riqueza que representa la diversidad cultural de la humanidad.

Partiendo de ese razonamiento, la Convención considera que dicho ámbito debe considerarse como patrimonio cultural y define el concepto de "patrimonio cultural inmaterial". Si bien es cierto que el término ya se usaba en algunos países, no estaba claramente definido y en cualquier caso la Unesco lo fija como referente, tras varios años de reflexión y debate en los que participaron cientos de personas de todo el mundo, representantes gubernamentales, del mundo académico, de la sociedad civil. En cierto modo, era la culminación de un proceso de reflexión que ya en 1982 se plasmaba en la declaración aprobada por la Conferencia Mundial sobre Políticas Culturales celebrada en México:

"El patrimonio cultural de un pueblo comprende las obras de sus artistas, arquitectos, músicos, escritores y sabios, así como las creaciones anónimas, surgidas del alma popular, y el conjunto de valores que dan un sentido a la vida. Es decir, las obras materiales y no materiales que expresan la creatividad de ese pueblo: la lengua, los ritos, las creencias, los lugares y monumentos históricos, la literatura, las obras de arte y los archivos y bibliotecas."

Años más tarde, en 1989, la Unesco aprobaba la Recomendación sobre la salvaguardia de la cultura tradicional y popular, y en 2001 apuntaba ya el nuevo enfoque en su Programa de Obras Maestras del Patrimonio Oral e Inmaterial de la Humanidad. Así pues, la Convención puede considerarse como el instrumento que establece un nuevo marco de referencia, también conceptual, sobre una realidad que hasta ese momento había sido objeto de distintos enfoques, vinculados a conceptos como "folklore", "patrimonio etnológico" o "cultura popular y tradicional", entre otros, para los cuales no existía, ni existe, una definición única y generalmente aceptada. El nuevo concepto de patrimonio cultural inmaterial se refiere, globalmente, a la misma realidad, pero se diferencia de los anteriores fundamentalmente en dos aspectos: se 
aplica solo a elementos vivos y la decisión de si algo es o no patrimonio le incumbe a la comunidad practicante. Además, sí tiene una definición consensuada, que 180 estados ya han ratificado, lo cual refleja el interés despertado por ese instrumento normativo y la necesidad compartida de actuar.

En este sentido, es importante no olvidar que la Convención es, ante todo, un compromiso de actuación coordinada, un acuerdo entre estados cuyo objetivo es tomar medidas ante una situación que preocupa a la comunidad internacional. Además, como instrumento jurídico que es, debe precisar su ámbito de actuación y definir los conceptos claves a los que hace referencia. Por ello no es de extrañar que, el primer artículo después de especificar qué entiende por "patrimonio cultural inmaterial" y por "salvaguardia", y de establecer los órganos de gobierno de la Convención, es decir, el artículo número 11, dedicado a las funciones de los Estados Partes, establezca: (a) "adoptar la medidas necesarias para garantizar la salvaguardia del patrimonio cultural inmaterial presente en su territorio y (b), entre ellas, "identificar y definir los distintos elementos del patrimonio cultural inmaterial presentes en su territorio." Ni que, abundando en la cuestión y para mayor claridad, el siguiente artículo disponga que "para asegurar la identificación con fines de salvaguardia, cada Estado Parte confeccionará con arreglo a su propia situación uno o varios inventarios del patrimonio cultural inmaterial presente en su territorio."

La lógica parece fuera de toda duda: si vamos a intervenir sobre un ámbito, primero debemos definir ese ámbito y a continuación acotarlo. Si vamos a intervenir sobre el patrimonio cultural inmaterial, debemos definir ese concepto y a continuación identificar los elementos que lo integran. Si no conocemos la realidad sobre la que vamos a actuar, ¿qué tipo de medidas vamos a tomar?

\section{EL PROYECTO DEL MONTSENY}

Esa evidencia y la falta de indicaciones en la Convención sobre cómo realizar esa identificación del PCI, fue lo que nos llevó, entonces desde el Centro Unesco de Cataluña, a imaginar un proyecto de inventario a partir del cual poder extraer unas orientaciones metodológicas que facilitaran ese cometido en el futuro. Corría el año 2009 y la Convención todavía se encontraba en una fase de aplicación muy incipiente. Había entrado en vigor en un tiempo récord, en abril de 2006, tras haber sido ratificada por 30 estados $^{1}$, pero no hay que olvidar que una convención internacional es una herramienta compleja, que necesita un tiempo considerable antes de poder empezar a funcionar plenamente: hay que constituir la Asamblea General de Estados Partes, aprobar su reglamento, elegir al Comité Intergubernamental, etc. Recordemos que las primeras inscripciones de nuevos elementos a la Lista Representativa del Patrimonio Cultural Inmaterial de la Humanidad no se aprobaron hasta ese mismo 2009.
1

La convenciones de la Unesco no entran en vigor hasta que se alcanza la cifra mínima de ratificaciones que cada una establece y solo se aplican en aquellos estados que las han ratificado. 
El Aplec de Sant Elies, en Sant Pere de Vilamajor, es una de las numerosas celebraciones colectivas que se organizan en el Montseny | foto Josep L. Òdena

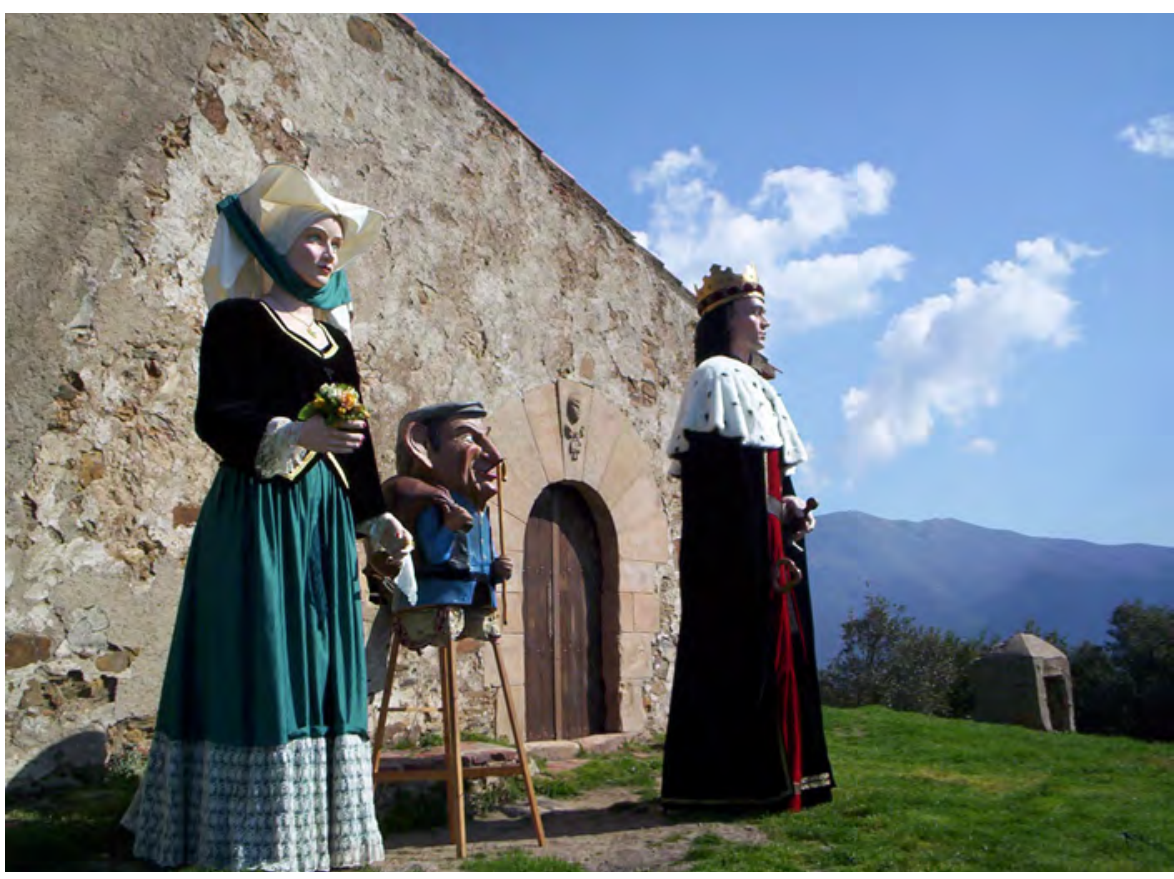

La idea se comparte en primer lugar con la Reserva de la Biosfera del Montseny, por considerarse un territorio muy apropiado, fundamentalmente por dos razones: se trata de una figura de la Unesco y tiene como objetivo el desarrollo sostenible, al cual también está muy ligado el patrimonio cultural inmaterial. Posteriormente, se suman a la iniciativa el Museo Etnológico del Montseny y la Dirección General de Cultura Popular y Asociacionismo Cultural (que en aquel momento se llamaba Centro de Promoción de la Cultura Popular y Tradicional Catalana) de la Generalidad de Cataluña, constituyéndose el equipo institucional que supervisará la iniciativa, sin olvidar a la Fundación Biodiversidad, adscrita actualmente al Ministerio para la Transición Ecológica, que aportó parte de los recursos necesarios y certificó la correcta ejecución del proyecto, ni a la Subdirección General de Participación de la Generalidad, que financió y dirigió un plan de participación. Además, las diputaciones de Barcelona y Girona, como gestoras de la Reserva de la Biosfera, también se implicaron en el proyecto, y el Departamento de Antropología de la Universidad de Barcelona aportó un asesoramiento científico. Según pudimos saber posteriormente, esta amplia y diversa red institucional fue un aspecto muy bien valorado para la inscripción del proyecto en el Registro de Buenas Prácticas de la Convención.

Tras un año de preparación, el proyecto se ejecutó en 2010 y 2011, alcanzando los tres resultados que se había fijado: elaborar una metodología, realizar un inventario y profundizar en la contribución del patrimonio cultural inmaterial al desarrollo sostenible ${ }^{2}$. Aquí nos centraremos solo en los dos primeros.
Los documentos resultantes pueden consultarse en: https://parcs.diba.cat/es/web/el-pa trimoni-cultural-immaterial-del-montseny documentacio-del-projecte-original [Consulta 06/04/2021] 
La metodología no pretendía otra cosa que adaptar la idea de inventario al nuevo concepto de patrimonio cultural inmaterial y a la Convención que le sirve de marco. Por ello, insiste en la importancia de la fase preparatoria y se centra en la comprobación de los criterios que se desprenden de la definición fijada en el artículo 2.1 de la Convención: que ese patrimonio está vivo, que se ha transmitido entre generaciones, que es la comunidad quien decide qué es patrimonio cultural inmaterial y que éste le infunde a la comunidad un sentimiento de identidad y de continuidad. No siempre es fácil comprobar si se cumplen todos estos factores y puede dar la sensación de que el margen de interpretación es muy amplio, que todo eso es muy subjetivo: quién es la comunidad, cuántas generaciones, sobre qué base decide la comunidad, etc. Indudablemente son aspectos en los que hay que profundizar, que es necesario ir delimitando y que hay que acotar en cada inventario. Si no establecemos unos criterios para valorar cada uno de esos puntos, la aleatoriedad -cuando no la arbitrariedad o los intereses de determinados sectores- acabará imponiéndose, en perjuicio del conjunto del patrimonio cultural. Al tratarse de un concepto nuevo, es lógico que todavía queden muchas cuestiones por resolver, todavía no se han acumulado las décadas de experiencia que existen sobre el patrimonio monumental. Además, al fin y al cabo, un cierto grado de subjetividad es inherente a la propia definición de patrimonio cultural. Basta con repasar la legislación vigente para comprobar que, en el fondo, lo que se considera patrimonio cultural son aquellos bienes que poseen interés desde el punto de vista artístico, histórico, científico, antropológico, etc. ${ }^{3}$; un interés que no queda claro cómo se valora y que por consiguiente deja mucho margen a la subjetividad.

El inventario, y en especial el trabajo de campo, permitió descubrir algo relevante: el hecho de que alguien se interese por lo que uno hace mejora nuestra autoestima, nos hace reflexionar sobre el valor que damos a ciertas prácticas y conocimientos. En un mundo donde la modernidad y la novedad, siempre cambiantes y cada vez más aceleradas, marcan la pauta, no es de extrañar que, en muchos casos, las costumbres heredadas sean vistas por quienes las practican como cosas fuera de lugar, que inevitablemente tienen que desaparecer. Por eso, que desde el mundo académico o institucional se les preste atención constituye una agradable sorpresa y suele convertirse en aliciente para la revaloración de otras prácticas. De este modo, el inventario se convierte en la primera herramienta de salvaguardia, incitando a un cambio en la mirada a la tradición.

El proceso de inventario comprendió un año de trabajo de campo y culminó con cuatro sesiones públicas para que la población del Montseny ratificara los resultados. En ellas se manifestó una clara oposición a la inclusión del motociclismo, que se había identificado en una zona del Montseny donde es muy popular, por lo que se eliminó del inventario, que finalmente incluyó 279 elementos. Este inventario se publicó en un sitio web específico, donde se

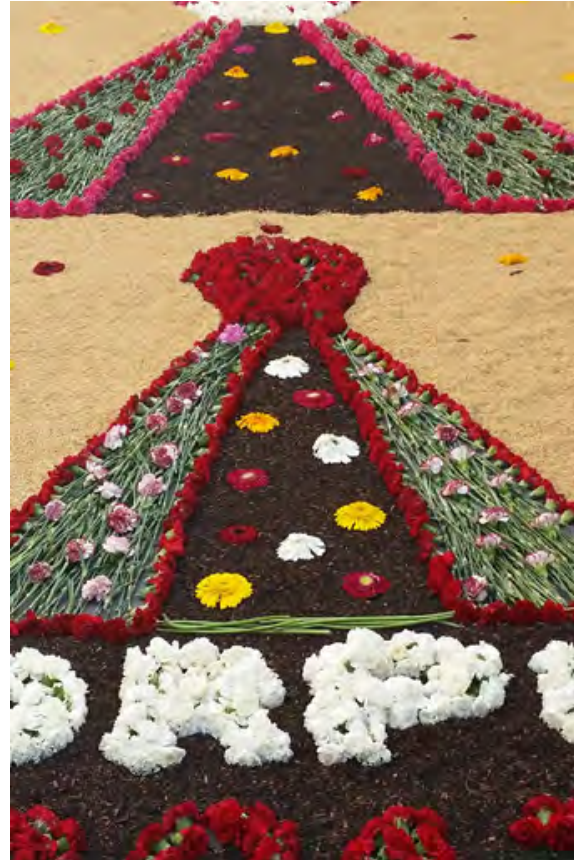

Las alfombras de flores de la Garriga son una tradición centenaria de La Garriga que repite cada año el día del Corpus Christi | foto Lluís García Petit

\section{3}

Véase, entre muchos otros, el artículo 1.2 de la Ley 16/1985 del Patrimonio Histórico Español, el artículo 2.1 de la Ley 3/1999 del Patrimonio Cultural Aragonés, el artículo 2 de la Ley 14/2007 del Patrimonio Histórico de Andalucía o el artículo 2 de la más reciente Ley 6/2019 de Patrimonio Cultural Vasco. 


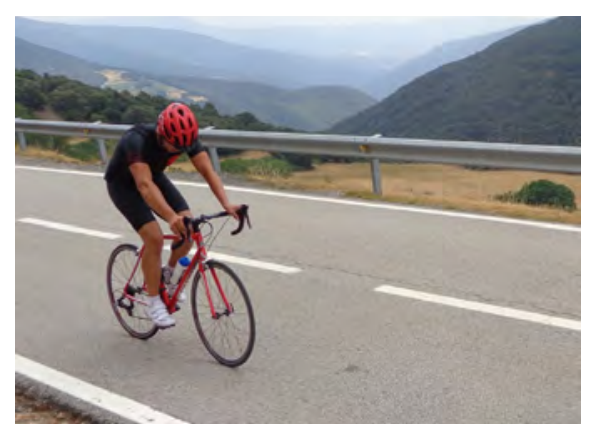

El ciclismo es uno de los deportes que se practican popularmente en el Montseny | foto Lluís García Petit presentaba una breve descripción de cada elemento, acompañada en algunos casos de una fotografía o vídeo.

A finales de 2012, el Centro Unesco de Cataluña, que había impulsado y coordinado el inventario, cesó sus actividades y la Diputación de Barcelona tomó el testigo para recoger toda la información en su sitio web. Por otra parte, algunos miembros de la plantilla del Centro decidieron fundar en 2015 el Instituto del Patrimonio Cultural Inmaterial (IPACIM), con el fin de continuar con su labor en el campo del patrimonio. En 2017, esta organización, con el apoyo de la Diputación, desarrolló el proyecto Dinamización del inventario del patrimonio cultural inmaterial del Parque Natural del Montseny y Reserva de la Biosfera del Montseny, como consecuencia del cual se eliminaron una fiesta y una feria que habían dejado de celebrarse, se incorporaron nuevos elementos propuestos por instituciones o asociaciones locales, se añadió documentación fotográfica y se mejoró la difusión del inventario. Así mismo, se constituyó un Consejo Supervisor integrado por la Reserva de la Biosfera, el Museo Etnológico, la Dirección General de Cultura Popular y Asociacionismo Cultural, el Departamento de Antropología de la Universidad de Barcelona y el IPACIM, que asume su coordinación.

Paralelamente, desde 2016 se organiza cada año el Concurso de Recetas de la Biosfera, una iniciativa que surgió de la Red Española de Reservas de la Biosfera como proyecto único y que en el Montseny ha tenido continuidad. Con él se pretende el doble objetivo de recopilar un patrimonio inmaterial relacionado con la alimentación y al mismo tiempo aprovechar este ámbito tan popular para sensibilizar sobre la importancia del patrimonio cultural inmaterial en general. A la hora de escribir este artículo, está a punto de

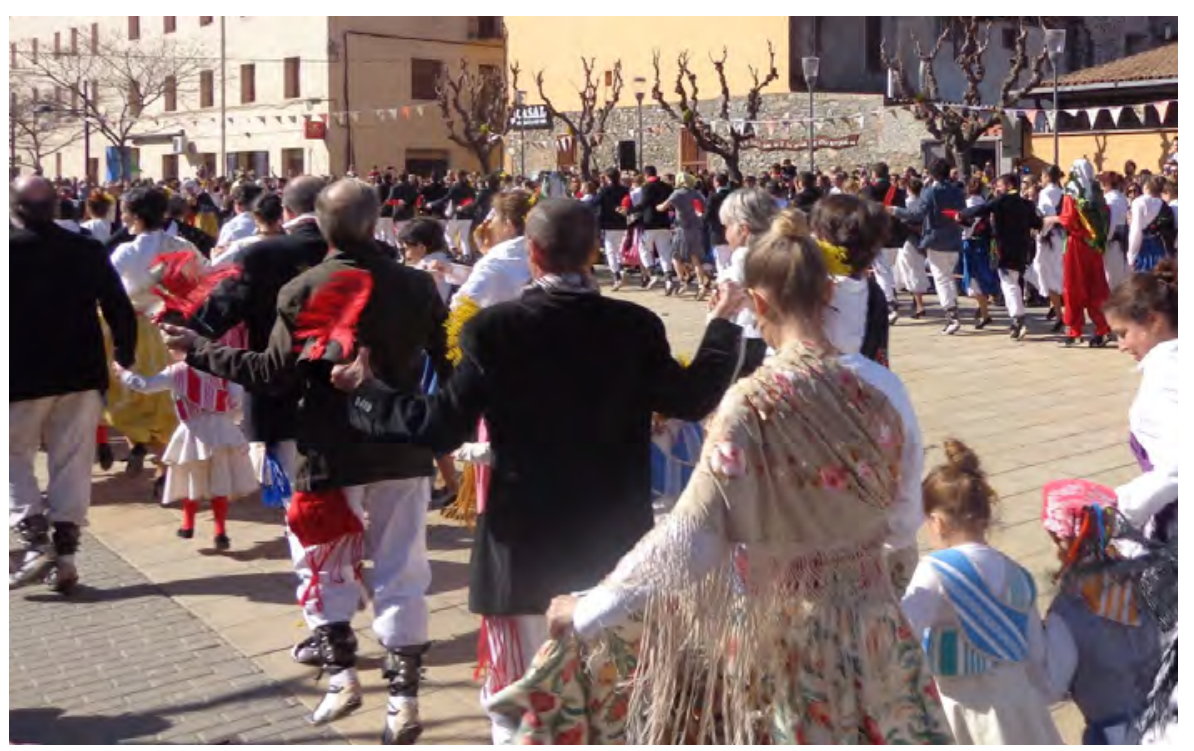

El baile de gitanas se celebra el domingo de Caranaval en Sant Esteve de Palautordera y otras poblaciones | foto Lluís García Petit 


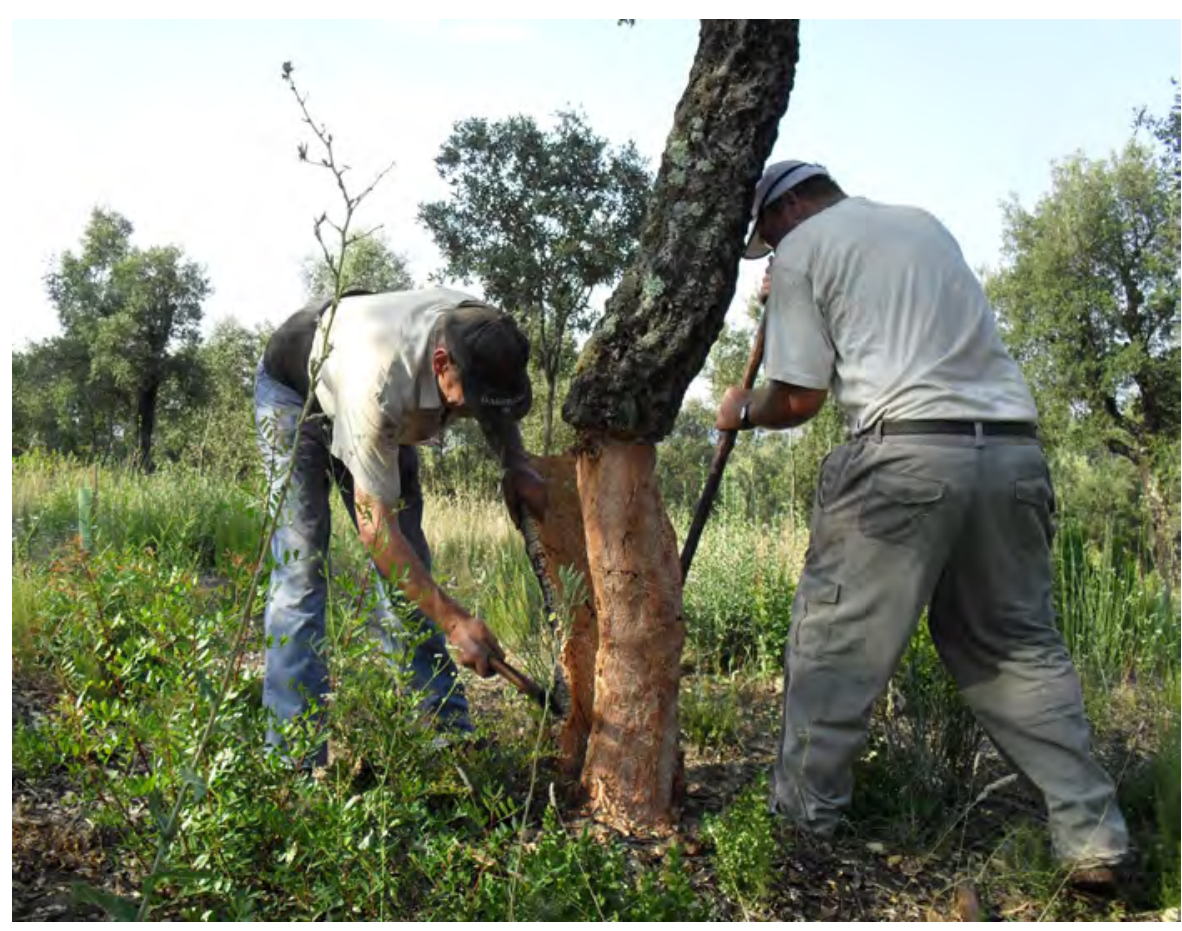

publicarse un libro que presentará las 150 recetas recogidas, relacionándolas con su marco natural y su patrimonio cultural inmaterial.

\section{LOS INVENTARIOS, DESPUÉS DEL MONTSENY}

En el año 2013, el Comité Intergubernamental para la Salvaguardia del Patrimonio Cultural Inmaterial decidió inscribir en el Registro de Buenas Prácticas de la Convención el proyecto Metodología para el inventario del patrimonio cultural inmaterial en reservas de la biosfera: la experiencia del Montseny, con el fin de que pudiera "servir como modelo metodológico para inventariar el patrimonio cultural inmaterial de las reservas de la biosfera, así como de parques y reservas naturales". La decisión del Comité aseguraba asimismo que "el programa podría aplicarse a las necesidades de los países en vías de desarrollo, ofreciendo una sólida base de reflexión metodológica para la elaboración de inventarios, que les permitiría ganar tiempo y eficacia."

Estimulada por ese reconocimiento, la Generalidad de Cataluña llevó a cabo, entre 2015 y 2017 , el inventario del patrimonio cultural inmaterial de la nueva Reserva de la Biosfera de las Terres de l'Ebre ${ }^{5}$, tomando como base la metodología del Montseny. El mismo modelo metodológico, adaptado a las circunstancias de cada lugar, ha inspirado los inventarios que se están llevando a cabo en las comarcas del Penedés ${ }^{6}$ y del Vallés ${ }^{7}$, en el Parque Natural
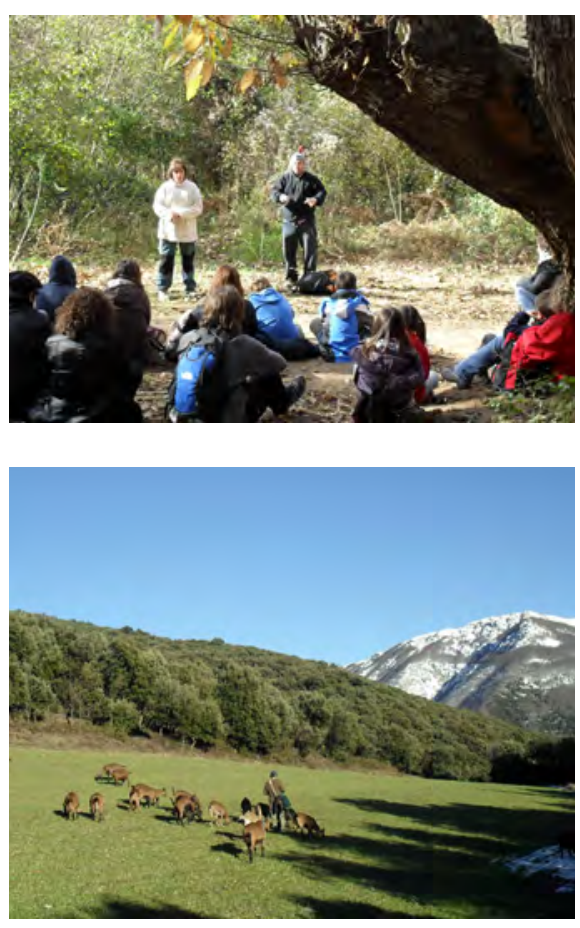

A la izquierda, la explotación de corcho requiere conocimientos del medio natural y técnicos; arriba, un grupo de niños y niñas aprende leyendas en su escenario natural; abajo, el pastoreo es una actividad tradicional en el Montseny | fotos Josep Lluis Òdena

Decisión 8.COM 7.b.2. Disponible en: https:// ich.unesco.org/es/Decisiones/8.COM/7.b.2 [Consulta: 15/04/2021].

https://ipcite.cat/ [Consulta: 15/04/2021].

https://www.immaterialpenedes.cat/ [Consulta: $15 / 04 / 2021]$.

7

http://immaterialvalles.cat/ [Consulta: 15/04/2021] 
Miembros de la comunidad local comparten sus conocimientos para el inventario | foto Josep Lluis Òdena

$$
8
$$

https://www.ipcime.cat/ [Consulta: 15/04/2021]

https://ich.unesco.org/doc/src/50279-ES.pdf [Consulta: 18/04/2021].

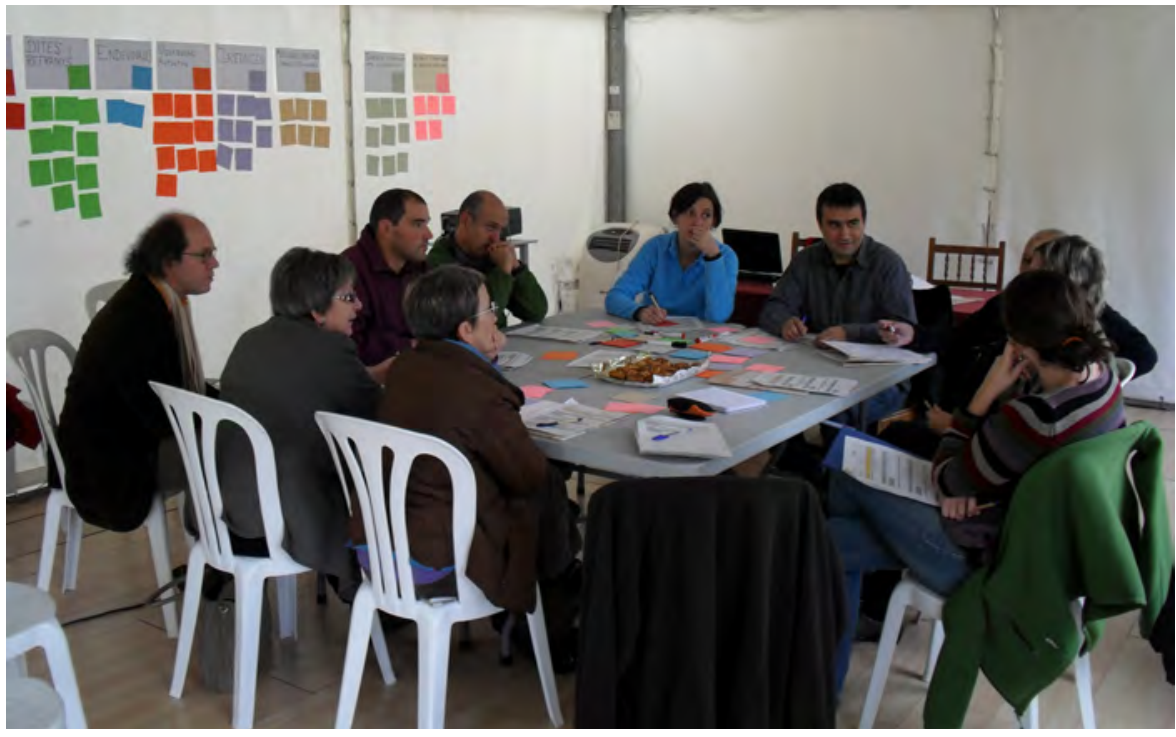

del Cadí-Moixeró y en Menorca ${ }^{8}$, estos dos últimos a cargo del IPACIM. La metodología también despertó el interés de distintos países, ya que hasta ese momento no se disponía de ninguna orientación para la elaboración de inventarios. Pero a medida que se iba desplegando la Convención y que el Comité iba tomando decisiones sobre su aplicación, se acumulaban indicaciones que, directa o indirectamente, se referían a ellos. En 2017, atendiendo a una solicitud del Comité, la Unesco elaboró unas Notas de orientación para la confección de inventarios del patrimonio cultural inmaterial ${ }^{9}$, que reúnen y ordenan las pautas que se han ido marcando hasta ese momento, convirtiéndose así en el documento de referencia.

En él se establecen ocho principios rectores o requisitos para la confección de inventarios:

1. Deberán basarse en procedimientos que hayan sido acordados con las comunidades, grupos y, si procede, individuos interesados. Se deberá contar con el consentimiento de éstos antes de dar inicio al proceso de inventario y para las decisiones sustanciales que se adopten durante dicho proceso.

2. Deberán presentar elementos del patrimonio cultural inmaterial que hayan sido identificados con la participación de las comunidades, los grupos y las organizaciones no gubernamentales implicadas.

\section{Deberán ser inclusivos.}

4. Deberán contener información sustancial de los elementos incluidos en el inventario. 
5. Deberán realizarse de tal forma que contribuyan a los objetivos de la Convención, y a la salvaguardia en primer término.

6. Deberán actualizarse de manera periódica, con la participación de las comunidades, grupos e individuos interesados.

7. Se deberá informar sobre los inventarios en los informes periódicos que los Estados Partes deben presentar al Comité cada seis años.

8. Deberán respetar los usos consuetudinarios que rigen el acceso al patrimonio cultural inmaterial.

Actualmente, la gran mayoría de los estados que han ratificado la Convención están realizando algún tipo de inventario. Esto se deduce de las inscripciones en la Lista Representativa, ya que uno de los criterios requeridos es figurar en un inventario oficial y que los elementos inscritos corresponden a 128 países. Sin embargo, no sabemos hasta qué punto contemplan esos criterios, ya que la información sobre los mismos aportada por los estados en sus informes periódicos al Comité Intergubernamental ${ }^{10}$ es anterior al citado documento. Lo que sí conocemos es que algunos de esos inventarios se van construyendo a partir de convocatorias públicas anuales, en las que pueden presentarse propuestas de elementos, debidamente documentadas.

En el caso de España, el informe presentado en 2014 detalla que cuenta con 16 inventarios y atlas para su $\mathrm{PCl}$, muchos de los cuales se iniciaron antes de que España ratificara la Convención ${ }^{11}$. Posteriormente, la Ley para la Salvaguardia del Patrimonio Cultural Inmaterial, de 2015, establece la creación de un Inventario General de Patrimonio Cultural Inmaterial, que "deberá incluir aquellos bienes culturales inmateriales declarados por las Comunidades Autónomas con el máximo grado de protección, así como los protegidos por la Administración General del Estado bajo la categoría de Manifestación Representativa del Patrimonio Cultural Inmaterial" (artículo 14.3).

\section{CONSIDERACIONES FINALES}

A pesar de tratarse de una de las primeras obligaciones establecidas en la Convención, 15 años después de su entrada en vigor, no parece que ningún país haya realizado un inventario exhaustivo del patrimonio cultural inmaterial presente en su territorio. Esto contrasta con el formidable volumen de candidaturas que se presentan a la Lista Representativa, que ha obligado a establecer unos límites operativos. Al mismo tiempo, el concepto de "patrimonio cultural inmaterial" está cada vez más presente y se aplica de manera generosa a prácticas, conocimientos e incluso a valores, de los que se supone que se adecúan a la definición establecida por la Convención. No obstante,
10

https://ich.unesco.org/en/submissions-and-deadlines-00861 [Consulta: 18/04/2021].

11

https://ich.unesco.org/en/state/spain-ES?info=periodic-reporting [Consulta: 18/04/2021]. 
en muchos casos parece darse un uso inadecuado, o al menos confuso, del término. Me limitaré a poner como ejemplo el Catálogo abierto del patrimonio inmaterial de las reservas de la biosfera españolas, donde pueden encontrarse elementos como el Conjunto Histórico-Artístico de Santa Mariña de Augas Santas e Os Fornos de Armea, la Zona Arqueológica de Siega Verde o la Minería y Siderurgia en el siglo XIX, entre otros.

Ciertamente el concepto, más allá de las palabras, es aún poco conocido y ello dificulta la propia labor de inventario, ya que resulta difícil que una comunidad pueda reconocer algo como patrimonio cultural inmaterial si no comprende exactamente qué significa. Por eso es necesario que, en el proceso de identificación, exista un diálogo fluido entre comunidad, expertos e instituciones, que le dé coherencia y solidez. Esto lleva también a considerar que los inventarios donde no existe una búsqueda activa de posibles elementos del patrimonio cultural inmaterial corren el peligro de resultar incompletos o sesgados. Sin perjuicio de la responsabilidad última de la comunidad, es necesario combinar su iniciativa con las de expertos e instituciones, en un proceso conjunto que evite el riesgo de privilegiar, involuntariamente, a aquellos elementos que ya gozan de mayor visibilidad, en detrimento del patrimonio más frágil y más amenazado.

Todo esto tiene que ver también con un aspecto que ya subrayaba la metodología del Montseny, recogiendo lo dispuesto en la Convención, a saber, que un inventario es solo el primer paso para la salvaguardia, pero que debe ubicarse en un marco más amplio que la garantice a largo plazo y que incluya su valoración, su estudio, su transmisión, su difusión, su contribución al desarrollo sostenible, etc.

Por último, el proyecto del Montseny demostró que el carácter gubernamental de la Convención y la responsabilidad oficial de su aplicación no es un impedimento para que, desde las asociaciones u otras instancias, se tomen iniciativas para proteger ese patrimonio tan necesario para nuestra cultura y nuestra sociedad. La Convención, con todas sus limitaciones, es una herramienta muy útil que debemos aprovechar. 


\section{BIBLIOGRAFÍA}

- Ley 14/2007, de 26 de noviembre, del Patrimonio Histórico de Andalucía. Boletín Oficial del Estado, n. ${ }^{\circ} 38$, de 13 de febrero de 2008. Disponible en: https://www.boe. es/buscar/pdf/2008/BOE-A-2008-2494-consolidado.pdf [Consulta: 06/04/2021]

- Ley 16/1985, de 25 de junio, del Patrimonio Histórico Español. Boletín Oficial del Estado, n. ${ }^{\circ} 155$, de 29 de junio de 1985. Disponible en: https://www.boe.es/buscar/act. php?id=BOE-A-1985-12534 [Consulta: 06/04/2021]

- Ley 3/1999, de 10 de marzo, del Patrimonio Cultural Aragonés. Boletín Oficial del Estado, n. ${ }^{\circ} 88$, de 13 de abril de 1999. Disponible en: https://www.boe.es/buscar/pdf/1999/ BOE-A-1999-8270-consolidado.pdf [Consulta: 06/04/2021]

- Ley 6/2019, de 9 de mayo, de Patrimonio Cultural Vasco. Boletín Oficial del Estado, n. ${ }^{\circ} 128$, de 29 de mayo de 2019. Disponible en: https://www.boe.es/eli/es-pv/l/2019/05/09/6 [Consulta: 06/04/2021]

- UNESCO (1989) Recomendación sobre la salvaguardia de la cultura tradicional y popular. Disponible en: http://portal. unesco.org/es/ev.php-URL_ID=13141\&URL_DO=DO_ TOPIC\&URL_SECTION=201.h̆tml [Consulta: 03/04/2021]

- UNESCO (2003) Convención para la Salvaguardia del Patrimonio Cultural Inmaterial. Disponible en: https://unes doc.unesco.org/ark:/48223/pf0000132540_spa [Consulta: 03/04/2021]

- UNESCO (2018) Directrices Operativas para la aplicación de la Convención para la Salvaguardia del Patrimonio Cultural Inmaterial. Disponible en: https://ich. unesco.org/doc/src/ICH-Operational_Directives-7.GA-ES. docx [Consulta: 03/04/2021] 


\section{El patrimonio inmaterial y la construcción de paz: la actividad del Centro de Memoria, Paz y Reconciliación de Bogotá D.C.}

José Antequera Guzmán | Centro de Memoria, Paz y Reconciliación

URL de la contribución <www.iaph.es/revistaph/index.php/revistaph/article/view/4941>

\section{RESUMEN}

En este escrito se describe la labor del Centro de Memoria, Paz y Reconciliación de Bogotá (Colombia), como un proyecto funcional a la construcción de paz a partir de sus elementos particulares. Estos han sido resultado de la decisión consciente de cuestionar retóricas instaladas sobre la labor que correspondería a los llamados sitios de la memoria, pero disfuncionales, directamente inconvenientes y poco efectivas. El abordaje de esos elementos particulares y perspectivas de actuación es un aporte al conocimiento sobre la cuestión del patrimonio inmaterial para la resolución de conflictos, así como un referente de análisis para otras experiencias en curso o por construir.

\section{Palabras clave}

Bogotá (Colombia) | Centro de Memoria, Paz y Reconciliación | Conflictos | Memoria | Patrimonio inmaterial | 


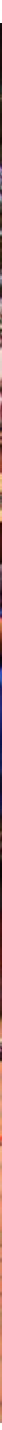

Ceremonia de armonización de pueblos indígenas (2018) | foto todas las imágenes son propiedad del Centro de Memoria, Paz y Reconciliación 


\section{EL CENTRO}

El Centro de Memoria, Paz y Reconciliación de Bogotá D.C. se comenzó a construir en el año 2008 como parte de un plan de desarrollo para la capital de Colombia de corte progresista. Su construcción inicialmente sintetizaba la inquietud de la coalición de gobierno alternativo en la capital del país por reivindicar la experiencia histórica de exclusión y de violaciones a los derechos humanos, siendo una coalición con muy poca experiencia de gobierno y que reunía a quienes habían disputado el poder al bipartidismo liberal-conservador a lo largo del siglo XX: agrupaciones políticas de izquierda, en algunos casos vinculadas con guerrillas que habían firmado pactos de paz, sindicatos y diferentes movimientos sociales, entre otros. Tal coalición pretendía representar especialmente a los grupos sociales que históricamente habían sufrido la mayor cantidad y las más graves violaciones a los derechos humanos por razones políticas en el país por haber defendido, y aún lo hacían, la posibilidad de una solución dialogada del conflicto armado interno en Colombia.

Tres años antes, desde el año 2005, en el país se había desarrollado un proceso nacional de desmovilización de grupos paramilitares que significó la afirmación de que los derechos de las víctimas debían ser insoslayables de cualquier proceso de paz. Así, gracias a la incidencia de un movimiento creciente, que vio en la construcción del Centro en la capital del país una oportunidad de fortalecimiento de sus demandas sin renunciar al gran objetivo de la solución política del conflicto, lo que inicialmente se había proyectado como una obra pequeña, se convirtió en la primera gran obra emprendida de su tipo, ligada además a las conmemoraciones por el Bicentenario de la

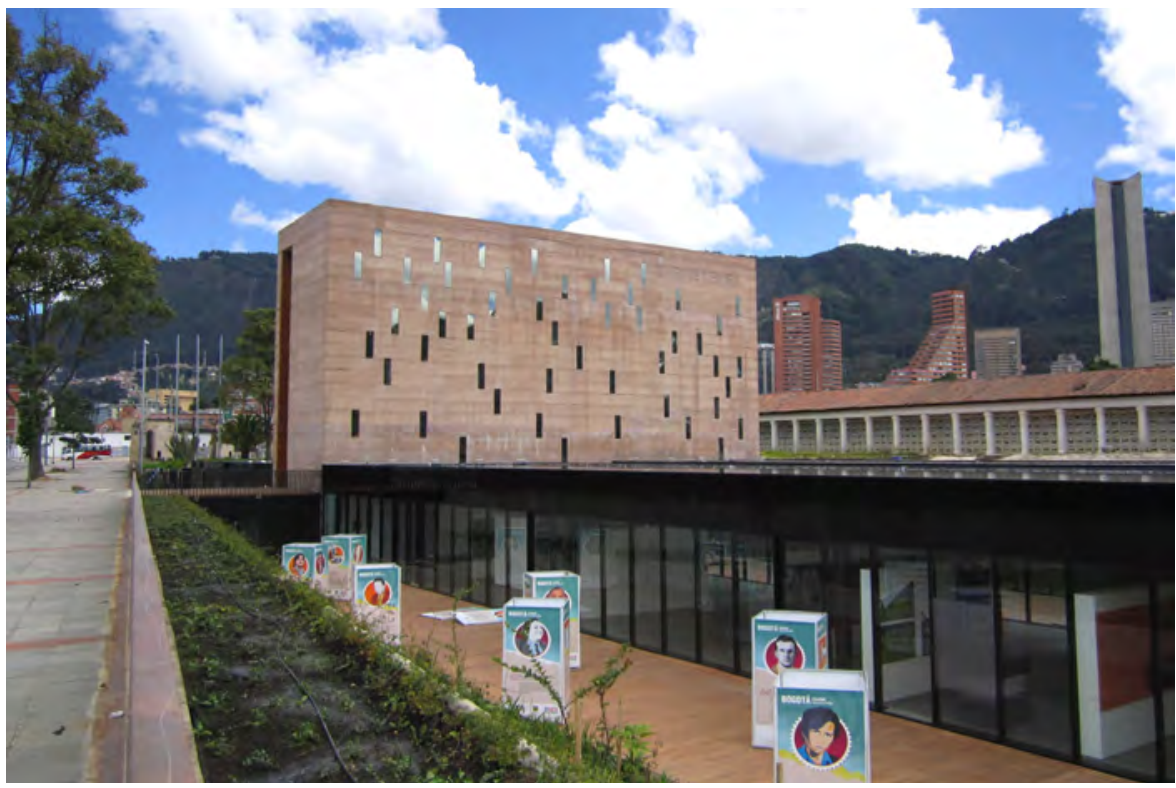


Independencia con el nombre del Centro del Bicentenario, Memoria, Paz y Reconciliación. Esta sería levantada a partir de un gran concurso arquitectónico en un lote de miles de metros cuadrados con auditorio para 300 personas, aulas múltiples, salas de exposición y un Memorial por la vida, todo ello en un área de gran valor patrimonial por ser antiguo cementerio de pobres y NN (personas sin identificar).

El Centro de Memoria, Paz y Reconciliación sería además un proyecto dentro de la categoría de los llamados sitios de memoria o sitios de conciencia, como los campos de concentración preservados como patrimonio de la experiencia de las guerras, las dictaduras, los conflictos internos y las graves violaciones a los derechos humanos. Centros de tortura y detención en América Latina, como el espacio de la antigua Escuela de Mecánica de la Armada ESMA en Argentina, Villa Grimaldi en Chile y otros tantos, se reúnen en la Coalición Internacional de Sitios de Conciencia y en la Red Latinoamericana de Lugares de Memoria, en la que el Centro de Memoria, Paz y Reconciliación encontraba inspiración y alianzas.

\section{MEMORIA, PATRIMONIO INMATERIAL Y CONSTRUCCIÓN DE PAZ}

Como en muchos lugares del mundo, la memoria para la paz como problema de políticas que incluyen el asunto de la preservación y usos del patrimonio cultural inmaterial tiene su historia particular.

En un amplísimo escenario de múltiples formas de producción de historia, estas políticas de usos del pasado en Estados democráticos occidentales surgieron ligadas al referente de la conmemoración del Holocausto y la búsqueda de lecciones universales desde allí, así como a los procesos de descolonización del sur que suponen el reclamo de existencia nacional y/o identitaria de lugares tratados como periféricos y de luchas que reclaman su lugar en la formación de la democracia misma (Rufe 2010).

En la Colombia de 2005, estas vertientes se cruzan en la resistencia al proyecto de impunidad para el paramilitarismo, responsable de la mayor cantidad de violaciones de los derechos humanos al menos desde los años 80 , con la afirmación de los derechos de las víctimas del conflicto armado interno ya degradado, y la demanda desde aquellos lugares en los que se habían ejercido masacres y grandes actos de despojo de tierras como lugares "abandonados por el Estado" considerados en el mapa nacional sobre todo a partir de las tragedias del llamado orden público en la periferia.

En este contexto, "en medio del conflicto", era difícil, si no imposible, la identificación e intervención de lugares que hubieran funcionado como escenarios de ocurrencia de hechos. Así, la memoria debería ejercerse, porque así 

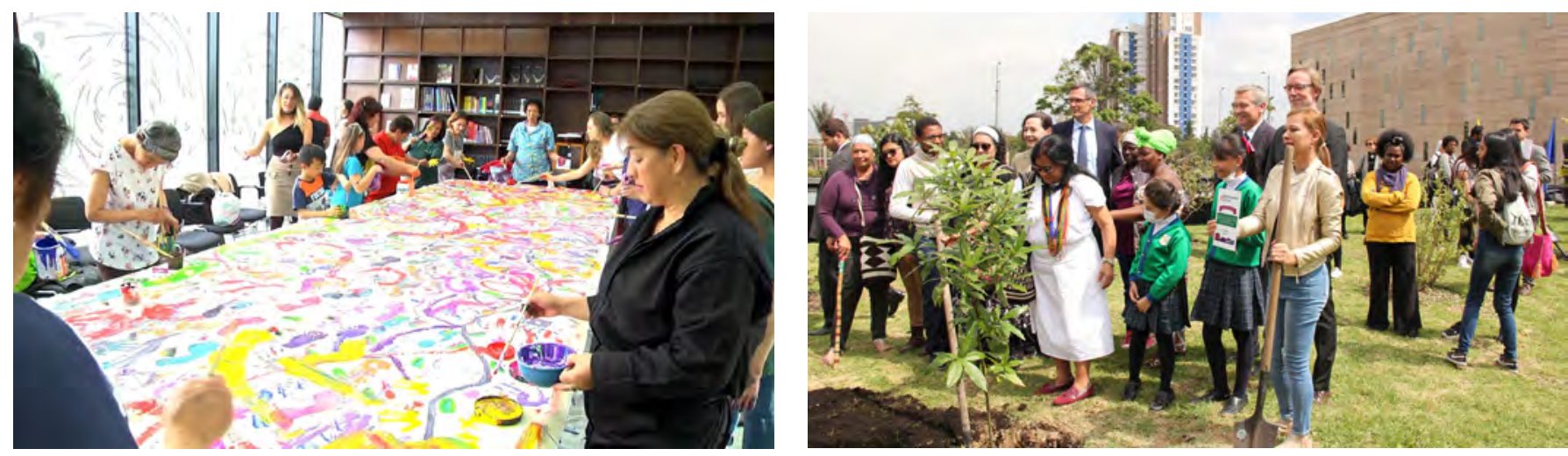

Galería Itinerante Bogotá Ciudad memoria. A la izquierda, actividad pedagógica (2018); a la derecha, siembra de embajadas de la Unión Europea en homenaje a líderes sociales asesinados después de la firma del acuerdo de paz (2020)

imponían las circunstancias en lugares diferentes, ocupados o construidos, donde circulara un acervo de experiencia y documentación que, de facto, vendría a ser reconocido como patrimonio inmaterial vinculado con investigaciones en desarrollo que serían de memoria histórica si se basaban fundamentalmente en testimonios de víctimas.

Mientras los movimientos sociales desarrollaban múltiples iniciativas, a nivel oficial se iniciaron proyectos desde donde se pretendía el reconocimiento autorizado de lo memorable y, en ese sentido, pudiendo ser incluido en el Patrimonio, con mayúscula. Así, por iniciativa del gobierno nacional, se creó en 2005 el Grupo de Memoria Histórica para investigar "el origen y desarrollo de los grupos armados organizados al margen de la Ley". Por iniciativa de la coalición de gobierno en Bogotá desde el 2008, se impulsó la construcción del Centro de Memoria, Paz y Reconciliación. Emulando la experiencia de la capital, se inició la construcción de la Casa Museo de Memoria de Medellín. Y como gran think tank avalado por el Estado para la producción de contenidos, se creó en 2011 el Centro Nacional de Memoria Histórica gestionado por algunos de los intelectuales vivos más destacados en el estudio de la violencia y el conflicto.

Tales iniciativas oficiales aportaron a la construcción de un campo de acontecimientos memorables, mayormente iluminados dentro del conjunto que llamaríamos patrimonio inmaterial, con sus significados e implicaciones diferentes, pero con el común denominador de su carácter como argumentos para la necesidad de la paz entre el gobierno y las guerrillas.

La memoria, aunque se tratara de un concepto muy amplio vinculado a la cultura, era entendida como el recuerdo de las víctimas definidas como experimentadoras directas de dolor y sufrimiento y por ello voceras legítimas exclusivas del pasado. La paz debiera ser el resultado, sobre todo, de la satisfacción de los derechos de las víctimas así consideradas sobre la afirmación de que diferentes países que habían emprendido procesos de transición en el mundo habían caído de nuevo en la violencia fundamentalmente 


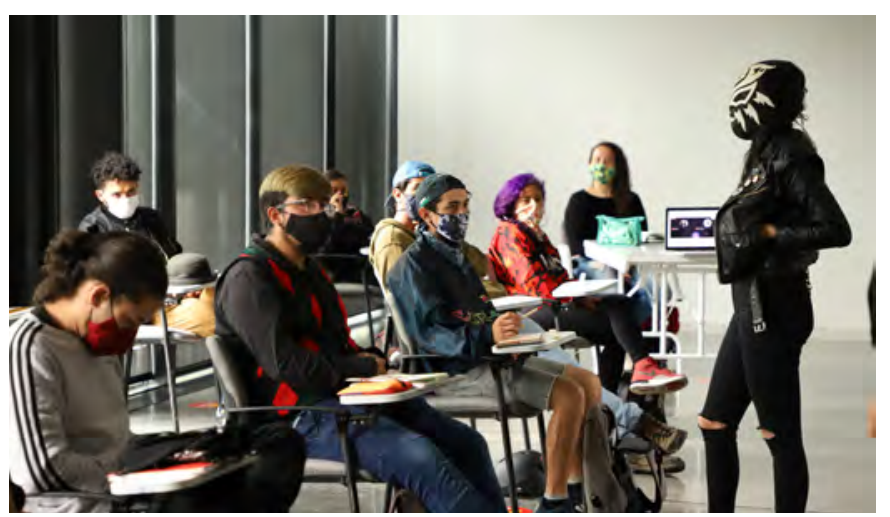

por no haber avanzado realmente en esa satisfacción de verdad, justicia y reparación para la no repetición. Las políticas de memoria, como islas en las políticas culturales, debieran ser conjuntos de medidas emanadas de tales presupuestos para un tipo de patrimonialización aparte del conjunto, hacia la paz como fin de las confrontaciones armadas.

Hoy tenemos razones para cuestionar estos planteamientos, sin desconocer las afirmaciones ciertas que contienen y la importancia que representan como justificación de políticas oficiales que no pretendemos desmontar.

Claramente la memoria como problema público es inherente a la sociedad visto el mundo como un foro para la acción, como diría Jordan Peterson (2020). Los movimientos sociales, sobre todo desde que el llamado occidente se marca por aquello de que "todo lo sagrado se hace profano y todo lo sólido se desvanece en el aire", han impulsado la reivindicación del reconocimiento como experiencia histórica y efectos presentes del curso del progreso modernizante, con su explotación, sus despojos, sus opresiones, sus violencias, y claro, la oposición frente al mismo.

En ese foro para la acción, que la memoria signifique legitimidad exclusiva de las víctimas a partir de la experiencia de sufrimiento con respecto a los períodos de violencia política, conflicto o dictadura, y que la repetición o no de las marcas de estos períodos dependa fundamentalmente de la satisfacción de derechos reconocidos para éstas, resulta problemático.

Desde una mirada democrática, lo memorable en la memoria no es solo el dolor. También son memorables, necesariamente memorables, la transgresión, la resistencia frente a las violaciones a los derechos humanos y el aporte constructivo a la convivencia, entre otras (Ricard 2009).

A su vez, la construcción de sociedades democráticas de manera sustantiva supone la igualdad política que resulta incompatible con el reclamo de legi-
A la izquierda, laboratorio artístico de co-creación (2020), a la derecha, audiencia de la Corte Interamericana de Derechos Humanos del caso de la periodista Jineth Bedoya (2021) 


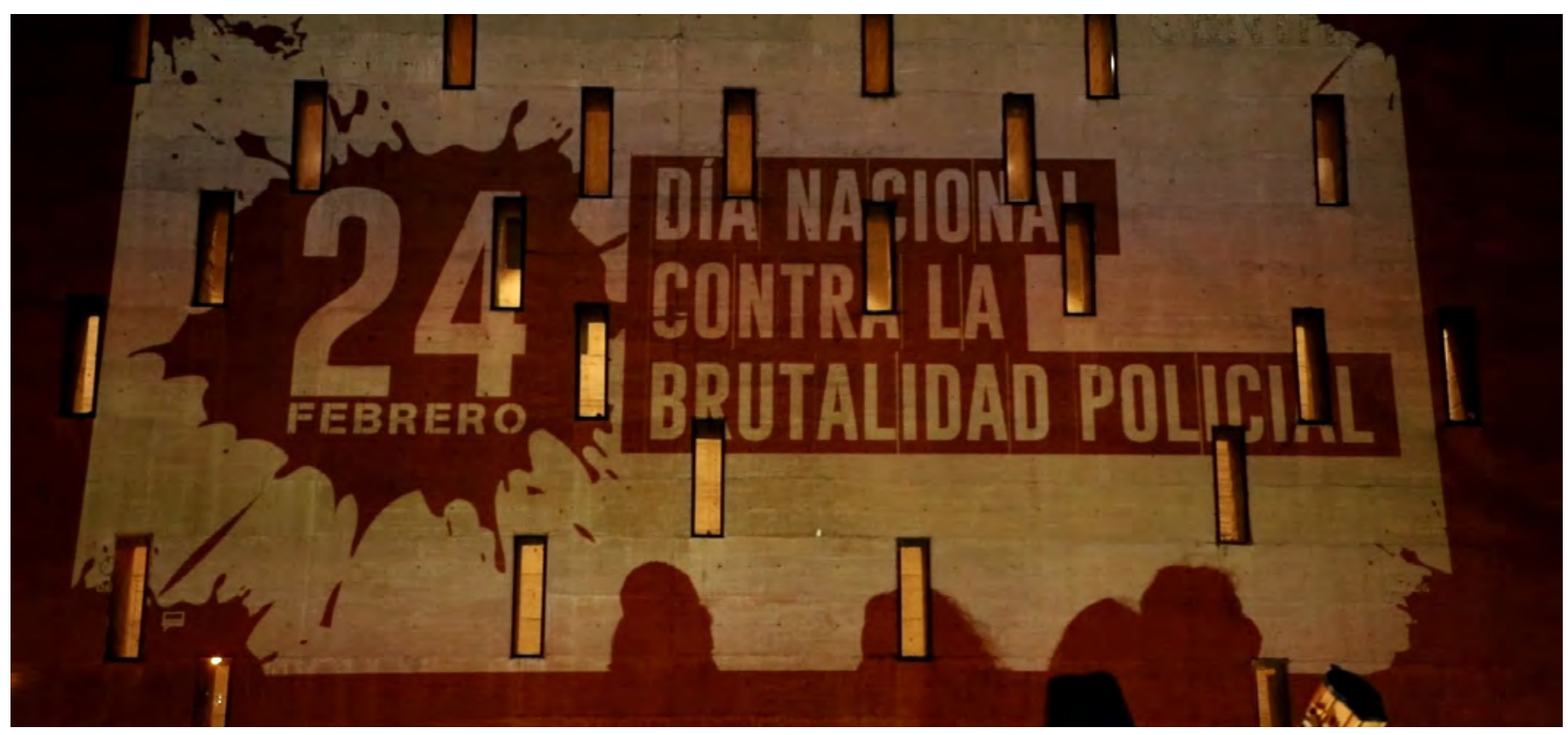

Conmemoración del Día Nacional contra la Brutalidad Policial (24 de febrero 2021)

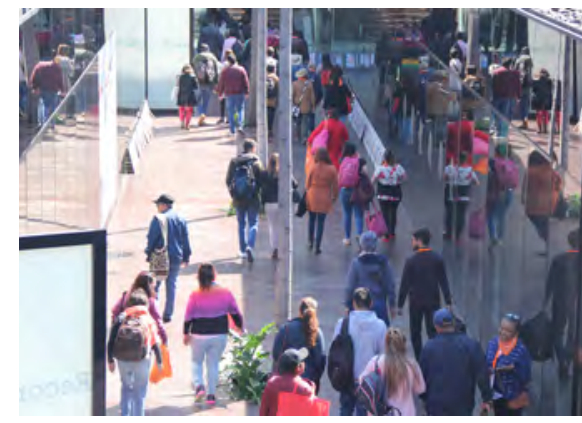

Encuentro del Movimiento Nacional de Víctimas de Crímenes de Estado (2020) timidad exclusiva para la acción democrática Butler 2020), lo que no implica desconocimiento de la legitimidad moral soportada en la experiencia para la exigencia de derechos. Más allá, lo que indica la evidencia de las experiencias de diferentes países con respecto a la superación o repetición de las marcas de la violencia, el conflicto y las dictaduras, es que con diferentes niveles de satisfacción o de los derechos de las víctimas, es fundamental que los procesos de transición impliquen transformaciones que rebasen los mandatos de la justicia transicional de modo que puedan implicar soluciones a problemas estructurales que no se refieren solo a quienes han sufrido acontecimientos específicos.

Digo más. En la medida en que la memoria puede ser también un instrumento de afirmación de la razón de la guerra, como lo ha sido, el impulso de la memoria para la paz es necesariamente la promoción de la cultura de lo común y de las causas comunes humanas sobre el reconocimiento de las diferencias, y no solo del reconocimiento de las diferencias, por ejemplo, por intensidad de sufrimiento.

Podemos decir que el Centro de Memoria, Paz y Reconciliación de Bogotá D.C. ha podido desarrollarse en debate permanente con la retórica de la que hablo considerando muchas visiones críticas, teniendo siempre una perspectiva amplia. Mientras otras instituciones, como el Centro Nacional de Memoria Histórica, que fue creado bajo un marco regulatorio detallado (Ley 1448 de 2011) donde se habían concentrado las expectativas de corrección política del gobierno nacional, el Centro de Bogotá pudo ser un lugar abierto 


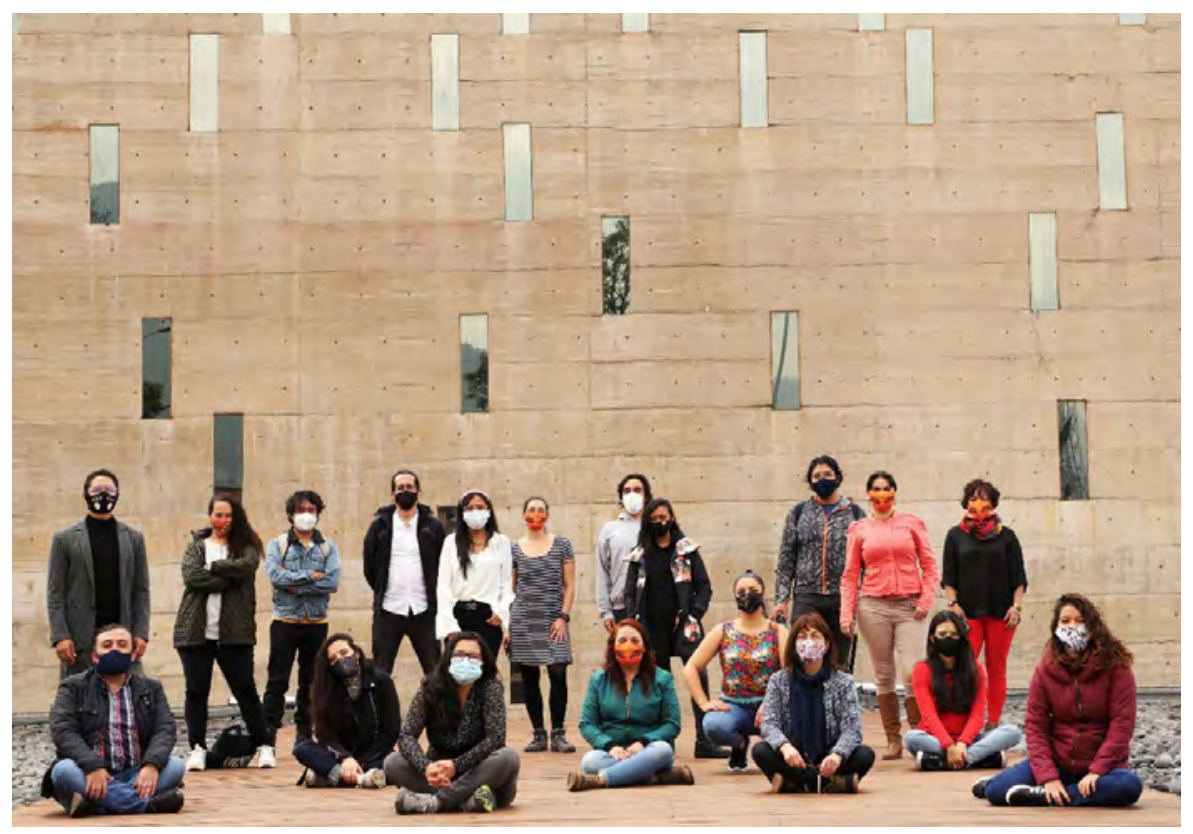

Equipo del Centro de Memoria, Paz y Reconciliación de Bogotá (2020)

a debates y activismos, no solo para los sectores y movimientos progresistas, sino para la academia.

\section{LA LABOR DEL CENTRO}

Siguiendo lo anterior, el Centro de Memoria, Paz y Reconciliación se organiza por líneas de trabajo cuyos proyectos reflejan el interés por rebasar la exhibición de "lo ocurrido en el pasado como sufrimiento de las víctimas", implementando estrategias de amplitud de lo memorable y de la capacidad de convocatoria, buscando que la paz no sea el resultado esperado por la evidencia de hechos trágicos, sino el objetivo a alcanzar por la relación de las víctimas y de la ciudadanía con su experiencia histórica, y el esfuerzo consciente por el posicionamiento de causas comunes.

Un instrumento básico en las actividades, transversal, es la cartografía Bogotá, ciudad memoria. En principio, se trata de un instrumento pedagógico diseñado para que la ciudadanía pueda dimensionar lo ocurrido en la capital a lo largo de un periodo que no se considera acabado. Más allá, es un mapa de la ciudad que funciona como magnitud de los muchos casos, hechos, acontecimientos y procesos que son, con o sin reconocimiento formal, irradiadores de patrimonio inmaterial para la paz en la capital, tan recientes como los casos más actuales de abuso y brutalidad policial exacerbados a partir de la pandemia y tan remotos como los acontecimientos del 9 de abril de 1948 y el asesinato de Jorge Eliécer Gaitán. 


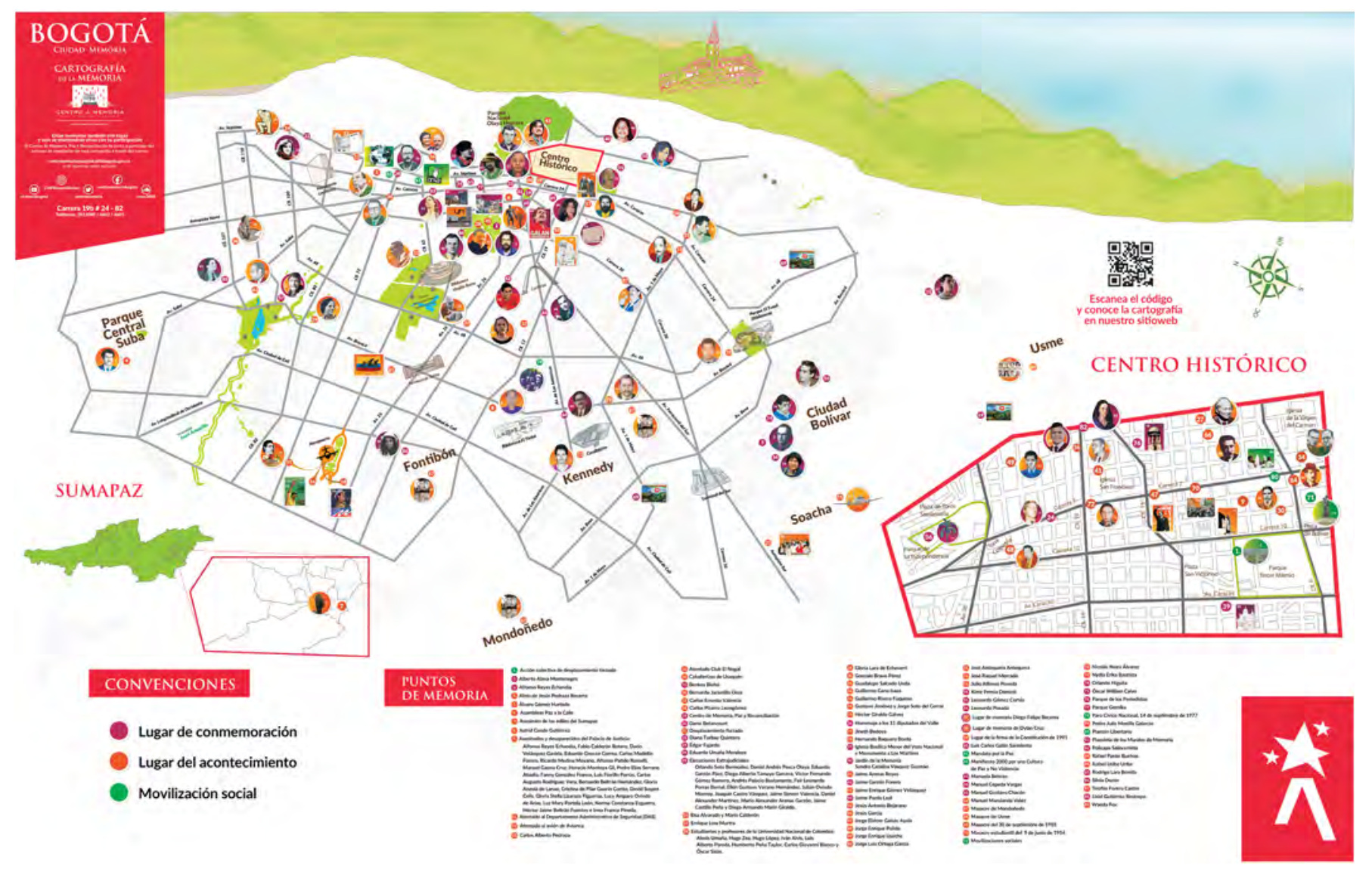

Cartografía Bogotá Ciudad Memoria, con georreferenciación de acontecimientos de violación a los derechos humanos y construcción de paz en la ciudad

Este mapa incluye características interesantes. Por un lado, no es un ejercicio cerrado y se alimenta permanentemente a partir del diálogo y la participación con las víctimas y la ciudadanía; en segundo lugar, está vinculado con sitios, marcas y huellas territoriales en la ciudad de carácter patrimonial como monumentos, placas, nombres de calles, instituciones, colegios, etc. Por último, se construye con un criterio amplio sobre el "capital transmisible de la memoria", de modo que no incluye solo lugares de acontecimientos de vulneración a derechos humanos, sino lugares emblemáticos de movilización social o construcción de paz transgresores.

Este instrumento, si bien no es el único trasversal, es utilizado por las diferentes líneas de trabajo del Centro que se organiza por líneas, insisto, con objetivos y orientaciones ligadas a los planteamientos expuestos:

> Dinamización del Centro:

Al ser un lugar de memoria, esta línea se propone una convocatoria amplia, a las víctimas y la ciudadanía, para la ocupación y uso del Centro como lugar 
físico, al tiempo que acompaña la preservación de lugares de memoria oficiales y no oficiales como monumentos, lugares de conmemoración, etc., que existen en la ciudad por iniciativa de las víctimas y la ciudadanía, todo lo cual se desarrolla en alianza con las instituciones distritales encargadas de la cultura.

Esta línea incluye la exposición central, las exposiciones temporales, la disposición técnica de espacios del Centro, las convocatorias para cursos o talleres de carácter artístico, la coordinación de la agenda de actividades virtuales (fortalecida a partir de la pandemia), y las convocatorias de estímulos para apoyo a proyectos de memoria, paz y reconciliación en la ciudad.

La clave central de esta línea es su trabajo convocante para la movilización ciudadana, lo que se desarrolla a través del ofrecimiento de herramientas y apoyos para la expresión de las víctimas y la ciudadanía, que no pretende nunca ser sustituida por la institucionalidad.

\section{> Gestión del conocimiento:}

Esta línea incluye el desarrollo de investigaciones, el espacio "Diálogos con memoria", la producción de artículos periodísticos, la gestión de archivos documentales, físicos, virtuales, escritos y audiovisuales, la exhibición de películas y documentales, la oferta de servicios archivísticos poscustodiales, y los eventos como seminarios y ciclos en alianza.

La clave de esta línea es la concepción de la memoria en términos explícitamente democráticos, como lo ha planteado Ricard Vinyes (2009), es decir, descentrada del capital transmisible del dolor y el sufrimiento como valor en sí y amplia con respecto a los múltiples factores memorables de la experiencia histórica a considerar para la construcción de la paz.

\section{> Pedagogías de la memoria:}

A través de esta línea se desarrollan procesos pedagógicos dirigidos especialmente a niños, niñas y jóvenes, en alianza con otras instituciones distritales como la Secretaría de Educación y la Secretaría de Integración social, ofreciendo espacios e instrumentos pedagógicos vinculados con la conformación de redes de estudiantes y maestros comprometidos con el impulso de la memoria, la paz y la reconciliación en la ciudad.

En esta línea se desarrollan proyectos vinculados con la Sala "Camino a casa" del Centro, adecuada específicamente para actividades con niños y niñas, producción de material útil para colegios y universidades, bitácoras pedagógicas, cartillas de trabajo e instrumentos de interés de jóvenes como stopmotion, juegos y contenidos para redes sociales. 
Tratándose de una línea dedicada a esta franja poblacional, su clave es, en primer lugar, la afirmación de los derechos y avances posicionados hasta el momento en el país en conexión con objetivos y causas comunes para las nuevas generaciones, especialmente en torno a problemáticas de la humanidad como la crisis climática o los efectos de la nueva revolución de internet y las nuevas tecnologías.

> Memorias locales, sectoriales y poblacionales:

La promoción de la memoria para la construcción de paz implica el fortalecimiento de iniciativas y fuerzas locales, de sectores sociales organizados (docentes) y de poblaciones (indígenas y afros), así como de esfuerzos desde la sociedad civil, artistas y demás promotores. Desde esta línea, se prioriza el apoyo de dichas iniciativas allí donde se desarrollan, en el barrio, la localidad, los ámbitos de movimiento de la sociedad civil y los demás lugares de la ciudad que sirven como irradiadores y convocantes.

De esta manera, desde aquí se impulsan proyectos como Barrios con memoria, donde se incluyen los relatos sobre los procesos de construcción y defensa de territorios, el "poder de lo local" con intercambios con experiencias en otros municipios y ciudades de Colombia y del mundo, el acompañamiento a los proyectos de las propias víctimas ante sus autoridades locales y los demás procesos de participación que se han establecido en la ciudad.

La orientación y el trabajo del Centro de Memoria, Paz y Reconciliación en Bogotá, Colombia, son un aporte al conocimiento sobre la cuestión del patrimonio inmaterial para la resolución de conflictos.

Por supuesto, todo lo anterior implica una perspectiva: el patrimonio inmaterial se considera vivo, como herencia, identidad y fuente de vínculos comunitarios. Para que sea útil, debe ser acción, lo que supone exposición y disposición a la recreación en sus múltiples formas.

En el ámbito de la memoria sobre la violencia política, las violaciones a derechos humanos y las transgresiones y resistencias, esa utilidad implica amplitudes de lo memorable y de quienes han de involucrarse. Supone el cuestionamiento a los efectos automáticos que produce el reconocimiento del pasado de dolor y sufrimiento, tomando en serio la obligación de considerar el presente y el futuro de causas y objetivos comunes desde la diferencia y no solo reafirmaciones de diferencias. 


\section{BIBLIOGRAFÍA}

- Butler, J. (2020) La fuerza de la no violencia. Colombia: Paidós, 2020

- Peterson, J. (2020) Mapas de sentido: una arquitectura de la creencia. Colombia: Planeta

- Rufer, M. (2010) La nación en escenas: memoria pública y usos del pasado en contextos coloniales. México: El Colegio de México

- Vinyes, R. (2009) La memoria como política pública. En: Guixé, J. y Monserrat, I. y (ed). Políticas públicas de la memoria: I Coloquio internacional Memorial Democratic. Barcelona: Milenio Publicaciones, pp. 23-39 


\section{El Museu Faller de València: buenas prácticas comunitarias y en gestión del turismo}

Gil-Manuel Hernàndez i Martí | Universitat de València, Director del Museu Faller de València

URL de la contribución <www.iaph.es/revistaph/index.php/revistaph/article/view/4882>

\section{RESUMEN}

El artículo aborda las buenas prácticas comunitarias y en gestión del turismo del Museu Faller de València, perteneciente al Ayuntamiento de València. En primer lugar se describen las características, trayectoria y singularidades del Museu Faller, especialmente el hecho de que su principal colección, la de los ninots indultados, se vaya conformando en el tiempo por votación popular. También se hace referencia a la reciente reorganización del museo, que ha incluido su homologación oficial y una reforma museográfica. En segundo lugar se señalan las diversas buenas prácticas comunitarias, en gran medida a partir de la declaración de la fiesta de las Fallas como Patrimonio Cultural Inmaterial por la Unesco en 2016, como han sido la diversidad de visitas guiadas planteadas, los ciclos de actividades culturales, el enfoque pedagógico adoptado, la política de preservación documental, el trabajo en red con otros museos falleros valencianos y la participación en diversos proyectos que ponen los museos al servicio de la salud de la ciudadanía. Finalmente se describen las buenas prácticas en gestión del turismo, enfatizando la considerable proyección del área turística donde está instalado el Museu Faller de València.

\section{Palabras clave}

Buenas prácticas | Comunidad | Cultura festiva | Cultura popular | Fallas de Valencia | Fiesta | Gestión cultural | Identidad cultural | Museos | Museu Faller de València Museo | Participación ciudadana | Patrimonio inmaterial | Patrimonio festivo | Turismo | València | 


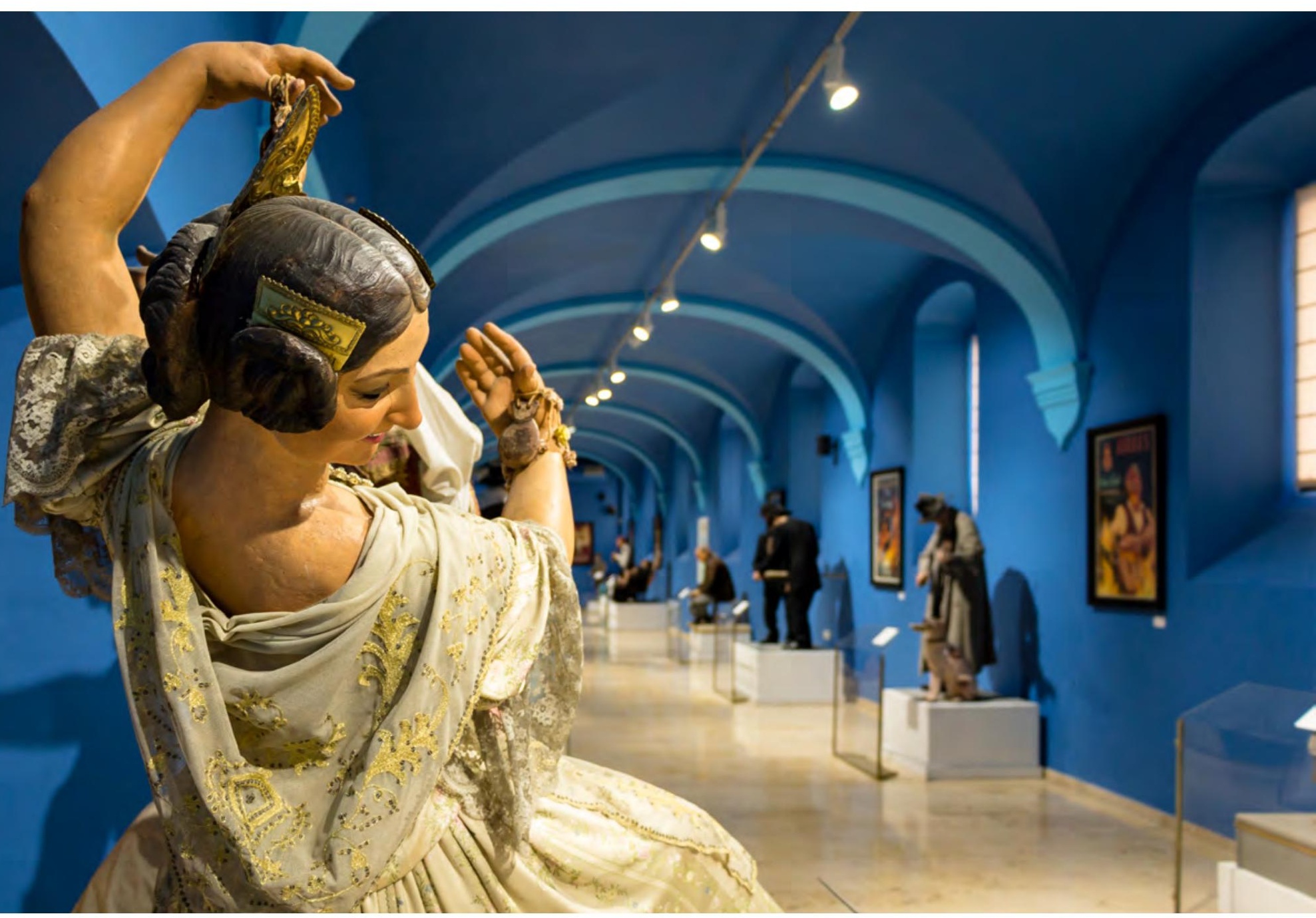

En el Museo Fallero de Valencia se almacenan todos los ninots indultats, con lo que se puede comprobar la evolución en técnicas, materiales y estilos | foto Rafa Esteve 


\section{EL MUSEU FALLER DE VALÈNCIA}

El desarrollo e institucionalización, a partir de los tiempos de la Transición, de una política cultural festiva en España, junto con una revitalización turístico-patrimonial de las fiestas, y la intensificación de sus connotaciones identitarias (García Pilán 2010), supusieron la puesta en marcha, especialmente a nivel local, de museos de cultura festiva. Esta modelo de museo etnológico está orientado a poner en valor el patrimonio festivo de aquellas ciudades o localidades con manifestaciones festivas singulares o destacadas, algunas de ellas con reconocimientos patrimoniales de prestigio, como es el caso de València.

El Ayuntamiento de València, a través de su Concejalía de Cultura Festiva (denominada así desde 2015), gestiona tres museos de titularidad municipal, como son el Museu Faller de València (inaugurado en 1971), el Museu del Corpus-Casa de les Roques (inaugurado en 2006) y el Museu de la Semana Santa Marinera "Salvador Caurín" (inaugurado en 2000). Los tres museos hacen referencia a las principales fiestas de la ciudad: las Fallas, consideradas fiesta principal de València y declarada en 2016 como Patrimonio Cultural Inmaterial de la Humanidad por la Unesco; la Semana Santa Marinera, la principal festividad del distrito marítimo de València; y el Corpus Christi, que entre los siglos XIV y XIX fue la fiesta principal de la ciudad.

Se trata, pues, de museos vinculados a fiestas de larga historia, muy dinámicas y sometidas a importantes procesos de patrimonialización y revitalización, que además se arraigan a una extensa y fuerte red de sociabilidad popular festiva (Hernàndez 2016). En nuestro caso, el museo de cultura festiva se despliega como un espacio doblemente ritual: en tanto que museo que implícitamente funciona como un ritual de civilización (Duncan 2007), y como recinto en el que se desarrolla una reflexión museográfica específica sobre el ritual festivo. En ese sentido, los museos de cultura festiva se configuran como ámbitos de rememoración festiva permanente, actuando como altavoces y promotores privilegiados de la fiesta viva en el espacio público.

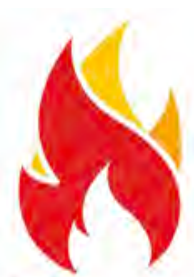

MUSEU FALLER DE U A L Ė C C I A

Logo oficial del Museu Faller de València | fuente Museu Faller de València
El ejemplo del Museu Faller de València es paradigmático de esta concepción del museo de cultura festiva. Se trata de un caso singular en el ámbito de los museos, pues su principal colección, la de ninots indultados, se ha ido conformando desde 1934 por votación popular, y no por la decisión de un técnico o especialista en museos. Fue ese año cuando el artista fallero Regino Más consiguió que se activara oficialmente por el Ayuntamiento de València la iniciativa L'Indult del Foc (El Indulto del Fuego), según la cual se indultaría del fuego un ninot entre todos los presentados a la llamada Exposició del Ninot por parte de las diversas comisiones falleras que plantaran falla en la ciudad. Posteriormente, la colección de ninots indultados, resultado de las diversas ediciones de la Exposición del Ninot, transitó por 
sedes diversas e inestables, y siempre en condiciones frágiles de conservación, lo que provocó la degradación de buena parte de la colección, ya que los ninots están construidos para ser quemados con sus respectivas fallas. Pero en 1971 el antiguo convento de la Casa Misión de San Vicente de Paül de Monteolivet, comprado por el Ayuntamiento de València al Ejército, se convirtió en la sede definitiva y permanente del Museu Faller de València. En 1995 el Ayuntamiento de València rehabilitó íntegramente el edificio en el que estaba ubicado el Museu Faller, practicándose un conjunto de restauraciones de los ninots indultados, que presentaban un alto grado de deterioro. Junto a estos se expondría también la colección de ninots indultados infantiles, que empezó a formarse en 1963, la colección de carteles oficiales anunciadores de las Fallas, formada desde 1929, y la de los cuadros de las falleras mayores de València, iniciada en 1995, así como la colección de insignias de las comisiones falleras de la ciudad.

Posteriormente, el Ayuntamiento de València publicó un catálogo razonado del Museo Fallero en tres volúmenes $(2002,2003,2005)$ y una guía en cuatro idiomas (2010), obra de la Associació d'Estudis Fallers. En el área urbana alrededor del Museu Faller fue creciendo la fastuosa y mediática Ciutat de les Arts i les Ciències, que en pocos años se convirtió en el espacio emblemático de la modernidad valenciana, capaz de transformarse en el principal atractivo de València para visitantes (Hernàndez 2009), situación que posibilitó que el Museu Faller atrajera cada vez más visitantes, pasando de 58.337 en 2005 a 124.252 en 2019.

La visita a las galerías del Museo Fallero de València permite un repaso muy interesante de la historia de la fiesta fallera y de la misma ciudad de València, además de reflejar las transformaciones sociales, económicas y culturales de nuestro mundo. Igualmente, se pueden conocer las diversas sensibilidades estéticas, estilos y artistas falleros de la fiesta, así como las principales técnicas constructivas y los materiales que se emplean para confeccionar las fallas. Además, la colección de carteles reúne muchos de los más grandes cartelistas valencianos, mostrando la manera en que históricamente se ha publicitado la fiesta fuera de la ciudad. La colección de insignias permite captar gráficamente la capital importancia de esa extensa red de sociabilidad festiva que son las comisiones falleras. Finalmente, la colección de cuadros de falleras mayores de València introduce una reflexión sobre el papel de la mujer en las Fallas. Al fin y al cabo, el Museo Fallero de València guarda los pocos restos materiales que quedan de las fallas que se plantan cada año, hecho que potencia paradójicamente su valor como testigo de la materialidad de una fiesta que destaca por el carácter efímero de sus producciones artísticas.

El recorrido por las diversas piezas del Museo Fallero permite, desde una perspectiva etnológica, ligar la cultura local con las diversas manifestaciones iconográficas de la cultura global. Esto convierte el Museo Fallero de

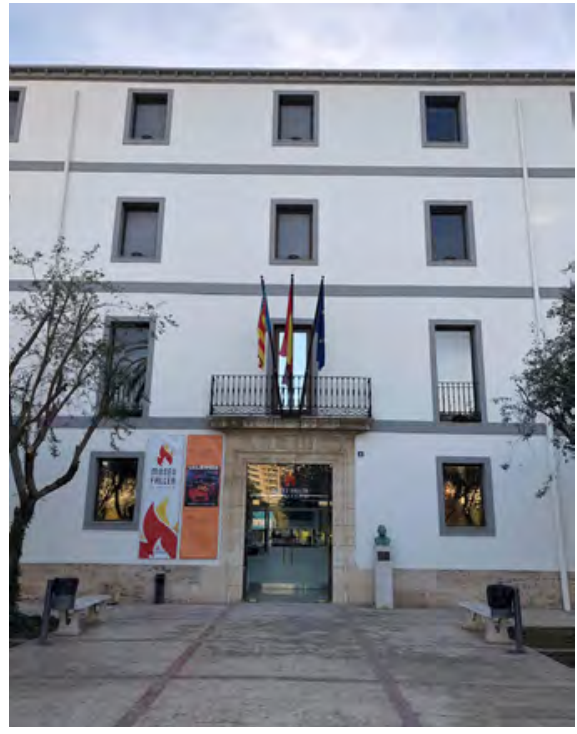

Fachada principal del Museu Faller de València | foto Museu Faller de València 
València en una auténtica exposición permanente de la globalización cultural, entendida esta como espacio de continuas hibridaciones entre culturas. Si a esto añadimos la nueva consideración de las Fallas como patrimonio cultural inmaterial por la Unesco desde 2016, resulta importante subrayar que el Museo Fallero actúa como un espacio privilegiado de preservación de esa condición patrimonial de la fiesta fallera.

\section{LA REORGANIZACIÓN DEL MUSEU FALLER DE VALÈNCIA}

La declaración de 2016 supuso la necesidad de dinamizar el Museu Faller de València, poniéndolo verdaderamente en valor patrimonial, potenciando su uso pedagógico y, sobre todo, convirtiéndolo en un lugar de difusión, promoción y reconocimiento de la cultura fallera y de la obra de los artistas falleros y los cartelistas. Por eso, desde la Concejalía de Cultura Festiva se hicieron los esfuerzos necesarios porque el Museu Faller fuera finalmente homologado por la Generalitat Valenciana ese mismo año.

Conseguida la homologación, en los últimos años se ha llevado a cabo una serie de reformas e iniciativas que eran absolutamente necesarias para dignificar y revalorizar el Museu Faller. Así, se cambió el cromatismo de las

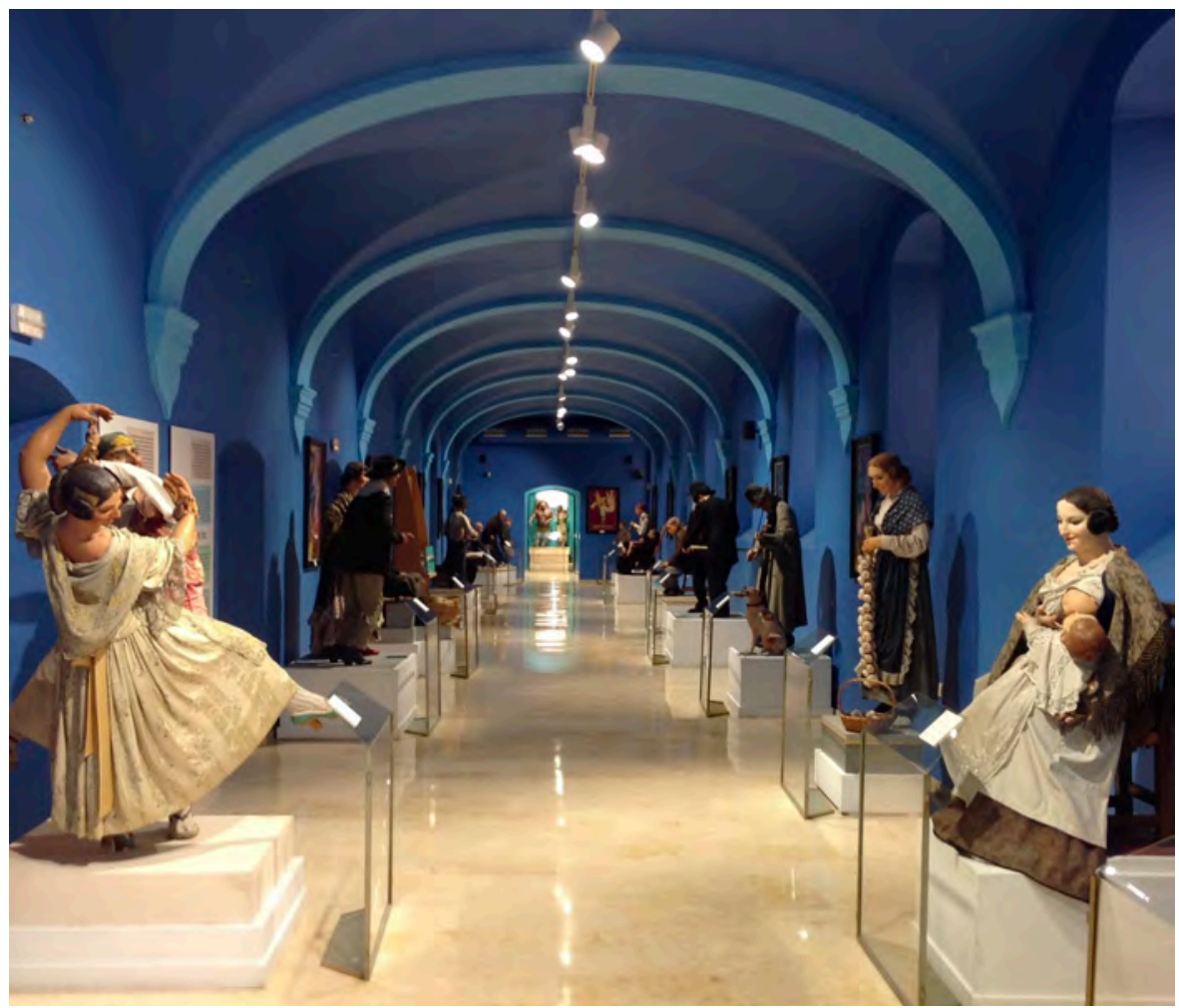




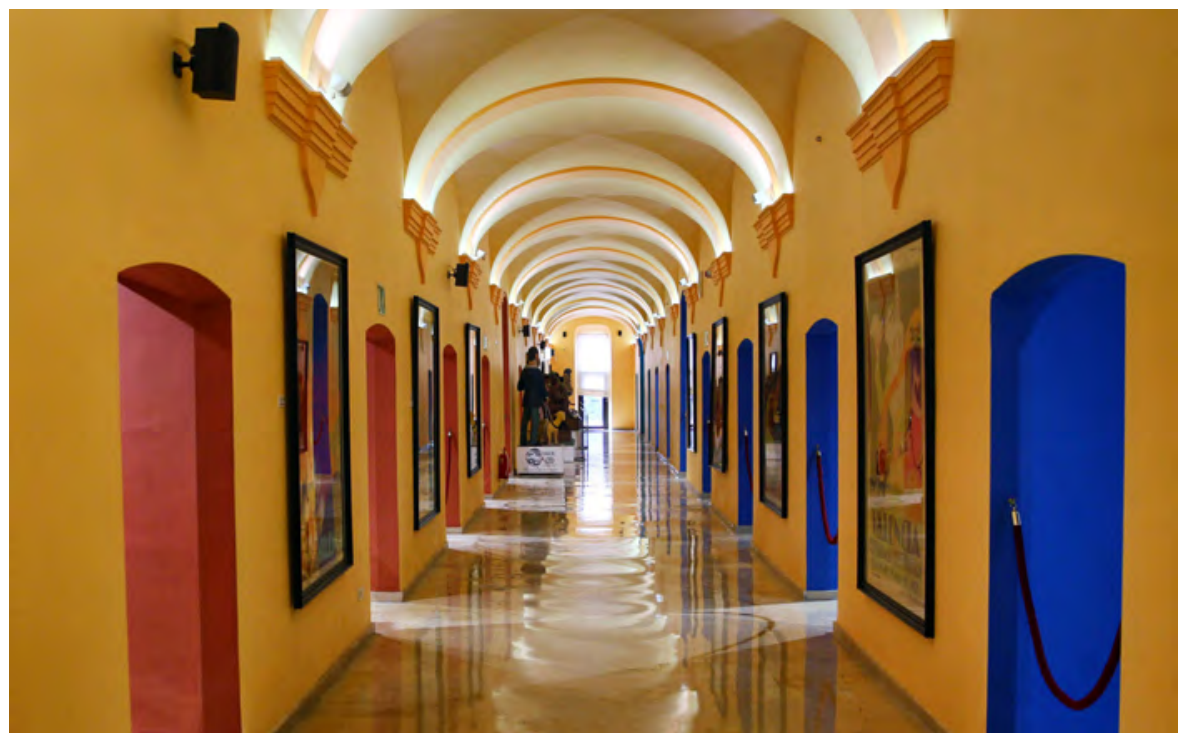

Sala de primeros carteles oficiales de Fallas | foto Museu Faller de València

salas y su iluminación, se reorganizaron las colecciones, se creó una nueva imagen corporativa, se activaron las redes sociales del museo y se inauguró una sala de exposiciones temporales para dar cabida a la obra artística de los artistas falleros más destacados. También se han restaurado ninots indultados y carteles de falla, se ha activado una visita virtual en 3D, se han preparado nuevos elementos gráficos orientados a mejorar la contextualización de las colecciones o se ha puesto en marcha la Xarxa Valenciana de Museus Fallers (Red Valenciana de Museos Falleros) con los museos falleros de Gandía, Xàtiva, Cullera, Alzira, Burriana y el Museo del Artista Fallero de València para reforzar la visibilidad patrimonial y turística de los museos falleros. Simultáneamente, se han reforzado los dispositivos museográficos destinados a promover los elementos emocionales asociados a la visita, mediante modernas audioguías, la venta de merchandising propio y la nueva pintura exterior del edificio. Como elemento complementario, se han articulado varias visitas guiadas a través de varios itinerarios temáticos, en clave histórica, social, artística, de enseñanza, de género y LGTBI+.

$Y$ es que las personas que entran en el Museo de València lo hacen en un espacio de memoria viva de la fiesta, un espacio que busca despertar las sensaciones que se pueden tener ante las fallas plantadas, o al menos recrear algunas de las emociones y sentimientos que la fiesta fallera suscita. No en vano, los rituales festivos suelen ser muy importantes para la comunidad, en tanto que generan identidad compartida e intensas movilizaciones emocionales (Ariño Villarroya y Gómez i Soler 2012). De modo que el objetivo es que los visitantes salgan del Museo Fallero de València sorprendidos y cautivados por un universo festivo absorbente, singular y desbordante, consiguiendo así captar los motivos por los cuales las Fallas son 
ya un patrimonio cultural mundial. Porque, como plantea Duncan (2007), los museos actúan como espacios rituales de la modernidad donde se abre una experiencia de otra calidad, con impactos emocionales y de aprendizaje, de forma que los objetos expuestos y dispositivos de narración y exposición son diseñados para favorecer la experiencia transformadora de la visita. En ese sentido, y todavía con más motivo, un museo de cultura festiva como el Museo Fallero funciona como un espacio de rememoración permanente del ritual festivo, la función principal del cual es estimular y promover la experiencia de la fiesta viva.

\section{BUENAS PRÁCTICAS COMUNITARIAS}

Como bien sabemos, la Unesco define como buenas prácticas de salvaguarda las operaciones de identificación, documentación, investigación, preservación, protección, promoción, valoración, transmisión y revitalización, que devienen comunitarias en la medida en que se implica a las comunidades celebrantes o depositarias del patrimonio festivo en dichas buenas prácticas. En el caso de las Fallas, desde la Declaración de 2016, desde las instituciones públicas se ha puesto en marcha una serie de acciones que de una manera progresiva han ido reforzando el apoyo popular, estimulando iniciativas desde la sociedad civil y especialmente desde el asociacionismo fallero con una perspectiva abierta, constructiva y orgánica. En el caso del Museu Faller de València debemos subrayar las buenas prácticas comunitarias que seguidamente se exponen.

En primer lugar, se han desarrollado y articulado las visitas guiadas a través de itinerarios temáticos, abordando enfoques históricos, sociales, ambientalistas, artísticos y con perspectiva de género, o bien con planteamientos específicamente dirigidos a las comisiones falleras y otros colectivos. Debe tenerse en cuenta que las Fallas son posibles por la existencia de la comisiones o asociaciones falleras, que sufragan las fallas plantadas y co-organizan la fiesta junto a las instituciones públicas. De hecho, solo en la ciudad de Valencia hay 100.000 falleros y falleras agrupadas en 385 comisiones falleras. De modo que con estas visitas o actividades dirigidas a las comisiones se pretende incentivar la vocación del Museu Faller como museo ligado a la comunidad festiva y al territorio urbano que esta ocupa y dinamiza desde lo festivo. También se han elaborado visitas guiadas especiales orientadas a grupos de migrantes y refugiados, a través de entidades como organizaciones de ayuda al refugiado o Cruz Roja.

En segundo lugar debe destacarse el ciclo de actividades culturales L'Indult del Foc, con motivo de la instalación de la Exposició del Ninot en el Museu de les Ciències. El hecho de que en 2016 se trasladara la Exposición del Ninot desde una carpa junto al centro comercial Nuevo Centro al Museu de 


\section{L'INDULT DEL FOC} Falles 2019 Lalència

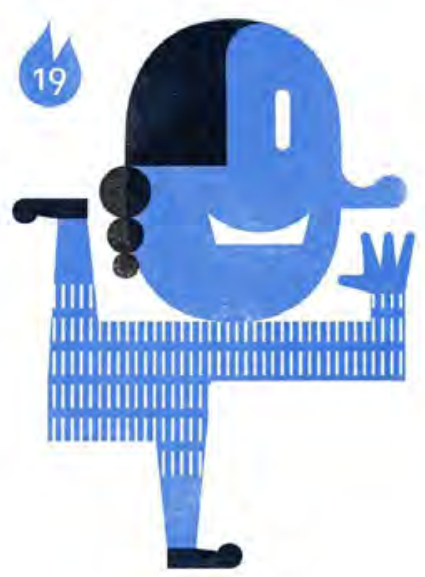

\section{VISITES GUIADES}

A L'EXPOSICIÓ DEL NINOT

Dimarts 19 febrer $-18.00 \mathrm{~h}$

Els ninots amb representacions de la infància de l'exposició infantil Judith Martinez Mayor i Adrián García Payá (tècnics del Museu Foller de València).

Dijous 28 febrer - 18.00 hores

Els ninots de caricatura

Enric Cuenca (gestor cultural de la Regidoria de Cultura Festiva).

Dimarts 5 març - 18.00 hores

Els ninots de retrat

Adrián Garcia Payá (tècnic del Museu

Faller de València).

Dijous 7 març - 18.00 hores

Els ninots de representacions femenines Judith Martinez Mayor

(tècnica del Museu Faller de València).

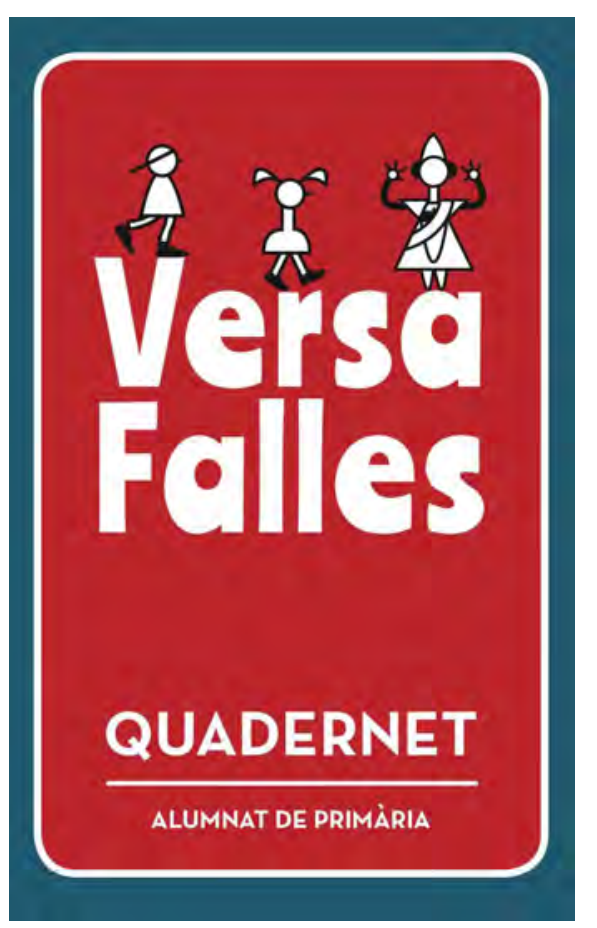

A la izquierda, portada programa actividades de L'Indult del Foc; a la derecha, portada del cuaderno del Versafalles | fuente Ayuntamiento de València les Ciències, en la Ciutat de les Arts i les Ciències, el lugar más visitado de València, significó todo un reconocimiento del valor patrimonial de los ninots falleros, permitiendo una mayor afluencia de público y una mayor difusión de la cultura fallera. En este sentido, debe valorarse la programación cultural organizada desde el Museu Faller bajo la denominación de L'Indult del Foc, con un programa centrado en la valorización y divulgación del patrimonio fallero entra los casi 100.000 visitantes de l'Exposició del Ninot, con tertulias, charlas, visitadas guiadas o el ciclo cinematográfico Falles de Cel·luloide, centrado específicamente en la relación entre las Fallas y el cine.

En tercer lugar debemos mencionar el proyecto educativo Versafalles, que relaciona el conocimiento de la poesía contemporánea en valenciano, tomando como referencia poetas clásicos y modernos, con los temas que aborda la colección de ninots indultados del Museo Fallero de València, para su uso pedagógico con estudiantes de primaria y secundaria. El proyecto, puesto en marcha en 2018, y organizado con el Gabinete de Normalització Lingüística del Ayuntamiento de València, ha incluido la publicación de varios cuadernos didácticos con los poemas utilizados dirigido a los estudiantes, que de este modo se sensibilizan simultáneamente con la cultura fallera y con la poesía en valenciano.

Una cuarta buena práctica comunitaria a resaltar es la supervisión y coordinación por parte del Museu Faller del Centre de Documentació de les Falles 


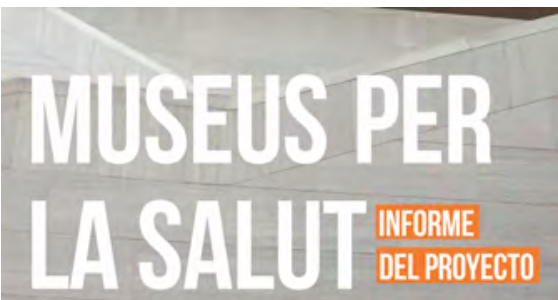

RECORDS DE FESTA AL MUSEU FALLER DE VALENNGIA

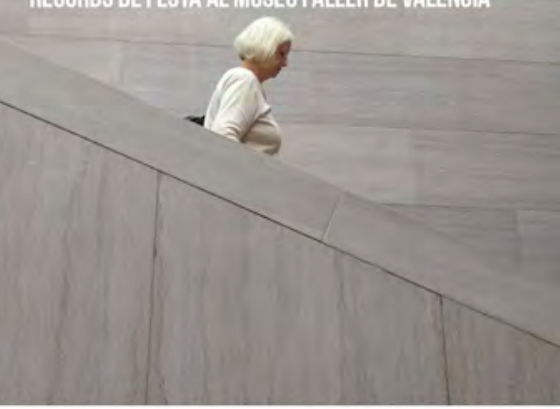

형 Lasnaves ( D

Portada informe Museus per la Salut | foto Las Naves-Ayuntamiento de València
(CDF), inaugurado en 2005, cerrado en 2011 por la crisis y vuelto a reabrir en 2017, que funciona como un espacio de investigación, conservación y difusión documental vinculado tanto a la trama asociativa fallera como a los coleccionistas y estudiosos de la fiesta. El CDF está ubicado en el edificio del Gremi Artesà d'Artistes Fallers y está gestionado científicamente por l'Associació d'Estudis Fallers, declarada en 2016 por la Unesco como entidad colaboradora en temas de patrimonio cultural. En el CDF se realiza un trabajo de inventario, catalogación y digitalización de la documentación producida por la fiesta (escrita, fotográfica y cinematográfica), poniéndola al alcance del colectivo fallero y de la ciudadanía en general.

Por su parte, y en quinto lugar, en 2016 desde el Museu Faller de València se impulsó y activó la creación de la Xarxa Valenciana de Museus Fallers (Red Valenciana de Museos Falleros) junto con los museos falleros de Gandía, Alzira, Xàtiva, Cullera, Museu de l'Artista Faller de València, incorporándose el de Burriana en 2019. El objetivo de la Xarxa es potenciar un trabajo en común para dar una respuesta eficiente, desde la realidad de unos museos modestos, a los retos que plantea la preservación del patrimonio cultural fallero y su aprovechamiento en clave de turismo cultural sostenible y de calidad. Un trabajo coordinado para sumar recursos y personas para dignificar los museos falleros como herramientas de conservación, investigación y divulgación del patrimonio festivo de la Fallas en las mejores condiciones de dignidad, profesionalidad y excelencia.

En sexto lugar hay que destacar el proyecto innovador y pionero Museus per la Salut. Records de festa al Museu Faller de València, orientado a la utilización del museo para la terapia de memoria con pacientes de Alzheimer, realizado con el concurso de la Asociación de Familiares de Alzheimer de València, la Universidad de Valencia, el centro de innovación municipal Las Naves y el Gremi Artesà d'Artistes Fallers. Con este proyecto, que ya ha tenido dos ediciones (2018 y 2019), se ha perseguido generar bienestar a través de la estimulación de la memoria a largo plazo (terapia de reminiscencia) en personas en las primeras fases de Alzheimer con los recuerdos que la fiesta fallera suscitara en la visita guiada al Museu Faller, reforzada por las explicaciones de artistas falleros jubilados y con el apoyo técnico y científico del personal especializado que está presente en las visitas. La evaluación del proyecto ha demostrado su éxito y la capacidad de generar bienestar en los pacientes participantes (Baños et ál. 2021). En 2019 el Museu Faller también participó en la iniciativa Receta Cultura, impulsada por la Conselleria de Sanidad Universal y Salud Pública de la Generalitat Valenciana y Las Naves, centro de innovación del Ayuntamiento de València. Receta Cultura consistía en la prescripción por los centros de salud pública de València de visitas guiadas a diversos museos, enfocadas a pacientes con problemáticas de soledad no deseada o síndromes depresivos. No obstante, el programa se tuvo que ser suspendido en marzo de 2020, debido a la pandemia de la COVID-19. 
Asimismo, el Museu Faller de València realiza una constante difusión de la cultura fallera a través de redes sociales propias, medios de comunicación, y a través de colaboraciones con entidades festivas, universidades e instituciones públicas, participando asimismo en la organización anual de las actividades culturales por el aniversario de la Declaración de 2016.

\section{BUENAS PRÁCTICAS EN GESTIÓN DEL TURISMO}

A la hora de plantear las buenas prácticas en gestión del turismo en el Museu Faller de València e han tenido en cuenta los objetivos fundamentales de servicio público y dinámico, la interpretación del patrimonio como vehículo para la transmisión de valores sociales fundamentales, la protección de fondos, el fomento de un ocio saludable y gratificante para los visitantes.

Como dato a tener en cuenta, el público familiar e individual del año 2019 estuvo en torno a las 50.000 visitas, viniendo el resto, casi 75.000 personas, en grupos organizados que, en su gran mayoría, alrededor del $90 \%$, lo hicieron con reserva previa confirmada. Estas cifras nos llevan a dos campos completamente distintos a la hora del tratamiento de acogida al propio museo: las visitas que se realizan de forma individual o familiar y las que se realizan en grupos organizados.

Respecto a las visitas individuales, familiares o grupos pequeños (hasta diez personas) se intenta transmitir la importancia de una fiesta única en el mundo y las ganas del público de vivir la fiesta en la calle. Para este público se ofrece una visita guiada gratuita al día, cuando se dispone de personal para ello. En cuanto a las visitas de grupos organizados (para grupos de más de diez personas), se recomienda la reserva previa, que suele ser la práctica habitual, con una tramitación personalizada según las características y necesidades de cada grupo y una gestión por anticipado que agradecen especialmente las agencias de viajes.

Entendemos que el público suele visitar el Museu Faller en un viaje programado, por ello se respeta y facilita la entrada preferente de aquellos grupos que vienen con reserva previa. Se intenta que todas las agencias con las que se trabaja, 177 justo antes de la pandemia, conozcan y comprendan el museo. Para ello, se invita a sus representantes siempre que tienen ocasión de visitar València y se les ofrece una visita guiada personalizada. Con ello persiguen tres objetivos: que puedan valorar y ubicar el museo y calibrar el tiempo que les puede llevar visitarlo a los grupos que envían; que comprendan la necesidad de anticipar sus reservas con la ventaja que apareja entrar con una espera máxima de 15 minutos para los grupos concertados; y poder establecer una relación personal con las personas que promocionan el museo de forma profesional, además de facilitar la comunicación y la 


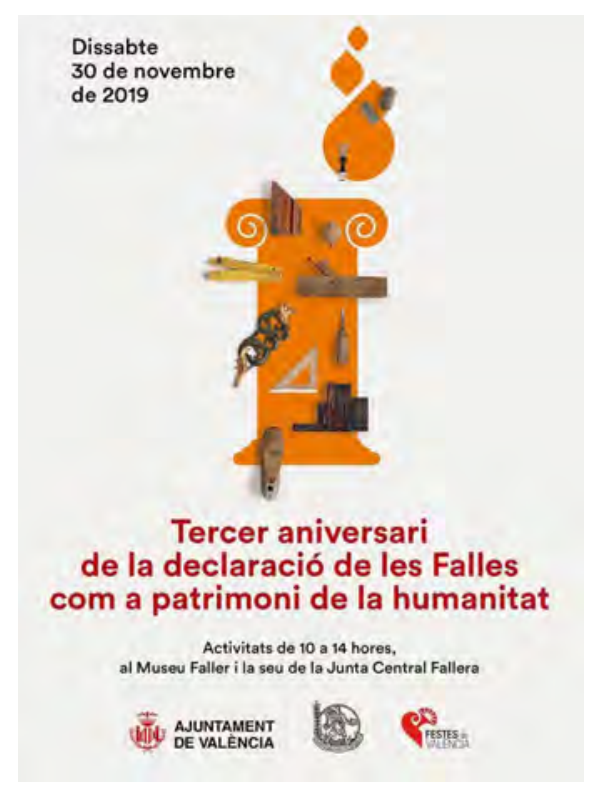

Cartel de la celebración del tercer aniversario de la Declaración de 2016 | foto Ayuntamiento de València comprensión en caso de situaciones imprevistas, lo que resulta muy positivo en cuanto a la fidelización de la clientela profesional. De hecho, las agencias que lo han visitado han incluido el Museu Faller de València, máximo exponente material permanente del carácter de las Fallas como Patrimonio Cultural Inmaterial de la Humanidad, en todos los circuitos que traen a la ciudad.

En cuanto a los agentes de turismo local y guías oficiales, el Museu Faller mantiene con ellos una relación fluida respetando y facilitando su trabajo en la medida de lo posible aconsejando franjas horarias más tranquilas y respondiendo a sus peticiones de reservas. Se intenta informar de los cambios de horarios, cierres programados y cualquier circunstancia que pueda afectar a la marcha normal del museo a través de las distintas webs en las que se publican los datos del museo y en las plataformas especialistas en turismo, como Tripadvisor y Google Business, en las que se contesta diariamente las opiniones recogidas y se publican dichos cambios en tiempo real.

Con respecto a las visitas guiadas, todas se realizan en lenguaje no sexista y en ellas se trabajan aspectos festivos, históricos, igualitarios, tolerantes, integradores, artísticos, divertidos y evolutivos de la fiesta y de la sociedad que la hace posible. Se intenta que sean participativas y que el público comprenda la esencia de las fallas como arte efímero, pero nunca intrascendente.

\section{CONCLUSIONES}

En suma, todas las intervenciones realizadas en el Museu Faller de València están encaminadas al reforzamiento de un museo que busca su diferenciación dentro de la amplia oferta de museos de la ciudad de València. De modo que las transformaciones museográficas y de promoción reseñadas solo son un paso en el un proyecto que pretende hacer del Museu Faller de València el gran museo etnológico de la fiesta de las Fallas, capaz de mostrar todos sus elementos y dimensiones reconocidas por la Unesco a través del reconocimiento de las Fallas como Patrimonio Inmaterial del Humanidad. Por ello, los trabajos y buenas prácticas que están en marcha en el Museu Faller de València implican avanzar en ese camino, lo que demanda nuevos esfuerzos, inversiones y trabajos, que tienen que implicar necesariamente al mundo fallero, a la esfera artística, a los investigadores, a los gestores culturales y a las instituciones públicas. 


\section{BIBLIOGRAFÍA}

- Ariño Villarroya, A. y Gómez i Soler, S. (2012) La festa mare. Les festes en una era postcristiana. València: Museu Valencià d'Etnologia-Diputació de València

- Baños, R.M., Etchemendy, E., Espinoza, M. y Rocher, E. (2021) Museus per la Salut, Records de la Festa: algunes dades sobre l'experiència amb persones amb alzhèimer en el Museu Faller de València. Revista d'Estudis Fallers, n. ${ }^{\circ}$ 26, pp. 88-95

- Duncan, C. (2007) Rituales de civilización. Murcia: Nausícaä

- García Pilán, P. (2010) Tradición en la modernidad avanzada: la Semana Santa Marinera de Valencia. Valencia: Museu Valencià d'Etnologia

- Hernàndez, G.M. (2009) La ciudad y la fiesta glocal. La reconversión turística-patrimonial del Museo Fallero de Valencia. Zainak. Cuadernos de Antropología-Etnografía, $n^{\circ} .32$, pp. 933-954

- Hernàndez, G.M. (2016) Cultura festiva, colectiva y política cultural en el espacio global. En: Rius Ulldemolins, J. y Rubio Arostegui, J.A. (coord.) Treinta años de políticas culturales en España. Participación cultural, gobernanza territorial e industrias culturales. València: Universitat de València, Servei de Publicacions, pp. 231-247 


\title{
La Ruta 66 en Estados Unidos: allanando el camino para la protección y gestión de las carreteras históricas
}

\author{
Kaisa Barthuli | Route 66 Corridor Preservation Program, National Trails \\ Intermountain Region, National Park Service, USA \\ Michael Romero Taylor | Retired National Park Service, USA \\ URL de la contribución <www.iaph.es/revistaph/index.php/revistaph/article/view/4952>
}

\section{RESUMEN}

La famosa Ruta 66 se extiende por, aproximadamente, $3.900 \mathrm{~km}$, desde Chicago hasta Santa Mónica. Se trata de una mítica carretera que ha contribuido de manera significativa al desarrollo y a la iconografía de Estados Unidos en el siglo XX. Reconociendo los valores patrimoniales de la Ruta 66 (también llamada The Mother Road o La carretera madre), el Congreso de los Estados Unidos ha establecido un programa a través del Servicio de Parques Nacionales para proveer soporte técnico y financiación que permitan la adecuada conservación de esta vía. El programa sienta un precedente en el reconocimiento de la importancia de las carreteras como hitos de la evolución tecnológica, del transporte y del comercio en Estados Unidos. El programa trabaja con numerosas entidades privadas, sin ánimo de lucro, tanto locales como estatales, nacionales y federales, para concienciar sobre la relevancia histórica de la Ruta 66, la necesidad de establecer medidas para su conservación y las oportunidades económicas que su puesta en valor puede plantear en términos de turismo. Precisamente, con el presente artículo se pretende analizar las estrategias que, tanto el Servicio de Parques Nacionales como otras instituciones, están desarrollando para la protección, gestión y promoción de esta histórica ruta.

\section{Palabras clave}

Carreteras históricas | Conservación (Patrimonio) | Estados Unidos | Gestión cultural | Historia | Protección | Ruta automovilística | Ruta 66 | Servicio de Parques Nacionales de Estados Unidos | Transporte | 


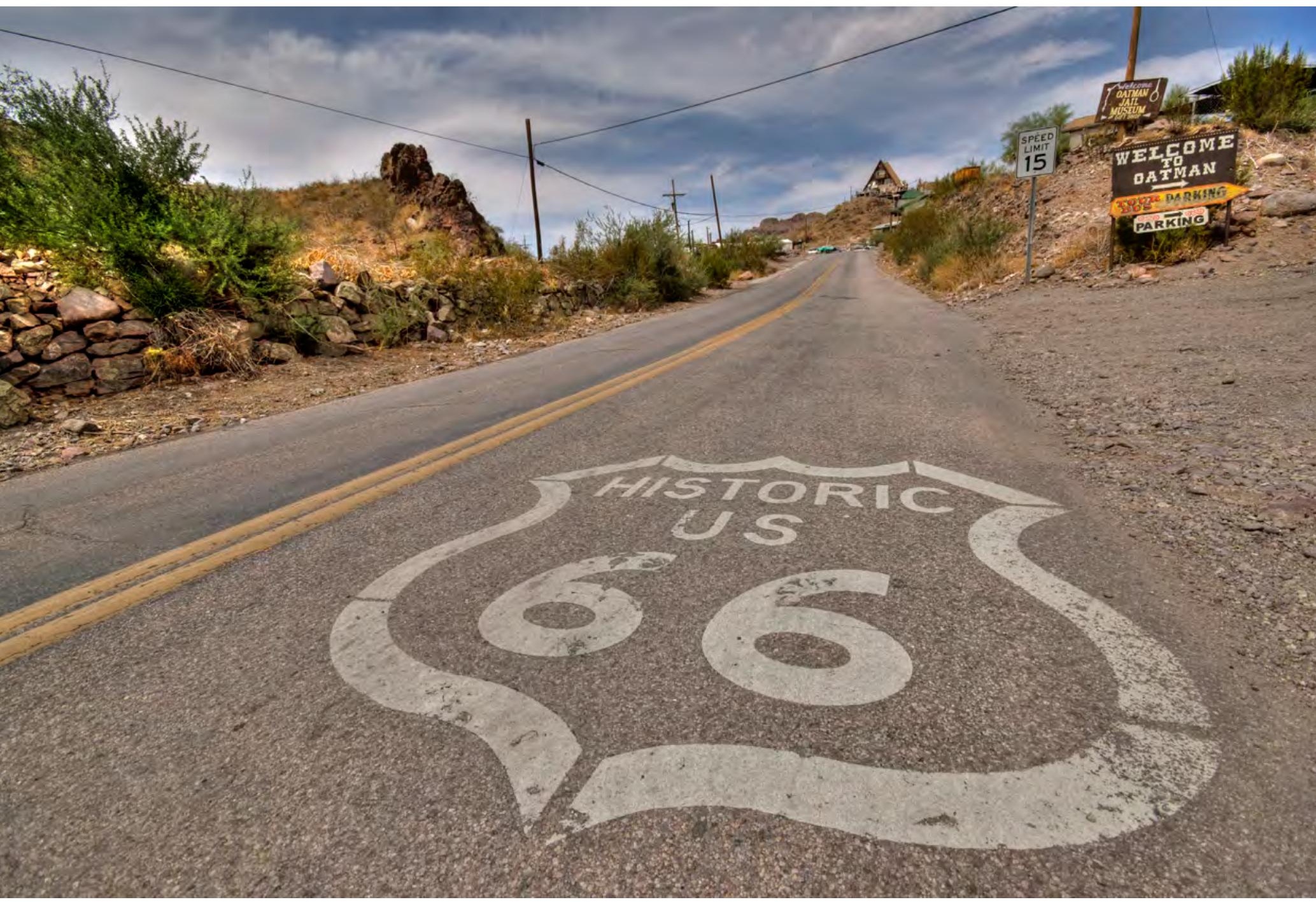

Ruta 66. Oatman, pequeño poblado vaquero en Arizona | foto Vicente Villamón 
1

El presente trabajo es una revisión actualizada de una versión anterior publicada en: Barthuli, K. y Taylor, M. (2015) Route 66: Ouvrir la Voie pour la Protection et la Gestion des Routes Historiques. En: Thema \& Collecta, Itineraires Culturels. Wallonie-Bruxelles: ICOMOS adaptándose a los objetivos del proyecto PID2019-105877RA-I00 Análisis y definición de estrategias para la caracterización, recuperación y puesta en valor del patrimonio de las obras públicas. Una aproximación desde la escala territorial, del Ministerio de Ciencia Innovación y Universidades, y a los del presente número monográfico de revista $P H$. E texto ha sido traducido por Fidelia Linguistic Solutions y revisado por Rita Ruiz Fernández.

\section{DEBATE}

Frente a otros itinerarios culturales ampliamente reconocidos, como el Qhapaq Ñan en Sudamérica o el Camino de Santiago en España y Francia, las rutas automovilísticas a menudo se pasan por alto como importantes aportaciones al patrimonio cultural por, en muchas ocasiones, considerar que son demasiado modernas como para ser objeto de un proyecto de conservación o de atención académica.

Sin embargo, al igual que otras rutas que históricamente se recorrían a pie, a caballo, en carretas o en barco, las vías para automóviles representan un importantísimo hito en la evolución del transporte, con impactos sin precedentes en el paisaje, el entorno, el comercio, la política y la cultura, que no deben ser ignorados.

Una de estas rutas en la que, en la actualidad, se está iniciando las gestiones para su reconocimiento y protección como carretera con marcado significado histórico es la Ruta $66^{1}$, en Estados Unidos. Construida en 1926 como parte del primer sistema federal de carreteras para automóviles de Estados Unidos, la US Highway 66 o Ruta 66 siguió el trazado de otros itinerarios culturales que ya existían previamente, como el Camino Real de Tierra Adentro o el antiguo Camino de Santa Fe. Si bien la Ruta 66 no era ni la carretera más larga ni la más antigua, sí que conectaba estratégicamente el Medio Oeste industrial con la costa de California, lo que la convertía en una ruta clave a nivel migratorio, económico y de defensa militar del país. También se hizo famosa por ser un símbolo del American's love affair con el automóvil y de su tremendo impacto en la sociedad.

A lo largo de $3.900 \mathrm{~km}$, el extremo oriental de la carretera comienza en Chicago, en el estado de Illinois, atraviesa los estados de Misuri, Kansas, Oklahoma, Texas, Nuevo México y Arizona, hasta llegar a la ciudad de Los Ángeles, en el estado de California. En la década de 1930, la Ruta 66 sirvió como "vía de escape" para miles de refugiados del Dust Bowl que buscaban una vida mejor en California. En la década de 1940 fue un elemento fundamental de la Red Estratégica de Carreteras, permitiendo la movilización de tropas y de su equipamiento en la Segunda Guerra Mundial. Después de la guerra, a medida que crecía el parque móvil americano, la Ruta 66 facilitó el auge de las vacaciones familiares. Durante este tiempo, las familias se echaron en masa a la carretera para explorar el exótico Suroeste, las costas doradas de California, Disneylandia y los parques nacionales, como el Gran Cañón. A lo largo de los años, la pasión de Estados Unidos por la carretera quedó reflejada en su continua representación en las diferentes artes: a través de la música, la literatura, la televisión y el cine, la carretera quedó inmortalizada como icono del sueño americano. Como ejemplo, la canción Get Your Kicks on Route 66, escrita por Bobby Troup, llegó 


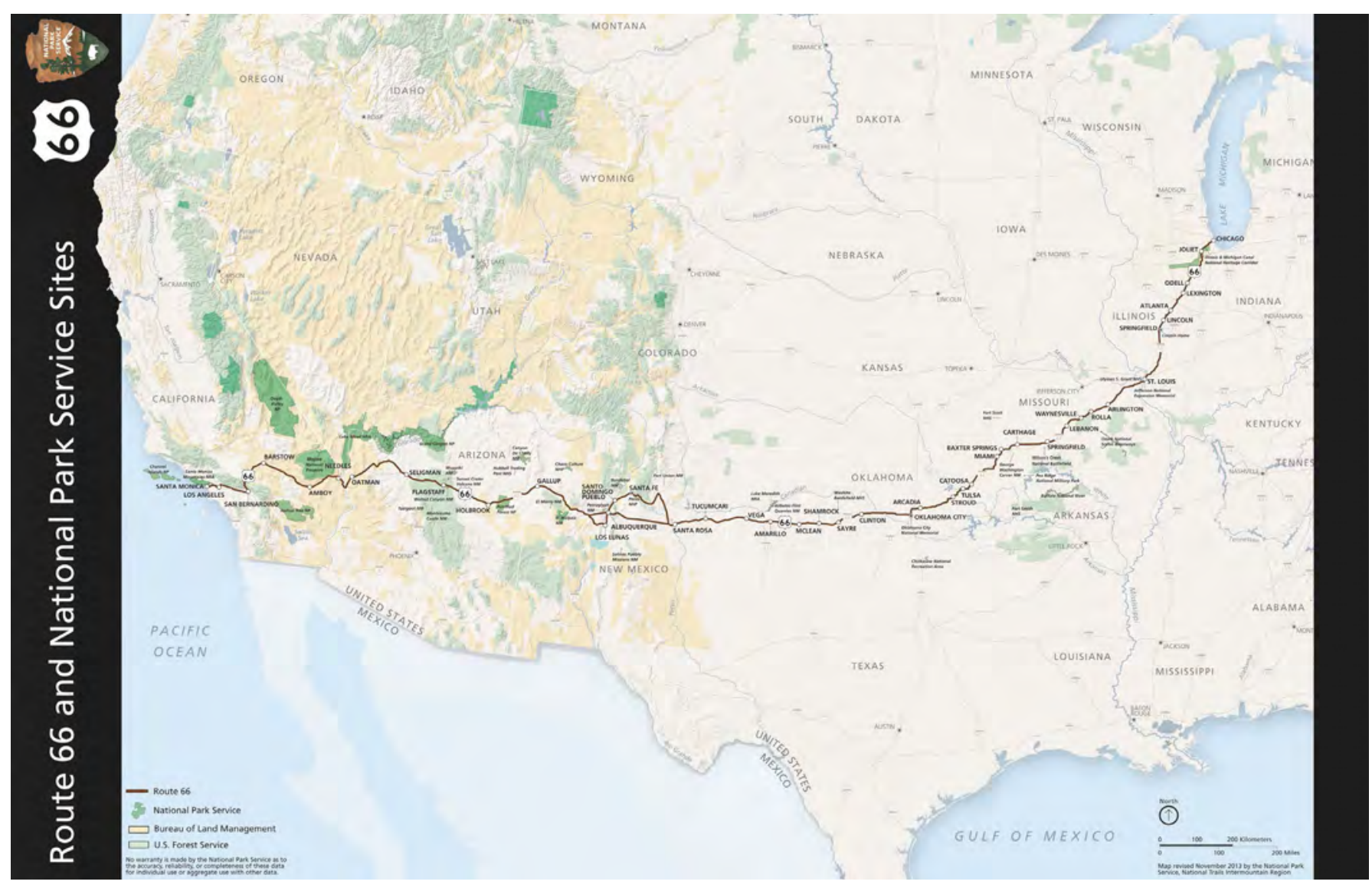

a ser interpretada por más de 110 artistas, entre ellos, Nat King Cole y The Rolling Stones.

Con la llegada del sistema interestatal, concretamente a partir de 1985, la Ruta 66 fue desmantelada. Debido a que su recorrido era altamente estratégico al atravesar todo el país, fue reemplazada de forma gradual por cinco nuevas carreteras interestatales. A diferencia de la mayoría de carreteras estadounidenses que, a día de hoy, siguen en uso, la Ruta 66 fue una de las pocas que se dividió en múltiples jurisdicciones privadas, locales, estatales y federales. Algunas secciones de la Ruta 66 fueron pavimentados por el Sistema Estatal de Autopistas, mientras que otras fueron reconvertidas en vías de servicio. Determinadas partes de la Ruta fueron incorporadas a la red de carreteras estatales, otras pasaron a formar parte de propiedades privadas y algunos tramos fueron abandonados o, incluso, demolidos. En la actualidad, aproximadamente, el $85 \%$ de la carretera original sigue siendo transitable.

Con el desmantelamiento de la carretera, el pueblo americano se opuso a la desaparición de lugares emblemáticos y, con ello, de la memoria de la legen- 
Histórico motel-cafe Roy's en Amboy (California). Uno de los lugares emblemáticos de la Ruta 66, entre Palm Springs y Las Vegas. Durante algunos años, Roy's estuvo cerrado. Pero ahora está siendo rehabilitado y vuelve a abrir sus puertas | foto Marc daria carretera. En 1990, los ciudadanos crearon, en cada uno de los ocho estados por los que pasaba la Ruta 66, organizaciones sin ánimo de lucro dirigidos a conseguir su preservación y promover su uso. En cada estado, estos grupos solicitaron a sus legisladores y a los departamentos de transporte estatales que señalizaran de nuevo la carretera pero, esta vez, con señalética marrón, color que, en Estados Unidos, es indicador de los lugares históricos. También solicitaron al Congreso de Estados Unidos que el Servicio de Parques Nacionales de Estados Unidos se involucrase en la protección y gestión de la carretera.

Ante este contexto, en 1990, el Congreso aprobó una ley por la que autorizaba al Servicio de Parques Nacionales (NPS por sus siglas en inglés) a llevar a cabo un Estudio Especial sobre Recursos para determinar la importancia histórica de la carretera y para definir diferentes opciones de conservación en las que se estimase la conveniencia de una posible participación federal (United States, National Park Service 1995). El estudio se culminó en 1995, determinando que: "La Ruta 66 tiene una gran importancia a nivel nacional como símbolo de la historia del transporte estadounidense. Las

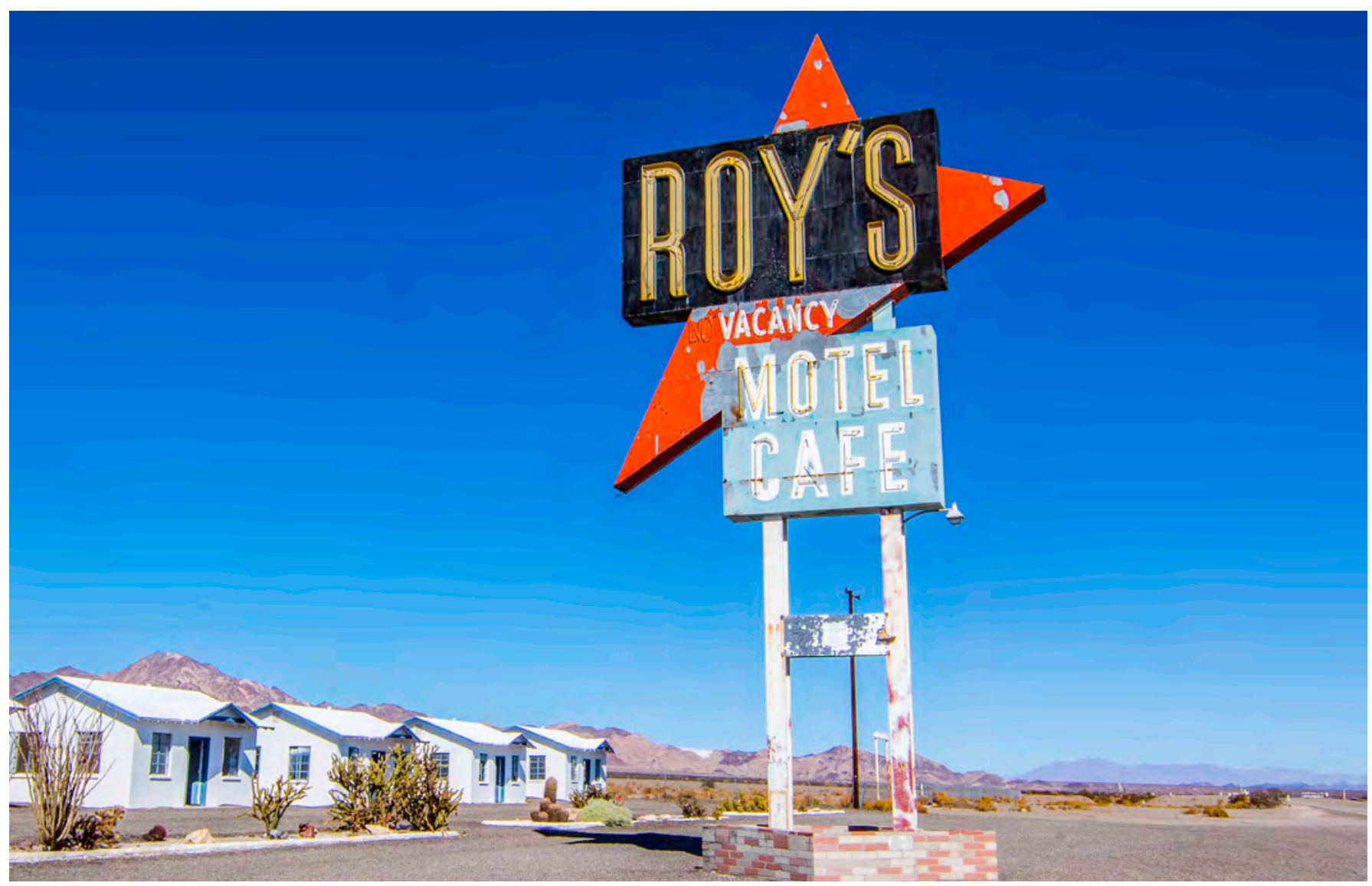


gasolineras, cafés y moteles que definen el corredor son importantes vínculos tangibles con esta historia, debiéndose preservar los activos más representativos y significativos."

Asimismo, se esbozaron diversas alternativas para la gestión de la ruta y, en concreto:

1. Definir uno o más lugares de la Ruta 66 como unidades del Parque Nacional.

2. Designar la ruta como Camino Histórico Nacional (National Historic Trail).

3. No contar con la participación federal.

4. Instalar señalética interpretativa por parte del Servicio de Parques Nacionales a lo largo de toda la longitud de la carretera.

5. Establecer un programa de preservación del Servicio de Parques Nacionales de ayuda técnica y financiera.

A continuación, se celebraron una serie de reuniones con participación pública para evaluar todas las opciones. Durante estos encuentros se reconoció la necesidad de preservar las condiciones locales, la idiosincrasia y el mom and pop de la carretera, por ser sus principales rasgos identitarios.

En este sentido, se concluyó que la Ruta 66 ha representado, y todavía representa, una experiencia única e impredecible de los viajes en automóvil antes de que llegase la sistemática corporativización de hoteles, gasolineras y restaurantes de comida rápida.

Con respecto a las alternativas planteadas por el Servicio de Parques Nacionales, la opción 1 fue rechazada por considerarse que seleccionar y preservar solo unos pocos espacios concretos a lo largo de la carretera no sería representativo y se descuidaría la asimilación de la carretera como un recurso y experiencia de ámbito nacional. Además, centrarse en algunos lugares concretos del paisaje no trasladaría el definitorio carácter de movimiento a través del tiempo, el espacio y la cultura que solo puede percibirse conduciendo a lo largo de la carretera.

La opción 2 fue también descartada porque, aunque la Ruta 66 cumplía con los requisitos para ser designada como camino histórico nacional, había preocupación o una idea errónea preconcebida de que esta designación podría traer consigo demasiada participación federal y, por tanto, una considerable pérdida del control local. 
La opción 3 fue desechada porque, si bien no se deseaba una fuerte participación federal, sí se quería un cierto nivel de participación y reconocimiento a nivel federal.

La opción 4 fue rechazada por la posibilidad de que un sistema de señales del Servicio de Parques Nacionales a través de la ruta pudiera "neutralizar" la experiencia idiosincrática de la Ruta 66. En su lugar, se decidió que los sistemas de información e interpretación debían gestionarse a nivel local o regional.

En última instancia, la opción 5 fue la alternativa mejor valorada por permitir mantener el control local de la carretera a la vez que se proporcionaba un cierto apoyo federal. Esta opción no proporcionaría a la Ruta 66 una designación federal formal, sino que crearía un programa del Servicio de Parques Nacionales destinado a proporcionar tanto asistencia técnica como subvenciones que permitiesen cofinanciar proyectos de rehabilitación y a la creación de un centro de información y ayuda para la preservación e interpretación a nivel local, estatal y nacional de la carretera.

En 1999, el Congreso de los Estados Unidos aprobó la legislación pertinente para crear el Programa de Preservación del Corredor de la Ruta 66 (United States Congress 1999). Dos años más tarde, se concedieron los fondos y se designó a la oficina del National Trails Intermountain Region del Servicio de Parques Nacionales, con sede en Santa Fe, Nuevo México, responsable del programa.

El programa se concibió como un programa "semilla" o de estímulo a corto plazo que concluiría en 2009. Sin embargo, tras recibir la opinión favorable del público, el programa fue reautorizado en 2009 para continuar sus operaciones durante 10 años más. Desde 2019, el programa funciona con aprobaciones anuales.

Una de las prioridades del programa fue redactar tanto un contexto histórico de la ruta en el ámbito nacional (Cassity 2012), como contextos estatales individuales que describiesen el desarrollo y las particularidades de la ruta en cada uno de los ocho estados.

En la actualidad, todos los edificios y construcciones de la Ruta 66 con interés histórico han sido documentados y, de entre ellos, se han identificado aquellos que pueden ser candidatos a ser incluidos en el Registro Nacional de Lugares Históricos del Servicio de Parques Nacionales. Este trabajo se ha realizado a través de convenios establecidos con las Oficinas Estatales de Preservación Histórica de los ocho estados que atraviesa la Ruta 66 y, a día de hoy, se han registrado más de 3.800 propiedades de las que, aproximadamente, 250 figuran en el Registro Nacional de Lugares Históricos. Toda esta información se compila en una única base de datos SIG interactiva y de uso público. 


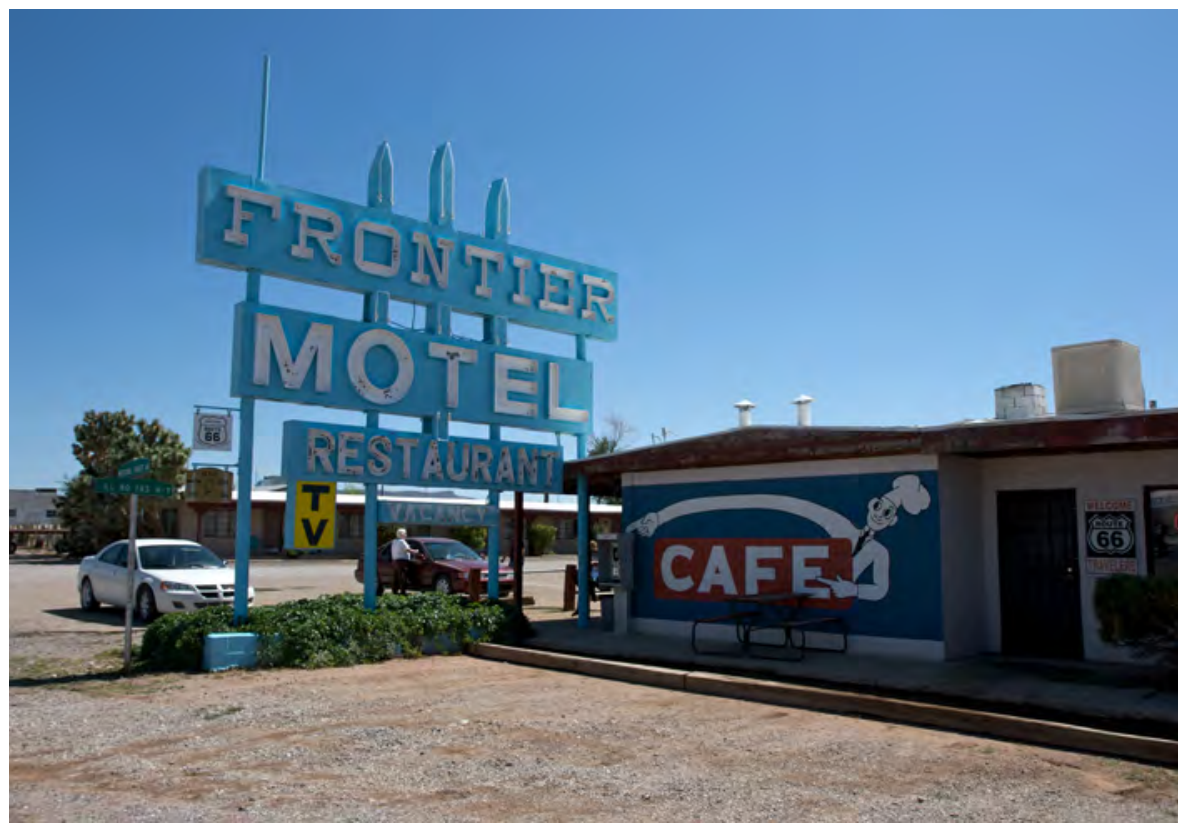

Una vez realizado el proceso de inventario, los elementos patrimoniales de la Ruta 66 se clasificaron en las siguientes categorías: Trazado y estructuras vinculadas, tales como dispositivos de protección lateral, señalización y elementos de drenaje; puentes; aparcamientos y áreas de descanso; zonas para aparcamiento de caravanas, moteles, hoteles; gasolineras, garajes, concesionarios de coches, empresas de autolavado; restaurantes, cafés, drive-ins; puestos comerciales y tiendas de souvenirs y curiosidades; señalización comercial, que incluye letreros de neón y vallas publicitarias.

También se identificaron varias amenazas para estos elementos y, entre ellos: obsolescencia; abandono; falta de sensibilidad hacia su importancia histórica; falta de un mantenimiento adecuado; añadidos y rehabilitaciones inapropiadas; fin de la vida funcional/deficiencias estructurales de la carretera y sus puentes; nuevos desarrollos invasivos; dificultad para que las pequeñas empresas instaladas en los edificios históricos compitan con nuevas empresas/corporaciones de gran tamaño; pérdida de espacios abiertos y paisajes agrícolas; vandalismo.

Dado que el programa federal no posee ni administra el corredor, el Servicio de Parques Nacionales es consciente de que, para que determinadas cuestiones o problemas puedan ser abordados de la manera más efectiva posible, la participación pública y la labor didáctica y de divulgación son fundamentales. En este sentido, el Servicio de Parques Nacionales ha desarrollado un programa de visitas regulares, reuniones y talleres a lo largo de la carretera para concienciar sobre la importancia histórica y patrimonial de la ruta y 
fomentar la colaboración de la ciudadanía en las estrategias puestas en marcha para su recuperación y preservación.

El Servicio de Parques Nacionales también ha creado un programa de subvenciones para cofinanciar proyectos de preservación, investigación y divulgación. En este sentido, desde el inicio del programa, se han adjudicado 158 proyectos que suman un total de 2,4 millones de dólares y otros 3,7 millones de dólares más en partidas de coste compartido. En total, a través del programa se han invertido hasta la fecha 6,1 M\$ en subvenciones.

Además de la conservación de determinados bienes patrimoniales, el Servicio de Parques Nacionales también está liderando una iniciativa para conservar la memoria e historia de la Ruta 66. Para ello, colabora con los archivos que existen a lo largo de toda la ruta en la implementación del programa denominado Ruta de Investigación 66. La misión de este programa es fomentar la recopilación y preservación de registros históricos y aumentar su accesibilidad al público. La importancia de las fuentes de archivo es indudable, con cada mapa, folleto turístico, diario o fotografía, se puede aprender más sobre la carretera: cómo era, cómo eran las primeras experiencias de viaje en automóvil y cómo este vehículo cambió la sociedad, el comercio, el medio ambiente, etc. La información de archivo es útil no solo para académicos o estudiantes, sino también para aquellos turistas que pretenden enriquecer su experiencia de viaje, los propietarios que desean aprender más sobre su edificio o negocio, las comunidades locales que quieren promover su historia local y las agencias gubernamentales responsables de la gestión de la carretera. Con el Servicio de Parques Nacionales se han asociado diez instituciones a lo largo de la ruta para promover la identificación de colecciones históricas de importancia para la Ruta 66 en todos los estados, fomentar la colaboración cruzada entre archivos, bibliotecas y museos, y desarrollar un sitio web como un centro de investigación online.

Sin embargo, y a pesar de estas iniciativas y de otras emprendidas por particulares y comunidades, muchos tramos de la carretera, puentes, propiedades y paisajes continúan hoy muy degradados.

Para incrementar la sensibilización sobre las amenazas a las que esta carretera está sometida, en 2007, la organización nacional sin ánimo de lucro National Trust for Historic Preservation incluyó los moteles de la Ruta 66 en su Lista de lugares más amenazados de Estados Unidos. Al año siguiente, la organización internacional World Monuments Fund (WMF) recogió la totalidad de la Ruta 66 en su Lista de Sitios de Interés, junto con otros lugares de renombre mundial como Machu Picchu o los centros culturales de Irak. En 2018, National Trust for Historic Preservation recogió la totalidad de la Ruta 66 en la Lista de los Once Lugares Más Amenazados de Estados Unidos, y la calificó como uno de sus Tesoros Nacionales. 
Estas listas han ayudado, sin duda, a incrementar considerablemente el interés por conservar la Ruta 66. Además, la inclusión de la Ruta 66 en las mismas incentivó a la asociación de American Express, World Monuments Fund (WMF) y el Servicio de Parques Nacionales (NPS) que, aportando una generosa asignación de fondos, han costeado varios proyectos que, entre otros asuntos, han permitido abordar la elaboración del inventario histórico de bienes vinculados a la carretera, un proyecto de realidad virtual, un Itinerario de Viaje del Registro Nacional o un estudio sobre el impacto económico de su preservación (Listokin 2012). Con este último se evidenció que, además de los beneficios sociales y económicos para la población que vive a lo largo de la carretera, la puesta en valor de la Ruta 66 genera un gran sentimiento de orgullo nacional entre los viajeros que la visitan. Asimismo, este estudio reveló datos demográficos de la población que vive en torno al trazado. Concretamente, se comprobó que, a lo largo de la ruta, el porcentaje de población hispana duplica la media nacional y que el porcentaje de indios americanos es tres veces superior a la media nacional. Teniendo en cuenta estos datos, el Servicio de Parques Nacionales ha comenzado a colaborar con el Programa de Prácticas del Patrimonio Hispano para la creación del proyecto Herencia Hispana de la Ruta 66 (todavía en desarrollo) y con la Asociación Americana de Turismo Nativo de Alaska para implementar el programa American Indian y Route 66 Travel Guide (AIANTA 2017). En la misma línea, el Servicio de Parques Nacionales ha financiado un documental de Assertion Films con nombre Route 66 Women: The Untold Story of the Mother Road (todavía en curso de producción), y otro llamado Route 66 and the Historic Negro Motorist Green Book centrado en las vivencias de la población negra en torno a la Ruta 66 (Estados Unidos. Servicio de Parques Nacionales 2015).

Otro resultado del estudio elaborado por Listokin (2012) fue la celebración del simposio Ruta 66: Mesa Redonda Estratégica sobre el Camino por Recorrer, que reunió a representantes de la industria y del gobierno y a organizaciones sin ánimo de lucro para explorar nuevas e innovadoras formas de fomentar el sector del turismo patrimonial y la preservación histórica de la Ruta 66. Durante este encuentro, se alcanzó un consenso abrumador, que permitió establecer un marco nacional de colaboración que serviría para tejer los intereses de las diversas entidades a lo largo de la carretera (con anterioridad a la celebración de esta mesa redonda existían ocho asociaciones estatales y cinco internacionales en torno a la Ruta 66 que no contaban con ningún tipo de foro de comunicación o colaboración) y aprovechar así sus respectivos esfuerzos para alcanzar estos objetivos.

Así, y bajo el amparo de la WMF y el Servicio de Parques Nacionales, se creó una organización a nivel nacional y sin ánimo de lucro denominada Asociación Camino por Recorrer de la Ruta 66 (RAP en sus siglas en inglés: Route 66 Road Ahead Partnership). Los objetivos que se marcó la RAP 


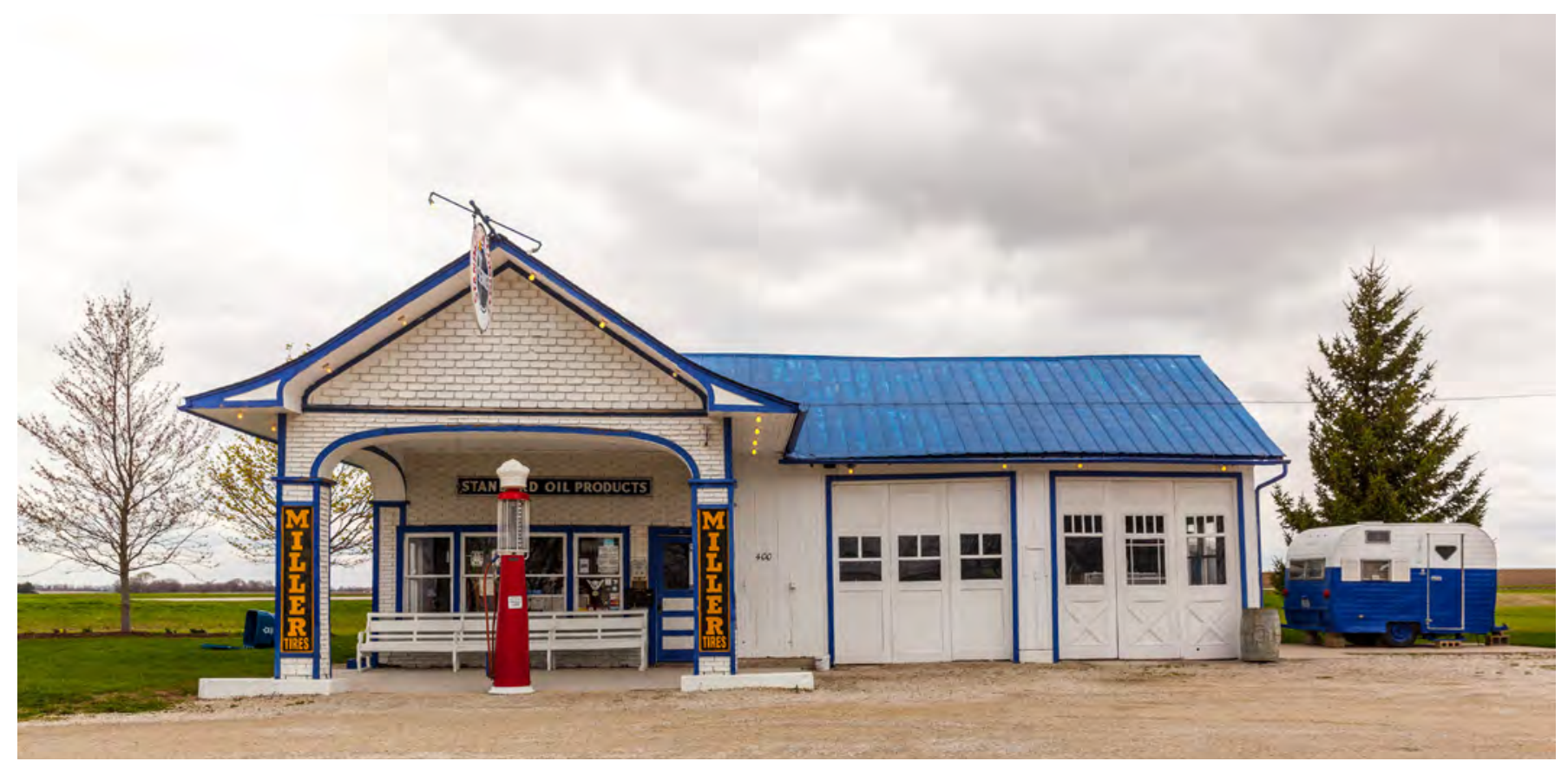

Estación de servicio en la Ruta 66, Illinois | foto russellstreet

fueron: estrechar la coordinación entre las instituciones educativas y las organizaciones sin ánimo de lucro con la idea de seguir trabajando en la preservación del corredor; conservar y el mantener el diseño original de la carretera, de sus edificios, paisajes, tradiciones y experiencias; aumentar el número de visitantes, tanto nacionales como internacionales; asegurar el desarrollo económico y comunitario de las personas que viven y trabajan a lo largo de la Ruta 66; garantizar la rentabilidad de las empresas ya existentes y ayudar a las nuevas a establecerse y crecer; y fomentar la investigación y la educación con el fin de lograr una mayor precisión del relato histórico y de las experiencias asociadas a la Ruta 66.

De entre los impresionantes logros que la RAP ha conseguido hasta hoy, ha de reseñarse la labor realizada en colaboración con legisladores federales para aprobar la Ley del Centenario de la Ruta 66 (United States Congress 2020). La unanimidad obtenida en el Congreso permitió aprobar esta disposición en diciembre de 2020, que exige la formación de una comisión a nivel federal con el propósito de conmemorar el centenario de la Ruta 66 en 2026. Asimismo, la RAP también está trabajando en un proyecto de ley que permita considerar de forma permanente la Ruta 66 como un National Historic Trail por parte del Servicio de Parques Nacionales (United States House 2020).

Mientras sigue creciendo el reconocimiento de la Ruta 66 como tesoro nacional, también lo hace la conciencia ciudadana sobre la importancia de las 
carreteras históricas en general. De hecho, y en paralelo a los esfuerzos realizados para preservar la Ruta 66 , se están implementando otra serie de acciones para permitir la conservación y promoción de otras carreteras históricas en Estados Unidos, como en el caso de la Carretera Nacional de Maryland a Ohio, la Autopista Lincoln (US 40) de Nueva York a California, el Antiguo Camino Español (Old Spanish Trail Highway US 90/289/80) de Florida a California, la Ruta 1 de Maine a Florida o la Autopista Dixie que conecta Michigan con Florida. Además, durante los últimos 20 años, la Conferencia Internacional de Preservación de las Carreteras Históricas (la conferencia líder dedicada a la identificación, preservación y gestión de carreteras históricas) reúne, de forma bianual, a profesionales del ámbito de la conservación y el transporte, académicos y otros actores en un foro que debate y amplía el conocimiento sobre los valores de estas infraestructuras.

Asimismo, en otros países, también se están desarrollando otras acciones encaminadas al reconocimiento patrimonial de los caminos y las carreteras. En Bélgica, la asociación Musées et Société en Valonie se dedica a fomentar el uso y la apreciación por parte de los visitantes de la Viae Romanae (tramo Bavay-Tongres). En Australia, varias carreteras históricas, como la Autopista Stuart y la Great Ocean Road, han sido objeto de estudios recientes, y en España, por ejemplo, se ha publicado una investigación sobre carreteras históricas datadas entre 1748 y 1936, que, entre otros asuntos, recoge algunas de las estrategias que se podrían desarrollar para conservar determinados tramos de la carretera de Valencia (Rodríguez Lázaro et ál. 2007; Rodríguez Lázaro, Coronado Tordesillas y Ruiz Fernández 2009).

Por último, ha de reseñarse que, en los últimos años, el Comité Internacional de Rutas Culturales (CIIC), perteneciente al Consejo Internacional de Monumentos y Sitios (ICOMOS), está evaluando la posibilidad de definir y calificar diversos caminos, vías o calzadas históricas, incluidas carreteras, en el contexto de las rutas culturales. En este sentido, la resolución del CIIC sobre carreteras históricas establece que:

"Las carreteras históricas son fruto del paso del tiempo y corresponden a la necesidad del ser humano de desplazarse físicamente de un lugar a otro en vehículo y, en su caso, de transportar bienes y mercancías. Los caminos históricos pueden estar diseñados para el tránsito de vehículos impulsados tanto por animales como a motor.

Las rutas o caminos históricos significativos pueden haber tenido un gran impacto cultural, social, económico, político y tecnológico a lo largo del tiempo en las regiones geográficas/naciones asociadas...

...puede haber rutas históricas o tramos de rutas históricas, al igual que otras propiedades patrimoniales de diversa naturaleza, que ayudan a conformar 
las características propias de un itinerario cultural, aunque en muchas otras ocasiones esto puede no ser así, ya que puede que existan independientemente de las citadas rutas culturales. En ocasiones, un camino o una carretera histórica significativa puede cumplir con los criterios de una ruta cultural en sí misma." (ICOMOS CIIC 2018).

La comunidad internacional entiende que ciertas carreteras históricas para automóviles, con suficiente importancia e integridad como para serlo, deben considerarse parte importante de nuestro patrimonio cultural y que, por ello, merecen ser conservadas. Según lo indicado anteriormente, muchas vías automovilísticas han evolucionado a partir de senderos más antiguos. Sirva como ejemplo el Camino Real de Cuba, ahora reconvertido en la Carretera Central de Cuba, que en el siglo XVI, servía de conexión entre los primeros campos de oro, y más tarde las tierras agrícolas, con la ciudad portuaria de La Habana. Este camino fue transformado en la Autopista Central en 1925 por el gobierno cubano, siguiendo en su mayoría el antiguo trazado del Camino Real (Rojas 2009).

\section{CONCLUSIÓN}

Históricamente y en la actualidad, la Ruta 66 ha sido conocida en todo el mundo por su protagonismo en las artes populares. Desde la novela épica de 1939 The Grapes of Wrath de John Steinbeck, y continuando con obras icónicas como la canción Get your Kicks on Route 66 o la reciente película de Disney/Pixar Cars, esta carretera ha acaparado la atención de millones de personas en todo el mundo en sus 95 años de su existencia. Sin embargo, hay muchas otras carreteras históricas que son importantes por sus contribuciones a la historia y al patrimonio que merecen ser objeto de conservación y protección. Además, la preservación de estas rutas automovilísticas puede brindar grandes oportunidades para el desarrollo económico centrado en el patrimonio de las comunidades y regiones que recorren. Se espera que las lecciones aprendidas de los esfuerzos realizados para la preservación, protección y documentación de la Ruta 66 en Estados Unidos sirvan de ejemplo para que otros países consideren la posibilidad de conservar otras carreteras que, aunque menos conocidas, son altamente significativas. 


\section{BIBLIOGRAFÍA}

- AIANTA [American Indian Alaska Native Tourism Association] (2017) American Indians and Route 66 Travel Guide. Disponible en: https://www.aianta.org/wpcontent/uploads/2020/03/American_Indians_Route66.pdf [Consulta: 02/05/2021]

- Cassity, M. (2012) Historic Properties Associated with U.S. Highway 66, from Chicago to Santa Monica, 19261985: Multiple Property Documentation Form. Form prepared on August 27, 2011; Form registred on March 14, 2012. U.S. Department of the Interior, National Park Service, National Center for Preservation Technology. Disponible en: http://ncptt.nps.gov/rt66/wp-content/uploads/2014/05/ NationalMPDF.pdf [Consulta: 02/05/2021]

- Historic Environments (2013) vol. 25, n. ${ }^{\circ}$ 3, 2013, Connecting Cultures and Continents: the Heritage of Routes and Journeys 1. Disponible en: http://australia.icomos.org/ publications/historic-environment/he-vol-25-no-3-2013connecting-cultures-and-continents-the-heritage-of-routesand-journeys-1/ [Consulta: 02/05/2021]

- ICOMOS CIIC [Scientific Committee on Cultural Routes] (2008) The ICOMOS Charter on Cultural Routes, 4 de octubre de 2008. Disponible en: http://www.international. icomos.org/charters/culturalroutes e.pdf [Consulta: 02/05/2021]

- ICOMOS CIIC [Scientific Committee on Cultural Routes] (2018) Historic Roads as a New Category of Cultural Heritage: Their Differences with Respect to Cultural Routes Committee Report. Literatura gris

- Listokin, D (coord.) (2012) Route 66. Economic Impact Study. New Brunswick, N.J.: Rutgers Center for Urban Policy Research, Edward J. Bloustein School of Planning and Public Polity, vol 1. History, characteristics, and economic contributions. Disponible en: https://www.wmf.org/sites/default/files/article/pdfs/ Route $\% 2066 \% 20$ Economic $\% 20$ Impact $\% 20$ Study $\%$ E2\%80\%94Volume\%20I.pdf [Consulta: 17/06/2021]

- Rodríguez Lázaro, F.J., Coronado Tordesillas, J.M., Ruiz Fernández, R. y Garcilaso de la Vega, J. (2007) Análisis y valoración del patrimonio histórico de las carreteras españolas 1748-1936. Madrid: Centro de Estudios y Experimentación de Obras Públicas

- Rodríguez Lázaro, F.J., Coronado Tordesillas, J.M. y Ruiz Fernández, R. (2009) El camino de Valencia en Alarcón y Contreras 1845-1998: análisis de viabilidad para su recuperación como carretera histórica. Madrid: Centro de Estudios y Experimentación de Obras Públicas

- Rojas A. (2009) Transmission of World Heritage to Future Generations and Interpretation. Examples in Cultural Routes. En: World heritage International Exchange Symposium. Ise City, Japan, 1 November 2009. ICOMOSCIIC Report
- Ruiz Fernández, R. (2014) Heritage Identification and Assessment of Historic Roads in Spain, 1748-1967. Tesis doctoral inédita. Universidad de Castilla-La Mancha

- United States Congress (1999) Route 66 Corridor, Historic Preservation. Public Law 106-45, 10 de agosto de 1999. Disponible en: https://www.congress.gov/106/plaws/ publ45/PLAW-106publ45.pdf [Consulta: 02/05/2021]

- United States Congress (2020) Route 66 Centennial Commission Act. Public Law 116-256, 23 de diciembre de 2020. Disponible en: https://www.congress.gov/116/plaws/ publ256/PLAW-116publ256.pdf [Consulta: 02/05/2021]

- United States, National Park Service (1995) Special Resource Study, Route 66: Illinois, Missouri, Kansas, Oklahoma, Texas, New Mexico, Arizona, California. Denver Service Center. Disponible en: http://ncptt.nps.gov/rt66/ wp-content/uploads/2015/03/SpecialResourceStudy.pdf [Consulta: 02/05/2021]

- United States, National Park Service (2015) Route 66 and the Historic Negro Motorist Green Book. Disponible en: https://ncptt.nps.gov/rt66/route-66-and-the-historic-negromotorist-green-book/ [Consulta: 02/05/2021]

- United States House (2020) Route 66 National Historic Trail Designation Act. H.R. 8240. Disponible en: https:// www.congress.gov/bill/116th-congress/house-bill/8240?q= $\% 7 \mathrm{~B} \% 22$ search $\% 22 \% 3 \mathrm{~A} \% 5 \mathrm{~B} \% 22$ route+66+national+his toric+trail\%22\%5D\%7D\&s=2\&r=2 [Consulta: 02/05/2021] 


\section{La Calzada México-Tacuba: retos en la regeneración y reactivación de un camino histórico}

Gerardo A. Hernández Septién | Dpto. de Arquitectura, Urbanismo e Ingeniería Civil, Universidad Iberoamericana Ciudad de México

URL de la contribución <www.iaph.es/revistaph/index.php/revistaph/article/view/4943>

\section{RESUMEN}

La antigua calzada México-Tacuba se encuentra en la Ciudad de México, capital del país al que dio nombre. Creada en un entorno lacustre en el siglo XIV, esta avenida de casi $10 \mathrm{~km}$ de longitud es considerada la vía más antigua del continente americano. Por ella han desfilado importantes acontecimientos de la historia nacional, de los cuales aún hay algunos testimonios tangibles. El presente artículo pretende hablar de la importancia histórica y urbana de la calzada México-Tacuba, como una vía viva con un gran potencial como detonador del desarrollo urbano, cultural y turístico, pero que, por desgracia, ha visto mermada sus cualidades espaciales y sus valores tangibles e intangibles, a manos de la falta de regulación y con un entorno conflictivo y hostil en casi toda su trayectoria. El paisaje urbano histórico de la calzada, unido a la dinámica de sus barrios aledaños, debe contar el día de hoy con políticas públicas y privadas que permeen a la sociedad en conjunto para que se dé, de manera continuada y sostenible, su rescate y puesta en valor. Estos temas también se analizan en el presente artículo.

\section{Palabras clave}

Calzadas | Ciudad de México | Conservación (Patrimonio) | México | Paisaje urbano histórico | Periodo prehispánico | Tacuba | 


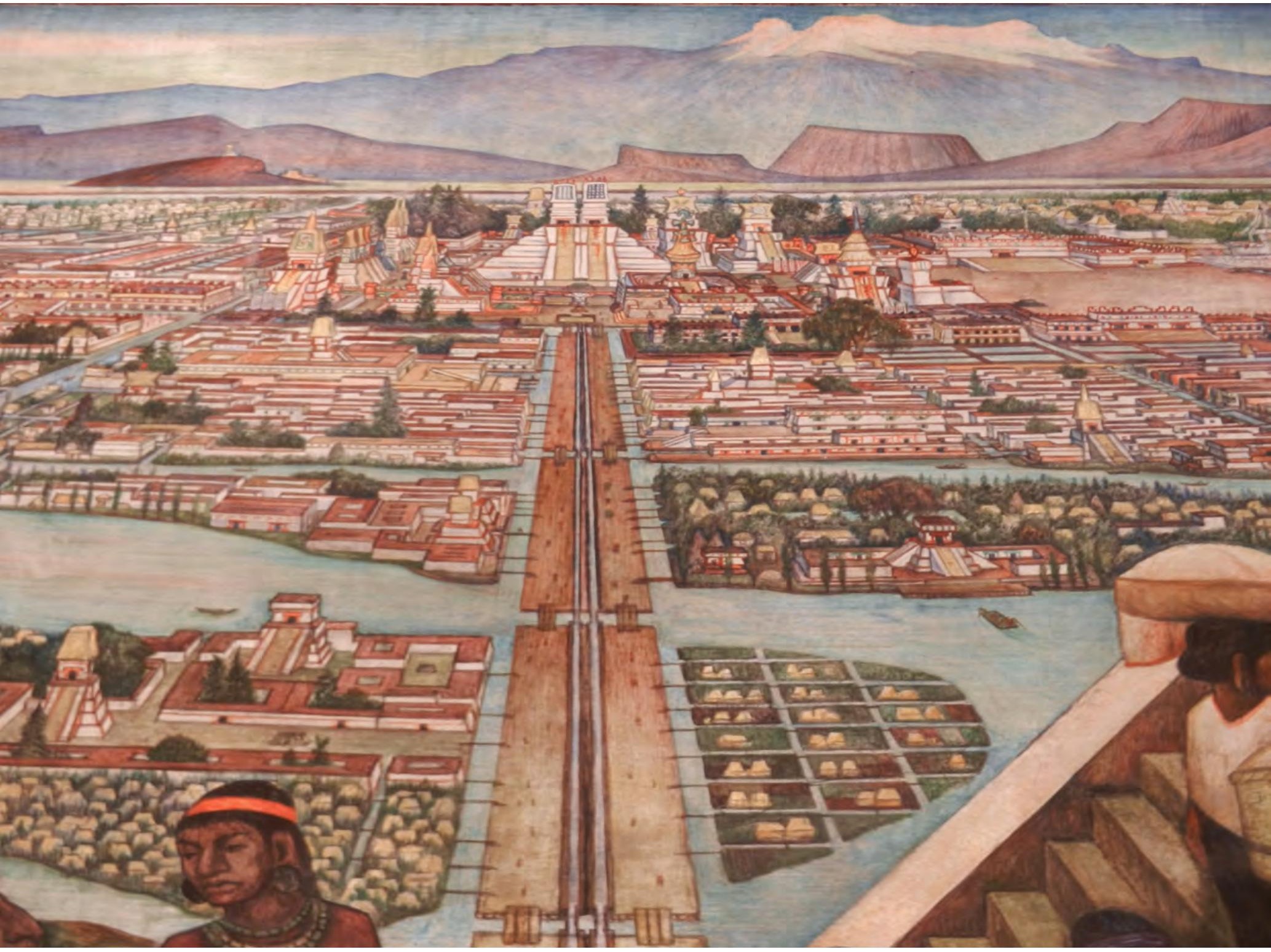

Recreación de México-Tenochtitlan durante la época prehispánica con la Calzada México-Tacuba en primer plano | foto Travis 


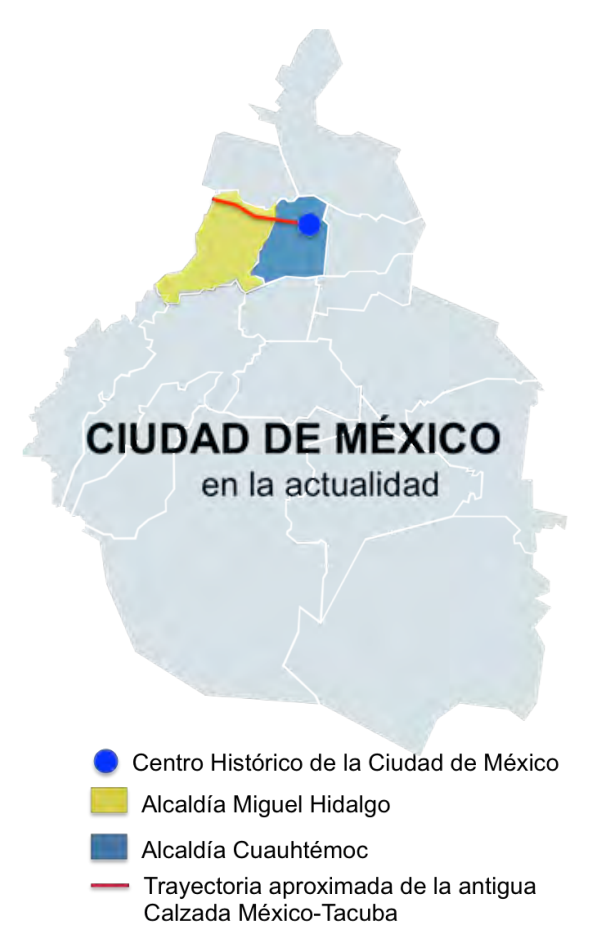

Ubicación de la antigua Calzada México-Tacuba en la actualidad
México-Tacuba es el nombre de una antigua calzada de origen prehispánico de casi $10 \mathrm{~km}$ de extensión que conecta al centro histórico de la Ciudad de México con la antigua zona de Tacuba, al poniente de la capital mexicana, y cuyos tramos en la actualidad, en el sentido oriente-poniente, reciben diferentes nombres: calle República de Guatemala, calle de Tacuba, Avenida Hidalgo, Puente de Alvarado, Ribera de San Cosme, dentro de la alcaldía Cuauhtémoc; y Calzada México-Tacuba (su nombre original), dentro de la alcaldía Miguel Hidalgo, entre el Circuito Interior Melchor Ocampo y la Avenida Ingenieros Militares.

Esta larga vía, a manera de "columna vertebral", aglutina a su alrededor diversos barrios pertenecientes a las dos alcaldías capitalinas antes mencionadas. La realidad de todo su recorrido es contrastante y heterogénea en lo económico, social, patrimonial, histórico y medioambiental. Su entorno ha cambiado enormemente a lo largo de sus siglos de existencia. Es por lo mismo que en algunas partes sus cualidades y valores no son tan evidentes y es, no solo deseable sino necesaria, su puesta en valor y reactivación.

En noviembre de 2020 se celebró el simposio-taller Internacional La Ciudad y el Paisaje Urbano: La Regeneración de un Territorio, que tuvo como objeto de estudio a un tramo de la antigua Calzada México-Tacuba (la sección comprendida dentro de la alcaldía Miguel Hidalgo), con el auspicio de la Unesco, la Universidad del Claustro de Sor Juana y la alcaldía Miguel Hidalgo. Durante este acto académico, se contó con la participación magistral de diversos ponentes nacionales e internacionales que debatieron en torno a diversos aspectos del paisaje urbano histórico desde el punto de vista conceptual, pero también analizando ejemplos análogos que pudieran servir de modelo de buenas prácticas en el planteamiento de propuestas concretas en la Calzada.

Este año, 2021, es el marco conmemorativo de los 500 años de la Conquista, valdría la pena no quitar el dedo del renglón y mantener el foco de atención en la antigua Calzada, que es la vía histórica más antigua del país y cuya existencia y relevancia es frecuentemente ignorada. Este antiguo camino ha sido testigo de grandes transformaciones a lo largo de 600 años, desde su pasado prehispánico, virreinal, independiente y moderno, hasta llegar a la realidad contemporánea de una megalópolis latinoamericana enorme y sobrepoblada.

Siempre la regeneración de un objeto de esta escala se plantea como un problema complejo, que involucra una gran cantidad de actores; es, en todos los casos, un gran reto cuya solución se tiene que planear por etapas y metas asequibles, por lo que la existencia de un plan maestro para esta vía, cuyos orígenes se remontan a la segunda mitad del siglo XIV, tendrá impacto no solo a nivel territorial y local, sino nacional. 


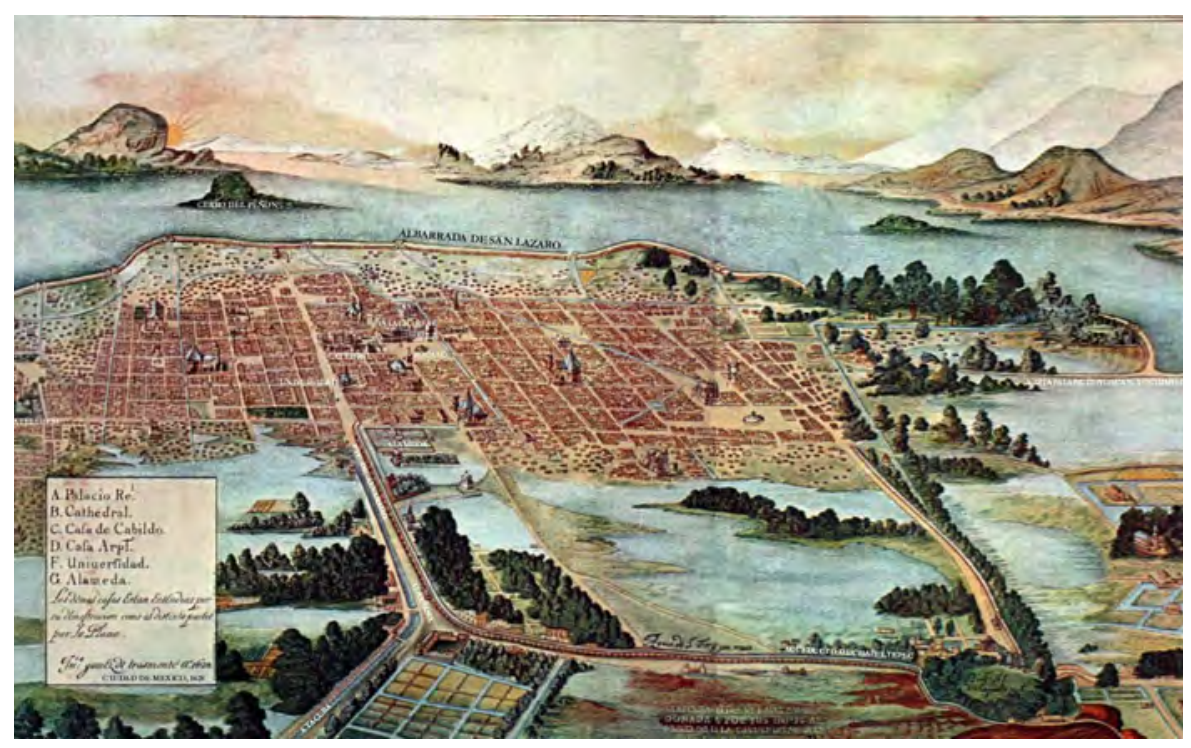

México-Tenochtitlan (frecuentemente solo llamada "Tenochtitlan") es el nombre compuesto que los aztecas o mexicas dieron a su ciudad capital, fundada en 1325. Con el pasar de los años, esta urbe se convertiría en el axis mundi de un poderoso imperio militarizado que abarcaba una gran parte de Mesoamérica.

Al cabo de casi dos siglos, los mexicas, originalmente asentados en un pequeño islote al poniente del gran lago de Texcoco ${ }^{1}$, hicieron crecer físicamente a la ciudad ganando territorio a las aguas salobres que rodeaban a la ciudad por medio de un sistema de jardines flotantes cultivables conocidos como "chinampas", que se convertirían, junto con el comercio y la guerra, en parte del sistema primordial de su economía.

Si bien es cierto que al encontrarse en una isla, México-Tenochtitlan -apodada "la Venecia de América" en el periodo colonial mexicano- se volvió una fortaleza inexpugnable sin muralla, no podía mantenerse aislada en el sentido literal de la palabra. Como una cuestión defensiva, funcionaba bien, pero debía tener conexiones y vías hacia las riberas del lago por razones comerciales y de movilidad.

Con este propósito, y junto con el crecimiento y poblacional y urbano de la ciudad, se crearon cuatro calzadas sobre el agua, una especie de plataformas segmentadas de tierra compactada que sobresalían pocos metros por encima del nivel de las aguas del lago. Dichos tramos eran unidos por tablones que se colocaban de día para darle continuidad y se quitaban de noche para aislar a la ciudad, a manera de "puentes levadizos". Estas calzadas estaban orientadas hacia los puntos cardinales, y de todas, la primera que se construyó hacia el poniente fue la de México-Tacuba, para unir a la ciudad
La Ciudad de México en el siglo XVII con la Calzada México-Tacuba en primer plano. Plano de Juan Gómez de Trasmonte, 1628 | fuente wikimedia

$$
1
$$

El Lago de Texcoco formaba parte de un sistema de cinco lagos que conformaron una cuenca hidráulica conocida hasta la fecha como Valle de México. 
En rojo vemos la ubicación de la antigua calzada comunicando México-Tenochtitlan con Tacuba (época prehispánica)

\section{2}

En el nombre de la Calzada, la palabra "México" hace referencia a la ciudad, no al país, que tomó el nombre de la ciudad hasta el siglo XIX al volverse independiente de España.

3

Este eje en el sentido oriente-poniente llamado "Triple Alianza" unía a las tres "T": Tenochtitlan, Texcoco y Tacuba, y generaba un sistema lacustre perfectamente organizado.

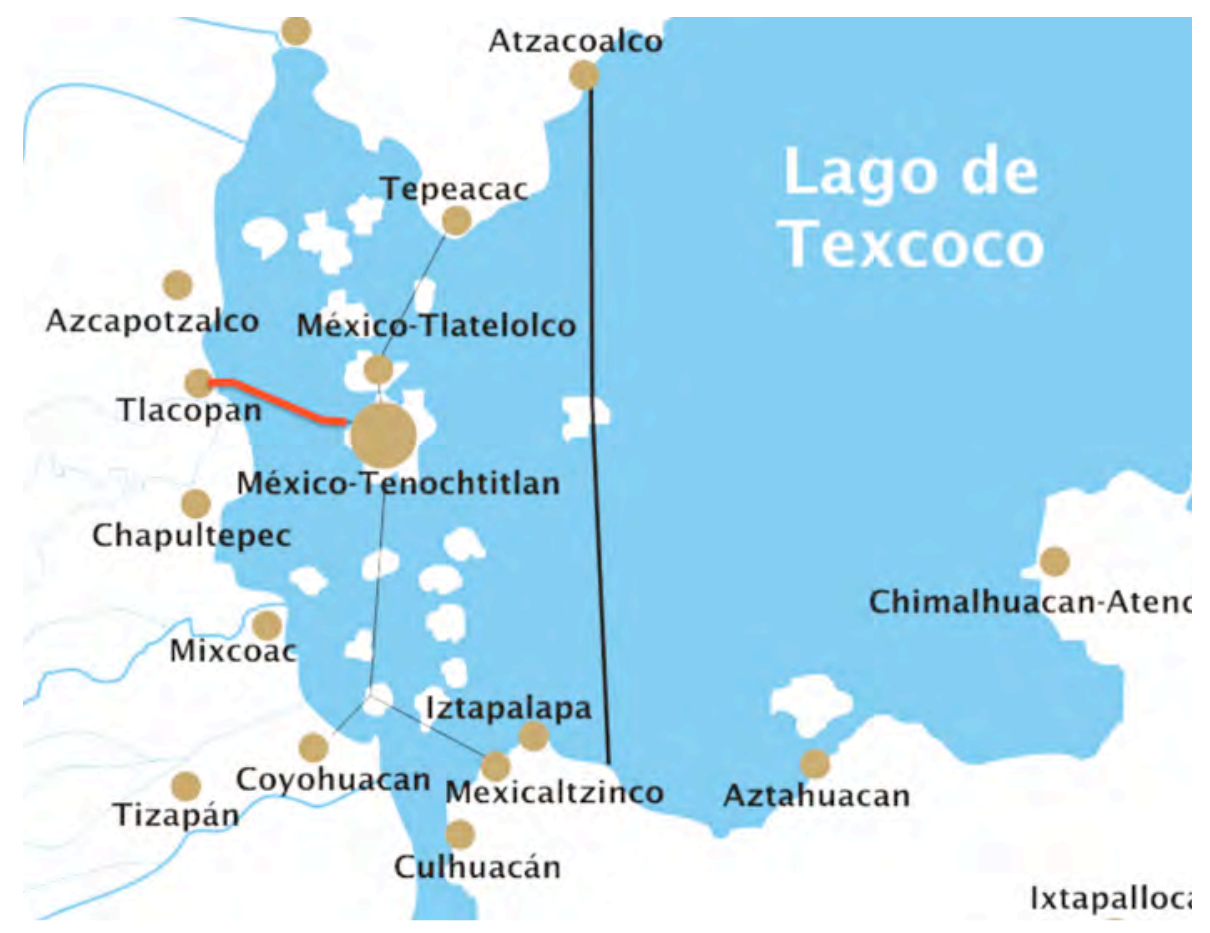

mexica con el antiguo pueblo ribereño de Tlacopan (término castellanizado como "Tacuba"), que se había conformado como un señorío aliado de los mexicas $^{2}$. Hacia el norte se haría la Calzada al Tepeyac (lugar mejor conocido por haber sido, según la tradición, el sitio de las apariciones de la Virgen de Guadalupe en 1521); hacia el sur, la Calzada de Iztapalapa-Coyoacán, y hacia el oriente, la misma calzada México-Tacuba se continuaba hacia un embarcadero, que llevaba por agua a la tierra firme, donde se encontraba la ciudad Texcoco, también aliada de los mexicas ${ }^{3}$. En la confluencia de estas cuatro vías, estaba el corazón religioso y simbólico de México-Tenochtitlan, su recinto ceremonial donde se encontraba el Templo Mayor, cuyos vestigios aún son visibles en el centro histórico de la Ciudad de México.

Dada su particular situación, con la creación de estas calzadas y sus ramificaciones que llevaban al centro de la ciudad agua potable de los manantiales de los alrededores, México-Tenochtitlan se convertiría en una "ciudad anfibia", cuya imagen perduraría por varios años; incluso, después de la llegada de los españoles a este territorio en el siglo XVI, momento a partir del cual se comenzaría un lento pero sistemático proceso de la desecación de las poco profundas aguas de los lagos y el lento crecimiento de la ciudad sobre todo hacia el poniente y hacia el sur.

En 1520, por la Calzada México-Tacuba, se llevó a cabo el pasaje llamado "la Noche Triste", cuando el conquistador Hernán Cortés y sus hombres, acom- 
pañados por una gran cantidad de indígenas aliados, cargados de oro, intentaban escapar secretamente de México-Tenochtitlan, debajo de una oscura noche lluviosa. Habiendo sido descubiertos por los mexicas, estos los atacaron por tierra y por agua y se verificó una sangrienta y mortífera batalla en la cual Hernán Cortés salvó la vida, hasta llegar, continuando por la Calzada hacia el poniente, a las puertas de Tacuba, donde se dice que lloró su derrota a los pies de un árbol, cuyos restos aún existen en el rumbo de Popotla y que se conoce como "Árbol de la Noche Triste". Un año más tarde, en 1521, y después de un sitio de ocho meses, México-Tenochtitlan sería vencida por los españoles y sus aliados indígenas y comenzaría su era hispana bajo el nombre de "Ciudad de México", capital del virreinato de la Nueva España, existente entre 1535 y 1821.

En los siglos virreinales, la antigua Calzada México-Tacuba era ya un camino terrestre tras la desecación de esa porción del lago, al poniente de la Ciudad de México, pero seguía uniendo a la ciudad con el pueblo de Tacuba, sitio en el que sobre ruinas prehispánicas se edificaría la gran parroquia conventual de San Gabriel Arcángel, fundación franciscana del siglo XVI existente hasta al día de hoy. En esta misma época, a lo largo de un tramo de la antigua calzada y como punto intermedio entre la Ciudad de México y Tacuba, se estableció el hospital y convento franciscano de los Santos Cosme y Damián, cuyo rumbo, conocido como San Cosme, se convertiría por muchos años en un enclave preferido por la aristocracia local para la construcción de grandes casas campestres con huertas ${ }^{4}$.

Entre los siglos XVI y XIX, corrió por la calzada un acueducto soportado por una estructura de arcos de mampostería que llevaba agua potable al centro de la Ciudad de México desde manantiales en los alrededores, convirtiendo a esa zona en un punto agradable y codiciado por su alta productividad agrícola y ganadera. Este acueducto se conoció como "de Santa Fe" o "de la Verónica, y de sus 900 arcos, hoy no queda ninguno. Ya en el siglo XIX, a su alrededor, se crearon primeros fraccionamientos "suburbanos" de la Ciudad de México, los mismos que hoy se encuentran completamente insertos en la mancha urbana: San Rafael y Santa María la Ribera. Estos barrios -llamados "colonias" en el contexto mexicano- abrieron el crecimiento de la Ciudad de México y su voracidad constructiva hacia el poniente. En esta área, subsisten pocos ejemplos de arquitectura colonial y tan solo perduran algunas casonas y edificios de apartamentos construidos a finales del siglo XIX e inicios del siglo XX, bajo el impulso modernizador del gobierno de Porfirio Díaz ${ }^{5}$.

Tranvías y vehículos automotores cambiaron el paisaje de la zona, y por el lugar exacto por donde corría el antes mencionado acueducto de la Verónica, hoy corre de manera subterránea la línea del metro que conecta el Centro Histórico con el antiguo pueblo de Tacuba, siguiendo la trayectoria exacta de la antigua Calzada prehispánica.
4

Hoy, por desgracia, quedan muy pocos ejemplos de estas construcciones en medio de un entorno urbano heterogéneo y degradado. Justo en este tramo, la antigua Calzada se llama Ribera de San Cosme.

5

Presidente de México de 1876 a 1880 y de 1884 a 1910 . 


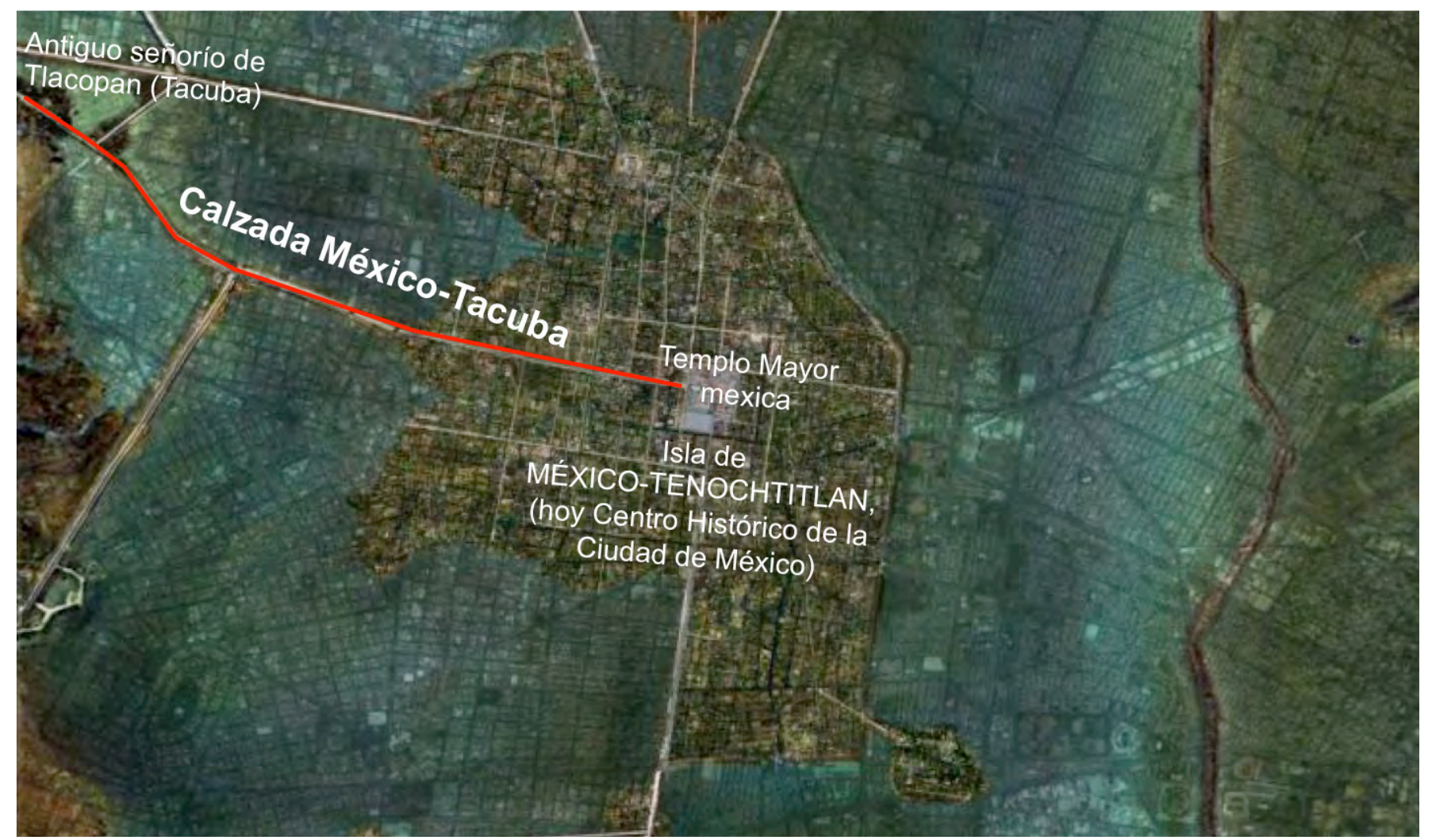

Recreación del islote de México-Tenochtitlan y la su calzada hacia Tacuba. La imagen está sobrepuesta a la traza actual de la Ciudad de México

La falta de regulación del transporte público, estaciones y nodos del metro, han ocasionado la proliferación en la zona de paraderos clandestinos de autobuses y la presencia de un sólido comercio informal, alimentado por la presencia de grandes masas de miles de personas que cruzan el área diariamente. Esta realidad, en cuanto a movilidad en una megalópolis sobrepoblada como lo es la Ciudad de México, puede resultar verdaderamente abrumadora y complicada, situación incomprensible quizá en contextos europeos, en donde la comunicación entre barrios, ciudades e incluso países, no representa una barrera difícil de vencer, y la escala de todos los elementos resulta más manejable.

Volvamos a la situación de la antigua Calzada en su porción incluida en el Centro Histórico de la Ciudad de México, declarado Patrimonio Mundial por la Unesco en 1987. Esta zona tiene el mayor grado de protección en todos los sentidos. Las actuales calles República de Guatemala, Tacuba, Avenida Hidalgo y parte de Puente de Alvarado, nombres que, como se mencionó, son los que bautizan a los primeros fragmentos de la Calzada, quedan dentro de esta zona de monumentos históricos y artísticos, área protegida y regulada, además de por la Unesco, por las autoridades federales mediante dos institutos pertenecientes a la Secretaría (Ministerio) de 
Cultura: el Instituto Nacional de Antropología e Historia (INAH), y el Instituto Nacional de Bellas Artes y Literatura (INBAL). A esto, sumemos la participación del Gobierno de la Ciudad de México a través de las oficinas de la Autoridad y del Fideicomiso del Centro Histórico de la Ciudad de México, de la SEDUVI, y de la alcaldía Cuauhtémoc. Con esto, vemos el esfuerzo de actores involucrados en la conservación del área, al que se suman la participación activa de fundaciones, de la sociedad civil, comerciantes, hoteleros, y turistas nacionales y extranjeros. En los últimos años, esto ha significado una importante derrama económica y el consecuente mejoramiento para los usuarios y habitantes del centro histórico.

No ocurre lo mismo en el tramo de la antigua Calzada comprendido entre las avenidas Guerrero (límite poniente del centro histórico) y Marina Nacional, a $5 \mathrm{~km}$. En esta sección, la antigua vía cruza las colonias Tabacalera, Buenavista, San Rafael y Santa María la Ribera (alcaldía Cuauhtémoc); así como Agricultura, Tlaxpana, Anáhuac, Popotla y Tacuba (alcaldía Miguel Hidalgo). En todo este recorrido existe solamente un pequeño parque sobre la Calzada, Cañitas, y unos diez sitios históricos y patrimoniales de alta relevancia y muy reconocidos ${ }^{6}$, pero que se encuentran aislados y encerrados en sí mismos ante un hostil paisaje urbano. La depredación del entorno natural y cultural en esta parte de la antigua Calzada son alarmantes. No es de extrañarse, por tanto, que la pérdida simbólica de la importancia de la antigua Calzada en el tramo mencionado, donde arquitectura patrimonial llega a ser muy dispersa o nula, vaya de la mano de graves problemas de tránsito, movilidad, comercio informal, inseguridad, y contaminación visual y auditiva.

En ese sentido, la falta de regulación ha provocado que los valores de la Calzada México-Tacuba queden escondidos y que no se pueda interpretar fácilmente como un sistema integrado, comenzando por lo confuso que puede ser el hecho de que tenga seis nombres diferentes a lo largo de su extensión, y que sus cualidades y características sean relacionadas siempre con un tramo en particular y leídas por separado. Parece que, conforme nos alejamos del área declarada como Patrimonio Mundial, los elementos patrimoniales y las áreas verdes de la Calzada presentan una degradación más acusada que es proporcional al deterioro que presenta esta área urbana.

El concepto de paisaje urbano histórico es relativamente nuevo. Pensemos que hace unos años el mayor énfasis estaba volcado en reconocer y declarar monumentos históricos y artísticos, hablando de patrimonio material. Fue un buen avance, y por todo México se reconocieron, incluso varias zonas de monumentos, con una alta concentración de los mismos. Hacia una creciente preocupación acerca del entorno natural del planeta, poco tiempo después se comenzó a concientizar de la importancia del patrimonio natural y su inextricable nexo con el patrimonio cultural, sobre todo tangible.
6

El Museo Nacional de San Carlos, la casa de los Mascarones, la parroquia de los Santos Cosme y Damián, el antiguo cementerio británico-americano, el cine Cosmos, la escuela normal de maestros, el gran colegio militar, la capilla de Merced de las Huertas, el Árbol de la Noche Triste y la parroquia y ex convento de San Gabriel Arcángel, en el centro de Tacuba, junto a la estación del metro del mismo nombre. Parecen no pocos elementos patrimoniales, pero si consideramos que se encuentran a lo largo de $5 \mathrm{~km}$ lineales (prácticamente la mitad de la extensión total de la Calzada), la densidad de los mismos es verdaderamente baja. 

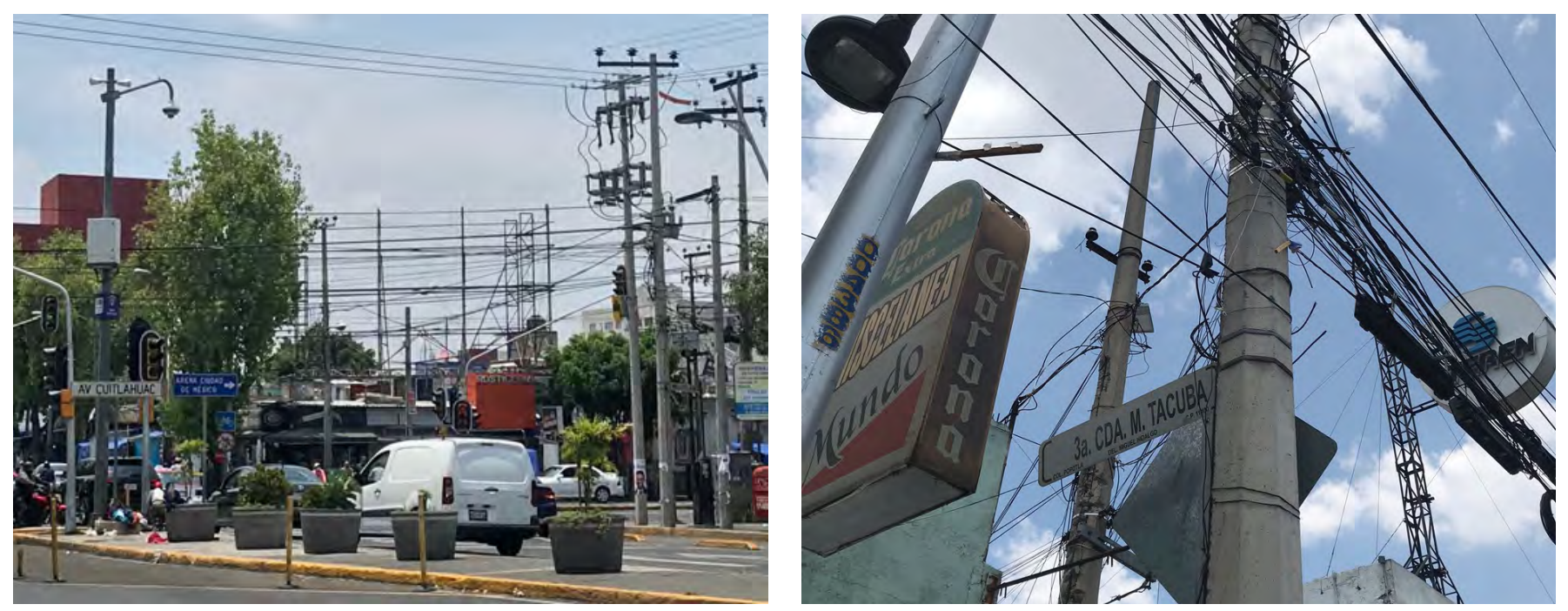

El paisaje urbano luce saturado visualmente, y con un tráfico vehicular constante | fotos Gerardo Hernández Septién

El concepto de patrimonio se enriqueció cuando se amplió a la esfera de lo intangible, y en México se comenzaron a valorar manifestaciones populares y vernáculas como la gastronomía, las fiestas, danzas, trajes típicos, etc.

Estas premisas se han aplicado en ocasiones de modo muy delimitado y hasta cierto punto de manera excluyente. Esto ha sucedido cuando los elementos patrimoniales se han mirado de una manera separada y con límites muy marcados. Por el contrario, el concepto de paisaje urbano histórico se aplica a un determinado contexto que ha sido construido de manera artificial en un entorno natural, idea que rompió con el paradigma de que solo un paisaje natural "intocado" tenía cualidades medioambientales. El concepto de patrimonio urbano histórico ha abierto la posibilidad de un ámbito amplio en el que confluyen los patrimonios culturales tangibles e intangibles, el patrimonio natural y el construido, el arte, la arquitectura, el diseño, el urbanismo, las transformaciones urbanas y las posibilidades que ofrece un sitio en cuanto a su historia como lugar de convivencia, sus aprovechamientos y sus dinámicas urbanas, así como la necesidad de proceder a su regulación visual y acústica. Este concepto implica asimismo temas como los usos del suelo, las políticas de movilidad y las infraestructuras de transporte, las actividades productivas, etc., todo ello con la idea fundamental de la necesidad de contar con un plan de acción que, siendo lo más incluyente posible, nos ayude a valorar, promover y potenciar un área o un lugar que actúe como detonador de desarrollo sostenido y sostenible.

Tendemos a pensar que el pasado es lo valioso, sin darnos cuenta de que todo pasado fue tan presente como lo es este momento, y que las buenas prácticas actuales en el manejo y gestión de un sitio derivarán directamente en la calidad de vida de sus habitantes y usuarios. 


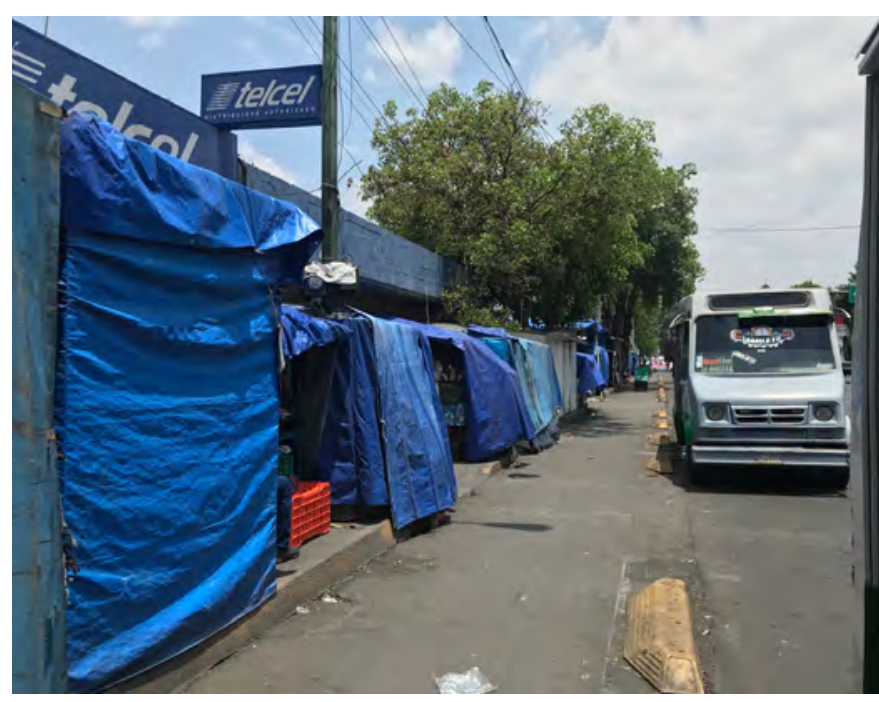

En ese sentido, y volviendo a la Calzada México-Tacuba, el simposio-taller que se organizó en noviembre de 2020 juntó a varios actores en torno a un interesante caso de estudio, como se mencionó. Sin embargo, habría que continuar la inercia ya comenzada, para aterrizar en soluciones concretas que no se queden solo en buenos deseos.

Resulta de total relevancia en un proyecto tan ambicioso como este contar con el apoyo comunitario de la población civil. Este factor tan delicado, "la gente", es parte de ese paisaje y de su realidad diaria, y será el factor definitivo para el éxito o el fracaso de un proyecto. Me refiero a los habitantes y usuarios de la Calzada y sus barrios aledaños, ya que, si no se "vende" la idea de que cualquier mejora realizada en la zona va directamente relacionada con una mayor derrama económica y su impacto directo en la mejora de su calidad de vida, todo esfuerzo será en vano.

Se antoja a momentos abrumador tener en cuenta todas las consideraciones implicadas en un paisaje urbano histórico tan sui generis como la Calzada México-Tacuba, por lo que, en este momento, lo deseable sería retomar el tema, determinar a los actores implicados, continuar viendo ideas y casos análogos surgidos en el marco del simposio-taller (sobre todo en lo tocante al desarrollo de proyectos y gestión de un paisaje urbano histórico con una direccionalidad francamente lineal), y crear un plan maestro rector para la zona, que incluya etapas y metas muy puntuales que aseguren el éxito y la posibilidad de continuar concretando resultados para fases posteriores de manera gradual.

La sostenibilidad no se da solo en el aspecto medioambiental. Junto con la regeneración urbana y natural de la zona se pretende incidir también en la
Ala izquierda, aceras saturadas, sucias y con poco espacio para el peatón junto a las desordenadas estaciones del metro sobre la calzada; a la derecha, el vandalismo y poco cuidado por la arquitectura patrimonial en la zona son una constante | fotos Gerardo Hernández Septién 
Sobre la calzada, se encuentra el Árbol de la Noche Triste, donde según la tradición Hernán Cortés lloró su derrota a manos de los mexicas en 1520 | foto Gerardo Hernández Septién

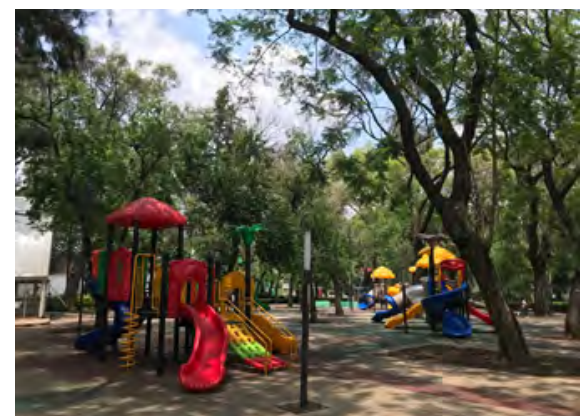

El parque Cañitas es el único pulmón verde en todo el recorrido de la calzada, además de la alameda central, parque monumental ubicado en el centro histórico de la Ciudad de México, a varios kilómetros al oriente | foto Gerardo Hernández Septién

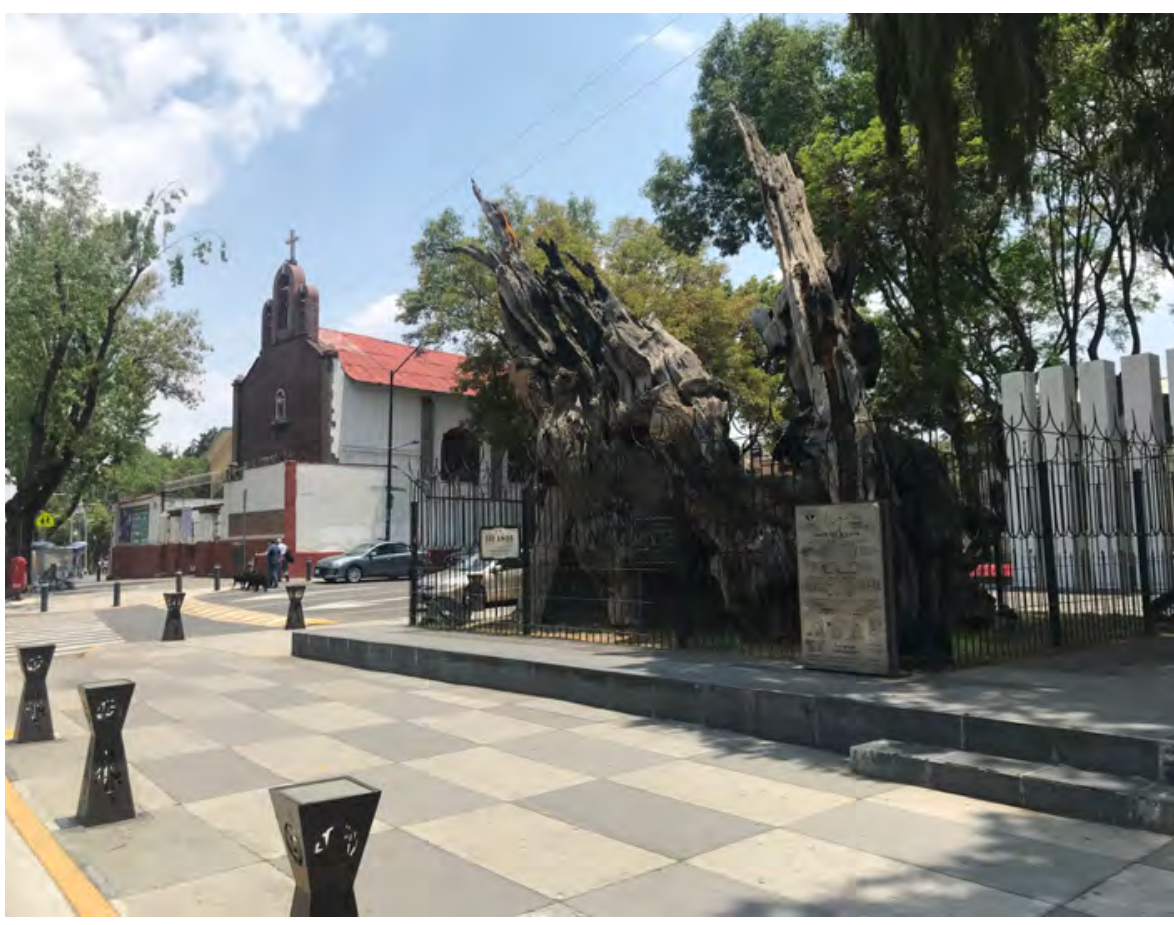

regeneración de tejido social para que un proyecto pueda ser sostenible en varios aspectos.

Una de las primeras acciones necesarias es hacer evidente lo que no lo es, y crear un proyecto de señalética e interpretación histórica en todo el recorrido de la Calzada en espacios públicos que permita su comprensión como sistema y como paisaje urbano-histórico, es decir, que se pueda ver como un sistema completo por primera vez. Esto sacará a la luz su valor bajo la premisa de que "nadie puede conservar lo que no sabe que existe". Habrá, sin embargo, que crear las condiciones que aseguren que la gente quiera ir y que pueda hacer este recorrido de manera placentera y segura (urge reforzar las medidas de seguridad en la zona), desde el centro histórico hasta Tacuba, unificando criterios de diseño urbano por etapas: iluminación, cableado subterráneo, colocación de arbolado y vegetación, mobiliario, pavimentos, etc., en las zonas en donde se carece de una regulación efectiva y aplicable.

También por etapas, habría que crear políticas para la regulación del comercio informal desmedido, que en la actualidad provoca una gran cantidad de basura y de contaminación visual y auditiva; ello ligado a acciones que garanticen la inclusión social en el espacio y su accesibilidad. A la par, hay que concretar acciones para el ordenamiento vial que frecuentemente es un obstáculo y un factor de alta contaminación ambiental en la zona, creando 


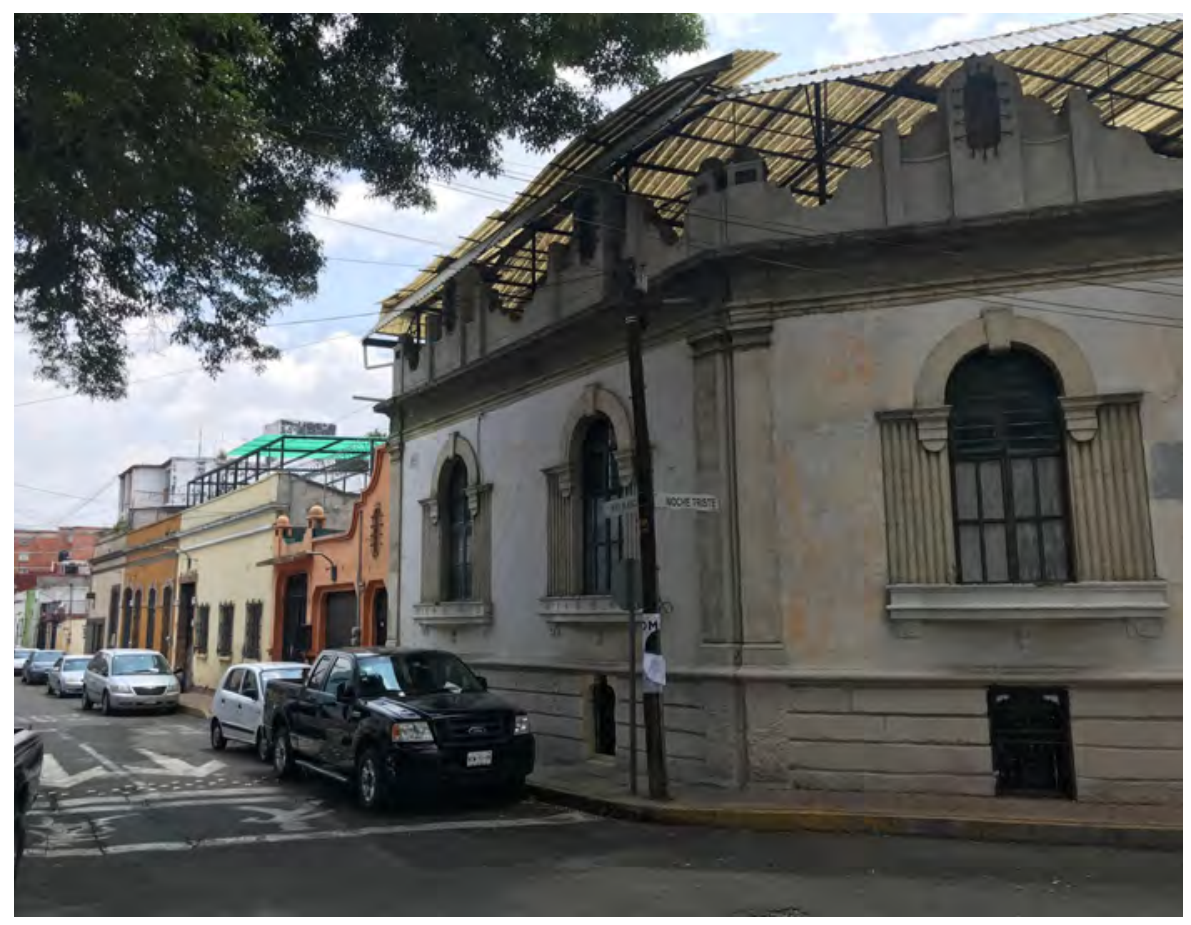

posibilidades para los peatones y ciclistas. Cada vez se pone más el foco Al sur de la calzada, el barrio de Popotla conserva algunos rincones característicos de la arquitectura de inicios del siglo XX en la zona | foto Gerardo en zonas patrimoniales en contextos urbanos como bienes sociales y colecHernández Septién 


\section{Carta de Reutilización del Patrimonio Edificado. Propuesta de principios y nuevas prácticas}

Francisco Haroldo Alfaro Salazar | Universidad Autónoma Metropolitana Unidad Xochimilco, México

URL de la contribución <www.iaph.es/revistaph/index.php/revistaph/article/view/4947>

\section{RESUMEN}

La noción de reutilización se propone desde la perspectiva de la valoración y uso de los recursos que tienen a su mano las sociedades. En el caso de la cultura, en su vertiente material, las preexistencias territoriales y de paisaje, de conjuntos urbanos y de arquitectura no solo son un reflejo material de una evolución en el tiempo, sino permanencias que se vuelven recursos que por generaciones han sido o pueden ser utilizados por la sociedad actual. En los últimos cien años se ha planteado una idea de permanencia de las construcciones de antaño, a partir de los diferentes valores que se le pueden asignar, a través de la conservación y acciones de restauración, y a la par se han consolidado principios teóricos y normativos para argumentar las razones para tal conservación. Esta participación sostiene que existe un patrimonio edificado que puede ser conservado a partir de proyectos de reutilización y que, en el caso de las preexistencias, sin perder de vista la permanencia del patrimonio cultural, plantea una serie de principio del valor de uso de los inmuebles y de la relevancia del proyecto de reutilización.

\section{Propuesta palabras clave}

Arquitectura | Edificios | Conservación (Patrimonio) | Patrimonio edificado | Patrimonio inmueble | Reutilización | Usos | 


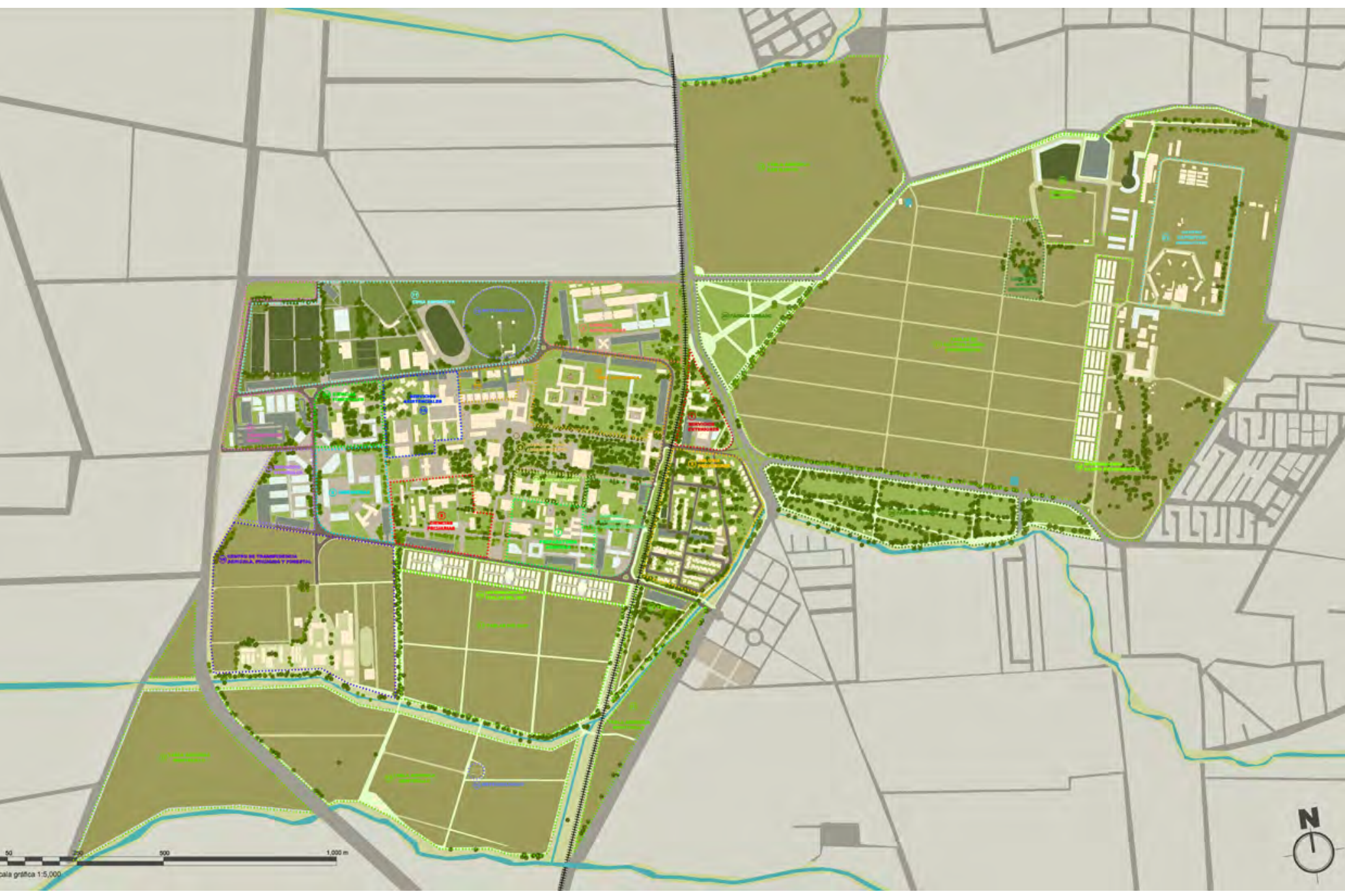

Como parte del proceso de actividades de servicio universitario, la labor extramuros de la institución incluye la realización de proyectos, como el Plan Rector para la Universidad Autónoma Chapingo, elaborado por ACRPE en 2009 | fuente Archivo ACRPE 
1

El presente documento es una versión en extenso de un texto de divulgación que, a manera de relatoría, muestra el resultado de un Foro Académico. En Alfaro, Francisco y Javier Soria (2019) Reflexiones sobre la Reutilización. Boletín Espacio Diseño, n. ${ }^{\circ} 268-269$, pp. 62-66

\section{2}

Con la idea de establecer una nueva universidad en la llamada zona metropolitana de la Ciudad de México, se propuso una universidad pública, metropolitana, autónoma, e innovadora en lo educativo y en lo organizacional. Es así como la ley para la creación de la Universidad Autónoma Metropolitana entra en vigor 1 de enero de 1974.

\section{INTRODUCCIÓN ${ }^{1}$}

Hacer un recorrido tratando de reconocer los espacios edificados que han permanecido a lo largo de generaciones es una tarea que ofrece la posibilidad de analizar aspectos como la conservación y la pervivencia de muchos ejemplos. Y si bien de ello se puede derivar una lectura sobre el patrimonio como un signo de cultura, es posible pensar también en su potencialidad como satisfactor de necesidades contemporáneas, en especial si hablamos de espacios habitables que, por su origen y destino, llegaron a un momento de obsolescencia y abandono. La fragilidad del concepto de uso a lo largo del tiempo ha permitido designar decadente a aquello que se ha vuelto inútil y que por ello pudiera pensarse en su sustitución. En beneficio de esas permanencias, desde galpones hasta edificios especializados, lo mismo inmuebles centenarios u obras de apenas algunas décadas, es que hoy debemos pensar en realizar proyectos para su reutilización, y brindar con ello posibilidades de espacios para nuevas demandas. Se trata de entender a la preexistencia como partícipe de un nuevo círculo virtuoso, que permita comprender y valorar la cultura material de todo ese patrimonio edificado, para asumir conscientemente su utilización.

\section{SOCIEDAD PENSANTE, SOCIEDAD ACTUANTE}

Los actores que pueden involucrarse tanto con el proceso reflexivo y analítico, como en la toma de decisiones, componen un universo amplio. Ello incluye a la propiedad, las personas usuarias, administradoras de la cosa pública, vecindario y hasta el personal calificado para intervenir de manera material. Un ámbito relevante en ese sentido es el mundo académico, que se compone lo mismo de investigadores especializados como de docentes que de manera sistemática están involucrados en los procesos de enseñanza-aprendizaje con quienes serán futuros profesionales.

En el ámbito de México, particularmente de la zona metropolitana de la Ciudad de México, el tema educativo a nivel universitario ha sido permeado por este universo del patrimonio edificado y la reutilización de preexistencias urbanas y arquitectónicas. El caso de la Universidad Autónoma Metropolitana $(U A M)^{2}$ es de especial interés, entre otras razones porque se erige, en la primera mitad de los años setenta del siglo XX, como una institución educativa que pretender observar, analizar y proponer respuestas a los problemas metropolitanos. Para resolver su organización se estableció una distribución de cuatro unidades o sedes, siendo una de ellas la Unidad Xochimilco.

Una de las tres divisiones académicas que conforman esa unidad es la de Ciencias y Artes para el Diseño (CyAD) la cual hoy en día se configura con cuatro programas de licenciatura, tres de maestría y uno de doctorado. 
Grados y posgrados que dan sentido al trabajo de investigadores y profesores que trabajan sobre temas amplios en sus procesos cotidianos. En las condiciones actuales, integrarse a la perspectiva del patrimonio edificado y la reutilización de edificios y entornos preexistentes y derivar proyectos de intervención es algo normal, pero hace 43 años ${ }^{3}$ era posible pensarlo solo en programas académicos de una especialización o un posgrado, pero difícilmente concebirlo en una licenciatura de arquitectura. La entonces naciente UAM Xochimilco se interesó en abordar el tema de las prácticas emergentes, aquellas que se entendían como respuesta a nuevas dinámicas sociales, con problemáticas que no tenían una respuesta profesional en el ámbito de licenciaturas, pero que debían abordarse desde la formación académica, con una necesaria visión alternativa a la educación tradicional, factor que desde entonces ha sido un motor en la vida académica de CyAD. Como parte de esa visión de época también se propusieron aproximaciones medioambientales, urbanas y territoriales. La visión ecológica no solo abordaba la relación de la arquitectura y el medio ambiente natural, se proponía el reconocimiento del paisaje, la ciudad y la arquitectura como componentes de un medio ambiente artificial, por lo que equilibrar el desarrollo y la conservación de los recursos naturales y culturales, dentro de una misma lógica, fue otra propuesta dentro aquella perspectiva.

La evolución y la trasformación de las ideas originarias es natural y por ello es claro que las realidades actuales están en otro estadio en relación con las de hace 43 años. Las labores que se realizan en el campo del patrimonio edificado y el proyecto de reutilización son medidas entre la generación de nuevo conocimiento a través de la investigación, la transmisión crítica de ello en las aulas y, por último, en la aplicación a través de propuestas sobre casos reales, que permiten constatar y contrastar posiciones conceptuales, metodológicas y técnicas.

Un medio alternativo, para elaborar sustantivamente ese contraste de ideas, ha sido la realización de encuentros de académicos y profesionales para reflexionar el vínculo que media entre lo que se piensa y lo que se hace. Desde CyAD, estos han sido periódicos y constantes hasta que llegó la pandemia de la COVID-19. El encuentro realizado en $2018^{4}$ se denominó Foro Académico Reflexiones sobre la Reutilización del Patrimonio Edificado.

Ese foro fue propuesto por el cuerpo académico Conservación y Reutilización del Patrimonio Edificado, Área de Investigación de CyAD (ACRPE). La conformación original del $\mathrm{ACRPE}^{5}$ posibilitó reunir en un grupo de trabajo a docentes que han estado impartiendo el programa de Revitalización de Zonas con Valor Patrimonial y Reutilización de Espacios Preexistentes. El motivo fue mejorar tanto la calidad de la investigación que se realiza en torno a la conservación, valoración y reutilización del patrimonio edificado, como los contenidos, alcances, operación y desarrollo académico del área termi-
3

El Plan y Programa Académico de la Licenciatura en Arquitectura, con los énfasis referidos, fue aprobado en 1978.

4

El foro se realizó los días 17 y 18 de octubre de 2018, en la Casa Galván de la propia UAM.

5

El Consejo Académico de la UAM Xochimilco aprobó esta área de investigación en la sesión 1.12 del 30 de marzo de 2012. 


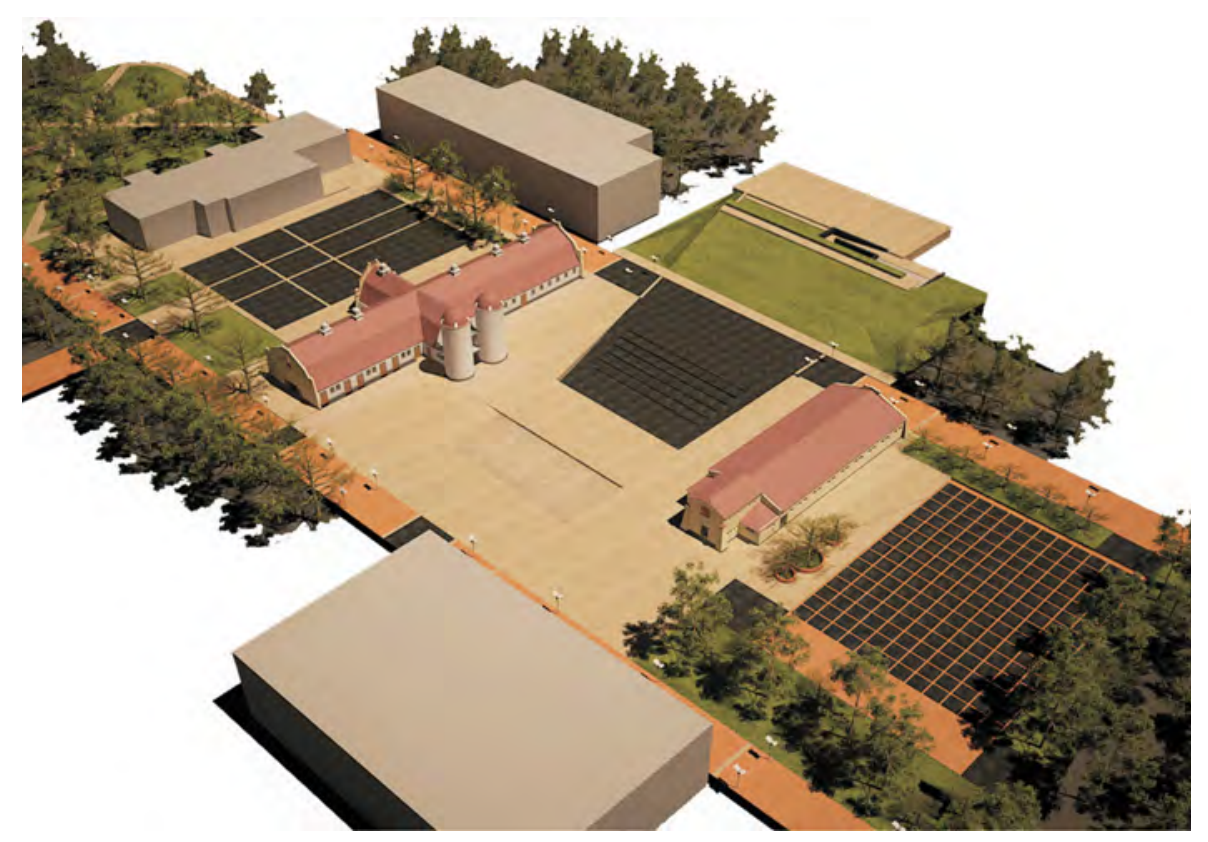

Dentro de los proyectos de reutilización que el cuerpo académico ha realizado se encuentra el Proyecto Ejecutivo de Restauración y Reutilización Arquitectónica del Antiguo Establo y Caballerizas de la Universidad Autónoma Chapingo realizado en 2012 | fuente Archivo ACRPE nal de la Licenciatura en Arquitectura y de la Maestría en Reutilización del Patrimonio Edificado. Así, el grupo de ACRPE tiene su tema de investigación centrado en la valoración, conservación y reutilización del patrimonio edificado, con los siguientes campos de investigación:

$>$ Aspectos teóricos de la reutilización del patrimonio edificado.

> Metodología para la conservación y reutilización del patrimonio edificado.

> Técnicas para la intervención en el patrimonio urbano-arquitectónico.

$>$ El proyecto y la práctica de la reutilización del patrimonio edificado.

> Historiografía de la reutilización urbano-arquitectónica.

Sus objetivos son:

$>$ Generar nuevos conocimientos teóricos y metodológicos sobre la reutilización del patrimonio edificado.

> Analizar los procesos históricos de la reutilización del patrimonio edificado.

$>$ Aplicar métodos y técnicas para el desarrollo de proyectos arquitectónicos dirigidos a la conservación y reutilización del patrimonio edificado, a través de su identificación y valoración. 
> Consolidar la labor de investigación, análisis crítico y trabajo profesional sobre el proyecto de reutilización que realizan tanto los docentes como los alumnos que conforman los distintos programas académicos.

$>$ Preparar y formar investigadores, profesores y profesionales de alto nivel académico capaces de abordar problemas complejos de intervención en zonas patrimoniales, proponiendo alternativas para su conservación y revitalización

$>$ Vincular el trabajo académico con necesidades y demandas externas que permitan aplicar conocimientos teóricos y metodológicos sobre la reutilización del patrimonio edificado, resolviendo problemas específicos, a través de proyectos concretos.

Sus líneas de acción/investigación específicas son:

$>$ Caracterización de los planteamientos generados en relación con los criterios y límites de las intervenciones en el patrimonio edificado a lo largo de la historia.

> Sistematización de la información, documentación, análisis y comprensión de los aspectos de orden histórico, material, cultural y natural.

$>$ Registro y valoración del patrimonio edificado de nuestro pasado reciente, como labor urgente ante los cambios vertiginosos de la sociedad contemporánea que pone en riesgo su conservación.

$>$ Evaluación de la práctica profesional como fundamento para el desarrollo de conceptos teóricos, metodológicos y tecnológicos.

> Estudio diacrónico de la manera en que se ha insertado la nueva arquitectura en espacios preexistentes.

Es posible plantear, con esos antecedentes, que el encuentro se concibió como un espacio para la deliberación de ideas, cuyo objetivo era abonar en la construcción de un cuerpo teórico-metodológico dirigido hacia la manera en que debía abordarse la concepción, problemática, valoración y atención del patrimonio edificado, encaminado principalmente a su conservación y reutilización. El planteamiento de origen estaba diseñado para sostener que ese tipo de intervenciones son una oportunidad de desarrollo social y ambiental.

Los principios que delinearon el Foro Académico fueron los siguientes:

$>$ La Conservación y Reutilización del Patrimonio Edificado (CRPE) es una idea prefigurada en el tiempo que, hermanada con la conservación y restau- 
ración del patrimonio cultural, tiene un componente conceptual que debe ser teorizado.

$>$ La CRPE puede entenderse como un cuerpo metodológico en construcción, para ser aplicado en los procesos de enseñanza- aprendizaje de las áreas de diseño.

$>$ La CRPE es una realidad práctica, profesional, que se construye desde el proyecto urbano y/o arquitectónico y en el tiempo ha derivado en la concreción de un oficio con conocimientos específicos a aplicar.

$>$ La CRPE como práctica conceptual y material debe ser reflexionada desde una visión crítica de la realidad.

Como resultado de este proceso, y para generar ideas sobre el debate, se preparó un documento en torno a "principios para la reutilización", y fue planteado como un pretexto para abrir el diálogo, pero con una condición flexible, abierto para la reflexión dentro del foro y con una visión prospectiva para continuar moldeándolo hasta llegar a ser una declaración de principios, que en este momento sigue siendo un constructo no finalizado, quizá con la claridad de que estará en constante adecuación.

La participación dentro del foro se realizó a través de presentaciones, preguntas y respuestas y mesa redonda, dividido en dos grandes sesiones: Teoría y Formación Académica, por un lado, y Profesión y Crítica, por otro. Los ponentes principales fueron Ignacio González-Varas Ibáñez (Catedrático de composición arquitectónica de la Escuela de Arquitectura de Toledo y de la Universidad de Castilla-La Mancha), Rodolfo Santa María González (ProfesorInvestigador de la Universidad Autónoma Metropolitana-Xochimilco), Luis Carlos Bustos Reyes (Coordinador Académico del Programa de Maestría en Conservación y Restauración de Bienes Culturales Inmuebles. Escuela Nacional de Conservación, Restauración y Museografía-INAH), Mariza Flores Pacheco y Alejandro Sánchez García (socios directores de Taller 6A, Taller de arquitectura), José de Arimatea Moyao López (fundador del despacho de arquitectura Moyao Arquitectos); y Lorenzo Rocha Cito (Director General de Oficina de Arte).

\section{PRINCIPIOS PARA LA REUTILIZACIÓN. AVANZANDO EN LA CONSTRUCCIÓN DE UNA CARTA}

Acercarnos a cualquier campo de conocimiento que se mueva entre la academia, la profesión y la reutilización tiene una complejidad implícita por lo que, aun cuando están presentes, deben evitar las simplificaciones. La intervención para la reutilización del entorno construido requiere posición y com- 


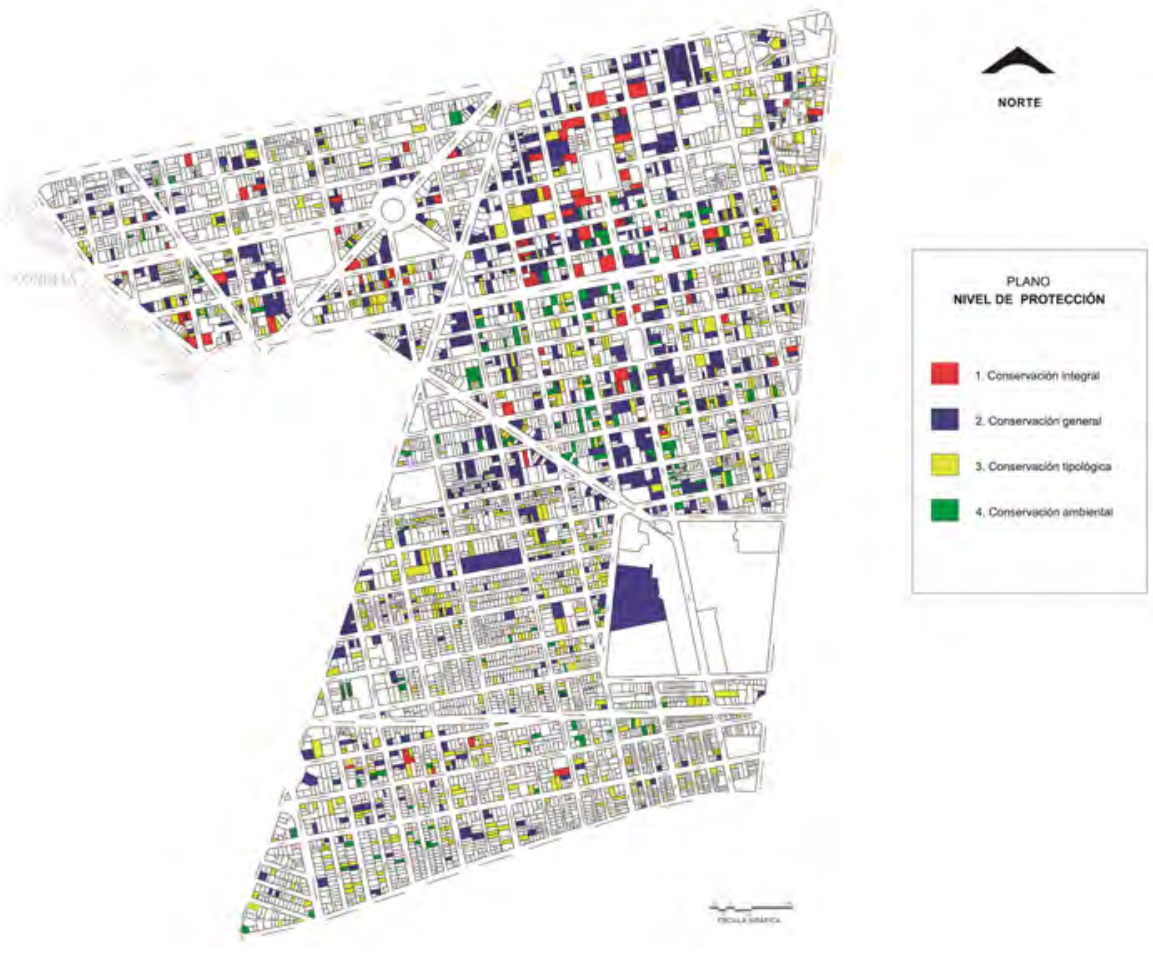

promiso en cualquier actuación. Por ello, es necesario trazar, y así se pensó para el foro, algunas condiciones y características comunes o esenciales que ayuden a distinguir la práctica proyectual, entendida como una disciplina. El énfasis es el desarrollo del proyecto para la intervención urbana y arquitectónica en espacios y edificios preexistentes.

Al partir de un texto preparado exprofeso, y después de una reflexión en torno a la reutilización del patrimonio edificado, que involucró la vista conceptual y la práctica profesional, se pudo delinear un nuevo documento, en el que se plantean algunos de sus contenidos como parte del proceso de proyecto de arquitectura ${ }^{6}$ :

1. La reutilización del patrimonio edificado puede y debe abordarse en sus diferentes escalas, que van desde la amplitud de lo territorial y urbano, hasta lo específico de conjuntos y edificios arquitectónicos. La reutilización del patrimonio edificado, entendido este último como todo espacio, edificio, infraestructura, ciudad, sistemas e instalaciones que ocupan territorios extensos, edificados por el hombre para generar sus espacios de vida, lugares habitables, puede desarrollarse a distintas escalas y tamaños.

2. La reutilización del patrimonio edificado se desarrolla siempre a partir de un proceso previo de valoración. Esta premisa es de la mayor importancia
Plano de la lectura del estado de conservación de los inmuebles de valor patrimonial en las colonias Roma Norte y Roma Sur, parte del proyecto

Catálogo de Inmuebles y Elementos Afectos a Patrimonio Cultural Urbano de las Colonias Roma Norte Y Roma Sur, realizado en 2013 | fuente Archivo ACRPE

6

Las ideas aquí descritas corresponden al trabajo mancomunado de Francisco Javier Soria López y Francisco Haroldo Alfaro Salazar. 
Como parte de las actividades formativas del alumnado de la licenciatura en arquitectura, periódicamente se les integra en talleres prácticos para reconocer técnicas constructivas tradicionales, vinculadas con el patrimonio edificado | foto Archivo ACRPE

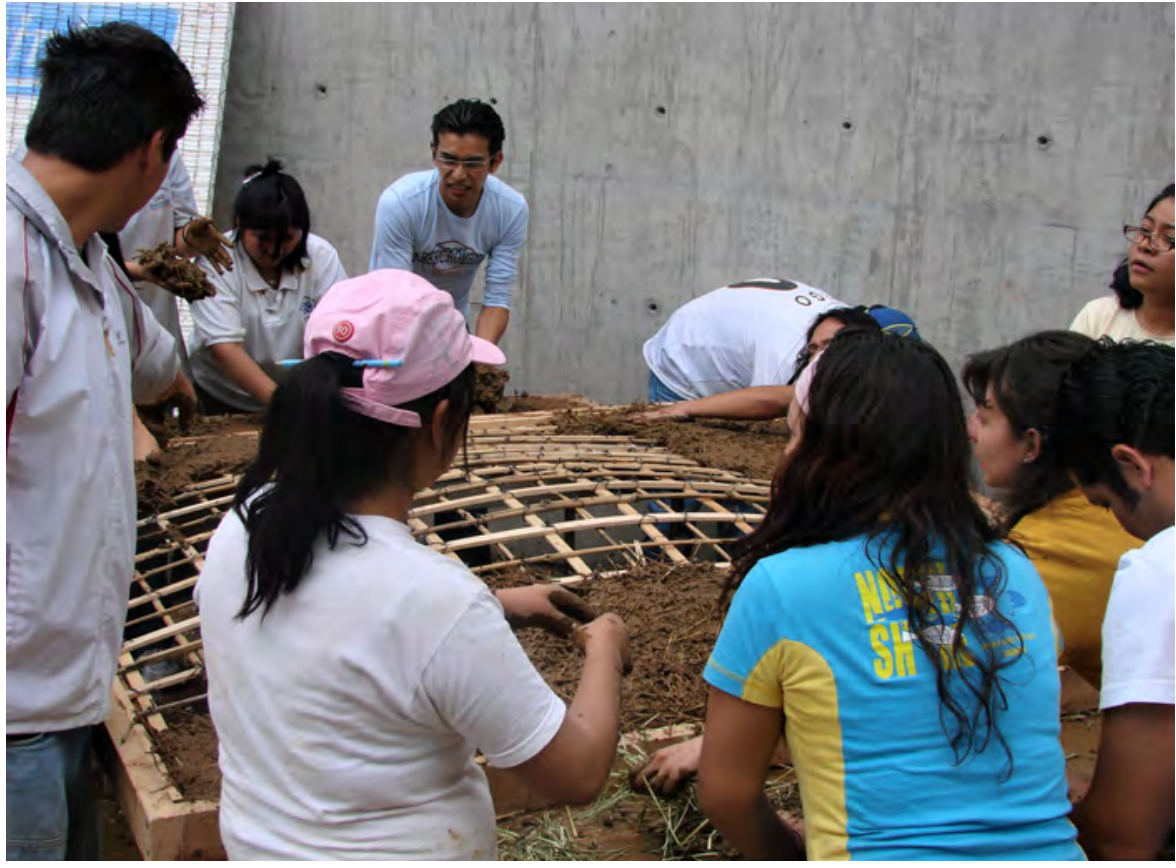

pues permite establecer las "razones" (por simples que sean) por las cuales se considera necesario, adecuado, conveniente o práctico conservar el lugar para darle un nuevo uso o, en su caso, un uso actualizado.

3. La reutilización del patrimonio edificado implica un proceso de conservación de sus elementos tangibles e intangibles esenciales. No hay reutilización si no hay conservación, sin embargo, no es posible predeterminar un grado "óptimo" de preservación, ya que por un lado no se trata de dejar la preexistencia intocada y por otro es necesario mantener las "fuentes interpretativas" del lugar a intervenir.

4. La reutilización del patrimonio edificado implica un proceso de diseño que aporta, transforma, innova y actualiza, mediante el proyecto, el sitio preexistente. La intervención en la preexistencia implica siempre un cierto grado de modificación, pero debe ser respetuosa de las características esenciales que le dan el valor al lugar, una suerte de simbiosis armónica o equilibrada entre lo existente y lo que se incorpora.

5. La reutilización del patrimonio edificado consiste en dotar de un uso a espacios y estructuras preexistentes mediante un proceso de diseño que conserve y simultáneamente enriquezca sus valores patrimoniales. La reutilización se visualiza entonces como un proyecto contemporáneo de arquitectura, que respeta y se apropia de los elementos significativos del lugar, aquellos que le dan precisamente el "valor" que justifica su preservación, 
pero simultáneamente ha de aportar lo propio como parte del proceso de "apreciar", "acumular" y "transmitir" valor.

6. La reutilización del patrimonio edificado reconoce e integra una visión amplia y diversa de valores que pueden ser atribuidos a los edificios y lugares preexistentes. Los valores asignados por individuos y colectivos a los espacios preexistentes no solo son diversos, sino también cambiantes en el tiempo y relativos al lugar social donde se verifican y que van desde su carácter cultural (histórico, estético, técnico), simbólico (significativo, representativo, sentimental, evocativo), ambiental (contextual, paisajístico, energético, de impacto), arquitectónico (funcional, compositivo, espacial, constructivo), hasta su consideración económica (valor monetario, de mercado, de rentabilidad).

7. El proyecto de reutilización del patrimonio edificado debe cubrir, en simultaneidad con la conservación del inmueble, las necesidades de seguridad, accesibilidad, funcionalidad y habitabilidad del usuario. Al tratarse de un diseño de arquitectura contemporánea, el proyecto de reutilización está obligado con las personas que usarán y habitarán los espacios; son quienes darán continuidad al espacio mediante su uso en condiciones actuales.

8. La reutilización del patrimonio edificado se beneficia de una mayor compatibilidad entre las condiciones arquitectónicas previas y los requerimientos del nuevo uso. La lectura de las condiciones arquitectónicas previas y el potencial uso o usos posibles deben ser preferentemente compatibles, que se adapte lo más posible el programa arquitectónico a condiciones espaciales, constructivas o funcionales previas que favorecerá la conservación.

9. La reutilización del patrimonio edificado no aplica soluciones predeterminadas o estandarizadas, sino que compromete su desarrollo a las particularidades de cada caso buscando la mayor conservación de lo preexistente y la mejor aportación con lo que se incorpora, para la puesta en valor del inmueble preexistente. La aplicación de soluciones preestablecidas o de "receta" no se consideran apropiadas dado el carácter único e irrepetible de arquitecturas preexistentes creadas en un tiempo y espacio con condiciones sociales, culturales, económicas y técnicas propias, que no es posible reproducir en el presente.

10. La reutilización del patrimonio edificado incorpora una amplia gama de modalidades de intervenciones, que incluyen la remodelación, la rehabilitación, la reconversión y la restauración. Las posibilidades de intervención de reutilización varían en grado, desde la denominada remodelación que cambia la identidad de la preexistencia, hasta la aplicación de una mínima intervención para preservar al máximo el sitio, modalidades graduadas precisamente por los valores a destacar y conservar. Si bien la práctica de moda- 

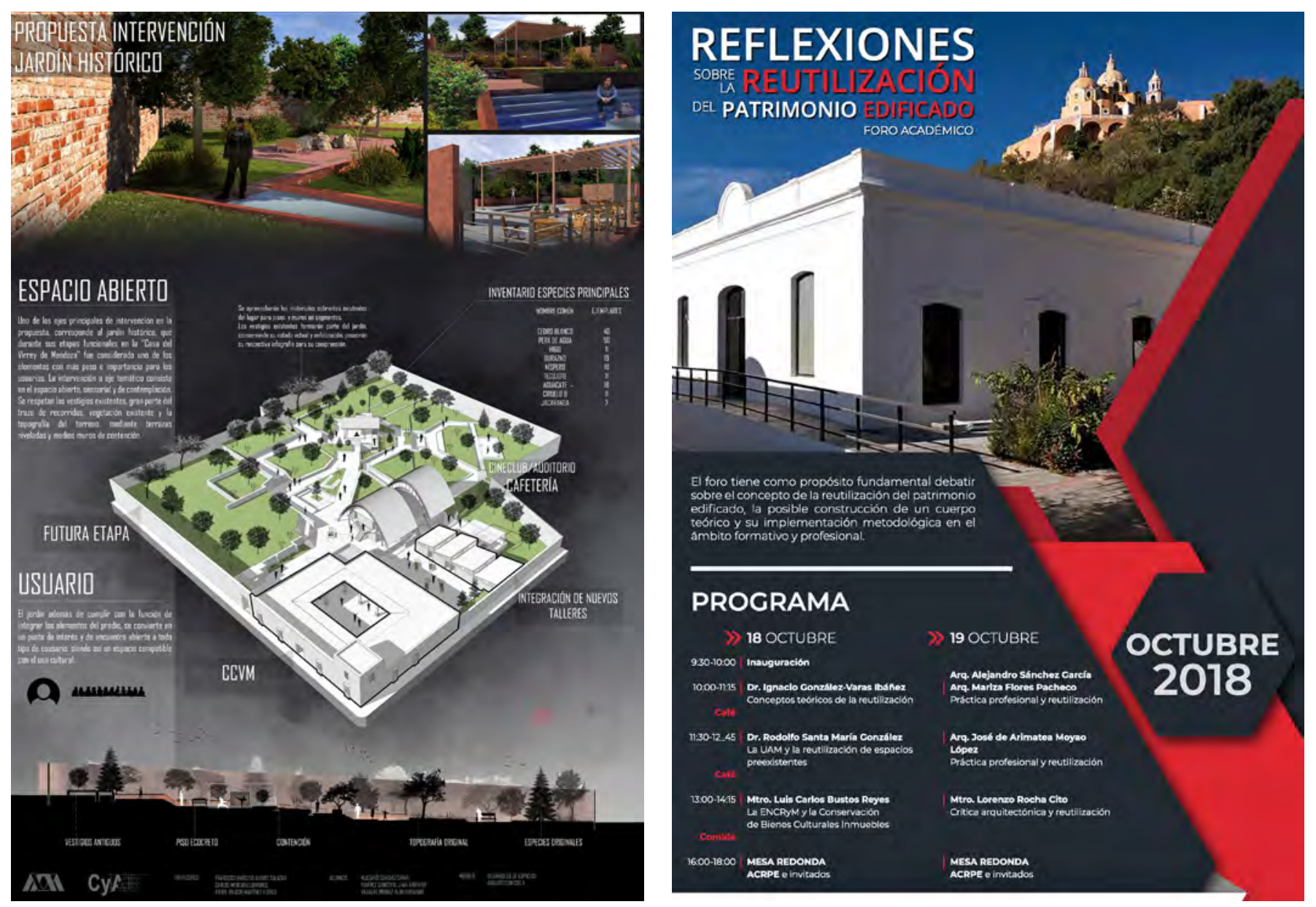

Durante una parte de su etapa formativa, el alumnado realiza un proyecto de reutilización arquitectónica en un edificio con valor patrimonial en zonas urbanas previamente estudiadas. A la derecha, cartel del foro académico Reflexiones sobre la Reutilización del Patrimonio Edificado, realizado en octubre de 2018 | fuente Archivo ACRPE

lidades como la remodelación no son tanto del interés en el ámbito de la reutilización y restauración de inmuebles con reconocidos valores culturales, arquitectónicos o simbólicos, sí se entiende como una actividad que se desarrolla sobre un gran parque edificado (casi siempre de reciente creación) que interesa por su valor económico, de uso, ubicación, rentabilidad e incluso por factores de orden ambiental.

11. La reutilización del patrimonio establece un diálogo abierto con actores sociales, que abarca al proyectista y al habitante, de la misma manera que a autoridades e inversionista. El proyecto reconoce los marcos normativos aplicables a la conservación del patrimonio, de la misma manera que las condiciones de un mercado inmobiliario que puede ser receptivo a la conservación y uso de lo preexistente.

12. Se puede interpretar la reutilización como un puente que reestablece la continuidad entre pasado y presente del edificio existente a través del 
uso. La definición del uso y destino del inmueble a reutilizar resulta de la mayor importancia en el proceso de diseño, donde lo nuevo y lo existente se complementan al generar un equilibrio entre conservación y transformación, entre pasado y presente. El uso de los espacios preexistentes parte de sus posibilidades de absorber otras actividades, siempre compatibles con su tamaño, escala, decoración, pues se trata de no eliminar la 'fuentes interpretativas' que permiten conocer lo que 'ha sido' y proponer nuevas lecturas.

\section{CONCLUSIÓN}

Al momento de concluir el foro se inició un proceso de reflexión al interior del ACRPE. Los proyectos de investigación vigentes en este momento tratan de hacer aportes a esta necesaria condición de encaminar un cuerpo teórico-metodológico de amplio espectro, con la pretensión de formalizar y consolidar los principios para la actuación sobre los bienes patrimoniales. A lo largo del tiempo se ha demostrado que el componente cultural es importante para la valoración del patrimonio, pero existen variables sociales, ambientales y técnicas que deben estar siempre presentes tanto en los estudios previos como en las propuestas y proyectos de intervención.

Las experiencias colectivas que fluyen con la comunicación e intercambio de ideas son un instrumento de diálogo y debate que el ACRPE busca y promueve, por lo que se está en la persecución de objetivos que permitan mantener estos encuentros académicos, pero también en construir espacios de colaboración tanto con instituciones de Educación Superior, como con profesionales y gremios del proyecto y la edificación. Exponer estos principios está en la lógica de consolidar, junto con otros ojos y miradas, el cuerpo teórico en vinculación con la práctica profesional, y pensando que con ello se fortalezca la investigación y la docencia de licenciatura y posgrado en la División de Ciencias y Artes para el Diseño de la UAMX. Desde nuestro espacio interior, asumimos y reconocemos que egresados con saberes y conocimientos en este ámbito pueden generar actuaciones mejor estudiadas, argumentadas y desarrolladas en beneficio de ese patrimonio edificado, que es a la larga en beneficio de las sociedades de todo lugar. 


\section{Buenas prácticas para la conservación y revitalización del patrimonio conventual de Toledo}

Ignacio González-Varas Ibáñez | Área de Composición Arquitectónica, Universidad de Castilla-La Mancha

URL de la contribución <www.iaph.es/revistaph/index.php/revistaph/article/view/4948>

\section{RESUMEN}

El patrimonio conventual presenta unos rasgos distintivos que lo singularizan y entre los que nos interesa destacar los dos siguientes: en primer lugar, se trata de un patrimonio que, cuando aún permanece vivo, se vincula de modo estrecho e indisociable a las comunidades de religiosos/as que lo habitan; $y$, por otro lado, en aquellas ciudades en las que este patrimonio asume un peso muy significativo, y que por eso mismo han sido caracterizadas en algunos momentos de su historia como "ciudades conventuales", estos edificios forman una "red patrimonial" que ha contribuido de modo decisivo a la formación de la estructura e imagen de la ciudad. Cuando confluyen ambas características, como es el caso muy significativo del patrimonio conventual de Toledo, pensamos que, más allá de la problemática específica que presenta cada edificio histórico o cada comunidad religiosa (y que, por supuesto, requerirá de estudios y tratamientos individualizados), es necesario partir de una consideración en conjunto de este patrimonio y considerar la agrupación de edificios conventuales como un "sistema patrimonial". En este texto queremos plantear un conjunto de buenas prácticas que se derivan para la conservación y revitalización del patrimonio conventual de Toledo, especialmente en cuanto implantación de una novedosa metodología de estudio de este patrimonio que tienen en cuenta su condición de "sistema" y como aportaciones para atender a las necesidades derivadas de sus tres situaciones posibles, esto es, conventos con comunidad activa, conventos recientemente extinguidos y conventos cuya comunidad ha desaparecido hace tiempo y que han reutilizados para otros usos y funciones.

\section{Palabras clave}

Buenas prácticas | Ciudades | Conventos | Conservación (Patrimonio) | Órdenes religiosas | Paisaje urbano arquitectónico | Patrimonio inmueble | Patrimonio mueble | Patrimonio inmaterial | Reutilización | Revitalización | Sistemas patrimoniales | Toledo | 


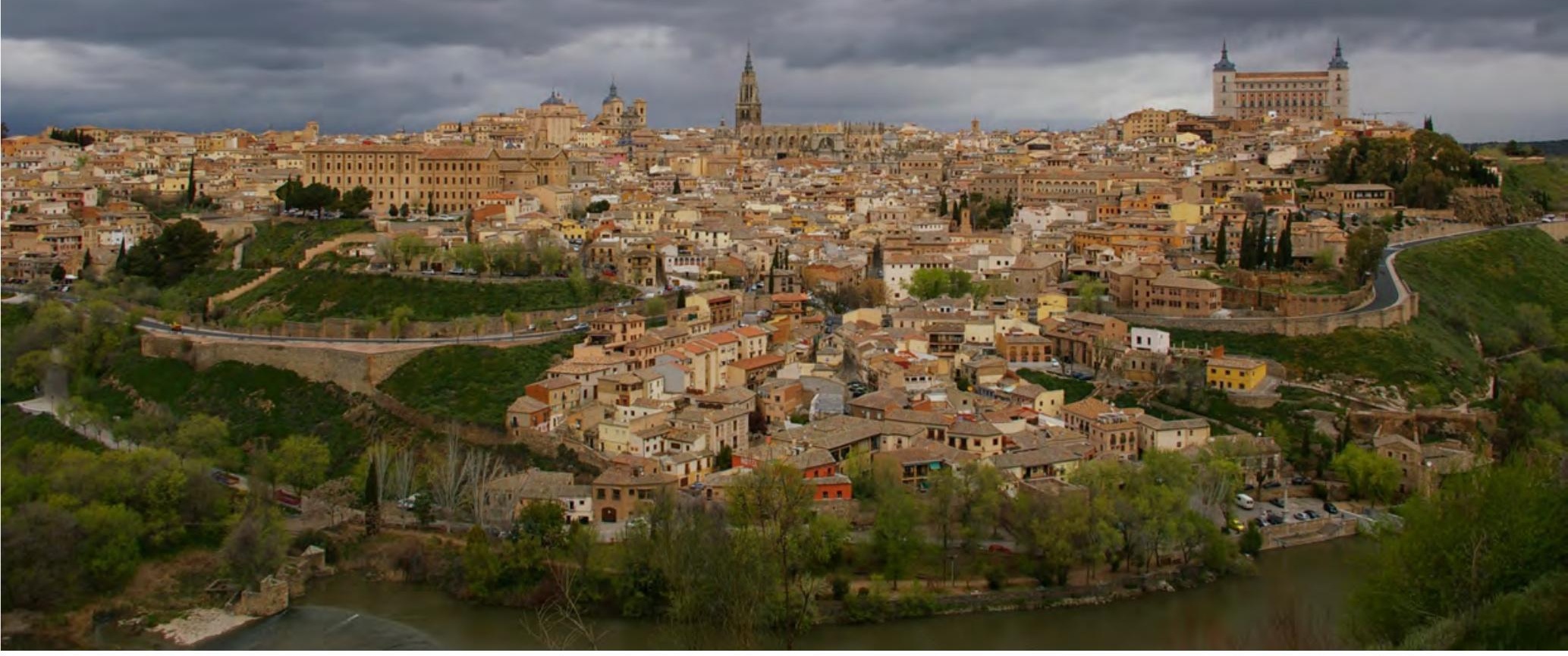

Vista general del casco histórico de Toledo desde los Cigarrales | foto Ignacio González-Varas Ibáñez 
Texto vinculado al subproyecto de investigación El conjunto monumental de los conventos de Toledo: análisis de propuestas de conservación, mantenimiento y reutilización, incluido dentro del proyecto coordinado Claustrat. E patrimonio material e inmaterial de los conventos de Toledo y su Diócesis, Junta de Comunidades de Castilla-La Mancha (SBPLY/19/180501/000096).

\section{EL PATRIMONIO CONVENTUAL: ELEMENTOS MATERIALES E INMATERIALES ${ }^{1}$}

El patrimonio conventual está integrado por elementos materiales e inmateriales y conforma una realidad patrimonial compleja, como ha sido ampliamente estudiado (Braunfels 1974). Los conventos son "una ciudad dentro de la ciudad" y configuran espacios diversos y contrastados, pues se alternan edificios simbólicos y solemnes (iglesias, capillas, torres, salas capitulares o claustros) con otras estancias de carácter cotidiano (celdas, pasillos, patinillo o refectorios). Se puede establecer, por tanto, una división entre espacios comunitarios y espacios privados. Pero la división espacial se hace aún más compleja, pues en el convento también existen lugares de invierno y de verano, estancias de recogimiento y descanso y ámbitos de trabajo y de labor, espacios de circulación y comunicación y de reunión y esparcimiento, del mismo modo que se alternan espacios para la vida con otros para la muerte, como las salas de profundis y los ámbitos reservados para los enterramientos, tanto de miembros de la comunidad como de sus fundadores o patrones. La arquitectura resultante congrega así a edificios que a veces presentan una elaborada factura artística que se alzan junto a otros más bien vinculados a la arquitectura vernácula de sabor popular. El mantenimiento de la vida comunitaria, en aquellos casos en los que todavía perdura, ha permitido preservar no solo la arquitectura conventual y esta diversidad de espacios a la que aludimos, sino también su cualificación y riqueza, su sentido transcendente y cotidiano y los significados adquiridos a través del tiempo, que han podido ser sostenidos o transformados a través del uso continuado. El patrimonio material e inmaterial, mueble e inmueble, supone, en su conjunto, una herencia viva que, además de los edificios, vehicula la transmisión de valores espirituales, como pueden ser el silencio creador, el trabajo y la oración o la apertura a la transcendencia que se desarrollan en el contexto de una vida en comunidad, al mismo tiempo que los conjuntos conventuales aportan toda una serie de valores histórico-artísticos, sociales y antropológicos que se prolongan en el tiempo a través de ritos, costumbres y hábitos mantenidos a lo largo de su historia.

\section{LOS CONVENTOS COMO CONJUNTOS Y SU RELACIÓN CON LA TRAMA URBANA DE LA CIUDAD}

En algunas ciudades históricas, uno de los semblantes que antaño fue dominante y que en la actualidad nos hemos de esforzar en descubrir, pues permanece recóndito entre sus calles y adarves, es el configurado por la imagen de la "ciudad conventual". El caso de Toledo es sumamente relevante al respecto. Como afirmara Gregorio Marañón, "esparcidos por el laberíntico y noble caserío toledano, (los conventos) representan la parte esencial y permanente del alma de la ciudad, más que la conciencia de Toledo, son su 
verdadera subconsciencia" (Marañón 1941). El médico humanista hablaba de esa "subconsciencia" como un estado latente y no perceptible en una primera impresión, pues sus adustos muros y cercas hacen de la arquitectura conventual un patrimonio siempre introvertido y muchas veces inadvertido, pues permanece volcado al interior, con tapias y cierres que son como una férrea caja torácica que protege y esconde el corazón conventual. Pero, a la vista del plano que hemos elaborado para obtener un primer reconocimiento de este rostro recóndito de la ciudad, vemos cómo los conventos toledanos emergen y articulan en gran medida la trama urbana de su casco histórico: cuantitativamente constituyen alrededor de un $30 \%$ de la extensión total del centro histórico y rápidamente se capta la fuerte impronta que estos conjuntos han ejercido y ejercen en la configuración de la trama y el paisaje urbanos. La arquitectura conventual está muy presente en las vistas panorámicas y en las perspectivas exteriores e interiores de la ciudad, donde despuntan y emergen sobre el caserío circundante sus elementos monumentales más característicos, como torres, campanarios, cubiertas o tejados. Muchos de estos conventos, como nos narran las crónicas y documentos, resultaron de donaciones de casas nobiliarias y asimilaron como su matriz formativa elementos de la arquitectura residencial y/o religiosa precedente y se fueron configurando mediante un proceso casi biológico de expansión hasta condicionar el trazado urbano circundante.

El análisis del sistema conventual trata de dilucidar la incidencia de estos conjuntos en la conformación de manzanas y en la configuración de calles y plazas, así como en la ocupación de vacíos urbanos o, por el contrario, en procesos de asimilación y reutilización del caserío preexistente, examinando tanto implantaciones singulares como las relaciones de posición entre los conventos. En este análisis hemos de fijarnos en la relación del conjunto conventual con el exterior, con la trama urbana en la que el convento se encaja, y tratar de averiguar cómo se relacionan las fachadas con la ciudad, en una arquitectura de carácter hermético y cerrado, con tapias y fachadas oclusivas para preservar la clausura.

\section{SITUACIÓN CRÍTICA DE LOS CONVENTOS FEMENINOS}

A pesar de los procesos de desamortización y de la crisis actual de las vocaciones religiosas, gran parte de los conventos femeninos de Toledo mantiene su vida religiosa y por ello han permanecido prácticamente inaccesibles al público, a la vez que han permitido la continuidad de ese difuso y discreto rostro recóndito de ciudad conventual. Estos conventos ostentan un valioso patrimonio mueble e inmueble, como han puesto de relevancia estudios como los realizados por Balbina Martínez Caviró (1980, 1990, 1993), Laura Cabanal Rodríguez (1997), Manuela Herrejón Nicolás (1990) o Palma Martínez-Burgos (2019), entre otros. 


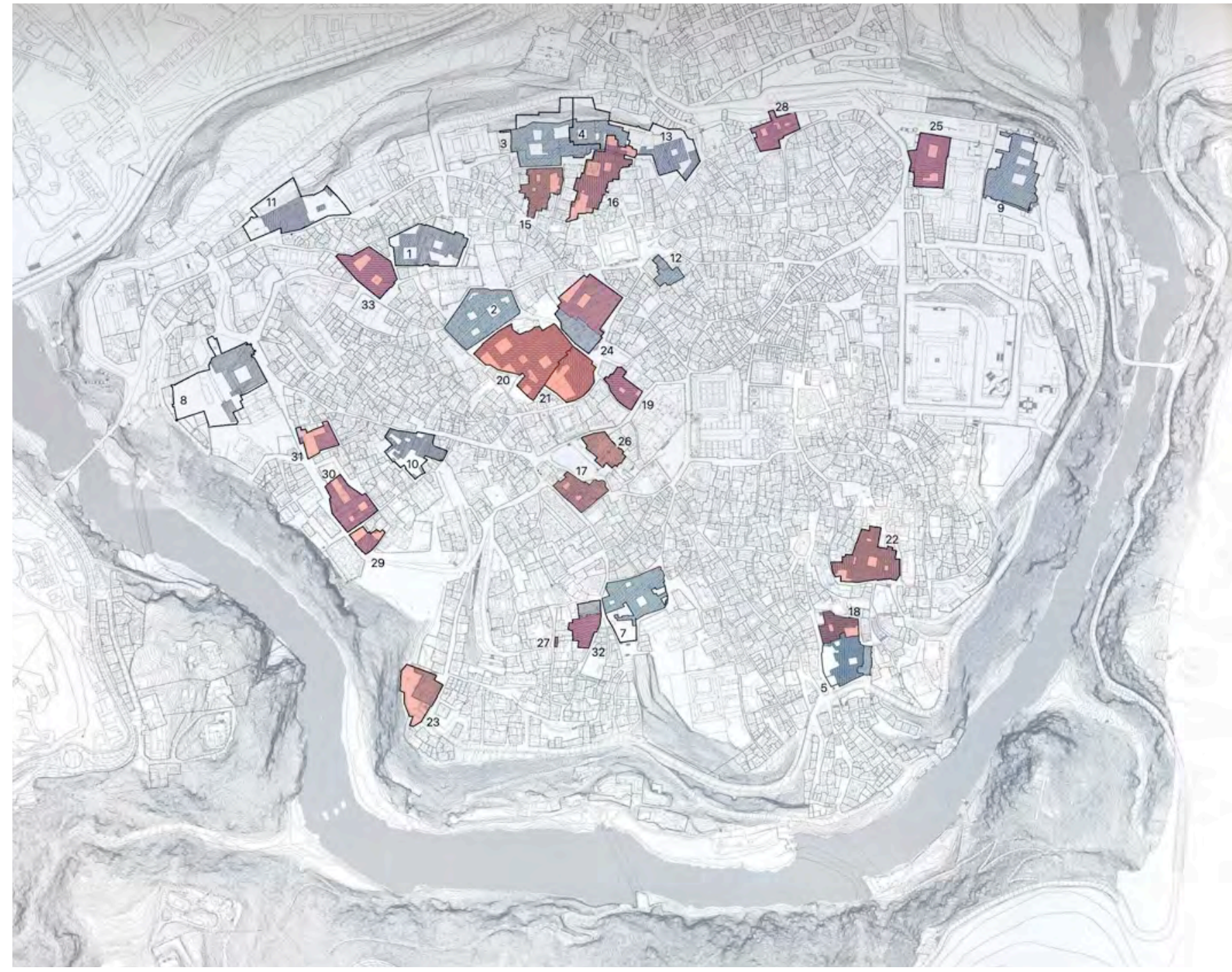

Plano del casco histórico de Toledo con la localización del sistema patrimonial de conventos: en rayado azul, conventos con comunidad religiosa; en rayado rojo, conventos sin comunidad religiosa y/o reutilizados | plano Ignacio González-Varas Ibáñez

\section{CONVENTOS DE TOLEDO. LOCALIZACIÓN EN EL PLANO}

\section{En rayado azul: conventos con comunidad-uso religioso}

1 Convento de Santo Domingo el Antiguo (orden del Císter-1085)

Femenino

2 Convento de San Clemente (orden del Císter-1130)

Femenino

3 Convento de Santo Domingo el Real (orden de Predicadores, Dominicas-1363)

Femenino

4 Convento de las Comendadoras de Santiago (orden militar de Santiago-1365-1935)

Femenino

5 Convento de las Jerónimas de San Pablo (orden de San Jerónimo-1373)

Femenino

6 Convento de Nuestra Señora de Monte Sion (orden de Císter-1426)

Masculino (fuera del casco)

7 Convento de Santa Isabel de los Reyes (orden de san Francisco, Clarisas-1477) Femenino 
11 Convento de las Carmelitas Descalzas de San José (orden del Carmen-1614)

Femenino

12 Convento de la Inmaculada Concepción de N. a Sra. o Gaitanas (orden de San Agustín-1627)

Femenino

13 Convento de los Carmelitas Descalzos del Espíritu Santo (orden de los Carmelitas-1643)

Masculino

14 Convento de Jesús y María (orden de Predicadores, Dominicas-1984)

Femenino (fuera del casco)

\section{En rojo: conventos sin comunidad}

15 Convento de la Concepción Capuchina (orden de San Francisco, Capuchinas-1655)

Femenino

16 Convento de Santa Clara (orden de San Francisco, Clarisas-1254)

Femenino

17 Convento de Santa Úrsula (orden de San Agustín, Agustinas-1259)

Femenino

18 Convento de la Purísima Concepción de N. ${ }^{\text {a }}$ Sra. o Benitas (orden de San Benito-1484)

Femenino

\section{En rojo: conventos reutilizados}

19 Convento de Jesús y María (orden de Predicadores): Archivo Histórico Provincial de Toledo

Femenino

20 Convento de San Pedro Mártir (orden de Predicadores): Universidad de Castilla-La Mancha

Masculino

21 Convento de la Madre de Dios (orden de Predicadores): Universidad de Castilla-La Mancha

Femenino

Convento de San Juan de la Penitencia (orden de San Francisco): Conservatorio de Música y Centro de

Estudios Internacionales de la Fundación Ortega y Gasset

Femenino

Convento de San Gil (orden de San Francisco: Franciscanos descalzos o Gilitos): Cortes de Castilla-La Mancha

Masculino

Compañía de Jesús (orden de los Jesuitas): permanece la Iglesia de San Ildefonso-Colegio: Delegación de Hacienda

Convento de Santa Fe (Concepción Francisca: Orden de la Inmaculada, 1492) o Monasterio de las

25 Comendadoras de Santiago (Orden Militar de Santiago, 1503), Convento de la Sagrada Familia de Loreto (Ursulina, 1873) - abandonado en 1973: Centro de Arte Contemporáneo Roberto Polo

Convento de la Santísima Trinidad (orden de los Trinitarios Descalzos): Iglesia de San Marcos: Centro Cultural, Ayuntamiento de Toledo

27 San Torcuato (orden de San Agustín): iglesia del antiguo convento de Agustinas

\section{Femenino}

28 Convento de Nuestra Señora de la Asunción (orden de Bernardas Recoletas): Colegio Medalla Milagrosa

29 Convento de El Tránsito (orden de Calatrava): Museo Sefardí

Femenino

Convento-Hospital de San Juan de Dios (orden de Hermanos Hospitalarios de San Juan de Dios): Hogar de Ancianos de San Juan de Dios

Masculino

Masculino

31 Beaterio de Santa María la Blanca: monumento

Femenino, incluido en la red "Toledo monumental"

32 Convento de Jerónimas de la Visitación-Convento de la Reina

Femenino

Femenino, monumento incluido en la red "Toledo monumental" 
Convento de Santo Domingo el Real. Proyecto para la restauración de la bóveda de la Iglesia de Convento de Santo Domingo el Real. Planta de bóvedas (2009). Consorcio de Toledo. Programa de Patrimonio Monumental. B.A.B. Arquitectos | plano Ignacio Barceló de Torres
El balance actual de la presencia de la arquitectura conventual en el casco histórico de Toledo es el que se refleja en el plano que aquí reproducimos: de los cincuenta y tres conventos de los que se tienen noticias documentales, han permanecido los edificios de treinta y cuatro, pero de ellos tan solo doce aún albergan comunidades religiosas, pues cuatro han sido recientemente cerrados y aún no se les ha dotado de nuevo uso. En el plano también se detallan los quince conventos desamortizados que han sido reutilizados para distintas funciones en diferentes fechas, a los que habría que sumar los tres conventos situados fuera del casco histórico, uno de ellos, el cisterciense de Nuestra Señora de Monte Sion, aún activo. También hemos de mencionar los diecinueve conventos extinguidos que fueron posteriormente demolidos y de los que nos quedan noticias documentales. Pero el descenso de la población de monjas y su alarmante envejecimiento (el $37 \%$ de la población religiosa cuenta con más de 75 años) ha provocado en los últimos años una situación sumamente comprometida para el patrimonio conventual toledano expresada, como decimos, con el cierre de cuatro conventos en el último lustro, situación a la que debemos sumar los procesos de aculturación derivados de la presencia de religiosas procedentes de latitudes lejanas que introducen nuevos usos y valores en las comunidades, con la consiguiente ruptura en la transmisión de los usos tradicionales,

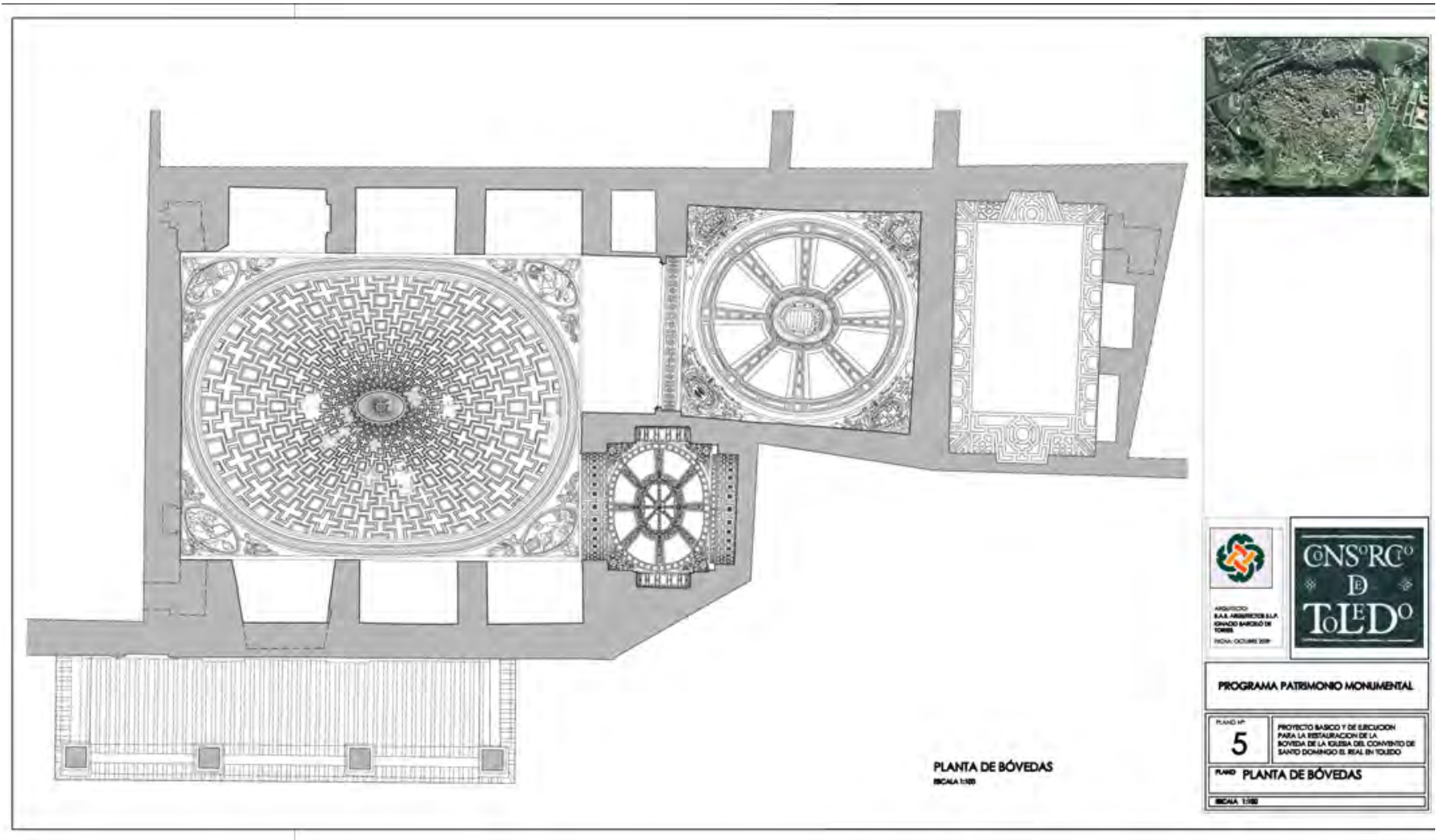


así como cambios litúrgicos que a veces desembocan en la eliminación o transformación de algunos elementos, como coros, púlpitos, rejas, etc. Los conventos que perviven experimentan por lo general un considerable descenso en el número de religiosas y una elevada edad media de sus comunidades (Vizuete Mendoza 2019). Todo ello, unido a la falta de ingresos regulares, puede provocar el deterioro de los inmuebles y agrava la situación crítica de algunas comunidades.

Se han realizado algunas importantes acciones para la conservación y restauración de los conventos. En este sentido hemos de destacar la actividad desarrollada por el Consorcio de la Ciudad de Toledo que, desde su fundación en 2001, ha desarrollado un programa de recuperación sistemática del casco histórico que ha incluido los conventos en su Programa de Patrimonio Monumental. Pero las actuaciones realizadas por esta institución, encomiables por su rigor metodológico, se han limitado a intervenciones de reparación y/o restauración de sus fábricas. Estas operaciones han oscilado desde la reparación de sucesos puntuales, como el robo de un tambor de columna en la portada plateresca del convento de San Clemente, hasta obras de mayor calado y envergadura, como, por ejemplo, la recuperación del arrimadero de azulejos y patio de la Mona del convento de
Convento de Santo Domingo el Real. Proyecto para la restauración de la bóveda de la Iglesia del Convento de Santo Domingo el Real. Sección longitudinal norte (2009). Consorcio de Toledo. Programa de Patrimonio Monumental. B.A.B. Arquitectos | plano Ignacio Barceló de Torres

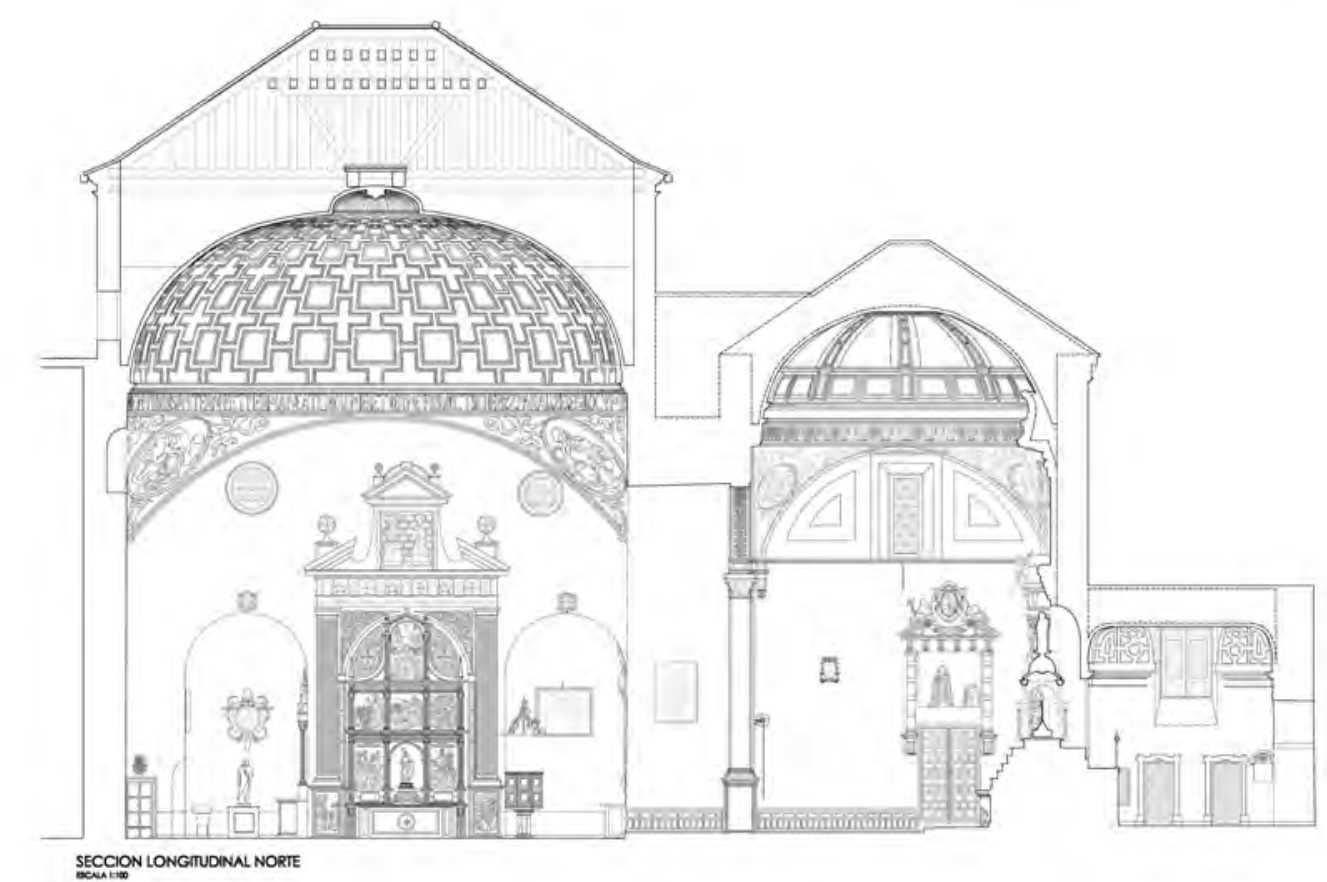




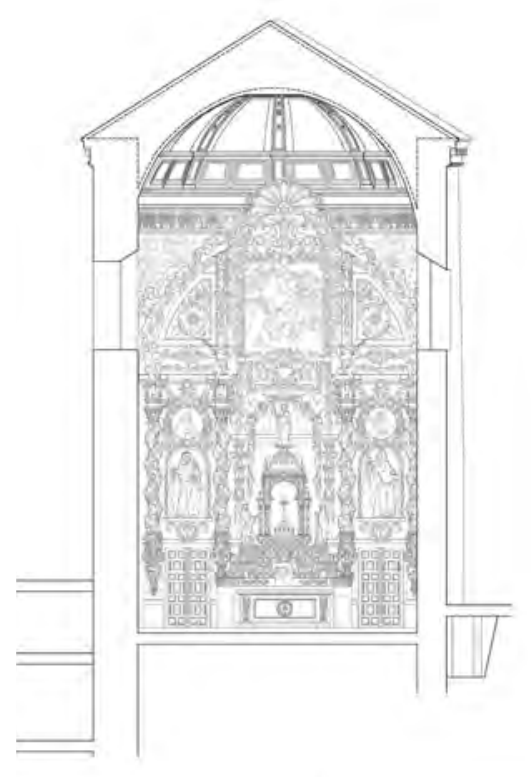

Convento de Santo Domingo el Real. Proyecto para la restauración de la bóveda de la Iglesia del Convento de Santo Domingo el Real. Secciones transversales (2009). Consorcio de Toledo. Programa de Patrimonio Monumental. B.A.B. Arquitectos | plano Ignacio Barceló de Torres

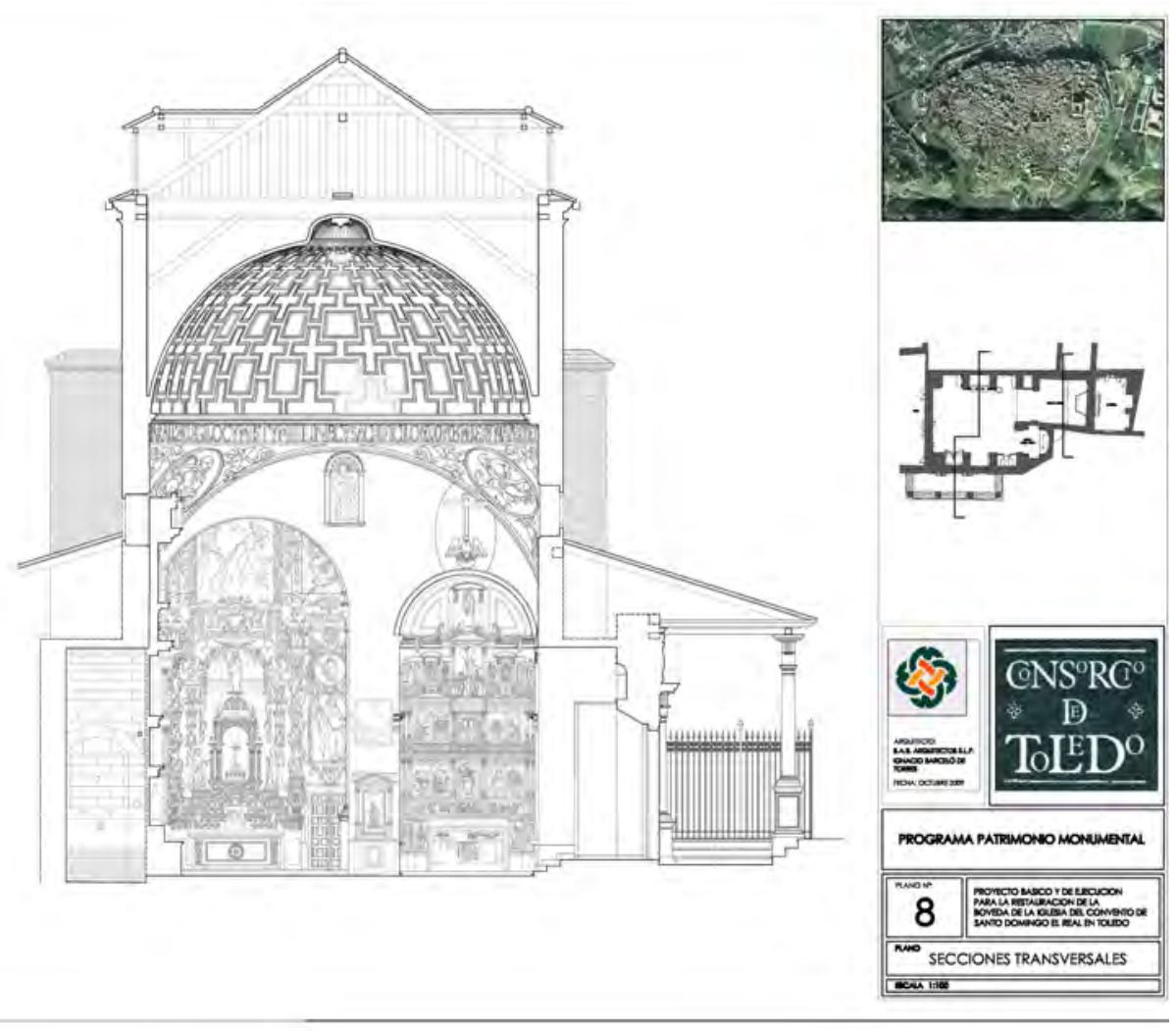

las Comendadoras de Santiago, la restauración de la iglesia y la capilla de San Jerónimo del convento de la Concepción Francisca, la restauración de la sala capitular del monasterio de San Clemente, la recuperación del claustro de las Procesiones y el jardín del convento de San Clemente, la restauración de las bóvedas del convento de Santo Domingo el Real, la intervención en las celdas y el patio de la Enfermería del convento de Santa Isabel, la rehabilitación de las cubiertas del patio grande, coro viejo y fachadas del convento de Santa Úrsula, la restauración de las cubiertas de la iglesia de los Carmelitas Descalzos o la recuperación de los espacios libres privados del recientemente extinguido convento de Santa Clara. Como muestra de la calidad y rigor metodológico de estas intervenciones, reproducimos aquí tres planos del mencionado proyecto para la restauración de la bóveda de la iglesia de Santo Domingo el Real elaborado por el estudio B.A.B Arquitectos encabezado por Ignacio Barceló de Torres que cuenta con una prolongada y destacada trayectoria en el campo de la restauración monumental. Son intervenciones arquitectónicas de restauración o rehabilitación, que inciden únicamente en el patrimonio material, pero, como es lógico por su propia naturaleza y objetivos, no atienden a la realidad integral del sistema conventual. 


\section{EL CONVENTO COMO PATRIMONIO "VIVO"}

El estudio y mantenimiento de los doce conventos actualmente activos en Toledo parte de la premisa de que uno de los valores patrimoniales más importantes que se debe proteger y conservar es la vida de la propia comunidad monástica. Con esta finalidad se ha tratado de establecer un conjunto de buenas prácticas orientadas a la conservación integral de estos conjuntos patrimoniales. El punto de partida se centra en conocer la realidad de cada convento y los usos de los distintos espacios en función de la vida de la comunidad. Estas intenciones deben tener en cuenta que cada orden religiosa, de acuerdo con la regulación canónica, es autónoma y se rige por sus propios estatutos aprobados por la Santa Sede, autonomía que incluso se extiende a cada convento en particular dentro de la propia orden. El régimen jurídico y de propiedad de cada convento presenta, por tanto, sus peculiaridades. La instrucción pontificia Cor Orans, dictada por el papa Francisco el 1 de abril de 2018, se ha erigido en un documento fundamental a este respecto. Este documento, por un lado, ha reforzado el papel de la Federación de monasterios autónomos del mismo Instituto y crea la Asociación de Monasterios Autónomos, esta última con el objetivo de integrar a varios monasterios para procurar su colaboración (Campos y Fernández de Sevilla 2019). También ha sido muy estimulante la voluntad de este decreto pontificio de organizar las relaciones de los conventos femeninos con las autoridades civiles (en sus ámbitos estatal o regional) y con las autoridades eclesiásticas (diocesanas, institutos religiosos y órdenes monacales).

En el sistema de conventos de Toledo especial preocupación suscita en nuestros días la situación de los cuatro conventos señalados cuya vida religiosa se ha extinguido en fechas recientes, como son el convento de la Concepción Capuchina, fundado en 1655 y extinguido entre 2007 y 2019, el convento de Santa Clara, fundado en 1254 y extinguido en 2016, el convento de agustinas de Santa Úrsula, fundado en 1259 y extinguido en 2016 y el convento de la Purísima Concepción de Nuestra Señora o Benitas, fundado en 1484 y extinguido en 2019. La administración de los bienes de los conventos, según la mencionada instrucción Cor Orans, establece que estos bienes, respetando la voluntad de los fundadores y los donantes, "se trasladan con las monjas que aún quedan y se distribuyen, de forma proporcional, en los monasterios que las acogen" (n. ${ }^{\circ} 72$ ) o bien, cuando ya no quedan monjas en la congregación, pasan "a la Federación de monasterios o a otra estructura de comunión entre los monasterios similar a la misma o bien a la Congregación monástica femenina" (n. $\left.{ }^{\circ} 73\right)$. A estas prescripciones debemos sumar aquellas otras procedentes de las leyes de patrimonio. De este modo, el uso del convento, su mantenimiento o las perspectivas de desaparición de la vida conventual, son, como vemos, capítulos fundamentales para administrar su naturaleza patrimonial y establecer un conjunto de buenas prácticas que posibiliten tanto gestionar la situación actual 


\section{CONVENTOS DESAPARECIDOS Y} DEMOLIDOS*

\section{Órdenes masculinas}

Convento de Santa Catalina (orden de los Mercedarios Descalzos)

Convento de los Trinitarios Descalzos Convento de Nuestra Señora del Carmen (orden de los Carmelitas Descalzos)

Convento de San Servando (orden del Císter)

Convento de Santa María de la Sisla (orden de los Jerónimos)

Convento de Santa María de las Nieves (orden de Predicadores)

Convento de San José (orden de los Carmelitas Descalzos)

Convento de San Agustín (orden de San Agustín)

Convento de Agaliense (orden de San

Benito)

Convento de San Cosme y San Damián

(orden de San Benito)

Convento de San Félix de Saelices (orden de San Benito)

Convento de San Bartolomé de la Vega

(orden de Mínimos)

Convento de la Purísima Concepción

(orden de Agustinos Recoletos)

Convento de San Julián (orden de clérigos menores)

\section{Órdenes femeninas}

Convento de San Miguel de los Ángeles

(orden de San Francisco)

Convento de Santa Ana (orden de San

Francisco)

Convento de la Purísima Concepción

(orden de San Francisco)

Convento de Vida Pobre (orden de San Jerónimo)

Convento de San Pedro de Dueñas

*De los que se tiene registro documental. de las comunidades religiosas y su patrimonio como prever posibles situaciones de abandono y desacralización de los conventos. La búsqueda de soluciones específicas para este patrimonio dio lugar a la elaboración del Plan Nacional de Abadías, Monasterios y Conventos, suscrito el 25 de marzo de 2004 por el Ministerio de Educación, Cultura y Deporte y la Conferencia Episcopal Española. Sin embargo, este documento no llegó a entrar oficialmente en vigor, aunque debemos decir que el Instituto de Patrimonio Cultural de España mantiene activa una comisión que trabaja en torno a ese Plan Nacional, con su seguimiento y actualización (2011, 2013, 2015 y 2018). Pero no existe una acción coordinada de buenas prácticas para actuar en este patrimonio que, como vemos, presenta una problemática propia derivada en gran medida del complejo estatuto jurídico de las órdenes religiosas. La preocupación demostrada por la Santa Sede no se plasma en acuerdos o convenios de carácter general. Por eso actuaciones de interés orientadas a la restauración y/o rehabilitación de los conjuntos conventuales, como las que mencionábamos más arriba, se han llevado a cabo a través de organismos específicos como el Consorcio de la Ciudad de Toledo. Estas experiencias, aunque, como hemos dicho, se han centrado en la intervención de elementos concretos de sus fábricas, ya apuntaban que, en realidad, la problemática del patrimonio conventual es mucho más amplia. Así lo establecía con claridad la Directora de Gestión Patrimonial de este organismo cuando, a la vez que indicaba el carácter del convento como "museo vivo", reconocía que "con la intervención (...) en los conventos, nos hemos cuestionado el uso en el patrimonio y del patrimonio. Algunos de estos inmuebles han perdido su función original y hoy nos debemos cuestionar el fin último de estas rehabilitaciones. Conservar y usar para dotar de significado a estos espacios en el siglo XX" (Sánchez Chiquito de la Rosa 2017, 16).

\section{REUTILIZACIÓN DEL PATRIMONIO ABANDONADO}

La consideración de la arquitectura conventual como "sistema patrimonial" nos ha de llevar a integrar en estudio y tratamiento de este conjunto monumental no solo a los edificios actualmente dotados de uso religioso comunitario, sino también a aquellos que han sido reutilizados en distintos momentos y bajo diferentes circunstancias. Es preciso, por tanto, realizar asimismo un estudio o balance crítico del tratamiento que han recibido estos conventos extinguidos, pero de los que han perdurado sus fábricas hasta nuestros días. Algunas de estas cuestiones las hemos tratado con más extensión en otras ocasiones, pues el carácter sacro de este patrimonio impone unas consideraciones especiales en el momento de su reutilización y de las acciones posteriores de conservación o revitalización que se desprenden de los nuevos usos (González-Varas Ibáñez 2016a, 2016b). Los aspectos estudiados contemplan la reconstrucción histórica de los procesos de desamortización, exclaustración y reutilización para comprobar la sucesión de usos que ha 


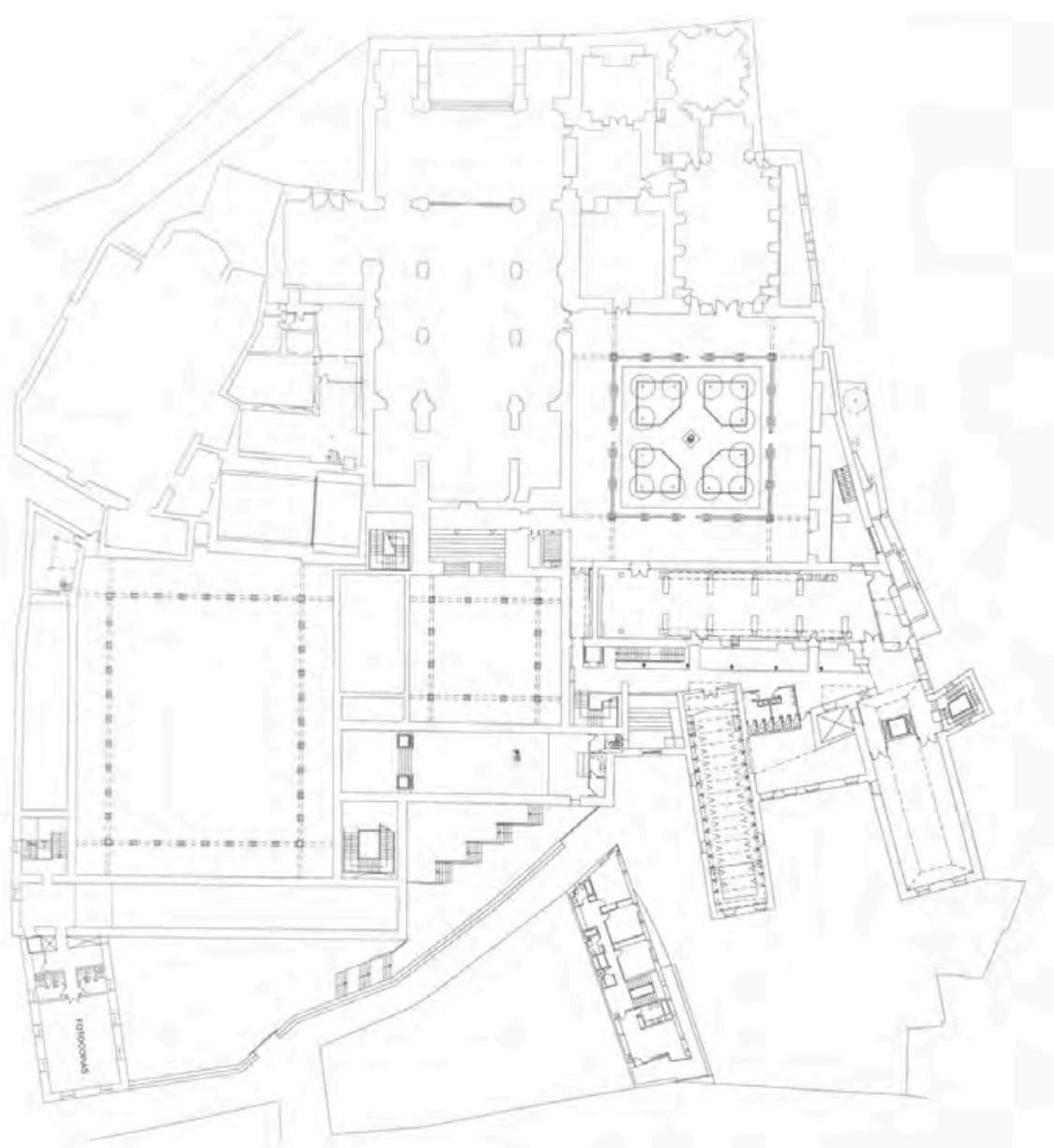

experimentado el conjunto monumental hasta llegar al momento actual. En esta estimación se trata de observar y recomponer gráficamente los espacios conventuales (iglesia, coro, claustro, refectorio, sala capitular, locutorios, dormitorios, etc.) y señalar el uso que se ha asignado a cada uno de esos espacios en la actualidad. En el análisis y valoración crítica del uso actual del antiguo convento se tratan de establecer parámetros como el grado de compatibilidad del uso actual con el edificio histórico, el nivel de aceptación social del uso otorgado y los nuevos valores y significados que el conjunto ha adquirido en este proceso. Es decir, se pretende llegar a una estimación crítica acerca del mantenimiento y/o alteración de los valores patrimoniales de cada edificio conventual que también incluye una revisión crítica del proyecto de restauración, rehabilitación y/o reutilización que se ha ejecutado sobre el antiguo convento. Esto incluye la revisión de operaciones frecuentes como la apertura del edificio al exterior y el replanteamiento de sus sistemas de accesos, las operaciones de reconfiguración de las circulaciones interiores, la compatibilización de usos colectivos o públicos y la dotación de espacios
Convento de San Pedro Mártir. Reutilización como sede de la Facultad de Ciencias Sociales y Jurídicas de la Universidad de Castilla-La Mancha según proyecto del arquitecto Mario Muelas. Planta general | plano Universidad de Castilla-La Mancha 
Convento de San Pedro Mártir. Reutilización como sede de la Facultad de Ciencias Sociales y Jurídicas de la Universidad de Castilla-La Mancha. Patio mayor | foto Ignacio González-Varas Ibáñez

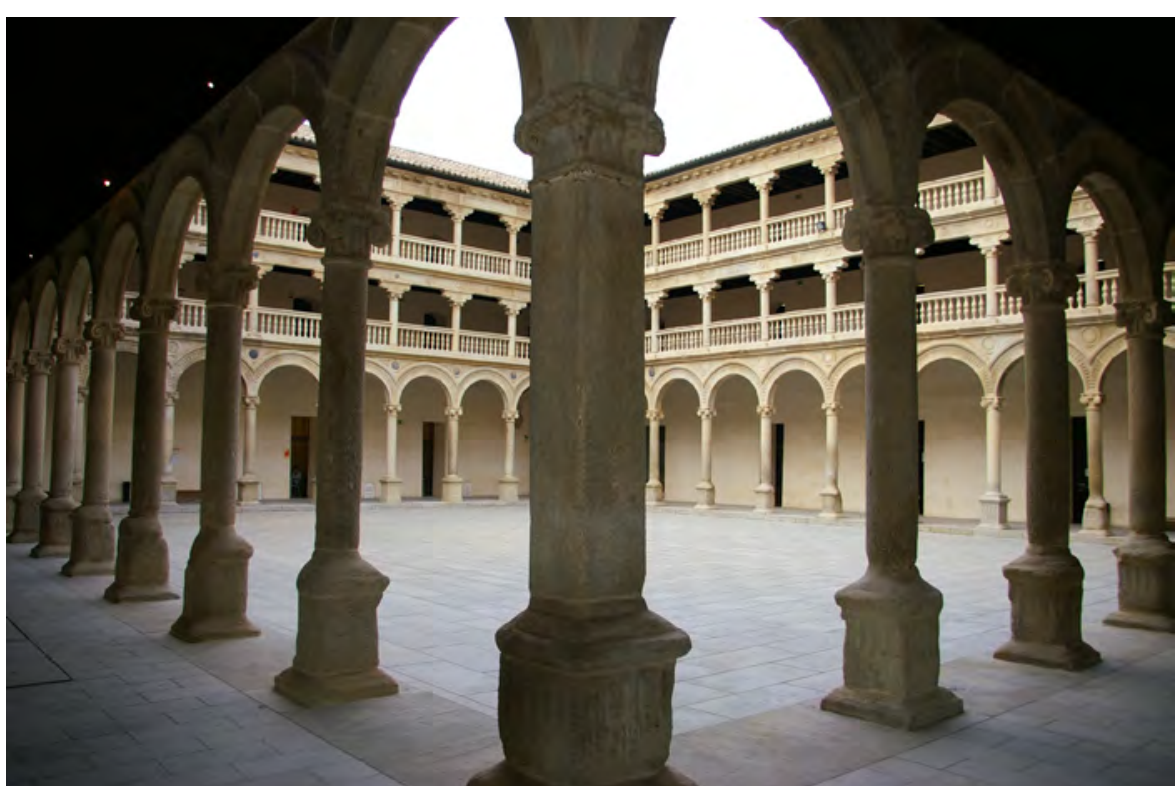

o ámbitos privados, así como las transformaciones en el uso y significados de los espacios o incluso las modalidades de inserción de nuevos materiales en las viejas fábricas. También se lleva a cabo el análisis de la incidencia que este proceso de reutilización del edificio ha suscitado en la ciudad, estudiada en aspectos tales como el replanteamiento de las circulaciones en el área urbana afectada, la reconfiguración del paisaje urbano, la revitalización social y económica del área urbana en relación con las nuevas actividades, los usos otorgados al edificio o la transformación de los significados que el edificio ha asumido para la colectividad en relación con los nuevos usos. Este análisis puede proporcionar interesantes resultados para establecer un conjunto de buenas prácticas para la previsión de posibles nuevos usos en aquellos conventos que se encuentran en situación de abandono o que corren el riesgo de sufrirlo para así tratar de prevenir y anticipar estas situaciones críticas.

\section{EL PATRIMONIO INMUEBLE DE LOS CONVENTOS TOLEDANOS: ABANDONO Y REUTILIZACIÓN}

La dotación de un nuevo uso a los edificios conventuales abandonados es una de las cuestiones fundamentales para la que, como decimos, es preciso articular un decálogo de buenas prácticas. En efecto, si se pierde el uso, el edificio se abandona y comienza un ciclo de degradación que puede acabar con su ruina. Pero hay que ser especialmente cuidadosos, porque tan peligroso puede ser el abandono como un uso inadecuado. Ante el reciente abandono de cuatro conventos en Toledo por parte de sus comunidades reli- 
giosas, se plantean las incógnitas acerca de su posible reutilización. Esta decisión incumbe en primer lugar, por supuesto, a sus propietarios, a las comunidades religiosas, pero su naturaleza cultural impone que, si no es posible mantener el uso conventual originario, se articulen procedimientos para lograr la continuidad y transmisión de su memoria en el tiempo. El contexto de crisis en que nos encontramos este desafío presenta un doble e inquietante semblante: por un lado, los edificios conventuales, ante la falta de recursos económicos para su mantenimiento, pueden sucumbir; pero también es peligrosa una concepción puramente crematística de su valor como "inmueble", la concepción del edificio histórico como puro "bien de cambio", que lleve a anteponer su valor de mercado o la simple oportunidad de disponer de espacio en la ciudad histórica, lo que puede bastardear su significado hasta perderse la memoria cultural del conjunto monumental. Si no es posible su continuidad de uso como establecimientos dedicados a la vida contemplativa, es legítimo buscar otras opciones, en primer lugar, las culturales, con preferencia de aquellas que se puedan vincular con el primer uso o que no estén lejos del alto concepto cultural por el que fueron fundados los conventos: archivos, bibliotecas, auditorios, espacios expositivos, museos o también otras utilizaciones sociales, como lugares de reunión, esparcimiento, escuelas o alojamientos, son las soluciones más frecuentemente escogidas. Pero incluso dentro de la Iglesia se alzan voces que reclaman no solo la conservación de la "dignidad" de estos espacios y su reutilización para estos fines públicos y culturales, sino también el mantenimiento en algunos casos de su vocación asistencial originaria y su posible reutilización como hogares de ancianos o centros de acogida, entroncando así con la vocación caritativa y asistencial de la Iglesia.

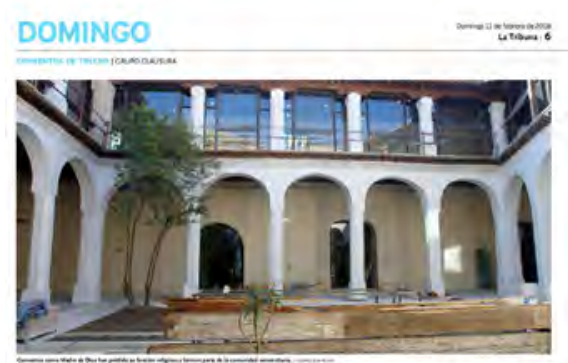

La UCLM calcula que en dos décadas pueden cerrar todos los conventos

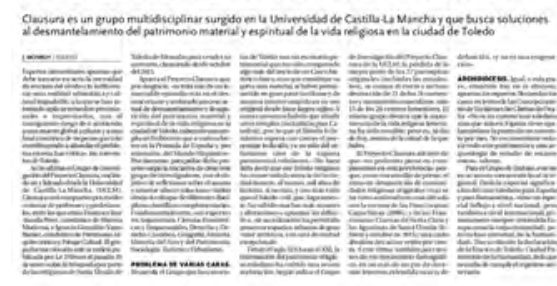

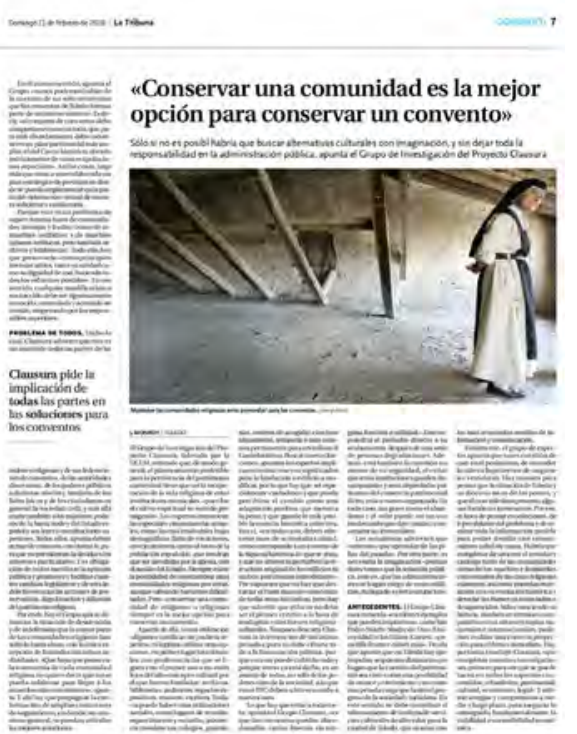

Artículo publicado en el diario La Tribuna de Toledo para exponer la situación del patrimonio conventual de Toledo (11 de febrero de 2018)

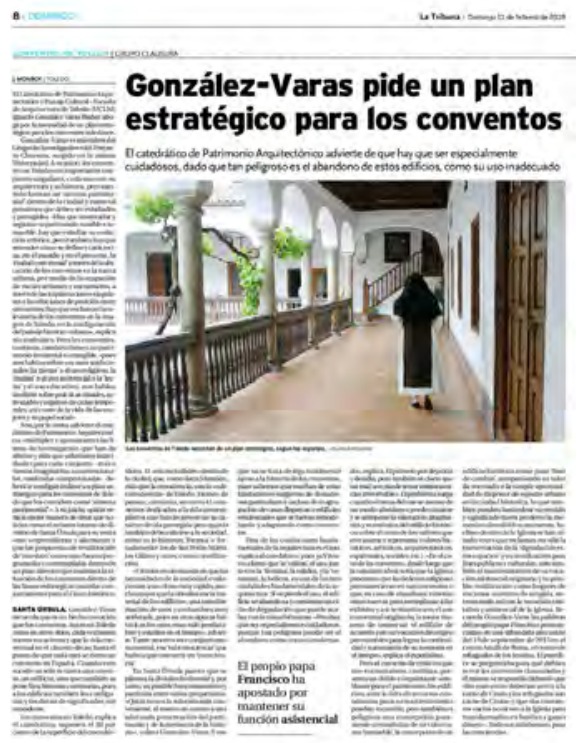




\section{CONCLUSIONES}

Hemos visto cómo la elaboración de un posible decálogo de buenas prácticas para el patrimonio conventual de Toledo establece tres momentos, a saber: buenas prácticas orientadas a la definición de metodologías eficaces para la investigación histórica del patrimonio de los conventos en relación con sus bienes muebles e inmuebles, su contexto urbano y su paisaje cultural; buenas prácticas para el esclarecimiento de un diagnóstico y una valoración crítica precisa de cada comunidad en particular y de la situación de su patrimonio; y, por último, buenas prácticas para articular posibles propuestas de mantenimiento, conservación, revitalización y/o reutilización de los conventos. Además de las posibles soluciones individuales para cada conjunto en particular, es necesario configurar un plan estratégico para los conventos de Toledo que los considere como "sistema patrimonial"; esto es, un plan director que asuma la situación de los conventos e incluya su tratamiento dentro de las líneas estratégicas trazadas conjuntamente para el casco histórico. Hemos visto asimismo que una de las ideas fundamentales se asienta en la que este patrimonio está indisolublemente unido a las comunidades religiosas. En relación con este principio, el "sistema patrimonial" de conventos de Toledo, como el de otras muchas ciudades caracterizadas por la presencia de este patrimonio, contempla tres posibles situaciones: conventos vivos en los que aún habita una comunidad religiosa, conventos extinguidos en fechas recientes, pero a los que todavía no se ha otorgado un uso nuevo, y, por último, conventos extinguidos hace tiempo y cuyos edificios han sido reutilizados para otras funciones. Una especial atención han de recibir los dos primeros casos, pues son los más vulnerables: el considerable descenso del número de monjas y la elevada edad de las comunidades de religiosas son datos que sitúan a los conventos actualmente activos en una situación crítica. Y aquellos cuya vida conventual se ha extinguido en fechas recientes, además de haber perdido su patrimonio inmaterial como consecuencia de este abandono, con la pérdida de las formas de vida religiosa y cotidiana y de la espiritualidad de estos lugares, asimismo corren un serio peligro de sufrir pérdidas en su patrimonio mueble e inmueble. Pero la coordinación de medidas conjuntas para los conventos debe tener en cuenta el carácter autónomo que asume cada orden religiosa e incluso cada convento en relación con la propia orden, pues cada uno de ellos es autónomo y propietario del edificio que habita desde su fundación o desde el regreso de la comunidad después de procesos de desamortización o de abandono forzoso por guerras u otro tipo de catástrofes. La vulnerabilidad de este patrimonio material e inmaterial debe activar acuerdos o convenios para que las distintas instituciones religiosas y civiles dispongan de un marco en el que poder intervenir tanto para la revitalización de este patrimonio, como para prever situaciones de cierre, así como para actuar de urgencia en el caso del anuncio de un abandono, todo ello mediante unas buenas prácticas que orienten hacia una adecuada conservación y/o revitalización de este patrimonio.

$>19$ conventos extinguidos y demolidos. Conventos masculinos: 24 conventos

$>2$ conventos activos. servado y reutilizado.

$>14$ conventos extinguidos y demolidos. Conventos femeninos: 29 conventos $>11$ conventos activos.

$>13$ conventos extinguidos con edificio conservado y/o reutilizado.

$>5$ conventos extinguidos y demolidos. 


\section{BIBLIOGRAFÍA}

- AA.VV. (2017) Pasión por Toledo. 15 años del Consorcio de la Ciudad de Toledo. Toledo: Consorcio de la Ciudad de Toledo

- Braunfels, W. (1974) Historia de la arquitectura monacal en Occidente. Barcelona: Barral

- Cabanal Rodríguez, L. (1997) Los conventos femeninos en Toledo (siglos XII-XVI). Tesis doctoral inédita. Universidad Complutense de Madrid

- Campos y Fernández de Sevilla, F.J. (2019) Reflexión sobre un plan nacional de conventos. Anuario jurídico y económico escurialense, n. ${ }^{\circ}$ 52, pp. 613-626

- González-Varas Ibáñez, I. (2016a) Ciudad, paisaje y territorio. Conceptos, métodos y experiencias. Madrid: Munilla-Lería

- González-Varas Ibáñez, I. (2016b) El templo cristiano, arquitectura, símbolo y patrimonio: destrucción, abandono, restauración, reutilización, transformación. En: Giráldez Fernández, P. y Vendrell Saz, M. (coord.) Transformació, destrucció i restauració del espais medievals. Barcelona: Patrimoni 2.0 Ediciones, pp. 105-128

- Herrejón Nicolás, M. (1990) Los conventos de clausura femeninos de Toledo. Toledo: Diputación Provincial de Toledo

- Marañón, G. (1941) Elogio y nostalgia de Toledo. Madrid: Espasa-Calpe

- Martínez-Burgos García, P. (2019) Devoción, arte y sociedad. El patrimonio conventual en Toledo. Anuario jurídico y económico escurialense, n. ${ }^{\circ} 52$, pp. 627-638

- Martínez Caviró, B. (1980) Mudéjar toledano: palacios y conventos. S.I. : s.n. (Madrid: Vocal Artes Gráficas)

- Martínez Caviró, B. (1993) El arte en los conventos de Toledo. En: Viforcos, M.I. y Paniagua, J. (coord.) Congreso Internacional del Monacato Femenino en España. Portugal y América. León: Universidad de León, pp. 495-522

- Martínez Caviró, B. (1999) Los conventos de Toledo. En: Botella Llusiá, J. y Fernández Molina, A. (coord.) Marañón en Toledo (sobre Elogio y Nostalgia de Toledo). Toledo: Universidad de Castilla-La Mancha, Ediciones de la Universidad de Castilla-La Mancha, pp. 85-94

- Sánchez Chiquito de la Rosa, S. (2017) Pasado, presente y futuro del Consorcio de la Ciudad de Toledo. En: AA.VV. Pasión por Toledo. 15 años del Consorcio de la Ciudad de Toledo. Toledo: Consorcio de la Ciudad de Toledo, pp. 13-17

- Vizuete Mendoza, J.C. (2019) Patrimonio Conventual: presente y futuro. Anuario jurídico yeconómico escurialense, n. ${ }^{\circ} 52$, pp. $599-612$ 


\title{
Energía y medioambiente para la habitabilidad en la ciudad histórica de Santiago de Compostela. 1994-2012
}

\author{
Ángel Panero Pardo | Oficina Técnica del Consorcio de Santiago de Compostela \\ URL de la contribución <www.iaph.es/revistaph/index.php/revistaph/article/view/4965>
}

\section{RESUMEN}

El artículo hace un recorrido sintético y subjetivo por el proceso de recuperación urbana de la ciudad histórica de Santiago de Compostela puesto en marcha tras su reconocimiento como Patrimonio de la Humanidad en 1985. En función de la complejidad de este proceso de recuperación del patrimonio en el marco de un proyecto general para la ciudad completa, que asumía simultáneamente en aquel momento la designación como capital de Galicia, el texto aborda algunas de las claves del proceso y del conocimiento adquirido durante su ejecución. Tras referir una última década del siglo XX que incorporó la consideración específica y central de las circunstancias de la vida cotidiana de los habitantes que resistían en la ciudad histórica, el texto se centra en el periodo 2006-2012, en el que se trató de construir una propuesta de recuperación urbana donde la ciudad histórica se contempla más como un ecosistema que como un monumento.

Este intento de reformular la recuperación urbana de una ciudad patrimonio de la humanidad ensayado en Santiago de Compostela, y la estimulante construcción de nuevos discursos urbanos que genera, se debe entender coherente con la Recomendación sobre Paisaje Urbano Histórico Unesco del año 2011 y con los Objetivos del Desarrollo Sostenible definidos en 2015 por la ONU. El artículo pretende evidenciar el esfuerzo por transformar el discurso tradicional de la conservación del patrimonio urbano, anclado en ocasiones en criterios ambientalistas decimonónicos, tratando de vincularlo con estrategias de conservación del cambio continuo característico de cualquier "ciudad viva".

\section{Palabras clave}

Centros históricos | Ciudades históricas | Conservación (Patrimonio) | Custodia del territorio | Eficiencia energética | Gestión administrativa | Habitabilidad | Mantenimiento | Medioambiente | Oficina Técnica del Consorcio de Santiago de Compostela | Participación ciudadana | Patrimonio urbano | Recuperación urbana|Rehabilitación arquitectónica|Revitalización | Santiago de Compostela (Galicia) | Sostenibilidad | Viviendas | 


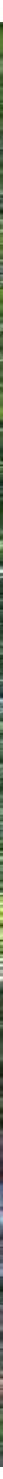

Desde el año 2006, la conservación del patrimonio urbano de Compostela se comenzó a abordar desde una perspectiva ecosistémica. La recomendación Unesco sobre paisaje urbano histórico y los ODS2030 reforzaron más tarde una línea de trabajo que hoy es ya indispensable para gestionar las consecuencias del cambio climático y los déficits urbanos que dejó al descubierto la COVID-19 | foto Ángel Panero Pardo 
Pocos días antes del comienzo del presente Año Santo 2021, se cumplieron 35 años de la incorporación de Santiago de Compostela a la lista Unesco de ciudades Patrimonio de la Humanidad. A continuación expondré una historia necesariamente subjetiva y sintética de las iniciativas desplegadas tras aquel reconocimiento, con especial atención al periodo 20062012, en el que tuve la responsabilidad de promover desde el Consorcio de Santiago el esfuerzo colectivo por formular una estrategia innovadora de actuación en la que, a los programas tradicionales de intervención, focalizados durante el siglo XX desde la perspectiva dominante de la conservación del patrimonio, se incorporaron principios propios de la, en aquel entonces incipiente, reflexión colectiva mundial contemporánea sobre ciudad, desarrollo sostenible y combate del cambio climático antropogénico. Este cambio sustancial en la forma de entender la ciudad histórica y la estrategia para garantizar su conservación en el marco de una realidad urbana compleja se había iniciado con la experiencia de intervención de la última década del siglo XX en la ciudad de Santiago, en la que cobraron importancia prioritaria la ciudadanía y las necesidades de sus vidas cotidianas, como bien ilustra el nombre No todo es fachada del primer programa de rehabilitación lanzado en 1994.

Más de una década después de aquel primer programa se comenzó a construir desde el Consorcio de Santiago una propuesta de intervención en la que la ciudad histórica se aborda, definitivamente, más como un ecosistema que como un monumento. Esta nueva perspectiva ecosistémica de la conservación del patrimonio urbano en un planeta cada vez más urbanizado se ha venido reforzando progresivamente hasta hoy, no ya por la conciencia de reacción necesaria asumida por la humanidad en su conjunto para combatir las consecuencias del cambio climático, sino hoy con todavía mayor actualidad, como consecuencia de los déficits urbanos que ha dejado al descubierto la pandemia provocada por la COVID-19 que asola el mundo desde los primeros meses del año 2020.

Aunque pueda parecer inicialmente ajena a la metodología del objetivo de conservación del patrimonio urbano tal y como se ha entendido mayoritariamente durante un siglo, en realidad, esta nueva forma de abordar los problemas de los centros históricos desde la energía, el medioambiente y los asuntos esenciales de la vida cotidiana nos sitúa ante la gran oportunidad de reintroducir en la agenda urbana de los centros históricos aspectos elementales de la gestión de las ciudades ignorados durante más de un siglo por políticos, ciudadanos, economistas, arquitectos, urbanistas y especialistas en conservación del patrimonio urbano. Y la buena noticia es que esos aspectos imprescindibles para enfrentar con garantías la recuperación del patrimonio urbano se encuentran ya, implícita y explícitamente, dentro de la recomendación de la Unesco relativa al denominado paisaje urbano histórico (Unesco 2011). 


\section{LA CIUDAD COMO ECOSISTEMA}

Creo que la experiencia en la gestión de programas de rehabilitación urbana nos ha hecho empezar a sospechar que la intervención sobre la ciudad histórica tiene más que ver con el manejo de la transformación permanente y el cambio continuo que con la estricta conservación del patrimonio. Si bien creo que aún no hemos sido capaces de superar con nitidez el lastre patrimonialista que ha destrozado la gestión efectiva de las áreas urbanas señaladas por su valor cultural, las políticas de recuperación urbana de centros históricos en los últimos 50 años parecen haber evolucionado afortunadamente desde el ensimismamiento decimonónico centrado en la conservación de la apariencia, para incorporar, primero, la atención por las arquitecturas civiles anónimas o secundarias; más tarde, cuando ya casi todos se habían ido, la atención a los asuntos de la vida cotidiana de los habitantes; $y$, finalmente, la reflexión integrada de la ciudad histórica en la ciudad completa y su territorio de vida.

En realidad, creo que este cambio sustancial en la forma de manejar el patrimonio cultural que representan las ciudades históricas ha venido inducido, en primer lugar, por el fracaso estrepitoso de las metodologías conservacionistas al uso, ineficientes y muy inadaptadas a la compleja realidad urbana de un centro histórico, y, en segundo lugar, por la transformación que en la cultura dominante ha provocado la constatación de que el cambio climático está vinculado con la actividad de los seres humanos y por tanto, en gran medida, con la forma de habitar en las ciudades. En este contexto es en el que las ciudades históricas progresivamente se han podido empezar a contemplar como ecosistemas de éxito contrastado en el tiempo para la vida en comunidad de las personas, y por tanto, y esto me parece muy importante, como modelos de referencia más que como áreas a rescatar o escenografías amables a conservar por su belleza, trascendencia o contribución a la construcción del discurso histórico-artístico oficial.

\section{CIUDAD DE LA RENTA VERSUS CIUDAD DE LA REPRODUCCIÓN SOCIAL}

Desde el respeto que merece la legislación vigente, nacida con carácter eminentemente defensivo, y más que solamente respeto, desde mi solidaridad y obediencia debida a los técnicos e incluso políticos que desarrollan su actividad al servicio de la administración en relación con la protección del patrimonio urbano, tengo la sensación de que aún hoy en demasiados casos, el enfoque oficial de aproximación a la conservación de las ciudades históricas tiene tintes de cierta ingenuidad, o quizás romanticismo naíf, que se hace muy evidente precisamente por ignorar, o no querer ver, el contexto de extraordinarias tensiones por los intereses económicos y poderes fácticos afectados en el que se desarrollan las políticas de protección. Yo reconozco ahí una palanca letal para la conservación del patrimonio urbano, que se 
produce cuando se coordinan nefastamente las legislaciones culturalmente bienintencionadas de protección del patrimonio, por ejemplo en relación con el señalamiento de catalogación, con la realidad de la expectativa de renta que con naturalidad domina cualquier movimiento en la ciudad, y con mayor razón, en la ciudad histórica, que ostenta por definición una posición de referencia y centralidad estratégica y representativa en el teatro de operaciones urbano. No me extiendo sobre este modelo vigente, económico pero también cultural, de "ciudad de la renta" frente al modelo de "ciudad de la reproducción social", porque lo mejor que recomiendo es leer al profesor Alfonso Álvarez Mora (2016) sobre el particular. Pero sí quiero insistir antes de seguir en que debemos tener siempre presente que nuestro trabajo con el objetivo de la conservación de las ciudades históricas se produce sobre suelo urbano tenso, en un contexto eminentemente expectante desde el punto de vista inmobiliario, muy asumido socialmente y organizado para producir renta y plusvalías con naturalidad. No quiero entrar aquí a opinar sobre esta circunstancia, por otro lado consustancial y coherente con el sistema económico establecido, pero sí quiero denunciar primero, que el único discurso sobre la ciudad que fuimos capaces de construir y enriquecer en la última mitad del siglo XX fue ese discurso inmobiliario neoliberal, y reivindicar después, que, más allá de la discusión ideológica, debemos emplearnos a fondo para construir colectivamente y cuanto antes otros discursos alternativos al de las plusvalías inmobiliarias, en muchos casos esenciales incluso para la supervivencia, que es en mi opinión la mejor forma de neutralizar el dominio de la "ciudad de la renta" sobre la "ciudad de la reproducción social", y encontrar razones y argumentos de peso tanto para hacer crecer la ciudad como para rehabilitar la ciudad histórica (Rueda Palenzuela 2018). Esta conciencia de actuar en suelo urbano tenso y la conveniencia de neutralizar la expectativa de renta es por tanto la primera condición previa que me gustaría apuntar para armar un proyecto de renovación urbana. Creo que el Plan Especial de Santiago supo apoyar su estrategia de recuperación en ello y eso abrió la oportunidad a que sucedieran otras cosas interesantes.

\section{COMPETENCIA MUNICIPAL, COOPERACIÓN INTERADMINISTRATIVA Y PROYECTO URBANO}

Las otras consideraciones previas que me parecen determinantes y que, a pesar de su obviedad, son sin embargo muy difíciles de encontrar en la práctica, son las siguientes:

1. Competencia municipal. Que significa que la rehabilitación de la ciudad histórica y su puesta en valor es un proyecto de competencia e iniciativa municipal que necesariamente debe implicar a la ciudad en su conjunto y formularse en el marco de la ciudad completa y su territorio de vida. La figura esencial es desde mi punto de vista el alcalde, que es quien debe liderar el 
proyecto. A pesar del asincronismo entre los tiempos de la política y los tiempos del proyecto urbano, sigo convencido de la importancia determinante de la política en los procesos de recuperación urbana de las ciudades históricas, no solo para formular y poner en marcha un proyecto de recuperación sino, y quizás más complicado, para sostenerlo en el tiempo.

2. Cooperación entre las administraciones. La complejidad y transversalidad de las cuestiones que es preciso abordar requieren de la cooperación y coordinación entre administraciones. La cooperación entre administraciones genera confianza entre la ciudadanía y permite abordar con ventaja muchas de las acciones de oportunidad que pueden tirar del proceso. El Consorcio de la ciudad de Santiago, creado en 1992 y participado por el Gobierno de España, el Gobierno de Galicia y el Gobierno municipal, ha sido, bajo la presidencia del alcalde y ejecutando los acuerdos del Real Patronato de Santiago de Compostela que preside S.M. el Rey de España, una herramienta esencial en el proceso de modernización urbana y rehabilitación de la ciudad histórica de Santiago.

3. Proyecto urbano. Frente a la tentación de impulsar la rehabilitación de la ciudad histórica a golpe de ocurrencias, que es bastante corriente, es hoy más necesario que nunca reivindicar la importancia de tener un proyecto para la ciudad completa y una estrategia para su ejecución.

Estas consideraciones previas, entre otras que se podrían añadir, se refieren a condiciones de contexto que, desde mi punto de vista, son indispensables para poner en marcha con garantías de éxito la compleja recuperación urbana de una ciudad histórica.

Las ciudades históricas han sobrevivido a situaciones aún peores en la historia y son un modelo de referencia. Yo estoy convencido de que la preservación del patrimonio urbano ya no requiere tanto de cautelas y políticas públicas defensivas, como de un amplio compromiso colectivo con el futuro en el que siguen teniendo plena vigencia y actualidad las salvaguardas de la urbanística que definió ya en 1976 el profesor Campos Venuti: pública, social, productiva, ambiental y programática (Campos Venuti 1981). Hoy en día, creo que cualquier proyecto de recuperación urbana de una ciudad histórica, además de las condiciones mínimas de contexto referidas, debe armarse incorporando coherentemente otras consideraciones relativas a la energía, el medioambiente, la política de vivienda o la formación para el empleo.

\section{LOS PRIMEROS AÑOS 1994-1999}

La etapa inicial entre 1994 y 1999 permitió consolidar bajo la dirección del arquitecto Javier Ramos Guallart una metodología de intervención basada 
en la atención especializada directa y personalizada a los ciudadanos. Los técnicos de la administración se implicaban de la mano de los habitantes en la búsqueda de soluciones con el objetivo de mejorar la habitabilidad de sus viviendas, caso a caso. Yo en esta etapa le concedo gran importancia al ritmo de implementación y a una cuestión de género. La cuestión de género tiene que ver con el hecho de que normalmente las interlocutoras eran las mujeres de la casa, poseedoras de un conocimiento más preciso e inteligente de las claves de habitabilidad del hogar familiar. El ritmo de implementación de los programas tiene que ver con que se difundieron por capilaridad entre los habitantes mediante un proceso de transmisión boca a boca en el que el éxito constructivo de las pequeñas intervenciones, basadas en la coherencia tecnológica con la construcción vernácula, y las evidentes mejoras de las condiciones de habitabilidad que sin embargo se materializaban, terminaron por conquistar la confianza de los ciudadanos y demostrar que la rehabilitación pacífica del patrimonio urbano no solo era posible, sino también rentable económica y socialmente. Muchas de las intervenciones se realizaron sobre viviendas ocupadas con alquileres de renta antigua, lo que fue posible porque el porcentaje de subvención se establecía con la autorización del propietario pero en base a los ingresos de los inquilinos, a condición de que se mantuvieran en la casa tras las obras de mejora. Esto permitió establecer indirectamente un escudo de salvaguarda sobre habitantes en la tercera edad, que en muchos casos habían resistido en la ciudad histórica sencillamente porque no se podían ir a otro sitio. Se recuperaron cientos de

El trabajo inicial de la Oficina Técnica del Consorcio, entre los años 1994 y 1999, permitió consolidar bajo la dirección de Javier Ramos Guallart una metodología de intervención basada en la atención especializada, directa y personalizada, a los ciudadanos. Se pusieron en marcha más de 1.000 pequeñas intervenciones de mejora de la habitabilidad con el programa "No todo es fachada" | foto Ángel Panero Pardo

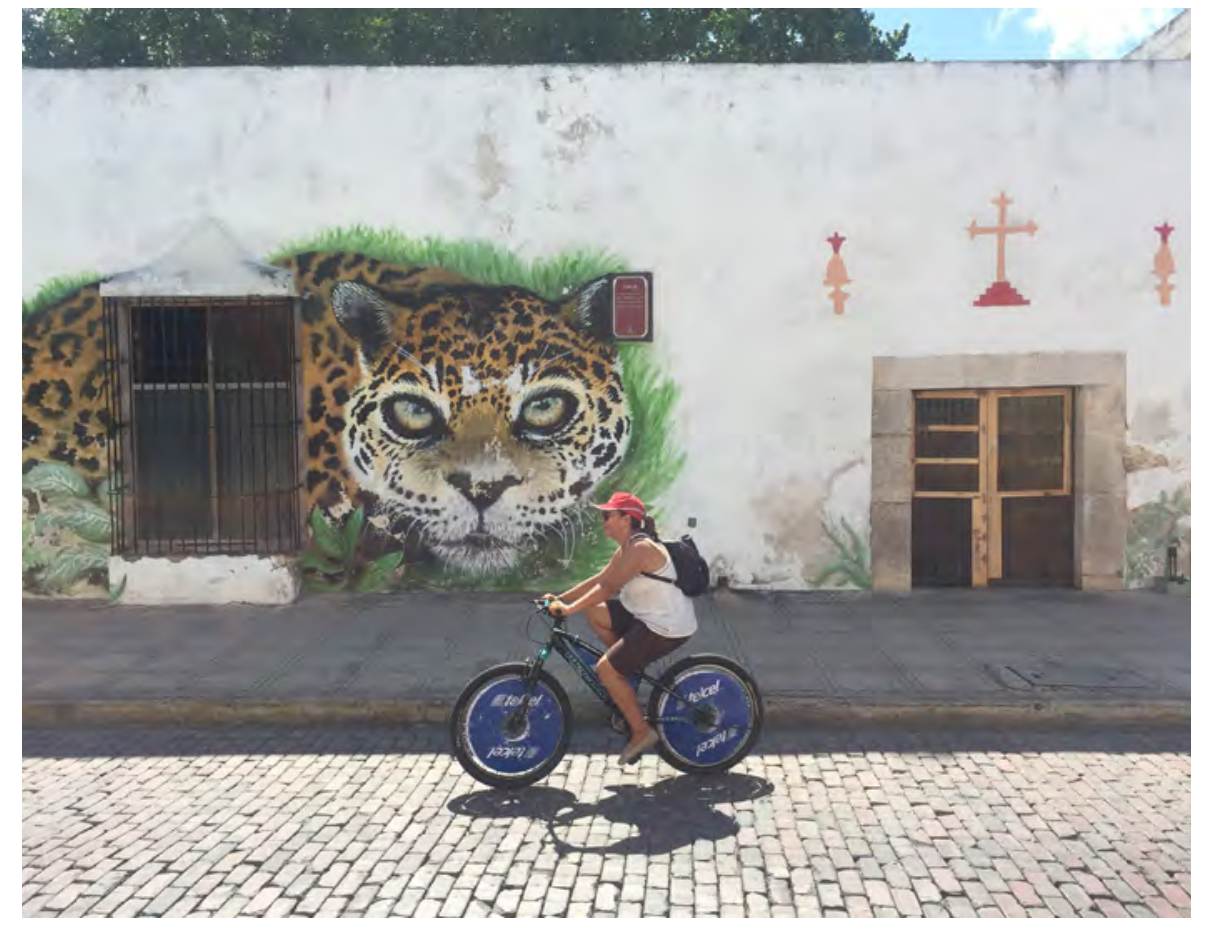


viviendas y, lo más importante, se consiguieron extraordinarios avances en la cultura constructiva coherente con las características de la arquitectura vernácula de la ciudad histórica de Santiago. El paso del tiempo matizó por ley natural el éxito de esta etapa, pues la mejora en el soporte físico de las viviendas, con la llegada de nuevos inquilinos, terminó por dejar las viviendas rehabilitadas en el rango más alto de precios de alquiler o venta de toda la ciudad.

La etapa de recuperación urbana de la ciudad histórica dirigida por Javier Ramos Guallart, en la que el trabajo de la Oficina Técnica del Consorcio recibió, entre otros, el Premio Europa Nostra 1996, el Premio Gubbio 1996, el Primer Premio Europeo de Urbanismo apartado Local Planning 1997 y el Premio Internacional Dubai de Buenas Prácticas 2002, concluyó en el año 2000 con una operación mediática de acoso y derribo, promovida, con algún que otro apoyo interno, por algunos poderes fácticos agraviados por la dinámica de recuperación urbana impulsada. La operación frenó la dinámica de rehabilitación urbana normalizada y el Consorcio de Santiago entró en una etapa de perfil muy bajo durante 5 años. Javier Ramos pasó a ser Secretario General de Vivienda del Gobierno de España entre el año 2004 y el 2010 (Ramos Guallart et ál. 2002a, 2002b).

\section{EL PERÍODO 2006-2011, ENERGÍA Y MEDIOAMBIENTE PARA IMPULSAR EL PROCESO DE RECUPERACIÓN URBANA DE LA CIUDAD HISTÓRICA DE SANTIAGO DE COMPOSTELA}

En el año 2006, tras la llegada de Xosé Manuel Villanueva a la gerencia del Consorcio, se inició el diseño de una nueva programación plurianual de iniciativas con el objetivo de reactivar el aletargado proceso de recuperación urbana de la ciudad histórica de Santiago. La experiencia acumulada en Compostela, la coyuntura global en relación con la ciudad y el territorio, la contrastada insuficiencia de las herramientas y estrategias tradicionales de conservación del patrimonio, requerían innovación desarrollando fórmulas para comprometer la responsabilidad activa de la ciudadanía y promover enfoques alternativos a los tradicionales para la conservación y puesta en valor del patrimonio urbano. Y todo ello con el convencimiento de que el patrimonio cultural urbano es ante todo expresión de la vida cotidiana de las personas y solo puede permanecer vivo en un proceso de cambio continuo y transformación permanente, lo que por otro lado explica su permanencia en el tiempo hasta nuestros días, y es por tanto garantía de su conservación.

Se puede decir que, en resumen, el espíritu central de aquella programación definida durante el año 2006 giraba en torno a la idea de introducir la energía en la agenda urbana de la renovación y revitalización de una Ciudad Patrimonio de la Humanidad. No se trataba de volver a desplegar políticas 
tradicionales de rehabilitación, que por otro lado se habían implementado con éxito como se ha dicho durante el último decenio del siglo $X X$, sino de inducir una reflexión transversal y profunda sobre el hecho urbano, reincorporando aspectos determinantes en la vida cotidiana de los habitantes y en la mejora de su calidad de vida lamentablemente olvidados en la gestión de la ciudad durante el siglo pasado. La forma en la que gestionamos el agua o la vegetación en la ciudad, el diseño de programas de habitabilidad y mantenimiento más que de rehabilitación, la reflexión sobre las infraestructuras urbanas o el uso del espacio público, más allá de su recurrente acondicionamiento epidérmico, la generación de conocimiento y empleo local asociado al proceso de recuperación urbana, la implicación activa de los ciudadanos en procesos de custodia del patrimonio urbano, o cómo los suelos fértiles agrícolas pueden ser un factor en la ordenación del suelo y la economía local, están en el código genético de todas las ciudades históricas, y no tenemos más remedio que volver a incorporarlos en la reflexión sobre la ciudad futura con la que soñamos.

Entre otras en las que no entraré por razones de espacio, quiero destacar aquí las siguientes líneas de trabajo principales:

> Gestión de la información y diligencia burocrática.

> Política de vivienda en la ciudad histórica.

$>$ Energía y medioambiente para la habitabilidad.

\section{Gestión de la información y diligencia burocrática}

La reforma de la administración pública y de la gestión de las ciudades históricas, derrocando el imperio actual de la decimonónica burocracia defensiva que ralentiza cuando no bloquea todo tipo de iniciativas, es indispensable para impulsar la senda de la revitalización de los centros históricos. También porque resulta vital aprender a manejar con precisión y precocidad la ingente información y establecer un criterio de indicadores de referencia que nos permitan conocer las consecuencias y efectos de los programas de recuperación urbana, porque muchas veces, cuando esos efectos son evidentes es demasiado tarde para hacer correcciones.

Por esta razón, en colaboración con el Instituto Geográfico Nacional, y con la colaboración del Consejo Superior de Investigaciones Científicas, el Consorcio de Santiago desarrolló el Sistema de Información Patrimonial (SIP) de la ciudad, pensado no solo como un depósito de información al servicio del conocimiento, sino como una herramienta efectiva de gestión cotidiana de la ciudad histórica. Además de la agrupación fácilmente accesible de todo tipo de información gráfica y escrita sobre el patrimonio inmue- 
ble de la ciudad histórica de Santiago, el objetivo superior era normalizar la gestión del día a día de la administración pública utilizando esta poderosa herramienta de información geográfica, única forma razonable de mantener actualizados sus contenidos. Desgraciadamente la incorporación normalizada de su uso al día a día de la gestión administrativa de las diferentes administraciones públicas implicadas está hoy en día todavía pendiente. Los tiempos y procesos de la tramitación administrativa de las licencias de obras que estamos manejando hoy en día en cualquier centro histórico del mundo son sencillamente inadmisibles, y lastran de forma irreversible cualquier dinámica de revitalización. Hay un porcentaje no menor de licencias de construcción para intervenir en la ciudad histórica que se podrían llegar a tramitar con normalidad en cuestión de minutos. Un Plan Especial vigente, el Sistema de Información Patrimonial y la colaboración de arquitectos y aparejadores a modo de fedatarios públicos creemos que lo harían posible.

\section{Política de vivienda en la ciudad histórica}

España es un país de viviendas vacías. El 13,7 \% de las viviendas de España están vacías. En Galicia, aún peor, están vacías 1 de cada 5 viviendas (Verdú 2011). Es urgente e imprescindible reorientar las políticas de rehabilitación urbana y la inversión pública en rehabilitación hacia la política de vivienda. Sobre todo, pero no solo, en los centros históricos. La cultura inmobiliaria, y la irrupción de las nuevas fórmulas de mercado asociadas a las plataformas tecnológicas, obliga a abordar sin demora con intensidad el problema de la vivienda en los ámbitos de las ciudades históricas, y con mayor razón en las ciudades patrimonio de la humanidad, que se encuentran singularmente asediadas.

El Consorcio de Santiago lanzó en 2008 un programa de rehabilitación de edificios tutelados (Bases 2008), en el que básicamente se ofrecía al propietario la rehabilitación del edificio a cambio del usufructo durante un plazo determinado gestionando las viviendas resultantes en alquiler hasta equilibrar la inversión realizada por la administración pública en la rehabilitación física del inmueble. Se llegó a realizar a través de la Empresa Municipal de la Vivienda el expediente de un inmueble con tres viviendas, cuya rehabilitación costó $279.000 €$ y el periodo de usufructo se estableció en 17 años. (Panero Pardo 2012).

\section{Energía y medioambiente para la habitabilidad}

En la búsqueda de innovación y nuevas fórmulas de aproximación urbana, uno de los objetivos esenciales de la programación trataba de introducir el discurso de la energía en la agenda del proceso de recuperación. Y se promovió la construcción de un discurso urbano de la energía a diferentes escalas que sucintamente refiero a continuación. 


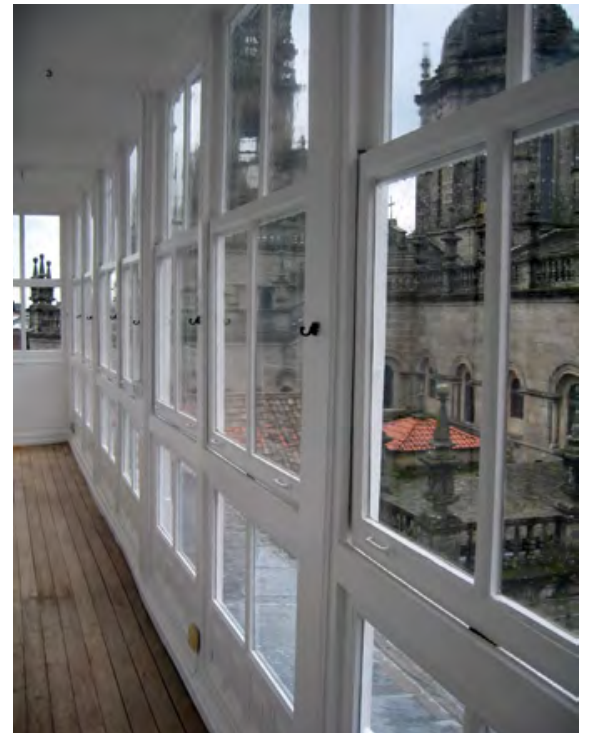

La aproximación desde la energía al patrimonio histórico urbano permitió sustituir el catálogo tradicional de elementos arquitectónicos seleccionados con criterios histórico-artísticos que, por defecto, se suele acabar gestionando con criterios ambientalistas, por un catálogo en base al valor de los elementos arquitectónicos para la gestión higrotérmica de los edificios, que se puede gestionar fácilmente con criterios de habitabilidad y uso. Al final, ambos catálogos terminan siendo muy similares, pero hablando de habitabilidad y uso es más fácil entenderse con los habitantes. Los muros de mampostería medievales se convierten en acumuladores de energía y las galerías en colectores solares | foto Adrián Martín Prieto
En primer lugar y con carácter básico, se trabajó en una revisión crítica de las características físico-constructivas de las arquitecturas históricas, en la que el análisis y valoración de estas arquitecturas trata de desprenderse del ensimismamiento característico de la visión patrimonialista para construir un argumentario basado en la comprensión de su funcionamiento higrotérmico y constructivo. Con ese objetivo se impulsó el denominado Laboratorio Urbano de la Energía, se participó en el proyecto Europeo Energy Efficiency for EU Historic District's Sustainability (EFFESUS) y se estableció un convenio de colaboración con el Departamento de Energía y Medio Ambiente de la Architectural Association School of Architecture.

Esta nueva forma de aproximarse al patrimonio urbano permitió descartar el catálogo tradicional de elementos arquitectónicos a proteger por su valor histórico, para comenzar a hablar en su lugar de un catálogo de elementos arquitectónicos con valor para la gestión higrotérmica de los edificios y viviendas. Suena radical, pero se pudo comprobar que, al final, ambos catálogos terminan siendo bastante similares. Los muros de mampostería medievales se convierten en acumuladores de energía y las galerías en colectores solares, pero con la ventaja de que es más fácil entenderse con los ciudadanos hablando de energía que del valor histórico abstracto de cualquier elemento arquitectónico. Así, por ejemplo, la madera ya no es un material a conservar por ser tradicional, sino porque es uno de los raros materiales de construcción que se producen con energía solar, y, en lugar de emitir gases de efecto invernadero en su producción, los captura.

\section{MANTENIMIENTO VERSUS REHABILITACIÓN}

El trabajo realizado desde la Oficina Técnica del Consorcio de Santiago durante los últimos años del siglo XX en la ciudad histórica conquistó la confianza de los ciudadanos demostrando que la rehabilitación en términos de mejora de habitabilidad y condiciones de vida era posible. El discurso de la energía y esa cultura de la rehabilitación consolidada en Santiago de Compostela permitió establecer a partir de 2006 un diálogo colaborativo entre la administración y los ciudadanos en el que, en lugar de rehabilitación, se prefirió comenzar a hablar de habitabilidad. En ese contexto y convencidos de que es el mantenimiento, mucho más que la rehabilitación, la clave de la conservación del patrimonio urbano, se lanzaron los programas de mantenimiento Ter é manter (Tener es mantener), destinado a edificios y viviendas, y A Pedra que Pisas (La piedra que pisas), dirigido al mantenimiento de los pavimentos históricos de Compostela.

El ritmo natural de la transformación de la ciudad histórica tiene más que ver con el mantenimiento que con la rehabilitación. El abandono de la cultura del mantenimiento contribuyó significativamente al progresivo deterioro de 


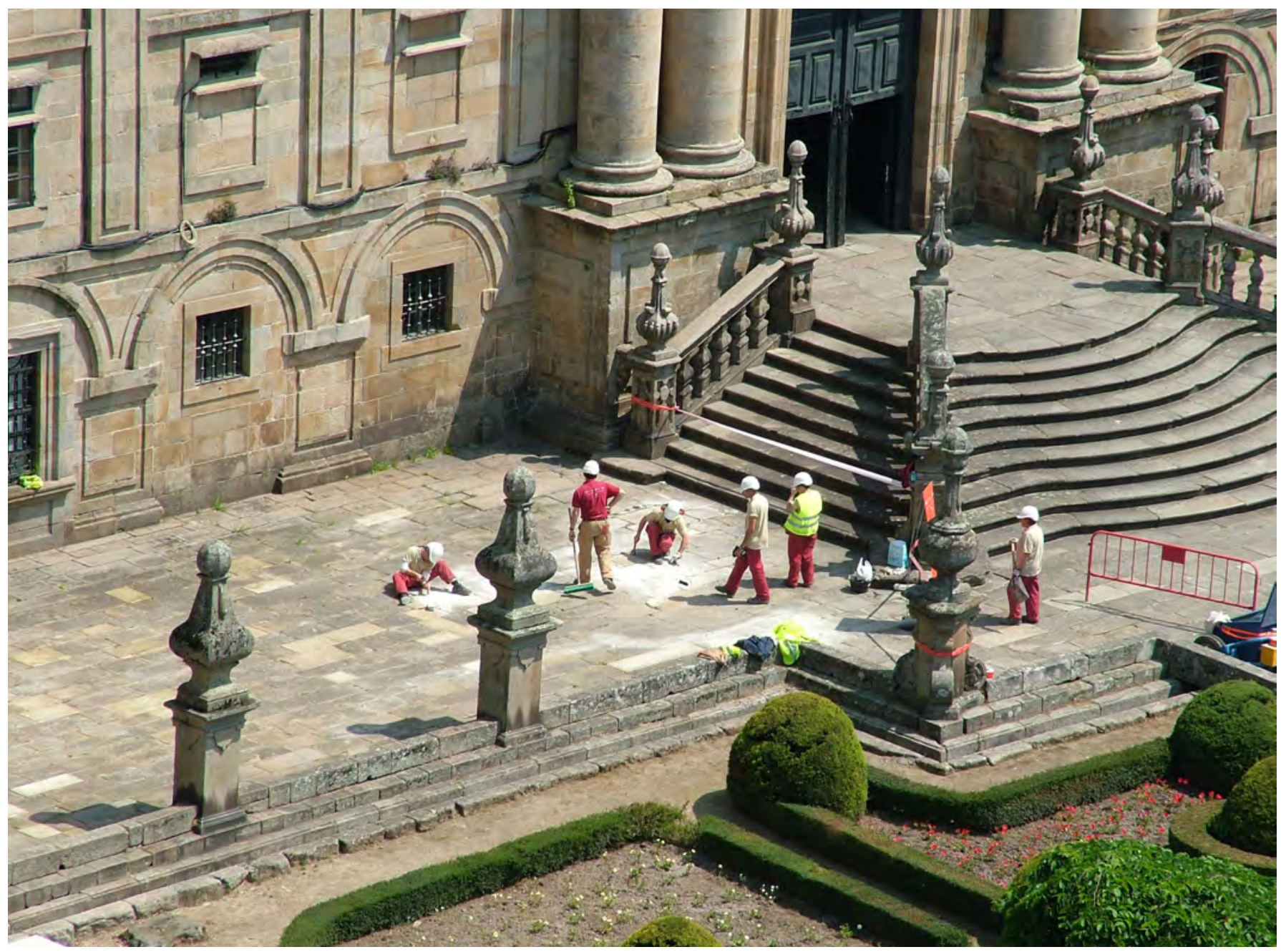

La cultura del mantenimiento, mucho más que la rehabilitación, es la clave de la conservación del patrimonio urbano. El programa "A Pedra

las arquitecturas de la ciudad histórica y está directamente relacionado con el proceso de colapso constructivo de los centros históricos. Se trata de un colapso coherente con el predominio de la "ciudad de la renta" sobre la "ciudad de la reproducción social", pues la expectativa de renta no solo se alique Pisas", aún hoy vigente, se puso en marcha en el año 2007 para impulsar una dinámica de mantenimiento constante de los $60.000 \mathrm{~m}^{2}$ de enlosados de granito del pavimento de la ciudad histórica | Adrián Martín Prieto menta con el progresivo colapso físico y el desalojo de habitantes, sino que necesita por definición el deterioro irreversible del centro histórico para materializarse como alternativa. El avanzado estado de abandono y decaimiento de muchas ciudades históricas nos acostumbró a pensar en términos de rehabilitación, restauración o reestructuración a la hora de programar estrategias de intervención, pero el verdadero soporte de su realidad constructiva es y ha sido la cultura del mantenimiento. El mantenimiento es naturalmente también una razón elemental de sostenibilidad y eficiencia en la administración de recursos, pero, sobre todo, la normalización de la cultura y hábito del mantenimiento en los centros históricos permite garantizar su conservación 
El programa "Ter é Manter" (Tener es mantener) fue el primer programa de subvenciones a mantenimiento desarrollado en un centro histórico Patrimonio de la Humanidad. Su primera convocatoria se hizo en el año 2006 con el objetivo de recuperar el hábito del mantenimiento de

edificios y viviendas. Hoy en día sigue vigente bajo

la dirección de la arquitecta Lourdes Pérez Castro | fuente Cenlitrosmetrocadrado y Consorcio de Santiago

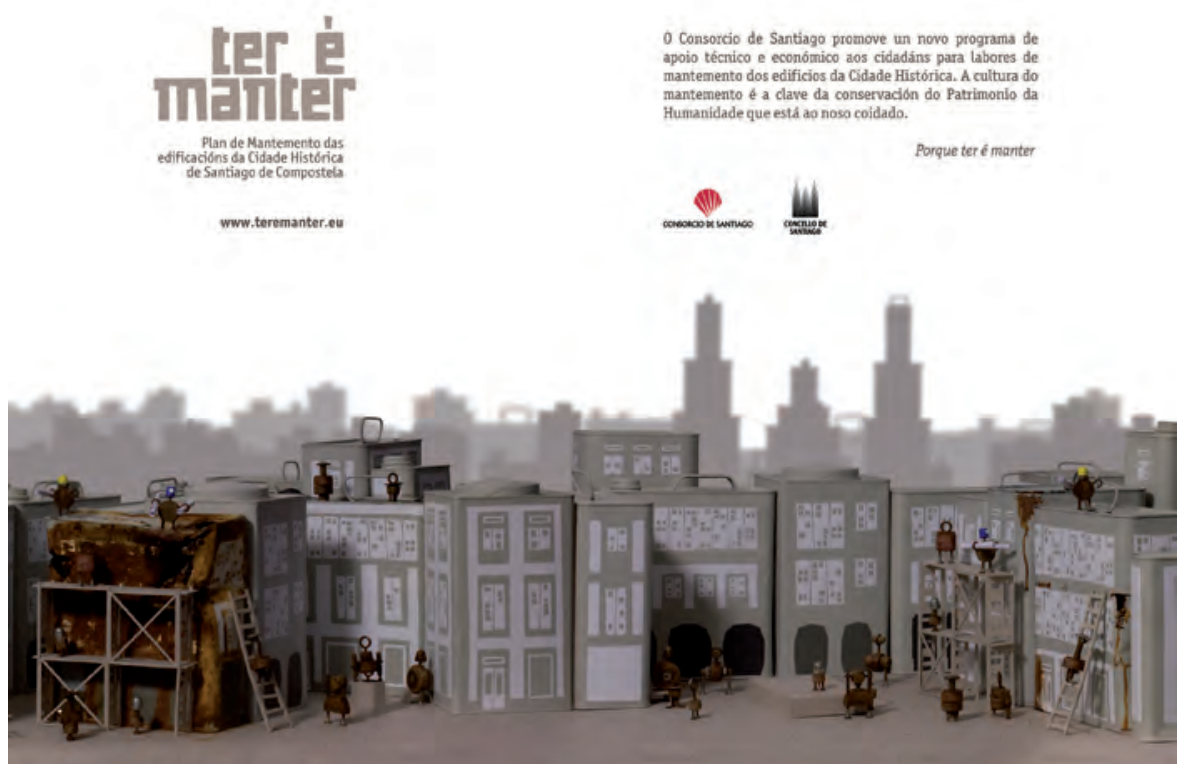

creando empleo local especializado y estable. Además, como se acreditó en los estudios previos realizados en Santiago, la inversión en mantenimiento preventivo es más rentable y genera ya, en el medio plazo, ahorro significativo, público y privado, en el gasto de conservación del patrimonio urbano.

\section{EL PLAN DIRECTOR DE INFRAESTRUCTURAS}

Esta propuesta de transformación en la forma de entender la conservación y puesta en valor de una ciudad Patrimonio de la Humanidad fue posible porque la denominada rehabilitación pacífica de los edificios y viviendas de la ciudad histórica estaba en el año 2006 socialmente asumida, incluso fuera de los programas oficiales de ayudas. Este era un factor de éxito de las políticas desarrolladas, pero muy pronto puso en evidencia que el punto débil de la habitabilidad de los edificios de la ciudad histórica estaba en la red urbana de infraestructuras y suministros. En efecto, la red de infraestructuras y suministros de la ciudad histórica, desplegada en su mayor parte con cierta improvisación durante el siglo XX, se puede considerar obsoleta, ineficiente e inadaptada a las exigencias contemporáneas de habitabilidad. Incluso independientemente del estado de ruina técnica de estas infraestructuras, no es solamente una cuestión de habitabilidad o eficiencia energética, sino, sobre todo, de competitividad y productividad de las viviendas, oficinas o locales comerciales de la ciudad histórica. Creíamos entonces, y seguimos creyendo hoy, que el plan director de infraestructuras es indispensable para garantizar la vigencia habitacional de la ciudad histórica, para garantizar su eficiencia energética y, en definitiva, para garantizar su viabilidad como espacio de convivencia. 


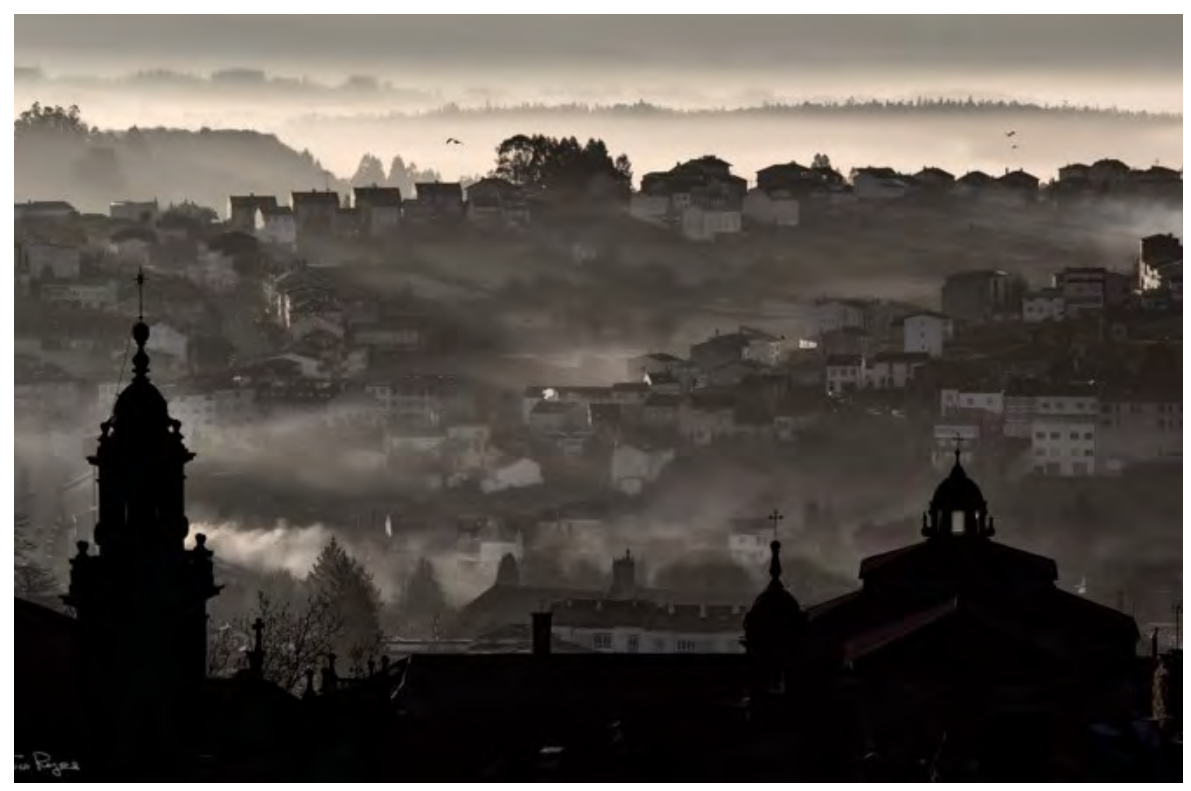

La hoja de ruta para impulsar el Plan Director de Infraestructuras de la ciudad histórica de Santiago se propuso en el año 2009, con un horizonte de desarrollo ejecutivo de 10 años y una inversión total superior a los 110 millones de euros. El plan se apoya en la puesta en valor del dominio público subterráneo y contempla la incorporación del suministro de energía, district heating, a todos los edificios del área Patrimonio de la Humanidad.

En realidad hay que advertir que la eliminación del cableado aéreo es una vieja aspiración en relación con la apariencia de la ciudad histórica, pero cuando se estudia la verdadera trascendencia de la modernización del equipamiento de infraestructuras que es necesario realizar urgentemente en las ciudades históricas por razones estrictas de habitabilidad, competitividad y productividad, el mandato de eliminación de cableado aéreo por razones ambientalistas vuelve a sonar francamente intrascendente. El Plan Director de Infraestructuras Urbanas se entendía complementario de un Plan inteligente de Logística y Gestión de Mercancías. Ambos estaban destinados tanto a multiplicar la competitividad de las empresas que optasen por radicarse en la ciudad histórica como a resolver problemas cotidianos de los habitantes dando soporte al proceso de peatonalización indispensable para recuperar el espacio público.

\section{ESTRATEGIA DE VERDE URBANO Y GESTIÓN DEL AGUA}

La estrategia de rehabilitación urbana sostenida en Santiago durante los últimos 30 años supuso la incorporación a dominio público a través del Consorcio de Santiago de miles de metros cuadrados de huertas y otros
Con las dinámicas de rehabilitación en marcha, se hizo evidente que la habitabilidad de la ciudad histórica de Santiago dependía de las infraestructuras urbanas. La subterraneización de los cableados muy lejos de tener que ver con la apariencia, es indispensable por razones de habitabilidad, competitividad y productividad urbana. El Consorcio de Santiago formuló en el año 2010 un Plan para la renovación de infraestructuras urbanas, que incluía el suministro de energía. La estrategia verde, el Plan de Infraestructuras y el Plan de logística y gestión de mercancías estaban llamados a ser la locomotora de la transformación urbana de Compostela | foto Fuco Reyes 
La protección en el Plan General de 1989 de huertas y otros vacíos urbanos y su incorporación a dominio público promovida por el Consorcio de Santiago desde el año 1994, representa una oportunidad excepcional de impulsar programas de estímulo de la economía local, agricultura urbana, gestión de las consecuencias del Cambio Climático, salud pública, gestión del agua y movilidad sostenible. Con ese objetivo el Consorcio de Santiago impulsó en el año 2008 en colaboración con la UPC y bajo la dirección de Albert Cuchí "La estrategia verde de Compostela" | fuente Consorcio de Santiago vacíos urbanos. Ese patrimonio público de vacíos urbanos representaba ya en el año 2008 una oportunidad única de incorporar al proceso de recuperación urbana de Compostela una gran variedad de programas de estímulo de la economía local, de agricultura urbana, de salud pública o de movilidad sostenible.

Y con ese objetivo se impulsó la construcción de un discurso del agua y del verde urbano en confluencia con el Plan Director de Infraestructuras y el Plan de logística y gestión de mercancías. "La estrategia verde de Compostela" se promovió en colaboración con la Universidad Politécnica de Catalunya, bajo la dirección del profesor Albert Cuchí (Cuchí Burgos 2010), tratando de argumentar las posibilidades que ofrece un nuevo enfoque, caracterizado por la consideración de la sostenibilidad como un reto ineludible, como un instrumento transformador de nuestra sociedad y, con ella, de nuestras ciudades. El programa pretendía documentar y dar fundamento a la gran transformación de las políticas y objetivos de conservación del patrimonio urbano de Compostela que proponía el Consorcio de Santiago. Desde la energía, el medioambiente y la sostenibilidad, la conservación del patrimonio se enriquece con valores y argumentos que desbordan el concepto tradicional de conservación urbana. Y esto es así porque el patrimonio entonces deja de estar solo relacionado con la continuidad histórica, las raíces o la identidad,

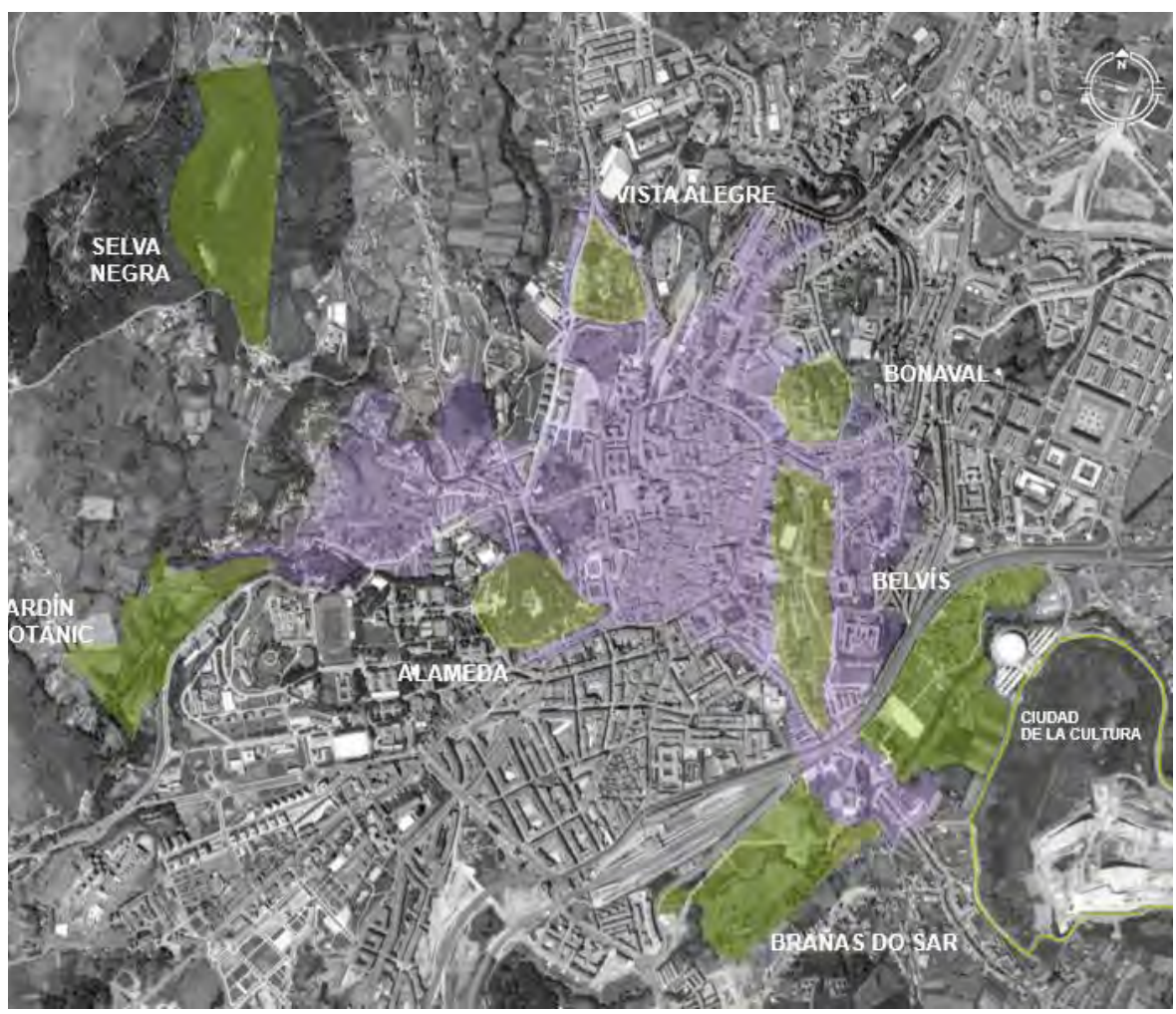




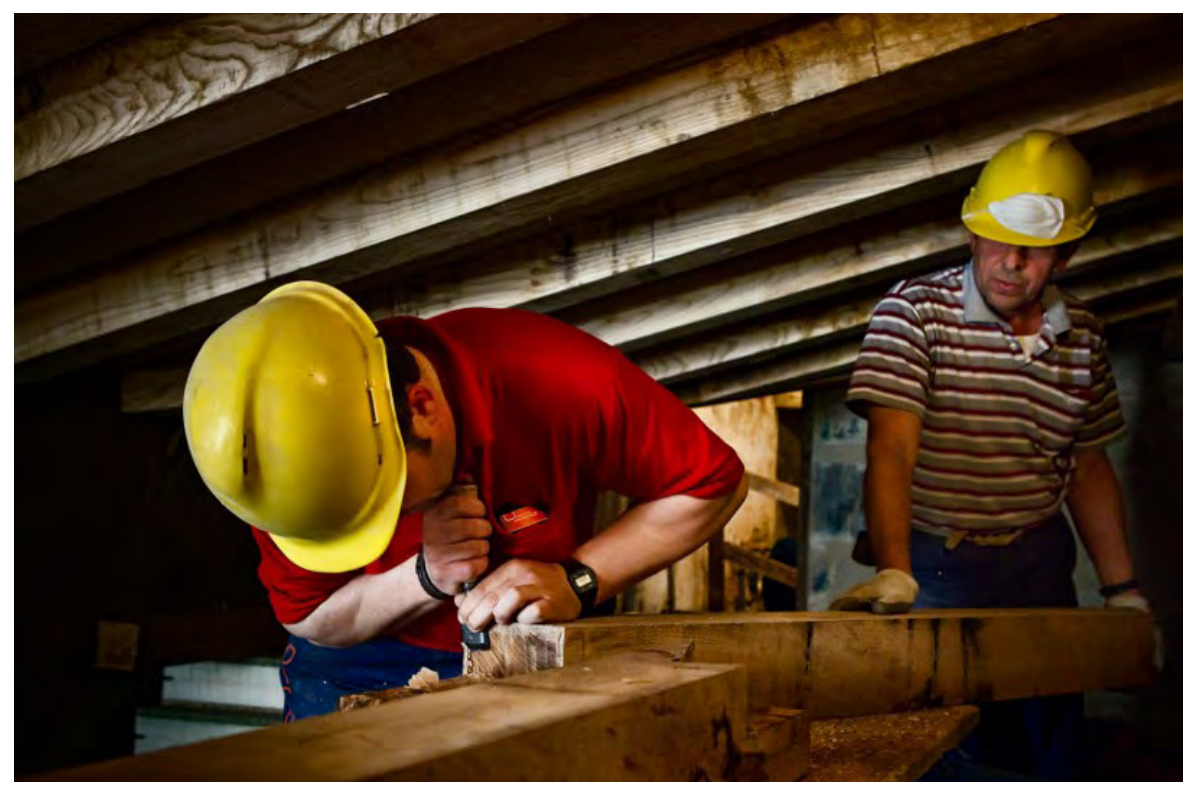

para incorporar valores que deben ser recuperados y salvaguardados porque encierran lecciones de gestión de recursos en el territorio que debemos recuperar y transmitir si queremos avanzar hacia la construcción de una sociedad ambientalmente sostenible. Y esa es la clave de rehabilitar para garantizar un mundo mejor.

\section{EPÍLOGO}

La formulación de estas iniciativas pretendía impulsar una nueva forma de gestionar la regeneración y revitalización de una ciudad histórica Patrimonio de la Humanidad, superando los modelos patrimonialistas que, francamente, más bien parecen agotados e incluso, en muchos casos, responsables de la pérdida de pulso ciudadano que tanto devalúa los centros históricos. Pero esta transformación en la forma de entender y manejar una ciudad Patrimonio de la Humanidad solo es posible en el marco de estas dos últimas condiciones generales:

La primera tiene que ver, a imagen de lo que sucede en relación con la salvaguarda del patrimonio natural, con la denominada custodia del territorio (Basora Roca y Sabaté y Rotés 2006), con el estímulo entre los ciudadanos de una dinámica de custodia de la ciudad histórica. La implicación ciudadana debe ser activa y protagonista de la gestión de la ciudad histórica. Necesitamos construir una estrategia de implicación de los ciudadanos que no se limite a la estricta participación. Para ello es indispensable la información, el conocimiento y la educación, que nos lleva a la segunda condición

El estímulo entre los ciudadanos de una dinámica de custodia activa de la ciudad histórica no debe limitarse a la estricta participación ciudadana o interpretación de la ciudad histórica. Es indispensable la información, el conocimiento y la educación activa, entendidas como herramientas de gestión y estímulo de economías locales, capaces de generar no solo oportunidades, sino empleo cualificado y estable | foto Fuco Reyes 


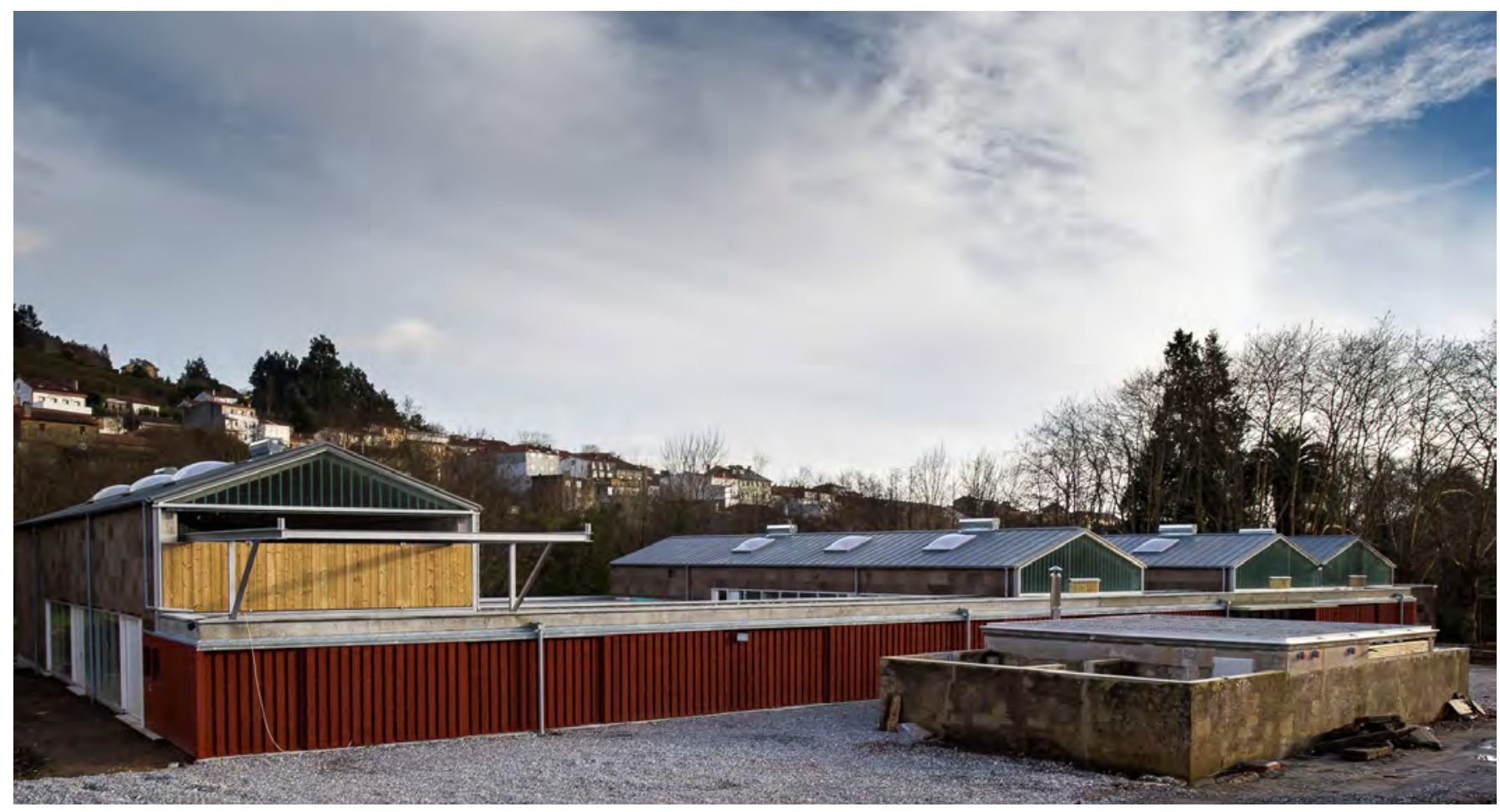

Con el objetivo de hacer de la rehabilitación urbana una oportunidad para el empleo, el Consorcio de Santiago y la Fundación Laboral de la Construcción impulsaron en el año 2008 la creación del Centro Nacional de referencia en formación en materia de rehabilitación en la antigua fábrica de curtidos de Pontepedriña de arriba. El Centro Nacional de referencia funciona desde el año 2018 a unos 2 $\mathrm{km}$ del la Plaza del Obradoiro en las instalaciones rehabilitadas de la antigua fábrica de curtidos, proyecto que mereció el Premio Galicia de Arquitectura y Urbanismo 2017-2018 | foto Fuco Reyes

general. Estoy convencido de que solo a medio plazo, de la mano de la educación, el conocimiento y la formación profesional, podremos avanzar con el objetivo declarado. Por eso el Consorcio de Santiago, en colaboración con la Fundación Laboral de la Construcción, impulsó el Centro Nacional de Formación en materia de rehabilitación de Santiago de Compostela que es hoy ya una realidad en las instalaciones rehabilitadas de una antigua fábrica de curtidos en la ribera del río Sarela.

Me gustaría terminar recopilando las citas de referencia que he utilizado para finalizar otros artículos o conferencias durante este tiempo. Empecé haciendo referencia hace 25 años, cuando estaba implicado principalmente con la intervención física desde la arquitectura y la construcción, a los versos de Isabel Escudero, "De la mano del aire", que era una declaración de intenciones y posición de partida como arquitecto a la hora de intervenir sobre lo construido. Más adelante y a medida que la experiencia de gestión integrada de la ciudad histórica crecía, terminaba optimista con la "ciudad histórica es un arma cargada de futuro", parafraseando los versos de Gabriel Celaya dedicados a la poesía. Hoy quiero terminar con una reflexión de Walter Benjamin que creo explica muy bien la dificultad colectiva para avanzar en la gestión del patrimonio urbano: "En cada época, se debe hacer un nuevo intento por arrancar a la tradición de los brazos del conformismo, que está siempre dispuesto a dominarla". 


\section{BIBLIOGRAFÍA}

- Álvarez Mora, A. (2016) Ciudad como producto versus la ciudad como obra. La realidad urbana entre el espacio de la renta y el espacio social. Lección inaugural curso 20152016. Valladolid: Ediciones Universidad de Valladolid

- Bases reguladoras do procedemento de edificios para a súa inclusión en programas de edificios tutelados (PET) Boletín Oficial de la Provincia de A Coruña, n. ${ }^{\circ} 297,27$ de diciembre de 2008, pp. 15249-15253. Disponible en: https://bop.dicoruna.es/bopportal/publicado/2008/12/27/ Bop20081227.pdf [Consulta: 29/06/2021]

- Basora Roca, X. y Sabaté y Rotés, X., (2006) Custodia del territorio en la práctica. Manual de introducción a una nueva estrategia participativa de conservación de la naturaleza y el paisaje. Fundació Territori i Paisatge. Disponible en: https://custodia-territorio.es/manual-decustodia-del-territorio-en-la-practica [Consulta: 14/06/2021]

- Campos Venuti, G. (1981) Urbanismo y austeridad. Madrid: Siglo XXI Editores

- Cuchí Burgos, A. (2010) Una estrategia verde para Santiago. Santiago de Compostela: Consorcio de Santiago. Disponible en: http://www.consorciodesantiago.org/es/unaestrategia-verde-para-santiago [Consulta:14/06/2021]

- Panero Pardo, A. (coord.) (2012) Programa de Edificios Tutelados, rúa do Medio, 65. Santiago de Compostela: Consorcio de Santiago (Cuadernos Técnicos). Disponible en: http://www.consorciodesantiago.org/sites/default/files/ 20120322_tutelados_rua_do_medio_small.pdf [Consulta: 29/06/2021]

- Ramos Guallart, J., Panero Pardo, A., Camiruaga Osés, I., Tomé Ferreiro, P. y Fernández Hermida, R. (2002a) La arquitectura histórica y los criterios de rehabilitación. La rehabilitación de Santiago. La ciudad histórica de Santiago de Compostela, soporte de la vivienda del siglo XXI. Santiago de Compostela: Consorcio de Santiago. Disponible en: http:// www.consorciodesantiago.org/sites/default/files/tiii_los_ criterios_espanol.pdf [Consulta: 29/06/2021]

- Ramos Guallart, J., Panero Pardo, A., Camiruaga Osés, I., Tomé Ferreiro, P. y Fernández Hermida, R. (2002b) La gestión de la rehabilitación. La rehabilitación de Santiago. La ciudad histórica de Santiago de Compostela, soporte de la vivienda del siglo XXI. Santiago de Compostela: Consorcio de Santiago. Disponible en: http://www. consorciodesantiago.org/sites/default/files/tii_la_gestion_ espanol.pdf [Consulta: 29/06/2021]

- Rueda Palenzuela, S, (coord.) (2018) Carta para el diseño de nuevos desarrollos urbanos y la regeneración de los existentes. Agencia de Ecología Urbana de Barcelona. Disponible en: https://cartabcnecologia.files.wordpress. com/2018/05/carta-para-el-disec3b1o-de-nuevosdesarrollos-urbanos.pdf [Consulta: 26/08/2021]
- Unesco (2011) Recomendación sobre el paisaje urbano histórico, con inclusión de un glosario de definiciones, 10 de noviembre de 2011. Disponible en: http://portal.unesco.org/ es/ev.php-URL_ID=48857\&URL_DO=DO_TOPIC\&URL_ SECTION=201.html [Consulta:14/06/2021]

- Verdú Martínez, M.T. (2018) Herramientas en relación con la vivienda vacía en España. Ciudady Territorio, vol. L, n. ${ }^{\circ} 197$ pp. 577-608. Estudios comparados. Disponible en: https:// recyt.fecyt.es/index.php/CyTET/article/view/76683/46999 [Consulta: 27/08/2021] 


\section{El análisis de riesgos en los centros históricos: estudio de las fortificaciones urbanas del centro histórico de Sevilla}

Rocío Ortiz Calderón, Mónica Moreno Falcón, Javier Becerra Luna, Samuel Corona Corrales, Pilar Ortiz Calderón | Dpto. de Sistemas Físicos, Químicos y Naturales, Universidad Pablo Olavide de Sevilla

URL de la contribución <www.iaph.es/revistaph/index.php/revistaph/article/view/4942>

\section{RESUMEN}

Los centros históricos son espacios culturales complejos que albergan gran cantidad y diversidad de bienes patrimoniales, y cuya conservación obliga a disponer de metodologías capaces de evaluar escenarios de riesgo múltiples. Como respuesta a esta situación, los modelos metodológicos desarrollados en los proyectos RIVUPH y ART-RISK ofrecen herramientas de análisis multi-riesgo en entornos urbanos mediante el uso de sistemas de información geográfica, inteligencia artificial, y/o modelos de consulta a expertos tipo DELPHI.

Este estudio explora la aplicabilidad del análisis multi-riesgo en la evaluación de las peligrosidades y vulnerabilidad que presentan la muralla urbana y los cercos exteriores del Alcázar ubicados en el centro histórico de Sevilla. Para su análisis las fortificaciones han sido divididas en tramos y unidades de análisis, se han evaluado las amenazas e índices de vulnerabilidad, y se ha normalizado e interrelacionado la información en un Sistema de Información Geográfica que permite conocer los riesgos según un modelo multi-escenario. El modelo aplicado permite realizar un análisis descriptivo de las variables de peligrosidad que afectan a las fortificaciones de Sevilla y compararlo con la vulnerabilidad de los tramos analizados. En los muros de tapia estudiados en Sevilla, la ascensión de agua subterránea por capilaridad es la principal amenaza y las patologías por humedades afectan al $90 \%$ de las unidades analizadas. El modelo utilizado es aplicable a otras ciudades y tipologías constructivas, permite realizar una conservación preventiva sostenible y monitorizar los efectos de las amenazas en función de cómo varía la vulnerabilidad con el paso de los años.

\section{Palabras clave}

Alcázar | Centros históricos | Conservación preventiva | Evaluación | Fortificaciones | Gestión | Metolodología | Murallas | Riesgos | Sevilla | Sistemas de Información Geográfica | Tapial | Vulnerabilidad | 


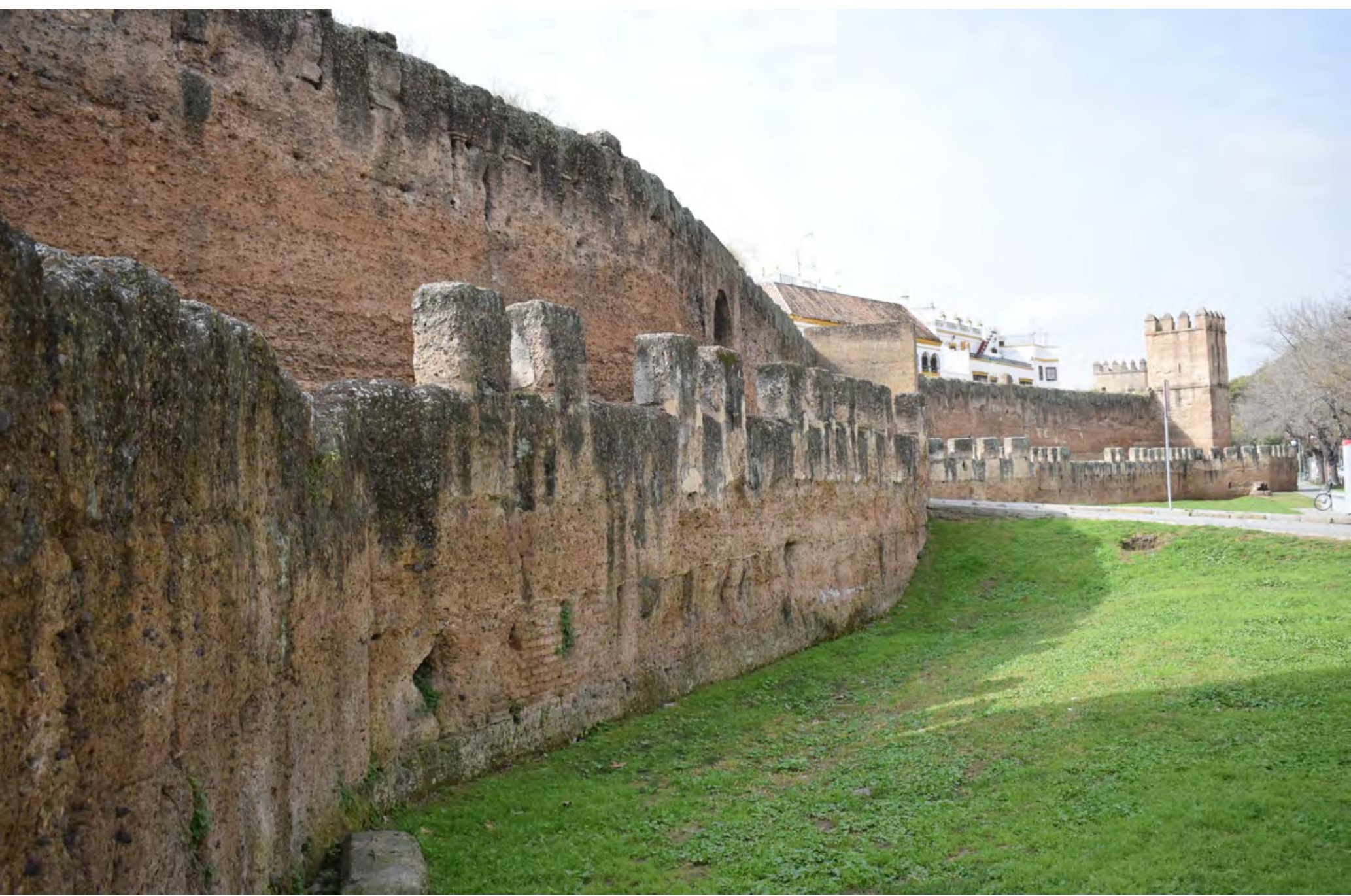

Muralla urbana de Sevilla, tramo de la Macarena, 2019 | foto Mónica Moreno Falcón 


\section{GESTIÓN DE RIESGOS EN CENTROS HISTÓRICOS: CORRIENTES Y LÍNEAS DE INVESTIGACIÓN ACTUALES}

El patrimonio arquitectónico es uno de los rasgos distintivos de los centros históricos de pueblos y ciudades así como uno de los atractivos más valorados por sus habitantes y turistas. Edificios, calles y paisajes son el resultado de las distintas formas en las que estos espacios han sido habitados a lo largo de la historia y, por tanto, se han convertido en seña de identidad de sus poblaciones.

Para el caso del sur peninsular, la presencia de fortificaciones en tapia en los centros históricos es algo muy frecuente (Graciani y Canivell 2019). Según la Guía Digital del Patrimonio Cultural de Andalucía solo para el territorio andaluz se conservan 296 restos de murallas medievales y alcázares. Para entender su función actual dentro del contexto urbano, a su valor como elementos culturales e identitarios, hay que sumar su capacidad para actuar como foco de atracción de turismo y motor de desarrollo de empleo.

Actualmente existe un claro interés del gobierno, los especialistas y la ciudadanía en el mantenimiento y disfrute de los centros históricos y sus bienes patrimoniales, si bien las dificultades asociadas a su gestión deben estar analizadas para evitar pérdidas irreparables (Ortiz et ál. 2014). Su preservación obliga a realizar enormes esfuerzos de coordinación entre distintas instituciones y a invertir ingentes cantidades económicas en la conservación-restauración de fortificaciones en cascos históricos que se ven afectados por el crecimiento urbano o por condiciones ambientales inusuales como inundaciones, incendios o por la falta de recursos en situaciones como la causada por la pandemia del COVID-19.

Desde el punto de vista de la gestión del riesgo, es habitual que los proyectos de conservación apliquen un análisis mono-riesgo de los principales agentes de alteración desde los que desarrollar distintas estrategias de prevención (Di Salvo et ál. 2019; Ferreira, Mendes y Silva 2019; Chieffo y Formisano 2019; Sesana et ál. 2020; Spezzano 2021). Sin embargo, la degradación patrimonial es un proceso complejo que raramente puede asociarse a un único agente de alteración. Junto a situaciones de emergencia, la presencia cotidiana de amenazas como la contaminación, la erosión eólica, la humedad por capilaridad, etc. también influyen en la lenta degradación de los materiales de construcción de las edificaciones patrimoniales. Es por este motivo que analizar escenarios de riesgo requiere de estudios integrales y de una visión interdisciplinar que aúne la opinión de diferentes expertos.

En los últimos años, los avances efectuados en el campo de las matemáticas predictivas y las herramientas informáticas han abierto nuevas posibilidades al análisis conjunto de escenarios complejos como los descritos. 
Actualmente, se están aplicando en redes neuronales modelos de inteligencia artificial (Michard y Teboul 2019) y análisis predictivos del ciclo de vida para el estudio de la durabilidad de diversos materiales (revestimientos de fachadas, piedras, hormigones, etc.) y elementos arquitectónicos (Perles et ál. 2018). También hay ejemplos de usos para comparar la sostenibilidad de determinados tipos constructivos (viviendas, hospitales, etc.), el control de las instalaciones de ventilación y la sensación térmica y las clasificaciones de la entrada de luz natural en oficinas (Ngo, Hwang y Zhang 2020).

Los proyectos RIVUPH, ART-RISK y FENIX surgen como consecuencia de esa necesidad técnica, social y económica de establecer herramientas de trabajo eficaces para la toma de decisiones en la gestión de riesgos y la conservación de edificaciones patrimoniales. Con este objetivo se han diseñado y validado modelos metodológicos y software libre basados en las matemáticas predictivas, la inteligencia artificial (Al), los sistemas de información geográfica (GIS) y/o el encuestado mediante método DELPHI, capaces de aproximarse al diagnóstico que realizaría un equipo plural de profesionales en la diagnosis de un número finito de bienes patrimoniales. A diferencia de otros modelos existentes actualmente, evalúan la vulnerabilidad como un número complejo que depende del análisis multi-riesgo del monumento en su entorno urbano y permiten realizar una prelación de los bienes arquitectónicos a intervenir en función de su vulnerabilidad, las peligrosidades a las que se encuentran expuestos los bienes arquitectónicos y/o su vida útil (Ortiz et ál. 2014a; Ortiz et ál. 2014b; Ortiz y Ortiz 2016; Ortiz et ál. 2019; Moreno, Ortiz y Ortiz 2019; Prieto et ál. 2019; Prieto et ál. 2020; Universidad Pablo de Olavide y Universidad de Sevilla 2021).

Los logros alcanzados por estos proyectos se enmarcan en un contexto internacional más amplio, en el que la preocupación por el desarrollo de nuevas herramientas y modelos para la conservación patrimoniales se hace patente en el aumento del número de publicaciones científicas en estas temáticas que se ha producido en los últimos 20 años. El estudio bibliométrico de las publicaciones indexadas en Scopus permite identificar los principales logros e intereses de los diferentes grupos de investigación internacionales. Los gráficos de la p. 346 muestran la evolución del número de artículos científicos publicados desde los años 70 referidos a los términos de búsqueda \#Artificial Intelligence, \#Monitoring y \#DELPHI, palabras clave relacionadas con estas nuevas lineas de investigación. La búsqueda combinada de estos términos junto al de \#Heritage permite observar un uso inicial desde otras disciplinas y un trasvase de conocimientos que desde mediados de los años 90 está permitiendo el desarrollo de nuevas líneas de investigación con relación al estudio de bienes patrimoniales (gráficos a, b y c). El resultado es una clara tendencia creciente que se materializa en la aparición de múltiples modelos de control y predictivos que pretenden minimizar los factores de riesgo sobre el patrimonio cultural. La diferencia ente el número de estudios 

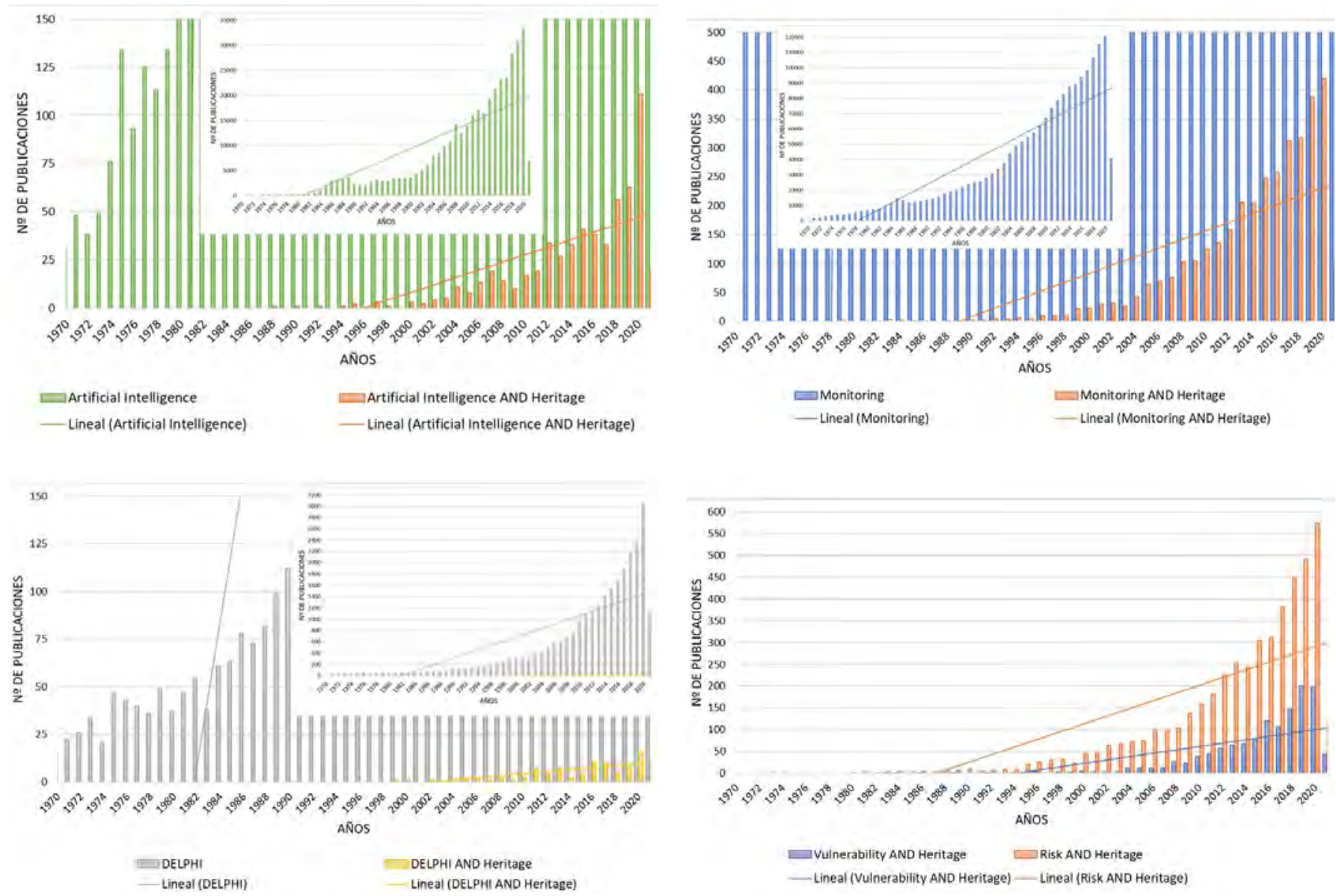

Evolución del número de artículos científicos publicados desde los años 70 referidos a los términos Artificial Intelligence y Artificial Intelligenge AND Heritage (a), Monitoring y Monitoring AND Heritage (b), DELPHI y DELPHI AND Heritage (c) y Vulnerability AND Heritage y Risk AND Heritage (d) Así mismo, se muestra la tendencia lineal creciente en la evolución del número de artículos referidos a cada término. Debe tenerse en cuenta que estas búsquedas fueron llevadas a cabo en abril de 2021 por lo que este año no incluye el cómputo total de publicaciones para dicho periodo basados en el análisis de riesgo (Risk AND Heritage) frente a los de vulnerabilidad (Vulnerability AND Heritage) muestra el interés de la comunidad científica en el desarrollo de modelos integrales que aseguren la sostenibilidad, mitiguen los efectos del riesgos sobre el patrimonio cultural (gráfico d) y favorezcan la resiliencia en los centros y cascos históricos.

La aplicación de estas nuevas líneas de investigación permite a los gestores patrimoniales, de forma sencilla y eficiente, establecer políticas de conservación y optimizar la gestión de los recursos técnicos y económicos. Este aspecto es especialmente importante en situaciones como el actual contexto socioeconómico de pandemia, donde se han visto muy mermados los recursos destinados al patrimonio cultural.

Desde esta corriente teórica, el trabajo presentado en este artículo parte de la metodología desarrollada por los proyectos RIVUPH y ART-RISK, para exponer su aplicabilidad al estudio de los factores de peligrosidad que afectan a las fortificaciones en tapia urbanas ubicadas en el centro histórico de Sevilla. 


\section{METODOLOGÍA}

\section{Modelos de análisis multi-riesgo}

La metodología empleada ha sido desarrollada por los proyectos RIVUPH y ART-RISK para identificar las amenazas que afectan al patrimonio urbano mediante el uso de GIS, modelos de consulta a expertos e inteligencia artificial (Ortiz et ál. 2014a; Ortiz et ál. 2014b; Ortiz et ál. 2019; Ortiz, MacíasBernal y Ortiz 2018; Prieto et ál. 2020). Para el procesado de los datos cartográficos se ha empleado el software GIS ArcGIS 10.5.

La vulnerabilidad de las fortificaciones urbanas de Sevilla ha sido entendida como la capacidad de respuesta que presentan ante una situación de amenaza. Los datos han sido obtenidos a partir de los análisis efectuados por Mónica Moreno, Pilar Ortiz y Rocío Ortiz (2019) según el modelo de vulnerabilidad ART-RISK 1 (Ortiz, Macías-Bernal y Ortiz 2018). Para ello, las fortificaciones fueron divididas en unidades arquitectónicas mínimas (UAM) y se analizó la vulnerabilidad en función del estado de conservación en inspecciones realizadas en 2018 y 2019.

La peligrosidad ha sido entendida como las amenazas ambientales y estructurales existentes en el contexto, evaluada a partir del modelo de cartografía desarrollado por el proyecto RIVUPH (Ortiz 2014). Se trata en realidad de archivos vectoriales compuestos por una serie de polígonos que representan la variación cuantitativa del fenómeno en el espacio en función de una escala común de peligrosidad (1: muy baja-5: muy alta). La escala de peligrosidad ha sido incluida como información cuantitativa que está almacenada en tablas asociadas a los polígonos.

Las variables de peligrosidad ambiental incluidas, por su posible afección a las murallas, han sido: A2. Erosión por lluvia, A3. Precipitación y A4. Heladas. Las variables de peligrosidad estructural incluidas han sido E1. Sismicidad, E2. Inundaciones, E3. Permeabilidad, E4. Ascensión capilar y E5. Geotecnia. Las variables A1 (erosión por viento) y A7 (tráfico), si bien no han sido consideradas en el cálculo por no ser variables continuas en todo el espacio urbano, han sido incluidas como variables informativas. La tabla de las páginas 348-349 muestra la escala de peligrosidad original y su conversión a escala de riesgos 1-5 para cada una de las capas analizadas.

Los datos de erosión por lluvia provienen de la Norma para la Instrucción de carreteras 5.2-1C: "Drenaje superficial" del Ministerio de Obras Públicas y Urbanismo (MOPU 1990). La precipitación ha sido obtenida a partir del Atlas climático ibérico desarrollado por la Agencia Española de Meteorología (AEMET 2011). Las heladas del Mapa de riesgo: heladas y horas de frío en la España peninsular (2002-2012) (AEMET 2015). La geotecnia del Mapa 


\section{ESCALAS Y PONDERACIONES DE LAS VARIABLES DE PELIGROSIDAD}

Variable

Variable

A1. Erosión por viento

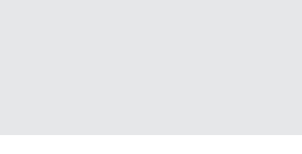

A2. Erosión por lluvia

A7. Tráfico

E2. Inundaciones

\section{Escala original}

Orientación Sur-Este

Orientación Nor-Oeste

Orientación Norte y Este

Orientación Sur, Oeste y Nor-Este

Orientación Sur-Oeste

La peligrosidad disminuye en 1 punto su valor cuando los edificios situados al otro lado de la calle están a una distancia menor de $4 \mathrm{~m}$.

Coeficiente de intensidad de lluvia $(<7)$

Coeficiente de intensidad de lluvia (7-8)

Coeficiente de intensidad de lluvia (8-9)

Coeficiente de intensidad de lluvia (9-10)

Coeficiente de intensidad de lluvia $(>10)$

Precipitación media anual (<600 mm)

Precipitación media anual (600-1000 mm)

Precipitación media anual (>1000 mm)

Días de heladas anuales (<1 día)

Días de heladas anuales (1-5 días)

Días de heladas anuales (5-20 días)

Días de heladas anuales (20-60 días)

Días de heladas anuales (>60 días)

Calles peatonales (calles peatonales)

Calles con una intensidad baja de tráfico (resto de las calles)

Calles con una intensidad media de tráfico (transito de transporte público)

Calles con una intensidad alta de tráfico (Entradas y salidas al centro histórico)

Calles con una intensidad muy alta de tráfico(Rondas de circunvalación) y con una anchura menor a 5 metros.

Aceleración sísmica básica $(<0,04 \mathrm{~g})$

Aceleración sísmica básica $(0,04-0,08 \mathrm{~g})$

Aceleración sísmica básica $(0,08-0,12 \mathrm{~g})$

Aceleración sísmica básica $(0,12-0,16 \mathrm{~g})$

Aceleración sísmica básica $(>0,16 \mathrm{~g})$

Zonas de riesgo muy bajo según la PGOU de Sevilla

Zonas de riesgo medio según la PGOU de Sevilla

Zonas de riesgo muy alto según la PGOU de Sevilla

Zonas de riesgo mínimo de permeabilidad según el mapa geológico del IGME

Zonas de riesgo bajo de permeabilidad según el mapa geológico del IGME

Zonas de riesgo medio de permeabilidad según el mapa geológico del IGME

Zonas de riesgo alto de permeabilidad según el mapa geológico del IGME

Zonas de riesgo muy alto de permeabilidad según el mapa geológico del IGME

\section{Escala de peligrosidad}

(1) Peligrosidad muy baja

(2) Peligrosidad baja

(3) Peligrosidad media

(4) Peligrosidad alta

(5) Peligrosidad muy alta "+/-1"

(1) Peligrosidad muy baja

(2) Peligrosidad baja

(3) Peligrosidad media

(4) Peligrosidad alta

(5) Peligrosidad muy alta

(1) Peligrosidad muy baja

(3) Peligrosidad media

(5) Peligrosidad muy alta

(1) Peligrosidad muy baja

(2) Peligrosidad baja

(3) Peligrosidad media

(4) Peligrosidad alta

(5) Peligrosidad muy alta

(1) Peligrosidad muy baja

(2) Peligrosidad baja

(3) Peligrosidad media

(4) Peligrosidad alta

(5) Peligrosidad muy alta

(1) Peligrosidad muy baja

(2) Peligrosidad baja

(3) Peligrosidad media

(4) Peligrosidad alta

(5) Peligrosidad muy alta

(1) Peligrosidad muy baja

(3) Peligrosidad media

(5) Peligrosidad muy alta

(1) Peligrosidad muy baja

(2) Peligrosidad baja

(3) Peligrosidad media

(4) Peligrosidad alta

(5) Peligrosidad muy alta 
ESCALAS Y PONDERACIONES DE LAS VARIABLES DE PELIGROSIDAD

$\begin{array}{lll} & >15 \mathrm{~m} \text { de altitud } & \text { (1) Peligrosidad muy baja } \\ \text { E4. Ascensión capilar } & 10-15 \mathrm{~m} \text { de altitud } & \text { (2) Peligrosidad baja } \\ & 7-10 \mathrm{~m} \text { de altitud } & \text { (3) Peligrosidad media } \\ & 5-7 \mathrm{~m} \text { de altitud } & \text { (4) Peligrosidad alta } \\ & <5 \mathrm{~m} \text { de altitud } & (5) \text { Peligrosidad muy alta } \\ & \text { Condiciones para la edificación muy favorables según el IGME } & \text { (1) Peligrosidad muy baja } \\ \text { E5. Geotecnia } & \text { Condiciones para la edificación favorables según el IGME } & \text { (2) Peligrosidad baja } \\ & \text { Condiciones para la edificación aceptables según el IGME } & \text { (3) Peligrosidad media } \\ & \text { Condiciones para la edificación muy desfavorables según el IGME } & \text { (4) Peligrosidad alta }\end{array}$

Geotécnico General a escala 1:200.000 realizado por el Instituto Geológico y Minero de España (IGME 1974). La sismicidad de la Norma de construcción sismorresistente: parte general y edificación: NCSE-02 del Ministerio de Fomento de España (MFOM 2009). Las inundaciones del Catálogo de Servicios de Visualización Inspire del Agua (MITECO 2020). La permeabilidad del Mapa de Permeabilidad a escala 1:400.000 elaborado a partir del mapa litológico de Andalucía actualizado asignando una permeabilidad en función de la litología (REDIAM 2021). La ascensión capilar ha sido derivada a partir de los datos del modelo digital de elevaciones del terreno de la Junta de Andalucía (REDIAM 2021).

La peligrosidad de los vientos ha sido establecida en relación con la rosa de los vientos de la ciudad de Sevilla. Esta identifica dos flujos predominantes: el viento del sur-oeste y el viento del nor-este. Los flujos del sur-oeste han sido considerados los más peligrosos por estar asociados a temperaturas templadas y altos porcentajes de humedad. Los flujos del nor-este también presentan una peligrosidad alta y están asociados a temperaturas muy frías en invierno y muy secas en verano (Ortiz 2014).

Los restos de fortificaciones conservados en Sevilla han sido georreferenciados y volcados como datos vectoriales sobre los mapas de peligrosidad implementados.

Los resultados obtenidos permiten identificar según una escala de riesgos de tipo semáforo (verde-amarillo-rojo) los espacios que suponen una mayor peligrosidad para la conservación de las estructuras analizadas, para compararlos con los patrones de degradación actuales y la vulnerabilidad de las estructuras y poder establecer herramientas que sirvan a los gestores del patrimonio. 
Tramos analizados en Sevilla | croquis generado a partir de imagen obtenida de Google Maps.

Imágenes @2021 Google, Imágenes @2021 CNES / Airbus, Instituto de Cartografl355a de Andalucía, Landsat/Copernicus, Maxar Technologies, Datos de mapa $\odot 2021$ Inst. Geogr. Nacional

\section{Área de estudio}

El área de estudio es el centro histórico de la ciudad de Sevilla. Ubicado en el valle del Guadalquivir, presenta una orografía llana que se enclava sobre un promontorio. Históricamente, su ocupación ha estado muy relacionada con el paso por la ciudad del río Guadalquivir y de dos de sus afluentes: los arroyos Tamarguillo y Tagarete.

Dentro de este contexto han sido identificadas como fortificaciones la muralla medieval de Sevilla y el cerco de los Reales Alcázares. Los Reales Alcázares de Sevilla son una compleja estructura militar y palatina conformada por distintos palacios y defensas urbanas. Respecto a la muralla urbana, si bien su origen puede ser almorávide, los restos conservados responden a una ampliación almohade también del s. XII y XIII que perduraría, a excepción de algunos tramos, hasta el siglo XIX.

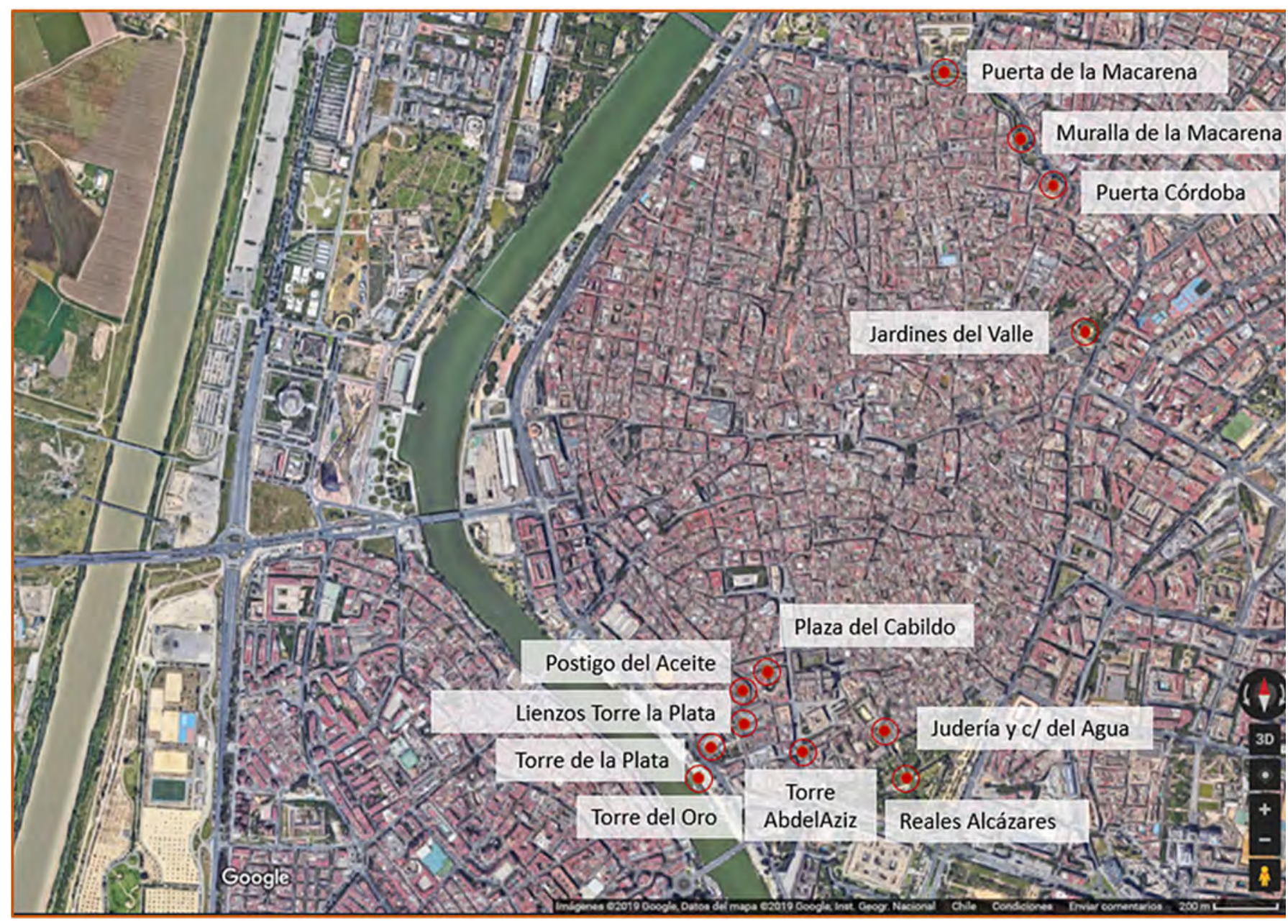


Materialmente, se trata de fortificaciones construidas en hormigón de tapia. Los muros han sido conformados mediante el moldeado por compactación de tierra y guijarros al interior de un gran encofrado o tapial. Esta técnica fue muy usada en arquitectura defensiva en el sur peninsular debido a su gran resistencia y rapidez de fabricación.

Los tramos analizados han sido: Puerta de la Macarena (PMS); Tramo de la Macarena (MAC); Puerta de Córdoba (PCS); Jardines del Valle (JAV); Callejón del Agua (AGU); Judería (JUD); Exteriores del Alcázar (ERA); Plaza del Cabildo (CAB); Postigo del Aceite (PAS); Torre de la Plata (PLA) y Torre del Oro (TOS). La imagen de la página 350 muestra su distribución urbana.

En relación con el grado de protección legal, todos los restos analizados han sido declarados bien de interés cultural y por lo tanto están protegidos por la Ley de Patrimonio Histórico Español (Ley 16/1985) y la Ley de Patrimonio Histórico de Andalucía (Ley 14/2007).

\section{Modelo de monitorización de peligrosidades y vulnerabilidad de las fortificaciones del centro histórico de Sevilla}

Los especialistas coinciden al identificar las amenazas hídricas como los principales factores que afectan la preservación de estructuras en tapia, siendo la base del muro y la coronación las zonas más afectadas (Canivell 2011; Mileto, García Soriano y Vegas López-Manzanares 2014; Mileto y Vegas López-Manzanares 2017; Moreno, Ortiz y Ortiz 2019). Es por ello que el modelo de análisis multi-escenario que se ha aplicado tiene por objetivo evaluar conjuntamente diferentes variables hídricas que influyen en los procesos de degradación de la tapia en función de su goe-referenciación como modelo de buenas prácticas de conservación preventiva.

A escala de comunidad autónoma, el mapa de precipitaciones (imagen de la página 252) arroja valores de peligrosidad medios para el centro histórico de Sevilla asociados a medias anuales de precipitación que oscilan entre 600 y $1000 \mathrm{~mm}$. El mapa de intensidad de la lluvia muestra un grado de peligrosidad medio y está asociado a un índice de torrencialidad (IT) con coeficientes de intensidad entre 8 y 9. La permeabilidad del terreno también presenta un grado de peligrosidad medio. El análisis conjunto de estas tres amenazas describe un entorno urbano con una gran peligrosidad hídrica media. Si bien estas variables arrojan un único valor para todo el casco histórico, pueden ser mejoradas a escalas local mediante los estudios de sondeos (Polo Velasco 2017).

Para una escala urbana, el mapa de ascensión capilar (figura de la página 153) permite identificar zonas con una menor cota de altitud y por tanto más propensas a presentar manchas de humedad por capilaridad en los muros. Debido a la orografía de Sevilla, gran parte de las estructuras (la Torre del 

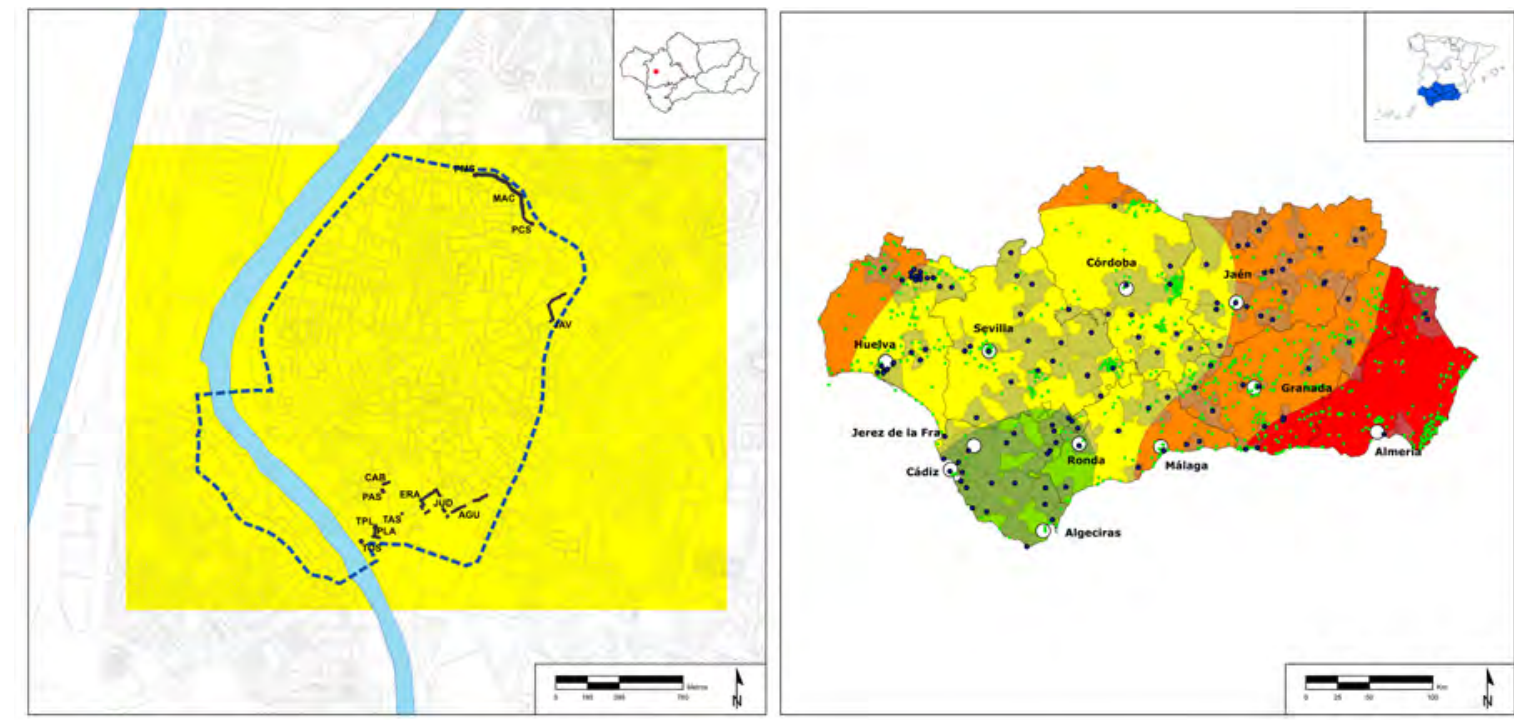

MAPA DE PELIGROSIDAD
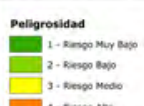

-

T.t.

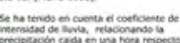

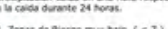

2)

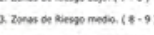

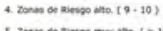

O clatsent

- compinto restina

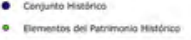

- Fonteracion

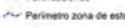
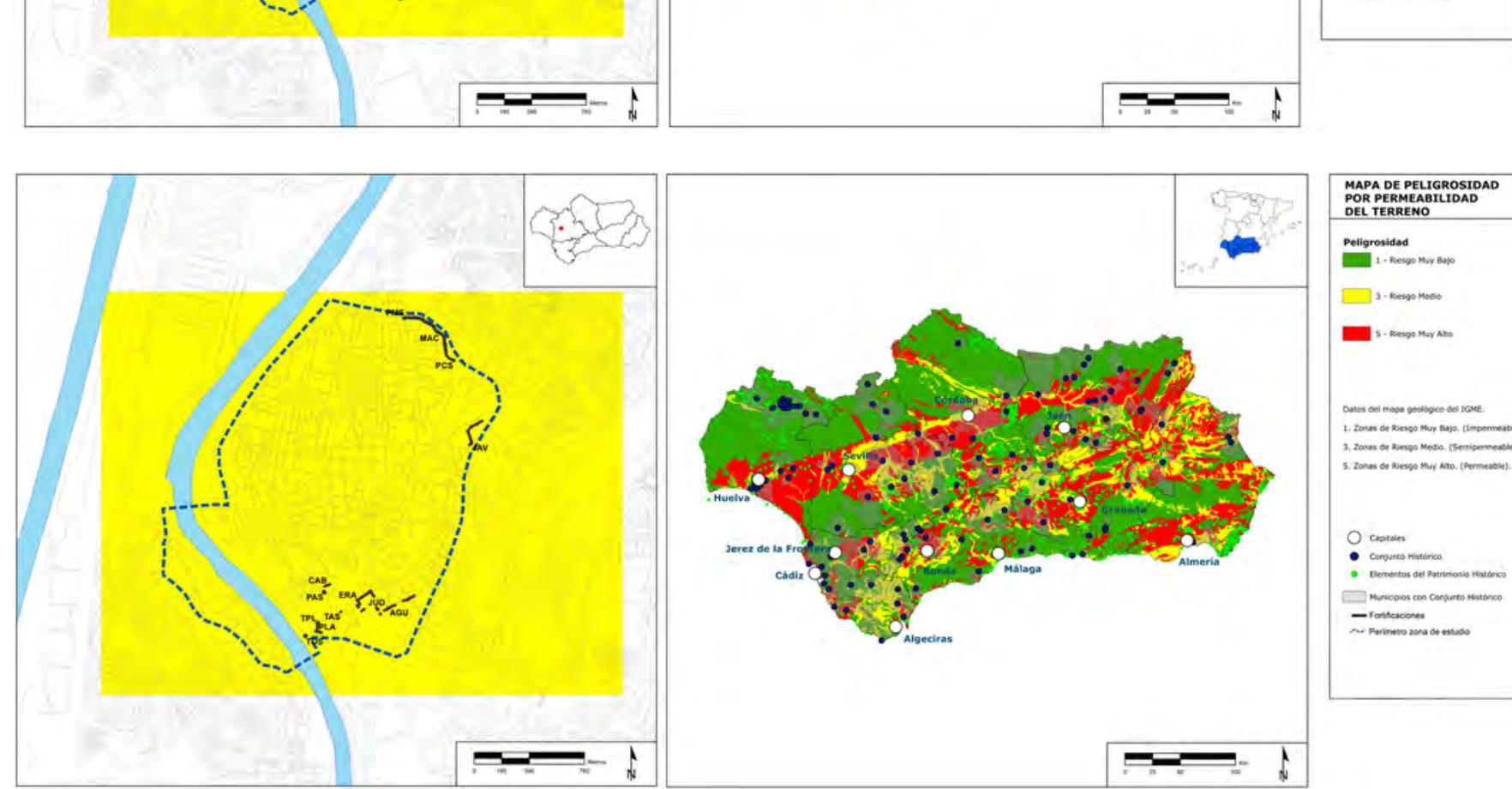

MAPA DE DELL TERREN
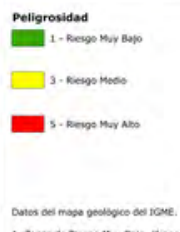

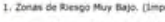

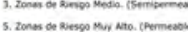

Oeptoms

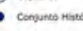

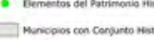

- rontesososes

Mapas de precipitación anual, intensidad de la lluvia y permeabilidad (arriba en la página siguiente) del terreno para el centro histórico de Sevilla y toda Andalucía

Oro, el tramo de la Macarena, la Plaza del Cabildo, la torre de la Plata y la torre de Abd al-Aziz) están ubicadas en espacios urbanos de alta peligrosidad por ascensión capilar. Este tipo de problemáticas se ven magnificadas en presencia de suelos asfaltados como los urbanos (Canivell 2011).

Los modelos cartografiados permiten identificar la incidencia de otros factores estructurales. El centro de Sevilla es considerado un punto de baja peligrosidad sísmica y la geotecnia del terreno muestra unos niveles de riesgo medio que aumentan su peligrosidad en las zonas cercanas al cauce del río Guadalquivir. 

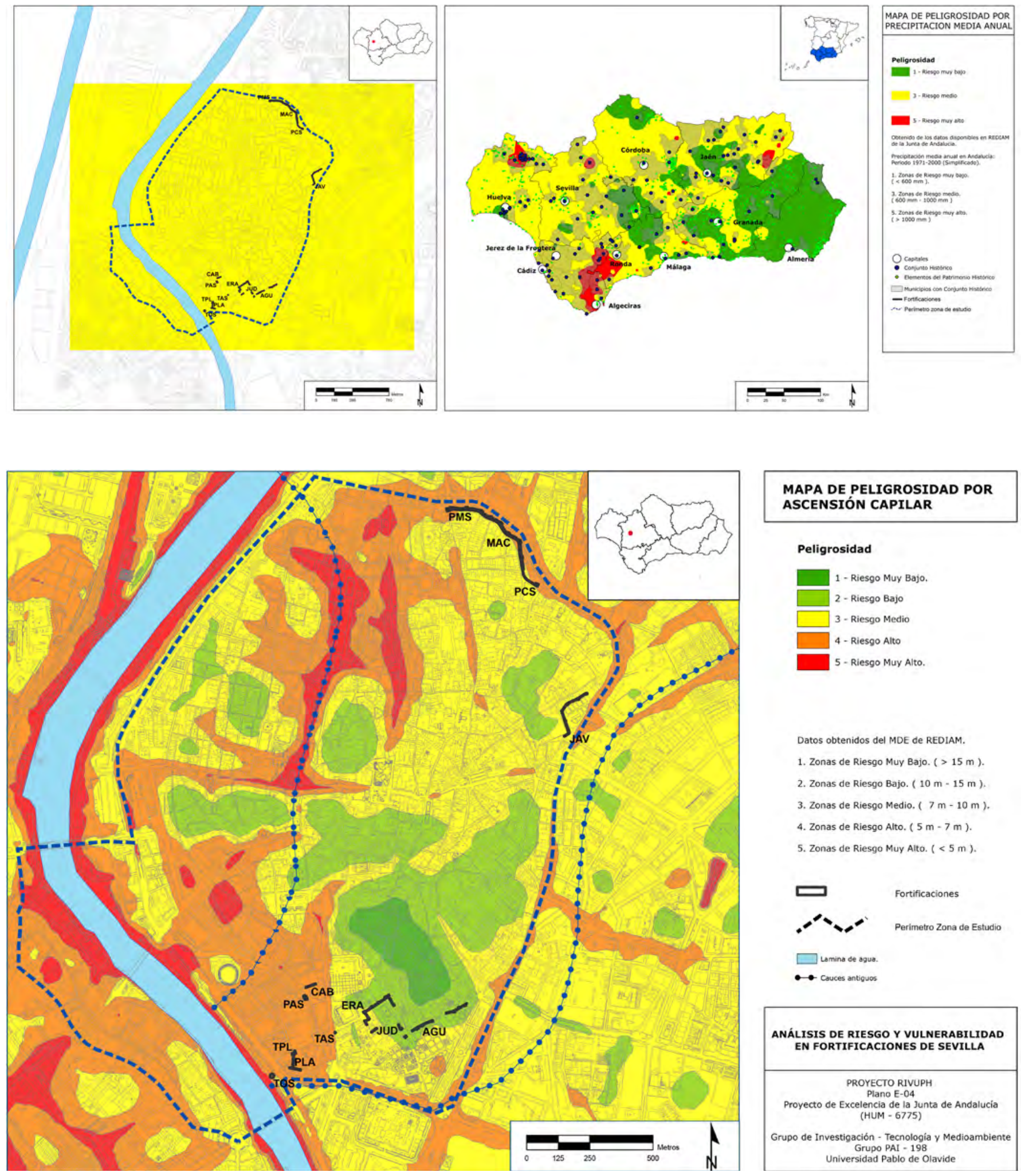

Datos obtenidos del MOE de REDIAM.

1. Zonas de Riesgo Muy Bajo. (>15 m).

2. Zonas de Riesgo Bajo. ( $10 \mathrm{~m}-15 \mathrm{~m}$ )

3. Zonas de Riesgo Medio. ( $7 m-10 m)$.

4. Zonas de Riesgo Alto. ( $5 m-7 m$ ).

5. Zonas de Riesgo Muy Alto. $(<5 \mathrm{~m}$ ).

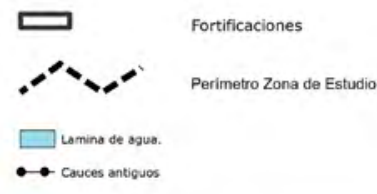

ANÁLISIS DE RIESGO Y VULNERABILIDAD EN FORTIFICACIONES DE SEVILLA

PROYECTO RIVUPH
Plano E-04
Proyecto de Excelencia de la Junta de Andalucía
(HUM - 6775)
Grupo de Investigación - Tecnología y Medioambiente
Grupo PAI - 198
Universidad Pablo de Olavide



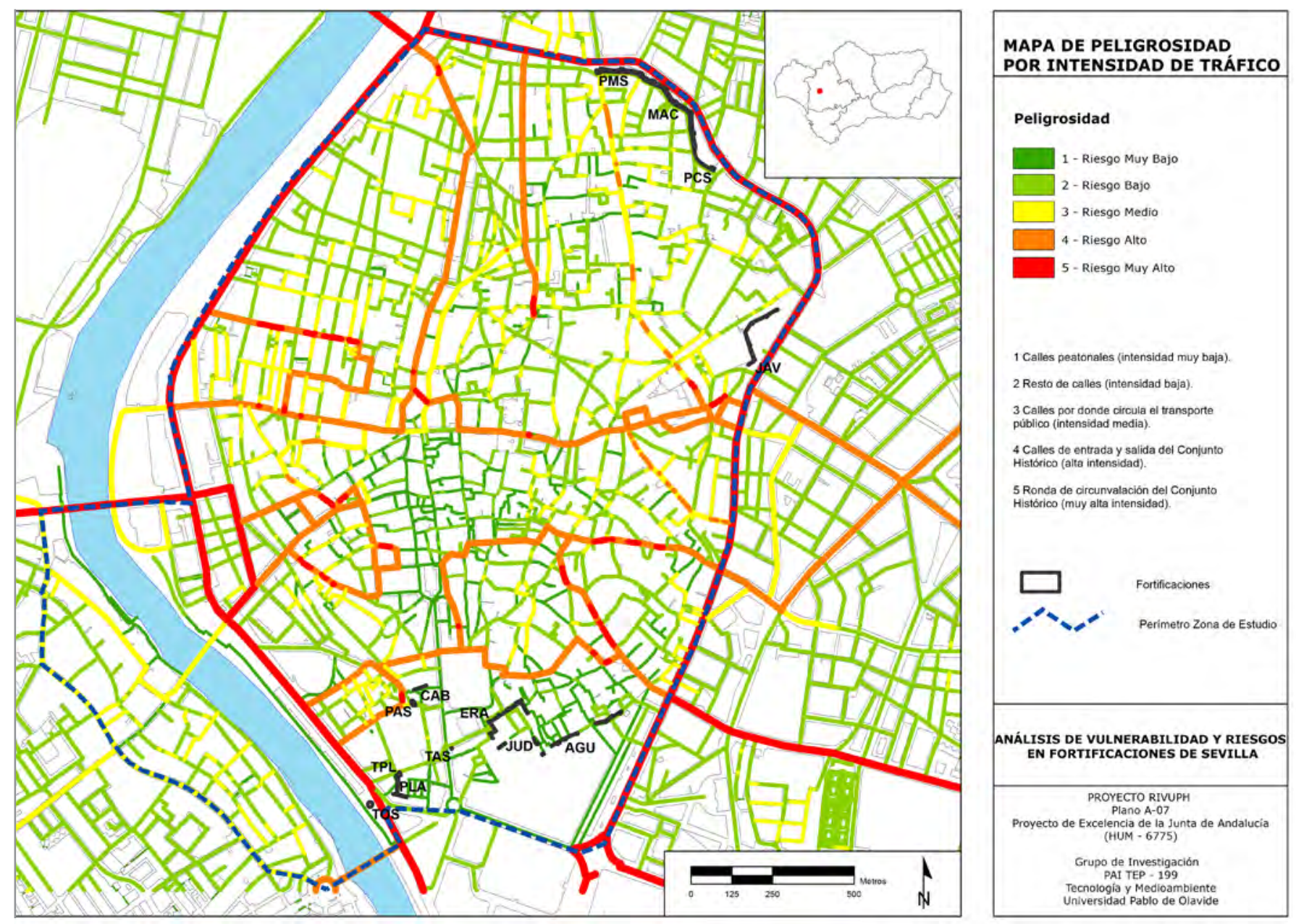

Mapa de peligrosidad por tráfico para el centro histórico de Sevilla

Otro agente a tener en cuenta en los centros históricos es la influencia del tráfico (Ortiz et ál. 2017). Los mapas de tráfico permiten monitorizar aquellos puntos en los que se espera una mayor presencia de contaminantes. La Torre del Oro y la muralla de la Macarena son los tramos que se encuentran en un entorno de mayor peligrosidad debido a su cercanía a la ronda de circunvalación. A pesar de ello, las zonas ajardinadas y paseos que las bordean han ejercido una función de barrera protectora y durante el estudio no se observaron patologías directamente relacionadas con el tráfico, como costras negras, en estos tramos. Los tramos más afectados por la contaminación del tráfico rodado se ubican en aquellas zonas en las que existen aparcamientos cercanos a la muralla, como la torre de la Plata o el lateral oeste del tramo de la Macarena. Los procesos de peatonalización del centro de Sevilla han modificado la presencia de contaminantes en las zonas colindantes al Alcázar, donde a pesar de no estar permitido actualmente el tránsito en esta área, todavía estos tramos están afectados por costras negras. 


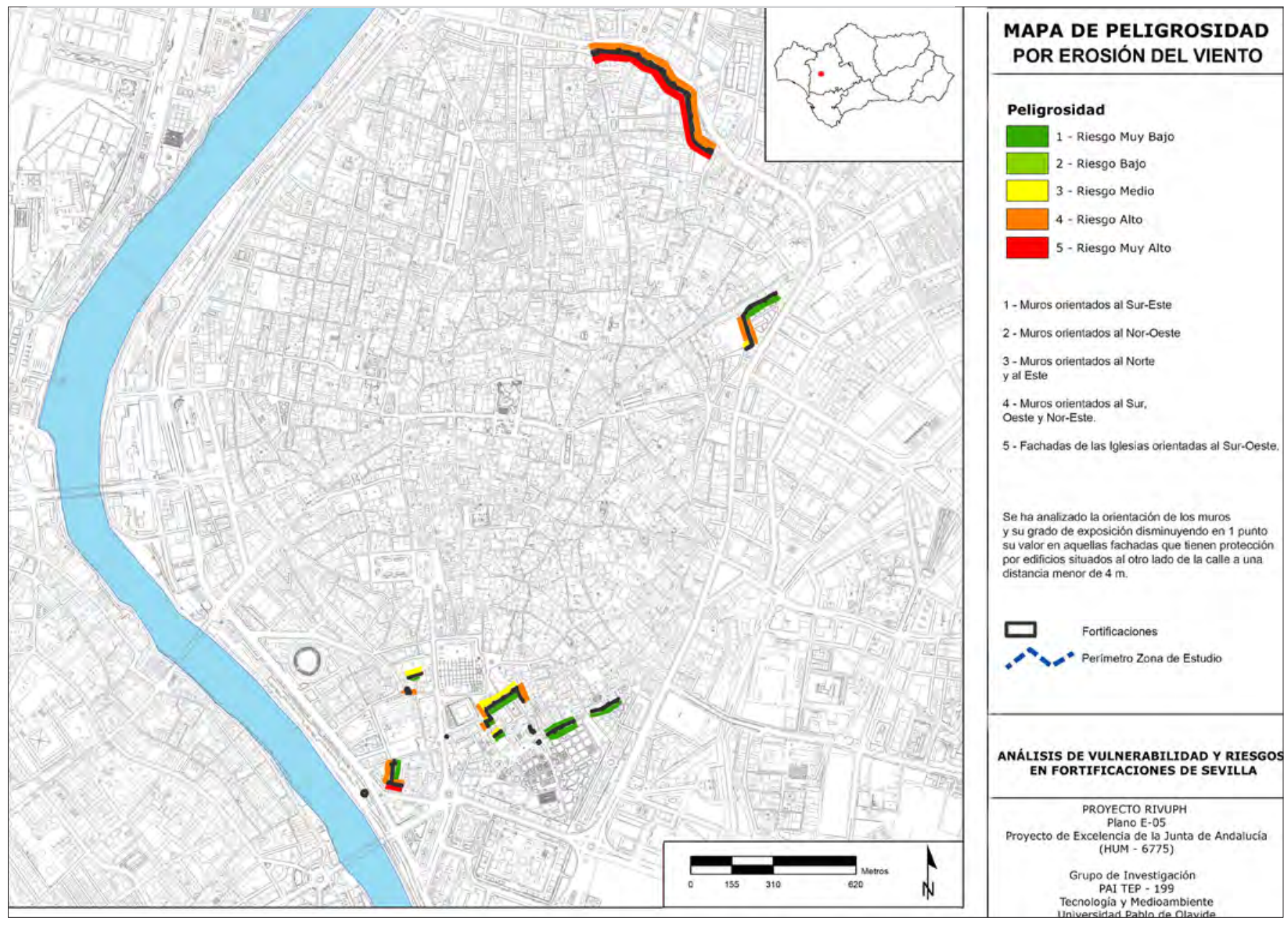

Mapa de peligrosidad por viento para las fortificaciones analizadas

El mapa de erosión por viento permite identificar los tramos que están expuestos a un mayor riesgo por la presencia de fuertes vientos. De los tramos analizados, el de la Macarena es el que presenta orientaciones más expuestas a los efectos del viento. Su ubicación en avenidas amplias, lejos de edificaciones que lo protejan de los efectos dañinos del viento, aumenta el riesgo de sufrir deterioro por erosión.

El análisis de amenazas efectuado identifica el ascenso de humedad por capilaridad desde el subsuelo y la geotecnia como los peligros que pueden suponer una mayor peligrosidad para las fortificaciones ubicadas en el centro histórico de Sevilla. Las precipitaciones medias anuales y la intensidad de las lluvias pueden agravar los fenómenos de erosión en las zonas altas, el riesgo asociado se puede considerar medio-bajo, y que se incremente en las zonas más vulnerables por estar ya dañadas. Desastres debidos a inundaciones, heladas y amenazas sísmicas tienen un nivel bajo-medio de peligrosidad, si 
Indicadores de alteración registrados en las fortificaciones de Sevilla (*Frecuencia baja, media y alta indican la regularidad con la que aparece el indicador en la UAM analizada. ** La frecuencia total es la suma de las 3 frecuencias e indica el número total de UAM afectadas por esa patología) bien deben ser monitorizados en las zonas de vulnerabilidad estructural, con fracturas y fragmentaciones. De los tramos analizados, las UAM más cercanas al río Guadalquivir como la Torre del Oro, la torre de la Plata o la Plaza del Cabildo son los que están sometidos a amenazas mayores.

Los datos obtenidos en el estudio de peligrosidades se han comparado con los estudios de vulnerabilidad efectuados por Mónica Moreno, Pilar Ortiz y Rocío Ortiz (2019). Estos estudios dividieron las fortificaciones en 13 tramos y 199 UAM para analizar su vulnerabilidad en función a su estado de conservación.

\begin{tabular}{|c|c|c|c|c|}
\hline \multirow[t]{2}{*}{ Indicador Alteración } & \multicolumn{3}{|c|}{ Frecuencia relativa de UAM } & \multirow[b]{2}{*}{ Frecuencia total ** } \\
\hline & Frecuencia baja* (1) & Frecuencia media* (2) & Frecuencia alta* (3) & \\
\hline Biocostra & $23 \%$ & $57 \%$ & $16 \%$ & $95 \%$ \\
\hline Humedades & $28 \%$ & $50 \%$ & $14 \%$ & $91 \%$ \\
\hline Erosión & $27 \%$ & $50 \%$ & $13 \%$ & $89 \%$ \\
\hline Reposiciones/incrustaciones & $41 \%$ & $32 \%$ & $0 \%$ & $72 \%$ \\
\hline Vegetación & $39 \%$ & $23 \%$ & $6 \%$ & $68 \%$ \\
\hline Pérdida de material & $32 \%$ & $25 \%$ & $6 \%$ & $63 \%$ \\
\hline Arenización & $16 \%$ & $35 \%$ & $5 \%$ & $56 \%$ \\
\hline Desplacado & $21 \%$ & $29 \%$ & $6 \%$ & $56 \%$ \\
\hline Fracturación & $8 \%$ & $19 \%$ & $21 \%$ & $48 \%$ \\
\hline Depósito superficial & $9 \%$ & $17 \%$ & $2 \%$ & $28 \%$ \\
\hline Cavernización & $11 \%$ & $8 \%$ & $0 \%$ & $19 \%$ \\
\hline Fragmentación & $2 \%$ & $8 \%$ & $8 \%$ & $18 \%$ \\
\hline Alteración cromática & $14 \%$ & $3 \%$ & $0 \%$ & $16 \%$ \\
\hline Alveolización & $6 \%$ & $7 \%$ & $0 \%$ & $14 \%$ \\
\hline Concreciones & $8 \%$ & $4 \%$ & $1 \%$ & $13 \%$ \\
\hline Fisuración & $5 \%$ & $5 \%$ & $2 \%$ & $11 \%$ \\
\hline Eflorescencia & $3 \%$ & $7 \%$ & $0 \%$ & $10 \%$ \\
\hline Rubefacción & $7 \%$ & $1 \%$ & $1 \%$ & $9 \%$ \\
\hline Alteración diferencial & $5 \%$ & $1 \%$ & $3 \%$ & $8 \%$ \\
\hline Excoriación & $4 \%$ & $0 \%$ & $0 \%$ & $4 \%$ \\
\hline Depósito de guano & $0 \%$ & $2 \%$ & $0 \%$ & $2 \%$ \\
\hline Deformación (abombado) & $0 \%$ & $2 \%$ & $0 \%$ & $2 \%$ \\
\hline Picado & $2 \%$ & $0 \%$ & $0 \%$ & $2 \%$ \\
\hline
\end{tabular}




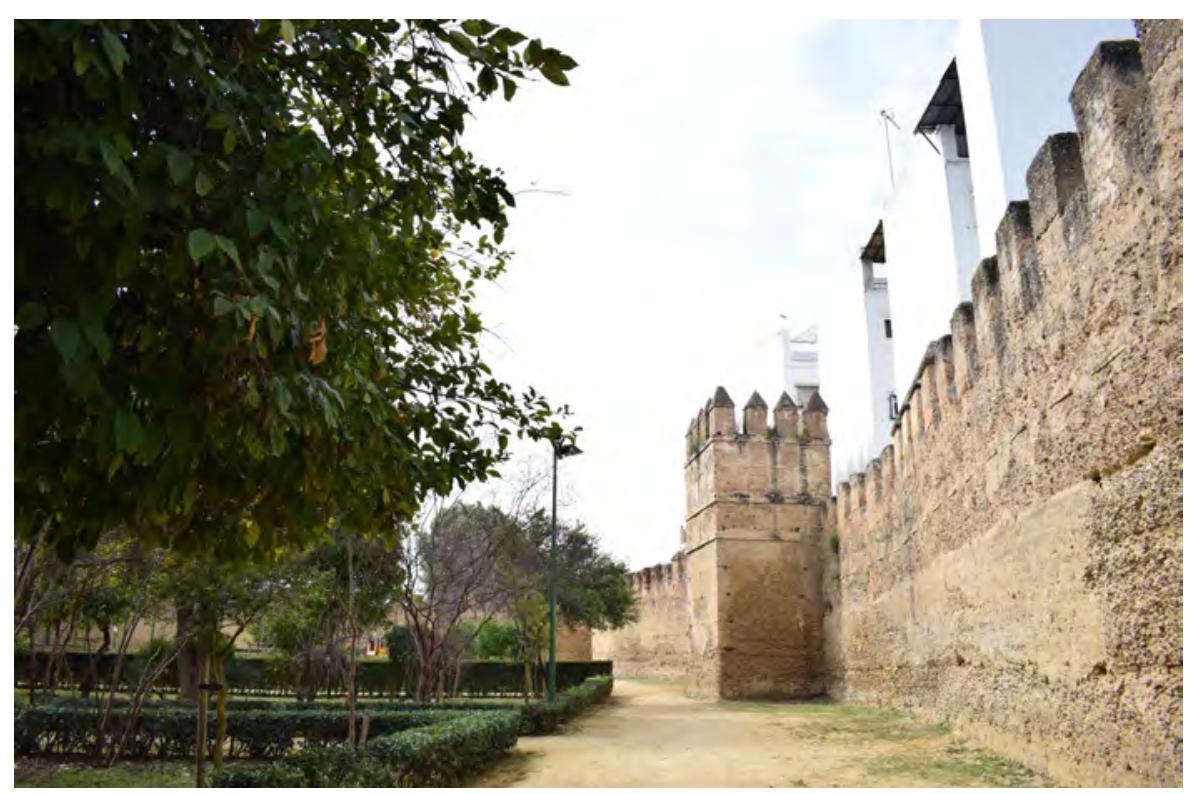

En la tabla de la página 356 se recogen las patologías detectadas durante las inspecciones y su frecuencia de aparición por UAM. La presencia de biocostras (95\%) y manchas de humedad (91\%) son los indicadores más comunes, seguidos de la erosión (89\%). Su frecuente localización en la parte baja de torres y lienzos de terrenos ajardinados y asfaltados se asocia al agua por capilaridad. Los procesos de arenización y desplacados observados en un $56 \%$ de las UAM también pueden ser generados por al ascenso de agua por capilaridad. Estos deterioros suelen estar localizados en los estratos inferiores de las hiladas de tapia intervenidas y aparecen asociados a manchas de humedad y biocostras.

En relación con la presencia de grietas, un $48 \%$ de las UAM analizadas en Sevilla presenta fracturas. Se trata de fracturas verticales, ubicadas en los puntos más débiles estructuralmente como uniones de muros, apoyos del sistema de almenado o en estructuras no intervenidas.

Los depósitos superficiales, asociados a la presencia de contaminantes, afectan solo un $28 \%$ de las UAM analizadas. Los tramos más afectados son los ubicados cerca de aparcamientos y en los exteriores del Alcázar y su presencia puede estar asociada al intenso tráfico en la zona antes de la peatonalización de esos espacios.

La aplicación del modelo ART-RISK -1 a las murallas de Sevilla permite clasificar los tramos y UAM analizadas en función de su estado de conservación. La figura de la página 358 muestra los índices de vulnerabilidad de los 13 tramos analizados. Aquellos que presentan una mayor vulnerabilidad se ubican en el
Manchas de humedad, biocostras, desplacados y procesos de arenización. Murallas de Sevilla, tramo del Jardín del Valle, 2019 | foto Mónica Moreno Falcón 
Resultados: índice de vulnerabilidad, Sevilla

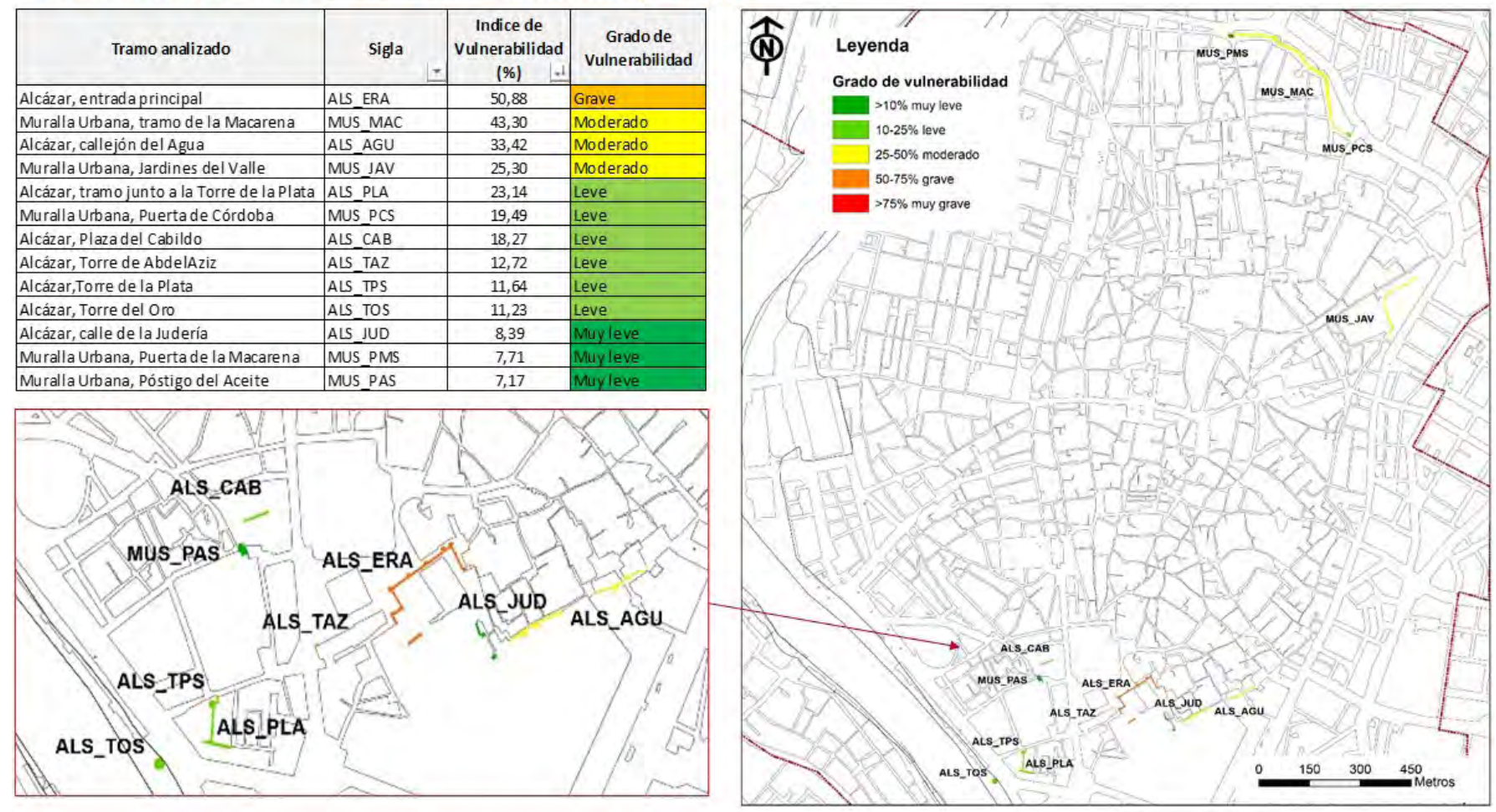

Índices de vulnerabilidad por tramo para las fortificaciones analizadas en Sevilla, 2019
Alcázar, debido sobre todo a la mayor complejidad arquitectónica y diversidad de fábricas que presenta. Los tramos de la Macarena y los Jardines del Valle presentan una vulnerabilidad media, que refleja la necesidad de ser intervenidas para mejorar su estado de conservación. Estos resultados del índice de vulnerabilidad, unidos al análisis multi-escenario mediante SIG, se presentan como modelos útiles para monitorizar las amenazas, especialmente las hídricas y el acceso de agua por capilaridad desde el subsuelo como uno de los procesos a tratar para la conservación de las murallas en Sevilla.

\section{CONCLUSIONES}

La metodología propuesta permite llevar a cabo un análisis multi-escenario de las amenazas que acechan a diferentes elementos constructivos en ciudades históricas. La revisión conjunta de la peligrosidad y la vulnerabilidad mediante sistemas de información geográficos permite identificar escenarios de riesgo, evaluar las amenazas que se deben monitorizar y priorizar las intervenciones. La aplicación de este tipo de modelos supone un manejo sostenible de los recursos técnicos y económicos para una conservación preventiva del patrimonio, que va más allá del diagnóstico hacia un análisis de las amenazas y monitorización de los peligros y de la vulnerabilidad. 
Para municipios y/o regiones con bajos presupuestos destinados a la conservación del patrimonio, y/o que buscan introducir criterios de sostenibilidad, la metodología propuesta es de fácil implantación y económica, por lo que puede mejorar la gestión y favorece el desarrollo socioeconómico a partir de la conservación de los recursos patrimoniales. Su uso puede facilitar la gestión sostenible de espacios patrimoniales complejos, racionalizar el gasto técnico y económico destinado a la preservación, minimizar las intervenciones y priorizar políticas de conservación preventiva en municipios que albergaban un gran número de bienes patrimoniales.

Su aplicación al caso concreto de las fortificaciones en tapia de Sevilla permite priorizar qué tramos presentan una mayor vulnerabilidad debido a su estado de conservación y qué espacios urbanos suponen una mayor peligrosidad para su conservación a largo plazo.

Los resultados alcanzados hasta la fecha en este y otros estudios efectuados confirman la versatilidad de los modelos propuestos en el análisis de diferentes contextos urbanos (de interior y costa, nacionales e internacionales), así como en diferentes tipologías edilicias (iglesias, murallas, teatros, etc.).

\section{Agradecimientos}

Este estudio ha sido desarrollado gracias a la metodología desarrollada por los proyectos: RIVUPH (HUM-6775: Proyecto de excelencia de la Consejería de Economía, Innovación y Ciencia de la Junta de Andalucía); Art-Risk (BIA201564878-R: proyecto RETOS del Ministerio de Economía y Competitividad y Fondo Europeo de Desarrollo Regional (FEDER); FENIX: (PID2019- 107257RB-I00: Proyecto RETOS de la Agencia Estatal de investigación (Ministerio de Ciencia e Innovación). El/10.13039/501100011033); UPO.20-01 (Proyecto de la Consejería de Fomento, Infraestructuras y Ordenación del Territorio de la Junta de Andalucía); y los equipos de investigación TEP-199 (Patrimonio, Tecnología y Medioambiente) y el laboratorio Sanit-ARTE. El proyecto ART-RISK ha sido reconocido con el sello del Plan Nacional de Investigación en Conservación del Patrimonio Cultural (PNIC) que reconoce el Instituto del Patrimonio Cultural de España (IPCE) y ha sido galardonado con un Premio Europa Nostra a la investigación en conservación del patrimonio cultural 2021 que otorga la Comisión Europea y la Institución Europa Nostra. Para más información pueden acceder a la web del proyecto Art-Risk/FENIX (https://www. upo.es/investiga/art-risk/).

Mónica Moreno agradece al Programa Estatal de Promoción del Talento y su Empleabilidad en I + D + i del Ministerio de Ciencia e Innovación de España por su beca técnica (PTA2019-016882). 


\section{BIBLIOGRAFÍA}

- AEMET [Agencia Estatal de Meteorología de España] (2015) Mapa de riesgo: heladas y horas de frío en la España peninsular (2002-2012). Madrid: Ministerio de Agricultura, Alimentación y Medio Ambiente Agencia Estatal de Meteorología. Disponible en: http://www.aemet. es/documentos/es/serviciosclimaticos/datosclimatologicos/ atlas_climatico/Mapas_de_riesgo_2002-2012_WEB.pdf [Consulta: 02/07/2021]

- AEMET [Agencia Estatal de Meteorología de España] (2011) Atlas climático ibérico. Madrid: Ministerio de Medio Ambiente, y Medio Rural y Marino, Agencia Estatal de Meteorología, Instituto de Meteorología de Portugal. Disponible en: http://www.aemet.es/es/ conocermas/recursos_en_linea/publicaciones_y_estudios/ publicaciones/detalles/Atlas-climatologico [Consulta: 02/07/ 2021]

- Canivell, J. (2011) Metodología de diagnóstico y caracterización de fábricas históricas de tapia. Tesis doctoral inédita, Universidad de Sevilla. Disponible en: https://idus. us.es/handle/11441/23954 [Consulta: 02/07/2021]

- Chieffo, N., y Formisano, A. (2019) The Influence of GeoHazard Effects on the Physical Vulnerability Assessment of the Built Heritage: An Application in a District of Naples. Buildings, vol. 9, n. ${ }^{\circ}$ 1, 26. Disponible en: https://doi. org/10.3390/buildings9010026 [Consulta: 30/06/2021]

- Di Salvo, C., Pennica, F., Ciotoli, G. y Cavinato, G.P. (2018) A GIS-based procedure for preliminary mapping of pluvial flood risk at metropolitan scale. Environmental modelling \& software, vol. 107, pp. 64-84. Disponible en: https://doi.org/10.1016/j.envsoft.2018.05.020 [Consulta: 30/06/2021]

- Ferreira, T.M., Mendes, N. y Silva, R. (2019) Multiscale Seismic Vulnerability Assessment and Retrofit of Existing Masonry Buildings. Buildings, vol. 9, n. ${ }^{\circ} 4,91$. Disponible en: https://doi.org/10.3390/buildings9040091 [Consulta: 30/ 06/2021]

- Graciani, A., y Canivell, J. (2019) Unas notas para la caracterización y la evaluación de estudio de vulnerabilidad en fortificaciones urbanas. En: Di Sivo, M. y Ladiana D. (coord.) Le mura urbane crollano: conservazione e manutenzione programmata della cinta muraria dei centri storici. Pisa: Pisa University Press, pp. 57-69

- IAPH [Instituto Andaluz del patrimonio Histórico] (2021) Guía Digital del Patrimonio Cultural de Andalucía. Disponible en: https://guiadigital.iaph.es/ [Consulta: 02/07/2021]

- IGME [Instituto Geológico y Minero de España] (1974) Mapa Geotécnico General a escala 1:200.000: Mapa de interpretación geotécnica. Disponible en: https://info. igme.es/cartografiadigital/tematica/Geotecnico200.aspx [Consulta: 02/07/2021]

- Ley 16/1985, de 25 de junio, del Patrimonio Histórico
Español. Boletín Oficial del Estado, n.o 155, de 29 de junio de 1985. Disponible en: https://www.boe.es/buscar/doc. php?id=BOE-A-1985-12534 [Consulta: 02/07/2021]

- Michard, F. y Teboul, J.L. (2019) Predictive analytics: beyond the buzz. Annals of Intensive Care, vol. 9, n. 46. Disponible en: https://doi.org/10.1186/s13613-019-0524-9 [Consulta: 30/06/2021]

- Mileto, C., García Soriano, L. y Vegas LópezManzanares, F. (2014) Los fenómenos de degradación más comunes en fábricas de tapia. En: Mileto, C. y Vegas López-Manzanares, F. (coord.) La restauración de la tapia en la Península Ibérica: criterios, técnicas, resultados y perspectivas. Valencia: TC Cuadernos, pp. 52-61

- Mileto, C. y Vegas López-Manzanares, F. (2017) Proyecto COREMANS. Criterios de intervención en la arquitectura de tierra. Madrid: Ministerio de Cultura y Deporte, Subdirección General de Documentación y Publicaciones

- MFOM [Ministerio de Fomento de España] (2009) Norma de construcción sismorresistente: parte general y edificación: NCSE-02. Disponible en: https://www.mitma. gob.es/recursos_mfom/0820200.pdf [Consulta: 02/07/20 21]

- MITECO [Ministerio para la Transición Ecológica y el Reto Demográfico] (2020) Infraestructura de Datos Espaciales: Catálogo de Servicios de Visualización Inspire del Agua. Disponible en: https://www.miteco.gob.es/es/ cartografia-y-sig/ide/directorio_datos_servicios/agua/wmsinspire-agua.aspx [Consulta: 02/07/2021]

- MOPU [Ministerio de Obras Públicas y Urbanismo] (1990) Norma para la Instrucción de carreteras 5.2-1C: "Drenaje superficial". Disponible en: https://www.boe.es/eli/ es/o/1990/05/14/ [Consulta: 02/07/2021]

- Moreno, M., Ortiz, P. y Ortiz, R. (2019) Vulnerability study of earth walls in urban fortifications using cause effect matrixes and GIS: the case of Seville, Carmona and Estepa defensive fences. Mediterranean Archaeology and Archaeometry, vol. 19, n. $^{\circ} 3$, pp. $119-138$

- Ngo, J., Hwang, B. y Zhang, C. (2020) Factor-based big data and predictive analytics capability assessment too for the construction industry. Automation in Construction, vol. 110. Disponible en: https://doi.org/10.1016/j.autcon. 2019.103042 [Consulta: 30/06/2021]

- Ortiz, R. (2014) Análisis de vulnerabilidad y riesgos en edificios singulares de Sevilla. Tesis doctoral inédita, Universidad Pablo de Olavide. Disponible en: https://rio. upo.es/xmlui/handle/10433/1336 [Consulta: 02/07/2021]

- Ortiz, R., Garrido-Vizuete, M.A., Prieto, A.J., MacíasBernal, J.M., Becerra, J., Benítez, J., Gómez-Morón, A., Martín, J.M., Segura-Pachón, D., Tirado-Hernández, A., Turbay, I., Chávez, M.J., Vázquez-González, A., Contreras- 
Zamorano, G.M., Cisternas, V., Ortiz, P. y Cagigas-Muñiz, D. (2019) Preventive conservation of monuments based on DELPHI method and fuzzy logic. En: Dobran, F. (ed.) Resilience and sustainability of cities in hazardous environments. Nápoles: GVES, pp. 10-13

- Ortiz, R., Macías-Bernal, J.M. y Ortiz, P. (2018) Vulnerability and buildings service life applied to preventive conservation in cultural heritage. International Journal of Disaster Resilience in the Built Environment, vol. 9, n. ${ }^{\circ} 1$, pp. 31-47

- Ortiz, R. y Ortiz, P. (2016) Vulnerability Index: A New Approach for Preventive Conservation of Monuments. International Journal of Architectural Heritage, vol. 10, n. ${ }^{\circ} 8$, pp. 1078-1100. Disponible en: https://doi.org/10.1080/1558 3058.2016.1186758 [Consulta: 30/06/2021]

- Ortiz, R., Ortiz, P., Macías, J.M., Martín, J.M. y Vázquez M.A. (2014a) New vulnerability approach for monument diagnosis. En: Science, Technology and Cultural Heritage. Sevilla: Instituto de Recursos Naturales y Agrobiología de Sevilla, IRNAS-CSIC, pp. 489-493

- Ortiz, R., Ortiz, P., Vázquez, M.A., Martín, J.M. (2017) Integration of georeferenced informed system and digital image analysis to assess the effect of cars pollution on historical buildings. Construction and Building Materials, vol. 130, pp. 320-333. Disponible en: 10.1016/j.conbuildmat.2017.02.0300950-0618/ [Consulta: 02/07/2021]

- Ortiz, P., Antunez, V., Martín, J.M., Ortiz, R., Vázquez, M.A. y Galán, E. (2014b) Approach to environmental risk analysis for the main monuments in a historical city. Journal of Cultural Heritage, vol. 15, n. ${ }^{\circ} 4$, pp. 432-440. Disponible en: https://doi.org/10.1016/j.culher.2013.07.009 [Consulta: 30/06/2021]

- Perles, A., Pérez-Marín, E., Mercado, R., Segrelles J.D., Blanquer, I., Zarzo, M. y García-Diego, F.J. (2018) An energy-efficient internet of things (IOT) architecture for preventive conservation of cultural heritage. Future Generation Computer System, vol. 81, pp. 566-581. Disponible en: https://doi.org/10.1016/j.future.2017.06.030 [Consulta: 30/06/2021]

- Polo Velasco, J.L. (2017) Modelo para determinar la solución constructiva de cimentaciones en edificación, en función de los condicionantes geotécnicos de Sevilla. Tesis doctoral inédita, Universidad de Sevilla. Disponible en: https://idus.us.es/handle/11441/71097 [Consulta: 02/07/2021]

- Prieto,A.J., Macías-Bernal, J.M., Silva, A. y Ortiz, P. (2019) Fuzzy decision-support system for safeguarding tangible and intangible cultural heritage. Sustainability, vol. $11, n{ }^{\circ}$ 14. Disponible en: https://doi.org/10.1155/2019/3578083 [Consulta: 30/06/2021]
- Prieto, A.J., Turbay, I., Ortiz, R., Chávez, M.J., MacíasBernal, J.M. y Ortiz, P. (2020) A Fuzzy Logic Approach to Preventive Conservation of Cultural Heritage Churches in Popayán, Colombia. International Journal of Architectural Heritage. Disponible en: https://doi.org/10.1080/15583058 .2020.1737892 [Consulta: 30/06/2021]

- REDIAM [Red de Información Ambiental de Andalucía] (2021) Disponible en: https://www.juntadeandalucia.es/ medioambiente/portal/datos-ambientales?category Val= [Consulta: 09/08/2021]

- Sesana, E., Gagnon, A.S., Bonazza, A. y Hughes, J.J. (2020) An integrated approach for assessing the vulnerability of World Heritage Sites to climate change impacts. Journal of Cultural Heritage, vol. 41, pp. 211-224. Disponible en: https://doi.org/10.1016/j.culher.2019.06.013 [Consulta: 30/06/2021]

- Spezzano, P. (2021) Mapping the susceptibility of UNESCO World Cultural Heritage sites in Europe to ambient (outdoor) air pollution. Science of the Total Environment, vol. 754. Disponible en: https://doi.org/10.1016/j. scitotenv.2020.142345 [Consulta: 30/06/2021]

- Universidad Pablo de Olavide y Universidad de Sevilla (2021) Art-Risk: Inteligencia artificial aplicada a la conservación preventiva de edificios patrimoniales. Disponible en: https://www.upo.es/investiga/art-risk-service/ art-risk3/index.html [Consulta: 09/08/2021] 


\section{La Red Andaluza de Semillas, buenas prácticas en el mantenimiento sostenible del ecosistema agrario}

Juan José Soriano Niebla | Red Andaluza de Semillas

URL de la contribución <www.iaph.es/revistaph/index.php/revistaph/article/view/4944>

\section{RESUMEN}

En sus más de 18 años de recorrido, la Red de Andaluza de Semillas ha venido desarrollando y documentando una importante experiencia en la defensa, recuperación y utilización de la biodiversidad cultivada. Esta experiencia ha servido de base para reflexionar sobre la complejidad de este legado rural y las diferentes formas de nombrarlo y entenderlo: recursos genéticos, variedades tradicionales y locales, conocimiento campesino, memoria biocultural... En este extenso patrimonio, de naturaleza tanto cultural como natural, se encuentran claves para conciliar los objetivos de desarrollo con el uso sostenible de los recursos a escala local. Las visiones desarrolladas en los ámbitos de la agroecología y la soberanía alimentaria permiten interpretar esta sabiduría y contextualizarla para dar respuesta a retos actuales. Así han surgido estas buenas prácticas para el cultivo y la elaboración de alimentos, respetuosas con la protección del medio natural y basadas en la valorización del patrimonio genético agrícola.

\section{Palabras clave}

Agroecología | Biodiversidad | Campesinado | Conocimiento | Conservación (patrimonio) | Investigación-acción participativa | Patrimonio agrícola | Red Andaluza de Semillas "Cultivando Biodiversidad" (RAS) | Soberanía alimentaria | 


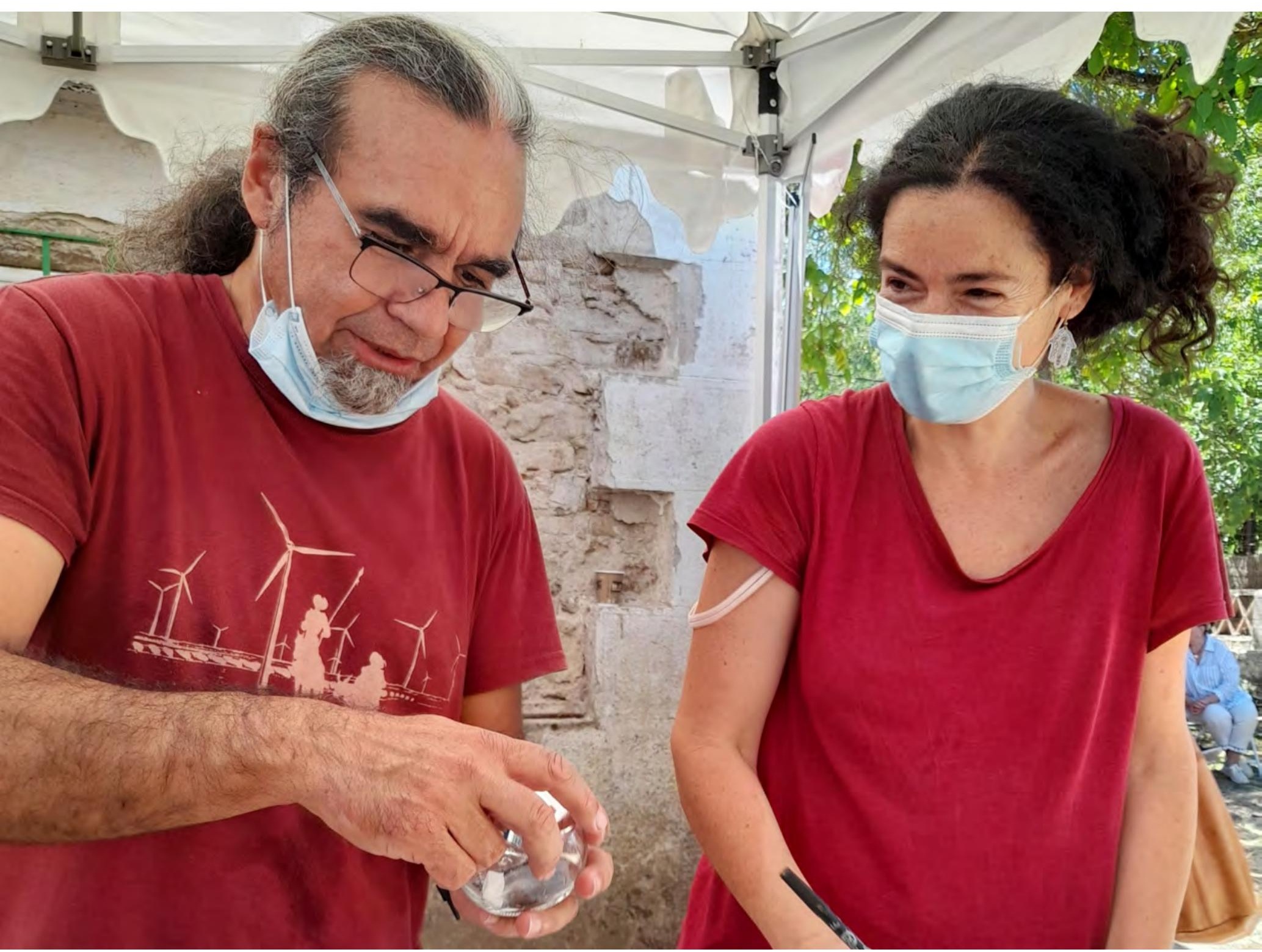

Intercambio de semillas de variedades locales en Cortes de la Frontera (Málaga) | foto Red Andaluza de Semillas "Cultivando Biodiversidad", quien ha facilitado todas las imágenes que ilustran este artículo 
La Red Andaluza de Semillas "Cultivando Biodiversidad" (RAS) es una organización de la sociedad civil que tiene entre sus fines contribuir a la recuperación de las variedades locales y el saber campesino tradicional, promover la gestión colectiva de la biodiversidad cultivada y fomentar los sistemas alimentarios campesinos y agroecológicos, como fuente de alimentos asequibles y saludables para todas las personas y como medio de vida digno para quienes los cultivan. La RAS se originó como diálogo de diferentes sensibilidades, prácticas y saberes que desde finales del siglo pasado han ido evolucionando y conformándose hasta nuestros días. En este diálogo han tenido un papel fundamental los agricultores locales, especialmente los vinculados al movimiento jornalero andaluz, que aportaron su visión crítica al sistema alimentario, y los hortelanos tradicionales, que nos han ido legando su formidable conocimiento en la gestión y manejo de la biodiversidad cultivada, y también el movimiento campesino internacional, que nos ha brindado un marco fundamental para la acción a través del concepto de soberanía alimentaria.

En este recorrido han tenido también un papel muy importante instituciones del mundo académico que, desde la reivindicación del campesinado y sus formas de conocimiento, dieron lugar a la agroecología como disciplina científica y como cuerpo de conocimientos prácticos que abordan integralmente la producción de alimentos desde un enfoque que promueve al mismo tiempo la sostenibilidad ambiental y la equidad social e intergeneracional.

Aunque desde sus inicios la RAS ha procurado nutrirse de ideas y saberes, su vocación es indudablemente la acción, dirigida a promover el uso de los recursos genéticos que permitan que la actividad de producción y elaboración de los alimentos siga siendo uno de los pilares del desarrollo sostenible local. Para ello nos coordinamos con otras organizaciones locales o globales que comparten nuestra misión hacia una agricultura en armonía con nuestro entorno y nuestra salud, en la que la biodiversidad cultivada y las comunidades agrarias que la desarrollan y gestionan tienen un papel fundamental.

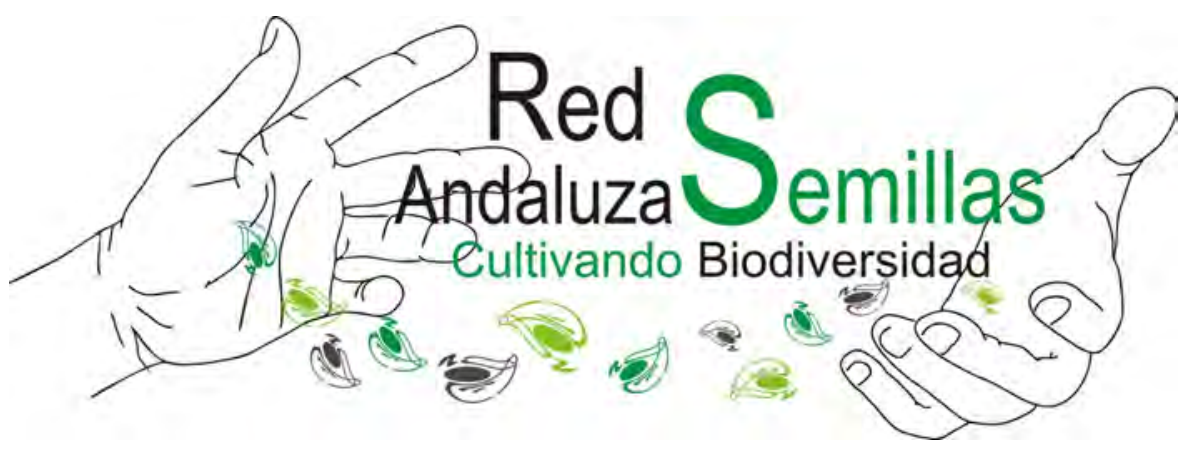




\section{LA BIODIVERSIDAD CULTIVADA COMO PATRIMONIO MATERIAL Y CULTURAL EN EVOLUCIÓN}

Las definiciones en el ámbito de la biodiversidad suelen ser complejas, ya que si bien siempre tienen como base el conocimiento científico, existen multitud de elementos que cobran peso en función del punto de vista y la finalidad de quienes las manejan.

En la práctica de la RAS, la biodiversidad cultivada es el elemento central. En este sentido la biodiversidad cultivada la conforman tanto los recursos materiales vivientes que utilizan los agricultores y agricultoras para perpetuar el sistema productivo de alimentos, como el cuerpo de conocimientos que permite su gestión y su adaptación a los cambios.

Tal como le ocurre a la propia agricultura, la biodiversidad cultivada desafía las clasificaciones clásicas de lo que se define como patrimonio, ya que participa a la vez de las características del patrimonio natural y cultural y también del patrimonio material e inmaterial. Estas cualidades y otras que trascienden este ámbito son las responsables de su riqueza y complejidad.

Desde el ámbito natural, el manejo de la biodiversidad está condicionado por los sistemas reproductivos de las plantas. Estos sistemas tienen en sí mismos una gran diversidad de manifestaciones desarrolladas a lo largo de la historia evolutiva de los vegetales y que hacen que existan formas vegetativas y sexuales de reproducción, como esquejes, bulbos o semillas por nombrar algunas de las más comunes.

En este mismo ámbito natural la biodiversidad cultivada posee a su vez un elemento informativo propio del material germinativo de los seres vivos que es la información codificada en su genoma. Los elementos reproductivos y la trasmisión de la información intergeneracional en las plantas está vinculado a sus formas de reproducción. Así en las formas de reproducción vegetativa esta información se conserva a medio-largo plazo de forma más o menos invariable, a excepción de mutaciones puntuales. Por el contrario, en el caso de la reproducción por semillas, la información genética trasmitida a los descendientes sufre una modificación respecto de los progenitores, que a su vez varía en función del grado de autogamia/alogamia de la especie y también, en cierto grado, de las estrategia floral (hermafroditismo, dioecia, etc.) y las formas de polinización (anemofilia, entomofilia, etc).

Con estas dimensiones naturales se entrecruzan los elementos culturales de manejo que están fuertemente condicionados a su vez por cuestiones materiales, como ocurre por ejemplo con las prácticas de conservación en función de las semillas, que pueden ser elementos de resistencia que permitan preservar durante un tiempo más o menos largo la viabilidad para generar un
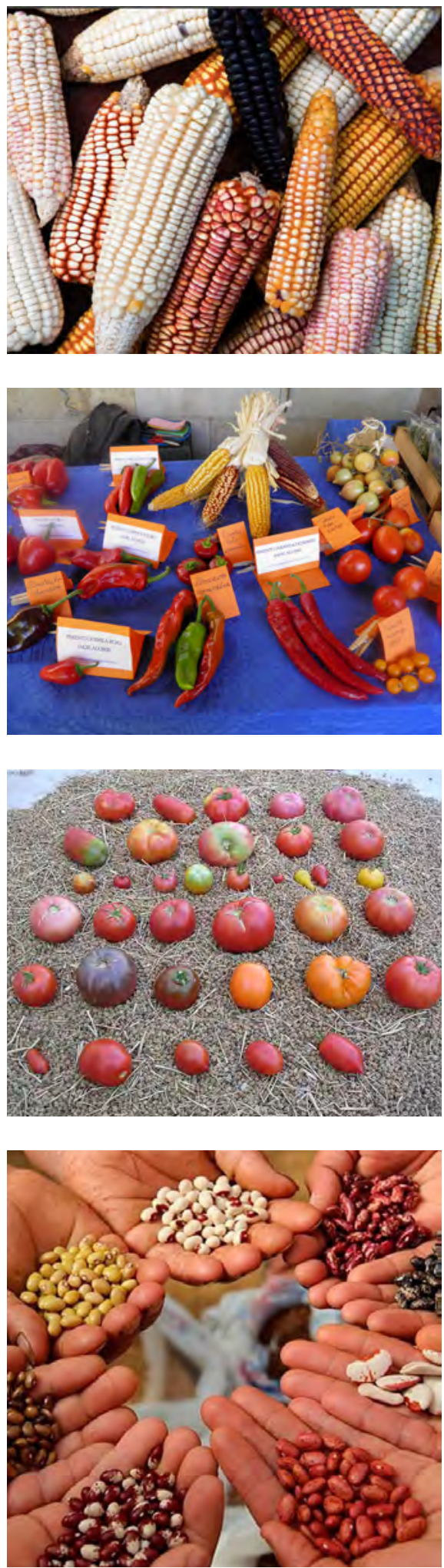
Encuentro de agricultores sabios durante trilla tradicional en Cuevas del Becerro (Málaga)

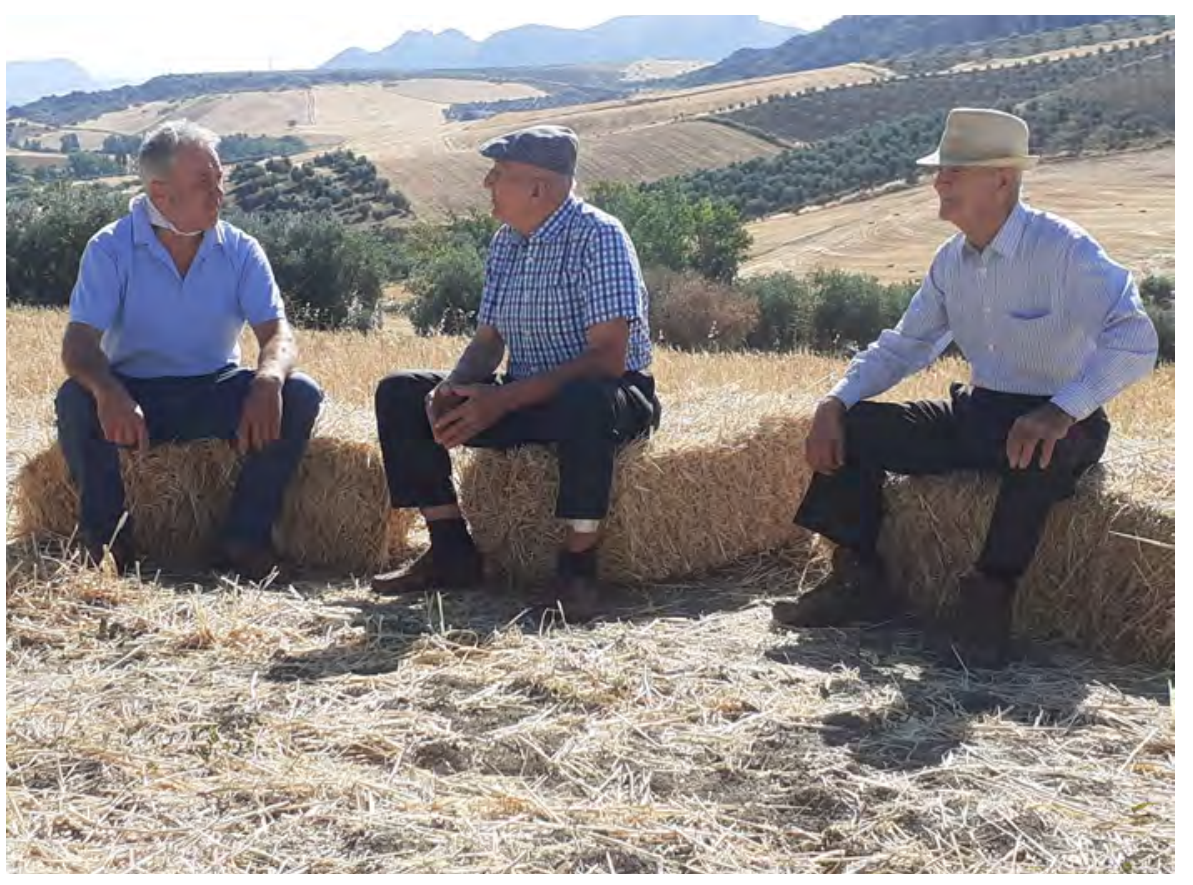

nuevo individuo o recalcitrantes que pierden su viabilidad germinativa en un periodo corto de tiempo.

A estos condicionantes materiales del elemento cultural se superpone a su vez una sabiduría campesina compleja sobre el manejo de las plantas que nos ha permitido a la humanidad sobrevivir y proliferar como especie durante cientos de años. Desde la RAS asumimos el reto de lograr el reconocimiento del conocimiento campesino andaluz como un conocimiento válido que ha asegurado la alimentación de nuestras comunidades a lo largo del tiempo y aún hoy sigue siendo esencial y también de racionalizar y reelaborar este conocimiento local de nuestros campesinos y campesinas para construir un nuevo edificio conceptual que sirviese de base para un modelo agroecológico de manejo de la biodiversidad cultivada (Soriano Niebla 2004).

Siendo conscientes de esta complejidad, desde la RAS hemos ido desarroIlando en nuestros 18 años de experiencia diversas iniciativas que vinculan el valor patrimonial de la biodiversidad cultivada con los fines de conservación y revitalización del patrimonio agrícola, la sostenibilidad de los modos de vida en el ámbito rural, la soberanía alimentaria y el equilibrio medioambiental y la protección de la biodiversidad.

Dentro de estas experiencias hemos tomado como ejemplo de buenas prácticas las aprendidas durante nuestra participación en el proyecto CERERE. Durante este proyecto hemos obtenido conocimientos sobre los múltiples 
aspectos que ligan los cereales tradicionales, su cultivo, su transformación y elaboración y su consumo desde una perspectiva actual.

El proyecto CERERE ha sido una iniciativa de 13 entidades europeas, aglutinando organizaciones de base del sector agrario, incluyendo a la RAS, e instituciones de investigación y de divulgación científica. Se desarrolló entre 2016 y 2019 y recibió financiación del programa de investigación e innovación Horizonte 2020 de la Unión Europea.

A través de CERERE hemos buscado una síntesis de prácticas innovadoras y los resultados de la investigación utilizados para construir sistemas alimentarios de cereales basados en la agrobiodiversidad, ecológicos y con bajos insumos. Para ello hemos trabajado con todos los actores implicados para encontrar las mejores prácticas existentes, los resultados más relevantes de la investigación y los casos de innovación y hemos impulsado su difusión.

Una de los motivos para incorporarnos a esta iniciativa fue compartir el enfoque de investigación participativo. Desde la práctica de la RAS el enfoque agroecológico se ha llevado a cabo a través de experiencias de investigación-acción participativa. Esto implica que el personal investigador profesional pasa a ser un agente mediador de la investigación, dando paso como sujetos a la comunidad que desarrolla y se beneficia de la investigación, que en nuestro caso la conforman los agricultores y agricultoras, las personas que producen el pan y la pasta y quienes se involucran en su consumo responsable.

La práctica de la investigación participativa implica también cambiar la realidad investigada de forma que la dialéctica entre la comunidad que investiga y el objeto de la investigación se plasma en una praxis de transformación colectiva para avanzar en la soberanía alimentaria local (Soriano et ál. 2013).

Para poder abarcar la complejidad que supone trabajar a la vez con la totalidad de actores relacionados con la valorización de los cereales tradicionales, se ha estructurado el trabajo en tres ámbitos: sistemas alimentarios alternativos y sostenibles, salud y nutrición, y agronomía y transformación alimentaria, lo que en primera instancia dio lugar a dos compilaciones sobre la literatura científica que apoyasen el desarrollo del proceso de investigación participativa (Sofi et ál. 2018; Sacchi et ál. 2018).

\section{BUENAS PRÁCTICAS EN EL CONOCIMIENTO Y MANEJO DE LA BIODIVERSIDAD CULTIVADA}

Para facilitar la comprensión de las interrelaciones entre la ecología y la producción se identificaron las especies de los principales cereales de invierno con presencia en los sistemas de cultivo tradicional en nuestro entorno 
1

DIVERSIFOOD es un proyecto del programa de investigación e innovación Horizonte 2020 de la Unión Europea Diversifood-High quality food systems.

Encuentro de agricultores sobre la recuperación de cereales antiguos en Alozaina Málaga (2012)

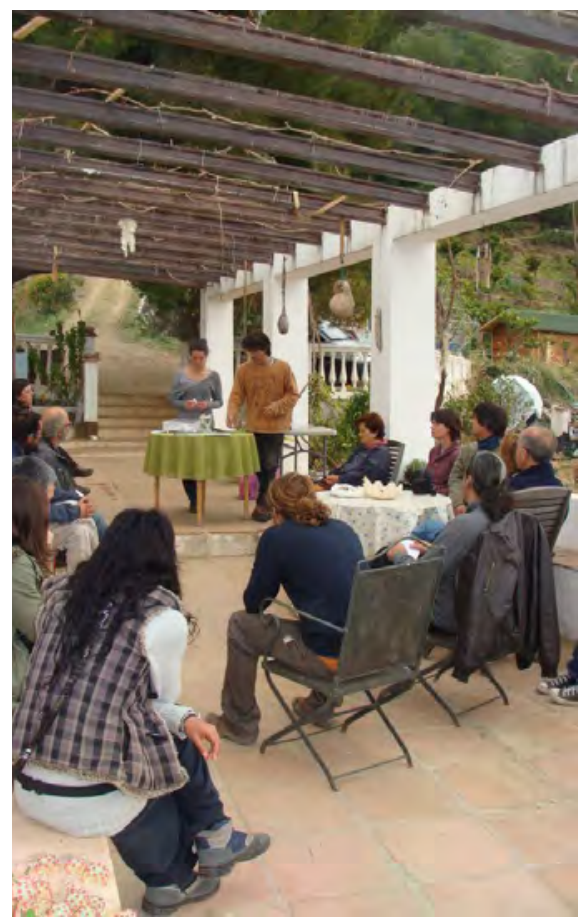

(escañas, escandas, espeltas, trigos duros y blandos, cebada, centeno y avena) y se describieron las características botánicas, así como la evolución de las diferentes especies y de la diversificación, dentro del género Triticum, entre los diferentes grupos en función de su poliploidía y su fruto desnudo o vestido.

Uno de los principales retos del trabajo con la biodiversidad cultivada es la descripción de las variedades para poder diferenciarlas, reconocerlas y, en trabajos más avanzados, llegar a su caracterización, incluyendo elementos relativos a su manejo, cualidades y formas de consumo.

Desde los inicios de la RAS se desarrollaron experiencias participativas de descripción y caracterización, sobre todo centradas en hortícolas y legumbres (Muñoz Pineda 2010; Toledo et ál. 2011a; Toledo et ál. 2011b; González et ál. 2014; Red Andaluza de Semillas 2012).

El trabajo de caracterización de variedades de trigo y asociaciones de cultivo locales se inició más tardíamente, a raíz de la participación en el proyecto europeo DIVERSIFOOD ${ }^{1}$. Las variedades locales de trigo que se describieron fueron Recio de Ronda, Chamorro de Los Portales, Capelli de Cañete, Trigo de Juan de Coín, Castellano, Chamorro de Albacete, Trigo del Corazón (Khorasan), Pichi de Antequera, Raspinegro de Jubrique, una accesión de trigo recio facilitada por el Centro de Recursos Fitogenéticos del INIA

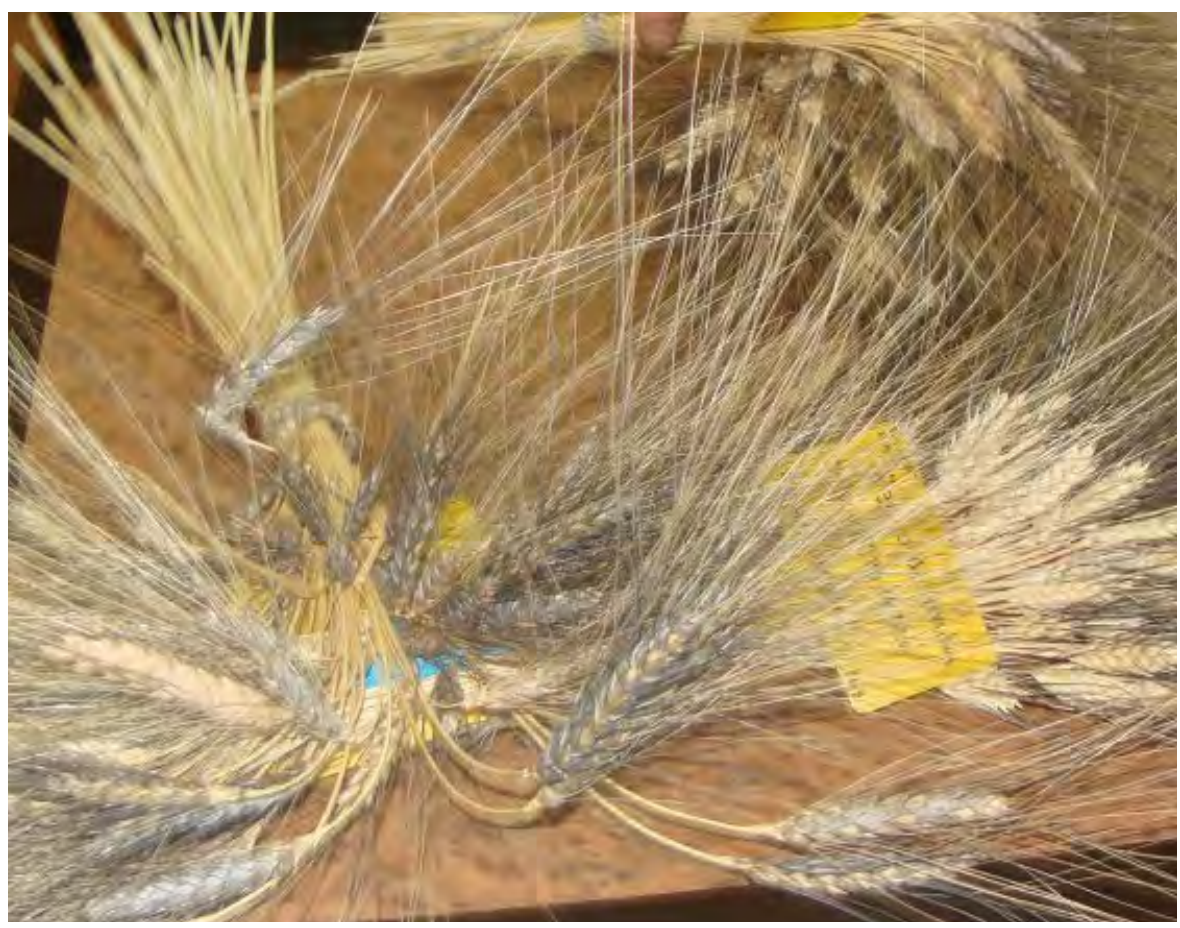


y la variedad comercial "Bronte". Los ensayos se llevaron a cabo en la fincas Ortuño, José Madalena y Antonio Campos en el municipio de Alozaina (Málaga) y en la finca Los Portales en Castilblanco de los Arroyos (Sevilla) (Carrascosa-García et ál. 2019).

Si bien las variedades tradicionales presentan una gran diversidad que permite adaptarse a las fluctuaciones de los sistemas de cultivo de secano, los sistemas agrícolas actuales y la demanda de productos locales no es la misma que la de hace unos años. Se hace pues necesaria continuar la mejora, integrando los conocimientos tradicionales practicados por los agricultores locales con las técnicas de selección vegetal desarrolladas a partir del redescubrimiento de las leyes de la genética.

La carencia de un sistema local de mejora, que integre ambas fuentes de conocimiento, había quedado patente en años anteriores a través de las experiencias desarrolladas en el marco del proyecto Farm Seed Opportunities ${ }^{2}$ (Valero et ál. 2010). Para paliar esta carencia, en la mejora participativa de trigos desarrollada en el proyecto CERERE se elaboró un protocolo para la selección de mezclas de poblaciones de cereales, dando la posibilidad a los agricultores/as de elegir las prácticas de selección en función de sus objetivos (van Frank 2018).

El trigo es una planta que en condiciones naturales se autopoliniza en un $95 \%$ y el polen restante se dispersa por medio del viento a las plantas cercanas, por lo que se dan pocos cruzamientos dentro de una población. Con el fin de aumentar la diversidad en caso de considerarlo necesario para la mejora se ha adaptado un protocolo para que los agricultores puedan fácilmente forzar de manera manual los cruzamientos (CERERE 2018a).

\section{BUENAS PRÁCTICAS EN EL PROCESAMIENTO Y ELABORACIÓN DE LOS PRODUCTOS BASADOS EN LA BIODIVERSIDAD LOCAL}

La puesta en valor de la biodiversidad cultivada está estrechamente vinculada a la recuperación de la demanda local. Mientras en algunos cultivos es posible la comercialización directa del producto, como pasa en el caso de hortalizas, frutales y legumbres, en el caso de los cereales su consumo se realiza en forma de pan y pasta, por lo que es necesario un proceso de transformación y elaboración.

Estos procesos tradicionales también han sufrido una importante erosión, habiendo sido sustituidos por otros industriales. En el caso de la molienda industrial el molido con piedras ha sido sustituido por el molido con cilindros metálicos que tiene mayor potencia, lo que afecta al contenido en salvado y germen de las harinas.

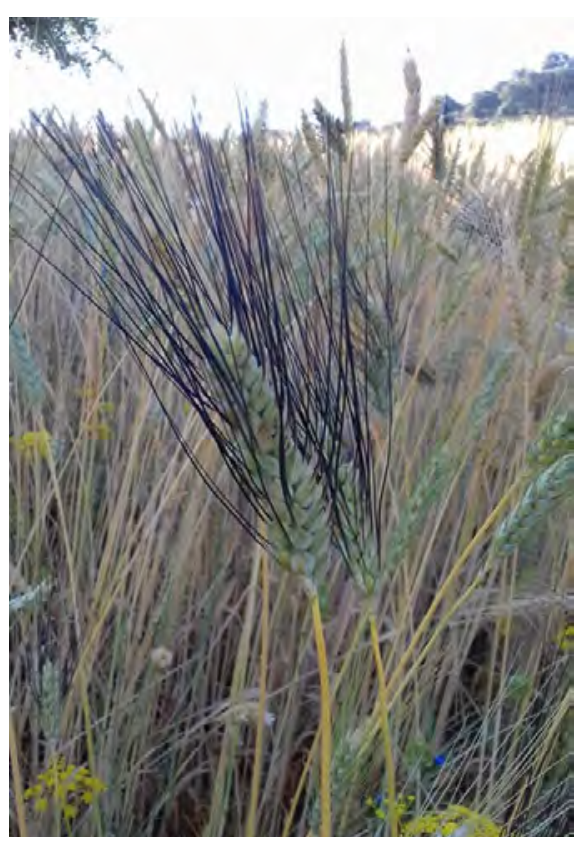

Ensayo de descripción de variedades de trigo recio de Ronda

$$
2
$$

FSO Farm Seed Opportunities es un proyecto de investigación del $6^{\circ}$ Programa Marco de la Unión Europea. Disponible en: http://www. louisbolk.org/downloads/2529.pdf [Consulta: 28/09/2021]. 
Lo importante del proceso artesanal es realizar la molienda del grano entero, sin separar el germen ni todo el salvado, aportando mayor sabor y nutrientes a la harina. Generalmente la industria convencional prefiere harinas que no contengan germen porque se oxida con relativa rapidez y la enrancia, imposibilitando el almacenamiento durante largos periodos. Por el contrario, en panaderías artesanales se valora este tipo de harina, porque al ser frescas tienen mejores propiedades organolépticas y nutracéuticas que las que ya llevan tiempo procesadas.

En la panificación influyen diversos elementos, algunos de ellos derivados directamente de las propiedades de las variedades de trigo y otros relacionados con la masa madre utilizada en el proceso de fermentación y en las condiciones en las que se realiza el amasado, reposo y horneado. Para atender a estas cuestiones se han planteado soluciones basadas en la colaboración participativa de quienes hacen el pan con quienes cultivan el trigo y quienes lo consumen (Vindras-Fouillet y Serpolay-Besson 2020).

En Andalucía contamos con experiencias de panificación artesanal. Una de ellas es fruto de la colaboración entre la iniciativa Pan Para Todos y Más y la RAS. La molienda del grano la realizan en su propio molino eléctrico que trabaja con energía solar. La elaboración de pan sigue siendo de forma totalmente artesanal, amasados a mano, con masa madre y fermentación lenta y el horneado se hace en horno de leña. Disponen de su propia variedad tradicional de trigo Chamorro que les da singularidad a sus panes y experimentan con nuevas variedades tradicionales para mejorar su oferta (Chable et ál. 2019a, 26-32; Carrascosa et ál. 2019).

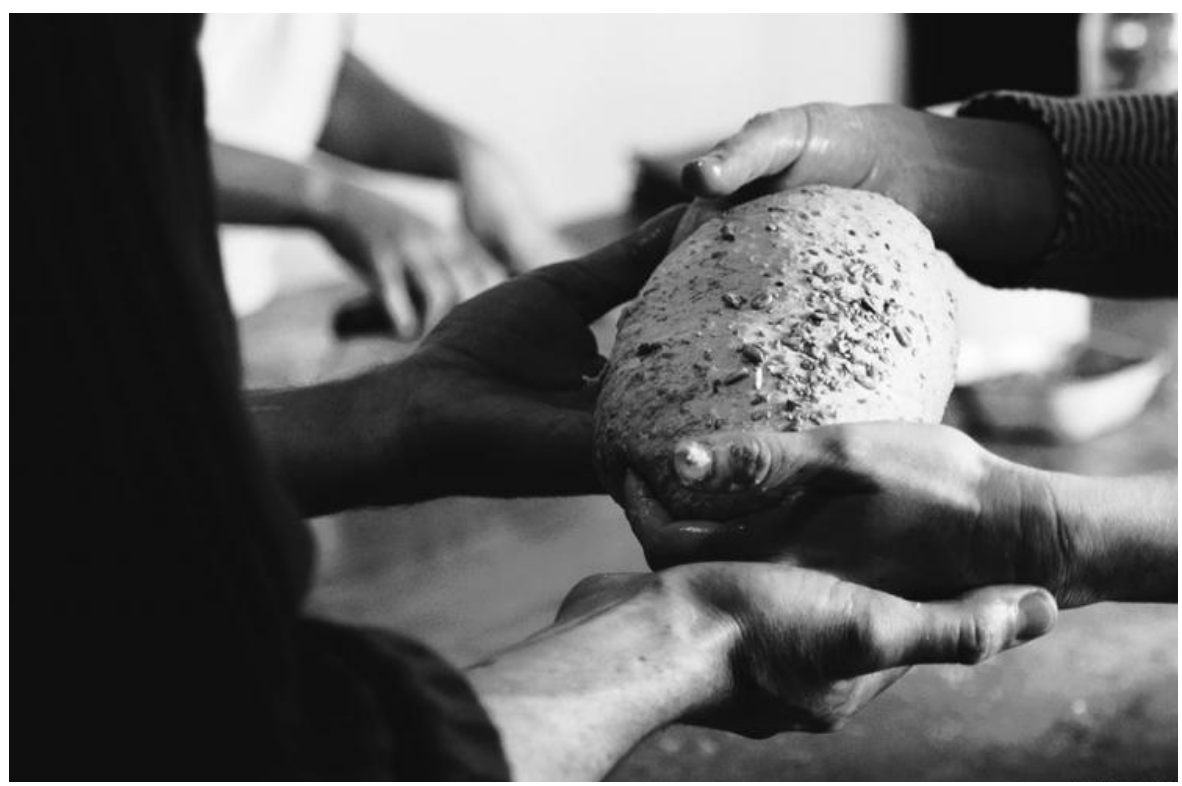




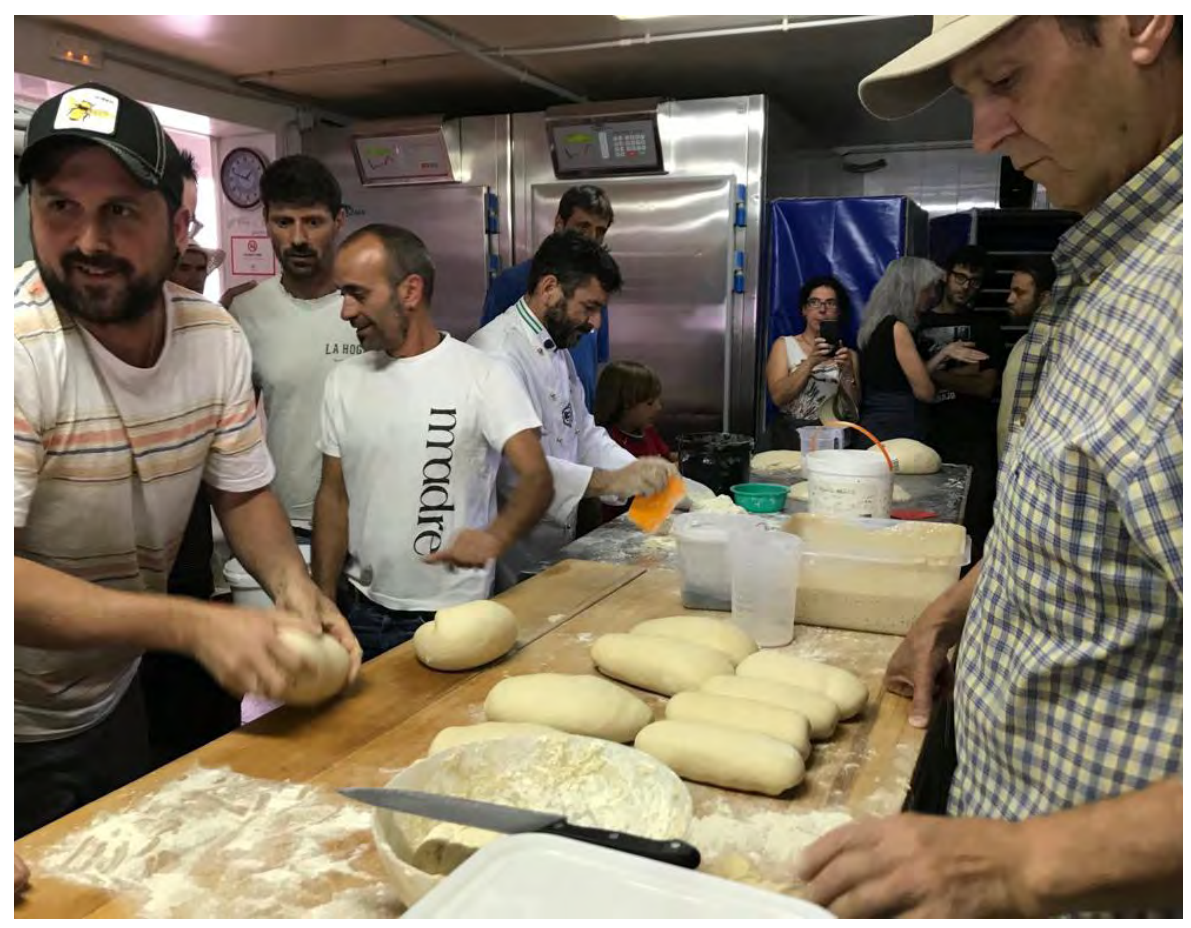

Otra experiencia se está desarrollando con La Artesa, panadería artesana situada en Sevilla, que ha incorporado dos variedades tradicionales (trigo duro Recio de Ronda y trigo blando Chamorro) para la elaboración de panes (Red Andaluza de Semillas 2018). En ambas iniciativas la comercialización de los panes se realiza a través de grupos de consumo, comercio local y ecomercados, esto permite generar un compromiso entre las partes implicadas, a nivel de cantidades y formatos suministrados y de precios adecuados a las diferentes necesidades.

También en la elaboración de pasta mediante procedimientos tradicionales se están desarrollando experiencias en Andalucía por parte de la empresa local Spiga Negra, un proyecto de elaboración artesanal de pasta. Spiga Negra cuenta con su propio molino ecológico y la infraestructura necesaria (prensa, moldes, armarios secadores). Para la elaboración artesanal de pasta de calidad siguen la tradición italiana, utilizando moldes de bronce que otorgan una rugosidad característica que permite un sabor más intenso al ser cocinadas. Posteriormente el secado se realiza de forma lenta, y a temperaturas siempre inferiores a los $40^{\circ} \mathrm{C}$. Un aspecto a destacar de esta iniciativa es el vínculo establecido con los productores y productoras de cereales con quienes planifican la producción y acuerdan los precios y cantidades de manera conjunta. Para ampliar las variedades de trigo que utilizan están colaborando con la Universidad Pablo de Olavide (UPO) en la evaluación de variedades (Chable et al. 2019b).
Taller de elaboración de pan con variedades locales de trigo en Cuevas del Becerro (Málaga) 


\section{BUENAS PRÁCTICAS PARA LA INTEGRACIÓN DE LA COMERCIALIZACIÓN Y EL CONSUMO EN EL CONOCIMIENTO Y VALORIZACIÓN DEL PATRIMONIO GENÉTICO AGRÍCOLA}

Uno de los actores colectivos con mayor trascendencia en el éxito de estas experiencias de conservación y revitalización del patrimonio cultural basadas en la biodiversidad cultivada lo constituyen los grupos de consumo. La RAS tiene una amplia trayectoria de trabajo con personas consumidoras de productos derivados de variedades locales a través de experiencias de evaluación participativa de variedades locales (Carrascosa et ál. 2012). La experiencia con trigos ha contribuido a mejorar la colaboración en el ámbito del consumo, organizando visitas a las fincas donde se han ensayado las variedades y recopilando información sobre la evaluación de la calidad de los panes tradicionales.

Para la evaluación de la calidad sensorial se ha adaptado un protocolo que permite aprovechar la experiencia de los panaderos expertos en la elaboración de masas (consistencia, fermentación ideal) hasta el horneado y poder formar a las personas consumidoras en el conocimiento de metodologías sensoriales. Para ello se ha partido del método del Napping, basado en una representación de la distancia sensorial, que se aplica y se modula constantemente a la luz de los resultados. Este test consiste en medir la distancia sensorial percibida entre los diversos panes por cada degustador. De los datos obtenidos, analizados en su conjunto, se desprenden las diferencias principales que perciben la mayoría de los degustadores (CERERE 2018b).

Otra intervención de los grupos de consumo que cada día adquiere una mayor relevancia son los sistemas participativos de garantía (SGP). Se trata de procedimientos acordados entre todos los intervinientes en la cadena de producción para certificar que el producto ha sido cultivado, procesado y comercializado siguiendo prácticas respetuosas con la producción local.

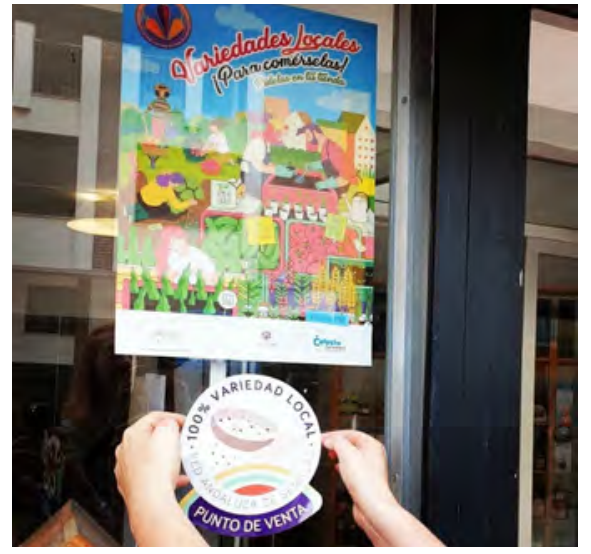
Esto permite crear distintivos identificables en los puntos de consumo que proporcionan confianza a quienes desean apoyar el desarrollo local y mejorar la calidad de su alimentación.

En uno de los estudios de caso de CERERE, se recoge una experiencia de sistema de garantía participativo, el de la Associazione Grani Antichi Montespertoli. Han desarrollado un sistema de control, basado en la participación activa de todas las partes interesadas (agricultores, molinero y panaderos), que es muy eficaz en el contexto local gracias a la confianza de los actores en el trabajo recíproco y a los mecanismos de construcción de la reputación fuera de la cadena. torno a una estrategia más amplia de comunicación para visibilizar y diferen- 


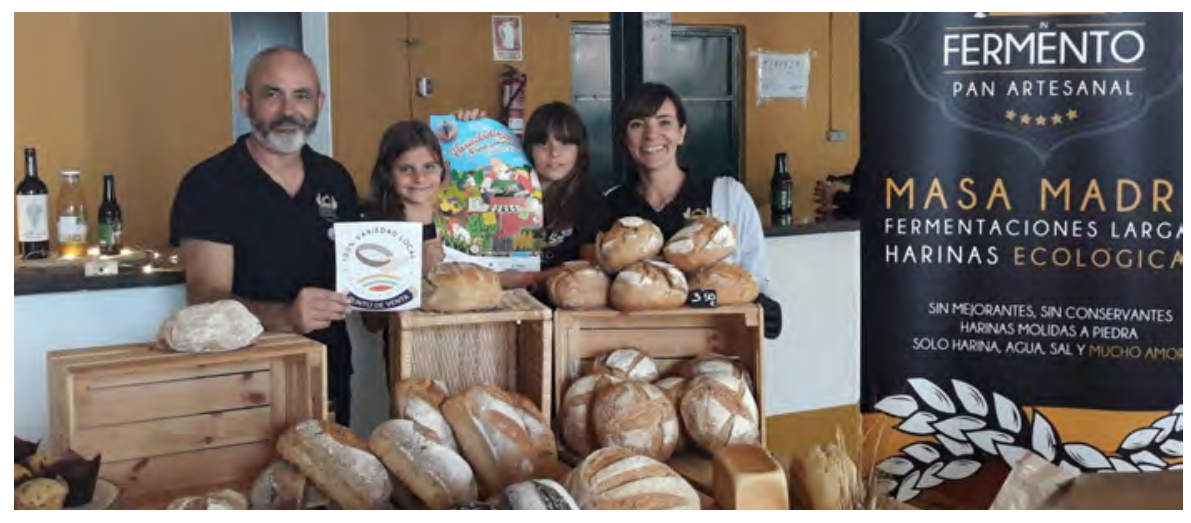

In Fermento, obrador de pan artesanal y ecológico

ciar los productos procedentes de variedades locales de cultivo disponibles en el mercado. Se ha creado el distintivo $100 \%$ variedad local como elemento clave para la valorización de la biodiversidad cultivada y se han establecido una serie de criterios protocolarios de uso: en qué tipo de variedades se va a utilizar, el tipo de origen de la semilla, los lugares a los que está destinado, etc. (Vara Sánchez et ál. 2020).

Los SGP representan un modelo de innovación social capaz de interpretar las necesidades de los territorios locales que a menudo las normativas nacionales y/o europeas no consiguen reflejar. De hecho, el desarrollo de los SGP facilita varios procesos sociales que, por una parte, favorecen la inclusión social y la cohesión al reforzar las relaciones de confianza entre los pertenecientes a redes agrícolas y, por otra, crean un círculo virtuoso en el que las reglas de la red y el conocimiento recíproco invitan a implantar un sistema de garantía eficiente (CERERE 2019).

\section{A MODO DE CONCLUSIÓN}

El mantenimiento sostenible de los agroecosistemas requiere generar un nuevo conocimiento que integre los avances científicos y técnicos en el ámbito de la agronomía con el conocimiento tradicional desarrollado localmente por generaciones de agricultores y agricultoras.

Este camino pasa necesariamente por intensificar la investigación participativa en el ámbito de la agroecología, fortaleciendo la cooperación entre los organismos de investigación y las organizaciones de base comprometidas con el desarrollo local y la soberanía alimentaria.

Como se ha intentado ilustrar en este capítulo, el fruto de esta colaboración, se traduce en buenas prácticas que permiten poner en valor nuestro extenso patrimonio genético agrícola. 


\section{BIBLIOGRAFÍA}

- Carrascosa, M.; J.M. González, L. Toledo, J.J. Soriano, P. López, T. García-Muñoz, P. González y I. Sanz (2012) Recuperación de variedades tradicionales, una estrategia combinada de conservación de la biodiversidad agrícola, agroecología y desarrollo sostenible del medio rural en Andalucía. En: Labrador, J. y Gonzálvez, V. (coord.) Actas del $X$ Congreso de SEAE "20 años impulsando la producción ecológica". Albacete, 26-29 septiembre 2012. Valencia: SEAE-Sociedad Española de Agricultura Ecológica. Disponible en: https://www.agroecologia.net/ recursos/publicaciones/actas/cd-actas-xcongresoseae/ index.html [Consulta:05/07/2021]

- Carrascosa-García, M., Soriano Niebla, J.J., Navarro Chaves, A., Toledo, L., Roldán, E., Fulgado, J.A., González, P., González, M., Martínez, I. y Ceccarelli, S. (2019) Evaluación participativa de variedades locales de trigo y tomate en Andalucía. Red Andaluza de Semillas. Disponible en: https://www.redandaluzadesemillas.org/ sites/default/files/recursos/2019/190821\%20Informe\%20 DIVERSIFOOD\%20 evaluacion $\% 20$ trigos $\% 20 y \% 20$ tomates.pdf [Consulta:05/07/2021]

- Chable, V., Ducottet, Ch., Kutelmach, M. Flipon, E., De Santis, G. Rodríguez, I. (ed.) (2019a) Biodiversidad agrícola: historias de éxito en Europa. CERERE Project. Disponible en: http://cerere2020.eu/wp-content/uploads/2021/01/CERE RE_Book_Case_studies_SPANISH.pdf [Consulta: 06/07 /2021]

- Chable, V., Ducottet, Ch., Kutelmach, M. Flipon, E., De Santis, G. Rodríguez, I. (2019b) Spiga Negra, una iniciativa local de producción de pasta artesanal y ecológica. En: Biodiversidad agrícola: historias de éxito en Europa. CERERE Project. Disponible en: http://cerere2020.eu/wpcontent/uploads/2021/01/CERERE Book Case studies SPANISH.pdf [Consulta:06/07/2021]

- CERERE [CEreal REnaissance in Rural Europe] (2018a) Cruzamientos manuales para impulsar la diversidad genética de las poblaciones de cereales. Ficha informativa sobre innovación CERERE \#9, marzo 2018. Disponible en: http://cerere2020.eu/wp-content/uploads/2020/03/9 ES.pdf [Consulta:06/07/2021]

- CERERE (2018b) Estudio sobre la calidad de los panes campesinos. Ficha informativa sobre innovación CERERE \#6. septiembre 2018. Disponible en: http:// cerere2020.eu/wp-content/uploads/2020/03/6_ES.pdf [Consulta:06/07/2021]

- CERERE (2019) Los sistemas de garantía participativa (sgp) para valorar y asegurar la autenticidad de las cadenas de cereales antiguos. Ficha informativa sobre innovación CERERE \#19, marzo 2019. Disponible en: http://cerere2020.eu/wp-content/uploads/2020/03/19 ES.pdf [Consulta:06/07/2021]
- González, J., Carrascosa, M., Soriano, J., GarcíaMuñoz, T., Toledo, L., López, P., Hidalgo, J., y Navarro, A. (2014) Investigación-Acción Participativa como herramienta de empoderamiento: El caso de la descripción participativa de variedades tradicionales en las redes de intercambio de semillas. En: Herrera Molina, F., Tarifa García, F. y Hernández Bermejo, E. (ed.): ICEB 2014 : VI Congreso Internacional de Etnobotánica, 17-21 de Noviembre, Córdoba. Córdoba : IMGEMA, Jardín Botánico de Córdoba

- Muñoz Pineda C. (2010) Caracterización de variedades locales hortícolas andaluzas. TFMáster de Agricultura Ecológica inédito, Universidad de Barcelona. Disponible en: https://www.redandaluzadesemillas.org/sites/default/files/ recursos/2020/proyecto\%20UB.pdf [Consulta:05/07/2021]

- Red Andaluza de Semillas (2012) Informe Descripción de variedades tradicionales andaluzas en fincas agroecológicas de Sevilla, Córdoba, Cádiz y Málaga. Temporada Primavera-Verano 2012. Disponible en: https://www.redandaluzadesemillas.org/sites/default/ files/recursos/2020/121231_informe\%20descripcion\%20 VL\%20en\%20Sevilla\%20Cordoba\%20Cadiz\%20y\%20 Malaga.pdf [Consulta:05/07/2021]

- Red Andaluza de Semillas (2018) Elaboración de pan artesano y ecológico con variedades tradicionales de trigo duro y trigo blando. Resumen de prácticas CERERE \#2, mayo 2018. Disponible en: http://cerere2020.eu/wpcontent/uploads/2019/01/211205-2PA-Baking-traditionalvarieties-RAS-ESP.pdf [Consulta:06/07/2021]

- Sacchi, G., Cei, L., Stefani, G., Lombardi, G.V., Rocchi, B., Belletti, G., Padel, S., Sellars, A., Gagliardi, E., Nocella, G., Cardey, S., Mikkola, M., Ala-Karvia, U., MackenWalsh, À., McIntyre, B., Hyland, J., Henchion, M., Bocci, R., Bussi, B., De Santis, G., Rodriguez y Hurtado, I., De Kochko, P., Riviere, P., Carrascosa-García, M., Martínez, I., Pearce, B., Lampkin, N., Vindras, C., Rey, F., Chable, V., Cormery, A. y Vasvari, G. (2018) A Multi-Actor Literature Review on Alternative and Sustainable Food Systems for the Promotion of Cereal Biodiversity. Agriculture, 2018, vol. 8, n. ${ }^{\circ} 11,173$. Disponible en: https://www.mdpi.com/20770472/8/11/173 [Consulta: 08/09/2021]

- Soriano Niebla, J.J. (coord.) (2004) Hortelanos de la Sierra de Cádiz. Las variedades locales y el conocimiento campesino sobre el manejo de los recursos genéticos. Villamartín, Cádiz: Mancomunidad de municipios de la Sierra de Cádiz

- Soriano, J.J., Carrascosa, M., González, J.M., García, T. y Sanz, I. (2013) Mejora agroecológica participativa (MAP) y biodiversidad agrícola. Aplicación de la investigación-acción participativa al manejo de las variedades tradicionales en Andalucía. Agroecología, vol. 7, n. ${ }^{\circ}$ 2, pp. 21-30. Disponible en línea: https://revistas.um.es/agroecologia/article/view/ 182821 [Consulta: 05/07/2021] 
- Sofi, F., Dinu, M., Pagliai, G., Cei, L., Sacchi, G., Benedettelli, S., Stefani, G., Gagliardi, E., Tosi, P., Bocci, R., Bussi, B., De Santis, G., Rodriguez y Hurtado, I., De Kochko, P., Riviere, P., Carrascosa-García, M. y Martínez, I. (2018) Health and Nutrition Studies Related to Cereal Biodiversity: A Participatory Multi-Actor Literature Review Approach. Nutrients 2018, 10(9), 1207. Disponible en: https://doi.org/10.3390/nu10091207 [Consulta: 05/07/2021]

- Toledo, L., González, J.M., Carrascosa-García, M., y López, P. (2011a) Informe Huerta experimental. Red de Resiembra e Intercambio de variedades locales de cultivo. Temporada Otoño-Invierno 2010-2011. Sevilla: Red Andaluza de Semillas. Disponible en: https:// www.redandaluzadesemillas.org/sites/default/files/ recursos/2020/Informe_RAS_Huerta_Experimental_OI_2010-2011_01feb2011.pdf [Consulta: 05/07/2021]

- Toledo, L., González, J.M., Muñoz, C., Soriano, J.J., y García-Muñoz, T. (2011b) Informe de la Huerta experimental de la Red de Resiembra e Intercambio de variedades locales de cultivo. Temporada Primavera-Verano 2011. Sevilla: Red Andaluza de Semillas

- van Frank, G. (2018) Gestion participative de la diversité cultivée et création de mélanges diversifiés de blé tendre à la ferme. Génétique des populations. Tesis doctoral inédita, I'Universitè Paris-Saclay. Disponible en: https://tel.archivesouvertes.fr/tel-02301993/document [Consulta: 06/07/2021]

- Valero, T., González, J.M., Soriano, J.J. y López, P. (2010) Oportunidades para la conservación, mejora y producción de las semillas campesinas. En: Gonzálvez, V. (coord.) Actas del IX Congreso de SEAE: Calidad y seguridad alimentaria. Lleida, 6-9 de octubre 2010. Valencia: SEAESociedad Española de Agricultura Ecológica, pp. 226-238. Disponible en: http://orgprints.org/29758/1/actas-Ileida-vd. pdf [Consulta: 26/07/2021]

- Vara Sámchez, I., Soriano Niebla, J.J., Gallar Hernández, D. y Iglesias Losada, B. (2020) Variedades locales en Andalucía. Debates y recomendaciones para fomentar su producción, comercialización y consumo en sistemas alimentarios sostenibles. Sevilla: Red Andaluza de Semillas. Disponible en: https://www.redandaluzadesemillas.org/sites /default/files/recursos/2020/Variedades\%20locales\%20 en\%20Andalucia\%20Debates\%20y\%20recomendaciones. pdf [Consulta: 26/07/2021]

- Vindras-Fouillet, C. y Serpolay-Besson, E. (2020) Recopilación de soluciones para la panificación. Booklet \#3, CERERE Project. Disponible en: http://cerere2020.eu/ wp-content/uploads/2020/06/Booklet3_ESP.pdf [Consulta: 06/07/2021] 


\section{Conocimientos locales y desarrollo sostenible en Perú. El proyecto SIPAM Agrosistemas de alta montaña}

Beatriz Pérez Galán | Dpto. de Antropología Social y Cultural, Universidad Nacional de Educación a Distancia (UNED)

URL de la contribución <www.iaph.es/revistaph/index.php/revistaph/article/view/4949>

\section{RESUMEN}

En esta contribución se reflexiona sobre las bases sociales y culturales de los sistemas agrícolas tradicionales en el caso de los pueblos indígenas al sur de los andes peruanos. El ejemplo se extrae del proyecto piloto Agroecosistemas de alta montaña de Machupichhu al lago Titicaca, integrado al programa SIPAM (FAO-GEF). Desde una perspectiva antropológica crítica y con el énfasis puesto en la matriz cultural de las prácticas agrícolas tradicionales indígenas, en este texto se analiza la concepción estática, reificada, homogénea y esencialista que es atribuida en la práctica por el discurso conservacionista y del desarrollo sostenible a los conocimientos locales indígenas en este proyecto, lo que dificultaría en la práctica su conservación.

\section{Palabras clave}

Conocimientos locales | Desarrollo sostenible | Los Andes | Patrimonio agrícola | Pueblos indígenas | SIPAM | Perú | 


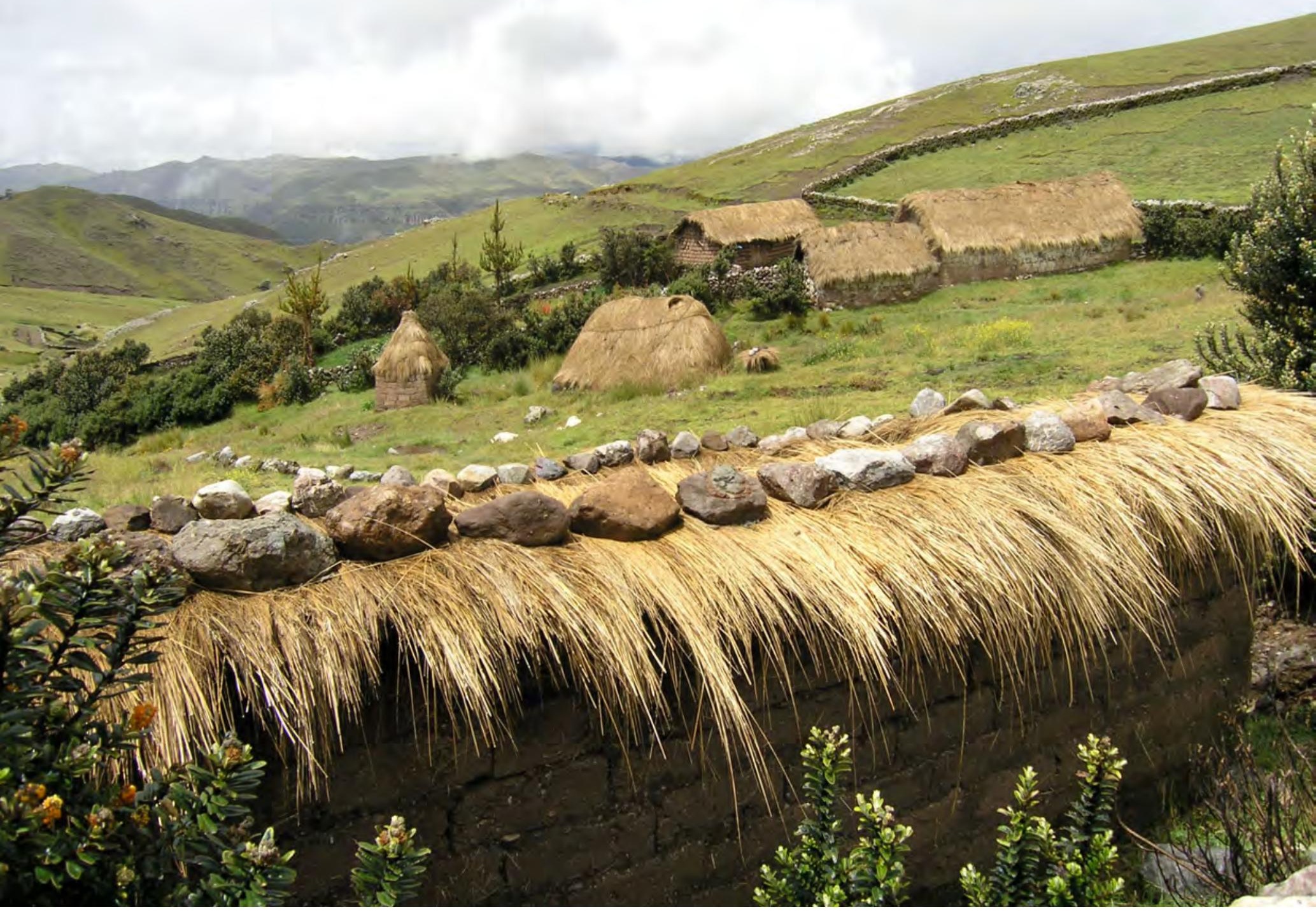

Casas tradicionales. Distrito de Accha, Paruro, Cuzco | foto Beatriz Pérez Galán, autora de todas las imágenes que ilustran este artículo, salvo que se indique lo contrario 
Una versión previa de este texto fue publicada en 2015 (Pérez Galán, 2015) en el marco del proyecto de investigación El patrimonio agrario. La construcción cultural del territorio a través de la actividad agraria financiado por el Ministerio de Ciencia e Innovación, Plan Nacional de I+D+i, 2011-14.

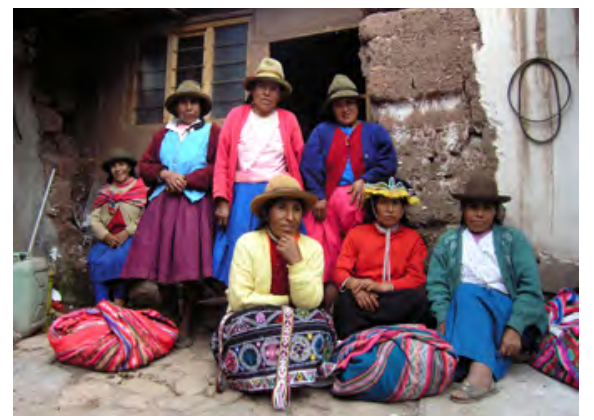

Fila india de autoridades mujeres o wachu, Pisac, Cuzco

\section{BASES SOCIOCULTURALES DE LOS SISTEMAS AGRÍCOLAS TRADICIONALES ANDINOS ${ }^{1}$}

En la literatura antropológica existen numerosos ejemplos en los que se analizan metáforas mediante las cuales concebimos y ordenamos simbólicamente nuestra experiencia cotidiana en categorías culturales (Lakoff y Johnson 1995). En el caso de los pueblos y comunidades indígenas de los Andes las analogías más habitualmente utilizadas proceden de los elementos de una naturaleza profundamente sacralizada, de los animales y, de forma singular, de las prácticas agrícolas. Concretamente, la imagen que emplean los indígenas quechuas del valle del río Vilcanota en el Dpto. de Cuzco para referirse a un tipo de ordenamiento normativo social, cosmológico y político es el wachu o surco de la siembra más profundo y con lomos más altos de lo habitual. Otras técnicas tradicionales del trabajo agrícola son los campos elevados (camellones o suqakollo) y las terrazas de cultivo (andenes, bancales o pata-pata), que constituyen algunos de los paisajes más emblemáticos de América Latina.

En concreto, la metáfora del surco de la siembra se emplea actualmente por esta población para designar un conjunto amplio de prácticas culturales relativas a la organización social, económica, política y religiosa. Entre los ejemplos más evidentes del paralelismo que los runas (seres humanos) establecen entre uno y otro campo semántico podemos mencionar: la alternancia de ciclos de cultivos y descanso de las parcelas, y su obligación de atender por turno los trabajos comunitarios; entre los sistemas de trabajo agrícola basados en la reciprocidad (ayni, minka), y la serie de derechos y obligaciones que estructuran su sistema de autoridades tradicionales; entre la forma de cultivar la tierra en parejas warmi-qari (varón-mujer), y la manera en que son asumidos y realizados los cargos de representación comunal; y quizás, el más evidente de todos ellos: entre la distribución lineal de las semillas en el surco de la siembra o wachu, propiamente dicho, y la colocación también lineal en cualquier faena comunal o evento festivo-religioso de las autoridades tradicionales, cuya cabeza visible son los alcaldes envarados (varayoq) (Pérez Galán 2004).

Este breve ejemplo etnográfico ilustra además la continuidad que las cosmovisiones indígenas establecen entre el mundo biofísico, el humano y el sobrenatural como parte de una misma comunidad social integrada por animales, plantas y el resto de seres que habitan el entorno natural. La antropología (Ploeg 1990; Escobar 1999; Descola 2001; Viveiros de Castro 2013), la etnoecología (Toledo 1992), y la agroecología (Hecht 1999; Altieri 1999) son algunas de las disciplinas que apuestan por superar la dicotomía naturaleza-cultura característica del pensamiento occidental y considerar las bases socioculturales de las prácticas agrícolas y los sistemas de conocimiento local en que estas se sustentan. Desde esa perspectiva, el valor cultural 


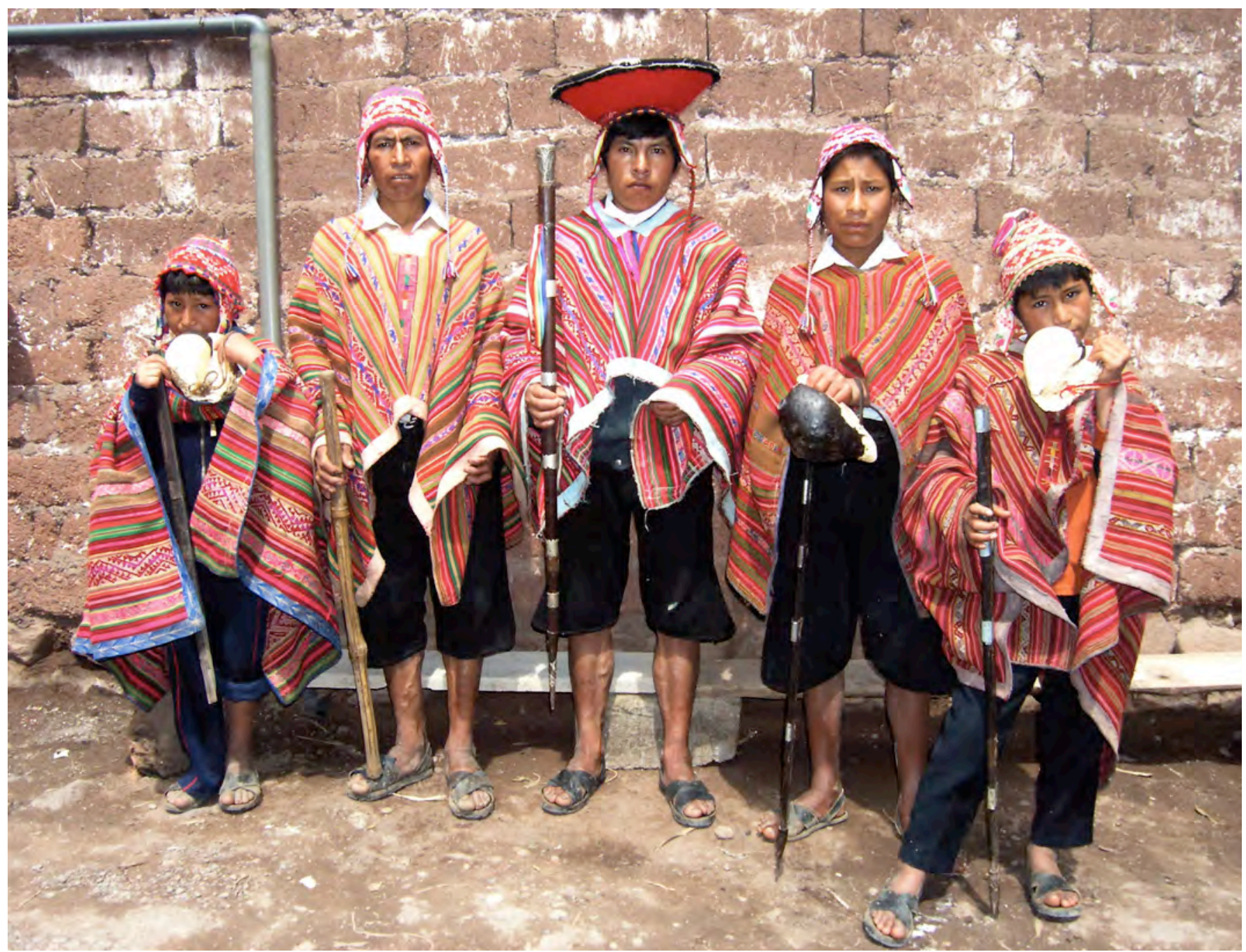

Fila india o wachu de las autoridades tradicionales de vara. Pisac, Cuzco

de los sistemas agrícolas tradicionales indígenas residiría no tanto en su asociación a un entorno natural extraordinario que es necesario conservar (parques naturales y arqueológicos, reservas de la biosfera o centros de diversidad genética), sino además por constituir un conglomerado de significados a la vez ordenados y ordenadores de la cosmología del grupo que transmite un modo de vida de la gente que habita ese territorio (Cosgrove 1984; Connerton 1989; Küchler 1993; Hirsch 1995).

Con el énfasis puesto en la matriz cultural de los sistemas agrícolas, en este texto entendemos el conocimiento de las poblaciones locales como una actividad práctica sociocultural, situada y cambiante. Siguiendo a distintos autores (Ploeg 1990; Warren, Slikkerveer y Brokensha 1995; Reyes-García 2007), estas formas de conocimiento se caracterizarían por su alto grado de 
Impulsado en 2002 por la Organización de las Naciones Unidas para la Agricultura y la Alimentación (FAO), los SIPAM (GIAHS, siglas en inglés) son definidos como "sistemas de uso de la tierra y paisajes extraordinarios ricos en diversidad biológica de importancia mundial, evolucionando desde la co-adaptación de una comunidad con su ambiente y sus ne cesidades y aspiraciones para un desarrollo sostenible" (Koohafkan y Altieri 2010, 1)

\section{3}

Entre los antecedentes directos del SIPAM peruano, se incluyen: el Proyecto Conservación in situ de Cultivos Nativos y de sus Parientes Silvestres (2001-06), una de las experiencias más completas en ese ámbito coordinada de varias organizaciones peruanas públicas y privadas dedicadas a la conservación (ARARIWA, CCTA, CESA, IIAP, INIA y PRATEC) Otras iniciativas de conservación menos ambiciosas y con resultados dispares han sido promovidas por el Servicio Silvo Agropecuario (SESA), la ONG Jorge Basadre, ASPADERUC, CONDESAN, y el proyecto Conserva ción in situ de Raíces y Tuberosas Andinas, ejecutado por el PRONIRGEB-INIA. En e sector de las ONGs destacan CIED, IDEAS CEDEP, DESCO, PISCA, e IDEMA, la aso ciación Andes-Parque de la Papa (Pisac), la Red de Agricultura Ecológica, y la Asociación Nacional de Productores Ecológicos (ANPE).

4

El Fondo Mundial para el Medio Ambiente o GEF (en sus siglas en inglés) es una asociación global integrada por 178 países, instituciones internacionales, organizaciones no gubernamentales y el sector privado. Creada en 1991 como un programa específico del Banco Mundial para la protección del medio ambiente y el desarrollo sostenible, se reestructura en 1994 como institución independiente para convertirse en un mecanismo financiero de las convenciones de Río. Más información en: https://www.thegef.org/project/cbpf-conservation-and-adaptive-management-globally-important-agricultural-heritage-systems [Consulta: $28 / 05 / 2021]$ heterogeneidad, por ser subjetivas (dependientes de sujetos que lo significan), por transmitirse oralmente, por su origen híbrido (mezcla de tradiciones de diversa procedencia reapropiadas históricamente), por su recurrencia a la "tradición" como criterio de autoridad, y por formar parte de un todo que está integrado práctica y conceptualmente en sistemas de valores y creencias (cosmovisión). Esta concepción antropológica se aleja de la naturaleza estática, reificada, homogénea, aborigen y ancestral atribuida frecuentemente por el discurso conservacionista y del desarrollo sostenible a los conocimientos locales que dificulta en la práctica su conservación (Erickson 2006; Herrera 2013; Pérez Galán 2015).

Para ilustrar esta idea, el ejemplo etnográfico procede del proyecto piloto Agroecosistemas de alta montaña de Machupicchu al Lago Titicaca, integrado en el programa Sistemas Importantes del Patrimonio Agrícola Mundial² (FAO 2008; Koohafkan y Altieri 2010). En este territorio se concentra una enorme variedad de especies endémicas (papas, maíces, quinoas y frutales nativos), crianzas nativas (alpacas), y el uso de tecnologías tradicionales agrícolas como los wachus, los andenes, los campos elevados y la cosecha del agua de lluvia en lagos artificiales, muchas en desuso en la actualidad. Para paliar las amenazas que afectan a este territorio como la migración a la ciudad, la modernización tecnológica, el cambio climático, la erosión, la pérdida de la biodiversidad asociada y las barreras de la competencia con alimentos importados y subsidiados, el SIPAM peruano se une a otras iniciativas de conservación in situ de la biodiversidad que en las últimas dos décadas han tratado de conservar y poner en valor los sistemas agrícolas tradicionales en la región ${ }^{3}$. En particular, como antropóloga, en esta oportunidad me interesa explorar el papel otorgado de facto en este proyecto a la población local y cuál es la contribución efectiva de sus formas de organización socioeconómicas y políticas y de sus conocimientos locales sobre sistemas de cultivo, tecnologías agrícolas y manejo del suelo, aspectos que distinguirían sobre el papel al programa SIPAM de otros (Howard et ál. 2008; Koohafkan y Altieri 2010).

\section{EL SIPAM PERUANO}

El proyecto SIPAM-Perú es resultado de un largo proceso de gestación que se remonta al año 2003 cuando reconocidos expertos peruanos en agrobiodiversidad y tecnologías agrícolas andinas se unen para elaborar una propuesta que combinase los conocimientos tradicionales agrícolas andinos y la innovación tecnológica. En 2004 esta propuesta se eleva a la FAO y a GEF4 a través del Consejo Nacional del Ambiente (CONAM), entonces el órgano gestor del Ministerio del Ambiente (MINAM) en materia de política ambiental y patrimonio natural en el país. Este proyecto contará con la colaboración del entonces Ministerio de Agricultura (MINAG) a través del Instituto Nacional de 


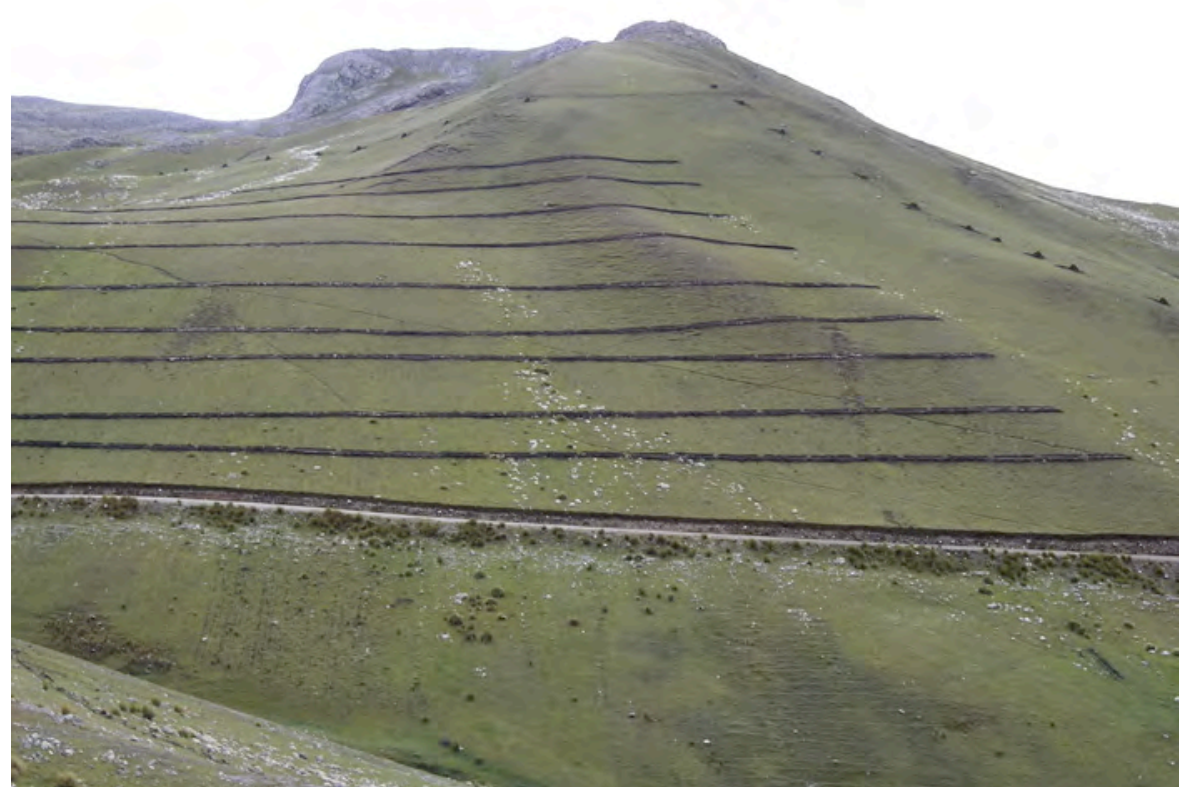

Investigación Agraria y del Proyecto "Corredor Puno-Cusco" (CONAM 2006, 2007).

Una vez seleccionado como uno de los seis sitios piloto donde poner en práctica las tesis de la conservación dinámica del patrimonio agrícola que propone el programa SIPAM, se inicia un tortuoso proceso de planificación, ajustes presupuestarios y programáticos que retrasan más de seis años el comienzo de actividades. Como resultado de estos ajustes, el proyecto originalmente diseñado para cinco años y con un presupuesto de casi dos millones de dólares (USA) queda reducido a algo menos de un tercio (600.000\$), la mitad del tiempo (de enero de 2011 a junio de 2013), y a un equipo formado por solo dos coordinadores. Ellos serán los encargados de abarcar el trabajo en 17 comunidades -unas 2500 familias-, pertenecientes a dos grupos étnicos -quechuas y aymaras-, dispersas en un área de $350 \mathrm{~km}$ (distritos de Lamay y Lares en Cuzco, y San José y Ácora en Puno), con una deficiente conectividad, sin técnicos de campo, sin oficinas y sin vehículo propio, circunstancias que lastrarán en gran medida los resultados de este proyecto.

La selección de este vasto territorio responde a un conjunto de criterios combinados. Además de poseer una excelsa biodiversidad seriamente amenazada, estas comunidades se diferencian de sus vecinas en dos aspectos clave: por un lado, la existencia de un capital social en la población de las comunidades que deriva de la experiencia previa acumulada por su participación en proyectos de recuperación de tecnologías indígenas coordinados por los mismos técnicos ${ }^{5}$. Y por otro, por el emplazamiento del proyecto
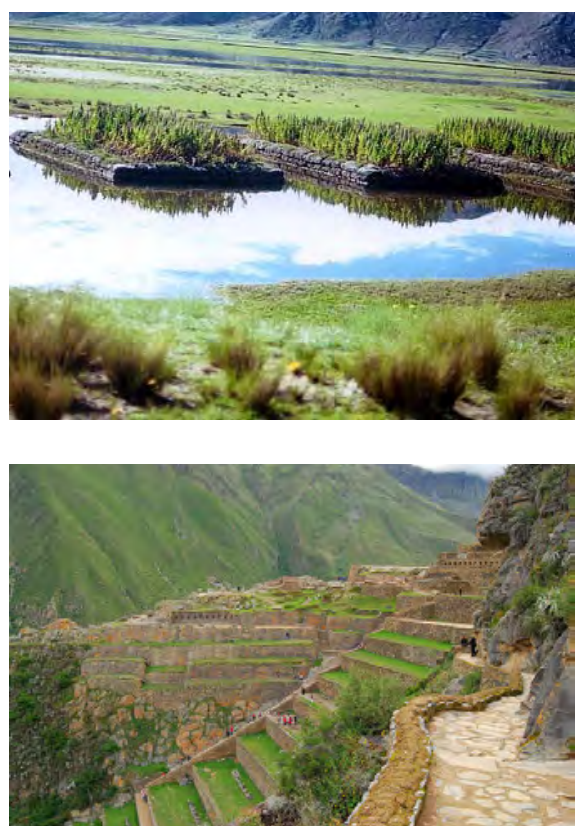

A la iaquierda, andenes o terrazas de cultivo. Accha, Paruro, Cuzco

Arriba, sukaqollos o camellones. Comunidad de Caritamaya, Ácora, Puno | fuente CONAM 2007, 22

Abajo, pata-pata o terrazas de cultivo. Parque arqueológico de Ollantaytambo, Urubamba, Cuzco

Desde finales de la década de 1980 se implementan en este territorio varios proyectos orientados a la recuperación de tecnologías, cultivos y crianzas autóctonas: Proyecto de Investigación de los Sistemas Agropecuarios Andinos (PISA), Proyecto de Investigación de los Sistemas de Cultivos Andinos (PISCA), Programa Interinstitucional de Waru-Waru (PIWA), y Programa Conservación in situ de Cultivos Nativos y de sus Parientes Silvestres. Ver nota 3. 


\section{PROYECTO SIPAM}

\section{MAPA DE UBICACION DEL PROYECTO EN PERU}

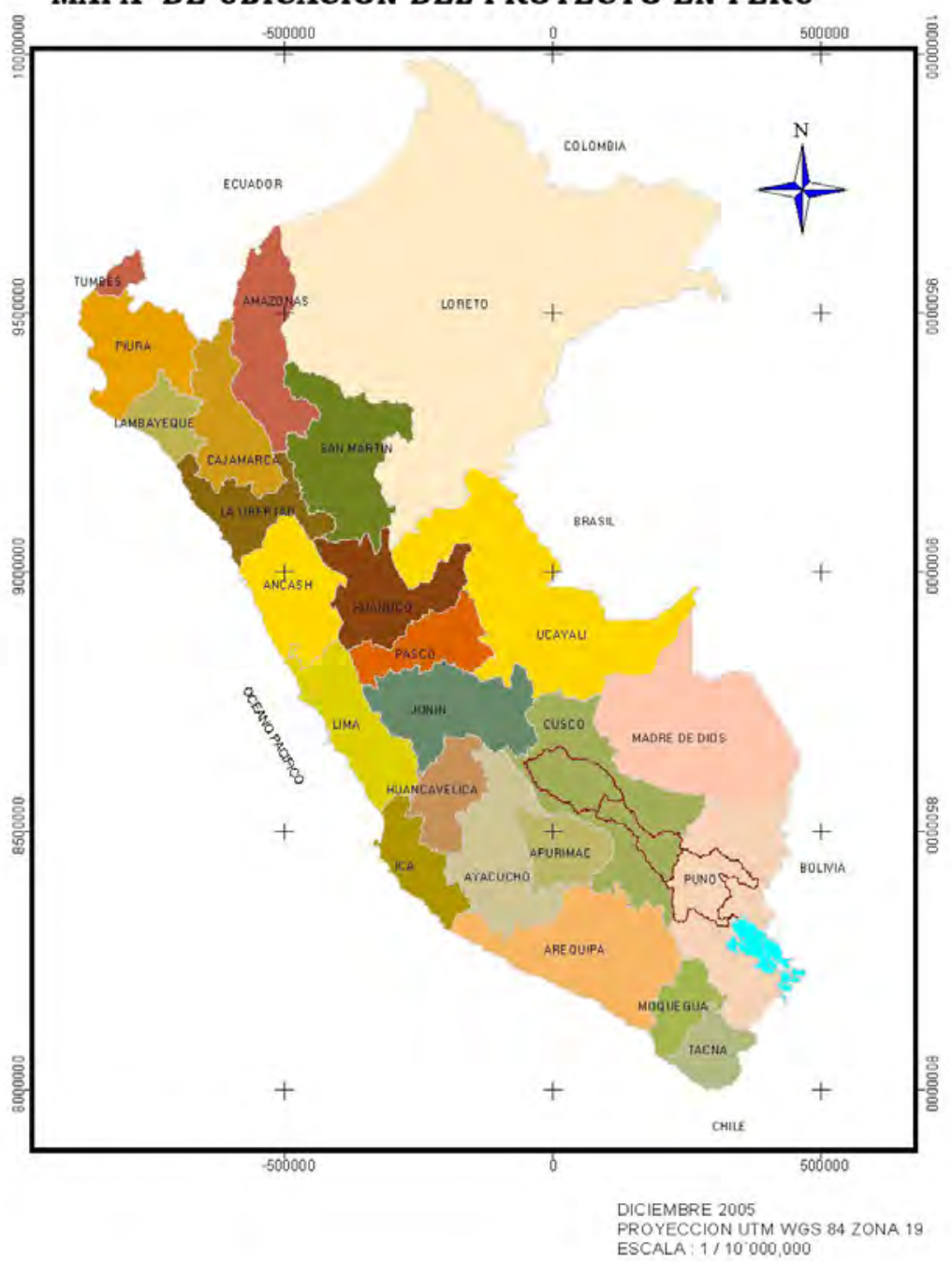

Mapa de ubicación del proyecto en el Perú | fuente CONAM 2007 en una de las rutas turísticas de gran belleza paisajista y más reconocidas internacionalmente de donde extraerá su nombre: el Santuario Histórico de Machu Picchu, integrante de la lista de Patrimonio Cultural y Natural de la Humanidad desde 1983, y el lago Titicaca, candidato a ese reconocimiento desde 2006 .

Al igual que en otros casos del mismo programa (Howard et ál. 2008), la adscripción técnica y operativa del SIPAM peruano recae en la Dirección de Diversidad Biológica del Ministerio del Ambiente (MINAM), lo que tendrá importantes consecuencias. En parte, estas consecuencias derivan de la tensión no resuelta entre "conservación" (MINAM), enfocada a la protección 
del medio natural per se, versus "productividad" (MINAG), más preocupada a garantizar la seguridad alimentaria y un mayor acceso a los mercados, asuntos que por lo general son de mayor interés para la población campesina. Esa fractura entre actividad productiva y conservación ambiental que se superpone a la atribuida entre naturaleza y cultura es reproducida en la política de protección de los organismos internacionales y sería, en parte, causante de la escasa valoración real con que cuenta este patrimonio. Pues, como recuerda Castillo $(2013,17)$, aunque las prácticas agrícolas y ganaderas sean actividades claramente antropogénicas y dinámicas, los reconocimientos más importantes de que han sido objeto a nivel internacional están relacionados de forma abrumadora con lo medioambiental (es decir los efectos sobre el medio de dicha actividad) y no tanto la actividad en sí misma y los aspectos sociales y culturales en los que es preciso considerar a los sistemas agrícolas (Pérez Galán 2012; Herrera Wassilowsky 2013).

\section{OBJETIVOS, METODOLOGÍA Y RESULTADOS DEL PROYECTO}

"Las actividades productivas agrícola y ganadera involucran al $100 \%$ de la población económicamente activa de las comunidades quechuas y aymaras de los sitios piloto, lo cual implica que toda la población está sumamente interesada en acciones orientadas a la recuperación, consolidación y desarrollo de la agrobiodiversidad, sus tecnologías de uso y manejo y a las normas de acceso y aprovechamiento en base a sus conocimientos y prácticas, que no les son muy caras" (CONAM 2007, 61).

En el diseño de cualquier proyecto de desarrollo una de las variables más importantes es la identificación de los beneficiarios de las acciones al que van dirigidas. La antropología del desarrollo ha contribuido a la crítica sobre el uso retórico en los proyectos de términos como "participación" y "conocimientos locales", sin que ello se traduzca en un control efectivo por parte de la población (Rahnema 2012). El extracto precedente del apartado de viabilidad social del SIPAM peruano es un buen ejemplo de ello.

Replicando los principios del programa a nivel local, este proyecto persigue "revalorar los sistemas ingeniosos de gestión sostenible de los agroecosistemas de alta montaña de las comunidades originarias en el transecto Cusco y Puno como patrimonio de la humanidad" (CONAM 2007, 37). Este objetivo general se concreta en cuatro componentes específicos, a saber: a) el fortalecimiento de la "gobernanza local", entendida como "estructuras consuetudinarias ancestrales"; b) la mejora de la dieta familiar (seguridad alimentaria), a través de la implementación de tecnologías de producción agrícola (andenes, sukaqollos, qochas, bofedales, siembras asociadas y manejo de pastizales); c) la potenciación de los saberes y capacidades técnicas campesinas de manejo del clima, agua y suelo, a través de talleres dirigidos a los campe- 


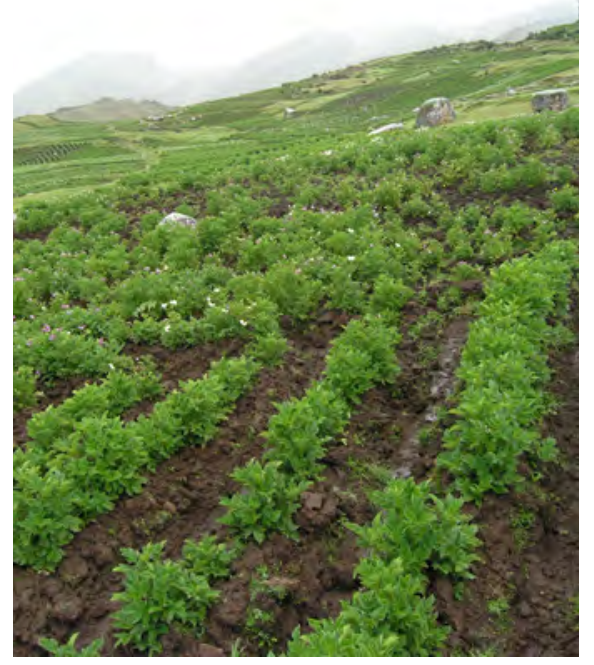

Wachu o surco de la siembra. Comunidad de Chahuaytire, Pisac, Cuzco

\section{6}

Contamos con dos versiones publicadas del proyecto, ambas elaboradas por Corredor Puno Cusco-FAO-CONAM (2006 y 2007). La de 2007 es una versión reducida (de 76 páginas) que recoge el proyecto original (de 118 páginas) elaborado en 2005 y publicado en abril de 2006. Ninguna de las dos refleja los ajustes en contenidos, duración y presupuestos realizados entre 2005 y el inicio de actividades en 2011. El documento más actualizado es un informe inédito encargado al coordinador del proyecto en marzo de 2012 (Tapia 2012). Este informe y el resto de documentos disponibles fueron contrastados mediante visitas in situ y entrevistas en pro fundidad realizadas en 2014 a una parte de la población participante del distrito de Lamay (Cuzco), y a los técnicos y gestores responsables del proyecto en Puno y en Lima, respectivamente. sinos; d) el conocimiento y la difusión científica del funcionamiento de estos agroecosistemas, mediante la elaboración de catálogos de recursos genéticos, cultivos andinos y de crianzas de alpacas de colores. No obstante, teniendo en cuenta el largo proceso de ajustes y el énfasis en los aspectos técnicos y medioambientales desde los cuales el proyecto propone la gestión del patrimonio agrícola indígena, el informe de 2012 reduce las actividades concretas a realizar durante esa campaña al último de los objetivos "registro y sistematización del conocimiento campesino sobre los principales recursos genéticos nativos en el sur del Perú (ver nota 6). Como recomienda el programa SIPAM, para visibilizar esta tarea se propone contar con la opinión y la mano de obra de los campesinos a través de sus "estructuras de organización ancestrales" en el marco de las cuales debe desarrollarse la conservación in situ de la agrobiodiversidad.

Una lectura atenta del proyecto en sus dos versiones ${ }^{6}$ arroja pobres resultados en cuanto a la identificación y caracterización de las formas de organización preexistentes en estas comunidades y su relación con los sistemas agrícolas. De hecho, en ninguna parte se explica cómo operan estas formas de organización en la toma de decisiones, en qué lugares y momentos se realizan, quiénes son las autoridades y cómo consiguen ese estatus, cómo participa en este sistema el resto de la comunidad, o cómo se establece y se significa su relación con el territorio, por mencionar solo algunos de los aspectos necesarios para viabilizar la participación local en este proyecto. En su lugar, el informe se limita a señalar la utilidad ad hoc de las formas de organización ancestrales en relación con los objetivos del proyecto: "este sistema se rige por una serie de valores y principios andinos particularmente asociados al acceso y al uso y aprovechamiento sostenible de la agro-biodiversidad en el paisaje" (CONAM 2007, 40). El bajo perfil que aparentemente presentan estas formas de autoridad tradicional en estas comunidades actualmente se justifica debido a factores externos:

"Tradicionalmente, funcionaban y funcionan en algunas comunidades los vigilantes o cuidantes de campos de cultivo en rotación sectorial, llamados arariwas y yapu campus en quechua y aimara, respectivamente. Con el proyecto SIPAM, se ha sugerido revivir y fortalecer a esas autoridades, con éxito relativo porque intervenciones externas con la creación de nuevos comités (conservacionistas, semilleristas, vaso de leche, forestación, artesanías, educación, de riego, etc.) tratan de debilitar su presencia y autoridad, con incentivos varios" (Canahua 2014, 38).

El desconocimiento sobre qué son y cómo funcionan los sistemas tradicionales de organización social y política indígenas que articulan la cosmovisión del grupo y su relación con el territorio y las prácticas agrícolas se traduce en una visión folclórica y esencialista, frecuentemente compartida por la mayoría de proyectos de desarrollo. Más allá de escuetas referencias des- 


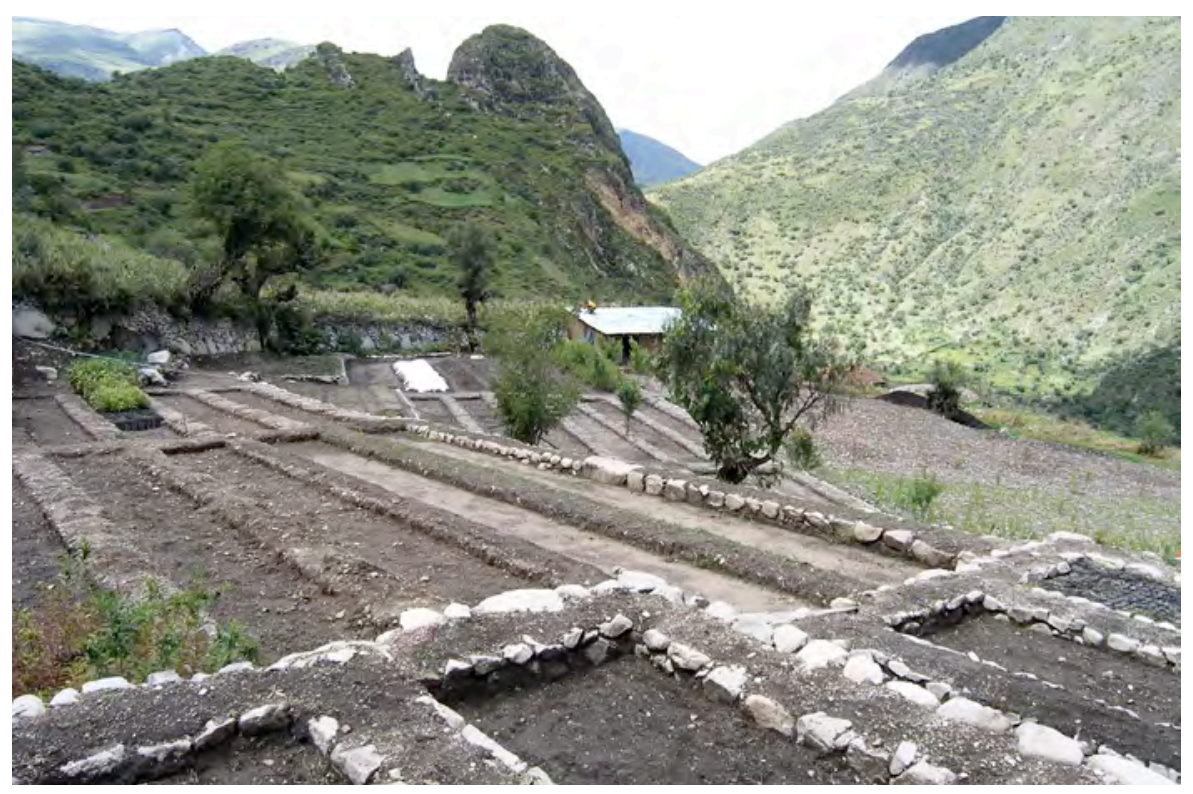

contextualizadas a los arariwas y a los alcaldes envarados (el wachu), esta visión se materializa en las actividades concretas previstas para fomentar las "estructuras ancestrales" (sic) de estas comunidades: 8 planes de gestión territorial, 8 convenios para el fortalecimiento de acuerdos comunales y, de modo singular, la celebración de 8 festivales sobre conservación dinámica de la biodiversidad agrícola.

"Canciones, música, danza, cuentos, ritos, etc. que tengan relación con las actividades agropecuarias locales y expresen mensajes y contenidos con la conservación dinámica (...) Teniendo en cuenta que el ecosistema en el mundo andino se refiere a la Pachamama donde las actividades agroproductivas se realizan en un marco lúdico, [esta actividad] se efectuará mediante festivales y concursos en cada sitio piloto y entre sitios piloto, además de que se recogerán testimonios grabados" (CONAM 2007, 40).

De hecho, si prescindimos de la narrativa sobre la conservación de la biodiversidad agrícola y la importancia otorgada sobre el papel al conocimiento indígena, nos encontramos con un conjunto de actividades dispersas, condicionadas a la definición y a los protocolos de funcionamiento del financiamiento internacional pero sin una planificación real a nivel social y cultural. Esto es, desprovistas de actores de carne y hueso y de sus relaciones sociales. Concretamente, en el SIPAM peruano estas acciones se resumen en la compra y distribución de semilla nativa entre los campesinos "conservacionistas", esto es, los participantes en el proyecto; de conos de lana de alpaca para asociaciones de tejedoras indígenas constituidas a tal efecto; de bidones de plástico para la preparación de abono orgánico líquido ("biol");
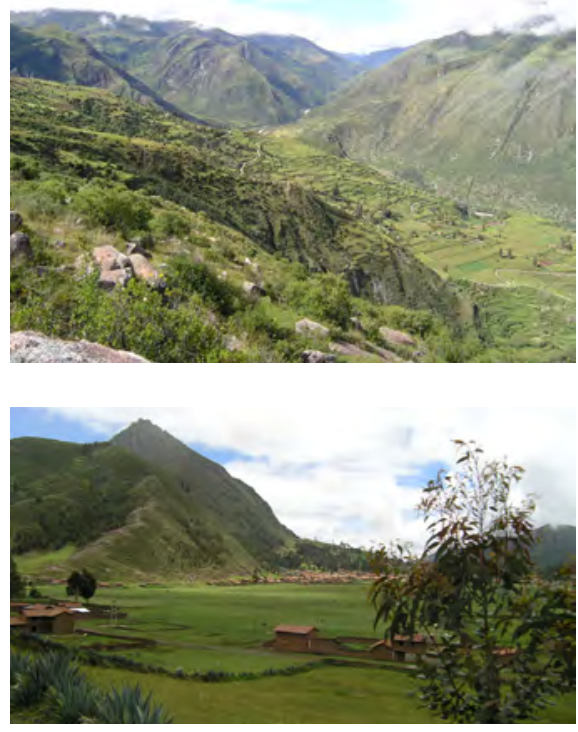

Paisajes agrícolas, distritos de Accha y Omacha, Paruro, Cuzco 
7

En un estudio clásico sobre los efectos de aparato conceptual del desarrollo en Lesoto, Ferguson (1990) concluye que más allá de los objetivos explícitos de los proyectos lo que éstos consiguen es la despolitización de los asuntos realmente relevantes para el desarrollo. la implementación de módulos de crianza de animales menores (cuyes); la construcción de almacenes rústicos de semillas de papas nativas; la organización de varias ferias locales y regionales de agro-biodiversidad para la exposición y venta de productos nativos; el acondicionamiento por parte de los técnicos de campo de varias parcelas demostrativas, y la organización de varios talleres de capacitación sobre conservación impartidos por los coordinadores del proyecto. Estas actividades y más específicamente el producto resultante de ellas donado por el proyecto constituyen para los indígenas la materialización concreta de la conservación dinámica de la agro-biodiversidad: "cuyes", "lana de alpaca", "biol" y "semillas nativas".

Llegados a este punto parece que lo que singulariza al SIPAM peruano en la práctica frente a otros proyectos de desarrollo rural en estas comunidades no es la recuperación y conservación de los sistemas agrícolas tradicionales, ni la puesta en valor de los conocimientos locales, ni tampoco el aumento de la productividad o la seguridad alimentaria. En su lugar, el efecto directo parece ser la normalización y legitimación del discurso de desarrollo, ahora "sostenible", y su introducción en las agendas nacionales. Un "aparato conceptual", al modo planteado por Ferguson $(1990)^{7}$, que en el caso de este proyecto se concreta en su contribución a la difusión del patrimonio agrícola tradicional de origen indígena de esta región como una marca que agrega valor añadido en el mercado exportador que demanda cada vez más alimentos ecológicos y de gran valor nutritivo, como se reconoce desde FAO:

"SIPAM refuerza la identidad local y nacional a través de productos y servicios únicos que [estos sitios] producen o proveen especialmente en relación con la gastronomía y el ecoturismo. Además, la marca SIPAM ofrece a los consumidores de los países en desarrollo la oportunidad de comprar estos productos y servicios para apoyar el desarrollo sostenible de los sistemas agrícolas de los que proceden. Esta estrategia es mucho más útil que comprar productos simplemente etiquetados como orgánicos o que procedan de las redes de mercado justo" (Olding y Warren 2014, 15, traducción propia).

\section{A MODO DE REFLEXIÓN FINAL}

EI SIPAM peruano, vinculado a dos de los lugares más emblemáticos a nivel natural y turístico de América Latina, es un buen ejemplo de la tendencia global en el desarrollo sostenible que concilia dos posturas aparentemente divergentes. Por un lado, la protección de paisajes muy conocidos, de gran biodiversidad cuya prioridad es la conservación y catalogación de inventarios elaborada por y para expertos y, simultáneamente, su conversión en un recurso económico orientado a mercados exclusivos como productos y servicios con un alto valor agregado por su relación con la población indígena. Un modelo de desarrollo verde en el que la dimensión ecológica y la propia 
noción de sostenibilidad son despolitizadas y despolitizadoras, y desprovistas de cultura y prácticas sociales (Arenas y Pérez Galán, 2019).

De acuerdo con Gallar y Matarán $(2015,78)$ en su estudio sobre la patrimonialización de la actividad agrícola, ese modelo que dirige el rumbo de la nueva ruralidad en las últimas dos décadas se especializa en tres sectores económicos: la agricultura industrial, la gestión de la naturaleza y el pastiche del espectáculo de la ruralidad auténtica-exótica-tradicional-indígena. En los andes peruanos estos sectores conviven con pautas estructurales de un mercado laboral y productivo que fomentan la desigualdad a través del desarrollo de fronteras étnicas entre indígenas y no indígenas, de la inversión en ciertos territorios con mayor biodiversidad y por tanto más atractivos para la conservación ambiental y el turismo, y entre campesinos pobres que constituyen la mayoría en las comunidades frente a los ejemplos exitosos de otros con mayor capital social y económico y dotes para el emprendimiento.

Por último, como ilustra el caso de la aplicación práctica de este proyecto, el discurso global del desarrollo sostenible solo trata de manera estereotipada y esencialista los sistemas de conocimiento y las formas de organización indígenas pero hace poco para confrontar la cada vez más rápida pérdida de la diversidad biológica y cultural y los derechos de uso, acceso y control de recursos y territorios de los pueblos y comunidades que habitan estos territorios (IIED et ál. 2005). Frente a esa posición es preciso avanzar en un acercamiento integral, desde una perspectiva holística, enfocado en la protección de las formas de vida y los derechos humanos de los pueblos indígenas no solo como proveedores de productos ecológicos para satisfacer las modas de consumo de mercados globales. Pero, en tal caso, es muy probable que no se llame "desarrollo". 


\section{BIBLIOGRAFÍA}

- Altieri, M. A. (1999) Agroecología. Bases científicas para una agricultura sustentable. Montevideo: NordanComunidad

- Arenas, M.A. y Pérez Galán, B. (2019) Naturaleza, conservación e identidad verde en Costa Rica. Antropología Experimental, n. ${ }^{0}$ 19. Disponible en: https:// revistaselectronicas.ujaen.es/index.php/rae/article/ view/4912 [Consulta: 22/04/2021]

- Calavia, O. (2006) El indio ecológico. Diarios a través del espejo. Revista de Occidente, n. ${ }^{\circ} 298$, pp. 27-42

- Canahua, A. (2014) Informe de Evaluación Final del Proyecto Sistemas Importantes del Patrimonio Agrícola Mundial. Informa inédito

- Castillo, J. (dir.) (2013) Carta de Baeza sobre Patrimonio Agrario. Sevilla: Universidad Internacional de Andalucía. Disponible en: https://www.unia.es/explorar-catalogo/item/ carta-de-baeza [Consulta: 07/07/2021]

- Castillo, J. y Martínez, C. (coords.) (2015) Patrimonio Agrario. La construcción cultural del territorio a través de la actividad agraria. Sevilla: Universidad Internacional de Andalucía. Disponible en: https://dspace.unia.es/ bitstream/handle/10334/3525/2015 978-84-7993-264-0 patrimonioagrario.pdf?sequence $=1$ [Consulta: 28/08/2021]

- cONAM [Consejo Nacional del Ambiente] (2006) Proyecto: Sistemas ingeniosos del patrimonio agrícola mundial Corredor Puno-Cusco. Resumen ejecutivo. Consejo Nacional del Ambiente-CONAM, Fao. Lima, abril de 2006. Disponible en: https://repositoriodigital.minam gob.pe/handle/123456789/107 [Consulta: 28/04/2021]

- CONAM [Consejo Nacional del Ambiente] (2007) Proyecto: Sistemas Ingeniosos del Patrimonio Agrícola Mundial. Corredor Puno-Cusco. Resumen ejecutivo. Consejo Nacional del Ambiente-CONAM, Fao. Lima, septiembre de 2007

- CONAM-INIA [Consejo Nacional del Ambiente-Instituto Nacional de Investigación Agraria] (2003) Documento base del Programa Nacional de Agrobiodiversidad

- Connerton, P. (1989) How societies remember. Cambridge: Cambridge University Press

- Cosgrove, D. (1984) Social formation and symbolic landscape. New Jersey: Barnes \& Noble Books

- Descola, P. (2001) Construyendo naturalezas. Ecología simbólica y práctica social. En: Descola, P. y Pálsson, G. Naturaleza y Sociedad. Perspectivas antropológicas. México: Siglo XXI, pp. 101-123

- Erickson, C.L. (2006) El valor actual de los camellones de cultivo precolombinos: experiencias del Perú y Bolivia. En: Valdez, F. (ed.) Agricultura ancestral. Camellones y albarradas. Contexto social, usos y retos del pasado y del presente. Quito-Ecuador: Ediciones Abya-Yala, pp. 315339

- Escobar, A. (1999) El lugar de la naturaleza y la naturaleza del lugar: globalización o posdesarrollo. En: Viola, A. (comp.) Antropología del desarrollo. Teorías y estudios etnográficos en América Latina. Barcelona: Paidós Studio, pp. 169-216

- FAO [Organización de las Naciones Unidas para la Agricultura y la Alimentación] (2008) Conservation and Adaptive Management of Globally Important Agricultural Heritage Systems (GIAHS). Terminal Report. Project ID: 137561 Disponible en: http://www.fao.org/fileadmin/ templates/giahs/PDF/GIAHS_B_terminalReport.pdf [Consulta: 27/05/2021]

- Ferguson, J. (1990) The Anti-politics machine: "Development", Depoliticization, and bureaucratic power in Lesotho. Nueva York: Cambridge University Press

- Gallar. D. y Mataran, A. (2015) La construcción social de la ruralidad. Coevolución, sustentabilidad y patrimonialización. En: Castillo, J. y Martínez, C. (coord.) (2015) Patrimonio Agrario. La construcción cultural del territorio a través de la actividad agraria. Sevilla: Universidad Internacional de Andalucía, pp. 73-117

- Hecht, S. (1999) La evolución del pensamiento agroecológico. En: Altieri, M. (ed.) Agroecología. Bases científicas para una agricultura sustentable. Montevideo: Nordan-Comunidad. pp. 1-14

- Herrera Wassilowsky, A. (2011) La recuperación de tecnologías indígenas. Arqueología, tecnología y desarrollo en los Andes. Lima-Bogotá: Instituto de Estudios PeruanosUniversidad de Los Andes

- Herrera Wassilowsky, A. (2013) Arqueología y desarrollo en el Perú. En: Herrera Wassilowsky, A. (comp.) Arqueología y Desarrollo en América del Sur. Bogotá-Lima: Instituto de Estudios Peruanos-Universidad de los Andes, pp. 75-93

- Hirsch, E. (1995) Landscape: between place and space. En: Hirsch, E. y O'Hanlon, M. (ed.) The anthropology of landscape. Perspectives on place and space. Oxford: Clarendon, pp. 1-30

- Howard, P., Puri, R., Jane Smith, L. y Altierri, M. (2008) Globally Important Agricultural Heritage Systems: A Scientific Conceptual Framework and Strategic Principles. Roma: FAO. Disponible en: http://www.fao.org/3/ap025e/ ap025e.pdf [Consulta: 06/07/2017]

- IIED [Instituto Internacional para el Medio Ambiente y Desarrollo], Fundación Dobbo-Yala, Universidad de Panamá, Centro Chino de Política Agrícola, Instituto de Investigación Políticas del Medio Ambiente y Agricultura del Sur, Kenya Instituto de Investigación Forestal, Centro para Sistemas de Cultivos Indígenas, Ecoserve y Centro 
de Investigación Herbal y del Folclore (2005) Protección de Conocimiento Tradicional y Patrimonio Culturalel Concepto del 'Patrimonio Bio-Cultural Colectivo'. Grupo de Trabajo de Poblaciones Indígenas, Sesión 23. Disponible en: https://pubs.iied.org/es/g01068 [Consulta: 02/05/2021]

- Koohafkan, P. y Altieri, M. (2010) Sistemas importantes del Patrimonio Agrícola Mundial. Un legado para el futuro. Roma: FAO

- Küchler, S. (1993) Landscape as memory: the mapping of process and its representation in a Melanesian Society. En: Bender, B. (ed.) Landscape. Politics and perspectives. Oxford: Berg, pp. 85-106

- Lakoff, G. y Johnson, M. (1995) Metáforas de la vida cotidiana. Valencia: Cátedra

- Moose D., (2012) Una etnografía de las políticas de la ayuda en la práctica. En: Pérez Galán, B. (ed.) Antropología y Desarrollo. Discurso, Práctica y actores. Madrid: La Catarata, pp. 258-281

- Olding W. y Warren, P. (2014) Conservation and Adaptive Management of Globally Important Agricultural Heritage Systems (GIAHS). Project-GCP/GLO/212/ GFF. Final evaluation of the GIAHS initiative. Roma: FAO

- Pérez Galán, B. (2004) Somos como Incas. Autoridades tradicionales en los Andes peruanos. Madrid- Frankfurt: Iberoamericana-Vervuert

- Pérez Galán, B. (2012) (ed.) Contribuciones antropológicas al desarrollo. En: Pérez Galán, B. (ed.) Antropología y Desarrollo. Discurso, Práctica y actores. Madrid: La Catarata, pp. 18-36

- Pérez Galán, B. (2015) Discursos globales y prácticas locales sobre agrobiodiversidad y conocimientos tradicionales en comunidades indígenas. El programa SIPAM en el sitio piloto de Machu Picchu al Lago Titicaca (Perú). En: Castillo, J. y Martínez, C. (coords.) (2015) Patrimonio Agrario. La construcción cultural del territorio a través de la actividad agraria. Sevilla: Universidad Internacional de Andalucía, pp. 231-267

- Pérez Galán, B. (2017) Desarrollo sostenible y usos del patrimonio agrícola en los Andes. En Tomé, P. (ed.) Reflexiones Rayanas. Vol. II. Ávila: Asociación de Antropología de Castilla y León "Michael Kenny", pp. 3-30

- Ploeg, J. (1990) Sistemas de conocimiento, metáfora y campo de interacción: el caso del cultivo de la patata en el altiplano peruano. Agricultura y Sociedad, n. ${ }^{\circ}$ 5, pp. 143-166

- Rahnema, M. (2012) Participación. En: Pérez Galán, B. (ed.) Antropología y Desarrollo. Discurso, Práctica y actores. Madrid: La Catarata, pp.187-207
- Reyes-García, V. (2007) El conocimiento tradicional para la resolución de problemas ecológicos contemporáneos. Papeles, n. ${ }^{\circ}$ 100, pp. 109-116

- Tapia, M. (1997) Los sistemas de producción agrícola campesina en los Andes del Perú. En: La sostenibilidad de los sistemas de producción campesina en los andes. Lima: CONDESAN

- Tapia, M. (2012) Consultoría Proyecto SIPAM-Perú. Informe inédito

- Toledo, V. (1992) What is ethnoecology? Origins, scope, and implications of a rising discipline. Etnoecologica, n. ${ }^{0} 1$, pp. 5-21

- Viveiros de Castro, E. (2014) La mirada del jaguar. Introducción al perspectivismo amerindio. Entrevistas. Buenos Aires: Tinta Limón

- Warren, D.M., Slikkerveer, J.L. y Brokensha, D. (ed.) (1995) The cultural dimension of development: Indigenous knowledge systems. London: Intermediate Technology Publications 


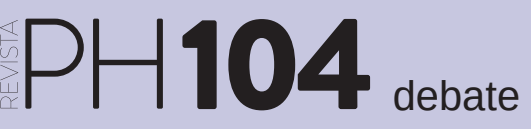

Patrimonio cultural y cambio climático

coordina Alejandro García Hermida

El cambio climático es una amenaza global para la conservación de nuestro patrimonio cultural. Las lluvias torrenciales en lugares históricamente secos o áridos están destruyendo arquitecturas que no estaban preparadas para tales fenómenos meteorológicos. Catastróficas nevadas acaban con estructuras que habían sobrevivido a centenares de inviernos. En regiones costeras, conjuntos urbanos, paisajes enteros y multitud de prácticas tradicionales ligadas a ellos están sufriendo los efectos de la progresiva subida del nivel del mar. Las dunas de los desiertos arenosos devoran indistintamente los palmerales, los sistemas hidráulicos que los sostienen y el patrimonio material e inmaterial al que han servido de sustento y de cobijo. Plagas propias de climas ajenos acaban progresivamente no sólo con cultivos y materiales de construcción, sino con manifestaciones culturales completas desarrolladas en torno a ellos. En definitiva, la desaparición y la transformación de los ecosistemas y los paisajes existentes suponen ya, en general, un riesgo sin precedentes para el mundo que hemos heredado.

Al mismo tiempo, el patrimonio construido y las culturas tradicionales de las diversas regiones del mundo ofrecen un repositorio inigualable e insustituible de conocimientos y estrategias no ya para paliar los aciagos efectos del cambio climático, sino para combatir algunas de sus principales causas.

El impacto de la actividad antrópica sobre el clima no es una novedad de nuestro tiempo, pero sí lo es la magnitud de ese impacto y de las consecuencias que está teniendo para nuestro hábitat y patrimonio. El enorme cambio de escala operado en este fenómeno no es el mero resultado del incremento de población, sino que está estrechamente relacionado con la forma en que habitamos nuestro mundo y hacemos uso de sus recursos. Hemos ignorado principios tradicionales que permitían habitar y transformar de forma relativamente racional y sostenible cada uno de nuestros diversos paisajes culturales. Durante varias décadas los hemos considerado prescindibles o superados y hemos renunciado a seguir actualizándolos y continuándolos. Al hacerlo, hemos perdido buena parte de un conocimiento empírico que había sido acumulado, atesorado y progresivamente adaptado por innumerables generaciones.

Pese a la gran pérdida sufrida, sin embargo, conservamos aún en la mayoría de nuestras regiones un valioso y rico patrimonio cultural. Conservarlo, continuarlo y recuperar sus principios como modelo para la cultura material de nuestro tiempo puede orientar las políticas dirigidas a luchar contra el cambio climático. Este legado, por tanto, puede y debe ser hoy reconocido, estudiado, difundido y actualizado para adecuarlo a nuestras necesidades con cuantos medios podamos disponer para ello antes de que sea demasiado tarde para hacerlo.

El patrimonio nos proporciona la quizá sea nuestra última oportunidad para la recuperación y la continuación de aquellos aspectos que pueden seguir teniendo validez hoy en día de la forma en que tradicionalmente nos hemos asentado en un territorio y hemos transformado y explotado sus recursos, la manera en que históricamente hemos conformado nuestras comunidades, con calles, plazas, manzanas y edificios adecuados para cada clima y para cada lugar, y las prácticas culturales que hemos desarrollado para utilizar de forma bella y duradera los materiales que sus condiciones naturales ofrecen.

Alejandro García Hermida | Dpto. de Composición Arquitectónica, Universidad Politécnica de Madrid

URL de la contribución <www.iaph.es/revistaph/index.php/revistaph/article/view/4962> 


\section{Dinámica de funcionamiento de la sección DEBATE}

Este espacio de revista $\mathrm{PH}$ pretende poner en común los distintos puntos de vista sobre los temas de debate que se propongan, atendiendo a dos principios básicos: máxima libertad y respeto.

Tres veces al año, se sugerirá un tema para discutir, con un texto de presentación, redactado por la persona que coordine el debate, y un guión de cuestiones que puedan animar el intercambio de ideas.

A partir de este momento se abrirá un plazo de envío de contribuciones breves (1000 palabras + 1 o 2 imágenes). Dichas aportaciones deben adecuarse a los temas planteados en el texto y guión de presentación del debate. Estas contribuciones se revisarán y publicarán todas, siempre y cuando se ajusten al hilo argumental propuesto, se trate de textos originales y resulten de calidad.

Para facilitar la posibilidad de comentar las distintas aportaciones que vayan llegando, se incluirán de manera provisional como preprints en el número de la revista en preparación, hasta una segunda fase en la que se maquetarán y paginarán en el número definitivo.

Recuerda que para enviar contribuciones hay que registrarse. Si tienes perfil en alguna red social profesional o mantienes un blog especializado incorpora a tu texto sus direcciones para aumentar las posibilidades de comunicación.

Los debates se difundirán a través de los perfiles de Facebook, Linkedln y Twitter del IAPH: <www.facebook.com/ patrimoniolAPH>; <https://twitter.com/IAPHpatrimonio>; <https://www.linkedin.com/company/instituto-andaluz-delpatrimonio-hist-rico> 


\section{$\mathrm{PH} 104_{\text {debale }}$}

a debate Patrimonio cultural y cambio climático

| coordina Alejandro García Hermida

\section{Patrimonio y cambio climático}

Alejandro García Hermida | Dpto. de Composición Arquitectónica, Universidad Politécnica de Madrid

URL de la contribución <www.iaph.es/revistaph/index.php/revistaph/article/view/5013>

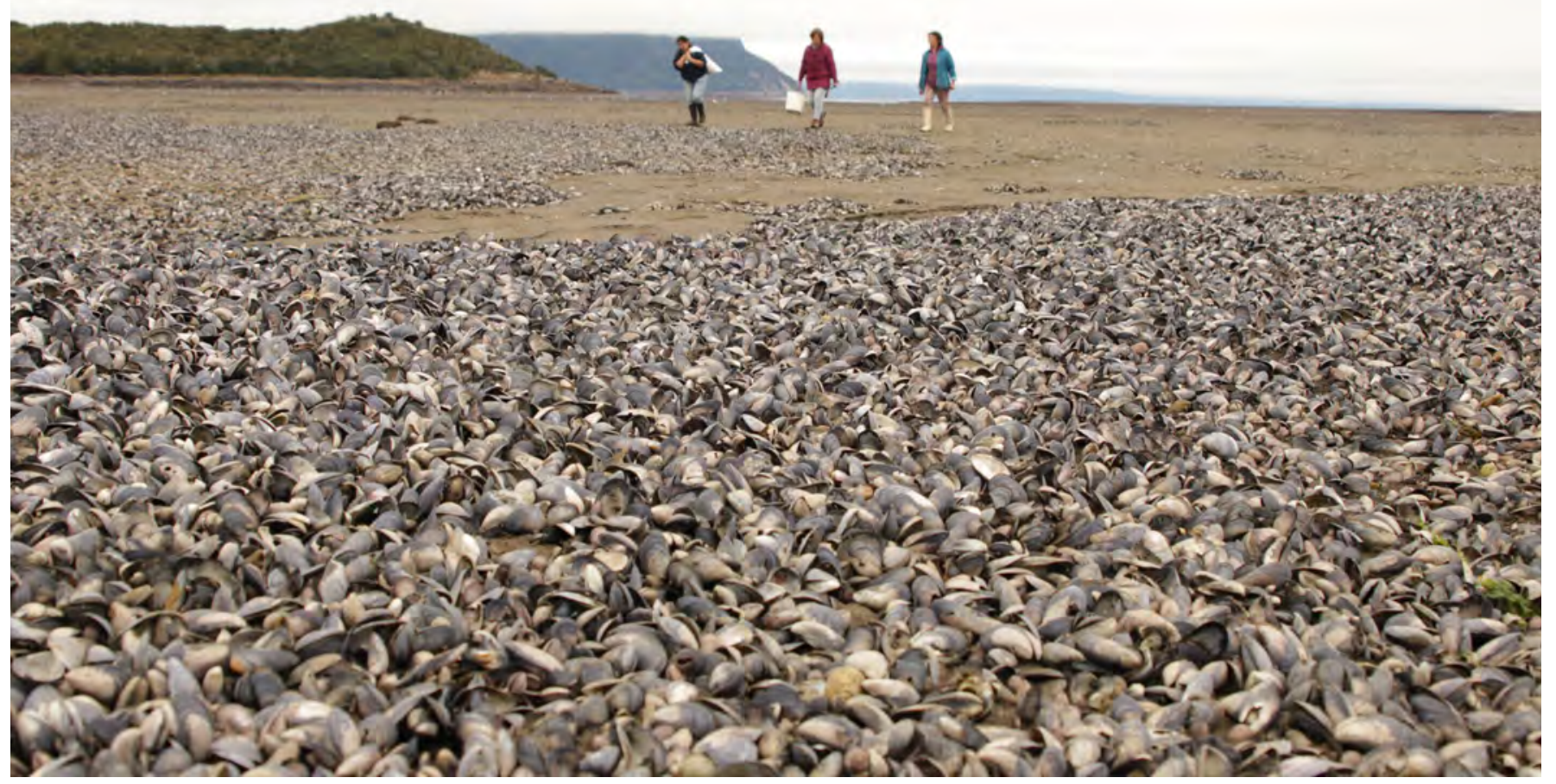

Proyecto Fortalecimiento de la capacidad de adaptación en el sector pesquero y acuícola chileno al cambio climático, Caleta El Manzano-Hualaihué, Chile | foto FAO/Max Valencia

La emergencia que supone el calentamiento global que se ha producido durante las últimas décadas está ya fuera de toda duda. Si bien tenemos evidencias de la existencia de ciclos de variación climática cada aproximadamente 1.500 años, los causantes de las prehistóricas glaciaciones, no hay precedentes de variaciones climáticas acaecidas a la velocidad a actual.

Las fluctuaciones climáticas pasadas guardan relación con cambios en la actividad solar y con fenómenos volcánicos. Sin embargo, los estudios de la radiación solar no permiten atribuir a estas causas por sí solas el aumento de temperatura que estamos experimentando en esta ocasión. Pese a los muchos debates generados en torno a esta cuestión, existen evidencias, al menos desde la década de los 60 del pasado siglo, de que este anormal incremento de temperatura se debe al también anormal incremento de emisiones de gases de efecto invernadero a la atmósfera. Ya en 1965 el presidente norteamericano Lyndon Johnson, alarmado por los informes que recibía, advertía en el Congreso de los Estados Unidos sobre esta amenaza, pero el mundo siguió mirando hacia otro lado o negando la validez de las evidencias recabadas (Corneliussen 2015). 
El Grupo Intergubernamental de Expertos sobre Cambio Climático (conocido comúnmente por sus siglas en inglés, IPCC) fue creado en 1988 con el auspicio de las Naciones Unidas para estudiar este proceso. En los avances ya publicados de su Sexto Informe de Evaluación (IPCC 2021), que se sintetizarán en un último documento que se publicará en 2022, este grupo concluyó que es ya inequívoco que en los últimos 50 años las actividades humanas han causado la mayor parte de ese atípico calentamiento. Además, apunta específicamente a los gases de efecto invernadero emitidos por esas actividades, como el dióxido de carbono, el metano y el óxido nitroso, como principales causantes del anormalmente rápido incremento de temperatura que está experimentando el planeta.

También se señala en este informe que aún estamos a tiempo de adoptar medidas para contrarrestar este fenómeno, pero estas emisiones están siendo de tal magnitud que, incluso si en adelante fuera posible interrumpir dichas emisiones por completo, el impacto de lo ya emitido se prolongaría durante siglos y la temperatura de la superficie del planeta continuaría aumentando hasta al menos mediados del presente siglo. Algunos cambios serán ya de hecho irreversibles durante siglos o milenios, y en especial se destacan en este sentido las alteraciones que se han producido sobre los océanos. Según las predicciones actuales, sólo a través de un cambio radical en nuestras actividades desde este momento para evitar esta tragedia, en unos veinte años comenzaríamos a poder apreciar su efecto atenuante en el proceso de calentamiento. Tras el respiro dado por la reciente pandemia global, el presente retorno al rápido crecimiento de las emisiones no invita al optimismo.

A través del Acuerdo de París la mayor parte de las naciones adquirieron el compromiso de combatir el cambio climático de forma urgente y decidida. Entre los principales emisores de gases de efecto invernadero, los Estados Unidos y la Unión Europea se han fijado como objetivo que sus emisiones sean climáticamente neutrales en 2050. China, que lo sean en 2060. Otros países, como la India o Rusia, han eludido por el momento asu- mir firmemente su responsabilidad al respecto. Hoy por hoy, las únicas naciones que cumplen con el objetivo de neutralidad son Bután y Surinam. Todo ello compone un panorama poco prometedor en el que, incluso con los compromisos actuales, las emisiones globales parece que se reducirán demasiado tarde y de forma insuficiente como para poder evitar el desastre que, según todas las previsiones, se cierne ya sobre nosotros.

Los principales impactos potenciales del cambio climático incluyen fenómenos climáticos extremos, como olas de frío y de calor; nevadas, lluvias, sequías y ciclones anormalmente intensos y/o prolongados; grandes incendios avivados por las sequías; desertificación de amplias regiones; reducciones significativas de las superficies permanentemente heladas o nevadas; y un importante aumento del nivel del mar.

Como consecuencia, los efectos que estos eventos climáticos están produciendo sobre las personas incluyen las inundaciones, la pérdida de zonas pesqueras, de bosques y de suelos cultivables, la escasez de agua y alimentos y el aumento de la pobreza, al fallar los usos tradicionales del medio. $Y$ todo ello contribuye también al aumento de las migraciones masivas, a generar inestabilidad política y social no sólo en las regiones más afectadas, sino en todo el mundo, y, en consecuencia, al estallido de conflictos de todo tipo.

En el caso español, la AEMET estima un aumento anual de las temperaturas máximas de entre 2 y $6,4^{\circ} \mathrm{C}$ que afectará especialmente al interior peninsular, una reducción generalizada de las precipitaciones, un cambio global en la velocidad del viento y un incremento de los fenómenos meteorológicos extremos que estamos ya experimentando. A su vez, la Oficina Española de Cambio Climático del Ministerio para la Transición Ecológica y el Reto Demográfico señala que el cambio climático está teniendo ya importantes impactos como la pérdida de recursos hídricos y, con ellos, no sólo está provocando problemas de abastecimiento de agua, sino también para la generación de energía hidroeléctrica; la desertificación y la pérdida de suelos fértiles; la altera- 
ción de los ecosistemas terrestres y la pérdida masas forestales, con el aumento de plagas y enfermedades, la generalización de grandes incendios y la desaparición progresiva de aquellas especies que por su aislamiento no puedan trasladarse hacia hábitats más favorables; el incremento de la vulnerabilidad de la agricultura y la ganadería, con una reducción de la producción de cultivos tanto herbáceos como leñosos, y en especial de los de secano, un desplazamiento ya notorio de las estaciones, con los problemas que esto supone para el desarrollo de algunas especies, y cambios en la distribución de patógenos y enfermedades; la disminución del potencial pesquero y acuícola a causa del aumento de la temperatura del mar, la acidificación del agua, la pérdida de oxígeno y la redistribución de las especies marinas, problemas ya documentados en todas las regiones pesqueras del país; la erosión de las costas y la destrucción progresiva de regiones costeras; los riesgos para los núcleos urbanos, en especial por el aumento del nivel del mar, el oleaje extremo, las precipitaciones o fenómenos atmosféricos extremos, el aumento de las temperaturas y de las olas de calor, los vendavales, etc., con una repercusión mayor sobre los colectivos más desfa-

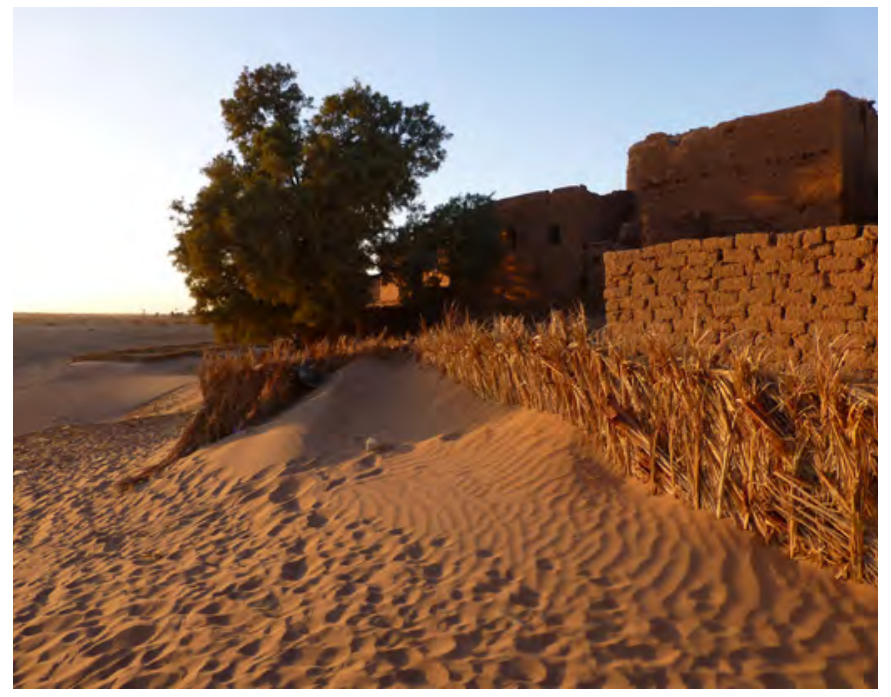

Las dunas invaden pueblos y cultivos en el Oasis de Mhamid, Marruecos. Ksar de Bounou | foto Alejandro García Hermida, autor de todas las imágenes que ilustran el artículo si no se indica lo contrario vorecidos, con menor capacidad de respuesta y de recuperación; el aumento de la morbilidad y la mortalidad, y singularmente de las enfermedades respiratorias y cardiovasculares, el estrés térmico y las derivadas de la redistribución de los agentes patógenos y de sus vectores de transmisión; los daños a las infraestructuras y las redes de transporte causados por los fenómenos extremos; y los perjuicios que estos eventos están ya ocasionando en el sector turístico, uno de los pilares de la economía del país (Sanz y Galán 2020).

Hemos puesto por tanto el medio en el que vivimos en una situación crítica que no va a poder revertirse más que a medio o largo plazo y únicamente si todos los principales emisores de gases de efecto invernadero del mundo asumen a tiempo sus responsabilidades y se hace un esfuerzo colectivo firme y sostenido para alcanzar este objetivo. Con ello, la conservación de nuestro patrimonio natural y cultural está, por supuesto, en riesgo.

\section{El cambio climático como amenaza para el patrimonio} La alteración o la destrucción de los ecosistemas y los paisajes que implica el cambio climático y, en consecuencia, la transformación o la desaparición de las actividades y las formas de vivir tradicionalmente asociadas a ellos suponen una pérdida patrimonial de tales amplitud y magnitud que resulta complicado acotarla o cuantificarla, e incluso sintetizarla en cualquier formato sin que adquiera un tinte apocalíptico.

Se trata en este debate de la amenaza que supone el cambio climático para elementos patrimoniales tan diversos como el patrimonio arbóreo monumental (Francisca Ramón Fernández), los paisajes salineros (Antonio Fajardo de la Fuente), la arquitectura tradicional (Jaime de $\mathrm{Hoz}$ Onrubia), el patrimonio construido y los paisajes del medio rural (José Manuel Baena Gallé, Anna Martínez Durán y Montserrat Villaverde Rey), el patrimonio ligado a actividades agrícolas tradicionales (José Damián Ruiz Sinoga), los conjuntos históricos edificados en zonas afectadas por la subida del nivel del mar (Xira Ruiz Campillo y María Pilar Montero Vilar) y el patrimonio arqueológico (Laura Brum Bulanti). 


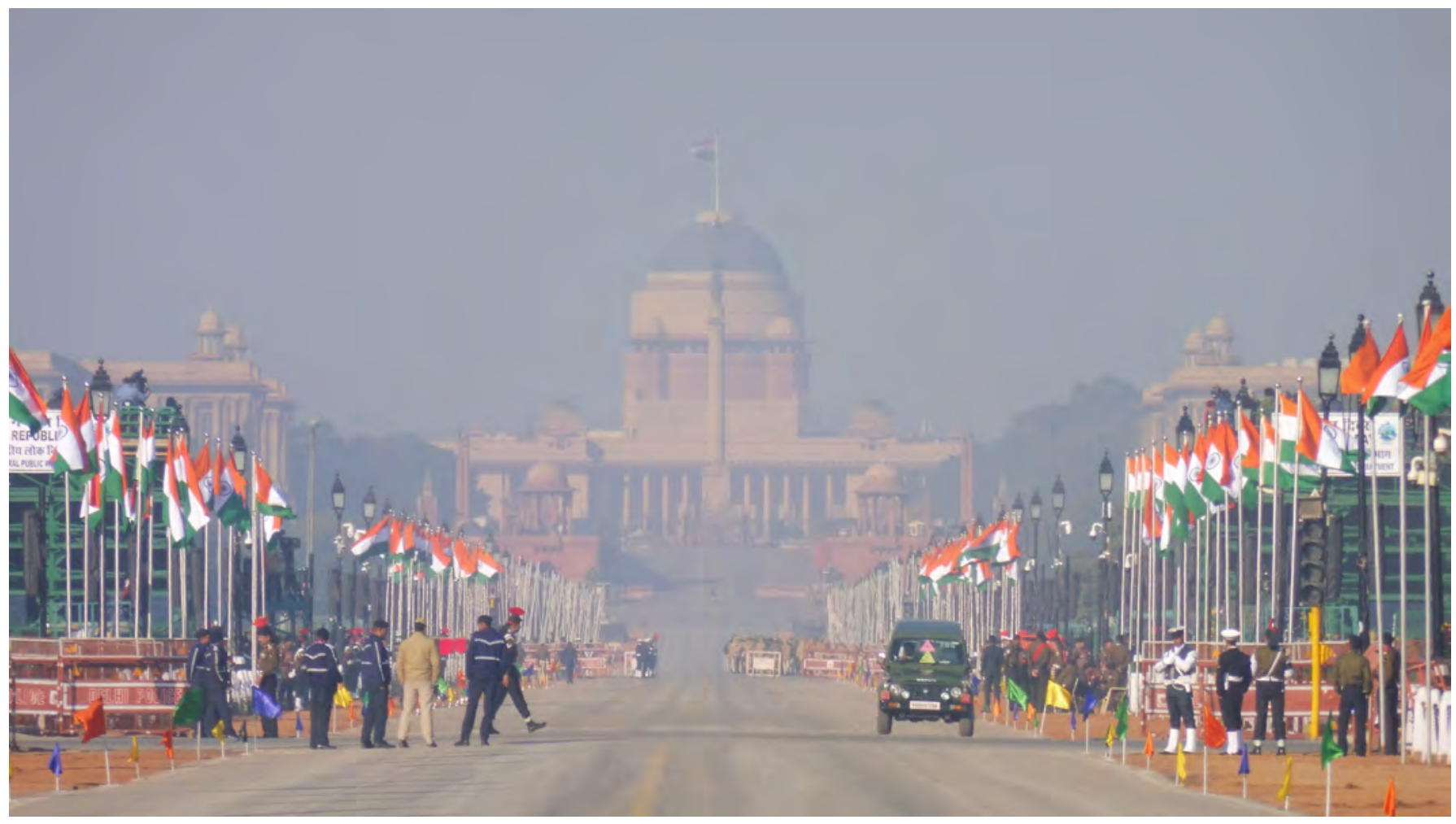

Vista del Rajpath de Nueva Delhi en 2020, velada por la contaminación del aire

Podríamos ampliar esta lista con innumerables ejemplos más, como los paisajes marinos, los glaciares y las cumbres nevadas, los paisajes de la tundra, los oasis, las costas y playas en su conjunto, el patrimonio edificado en regiones desérticas o áridas, etc.

Con solo considerar las regiones enteras que quedarán sumergidas bajo las aguas si no se produce pronto un cambio radical en nuestros hábitos, nuestras políticas y nuestras estructuras urbanas, estamos ya ante una pérdida incalculable. Todos deberíamos tener presentes los mapas interactivos elaborados por la entidad norteamericana sin ánimo de lucro Climate Central y los datos que arrojan sus informes. Según sus proyecciones, tierras en las que habitan más de 300 millones de personas estarán sumergidas en sólo 30 años (Climate Central, 2019). Con una subida del nivel del mar de sólo 90 centímetros (3 pies), amplias regiones de países como China, Bangladés, Irak, los Países Bajos o Vietnam pasarían a engrosar el patrimonio submarino, y, en el caso español, serían pasto de las aguas lugares como el Parque Nacional de Doñana, el Bajo Guadalquivir, el entorno de la Albufera de Valencia y el Delta del Ebro, por citar sólo las pérdidas territoriales más extensas.

Se han presentado y analizado también en este debate algunas herramientas para poder anticiparnos al menos a parte de estas amenazas, como los sistemas de análisis de riesgo de incendio (Mónica Moreno Falcón, Rocío Ortiz Calderón y Pilar Ortiz Calderón) o de riesgo a causa del cambio climático en general (Mauro G. García Santa Cruz, M. Jimena García Santa Cruz, Guillermo R. García, Carmen Muñoz González, Jonathan Ruiz Jaramillo e Isabel Ordieres Díez) y se ha destacado la urgencia de poner en marcha cuantos mecanismos de pronóstico puedan ayudarnos a dar respuesta al reto que enfrentamos. También será más importante si cabe adoptar prácticas sistemáticas de documentación de 
a debate Patrimonio cultural y cambio climático

| coordina Alejandro García Hermida

aquellos patrimonios más amenazados (Teófilo Victoria y Ricardo López) y la adopción de criterios más sostenibles y armoniosos de intervención sobre el patrimonio construido, para evitar que las necesarias adaptaciones que la mejora de su rendimiento energético pudiera requerir supongan un menoscabo de sus valores si éstas se realizan con el énfasis en la diferenciación y la ruptura con el pasado que tan comunes son aún en muchas intervenciones (Robert Adam).

En general, serán fundamentales en conjunto las actuaciones de conservación preventiva y, con todo, las poblaciones de muchas de las regiones más frágiles ante los fenómenos previstos no podrán hacer frente a tan ingente labor, ni resultará sencillo incluso con los mejores medios y una óptima financiación cuantificar y anticipar los muchos daños directos e indirectos que puedan causar.

\section{Oportunidades ofrecidas por patrimonio para combatir el cambio climático}

Tal como se señala en el Plan Nacional de Adaptación al Cambio Climático 2021-2030 del Ministerio para la Transición Ecológica y el Reto Demográfico (2020, 159): "El conocimiento vernáculo y tradicional tiene un evidente valor potencial en la lucha contra el cambio climático", y $(2020,157)$ : "El patrimonio cultural, entendido como repositorio de la experiencia y el conocimiento acumulados por la humanidad a lo largo del tiempo, constituye un activo valioso para la adaptación. Las sociedades humanas, a través de métodos de prueba y error, han construido culturas adaptadas a los climas en que se han desarrollado, dando forma a estrategias y soluciones en campos tan relevantes como la agricultura, la vivienda o el urbanismo. El conocimiento de esas soluciones puede inspirar nuevas prácticas, convirtiendo al patrimonio cultural en un recurso para la adaptación".

En la dirección marcada por el citado Plan, se ha tratado en este debate de los recursos y las lecciones que nos ofrece el patrimonio tradicional para reconducir la situación y atenuar todo lo posible la velocidad a la que se está produciendo el cambio climático. Se han enfatizado

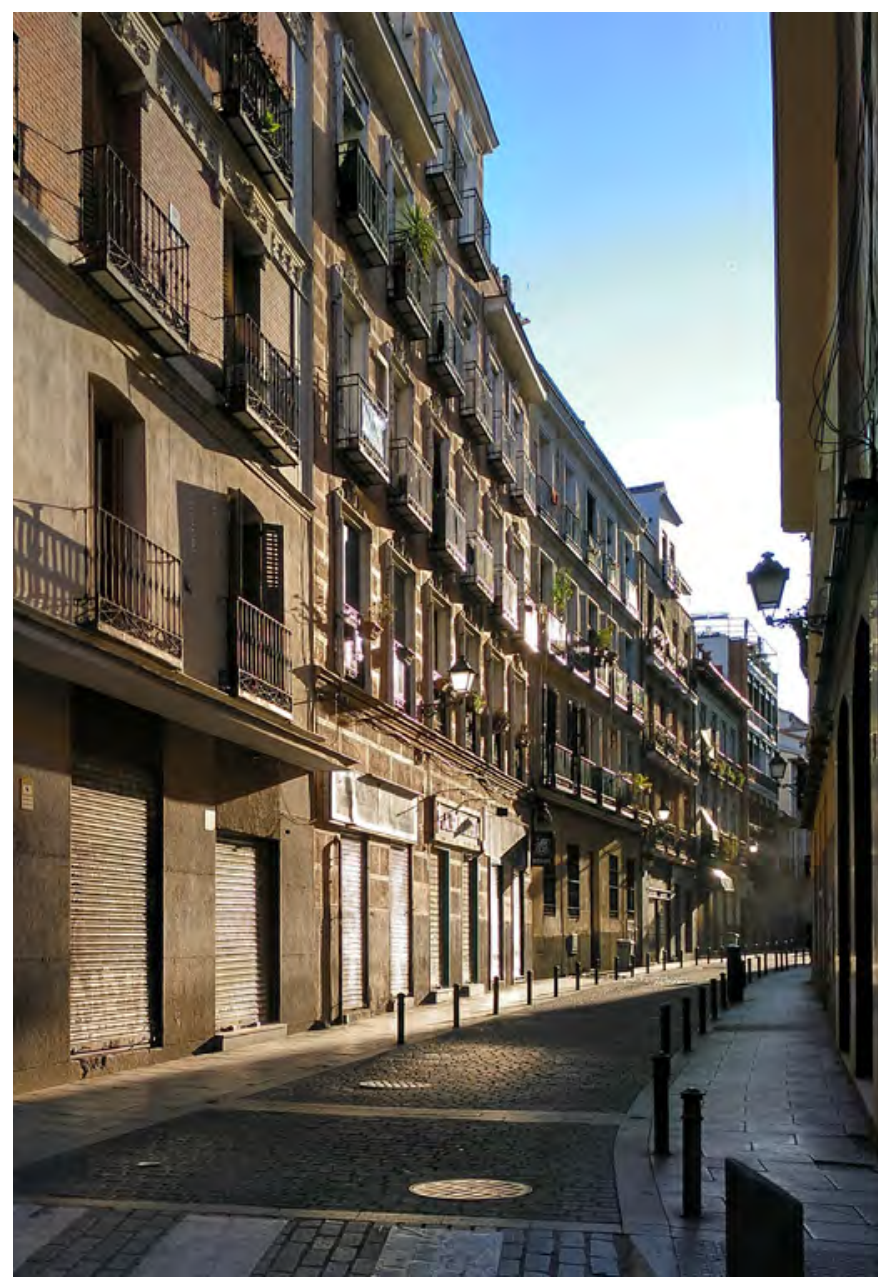

El urbanismo tradicional como modelo para combatir el cambio climático. Calle de Madrid

en este sentido la relevancia actual de aprender de los sistemas tradicionales de gestión de los recursos hídricos (Celia López-Bravo, José Peral López, Alejandra González Biffis e Isabel Ordieres Díez) y de recuperar sus principios y métodos, así como de los conocimientos tradicionales sobre cómo construir y diseñar edificios y conjuntos urbanos más sostenibles y duraderos (Mónica Alcindor, Olga Muñoz i Frigola, Julián García Muñoz, Teófilo Victoria y Ricardo López), si bien se ha señalado también la necesidad de adecuar estas enseñanzas a la escala y los actuales condicionantes del problema a enfrentar (Julián García Muñoz). 
También se ha atendido al valor del patrimonio como medio para reforzar la identidad de las comunidades afectadas por las consecuencias del cambio climático (Robert Adam), aspecto que puede ser especialmente relevante por la magnitud de las pérdidas que pueden conllevar para muchos grupos de población, y en especial para los más desfavorecidos.

En muchos de los textos se ha mirado, en definitiva, hacia la necesidad de volver a aprender de muchas de las tradiciones que han sido desechadas a causa de una dañina visión del progreso y de reorientar de forma global la educación en campos que se han alejado tanto de las enseñanzas de esas tradiciones como los de la arquitectura, la planificación y el diseño urbanos, la conservación del patrimonio natural y cultural o la construcción (Mónica Alcindor, José Baganha, Jaime de Hoz, Pedro Paulo Palazzo, Olga Muñoz i Frigola, Alejandra González Biffis, Teófilo Victoria y Ricardo López). Entre ellos, Pedro Paulo Palazzo ha ido un paso más en esta dirección al plantear un interesante programa de estudios para cambiar la forma en que actualmente transformamos nuestro entorno.

Este amplio consenso refleja cómo existe un entendimiento generalizado del patrimonio tradicional, y de los conocimientos a él asociados sobre cómo transformar y mantener nuestro entorno de forma armoniosa, sostenible y duradera, como una vía para poder salir de la crisis en la que nos encontramos, o al menos para no seguir agravándola día tras día.

Se trata de una visión nueva del patrimonio, que trasciende sus valores históricos, artísticos, identitarios e incluso económicos, para pasar a ser además una fuente de referencias para abordar con éxito los retos que enfrentamos.

El cambio climático y la necesidad de un enfoque más amplio en la forma en que abordamos la conservación del patrimonio

En el contexto aquí presentado, resulta inexorable comprender nuestro hábitat como un sistema con un frágil equilibrio en el que cualquier acción o cualquier política en cualquier campo y en cualquier lugar del mundo tienen un impacto global. Se impone la asunción de la unidad frente a la fragmentación. La conservación del patrimonio no puede concebirse ya como una forma particular de abordar cómo se gestionan o transforman determinados elementos singulares de nuestro entorno, sino cómo se gestiona o transforma nuestro entorno de forma general.

Así, reducir drásticamente la fabricación y la utilización de materiales que generen altas emisiones, como los plásticos, el acero o el cemento, y sobre todo de aquellos difícilmente reciclables, se convierte en una importante contribución a la conservación del patrimonio. No puede entenderse ésta tampoco sin asumir la necesidad de transformar radicalmente las estructuras urbanas insostenibles que han proliferado en las últimas décadas en el entorno de nuestros tradicionales tejidos urbanos, y desde luego reconsiderar la forma en que diseñamos las de nueva creación. Crear calles y plazas con una escala, un trazado y una sección acordes con el clima de cada lugar, agradables y caminables, que reduzcan el tráfico rodado, pasa a ser una herramienta para la conservación del patrimonio. Reflejar en normativas y legislaciones que la eficiencia energética de los edificios pasa por atender también a la eficiencia energética de los propios espacios abiertos colindantes es hoy una vía para la preservación de nuestro legado cultural. Apostar por los saberes tradicionales, y por los maestros artesanos que los atesoran, adquiere un nuevo significado. Incluso elegir adquirir una silla de madera en lugar de una de plástico pasa a ser una forma de compromiso con la continuación de ese legado.

La propia conservación del patrimonio, atendiendo, como señala en su artículo Robert Adam, a que conservar y adaptar lo ya existente es por lo común más sostenible en sí mismo que recomponerlo por completo, se convierte hoy en una práctica medioambientalmente positiva.

A su vez, diseñar y construir edificios de forma que requieran un constante uso del aire acondicionado para hacerlos habitables durante los meses más cálidos, e incluso 


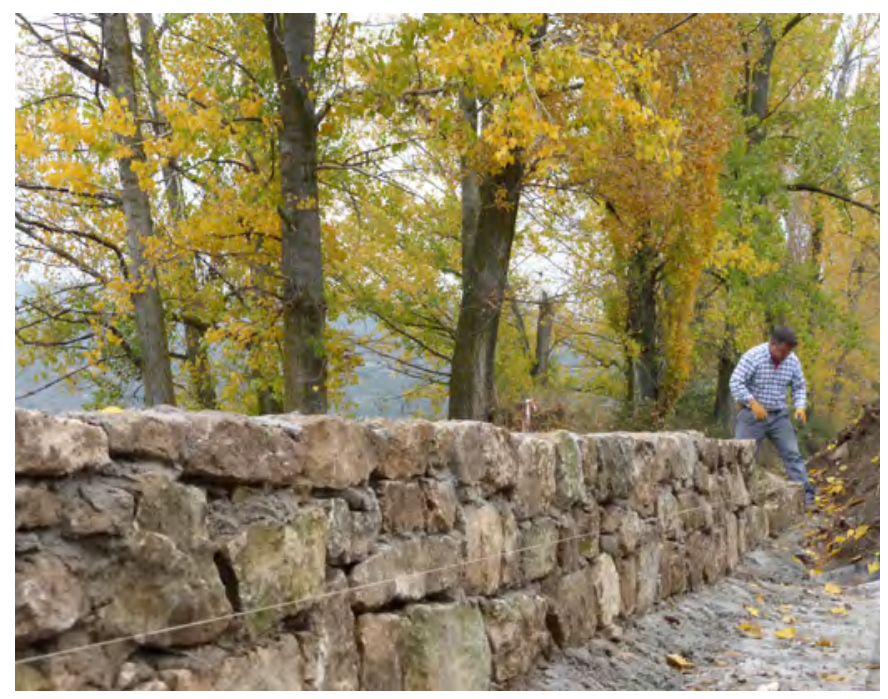

Muro de mampostería en construcción, reciclable y sin emisiones. Canal de Cabarrús, Madrid

pretender mantener inalterados los edificios de este tipo ya existentes, se convierte así en algo que no sólo pone en peligro nuestra salud y nuestro bienestar futuros, sino también nuestro patrimonio. Es también en esta situación una grave amenaza para el patrimonio mantener, planificar, normalizar o diseñar nuestro entorno como un conjunto fragmentado y disgregado de áreas monofuncionales: zonas de rascacielos que sólo contengan oficinas, que imponen que los usuarios de las mismas tengan que acudir a ellas desde lugares distantes; urbanizaciones compuestas sólo por viviendas, y en especial si se trata de unifamiliares, que imponen un uso constante y frecuente del transporte privado; centros comerciales a los que sólo puede accederse por carretera; polígonos industriales desligados del resto de la trama urbana; espacios públicos sobredimensionados e informes, diseñados de forma que se conviertan en barreras caracterizadas por la monotonía y la inseguridad en lugar de en conectores que promuevan la estancia, el paseo y el bienestar; grandes explotaciones industriales agrícolas y ganaderas, que arruinan la biodiversidad, erosionan los suelos y contaminan los acuíferos; etc.

Se trata de prácticas comunes hoy en día y aparentemente desconectadas de lo que normalmente entende-

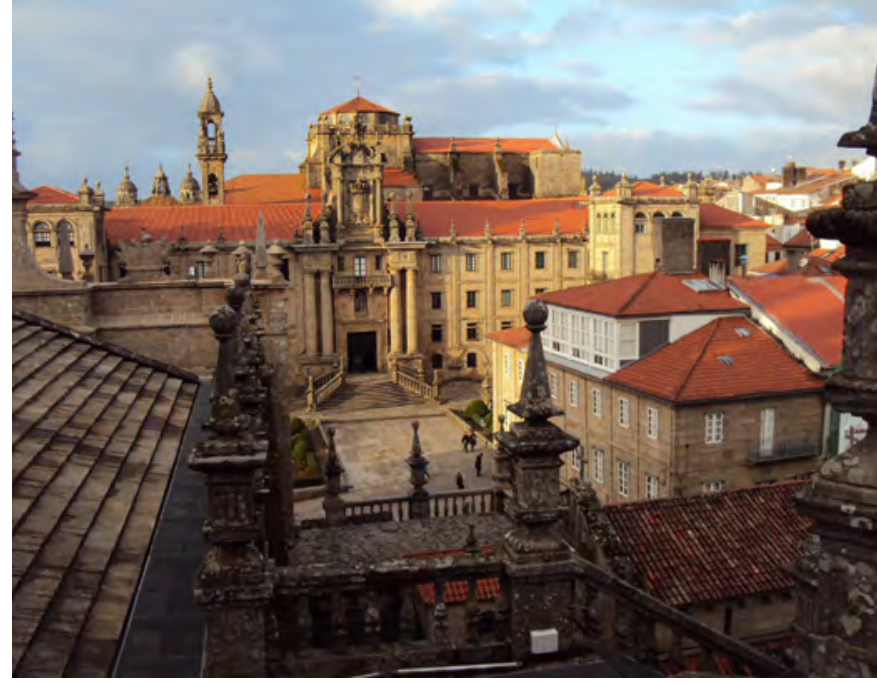

El patrimonio como repositorio de soluciones para construir un futuro más sostenible. Vista de la Plaza de la Azabachería de Santiago de Compostela

mos como conservación del patrimonio, pero que nos conducen inexorablemente a la catástrofe climática de la que todas las previsiones nos vienen advirtiendo y que, con ello, se convierten también sin excepción en pequeños o grandes atentados contra nuestro patrimonio.

En conclusión, el cambio climático supone una amenaza integral para la conservación de nuestro hábitat en su conjunto, y no escapa de ello nuestro patrimonio natural y cultural. Hacerle frente requiere, por tanto, una visión también integral de lo que hoy implica la conservación de dicho patrimonio.

Mientras sigamos percibiendo como algo normalizado y no como un riesgo inasumible prácticas nocivas para el medioambiente tan convencionales como las mencionadas, seguiremos en la senda conducente hacia una pérdida irreparable. Una conservación preventiva realmente efectiva pasa hoy por la concienciación al respecto de todos y cada uno de nosotros. 


\section{BIBLIOGRAFÍA}

- Climate Central (2021) Coastal Risk Screening Tool: Map By Water Level. Princeton, EEUU. Disponible en: https://sealevel. climatecentral.org/maps/ [Consulta: 09/09/2021]

- Climate Central (2019) Flooded Future: Global vulnerability to sea level rise worse than previously understood. Princeton, EEUU. Disponible en: https://www.climatecentral.org/news/ report-flooded-future-global-vulnerability-to-sea-level-riseworse-than-previously-understood [Consulta: 09/09/2021]

- Comisión Europea (2020) Comunicación de la Comisión al Parlamento Europeo, al Consejo, al Comité Económico y Social Europeo y al Comité de las Regiones. Intensificar la ambición climática de Europa para 2030: Invertir en un futuro climáticamente neutro en beneficio de nuestros ciudadanos. (Stepping up Europe's 2030 climate ambition. Investing in a climate-neutral future for the benefit of our people). Bruselas, 17 de septiembre de 2020. Disponible en: https://eur-lex.europa.eu/legal-content/ES/TXT/ PDF/?uri=CELEX:52020DC0562\&from=EN

[Consulta: 26/08/2021]

- Corneliussen, S.T. (2015) Climate Science, 50 Years Later. Physics Today, 14 de diciembre de 2015. Disponible en: https://physicstoday.scitation.org/do/10.1063/PT.5.8153/full/ [Consulta: 26/08/2021]

- IPCC [Grupo Intergubernamental de Expertos sobre Cambio Climático] (2021) Summary for Policymakers. En Masson-Delmotte, V., Zhai, P., Pirani, A., Connors, S.L., Péan, C., Berger, S., Caud, N., Chen, Y., Goldfarb, L., Gomis, M.I., Huang, M., Leitzell, K., Lonnoy, E., Matthews, J.B.R., Maycock, T.K., Waterfield, T., Yelekçi, O., Yu, R. y Zhou, B. (ed.) Climate Change 2021: The Physical Science Basis. Contribution of Working Group I to the Sixth Assessment Report of the Intergovernmental Panel on Climate Change.Cambridge University Press, en imprenta. Disponible en: https://www.ipcc. ch/report/ar6/wg1/downloads/report/IPCC_AR6_WGI_SPM. pdf [Consulta: 26/08/2021]

- MITECO [Ministerio para la Transición Ecológica y el Reto Demográfico] (2020) Plan Nacional de Adaptación al Cambio Climático 2021-2030. Madrid. Disponible en: https:// www.miteco.gob.es/es/cambio-climatico/temas/impactosvulnerabilidad-y-adaptacion/pnacc-2021-2030_tcm30-512163. pdf [Consulta: 07/09/2021]

- Naciones Unidas (1992) Convención marco de las Naciones Unidas sobre cambio climático. Nueva York. Disponible en: https://unfccc.int/files/essential_background/background_ publications_htmlpdf/application/pdff/convsp.pdf [Consulta: 10/08/2021]

- Sanz, M.J. y Galán, E. (ed.) (2020) Impactos y riesgos derivados del cambio climático en España. Madrid: Ministerio para la Transición Ecológica y el Reto Demográfico.
Disponible en: https://www.miteco.gob.es/es/ceneam/ recursos/pag-web/impactos-cambio-climatico-espana.aspx [Consulta: 07/09/2021]

- UNESCO (2009) Cambio climático y Patrimonio Mundial. Estudios de caso. París. Disponible en: https://www.iccrom. org/sites/default/files/2020-02/unesco estudios-caso-cambioclimatico-patrimonio-mundial.pdf [Consüulta: 10/08/2021] 


\section{$\mathrm{PH} 104_{\text {debate }}$}

a debate Patrimonio cultural y cambio climático

| coordina Alejandro García Hermida

\section{Cambio climático y patrimonio arbóreo monumental: un paisaje cultural amenazado}

Francisca Ramón Fernández | Dpto. de Urbanismo, Universitat Politècnica de València

URL de la contribución <www.iaph.es/revistaph/index.php/revistaph/article/view/4961>

El patrimonio arbóreo monumental: un patrimonio vivo $^{1}$

Cuando hablamos de patrimonio cultural siempre se identifica, en la mayoría de las ocasiones, con un monumento, con una construcción arquitectónica. Pero el patrimonio engloba mucho más. Estamos hablando de los árboles, del llamado patrimonio arbóreo monumental. Un patrimonio vivo porque es un ser vivo el que lo integra.

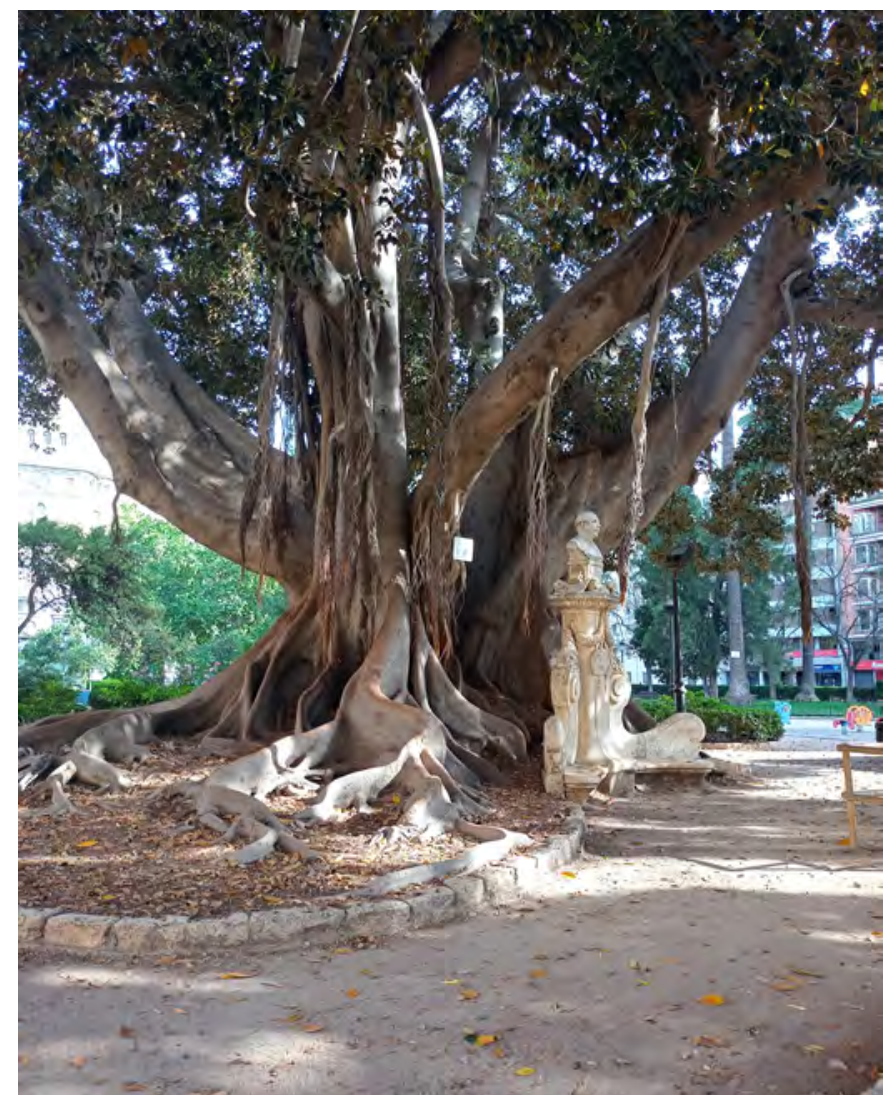

Árbol monumental protegido, en el Parterre, Valencia | foto Francisca Ramón Fernández
La protección del patrimonio arbóreo se contempla en las leyes 4/2006, de 19 de mayo, de la Comunitat Valenciana, y 14/2006, de 7 de noviembre, de la Región de Murcia, ambas de patrimonio arbóreo monumental (Ramón Fernández 2018). Son leyes territoriales, cuyo ámbito de aplicación es la comunidad autónoma respectiva, ya que a nivel nacional no se dispone de una legislación específica que proteja el patrimonio arbóreo monumental.

Se protegen aquellos ejemplares arbóreos que disponen de unas características botánicas de monumentalidad o circunstancias extraordinarias de edad, porte o relación con acontecimientos históricos, culturales, científicos, de recreo o ambientales.

\section{Cambio climático y patrimonio arbóreo monumental} El patrimonio arbóreo monumental como parte de la biodiversidad puede verse amenazado por distintas acciones y emisiones que pongan en peligro la vida de los ejemplares. La reciente Ley $7 / 2021$, de 20 de mayo, de cambio climático y transición energética, hace referencia a medidas para la protección de la biodiversidad y sus hábitats frente al cambio climático, mediante la elaboración de directrices básicas para su adaptación de los ecosistemas naturales.

La sostenibilidad resulta primordial, ya que uno de los objetivos es mantener los ejemplares arbóreos que han sido protegidos durante el mayor tiempo posible, para disfrute de las generaciones futuras y evitar su pérdida o daños (de hecho, se prohíben las talas no controladas e incluso la recolección indiscriminada de los frutos).

Si el cambio climático en el patrimonio cultural resulta especialmente preocupante (por ejemplo, en los casos 
de Londres por la subida del río Támesis, Venecia por I'acqua alta, en la que se ve sumergida la ciudad bajo el mar, o el lago Baikal, por la reducción del nivel del agua, o las Islas Salomón, a causa de la sobreexplotación forestal, los moáis de la Isla de Pascua, a causa del aumento del nivel del mar y las tormentas que socavan los acantilados, o Doñana, cuyas especies que se encuentran en dicho hábitat ven amenazada su existencia por el calentamiento global) (National Geographic 2019; Aguado 2020), también al patrimonio arbóreo le puede afectar. Piénsese en las lluvias, las emisiones de carbono y la contaminación atmosférica de las ciudades que afectan de forma directa a estos ejemplares que normalmente encontramos en los parques de las grandes ciudades o en los jardines históricos. Es el caso, por ejemplo, de los ficus milenarios del Parterre y la Glorieta y las palmeras del Jardín Botánico de Valencia. Por no olvidarnos de los olivos milenarios que se encuentran en distintas zonas de Castellón y su provincia (Ramón Fernández 2011).

\section{La necesidad del mantenimiento del paisaje cultural ante la amenaza climática}

El patrimonio arbóreo monumental lo debemos también poner en relación con el paisaje. La identificación de un territorio pasa precisamente por sus especies vegetales, además de por su patrimonio cultural. Somos capaces de identificar un lugar por su vegetación (por ejemplo, el denominado paisaje mediterráneo con su singularidad, a diferencia del paisaje gallego; o el paisaje del norte o del sur de España). Impera la protección del paisaje a través de lo que se ha denominado "ordenamiento ecológico del territorio".

Pero ese paisaje también puede estar amenazado por el cambio climático: la subida de la temperatura puede poner en peligro a las especies; el mayor riesgo de incendios y erosión conlleva la desaparición de dicho paisaje. Así se ha indicado en el informe World Heritage and Tourism in a Changing Climate, que fue elaborado por el Programa de las Naciones Unidas para el Medio Ambiente (PNUMA), así como la Unión de Científicos Comprometidos (USC).

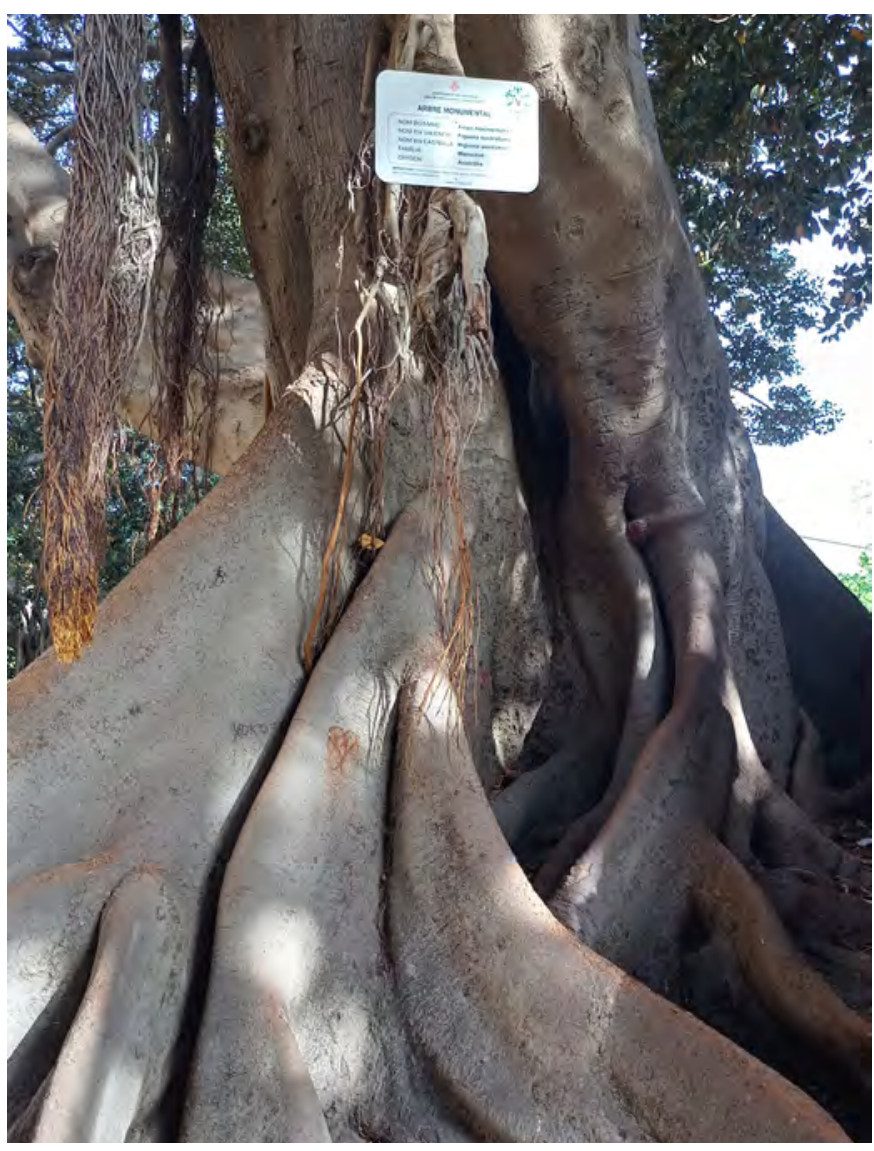

Higuera australiana, en el Parterre, Valencia. Declarado árbol monumental | foto Francisca Ramón Fernández

\section{Cambio climático, patrimonio arbóreo monumental y sus efectos en el turismo}

El patrimonio arbóreo monumental es un atractivo turístico para un perfil de turista que muestre interés por la naturaleza. Los efectos del cambio climático, al verse afectados los ejemplares protegidos, pueden tener consecuencias negativas en el ámbito turístico, ya que las rutas que se diseñen para mostrar los ejemplares podrían variar en el caso de su desaparición. Se trata, pues, de un patrimonio vulnerable y que está relacionado con las tradiciones y la cultura. Hemos indicado que en el patrimonio arbóreo también se protegen los ejemplares que están asociados a un acontecimiento de la cultura, con lo que está también en conexión con el patrimonio cultural inmaterial o intangible (festividades, tradiciones) que 
tengan como protagonista un árbol y forman parte de los derechos del pueblo (Equipo DESC 2021). En este sentido, resulta de interés el informe de Bennoune, la relatora especial de Naciones Unidas sobre los derechos culturales (Naciones Unidas. Asamblea General 2020).

\section{A modo de conclusión}

La necesidad de protección del patrimonio arbóreo monumental no puede considerarse de forma aislada, ya que una de las principales amenazas a ese patrimonio vivo es precisamente los efectos del cambio climático y también la contaminación atmosférica por las emisiones de gases que merman la vida de los ejemplares. En este caso, además, se trata de un patrimonio especialmente vulnerable, ya que tanto la erosión como los incendios devastarían por completo los árboles, unos árboles milenarios, únicos y vinculados al patrimonio cultural inmaterial, que es muestra de las tradiciones y costumbres de los pueblos, y que, en ocasiones, se han convertido en un símbolo.

\section{NOTAS}

1. Trabajo realizado en el marco de los proyectos I+D+i Retos investigación RTI2018-097354-B-100 (20192022) y Retos MICINN PID2019-108710RB-I00 (20202022).

\section{BIBLIOGRAFÍA}

- Aguado, M.G. (2020) El patrimonio que resiste al tiempo... pero no al cambio climático. Ethic, 30 de enero de 2020Disponible en: https://ethic.es/2020/01/el-patrimonioque-resiste-al-tiempo-pero-no-al-cambio-climatico/ [Consulta: 09/06/2021]

- Naciones Unidas. Asamblea General (2020) Report of the Special Rapporteur in the field of cultural rights, KarimaBennoune. A/75/298, 10 August 2020. Disponible en: https://www.ohchr. org/en/issues/culturalrights/pages/srculturalrightsindex.aspx [Consulta: 09/06/2021]

- Equipo DESC (2021) Repercusiones del cambio climático en la cultura, el patrimonio cultural y los derechos culturales. Amnistía Internacional España, 30 abril de 2021. Disponible en: https:// blogs.es.amnesty.org/madrid/2021/04/30/repercusiones-delcambio-climatico-en-la-cultura-el-patrimonio-cultural-y-losderechos-culturales/ [Consulta: 08/06/2021]

- El impacto del cambio climático en el patrimonio (2019) National Geographic España, actualizado a 2 de diciembre de 2019, originalmente publicado el 21 de diciembre de 2015. Disponible en: https://www.nationalgeographic.com.es/ciencia/ grandes-reportajes/el-impacto-del-cambio-climatico-en-elpatrimonio-2_9771/2 [Consulta: 09/06/2021]

- Ramón Fernández, F. (2011) Los olivos centenarios y milenarios y su protección en la Ley de Patrimonio arbóreo monumental de la Comunidad Valenciana. En: El aceite de oliva: actas del Simposium Científico-Técnico EXPOLIVA 2009, Jaén, 13 al 15 de mayo: ponencias, comunicaciones científicas. Jaén: Fundación para la Promoción y el Desarrollo del Olivar y el Aceite de Oliva, 2011

- Ramón Fernández, F. (2018) La protección del patrimonio arbóreo monumental en la legislación española. Su aplicación al turismo y al paisaje. Ius et Praxis, vol. 24, n. ${ }^{\circ} 3$, diciembre, pp. 109-132. Disponible en: https://scielo.conicyt.cl/scielo. php?script=sci arttext\&pid=S0718-00122018000300109 [Consulta: 09/06/2021]

- United Nations Environment Programme, United Nations Educational, Scientific and Cultural Organization, Union of Concerned Scientists (2016) World Heritage and Tourism in a Changing Climate. París: UNESCO; UNEP. Disponible en: https:// whc.unesco.org/document/139944 [Consulta: 08/06/2021] 


\section{Water-Wise Cities, ¿puede el patrimonio cultural del agua aportar estrategias ante el futuro cambio hidrológico?}

Celia López-Bravo, José Peral López | Dpto. de Historia, Teoría y Composición Arquitectónicas, Universidad de Sevilla

URL de la contribución <www.iaph.es/revistaph/index.php/revistaph/article/view/4963>

Nos encontramos en un momento en el que el agua es totalmente dependiente de modelos tecnológicos de consumo energético, recursos financieros y un mercado privado altamente competitivo (Marat-Mendes, Mourão y d'Almeida 2016, 159) y, pese a que las ciudades europeas disponen de avanzados sistemas de captación, depuración, distribución y recogida de aguas, se prevé que el proceso de hiperurbanización lleve a 2,5 mil millones de nuevos habitantes a las ciudades (ONU 2018a). Además de este desplazamiento demográfico, nuestro planeta se avecina a un profundo cambio hidrológico, de modo que, actualmente, la gestión de los recursos y las infraestructuras constituyen el principal desafío de la ciudad del futuro.

Ante este complicado escenario, han sido puestas en marcha múltiples iniciativas de gobernanza por parte de diversas entidades y organizaciones a nivel mundial, entre las que destacan el establecimiento del periodo 2018-2028 como el Decenio Internacional para la Acción "Agua para el Desarrollo Sostenible" por parte de Naciones Unidas (ONU 2018b) o la elaboración de la guía 17 Principios para las ciudades water-wise elaborada por la International Water Association (IWA 2017a).

Estos principios se sustentan en 4 niveles de acción entre los que cabe destacar: la implementación de un diseño urbano sensible al agua, la mayor relación de la ciudad con su cuenca hidrológica y la creación de comunidades water-wise. Para ello entran en juego la planificación de diseños urbanos que propicien servicios regenerativos de agua, la acción urbana en la gestión de las cuencas y el aumento de la visibilidad del agua a través del diseño de infraestructuras verdes y azules que ofrezcan oportunidades de inclusión social (IWA 2017b).
Para alcanzar todas estas estrategias, que apuntan al (re)conocimiento del entorno hidrográfico y al cuestionamiento social sobre cómo habitamos las ciudades y qué uso hacemos de los recursos, la valoración del patrimonio cultural del agua y de determinadas infraestructuras históricas resulta el primer paso a considerar por los municipios. El estudio de estos elementos intrínsecos de la forma urbana nos permite comprender, además de su innegable valor histórico y técnico, la estructura y el funcionamiento ambiental de las ciudades en el pasado. Esta base histórica puede suponer importantes claves a la hora de reducir la contaminación y el impacto ambiental de los sistemas contemporáneos, acortar las cadenas de suministro o restablecer relaciones territoriales.

La evolución del abastecimiento de agua en las ciudades hasta alcanzar los sistemas sanitarios modernos es discontinua y variada en función de los condicionantes técnicos, económicos, políticos y, fundamentalmente, geográficos. Los primeros sistemas griegos, basados en la complementariedad de depósitos privados y redes públicas, y el perfeccionamiento, la centralización y la monumentalidad de los sistemas romanos constituyen una primera época de esplendor, en la que afloran necesidades como la seguridad del agua, la materialidad o el mantenimiento de las infraestructuras. Menos reconocida es, en este aspecto, la Edad Media, una época oscura en la que las ciudades no alcanzaron los equipamientos ni el esplendor clásico, marcada por la inestabilidad política y económica y las limitaciones tecnológicas. Es, en cambio, un periodo de interés para el estudio de la gestión del agua. En esta época, se desarrolla una cultura del agua basada en el uso racional, la seguridad y el aprovechamiento máximos, el mantenimiento de las instalaciones y la reutilización. Son pocos los ejemplos de ciudades medievales que emprendieron 
a debate Patrimonio cultural y cambio climático

| coordina Alejandro García Hermida

sofisticados sistemas de abastecimiento, pero casi todos los de este reducido grupo perpetuaron su uso hasta inicios del siglo $\mathrm{XX}$, desarrollando comunidades prósperas y competitivas.

En Europa, algunas ciudades italianas como Venecia, Siena o Bolonia constituyen ejemplos de gran interés. El aprovechamiento de sus particulares condiciones geográficas -sobre el agua, en el caso de Venecia; en altura, en el caso de Siena; o en piedemonte, en el caso boloñés- las llevaron a adelantarse a los preceptos actuales de conectividad ecológica.

Sus proyectos urbanos contaban con un enfoque sistémico, en el que reciclaban estructuras existentes y consideraban un todo al conjunto del sistema hídrico y el espacio público urbano. Desde las cisternas lagunares en los campi vencianos (Rizzi 2020), las fuentes públicas en ladera y el sistema de bottini sienés (Constantini y Martini 2010) y el imbricado sistema de canales y la llamada chiavica boloñesa (Lucci y Ruzzon 2013), estas ciudades superaban las estrategias coetáneas más comunes en la materia, como la recogida doméstica y las captaciones superficiales de agua a nivel privado. Introduciendo el recurso y la necesidad del agua en el
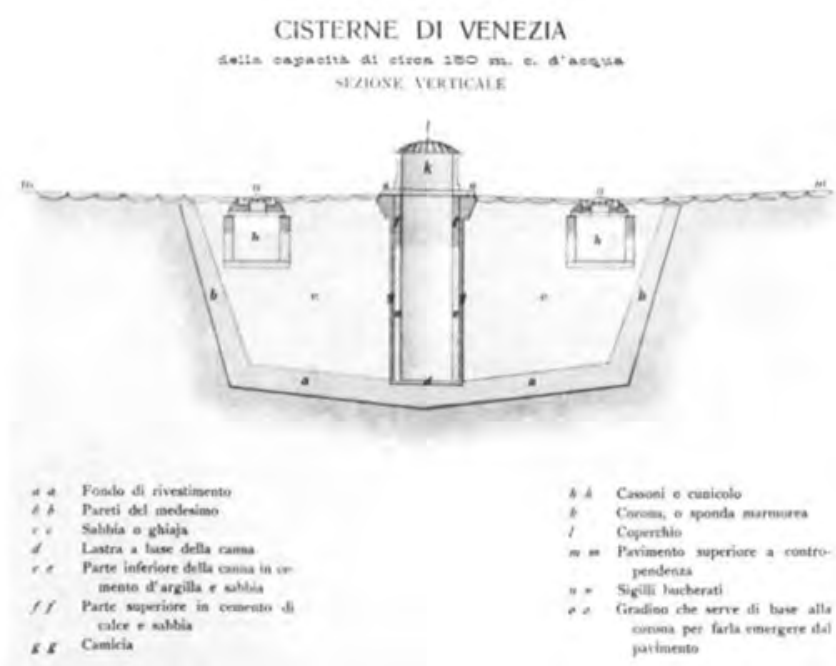

Sección de un pozo veneciano y su área de dotación | fuente Bianco 2020

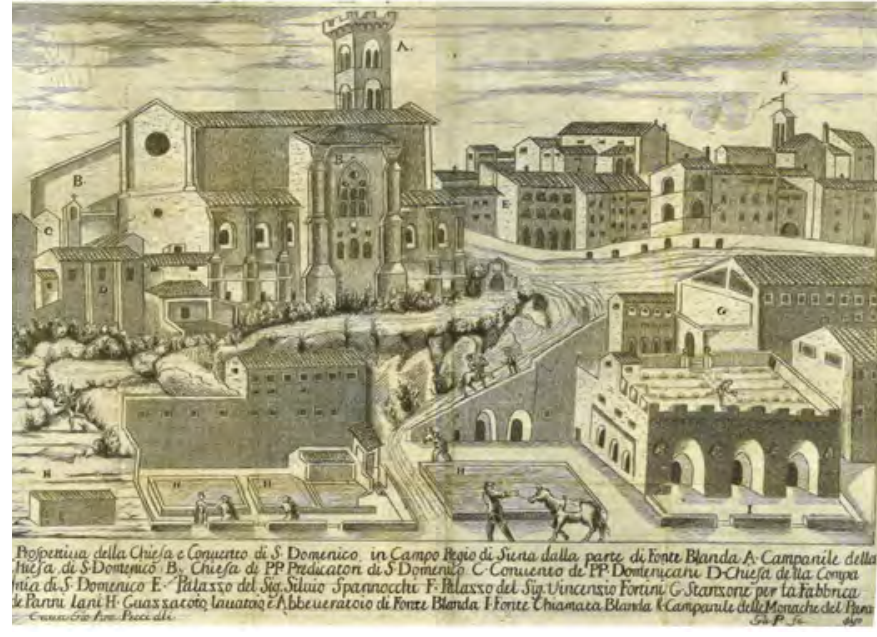

Dibujo de Fonte Branda en el que se representan los edificios principales y las funciones de cada una de las superficies de agua | fuente Pecci G.A. Ristretto delle cose più notabili della città di Siena ad uso de' forestieri ricorretto, e accresciuto. Siena, Bonetti nella stamp. Del pubblico per Francesco Rossi stampatore, 1759

diseño de sus edificios y espacios públicos, aportaron gran innovación y complejidad a su trazado, empleando el agua para consumo humano y como motor de una primitiva industrialización.

Máximas como el aprovechamiento de agua de precipitación, la autosuficiencia y el empleo de recursos "kilómetro 0", el mantenimiento y la conciencia ciudadana del cuidado, el uso racional del agua -cuyo derroche llegaba a ser considerado un delito mayor- y su reutilización, son hoy considerados principios de las llamadas waterwise cities que ya estaban presentes en estas infraestructuras preindustriales.

Evidentemente, hoy estos criterios se enmarcan en un contexto tecnológico distinto, donde los estándares de caudal de uso, calidad y salubridad de agua son otros. Pero su estudio puede colaborar en el diseño de estrategias más conscientes, apoyadas en valores y técnicas tradicionales de cara al futuro. Además, su reutilización constituye una gran oportunidad para suplementar el ciclo integral del agua urbana, reduciendo el consumo energético y el daño ambiental derivado de ciertos procesos de potabilización como la desalinización. 


\section{BIBLIOGRAFÍA}

- Bianco, G. "Relazione tecnica del 1860", Comune di Venezia. En: Rizzi, A. (2020) Vere da pozzo di Venezia. Caselle di Sommacampagna (Verona): Cierre Edizioni (Quaderni delle Regaste, 14)

- Costantini, A. y Martini, P. (2010) Landscape influence on the development of the medieval City-State of Siena, Italy. Italian Journal of Quaternary Sciences, n. ${ }^{\circ} 23$, pp. 283-298

- International Water Association [IWA] (2017a) The 17 IWA Principles for Water-Wise Cities. Disponible en: https:// iwa-network.org/projects/water-wise-cities/\#download_the principles [Consulta: 07/06/2021]

- International Water Association [IWA] (2017b) Los principios de la IWA para las ciudades Water-Wise. Disponible en: https:// iwa-network.org/wp-content/uploads/2017/06/IWA Brochure Water_Wise_Communities_screen_SP.pdf - [Consulta 07/06/2021]

- Lucci, P. y Ruzzon, D. (2013) Citta' d'acqua: Matera, Bologna e Modena. En: Focus su Acque e ambiente urbano. Qualità dell'ambiente urbano IX Rapporto. Roma: Istituto Superiore per la Protezione e la Ricerca Ambientale, pp. 41-51

- Marat-Mendes, T., Mourão, J. y Almeida, P.B. (De) (2016) Access to water in the Lisbon region in 1900. Water History, vol. 8, n. ${ }^{\circ}$ 2, pp. 159-189. Disponible en: https://doi.org/10.1007/ s12685-016-0160-3 [Consulta 14/06/2021]

- ONU [Organización de las Naciones Unidas] (2018a) Las ciudades seguirán creciendo sobre todo en los países en desarrollo, 16 de mayo de 2018. Disponible en: https://www. un.org/development/desa/es/news/population/2018-worldurbanization-prospects.html [Consulta: 09/06/2021]

- ONU [Organización de las Naciones Unidas] (2018b) Decenio Internacional para la Acción "Agua para el Desarrollo Sostenible". Disponible en: https://www.un.org/es/events/ waterdecade/ [Consulta 09/06/2021]izzi, A. (2020) Vere da pozzo di Venezia. Verona: Cierre Edizioni 


\title{
El patrimonio intangible de la arquitectura tradicional: un recurso en la lucha contra el cambio climático
}

\author{
Mónica Alcindor | Escola Superior Gallaecia, Portugal \\ URL de la contribución <www.iaph.es/revistaph/index.php/revistaph/article/view/4970>
}

Uno de los principales retos al que se enfrenta la sociedad en su conjunto es el cambio climático. Los motivos que han creado esta situación son múltiples, pero de lo que no hay duda es de que la actividad humana tiene una gran influencia en el mismo, basada principalmente en la quema de combustible fósil, la tala de selvas tropicales, así como una sobreexplotación del ganado.

El registro de datos termométricos se inició en 1850 y desde esa fecha se ha podido comprobar cómo desde mediados del siglo XX el aumento de las temperaturas ha sido el patrón establecido, con un incremento de la concentración de $\mathrm{CO}_{2}$ del $40 \%$. Consecuencia, con toda probabilidad, de la actividad humana promovida por la expansión de la Revolución Industrial a mediados del siglo XIX (Foer 2019).

Actualmente el planeta únicamente puede soportar una cantidad determinada de incremento de temperatura antes de que los bucles, es decir, las cadenas de consecuencias, se retroactiven y den paso a un cambio climático desbocado. Por todo ello en el Acuerdo de París adoptado en la Conferencia sobre el Clima de París en 2015 se estableció como objetivo mantener el calentamiento global por debajo de los $2^{\circ} \mathrm{C}$.

Para conseguir este objetivo hace falta un esfuerzo colectivo en muchas áreas de la actividad humana con el fin de reducir las emisiones de carbono a cero. Cada sector debe innovar y cooperar en busca del cumplimiento de este objetivo.

Desde el área de la edificación las emisiones de carbono representan un $6 \%$ del total de las emisiones anuales de gases con efecto invernadero, por lo tanto es importante asumir el reto necesariamente desde esta activi- dad. Pero para conseguirlo no hace falta reinventar la construcción, sino "desinventarla", es decir, el futuro de la construcción necesita parecerse al pasado.

Las formas de vida introducidas después de la Revolución Industrial arrasaron de manera sin precedentes todas las modalidades tradicionales del orden social. Tanto en extensión como en intensidad, las transformaciones que ha acarreado han sido profundas (Giddens 2011). Los sistemas nacidos de la Revolución Industrial encajan perfectamente en un medio cultural en el que se priorizan la regulación administrativa, los negocios y la conveniencia técnica, aunque desgraciadamente sin atender a un equilibrio ecológico. Estos sistemas han favorecido la desaparición de técnicas de base social tradicionales, elaboradas mediante un método a menudo polifuncional, y que partían de un enfoque integrado y estrictamente ligado a una concepción del mundo fundada en la cuidadosa gestión de los recursos locales (Laureano 1999).

Desde el ámbito de la arquitectura se hace necesario realizar un balance serio y reorientar la investigación científica y técnica en función de las nuevas aspiraciones. Uno de los pasos previos sería el reconocimiento y la valoración de aquellas técnicas locales que alguna vez en el pasado proporcionaron soberanía tecnológica con una cuidadosa gestión de los recursos y bajas emisiones de $\mathrm{CO}_{2}$.

Por lo tanto, un ejercicio fundamental a realizar es saber reconocer de nuestro pasado todo aquello que el "progreso" ha dejado atrás pero que sería de gran interés recuperar y "reproponer" en futuras actuaciones, ya que tal como pronunció Claude Lévi-Strauss en su legendario ensayo Raza y Cultura: 


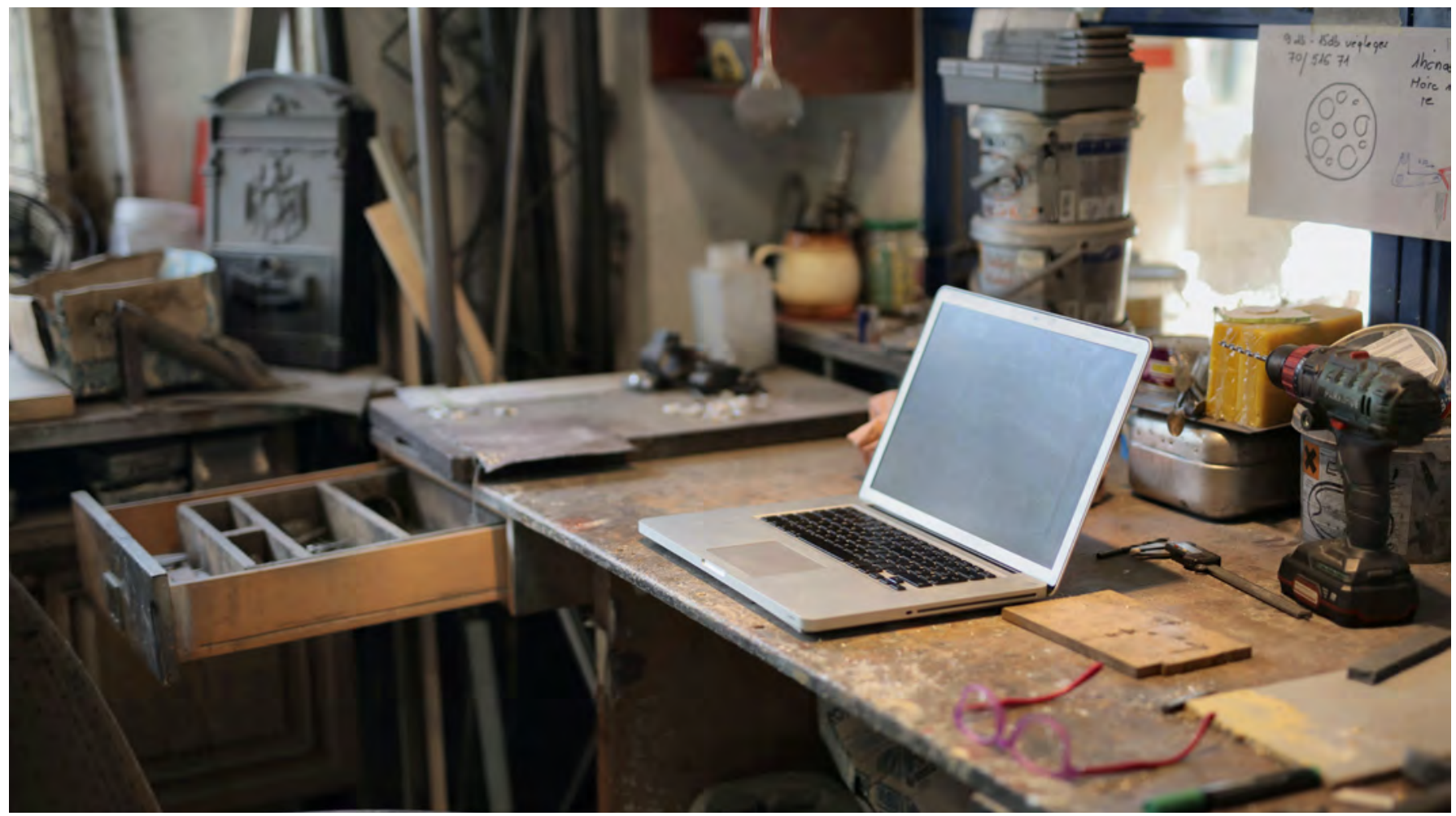

Laptop en la mesa del taller | foto Andrea Piacquadio

"el progreso no es necesario ni continuo; procede por saltos, o, como dirían los biólogos, por mutaciones. Estos saltos no consisten en llegar cada vez más lejos en la misma dirección; van acompañados de cambios de orientación, un poco al modo del caballo del ajedrez, que siempre tiene a su disposición varias progresiones, pero nunca en el peldaño de una escalera. (...) Lo que se gana con uno siempre se corre el riesgo de perderlo con otro, y sólo de vez en cuando es acumulativa la historia, es decir, los cambios se suman para formar una combinación favorable" (Lévi-Strauss 1993, 24-25).

Se trata de conseguir que el sistema actual "coevolucione" adaptándose a las exigencias ecológicas, como habría ocurrido durante buena parte de la historia de la humanidad (Naredo 2006). Estudiar un modelo constructivo que permita una nueva concepción orientada a reconstruir la ligazón con las culturas locales, dar espacio para la fusión y mezcla de sistemas posindustriales con las técnicas históricas locales ligadas al territorio y, por lo tanto, de menor consumo energético.

El concepto principal que se pretende es la permanencia, entendida más allá de la simple durabilidad de los materiales o sistemas, sino también su reproducción a lo largo del tiempo ya que no pone en peligro la estabilidad del medio físico y social. Significa reorientar la ciencia y la tecnología hacia lo permanente en todas las esferas que intervienen.

Esto exige la identificación y análisis de los elementos y técnicas constructivas utilizados por las comunidades locales en la construcción del patrimonio existente en aras de su readaptación a las actuales condiciones de la tardomodernidad.

El hecho de que la globalización del mercado haya desencadenado problemas muy parecidos en los dis- 
tintos territorios no significa que para dichos problemas sólo existan soluciones únicas. Consistiría en "pensar y actuar glocalmente", rechazando el paradigma eurocéntrico que prioriza lo global sobre lo local, lo general y abstracto sobre lo concreto y específico.

Se trata de analizar los sistemas constructivos tradicionales locales que son de baja tecnología y bajo consumo energético por antonomasia para identificar de qué modo se pueden adaptar a los requisitos de la actual sociedad altamente tecnificada, apoyados mediante normativas que, actualmente, no contemplan la reintroducción de sistemas tradicionales.

Aunque desde la enseñanza de la arquitectura también se hace necesario un replanteamiento, ya que los abordajes de los temarios suelen ser universalistas tal como la burocratización de las instituciones educativas exige. La introducción de conocimientos locales podría crear mucha discordancia al generar más variedad de la que se sería capaz de soportar, con un exceso de diversidad que dificultaría la capacidad de gestión (Díaz de Rada 2008). Por lo tanto, el reto de proporcionar una respuesta a los problemas medioambientales exige, desde la enseñanza, un desplazamiento de los contenidos a los códigos y de los códigos a los procesos cognitivos (Velasco, García y Díaz de Rada 1993) que asegure que arquitectos y arquitectas puedan plantear soluciones constructivas ligadas a cada lugar mediante la "reproposición" de técnicas tradicionales apoyados en la base suministrada por el pasado y, de este modo, contribuir a una reducción en la emisión de $\mathrm{CO}_{2}$ desde el campo arquitectónico.

\section{BIBLIOGRAFÍA}

- Díaz de Rada, A. (2008) ¿Qué obstáculos encuentra la etnografía cuando se practica en las instituciones escolares?. En: Jociles, M.I. y Franzé, A. (ed.) ¿Es la escuela el problema? Perspectivas socio-antropológicas de etnografía y educación. Madrid: Trotta editorial

- Foer, J.S. (2019) We are the weather: Saving the planet begins at breakfast. Reino Unido: Penguin
- Giddens, A. (2011) Consecuencias de la modernidad. Madrid: Alianza Editorial

- Laureano, P. (1999) Agua: el ciclo de la vida. Barcelona: Naciones Unidas; Agbar; CCD

- Lévi-Strauss, C. (1993) Raza y cultura. Madrid: Cátedra

- Naredo, J.M. (2006) Raíces económicas del deterioro ecológico y social: Más allá de los dogmas. Madrid: Siglo XXI

- Velasco, H., García, F.J. y Díaz de Rada, A. (1993) Introducción. En: Velasco, H., García, F.J. y Díaz de Rada, A. (ed.) Lecturas de antropología para educadores. El ámbito de la antropología de la educación y de la etnografía escolar. Madrid: Trotta, pp. 13-20 


\title{
Amenazas sobre los paisajes y actividades salineras del suroeste español por el cambio climático
}

\author{
Antonio Fajardo de la Fuente | Junta de Andalucía \\ URL de la contribución <www.iaph.es/revistaph/index.php/revistaph/article/view/4975>
}

En el sureste de la provincia de Sevilla, en terrenos de campiña y de la Subbética de las comarcas de Écija, Osuna y Estepa, se extiende un territorio en el que los materiales del Triásico, fundamentalmente margas y yesos, confluyen con la presencia de una zona endorreica (llanura esteparia sin desagüe al mar por la debilidad de la red hidrográfica), lo que favoreció la presencia de multitud de lagunas y zonas encharcadizas, alimentadas por arroyos salados, por lo que los humedales constituyen saladares que no solo resultan un ecosistema único habitado por una fauna acuática y esteparia y una vegetación singular, sino que también conforman un paisaje cultural en el que la sal ha sido explotada históricamente por parte de los centros coloniales de Astigi y Urso, siendo una fuente de recursos para sus comunidades en la Antigüedad (Castro García 2019). Las huellas de estas actividades han llegado a nuestros días en muy distintas manifestaciones: extraída de las lagunas de la zona esteparia y saladares localizados entre Écija y Osuna, donde se precipitaba en costras; las fábricas de sal controladas por la Corona; y, en los últimos tiempos, las pequeñas salinas de subsistencia que constituían un apoyo a la economía familiar. Pero han llegado al presente muy debilitadas, y el cambio climático es un factor más que acentúa la pérdida de las huellas de este recurso patrimonial.

El proceso de deterioro de los humedales de las cuencas esteparias situadas entre Écija y Osuna, una de las zonas con mayor concentración de lagunas y zonas encharcadizas de Andalucía, ha sido un tema poco estudiado (Fajardo 2018). De dos decenas de lagunas existentes a mediados del siglo XX, que ocupaban cerca de 1.000 ha de lámina de agua, tras la ejecución por el Instituto Nacional de Colonización de un plan de saneamiento, solo dos sobrevivieron, con una superficie inundada de 150 ha. Con la Ley $2 / 89$, por la que se aprueba el Inventario de Espacios Naturales Protegidos de Andalucía, se protegieron mediante la figura de reserva natural estos reductos. A partir de aquí se produce un cambio de tendencia, primero timorata y luego más ambiciosa, en la que se intenta recuperar la función original de algunas de las lagunas más representativas, que tiene como actuación más destacada la compra y recuperación ambiental en el 2010 de la desecada laguna de Ruiz Sánchez (350 ha). El avance de la investigación sobre estos fenómenos ha permitido además conocer mejor el interés ecológico de estos espacios, y el potencial que tiene su recuperación, así como los procesos que los amenazan, derivados del cambio climático y de la presión antrópica.

Las lagunas esteparias presentan una dinámica marcadamente estacional, llenándose con las precipitaciones otoñales, con profundidades máximas de 1 metro, y permaneciendo inundadas hasta la primavera, período en el que habitualmente se produce su desecación. No obstante, su estrecha dependencia del balance precipitación/evaporación condiciona la variabilidad en la mayor o menor persistencia de estos humedales. Las lagunas también presentan una salinidad variable asociada al patrón de concentración por evaporación típico de las lagunas endorreicas. Respecto a la hidrología se ha investigado un tema de gran interés: las relaciones entre el sistema lacustre y el acuífero de Los Llanos de OsunaLantejuela, ya que las lagunas constituían los ojos del acuífero, donde sus aguas afloraban en superficie, pues las cubetas interceptan con el nivel piezométrico. Esta situación ha sufrido cambios drásticos por drenaje de la zona palustre, y por la explotación de las aguas subterráneas, ya que el acuífero se encuentra sobreexplotado por la existencia de aproximadamente 600 captaciones (López Geta et ál. 2011), así como por la evidencia de una reducción de las precipitaciones. 


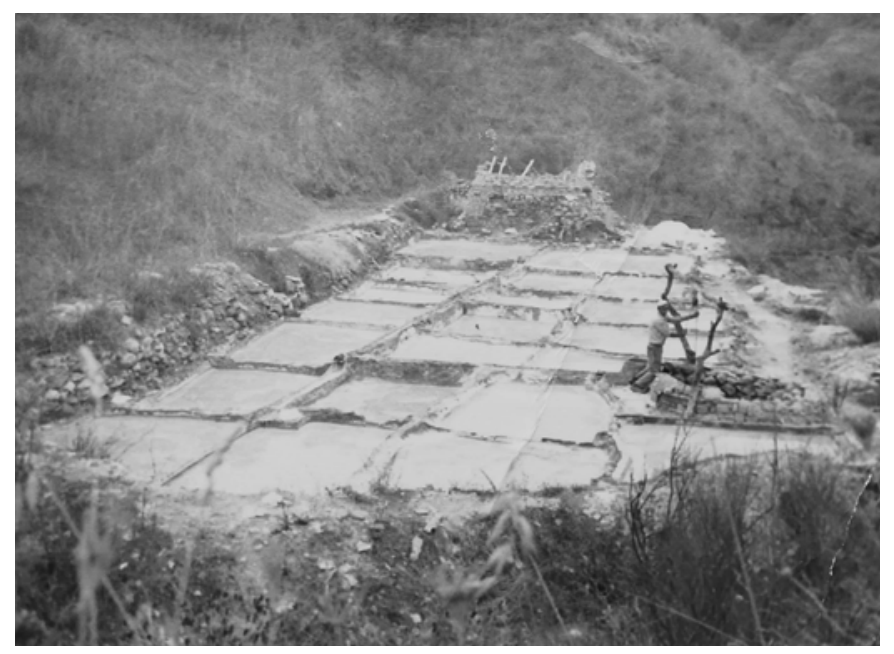

Salina de Escamilla (Osuna), explotada rudimentariamente por jornalero que completaba su renta, ca 1980 | foto Anónimo. Propiedad de la familia Sánchez Borrego

Se ha avanzado además en la identificación de los espacios encharcados de forma temporal, posiblemente antiguas lagunas o espacios en los que la actuación humana ha propiciado su desecación. Estos trabajos han permitido apreciar la dimensión del fenómeno, mayor que el estimado, y su capacidad de recuperación pese a la persistencia de circunstancias adversas ${ }^{1}$. Además de estas lagunas, se han identificado (Alba Morillo 2017) a partir de la fotointerpretación de la ortofotografía de 2010, un año especialmente húmedo, otras 11 zonas encharcadas que se extienden por 76,4 ha situadas en la zona central del área endorreica, posiblemente muchas de ellas antiguas lagunas.

Respecto a sus valores paisajísticos, han sido reconocidos por el Catálogo de paisajes de la provincia de Sevilla (Zoido Naranjo 2015). Concretamente la denominada "Unidad Campiñas de Osuna-Lantejuela" es caracterizada como un paisaje agrícola, con un relieve suave $y$ ondulado que favorece la intervisibilidad y que posee destacados valores estéticos y dinamismo estacional y en la que se destaca por contraste la presencia de los humedales del complejo endorreico. En el muy antropizado paisaje agrícola en secano, las lagunas endorreicas contribuyen a diversificar las escenas visuales, especialmente por los destacados ecosistemas representados en el complejo.

Después de décadas de abandono, en poco tiempo se ha avanzado mucho en la protección, conocimiento y reconocimiento social e institucional de este territorio, tan maltratado en el siglo XX. El proceso reciente vivido ha evidenciado el potencial de recuperación de este territorio encharcadizo. Sin embargo, de todas las lagunas y terrenos inundados periódicamente solo dos de ellas tienen garantizada la integridad de sus valores por una protección efectiva, las incluidas en la reserva natural. Otras como la laguna de Ruiz Sánchez, la del Gobierno, de la Turquilla y de Hoya de la Huerta, al ser propiedad pública, cuentan con el amparo efectivo por la voluntad de sus titulares. La inmensa mayoría del resto de los humedales está sometido al libre criterio de sus propietarios, por ello se estima que es conveniente seguir avanzando en la protección y recuperación del mayor número de humedales ya que, con los datos conocidos por los censos de aves, se llega a la conclusión de la fuerte interdependencia entre el conjunto de humedales y sus valores para la fauna acuática y esteparia (Fajardo de la Fuente 2018).

La principal amenaza que se cierne sobre estos saladares esteparios tiene que ver, dada la íntima relación del uso de las aves con la presencia de agua en las lagunas, con la sobreexplotación del acuífero y el cambio climático. Según el Proyecto Escenarios Locales de Cambio Climático de Andalucía (Consejería de Medio Ambiente y Ordenación del Territorio 2011), esta región será una de las zonas más vulnerables, lo que dará lugar a una mayor presión sobre las especies y los hábitats ${ }^{2}$.Por todo ello, resulta necesario desarrollar una experiencia de gestión compartida del territorio, propiciando el diálogo entre actores públicos y privados, para la implantación de buenas prácticas agrícolas que disminuya la presión sobre los acuíferos y que contribuyan a la adaptación y mitigación de las consecuencias del cambio climático y garanticen la persistencia de servicios en ecosistemas agrarios y naturales, favoreciendo la biodiversidad. 
Las actividades salineras están vinculadas a estos fenómenos geofísicos favorecedores de la presencia de estas bolsa de sales que afectan a los acuíferos y confieren el carácter salobre o salado a numerosas fuentes y cursos fluviales ${ }^{3}$. La extracción de sal ha revestido muchas manifestaciones de mayor o menor trascendencia económica y cultural: extraídos de los saladares, donde se forman costras de sal en los lechos de las lagunas, se aprovechaban también los espumeros, costras salinas que se forman en verano en las inmediaciones de los numerosos cursos de aguas salobres o saladas. Muchos cortijos elegían como emplazamiento la cercanía de algún manantial o pozo de agua salada, aprovechando estos recursos con pequeñas explotaciones de consumo local.

Las manifestaciones de mayor trascendencia y valor patrimonial son las fábricas de sal. Las salinas de interior constituyen un endemismo ibérico, pues prácticamente no existen en el continente europeo actividades parecidas (Carrasco Vayá y Hueso Kortekaas 2008). Es un elemento del patrimonio ligado a la explotación tradicional del territorio en el que confluyen historia, cultura, naturaleza y economía para constituir un paisaje único que contrasta en el entorno agrícola donde se implanta. Proceso productivo hermanado con la agricultura que exige una serie de labores de preparación hasta llegar a la cosecha, es también una actividad minero-industrial. Es además un ejemplo de explotación de los recursos naturales fruto de la adaptación ingeniosa a las mas ásperas circunstancias, utilizando tecnologías sostenibles: resultado del manejo del agua y del aprovechamiento de la energía solar sin producir prácticamente ningún residuo. Es sin embargo una actividad en vías de extinción ${ }^{4}$. En la comarca de Estepa y Osuna este autor ha inventariado 14 salinas explotadas en el siglo XX (Fajardo de la Fuente 2021), siendo el periodo comprendido entre 1940 y 1960 el de mayor actividad. De ellas solo 4 han sido salinas grandes y productivas, que exigían la contratación de personal y una estructura empresarial, siendo el resto explotadas a tiempo parcial por pequeños propietarios o por jornaleros. Al día de hoy solo sobreviven dos salinas, aunque la extracción de sal es testimonial

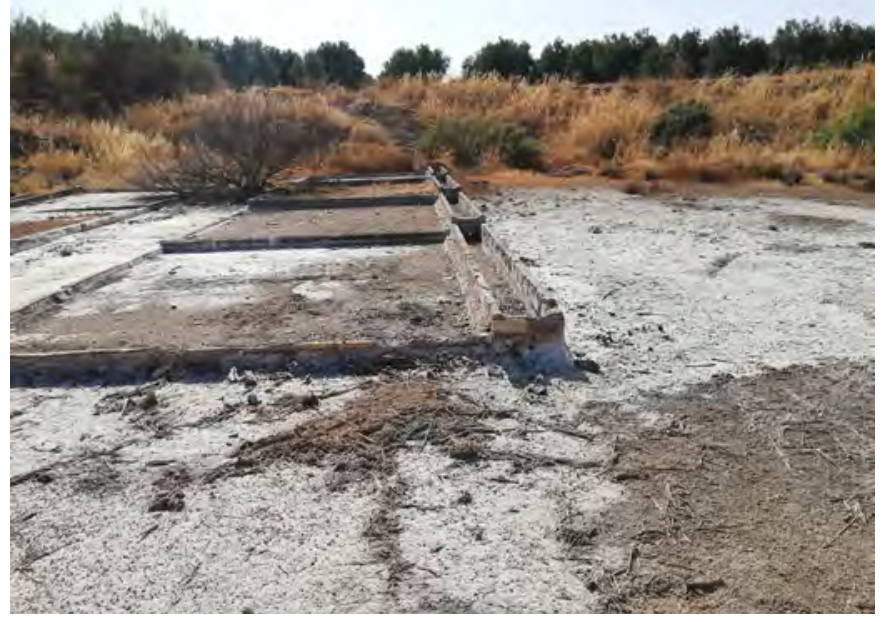

Salina EI Salinoso (Pedrera), explotación abandonada recuperable (2020) | foto Antonio Fajardo

ya que la orientación principal es la producción y venta de salmuera. Además, a este inventario hay que unirle las 5 salinas localizadas en el término municipal de Écija (García-Dils de la Vega et ál. 2009), algunas de gran interés patrimonial por su larga historia y por estar asociadas a un interesante patrimonio material, como sucede con las salinas de la Torre, Borreguero y Balmaseda.

Aunque las causas del abandono de las salinas están ligadas a su pérdida de interés económico, se tiene constancia de la desaparición de alguna explotación salinera por la pérdida o alteración del manantial, como sucedió con la salina del Navazo, o por el agotamiento de los pozos que suministraban a la salina. La interdependencia de las explotaciones con el estado del acuífero es manifiesta, y uno de los factores que lo condicionan es la disminución de los aportes por la reducción de las precipitaciones, sin embargo, estos procesos ligados al cambio climático son lentos. Es el aumento de la presión sobre los acuíferos por la proliferación de pozos ilegales el factor que, de una manera directa, está incidiendo en la disminución de los recursos disponibles, lo que está evidenciando el agotamiento de numerosas fuentes y manantiales y de los pozos que suministraban a las salinas, lo que condena la posible recuperación de las explotaciones salineras en un momento en el que empie- 
a debate Patrimonio cultural y cambio climático

| coordina Alejandro García Hermida

zan a emerger iniciativas de puesta en valor económico y patrimonial de viejas salinas, como está sucediendo felizmente con la de Valcargado (Utrera).

\section{NOTAS}

1. En la cartografía topográfica histórica se distinguen 9 lagunas. La inmensa mayoría fueron transformadas y desecadas, excepto Ballestera y Calderón Chica, aunque han seguido inundándose periódicamente tras periodos de lluvias intensas. Los trabajos de seguimiento y censo de población de anátidas han permitido identificar otros 11 humedales que se inundan periódicamente de forma estacional, que acogen acuáticas y son objeto de seguimiento. Las veinte lagunas suman la considerable superficie de 891,6 ha de lámina de agua.

2. Lo manifiesta un escenario para mediados de siglo XXI que contribuirá a la intensificación de las principales amenazas sobre los hábitats y especies de la ZEC, lo que afectará al régimen hídrico, reduciendo considerablemente el periodo de inundación de las cubetas lagunares y pudiendo conllevar, en algunos casos, la desecación casi definitiva de algunas de ellas. Esta circunstancia provocaría, a su vez, una disminución de la biodiversidad asociada a estos espacios naturales y agrícolas, pérdida que es máxima en el caso de las lagunas temporales endorreicas, con una biodiversidad rica y específica pero altamente amenazada.

3. El análisis de la toponimia de la comarca (Fajardo de la Fuente 2020) revela la fuerte impronta de la actividad salinera y de los rasgos físicos-naturales ligados a esta actividad.

4. La supervivencia en la actualidad de algunas salinas se explica por demandas muy locales de sal, para la alimentación del ganado, conservación de carne, o en algunos casos demandas vinculadas con el propio productor, pero sobre todo por la demanda desde la década de los 70 del siglo $\mathrm{XX}$ de salmuera para el aderezo de la aceituna, que ha permitido la supervivencia de las con- tadas salinas sevillanas, cordobesas o malagueñas que han llegado hasta nuestros días.

\section{BIBLIOGRAFÍA}

- Alba Morillo, B. (2017) Estudio comparativo de la intervención antrópica en el complejo palustre de La Lantejuela durante el periodo 1956-2010. Trabajo Fin de Grado inédito, Universidad de Sevilla

- Carrasco Vayá, J.F. y Hueso Kortekaas, K. (2008) Los paisajes ibéricos de la sal. Las salinas de interior. Guadalajara: Asociación de Amigos de las Salinas de Interior, Fundació Territori i Paisatge, Anser

- Castro García, M. (2019) La Lantejuela, un complejo endorréico entre dos colonias béticas: Astigi y Urso. En: Lagóstena Barrios, L. (coord.) Economía de los humedales. Prácticas sostenibles y aprovechamientos históricos. Barcelona: Universitat de Barcelona, pp. 137-276 (Colecció Instrumenta, 68)

- Zoido Naranjo, F. y Rodríguez Rodríguez, J. (2015) Catálogo de paisajes de la provincia de Sevilla. Sevilla: Centro de Estudios Paisaje y Territorio, Consejería de Medio Ambiente y Ordenación del Territorio

- Fajardo de la Fuente, A. (2018) Ocaso y resurrección de los humedales del complejo endorreico de las llanuras esteparias sevillanas. Écija y Osuna: tierras de lagunas. Cuadernos de los Amigos de los Museos, n. ${ }^{0} 20$, pp. 65-73

- Fajardo de la Fuente, A. (2020) La declinante huella de la actividad salinera en el Marquesado de Estepa, la Villa de Osuna y sus pueblas. Cuadernos de los Amigos de los Museos, n. ${ }^{\circ} 21$, pp. $159-172$

- Fajardo de la Fuente, A. (2021) Salinas de subsistencia en la Andalucía rural. Cultura del trabajo de los últimos salineros de Osuna y su comarca. Cuadernos de los Amigos de los Museos, n. ${ }^{\circ} 22$ (en prensa)

- García-Dils de la Vega, S., OrcheAmaré, P., Sáez Fernández, P. y Ordóñez Agulla, S.M. (2009) Estudio diacrónico de la explotación de la sal en el territorio histórico de Écija, Sevilla. En: Actas I Congreso Internacional "La explotación de la Sal: investigación y puesta en valor". Madrid: Sociedad Española de Historia de la Arqueología, pp. 73-90

- López Geta, J.A., Martos Rosillo, S., Rodríguez Rodríguez, M. y Moral Martos, F. (2011) Fascículo 3: Humedales de la campiña sevillana. En: Itinerarios del Agua en la Provincia de Sevilla. Sevilla: Instituto Geológico y Minero de España y Diputación Provincial de Sevilla

- Consejería de Medio Ambiente y Ordenación del Territorio (2011) Proyecto Escenarios Locales de Cambio Climático de Andalucía 


\title{
Incendios en paisajes patrimoniales naturales: análisis y evaluación de riesgos en fortificaciones mediante el uso del Global Wildfire Information System
}

\author{
Mónica Moreno Falcón, Rocío Ortiz Calderón, Pilar Ortiz Calderón | Dpto. de Sistemas Físicos, Químicos y Naturales,
} Universidad Pablo de Olavide

URL de la contribución <www.iaph.es/revistaph/index.php/revistaph/article/view/4976>

\section{Introducción}

Si bien los incendios forman parte de las dinámicas naturales de los ecosistemas, desgraciadamente los grandes incendios incontrolados generan daños irreversibles. La frecuencia, extensión y duración que presenta un incendio está estrechamente ligada con la variabilidad climática y la distribución de la cobertura vegetal (Cardil et ál. 2021; Fasullo, Otto-Bliesner y Stevenson 2018; Rodrigues et ál. 2021).

Esto hace que en un contexto de cambio climático y antrópico que incluye aumentos en las temperaturas, largas sequías e intensas tormentas, son muchos los investigadores que han establecido una estrecha relación entre los cambios ocurridos recientemente y el incremento de los grandes incendios incontrolados a nivel mundial (Abatzoglou, Williams y Barbero 2019; Rigo et ál. 2017).

Los grandes incendios plantean riesgos de salud para las poblaciones que habitan estos espacios, provocan la erosión del suelo y la contaminación del aire y el agua (Gill, Stephens y Cary 2013). En paisajes históricos implican además la pérdida de las estructuras e inmuebles patrimoniales allí conservados. A su vez, los grandes incendios aumentan la emisión de dióxido de carbono y otros gases invernadero a la atmósfera lo cual contribuye al cambio climático, favorece el aumento de la temperatura y promueve el desarrollo de nuevos incendios.

Ante la problemática descrita, registrar y efectuar un seguimiento de los niveles de riesgo de incendio permite a las instituciones encargadas de la gestión de paisajes patrimoniales diagnosticar zonas de riesgo, definir áreas prioritarias de actuación y plantear políticas de preservación respetuosas no solo con los bienes patrimoniales sino también con la diversidad de ecosistemas y recursos naturales.

En los últimos años la aparición de visores satelitales ha posibilitado a usuarios no especializados emplear la teledetección y las imágenes satelitales como fuente de información para muy diversas disciplinas. Un ejemplo aplicado a la evaluación del riesgo de incendios es la herramienta Global Wildfire Information System (GWIS) (Geo, NASA y Copernicus, 2021; Ambrosia et ál. 2019; Artés et ál. 2019). El uso de estos recursos en la gestión del patrimonio puede promover el diseño de políticas de conservación preventivas sostenibles y adaptadas a las necesidades de entornos cambiantes.

Partiendo de esta línea conceptual, se presenta un breve análisis de la dinámica de los eventos de incendio ocurridos en España actualmente y se testea la aplicabilidad de GWIS en la gestión sostenible de las fortificaciones en tapia ubicadas en Andalucía.

Las murallas de Niebla y Marchena, la Alcazaba de Almería o el Real Alcázar de Sevilla son solo algunos ejemplos de las más de 200 fortificaciones en tapia conservadas en Andalucía (IAPH 2021). La abundancia de este tipo de construcciones, características del paisaje histórico medieval peninsular, implica implementar planes de diagnosis capaces de analizar grandes territorios conjuntamente. Atendiendo a esta necesidad, los 
datos levantados permiten identificar la temporada del año y los usos de suelo que presentan un mayor índice de riesgo; evaluar la tendencia 2002-2020; y obtener el índice de peligrosidad existente actualmente.

\section{Metodología}

GWIS es un visor geográfico que permite analizar a escala mundial escenarios de riesgo de incendio a partir de datos obtenidos principalmente de imágenes satelitales. GWIS presenta 3 módulos de trabajo: herramienta de análisis, evaluación rápida y pronóstico.

La estacionalidad de los fuegos, la relación entre el número de hectáreas y tipos de coberturas terrestres quemadas y la tendencia registrada desde 2002 hasta 2021 han sido información obtenida del módulo de análisis de GWIS.

Las zonas quemadas entre 2002 y 2020 y los incendios acontecidos en 2020 han sido obtenidos del módulo de evaluación. Esta información se obtiene a partir de los datos de los sensores satelitales VIIRS (Schroeder et ál. 2014) y MODIS (Artés et ál. 2019; Giglio et ál. 2018) y presenta una resolución espacial de $350 \mathrm{~m}$ y $1 \mathrm{~km}$ respectivamente.

El módulo de pronóstico ha sido empleado para obtener el riesgo de incendio actual en España a partir del índice Forest Fire Weather Index System (FWI).

Este índice calcula el riesgo en función de la temperatura, la humedad, la velocidad del viento, las precipitaciones pasadas-presentes y los contenidos de humedad de los distintos combustibles vegetales (Wagner y Pickett 1985). Su uso está generalizado a nivel mundial (Di Giuseppe et ál. 2020). En función de los pronósticos medioambientales del ECMWF, GWIS arroja una previsión del riesgo de incendio hasta con 10 días de anticipación y una resolución espacial de 8 km.

Para interrelacionar los datos arrojados por GWIS con las fortificaciones conservadas en Andalucía, los datos del sensor MODIS sobre áreas quemadas han sido descargados del Fire Information for Resource Management System (FIRMS) (NASA, 2021) y trabajados mediante el uso de QGIS ${ }^{\circ}$ (QGIS Development Team 2012), sistema de información geográfica de uso libre.

La georreferenciación de las fortificaciones ha sido obtenida del Instituto Andaluz del Patrimonio Histórico (IAPH 2021) e introducida como una capa vectorial.

\section{Resultados y discusión}

\section{Análisis por país}

Para el caso de España, la figura 1 (p. 415) muestra la relación existente entre el número de incendios y hectáreas quemadas mensualmente durante el 2020. Febrero y marzo fueron los meses en los que acontecieron un mayor número de incendios ( $>35 /$ mes).

A pesar de ello la pequeña magnitud de estos eventos y la facilidad para controlarlos hizo que el número de hectáreas quemadas no fuese elevado durante estos meses (<6.000 ha). Por el contrario, los meses de junio y agosto presentan una gran cantidad de hectáreas quemadas (10.000-12.000 ha) con un número mucho menor de incendios(>15/mes). Las elevadas temperaturas de estos meses, la escasez de precipitaciones y las condiciones de sequía aumentaron la intensidad de los fuegos, dificultando el control y su extinción durante el verano.

La figura 2 (p. 415) muestra la tendencia en la ocurrencia de incendios en España desde 2002 hasta 2020. Respecto al número de hectáreas quemadas anualmente, los datos señalan una tendencia decreciente con bruscos aumentos en 2012 y 2017, picos que coinciden con años de fuertes sequías en España (Beguería et ál. 2021).

Respecto al tipo de coberturas quemadas, bosques, campos de cultivos y zonas de matorrales son las más tendentes a sufrir incendios en el territorio español. Los incendios en zonas de cultivo han decrecido considera- 


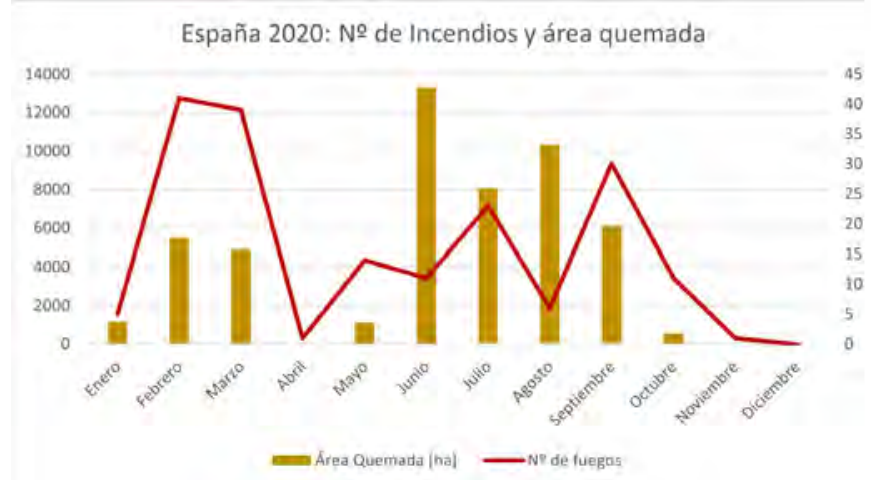

Figura 1. Número total de incendios y áreas quemadas en España durante el 2020 | fuente datos disponibles en GWIS

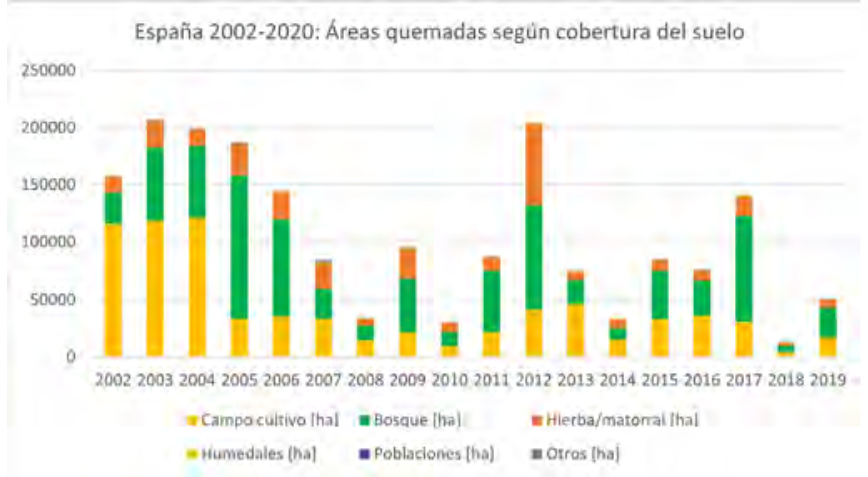

Figura 2. Áreas quemadas por cobertura del suelo en España desde 2002 hasta 2020 | fuente datos disponibles en GWIS

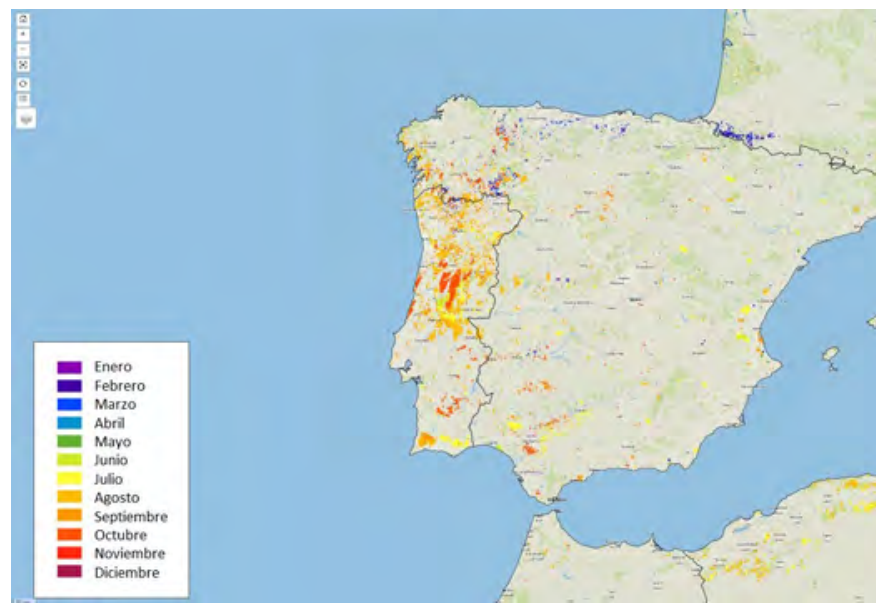

Figura 3. Áreas quemadas y meses de ocurrencia en España durante el 2020 | fuente visor GWIS blemente desde 2005 y los incendios en años de fuertes sequías (2012 y 2017) afectan sobre todo a zonas boscosas y matorrales.

La figura 3 permite conocer la ubicación geográfica de las áreas quemadas entre 2002 y 2020.

En Andalucía, las provincias que presentan más zonas afectadas por el fuego son Sevilla y Córdoba que han sufrido grandes incendios durante los meses de julio, agosto y septiembre. Por el contrario, el norte de España, registra áreas quemadas de menor magnitud asociados a incendios ocurridos en febrero y marzo.

El análisis efectuado permite identificar los meses de junio-agosto como la estación en la que ocurren los incendios de mayor peligrosidad en el territorio español; un aumento del riesgo en zonas boscosas y de matorral durante los años de sequía y una identificación del suroeste de España como zona especialmente afectada por los grandes incendios ocurridos entre 2002 y 2020.

\section{Evaluación de la temporada 2020}

La figura 4 (p. 416) permite identificar los fuegos ocurridos durante la temporada 2020 y comparar la tendencia nacional con la dinámica del entorno mediterráneo. La figura 4a muestra los datos recogidos por el sensor satelital MODIS y arroja incendios que afectaron a áreas de más de $1 \mathrm{~km}$. La figura 4b muestra los incendios recogidos por el sensor VIIRS y permite identificar eventos de fuego afectan a áreas con más de 350 m.

La diferencia entre ambas imágenes permite identificar aquellos eventos de fuego que acaban convirtiéndose en grandes incendios, así como los puntos más propensos a sufrir incendios incontrolados. Para el caso español, se observan 4 zonas de mayor peligrosidad: Barcelona; Alicante, Sevilla-Córdoba y Extremadura.

La figura 5 (p. 416) permite identificar los puntos que se han visto afectados por incendios de más de $350 \mathrm{~m}$ en los últimos 7 días y registra incendios en 3 de esas zonas: Sevilla, Barcelona y Alicante. 

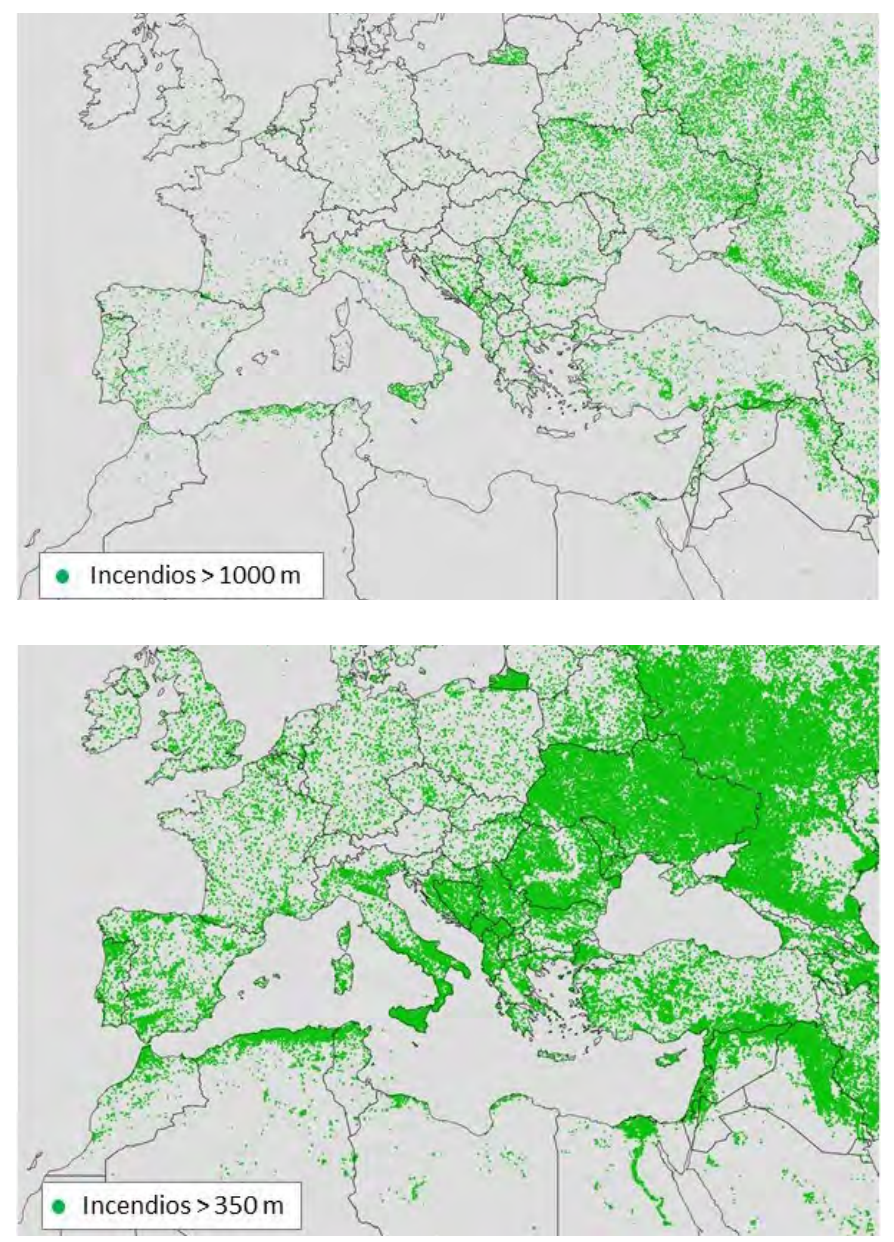

Figura 4 a y b. Incendios de más de 1 km ocurridos en 2020; Incendios de más de 350 m ocurridos en 2020 | fuente visor GWIS

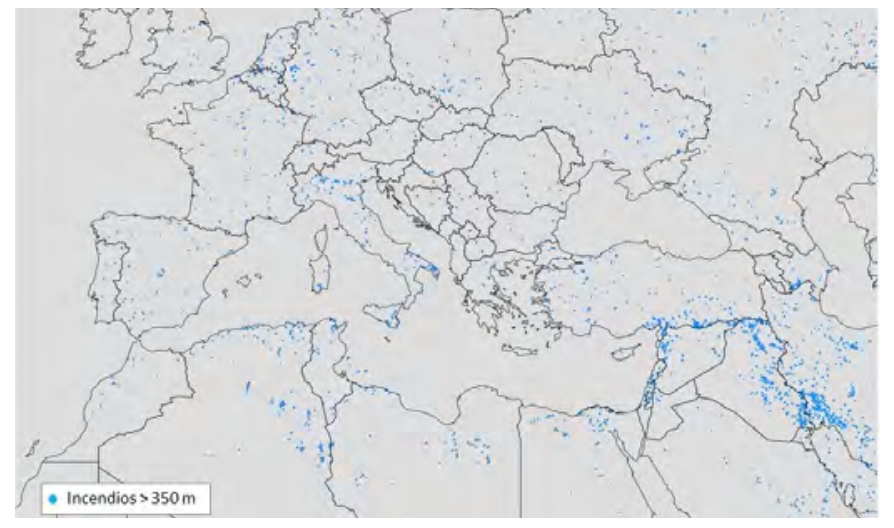

Figura 5. Incendios de más de 350 m ocurridos entre 07/06/2021 y el 13/06/2021 | fuente visor GWIS

\section{Aplicación al estudio de las fortificaciones en tapia del sur peninsular}

La presencia de fortificaciones medievales es uno de los atributos característicos del paisaje histórico del sur de Europa y el norte de África. Para el territorio andaluz se conservan más de 200 tramos de murallas, torres y fortificaciones medievales (IAPH 2021). Al tratarse de estructuras expuestas al aire libre, la presencia de amenazas medioambientales influye considerablemente en su preservación.

La figura 6 (p. 417) permite identificar aquellas estructuras cercanas a zonas que han sufrido incendios de más de 1 km entre 2002 y 2020. En estos espacios, las áreas quemadas implican una pérdida de los entornos ambientales y las identidades asociadas a los paisajes culturales (Butler et ál. 2018). A su vez, pueden provocar en las estructuras fortificadas cambios cromáticos, fracturaciones, pérdida de resistencia mecánica y aparición de manchas negras debido al shock térmico y a los gases producidos en los procesos de combustión (GómezHeras et ál. 2009; Martinho y Dionísio 2020).

Desde el punto de vista de la diagnosis, el uso de imágenes satelitales, a través de visores como GWIS permite identificar qué estructuras pueden haberse visto afectadas por eventos de fuego. Los resultados obtenidos evidencian un mayor riesgo para las estructuras ubicadas fuera de entornos urbanos y el desarrollo de incendios entre 2002-2020 en las inmediaciones de Turre Teresa y Turre Cabrera en Almería. La cercanía de muchas de las estructuras fortificadas a áreas quemadas también señala como posibles fortificaciones dañadas el Cerro Torrón en Marbella (Málaga) o el Cerro Castillejita (de Calañas, Huelva).

Desde el punto de vista de la conservación preventiva, conocer el grado de peligrosidad por incendio que presenta un entorno permite planificar las acciones necesarias para la conservación de los paisajes y bienes patrimoniales y se convierte en una herramienta que permite trabajar en la reducción de los niveles de riesgo. 


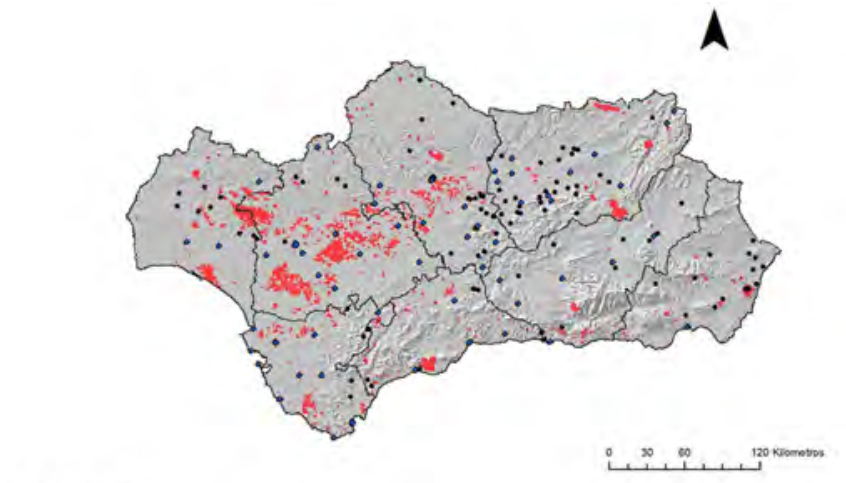

\section{Leyenda}

- Fortificaciones en entornos urbanos

- Fortificaciones entornos no urbanos

Áreas quemadas entre 2002 y 2020

Figura 6. Fortificaciones conservadas en Andalucía y áreas quemadas entre 2002 y 2020 | fuente propia a partir de los datos de áreas quemadas obtenidas de FIRMS (NASA 2021) y la georreferenciación de fortificaciones obtenidas de la Guía Digital del Patrimonio Cultural de Andalucía (IAPH 2021)
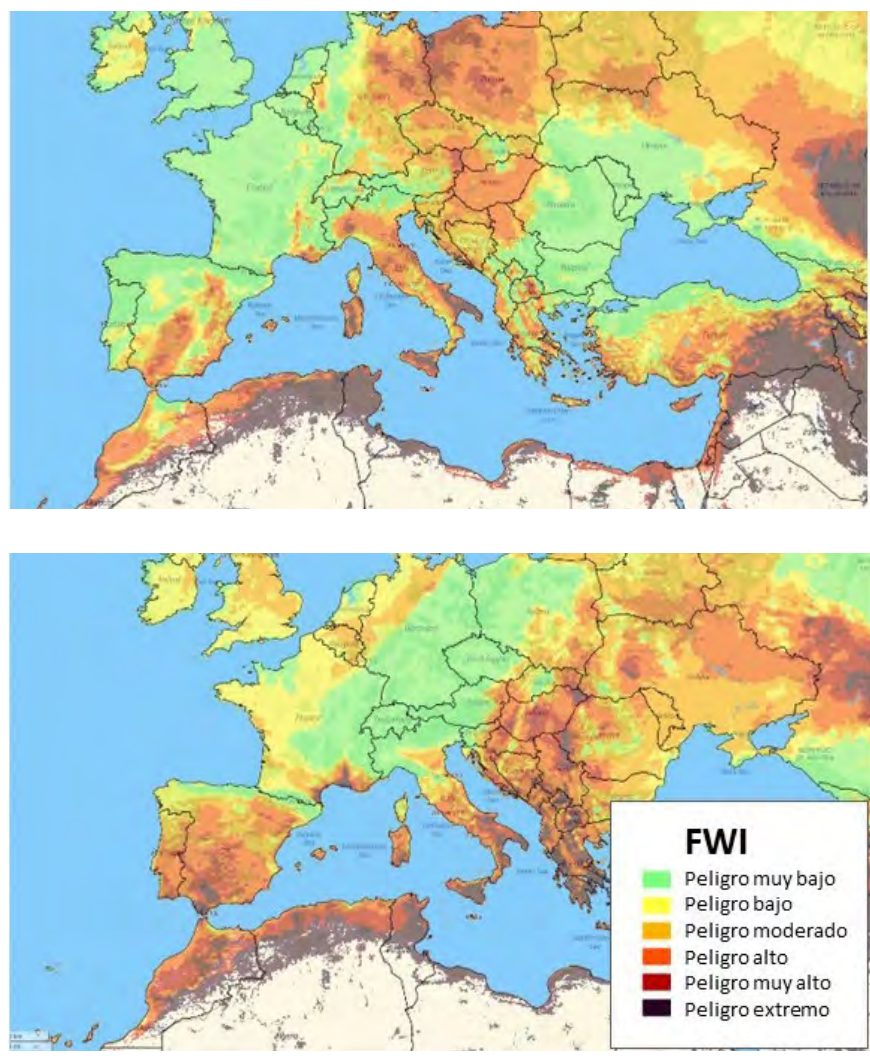

Figura 7a y b. A) Riesgo de Incendio en los países del área mediterránea, FWI del 13 de junio de 2021; B) pronóstico a 9 días | fuente visor GWIS
Para facilitar el monitoreo de los niveles de peligrosidad, el índice FWI permite diagnosticar el nivel de amenaza (Rodrigues el ál. 2021) que existe en un contexto cultural. La herramienta disponible en GWIS pronostica la peligrosidad según FWI con 9 días de antelación. Solo a modo de ejemplo, la figura 7 muestra el FWI existente el 13 de julio de 2021 y el pronóstico a 9 días efectuado. La comparación de ambas imágenes permite identificar rápidamente condiciones de aumento de peligrosidad en casi toda la Península Ibérica y tomar las medidas preventivas necesarias para minimizar el riesgo. Su uso continuado por parte de conservadores y especialistas encargados de la gestión patrimonial posibilita anticiparse a una emergencia y dar una rápida respuesta a un evento de fuego.

Para el caso de estudio analizado, los datos recogidos señalan la necesidad de incluir: (1) acciones preventivas que reduzcan la carga de combustible y aseguren el mantenimiento de las áreas cortafuegos durante los meses de marzo y abril; (2) y extremar la vigilancia-control durante los meses de junio a agosto. Fortificaciones ubicadas en paisajes culturales con coberturas vegetales boscosas y pastizales presentarían un riesgo extra y deberían vigilarse especialmente en años de extrema sequía. Estos paisajes son entornos especialmente vulnerables en contextos de cambio climático en los que se esperan eventos prolongados de fuertes sequías, altas temperaturas e intensas lluvias (Olcina 2020; Sesana et ál. 2021).

Así mismo, la posibilidad de afecciones en zonas contiguas a la frontera luso-española (figura $7 \mathrm{~b}$ ) conlleva la necesidad de trabajar de forma internacional coordinada para prevenir y controlar los eventos de incendio acontecidos.

\section{Conclusiones}

Identificar la tendencia y estacionalidad de los fuegos en entornos patrimoniales permite diagnosticar zonas de mayor peligrosidad y definir áreas prioritarias de actuación. Para el caso de estudio de las fortificaciones en tapia del sur de España, los datos levantados muestran 
una alta peligrosidad durante los meses de junio-agosto. Si bien la frecuencia de los incendios ocurridos en estos meses no es alta, la intensidad de los fuegos y la dificultad para controlarlos aumenta bruscamente el número de hectáreas quemadas en estos meses. Estos datos concuerdan con los altos niveles de FWI registrados en todo el sur peninsular durante los meses de verano e indican la necesidad de extremar el monitoreo de paisajes culturales naturales en estas épocas.

El seguimiento de la tendencia 2002-2020 muestra una disminución del número de hectáreas quemadas en los últimos años. Este decrecimiento refleja el cese de los eventos de quema de campos de cultivo y un mantenimiento de los incendios registrados en zonas boscosas y de matorral. Se observa una fuerte relación entre los años de mayor sequía y los aumentos drásticos en el número de hectáreas quemadas en este tipo de coberturas vegetales.

Ante la situación descrita, incluir actividades como la eliminación de carga de combustible en bosques y pastizales antes de la época de incendios y potenciar el desarrollo de áreas cortafuego resulta esencial para minimizar las pérdidas provocadas por grandes incendios incontrolados.

\section{Agradecimientos}

Este estudio ha sido apoyado por el proyecto FENIX (proyecto de Programas Estatales de Generación de Conocimiento y Fortalecimiento Científico y Tecnológico del Sistema de I+D+ i, código: PID2019-107257RB-I00), el equipo de investigación TEP-199 y el laboratorio Sanit-ARTE. M. Moreno agradece al Programa Estatal de Promoción del Talento y su Empleabilidad en I + D + i del Ministerio de Ciencia e Innovación de España por su beca técnica (PTA2019-016882).

\section{BIBLIOGRAFÍA}

- Abatzoglou, J.T., Williams, A.P. y Barbero, R. (2019) Global Emergence of Anthropogenic Climate Change in Fire Weather Indices. Geophysical Research Letters, vol. 46, n. ${ }^{\circ} 1$, 326336. Disponible en: https://doi.org/10.1029/2018GL080959 [Consulta: 05/07/2021]

- Ambrosia, V. G., San Miguel-Ayanz, J., Boschetti, L., Giglio, L. y Field, R.D. (2019) The Group on Earth Observation (GEO) Global Wildfire Information System (GEO-GWIS). American Geophysical Union, Fall Meeting 2019, abstract \#NH12A-02. Disponible en: https://ui.adsabs.harvard.edu/ abs/2019AGUFMNH12A..02A/abstract [Consulta: 05/07/2021]

- Artés, T., Oom, D., de Rigo, D., Durrant, T. H., Maianti, P., Libertà, G. y San-Miguel-Ayanz, J. (2019) A global wildfire dataset for the analysis of fire regimes and fire behaviour. Scientific Data, 6, article n. ${ }^{\circ}$ 296. Disponible en: https://doi. org/10.1038/s41597-019-0312-2 [Consulta: 05/07/2021]

- Beguería, S., Latorre, B., Reig F., Vicente-Serrano, S. (2021) SPEI Global Drought Monitor. Disponible en: https://spei.csic. es/index.html [Consulta: 5/07/2021]

- Butler, A., Sarlöv-Herlin, I., Knez, I., Ångman, E., Ode Sang, Å. y Åkerskog, A. (2018) Landscape identity, before and after a forest fire. Landscape Research, vol. 43, n. ${ }^{\circ}, 6$, pp. 878-889. Disponible en: https://doi.org/10.1080/01426397.2017.134420 5 [Consulta: 05/07/2021]

- Cardil, A., Rodrigues, M., Ramírez, J., de-Miguel, S., Silva, C.A., Mariani, M. y Ascoli, D. (2021) Coupled effects of climate teleconnections on drought, Santa Ana winds and wildfires in southern California. Science of the Total Environment, vol. 765 , 142788. Disponible en: https://doi.org/10.1016/j. scitotenv.2020.142788 [Consulta: 5/07/2021]

- Di Giuseppe, F., Vitolo, C., Krzeminski, B., Barnard, C., Maclel, P. y San-Miguel, J. (2020) Fire Weather Index: The skill provided by the European Centre for Medium-Range Weather Forecasts ensemble prediction system. Natural Hazards and Earth System Sciences, vol. 20, n. ${ }^{\circ}$ 8, pp. 2365-2378. Disponible en: https://doi.org/10.5194/nhess-20-2365-2020 [Consulta: 05/07/2021]

- Fasullo, J.T., Otto-Bliesner, B.L. y Stevenson, S. (2018) ENSO's Changing Influence on Temperature, Precipitation, and Wildfire in a Warming Climate. Geophysical Research Letters, vol. 45, n. ${ }^{\circ} 17$, pp. 9216-9225. Disponible en: https:// doi.org/10.1029/2018GL079022 [Consulta: 05/07/2021]

- Geo, NASA y Copernicus (2021) Global Wildfire Infromation System (GWIS). Disponible en: https://gwis.jrc.ec.europa.eu/ [Consulta: 05/07/2021]

- Giglio, L., Schroeder, W., Hall, J.V. y Justice, C.O. (2018) MODIS Collection 6 Active Fire Product User's Guide Revision B. NASA 
- Gill, A.M., Stephens, S.L. y Cary, G.J. (2013) The worldwide "wildfire" problem. Ecological Applications, vol. 23, n. ${ }^{\circ} 2$, 438-454.Disponible en: https://doi.org/10.1890/10-2213.1 [Consulta: 05/07/2021]

- Gómez-Heras, M., McCabe, S., Smith, B.J. y Fort, R. (2009) Impacts of fire on stone-built Heritage: An overview. Journal of Architectural Conservation, vol. 15, issue 2, pp. 47-58. Disponible en: https://doi.org/10.1080/13556207.2009.10785 047 [Consulta: 5/07/2021]

- IAPH [Instituto Andaluz del Patrimonio Histórico] (2021) Guía digital del Patrimonio Cultural de Andalucía. Disponible en: https://guiadigital.iaph.es/ [Consulta: 5/07/2021]

- Martinho, E. y Dionísio, A. (2020) Assessment Techniques for Studying the Effects of Fire on Stone Materials: A Literature Review. International Journal of Architectural Heritage, vol. 14, n. ${ }^{\circ}$ 2, pp. 275-299. Disponible en: https://doi.org/10.1080/1558 3058.2018.1535008 [Consulta: 05/07/2021]

- NASA (2021) FIRMS: Fire Information for Resource Management System. Disponible en: https://firms.modaps. eosdis.nasa.gov/ [Consulta: 05/07/2021]

- Olcina, J. (2020) Clima, cambio climático y riesgos climáticos en el litoral mediterráneo. Oportunidades para la geografía. Documents d'Anàlisi Geogràfica, vol. 66, n. ${ }^{\circ} 1$. Disponible en: https://doi.org/10.5565/rev/dag.629 [Consulta: 05/07/2021]

- QGIS Development Team (2012) QGIS Geographic Information System, Open Source Geospatial Foundation. Disponible en: http://qgis.osgeo.org [Consulta: 05/07/2021]

- Rigo, D., Libertà, G., Houston Durrant, T., Artés Vivancos, T., San-Miguel-Ayanz, J. (2017) Forest fire danger extremes in Europe under climate change: variability and uncertainty. Luxemburgo: Publications Office of the European Union. Disponible en: https://doi.org/10.2760/13180 [Consulta: 5/07/2021]

- Rodrigues, M., Pena-Angulo, D., Russo, A., ZúnigaAntón, M., y Cardil, A. (2021) Do climate teleconnections modulate wildfire-prone conditions over the Iberian Peninsula? Environmental Research Letters, vol. 16, n. ${ }^{\circ}$ 4, 44050. Disponible en: https://doi.org/10.1088/1748-9326/abe25d [Consulta: 5/07/2021]

- Schroeder, W., Oliva, P., Giglio, L., y Csiszar, I.A. (2014) The New VIIRS $375 \mathrm{~m}$ active fire detection data product: Algorithm description and initial assessment. Remote Sensing of Environment, vol. 143, pp. 85-96. Disponible en: https://doi. org/10.1016/j.rse.2013.12.008 [Consulta: 05/07/2021]

- Sesana, E., Gagnon, A.S., Ciantelli, C., Cassar, J.A. y Hughes, J.J. (2021) Climate change impacts on cultural heritage: A literature review. En: Wiley Interdisciplinary
Reviews: Climate Change, vol. 12, n. ${ }^{4} 4$ (p. e710). Disponible en: https://doi.org/10.1002/wcc.710 [Consulta: 05/07/2021]

- Van Wagner, C.E. y Pickett, T.L. (1985) Equations and FORTRAN program for the Canadian forest fire weather index system. Disponible en: https://scf.rncan.gc.cal publications?id=19973\&lang=fr_CA [Consulta: 16/09/2021] 


\section{$\mathrm{PH} 104_{\text {debate }}$}

a debate Patrimonio cultural y cambio climático

| coordina Alejandro García Hermida

\section{Arquitectura por el cambio climático}

José Franqueira Baganha | arquitecto, INTBAU-Portugal

URL de la contribución <www.iaph.es/revistaph/index.php/revistaph/article/view/4977>

Agradezco a este debate la oportunidad de compartir algunas reflexiones sobre problemas actuales y futuros que pueden surgir de la situación de emergencia que estamos viviendo, una emergencia ambiental y civilizatoria, y sobre la contribución de la arquitectura para que los edificios y lugares que diseñamos, o en los que intervenimos, se adapten mejor a las circunstancias climáticas.

No debemos omitir de esta reflexión el hecho de que el estado de la cuestión de la edificación, desde hace ya algunas décadas, podría considerarse inadecuado y peligroso para nuestra existencia (e incluso supervivencia) como especie. No será necesario describir (porque es sabido) toda la sucesión de errores, casi siempre desastrosos, que se repetían y acumulaban en la forma de construir los edificios y cómo las ciudades crecieron, algunas, o se vaciaron, otras, en el uso continuado de soluciones, tecnologías y materiales profundamente nocivos para la salud del planeta.

Las razones y los modelos que han contribuido a este "desastre" son conocidos, lamentablemente, demasiado bien, por cualquiera, aunque sorprendentemente (o quizás no) no todos asumen esta realidad y continúan actuando como si nada ocurriera, precipitándose al abismo en un proceso autodestructivo, ciego, a veces incluso con arrogancia y soberbia, arrastrándonos también al resto. La legislación y los modelos de enseñanza vigentes están muy lejos de poder dar respuesta a estos problemas, más o menos nuevos, y como consecuencia las instituciones públicas y las principales entidades de referencia también.

Coincidiremos todos reconociendo que el modelo de crecimiento de las ciudades basado en teorías de zonificación, separación de usos y concentración monofun-

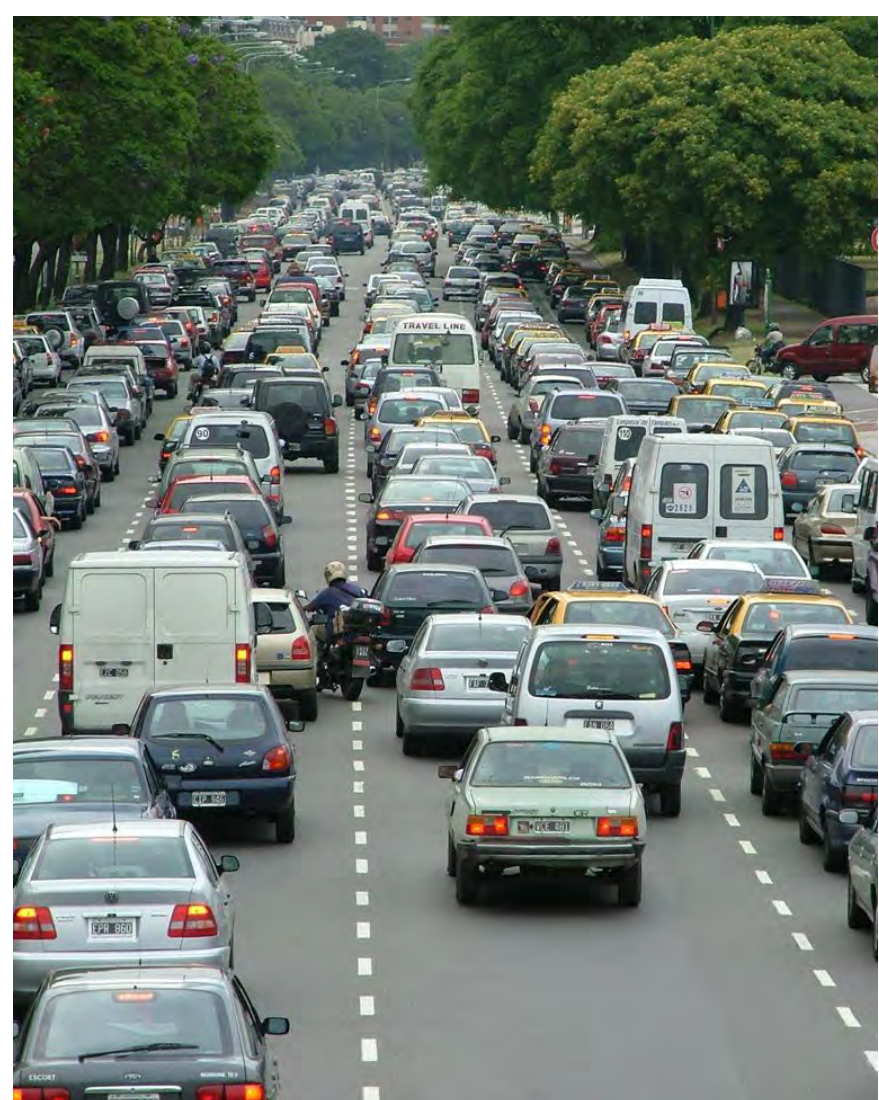

Excesiva congestión de tráfico en áreas urbanas | foto Luis Jou García

cional excesiva, genera necesidades inconmensurables en el movimiento de personas desde los lugares donde duermen a los que trabajan, estudian, se abastecen, etc., con la consiguiente e igualmente inconmensurable necesidad de infraestructura vial y de transporte, evidentemente insuficiente. De tal manera que es urgente corregir este estado de cosas.

¿Qué podemos hacer entonces? Tendremos que contrarrestar el desarrollo autodestructivo y promover el desarrollo sostenible. No hay duda de que el cambio no 
depende solo de los arquitectos (sería presuntuoso asegurar algo así) pero sí desde la arquitectura se puede realizar una significativa contribución al cambio, como se ha hecho en otros tiempos.

Nos referimos a cambios fundamentales, más urgentes, como eliminar de una vez por todas de la legislación todo el lastre de la política de zonificación, y promover una práctica basada en la mezcla de usos en los diferentes barrios, es decir, pensar la ciudad en unidades vecinales lo más autónomas posible en relación con necesidades básicas. Todo lo que es esencial para nuestra existencia debe estar a una distancia de 10 o 15 minutos como máximo. No debería ser necesario subirse a un autobús o en un automóvil para comprar un litro de leche o un medicamento, la escuela tampoco tiene que estar a kilómetros de distancia y los niños deberían poder acceder a ella de modo sencillo en bicicleta, a pie, solos o acompañados.

Entonces, aquellos servicios de uso más esporádico (el centro de salud, los servicios de apoyo ciudadano, el consejo parroquial o el departamento de finanzas, por ejemplo) pueden ubicarse en las áreas de separación de los diferentes barrios, junto con parques públicos, infraestructuras deportivas y de espectáculos.

Los servicios más importantes, como ministerios y otros departamentos gubernamentales, lugares de culto, grandes empresas... pueden estar dispersos por el tejido urbano, aprovechando los sitios más céntricos de cada barrio (plazas, avenidas principales...) y, localizadas en zonas limítrofes, las industrias.

Las ciudades deben tener límites claros y bien definidos que las separen del campo y otros tipos de ocupaciones de territorio, y deben contener, en sí mismas, estructuras de espacios libres, ajardinados y arbolados, tanto públicos como privados, que aseguren un adecuado equilibrio con el espacio edificado y colaboren en aspectos esenciales como infiltración de suelos, protección de acuíferos y drenaje de agua de lluvia o canales de aireación. Estos espacios también invitan a la convivencia y el

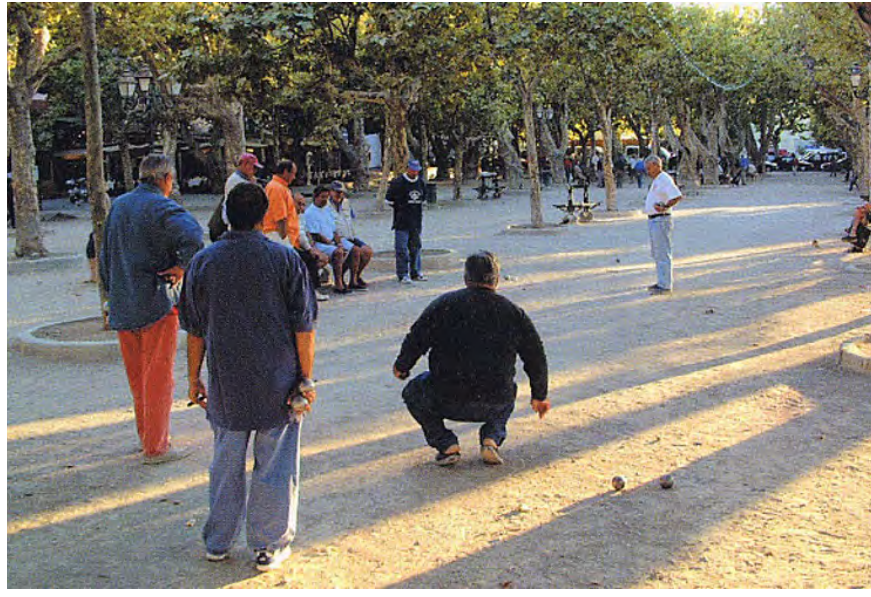

Place des Lices, Saint-Tropez, Francia | foto José Franqueira Baganha

esparcimiento de poblaciones en condiciones de proximidad. Espacios sociales fundamentales para la salud mental de las personas y para una sociedad también sana y verdaderamente próspera en todos los ámbitos.

La noción de "espacio canal", la calle, es igualmente esencial. La ciudad no funciona bien sin estos espacios. Las calles, en lugar de las carreteras que atraviesan y "cortan" nuestras ciudades, garantizan la movilidad, las relaciones vecinales, la seguridad y constituyen el espacio por excelencia para las actividades que complementan la vivienda (como el comercio, los servicios públicos del barrio, la escuela, etc.).

Además de la importancia de la calle en el funcionamiento de nuestras ciudades, existen otros elementos básicos que han demostrado, a lo largo de los siglos, su eficacia en el contexto de una experiencia urbana sana, segura y feliz: la manzana, su oferta variada, dependiendo del nivel de ingresos de los ciudadanos, permite asegurar una mezcla sana y rica, que siempre ha estado presente en las ciudades, como contrapunto a los actuales guetos de ricos y pobres, y el desplazamiento de las clases medias a los suburbios-dormitorios.

Al mismo tiempo, se deben adoptar medidas atractivas y efectivas que supongan un incentivo para que la población pueda instalarse en centros urbanos más peque- 
a debate Patrimonio cultural y cambio climático

| coordina Alejandro García Hermida

ños (en ciudades pequeñas y medianas), para frenar y revertir, en la medida de lo posible, el éxodo hacia la gran metrópoli. La llegada de Internet tiene desventajas, pero también nos brinda nuevas y buenas posibilidades: el ejercicio de la profesión en la actualidad, en muchos casos, puede realizarse desde casa o en otro lugar, sin requerir la presencia constante en el servicio, en la oficina o en el estudio. El espacio y el tiempo de trabajo, hoy, ya no presupone necesariamente la lógica de jornadas "de 9 a 5" del proletariado de fábrica, esto ya es parte de la historia. Las estadísticas más recientes parecen indicar que los nuevos modelos de ejercicio laboral han dado como resultado ganancias significativas en la productividad y la calidad de vida.

El éxodo de poblaciones hacia las grandes regiones metropolitanas es un hecho inexorable, y los efectos ambientales de esta excesiva aglomeración de personas, con todo lo que ello implica en relación con infraestructuras y equipamientos, contribuye en gran medida a agravar la situación en términos de cambio climático. Los niveles de contaminación son devastadores y la calidad de vida de las personas se deteriora drásticamente.

Contrarrestar este fenómeno de desplazamiento de población es extraordinariamente difícil, pero esencial. Las medidas deben ser radicales e inmediatas, sin ellas la situación podría agravarse hasta un punto sin retorno, con efectos desastrosos para el equilibrio ambiental, como ya estamos viendo en esta era planetaria.

Si en cuanto a la ciudad que debemos formar parece que no hay duda, que, en esencia, todos estamos de acuerdo, no ocurre lo mismo en lo que respecta a los edificios, su construcción, la arquitectura en sí. ¿Podemos mejorar también en este aspecto? Sería imprescindible, y se deberían abordar algunos aspectos ineludibles: La construcción debe dar más valor a las tipologías tradicionales, de región a región, tomando de las construcciones vernáculas las valiosas lecciones que nos brindan, promoviendo el uso de materiales y tecnologías de producción local, regional, con resultados probados de idoneidad para los lugares en los que se ubican las edi- ficaciones y menos la lógica de gran producción industrial, en serie, con efectos sumamente nocivos para el medio ambiente y, por tanto, para nuestra salud. Esta apuesta también contribuye a la creación de empleo y asentamiento de poblaciones en las zonas más sujetas al abandono.

También en estos asuntos, la legislación y los planes de estudios académicos deben cambiar. El sistema está diseñado de tal manera que muchas de las soluciones más adecuadas no pueden ser aprobadas por las distintas instituciones que licencian las obras. Construir con tierra (tapial, adobe, etc.), madera o piedra sin añadir materiales artificiales producidos industrialmente como poliestirenos, polietileno, aluminio, plástico, etc. es casi imposible.

Si tenemos en cuenta el efecto de la producción de estos materiales sobre el cambio climático, la contaminación del aire, de ríos y océanos, rápidamente concluimos que hay que cambiar, ahora.

Se necesita coraje, voluntad de cambio, determinación, pero sin esta transformación nos dirigimos inevitablemente hacia el desastre.

No creo que el uso de materiales y técnicas de construcción tradicionales inhiba la innovación, la creatividad y la prosperidad. Esta es una de las falacias más comunes entre quienes, por razones oscuras (codicia, generalmente) o ignorancia, se resisten al cambio.

Además de semejantes hallazgos, otros son igualmente inevitables en el contexto de cambios de actitudes o paradigmas (como está de moda decir ahora). Nos referimos a aspectos que contribuyen a salvaguardar la identidad de los lugares y sus poblaciones. La preservación del patrimonio construido (monumental o no), el cuidado con el que tratamos los barrios, sus calles, plazas, jardines y edificios, la forma en que protegemos determinados lugares y "hacemos ciudad" no puede ser indiferente a esta necesidad que todos sentimos de preservar los valores de nuestra historia, de la memoria colectiva, 
de la identidad que nos distingue, de región en región, de barrio en barrio, incluso en un mundo cada vez más globalizado.

La "política del espectáculo" (del Star Business), definitivamente, debe dar paso a prácticas de verdadera ciudadanía y sentido común.

Otra noción que parece muy pertinente en estas materias es la longevidad de los edificios y espacios públicos que diseñamos. La noción de longevidad aplicada a la construcción y la arquitectura ya no se basa solo en el hecho de que los edificios deben ser duraderos (lo cual es básico) sino también en la posibilidad de que sean cada vez más susceptibles de adaptarse al paso del tiempo y a las diferentes formas y modos de uso.

Los valores de libertad, paz, seguridad o amor deberán volver a estar en la base de una estética que integre a la humanidad en el orden cósmico, articulando factores materiales y espirituales.

En los tiempos venideros, los arquitectos y otros agentes que intervienen en nuestras ciudades, pueblos, aldeas y territorios, así como en los edificios, se enfrentarán a desafíos extraordinarios, difíciles, pero también emocionantes y estimulantes. De modo que todos sepamos cómo aprovechar esta rara oportunidad de participar en el cambio.

\section{BIBLIOGRAFÍA}

- Adam, R. (2008) Globalization and Architecture: The challenges of globalization are recently shaping architecture's relationship with society and culture. The Architectural Review, n. ${ }^{\circ} 223(1332)$, pp. $74-77$

- Adam, R. y Hardy, M. (ed.) (2008) Tradition Today, Continuity in Architecture and Society. Southtampton: INTBAU, WITPress

- Asquith, L. y Vellinga, M. (ed.) (2006) Vernacular Architecture in the Twenty-First Century, theory, education and pratice. New York: Taylor \& Francis

- Chueca Goitia, F. (1989) Breve história do urbanismo. 2.a edición. Lisboa: Editorial Presença
- Franqueira Baganha, J.A. (2006) Casas com tradição. Lisboa: Editorial Caleidoscópio

- Jacobs, J. (2003) Morte e vida de grandes cidades. S. Paulo: Martins Fontes

- Krier, L. (1999) Arquitectura: escolha ou fatalidade. Lisboa: Estar

- Lino, R. (1945) Quatro Palavras sobre Urbanização. Lisboa: Valentim de Carvalho

- Maillard, Ch. (1992) La creación por la metáfora: introducción a la razón-poética. Barcelona: Anthropos

- Olgyay, V. (1998) Arquitectura y clima, manual de diseño bioclimático para arquitectos y urbanistas. Barcelona: Ed. Gustavo Gili

- Portoghesi, P. (2005) Geoarchitettura, verso un'architettura della responsabilità. Milano: Skira editore

- Sitte, C. (1992) Aconstrução das cidades segundo seus princípios artísticos. S. Paulo: Ática

- Sola-Morales, M. (1997) Las formas de Crecimiento Urbano. Barcelona: UPC

- Távora, F. (1962) Da organização do espaço. 1.ª edición. Porto: FAUP

- Venturi, R. (1984) Complexity and Contradictions in Architecture. 2. ${ }^{\text {a }}$ edición revisada. New York: The Museum of Modern Art 


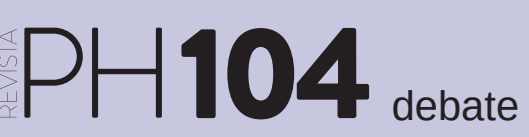

a debate Patrimonio cultural y cambio climático

| coordina Alejandro García Hermida

\section{Arquitectura tradicional y sostenibilidad. Arquitectura industrial e insostenibilidad}

Jaime de Hoz Onrubia | Área de Composición Arquitectónica, Universidad Alfonso X el Sabio

URL de la contribución <www.iaph.es/revistaph/index.php/revistaph/article/view/4984>

Frente a la arquitectura que figura en los libros de historia del arte, la denominada "monumental", "culta" o "intelectual", estudiada y aprendida en las escuelas de arquitectura, vinculada siempre a la idea de "estilo" y generalmente a una autoría con frecuencia precisa, podemos establecer otros conceptos edificatorios, marginales en su observación académica, y casi siempre ajenos a las obras de referencia, como son los de construcción "popular" y arquitecturas tradicional y vernácula. Han sido estas formas constructivas, sin embargo, las habituales en el devenir de la civilización, pues se vinculan directamente con el espacio de habitación de las gentes, su forma de vida y sus costumbres cotidianas. Las define el aprovechamiento máximo de los recursos naturales, empleando como materiales de construcción aquellos que el medio cercano ha podido proporcionarles sin tener que hacer grandes esfuerzos para obtenerlos (piedra, madera, tierra...). Las distingue, así mismo, la austeridad económica, pero no necesariamente la miseria, implicando al propio usuario en su creación, lo que da prioridad en ellas a la experiencia devenida de las numerosas generaciones que han habitado el mismo territorio durante largos siglos, posibilitando su perfecta adaptación, empírica y pragmática, al medio, que les proporciona una enorme eficacia energética, pensando prioritariamente en el beneficio del usuario.

La arquitectura que llamamos "tradicional" es, pues, el resultado de un largo proceso de adaptación. Se transmite de generación en generación, aportando el conocimiento de las nuevas experiencias, y se va readecuando a procesos de cambio que han sido siempre lentos y dilatados en el tiempo. Su apariencia ha resultado casi imperturbable y las técnicas con las que se ha realizado su edificación nunca han sido ni traumáticas ni agresivas con su medio físico. La escasa mutabilidad es una de sus principales características y ello ha hecho que el cromatismo de los materiales empleados, las formas de sus cubiertas y la textura de sus muros hayan contribuido a proporcionar los rasgos exclusivos y peculiares, "vernáculos", de los edificios propios de una determinada región o de un lugar concreto. Así, la arquitectura tradicional se compenetra con el paisaje de su entorno, condicionado antrópicamente y asociado, al igual que las casas y las otras construcciones, a la economía local y a sus condiciones climáticas, a su vegetación, a su tipo de suelo...

Contradictoriamente con lo que después ha terminado sucediendo, contribuyendo a su desaparición o a su deterioro, los primeros arquitectos del llamado movimiento moderno ensalzaron sus virtudes arquitectónicas y sus valores estéticos, incluso usándolas como referente para sus novedosas propuestas. De este modo Adolf Loos elogiaba y reclamaba estos edificios como parte del paisaje natural y aplaudía su sobria belleza: "No parecen creados por la mano del hombre. Están como recién salidos del taller de Dios, como las montañas y los árboles, las nubes y el cielo. Y todo respira belleza y silencio [...]" (Architektur, publicado en la revista Der Sturm el 15 de diciembre de 1910). El problema devino de la absoluta falta de conocimiento real que los vanguardistas arquitectos tenían sobre la razón constructiva de estas edificaciones, desdeñando su auténtico valor funcional o el sentido ecológico con el que se concebían, quedando toda observación en una mera banalización snob de su estética o en una reducción trivializada de su realidad, lo que ha ido generando horribles monstruos seudorrurales o falsamente vernáculos, como las viviendas "recreadas" por artistas inspirados, caso de César Manrique en Lanzarote, quien terminó por implantar un modelo ibicenco donde la realidad era bastante 


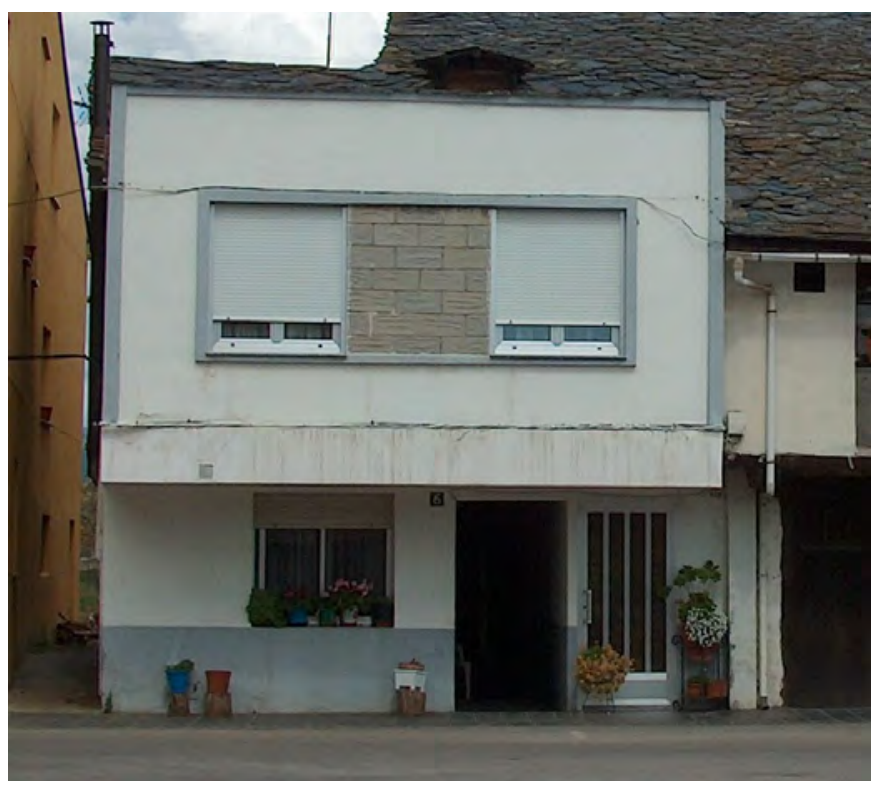

Adición modernizada según los patrones indicados por la "doctrina" de las Escuelas de Arquitectura en Cacabelos (León) | foto Jaime de Hoz Onrubia

diferente, aniquilando la auténtica huella de los edificios tradicionales de esta isla, a los que supuestamente pretendía enaltecer y a los que se ha terminado, prácticamente, por hacer desaparecer, no siendo todo ello sino el resultado de una reprobable falta de estudio por parte de la mayoría de los arquitectos contemporáneos, por no hablar de los intereses de constructores y fabricantes de cemento y hormigón, y por supuesto por una actitud no siempre socialmente conveniente de los políticos ni de los responsables del patrimonio.

Esta falta de criterio ha generado la imposición doctrinal desde las Escuelas de Arquitectura de un modelo "mediterráneo" de vivienda, siempre de forma cúbica, con cubierta plana y huecos distribuidos aleatoriamente por las fachadas sin haber comprendido su gnosis lógica y su obligada adaptación a cada territorio particular, sin importarles la orientación, el clima o el índice de pluviosidad o de soleamiento del sitio en el que se han de erigir sus "creativas" indecencias, arrasando toda forma de arquitectura que no respondiese a sus principios doctrinales e incuestionables dogmas de fe, como los dictados por las ocurrencias del "mesías" Le Corbusier, quien ni era arquitecto ni tenía una formación académica y artesanal adecuadas, generando de tal guisa auténticas aberraciones en toda nuestra geografía, sólo para saciar el muy cuestionable gusto de ignaros acomplejados y de gentes ávidas de ganancias fáciles, donde por desgracia hay que incluir a religiosos y destacados docentes.

Tal banalización ha tenido, igualmente, una consecuencia funesta para la habitabilidad de las personas, pues a menudo se les obliga a vivir en esculturas gigantes y no en espacios adecuados, reduciendo lo arquitectónico a un mero referente "estético", aunque con frecuencia se ignore de dónde procede y lo que significa aquello que Vitrubio denominaba venustas, por lo que todo ha derivado en una suerte de "estética y descomposición”. El resultado último es el consumo excesivo de energía para refrigerar unas casas inadaptadas de por sí al lugar o unos gastos insoportables para calefactarlas. Los tan traídos ejemplos de la Villa Saboya o de la casa Farnsworth son de notorio conocimiento, sirviendo, desgraciadamente, de modelo para los estudiantes y de referencia imperativa para la vivienda unifamiliar, si bien nunca explicándoseles a aquéllos la incapacidad de tales "gloriosos" ejemplos para ser vividos, la ruina que supusieron para sus propietarios y las numerosas y costosas restauraciones y reconstrucciones que se han tenido que operar en ellos para mero disfrute de algunos intelectos vivificados por la "modernidad".

La mala comprensión del funcionamiento de este patrimonio arquitectónico, y aun urbano (fondos de saco, pozos de ventilación, etc.), devenido de la tradición, substituido por formas "actualizadas", ha conllevado el empleo de materiales industriales, cuyo rendimiento no es ni mucho menos el mismo que el empleado por aquellas construcciones heredadas (inercia térmica, aislamiento pasivo, transpiración...), pues al no atender a la orientación, abrir huecos excesivamente grandes o no respetar los estándares de muros y cubiertas obliga, como consecuencia, a un consumo de energía que indudablemente provoca una mayor contaminación medioambiental, la cual contribuye a generar condiciones apropiadas para un cambio climático. 
$\mathrm{PH} 104_{\text {debale }}$

a debate Patrimonio cultural y cambio climático

| coordina Alejandro García Hermida

\section{Patrimonio rural y cambio climático}

José Manuel Baena Gallé | IES Luca de Tena (Sevilla), Consejería de Educación y Deporte, Junta de Andalucía

URL de la contribución <www.iaph.es/revistaph/index.php/revistaph/article/view/4982>

\section{Introducción}

Según el Ministerio español para la Transición Ecológica y el Reto Demográfico el cambio climático se define como la variación global del clima de la tierra por causas naturales o humanas. En ese sentido, remarca la idea de que el modo de producción y de consumo energético causan en gran medida el cambio climático (2021). Las consecuencias de este fenómeno resultan incalculables y tan negativas como impredecibles. El Alto Comisionado de las Naciones Unidas para los Refugiados (ACNUR) habla del coste humano del cambio climático, responsable del $75,8 \%$ de los nuevos desplazamientos internos en 2020; aproximadamente afecta a unos 30,7 millones de personas (Sciacia 2021).

\section{Patrimonio cultural y cambio climático}

¿Pero cómo afecta el cambio climático al patrimonio cultural? Una simple búsqueda en Internet aporta diversidad de resultados. En muchos de ellos se señala cómo el cambio climático perturba aquellos bienes declarados por la UNESCO Patrimonio Mundial, con toda la importancia simbólica de estos (UNESCO 2009). Pero no se puede señalar como única consecuencia la afectación que el cambio climático provoca en elementos materiales del patrimonio, sino que hay que ir más allá. Si se observa la información antes aludida de ACNUR, se concluye que tiene consecuencias mucho más terribles. Esta población que se desplaza abandona sus espacios vitales y deja de protegerlos y cuidarlos, pero también abandona sus formas de vida (relaciones sociales, costumbres, alimentación, etc.), con lo que se pierde un patrimonio inmaterial irrecuperable.

Evidentemente, una de las dimensiones que más incide en este asunto es la de carácter económico. Las grandes transformaciones industriales y productivas que se iniciaron con la Revolución Industrial y que se han ace- lerado en los últimos tiempos han provocado diversos fenómenos que precipitan el cambio climático. Estos cambios en los modos de producción han llevado a dos consecuencias fundamentales con respecto al patrimonio cultural. Por un lado, la desaparición y el abandono de formas de vida tradicionales que protegían el ecosistema y, asociados a ella, estructuras materiales que pierden su funcionalidad. Por otro lado, el aumento de un fenómeno de consumismo que potencia a su vez la producción y la no reutilización de muchos elementos que afectan a las dinámicas ambientales. Los avances tecnológicos y los cambios en los sistemas productivos han supuesto evidentes beneficios para la vida de los ciudadanos. No obstante, también ha traído consecuencias negativas como la producción masiva, el consumismo, la globalización, el uso de instrumentos y productos nocivos que afectan al clima provocando una transformación de muchos parámetros de nuestra vida. Entre ellos se encuentra la desaparición de todos aquellos elementos del patrimonio cultural relacionados con formas de vida anteriores: instalaciones, edificios, oficios, costumbres, gastronomía, etc. Esta estrecha relación entre ambos conceptos se puede observar en múltiples ejemplos a nivel global pero también en nuestro entorno más cercano.

\section{Sector primario y cambio climático}

Todo este proceso ha llevado a una profunda metamorfosis de numerosos elementos patrimoniales, que, a su vez, han influido en el cambio climático, sin olvidar en muchas ocasiones su aportación positiva. Así, por ejemplo, la continua mecanización y modernización de la producción agraria y ganadera en España permitió la desaparición en nuestro país de fenómenos relacionados con las hambrunas y todas sus consecuencias -enfermedades, pobreza, etc.-. No obstante, estos efectivos avances han traído como consecuen- 


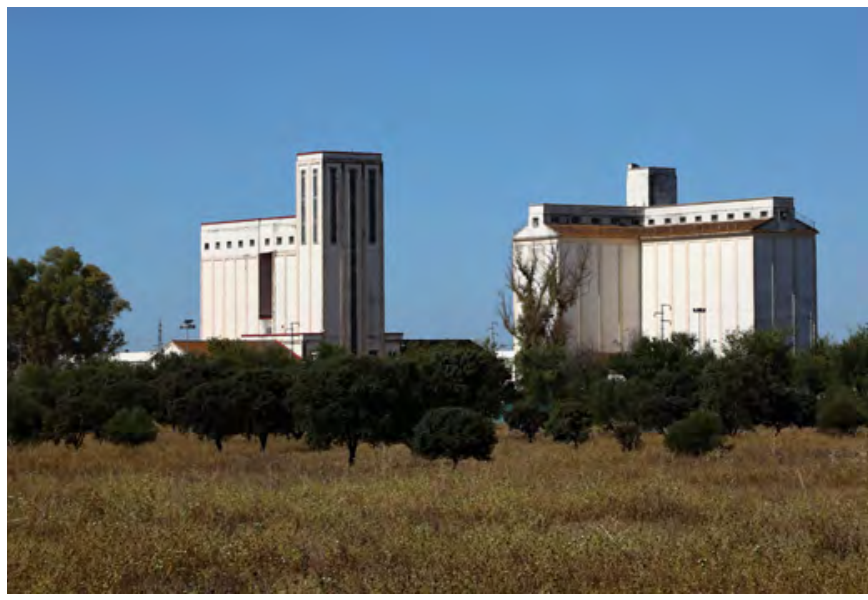

Silos de Bellavista (Sevilla)

cia, en muchas ocasiones, una sobreexplotación de los recursos que a la larga potencian el cambio del clima por el uso de productos químicos que afectan al suelo y la atmósfera; el aumento de la superficie de cultivo y la pérdida de ecosistemas que ayudaban a regular nuestro clima; la agricultura intensiva que puede llevar a la desertificación; una gestión del agua derrochadora; o la estabulación excesiva del ganado.

Pero la propia actividad agraria y ganadera, a su vez, se ve afectada por el cambio climático. Encontramos múltiples ejemplos, como el aumento de las plagas, la erosión de los suelos, las inundaciones o las sequías. El incremento de las temperaturas incide en el rendimiento de los cultivos y la alteración de la floración e, incluso, en la capacidad de resistencia del ganado (Benito 2021). Esta situación está obligando a tomar medidas que superen las políticas actuales, para ajustarse a las consecuencias del cambio (Iglesias, Quiroga y Sotes 2011, 19), como por ejemplo la modificación en los hábitos alimenticios del ganado para que las emisiones de metano se reduzcan o un uso más eficiente del agua en los regadíos (Rico 2018). Si esta situación está ocurriendo en la actividad humana, el mismo fenómeno sucede en los elementos que conforman el patrimonio natural y paisajístico.

La que se podría llamar "industrialización" de la producción agraria y ganadera ha conllevado además de estas

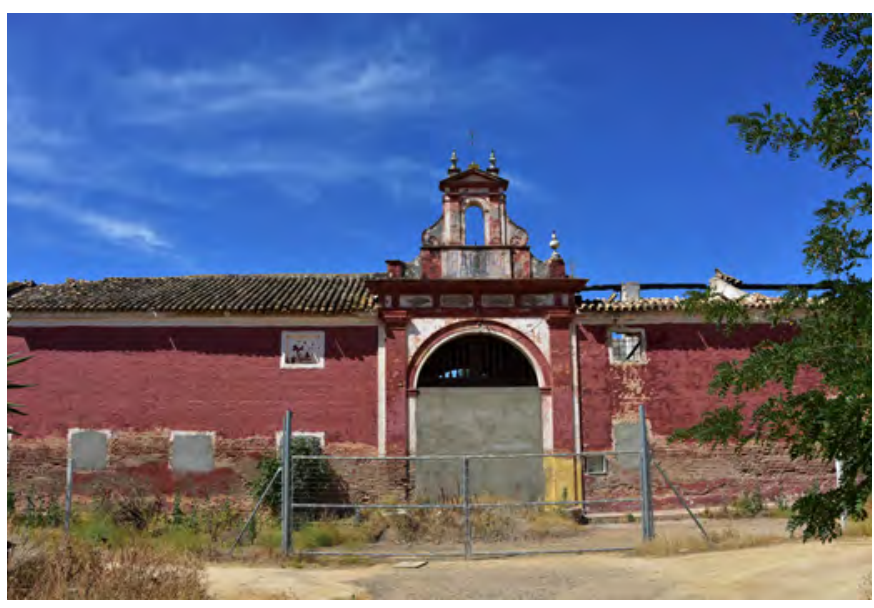

Hacienda Ibarburu (Dos Hermanas, Sevilla) | fotos José Manuel Baena Gallé

consecuencias negativas, el abandono de formas de producción tradicionales, junto con todo su patrimonio material e inmaterial, e incluso el abandono de localidades completas por el fenómeno del éxodo rural a los grandes núcleos urbanos.

Podríamos citar como ejemplo la situación de las haciendas de olivar diseminadas por todo el campo andaluz. La hacienda es una explotación agrícola que se dedicaba al cultivo del olivo y la producción de aceite fundamentalmente. Las haciendas de olivar forman un conjunto arquitectónico donde existen diversas dependencias como la residencia señorial, las almazaras para la transformación de la aceituna y las dependencias para las labores agrícolas y ganaderas (Aguilar García 1992, 27). En la actualidad muchas de ellas se encuentran en total abandono y en proceso de ruina dado que el sistema de transformación de aceituna ha variado totalmente. Sin ir más lejos, la hacienda Ibarburu en la localidad sevillana de Dos Hermanas.

Esta hacienda tiene su origen en el siglo XVII, aunque el edificio actual fue construido en 1748 con todos los elementos propios de estas instalaciones, inscrito en 2002 como BIC, con la tipología jurídica de monumento. En la actualidad se encuentra en un estado de desidia lamentable y ha sido expoliada lo que incluso ha sido señalado en la prensa local. 
Otro caso es el de los silos agrícolas españoles del siglo $\mathrm{XX}$. Aunque el fenómeno del almacenamiento de granos tuvo su origen en el neolítico y se ha ido desarrollando a través del tiempo, este se transformará totalmente con la revolución industrial y la aparición de nuevos materiales. En España resulta fundamental la aparición del problema de abastecimiento del trigo en torno a la Guerra Civil y cómo se planteó una política estatal de intervención en el proceso. Esto se ve acentuado durante el régimen franquista, que crea en 1937 el Servicio Nacional del Trigo y, en 1945, el Plan General de la Red Nacional de Silos y Graneros planificando la construcción de 437 silos y 631 graneros (Silosygraneros.es 2021). En 1984 desaparece el monopolio triguero del estado pasando muchas competencias a las comunidades autónomas e iniciándose un proceso de abandono de la red de silos española que están teniendo una suerte desigual con situaciones de ruina, ocupación ilegal o vandalismo. Estas edificaciones que marcaban un perfil especial de nuestros pueblos y ciudades se encuentran en claro peligro, como ocurre con los dos silos de Bellavista en Sevilla. La primera de estas edificaciones se construyó en 1967 y se dedicaba a la recepción y conservación del grano. El otro gran silo es de 1971 encargado de la selección de semilla. En la actualidad se está planteando un proceso de construcción inmobiliaria en los terrenos aledaños, aunque hay propuestas para su rehabilitación y reutilización.

\section{Conclusión}

La pregunta o el debate que se debería plantear sería la relación entre progreso y bienestar. La humanidad habita en el planeta Tierra, al que hay que proteger desde el punto de vista natural para poder seguir habitándolo. Pero también como comunidades de convivencia necesitamos referentes que nos enlacen con el pasado y permitan tender lazos comunes. $Y$ en ese aspecto resulta fundamental el patrimonio cultural. Cada elemento del patrimonio -material o inmaterial-que se pierde es algo irrecuperable y su ausencia supone un paso más hacia la desaparición del mundo y la vida tal y como lo conocemos.

\section{BIBLIOGRAFÍA}

- Aguilar García, M. ${ }^{a}$ C. (1992) Las haciendas. Arquitectura culta en el olivar de Sevilla. Sevilla: Universidad de Sevilla

- Benito, F.J. (2021) Así impactará el cambio climático en los cultivos y la ganadería de España. Verde y Azul, 17 de mayo de 2021. Disponible en: https://verdeyazul.diarioinformacion.com/ ganaderia-y-cultivos-bajo-el-impacto-del-cambio-climatico. html [Consulta 06/07/2021]

- Guzmán, M.J. (2021) Silos de Bellavista: los hitos invisibles del patrimonio industrial. Diario de Sevilla, 6 de junio de 2021. Disponible en: https://www.diariodesevilla.es/sevilla/SilosBellavista-hitos-patrimonio-industrial-Sevilla_0_1580543080. html [Consulta: 12/07/2021]

- Guzmán, M.J. (2019) La larga agonía de la Hacienda Ibarburu. Diario de Sevilla, 18 de septiembre de 2019. Disponible en: https://www.diariodesevilla.es/provincia/largaagonia-hacienda-ibarburu_0_1392761074.html [Consulta: 12/07/2021]

- Iglesias, A., Quiroga, S. y Sotes, V. (2011) La agricultura española y el cambio climático. Economistas, n. ${ }^{\circ} 127$, pp.19-27

- Ministerio para la Transición Ecológica y el Reto Demográfico (2021) Qué es el cambio climático. Disponible en: https://www. miteco.gob.es/es/cambio-climatico/temas/cumbre-cambioclimatico-cop21/el-cambio-climatico/ [Consulta: 12/07/2021]

- Rico, J. (2018) La agricultura española, contra el cambio climático. Campus: la revolución de las ideas, 11 de diciembre de 2018. Disponible en: https://www.fundacionaquae.org/laagricultura-espanola-contra-el-cambio-climatico/ [Consulta: 06/07/2021]

- Sciacca, F. (2021) Necesitamos tu firma. Refugiados, n. ${ }^{\circ}$ 2, monográfico El coste humano del cambio climático, p. 3. Disponible en: https://eacnur.org/files/reports/file/af_2021_ revistajunio_sp_web.pdf [Consulta: 12/07/2021]

- Silosygraneros.es (2021) Red Nacional de Silos y Graneros de España. Disponible en: https://silosygraneros.es/ [Consulta: 12/07/2021]

- UNESCO (2009) Cambio climático y Patrimonio Mundial: Estudios de caso. París: Centro del Patrimonio Mundial de la UNESCO. Disponible en: https://www.iccrom.org/sites/ default/files/2020-02/unesco_estudios-caso-cambio-climaticopatrimonio-mundial.pdf [Consulta: 12/07/2021] 


\title{
Programa de estudios para una arquitectura sostenible y sensible al patrimonio
}

\author{
Pedro Paulo Palazzo | Universidad de Brasilia \\ URL de la contribución <www.iaph.es/revistaph/index.php/revistaph/article/view/4983>
}

\section{Principios}

Se proclama a menudo que el desarrollo sostenible, la conservación del patrimonio y la práctica corriente de la construcción son aspectos de una misma disciplina integrada de la arquitectura. La misma existencia de cierto edificio histórico implica ahorro energético y captura de carbono mucho más grandes que la más eficiente nueva construcción (Elefante 2012). Sin embargo, las capacidades técnicas para dar mantenimiento a las estructuras tradicionales suelen ser muy distintas de la tecnología industrial asociada al desarrollo sostenible. Estas diferencias no son disparidades superficiales entre objetivos convergentes, sino que muestran una incompatibilidad de principios entre determinada cultura de patrimonio a la que interesa lo existente, lo regional y lo artesanal, y la cultura del desarrollo industrial dedicada a producir y desechar siempre más, aunque produzca y deseche productos con la etiqueta "ecológica".

Desde luego, la crisis provocada por la construcción industrializada no es solo climática y cultural, sino sobre todo económica y social. Además de los resultados ambientales que advienen de las propiedades intrínsecas de los materiales, la construcción tradicional favorece un proceso productivo sostenible en otros aspectos (Vellinga 2006).

Una de las más críticas consecuencias del cambio climático es el desplazamiento de procesos productivos que se organizan en cadenas globales y la consecuente privación económica de comunidades locales (Hallegatte, Fay y Barbier 2018). La construcción tradicional y la conservación de edificios históricos no solo contribuyen a la lucha directa contra el cambio climático, como también refuerzan cadenas productivas en escala local y regional (Robertson 2012).

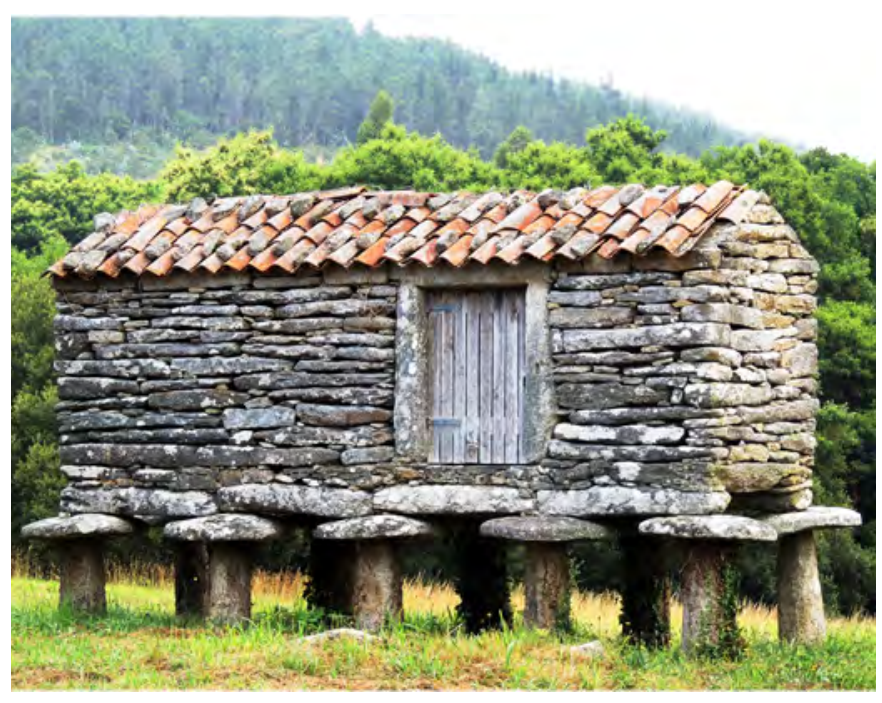

Hórreo en el Pazo do Allo en Zas (Coruña) | foto Jose Luis Cernadas Iglesias

Es cierto que, para solucionar la crisis climática, habrá que actuar sobre las estructuras productivas del mercado inmobiliario, pero para que cambien las estructuras debe existir aptitud técnica alternativa en la construcción y en su regulación. Por eso, la formación de arquitectos tiene un papel central en este proceso. La aptitud para emplear de modo corriente materiales de baja energía incorporada (Röck et ál. 2020) y para hacerlo en armonía con el carácter de las construcciones vernáculas será capaz de cerrar la brecha conceptual entre la conservación de edificios de valor patrimonial y las metas de reducción de emisiones de carbono en la industria de la construcción. Para capturar localmente las ganancias socioeconómicas que puede generar la conservación de la construcción tradicional como materia y como práctica, se necesita ubicar la enseñanza de los métodos tradicionales de construcción con materiales regionales en el centro del programa de estudios en arquitectura. 
El programa de estudios que planteo a continuación privilegia desde luego la materialidad de la construcción como punto de partida, más que la noción de diseño puramente formal y abstracto que domina la didáctica de arquitectura hoy día. Este orden de prioridades ya fue una vez normal en las escuelas de bellas artes (Curtis 1923; Guadet 1901). El programa se podrá adaptar a un sistema universitario, o incluso ser ofrecido como educación continuada para profesionales. El hilo conductor del programa es mostrar cómo la apariencia de "ineficiencia" de la construcción tradicional resulta en realidad más resiliente a largo plazo que la "eficiencia" de los cálculos, productos y métodos de la arquitectura industrializada convencional.

\section{Programa de estudios. Propuesta}

Se estructuraría en tres ciclos:

\section{El primer ciclo dedicado a los elementos:}

> Los elementos de construcción: los materiales naturales y elementos que pertenecen a la tradición constructiva de cada región (Asquith y Vellinga 2006); las estructuras eficientes no son resilientes; fundaciones, tapias, estructuras trabeadas y arqueadas, cubiertas y revestimientos; y priorizar la mantenencia local sobre el reemplazo (Thomsen y Van der Flier 2011).

> Los elementos de composición: las respuestas holísticas al clima regional (Correia, Gilberto y Rocha 2014): ventilación natural y gestión de la humedad, los riesgos de la impermeabilización y de la estanqueidad para la salud humana y la durabilidad de los edificios; el carácter de las plantas bajas como expresión de propósitos sociales básicos (Westfall 1991); y la composición de casas y del espacio público con volúmenes de formas definidas (Krier 1988).

> Hacer arquitectura tradicional: generar "estructuras vivas" (Alexander 2002; Cogdell 2019) en vez de diseñar conceptos "de autor"; el desarrollo incremental de la forma (Bacon 1974); las cuatro operaciones vitruvianas: ordenar, articular, apropiar y proporcionar (Scranton 1974).
2. El segundo, a las prácticas:

> Tipología y proyecto: la intervención en el ambiente construido es un proceso y no forma estática (Caniggia y Maffei 1987); contra el concepto de "diseño" abstracto, la "composición" como manipulación de tipos y espacios con sentido cultural (Amoruso 2018).

> Estilo y otras convenciones culturales: los "estilos" de la arquitectura son respuestas holísticas y resilientes a retos constructivos, climáticos y culturales, y hace falta respetarlos por eso. Se exploraría el continuo entre la arquitectura vernácula y la erudita (Krier 2009) y la analogía formal y técnica en el patrimonio histórico (Capitel 1988).

$>$ Vegetación y agua: la gestión del paisaje urbano y rural es el reto de la arquitectura (Muratori 1967; Upton 1991); también la adaptación al clima y soluciones regionales de manejo del agua y de la vegetación.

> Urbanización: la interdependencia entre la subdivisión del espacio urbano y la tipología arquitectónica (Corona Martínez 2009; Panerai 2012); romper el paradigma tecnocrático de megaproyectos públicos o privados en favor de una urbanización gradual y descentralizada; y el proceso tipológico en la escala del territorio (Caniggia 1997).

\section{El tercer ciclo abordaría problemas complejos:}

Es decir, retos específicos a cada región y sus problemas climáticos, socioeconómicos y culturales, deteniéndose en el pensamiento crítico de las normas y los instrumentos de gestión (Tafuri 1980) que promueven u obstan la construcción tradicional y la conservación del patrimonio. 


\section{BIBLIOGRAFÍA}

- Alexander, C. (2002) The Nature of Order. Berkeley, California: Center for Environmental Structure

- Amoruso, G. (2018) Rappresentare la resilienza: modelli conoscitivi per la ricostruzione. Milano: Lampi di Stampa. Disponible en: https://re.public.polimi.it/handle/11311/1095492 [Consulta: 14/09/2021]

- Asquith, L. y Vellinga, M. (ed.) (2006) Vernacular Architecture in the Twenty-First Century: Theory, Education and Practice. London; New York: Taylor \& Francis

- Bacon, E.N. (1974) Design of Cities. New York: Penguin

- Caniggia, G. (1997) Ragionamenti di tipologia: operatività della tipologia processuale in architettura. Firenze: Alinea

- Caniggia, G. y Maffei, G.L. (1987) I/ progetto nell'edilizia di base: composizione architettonica e tipologia edilizia: 2. Biblioteca di Architettura e Urbanistica. Venezia: Marsilio

- Capitel, A. (1988) Metamorfosis de monumentos y teorías de la restauración. Madrid: Alianza

- Cogdell, C. (2019) Toward a Living Architecture? Complexism and Biology in Generative Design. Minneapolis: University of Minnesota Press. Disponible en: https://doi.org/10.5749/j. ctv9b2tnw [Consulta: 13/07/2021]

- Corona Martínez, A. (2009) Ensayo sobre el proyecto. Buenos Aires: Nobuko

- Correia, M.; Gilberto,C. y Rocha, R. (ed.) (2014) Vernacular Heritage and Earthen Architecture: Contributions for Sustainable Development; Proceedings of CIAV 2013, 7th ATP, Versus, Vila Nova de Cerveira, Portugal, 16-20 October 2013. Leiden: CRC Press

- Curtis, N.C. (1923) Architectural Composition. Cleveland, Ohio: J. H. Janson

- Elefante, C. (2012) The Greenest Building Is... One That Is Already Built. Forum Journal, vol. 27, n. ${ }^{\circ} 1$, pp. 62-72. Disponible en: https://muse.jhu.edu/article/494514 [Consulta: 12/07/2021]

- Guadet, J. (1901) Éléments et théorie de l'architecture. Paris: Aulanier

- Hallegatte, S., Fay, M. y Barbier, E.B. (2018) Poverty and Climate Change: Introduction. Environment and Development Economics, vol. 23, n. ${ }^{\circ}$ 3, pp. 217-33. Disponible en: https://doi.org/10.1017/S1355770X18000141 [Consulta: 12/07/2021]

- Krier, L. (2009) The Architecture of Community. Washington, D.C.: Island Press (Thadani, D.A. y Hetzel, P.J. edicion)

- Krier, R. (1988) Architectural Composition. New York: Rizzoli
- Muratori, S. (1967) Civiltà e territorio. Roma: Centro studi di storia urbanistica

- Panerai, P. (2012) Analyse urbaine. Marseille: Parenthèses

- Robertson, M. (ed.) (2012) Sustainable Cities: Local Solutions in the Global South. Rugby, Warwickshire: Practical Action

- Röck, M., Saade, M.R.M., Balouktsi, M., Rasmussen, F.N., Birgisdottir, H., Frischknecht, R., Habert, G., Lützkendorf, T. y Passer, A. (2020) Embodied GHG Emissions of BuildingsThe Hidden Challenge for Effective Climate Change Mitigation. Applied Energy, vol. 258, 114107. Disponible en: https://doi. org/10.1016/j.apenergy.2019.114107 [Consulta: 12/07/2021]

- Scranton, R.L. (1974) Vitruvius' Arts of Architecture. Hesperia: The Journal of the American School of Classical Studies at Athens, vol. 43, n. ${ }^{\circ} 4$, pp. 494-99. Disponible en: https://doi.org/10.2307/147496 [Consulta: 12/07/2021]

- Tafuri, M. (1980) La Sfera e il labirinto: avanguardie e architettura da Piranesi agli anni '70. Torino: G. Einaudi

- Thomsen, A. y Van der Flier, K. (2011) Understanding obsolescence: a conceptual model for buildings. Building Research \& Information, vol. 39, n. ${ }^{\circ} 4$, pp. 352-62. Disponible en: https://doi.org/10.1080/09613218.2011.576328 [Consulta: 12/07/2021]

- Upton, D. (1991) Architectural History or Landscape History? Journal of Architectural Education, vol. 44, n. ${ }^{\circ} 4$, pp. 195-99. Disponible en: https://doi.org/10.2307/1425140 [Consulta: 12/07/2021]

- Vellinga, M. (2006) The Inventiveness of Tradition: Vernacular Architecture and the Future. Perspectives in Vernacular Architecture, vol. 13, n. ${ }^{\circ}$ 2, pp. 115-28. Disponible en: https:// www.jstor.org/stable/20355388 [Consulta: 12/07/2021]

- Westfall, C.W. (1991) Building Types. En: Westfall, C.W. y Jan van Pelt, R. (ed.) Architectural Principles in the Age of Historicism, 138-67. New Haven: Yale University Press 


\title{
$\mathrm{PH} 104_{\text {debate }}$
}

a debate Patrimonio cultural y cambio climático

| coordina Alejandro García Hermida

\section{El valor patrimonial del SIPAM}

\author{
José Damián Ruiz Sinoga | Dpto. de Geografía, Universidad de Málaga
}

URL de la contribución <www.iaph.es/revistaph/index.php/revistaph/article/view/4987>

En el actual contexto de cambio climático existe una natural preocupación por determinar la vulnerabilidad de diferentes espacios a los efectos de este, dado que, en el ámbito mediterráneo, algunos indicadores comienzan a ser especialmente preocupantes. Uno de ellos es el constituido por el SIPAM (Sistemas Importantes del Patrimonio Agrícola Mundial) de la uva pasa de la comarca malagueña de la Axarquía, referido a un paisaje con un alto valor estético donde se combinan la biodiversidad agrícola, el patrimonio cultural y los ecosistemas resilientes, constituyendo un territorio de subsistencia económica para pequeñas comunidades agrícolas, agrupadas en más de 20 pueblos, a través de actividades sostenibles, en este caso, vinculadas a la uva pasa.

Este territorio que tiene como eje estructural la actividad vitícola, a lo largo de sus más de cinco siglos de existencia, ha superado multitud de crisis climáticas, económicas, demográficas, con lo que, a la hora de determinar los mecanismos de adaptación a las nuevas condiciones climáticas, resulta difícil establecer un marco general para el análisis de vulnerabilidad, puesto que ya ha mostrado su capacidad de recuperación. Su capacidad para sobrevivir, reinventarse y desarrollarse frente a las debilidades puede definirse como resiliencia, e involucra a cada una de las partes que lo componen, por lo que la gestión pública y la ordenación del territorio deben ser herramientas clave para dotar de calidad un espacio, cuyo principal valor es el patrimonial, el haber sido vehículo conductor de las actividades de una comarca durante más de cinco siglos.

En el SIPAM de la uva pasa de la Axarquía existe una capacidad adaptativa muy diversa en diferentes aspectos: paisajístico, agrícola, demográfico, sociológico o cultural; y esa, entendemos, es su verdadera fortaleza, su patrimonio cultural.
Un paisaje que nos muestra cómo los procesos de escorrentía han sido históricamente controlados a través de las "agüaeras", constituyendo un elemento paisajístico altamente integrado, junto con los antiquísimos muretes de piedra seca que no solo reducen la pendiente, sino que incrementan la capacidad de retención de los suelos, controlando la erosión de los mismos.

Muchas de estas técnicas tradicionales son aplicadas en la ingeniería civil para retener procesos de erosión de suelos en laderas, o evitar acarcavamientos excesivos mediante la creación de vías preferenciales de evacuación de escorrentías. Incluso la permanencia de la excesiva pedregosidad en las laderas pizarrosas vitícolas supone un elemento clave en la protección de los escasos suelos ante las precipitaciones agresivas, dado que ejercen de denominado efecto tejado, al permitir la lenta infiltración del agua de lluvia, evitando el efecto salpicadura y, por tanto, la movilización de partículas de suelo.

Un cultivo, el viñedo, con una gran capacidad de adaptación a condiciones extremas, tanto térmicas, como pluviométricas, que con más de 500 años de tradición ha sobrevivido a condiciones climáticas muy diferentes, especialmente frente a los riesgos derivados del déficit hídrico. Así, si bien el contexto climático actual podría tener repercusiones específicas en el cultivo de la vid, relacionadas con su período fenológico, con la aparición de plagas o enfermedades o con la pérdida de calidad del producto final, la capacidad de adaptación y resiliencia hacen del viñedo uno de los más resistentes a las alteraciones provocadas por el "cambio climático". Y, especialmente, frente a la expansión de cultivos subtropicales y a la disponibilidad cada vez más escasa de agua. La necesidad de ordenación agrohidrológica sigue siendo clave. 


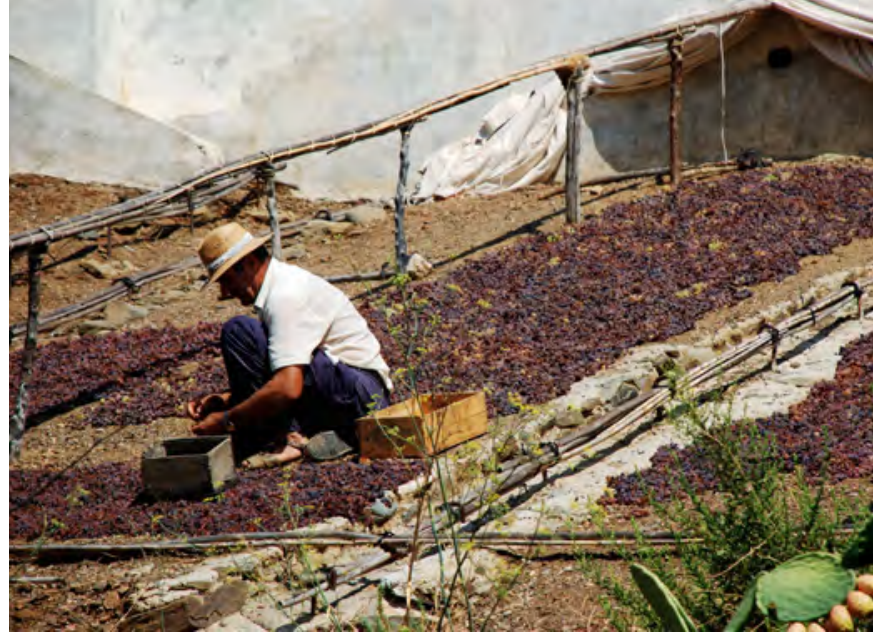

Recogiendo las pasas. Málaga | foto Antonio

La demografía del territorio SIPAM es similar a la de cualquier zona rural de Andalucía, con toda una problemática basada en la despoblación, el envejecimiento y el relevo generacional. Así, las políticas enfocadas en este gran desafío demográfico deben ser el principal soporte para reducir la tasa de despoblación y obtener una diversificación de servicios que favorezca la estabilización del éxodo rural. Sin embargo, la generación de una economía natural basada en la viticultura es compleja, con lo que en la actualidad es más una actividad patrimonial que verdaderamente económica.

La fuerte influencia cultural de la actividad vitivinícola en el territorio puede considerarse un pilar clave en la resiliencia del área SIPAM, dado que los municipios organizan numerosos eventos culturales vinculados tanto al proceso de vendimia como al consumo de los productos finales. La Fiesta de la Uva Moscatel, el primer sábado de agosto en Iznate; la Noche del Vino el 15 de agosto en Cómpeta; la Fiesta de Viñeros, el segundo domingo de septiembre en Cómpeta; la Fiesta de la Pasa el tercer sábado de septiembre en La Viñuela; la Fiesta de la Pasa el tercer domingo de septiembre en El Borge; o la Fiesta del Mosto y la Chacina el primer domingo de diciembre en Colmenar, son algunas de las actividades de ocio vinculadas a la historia, tradición y cultura de la población SIPAM.
Además de estos eventos, el emprendimiento está jugando un papel fundamental en la consolidación de las fuertes raíces de la tradición de la pasa en esta zona de Málaga. De esta manera, la creación de rutas turísticas como la "ruta de la pasa" con actividades como contemplar un atardecer entre viñedos, visitar un lagar, conocer el funcionamiento de una cooperativa o tomar una copa de vino moscatel en un pueblo rural de la zona, están contribuyendo a fortalecer verdaderamente la tradición y la actividad ligada a la vid.

Así, la puesta en marcha de nuevas asociaciones o la creación de museos con herramientas e instrumentos relacionados con la vendimia puede dar lugar a un mayor alcance de este distintivo territorial $\mathrm{y}$, directamente, de sus productos, aumentando su oferta si se utilizan los medios adecuados, como señalización del área SIPAM en carreteras, promoción en congresos, ferias, exposiciones y conferencias o la publicidad y marketing de una etiqueta SIPAM a través de webs o plataformas virtuales, etc.

En definitiva, el objetivo sería traducir el fuerte arraigo de la población-territorio en un sello de calidad local que sea capaz de ampliarse y generar un espacio de mercado a su alrededor. 


\section{$\mathrm{PH} 104_{\text {debate }}$}

a debate Patrimonio cultural y cambio climático

| coordina Alejandro García Hermida

\section{Paisajes rurales y energías renovables. Un patrimonio cultural bajo amenaza}

Anna Martínez Durán, Montserrat Villaverde Rey | Escola Arquitectura La Salle, Universitat Ramon Llull

URL de la contribución <www.iaph.es/revistaph/index.php/revistaph/article/view/4986>

Una de las consecuencias del cambio climático es el paso del sistema de producción de energías fósiles a energías renovables. Con este escrito se quiere poner de manifiesto la destrucción del patrimonio tradicional que va a suponer la implantación de macroproyectos de instalaciones eólicas y fotovoltaicas. Su aterrizaje en las zonas rurales más frágiles de nuestro país representará en muchos casos la desaparición de unos paisajes de gran belleza y dignidad, que residen en la memoria del pueblo y construyen su identidad (Nogué i Font 2010). También de una forma de vida y una cultura heredadas, y del sistema económico y social que los mantiene vivos. Proyectos emplazados lejos de los centros de consumo, que se instalan en zonas deprimidas por su bajo valor, por la poca resistencia social que encuentran, en definitiva, porque la producción es más fácil y rentable (Saladié 2018).

Nuestro planteamiento parte de poner en valor estos territorios ocultos, construidos a lo largo de siglos, por y a escala de hombres y mujeres que aprovecharon los recursos del lugar para transformar lo inhóspito en un paraíso. Lugares que siguen siendo ricos en biodiversidad: flora, fauna, suelos, agua... porque el hombre estableció, en su asentamiento, un pacto de equilibrio con la naturaleza.

El caso de estudio se desarrolla en los alrededores de la población de El Perelló (Baix Ebre, Tarragona), situado en un alto $(150 \mathrm{~m})$, entre las sierras del Cardó y del Boix y el mar, en una zona de geología calcárea cruzada por barrancos, con manantiales de aguas claras y cuevas, que han sido refugio desde la época neolítica (cuevas de Cabra i Feixet, del Duc, de la Masa). Restos arqueológicos lo sitúan en el trazado de la Vía Augusta (Izquierdo i Tugas 1989). Con una carta fundacional de
1294, fue ciudad amurallada, y en ella se construyó un hospital real (1313) (Boyer i Gil y Pallarès i Lleó 1978). Lugar de tránsito y de defensa, de mezcla de gente, en la época moderna estuvo en primera línea de la batalla de l'Ebre, fue reconstruida por la Dirección General de Regiones Devastadas y Reparaciones, y las curvas de la nacional N-340 aún están en el recuerdo de nuestros padres y abuelos en sus primeros periplos por la costa mediterránea.

Los habitantes de El Perelló transforman desde principios del s. XVIII un territorio árido y pedregoso en campo de cultivo. Con el pago de los censals redimen la propiedad y ganan su libertad: "durant el día treballaven a jornal, i per la nit arrabassaven garrigues, plantaven figueres i oliveres, feien marges, carboneres, etc. En definitiva, les terres de secà del nostre terme han estat regades per la suor de la que podríem dir que ha fet història" (Boyer i Gil y Pallarès i Lleó 1978). Casi 300 años después, bajo el viento de mistral, se siguen cultivando almendros, olivos, higueras y algarrobos, se sigue cazando, y se sigue habitando en casetas diseminadas, manteniendo el carácter familiar e independiente original: "tal com és la tradició, una casa de faena, de festa o de reunió" (Generalitat de Catalunya 2014).

La máxima frente al Mediterráneo de Le Corbusier de "mantener el tesoro de la escala" y la consecución de la libertad individual que dio lugar a la construcción de esta obra comunal: "va ser la gent la que va canviar la fesomia del paisatge" (Aragonés Gisbert et ál. 2010) son los dos ejes que están en el origen de este paisaje, y que se ven ahora amenazados.

Un patrimonio cultural escrito con minúsculas, una arquitectura tradicional sin nombres propios: "construida pels 

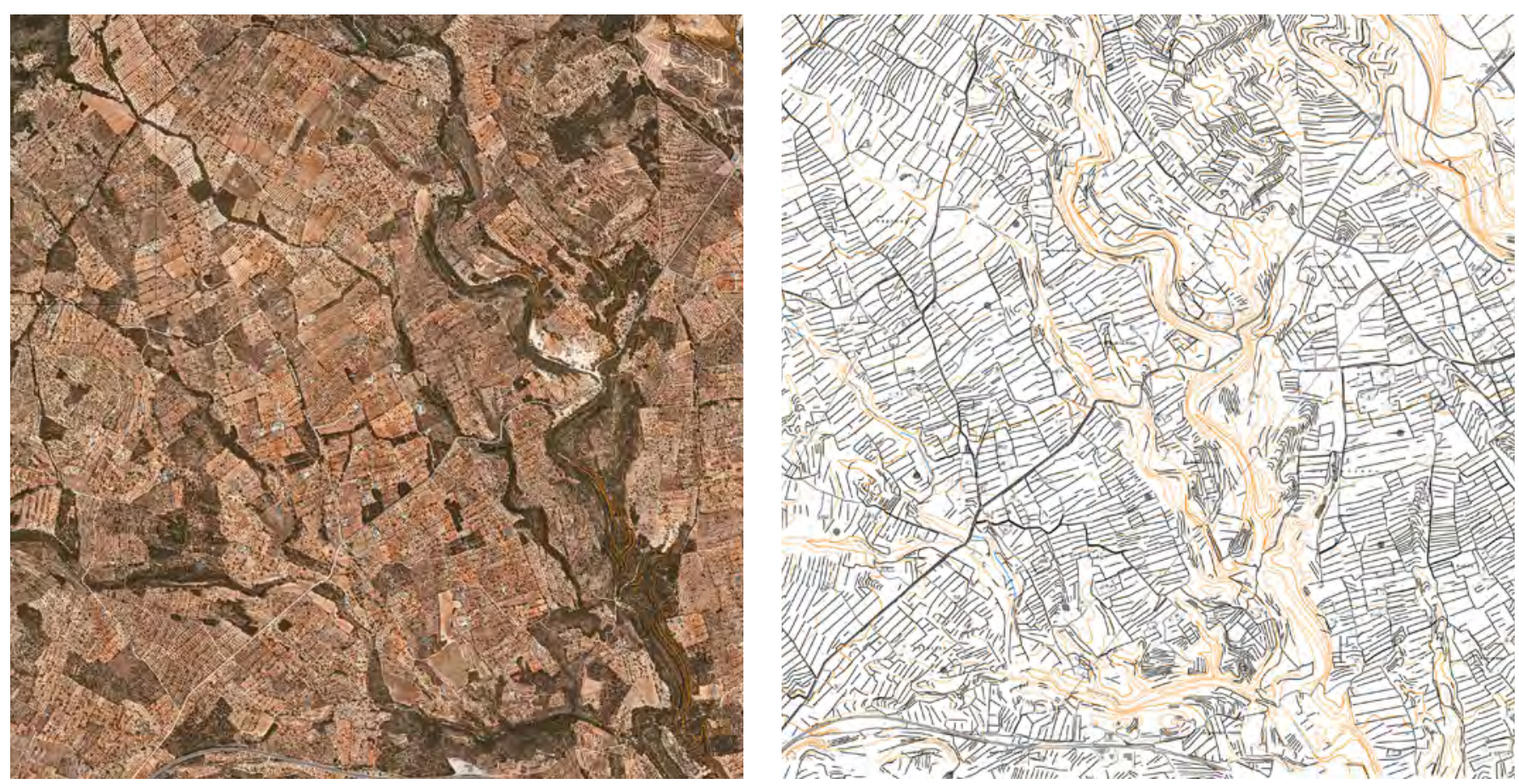

Visión aérea del paisaje rural: mosaico agrario, geometrías construidas, muros de piedra seca. Ortofoto y dibujo propio sobre base del ICGC | fuente Institut Cartògràfic i Geològic de Catalunya

habitants d'un territori a partir d'uns models compartits, creats de manera colectiva a través de les generacions" (Van Geert y Estrada Bonell 2018), fundamento de una gran cultura, la mediterránea.

El proyecto en curso propone revelar la existencia de este patrimonio cultural, material e inmaterial: grafiarlo, fotografiarlo (Cortellaro 2007), reconocer historias, costumbres y actividades para dar continuidad a la reflexión actual sobre el conflicto entre el paisaje y las energías renovables (ALIENTE 2021).

Características del patrimonio cultural de este lugar, y razones por las que deberíamos conservarlo, son:

> Una división parcelaria que conforma un atractivo "mosaico agrario" (Observatori del Paisatge 2010), con parcelas de pequeño tamaño (0,5-3 ha), lo tros (el trozo), que dan la medida del terreno abarcable por el trabajo de cada persona, para la subsistencia familiar.
> La antigua Nacional 340, asimilada popularmente a la Vía Augusta (Perea Paños 2016), estructura el territorio, con estrechos caminos de acceso a lado y lado, entre muros de piedra, que siguen la topografía (a pendiente y a nivel) y en continuidad cuando son paso de ganadería, los "pasos de ligallos".

$>$ No hay límites en el paisaje al paso de personas ni de animales, tampoco a las visuales que se extienden a lo lejos, por debajo de las copas de olivos y algarrobos.

> Los muros de piedra seca (en la Lista de Patrimonio Cultural Inmaterial de Unesco desde 2018) organizan el terreno en bancales horizontales para retener la escasa lluvia, definen los límites de la propiedad, son almacenes de piedra y refugio de cazadores. Sus trazados son pura geometría: líneas rectas y quebradas, curvas sinuosas.

> Las construcciones son menores en tamaño, no en servicio ni en calidad arquitectónica: con un alto nivel de 

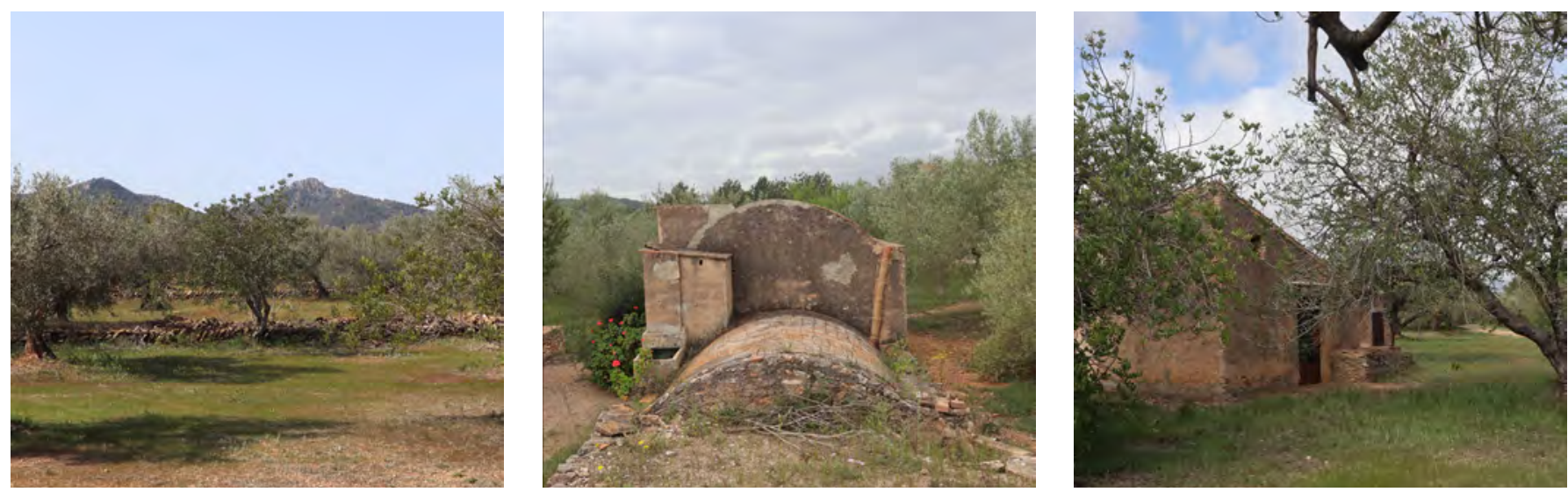

Elementos naturales y construidos de este paisaje mediterráneo: el Tossal de Montagut, cisterna de bóveda cerámica y caseta del tros | fotos Anna Martínez Durán

abstracción, son únicas de este lugar. Se esparcen por el territorio: masets y casetes del tros (Ferrer 2006), cisternes y valonas, eres, corrals y pallisses. Sencillos elementos que forman conjuntos orgánicos, de relaciones cercanas y geometrías compartidas. En estas construcciones domésticas se usan la piedra seca, la mampostería de barro, los techos de vigas de madera y las bóvedas de rasilla cerámica (García Lisón y Zaragozá Catalán 1983).

> Algarrobos y olivos centenarios, plantados con regularidad y orden por mentes sabias, producen un aceite compensado entre especies y sabores, sus raïls (raíces) expuestas en un terreno seco y ventoso.

> Las montañas de Cardó y del Boix presiden el llano, el monte más cercano es el Tossal de Montagut (394 m), paso de cátaros entre el Ebro y el Mediterráneo. Estos montes pedregosos son referencia de paisaje y memoria del lugar. La pintura moderna nace con la reflexión plástica de Paul Cézanne frente a Sainte Victoire porque en cada montaña reside una carga simbólica que nos ancla al territorio. Son lugar sagrado y la casa a la cual regresar, mantenerlas limpias es nuestra obligación.

Este territorio entre El Perelló y l'Ametlla de Mar sigue vivo, con tráfico de coches, tractores, bicicletas, caminantes y gentes que producen aceite y miel, recogen almendras, algarrobas, y residen en casetas que, en pleno siglo XXI, siguen siendo autosuficientes en el consumo de agua y energía. Un lugar con unos niveles muy altos de silencio y limpieza del aire, también lumínica, que en estos momentos está siendo amenazado por proyectos de gran envergadura, eólicos y fotovoltaicos, promovidos por grandes empresas ajenas al territorio.

Uno de ellos prevé la instalación de 10 aerogeneradores a ambos lados de la antigua $\mathrm{N}-340$, de 180 metros, 3,6 $\mathrm{mW}$ y $115,5 \mathrm{~dB}$ cada uno. Los más de $7 \mathrm{~km}$ de caminos abiertos para acceder unas alas de $64 \mathrm{~m}$, las plataformas de montaje, de 1 ha cada una, las cimentaciones y las zanjas, la central eléctrica y el nuevo tramo de evacuación aérea, van a convertir este paraje agrario, patrimonial, a escala humana, en un polígono industrial, ruidoso, a medida de las máquinas, y desierto, vacío de gente. En definitiva, estamos frente a la destrucción de un lugar histórico, patrimonial, y de su imaginario colectivo, de su identidad.

Como este, tantos otros lugares en nuestro país han llegado hasta nosotros en calma, en estado latente (Sala i Martí 2016). Paisajes patrimoniales que ahora podrían verse beneficiados por la inversión pública dando continuidad a esta obra comunitaria pero que, de ceder a la amenaza de estos macroproyectos en manos de las grandes empresas, verán su futuro humano y económico truncado, y su paisaje, su identidad, destrozados, sin vuelta atrás. 


\section{BIBLIOGRAFÍA}

- ALIENTE [Alianza Energía y Territorio] (2021) Por la conservación de la biodiversidad, el paisaje, y por el desarrollo de un modelo energético distribuido y justo. Manifiesto. Disponible en: https://aliente.org/manifiesto [Consulta: 15/09/2021]

- Aragonés Gisbert, J., Estorach Fatsini, M., Ferré Castell, C., López Daufí, A., Olivas Rodríguez, J. y Ollé Garcia, S. (2010) La pedra en sec a les comarques del Baix Ebre i del Montsià. Benicarló: Onada Edicions

- Boyer i Gil, A. y Pallarès i Lleó, A.(1978) Història d'El Perelló, vol. 1. [S.L : S.n]

- Cortellaro, S. (2007) Morna, Atzaró. La construcción del territorio de Eivissa. Palma de Mallorca: COAIB

- Ferrer, A. (2006) Les casetes del tros. Una arquitectura vernacular. Memòria del Perelló, n. ${ }^{0} 1$

- García Lisón, M. y Zaragozá Catalán, A. (il.) (1983) Monográfico La vivienda temporera en las comarcas del Maestrat i les Terres de l'Ebre. Centro de Estudios del Maestrazgo, año I, n. ${ }^{\circ} 1$ Disponible en: https://pedraseca. gva.es/documents/168838666/168851333/Garc\%C3\%ADaZaragoz\%C3\%A1\%20Pallisses+\%26+casetes+de+volta. pdf/82a1c11b-7e45-477b-ba91-3be63fb0bde1 [Consulta: 14/07/2021]

- Generalitat de Catalunya (2014) Pla Director Urbanístic de les construccions agrícoles tradicionals de les Terres de l'Ebre. Disponible en: https://territori.gencat.cat/ca/inici [Consulta 09/07/2021]

- Izquierdo i Tugas, P. (1989) Un tram de la Via Augusta al Perelló i una proposta d'urbanització. Butlletí Arqueològic. Reial Societat Arqueològica Tarraconense, n. ${ }^{\circ}$ 10-11, pp. 169-191. Disponible en: https://raco.cat/index.php/ButlletiArq/ article/view/315454 [Consulta: 18/07/2021]

- Nogué i Font, J. (2010) Paisatge, territori i societat civil. Valencia: Tres i Quatre

- Observatori del Paisatge (2010) Catàleg de Paisatge de les Terres de l'Ebre. Disponible en: http://www.catpaisatge.net/cat/ catalegs_presentats_E.php [Consulta: 09/07/2021]

- Observatori del Paisatge (2007) Paisatges de la pedra seca. Disponible en: http://www.catpaisatge.net/dossiers/pedra seca/cat/index.php [Consulta: 09/07/2021]

- Perea Paños, L. (2016) Entre Pinón i Tria Capita: Estudi del pas de la Via Augusta i d'una possible mutatio al municipi del Perelló. Universitat Autònoma Barcelona (TFG). Disponible en: https://docplayer.es/97839700-Entre-pinon-i-tria-capitaestudi-del-pas-de-la-via-augusta-i-d-una-possible-mutatio-almunicipi-del-perello.html [Consulta: 09/07/2021]
- Saladié, S. (2018) Conflicte entre el paisatge i l'energia eòlica. El cas de les comarques meridionals de Catalunya. Lleida: Pagès Editors

- Sala I Martí, P. (2016) Paisatges latents. Aportacions de l'Observatori del Paisatge de Catalunya. Presentación en el Simposio Sòl No Urbanitzable, en Olot, 14 de octubre de 2016, Colegio de Arquitectos de la Demarcación de Girona. Disponible en: https://es.slideshare.net/psala/paisatgeslatents-aportacions-de-lobservatori-del-paisatge-de-catalunya [Consulta: 09/07/2021]

- Van Geert, F. y Estrada Bonell, F. (2018) Construint el territori: arquitectura tradicional i paisatge a Catalunya. Departament de Cultura de la Generalitat de Catalunya. Disponible en: https://cultura.gencat.cat/web/.content/cultura popular/05 documents_i_recursos/04_exposicions_itinerants/Construint_ territori/SD_Construint_territori.pdf [Consulta: 15/09/2021] 


\title{
$\mathrm{PH} 104_{\text {debate }}$
}

a debate Patrimonio cultural y cambio climático

| coordina Alejandro García Hermida

\section{¿Cómo crees que afecta el cambio climático al patrimonio cultural?}

\author{
Robert Adam | Robert Adam Architectural Consultancy \\ URL de la contribución <www.iaph.es/revistaph/index.php/revistaph/article/view/4997>
}

Esta pregunta debería plantearse en futuro. El cambio climático está presente. Siempre lo ha estado. Pero, aparte de algunos acontecimientos significativos, las principales consecuencias de este son, en gran medida, predicciones.

Esto sucede en todos los aspectos de la vida: tenemos que predecir el futuro más probable para poder sobrevivir. Podemos utilizar medios más avanzados y científicos, pero puede aparecer, y a menudo ha aparecido, un "cisne negro", metáfora utilizada para referirnos a un gran acontecimiento imprevisible. Predecimos un cambio rápido de cierta relevancia en el clima basándonos en la actividad humana del pasado y muchos gobiernos están intentando modificar el comportamiento futuro para mitigar este cambio previsto. Sin embargo, como en todas las predicciones futuras, siempre hay algo de incertidumbre.

El patrimonio no son los objetos físicos o las tradiciones en sí mismas, sino aquello que la comunidad cree que debería representar un pasado significativo para su identidad. Esto está destinado a cambiar. Incluso ahora, se está viviendo este controvertido proceso en lugares como Sudamérica y en otras regiones, donde se están reevaluando aquellas partes de su pasado con las que creen que ya no deberían identificarse.

Todas estas son respuestas sociales al cambio climático y al patrimonio; y no es tanto el cambio climático en sí lo que afectará al patrimonio, como la forma en la que las sociedades reaccionen a cualquier presión para modificarlo o redefinirlo.

El cambio climático podría ser tan grave y convertirse en un imperativo moral de tal calibre que cualquier acti- vidad pasada relacionada con el despilfarro energético se convertiría en objetos o actividades con los que ya no querríamos identificarnos. A pesar de su antigüedad y su ubicuidad, que los convertía en un reflejo de su tiempo, toda asociación con estos objetos o actividades podría ser censuradas. Esto ocurre también con cualquier cosa o persona que haya tenido alguna vinculación con la esclavitud, que cumple con todas estas características, y que es ahora considerada por muchos como ofensiva. Aunque pensemos que esto es poco probable, podemos especular sobre lo que significaría para nuestro patrimonio ya construido.

Todo lo relacionado con actividades como la minería del carbón o la extracción de petróleo, y todo lo financiado por estas actividades, podría dejar de conside-

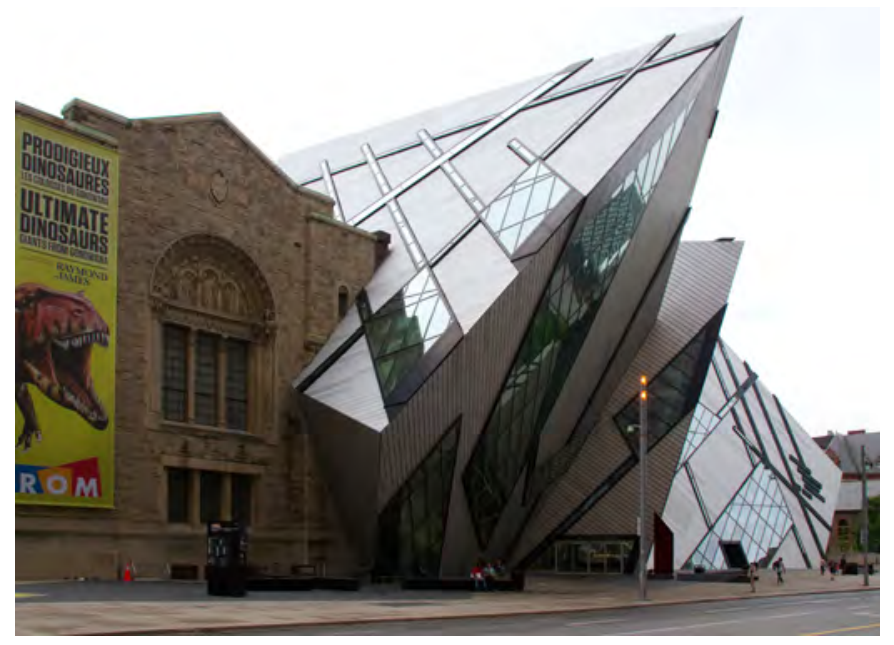

Ampliación del Museo Real de Ontario, Canadá. Daniel Libeskind, 2007. Descrito como "edificios históricos, complementados por una arquitectura atrevida y con visión de futuro", la moda del contraste basada en la teoría del arte-histórico finalmente destruye el valor patrimonial del original | foto Tony Hisget 


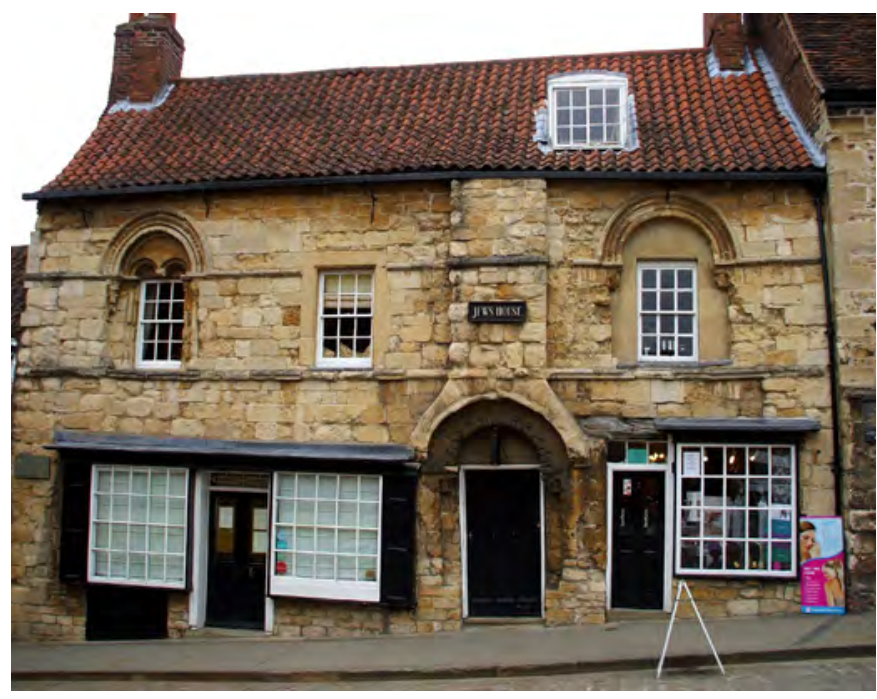

Jews House, Lincoln, Inglaterra. Continuamente ocupado, desde mediados del siglo XII, este edificio ha acumulado una importante cantidad de carbono | foto Marek69

rarse digno de ser llamado patrimonio. El impacto sería enorme. Muchas casas de campo en Gran Bretaña, incluso todo lo que tiene que ver con la Fundación Getty, y hasta lo que ha sobrevivido de la revolución industrial, merecerían la indiferencia, o incluso algo peor.

Un resultado opuesto, también basado en resultados climáticos graves, sería que las consecuencias se consideraran tan extremas que el desorden social y el desastre global provocaran que las comunidades colapsaran. Cualquier cosa que refuerce la identidad y proporcione un recuerdo de épocas mejores y de una localidad concreta tendría una consideración especial. El valor del patrimonio se vería reforzado y los nuevos aspectos o los más recientes del pasado podrían convertirse en patrimonio (como, de hecho, sucede todo el tiempo). Esto es lo más probable y constituiría una aceleración y extensión de la situación actual, donde la globalización tiene que reforzar el interés por lo local y la tradición.

Otra consecuencia del cambio climático extremo ( $y$, de hecho, proyectado) es el desplazamiento demográfico desde zonas recientemente degradadas por la pérdida de tierras productivas, o la subida del nivel del mar, hacia zonas con mejores condiciones agrícolas o más aptas para el asentamiento. Esto ya está ocurriendo. Si los lugares afectados por la deserción tienen un valor patrimonial y han de sobrevivir como lugares aptos para la ocupación, posiblemente de menor tamaño, habrá que crear condiciones económicas viables y considerar la demolición de los edificios sin valor patrimonial actual o probable para consolidar la población restante o entrante en los edificios a conservar. Lo más probable es que esto requiera de un cambio cultural y una acción política. Una de las consecuencias sería la reconsideración de cómo adaptar el patrimonio superviviente.

Actualmente se está debatiendo sobre si se debe mejorar la eficiencia energética cuando los edificios históricos siguen estando ocupados y cómo hacerlo. Esto ya está provocando dificultades. El aislamiento exterior, los paneles solares y el doble o triple acristalamiento se han propuesto como soluciones, pero su impacto en el aspecto de los edificios históricos puede alterar significativamente su apariencia, sobre todo cuando es el registro de la apariencia y el tejido del edificio lo que valida su conservación como patrimonio. Hay dos posibles respuestas a esto.

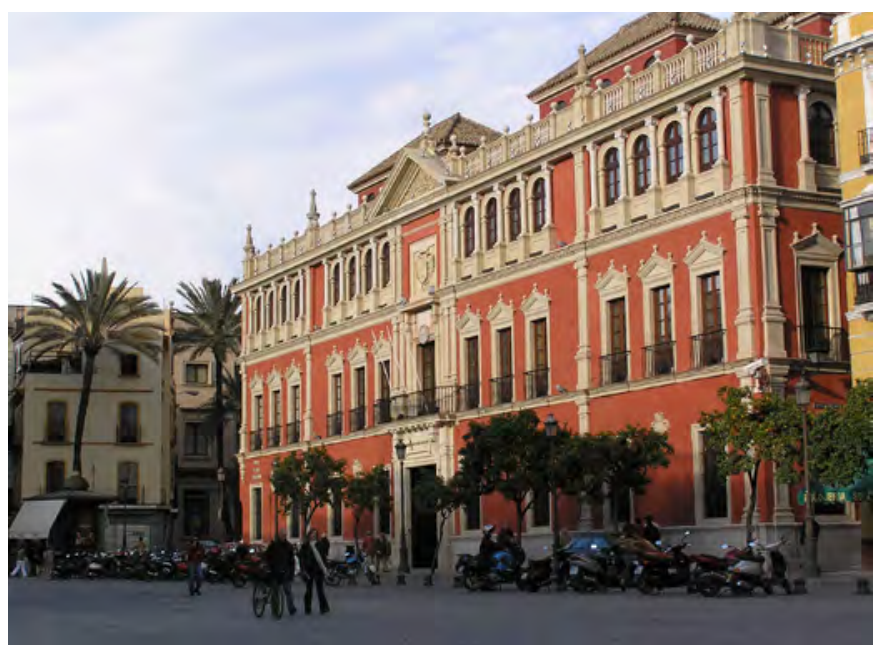

Real Audiencia de los Grados de Sevilla, reconvertida, alterada y ampliada como edificio Cajasol por Rafael Manzano. La alteración y extensión comprensiva de los edificios patrimoniales permitirá una reutilización más eficaz sin destruir el valor patrimonial | foto Dani svq 
La primera es adoptar una visión más evolutiva que preservacionista del patrimonio. Muchos edificios se han conservado en un momento arbitrario de su historia, deteniendo un proceso de cambio que habría continuado si no se hubieran adoptado medidas legales para detenerlo. El problema de muchas de las remodelaciones recientes de los edificios patrimoniales ha sido la naturaleza insolidaria de los materiales modernos, la actual cultura antihistórica de la arquitectura dominante y los principios de la Carta de Venecia de la Unesco, según los cuales las adiciones tienen que ser obvias y claramente "modernas". Una mayor tolerancia al cambio, por el que se mantiene el carácter del edificio, proporcionaría oportunidades para aumentar el rendimiento energético sin destruir o comprometer el valor de la memoria del patrimonio original.

La segunda es reconocer el ahorro de energía que ya está presente en las estructuras existentes. Cientos de años de uso continuado suponen un importante ahorro energético en relación con una estrategia de sustitución, incluso de una discreta. En la actualidad, el ahorro de energía se mide en términos del ahorro en la energía entrante activa que se produce por una mayor eficiencia ante la pérdida de energía en curso. En ninguna parte de estos cálculos aparece una medida acordada que haga referencia a una mayor importancia con respecto a la longevidad, como tampoco aparece en ninguna parte, incluso en las que reconocen el valor de la longevidad futura, ningún crédito para el ahorro de energía de forma retrospectiva.

A pesar de que el ahorro de energía de forma retrospectiva o el crédito energético puedan ser difíciles de aceptar con el concepto de una acción futura para moderar el cambio climático, el principio de que "el edificio más ecológico es el que ya está construido" está ganando cada vez más adeptos. Este principio afectará inevitablemente al patrimonio ya construido. Lo más probable es que tengamos que adoptar una visión más crítica y flexible de la adaptación y la modificación y, por lo tanto, de la integridad del patrimonio, y ofrecer un enfoque arquitectónico adecuado al cambio. 


\title{
Cambio climático y evaluación de riesgo para el patrimonio cultural
}

\author{
Mauro G. García Santa Cruz, M. Jimena García Santa Cruz, Guillermo R. García | Instituto de Investigación en Arquitectura y \\ Territorio, Facultad de Arquitectura y Diseño, Universidad Católica de La Plata
}

URL de la contribución <www.iaph.es/revistaph/index.php/revistaph/article/view/4988>

El Quinto Informe de Evaluación del IPCC (Grupo Intergubernamental de Expertos sobre Cambio Climático) afirma que desde 1950 se han observado cambios en la atmósfera y el océano debidos al aumento de las concentraciones de gases de efecto invernadero (GEI). También alerta de que las emisiones continuas de GEI causarán un mayor calentamiento y aumentará la probabilidad de impactos severos, generalizados e irreversibles en los ecosistemas (IPCC 2015). Se estima que las actividades humanas han causado un calentamiento global de aproximadamente $1,0^{\circ} \mathrm{C}$ con respecto a los niveles preindustriales. También es probable que el calentamiento global llegue a $1,5^{\circ} \mathrm{C}$ entre 2030 y 2050 si continúa aumentando al ritmo actual. Los riesgos relacionados con el clima dependen de la magnitud y el ritmo del calentamiento, la ubicación geográfica y los niveles de desarrollo y vulnerabilidad, así como de las opciones de adaptación y mitigación que se implementen. Los modelos climáticos prevén un aumento de la temperatura media, aumento de los episodios de calor extremo, aumento de las precipitaciones intensas, además advierten sobre la probabilidad de sequía y de déficits de precipitación en algunas regiones (IPCC 2019). Para mitigar el cambio climático es necesario reducir las emisiones de GEl e implementar medidas de adaptación. En ese sentido, existen estrategias, relacionadas con la conservación del patrimonio cultural y natural, que pueden contribuir con los objetivos propuestos en el Acuerdo de París y en la Agenda 2030 (García Santa Cruz, García Santa Cruz y García 2020; ONU 2015a, 2015b).

El informe El Futuro de Nuestros Pasados: Participación del Patrimonio Cultural en la Acción Climática analiza las intersecciones entre patrimonio cultural, cambio climático y desarrollo sostenible, correlaciona las com- petencias del patrimonio con las prioridades de acción climática, estudia medidas de adaptación y mitigación, analiza pérdidas y daños generados por el cambio climático. El informe concluye que un mejor entendimiento en la forma en que el cambio climático afecta al patrimonio cultural aumentaría la efectividad de las acciones de adaptación necesarias y permitiría generar herramientas de resiliencia para las comunidades (ICOMOS 2019). En diciembre de 2020, durante el quinto aniversario del Acuerdo de París, la 20. ${ }^{a}$ Asamblea General del ICOMOS aprueba la Declaración de Emergencia Climática y Ecológica. La declaración reconoce que el mundo no está cumpliendo los objetivos de París y que ya se están sintiendo los impactos adversos sobre el patrimonio cultural. También reconoce el inmenso potencial del patrimonio cultural para permitir una acción climática inclusiva, transformadora y justa. Pide a la comunidad que trabaje para aprovechar este potencial y salvaguardar el patrimonio de los impactos climáticos adversos, lograr un desarrollo sostenible resiliente al clima y reconocer la equidad y la justicia como dimensiones fundamentales de la acción climática (ICOMOS 2020).

En este contexto, a partir del trabajo colaborativo de ICOMOS Argentina, la Universidad Católica de La Plata, la Iniciativa Patrimonio y Cambio Climático, y la Fundación Ciudad de La Plata, fue posible organizar el curso en línea Cambio climático y evaluación de riesgo para el patrimonio cultural ${ }^{1}$.

Como actividad integradora de este curso virtual, los estudiantes y profesionales debieron realizar la evaluación de los riesgos que pueden afectar el patrimonio de una ciudad determinada. Para este estudio se consideraron los riesgos de origen natural y antrópico (Carrión 


\begin{tabular}{|c|c|c|c|c|c|c|c|c|c|c|c|c|c|c|c|c|}
\hline Origen & Riesgo analizado & C1 & $\mathrm{C} 2$ & C3 & $\mathrm{C} 4$ & C5 & C6 & C7 & $\mathrm{C} 8$ & C9 & C10 & C11 & C12 & C13 & C14 & C15 \\
\hline \multirow{10}{*}{$\begin{array}{l}\overline{\frac{\pi}{2}} \\
\frac{\pi}{2} \\
\frac{\pi}{2}\end{array}$} & Terremotos & 7 & 9 & $\overline{9}$ & 2 & 5 & 0 & 0 & 0 & 1 & 0 & 0 & 2 & 2 & 10 & 10 \\
\hline & Deslizamientos de tierra & 5 & 5 & 9 & 3 & 3 & 0 & 0 & 0 & 1 & 5 & 3 & 1 & 2 & 7 & 5 \\
\hline & Erupciones volcánicas & 6 & 6 & 0 & 0 & 0 & 0 & 0 & 0 & 0 & 0 & 0 & 0 & 0 & 0 & 0 \\
\hline & Maremotos & 4 & 7 & 0 & 5 & 0 & 0 & 0 & 0 & 0 & 0 & 7 & 2 & 0 & 10 & 7 \\
\hline & Huracanes & 10 & 0 & 0 & 8 & 0 & 8 & 8 & 2 & 2 & 0 & 4 & 2 & 0 & 0 & 0 \\
\hline & Inundaciones & 10 & 7 & 7 & 9 & 3 & 7 & 8 & 7 & 4 & 2 & 5 & 6 & 6 & 3 & 8 \\
\hline & Tornados & 5 & 0 & 0 & 6 & 2 & 5 & 0 & 4 & 2 & 3 & 2 & 2 & 4 & 0 & 0 \\
\hline & Nevadas & 0 & 4 & 6 & 7 & 0 & 6 & 0 & 2 & 0 & 9 & 0 & 0 & 2 & 1 & 0 \\
\hline & Lluvias & to & 8 & 8 & 9 & 4 & 8 & 8 & 8 & 3 & 8 & 9 & 5 & 8 & 8 & 5 \\
\hline & Incendios & 8 & 8 & 6 & 6 & 5 & 9 & 0 & 5 & 2 & 6 & 8 & 6 & 0 & 10 & 10 \\
\hline \multirow{10}{*}{$\begin{array}{l}\frac{0}{0} \\
\frac{0}{0} \\
\frac{1}{2} \\
\frac{1}{4}\end{array}$} & Pandemias & 10 & 5 & 8 & 6 & 6 & 7 & 5 & 7 & 8 & $\overline{10}$ & 7 & 5 & 6 & 5 & 5 \\
\hline & Negligencia & 8 & 6 & 7 & 8 & 4 & 7 & 6 & 5 & 7 & 9 & 6 & 8 & 9 & 6 & 9 \\
\hline & Errores técnicos & 8 & 5 & 9 & 8 & 3 & 5 & 4 & 5 & 6 & 9 & 6 & 7 & 7 & 3 & 6 \\
\hline & Falta de mantenimiento & 8 & 6 & 10 & 7 & 3 & 7 & 6 & 7 & 6 & 10 & 5 & 9 & 10 & 6 & 10 \\
\hline & Averias & 8 & 5 & 8 & 7 & 4 & 4 & 4 & 6 & 7 & 5 & 3 & 7 & 7 & 0 & 9 \\
\hline & Bélicos & 2 & 3 & 2 & 6 & 0 & 6 & 0 & 2 & 0 & 0 & 0 & 5 & 6 & 0 & 2 \\
\hline & Sabotajes & 2 & 3 & 8 & 7 & 0 & 6 & 0 & 4 & 3 & 0 & 6 & 6 & 8 & 0 & 0 \\
\hline & Vandalismo & 6 & 6 & 6 & 8 & 4 & 6 & 2 & 8 & 5 & 4 & 2 & 6 & 8 & 0 & 7 \\
\hline & Terrorismo & 4 & 0 & 6 & 9 & 5 & 8 & 0 & 4 & 0 & 0 & 0 & 5 & 0 & 0 & 0 \\
\hline & Psicopáticos & 4 & 0 & 6 & 7 & 2 & 7 & 0 & 6 & 2 & 4 & 3 & 4 & 5 & 0 & $\underline{0}$ \\
\hline \multirow{20}{*}{ 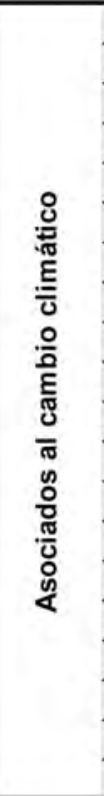 } & Aumento de la temperatura & $\overline{7}$ & 7 & 2 & 10 & 3 & $\overline{8}$ & 8 & 8 & $\overline{8}$ & 5 & $\overline{6}$ & $\overline{7}$ & $\overline{9}$ & 8 & $\overline{5}$ \\
\hline & Cambio en los ciclos de hielo-deshielo & 2 & 6 & 2 & 10 & 0 & 4 & 0 & 0 & 0 & 6 & 6 & 0 & 0 & 1 & 0 \\
\hline & Deshielo del permafrost & 0 & 4 & 2 & 10 & 0 & 0 & 0 & 0 & 0 & 0 & 6 & 0 & 0 & 0 & 0 \\
\hline & Aumento del contenido de vapor de agua en el aire & 7 & 7 & 4 & 10 & 4 & 7 & 6 & 6 & 9 & 6 & 2 & 7 & 6 & 0 & 7 \\
\hline & Aumento del viento & 10 & 6 & 8 & 8 & 2 & 8 & 0 & 6 & 6 & 5 & 8 & 7 & 5 & 0 & 7 \\
\hline & Incendios forestales influenciados por el clima & 4 & 9 & 7 & 0 & 0 & 9 & 0 & 5 & 8 & 0 & 8 & 6 & 0 & 10. & 10 \\
\hline & Cambios en la estacionalidad y la fenología & 6 & 7 & 4 & 7 & 6 & 4 & 0 & 4 & 8 & 5 & 4 & 7 & 9 & 9 & 5 \\
\hline & Propagación de especies invasoras y plagas & 4 & 4 & 4 & 7 & 2 & 9 & 2 & 6 & 4 & 7 & 8 & 6 & 6 & 10 & 7 \\
\hline & Cambios en rango, distribución y poblaciones de especies & 0 & 4 & 4 & 6 & 0 & 4 & 0 & 6 & 2 & 7 & 4 & 6 & 4 & 10 & 7 \\
\hline & Menos precipitación o sequía & 5 & 10 & 4 & 3 & 2 & 8 & 4 & 4 & 5 & 2 & 2 & 7 & 8 & 10 & 6 \\
\hline & Desertificación & 0 & 10 & 4 & 0 & 0 & 0 & 4 & 4 & 2 & 0 & 2 & 0 & 0 & 0 & 7 \\
\hline & Aumento precipitación y eventos de lluvia más intensos & 10 & 8 & 8 & 9 & 3 & 9 & 8 & 8 & 7 & 7 & 8 & 7 & 8 & 0 & 4 \\
\hline & Eventos agudos de inundaciones costeras & 10 & 8 & 0 & 9 & 2 & 8 & 8 & 6 & 4 & 0 & 9 & 4 & 8 & 0 & 6 \\
\hline & Aumento de tormentas (incluidos huracanes y ciclones) & 10 & 2 & 0 & 9 & 0 & 8 & 8 & 8 & 5 & 5 & 6 & 4 & 7 & 0 & 0 \\
\hline & Aumento de la erosión costera & 10 & 2 & 0 & 9 & 0 & 4 & 0 & 6 & 5 & 0 & 7 & 2 & 7 & 0 & 7 \\
\hline & Aumento del nivel freático & 6 & 2 & 6 & 9 & 4 & 7 & 2 & 4 & 5 & 7 & 5 & 4 & 5 & 0 & 6 \\
\hline & Intrusión de agua salada & 6 & 6 & 0 & 9 & 0 & 6 & 0 & 2 & 5 & 0 & 6 & 4 & 0 & 8 & 1 \\
\hline & Acidificación del océano (por aumento de CO2) & 9 & 2 & 0 & 10 & 0 & 7 & 0 & 0 & 7 & 0 & 6 & 6 & 0 & 0 & 6 \\
\hline & Contaminación (factor de estrés secundario) & 8 & 5 & 6 & 9 & 5 & 9 & 2 & 6 & 9 & 5 & 5 & 8 & 10 & 10 & 5 \\
\hline & Desarrollo impulsado por el clima & 8 & 4 & 6 & 2 & 2 & 7 & 0 & 2 & 2 & 3 & 8 & 6 & 6 & 0 & 4 \\
\hline
\end{tabular}

Matriz de riesgos para el patrimonio, estudio realizado sobre quince ciudades | fuente Construcción de la matriz y análisis de datos por M.G. García Santa Cruz, a partir de los estudios de caso analizados por estudiantes y profesionales de la edición 2021 del curso virtual 
Gútiez 2015), además de los riesgos asociados al cambio climático (ICOMOS 2019), que podrían afectar al patrimonio de esa ciudad. Se realizó una investigación sobre los eventos que habían afectado a la ciudad seleccionada como caso de estudio en los últimos cien años. La evaluación de riesgos considera diez riesgos de origen natural, diez riesgos de origen antrópico y veinte riesgos asociados al cambio climático. Luego determinaron la posibilidad de ocurrencia de los riesgos analizados, desde sin existencia (0) o muy baja (1), hasta muy alta (5), y el posible impacto que estos riesgos tendrían para el patrimonio de esa ciudad, desde sin impacto (0) o muy pequeño (1), hasta muy grave (5). Finalmente, considerando la posibilidad de que el riesgo acontezca y el impacto asociado, se determinaron las correspondientes "magnitudes de riesgo", desde sin impacto (0) o baja prioridad (2), hasta catastrófica (10). La "matriz de riesgos" compila los resultados para los siguientes casos de estudio²: Bidgetown (Barbados); Cusco (Perú); Dublín (Irlanda); El Cairo (Egipto); La Lima (Honduras); La Plata y Rosario (Argentina); Lisboa (Portugal); Montrose (Estados Unidos); Niteroi y Río de Janeiro (Brasil); Concepción, Valdivia y Valparaíso (Chile).

Finalmente, considerando la sumatoria de las magnitudes de los riesgos analizados para cada uno de los casos de estudio, se determina el porcentaje de los impactos relacionados a los riesgos de origen natural, riesgos de origen antrópico y riesgos asociados al cambio climático. Este análisis permite indicar que el impacto de los riesgos asociados al cambio climático representa entre el $40 \%$ y el $60 \%$ de los impactos totales, dependiendo del caso de estudio analizado. Considerando los resultados, cabe destacar la importancia de la implementación de estrategias de adaptación y mitigación que permitan reducir los riesgos asociados al cambio climático. En ese sentido, es posible implementar medidas de adaptación y mitigación frente al cambio climático basadas en la protección, restauración y conservación del patrimonio.

El documento El futuro de nuestros pasados propone una serie de estrategias de adaptación del patrimonio a

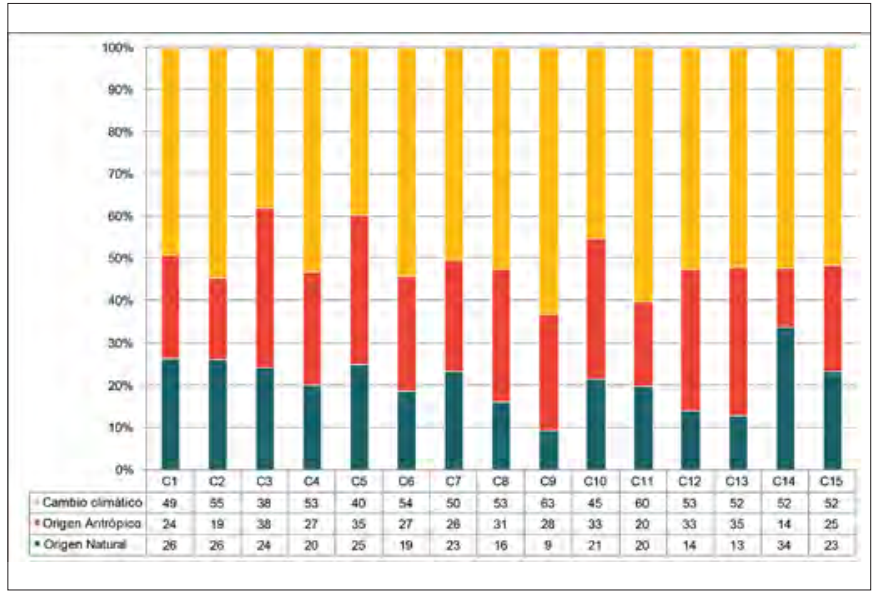

Porcentaje de impactos relacionados a riesgos de origen natural, antrópico y cambio climático | fuente Gráfico y análisis de datos por M.G. García Santa Cruz, a partir de los estudios de caso analizados por estudiantes y profesionales de la edición 2021 del curso virtual

Ios efectos del cambio climático, organizadas en tres grupos: conocimiento y comprensión; planificación e implementación; oportunidades, limitaciones y desafíos. En el primer grupo se encuentran las estrategias basadas en valores y centradas en las personas, recopilación de datos del patrimonio, monitoreo del patrimonio, ejemplos de buenas prácticas. En el segundo grupo se asocian las estrategias vinculadas con la reducción del riesgo de desastres, planificación de la adaptación, adaptación dentro de políticas más amplias. El último grupo lo integran las estrategias relacionadas con la gestión del cambio, oportunidades, incertidumbre, costes y beneficios, sostenibilidad (ICOMOS 2019).

El patrimonio cultural, con sus valores tangibles e intangibles, interactúa directa e indirectamente con el Acuerdo de París (ICOMOS 2019). La descarbonización es clave para mitigar las emisiones de gases de efecto invernadero. Para limitar el calentamiento a $1,5^{\circ} \mathrm{C}$ las emisiones anuales deben ser aproximadamente la mitad de su tasa actual para 2030 y las emisiones netas de gases de efecto invernadero, en promedio, deberán reducirse a cero para 2050 (ONU 2015a). El documento El futuro de nuestros pasados propone también una serie de estrategias de mitigación del cambio climático organizadas en siete grupos: vivir sosteniblemente; mitigación a través 
de medidas centradas en la demanda; mitigación a través de medidas en otros sectores; patrimonio y eliminación de $\mathrm{CO}_{2}$; mitigación a través de medidas centradas en la oferta; turismo cultural; y el patrimonio como motor de la mitigación (ICOMOS 2019).

En el documental Adaptación y Mitigación basadas en el patrimonio 3 (FOPS 2020a, 2020b, 2020c) profesionales de Argentina, Chile, España, Irlanda, México, Nueva Zelanda, Perú, Reino Unido y Estados Unidos reflexionan sobre la emergencia climática global y proponen medidas de adaptación y mitigación frente al cambio climático basadas en el patrimonio.

\section{Agradecimientos}

Agradecemos a las instituciones que organizaron y auspiciaron las tres ediciones del curso Cambio climático y evaluación de riesgo para el patrimonio cultural. A los profesores del curso Guillermo R. García, M. Gabriela Santibañez, Mauro García Santa Cruz, Jimena García Santa Cruz, y profesores invitados Pedro Delheye, Walter Di Santo, Miguel Iwadare, Toshiyuki Kono, Peter Cox, Andrew Potts, Christopher Marrion, Stacy Vallis. A los estudiantes y profesionales que participaron de las tres ediciones del curso, especialmente a quienes realizaron los estudios de caso presentados en este artículo.

\section{NOTAS}

1. El curso contó con el auspicio de Climate Heritage Network (CHN); UNESCO Oficina Regional de Ciencias para América Latina y el Caribe; International Council on Monuments and Sites (ICOMOS); Climate Change and Heritage Working Group (ICOMOS CCHWG); International Committee on Risk Preparedness (ICOMOS ICORP); International Emerging Professionals Working Group (ICOMOS EPWG); Asociación de Directores de Museos de la República Argentina (ADiMRA); Facultad de Arquitectura y Diseño, Universidad Católica de La Plata; Universidad de Congreso; Universidad de Mendoza; Instituto de Investigación en Turismo e Identidad (Universidad de Cuyo). La edición 2019 se realizó de forma presencial en el Museo de Arte Contemporáneo Beato Angélico (Universidad Católica de La Plata), contó con el patrocinio del Fondo Nacional de las Artes y la participación de cincuenta profesionales de la región de La Plata y Buenos Aires, en Argentina. Las ediciones 2020 y 2021 se realizaron de forma virtual y contaron con la participación de profesores de ICOMOS Argentina y profesores invitados de ICOMOS Japón, Irlanda, Estados Unidos, México y Nueva Zelanda. Estas ediciones virtuales contaron en total con la participación de ochenta profesionales que residen en Alemania, Argentina, Australia, Barbados, Bolivia, Brasil, Canadá, Chile, CoIombia, Costa Rica, Estados Unidos, Filipinas, Grecia, Honduras, Inglaterra, Irlanda, México, Perú, Portugal, Suecia y Turquía.

2. Los casos de estudio fueron analizados por Andrea Richards Cummins, Brian Michael Lione, Carmen Fajardo Cardona, Diana Santander Cjuno, Florentina Spiazzi, Francisca Reyes San Martín, Helena Martelo, Javiera Errázuriz, Karin Weil González, Layse Souza Costa, Michelle Tizuka, Petra Strakendal, Rocío Ramírez Zúñiga, Teresa Sweeney Meade y Valentina Maurino.

3. Este documental es resultado de la edición 2020 del curso virtual Cambio climático y evaluación de riesgo para el patrimonio cultural. Se estrenó en noviembre de 2020 en el marco de Culture by Climate 2020, un foro mundial para las artes, la cultura y la acción climática basada en el patrimonio organizado por Climate Heritage Network (http://climateheritage.org/). El documental puede verse en el canal de YouTube del Foro Patrimonio Sustentable (https://www.youtube.com/c/ForoPatrimonioSustentable), el mismo dispone de subtítulos en español, portugués e inglés. Además se puede consultar más información sobre las actividades mencionadas en este artículo en el Blog del Foro Patrimonio Sustentable (https://foropatrimoniosustentable.blogspot.com/) y en las redes sociales: Twitter @pacc_fops (https://twitter. com/pacc_fops), Facebook @pacc.fops (https://www.facebook.com/pacc.fops) e Instagram @pacc.fops (https:// www.instagram.com/pacc.fops/). 


\section{BIBLIOGRAFÍA}

- Carrión Gútiez, A. (coord.) (2015) Plan Nacional de Emergencias y Gestión de Riesgos en Patrimonio Cultural. Madrid: Secretaría General Técnica, Ministerio de Educación, Cultura y Deporte. Disponible en: https://www.libreria. culturaydeporte.gob.es/libro/plan-nacional-de-emergenciasy-gestion-de-riesgos-en-patrimonio-cultural_3255/ [Consulta: 14/07/2021]

- FOPS [Foro Patrimonio Sustentable] (2020a) Adaptación y Mitigación basadas en el patrimonio (Tráiler del documental). Disponible en: https://youtu.be/xTrLEgcdn7c [Consulta: 14/07/2021]

- FOPS [Foro Patrimonio Sustentable] (2020b) Adaptación y Mitigación basadas en el patrimonio. Parte 1: Emergencia climática global. Disponible en: https://youtu.be/DaHbD4KmNU [Consulta: 14/07/2021]

- FOPS [Foro Patrimonio Sustentable] (2020c) Adaptación y Mitigación basadas en el patrimonio. Parte 2: Adaptación y mitigación. Disponible en: https://youtu.be/cEkIUGOzW_o [Consulta: 14/07/2021]

- García Santa Cruz, M.G., García Santa Cruz, M.J. y García, G.R. (2020) A conservação do patrimônio cultural e natural como estratégia de mitigação das mudanças climáticas. Revista Fórum Patrimônio: Ambiente Construído e Patrimônio Sustentável, vol. 11 n. ${ }^{\circ}$ 1. Disponible en: https://periodicos. ufmg.br/index.php/forumpatrimo/article/view/34036 [Consulta: 15/07/2021]

- ICOMOS [Consejo Internacional de Monumentos y Sitios] (2019) The Future of Our Pasts: Engaging Cultural Heritage in Climate Action. Disponible en: https://indd.adobe.com/ view/a9a551e3-3b23-4127-99fd-a7a80d91a29e [Consulta: 15/07/2021]

- ICOMOS [Consejo Internacional de Monumentos y Sitios] (2020) Resolution 20GA/15-Cultural Heritage and the Climate Emergency. Disponible en: https://www.icomos.org/images/ DOCUMENTS/Secretariat/2020/Cultural_Heritage_and_the Climate_Emergency-Resolution_20GA_15_.pdf [Consulta: 15/07/2021]

- IPCC [Grupo Intergubernamental de Expertos sobre el Cambio Climático] (2015) Cambio climático 2014. Informe de síntesis. Disponible en: https://www.ipcc.ch/site/assets/ uploads/2018/02/SYR_AR5_FINAL_full_es.pdf [Consulta: 14/07/2021]

- IPCC [Grupo Intergubernamental de Expertos sobre el Cambio Climático] (2019) Calentamiento global de $1,5{ }^{\circ} \mathrm{C}$. Resumen para responsables de políticas. Disponible en: https://www.ipcc.ch/site/assets/uploads/sites/2/2019/09/IPCCSpecial-Report-1.5-SPM_es.pdf [Consulta: 14/07/2021]

- ONU [Organización de las Naciones Unidas] (2015a)
Acuerdo de París. Disponible en: https://unfccc.int/sites/default/ files/spanish_paris_agreement.pdf [Consulta: 14/07/2021]

- ONU [Organización de las Naciones Unidas] (2015b) Transformar nuestro mundo: la Agenda 2030 para el Desarrollo Sostenible (Resolución aprobada por la Asamblea General el 25 de septiembre de 2015). Disponible en: https://unctad. org/system/files/official-document/ares70d1_es.pdf [Consulta: 14/07/2021] 


\section{$\mathrm{PH} 1044_{\text {debate }}$}

a debate Patrimonio cultural y cambio climático

| coordina Alejandro García Hermida

\section{¿Cómo se puede reducir el impacto del cambio climático en la preservación de edificios patrimoniales?}

Carmen M. a Muñoz González, Jonathan Ruiz Jaramillo | Dpto. de Construcciones Arquitectónicas, Escuela de Arquitectura, Universidad de Málaga

URL de la contribución <www.iaph.es/revistaph/index.php/revistaph/article/view/4989>

Los edificios históricos se diseñaron y construyeron originalmente considerando las condiciones ambientales propias del lugar donde se construían. Esas características climáticas y su respuesta arquitectónica determinan, para un emplazamiento y momento dados, las condiciones interiores inherentes al edificio (Camuffo 1998).

En la actualidad, la preservación de esta arquitectura histórica y, sobre todo, de su contenido artístico, presenta muchas incertidumbres, debido al calentamiento global del planeta. Está confirmado que en los últimos 50 años se ha producido una elevación de la temperatura bastante significativa en todo el mundo por causas principalmente antropogénicas. Este cambio climático genera sucesos meteorológicos extremos que ponen en riesgo la estabilidad higrotérmica de estos espacios (Prieto et ál. 2020).

Los edificios históricos suelen mostrar una amplia oscilación de las medidas de humedad y temperatura, que pueden generar daños en los materiales que constituyen este patrimonio cultural. ¿Cómo actúa la envolvente de los edificios frente a la evolución de estos parámetros generada con el cambio climático? ¿Cómo reaccionan ante estos cambios las obras de arte que contienen? Estas preguntas demuestran que identificar las variaciones de los parámetros ambientales, así como sus complejas interacciones, es esencial para una evaluación global de riesgos y daños tanto de bienes muebles como inmuebles. Por ello, considerar el comportamiento de las obras de arte expuestas a los cambios de diferentes variables climáticas es un aspecto importante a tener en cuenta en el análisis del rendimiento general del edificio, especialmente cuando esta emplea sistemas activos para generar microclimas estables.
Este patrimonio cultural se ha conservado adecuadamente hasta nuestros días aunque, en la última década, ha surgido gran diversidad de investigaciones centradas en analizar su microclima interior (Herráez et ál. 2014). Estos estudios se basan en una monitorización continua de las condiciones ambientales para evaluar el estado de conservación presente y prever la implantación de sistemas de climatización que garanticen la preservación y el confort térmico.

De esta forma, las nuevas líneas de investigación deben dirigirse a anticipar los efectos del cambio climático. Para ello se están generando herramientas de simulación capaces de analizar las condiciones ambientales en un escenario futuro, facilitando una evaluación a largo plazo que permitirá intervenciones de restauración, rehabilitación o conservación del patrimonio más exactas y fiables al anticipar sus consecuencias de manera integral sobre espacios, ocupantes y bienes muebles (Valseca 2020).

Esta información es valiosa además para los gestores y administradores, que pueden diseñar estrategias para un mejor uso del edificio y sus instalaciones, reduciendo el consumo energético y, como consecuencia, las emisiones de carbono.

Estas nuevas tecnologías permiten realizar simulaciones de las condiciones ambientales del edificio tanto en la situación actual como en escenarios climáticos futuros como, por ejemplo, 2050 o 2100. Es posible realizar simulaciones climáticas en diferentes partes del mundo, estimando las posibles alteraciones de la estructura ambiental y estabilidad higrotérmica de los edificios históricos y de sus obras de arte (Muñoz González et ál. 2020). 


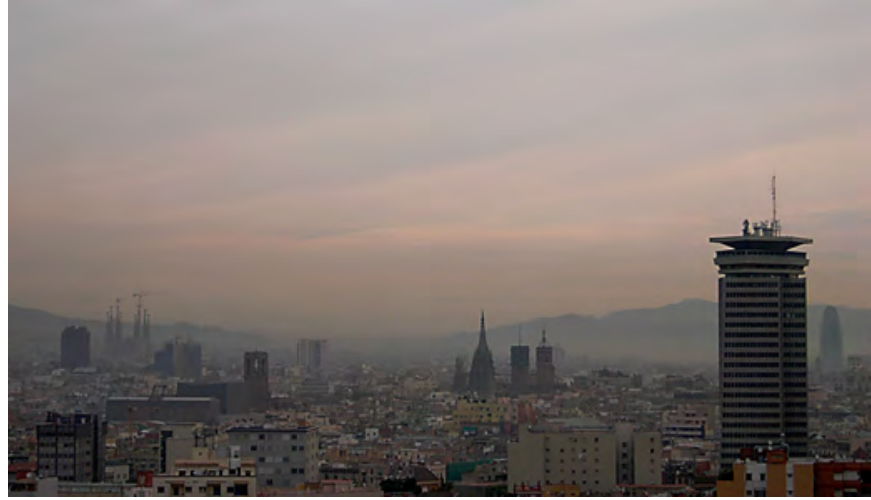

Smog sobre Barcelona | foto Alex R.F.

Los modelos climáticos globales plantean varios escenarios de futuro, pudiendo trabajar con una gran diversidad de variables climáticas que puede incluir lluvias, temperatura, presión, velocidad y dirección del viento o condiciones de cielo nublado. Los citados modelos, combinados con un software de simulación energética de edificios adaptado a espacios históricos, permiten la estimación de los cambios ambientales futuros y su potencial de daño en las obras de arte y en el propio edificio.

Las herramientas de simulación pueden representar el ambiente interior y los mecanismos de transporte higrotérmico en materiales de construcción históricos, teniendo en cuenta también el tipo de uso y los componentes de climatización HVAC (calefacción, ventilación y aire acondicionado). Este enfoque nunca se había realizado antes, ya que los modelos computacionales se utilizan para simular edificios contemporáneos. Hasta la fecha, la aplicabilidad de estos modelos de construcción a edificios históricos estaba siendo limitada, debido a que son construcciones que presentan propiedades y materiales a veces desconocidos.

Frente a la pregunta ¿cómo se puede reducir el impacto del cambio climático en la preservación de edificios patrimoniales?, respondemos que con innovación tecnológica y digital, capaz de anticipar la respuesta y proponer soluciones acordes que mitiguen el cambio climático y sus dramáticas consecuencias.

\section{BIBLIOGRAFÍA}

- Camuffo, D. (1998) Microclimate for cultural heritage. Amsterdam: Elsevier Science

- Herráez, J., Enríquez de Salamanca, G., Pastor, M.J. y Gil, T. (2014) Manual de seguimiento y análisis de condiciones ambientales. Madrid: Ministerio de Educación, Cultura y Deporte

- Muñoz González, C.M., León Rodríguez, A., Suárez Medina, R. y Ruiz Jaramillo, J. (2020) Effects of future climate change on the preservation of artworks, thermal comfort and energy consumption in historic buildings. Applied Energy, vol. 276, 2020, 115483

- Prieto, A., Verichev, J., Silva, A. y de Brito, J. (2020) On the impacts of climate change on the functional deterioration of heritage buildings in South Chile. Building and Environment, 1-15

- Valseca, R. (2020) Los edificios históricosse adaptanal cambio climático. IDESQBRE, ciencia para ti. Fundación descubre, 14 de diciembre de 2020. Disponible en: https://idescubre. fundaciondescubre.es/noticias/los-edificios-historicos-seadaptan-al-cambio-climatico/ [Consulta: 20/07/2021] 


\section{$\mathrm{PH} 104_{\text {debate }}$}

a debate Patrimonio cultural y cambio climático

| coordina Alejandro García Hermida

\section{Seguridad cultural, Venecia y el acqua alta}

Xira Ruiz Campillo | Dpto. de Relaciones Internacionales e Historial Global, Universidad Complutense de Madrid M. ${ }^{a}$ Pilar Montero Vilar | Dpto. de Pintura y Conservación-Restauración, Universidad Complutense de Madrid

URL de la contribución <www.iaph.es/revistaph/index.php/revistaph/article/view/4990>

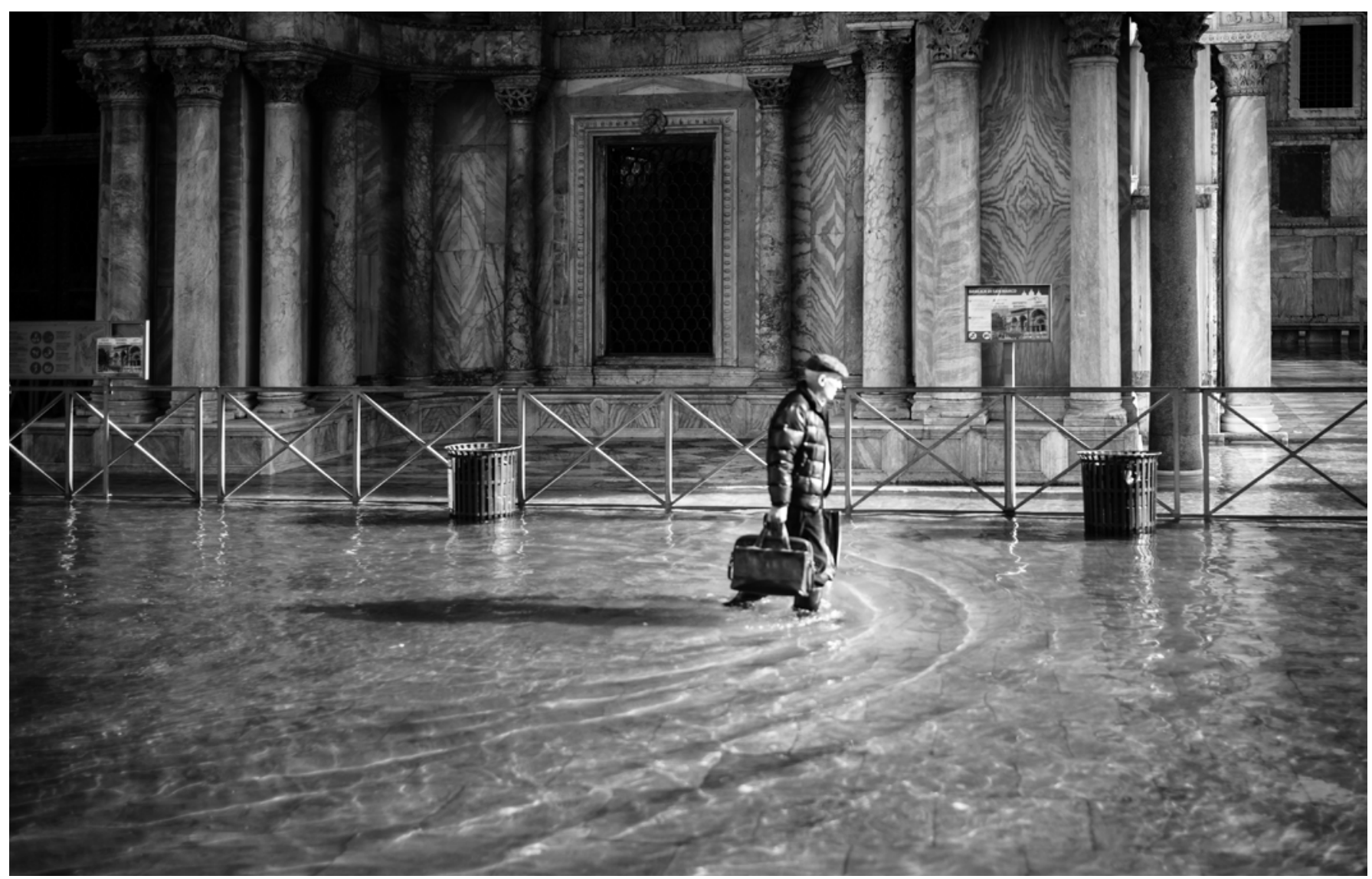

Acqua alta en Venecia, Italia | foto Tobi Gaulke

\section{Introducción}

Desde la adopción de la Convención Marco de las Naciones Unidas sobre el Cambio Climático en 1992, el conocimiento y la acción sobre este desafío global han aumentado en todo el mundo. Resulta de sobra conocido que el cambio climático está producido por la emisión de gases de efecto invernadero (GEI) procedentes de diversas actividades: desde la generación de energía hasta la producción de ropa, pasando por el reciente debate generado en España por el Ministro de Consumo sobre la relación entre la producción de carne y la emisión de GEI (Ligero y Robaina 2021). Somos conscientes de que el cambio climático impacta hasta en el más minúsculo ámbito de nuestras vidas.

Sabemos también las consecuencias de no reducir esas emisiones: el aumento de las temperaturas y su impacto 
en la falta de agua, las sequías o las olas de calor; el deshielo, los fenómenos meteorológicos extremos o la acidificación de los océanos (IPCC 2015; US Global Change Research Program 2014; Delbeke y Vis 2016; Worldwatch Institute 2009).

Sin embargo, menos se ha estudiado la relación entre el cambio climático y la cultura: ¿Hasta qué punto puede el cambio climático condicionar y cambiar nuestra cultura, nuestros valores, nuestro patrimonio histórico? ¿Por qué y cómo podemos perder nuestra seguridad cultural como consecuencia del cambio climático?

\section{Cambio climático y seguridad cultural}

El concepto de seguridad cultural ha recibido distintas definiciones en la literatura académica (Krupocin y Krupocin 2020). Algunos autores lo han relacionado especialmente con el impacto que el vandalismo y el robo, sobre todo en tiempos de guerra, puede ocasionar a la cultura de un país (Nemeth 2015). Para esta pieza de debate, vamos a tratar la seguridad cultural como una parte de la seguridad humana, concepto que se hizo muy conocido a partir de 1994 por su utilización en el Informe de Seguridad Humana del Programa de las Naciones Unidas para el Desarrollo. El concepto de seguridad humana identifica siete dimensiones en la seguridad de las personas: seguridad alimentaria, económica, salud, seguridad política, personal, medioambiental o seguridad dentro de la comunidad (UNDP 1994). Mucho se ha escrito sobre el impacto del cambio climático en cada una de ellas: en la economía (Jahn 2015), en la salud (Knowlton 2015), en la seguridad alimentaria (Crush 2012) o incluso en la seguridad personal, si relacionamos cambio climático y conflictos (Homer-Dixon 1994), pero menos sobre su impacto en la cultura.

La seguridad cultural puede contemplar desde la protección de lenguas o tradiciones y culturas ancestrales, hasta el patrimonio histórico y cultural (Krupocin y Krupocin 2020). Así, la seguridad cultural podríamos identificarla como parte de la dimensión de la seguridad de las comunidades dentro del concepto de seguridad humana. Formar parte de una comunidad nos proporciona una identidad cultural y una serie de valores y estructuras compartidas por el grupo que ofrece protección, sobre todo a los miembros más vulnerables de la sociedad. La subida del nivel del mar, los eventos meteorológicos extremos o las migraciones forzadas por la imposibilidad de continuar con la vida en la comunidad de pertenencia ponen en peligro todos estos aspectos de la seguridad cultural.

En esta pieza de debate, las autoras quieren utilizar el ejemplo de Venecia como un ejemplo vivo del impacto del cambio climático en nuestra seguridad cultural, pero también de cómo las autoridades están actuando para proteger esta ciudad tan valiosa en la cultura occidental.

\section{El acqua alta en Venecia}

La ciudad de Venecia y su laguna son patrimonio mundial de la Unesco desde 1987. La ciudad está construida sobre alrededor de cien islas, casi todas unidas entre sí por más de cuatrocientos puentes.

Su situación geográfica hace que la ciudad esté sujeta a variaciones del nivel del agua producidas por mareas y vientos que provocan que parte de la ciudad pueda verse inundada por el fenómeno conocido como acqua alta, que supone la concurrencia de varios fenómenos que en sí mismos no son generadores de desastre. Sin embargo, la simultaneidad de los mismos unidos a la vulnerabilidad del frágil equilibrio creado en el ecosistema veneciano puede llegar a provocar una pérdida irreparable.

Año tras año, entre otoño e invierno, la ciudad de los canales suele vivir en una constante disputa con el acqua alta, fenómeno que se considera cuando la subida de la marea es superior o igual a $80 \mathrm{~cm}$. Las condiciones meteorológicas que tienen que concurrir para que se produzca acqua alta en Venecia son el viento sirocco en el Adriático, que suele producirse entre octubre y enero, y ciclones extratropicales en el norte de Italia cerca de Los Alpes, que implican bajas presiones. A estas dos condiciones habría que añadirles el fenómeno astronómico de la marea alta, que también puede tener un componente 
a debate Patrimonio cultural y cambio climático

| coordina Alejandro García Hermida

meteorológico debido al estado atmosférico. Todo ello contribuye a la erosión debido a las mareas, al ataque de insectos xilófagos que consiguen alcanzar las maderas de las puertas de edificios históricos (Tagliapietra et al. 2019), o el peligro debido a la humedad que pone en riesgo murales y frescos difíciles o imposibles de trasladar y que por tanto se podrían perder. Además, hay un éxodo masivo de la ciudad, que ha pasado de 175.000 habitantes en 1951 a 51.000 en 2018, con cada vez menos gente joven y con una escasa actividad cultural propuesta centrada en la atracción de turismo y no en la retención de población (Settis 2019), lo que también contribuye a poner en peligro la seguridad cultural de la ciudad.

Desde 1872 hay registros de las veces que la ciudad se ha visto afectada por el acqua alta, observándose en 1966 la altura más alta jamás registrada, llegando el agua a $194 \mathrm{~cm}$. El aumento del nivel del mar, en crecimiento constante en los últimos 150 años (Comune de Venezia 2020), también contribuye a poner en peligro el patrimonio de la ciudad.

La laguna veneciana está altamente monitorizada como lo muestran los estudios realizados por el Instituto Superior de Investigación y Protección del Medio Ambiente (ISPRA), el Centro de Información y Previsión de Mareas del Municipio de Venecia (CPSM) y el Instituto de Ciencias Marinas de Venecia (ISMAR) del Consejo Nacional de Investigación (CNR). Los tres institutos han colaborado durante años en las actividades de vigilancia, análisis y predicción de fenómenos y de medidas del mar en la laguna de Venecia y en el Alto Adriático.

Actualmente se está estudiando cómo el cambio climático está afectando a Venecia, en la medida en que los eventos de acqua alta son más intensos en los últimos años. El año 2019 fue especialmente adverso desde el punto de vista de su frecuencia e intensidad.

El proyecto Mose(Modulo Sperimentale Elettromeccanico) comenzó a construirse en 2003 para evitar las inundaciones en los momentos de marea alta. La obra consta de 78 esclusas móviles de casi 300 toneladas y 60 metros de longitud instaladas en las bocas del puerto de la laguna: Lido norte y Lido sur, Malamocco y Chioggia. Este sistema de compuertas parece ser la única obra capaz de asegurar la protección completa del territorio contra las inundaciones, no interferir en el paisaje y no interferir en las actividades económicas de la ciudad (Ministero delle Infrastrutture e dei Trasport s.f.). El sistema mantiene las puertas de la laguna abiertas durante las mareas bajas de modo que sigue existiendo el movimiento natural del agua con la laguna. Cuando la marea sube más de 1,1 m sobre el nivel del mar, se inyecta aire en las compuertas que expulsa el agua que había en el interior, lo que bloquea la entrada de agua desde el Adriático hacia la laguna. El sistema Mose afirma poder proteger a Venecia y la laguna de mares de hasta tres metros de altura y de un aumento del nivel del mar de hasta $60 \mathrm{~cm}$ en los próximos cien años (Ministero delle Infrastrutture e dei Trasporti s.f.).

\section{Conclusión}

El impacto del cambio climático en la seguridad cultural merece mayor atención desde la literatura académica, dado que es un área aún poco explorada y desarrollada y no son pocas las consecuencias que el cambio climático puede tener en el patrimonio cultural. Aunque existen medidas de adaptación, como el sistema Mose, no están claras ni las consecuencias de este proyecto sobre el ecosistema y la biodiversidad de la laguna veneciana a medio y largo plazo, ni su funcionamiento en condiciones más adversas, ni mucho menos que este sea un sistema exportable a otros lugares con menos recursos o donde la seguridad cultural se vea amenazada por la pérdida de una lengua y costumbres.

\section{Nota}

Este trabajo forma parte del proyecto Observatorio de Emergencias y Gestión de Riesgos en Patrimonio Cultural, financiado por la convocatoria 2020 de Proyectos de Investigación Santander-Universidad Complutense de Madrid. 


\section{BIBLIOGRAFÍA}

- Comune de Venezia (2020) La subsidenza e l'eustatismo. Disponible en: https://www.comune.venezia.it/it/content/lasubsidenza-e-leustatismo [Consulta: 19/07/2021]

- Crush, J. (2012) Linking Migration, Food Security and Development. Queen (Canadá): Southern African Research Centre. Disponible en: https://media.africaportal.org/documents/ linking_migration_food_security.pdf [Consulta: 19/07/2021]

- Delbeke, J. y Vis, P. (2016) EU Climate Policy Explained. sl: European Union. Disponible en: https://ec.europa.eu/ clima/sites/clima/files/eu_climate_policy_explained_en.pdf [Consulta: 19/07/2021]

- Homer-Dixon, T. (1994) Environmental Scarcities and Violent Conflict: Evidence from Cases. International Security, vol. 19, n. ${ }^{\circ}$ 1, pp. 5-40. Disponible en: https://www.jstor.org/ stable/i323306 [Consulta: 19/07/2021]

- IPCC [Grupo Intergubernamental de Expertos sobre el Cambio Climático] (2015) Cambio climático 2014. Informe de síntesis. Disponible en: https://www.ipcc.ch/site/assets/ uploads/2018/02/SYR_AR5_FINAL_full_es.pdf [Consulta: $14 / 07 / 2021]$

- Jahn, M. (2015) Economics of extreme weather events: Terminology and regional impact models. Weather and Climate Extremes, vol. 10, part B, pp. 29-39. Disponible en: https://www. sciencedirect.com/science/article/pii/S2212094715300141 [Consulta: 19/07/2021]

- Knowlton, K. (2015) Ozone, oppressive air masses, and degraded air quality. En: Luber, G. y Lemery, J. (ed.) Global Climate Change and Human Health: from science to practice. San Francisco, CA: Jossey-Bass, a Wiley brand; Washington, DC: APHA Press, an imprint of American Public Health Association, p. 148

- Krupocin, D. y Krupocin, J. (2020) The Impact of Climate Change on Cultural Security. Journal of Strategic Security, vol. vol. 13, n. ${ }^{\circ} 4$, pp 1-28. Disponible en: https://scholarcommons. usf.edu/cgi/viewcontent.cgi ?article $=1847 \&$ context=jss [Consulta: 19/07/2021]

- Ligero, M. y Robaina, E. (2021) Comer menos carne o cuando la política engulle a la ciencia. Climática, 8 julio de 2021. Disponible en: https://www.climatica.lamarea.com/ politica-ciencia-carne-garzon/ [Consulta: 19/07/2021]

- Ministero delle Infrastrutture e dei Trasporti. Provveditorato Interregionale per le Opere Pubbliche del Veneto, Trentino Alto Adige, Friuli Venezia GiuliaMose Venezia (s.f.) Mose. Per la difesa di Venezia e della laguna dalle acque alte. Disponible en: https://www.mosevenezia.eu/ [Consulta: 19/07/2021]

- Nemeth, E. (2015) Cultural Security: Evaluating the Power of Culture in International Affairs. London: Imperial College Press
- Settis, S. (2019) Is it too late to save Venice? Apollo, 2 January 2019. Disponible en: https://www.apollo-magazine. com/is-it-too-late-to-save-venice/ [Consulta: 19/07/2021]

- Tagliapietra, D., Sigovini, M., Keppel, E., Guarneri, I., Parlanti, S., Veronese, N. y Abbate, A. (2019) Bioerosion effects of sea-level rise on the Doge's Palace water doors in Venice (Italy). Facies, 65, n. ${ }^{\circ} 34$, pp. 1-16

- United Nations Development Programme (UNDP) (1994) Human Development Report. New York; Oxford: Oxford University Press. Disponible en: http://hdr.undp.org/sites/ default/files/reports/255/hdr_1994_en_complete_nostats.pdf [Consulta: 19/07/2021]

- US Global Change Research Program (2014) The National Climate Assessment. Disponible en: https://nca2014. globalchange.gov/report [Consulta: 19/07/2021]

- Worldwatch Institute (2009) Climate Change Reference Guide. Disponible en: https://rosap.ntl.bts.gov/view/dot/17278 [Consulta: 19/07/2021] 


\title{
$\mathrm{PH} 104_{\text {debate }}$
}

a debate Patrimonio cultural y cambio climático

| coordina Alejandro García Hermida

\section{Aprender de la arquitectura anónima}

\author{
Olga Muñoz i Frigola | Associació GRETA \\ URL de la contribución <www.iaph.es/revistaph/index.php/revistaph/article/view/4992>
}

El origen de GRETA (Grupo de Recuperación y Estudio de la Tradición Arquitectónica), en el año 2011, se debió sobre todo a la preocupación por el estado del patrimonio más débil y menos protegido, lo que llamamos la arquitectura tradicional, popular o anónima. Fue su continua y paulatina desaparición, tanto por derribos como por intervenciones que la desvirtuaban, lo que nos llevó a estudiar, difundir y aportar todo lo que estuviera en nuestras manos en el intento de frenar tan triste proceso. Desde un inicio nuestra atención se centró en el estudio de las técnicas tradicionales y los materiales utilizados para construir este patrimonio como primera vía para su puesta en valor y conservación. Después de diez años de recorrido, profundizar en la arquitectura tradicional nos ha traído muchos efectos colaterales positivos. Todos ellos conocimientos muy útiles para una mayor sostenibilidad ambiental, sí, pero también para la tan necesaria sostenibilidad económica y social.

La arquitectura tradicional se construía con los recursos del lugar para responder a unas necesidades concretas definidas por un territorio y un clima específicos. Optimizar los recursos disponibles para obtener el máximo confort con el mínimo derroche de energía es exactamente la premisa necesaria para luchar contra el cambio climático. Para disminuir el calentamiento global se requiere reducir la emisión de $\mathrm{CO}_{2}$, y una buena vía para hacerlo es focalizar la inversión en el conocimiento de las personas y en su saber hacer en vez de invertir en el consumo de bienes fruto de largos procesos industriales que requieren buenas dosis de energía no renovable y contaminante, y largas distancias de transporte.

Esta es una de las mayores lecciones que nos da la arquitectura tradicional, pero, desgraciadamente, parte del conocimiento que la ha hecho posible se ha perdido. La trasmisión oral, establecida generación tras gene- ración, se vio interrumpida durante el último siglo, nos pareció que era un conocimiento superado y prescindible. Y aunque actualmente esta percepción ha perdido adeptos, encontrar testimonios para recuperar lo perdido no siempre es posible.

Desde GRETA ${ }^{1}$ entendemos el patrimonio construido como una fuente de información, como material donde extraer conocimiento incorporado cuando no se encuentra la fuente directa. Por este motivo, en los últimos años, estamos inmersos en el trabajo de campo. Nuestro primer territorio de estudio ha sido Les Gavarres, y más recientemente hemos incorporado la Alta Garrotxa y el Cap de Creus. Las tres zonas son áreas naturales protegidas de la provincia de Girona.

Zonas justamente escogidas porque uno de los ámbitos en que la arquitectura tradicional está más desatendida es en los espacios naturales protegidos. Posiblemente su riqueza en biodiversidad tiene que ver con su inaccesibilidad, consecuencia de una orografía muy accidentada. Son territorios que habían estado mucho más poblados de lo que lo están en la actualidad, con un modo de vida estrechamente vinculado a la agricultura y ganadería, que han sufrido en los últimos decenios el éxodo de gran parte de su población, con el correspondiente abandono de hogares.

Desde este año 2021 y hasta el 2023 dedicaremos gran parte de nuestros esfuerzos a analizar la arquitectura anónima de estos tres territorios, gracias al proyecto El patrimonio arquitectónico anónimo de los espacios naturales protegidos, dentro del PECT (programa de proyectos de especialización y competitividad territorial) Girona, patrimonio activo, que cuenta con el apoyo y financiación de la Diputació de Girona, de la Generalitat de Catalunya y de fondos europeos. 
El objetivo es estudiar la arquitectura tradicional de estas tres áreas, cercanas pero muy distintas entre sí. Con recursos disponibles específicos en cada una de ellas, debido tanto al diferente sustrato geológico como a los diversos microclimas, según su relación y posición respecto a los Pirineos y el litoral marítimo.

Para sacar el máximo provecho del conocimiento incorporado en el propio patrimonio y su entorno domesticado, se cuenta con la colaboración de especialistas de todas las disciplinas relacionadas con el territorio, su historia y los oficios propios de la construcción: historiadores, arqueólogos, arquitectos, geólogos; y profesionales y artesanos como restauradores, carpinteros, ceramistas, etc.

El estudio se completará con talleres realizados en obra real, con la restauración de elementos patrimoniales, utilizando las mismas técnicas con las que fueron construidos. La formación continua de técnicos y constructores resulta indispensable para mejorar la calidad día a día, y no se debe menospreciar el efecto divulgativo y de puesta en valor del patrimonio que tienen este tipo de actividades en espacios de uso público. Los mencionados talleres cuentan con profesorado diverso y alumnado plural, los futuros responsables tanto de la concepción como de la ejecución de las obras. Esta experiencia, ampliamente probada desde nuestros primeros cursos en 2014, ha llevado a establecer una red de contactos muy fructífera y estimulante. Porque para poder cambiar la manera de hacer, y aprender cómo se puede construir con materiales y técnicas más saludables y sostenibles, se necesita la complicidad de todos y cada uno de los actores que intervienen en las obras.

Todo este aprendizaje que nos permite el estudio del patrimonio arquitectónico va más allá del propiamente constructivo o de materiales. En el proceso de "reaprender" conocimientos específicos nos damos cuenta que se trata de otra manera de hacer, de otra manera de trabajar y de relacionarse con el contexto. Nos referimos tanto a la relación con el territorio más próximo, ya que el uso de los recursos disponibles cercanos requiere tener

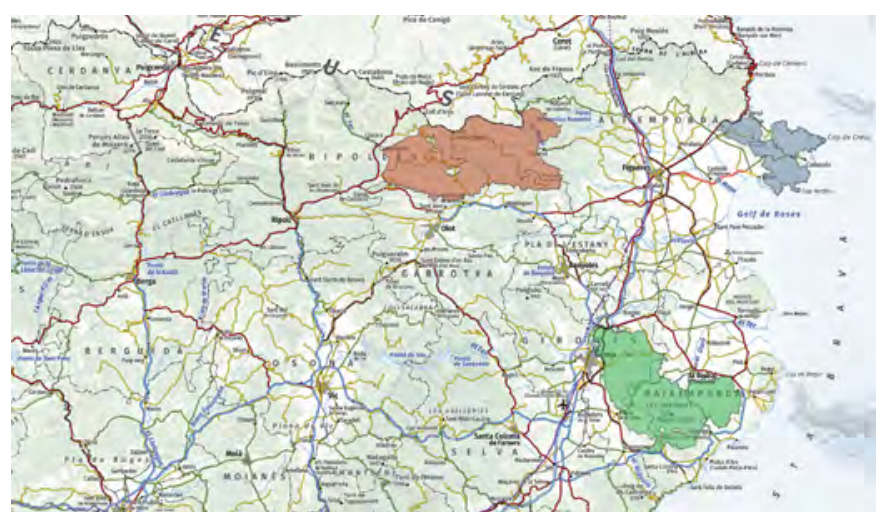

Áreas de estudio del proyecto El patrimonio arquitectónico anónimo en los espacios naturales protegidos, llevado a cabo por GRETA

un buen conocimiento del entorno, como a las relaciones humanas y laborables, que pasan a basarse en la confianza y el saber hacer.

Lo que comenzó inicialmente con la intención de cuidar y respetar el patrimonio arquitectónico y, de esa manera, traspasarlo a las siguientes generaciones manteniendo su espíritu y carácter, finalmente nos ha mostrado el camino de cómo podemos vivir y construir de otra manera. Significa un cambio de valores que afecta a toda nuestra actividad y, por lo tanto, puede tener un efecto exponencial en la lucha contra el cambio climático.

\section{NOTAS}

1. Redes Sociales del proyecto GRETA: https://www. projectegreta.cat/ca/; https://www.facebook.com/projectegreta; https://www.instagram.com/projectegreta/; https://twitter.com/projectegreta 


\title{
$\mathrm{PH} 104_{\text {eebate }}$
}

a debate Patrimonio cultural y cambio climático

| coordina Alejandro García Hermida

\section{Repensar la ciudad. Cuando el cambio climático pone en evidencia la desprotección del patrimonio. Inundaciones urbanas en la ciudad de La Plata}

\author{
Alejandra González Biffis | CONICET/CIUT-FAU-UNLP \\ URL de la contribución <www.iaph.es/revistaph/index.php/revistaph/article/view/4993>
}

La ciudad de La Plata (Argentina) ha sido materializada sobre una planicie continental $-20 \mathrm{~m} \mathrm{s.} \mathrm{n.} \mathrm{m.-,} \mathrm{sur-}$ cada por arroyos que desaguan en el Río de la Plata. El diseño fundacional ignoró el medio físico: los arroyos fueron entubados en su encuentro con el casco fundacional y la expansión urbana no ha sido planificada, con ocupaciones y usos del suelo que no han considerado el patrimonio natural, entubaciones sistemáticas de cauces y la impermeabilización de superficies urbanas absorbentes, y de suelos rurales mediante invernaderos.

El 2 y 3 de abril de 2013, la ciudad sufrió una trágica inundación que dio a conocer a los habitantes las características naturales ocultas. Una precipitación extraordinaria de $313 \mathrm{~mm}$ en 6 horas dejó como saldo 89 pérdidas humanas (informadas oficialmente) y otras incontables del patrimonio material e inmaterial.

Tanto el casco -arroyos entubados- como la periferia -arroyos de libre escurrimiento- fueron afectados. Este tipo de lluvias, que antes parecían excepcionales, comienzan a ser cada vez más recurrentes, y sus consecuencias afectan tanto al patrimonio natural y construido, como al social y económico-productivo de toda la ciudad en su conjunto, centro y periferia.

En este marco, uno de los mayores desafíos a los que se enfrentan las ciudades en la actualidad, considerando el constante aumento de la densidad poblacional, es el de conseguir un desarrollo sostenible ${ }^{1}$. Con esta preocupación, la Agenda $2030^{2}$, en consonancia con el Marco de Sendai para la Reducción del Riesgo de Desastres 2015-2030, ha propuesto dentro de sus 17 objetivos uno destinado a la acción por el cambio climático (objetivo
13), y otro enfocado en obtener ciudades y comunidades sostenibles (objetivo 11).

De este modo, los gobiernos se encuentran trabajando en la implementación de medidas no estructurales ${ }^{3}$ como estrategias de intervención que contribuyan con una gestión integral de riesgos ${ }^{4}$, que intenten revertir los reiterados procesos de décadas de desinterés en la protección del patrimonio, colaboren en la mitigación de la vulnerabilidad ${ }^{5}$ urbana, y en la adaptación de las ciudades a nuevas formas de convivencia pos-COVID prio-

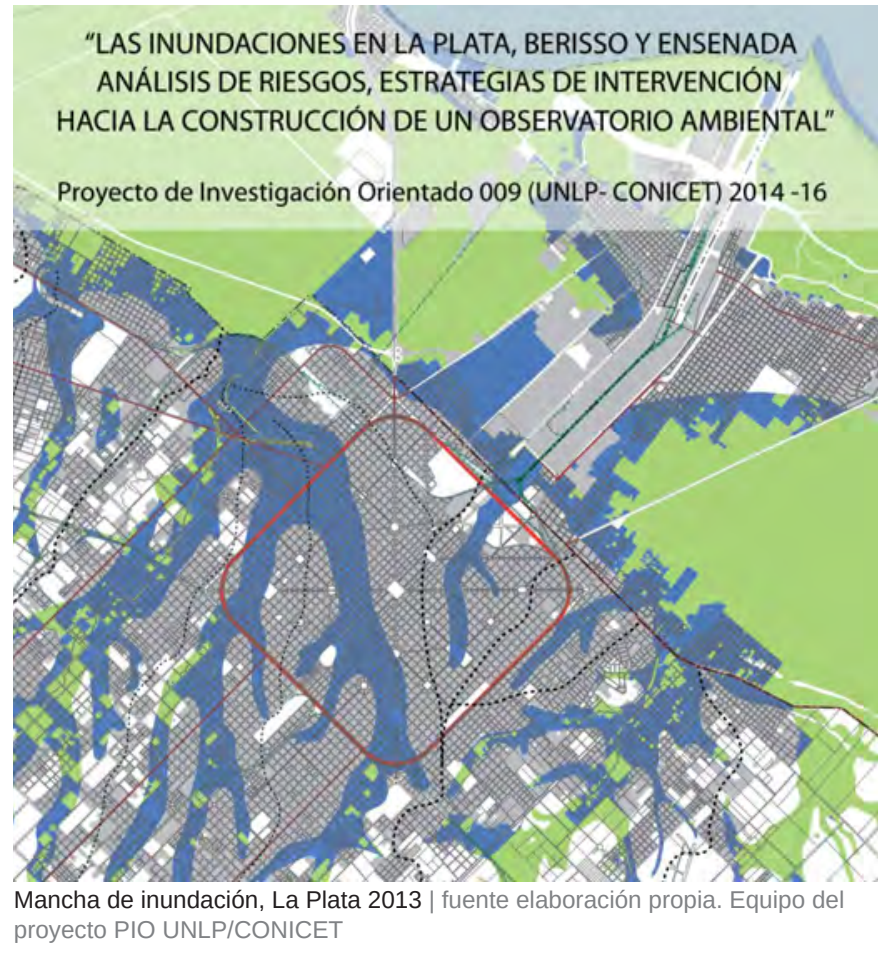




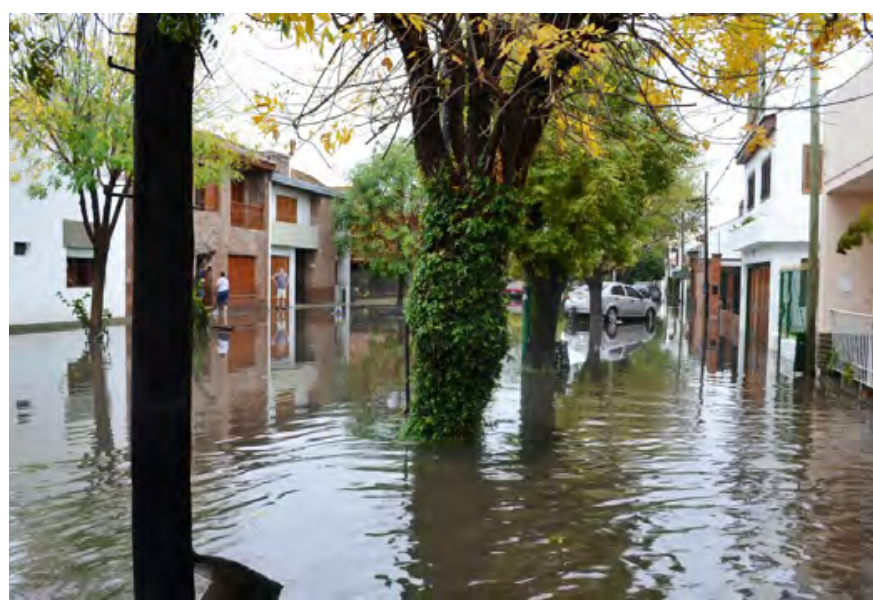

En 2013, la ciudad de La Plata sufrió una trágica inundación

rizando el desarrollo de infraestructuras verde ${ }^{6}$ y azul, como Soluciones Basadas en la Naturaleza (SbN) ${ }^{7}$.

El concepto de "infraestructura verde" toma un marco de desarrollo en la Estrategia de la Unión Europea para la Biodiversidad 2020 (Comisión Europea 2011), y es aprobada como Estrategia de Infraestructura Verde (Comisión Europea 2013). Se fundamenta en que "para que la sociedad aproveche los múltiples beneficios que le brinda la naturaleza, es necesario proteger y potenciar los procesos naturales". Con esta búsqueda, la infraestructura verde emplea sistemas de drenaje, infiltración, techos y terrazas verdes, agricultura urbana, entre otras, y funciona como sistema con la "infraestructura azul", que comprende todos los sistemas de gestión de agua de una ciudad (ríos, arroyos, humedales, suelos y terrazas absorbentes, y jardines de agua de lluvia). En este contexto, se han generado propuestas interesantes como el trabajo en los "huertos urbanos", la idea de proximidad -en los barrios- con "la ciudad en un cuarto de hora", las "supermanzanas", y la "re-naturalización de la ciudad".

Ahora bien, estas estrategias se presentan como atractivas y posibles de aplicar en el espacio público y privado, pero, frente a los requerimientos de una ciudad contemporánea y futura, que aporte a la resiliencia urbana de cara a los fenómenos asociados al cambio climático,

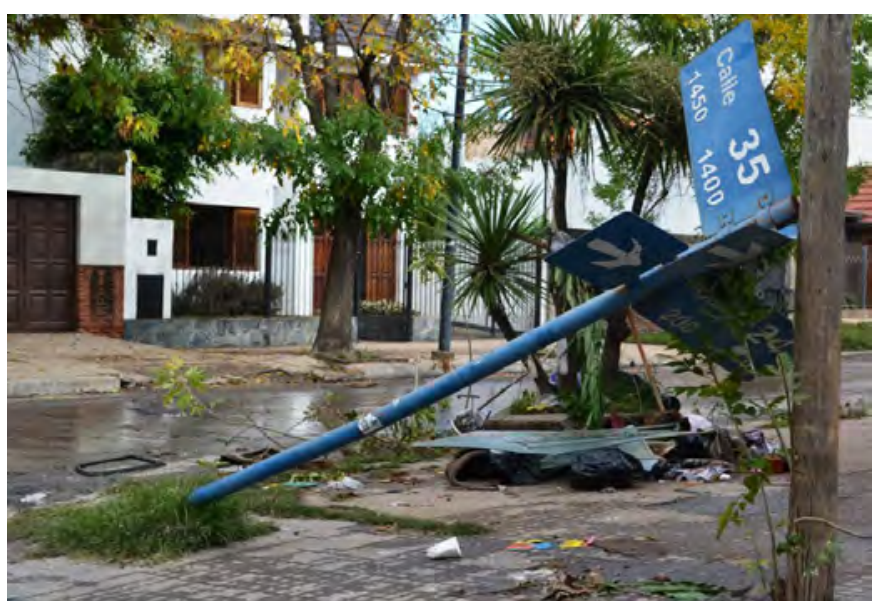

Una precipitación extraordinaria de 313 mm en 6 horas | fotos Aledinamarca

¿lograrán las infraestructuras verde y azul adaptar el patrimonio platense?, ¿será posible enfrentar este desafío y llevarlas a cabo con los escasos recursos con los que cuentan las ciudades latinoamericanas?, ¿cuánto tiempo, en años o décadas, se requiere para comenzar a ver resultados?, y los mismos, medibles cuantitativamente o porcentualmente, ¿en cuánto mitigarían las consecuencias devastadoras de una inundación?... A su vez, ¿en qué medida estas estrategias lograrán mejorar la resiliencia urbana si no se acompañan de medidas de control para evitar la impermeabilización de suelos absorbentes, o de incentivos-beneficios a privados que decidan incorporar estas estrategias?, ¿se conseguirá el cambio cultural necesario para lograr resultados exitosos?

\section{NOTAS}

1. Entendido como aquel que satisface las necesidades del presente sin comprometer las necesidades de las futuras generaciones. Implica un cambio muy importante en cuanto a la idea de sostenibilidad, principalmente ecológica, y a un marco que da también énfasis al contexto económico y social del desarrollo. Este término se utiliza por primera vez en el año 1987, donde se elabora para la ONU el denominado Informe Brundtland o Nuestro futuro común. 
a debate Patrimonio cultural y cambio climático

| coordina Alejandro García Hermida

2. La Agenda 2030 es el documento firmado en el año 2015, en la cumbre de las Naciones Unidas, que presenta un Plan de Acción mundial con miras a alcanzar un desarrollo sostenible.

3. Son aquellas en que los perjuicios ocasionados por las inundaciones son reducidos a través de una mejor convivencia de la población con el medio. Incluyen acciones de tipo social, económico y administrativo. También se las denomina "no obras" para diferenciarlas de las "estructurales", como señala Bertoni (citado en López 2018, 97).

4. Proceso social, impulsado por estructuras institucionales y organizacionales apropiadas, que persigue la permanente y continua reducción y el control de los factores de riesgo de la sociedad, a través de la implementación de políticas, estrategias o instrumentos, o acciones concretas, todo articulado con los procesos de gestión del desarrollo y ambiental sostenibles. Al actuar sobre la vulnerabilidad, se reduce el riesgo, lo que optimiza los efectos ante un posible evento, definición construida en base a bibliografía de diversos autores para los proyectos PIO UNLP-CONICET y UNLP (Herzer y Gurevich 1996; Lavell 1997; Natenzon 1995).

5. Reconociendo a la vulnerabilidad como la propensión de una sociedad de sufrir daño o de ser dañada. Define la capacidad que poseen personas, comunidades o sistemas para anticiparse, enfrentar, resistir y recuperarse de un peligro natural, definición construida en base a bibliografía de diversos autores para los proyectos PIO UNLP-CONICET y UNLP (Herzer y Gurevich 1996, Lavell 1997, Natenzon 1995).

6. Las infraestructuras verdes y azules constituyen herramientas de carácter estratégico para la adaptación y mitigación climáticas. Son medidas de muy diferente tipología y funcionamiento, pero que comparten atributos como la multi-funcionalidad, la generación de variados servicios ecosistémicos, y su elevada capacidad de adaptación a las dinámicas territoriales y socio-ambientales (Magdaleno, Cortés y Martín 2018).
7. Trabajan con la naturaleza, en lugar de hacerlo contra ella (ONU 2018).

8. Definición adoptada del documento de propuesta $L a$ Infraestructura Verde Urbana de Vitoria Gasteiz (Ayuntamiento de Vitoria Gasteiz 2014).

\section{BIBLIOGRAFÍA}

- Ayuntamiento de Vitoria Gasteiz (2014) Infraestructura Verde Urbana de Vitoria Gasteiz. Centro de Estudios Ambientales, Ayuntamiento de Vitoria Gasteiz. Disponible en: https://www. vitoria-gasteiz.org/docs/wb021/contenidosEstaticos/adjuntos/ eu/32/95/53295.pdf [Consulta: 21/07/2021]

- Comisión Europea (2011) Estrategia de la Unión Europea para la Biodiversidad 2020. Disponible en: https://ec.europa. eu/environment/nature/info/pubs/docs/brochures/2020\%20 Biod\%20brochure_es.pdf [Consulta: 21/07/2021]

- Comisión Europea (2013) Infraestructura verde: mejora del capital natural de Europa. Bruselas, 6.5.2013 COM(2013) 249 final. Disponible en: https://eur-lex.europa. eu/resource. $h t m l$ ?uri=cellar:d41348f2-01d5-4abe-b8174c73e6f1b2df.0008.03/DOC_1\&format=PDF [Consulta: 21/07/2021]

- Herzer, H. y Gurevich R. (1996) Construyendo el riesgo ambiental en la ciudad. Desastres y Sociedad, n. ${ }^{\circ}$, pp. 8-15

- Herzer, H. (2011) Construcción del riesgo, desastre y gestión ambiental urbana: perspectivas en debate. Revista Virtual REDESMA, vol. 5, n. ${ }^{\circ}$ 2. Disponible en: https://cebem. org/revistaredesma/vol12/articulo6.php?id=c1 [Consulta: 21/07/2021]

- Lavell, A. (comp.) (1997) Viviendo en riesgo: comunidades vulnerables y prevención de desastres en América Latina. Red de Estudios Sociales en Prevención de Desastres en América Latina-LA RED. Disponible en: https://www.desenredando.org/ public/libros/1994/ver/ver_todo_nov-20-2002.pdf [Consulta: 21/07/2021]

- Lavell, A. (2000) Sobre la Gestión del Riesgo: Apuntes hacia una definición. s.l, s.f. Disponible en: http://cidbimena. desastres.hn/docum/crid/Mayo2004/pdf/spa/doc15036/ doc15036-contenido.pdf [Consulta: 21/07/2021]

- López, I. (2018) Inundaciones por lluvia en el sur de Región Metropolitana de Buenos Aires. Riesgos y estrategias en La Plata, Berisso y Ensenada. Buenos Aires, Argentina: Espacio Editorial

- López I. y Etulain, J.C. (2019) Políticas, paisajes y territorios vulnerables. Tres miradas sobre el Gran La Plata (2006-2017). 
Buenos Aires, Argentina: Diseño

- Magdaleno, F., Cortés F., y Molina, B. (2018) Infraestructuras verdes y azules: estrategias de adaptación y mitigación ante el cambio climático. Ingeniería Civil, n. ${ }^{\circ} 191$, pp. 105-112

- Natenzon, C. (1995) Catástrofes naturales, riesgo e incertidumbre. Buenos Aires: FLACSO (Serie de Documentos e Informes de Investigación, n. ${ }^{\circ}$ 197)

- ONU [Organización de las Naciones Unidas] (1987) Informe de la Comisión Mundial sobre el Medio Ambiente y el Desarrollo. Asamblea General, Naciones Unidas, A/42/427, 4 de agosto de 1987 Disponible en: https://undocs.org/es/A/42/427 [Consulta: 21/07/2021]

- ONU [Organización de las Naciones Unidas] (2017) Nueva Agenda Urbana 2016-2036. Secretaría de Habitat III. Disponible en: http://habitat3.org/wp-content/uploads/NUASpanish.pdf [Consulta: 21/07/2021]

- ONU [Organización de las Naciones Unidas] (2018) Soluciones basadas en la naturaleza para la gestión del agua. Informe Mundial sobre el Desarrollo de los Recursos Hídricos. Disponible en: https://unesdoc.unesco.org/ark:/48223/ pf0000261494 [Consulta: 21/07/2021]

- ONU [Organización de las Naciones Unidas] (2015) Transformar nuestro mundo: la Agenda 2030 para el Desarrollo Sostenible. Asamblea General, 18 de septiembre de 2015. Disponible en: http://www.un.org/ga/search/view doc.asp?symbol=A/70/L.1\&Lang=S. Acceso: 07-04-2017 [Consulta: 21/07/2021]

- ONU [Organización de las Naciones Unidas] (2005) Informe de la Conferencia Mundial sobre la Reducción de los Desastres. Kobe, Hyogo (Japón), 18 a 22 de enero de 2005. Disponible en: https://www.unisdr.org/files/1037_finalreportwcdrspanish1. pdf [Consulta: 21/07/2021] 


\section{Actuaciones prometedoras frente al cambio climático: la patrimonialización del valle del Darro y la rehabilitación de las acequias de "careo" de Sierra Nevada}

Isabel Ordieres Díez | Dpto. de Arquitectura, Universidad de Alcalá de Henares

URL de la contribución <www.iaph.es/revistaph/index.php/revistaph/article/view/4999>

A finales del 2019, poco antes de que se desencadenara la pandemia de la Covid-19, fui invitada por el Patronato de la Alhambra y Generalife a participar en una mesa de debate sobre la influencia de la presión turística y el cambio climático en relación con la conservación y gestión del monumento granadino.

En tan poco tiempo han sucedido vertiginosamente acontecimientos que no dejan dudas del enorme problema al que vamos a tener que enfrentarnos. El fenómeno devastador de la borrasca Filomena, las catastróficas inundaciones centradas, por ahora, en el Levante y sur español, la creciente desertización en amplias zonas de nuestro país, resultan bastante elocuentes.

Ya en 2019 me pareció ineludible tratar el tema del cambio climático y su impacto sobre el patrimonio con una visión lo más holística posible, partiendo del concepto trasversal de paisaje cultural. Hoy creo, con mayor firmeza si cabe, que ese es el camino y así lo consideró de manera pionera el propio Patronato de la Alhambra y Generalife cuando lo introdujo como estrategia de aproximación para la gestión y conservación en su Plan Director 2007-2015. La idea nuclear que conectaba todas las nuevas medidas a adoptar por este Plan era la de considerar a la Alhambra y el Generalife como parte de un todo, de un amplio territorio que sobrepasaba los propios límites establecidos oficialmente en la declaración monumental, un territorio del que dependía de una manera mucho más profunda e insospechada frente a la habitual y más superficial mirada paisajística.

Las interrelaciones de los factores ecológicos y medioambientales se fueron asumiendo gracias a los trabajos y estudios de especialistas desde los más variados campos interdisciplinares. El tema del agua pasó, de esta manera, a cobrar cada vez mayor protagonismo y, por tanto, todo lo relativo a la red hidráulica histórica de la que se surte el recinto de la Alhambra. Su regadío, el agua de sus fuentes y estanques han dependido siempre de la Acequia Real, construida en el siglo XIII, que se surtió del agua proveniente del río Darro, cuyo cauce serpentea por debajo de la colina de la Sabika, donde se enclava la fortaleza de la Alhambra, y la separa del barrio del Albaicín. En 2017 se consiguió la declaración del valle del Darro (en los términos municipales de Beas de Granada, Granada y Huétor Santillán) dentro de la tipología de zona patrimonial.

Gracias a esta nueva metodología de acercamiento, que aceptaba la realidad dinámica de este territorio patrimonializado, se pudo realizar un diagnóstico claro de los problemas que aquejaban a toda la zona.

Las soluciones pasaban por la necesidad de implicar a las administraciones, tanto autonómica como locales, por ser temas de su competencia. Hablamos, por ejemplo, de la gestión de las aguas residuales de ciertos núcleos de poblamiento que están contaminando gravemente el Darro -y con ello todo el agua que llega a la Alhambra- o de cómo revertir la despoblación de las riberas del Darro, antes eficientemente cultivadas, que están provocando, entre otras consecuencias negativas, el abandono del mantenimiento de los barrancos y la colmatación vegetal de dichas riberas y del cauce, algo muy peligroso en caso de crecidas súbitas, especialmente en estas zonas de terreno bastante inestable. Sin embargo, las noticias de la prensa nos indican que 
muchas de estas actuaciones, que deberían haberse hecho de manera urgente, no acaban de acometerse.

En algunas Escuelas de Arquitectura, se están aplicando programas informáticos de simulación de riesgos, como, por ejemplo, en la Universidad Roma Tre, que estudian posibles desbordamientos del río Tíber a su paso por la ciudad con el fin de intentar calibrar futuros planes de prevención. Esta es una de las herramientas de análisis, como otras muchas impensables hace décadas, que tenemos que poner ya en marcha. La crisis que se inició en el 2008 no ha ayudado a la financiación de este tipo de actuaciones, pero, lo que está por venir, nos obliga a ello.

En estrecha relación con la gestión de los recursos hídricos y la creciente desertización -la otra cara del mismo fenómeno provocado por el cambio climático-, se ha puesto en marcha una iniciativa, en mi opinión ejemplar y muy esperanzadora por lo que implica de cambio de actitud, de recuperación de acequias. Me refiero en concreto al proyecto MEMOlab, coordinado desde la Universidad de Granada y financiado con fondos europeos, de recuperación del sistema de riego por "acequias de careo" en la zona de Sierra Nevada, que se encontraban en trance de desaparecer por abandono o degradación de su mantenimiento. Este sistema acequiero, desarrollado en zonas de alta montaña, se ideó para recoger el agua de las lluvias y el deshielo con el fin de infiltrarla en el suelo a la espera de liberarla y recargar los acuíferos en los momentos de mayor necesidad. Gusta definirse como "siembra" de agua, y demostraría un conocimiento empírico admirable del comportamiento geológico de esa zona. Su uso está considerado uno de los más antiguos de Europa, pues se remontaría a la etapa romano-visigoda aunque tuvo su mayor perfeccionamiento con los árabes.

Iniciativas tan magníficas son indicios de que estos saberes anónimos colectivos, hoy considerados patrimoniales, podrían convertirse en referentes en la lucha contra los efectos provocados por el cambio climático. Generar en un público cada vez mayor, especialmente infantil y juvenil, el interés por todo ello, es fundamen-

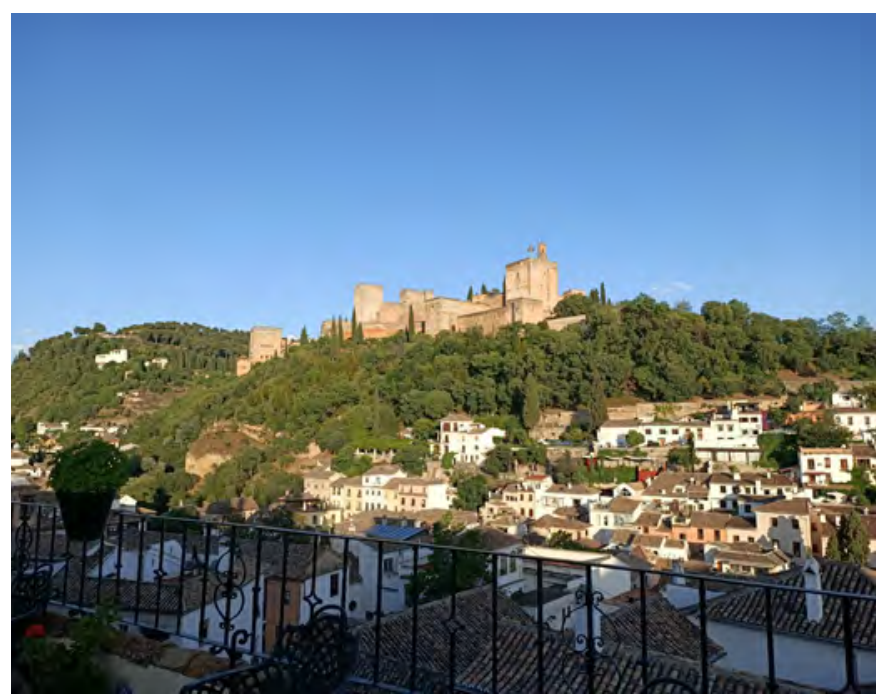

Colina de la Sabika, donde se enclava la fortaleza de la Alhambra (Granada) | foto Isabel Ordieres Díez

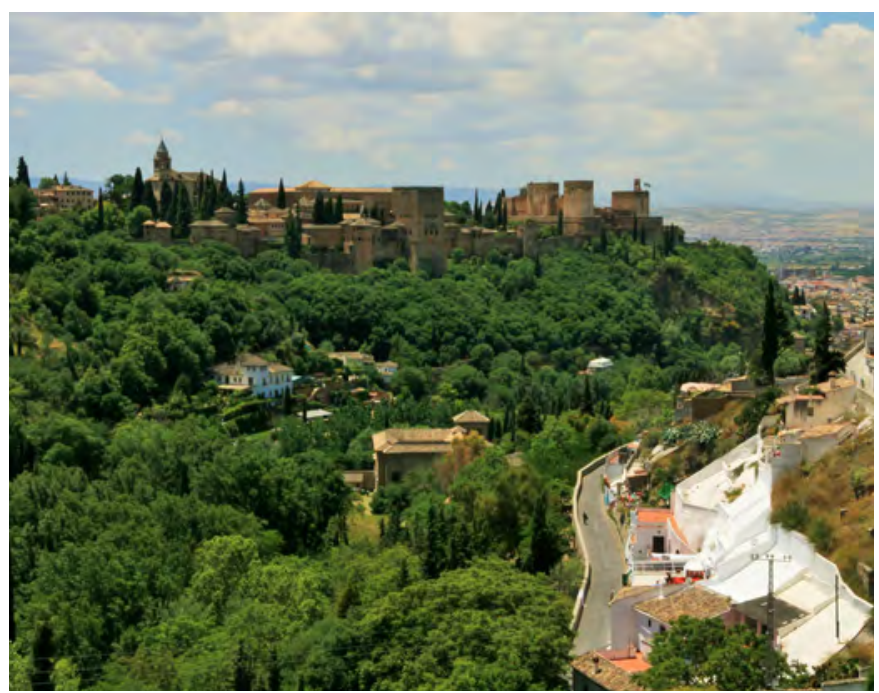

Valle del Darro | foto Øyvind Holmstad

tal. En este sentido, podría también ser muy prometedor para la formación de futuros profesionales, la creación del Centro de Paisaje y Jardinería, contemplado en el Plan Director de la Alhambra y Generalife, que actuaría como catalizador para la recuperación de esta herencia cultural tan necesaria en la toma de consciencia del impacto del hombre sobre el territorio y de su posicionamiento ante el cambio climático. 


\title{
$\mathrm{PH} 104_{\text {debate }}$
}

a debate Patrimonio cultural y cambio climático

| coordina Alejandro García Hermida

\section{Arquitectura de gran escala y sostenibilidad}

\author{
Julián García Muñoz | Dpto. Construcciones Arquitectónicas y su control, Universidad Politécnica de Madrid
}

URL de la contribución <www.iaph.es/revistaph/index.php/revistaph/article/view/4995>

\begin{abstract}
El patrimonio cultural contra el cambio climático
Con frecuencia se publican iniciativas que pretenden recuperar técnicas tradicionales de bajo impacto ambiental para sustituir modernos sistemas que requieren de más energía. El argumento de fondo es que el patrimonio cultural puede convertirse en una herramienta útil para la lucha contra el cambio climático. Estas propuestas, normalmente bienintencionadas, no siempre tienen en cuenta la escala del problema actual. En lo relativo a la construcción arquitectónica, por ejemplo, se estima que en los próximos sesenta años se construirán en el mundo unos 2.000 millones de viviendas. Es un ritmo vertiginoso, equivalente a levantar cada mes una nueva gran ciudad del tamaño de Nueva York.
\end{abstract}

Gran parte de esta obra nueva no se levantará ni en Europa ni en América. Asia es el centro del impulso constructor actual. Unos 4.600 millones de personas habitan el continente, más de el $60 \%$ de la población mundial. Solamente en China se construyen hoy unos 7 millones de viviendas anuales, a las que hay que sumar un cre-

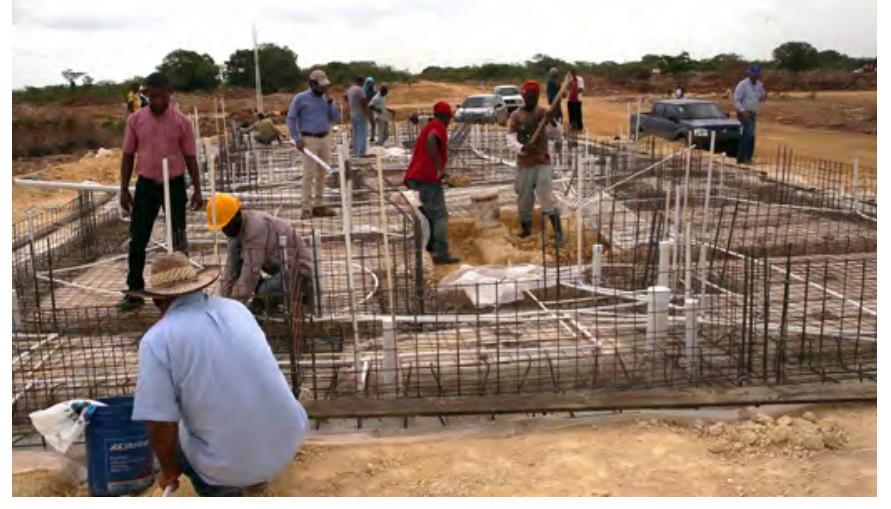

Inicio de la construcción de viviendas modelo en Ciudad Juan Bosch (República Dominicana) en 2015. El proyecto, iniciado en 2017, pretendía la construcción de 10.000 viviendas. Hoy aun no se ha concluido | foto Luis Burdies ciente número de edificios de oficinas y construcciones industriales.

El patrimonio cultural puede ser útil para luchar contra el cambio climático, pero es necesario que las propuestas de recuperación de técnicas tradicionales asuman la escala de este problema, y que se enfoquen allí dónde pueden ser útiles de forma global. Es decir: debemos pensarlas -al contrario de cómo se ha hecho hasta ahora- no tanto deseando reverdecer una tradición concreta, sino adelantándose a una determinada intervención de suficiente escala, en un lugar específico (una de estas grandes promociones de nuevos edificios, por seguir con el ejemplo previo) para integrar en ella técnicas tradicionales concretas que puedan reducir su impacto.

\section{El cambio climático contra el patrimonio cultural}

También son acuciantes los problemas que el cambio climático puede conllevar para el patrimonio cultural. Antes de considerar las afecciones que un cambio en el clima pueda conllevar para el patrimonio cultural, habría que dejar claro que éste es una especie de enfermo crónico con una extraña salud de hierro, siempre difícil estimar. En el momento actual observamos cómo, por un lado, la globalización está acabando con tradiciones centenarias; por otro, sucede que aquello que consideramos patrimonio es un terreno cada vez más amplio, y más cercano a nuestra contemporaneidad. Probablemente nos encontremos en un momento de crecimiento, en términos cuantitativos; pero de mengua o reducción, en términos de diversidad.

En todo caso, y sea por la dificultad de preservar determinadas manifestaciones del patrimonio cultural, o por el incremento cuantitativo de lo que consideramos patrimonio, lo cierto es que nuestra capacidad para preser- 
varlo no alcanza, hoy, a nuestra voluntad de hacerlo. No somos capaces de acomodar voluntad y capacidad en lo que se refiere al cuidado del patrimonio cultural. Con demasiada frecuencia deseamos proteger una determinada obra, o una tradición concreta, pero no tenemos capacidad para hacerlo.

Los cambios que se acercan, y en particular el cambio climático, debilitarán al enfermo, por vía de ensanchar aún más esa brecha entre voluntad y capacidad. Un entorno estable facilita la preservación del patrimonio; uno cambiante la dificulta. Los cambios en el clima supondrán la mayor alteración de nuestro entorno que hayamos conocido. Los extremos de la brecha voluntad-capacidad se alejarán: nuestra voluntad de conservar crecerá para intentar paliar las pérdidas impuestas por el nuevo clima; nuestra capacidad, que seguramente se verá requerida para todo tipo de menesteres que consideraremos más urgentes -casi siempre sin serlo-, difícilmente podrá adaptarse a ese crecimiento.

\section{Un mejor modelo de gestión patrimonial}

Parece evidente que lo que nos ha traído hasta aquí es cierto ensimismamiento local, seguramente originado por el instinto -casi de supervivencia- de atender a lo cercano, y no al largo plazo. De esto se sigue, por supuesto, que no tengamos conciencia de nuestra condición, como especie, de fenómeno global. Debemos dejar atrás este ensimismamiento, y para ello son necesarias mejores reglas; mejores modelos de gestión.

Necesitamos modelos de gestión patrimonial que se adelanten a estos problemas en la relación bidireccional entre patrimonio cultural y cambio climático. Modelos que no solo tengan en cuenta el cambio climático de un modo general, sino que permitan tanto el reciclaje de la tradición para su empleo en condiciones óptimas, allí donde sea posible, como una adecuada preservación del patrimonio allí donde los cambios en el clima puedan dañarlo. Por continuar discutiendo el problema en los términos voluntad-capacidad expresados antes $-\mathrm{y}$ es obvio que necesitamos de ambos-: un buen modelo de gestión patrimonial no debe limitarse a una simple catalogación, sino que debe ajustar esta a los cambios que se prevean, climáticos o no; y garantizar la provisión de los medios necesarios para cumplir con suficiencia las necesarias tareas de preservación, fomentando, a la vez, el empleo razonado del catálogo que ofrece la tradición allí donde pueda ser de utilidad.

\section{BIBLIOGRAFÍA}

- Bauer, M., Mösle., P. y Schwarż, M. (2009) Green Building: Guidebook for Sustainable Architecture. Heidelberg; New York: Springer Science \& Business Media

- PNUD [Programa de las Naciones Unidas para el Desarrollo] (2007) Informe sobre Desarrollo Humano 2007-2008. La lucha contra el cambio climático: Solidaridad frente a un mundo dividido. Madrid: Mundi-Prensa. Disponible en: http://hdr.undp. org/sites/default/files/hdr_20072008_sp_complete_nostats.pdf [Consulta: 23/07/2021]

- Sadek, R. (1999) Assessment of Terrestrial Ecosystems to Impacts of Climate Change. En: Lebanon's Initial National Communication on Climate Change. Líbano: Ministerio del Medio Ambiente, UNDP, GEF, B4, pp. 9-38 


\title{
$\mathrm{PH} 104_{\text {debate }}$
}

\section{Bajo la arena. Cambio climático y el pasado invisible del Uruguay. ¿Hablamos de patrimonio?}

\author{
Laura Brum Bulanti | Centro Universitario Regional del Este (CURE), Universidad de la República
}

URL de la contribución <www.iaph.es/revistaph/index.php/revistaph/article/view/4996>

El Uruguay desde hace poco más de una década viene incorporando el cambio climático en su agenda política, primero con la creación de un Sistema Nacional de Respuesta al Cambio Climático y la definición de un Plan Nacional aprobado en el año $2010^{1}$. Con una economía basada en la producción primaria (agrícola ganadera) y en el sector terciario (principalmente el turismo y servicios asociados, que se desarrollan a lo largo de su litoral marino y fluvial), los ejes principales para el desarrollo de una Política Nacional de Cambio Climático ${ }^{2}$ se centraron en el análisis de las vulnerabilidades en los sectores productivos y ecosistemas, energía, costa y hábitat urbano, salud, industria y servicios.

En base a ello definieron acciones estratégicas de adaptación y mitigación, que se integran en Planes Nacionales de Adaptación (agrícola, costera, en ciudades e infraestructuras y una estrategia de reducción de emisiones) en diverso grado de elaboración ${ }^{3}$. De la revisión de los informes técnicos, talleres y otros productos generados en esta década de trabajo institucional y gubernamental en torno al cambio climático sorprende la ausencia absoluta de las dimensiones culturales, y un análisis de los efectos del cambio climático en la cultura y en los derechos culturales de las poblaciones ${ }^{4}$. En particular, el Ministerio de Educación y Cultura, donde se encuentra la autoridad nacional competente en la gestión del patrimonio cultural (Comisión del Patrimonio Cultural de la Nación), es omitido de los ámbitos de discusión, diseño y aplicación de las políticas e instrumentos previstos. Los aspectos culturales recogidos en los informes y documentos se remiten a la necesidad de un cambio cultural, para lo cual se entiende necesario incrementar "el conocimiento de los asuntos relativos al cambio climático y difundirlo ampliamente, para entre otros, generar en la población una mayor conciencia y sensibilización"5, mejorando el compromiso de la población con las medidas de mitigación y adaptación propuestas.

Si bien el país avanzó y mucho en robustecer una agenda de derechos ciudadanos durante los gobiernos progresistas (entre 2005 y 2020), con la ratificación de diversas convenciones internacionales y leyes que consagraron derechos culturales de la ciudadanía, así como políticas de fomento al desarrollo cultural (Berger y Sequeira 2018), la gestión del patrimonio cultural permanece desactualizada ${ }^{6}$, con intentos fallidos de renovar el marco jurídico vigente (MEC 2014), con serias dificultades para articular y coordinar interinstitucionalmente esta actividad con la planificación ambiental y territorial (Gianotti et ál. 2019; Brum et ál. 2020; Villarmarzo Andreatta 2021) así como con otras políticas sociales.

Sabemos de las consecuencias del cambio climático en el patrimonio cultural, con pérdidas materiales, tanto en bienes culturales diversos (Sabbioni et ál. 2006; Erlandson 2012; Sesana et ál. 2019), como económicas (Hall et ál. 2015; Alexandrakis, Manasakis y Kampanis 2019) en aquellas actividades generadas en torno a estos bienes. La vasta literatura refiere a los diversos factores vinculados a la emergencia climática como sequías, inundaciones, eventos extremos, acidificación, entre otros, que impactan en la conservación e integridad de estos bienes, testimoniados en diferentes regiones del mundo. Estos impactos afectan, entre otros, al derecho al conocimiento y acceso a diversas culturas y a su historia, y comprometen su legado a generaciones futuras.

En lo que respecta al caso uruguayo, pondremos como ejemplo un caso vinculado a nuestro campo de estudio en la zona costera de la región este del país (Municipio 


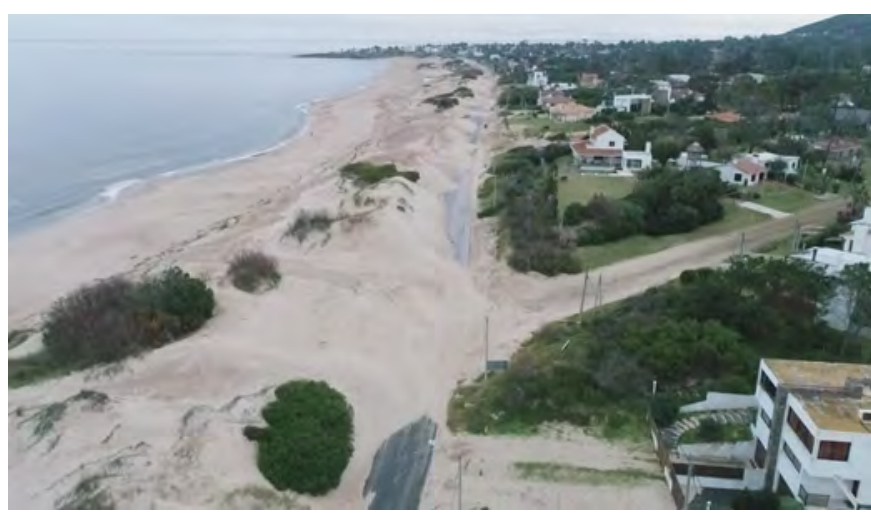

Voladura de arena sobre la rambla. Balneario San Francisco, año 2019 | foto Intendencia de Maldonado

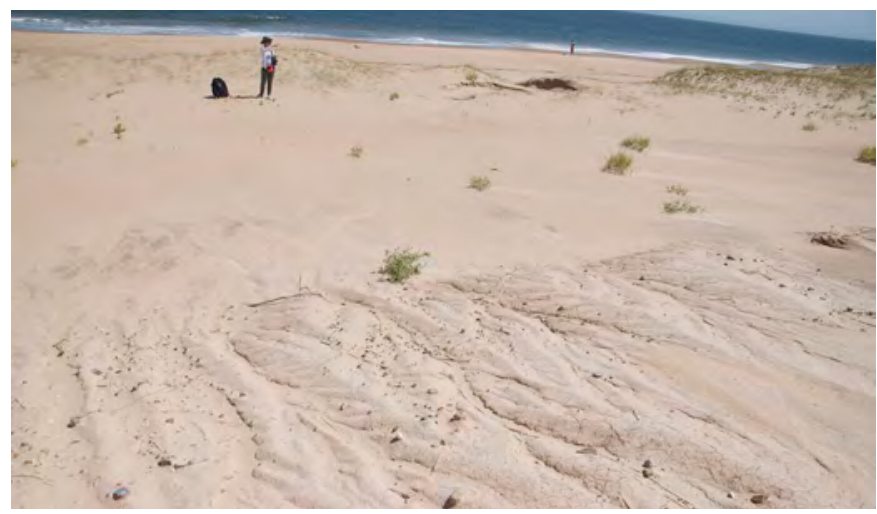

Paleosuperficie expuesta por erosión de dunas frontales de playa. Se observa el material lítico en superficie y marcas de escorrentía. Balneario Punta Colorada, año 2018 | foto Proyecto ARCOS

de Piriápolis, Maldonado) donde en el contexto de procesos de erosión costera vinculados a una intensa antropización del litoral por la actividad turístico-residencial, y frente a la incidencia de eventos climáticos extremos, emergen bajo las dunas grandes áreas arqueológicas y paleosuperficies, con restos culturales de grupos de cazadores recolectores del Holoceno. Áreas cuyo registro arqueológico queda expuesto al expolio, meteorización, erosión, entre otras amenazas.

Esto sucede además en playas de alto valor turístico, en medio de zonas urbanas, con una multiplicidad de actores y usuarios interesados en ese recurso playa (sociedad civil organizada, empresariado, gobierno local y

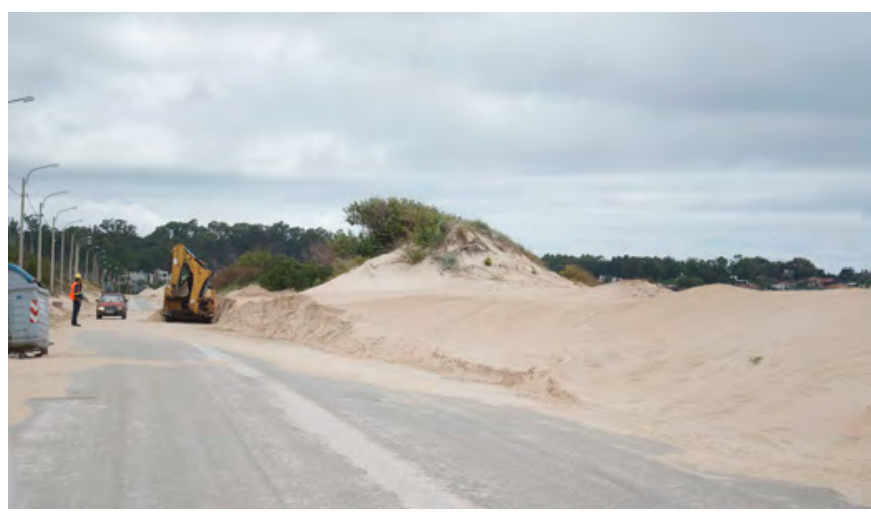

Retiro de arena con maquinaria pesada en rambla, año 2019 | fuente Proyecto ARCOS, oeste departamento Maldonado

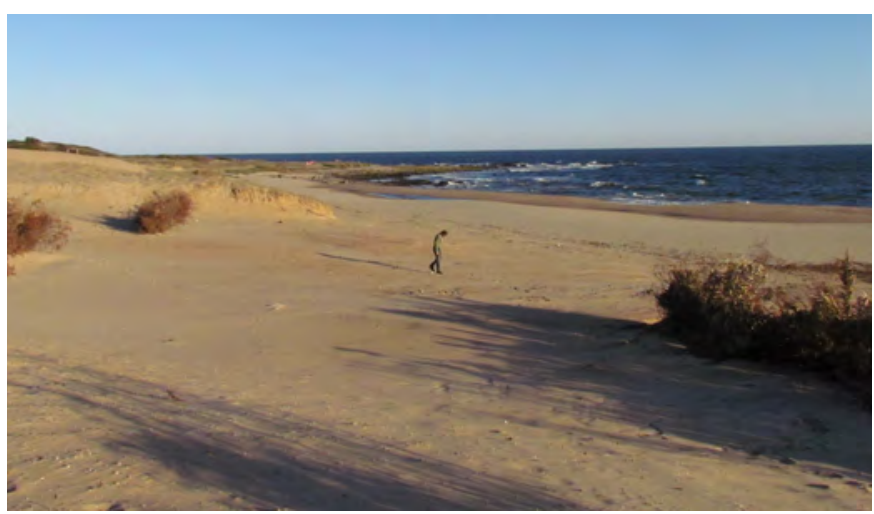

El mismo sector de playa, tras la colocación de cercas captoras por parte del gobierno departamental. Esta intervención no contó con una evaluación de impacto arqueológico, año 2019 | foto Proyecto ARCOS

nacional, académicos, entre otros). Playas que se han convertido en una zona de conflicto, donde los análisis de los problemas ambientales y las soluciones no son convergentes entre los diferentes actores y niveles de gobierno, y donde han primado intervenciones estéticas, que continúan el modelo de endurecimiento de la costa, y acciones de mitigación a muy corto plazo, destruyendo deliberadamente parte del registro arqueológico, ante una normativa e institucionalidad difusa.

En este contexto, somos conscientes de que, si hay un patrimonio valorado en este proceso, es la playa: como paisaje, como "bien común", como hábitat de especies singulares, como ámbito de esparcimiento, recreación, 
a debate Patrimonio cultural y cambio climático

| coordina Alejandro García Hermida

espiritualidad, pero no por los vestigios de culturas prehispánicas. La pérdida de estos contextos arqueológicos únicos y cada vez más endémicos en nuestra costa crecientemente antropizada se da en un marco donde la preocupación, a nivel de la opinión pública y de las autoridades locales, es la pérdida del ecosistema playa y su valor económico turístico, y no la de sus componentes o dimensiones histórico culturales. Si a ello sumamos las dificultades ya referidas de una gestión decimonónica del patrimonio cultural a nivel nacional y local; con un estatus casi ornamental del patrimonio, como símbolo estático de hitos (oficiales y políticos) destacados de una historia deliberadamente corta y modernizadora posconquista; con una mirada estática que lo extrae de su condición procesual de construcción social, multidimensional, conflictiva, y potencial como activador de desarrollo social, económico, entre otros; ¿cómo pensar en políticas y acciones que mitiguen las pérdidas ya constatables de una parte importante de la historia profunda del país?

El contexto político institucional no es favorable, ya vimos. Pero hay una preocupación creciente a lo largo de toda la costa uruguaya en las comunidades ante la constatación de la pérdida de calidad y de integridad de los ambientes costeros y sus paisajes. Hoy hablar de la gestión del patrimonio cultural y cambio climático no está en la agenda política, pero sí emerge en la agenda pública cuando suceden problemas asociados al cambio climático en diversos puntos de la costa, coincidiendo con zonas de proyectos de investigación ${ }^{7}$ y con equipos académicos trabajando en el territorio y con las comunidades. En esos contextos, es posible establecer diálogos situados, intercambiar con diversos actores en el análisis de los problemas vinculados a los impactos del cambio climático, aportando una mirada histórico-cultural del problema, desde la historia de ambientes que han tenido una larga evolución e interacciones con sociedades humanas a lo largo de mucho tiempo. Y desde allí dimensionar las pérdidas asociadas al cambio climático, discutir la necesidad de transformación en los modelos de desarrollo y gestión para mitigar integralmente sus efectos y adaptarse a los mismos.
Estos esfuerzos locales seguro no son suficientes, hay un trabajo de más largo aliento que requiere de un giro ontológico y decolonial en nuestra sociedad. $Y$ eso implica, entre otros, comenzar a asumirnos como un país con indios, en el pasado y en el presente (Verdesio 2005, 2014).

Las bases de la identidad nacional se han cimentado en una construcción sostenida en los principios de la modernidad, de una sociedad producto de la inmigración europea, que superó la "barbarie" y el "salvajismo" propios de las épocas de la independencia con el exterminio de la población indígena (esencializada en lo charrúa). Este proceso de alguna forma reseteó nuestro reloj histórico, dejándonos sin historia profunda (o prehistoria) digna de ser narrada.

Este imaginario, difundido y reproducido socialmente por las más diversas vías, desde la educación formal hasta las artes, está presente en las más variadas dimensiones de nuestra vida social e institucional. $Y$ eso se traduce en las políticas públicas que no reconocen la multiculturalidad de nuestro país, ni el legado de pueblos originarios: el Uruguay se construye, proyecta y piensa sin esa memoria, desde una sociedad pretendidamente homogénea, cohesionada, en una tierra limpia de conflictos étnicos y reclamos territoriales. Esta imagen que acompañó todo el proceso modernizatorio del país a lo largo del siglo XX se refuerza en el nuevo siglo con la marca país: Uruguay Natural, donde reemerge el mito de un territorio cuasi virgen, equilibrado, en armonía y estabilidad social e institucional, una postal que reproduce una visión cornocupiana de "la tierra de oportunidades" de las diferentes fases o prefijos del colonialismo. Ese Uruguay Natural es contestado, por movimientos sociales que reclaman derechos como pueblos originarios (Rodríguez y Michelena 2018), por movimientos sociales en reclamo por bienes naturales hoy comprometidos en el contexto del cambio climático, como el agua (Santos et ál. 2013), y en definitiva, por un país que comienza a mostrar señales de crisis de modelos económicos (agroproductivo exportador, turístico-residencial) con impactos en la calidad de los ambientes que sostienen dichas 
actividades y consecuencias en diversas actividades humanas asociadas a estos. La cultura prehistórica, ese patrimonio invisible, del que poco hablamos, es una oportunidad de re-pensarnos desde el pasado, de complejizar el cambio climático en su escala temporal y en su dimensión cultural, y de indagar en sus profundas consecuencias. Nos brinda la posibilidad de situar la pérdida no solo en tiempo futuro, sino en pasado: exponiendo la potencia de una historia inédita que se desvanece y que creemos merece ser contada para integrarse en el proceso de construcción de una sociedad más justa, sustentable y solidaria intra e intergeneracionalmente.

\section{NOTAS}

1. Sistema Nacional de Respuesta al Cambio Climático y Variablidad. 2010. Plan Nacional de Respuesta al Cambio Climático. Diagnóstico y lineamientos estratégicos. Gobierno de Uruguay (https://www.gub.uy/ministerio-ambiente/politicas-y-gestion/planes/plan-nacional-respuesta-cambio-climatico).

2. La Política Nacional de Cambio Climático se aprobó mediante Decreto Nacional, No.310/017 en el año 2017 por el poder ejecutivo del Uruguay, a través del Ministerio de Vivienda, Ordenamiento Territorial y Medio Ambiente (https://www.impo.com.uy/bases/decretos-originales/310-2017).

\section{Definidos en la política nacional mencionada antes.}

4. Al respecto, ver informe del 10 de agosto de 2020 de la Relatora Especial sobre los derechos culturales Informe sobre los Derechos culturales y cambio climático, presentado a la Asamblea General en su $75^{\circ}$ sesión, el 22 de octubre de 2020 (https://www.ohchr.org/SP/Issues/CulturalRights/Pages/ClimateChange.aspx).

\section{Véase Decreto No.310/017, párrafo 5.}

6. La Ley Nacional de Patrimonio data del año 1971 (República Oriental del Uruguay, año 1971. Ley n. 14.040.
Creación de la Comisión del Patrimonio Histórico, artístico y cultural de la Nación), y la gestión a nivel nacional recae en una institucionalidad débil, de carácter honorario y con una estructura funcional y territorial limitada e insuficiente.

7. Como el proyecto Arqueología costero-serrana, oeste departamento de Maldonado (Proyecto ARCOS) del Centro Universitario Regional del Este (CURE) de la Universidad de la República de Uruguay (Udelar).

\section{BIBLIOGRAFÍA}

- Alexandrakis, G., Manasakis, C. y Kampanis, N.A. (2019) Economic and societal impacts on cultural heritage sites, resulting from natural effects and climate change. Heritage, vol. 2, n. ${ }^{\circ}$, pp. 279-305

- Berger, D. y Sequeira, F. (2018) Centros MEC. Análisis de una política pública cultural con anclaje territorial en el Uruguay de la última década. Encuentros Latinoamericanos (segunda época), vol. 2, n. ${ }^{\circ} 1$, pp. 39-54. Disponible en: https://ojs.fhce. edu.uy/index.php/enclat/article/view/72 [Consulta: 26/07/2021]

- Brum Bulanti, L., Álava, D. (De), Chocca, J. y Marín, Y. (2020) De Espaldas al Mar. Desafíos para un Manejo Integrado del Patrimonio Arqueológico Costero y Marítimo del Uruguay. Revista Costas, vol. 2, n. ${ }^{\circ}$ 1, pp. 81-104. Disponible en: http:// hum117.uca.es/redibermar/art5/ [Consulta: 26/07/2021]

- Erlandson, J.M. (2012) As the world warms: rising seas, coastal archaeology, and the erosion of maritime history. Journal of Coastal Conservation, vol. 16, n. ${ }^{\circ} 2$, pp. 137-142

- Gianotti, C., Gascue, A., Puerto, L. (Del), Inda, H. y Villarmarzo, E. (2017) Archaeological heritage on the Atlantic coast of Uruguay: heritage policies and challenges for its management in coastal protected areas. En: Dawson, T., Nimura, C. López-Romero, E. y Daire, M.Y. (ed.) Public archaeology and climate change. Oxford: Oxbow Books pp. 149-161

- Hall, C.M., Baird, T., James, M. y Ram, Y. (2016) Climate change and cultural heritage: Conservation and heritage tourism in the Anthropocene. Journal of Heritage Tourism, vol. $11,{ }^{\circ}{ }^{\circ} 1$, pp. $10-24$

- MEC [Ministerio de Educación y Cultura] (2014) Sumar en patrimonio. Montevideo: Ministerio de Educación y Cultura de Uruguay, SUMAR Conferencias ciudadanas

- Rodríguez, M.E. y Michelena, M. (2018) Memorias charrúas en Uruguay: reflexiones sobre reemergencia indígena desde 
a debate Patrimonio cultural y cambio climático

| coordina Alejandro García Hermida

una investigación colaborativa. ABYA-YALA: Revista sobre acesso á justiça e direitos nas Américas, vol. 2, n. ${ }^{0} 2$, pp. 180210

- Sabbioni, C., Cassar, M., Brimblecombe, P., Tidblad, J., Kozlowski, R., Drdácký, M., Saiz-Jiménez, C., Grøntoft, T., Wainwright, I. y Ariño, X. (2006) Global climate change impact on built heritage and cultural landscapes. En: Ruiz-Conde, A., Arjonilla-Álvarez, M., Sánchez Soto, P.J., Durán Domínguez, G. y Rivero Cabello, J.C. (coord.) International Conference on Heritage, Weathering and Conservation (HWC), vol. 1. Londres: Taylor \& Francis, pp. 395-401

- Santos, C., Narbondo, I., Oyhantçabal, G. y Gutiérrez, R. (2013) Seis tesis urgentes sobre el neodesarrollismo en Uruguay. Revista Contrapunto, vol. 1, n. ${ }^{\circ} 2$, pp. 13-32

- Sesana, E., Bertolin, C., Gagnon, A.S. y Hughes, J.J. (2019) Mitigating climate change in the cultural built heritage sector. Climate, vol. 7, n. ${ }^{0} 7,90$. Disponible en: https://doi.org/10.3390/ cli7070090 [Consulta: 26/07/2021]

- Verdesio, G. (2005) La mudable suerte del amerindio en el imaginario uruguayo: su lugar en las narrativas de la nación de los siglos XIX y XX y su relación con los saberes expertos. Araucaria. Revista Iberoamericana de Filosofía, Política y Humanidades, vol. 7, n. ${ }^{\circ} 14$, pp. 161-195

- Verdesio, G. (2014) Un fantasma recorre el Uruguay: la reemergencia charrúa en un "país sin indios". Cuadernos de literatura, vol. 18, n. ${ }^{\circ} 36$, pp. 86-107. Disponible en: https://doi. org/10.11144/Javeriana.CL18-36.frur [Consulta: 26/07/2021]

- Villarmarzo Andreatta, E. (2021) Patrimonio arqueológico y políticas de conservación de la naturaleza en Uruguay. Sociedad y Ambiente, n. ${ }^{\circ}$ 24, pp. 1-29. Disponible en: https:// revistas.ecosur.mx/sociedadyambiente/index.php/sya/article/ view/2257 [Consulta: 26/07/2021] 


\title{
¿De qué manera puede el patrimonio cultural convertirse en herramienta para la lucha contra el cambio climático?
}

\author{
Teófilo Victoria, Ricardo López | Facultad de Arquitectura, Universidad de Miami
}

URL de la contribución <www.iaph.es/revistaph/index.php/revistaph/article/view/4994>

Hoy por hoy, por lo menos en nuestra alterada memoria como consecuencia de haber sido testigos del desastre que causó el huracán Dorian a los pueblos y ciudades en las islas del cayo de los Ábacos, en la Mancomunidad de las Bahamas, en vez de preguntarnos cómo afecta el cambio climático al patrimonio cultural, la pregunta fundamental es: cuáles son las características constructivas de los asentamientos históricos responsable por un desempeño superior. Es decir, qué nos enseña y cómo documentar el patrimonio urbano y arquitectónico (en este caso, los asentamientos históricos del Gran Caribe) en términos de resiliencia frente a cambios hidrológicos y al aumento de la frecuencia e intensidad de huracanes en el Atlántico sur y en el Gran Caribe.

El 1 de septiembre de 2019, a las 12:00 PM (UTC) el huracán Dorian, tormenta de Categoría 5 (la clasificación más alta en la escala de huracanes de SaffirSimpson), alcanzó tierra en el cayo de Elbow Cay, en el archipiélago de los Ábacos en las Bahamas. Con vientos sostenidos de $185 \mathrm{mph}(297 \mathrm{~km} / \mathrm{h})$ y presión barométrica central de un mínimo de 910 mbar, Dorian es el huracán más fuerte registrado que azota ha azotado las Bahamas desde que comenzaron los registros en 1851. Está a la par con el peor huracán del siglo XX, el huracán del Día del Trabajo de 1935, por los vientos sostenidos más altos en un huracán del Atlántico al tocar tierra; y, por la misma métrica, también es el huracán más fuerte del Atlántico desde el huracán Wilma en 2005. Más importante, tal vez, Dorian constituye el mayor desastre en la historia de las Bahamas.

Ese domingo la tormenta hizo tierra en el asentamiento histórico de Hope Town en el cayo Elbow Cay antes de proseguir a Marsh Harbour, capital del archipiélago de los Ábacos y, el lunes, a Freeport, capital de la isla conti-

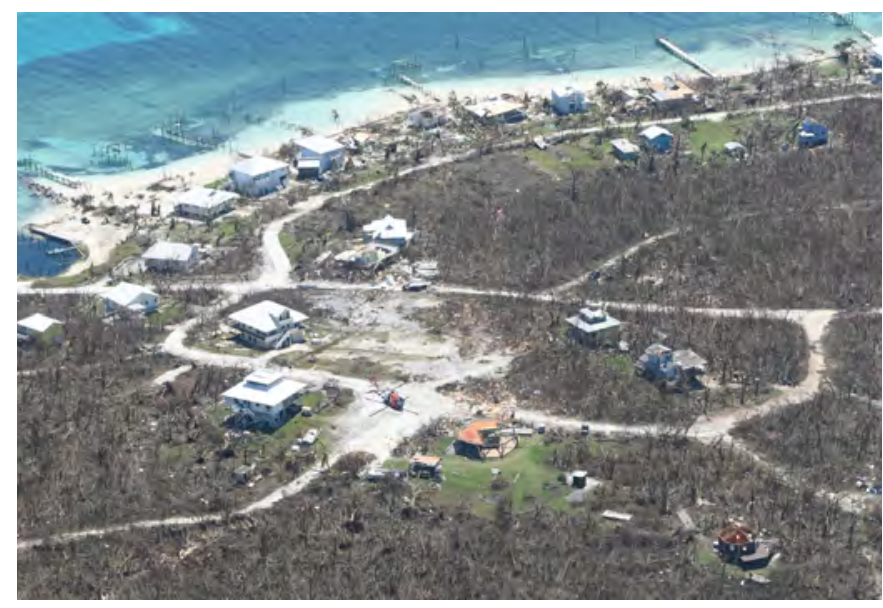

Cerca de Marsh Harbour, Bahamas, el 5 de septiembre de 2019 | foto Coast Guard News (Hunter Medley, suboficial de la Guardia Costera de Estados Unidos)

gua de Gran Bahamas. El huracán causó una marejada de 23 pies $(7.01 \mathrm{~m})$ sobre el nivel del mar y depositó 3 pies $(0.914 \mathrm{~m})$ de aguas torrenciales sobre las islas causando estragos incalculables. Milagrosamente hubo un mínimo de pérdida de vidas, pero la ciudad de Marsh Harbour fue destruida por completo y tuvo que ser evacuada el día después de la tormenta mientras que la otra ciudad moderna, Freeport, en la isla de Gran Bahama, fue rendida inoperable por las inundaciones.

Sin embargo, para asombro de todos, los asentamientos históricos construidos en madera hace dos siglos resistieron el azote de la tormenta, tanto los vientos como el embate de la marejada y las inundaciones por las lluvias, de una forma superior a las ciudades de la posguerra construidas en concreto armado.

Estos pueblos, Hope Town entre ellos, fundados a finales del siglo XVIII por Loyalist huyéndole a la revolución 


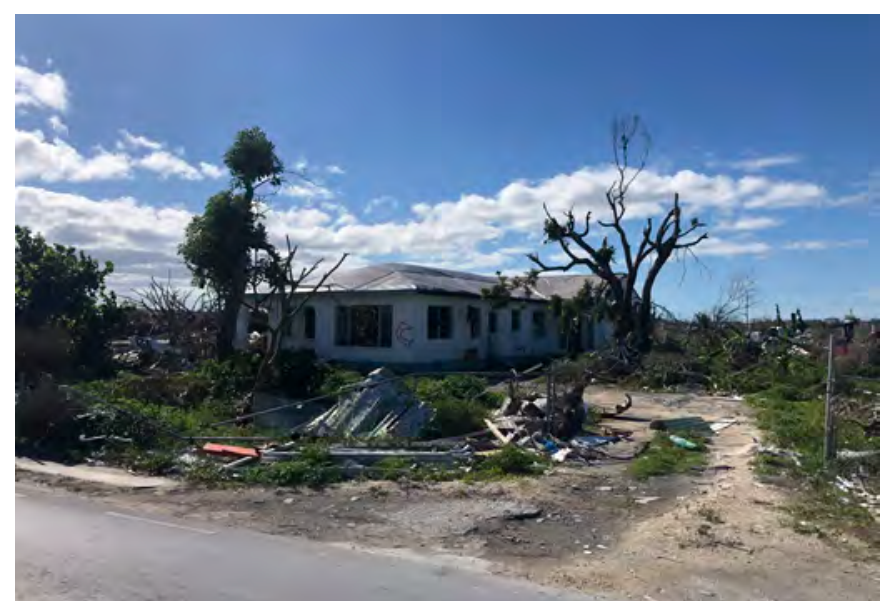

Marsh Harbour, Bahamas, tras el huracán Dorian en 2019 | foto Unitarian Universalist Service Committee

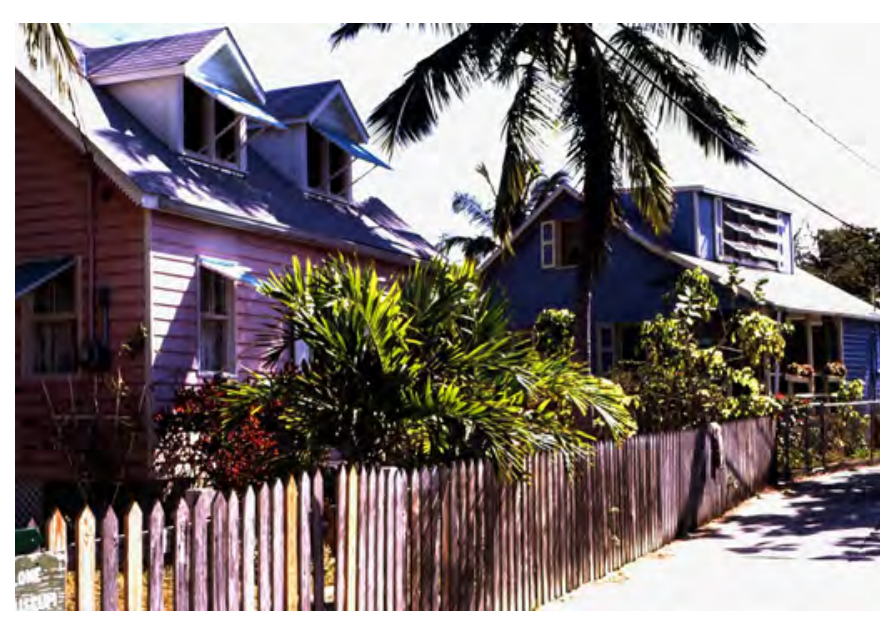

Hope Town, Elbow Cay, Bahamas 1989 | foto Rüdiger Stehn

americana de 1776, constituyen un patrimonio cultural singular, no solo de las Bahamas, sino que, además de compartir un origen común con "características constructivas y estilísticas" de las tradiciones edilicias en el Caribe angloafricano y las colonias inglesas en Norteamérica, constituyen un legado de alcance regional.

En una serie de talleres de dibujo y proyecto en la Facultad de Arquitectura de la Universidad de Miami se viene estudiando el legado histórico cultural de la arquitectura y urbanismo del Gran Caribe. En particular, las tradiciones edilicias del Caribe anglo-africano. Si en un primer momento nuestro enfoque estaba centrado en la preservación de este patrimonio, este interés se transformó, por las lecciones dadas, en el estudio de las características constructivas de la experiencia de nuestros antepasados, por su mayor resiliencia y correspondencia con el medio. Entre estas características encontramos, como fundamental, el cuidado en la selección del lugar de asentamiento. La posición de la trama urbana, su geometría y escala, fue uno de los factores principales en la mitigación de destrucción de la tormenta. Otro aspecto importante es el reconocimiento de la importancia de la geografía hidráulica del litoral isleño, su geología, patrones de vientos y, además, sorpresivamente, la incorporación en la construcción de materiales procedentes del medio. La piedra caliza oolítica, natural del arrecife, y la arena de las dunas, con su constituyente paisajista, contribuyeron tanto al remate de la marejada como a su disipación. Una tercera lección es el uso de la construcción de marco de madera, que ofrece como material y método de construcción, más allá de la tolerancia a la salinidad, obvia consideración, un nivel de elasticidad y flexibilidad estructural graduable a la velocidad y fuerza lateral de los vientos.

Cómo entonces se podrían documentar estos asentamientos es la consecuente pregunta. Hoy en día nuevas tecnologías pueden facilitar considerablemente la documentación del edificio, desplazamiento urbano y condiciones medio ambientales. Imágenes en 2D y 3D se pueden producir con mayor rapidez, precisión y de forma más económica que nunca. Con el acceso a los sistemas de posicionamiento global, con el software de procesamiento de gran alcance, y con el hardware fácilmente disponible una enorme cantidad de datos pueden ser recopilados y transformados a aplicaciones utilizables.

Por otra parte, estas nuevas tecnologías no sustituyen a los métodos tradicionales de grabación de estructuras históricas. La estabilidad de archivo de datos digitales es incierta, es deficiente en comparación a la estabilidad, de 500 años o más, de dibujos mecánicos producidos en tinta, ya sea en lienzo o mylar. Pero nuevas tecnologías ofrecen niveles elevados de precisión y facilidad en la 
interpolación de los datos, ya sea térmica, climatológica, o densidad de materiales en el medio o desplazamientos de bancos de arena, como ejemplo.

Un avión no tripulado equipado con cámara digital puede recolectar millones de píxeles de alta resolución, que se pueden transcribir a dibujos por ordenadores utilizados comúnmente en la arquitectura y la construcción. El proceso de documentación, sin embargo, aún requiere que una persona deba observar, analizar y componer dibujos de una forma precisa y completa.

En conclusión, creemos que, para el estudio y la documentación, el arquitecto, urbanista o paisajista puede integrar nuevas herramientas tecnológicas en su proceso tradicional de trabajo. La alta resolución digital de la ortofotografía, los levantamientos topográficos y las nubes de puntos complementan el conjunto de información que hasta ahora se obtenía de forma manual y dispersa. Y si esos datos pueden ser archivados en un formato fiable y estable facilitaría un nivel de interfaz adecuado para el acceso a múltiples escalas de dibujos y diversos tipos de información que nos aproxime a la resiliencia y sostenibilidad ambiental y cultural que demuestra el patrimonio cultural edilicio de nuestras respectivas tradiciones. 


\section{$\mathrm{PH} 104$ reseñas}

\section{HACIA UNA CULTURA SOSTENIBLE}
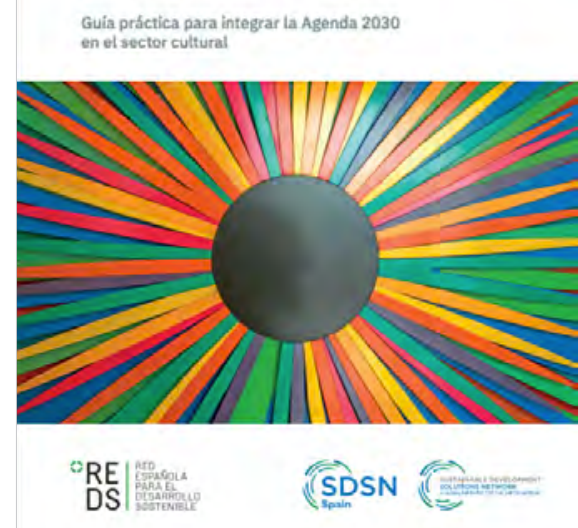

Martinell Sempere, A. y García Haro, M. (dir.)

Hacia una cultura sostenible. Guía práctica para integrar la Agenda 2030 en el sector cultural

sl: Red Española para el Desarrollo Sostenible, 2021

Este manual de la Red Española para el Desarrollo Sostenible (REDS) supone un primer ejercicio, pionero en España, para aterrizar la Agenda 2030 en el sector cultural y creativo, incluyendo orientaciones y acciones prácticas para todo el ecosistema cultural.

La guía se estructura en cuatro capítulos. La introducción aborda la dimensión cultural del desarrollo sostenible, por qué necesitamos seguir colaborando para obtener una cultura sostenible y las distintas conexiones que se producen en el sistema cultural.

El primer capítulo explica cómo contribuye la cultura a lograr un entorno más sostenible, desarrollando de ese modo los 17 Objetivos de Desarrollo Sostenible (ODS), los cuales son metas que garantizarán un futuro mejor para todos. Estos 17 ODS, tan importantes para esta guía, se convierten en un aviso o una llamada a la acción a todos los países y todas las personas para proteger el planeta y construir un mundo mejor y más sustentable.

El segundo capítulo plantea los principios generales (para toda la cultura) y específicos (para los distintos subsectores) que pueden servir de orientación para integrar el enfoque sostenible en el ámbito cultural. Por otra parte, en este capítulo se explica que el sistema cultural se caracteriza por la implicación y participación de un gran número de agentes. Se distinguen dos tipos de agentes culturales: los agentes directos, como la Administración pública, el sector privado, la sociedad civil, los creadores de contenido y el cuarto sector; y los agentes indirectos, como las empresas implicadas en la producción, patrocinadores y mecenas, suministradores de materiales de consumo y redes colaborativas.

El tercer capítulo incorpora una pequeña guía para elaborar un plan de acción sostenible. Se enumeran las distintas fases para integrar y aplicar el enfoque sostenible en una institución o proyecto cultural.

Las fases son las siguientes:

> Fase 1: Compromiso, en la cual se busca la voluntad de cambio.

> Fase 2: Diagnóstico, fundamental para comprender dónde estamos y hacia dónde nos dirigimos. 
> Fase 3: Integración en la gestión, en donde se establece una serie de objetivos y plazos.

$>$ Fase 4: Evaluación y seguimiento, en donde se evaluará y revisará todo lo descrito anteriormente.

> Fase 5: Comunicar las acciones realizadas.

Por último, el capítulo cuarto comprende cinco casos de estudio, dos anexos sobre los ODS y un tercer documento con recursos útiles (publicaciones, enlaces y webs).

La conclusión, tras la lectura de la Guía práctica para integrar la Agenda 2030 en el sector cultural, es que vivimos en un mundo globalizado, en el que la mayoría de la población coexiste de forma independiente, donde el bienestar ya no es importante y donde no se lucha por conseguir vivir en paz y en un mundo más cuidado, saludable y sostenible.

La Agenda se aprobó en septiembre de 2015 en la Asamblea General de Naciones Unidas. La Red Española para el Desarrollo Sostenible (REDS) lleva trabajando en la formación e integración de la Agenda 2030 en el sector cultural desde su fundación y, a partir de ese momento, todos los sectores de la sociedad se han activado para ponerla en marcha y lograr estos difíciles e increíbles objetivos. Sería importante que la sociedad actuase rápidamente y no se quedase de brazos cruzados y que pudiera asumir la obligación o el deber moral de actuar conjuntamente para lograr una verdadera transformación de las instituciones, del entorno y del mundo.

Patricia Pérez Muncunill | Graduada en Humanidades

URL de la contribución <www.iaph.es/revistaph/index.php/revistaph/article/view/4971> 


\section{$\mathrm{PH} 1044_{\text {reseñas }}$}

López Morales, F.J. (coord.)

\section{El patrimonio cultural inmaterial: usos sustentables del patrimonio}

Tlaxcala, México: Instituto Nacional de Antropología e Historia, 2017

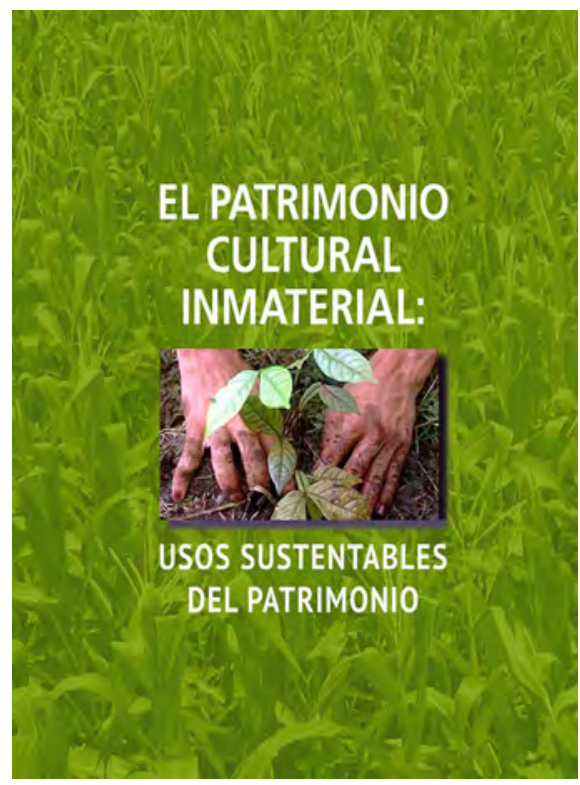

Este libro, coordinado por Francisco Javier López Morales (director de Patrimonio Mundial del INAH) y escrito por una veintena de autores expertos en la materia, se centra, principalmente, en tratar el tema de los usos sostenibles que ofrece el patrimonio cultural inmaterial $(\mathrm{PCl})$ en la sociedad actual. El texto pone en contexto al lector en el momento en el que más de 150 jefes de Estado y de Gobierno se reunieron en Nueva York para participar en la cumbre las Naciones Unidas sobre el Desarrollo Sostenible, en el año 2015.

En esa importantísima reunión, que fue clave y marcó un antes y un después en este tema, se aprobaron los 17 objetivos de la Agenda 2030, vigentes desde el 1 de enero de 2016 y que son de observancia universal, con el fin de alcanzar la meta de un mundo sustentable en el año 2030. Estos Objetivos de Desarrollo Sostenible que se aprobaron buscan ampliar los éxitos alcanzados y lograr lo que no pudo ser conseguido en el pasado. Por otro lado, la dificultad de otros nuevos objetivos radica en que motivan a los países, independientemente de sus niveles de riqueza, a implementar medidas para promover el combate a la pobreza, al tiempo que protegen el planeta.

En ese sentido, establecen que se debe favorecer el crecimiento económico a través de la atención de una serie de necesidades sociales, entre las que destacan, por ejemplo: las oportunidades de empleo, la salud, la cultura, la protección social, la educación, etc.

Dada esta situación, la Dirección de Patrimonio Mundial del Instituto Nacional de Antropología e Historia consideró oportuno celebrar la octava edición del Coloquio internacional sobre patrimonio inmaterial, cuyo tema protagonista fuera la contribución que el patrimonio cultural inmaterial es capaz de ofrecer al desarrollo sostenible o sustentable. Entonces, en el año 2017, se dieron cita diferentes expertos y especialistas provenientes de Guatemala, Colombia, Brasil, Argentina, Canadá, España y también de distintas entidades federativas de México, en la ciudad de Tlaxcala de Xicoténcatl. En esta reunión de expertos e investigadores se creó un espacio muy interesante de discusión, donde se habló sobre la necesidad de resaltar el papel del patrimonio cultural inmaterial como garante del desarrollo sustentable, tomando como referencia aquellos primeros 17 objetivos que se propusieron en un principio. 
Las investigaciones y discusiones sobre el tema, expuestas en aquella importante reunión y que están reflejadas esta obra, se organizaron en tres mesas de trabajo que analizaron con precisión las distintas cuestiones: la Mesa 1 "El patrimonio inmaterial y la gestión sustentable de la biodiversidad", donde se trataron casos concretos en los que las formas de gestión conforman en sí mismas un patrimonio cultural inmaterial que juega un papel importante en el acceso y disfrute de la biodiversidad; la Mesa 2 "El desarrollo social inclusivo basado en el patrimonio inmaterial", donde los expertos resaltaron la participación de las comunidades portadoras en la toma de decisiones respecto a proyectos de registro, documentación y gestión del patrimonio cultural inmaterial; y por último, la Mesa 3 "El patrimonio inmaterial como activo y catalizador del desarrollo económico", donde los expertos llegaron a las conclusiones debatiendo sobre destacar la relevancia de la gestión integral del $\mathrm{PCl}$ para lograr el impulso y desarrollo económico de comunidades.

En conclusión, con este libro hemos podido observar la importancia que tiene profundizar en el estudio del patrimonio cultural inmaterial y cómo este influye en nuestra sociedad y en el desarrollo sostenible, un tema de gran importancia para nuestros días.

José Miguel Marín Prieto | Historiador del arte

URL de la contribución <www.iaph.es/revistaph/index.php/revistaph/article/view/4982> 


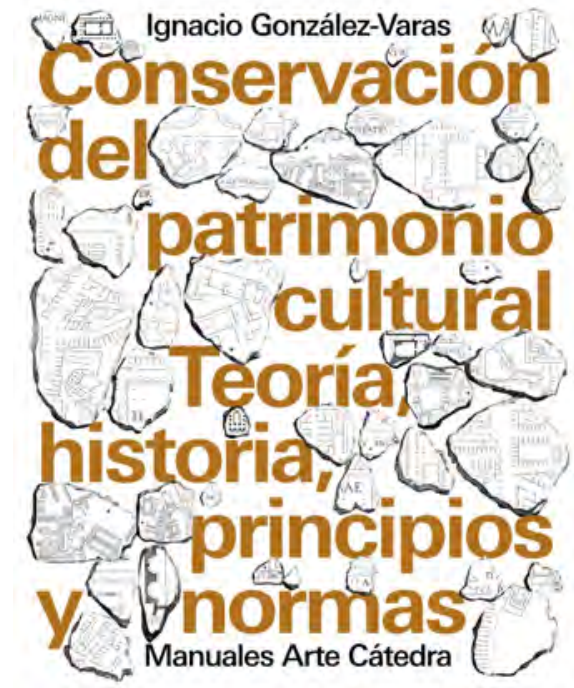

González-Varas, I.

Conservación del patrimonio cultural. Teoría, historia, principios y normas (2. ${ }^{a}$ ed.)

Madrid: Cátedra, 2018

El libro reseñado supone, en realidad, la puesta al día de una publicación que vino a llenar un vacío en la bibliografía española dedicada a la conservación del patrimonio cultural. Cuando se publicó su primera edición, en 1999, se convirtió en un manual de referencia para el campo disciplinar mencionado. El título con que salió entonces, Conservación de bienes culturales (reeditado en varias ocasiones), permite vislumbrar el cambio operado con respecto al actual. Su autor, Ignacio González-Varas, Catedrático de Composición Arquitectónica en la Escuela de Arquitectura de Toledo (Universidad de Castilla-La Mancha), ha publicado esta segunda edición (2018) que tiene la virtud de revisar, ampliar y actualizar aquel libro fundamental. Entre ambas ediciones, publicó tres libros más que, de algún modo, avanzaron algunas de las cuestiones ampliadas en el manual que ahora glosamos desde un enfoque ensayístico: Las ruinas de la memoria. Ideas y conceptos de una (im) posible teoría del patrimonio cultural (Siglo XXI, 2014); Patrimonio cultural. Conceptos, debates y problemas (Cátedra, 2015); y Ciudad, paisaje y territorio: conceptos, métodos y experiencias (Munilla-Lería, 2016).

Escrito con una prosa rica y fluida, el libro está estructurado en tres partes que suman un total de 14 capítulos, además de la introducción que las precede y de un glosario, apartado de notas, bibliografía y diversos índices (onomástico, de obras, de organismos, leyes, etc.) en la parte final, todos ellos bien nutridos y de gran utilidad. Como es habitual en la colección Manuales Arte Cátedra, el repertorio de ilustraciones es reducido respecto al texto -también su tamaño-y, con todo, son casi 300 imágenes las que ofrece.

La primera parte se dedica al "Concepto y problemas del patrimonio cultural. Los bienes culturales y su conservación". Compuesta por dos capítulos, conforma un marco teórico-conceptual imprescindible, con un repaso a la evolución histórica de los conceptos asociados al patrimonio y los bienes culturales, además de otro apartado sobre conservación y restauración. En ellos se han incorporado nuevos epígrafes respecto a la primera edición, como el que trata sobre el valor de la autenticidad o el que estudia el patrimonio y la identidad cultural, cuestiones que resultan de enorme interés. La gran expansión patrimonializadora en la época de la hipercultura ha generado nuevas problemáticas y retos que, sin duda, será necesario afrontar en el futuro.

La segunda parte versa sobre "La conservación del patrimonio cultural como disciplina. Restauraciones de facto y teorías de la restauración". Sus 9 capítu- 
los vertebran un recorrido muy completo por la evolución histórica de la disciplina, desde sus precedentes en la Antigüedad -mucho antes de adquirir tal distinción- hasta el presente, marcado por el signo de la hipermodernidad. Es al final de esta parte en la que se observan mayores diferencias respecto a la edición de 1999. En el capítulo 8 se ha añadido un interesante apartado sobre intervenciones de las últimas décadas en España; y en el siguiente se advierte una notable renovación, fruto, sin duda, del libro Ciudad, paisaje y territorio (2016). Además, haciéndose eco de las últimas corrientes y problemáticas que afectan a la consideración y a la conservación patrimoniales, el autor ha añadido dos capítulos más, referidos al patrimonio etnológico e inmaterial y a la relación entre patrimonio cultural y turismo.

La tercera parte aborda "La tutela del patrimonio cultural. Instituciones, legislación y normas generales". Se inicia con un capítulo dedicado a las cartas del restauro italianas, documentos cardinales en la orientación de la reflexión y de la acción conservadora y restauradora desde finales del siglo XIX. El siguiente se dedica a las instituciones y legislación del ámbito internacional, con especial atención a la UNESCO, el ICOMOS y otras instituciones europeas y latinoamericanas, con un extenso catálogo crítico de la normativa emanada de estos organismos. El último capítulo aborda la legislación nacional, asunto muy actual, cuando se acaba de aprobar el anteproyecto de Ley (22 de junio de 2021) por el que se modifica la Ley 16/1985, de 25 de junio, del Patrimonio Histórico Español y la Ley 10/2015, de 26 de mayo, para la salvaguarda del Patrimonio Cultural Inmaterial.

En definitiva, las 780 páginas de esta nueva edición constituyen por sí mismas un verdadero monumentum dedicado a la conservación del patrimonio cultural. Resulta difícil encontrar entre las empresas editoriales españolas un libro tan amplio y completo referido a este tema. Publicación que, en realidad, es parte de una magna obra con el que se han formado varias generaciones de historiadores del arte, arqueólogos, arquitectos, restauradores, gestores y otras personas ligadas al arte y la cultura: la colección Manuales Arte y la colección, más joven, Arte Grandes Temas, de Cátedra.

Jesús Ángel Sánchez Rivera | Dpto. de Didáctica de las CC. Sociales, Universidad Complutense de Madrid

URL de la contribución <www.iaph.es/revistaph/index.php/revistaph/article/view/4981> 


\section{$\mathrm{PH} 1044_{\text {reseñas }}$}

Valero Matas, J.A.

\section{Patrimonio cultural, sostenibilidad y desarrollo humano en lo rural}

Valencia: Tirant Lo Blanch, 2021

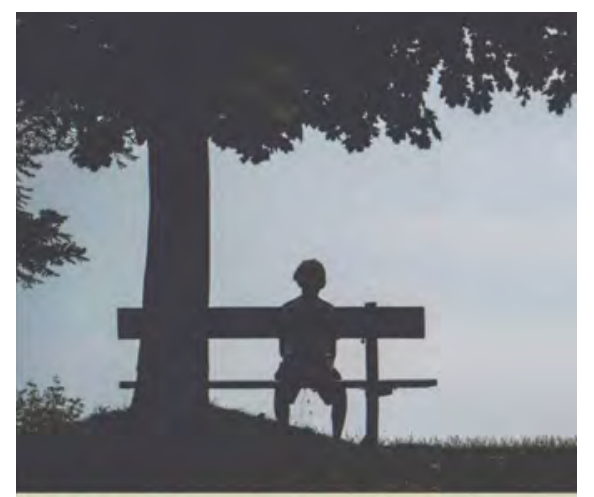

Patrimonio cultural, sostenibilidad y desarrollo humano en lo rural

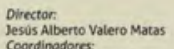

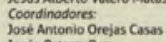
lesis Oriego osa
Universicod de vallodolid
Se trata de un libro que brinda una mirada multidisciplinar a través de una serie de textos para el análisis y la reflexión del patrimonio cultural en sus diversas dimensiones, para su valoración, para repensar las posibilidades de un nuevo modelo que dinamice espacios rurales con un humanismo sostenible. La obra se organiza en once capítulos, con un prólogo que destaca el esfuerzo conjunto de académicos e instituciones en comunicar sobre el despoblamiento y las políticas de territorialidad para emprender soluciones al abandono rural.

El primer capítulo presenta la labor de las fundaciones, su devenir acercándose al mundo empresarial. Se centra en la Fundación Santa María la Real del Patrimonio Histórico como modelo innovador, sostenible, ético y de buen gobierno. En el segundo se destaca rol de las ciudades intermedias, los cambios que generan en la geografía urbana, abriendo debate para proyectarlas como alternativa o complemento, como conexión entre las grandes ciudades y lo rural.

En el capítulo número tres, a través de un proyecto de investigación, se muestra la perspectiva museográfica de la cultura tradicional, para reflexionar sobre la representación de la cultura, el proceso de visibilizar y exponer el patrimonio cultural. Precisamente el capítulo que le sigue está referido al análisis del turismo rural, su evolución, características, etc., delimitando el trabajo a la Serranía Celtibérica, para vislumbrar oportunidades del turismo regenerativo contra la despoblación.

El siguiente capítulo enfatiza la necesidad de identificar y revisar dimensiones e indicadores de sostenibilidad de las ciudades, centrándose en la importancia de la gobernabilidad como factor clave para establecer acuerdos, fomentar la humanidad frente a la tecnología y la gestión de los espacios urbanos y rurales. El sexto capítulo, a través de un trabajo comparativo de tres valles pirenaicos en Aragón, analiza el medio físico, eventos históricos, demografía y economía de las últimas décadas, evaluando impactos y perspectivas de desarrollo turístico.

En el capítulo 7, ante la despoblación que considera la España "vacía" como referencia descriptiva y la España "vaciada" resultante de errores y omisiones de políticas públicas, se contrapone el papel de la cultura en el medio rural, presentando iniciativas como activadoras patrimoniales sostenibles. 
El octavo remite al surgimiento de la despoblación rural, procesos, desequilibrios y desigualdades territoriales, la densidad poblacional, dispersión y envejecimiento; la inmigración como tendencia laboral, opción de repoblación y recuperación demográfica. La visión realista de la sostenibilidad y complejidad que resulta de que los inmigrantes puedan poblar municipios rurales, la reflexión para toma de medidas y mantenimiento de espacios rurales viables.

El noveno incide en el reto demográfico y la despoblación. Superar la fase de desierto demográfico, mantener la vida de los pueblos, articular medio rural y medio urbano, realizar acciones y planes que repercutan en la natalidad. Así, ante el presente con la COVID-19, la grave crisis económica, la incidencia en los jóvenes como el colectivo más afectado, con proyectos de vida retrasados, un mercado de trabajo precarizado y opciones de empleo reducidas; la natalidad se afectará negativamente. Se plantea la hipótesis de oportunidad para el medio rural, ofreciendo mejores opciones de vida para enfrentar confinamientos, requiere de cambios globales que deben estructurarse, pero que aún no serán visibles a corto plazo. En el capítulo décimo encontramos una propuesta de interpretación de los usos simbólicos dados a ciertos objetos ganaderos y sus posibilidades expositivas. El significado y sentido metafórico crea nuevas analogías, como crítica a museografía etnográfica que genera exposiciones clasificadas por su funcionalidad práctica.

El undécimo identifica temas relevantes y prioritarios. Ofrece una muestra representativa de ciudades intermedias, defiende su contribución a la toma de decisiones, su adaptabilidad a características específicas. Asimismo, realiza el análisis comparativo de tres iniciativas de ciudades para entender y atender prioridades de las urbes, definiendo índices de ciudades creativas, caminables, competitivas, un análisis cuantitativo que puede dar pautas de las tendencias que se abren paso.

Finalmente, reconocer una publicación poliédrica, amplia y diversa, que permite e invitar a descubrir y reflexionar en torno al patrimonio cultural, la sostenibilidad y la contribución al desarrollo humano en el medio rural.

Silvia Isabel Quinto Fernández | Universidad Nacional de Ingeniería

URL de la contribución <www.iaph.es/revistaph/index.php/revistaph/article/view/4978> 


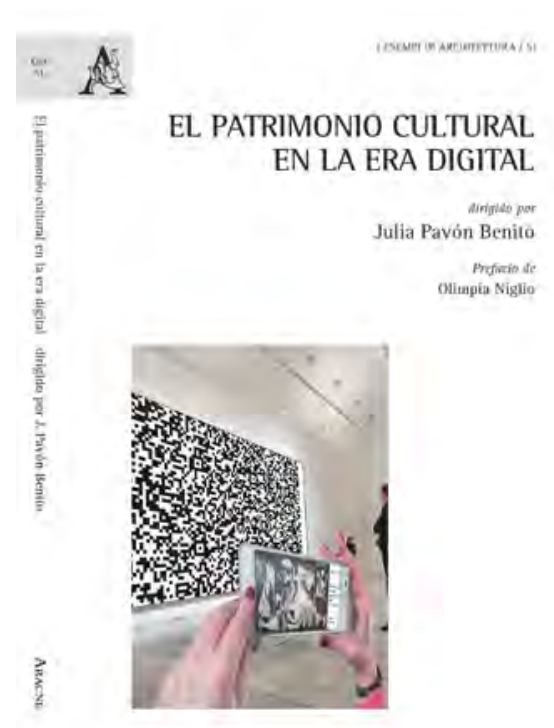

Pavón Benito, J. (dir.)

\section{El patrimonio cultural en la era digital}

Canterano: Aracne editrice, 2020

Como puede deducirse del título, El patrimonio cultural en la era digital, estamos ante una obra que en sí misma supone un desafío en materia de cultura, divulgación y museos. Un mundo cada vez más cambiante e hiperconectado exige un esfuerzo mayor a la hora de entender la realidad en la que vivimos, especialmente cuando ciertos canales comunicativos y lenguajes terminan por confluir.

Si aplicamos este planteamiento al mundo de los museos, observamos cómo la adopción de las nuevas tecnologías de la información ha hecho posible extender sus contenidos más allá de la materialidad de la institución en su sentido más tradicional. Sin embargo, esa irrupción de lo virtual en lo cotidiano merece un análisis sosegado, ya que disponibilidad o inmediatez no son, necesariamente, sinónimos de excelencia. Asumir que cualquier proyecto es válido por el mero hecho de ser creativo en forma, de poseer lo que podríamos llamar una identidad digital, supone incurrir en el grave error de descuidar los pormenores de los procesos cognitivos, o peor aún, de reducirlos a una visión utilitarista de las cosas.

En el libro se desarrollan media docena de contribuciones en las que se reúnen, valoran y sopesan distintas propuestas, todas ellas surcadas por el denominador común de la digitalización.

El primer trabajo, "Introducción. El laberinto del patrimonio cultural en la era digital", propone un recorrido en torno a la noción de museo desde el coleccionismo primigenio a nuestro tiempo. Indaga en la razón primaria por la cual existen estos espacios, introduciendo elementos esenciales que los fundamentan y legitiman, como lo son la memoria o la curiosidad. Al mismo tiempo, apuesta por estimular el aprendizaje continuo, aplicando toda esa experiencia previa al Museo de Navarra.

La segunda aportación, "El Museo en la web: los museos en la era de la reproductibilidad digital", realiza un repaso sobre la trayectoria divulgativa de los contenidos de la web del Museo del Prado como proyecto de ilustración digital a gran escala, accesible, sensorial y en constante crecimiento.

En una línea similar, y sin abandonar el rico debate en torno a la transformación digital, se desarrolla el siguiente trabajo: "Museo Reina Sofía: procesos y funciones en la era digital". En él se muestra la labor desarrollada por el departamento digital de la institución en su web, así como los ejes de 
actuación más importantes: el trabajo multimedia, la promoción de la radio digital o el galardonado Repensar el Guernica, un verdadero desafío a nivel artístico-documental.

Por su parte, "Centro Botín: artes, emociones y creatividad", pretende reivindicar un discurso en el que se premia la creatividad mediante propuestas artísticas propias que apelan a lo emocional. Este estímulo también está presente en el siguiente texto, "Museo Virtual de Sefarad", en el que se rompe una lanza en favor del legado judaico en la Península Ibérica, al tiempo que se analizan los parámetros que permiten calibrar y evaluar la viabilidad del proyecto (diseño y objetivos, accesibilidad, visibilidad, flexibilidad, costes...); ingredientes que, en suma, permiten avanzar en la definición de una misión, visión y valores propios.

El último estudio, "Del museo a la iglesia. La digitalización y reproducción del patrimonio sacro medieval del Valle de Arán", recoge el espíritu de los proyectos anteriores, impulsándose en la digitalización y mecanizado del material escultórico en este espacio mediante la aplicación de la tecnología 3D.

En resumen, estamos ante un trabajo sencillo en forma, pero extremadamente maduro en la exposición de sus contenidos. Una contribución que, como afirmábamos al comienzo, supone un desafío, pero también una oportunidad de conciliar pasado, presente y futuro.

\section{Ana Isabel Castro Carbonell | Gestora cultural}

URL de la contribución <www.iaph.es/revistaph/index.php/revistaph/article/view/4974> 


\section{$\mathrm{PH} 1044_{\text {reseñas }}$}

\section{Revert, X. (coord.) \\ Valencia: Patrimonio cultural y Objetivos de Desarrollo Sostenible}

Valencia: Universitat de València, 2019

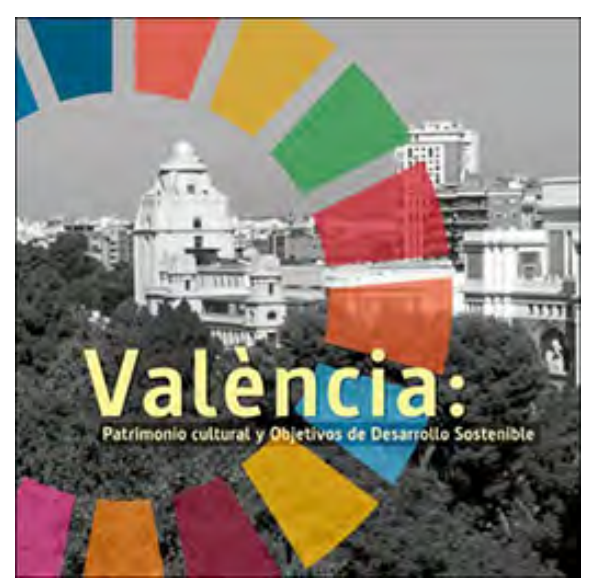

Si nos preguntamos cuál es el papel de la cultura para lograr los Objetivos del Desarrollo Sostenible (ODS), la respuesta puede ser compleja. Incluso podríamos pensar que la cultura está separada de los ODS y que ni siquiera la toman en consideración, puesto que los tres pilares que la Agenda 2030 considera son lo económico, lo social y lo medioambiental. Así pues se dejaría de lado a la cultura, aunque la consideremos inherente al ser humano. Quizás por eso la UNESCO ha luchado por convertir la cultura en el cuarto pilar de la Agenda 2030, redoblando esfuerzos para que sea considerada como un factor clave en el logro de los objetivos de Naciones Unidas. Para ello es necesaria la participación de distintos agentes, desde organismos públicos y privados hasta llegar a la sociedad civil.

En esa línea se inscribe el primer taller universitario para lograr una ciudadanía global a través del patrimonio, coordinado por Ximo Revert. El taller tuvo lugar en 2018 en la capital valenciana, y fue organizado por la Cátedra UNESCO de Estudios sobre el Desarrollo de la Universitat de València y el área de Cooperación de la Fundación General de dicha Universidad, contando también con el apoyo del Ministerio de Asuntos Exteriores y Cooperación y el Ayuntamiento de Valencia. Fruto de esa experiencia es el libro que reseñamos, València: Patrimonio cultural y Objetivos de Desarrollo Sostenible (Valencia: Universitat de València, 2019), cuyo coordinador es el propio Ximo Revert, doctor en patrimonio cultural por la Universitat de València $y$, actualmente, Jefe del área de voluntariado cultural de esta universidad. El libro nos propone un agente más dentro de este plan de apoyo a la cultura sostenible: la universidad. Entendiendo que no solo consiste en un espacio de creación de conocimientos, sino que también es un lugar de reflexión y de resiliencia que permite dar soluciones a los desafíos que se nos presentan en esta sociedad globalizada.

València: Patrimonio cultural y Objetivos de Desarrollo Sostenible, aborda el patrimonio cultural en el marco de los ODS, mostrando su transversalidad gracias a la participación de toda la comunidad universitaria, desde el profesorado, hasta el alumnado, sin olvidar al personal administrativo.

Dicha transversalidad se complementa a través de las diferentes ramas o disciplinas académicas en las que cada uno de estos participantes desarroIla su labor, ya sea académica o docente. A su vez nos permite acercarnos al pasado de una sociedad que ha buscado vivir en una cultura de paz a la vez 
que intentaba mejorar sus condiciones de vida. Formas de vida que pueden rescatarse en su sostenibilidad actual.

Como resultado de las intervenciones en el taller de ODS y ciudadanía global, el libro nos presenta distintos elementos patrimoniales precedidos de una descripción y una relación de los objetivos a los que contribuye. Entre ellos encontramos el Antiguo Foro Romano, o el Paradot de Sant Joan del Mercat pero también elementos intangibles que nos muestran el papel de la mujer en Valencia, con ejemplos como Germana de Foix, incluyendo lugares en los que estas mujeres desempeñaron un papel fundamental, como la Sala Matilde Salvador. En suma, el libro ofrece la posibilidad de realizar un recorrido por veintidós elementos patrimoniales que configuran una ruta por una Valencia comprometida por la sostenibilidad y la ciudadanía global.

El patrimonio cultural, contemplado desde la interdisciplinariedad, nos permite ver cómo los elementos patrimoniales influyen en la vida diaria de las personas, así como reconocer el trabajo de las comunidades pasadas y cómo han influido en el desarrollo de la sociedad actual. Aquí es cuando nos podemos preguntar qué tienen en común patrimonios artísticos, industriales e incluso personas como Margarida Borrás (primera mujer transexual ejecutada en Valencia) con los Objetivos de Desarrollo Sostenible. Pregunta que nos resuelve de manera sencilla la lectura de esta obra al darnos a conocer cómo los vestigios del pasado nos hablan de logros por mejorar las condiciones de vida y las libertades de las personas, fomentando, en quien se acerca al patrimonio y a las referencias culturales, la importancia de contribuir a soluciones sostenibles y de reconocernos con empatía en lo que otras personas hicieron por su dignidad y por una justicia sostenible.

Sofía L. Arellano Velázquez | Área de Filosofía Moral, Universidad de Córdoba

URL de la contribución <www.iaph.es/revistaph/index.php/revistaph/article/view/4967> 